\title{
Idaho National Laboratory PCB Annual Document Log and Annual Records Report for Calendar Year 2014
}

June 2015

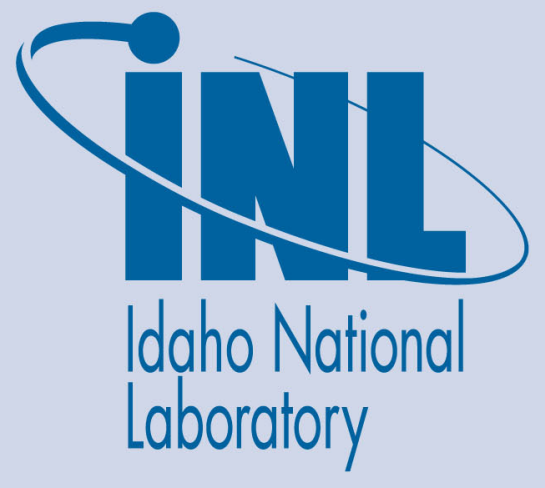

The INL is a U.S. Department of Energy National Laboratory operated by Battelle Energy Alliance 
INL/EXT-15-34774

\section{Idaho National Laboratory PCB Annual Document Log and Annual Records Report for Calendar Year 2014}

June 2015

Idaho National Laboratory
Idaho Falls, Idaho 83415

http://www.inl.gov

Prepared for the

U.S. Department of Energy

Office of Nuclear Energy

Under DOE Idaho Operations Office

Contract DE-AC07-05ID14517 
POLYCHLORINATED BIPHENYL (PCB) ANNUAL DOCUMENT LOG

AND RECORDS REPORT FOR

CALENDAR YEAR 2014

For the

IDAHO NATIONAL LABORATORY

P. O. BOX 1625

IDAHO FALLS, ID 83415

EPA ID Nos. ID4890008952 (INL Site) and ID6890190089 (INL Research Center)

Prepared by

Battelle Energy Alliance, LLC (BEA)

June 2015

\subsection{INTRODUCTION}

The requirements for the reporting of polychlorinated biphenyl (PCB)-related activities are found in 40 Code of Federal Regulations (CFR) 761 Subpart J, "General Records and Reports."

The PCB Annual Document Log is a detailed record of the PCB waste handling activities at the facility. The facility must prepare it each year by July 1 and maintain it at the facility for at least 3 years after the facility ceases using or storing PCBs and PCB items. While submittal of the PCB Annual Document Log to the U.S. Environmental Protection Agency (EPA) is not required by regulation, EPA has verbally requested in telephone conversations that this report be submitted to them on an annual basis. The Annual Records are not required to be submitted to EPA and are not considered to be part of the Annual Document Log, but are included to provide the complete disposition history or status of all PCB activities during the year.

The Annual Document Log section of this report (Section 2.0) meets the requirements of 40 CFR 761.180(a)(2), as applicable, while the Annual Records section (Section 3.0) meets the requirement of 40 CFR 761.180(a)(1). 


\subsection{PCB ANNUAL DOCUMENT LOG}

2.1 Remaining in Service for Calendar Year 2014 per 40 CFR 761.180(a)(2)(iv), (v), and (vi)

There are no PCB transformers, PCB capacitors (large high or low voltage capacitors), nor PCB containers remaining in service at the Idaho National Laboratory (INL).

2.2 Waste Activities during Calendar Year 2014

The data on the following pages are a detailed record of nonradioactive and radioactive PCB handling activities at the facility in compliance with 40 CFR

761.180(a)(2)(ii)(A),(B),(C), and(D), and 40 CFR761.180(a)(2)(iii) as applicable for the calendar year 2014 .

This section is separated into two parts, INL without Advanced Mixed Waste Treatment Project (AMWTP) and AMWTP. 
Idaho National Laboratory

(excluding Advanced Mixed Waste Treatment Project [AMWTP])

PCB Waste Document Log

Removed from Service, Shipped and/or Disposed During Calendar Year 2014

\begin{tabular}{|c|c|c|c|c|c|c|c|c|c|c|}
\hline Type* & Identification \# & $\begin{array}{l}\text { Radioactive } \\
\text { (Y/N) }\end{array}$ & Description & $\begin{array}{c}\text { Gross } \\
\text { Weight } \\
\text { (KGS) }\end{array}$ & $\begin{array}{c}\text { Net } \\
\text { Weight } \\
\text { (KGS) }\end{array}$ & $\begin{array}{c}\text { Date of } \\
\text { Removal } \\
\text { from Service }\end{array}$ & $\begin{array}{c}\text { Transport } \\
\text { Date }\end{array}$ & $\begin{array}{l}\text { Disposal } \\
\text { Date }\end{array}$ & $\begin{array}{l}\text { Manifest } \\
\text { Number }\end{array}$ & Notes \\
\hline AC $\quad C$ & 02-14-064-001-F & No $P$ & PCB Capacitors & 8 & 7 & $12 / 9 / 2014$ & & & & \\
\hline C & 02-14-064-002-F & No & PCB Debris & 5 & 4 & $8 / 25 / 2014$ & & & & \\
\hline $\mathrm{AC}$ & $10-11-200-032-\mathrm{F}$ & No & PCB Ballasts & 41 & 36 & $6 / 3 / 2014$ & & & & \\
\hline $\mathrm{C}$ & $1198-003$ & Yes & PCB Debris & 385 & 167 & $12 / 9 / 2014$ & & & & \\
\hline C & $1198-011$ & Yes & PCB Debris & 300 & 82 & $6 / 11 / 2014$ & & & & \\
\hline C & $16-02-249-006-F$ & Yes & PCB Debris & 10 & 2 & $11 / 18 / 2014$ & & & & $\mathrm{~b}$ \\
\hline C & $20-10-172-020-\mathrm{F}$ & Yes & PCB Debris & 11 & 6 & $10 / 8 / 2014$ & & & & $\mathrm{~b}$ \\
\hline C & $30-11-311-030-\mathrm{F}$ & No & PCB Debris & 20 & 5 & $8 / 25 / 2014$ & & & & $b$ \\
\hline C & $30-11-311-049-\mathrm{F}$ & Yes & PCB Debris & 23 & 8 & $8 / 5 / 2014$ & & & & $\mathrm{~b}$ \\
\hline C & $55-12-222-073-\mathrm{F}$ & Yes & PCB Debris & 45 & 18 & $10 / 30 / 2014$ & & & & \\
\hline C & $55-14-128-036-F$ & Yes & PCB Debris & 51 & 24 & $10 / 31 / 2014$ & & & & \\
\hline C & ATRX130070 & Yes & $\begin{array}{l}\text { INL ATR Complex TSCA Regulated MLLW } \\
\text { Debris and Lead }\end{array}$ & 108 & 80 & $7 / 17 / 2013$ & $3 / 18 / 2014$ & $3 / 24 / 2014$ & 002911381FLE & \\
\hline C & ATRX130083 & No & $\begin{array}{l}\text { INL ATR Complex TSCA Regulated Hazardous } \\
\text { Waste Debris }\end{array}$ & 30 & 15 & $7 / 18 / 2013$ & $2 / 18 / 2014$ & $3 / 27 / 2014$ & 002911379FLE & \\
\hline $\mathrm{C}$ & ATRX130127 & No & Liquid PCB Waste & 35 & 30 & $12 / 10 / 2013$ & $8 / 28 / 2014$ & $10 / 22 / 2014$ & 002911402FLE & \\
\hline C & ATRX140019 & No & $\begin{array}{l}\text { INL ATR Complex Leaking and Non-Leaking } \\
\text { PCB Fluorescent Light Ballasts and Small } \\
\text { Capacitors }\end{array}$ & 48 & 31 & $2 / 6 / 2014$ & $8 / 28 / 2014$ & $9 / 30 / 2014$ & 002911402FLE & \\
\hline C & ATRX140025 & Yes & $\begin{array}{l}\text { INL ATR Complex TSCA Regulated MLLW } \\
\text { Debris and Lead }\end{array}$ & 59 & 31 & $4 / 24 / 2014$ & $7 / 9 / 2014$ & $7 / 21 / 2014$ & 002911398FLE & \\
\hline C & ATRX140082 & No & $\begin{array}{l}\text { INL ATR Complex TSCA Regulated Hazardous } \\
\text { Waste Debris }\end{array}$ & 44 & 16 & $4 / 23 / 2014$ & $6 / 24 / 2014$ & $8 / 6 / 2014$ & 002911392FLE & \\
\hline C & ATRX140103 & Yes & $\begin{array}{l}\text { INL ATR Complex TSCA Regulated MLLW } \\
\text { Debris and Lead }\end{array}$ & 69 & 41 & $12 / 2 / 2014$ & & & & \\
\hline C & ATRX140115 & No & $\begin{array}{l}\text { INL ATR Complex TSCA Regulated Hazardous } \\
\text { Waste Debris }\end{array}$ & 32 & 20 & 7/7/2014 & $11 / 18 / 2014$ & $12 / 31 / 2014$ & 002911406FLE & \\
\hline C & ATRX140116 & No & $\begin{array}{l}\text { INL ATR Complex TSCA Regulated Hazardous } \\
\text { Waste Debris }\end{array}$ & 60 & 32 & $4 / 29 / 2014$ & 8/28/2014 & 9/30/2014 & 002911402FLE & \\
\hline C & ATRX140138 & No & $\begin{array}{l}\text { INL ATR Complex Leaking and Non-Leaking } \\
\text { PCB Fluorescent Light Ballasts and Small } \\
\text { Capacitors }\end{array}$ & & & $8 / 5 / 2014$ & & & & a \\
\hline C & ATRX140158 & No & $\begin{array}{l}\text { INL ATR Complex TSCA Regulated Hazardous } \\
\text { Waste Debris }\end{array}$ & 31 & 15 & $10 / 15 / 2014$ & & & & \\
\hline $\mathrm{AC}$ & CFA140020 & No & PCB ballasts & 62 & 47 & $4 / 8 / 2014$ & $11 / 18 / 2014$ & $12 / 9 / 2014$ & 006155128FLE & \\
\hline $\mathrm{C}$ & HFEF-10 & Yes & Lead Lined Steel Casks & 2727 & 2727 & $6 / 12 / 2014$ & $7 / 9 / 2014$ & $7 / 21 / 2014$ & 002907759FLE & \\
\hline C & HFEF-9 & Yes & Lead Lined Steel Casks & 2698 & 2698 & $6 / 12 / 2014$ & $7 / 9 / 2014$ & $7 / 21 / 2014$ & 002907759FLE & \\
\hline $\mathrm{AC}$ & IFF130011 & No & WOL PCB Metal Lathe & 2404 & 2291 & $7 / 7 / 2014$ & $10 / 8 / 2014$ & $10 / 29 / 2014$ & 006155106FLE & \\
\hline C & INTC130019 & No & $\begin{array}{l}\text { Used Potters Ballotini Impact Beads and } \\
\text { Process Residue with PCBs }\end{array}$ & 88 & 77 & $2 / 26 / 2013$ & $10 / 10 / 2013$ & $2 / 21 / 2014$ & 000372369JJK & \\
\hline
\end{tabular}


Idaho National Laboratory

(excluding Advanced Mixed Waste Treatment Project [AMWTP])

PCB Waste Document Log

Removed from Service, Shipped and/or Disposed During Calendar Year 2014

\begin{tabular}{|c|c|c|c|c|c|c|c|c|c|c|}
\hline Type* & Identification \# & $\begin{array}{l}\text { Radioactiv } \\
\qquad(\mathbf{Y} / \mathbf{N})\end{array}$ & Description & $\begin{array}{c}\text { Gross } \\
\text { Weight } \\
\text { (KGS) }\end{array}$ & $\begin{array}{c}\text { Net } \\
\text { Weight } \\
\text { (KGS) }\end{array}$ & $\begin{array}{c}\text { Date of } \\
\text { Removal } \\
\text { from Service }\end{array}$ & $\begin{array}{c}\text { Transport } \\
\text { Date }\end{array}$ & $\begin{array}{l}\text { Disposal } \\
\text { Date }\end{array}$ & $\begin{array}{l}\text { Manifest } \\
\text { Number }\end{array}$ & Notes \\
\hline $\mathrm{C}$ & INTC140040 & No & $\begin{array}{l}\text { Non-leaking/Suspect-leaking PCB light ballasts } \\
\text { and capacitors }\end{array}$ & 16 & 10 & $8 / 21 / 2013$ & $4 / 16 / 2014$ & $6 / 1 / 2014$ & 000372422JJK & \\
\hline C & INTC140207 & No & $\begin{array}{l}\text { Non-leaking/Suspect-leaking PCB light ballasts } \\
\text { and capacitors }\end{array}$ & 22 & 15 & $5 / 1 / 2014$ & $12 / 3 / 2014$ & & 000372277JJJK & \\
\hline C & INTC140260 & No & $\begin{array}{l}\text { Used Potters Ballotini Impact Beads and } \\
\text { Process Residue with PCBs }\end{array}$ & & & $11 / 13 / 2014$ & & & & a \\
\hline$A C$ & MDD140023 & Yes & PCB ballasts, not free releaseable & 24 & 17 & $7 / 14 / 2014$ & $9 / 24 / 2014$ & $9 / 30 / 2014$ & 000372489JJK & \\
\hline C & MFC130038 & No & $\begin{array}{l}\text { RCRA regulated Debris (circuit boards, } \\
\text { metal/plastic housings, PPE, etc.) }\end{array}$ & 156 & 129 & $8 / 27 / 2013$ & $11 / 19 / 2013$ & $1 / 23 / 2014$ & 002907730FLE & \\
\hline C & MFC130128 & Yes & Site-Wide RCRA Characteristic Metal Debris & 921 & 611 & $6 / 3 / 2014$ & $7 / 9 / 2014$ & $7 / 21 / 2014$ & 002907759FLE & \\
\hline C & MFC130135 & Yes & Site-Wide RCRA Characteristic Metal Debris & 2243 & 1936 & $7 / 16 / 2013$ & $3 / 18 / 2014$ & $3 / 24 / 2014$ & 002907740FLE & \\
\hline$A C$ & MFC130166 & No & Small PCB light ballasts and debris & 39 & 33 & $9 / 4 / 2013$ & $2 / 18 / 2014$ & $4 / 7 / 2014$ & 002907737FLE & \\
\hline C & MFC130189 & No & $\begin{array}{l}\text { RCRA regulated Debris (circuit boards, } \\
\text { metal/plastic housings, PPE, etc.) }\end{array}$ & 1868 & 1565 & $10 / 3 / 2013$ & $1 / 14 / 2014$ & $2 / 5 / 2014$ & 002909439FLE & \\
\hline C & MFC130193 & No & $\begin{array}{l}\text { RCRA regulated Debris (circuit boards, } \\
\text { metal/plastic housings, PPE, etc.) }\end{array}$ & 150 & 122 & $12 / 11 / 2013$ & $2 / 18 / 2014$ & $3 / 21 / 2014$ & 002907736FLE & \\
\hline $\mathrm{C}$ & MFC140002 & No & MFC - Devices Containing PCB Liquids & 78 & 66 & $1 / 28 / 2014$ & $8 / 28 / 2014$ & & 002907760FLE & \\
\hline$A C$ & MFC140007 & No & Small PCB light ballasts and debris & 26 & 18 & $1 / 28 / 2014$ & $8 / 28 / 2014$ & $9 / 30 / 2014$ & 002907760FLE & \\
\hline C & MFC140010 & No & $\begin{array}{l}\text { RCRA regulated Debris (circuit boards, } \\
\text { metal/plastic housings, PPE, etc.) }\end{array}$ & 1313 & 1006 & $2 / 11 / 2014$ & $4 / 2 / 2014$ & $4 / 22 / 2014$ & 002907742FLE & \\
\hline C & MFC140045 & No & $\begin{array}{l}\text { RCRA regulated Debris (circuit boards, } \\
\text { metal/plastic housings, PPE, etc.) }\end{array}$ & 104 & 76 & $4 / 2 / 2014$ & $5 / 13 / 2014$ & $6 / 3 / 2014$ & 002911388FLE & \\
\hline C & MFC140046 & No & $\begin{array}{l}\text { RCRA regulated Debris (circuit boards, } \\
\text { metal/plastic housings, PPE, etc.) }\end{array}$ & 126 & 98 & $4 / 9 / 2014$ & $5 / 13 / 2014$ & $6 / 3 / 2014$ & 002911388FLE & \\
\hline C & MFC140095 & No & $\begin{array}{l}\text { RCRA regulated Debris (circuit boards, } \\
\text { metal/plastic housings, PPE, etc.) }\end{array}$ & 1721 & 1415 & $5 / 15 / 2014$ & $8 / 28 / 2014$ & $9 / 23 / 2014$ & 002907761FLE & \\
\hline C & MFC140179 & No & $\begin{array}{l}\text { RCRA regulated Debris (circuit boards, } \\
\text { metal/plastic housings, PPE, etc.) }\end{array}$ & 2087 & 1781 & $6 / 19 / 2014$ & $8 / 28 / 2014$ & 9/23/2014 & 002907761FLE & \\
\hline C & MFC140188 & No & Small PCB light ballasts and debris & 61 & 56 & 9/10/2014 & & & & \\
\hline C & MFC140223 & No & $\begin{array}{l}\text { RCRA regulated Debris (circuit boards, } \\
\text { metal/plastic housings, PPE, etc.) }\end{array}$ & 1582 & 1277 & $8 / 11 / 2014$ & $10 / 8 / 2014$ & $10 / 30 / 2014$ & 002907769FLE & \\
\hline C & MFC140255 & No & $\begin{array}{l}\text { RCRA regulated Debris (circuit boards, } \\
\text { metal/plastic housings, PPE, etc.) }\end{array}$ & 347 & 318 & 9/17/2014 & $11 / 18 / 2014$ & $12 / 10 / 2014$ & 002907772FLE & \\
\hline C & MFC140266 & No & $\begin{array}{l}\text { RCRA regulated Debris (circuit boards, } \\
\text { metal/plastic housings, PPE, etc.) }\end{array}$ & 1115 & 810 & $10 / 1 / 2014$ & & & & \\
\hline C & NRF130088 & Yes & $\begin{array}{l}\text { Radioactive Sediments, PCB Remediation, and } \\
\text { Bulk Product PCB Material }\end{array}$ & 60 & 33 & $4 / 14 / 2013$ & $11 / 26 / 2013$ & $3 / 17 / 2014$ & 000372380JJK & \\
\hline$A C$ & NRF130101 & No & PCB Ballasts and Capacitors with RCRA metals & 4 & 3 & $11 / 1 / 2013$ & $12 / 18 / 2013$ & $1 / 13 / 2014$ & 000372387JJK & \\
\hline C & NRF140027 & Yes & MLLW Non-Debris with Organics & 5 & 1 & $11 / 26 / 2013$ & $3 / 19 / 2014$ & $4 / 24 / 2014$ & 000372416JJK & \\
\hline C & NRF140034 & Yes & Radioactive Sediments, PCB Remediation, and & 31 & 16 & $9 / 11 / 2013$ & $5 / 21 / 2014$ & $6 / 13 / 2014$ & 000372433JJK & \\
\hline
\end{tabular}


Idaho National Laboratory

(excluding Advanced Mixed Waste Treatment Project [AMWTP])

PCB Waste Document Log

Removed from Service, Shipped and/or Disposed During Calendar Year 2014

\begin{tabular}{|c|c|c|c|c|c|c|c|c|c|c|}
\hline Type* & Identification \# & $\begin{array}{l}\text { Radioactiv } \\
\qquad(\mathbf{Y} / \mathbf{N})\end{array}$ & Description & $\begin{array}{c}\text { Gross } \\
\text { Weight } \\
\text { (KGS) }\end{array}$ & $\begin{array}{c}\text { Net } \\
\text { Weight } \\
\text { (KGS) }\end{array}$ & $\begin{array}{c}\text { Date of } \\
\text { Removal } \\
\text { from Service }\end{array}$ & $\begin{array}{c}\text { Transport } \\
\text { Date }\end{array}$ & $\begin{array}{l}\text { Disposal } \\
\text { Date }\end{array}$ & $\begin{array}{c}\text { Manifest } \\
\text { Number }\end{array}$ & Notes \\
\hline $\mathrm{C}$ & NRF140038 & No & $\begin{array}{l}\text { Lamps contaminated with PCBs from leaking } \\
\text { light ballast }\end{array}$ & 2 & 1 & $3 / 19 / 2014$ & $6 / 11 / 2014$ & $7 / 3 / 2014$ & 000372447JJK & \\
\hline$A C$ & NRF140042 & No & PCB Light Ballasts/ Small Capacitors & 23 & 16 & 9/23/2013 & $6 / 11 / 2014$ & $7 / 2 / 2014$ & 000372447JJK & \\
\hline C & NRF140046 & Yes & $\begin{array}{l}\text { Radioactive, PCB, RCRA Metals, Asbestos } \\
\text { Contaminated Non-Incinerable Waste }\end{array}$ & 33 & 20 & $10 / 23 / 2013$ & $6 / 24 / 2014$ & $7 / 17 / 2014$ & 000372451JJK & \\
\hline C & NRF140047 & Yes & $\begin{array}{l}\text { Radioactive Sediments, PCB Remediation, and } \\
\text { Bulk Product PCB Material }\end{array}$ & 6 & 2 & $10 / 15 / 2013$ & $6 / 24 / 2014$ & $7 / 18 / 2014$ & 000372452JJK & \\
\hline C & NRF140052 & No & PCB Ballasts (Leaking) with clean up debris & 30 & 28 & $3 / 19 / 2014$ & $12 / 3 / 2014$ & & 000372278JJK & \\
\hline C & NRF140056 & No & PCB Ballasts (Leaking) with clean up debris & 15 & 9 & $11 / 7 / 2013$ & $7 / 16 / 2014$ & $8 / 6 / 2014$ & 000372458JJK & \\
\hline C & NRF140062 & No & PCB Ballasts (Leaking) with clean up debris & 46 & 18 & $3 / 19 / 2014$ & 9/24/2014 & 10/21/2014 & 000372483JJK & \\
\hline C & NRF140063 & No & PCB Ballasts (Leaking) with clean up debris & 12 & 7 & $3 / 19 / 2014$ & 9/24/2014 & 10/21/2014 & 000372483JJK & \\
\hline C & NRF140068 & Yes & $\begin{array}{l}\text { Radioactive, PCB, RCRA Metals, Asbestos } \\
\text { Contaminated Non-Incinerable Waste }\end{array}$ & 58 & 43 & 2/20/2014 & $10 / 29 / 2014$ & $11 / 20 / 2014$ & 000372494JJK & \\
\hline C & NRF140071 & No & PCB Ballasts (Leaking) with clean up debris & 67 & 40 & $3 / 19 / 2014$ & $12 / 3 / 2014$ & & 000372279JJK & \\
\hline C & NRF140077 & Yes & $\begin{array}{l}\text { Radioactive Sediments, PCB Remediation, and } \\
\text { Bulk Product PCB Material }\end{array}$ & 755 & 537 & $3 / 12 / 2014$ & $11 / 19 / 2014$ & $11 / 24 / 2014$ & 000372275JJK & \\
\hline C & NRF140080 & No & PCB Ballasts (Leaking) with clean up debris & 29 & 13 & $4 / 16 / 2014$ & $12 / 3 / 2014$ & & 000372278JJK & \\
\hline C & NRF140081 & No & $\begin{array}{l}\text { Lamps contaminated with PCBs from leaking } \\
\text { light ballast }\end{array}$ & 13 & 7 & $10 / 30 / 2014$ & $12 / 3 / 2014$ & $12 / 30 / 2014$ & 000372278JJK & \\
\hline$A C$ & SMC140058 & No & $\begin{array}{l}\text { PCB Ballasts (Leaking) and Contaminated } \\
\text { Debris }\end{array}$ & 0 & 0 & $11 / 17 / 2014$ & & & & d \\
\hline C & SRS140135 & Yes & $\begin{array}{l}\text { LDR compliant, PCB regulated, AMWTP sludge } \\
\text { repack secondary waste to NNSS }\end{array}$ & 1183 & 873 & $6 / 1 / 1968$ & $8 / 19 / 2014$ & $8 / 20 / 2014$ & 000372466JJK & \\
\hline C & SRS140499 & Yes & $\begin{array}{l}\text { LDR compliant, PCB regulated, AMWTP sludge } \\
\text { repack secondary waste to NNSS }\end{array}$ & 9471 & 4663 & $6 / 1 / 1968$ & $8 / 19 / 2014$ & $8 / 20 / 2014$ & 000372466JJK & c \\
\hline C & SRS140500 & Yes & $\begin{array}{l}\text { LDR compliant, PCB regulated, AMWTP sludge } \\
\text { repack secondary waste to NNSS }\end{array}$ & 9290 & 4482 & 6/1/1968 & $8 / 5 / 2014$ & 8/6/2014 & 000372465JJK & c \\
\hline C & $\begin{array}{l}\text { VAC-HEPA-2007- } \\
03\end{array}$ & Yes & PCB Asbestos Debris & 23 & 23 & $10 / 24 / 2014$ & & & & \\
\hline C & $\begin{array}{l}\text { VAC-HEPA-2009- } \\
08\end{array}$ & Yes & PCB Asbestos Debris & 18 & 18 & $11 / 3 / 2014$ & & & & \\
\hline C & $\begin{array}{l}\text { VAC-HEPA-2011- } \\
18\end{array}$ & Yes & PCB Asbestos Debris & 20 & 20 & $10 / 24 / 2014$ & & & & \\
\hline
\end{tabular}


Idaho National Laboratory

(excluding Advanced Mixed Waste Treatment Project [AMWTP])

PCB Waste Document Log

Removed from Service, Shipped and/or Disposed During Calendar Year 2014

Grand Total placed in storage in 2014 (out of service date in 2014)

Total number of Articles (A) placed in storage

Total number of Containers $(C)$ placed in storage

Total number of Article Containers (AC) placed in storage

Total number of Bulk Waste (BW) placed in storage

Total number of Equipment (E) placed in storage

Grand Total shipped, disposed, or removed from service

Grand Total placed in storage in 2014 and still in storage at end of 2014

Total number of Articles (A) in storage

Total number of Containers $(\mathrm{C})$ in storage

Total number of Article Containers (AC) in storage

Total number of Bulk Waste (BW) in storage

Total number of Equipment (E) in storage

Grand Total shipped for disposal in 2014 but not disposed at end of 2014

Total number of Articles (A) shipped

Total number of Containers (C) shipped

Total number of Article Containers (AC) shipped

Total number of Bulk Waste (BW) shipped

Total number of Equipment (E) shipped

Grand Total disposed in 2014

Total number of Articles (A) disposed

Total number of Containers (C) disposed

Total number of Article Containers (AC) disposed

Total number of Bulk Waste (BW) disposed

Total number of Equipment (E) disposed
51 Total Gross Weight : $\quad 19,733$

T Total Gross Weight :

44 Total Gross Weight : 17,168

7 Total Gross Weight : $\quad 2,565$

0 Total Gross Weight :

0 Total Gross Weight :

$\begin{array}{cr}\text { Total Net Weight : } & 16,627 \\ \text { Total Net Weight : } & 0 \\ \text { Total Net Weight : } & 14,211 \\ \text { Total Net Weight : } & \mathbf{2 , 4 1 6} \\ \text { Total Net Weight : } & 0 \\ \text { Total Net Weight : } & 0\end{array}$

72 Total Gross Weight : 44,58

Total Net Weight : $\quad \mathbf{3 0 , 7 4 2}$

21 Total Gross Weight:

Total Net Weight :

1,342

0

0 Total Gross Weight :

Total Net Weight :

Total Net Weight : $\quad 1,299$

18 Total Gross Weight :

2,187

Total Gross Weight :

Total Net Weight :

Total Gross Weight :

0 Total Gross Weight :

5 Total Gross Weight :

Total Gross Weight :

0

Total Net Weight :

Total Net Weight :

Total Net Weight :

Total Net Weight :

Total Net Weight :

Total Net Weight :

Total Net Weight :

Total Net Weight :

Total Net Weight : $\quad 29,238$

Total Net Weight :

Total Net Weight : $\quad \mathbf{2 6 , 8 1 3}$

Total Net Weight : $\quad \mathbf{2 , 4 2 5}$

Total Net Weight :

Total Net Weight :

0
299

43

162

162

Total Gross Weight : $\quad 42,12$

39 Total Gross Weight : $\quad 39,543$

Total Gross Weight : $\quad \mathbf{2 , 5 8}$

Total Gross Weight :

Total Gross Weight :

Total Weight. Weights are rounded to the nearest kilogram, except where the container weight is less than $0.5 \mathrm{Kg}$

Note a: Weight not available at end of CY2014

Note b: This container is located in a PCB storage area. The container is periodically emptied but is not removed from the storage area. For calendar year 2014, PCB waste was stored in the container.

Note c: See Repackage Report

Note d: Weight after rounding was less than $1 \mathrm{KG}$

Note e: Repackaged drums of sludge from AMWTP that do not

Note f: Wenservatively applied to all repackaged containers.

f: Weight changed from 2013 report.

NOTE: All of the above notes may not apply to this report. 
Idaho National Laboratory

Advanced Mixed Waste Treatment Project (AMWTP)

PCB Waste Document Log

Removed from Service, Shipped and/or Disposed During Calendar Year 2014

Date of

Gross Net Removal

Radioactive

\begin{tabular}{|c|c|c|c|c|c|c|c|c|c|c|}
\hline Type & * Identification \# & $(\mathrm{Y} / \mathrm{N})$ & Description & (KGS) & (KGS) & Service & $\begin{array}{l}\text { Date } \\
\text { Date }\end{array}$ & $\begin{array}{c}\text { Disposai } \\
\text { Date }\end{array}$ & Number & Notes \\
\hline C & 10004014 & Yes & Non-special Source Metal & 98 & 64 & $9 / 25 / 1981$ & $6 / 29 / 2014$ & $8 / 11 / 2014$ & 001942718GBF & \\
\hline C & 10004809 & Yes & Non-special Source Metal & 94 & 59 & $6 / 19 / 1980$ & $6 / 29 / 2014$ & $8 / 11 / 2014$ & 001942718GBF & 8 \\
\hline C & 10020386 & Yes & Non-special Source Metal & 63 & 28 & 1/7/1976 & $6 / 29 / 2014$ & $8 / 11 / 2014$ & 001942718GBF & \\
\hline C & 10027705 & Yes & Non-special Source Metal & 110 & 76 & 2/7/1977 & $6 / 29 / 2014$ & $8 / 11 / 2014$ & $001942718 \mathrm{GBF}$ & \\
\hline C & 10033436 & Yes & Non-special Source Metal & 111 & 77 & $5 / 19 / 1982$ & $6 / 29 / 2014$ & $8 / 11 / 2014$ & 001942718GBF & \\
\hline C & 10033444 & Yes & Non-special Source Metal & 98 & 64 & $4 / 24 / 1981$ & $6 / 29 / 2014$ & $8 / 11 / 2014$ & $001942718 \mathrm{GBF}$ & \\
\hline C & 10033445 & Yes & Non-special Source Metal & 95 & 61 & $2 / 27 / 1981$ & $6 / 29 / 2014$ & $8 / 11 / 2014$ & 001942718GBF & 2 \\
\hline C & 10036797 & Yes & Heavy Non-special Source Metal & 117 & 82 & $11 / 9 / 1978$ & $6 / 29 / 2014$ & $8 / 11 / 2014$ & 001942718GBF & \\
\hline C & 10094744 & Yes & Paper and Rags-Moist & 104 & 76 & 9/28/1973 & $6 / 29 / 2014$ & $8 / 11 / 2014$ & 001942718GBF & 8 \\
\hline C & 10097393 & Yes & Non-special Source Metal & 162 & 134 & $12 / 19 / 1973$ & $6 / 29 / 2014$ & $8 / 11 / 2014$ & 001942718GBF & \\
\hline C & 10098916 & Yes & Non-special Source Metal & 100 & 72 & 2/1/1974 & $6 / 29 / 2014$ & $8 / 11 / 2014$ & 001942718GBF & 2 \\
\hline C & 10100134 & Yes & Non-special Source Metal & 120 & 92 & $3 / 4 / 1974$ & $6 / 29 / 2014$ & $8 / 11 / 2014$ & 001942718GBF & \\
\hline C & 10141087 & Yes & Non-special Source Metal & 126 & 88 & $2 / 2 / 2007$ & $12 / 10 / 2014$ & & 001942816GBF & \\
\hline C & 10145188 & Yes & Pits $11 \& 12$ Debris & 115 & 50 & $10 / 25 / 1975$ & $12 / 10 / 2014$ & & 001942816GBF & 8 \\
\hline C & 10163211 & Yes & LSA Paper, Plastic, etc. & 93 & 58 & $5 / 16 / 1972$ & 6/29/2014 & $8 / 11 / 2014$ & 001942718GBF & \\
\hline C & 10166762 & Yes & Plastics, Teflon, Washables, PVC & 98 & 63 & $3 / 30 / 1973$ & $6 / 29 / 2014$ & $8 / 11 / 2014$ & $001942718 \mathrm{GBF}$ & 8 \\
\hline C & 10174234 & Yes & Paper and Rags-Dry & 75 & 46 & $12 / 27 / 1972$ & $6 / 29 / 2014$ & $8 / 11 / 2014$ & 001942718GBF & \\
\hline C & 10215834 & Yes & Paper and Rags-Dry & 79 & 44 & $2 / 28 / 1972$ & $6 / 29 / 2014$ & $8 / 11 / 2014$ & 001942718GBF & 8 \\
\hline C & 10217940 & Yes & Non-special Source Metal & 177 & 149 & $2 / 22 / 1972$ & $6 / 29 / 2014$ & $8 / 11 / 2014$ & 001942718GBF & \\
\hline C & 10218422 & Yes & Paper and Rags-Dry & 49 & 21 & $1 / 27 / 1972$ & $6 / 29 / 2014$ & $8 / 11 / 2014$ & 001942718GBF & \\
\hline C & 10227060 & Yes & Paper and Rags-Dry & 114 & 49 & $5 / 18 / 2008$ & $12 / 10 / 2014$ & & $001942816 G B F$ & \\
\hline C & 10230714 & Yes & Non-special Source Metal & 120 & 92 & $12 / 27 / 1971$ & $6 / 29 / 2014$ & $8 / 11 / 2014$ & 001942718GBF & 2 \\
\hline C & 10268013 & Yes & Pits 11 \& 12 Debris & 155 & 117 & $7 / 1 / 1975$ & $6 / 29 / 2014$ & $8 / 11 / 2014$ & 001942718GBF & 8 \\
\hline C & 10268414 & Yes & Pits $11 \& 12$ Debris & 104 & 66 & $7 / 1 / 1975$ & $6 / 29 / 2014$ & $8 / 11 / 2014$ & 001942718GBF & 8 \\
\hline C & 10268531 & Yes & Pits $11 \& 12$ Debris & 120 & 55 & $10 / 31 / 1969$ & $12 / 10 / 2014$ & & 001942816GBF & 8 \\
\hline C & 10270823 & Yes & Pits $11 \& 12$ Debris & 130 & 66 & $11 / 14 / 1969$ & $12 / 10 / 2014$ & & 001942816GBF & 4 \\
\hline C & 10272421 & Yes & Pits $11 \& 12$ Debris & 117 & 52 & $11 / 25 / 1969$ & $12 / 10 / 2014$ & & 001942816GBF & 4 \\
\hline C & 10288488 & Yes & Pits $11 \& 12$ Debris & 118 & 53 & $6 / 6 / 1970$ & $12 / 10 / 2014$ & & 001942816GBF & 8 \\
\hline C & 10291155 & Yes & Pits $11 \& 12$ Debris & 185 & 120 & $5 / 9 / 1972$ & $6 / 29 / 2014$ & $8 / 11 / 2014$ & 001942718GBF & 4 \\
\hline C & 10291381 & Yes & Pits $11 \& 12$ Debris & 112 & 47 & $6 / 2 / 2009$ & $12 / 10 / 2014$ & & 001942816GBF & 2 \\
\hline C & 10291543 & Yes & Pits $11 \& 12$ Debris & 142 & 77 & $7 / 7 / 2009$ & $6 / 29 / 2014$ & $8 / 11 / 2014$ & 001942718GBF & \\
\hline $\mathrm{C}$ & 10293756 & Yes & Pre-1980 INL-Exhumed SDA Heterogeneous Debris & 101 & 36 & $5 / 4 / 2009$ & $6 / 29 / 2014$ & $8 / 11 / 2014$ & 001942718GBF & \\
\hline C & 10295844 & Yes & Pits $11 \& 12$ Debris & 197 & 132 & $7 / 2 / 2009$ & $12 / 10 / 2014$ & & 001942816GBF & \\
\hline C & 10299577 & Yes & Pits $11 \& 12$ Debris & 129 & 64 & 3/7/1972 & $6 / 29 / 2014$ & $8 / 11 / 2014$ & 001942718GBF & 4 \\
\hline $\mathrm{C}$ & 10299587 & Yes & Pits $11 \& 12$ Debris & 147 & 82 & $4 / 5 / 1972$ & $6 / 29 / 2014$ & $8 / 11 / 2014$ & 001942718GBF & \\
\hline C & 10301265 & Yes & Pits $11 \& 12$ Debris & 63 & 35 & $11 / 3 / 1971$ & $6 / 29 / 2014$ & $8 / 11 / 2014$ & 001942718GBF & \\
\hline C & 10302522 & Yes & Pits $11 \& 12$ Debris & 150 & 85 & $7 / 10 / 2009$ & $12 / 10 / 2014$ & & 001942816GBF & \\
\hline$c$ & 10303995 & Yes & Pits $11 \& 12$ Debris & 91 & 53 & 7/1/1970 & $12 / 10 / 2014$ & & $001942816 G B F$ & 2 \\
\hline
\end{tabular}

* A=Article; $C=$ Container; $A C=$ Article Container, $B W=B u l k$ Waste, $E=E q u i p m e n t$ 
Idaho National Laboratory

Advanced Mixed Waste Treatment Project (AMWTP)

PCB Waste Document Log

Removed from Service, Shipped and/or Disposed During Calendar Year 2014

Date of

Gross Net Removal

Radioactive

\begin{tabular}{|c|c|c|c|c|c|c|c|c|c|c|}
\hline Type & * Identification \# & $(\mathrm{Y} / \mathrm{N}$ & Description & (KGS) & (KGS) & Service & $\begin{array}{l}\text { Date } \\
\text { Date }\end{array}$ & $\begin{array}{c}\text { Disposai } \\
\text { Date }\end{array}$ & Number & Notes \\
\hline C & 10305146 & Yes & Pits $11 \& 12$ Debris & 95 & 31 & $8 / 5 / 2009$ & $6 / 29 / 2014$ & $8 / 11 / 2014$ & 001942718GBF & 2 \\
\hline C & 10305486 & Yes & Pits $11 \& 12$ Debris & 135 & 71 & $7 / 31 / 2009$ & $6 / 29 / 2014$ & $8 / 11 / 2014$ & 001942718GBF & \\
\hline C & 10305954 & Yes & Pits $11 \& 12$ Debris & 177 & 112 & $8 / 2 / 2009$ & $12 / 10 / 2014$ & & 001942816GBF & \\
\hline C & 10306562 & Yes & Pre-1980 INL-Exhumed SDA Heterogeneous Debris & 93 & 28 & $11 / 30 / 1980$ & $12 / 10 / 2014$ & & $001942816 G B F$ & 8 \\
\hline C & 10307413 & Yes & Pits $11 \& 12$ Debris & 242 & 204 & $8 / 1 / 1970$ & $12 / 10 / 2014$ & & 001942816GBF & 8 \\
\hline $\mathrm{C}$ & 10308175 & Yes & Pits $11 \& 12$ Debris & 108 & 43 & 6/7/1972 & $12 / 10 / 2014$ & & $001942816 G B F$ & 4 \\
\hline C & 10308389 & Yes & Pits $11 \& 12$ Debris & 157 & 130 & $8 / 27 / 1970$ & $6 / 29 / 2014$ & $8 / 11 / 2014$ & $001942718 G B F$ & \\
\hline C & 10309548 & Yes & Pits $11 \& 12$ Debris & 158 & 93 & $3 / 10 / 1972$ & $6 / 29 / 2014$ & $8 / 11 / 2014$ & 001942718GBF & 8 \\
\hline C & 10309591 & Yes & Pits $11 \& 12$ Debris & 152 & 87 & $8 / 22 / 2009$ & $12 / 10 / 2014$ & & $001942816 G B F$ & \\
\hline C & 10309608 & Yes & Pre-1980 INL-Exhumed SDA Heterogeneous Debris & 137 & 73 & $8 / 20 / 2009$ & $12 / 10 / 2014$ & & $001942816 G B F$ & 8 \\
\hline $\mathrm{C}$ & 10310233 & Yes & Pits $11 \& 12$ Debris & 209 & 144 & $8 / 23 / 2009$ & $12 / 10 / 2014$ & & 001942816GBF & \\
\hline C & 10310252 & Yes & Pits $11 \& 12$ Debris & 163 & 98 & $8 / 22 / 2009$ & $6 / 29 / 2014$ & $8 / 11 / 2014$ & 001942718GBF & \\
\hline C & 10310268 & Yes & Pits $11 \& 12$ Debris & 146 & 81 & $8 / 22 / 2009$ & $6 / 29 / 2014$ & $8 / 11 / 2014$ & $001942718 \mathrm{GBF}$ & \\
\hline C & 10311055 & Yes & Pits $11 \& 12$ Debris & 96 & 31 & 9/9/1970 & $6 / 29 / 2014$ & $8 / 11 / 2014$ & 001942718GBF & 8 \\
\hline C & 10311118 & Yes & Pits $11 \& 12$ Debris & 215 & 150 & $8 / 28 / 2009$ & $6 / 29 / 2014$ & $8 / 11 / 2014$ & 001942718GBF & \\
\hline C & 10312442 & Yes & Pits $11 \& 12$ Debris & 185 & 120 & 9/5/2009 & $6 / 29 / 2014$ & $8 / 11 / 2014$ & $001942718 \mathrm{GBF}$ & \\
\hline C & 10313213 & Yes & Pits $11 \& 12$ Debris & 151 & 86 & 9/6/2009 & $12 / 10 / 2014$ & & 001942816GBF & \\
\hline C & 10314986 & Yes & Pits $11 \& 12$ Debris & 180 & 115 & $6 / 25 / 1971$ & $6 / 29 / 2014$ & $8 / 11 / 2014$ & $001942718 \mathrm{GBF}$ & 8 \\
\hline C & 10319462 & Yes & Pits $11 \& 12$ Debris & 84 & 20 & $10 / 6 / 2009$ & $12 / 10 / 2014$ & & $001942816 G B F$ & \\
\hline C & 10323328 & Yes & Pits $11 \& 12$ Debris & 64 & 12 & $3 / 15 / 1970$ & $6 / 29 / 2014$ & $8 / 11 / 2014$ & 001942718GBF & 4 \\
\hline C & 10324458 & Yes & Pits $11 \& 12$ Debris & 101 & 37 & $2 / 16 / 1970$ & $6 / 29 / 2014$ & $8 / 11 / 2014$ & 001942718GBF & 4 \\
\hline C & 10325058 & Yes & Pits $11 \& 12$ Debris & 82 & 18 & $3 / 15 / 1970$ & $6 / 29 / 2014$ & $8 / 11 / 2014$ & $001942718 \mathrm{GBF}$ & 4 \\
\hline C & 10327901 & Yes & Pits $11 \& 12$ Debris & 114 & 50 & $2 / 11 / 1970$ & $6 / 29 / 2014$ & $8 / 11 / 2014$ & 001942718GBF & 4 \\
\hline $\mathrm{C}$ & 10328284 & Yes & Pits $11 \& 12$ Debris & 116 & 51 & $4 / 10 / 1970$ & $6 / 29 / 2014$ & $8 / 11 / 2014$ & 001942718GBF & 4 \\
\hline C & 10330095 & Yes & Pits $11 \& 12$ Debris & 88 & 23 & $12 / 13 / 2009$ & $6 / 29 / 2014$ & $8 / 11 / 2014$ & 001942718GBF & \\
\hline C & 10333701 & Yes & Pits $11 \& 12$ Debris & 134 & 70 & $11 / 30 / 1980$ & $6 / 29 / 2014$ & $8 / 11 / 2014$ & 001942718GBF & 4 \\
\hline C & 10333747 & Yes & Pits $11 \& 12$ Debris & 114 & 49 & $12 / 29 / 2009$ & $12 / 10 / 2014$ & & 001942816GBF & \\
\hline C & 10342925 & Yes & LSA Metals, Glass, etc. & 82 & 54 & $11 / 3 / 1971$ & $6 / 29 / 2014$ & $8 / 11 / 2014$ & 001942718GBF & \\
\hline C & 10349170 & Yes & Pits $11 \& 12$ Debris & 274 & 209 & $7 / 4 / 1972$ & $12 / 10 / 2014$ & & 001942816GBF & 4 \\
\hline C & 10352439 & Yes & Non-special Source Metal & 87 & 59 & 10/13/1971 & $6 / 29 / 2014$ & $8 / 11 / 2014$ & 001942718GBF & 8 \\
\hline C & 10356127 & Yes & LSA Metals, Glass, etc. & 98 & 70 & $10 / 27 / 1971$ & $6 / 29 / 2014$ & $8 / 11 / 2014$ & 001942718GBF & \\
\hline C & 10362580 & Yes & Non-special Source Metal & 134 & 106 & $11 / 12 / 1971$ & $6 / 29 / 2014$ & $8 / 11 / 2014$ & 001942718GBF & \\
\hline C & 10367221 & Yes & RFP Debris & 118 & 90 & $12 / 27 / 1971$ & $6 / 29 / 2014$ & $8 / 11 / 2014$ & 001942718GBF & 1,4 \\
\hline C & 10369054 & Yes & RFP Debris & 166 & 139 & $12 / 27 / 1971$ & $6 / 29 / 2014$ & $8 / 11 / 2014$ & 001942718GBF & 1,4 \\
\hline C & 10370319 & Yes & Paper and Rags-Dry & 79 & 51 & $12 / 27 / 1971$ & $6 / 29 / 2014$ & $8 / 11 / 2014$ & 001942718GBF & 4 \\
\hline C & 10370406 & Yes & LSA Metals, Glass, etc. & 77 & 49 & $10 / 15 / 1971$ & $6 / 29 / 2014$ & $8 / 11 / 2014$ & 001942718GBF & \\
\hline C & 10443336 & Yes & LSA Metals, Glass, etc. & 243 & 178 & $5 / 24 / 2012$ & $6 / 29 / 2014$ & $8 / 11 / 2014$ & 001942718GBF & \\
\hline c & 10459538 & Yes & RFP Debris & 155 & 90 & $12 / 27 / 1971$ & $12 / 10 / 2014$ & & $001942816 G B F$ & 8 \\
\hline
\end{tabular}

* A=Article; $C=$ Container; $A C=$ Article Container, $B W=B u l k$ Waste, $E=E q u i p m e n t$ 
Idaho National Laboratory

Advanced Mixed Waste Treatment Project (AMWTP)

PCB Waste Document Log

Removed from Service, Shipped and/or Disposed During Calendar Year 2014

Date of

Gross Net Removal

Radioactive

Type* Identification \# (Y/N)

Weight Weight from Transport Disposal Manifest

$\begin{array}{lll}10476923 & \text { Yes } & \text { Organic Setups, Oil Solids } \\ 10476964 & \text { Yes } & \text { Organic Setups, Oil Solids } \\ 10476983 & \text { Yes } & \text { Organic Setups, Oil Solids } \\ 10478047 & \text { Yes } & \text { Organic Setups, Oil Solids } \\ 10478076 & \text { Yes } & \text { Organic Setups, Oil Solids } \\ 10479387 & \text { Yes } & \text { Organic Setups, Oil Solids } \\ 10479403 & \text { Yes } & \text { Organic Setups, Oil Solids } \\ 10480178 & \text { Yes } & \text { Organic Setups, Oil Solids } \\ 10480185 & \text { Yes } & \text { Organic Setups, Oil Solids } \\ 10480187 & \text { Yes } & \text { Organic Setups, Oil Solids } \\ 10480188 & \text { Yes } & \text { Organic Setups, Oil Solids } \\ 10480194 & \text { Yes } & \text { Organic Setups, Oil Solids } \\ 10480204 & \text { Yes } & \text { Organic Setups, Oil Solids } \\ 10480205 & \text { Yes } & \text { Organic Setups, Oil Solids } \\ 10480223 & \text { Yes } & \text { Organic Setups, Oil Solids } \\ 10480225 & \text { Yes } & \text { Organic Setups, Oil Solids } \\ 10480228 & \text { Yes } & \text { Organic Setups, Oil Solids } \\ 10480472 & \text { Yes } & \text { Organic Setups, Oil Solids } \\ 10480473 & \text { Yes } & \text { Organic Setups, Oil Solids } \\ 10480486 & \text { Yes } & \text { Organic Setups, Oil Solids } \\ 10480489 & \text { Yes } & \text { Organic Setups, Oil Solids } \\ 10480760 & \text { Yes } & \text { Organic Setups, Oil Solids } \\ 10480769 & \text { Yes } & \text { Organic Setups, Oil Solids } \\ 10480770 & \text { Yes } & \text { Organic Setups, Oil Solids } \\ 10480800 & \text { Yes } & \text { Organic Setups, Oil Solids } \\ 10481278 & \text { Yes } & \text { Organic Setups, Oil Solids } \\ 10481290 & \text { Yes } & \text { Organic Setups, Oil Solids } \\ 10481295 & \text { Yes } & \text { Organic Setups, Oil Solids } \\ 10481304 & \text { Yes } & \text { Organic Setups, Oil Solids } \\ 10482136 & \text { Yes } & \text { Organic Setups, Oil Solids } \\ 10482147 & \text { Yes } & \text { Organic Setups, Oil Solids } \\ 10482150 & \text { Yes } & \text { Organic Setups, Oil Solids } \\ 10482496 & \text { Yes } & \text { Organic Setups, Oil Solids } \\ 10482501 & \text { Yes } & \text { Organic Setups, Oil Solids } \\ 10483112 & \text { Yes } & \text { Organic Setups, Oil Solids } \\ 10483681 & \text { Organic Setups, Oil Solids } \\ 10483958 & & \\ 10484017 & & \end{array}$

(KGS) (KGS) Service
Date Date

Number Notes

6/1/1968 1/15/2014 1/25/2014 001600942GBF 2, 5

$\begin{array}{lllllll}71 & 12 & 6 / 1 / 1968 & 1 / 15 / 2014 & 1 / 25 / 2014 & 001600942 \mathrm{GBF} & 2,5\end{array}$

$96 \quad 37 \quad 6 / 1 / 1968 \quad 1 / 15 / 2014 \quad 1 / 25 / 2014 \quad 001600942$ GBF 2,5

$88 \quad 29$

$100 \quad 41$

6/1/1968 1/15/2014 1/25/2014 001600942GBF 2, 5

6/1/1968 1/15/2014 1/25/2014 001600942GBF 2, 5

6/1/1968 1/15/2014 1/25/2014 001600942GBF 2, 5

6/1/1968 1/15/2014 1/25/2014 001600942GBF 2, 5

6/1/1968 1/23/2014 1/26/2014 001600951GBF 2, 5

6/1/1968 1/23/2014 1/26/2014 001600951GBF 2, 5

6/1/1968 1/24/2014 1/28/2014 001600956GBF 2, 5

6/1/1968 1/28/2014 2/1/2014 001600962GBF 2, 5

6/1/1968 1/15/2014 1/25/2014 001600942GBF 2, 5

6/1/1968 2/1/2014 001600968GBF 2, 5

6/1/1968 2/4/2014 001600973GBF 2, 5

6/1/1968 1/28/2014 2/1/2014 001600963GBF 2, 5

6/1/1968 2/4/2014 001600973GBF 2, 5

6/1/1968 2/1/2014 001600968GBF 2, 5

6/1/1968 1/15/2014 1/25/2014 001600942GBF 2, 5

6/1/1968 1/15/2014 1/25/2014 001600942GBF 2, 5

6/1/1968 1/15/2014 1/25/2014 001600942GBF 2, 5

6/1/1968 1/15/2014 1/25/2014 001600942GBF 2, 5

6/1/1968 1/7/2014 1/12/2014 001600938GBF 2, 5

6/1/1968 1/15/2014 1/25/2014 001600942GBF 2, 5

6/1/1968 1/15/2014 1/25/2014 001600942GBF 2, 5

6/1/1968 1/15/2014 1/25/2014 001600942GBF 2, 5

6/1/1968 1/4/2014 1/17/2014 001600934GBF 2, 5

6/1/1968 1/4/2014 1/17/2014 001600934GBF 2, 5

6/1/1968 1/7/2014 1/12/2014 001600938GBF 2, 5

6/1/1968 1/4/2014 1/17/2014 001600934GBF 2, 5

6/1/1968 1/7/2014 1/12/2014 001600938GBF 2, 5

6/1/1968 1/7/2014 1/12/2014 001600938GBF 2, 5

6/1/1968 1/4/2014 1/17/2014 001600934GBF 2, 5

6/1/1968 1/7/2014 1/12/2014 001600937GBF 2, 5

6/1/1968 1/28/2014 2/1/2014 001600963GBF 2, 5

6/1/1968 2/4/2014 001600972GBF 2, 5

6/1/1968 1/15/2014 1/25/2014 001600942GBF 2, 5

6/1/1968 1/4/2014 1/17/2014 001600934GBF 2, 5

6/1/1968 1/4/2014 1/17/2014 001600934GBF 2, 5

* $A=$ Article; $C=$ Container AC=Article Container, $B W=B$ ulk Waste, E=Equipment 
Idaho National Laboratory

Advanced Mixed Waste Treatment Project (AMWTP)

PCB Waste Document Log

Removed from Service, Shipped and/or Disposed During Calendar Year 2014

Date of

Gross Net Removal

Radioactive

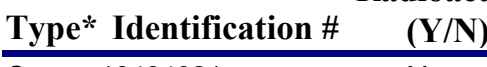

Weight Weight from Transport Disposal Manifest

\begin{tabular}{ccccccc} 
(KGS) & (KGS) & Service & $\begin{array}{c}\text { Date } \\
\text { Date }\end{array}$ Number & Notes \\
\hline 128 & 69 & $6 / 1 / 1968$ & $1 / 15 / 2014$ & $1 / 25 / 2014$ & $001600942 G B F$ & 2,5
\end{tabular}

Yes Organic Setups, Oil Solids

$1 / 15 / 2014 \quad 1 / 25 / 2014 \quad 001600942$ GBF 2,5

10484021

$6 / 1 / 1968$

$10484061 \quad$ Yes Organic Setups, Oil Solids

$127 \quad 68 \quad 6 / 1 / 1968 \quad 1 / 4 / 2014 \quad 1 / 17 / 2014 \quad 001600934$ GBF 2,5

$10484065 \quad$ Yes Organic Setups, Oil Solids

$10484492 \quad$ Yes Organic Setups, Oil Solids

$10484495 \quad$ Yes Organic Setups, Oil Solids

10485067 Yes Organic Setups, Oil Solids

10485069 Yes Organic Setups, Oil Solids

$10485072 \quad$ Yes Organic Setups, Oil Solids

10485075 Yes Organic Setups, Oil Solids

$10485078 \quad$ Yes Organic Setups, Oil Solids

10485079 Yes Organic Setups, Oil Solids

10485080

Organic Setups, Oil Solids

10485081

Organic Setups, Oil Solids

10485082

10485084

Organic Setups, Oil Solids

10485085

10485094

10485309

Organic Setups, Oil Solids

Organic Setups, Oil Solids

Organic Setups, Oil Solids

Organic Setups, Oil Solids

Organic Setups, Oil Solids

Organic Setups, Oil Solids

10485350

Organic Setups, Oil Solids

10485640

10485642

10485651

Organic Setups, Oil Solids

Organic Setups, Oil Solids

10485937

10486185

Organic Setups, Oil Solids

10486190

Organic Setups, Oil Solids

Organic Setups, Oil Solids

10486199

10486200

Organic Setups, Oil Solids

Organic Setups, Oil Solids

Organic Setups, Oil Solids

10486244

10486608

Organic Setups, Oil Solids

10486617

Organic Setups, Oil Solids

Organic Setups, Oil Solids

Organic Setups, Oil Solids

10486985

Organic Setups, Oil Solids

10486991

Organic Setups, Oil Solids

10486995

Organic Setups, Oil Solids

10486996

Organic Setups, Oil Solids

$6 / 1 / 1968$

$6 / 1 / 1968$

$6 / 1 / 1968$

$6 / 1 / 1968$

$6 / 1 / 1968$

$6 / 1 / 1968$

$6 / 1 / 1968$

$6 / 1 / 1968$

$6 / 1 / 1968$

$6 / 1 / 1968$

$6 / 1 / 1968$

$6 / 1 / 1968$

$6 / 1 / 1968$

$6 / 1 / 1968$

$6 / 1 / 1968$

$6 / 1 / 1968$

$6 / 1 / 1968$

$6 / 1 / 1968$

$6 / 1 / 1968$

$6 / 1 / 1968$

$6 / 1 / 1968$

$6 / 1 / 1968$

$6 / 1 / 1968$

$6 / 1 / 1968$

$6 / 1 / 1968$

$6 / 1 / 1968$

$6 / 1 / 1968$

$6 / 1 / 1968$

$6 / 1 / 1968$

$6 / 1 / 1968$

$6 / 1 / 1968$

$6 / 1 / 1968$

$6 / 1 / 1968$

$6 / 1 / 1968$

$6 / 1 / 1968$
$1 / 7 / 2014 \quad 1 / 12 / 2014 \quad 001600938$ GBF 2,5

$1 / 7 / 2014 \quad 1 / 12 / 2014 \quad 001600938 G B F \quad 2,5$

$1 / 7 / 2014 \quad 1 / 12 / 2014 \quad 001600938 G B F \quad 2,5$

$1 / 16 / 2014 \quad 1 / 21 / 2014 \quad 001600943 G B F \quad 2,5$

1/16/2014 1/21/2014 001600943GBF 2, 5

$1 / 4 / 2014 \quad 1 / 17 / 2014 \quad 001600933 G B F \quad 2,5$

$1 / 17 / 2014 \quad 1 / 26 / 2014 \quad 001600946 G B F \quad 2,5$

$1 / 17 / 2014 \quad 1 / 26 / 2014 \quad 001600946 G B F \quad 2,5$

$1 / 17 / 2014 \quad 1 / 26 / 2014 \quad 001600946 G B F \quad 2,5$

$1 / 17 / 2014 \quad 1 / 26 / 2014 \quad 001600946 G B F \quad 2,5$

$1 / 16 / 2014 \quad 1 / 21 / 2014$ 001600943GBF 2,5

1/4/2014 1/17/2014 001600933GBF 2, 5

1/4/2014 1/17/2014 001600933GBF 2, 5

$1 / 4 / 2014 \quad 1 / 17 / 2014 \quad 001600933$ GBF 2,5

1/31/2014 2/2/2014 001600966GBF 2, 5

$1 / 4 / 2014 \quad 1 / 17 / 2014 \quad 001600933 \mathrm{GBF} 2,5$

$1 / 17 / 2014 \quad 1 / 26 / 2014 \quad 001600946$ GBF 2,5

1/21/2014 001600943GBF 2,5

$1 / 16 / 2014 \quad 1 / 21 / 2014 \quad 001600943 G B F \quad 2,5$

$1 / 16 / 2014 \quad 1 / 21 / 2014 \quad 001600943 G B F \quad 2,5$

001600965GBF 2, 5

$1 / 16 / 2014 \quad 1 / 21 / 2014 \quad 001600943 G B F \quad 2,5$

$1 / 15 / 2014 \quad 1 / 25 / 2014 \quad 001600942$ GBF 2,5

$1 / 4 / 2014 \quad 1 / 17 / 2014 \quad 001600934 \mathrm{GBF} 2,5$

1/7/2014 1/12/2014 001600938GBF 2, 5

1/4/2014 1/17/2014 001600934GBF 2, 5

$1 / 4 / 2014 \quad 1 / 17 / 2014 \quad 001600934$ GBF 2,5

1/4/2014 1/17/2014 001600933GBF 2, 5

$1 / 4 / 2014 \quad 1 / 17 / 2014 \quad 001600933 \mathrm{GBF} 2,5$

$1 / 16 / 2014 \quad 1 / 21 / 2014 \quad 001600943 G B F \quad 2,5$

1/4/2014 1/17/2014 001600933GBF 2, 5

$1 / 4 / 2014 \quad 1 / 17 / 2014 \quad 001600933$ GBF 2,5

1/20/2014 2/2/2014 001600950GBF 2, 5

1/7/2014 1/12/2014 001600938GBF 2,5

$1 / 14 / 2014 \quad 1 / 19 / 2014 \quad 001600940$ GBF 2,5 
Idaho National Laboratory

Advanced Mixed Waste Treatment Project (AMWTP)

PCB Waste Document Log

Removed from Service, Shipped and/or Disposed During Calendar Year 2014

Date of

Gross Net Removal

Radioactive

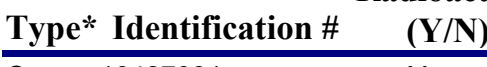

Weight Weight from Transport Disposal Manifest

$\begin{array}{lll}10487001 & \text { Yes } & \text { Organic Setups, Oil Solids } \\ 10487007 & \text { Yes } & \text { Organic Setups, Oil Solids } \\ 10487502 & \text { Yes } & \text { Organic Setups, Oil Solids } \\ 10487503 & \text { Yes } & \text { Organic Setups, Oil Solids } \\ 10487627 & \text { Yes } & \text { Organic Setups, Oil Solids } \\ 10487632 & \text { Yes } & \text { Organic Setups, Oil Solids } \\ 10487646 & \text { Yes } & \text { Organic Setups, Oil Solids } \\ 10488520 & \text { Yes } & \text { Organic Setups, Oil Solids } \\ 10488565 & \text { Yes } & \text { Organic Setups, Oil Solids } \\ 10488566 & \text { Yes } & \text { Organic Setups, Oil Solids } \\ 10488567 & \text { Yes } & \text { Organic Setups, Oil Solids } \\ 10488569 & \text { Yes } & \text { Organic Setups, Oil Solids } \\ 10488574 & \text { Yes } & \text { Organic Setups, Oil Solids } \\ 10488579 & \text { Yes } & \text { Organic Setups, Oil Solids } \\ 10488581 & \text { Yes } & \text { Organic Setups, Oil Solids } \\ 10488582 & \text { Yes } & \text { Organic Setups, Oil Solids } \\ 10488673 & \text { Yes } & \text { Organic Setups, Oil Solids } \\ 10488684 & \text { Yes } & \text { Organic Setups, Oil Solids } \\ 10488846 & \text { Yes } & \text { Organic Setups, Oil Solids } \\ 10488876 & \text { Yes } & \text { Organic Setups, Oil Solids } \\ 10489120 & \text { Yes } & \text { Organic Setups, Oil Solids } \\ 10489124 & \text { Yes } & \text { Organic Setups, Oil Solids } \\ 10489139 & \text { Yes } & \text { Organic Setups, Oil Solids } \\ 10489221 & \text { Yes } & \text { Organic Setups, Oil Solids } \\ 10489228 & \text { Yes } & \text { Organic Setups, Oil Solids } \\ 10489234 & \text { Yes } & \text { Organic Setups, Oil Solids } \\ 10489237 & \text { Yes } & \text { Organic Setups, Oil Solids } \\ 10489832 & \text { Yes } & \text { Organic Setups, Oil Solids } \\ 10490275 & \text { Yes } & \text { Organic Setups, Oil Solids } \\ 10490276 & \text { Yes } & \text { Organic Setups, Oil Solids } \\ 10490277 & \text { Yes } & \text { Organic Setups, Oil Solids } \\ 10490474 & \text { Yes } & \text { Organic Setups, Oil Solids } \\ 10490477 & \text { Yes } & \text { Organic Setups, Oil Solids } \\ 10490478 & \text { Yes } & \text { Organic Setups, Oil Solids } \\ 10490487 & \text { Yes } & \text { Organic Setups, Oil Solids } \\ 10490488 & \text { Yes } & \text { Organic Setups, Oil Solids } \\ 10490496 & & \text { Organic Setups, Oil Solids } \\ 10490498 & & \end{array}$

(KGS) (KGS) Service

Date Date Number Notes

$\begin{array}{lllllll}180 & 121 & 6 / 1 / 1968 & 1 / 7 / 2014 & 1 / 12 / 2014 & 001600938 G B F & 2,5\end{array}$

$141 \quad 82 \quad 6 / 1 / 1968 \quad 1 / 14 / 20141 / 19 / 2014 \quad 001600940 G B F 2,5$

$6 / 1 / 1968 \quad 1 / 16 / 2014 \quad 1 / 21 / 2014$ 001600943GBF 2, 5

$136 \quad 77 \quad 6 / 1 / 1968 \quad 1 / 16 / 2014 \quad 1 / 21 / 2014 \quad 001600943$ GBF 2,5

$\begin{array}{llllll}131 & 72 & 6 / 1 / 1968 & 1 / 17 / 2014 & 1 / 26 / 2014 & 001600946 G B F\end{array}$

$171 \quad 112 \quad 6 / 1 / 1968 \quad 1 / 17 / 2014 \quad 1 / 26 / 2014 \quad 001600946 G B F \quad 2,5$

$190 \quad 131 \quad 6 / 1 / 1968 \quad 1 / 21 / 2014 \quad 1 / 24 / 2014 \quad 001600952$ GBF 2,5

$185 \quad 126 \quad 6 / 1 / 1968 \quad 1 / 27 / 2014 \quad 1 / 31 / 2014 \quad 001600961$ GBF 2,5

$133 \quad 74 \quad 6 / 1 / 1968 \quad 1 / 31 / 2014 \quad$ 001600965GBF 2, 5

$4182 \quad 6 / 1 / 1968 \quad 1 / 31 / 2014 \quad 001600965$ GBF 2,5

$170111 \quad 6 / 1 / 1968 \quad 1 / 31 / 2014 \quad 001600965$ GBF 2,5

$13374 \quad 6 / 1 / 1968 \quad 1 / 31 / 2014 \quad 001600965$ GBF 2, 5

$\begin{array}{lllll}40 & 81 & 6 / 1 / 1968 & 1 / 31 / 2014 & 001600965 G B F\end{array}$

$4990 \quad 6 / 1 / 1968 \quad 1 / 31 / 2014 \quad 001600965 G B F \quad 2,5$

$\begin{array}{llllll}148 & 89 & 6 / 1 / 1968 & 1 / 28 / 2014 & 2 / 1 / 2014 & 001600963 G B F \\ 2,5\end{array}$

$163 \quad 104 \quad 6 / 1 / 1968 \quad 1 / 7 / 2014 \quad 1 / 17 / 2014 \quad 001600938$ GBF 2,5

$168 \quad 109 \quad 6 / 1 / 1968 \quad 1 / 24 / 2014 \quad 2 / 1 / 2014 \quad 001600957 G B F \quad 2,5$

$\begin{array}{llllll}50 & 91 & 6 / 1 / 1968 & 1 / 7 / 2014 & 1 / 17 / 2014 & 001600938 G B F \\ 2,5 & 5\end{array}$

$13576 \quad 6 / 1 / 1968 \quad 2 / 4 / 2014 \quad$ 001600972GBF 2,5

$\begin{array}{lllll}23 & 64 & 6 / 1 / 1968 & 2 / 1 / 2014 & 001600969 G B F \quad 2,5\end{array}$

$14586 \quad 6 / 1 / 1968 \quad 1 / 23 / 2014 \quad 1 / 26 / 2014 \quad 001600951$ GBF 2,5

$136 \quad 77 \quad 6 / 1 / 1968 \quad 1 / 16 / 2014 \quad 1 / 24 / 2014 \quad 001600944 G B F \quad 2,5$

$\begin{array}{llllll}37 & 78 & 6 / 1 / 1968 & 1 / 24 / 2014 & 1 / 28 / 2014 & 001600957 G B F \\ 2,5\end{array}$

$10142 \quad 6 / 1 / 1968 \quad 1 / 16 / 2014 \quad 1 / 24 / 2014 \quad 001600944$ GBF 2,5

$127 \quad 68 \quad 6 / 1 / 1968 \quad 1 / 4 / 2014 \quad 1 / 8 / 2014 \quad 001600933$ GBF 2,5

$15394 \quad 6 / 1 / 1968 \quad 2 / 4 / 2014 \quad 001600972$ GBF 2,5

$160 \quad 101 \quad 6 / 1 / 1968 \quad 1 / 28 / 2014 \quad 2 / 1 / 2014 \quad 001600962 \mathrm{GBF} 2,5$

$\begin{array}{lllllll}51 & 92 & 6 / 1 / 1968 & 1 / 27 / 2014 & 1 / 31 / 2014 & 001600961 G B F & 2,5\end{array}$

$159 \quad 100 \quad 6 / 1 / 1968 \quad 1 / 27 / 2014 \quad 1 / 31 / 2014 \quad 001600961$ GBF 2,5

$139 \quad 80 \quad 6 / 1 / 1968 \quad 1 / 28 / 2014 \quad 2 / 1 / 2014 \quad 001600962 G B F \quad 2,5$

$\begin{array}{llllll}20 & 61 & 6 / 1 / 1968 & 1 / 18 / 2014 & 1 / 24 / 2014 & 001600947 G B F\end{array} 2,5$

$2970 \quad 6 / 1 / 1968 \quad 2 / 4 / 2014 \quad 001600972$ GBF 2,5

$98 \quad 39 \quad 6 / 1 / 1968 \quad 1 / 24 / 2014 \quad 1 / 28 / 2014 \quad 001600956$ GBF 2,5

$1 / 27 / 2014 \quad 1 / 31 / 2014 \quad 001600961 \mathrm{GBF} 2,5$

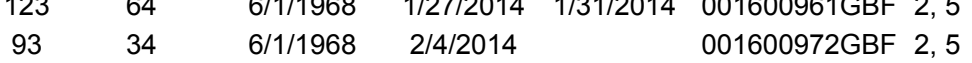

$\begin{array}{lllll}30 & 71 & 6 / 1 / 1968 & 2 / 1 / 2014 & 001600968 G B F \\ 2,5\end{array}$

$124 \quad 65 \quad 6 / 1 / 1968 \quad 1 / 24 / 2014 \quad 1 / 28 / 2014 \quad 001600956$ GBF 2,5

*A=Article; $C=$ Container; $A C=$ Article Container, $B W=B$ Bulk Waste, $E=$ Equipment 
Idaho National Laboratory

Advanced Mixed Waste Treatment Project (AMWTP)

PCB Waste Document Log

Removed from Service, Shipped and/or Disposed During Calendar Year 2014

Date of

Gross Net Removal

Radioactive

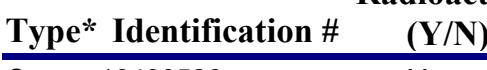

Weight Weight from Transport Disposal Manifest

0490526

Organic Setups, Oil Solids

(KGS) (KGS) Service

Date Date Number Notes

10490850

Organic Setups, Oil Solids

Organic Setups, Oil Solids

Yes Organic Setups, Oil Solids

10490859

Organic Setups, Oil Solids

10491055

10491093

Organic Setups, Oil Solids

10491183

10491186

10491187

10491188

10491189

10491190

10491197

10491198

10491199

10491200

10491201

10491203

10491204

10491205

10491206

10491207

10491208

10491211

10491212

10491214

10491216

10491218

10491219

1049122

10491430

10491432

10491550

10491579

10491619

Organic Setups, Oil Solids

Organic Setups, Oil Solids

Organic Setups, Oil Solids

Organic Setups, Oil Solids

Organic Setups, Oil Solids

Organic Setups, Oil Solids

Organic Setups, Oil Solids

Organic Setups, Oil Solids

Organic Setups, Oil Solids

Organic Setups, Oil Solids

Organic Setups, Oil Solids

Organic Setups, Oil Solids

Organic Setups, Oil Solids

Organic Setups, Oil Solids

Organic Setups, Oil Solids

Organic Setups, Oil Solids

Organic Setups, Oil Solids

Organic Setups, Oil Solids

Organic Setups, Oil Solids

Organic Setups, Oil Solids

Organic Setups, Oil Solids

Organic Setups, Oil Solids

Organic Setups, Oil Solids

Organic Setups, Oil Solids

Organic Setups, Oil Solids

Organic Setups, Oil Solids

Organic Setups, Oil Solids

Organic Setups, Oil Solids

Organic Setups, Oil Solids

Organic Setups, Oil Solids

Organic Setups, Oil Solids

6/1/1968

$6 / 1 / 1968$

$6 / 1 / 1968$

$6 / 1 / 1968$

$6 / 1 / 1968$

$6 / 1 / 1968$

$6 / 1 / 1968$

$6 / 1 / 1968$

$6 / 1 / 1968$

$6 / 1 / 1968$

$6 / 1 / 1968$

$6 / 1 / 1968$

$6 / 1 / 1968$

$6 / 1 / 1968$

$6 / 1 / 1968$

$6 / 1 / 1968$

$6 / 1 / 1968$

$6 / 1 / 1968$

$6 / 1 / 1968$

$6 / 1 / 1968$

$6 / 1 / 1968$

$6 / 1 / 1968$

$6 / 1 / 1968$

$6 / 1 / 1968$

$6 / 1 / 1968$

$6 / 1 / 1968$

$6 / 1 / 1968$

$6 / 1 / 1968$

$6 / 1 / 1968$

$6 / 1 / 1968$

$6 / 1 / 1968$

$6 / 1 / 1968$

$6 / 1 / 1968$

$6 / 1 / 1968$

$6 / 1 / 1968$

$6 / 1 / 1968$

$6 / 1 / 1968$

$6 / 1 / 1968$
$1 / 18 / 2014 \quad 1 / 24 / 2014 \quad 001600947 G B F \quad 2,5$

$2 / 4 / 2014$

$001600972 \mathrm{GBF} 2,5$

$1 / 7 / 2014 \quad 1 / 17 / 2014$ 001600938GBF 2, 5

$1 / 7 / 2014 \quad 1 / 17 / 2014 \quad 001600938 G B F \quad 2,5$

$1 / 7 / 2014 \quad 1 / 17 / 2014 \quad 001600938 G B F \quad 2,5$

$1 / 7 / 2014 \quad 1 / 17 / 2014 \quad 001600938 G B F \quad 2,5$

$1 / 23 / 2014 \quad 1 / 26 / 2014 \quad 001600954 G B F \quad 2,5$

001600972GBF 2, 5

1/28/2014 1/31/2014 001600963GBF 2, 5

1/31/2014 001600963GBF 2,5

2/4/2014 001600973GBF 2,5

1/28/2014 1/31/2014 001600963GBF 2, 5

$1 / 28 / 2014 \quad 2 / 2 / 2014 \quad 001600962 \mathrm{GBF} 2,5$

$1 / 27 / 2014 \quad 1 / 31 / 2014 \quad 001600961$ GBF 2,5

$1 / 28 / 2014 \quad 1 / 31 / 2014 \quad 001600963 G B F \quad 2,5$

$1 / 28 / 2014 \quad 2 / 2 / 2014 \quad 001600962 \mathrm{GBF} 2,5$

2/1/2014 001600968GBF 2, 5

1/28/2014 2/2/2014 001600962GBF 2,5

$1 / 28 / 2014 \quad 1 / 31 / 2014 \quad 001600963 G B F \quad 2,5$

1/28/2014 1/31/2014 001600963GBF 2, 5

$1 / 27 / 2014 \quad 1 / 31 / 2014 \quad 001600961 \mathrm{GBF} 2,5$

$1 / 27 / 2014 \quad 1 / 31 / 2014 \quad 001600961 G B F \quad 2,5$

1/31/2014 001600961GBF 2,5

2/4/2014 001600972GBF 2, 5

2/4/2014 001600973GBF 2, 5

$1 / 28 / 2014 \quad 1 / 31 / 2014 \quad 001600963 \mathrm{GBF} 2,5$

$1 / 28 / 2014 \quad 2 / 1 / 2014 \quad 001600963 G B F 2,5$

2/4/2014 001600967GBF 2,5

$1 / 23 / 2014 \quad 1 / 26 / 2014 \quad 001600954 G B F \quad 2,5$

2/4/2014 001600972GBF 2, 5

$1 / 28 / 2014 \quad 2 / 2 / 2014 \quad 001600962 \mathrm{GBF} \quad 2,5$

$1 / 4 / 2014 \quad 1 / 8 / 2014 \quad 001600933$ GBF 2,5

1/24/2014 1/28/2014 001600957GBF 2, 5

$1 / 18 / 2014 \quad 1 / 24 / 2014 \quad 001600947 \mathrm{GBF} 2,5$

$1 / 18 / 2014 \quad 1 / 24 / 2014 \quad 001600947$ GBF 2,5

$1 / 21 / 2014 \quad 2 / 2 / 2014 \quad 001600952 \mathrm{GBF} 2,5$

$1 / 23 / 2014 \quad 1 / 28 / 2014 \quad 001600954$ GBF 2,5 
Idaho National Laboratory

Advanced Mixed Waste Treatment Project (AMWTP)

PCB Waste Document Log

Removed from Service, Shipped and/or Disposed During Calendar Year 2014

Date of

Gross Net Removal

Radioactive

\begin{tabular}{|c|c|c|c|c|c|c|c|c|c|c|}
\hline Type & * Identification \# & $\begin{array}{c}\text { Radioacti } \\
(\mathbf{Y} / \mathrm{N})\end{array}$ & Description & $\begin{array}{c}\text { Weight } \\
\text { (KGS) }\end{array}$ & $\begin{array}{c}\text { Weight } \\
\text { (KGS) }\end{array}$ & $\begin{array}{c}\text { trom } \\
\text { Service }\end{array}$ & $\begin{array}{c}\text { Transport } \\
\text { Date }\end{array}$ & $\begin{array}{c}\text { Disposal } \\
\text { Date }\end{array}$ & $\begin{array}{c}\text { Manifest } \\
\text { Number }\end{array}$ & Notes \\
\hline $\mathrm{C}$ & 10491626 & Yes & Organic Setups, Oil Solids & 136 & 77 & $6 / 1 / 1968$ & $1 / 24 / 2014$ & $1 / 28 / 2014$ & $001600956 \mathrm{GBF}$ & 2,5 \\
\hline C & 10491720 & Yes & Organic Setups, Oil Solids & 110 & 51 & 6/1/1968 & $1 / 6 / 2014$ & $1 / 15 / 2014$ & $001600936 \mathrm{GBF}$ & 2,5 \\
\hline C & 10491740 & Yes & Organic Setups, Oil Solids & 148 & 89 & 6/1/1968 & $1 / 6 / 2014$ & $1 / 15 / 2014$ & $001600936 \mathrm{GBF}$ & 2,5 \\
\hline C & 10491742 & Yes & Organic Setups, Oil Solids & 148 & 89 & $6 / 1 / 1968$ & $1 / 6 / 2014$ & $1 / 15 / 2014$ & $001600936 \mathrm{GBF}$ & 2,5 \\
\hline C & 10491972 & Yes & Organic Setups, Oil Solids & 129 & 70 & $6 / 1 / 1968$ & $1 / 23 / 2014$ & $1 / 30 / 2014$ & $001600951 \mathrm{GBF}$ & 2,5 \\
\hline C & 10491990 & Yes & Organic Setups, Oil Solids & 143 & 84 & $6 / 1 / 1968$ & $1 / 18 / 2014$ & $1 / 24 / 2014$ & $001600947 \mathrm{GBF}$ & 2,5 \\
\hline C & 10491996 & Yes & Organic Setups, Oil Solids & 141 & 82 & $6 / 1 / 1968$ & $1 / 6 / 2014$ & $1 / 15 / 2014$ & $001600936 \mathrm{GBF}$ & 2,5 \\
\hline C & 10491997 & Yes & Organic Setups, Oil Solids & 145 & 86 & $6 / 1 / 1968$ & $1 / 6 / 2014$ & $1 / 15 / 2014$ & $001600936 \mathrm{GBF}$ & 2,5 \\
\hline C & 10491998 & Yes & Organic Setups, Oil Solids & 126 & 67 & $6 / 1 / 1968$ & $1 / 20 / 2014$ & $1 / 24 / 2014$ & $001600950 \mathrm{GBF}$ & 2,5 \\
\hline C & 10492246 & Yes & Sludge Repackage Project PCB Contaminated Debris & 926 & 618 & $12 / 19 / 2012$ & $8 / 17 / 2014$ & $8 / 18 / 2014$ & $001942735 \mathrm{GBF}$ & 2 \\
\hline C & 10492247 & Yes & Sludge Repackage Project PCB Contaminated Debris & 984 & 676 & $2 / 4 / 2013$ & $8 / 10 / 2014$ & $8 / 11 / 2014$ & 001942734GBF & 2 \\
\hline C & 10492248 & Yes & Sludge Repackage Project PCB Contaminated Debris & 875 & 567 & $1 / 9 / 2013$ & $8 / 10 / 2014$ & $8 / 11 / 2014$ & 001942734GBF & 2 \\
\hline C & 10492249 & Yes & Sludge Repackage Project PCB Contaminated Debris & 983 & 672 & $2 / 12 / 2013$ & $8 / 10 / 2014$ & $8 / 11 / 2014$ & $001942734 \mathrm{GBF}$ & 2 \\
\hline C & 10492250 & Yes & Sludge Repackage Project PCB Contaminated Debris & 1039 & 728 & $2 / 21 / 2013$ & $8 / 17 / 2014$ & $8 / 18 / 2014$ & $001942735 \mathrm{GBF}$ & 2 \\
\hline C & 10492251 & Yes & Sludge Repackage Project PCB Contaminated Debris & 905 & 595 & $2 / 25 / 2013$ & $8 / 17 / 2014$ & $8 / 18 / 2014$ & $001942735 \mathrm{GBF}$ & 2 \\
\hline C & 10492252 & Yes & Sludge Repackage Project PCB Contaminated Debris & 886 & 578 & $1 / 30 / 2013$ & $8 / 10 / 2014$ & $8 / 11 / 2014$ & $001942734 \mathrm{GBF}$ & 2 \\
\hline C & 10492253 & Yes & Sludge Repackage Project PCB Contaminated Debris & 985 & 674 & $2 / 26 / 2013$ & $8 / 10 / 2014$ & $8 / 11 / 2014$ & 001942734GBF & 2 \\
\hline C & 10492254 & Yes & Sludge Repackage Project PCB Contaminated Debris & 953 & 644 & $2 / 5 / 2013$ & $8 / 17 / 2014$ & $8 / 18 / 2014$ & $001942735 \mathrm{GBF}$ & 2 \\
\hline C & 10492255 & Yes & Sludge Repackage Project PCB Contaminated Debris & 966 & 655 & $2 / 5 / 2013$ & $8 / 10 / 2014$ & $8 / 11 / 2014$ & $001942734 \mathrm{GBF}$ & 2 \\
\hline C & 10492256 & Yes & Sludge Repackage Project PCB Contaminated Debris & 1047 & 736 & $2 / 6 / 2013$ & $8 / 10 / 2014$ & $8 / 11 / 2014$ & 001942734GBF & 2 \\
\hline C & 10492257 & Yes & Sludge Repackage Project PCB Contaminated Debris & 991 & 682 & $1 / 31 / 2013$ & $8 / 10 / 2014$ & $8 / 11 / 2014$ & $001942734 G B F$ & 2 \\
\hline C & 10492740 & Yes & Sludge Repackage Project PCB Contaminated Debris & 979 & 670 & $3 / 13 / 2013$ & $8 / 10 / 2014$ & $8 / 11 / 2014$ & $001942733 G B F$ & 2 \\
\hline C & 10492741 & Yes & Sludge Repackage Project PCB Contaminated Debris & 884 & 573 & $3 / 11 / 2013$ & $8 / 10 / 2014$ & $8 / 11 / 2014$ & 001942733GBF & 2 \\
\hline C & 10492742 & Yes & Sludge Repackage Project PCB Contaminated Debris & 1015 & 704 & $3 / 12 / 2013$ & $8 / 10 / 2014$ & $8 / 11 / 2014$ & 001942733GBF & 2 \\
\hline C & 10492743 & Yes & Sludge Repackage Project PCB Contaminated Debris & 1015 & 704 & $3 / 7 / 2013$ & $8 / 10 / 2014$ & $8 / 11 / 2014$ & 001942733GBF & 2 \\
\hline C & 10492744 & Yes & Sludge Repackage Project PCB Contaminated Debris & 1032 & 724 & $1 / 17 / 2013$ & $8 / 10 / 2014$ & $8 / 11 / 2014$ & 001942733GBF & 2 \\
\hline C & 10492745 & Yes & Sludge Repackage Project PCB Contaminated Debris & 973 & 665 & $1 / 28 / 2013$ & $8 / 10 / 2014$ & $8 / 11 / 2014$ & 001942734GBF & 2 \\
\hline C & 10492746 & Yes & Sludge Repackage Project PCB Contaminated Debris & 985 & 677 & $1 / 22 / 2013$ & $8 / 10 / 2014$ & $8 / 11 / 2014$ & $001942733 \mathrm{GBF}$ & 2 \\
\hline C & 10492747 & Yes & Sludge Repackage Project PCB Contaminated Debris & 942 & 634 & $1 / 24 / 2013$ & $8 / 10 / 2014$ & $8 / 11 / 2014$ & 001942734GBF & 2 \\
\hline C & 10492748 & Yes & Sludge Repackage Project PCB Contaminated Debris & 1074 & 763 & $3 / 7 / 2013$ & $8 / 10 / 2014$ & $8 / 11 / 2014$ & 001942734GBF & 2 \\
\hline C & 10492749 & Yes & Sludge Repackage Project PCB Contaminated Debris & 987 & 676 & $2 / 14 / 2013$ & $8 / 10 / 2014$ & $8 / 11 / 2014$ & $001942734 \mathrm{GBF}$ & 2 \\
\hline C & 10492750 & Yes & Sludge Repackage Project PCB Contaminated Debris & 919 & 611 & $1 / 29 / 2013$ & $8 / 10 / 2014$ & $8 / 11 / 2014$ & $001942734 \mathrm{GBF}$ & 2 \\
\hline C & 10492751 & Yes & Sludge Repackage Project PCB Contaminated Debris & 1014 & 703 & $2 / 13 / 2013$ & $8 / 10 / 2014$ & $8 / 11 / 2014$ & 001942734GBF & 2 \\
\hline C & 10492983 & Yes & Organic Setups, Oil Solids & 173 & 114 & $6 / 1 / 1968$ & $2 / 1 / 2014$ & & $001600969 \mathrm{GBF}$ & 2,5 \\
\hline C & 10492993 & Yes & Organic Setups, Oil Solids & 145 & 86 & $6 / 1 / 1968$ & $2 / 1 / 2014$ & & $001600969 G B F$ & 2,5 \\
\hline C & 10492994 & Yes & Organic Setups, Oil Solids & 114 & 55 & $6 / 1 / 1968$ & $1 / 16 / 2014$ & $1 / 24 / 2014$ & $001600944 G B F$ & 2,5 \\
\hline C & 10493124 & Yes & Sludge Repackage Project PCB Contaminated Debris & 1057 & 746 & $3 / 21 / 2013$ & $8 / 3 / 2014$ & 8/7/2014 & 001942730GBF & 2 \\
\hline C & 10493125 & Yes & Sludge Repackage Project PCB Contaminated Debris & 998 & 695 & $1 / 8 / 2013$ & $8 / 3 / 2014$ & $8 / 7 / 2014$ & $001942730 \mathrm{GBF}$ & 2 \\
\hline
\end{tabular}

*A=Article; $C=$ Container; $A C=$ Article Container, $B W=$ Bulk Waste, $E=E q u i p m e n t$

Tuesday, March 24, 2015 
Idaho National Laboratory

Advanced Mixed Waste Treatment Project (AMWTP)

PCB Waste Document Log

Removed from Service, Shipped and/or Disposed During Calendar Year 2014

Date of

Gross Net Removal

Radioactive

Type* Identification \#

adioactive

Weight Weight from

(KGS) (KGS) Service

ransport Disposal Manifest

0493126

Description

(KGS) (KGS) Service Date Date Number Notes

$\begin{array}{lllllll}916 & 605 & 3 / 27 / 2013 & 8 / 6 / 2014 & 8 / 4 / 2014 & 001942731 \mathrm{GBF} & 2\end{array}$

$\begin{array}{lllllll}1023 & 713 & 4 / 1 / 2013 & 8 / 3 / 2014 & 8 / 7 / 2014 & 001942730 G B F & 2\end{array}$

10493128

Sludge Repackage Project PCB Contaminated Debris

$958 \quad 647$

$3 / 25 / 2013$

$8 / 3 / 2014$

8/7/2014 001942730GBF 2

10493129

Sludge Repackage Project PCB Contaminated Debris

0493131 Sludge Repackage Project PCB Contaminated Debris Sludge Repackage Project PCB Contaminated Debris

10493132

10493133 Sludge Repackage Project PCB Contaminated Debris

10493134 Sludge Repackage Project PCB Contaminated Debris

10493135

10493248

Sludge Repackage Project PCB Contaminated Debris Sludge Repackage Project PCB Contaminated Debris Sludge Repackage Project PCB Contaminated Debris

10493249

10493250 Sludge Repackage Project PCB Contaminated Debris Sludge Repackage Project PCB Contaminated Debris

Sludge Repackage Project PCB Contaminated Debris Sludge Repackage Project PCB Contaminated Debris Sludge Repackage Project PCB Contaminated Debris Sludge Repackage Project PCB Contaminated Debris

10493253

10493254

10493255

10493256

10493257

10493258

10493259

10493478

10493481

10493484

10493515

10493516

10493517

10493521

10493523

10493524

10493525

10493527

10493528

10493529

10493530

10493531

10493533 Sludge Repackage Project PCB Contaminated Debris Sludge Repackage Project PCB Contaminated Debris Sludge Repackage Project PCB Contaminated Debris Sludge Repackage Project PCB Contaminated Debris Sludge Repackage Project PCB Contaminated Debris Organic Setups, Oil Solids Organic Setups, Oil Solids Organic Setups, Oil Solids Organic Setups, Oil Solids

Organic Setups, Oil Solids Organic Setups, Oil Solids Organic Setups, Oil Solids Organic Setups, Oil Solids Organic Setups, Oil Solids Organic Setups, Oil Solids Organic Setups, Oil Solids Organic Setups, Oil Solids Organic Setups, Oil Solids Organic Setups, Oil Solids Organic Setups, Oil Solids Organic Setups, Oil Solids

$900 \quad 590 \quad 4 / 8 / 2013$

$963 \quad 652 \quad 3 / 21 / 2013$

$961 \quad 651 \quad 3 / 22 / 2013$

1042731

$992 \quad 682$

$906 \quad 595$

$1085 \quad 775$

$991 \quad 680$

$953 \quad 642$

$972 \quad 661$

$968 \quad 657$

$1060 \quad 749$

$1046 \quad 738$

$904 \quad 593$

$940 \quad 631$

$973 \quad 66$
$3 / 27 / 2013$

$4 / 10 / 2013$

$3 / 22 / 2013$

$4 / 3 / 2013$

$3 / 18 / 2013$

$3 / 4 / 2013$

2/27/2013

2/27/2013

$2 / 18 / 2013$

$3 / 13 / 2013$

$3 / 20 / 2013$

$3 / 15 / 2013$

2/15/2013

$1 / 17 / 2013$

$3 / 1 / 2013$

$3 / 5 / 2013$

$6 / 1 / 1968$

6/1/1968

$6 / 1 / 1968$

6/1/1968

$6 / 1 / 1968$

$6 / 1 / 1968$

$6 / 1 / 1968$

$6 / 1 / 1968$

$6 / 1 / 1968$

$6 / 1 / 1968$

$6 / 1 / 1968$

6/1/1968

6/1/1968

$6 / 1 / 1968$

6/1/1968

$6 / 1 / 1968$
$8 / 7 / 2014 \quad 001942730$ GBF 2

8/3/2014 8/7/2014 001942730GBF 2

$8 / 7 / 2014 \quad 001942730$ GBF 2

$8 / 3 / 2014 \quad 8 / 7 / 2014 \quad 001942730 \mathrm{GBF} 2$

$8 / 3 / 2014 \quad 8 / 7 / 2014 \quad 001942730 \mathrm{GBF} \quad 2$

$8 / 3 / 2014 \quad 8 / 7 / 2014 \quad 001942730 \mathrm{GBF} \quad 2$

$8 / 3 / 2014 \quad 8 / 7 / 2014 \quad 001942730 \mathrm{GBF} \quad 2$

$8 / 6 / 2014 \quad 8 / 4 / 2014 \quad 001942731 \mathrm{GBF} \quad 2$

8/6/2014 8/4/2014 001942731GBF 2

8/6/2014 8/4/2014 001942731GBF 2

$8 / 6 / 2014 \quad 8 / 4 / 2014 \quad 001942731 \mathrm{GBF} \quad 2$

8/6/2014 8/4/2014 001942731GBF 2

8/6/2014 8/4/2014 001942731GBF 2

8/6/2014 8/4/2014 001942731GBF 2

8/6/2014 8/4/2014 001942731GBF 2

$8 / 6 / 2014 \quad 8 / 4 / 2014 \quad 001942731 \mathrm{GBF} \quad 2$

$8 / 6 / 2014 \quad 8 / 4 / 2014 \quad 001942731 \mathrm{GBF} \quad 2$

$8 / 6 / 2014 \quad 8 / 4 / 2014 \quad 001942731 \mathrm{GBF} \quad 2$

8/6/2014 8/4/2014 001942731GBF 2

2/4/2014 001600973GBF 2,5

1/26/2014 001600954GBF 2,5

2/4/2014 001600972GBF 2, 5

$1 / 24 / 2014 \quad 1 / 28 / 2014 \quad 001600956$ GBF 2,5

$1 / 23 / 2014 \quad 1 / 28 / 2014 \quad 001600954$ GBF 2,5

$1 / 23 / 2014 \quad 1 / 28 / 2014 \quad 001600954$ GBF 2,5

1/28/2014 001600956GBF 2,5

2/4/2014 001600973GBF 2, 5

$1 / 27 / 2014 \quad 1 / 31 / 2014 \quad 001600961 \mathrm{GBF} 2,5$

$1 / 27 / 2014 \quad 1 / 31 / 2014 \quad 001600961 \mathrm{GBF} 2,5$

$1 / 27 / 2014 \quad 1 / 31 / 2014 \quad 001600961 \mathrm{GBF} 2,5$

$1 / 27 / 2014 \quad 1 / 31 / 2014 \quad 001600961 G B F \quad 2,5$

2/4/2014 001600972GBF 2, 5

$1 / 27 / 2014 \quad 1 / 31 / 2014 \quad 001600961 \mathrm{GBF} 2,5$

001600965GBF 2,5

$1 / 27 / 2014 \quad 1 / 31 / 2014 \quad 001600961 G B F \quad 2,5$ 
Idaho National Laboratory

Advanced Mixed Waste Treatment Project (AMWTP)

PCB Waste Document Log

Removed from Service, Shipped and/or Disposed During Calendar Year 2014

Date of

Gross Net Removal

Radioactive

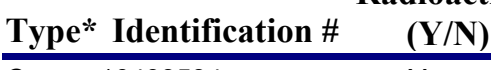

Weight Weight from Transport Disposal Manifest

$\begin{array}{lll}10493534 & \text { Yes } & \text { Organic Setups, Oil Solids } \\ 10493535 & \text { Yes } & \text { Organic Setups, Oil Solids } \\ 10493536 & \text { Yes } & \text { Organic Setups, Oil Solids } \\ 10493537 & \text { Yes } & \text { Organic Setups, Oil Solids } \\ 10493538 & \text { Yes } & \text { Organic Setups, Oil Solids } \\ 10493539 & \text { Yes } & \text { Organic Setups, Oil Solids } \\ 10493540 & \text { Yes } & \text { Organic Setups, Oil Solids } \\ 10493541 & \text { Yes } & \text { Organic Setups, Oil Solids } \\ 10493542 & \text { Yes } & \text { Organic Setups, Oil Solids } \\ 10493543 & \text { Yes } & \text { Organic Setups, Oil Solids } \\ 10493552 & \text { Yes } & \text { Organic Setups, Oil Solids } \\ 10493559 & \text { Yes } & \text { Organic Setups, Oil Solids } \\ 10493562 & \text { Yes } & \text { Organic Setups, Oil Solids } \\ 10493569 & \text { Yes } & \text { Organic Setups, Oil Solids } \\ 10493572 & \text { Yes } & \text { Organic Setups, Oil Solids } \\ 10493575 & \text { Yes } & \text { Organic Setups, Oil Solids } \\ 10493577 & \text { Yes } & \text { Organic Setups, Oil Solids } \\ 10493578 & \text { Yes } & \text { Organic Setups, Oil Solids } \\ 10493586 & \text { Yes } & \text { Organic Setups, Oil Solids } \\ 10493587 & \text { Yes } & \text { Organic Setups, Oil Solids } \\ 10493594 & \text { Yes } & \text { Organic Setups, Oil Solids } \\ 10493598 & \text { Yes } & \text { Organic Setups, Oil Solids } \\ 10493599 & \text { Yes } & \text { Organic Setups, Oil Solids } \\ 10493611 & \text { Yes } & \text { Organic Setups, Oil Solids } \\ 10493613 & \text { Yes } & \text { Organic Setups, Oil Solids } \\ 10493615 & \text { Yes } & \text { Organic Setups, Oil Solids } \\ 10493616 & \text { Yes } & \text { Organic Setups, Oil Solids } \\ 10493617 & \text { Yes } & \text { Organic Setups, Oil Solids } \\ 10493618 & \text { Yes } & \text { Organic Setups, Oil Solids } \\ 10493619 & \text { Yes } & \text { Organic Setups, Oil Solids } \\ 10493620 & \text { Yes } & \text { Organic Setups, Oil Solids } \\ 10493621 & \text { Yes } & \text { Organic Setups, Oil Solids } \\ 10493622 & \text { Yes } & \text { Organic Setups, Oil Solids } \\ 10493623 & \text { Yes } & \text { Organic Setups, Oil Solids } \\ 10493735 & \text { Yes } & \text { Organic Setups, Oil Solids } \\ 10493736 & \text { Organic Setups, Oil Solids } \\ 10493747 & \text { Organic Setups, Oil Solids } \\ 10493749 & & \end{array}$

(KGS) (KGS) Service
Date Service Date Date Number Notes

$142 \quad 83 \quad 6 / 1 / 1968 \quad 1 / 27 / 2014 \quad 1 / 31 / 2014 \quad 001600961$ B 2,5

$127 \quad 68$

$27 \quad 68$

$99 \quad 40$

$122 \quad 63$

$123 \quad 64$

$132 \quad 73$

$142 \quad 83$

$124 \quad 65$

13980

12364

$143 \quad 84$

$153 \quad 94$

$128 \quad 69$

$114 \quad 55$

$142 \quad 83$

$\begin{array}{ll}142 & 83 \\ 115 & 56\end{array}$

13273

$133 \quad 74$

$141 \quad 82$

$125 \quad 66$

$137 \quad 78$

$124 \quad 65$

$118 \quad 59$

$126 \quad 67$

$140 \quad 81$

$136 \quad 77$

13273

$162 \quad 103$

$106 \quad 47$

$187 \quad 128$

$121 \quad 62$

$115 \quad 56$

$143 \quad 84$

$\begin{array}{ll}143 & 84 \\ 131 & 72\end{array}$

$127 \quad 68$

$135 \quad 76$

001600965GBF 2,5

6/1/1968 1/27/2014 1/31/2014 001600961GBF 2, 5

6/1/1968 $1 / 31 / 2014 \quad 001600965$ GBF 2,5

6/1/1968 1/31/2014 001600965GBF 2, 5

6/1/1968 1/27/2014 1/31/2014 001600961GBF 2, 5

6/1/1968 1/27/2014 1/31/2014 001600961GBF 2, 5

6/1/1968 1/27/2014 1/31/2014 001600961GBF 2, 5

6/1/1968 2/4/2014 001600972GBF 2, 5

6/1/1968 2/4/2014 001600973GBF 2, 5

6/1/1968 1/24/2014 1/28/2014 001600956GBF 2, 5

6/1/1968 $1 / 21 / 2014 \quad 2 / 2 / 2014 \quad 001600952 \mathrm{GBF} 2,5$

6/1/1968 1/18/2014 1/24/2014 001600947GBF 2, 5

6/1/1968 1/21/2014 1/24/2014 001600952GBF 2, 5

2, 5

6/1/1968 1/18/2014 1/24/2014 001600947GBF 2, 5

6/1/1968 1/6/2014 1/15/2014 001600936GBF 2, 5

6/1/1968 1/31/2014 001600965GBF 2, 5

6/1/1968 2/4/2014 001600972GBF 2, 5

6/1/1968 1/23/2014 1/28/2014 001600954GBF 2, 5

6/1/1968 2/1/2014 001600968GBF 2, 5

6/1/1968 2/4/2014 001600972GBF 2, 5

6/1/1968 2/4/2014 001600972GBF 2, 5

6/1/1968 1/31/2014 001600965GBF 2, 5

6/1/1968 1/31/2014 001600965GBF 2, 5

6/1/1968 1/31/2014 001600965GBF 2, 5

6/1/1968 1/31/2014 001600965GBF 2, 5

6/1/1968 2/4/2014 001600972GBF 2, 5

6/1/1968 2/4/2014 001600972GBF 2, 5

6/1/1968 1/31/2014 001600965GBF 2, 5

6/1/1968 1/31/2014 001600965GBF 2, 5

6/1/1968 1/31/2014 001600965GBF 2, 5

6/1/1968 1/31/2014 001600965GBF 2, 5

6/1/1968 1/6/2014 1/15/2014 001600936GBF 2, 5

6/1/1968 1/6/2014 1/15/2014 001600936GBF 2, 5

6/1/1968 2/4/2014 001600973GBF 2, 5

6/1/1968 1/7/2014 1/12/2014 001600937GBF 2, 5 
Idaho National Laboratory

Advanced Mixed Waste Treatment Project (AMWTP)

PCB Waste Document Log

Removed from Service, Shipped and/or Disposed During Calendar Year 2014

Date of

Gross Net Removal

Radioactive

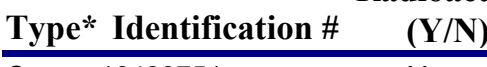

Weight Weight from Transport Disposal Manifest

0493751

Description

(KGS) (KGS) Service

Date Date Number Notes

$10493769 \quad$ Yes Organic Setups, Oil Solids

$10493779 \quad$ Yes Organic Setups, Oil Solids

10493859 Yes Organic Setups, Oil Solids

$10493861 \quad$ Yes Organic Setups, Oil Solids

$10493863 \quad$ Yes Organic Setups, Oil Solids

10493867

Organic Setups, Oil Solids

10493869

10493879

10493880

Organic Setups, Oil Solids

Organic Setups, Oil Solids

10493882

10493890

Organic Setups, Oil Solids

10493895

Organic Setups, Oil Solids

Organic Setups, Oil Solids

Organic Setups, Oil Solids

10493899

Organic Setups, Oil Solids

10494061

10494063

10494067

Organic Setups, Oil Solids

Organic Setups, Oil Solids

Organic Setups, Oil Solids

Organic Setups, Oil Solids

Organic Setups, Oil Solids

10494070

10494075

10494082

10494089

Organic Setups, Oil Solids

Organic Setups, Oil Solids

Organic Setups, Oil Solids

10494097

10494102

Organic Setups, Oil Solids

Organic Setups, Oil Solids

10494104

10494105

10494109

Organic Setups, Oil Solids

Organic Setups, Oil Solids

Organic Setups, Oil Solids

Organic Setups, Oil Solids

10494110

10494163

Organic Setups, Oil Solids

0494168

Organic Setups, Oil Solids

Organic Setups, Oil Solids

Organic Setups, Oil Solids

10494178

Organic Setups, Oil Solids

10494181

10494182

Organic Setups, Oil Solids

10494190

Organic Setups, Oil Solids

Organic Setups, Oil Solids

140 81

$15596 \quad 6 / 1 / 1968 \quad 1 / 20 / 2014 \quad 1 / 24 / 2014$ 001600950GBF 2, 5

$127 \quad 68 \quad 6 / 1 / 1968 \quad 1 / 18 / 2014 \quad 1 / 24 / 2014 \quad 001600947 G B F \quad 2,5$

$137 \quad 78 \quad 6 / 1 / 1968 \quad 2 / 4 / 2014 \quad 001600973$ GBF 2, 5

$173 \quad 114 \quad 6 / 1 / 1968 \quad 1 / 21 / 2014 \quad 1 / 24 / 2014 \quad 001600952 G B F \quad 2,5$

$156 \quad 97 \quad 6 / 1 / 1968-1 / 21 / 2014 \quad 1 / 24 / 2014 \quad 001600952 \mathrm{GBF} 2,5$

$134 \quad 75 \quad 6 / 1 / 1968 \quad 1 / 18 / 2014 \quad 1 / 24 / 2014 \quad 001600947$ GBF 2,5

$167 \quad 108 \quad 6 / 1 / 1968 \quad 1 / 21 / 2014 \quad 2 / 2 / 2014 \quad 001600952$ GBF 2,5

$171 \quad 112 \quad 6 / 1 / 1968 \quad 1 / 21 / 2014 \quad 2 / 2 / 2014 \quad 001600952 G B F \quad 2,5$

$124 \quad 65 \quad 6 / 1 / 1968 \quad 1 / 7 / 2014 \quad 1 / 12 / 2014 \quad 001600937$ GBF 2,5

$145 \quad 86 \quad 6 / 1 / 1968 \quad 1 / 7 / 2014 \quad 1 / 12 / 2014 \quad 001600937$ GBF 2,5

$\begin{array}{lllllll}37 & 6 & 6 / 1 / 1968 & 1 / 7 / 2014 & 1 / 12 / 2014 & 001600937 \mathrm{GBF} & 2,5\end{array}$

$123 \quad 64 \quad 6 / 1 / 1968 \quad 1 / 18 / 2014 \quad 1 / 24 / 2014 \quad 001600947$ GBF 2,5

$183 \quad 124 \quad 6 / 1 / 1968 \quad 1 / 6 / 2014 \quad 1 / 15 / 2014 \quad 001600936$ GBF 2,5

$166 \quad 107 \quad 6 / 1 / 1968 \quad 1 / 18 / 2014 \quad 1 / 24 / 2014$ 001600947GBF 2, 5

$\begin{array}{lllllll}54 & 95 & 6 / 1 / 1968 & 1 / 20 / 2014 & 1 / 24 / 2014 & 001600950 G B F & 2,5\end{array}$

$137 \quad 78 \quad 6 / 1 / 1968 \quad 1 / 21 / 2014 \quad 2 / 2 / 2014 \quad 001600952$ GBF 2,5

$149 \quad 90 \quad 6 / 1 / 1968 \quad 1 / 21 / 2014 \quad 1 / 24 / 2014 \quad 001600952 \mathrm{GBF} 2,5$

$\begin{array}{llllll}55 & 96 & 6 / 1 / 1968 & 1 / 21 / 2014 & 1 / 24 / 2014 & 001600952 G B F \\ 2,5\end{array}$

$\begin{array}{llllll}50 & 91 & 6 / 1 / 1968 & 1 / 21 / 2014 & 2 / 2 / 2014 & 001600952 G B F \quad 2,5\end{array}$

$\begin{array}{lllllll}170 & 111 & 6 / 1 / 1968 & 1 / 21 / 2014 & 2 / 2 / 2014 & 001600952 G B F & 2,5\end{array}$

$1869 \quad 6 / 1 / 1968 \quad 1 / 20 / 2014 \quad 1 / 24 / 2014$ 001600950GBF 2, 5

$132 \quad 73 \quad 6 / 1 / 1968 \quad 1 / 23 / 2014 \quad 1 / 28 / 2014 \quad 001600954$ GBF 2,5

$\begin{array}{lllllll}41 & 82 & 6 / 1 / 1968 & 1 / 24 / 2014 & 1 / 28 / 2014 & 001600956 G B F & 2,5\end{array}$

$15495 \quad 6 / 1 / 1968 \quad 1 / 20 / 2014 \quad 1 / 24 / 2014 \quad 001600950$ GBF 2,5

$\begin{array}{llllll}54 & 95 & 6 / 1 / 1968 & 1 / 21 / 2014 & 1 / 24 / 2014 & 001600952 G B F \quad 2,5\end{array}$

$159 \quad 100 \quad 6 / 1 / 1968 \quad 1 / 21 / 2014 \quad 2 / 2 / 2014 \quad 001600952$ GBF 2,5

$12364 \quad 6 / 1 / 1968 \quad 1 / 21 / 2014 \quad 1 / 24 / 2014$ 001600952GBF 2, 5

$15 \quad 56 \quad 6 / 1 / 1968 \quad 1 / 7 / 2014 \quad 1 / 12 / 2014 \quad 001600937$ GBF 2,5

$23 \quad 64 \quad 6 / 1 / 1968 \quad 1 / 7 / 2014 \quad 1 / 12 / 2014 \quad 001600937 \mathrm{GBF} 2,5$

$165 \quad 106 \quad 6 / 1 / 1968 \quad 1 / 6 / 2014 \quad 1 / 15 / 2014$ 001600936GBF 2, 5

$129 \quad 70 \quad 6 / 1 / 1968-1 / 6 / 2014 \quad 1 / 15 / 2014 \quad 001600936 G B F \quad 2,5$

$1354 \quad 6 / 1 / 1968 \quad 1 / 20 / 2014 \quad 1 / 24 / 2014 \quad 001600950$ GBF 2,5

$\begin{array}{llllll}133 & 74 & 6 / 1 / 1968 & 2 / 4 / 2014 & 001600973 G B F & 2,5\end{array}$

$1 / 6 / 2014$ 1/15/2014 001600936GB 2,5

$110 \quad 51 \quad 6 / 1 / 1968 \quad 1 / 6 / 2014 \quad 1 / 15 / 2014 \quad 001600936$ GBF 2,5

$132 \quad 73 \quad 6 / 1 / 1968 \quad 1 / 20 / 2014 \quad 1 / 24 / 2014 \quad 001600950$ GBF 2,5

10494195

Yes

$132 \quad 73$

$6 / 1 / 1968$

$1 / 20 / 2014 \quad 1 / 24 / 2014 \quad 001600950$ GBF 2,5 
Idaho National Laboratory

Advanced Mixed Waste Treatment Project (AMWTP)

PCB Waste Document Log

Removed from Service, Shipped and/or Disposed During Calendar Year 2014

Date of

Gross Net Removal

Radioactive

Type* Identification \# $\quad$ (Y/N)

Weight Weight from Transport Disposal Manifest

$\begin{array}{lll}10494425 & \text { Yes } & \text { Organic Setups, Oil Solids } \\ 10494427 & \text { Yes } & \text { Organic Setups, Oil Solids } \\ 10494428 & \text { Yes } & \text { Organic Setups, Oil Solids } \\ 10494429 & \text { Yes } & \text { Organic Setups, Oil Solids } \\ 10494430 & \text { Yes } & \text { Organic Setups, Oil Solids } \\ 10494433 & \text { Yes } & \text { Organic Setups, Oil Solids } \\ 10494434 & \text { Yes } & \text { Organic Setups, Oil Solids } \\ 10494435 & \text { Yes } & \text { Organic Setups, Oil Solids } \\ 10494436 & \text { Yes } & \text { Organic Setups, Oil Solids } \\ 10494438 & \text { Yes } & \text { Organic Setups, Oil Solids } \\ 10494439 & \text { Yes } & \text { Organic Setups, Oil Solids } \\ 10494452 & \text { Yes } & \text { Organic Setups, Oil Solids } \\ 10494514 & \text { Yes } & \text { Sludge Repackage Project PCB Contaminated Debris } \\ 10494515 & \text { Yes } & \text { Sludge Repackage Project PCB Contaminated Debris } \\ 10494516 & \text { Yes } & \text { Sludge Repackage Project PCB Contaminated Debris } \\ 10494517 & \text { Yes } & \text { Sludge Repackage Project PCB Contaminated Debris } \\ 10494518 & \text { Yes } & \text { Sludge Repackage Project PCB Contaminated Debris } \\ 10494519 & \text { Yes } & \text { Sludge Repackage Project PCB Contaminated Debris } \\ 10494520 & \text { Yes } & \text { Sludge Repackage Project PCB Contaminated Debris } \\ 10494521 & \text { Yes } & \text { Sludge Repackage Project PCB Contaminated Debris } \\ 10494522 & \text { Yes } & \text { Sludge Repackage Project PCB Contaminated Debris } \\ 10494523 & \text { Yes } & \text { Sludge Repackage Project PCB Contaminated Debris } \\ 10494595 & \text { Yes } & \text { Organic Setups, Oil Solids } \\ 10494597 & \text { Yes } & \text { Organic Setups, Oil Solids } \\ 10494608 & \text { Yes } & \text { Organic Setups, Oil Solids } \\ 10494611 & \text { Yes } & \text { Organic Setups, Oil Solids } \\ 10494617 & \text { Yes } & \text { Organic Setups, Oil Solids } \\ 10494620 & \text { Yes } & \text { Organic Setups, Oil Solids } \\ 10494621 & \text { Yes } & \text { Organic Setups, Oil Solids } \\ 10494623 & \text { Yes } & \text { Organic Setups, Oil Solids } \\ 10494624 & \text { Yes } & \text { Organic Setups, Oil Solids } \\ 10494629 & \text { Yes } & \text { Organic Setups, Oil Solids } \\ 10494630 & \text { Yes } & \text { Organic Setups, Oil Solids } \\ 10494631 & \text { Yes } & \text { Organic Setups, Oil Solids } \\ 10494635 & \text { Yes } & \text { Organic Setups, Oil Solids } \\ 10494640 & \text { Yes } & \text { Organic Setups, Oil Solids } \\ 10494645 & \text { Organic Setups, Oil Solids } \\ 10494647 & & \end{array}$

(KGS) (KGS) Service

Date Date Number Notes

$\begin{array}{lllllll}108 & 49 & 6 / 1 / 1968 & 1 / 23 / 2014 & 1 / 30 / 2014 & 001600951 G B F & 2,5\end{array}$

$\begin{array}{lllllll}108 & 49 & 6 / 1 / 1968 & 1 / 23 / 2014 & 1 / 30 / 2014 & 001600951 G B F & 2,5 \\ 144 & 85 & 6 / 1 / 1968 & 1 / 7 / 2014 & 1 / 12 / 2014 & 001600937 G B F & 2,5\end{array}$

$133 \quad 74 \quad 6 / 1 / 1968 \quad 1 / 6 / 2014 \quad 1 / 15 / 2014$ 001600936GBF 2, 5

$\begin{array}{lllllll}193 & 134 & 6 / 1 / 1968 & 1 / 4 / 2014 & 1 / 10 / 2014 & 001600934 G B F & 2,5\end{array}$

$164 \quad 105 \quad 6 / 1 / 1968 \quad 1 / 7 / 2014 \quad 1 / 12 / 2014 \quad 001600937$ GBF 2,5

$\begin{array}{llllll}146 & 87 & 6 / 1 / 1968 & 1 / 7 / 2014 & 1 / 12 / 2014 & 001600937 G B F \\ 2,5\end{array}$

$135 \quad 76 \quad 6 / 1 / 1968 \quad 1 / 6 / 2014 \quad 1 / 15 / 2014 \quad 001600936$ GBF 2, 5

$\begin{array}{lllllll}135 & 76 & 6 / 1 / 1968 & 1 / 6 / 2014 & 1 / 15 / 2014 & 001600936 G B F & 2,5 \\ 139 & 80 & 6 / 1 / 1968 & 1 / 4 / 2014 & 1 / 10 / 2014 & 001600934 G B F & 2,5\end{array}$

$118 \quad 59 \quad 6 / 1 / 1968 \quad 1 / 6 / 2014 \quad 1 / 15 / 2014 \quad 001600936$ GBF 2,5

$128 \quad 69 \quad 6 / 1 / 1968 \quad 1 / 4 / 2014 \quad 1 / 10 / 2014$ 001600934GBF 2, 5

$139 \quad 80 \quad 6 / 1 / 1968 \quad 1 / 4 / 2014 \quad 1 / 10 / 2014 \quad 001600934$ GBF 2,5

$\begin{array}{llllll}141 & 82 & 6 / 1 / 1968 & 1 / 6 / 2014 & 1 / 15 / 2014 & 001600936 G B F \quad 2,5\end{array}$

$\begin{array}{lllllll}978 & 666 & 5 / 7 / 2013 & 8 / 3 / 2014 & 8 / 4 / 2014 & 001942729 G B F & 2\end{array}$

$\begin{array}{lllllll}895 & 583 & 5 / 7 / 2013 & 8 / 3 / 2014 & 8 / 4 / 2014 & 001942729 G B F & 2\end{array}$

$\begin{array}{lllllll}978 & 666 & 5 / 9 / 2013 & 8 / 3 / 2014 & 8 / 7 / 2014 & 001942730 G B F & 2\end{array}$

$\begin{array}{llllllll}984 & 674 & 4 / 18 / 2013 & 8 / 3 / 2014 & 8 / 7 / 2014 & 001942730 G B F & 2\end{array}$

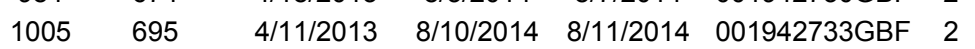

$\begin{array}{lllllll}957 & 647 & 4 / 23 / 2013 & 8 / 3 / 2014 & 8 / 7 / 2014 & 001942730 G B F & 2\end{array}$

$1003 \quad 691 \quad 5 / 8 / 2013 \quad 8 / 10 / 2014 \quad 8 / 11 / 2014 \quad 001942733 G B F \quad 2$

$\begin{array}{lllllll}1027 & 717 & 4 / 16 / 2013 & 8 / 10 / 2014 & 8 / 11 / 2014 & 001942733 G B F & 2\end{array}$

$\begin{array}{lllllll} & 7016 & 4 / 24 / 2013 & 8 / 10 / 2014 & 8 / 11 / 2014 & 001942733 G B F & 2,3\end{array}$

$\begin{array}{lllllll}942 & 632 & 4 / 11 / 2013 & 8 / 10 / 2014 & 8 / 11 / 2014 & 001942733 G B F & 2\end{array}$

$148 \quad 89 \quad 6 / 1 / 1968 \quad 1 / 6 / 2014 \quad 1 / 15 / 2014 \quad 001600936$ GBF 2,5

$11960 \quad 6 / 1 / 1968 \quad 1 / 23 / 2014 \quad 1 / 26 / 2014 \quad 001600954$ GBF 2,5

$\begin{array}{llllll}159 & 100 & 6 / 1 / 1968 & 1 / 23 / 2014 & 1 / 28 / 2014 & 001600954 G B F \\ 137,5\end{array}$

$\begin{array}{llllll}137 & 78 & 6 / 1 / 1968 & 1 / 23 / 2014 & 1 / 28 / 2014 & 001600954 G B F \quad 2,5\end{array}$

$119 \quad 60 \quad 6 / 1 / 1968 \quad 1 / 23 / 2014 \quad 1 / 28 / 2014 \quad 001600954 G B F \quad 2,5$

$\begin{array}{llllll}152 & 93 & 6 / 1 / 1968 & 2 / 1 / 2014 & 001600969 G B F & 2,5\end{array}$

$\begin{array}{lllllll}126 & 67 & 6 / 1 / 1968 & 1 / 6 / 2014 & 1 / 15 / 2014 & 001600936 G B F & 2,5\end{array}$

$\begin{array}{lllllll}137 & 78 & 6 / 1 / 1968 & 1 / 23 / 2014 & 1 / 28 / 2014 & 001600954 G B F & 2,5 \\ 133 & 74 & 6 / 1 / 1968 & 1 / 4 / 2014 & 1 / 10 / 2014 & 001600934 G B F & 2,5\end{array}$

$\begin{array}{llllll}146 & 87 & 6 / 1 / 1968 & 1 / 21 / 2014 & 1 / 24 / 2014 & 001600952 G B F \\ 2,5\end{array}$

$\begin{array}{lllllll}140 & 81 & 6 / 1 / 1968 & 1 / 4 / 2014 & 1 / 10 / 2014 & 001600934 G B F & 2,5\end{array}$

$124 \quad 65 \quad 6 / 1 / 1968 \quad 1 / 23 / 2014 \quad 1 / 26 / 2014 \quad 001600954$ GBF 2,5

$\begin{array}{llllll}118 & 59 & 6 / 1 / 1968 & 1 / 23 / 2014 & 1 / 30 / 2014 & 001600951 G B F \\ 163,5\end{array}$

$\begin{array}{lcccccc}118 & 59 & 6 / 1 / 1968 & 1 / 23 / 2014 & 1 / 30 / 2014 & 001600951 G B F & 2,5 \\ 163 & 104 & 6 / 1 / 1968 & 1 / 24 / 2014 & 1 / 28 / 2014 & 001600956 G B F & 2,5\end{array}$

$122 \quad 63 \quad 6 / 1 / 1968 \quad 1 / 4 / 2014 \quad 1 / 10 / 2014 \quad 001600934 G B F \quad 2,5$

$134 \quad 75 \quad 6 / 1 / 1968 \quad 1 / 7 / 2014 \quad 1 / 12 / 2014 \quad 001600937$ GBF 2,5 
Idaho National Laboratory

Advanced Mixed Waste Treatment Project (AMWTP)

PCB Waste Document Log

Removed from Service, Shipped and/or Disposed During Calendar Year 2014

Date of

Gross Net Removal

Radioactive

Type* Identification \# $\quad$ (Y/N)

$\begin{array}{lll}10494653 & \text { Yes } & \text { Organic Setups, Oil Solids } \\ 10494654 & \text { Yes } & \text { Organic Setups, Oil Solids } \\ 10494655 & \text { Yes } & \text { Organic Setups, Oil Solids } \\ 10494660 & \text { Yes } & \text { Organic Setups, Oil Solids } \\ 10494661 & \text { Yes } & \text { Organic Setups, Oil Solids } \\ 10494663 & \text { Yes } & \text { Organic Setups, Oil Solids } \\ 10494672 & \text { Yes } & \text { Organic Setups, Oil Solids } \\ 10494674 & \text { Yes } & \text { Organic Setups, Oil Solids } \\ 10494787 & \text { Yes } & \text { Sludge Repackage Project } \\ 10494788 & \text { Yes } & \text { Sludge Repackage Project } \\ 10494789 & \text { Yes } & \text { Sludge Repackage Project } \\ 10494790 & \text { Yes } & \text { Sludge Repackage Project } \\ 10494791 & \text { Yes } & \text { Sludge Repackage Project } \\ 10494792 & \text { Yes } & \text { Sludge Repackage Project } \\ 10494793 & \text { Yes } & \text { Sludge Repackage Project } \\ 10494794 & \text { Yes } & \text { Sludge Repackage Project } \\ 10494804 & \text { Yes } & \text { Organic Setups, Oil Solids } \\ 10494825 & \text { Yes } & \text { Organic Setups, Oil Solids } \\ 10494827 & \text { Yes } & \text { Organic Setups, Oil Solids } \\ 10494828 & \text { Yes } & \text { Organic Setups, Oil Solids } \\ 10494831 & \text { Yes } & \text { Organic Setups, Oil Solids } \\ 10494832 & \text { Yes } & \text { Organic Setups, Oil Solids } \\ 10494836 & \text { Yes } & \text { Organic Setups, Oil Solids } \\ 10494841 & \text { Yes } & \text { Organic Setups, Oil Solids } \\ 10494845 & \text { Yes } & \text { Organic Setups, Oil Solids } \\ 10494848 & \text { Yes } & \text { Organic Setups, Oil Solids } \\ 10494851 & \text { Yes } & \text { Organic Setups, Oil Solids } \\ 10494857 & \text { Yes } & \text { Organic Setups, Oil Solids } \\ 10494861 & \text { Yes } & \text { Organic Setups, Oil Solids } \\ 10495047 & \text { Yes } & \text { Organic Setups, Oil Solids } \\ 10495051 & \text { Yes } & \text { Organic Setups, Oil Solids } \\ 10495055 & \text { Yes } & \text { Organic Setups, Oil Solids } \\ 10495058 & \text { Yes } & \text { Organic Setups, Oil Solids } \\ 10495059 & \text { Yes } & \text { Organic Setups, Oil Solids } \\ 10495063 & \text { Yes } & \text { Organic Setups, Oil Solids } \\ 10495065 & \text { Yes } & \text { Organic Setups, Oil Solids } \\ 10495066 & & \text { Organic Setups, Oil Solids } \\ 10495068 & & \text { Organic Setups, Oil Solids } \\ & & \end{array}$

Weight Weight from Transport Disposal Manifest

(KGS) (KGS) Service $\begin{array}{ccccc}\text { Date } & \text { Date } & \text { Number Notes }\end{array}$

$139 \quad 80$

1/4/2014 1/10/2014 001600934GBF 2, 5

$\begin{array}{lllllll}124 & 65 & 6 / 1 / 1968 & 2 / 4 / 2014 & & 001600973 G B F & 2,5 \\ 158 & 99 & 6 / 1 / 1968 & 1 / 23 / 2014 & 1 / 28 / 2014 & 001600954 G B F & 2,5\end{array}$

$\begin{array}{lllll}143 & 84 & 6 / 1 / 1968 & 2 / 4 / 2014 & 001600973 G B F \quad 2,5\end{array}$

$\begin{array}{lllll}143 & 84 & 6 / 1 / 1968 & 2 / 4 / 2014 & 001600973 G B F 2,5 \\ 137 & 78 & 6 / 1 / 1968 & 2 / 1 / 2014 & 001600969 G B F \quad 2,5\end{array}$

$38 \quad 79 \quad 6 / 1 / 1968 \quad 1 / 24 / 2014 \quad 2 / 1 / 2014 \quad 001600957 G B F \quad 2,5$

$15293 \quad 6 / 1 / 1968 \quad 1 / 23 / 2014 \quad 1 / 26 / 2014 \quad 001600954$ GBF 2,5

$148 \quad 89 \quad 6 / 1 / 1968 \quad 2 / 1 / 2014 \quad$ 001600969GBF 2, 5

$\begin{array}{lllllll}956 & 650 & 5 / 1 / 2013 & 8 / 3 / 2014 & 8 / 4 / 2014 & 001942729 G B F & 2\end{array}$

$\begin{array}{lllllll}1031 & 721 & 4 / 8 / 2013 & 8 / 6 / 2014 & 8 / 4 / 2014 & 001942731 \mathrm{GBF} & 2\end{array}$

$\begin{array}{lllllll}1009 & 699 & 4 / 4 / 2013 & 8 / 10 / 2014 & 8 / 11 / 2014 & 001942733 G B F & 2\end{array}$

$\begin{array}{lllllll}1038 & 726 & 5 / 10 / 2013 & 8 / 3 / 2014 & 8 / 4 / 2014 & 001942729 G B F & 2\end{array}$

$\begin{array}{llllllll}1043 & 731 & 5 / 6 / 2013 & 8 / 3 / 2014 & 8 / 4 / 2014 & 001942729 G B F & 2\end{array}$

$\begin{array}{lllllll}962 & 655 & 5 / 1 / 2013 & 8 / 10 / 2014 & 8 / 11 / 2014 & 001942733 G B F & 2\end{array}$

$\begin{array}{lllllll}845 & 534 & 4 / 25 / 2013 & 8 / 3 / 2014 & 8 / 4 / 2014 & 001942729 G B F & 2\end{array}$

$\begin{array}{lllllll}950 & 639 & 4 / 25 / 2013 & 8 / 10 / 2014 & 8 / 11 / 2014 & 001942733 G B F & 2\end{array}$

$126 \quad 67 \quad 6 / 1 / 1968 \quad 1 / 24 / 2014 \quad 1 / 28 / 2014 \quad 001600956$ GBF 2, 5

$103 \quad 44 \quad 6 / 1 / 1968 \quad 1 / 4 / 2014 \quad 1 / 10 / 2014 \quad 001600934$ GBF 2,5

$\begin{array}{lllllll}134 & 75 & 6 / 1 / 1968 & 1 / 23 / 2014 & 1 / 30 / 2014 & 001600951 G B F & 2,5\end{array}$

$116 \quad 57 \quad 6 / 1 / 1968 \quad 1 / 20 / 2014 \quad 1 / 24 / 2014 \quad 001600950$ GBF 2,5

$11960 \quad 6 / 1 / 1968 \quad 1 / 23 / 2014 \quad 1 / 30 / 2014 \quad 001600951$ GBF 2,5

$11354 \quad 6 / 1 / 1968 \quad 1 / 23 / 2014 \quad 1 / 30 / 2014 \quad 001600951$ GBF 2,5

$\begin{array}{ccccccc}113 & 54 & 6 / 1 / 1968 & 1 / 23 / 2014 & 1 / 30 / 2014 & 001600951 G B F & 2,5 \\ 164 & 105 & 6 / 1 / 1968 & 1 / 20 / 2014 & 1 / 24 / 2014 & 001600950 G B F & 2,5\end{array}$

$\begin{array}{lllllll}137 & 78 & 6 / 1 / 1968 & 1 / 23 / 2014 & 1 / 30 / 2014 & 001600951 G B F & 2,5\end{array}$

$148 \quad 89 \quad 6 / 1 / 1968 \quad 1 / 23 / 2014 \quad 1 / 30 / 2014 \quad 001600951$ GBF 2,5

$\begin{array}{lllllll}148 & 89 & 6 / 1 / 1968 & 1 / 23 / 2014 & 1 / 30 / 2014 & 001600951 G B F & 2,5 \\ 148 & 89 & 6 / 1 / 1968 & 1 / 21 / 2014 & 1 / 24 / 2014 & 001600952 G B F & 2,5\end{array}$

$128 \quad 69 \quad 6 / 1 / 1968 \quad 1 / 4 / 2014 \quad 1 / 10 / 2014 \quad 001600934$ GBF 2,5

$196 \quad 137 \quad 6 / 1 / 1968 \quad 1 / 23 / 2014 \quad 1 / 30 / 2014$ 001600951GBF 2, 5

$129 \quad 70 \quad 6 / 1 / 1968 \quad 1 / 23 / 2014 \quad 1 / 30 / 2014 \quad 001600951$ GBF 2,5

$\begin{array}{lllllll}135 & 76 & 6 / 1 / 1968 & 1 / 24 / 2014 & 1 / 28 / 2014 & 001600956 G B F & 2,5 \\ 137 & 78 & 6 / 1 / 1968 & 1 / 23 / 2014 & 1 / 26 / 2014 & 001600954 G B F & 2,5\end{array}$

$162 \quad 103 \quad 6 / 1 / 1968 \quad 1 / 24 / 2014 \quad 2 / 1 / 2014 \quad 001600957 G B F \quad 2,5$

$141 \quad 82 \quad 6 / 1 / 1968 \quad 1 / 14 / 2014 \quad 1 / 17 / 2014 \quad 001600940$ GBF 2,5

$\begin{array}{lllllll}143 & 84 & 6 / 1 / 1968 & 1 / 14 / 2014 & 1 / 17 / 2014 & 001600940 G B F \quad 2,5\end{array}$

$12768 \quad 6 / 1 / 1968 \quad 1 / 16 / 2014 \quad 1 / 21 / 2014 \quad 001600943$ GBF 2,5

$\begin{array}{lllllll}127 & 68 & 6 / 1 / 1968 & 1 / 16 / 2014 & 1 / 21 / 2014 & 001600943 G B F & 2,5 \\ 128 & 69 & 6 / 1 / 1968 & 1 / 16 / 2014 & 1 / 21 / 2014 & 001600943 G B F & 2,5\end{array}$

$\begin{array}{lllllll}146 & 87 & 6 / 1 / 1968 & 1 / 14 / 2014 & 1 / 19 / 2014 & 001600940 G B F & 2,5\end{array}$

10495068

15798

$6 / 1 / 1968$

$1 / 14 / 2014 \quad 1 / 17 / 2014 \quad 001600940$ GBF 2, 5 
Idaho National Laboratory

Advanced Mixed Waste Treatment Project (AMWTP)

PCB Waste Document Log

Removed from Service, Shipped and/or Disposed During Calendar Year 2014

Date of

Gross Net Removal

Radioactive

\begin{tabular}{|c|c|c|c|c|c|c|c|c|c|c|}
\hline Type* & * Identification \# & $(\mathbf{Y} / \mathbf{N})$ & Description & $\begin{array}{l}\text { weignt } \\
\text { (KGS) }\end{array}$ & $\begin{array}{l}\text { weignt } \\
\text { (KGS) }\end{array}$ & Service & $\begin{array}{c}1 \text { ransport } \\
\text { Date }\end{array}$ & $\begin{array}{l}\text { Disposal } \\
\text { Date }\end{array}$ & $\begin{array}{l}\text { Manirest } \\
\text { Number }\end{array}$ & Notes \\
\hline $\mathrm{C}$ & 10495070 & Yes & Organic Setups, Oil Solids & 133 & 74 & $6 / 1 / 1968$ & $1 / 14 / 2014$ & $1 / 17 / 2014$ & 001600940GBF & 2,5 \\
\hline C & 10495071 & Yes & Organic Setups, Oil Solids & 130 & 71 & 6/1/1968 & $1 / 14 / 2014$ & $1 / 17 / 2014$ & 001600940GBF & 2,5 \\
\hline C & 10495073 & Yes & Organic Setups, Oil Solids & 132 & 73 & 6/1/1968 & $1 / 23 / 2014$ & $1 / 26 / 2014$ & $001600954 \mathrm{GBF}$ & 2,5 \\
\hline C & 10495078 & Yes & Organic Setups, Oil Solids & 122 & 63 & 6/1/1968 & $1 / 23 / 2014$ & $1 / 26 / 2014$ & $001600954 G B F$ & 2,5 \\
\hline C & 10495089 & Yes & Organic Setups, Oil Solids & 143 & 84 & 6/1/1968 & $1 / 25 / 2014$ & $1 / 28 / 2014$ & 001600959GBF & 2,5 \\
\hline C & 10495127 & Yes & Organic Setups, Oil Solids & 170 & 111 & $6 / 1 / 1968$ & $1 / 14 / 2014$ & $1 / 17 / 2014$ & $001600940 \mathrm{GBF}$ & 2,5 \\
\hline C & 10495129 & Yes & Organic Setups, Oil Solids & 139 & 80 & $6 / 1 / 1968$ & $1 / 14 / 2014$ & $1 / 19 / 2014$ & $001600940 G B F$ & 2,5 \\
\hline C & 10495131 & Yes & Organic Setups, Oil Solids & 134 & 75 & $6 / 1 / 1968$ & $1 / 14 / 2014$ & $1 / 19 / 2014$ & $001600940 \mathrm{GBF}$ & 2,5 \\
\hline C & 10495135 & Yes & Organic Setups, Oil Solids & 143 & 84 & $6 / 1 / 1968$ & $1 / 16 / 2014$ & $1 / 24 / 2014$ & $001600944 \mathrm{GBF}$ & 2,5 \\
\hline C & 10495136 & Yes & Organic Setups, Oil Solids & 165 & 106 & $6 / 1 / 1968$ & $1 / 16 / 2014$ & $1 / 24 / 2014$ & $001600944 G B F$ & 2,5 \\
\hline C & 10495138 & Yes & Organic Setups, Oil Solids & 94 & 35 & $6 / 1 / 1968$ & $1 / 17 / 2014$ & $1 / 26 / 2014$ & $001600946 \mathrm{GBF}$ & 2,5 \\
\hline C & 10495140 & Yes & Organic Setups, Oil Solids & 166 & 107 & $6 / 1 / 1968$ & $1 / 14 / 2014$ & $1 / 17 / 2014$ & $001600940 G B F$ & 2,5 \\
\hline C & 10495306 & Yes & Organic Setups, Oil Solids & 118 & 59 & $6 / 1 / 1968$ & $1 / 14 / 2014$ & $1 / 19 / 2014$ & $001600940 \mathrm{GBF}$ & 2,5 \\
\hline C & 10495307 & Yes & Organic Setups, Oil Solids & 160 & 101 & $6 / 1 / 1968$ & $1 / 16 / 2014$ & $1 / 24 / 2014$ & $001600944 G B F$ & 2,5 \\
\hline C & 10495308 & Yes & Organic Setups, Oil Solids & 129 & 70 & $6 / 1 / 1968$ & $1 / 25 / 2014$ & $1 / 28 / 2014$ & $001600959 G B F$ & 2,5 \\
\hline C & 10495309 & Yes & Organic Setups, Oil Solids & 129 & 70 & $6 / 1 / 1968$ & $1 / 25 / 2014$ & $2 / 1 / 2014$ & $001600959 \mathrm{GBF}$ & 2,5 \\
\hline C & 10495312 & Yes & Organic Setups, Oil Solids & 136 & 77 & $6 / 1 / 1968$ & $1 / 16 / 2014$ & $1 / 24 / 2014$ & $001600944 G B F$ & 2,5 \\
\hline C & 10495313 & Yes & Organic Setups, Oil Solids & 144 & 85 & $6 / 1 / 1968$ & $1 / 25 / 2014$ & $1 / 28 / 2014$ & $001600959 \mathrm{GBF}$ & 2,5 \\
\hline C & 10495314 & Yes & Organic Setups, Oil Solids & 136 & 77 & $6 / 1 / 1968$ & $1 / 14 / 2014$ & $1 / 19 / 2014$ & $001600940 \mathrm{GBF}$ & 2,5 \\
\hline C & 10495315 & Yes & Organic Setups, Oil Solids & 149 & 90 & $6 / 1 / 1968$ & $1 / 25 / 2014$ & $1 / 28 / 2014$ & 001600959GBF & 2,5 \\
\hline C & 10495316 & Yes & Organic Setups, Oil Solids & 127 & 68 & $6 / 1 / 1968$ & $1 / 14 / 2014$ & $1 / 19 / 2014$ & $001600940 G B F$ & 2,5 \\
\hline C & 10495317 & Yes & Organic Setups, Oil Solids & 166 & 107 & $6 / 1 / 1968$ & $1 / 25 / 2014$ & $2 / 1 / 2014$ & $001600959 \mathrm{GBF}$ & 2,5 \\
\hline C & 10495319 & Yes & Organic Setups, Oil Solids & 127 & 68 & $6 / 1 / 1968$ & $1 / 25 / 2014$ & $2 / 1 / 2014$ & 001600959GBF & 2,5 \\
\hline C & 10495336 & Yes & Organic Setups, Oil Solids & 140 & 81 & $6 / 1 / 1968$ & $1 / 25 / 2014$ & $1 / 28 / 2014$ & $001600959 \mathrm{GBF}$ & 2,5 \\
\hline C & 10495352 & Yes & Organic Setups, Oil Solids & 142 & 83 & $6 / 1 / 1968$ & $1 / 17 / 2014$ & $1 / 26 / 2014$ & $001600946 \mathrm{GBF}$ & 2,5 \\
\hline C & 10495354 & Yes & Organic Setups, Oil Solids & 124 & 65 & 6/1/1968 & $1 / 25 / 2014$ & $1 / 28 / 2014$ & $001600959 \mathrm{GBF}$ & 2,5 \\
\hline C & 10495355 & Yes & Organic Setups, Oil Solids & 141 & 82 & $6 / 1 / 1968$ & $1 / 14 / 2014$ & $1 / 19 / 2014$ & $001600940 G B F$ & 2,5 \\
\hline C & 10495356 & Yes & Organic Setups, Oil Solids & 160 & 101 & $6 / 1 / 1968$ & $1 / 25 / 2014$ & $2 / 1 / 2014$ & $001600959 \mathrm{GBF}$ & 2,5 \\
\hline C & 10495357 & Yes & Organic Setups, Oil Solids & 119 & 60 & 6/1/1968 & $1 / 25 / 2014$ & $2 / 1 / 2014$ & $001600959 \mathrm{GBF}$ & 2,5 \\
\hline C & 10495367 & Yes & Organic Setups, Oil Solids & 149 & 90 & $6 / 1 / 1968$ & $1 / 14 / 2014$ & $1 / 24 / 2014$ & $001600941 \mathrm{GBF}$ & 2,5 \\
\hline C & 10495368 & Yes & Organic Setups, Oil Solids & 120 & 61 & $6 / 1 / 1968$ & $1 / 25 / 2014$ & $2 / 1 / 2014$ & $001600959 \mathrm{GBF}$ & 2,5 \\
\hline C & 10495369 & Yes & Organic Setups, Oil Solids & 142 & 83 & $6 / 1 / 1968$ & $1 / 16 / 2014$ & $1 / 24 / 2014$ & $001600944 G B F$ & 2,5 \\
\hline C & 10495372 & Yes & Organic Setups, Oil Solids & 99 & 40 & $6 / 1 / 1968$ & $1 / 25 / 2014$ & $1 / 28 / 2014$ & $001600959 \mathrm{GBF}$ & 2,5 \\
\hline C & 10495374 & Yes & Organic Setups, Oil Solids & 109 & 50 & $6 / 1 / 1968$ & $1 / 14 / 2014$ & $1 / 24 / 2014$ & $001600941 \mathrm{GBF}$ & 2,5 \\
\hline C & 10495377 & Yes & Organic Setups, Oil Solids & 151 & 92 & $6 / 1 / 1968$ & $1 / 16 / 2014$ & $1 / 24 / 2014$ & $001600944 G B F$ & 2,5 \\
\hline C & 10495822 & Yes & Organic Setups, Oil Solids & 137 & 78 & $6 / 1 / 1968$ & $2 / 1 / 2014$ & & $001600969 G B F$ & 2,5 \\
\hline C & 10495823 & Yes & Organic Setups, Oil Solids & 95 & 36 & $6 / 1 / 1968$ & $2 / 1 / 2014$ & & $001600969 \mathrm{GBF}$ & 2,5 \\
\hline C & 10495829 & Yes & Organic Setups, Oil Solids & 130 & 71 & $6 / 1 / 1968$ & $1 / 18 / 2014$ & $1 / 24 / 2014$ & $001600947 G B F$ & 2,5 \\
\hline
\end{tabular}

* $A=$ Article; $C=$ Container; $A C=$ Article Container, $B W=$ Bulk Waste, $E=E q u i p m e n t$ 
Idaho National Laboratory

Advanced Mixed Waste Treatment Project (AMWTP)

PCB Waste Document Log

Removed from Service, Shipped and/or Disposed During Calendar Year 2014

Date of

Gross Net Removal

Radioactive

Type* Identification \# $\quad$ (Y/N)

Weight Weight from Transport Disposal Manifest

\begin{tabular}{l}
10495830 \\
10495832 \\
10495833 \\
10495834 \\
10495835 \\
10495837 \\
10495838 \\
10495839 \\
10495840 \\
10495842 \\
10495843 \\
10495844 \\
10495847 \\
10495849 \\
10495851 \\
10495870 \\
10495938 \\
10495940 \\
10495944 \\
10495945 \\
10495947 \\
10495950 \\
10495952 \\
10495953 \\
10495954 \\
10495955 \\
10495956 \\
10495957 \\
10495964 \\
10495969 \\
10495971 \\
10495973 \\
10495976 \\
10496043 \\
10496044 \\
10496045 \\
10496046 \\
10496047 \\
\hline
\end{tabular}

Yes

(KGS) (KGS) Service

Date

Date

Number Notes

Yes Organic Setups, Oil Solids

Organic Setups, Oil Solids

Organic Setups, Oil Solids

1/16/2014 1/21/2014 001600943GBF 2, 5

$138 \quad 79 \quad 6 / 1 / 1968 \quad 1 / 14 / 2014 \quad 1 / 24 / 2014 \quad 001600941$ GBF 2,5

$\begin{array}{lllllll}116 & 57 & 6 / 1 / 1968 & 1 / 7 / 2014 & 1 / 12 / 2014 & 001600937 G B F & 2,5\end{array}$

Yes Organic Setups, Oil Solids

Yes Organic Setups, Oil Solids

Yes Organic Setups, Oil Solids

Yes Organic Setups, Oil Solids

Yes Organic Setups, Oil Solids

Yes Organic Setups, Oil Solids

Organic Setups, Oil Solids

Organic Setups, Oil Solids

Organic Setups, Oil Solids

Organic Setups, Oil Solids

Organic Setups, Oil Solids

Organic Setups, Oil Solids

Organic Setups, Oil Solids

Organic Setups, Oil Solids

Organic Setups, Oil Solids

Organic Setups, Oil Solids

Organic Setups, Oil Solids

Organic Setups, Oil Solids

Organic Setups, Oil Solids

Organic Setups, Oil Solids

Organic Setups, Oil Solids

Organic Setups, Oil Solids

Organic Setups, Oil Solids

Organic Setups, Oil Solids

Organic Setups, Oil Solids

Organic Setups, Oil Solids

Organic Setups, Oil Solids

Organic Setups, Oil Solids

Organic Setups, Oil Solids

Organic Setups, Oil Solids

Sludge Repackage Project PCB Contaminated Debris

Sludge Repackage Project PCB Contaminated Debris

Sludge Repackage Project PCB Contaminated Debris

Sludge Repackage Project PCB Contaminated Debris

Sludge Repackage Project PCB Contaminated Debris

$\begin{array}{lllllll}117 & 58 & 6 / 1 / 1968 & 1 / 25 / 2014 & 2 / 1 / 2014 & 001600959 G B F & 2,5 \\ 148 & 89 & 6 / 1 / 1968 & 1 / 18 / 2014 & 1 / 24 / 2014 & 001600947 G B F & 2,5\end{array}$

2/1/25/2014 001600959GBF 2,5

$15596 \quad 6 / 1 / 1968 \quad 1 / 25 / 2014 \quad 1 / 28 / 2014 \quad 001600959 G B F 2,5$

$15293 \quad 6 / 1 / 1968 \quad 1 / 16 / 2014 \quad 1 / 24 / 2014 \quad 001600944 G B F \quad 2,5$

$138 \quad 79 \quad 6 / 1 / 1968 \quad 1 / 4 / 2014 \quad 1 / 8 / 2014 \quad 001600933 G B F \quad 2,5$

$11455 \quad 6 / 1 / 1968 \quad 1 / 7 / 2014 \quad 1 / 17 / 2014 \quad 001600938 G B F \quad 2,5$

$131 \quad 72 \quad 6 / 1 / 1968 \quad 1 / 25 / 2014 \quad 1 / 28 / 2014 \quad 001600959$ GBF 2,5

$136 \quad 77 \quad 6 / 1 / 1968 \quad 1 / 4 / 2014 \quad 1 / 8 / 2014 \quad 001600933 G B F \quad 2,5$

$128 \quad 69 \quad 6 / 1 / 1968 \quad 1 / 24 / 2014 \quad 1 / 28 / 2014 \quad 001600956 G B F \quad 2,5$

$132 \quad 73 \quad 6 / 1 / 1968 \quad 1 / 14 / 2014 \quad 1 / 17 / 2014 \quad 001600940$ GBF 2,5

$130 \quad 71 \quad 6 / 1 / 1968 \quad 1 / 7 / 2014 \quad 1 / 12 / 2014$ 001600937GBF 2, 5

$128 \quad 69 \quad 6 / 1 / 1968 \quad 1 / 14 / 2014 \quad 1 / 24 / 2014 \quad 001600941$ GBF 2,5

$\begin{array}{lllllll}149 & 90 & 6 / 1 / 1968 & 1 / 7 / 2014 & 1 / 12 / 2014 & 001600937 G B F & 2,5\end{array}$

$\begin{array}{lllllll}157 & 98 & 6 / 1 / 1968 & 1 / 21 / 2014 & 2 / 2 / 2014 & 001600952 \mathrm{GBF} & 2,5 \\ 133 & 74 & 6 / 1 / 1968 & 1 / 21 / 2014 & 2 / 2 / 2014 & 001600952 \mathrm{GBF} & 2,5\end{array}$
$2 / 1 / 2014$
$001600969 \mathrm{GBF} 2,5$

6/1/1968 1/24/2014 1/28/2014 001600956GBF 2, 5

6/1/1968 2/1/2014 001600969GBF 2,5

6/1/1968 2/4/2014 001600972GBF 2, 5

6/1/1968 2/4/2014 001600973GBF 2,5

6/1/1968 1/24/2014 1/28/2014 001600956GBF 2, 5

6/1/1968 2/1/2014 001600969GBF 2, 5

6/1/1968 2/1/2014 001600969GBF 2, 5

6/1/1968 2/1/2014 001600969GBF 2, 5

6/1/1968 2/1/2014 001600969GBF 2, 5

6/1/1968 1/24/2014 2/1/2014 001600957GBF 2,5

6/1/1968 1/24/2014 2/1/2014 001600957 GBF 2, 5

6/1/1968 1/24/2014 2/1/2014 001600957GBF 2, 5

6/1/1968 1/24/2014 2/1/2014 001600957GBF 2,5

$\begin{array}{cccccccc}127 & 68 & 6 / 1 / 1968 & 2 / 1 / 2014 & & 001600969 G B F & 2,5 \\ 1075 & 769 & 5 / 21 / 2013 & 8 / 3 / 2014 & 8 / 4 / 2014 & 001942729 G B F & 2\end{array}$

$\begin{array}{lllllll}967 & 657 & 4 / 18 / 2013 & 8 / 3 / 2014 & 8 / 4 / 2014 & 001942729 G B F & 2\end{array}$

$\begin{array}{lllllll}649 & 639 & 4 / 22 / 2013 & 8 / 3 / 2014 & 8 / 4 / 2014 & 001942729 G B F & 2\end{array}$

$\begin{array}{lllllll}792 & 480 & 5 / 14 / 2013 & 8 / 3 / 2014 & 8 / 4 / 2014 & 001942729 G B F & 2\end{array}$

$\begin{array}{lllllll}940 & 634 & 6 / 10 / 2013 & 7 / 20 / 2014 & 7 / 21 / 2014 & 001942724 G B F & 2\end{array}$

$* A=$ Article C $=$ Container AC=Article Container, $B W=B u l k$ Waste, $E=E q u i p m e n t$ 
Idaho National Laboratory

Advanced Mixed Waste Treatment Project (AMWTP)

PCB Waste Document Log

Removed from Service, Shipped and/or Disposed During Calendar Year 2014

Date of

Gross Net Removal

Radioactive

\begin{tabular}{|c|c|c|c|c|c|c|c|c|c|c|}
\hline Гуре* & * Identification \# & $(\mathbf{Y} / \mathbf{N})$ & Description & (KGS) & (KGS) & Service & Date & Date & Number & Notes \\
\hline C & 10496048 & Yes & Sludge Repackage Project PCB Contaminated Debris & 982 & 670 & $5 / 16 / 2013$ & $7 / 20 / 2014$ & $7 / 21 / 2014$ & $001942724 G B F$ & 2 \\
\hline C & 10496049 & Yes & Sludge Repackage Project PCB Contaminated Debris & 946 & 636 & $4 / 17 / 2013$ & $7 / 20 / 2014$ & $7 / 21 / 2014$ & 001942724GBF & 2 \\
\hline C & 10496050 & Yes & Sludge Repackage Project PCB Contaminated Debris & 960 & 648 & $5 / 16 / 2013$ & $7 / 20 / 2014$ & $7 / 21 / 2014$ & 001942724GBF & 2 \\
\hline C & 10496051 & Yes & Sludge Repackage Project PCB Contaminated Debris & 1008 & 696 & $5 / 14 / 2013$ & $8 / 3 / 2014$ & $8 / 4 / 2014$ & 001942729GBF & 2 \\
\hline C & 10496052 & Yes & Sludge Repackage Project PCB Contaminated Debris & 947 & 635 & $5 / 15 / 2013$ & $8 / 3 / 2014$ & $8 / 4 / 2014$ & 001942729GBF & 2 \\
\hline C & 10496053 & Yes & Sludge Repackage Project PCB Contaminated Debris & 947 & 637 & $4 / 18 / 2013$ & $8 / 3 / 2014$ & $8 / 4 / 2014$ & 001942729GBF & 2 \\
\hline C & 10496054 & Yes & Sludge Repackage Project PCB Contaminated Debris & 970 & 658 & $5 / 15 / 2013$ & $8 / 3 / 2014$ & $8 / 4 / 2014$ & 001942729GBF & 2 \\
\hline C & 10496141 & Yes & Organic Setups, Oil Solids & 141 & 82 & $6 / 1 / 1968$ & $1 / 25 / 2014$ & $2 / 1 / 2014$ & 001600959GBF & 2,5 \\
\hline C & 10496142 & Yes & Organic Setups, Oil Solids & 117 & 58 & $6 / 1 / 1968$ & $1 / 14 / 2014$ & $1 / 24 / 2014$ & $001600941 \mathrm{GBF}$ & 2,5 \\
\hline C & 10496143 & Yes & Organic Setups, Oil Solids & 119 & 60 & $6 / 1 / 1968$ & $1 / 14 / 2014$ & $1 / 24 / 2014$ & $001600941 \mathrm{GBF}$ & 2,5 \\
\hline C & 10496144 & Yes & Organic Setups, Oil Solids & 149 & 90 & $6 / 1 / 1968$ & $1 / 16 / 2014$ & $1 / 24 / 2014$ & $001600944 G B F$ & 2,5 \\
\hline C & 10496145 & Yes & Organic Setups, Oil Solids & 140 & 81 & $6 / 1 / 1968$ & $1 / 17 / 2014$ & $1 / 26 / 2014$ & $001600946 \mathrm{GBF}$ & 2,5 \\
\hline C & 10496148 & Yes & Organic Setups, Oil Solids & 135 & 76 & $6 / 1 / 1968$ & $1 / 16 / 2014$ & $1 / 24 / 2014$ & 001600944GBF & 2,5 \\
\hline C & 10496149 & Yes & Organic Setups, Oil Solids & 123 & 64 & $6 / 1 / 1968$ & $1 / 4 / 2014$ & $1 / 8 / 2014$ & $001600933 \mathrm{GBF}$ & 2,5 \\
\hline C & 10496150 & Yes & Organic Setups, Oil Solids & 132 & 73 & $6 / 1 / 1968$ & $1 / 7 / 2014$ & $1 / 12 / 2014$ & $001600937 \mathrm{GBF}$ & 2,5 \\
\hline C & 10496151 & Yes & Organic Setups, Oil Solids & 133 & 74 & $6 / 1 / 1968$ & $1 / 16 / 2014$ & $1 / 24 / 2014$ & 001600944GBF & 2,5 \\
\hline C & 10496153 & Yes & Organic Setups, Oil Solids & 163 & 104 & $6 / 1 / 1968$ & $1 / 24 / 2014$ & $1 / 28 / 2014$ & 001600956GBF & 2,5 \\
\hline C & 10496157 & Yes & Organic Setups, Oil Solids & 134 & 75 & $6 / 1 / 1968$ & $1 / 23 / 2014$ & $1 / 26 / 2014$ & $001600951 \mathrm{GBF}$ & 2,5 \\
\hline C & 10496158 & Yes & Organic Setups, Oil Solids & 110 & 51 & $6 / 1 / 1968$ & $1 / 23 / 2014$ & $1 / 26 / 2014$ & $001600951 \mathrm{GBF}$ & 2,5 \\
\hline c & 10496160 & Yes & Organic Setups, Oil Solids & 113 & 54 & $6 / 1 / 1968$ & $1 / 4 / 2014$ & $1 / 8 / 2014$ & $001600933 \mathrm{GBF}$ & 2,5 \\
\hline C & 10496162 & Yes & Organic Setups, Oil Solids & 141 & 82 & $6 / 1 / 1968$ & $1 / 7 / 2014$ & $1 / 12 / 2014$ & $001600937 \mathrm{GBF}$ & 2,5 \\
\hline C & 10496163 & Yes & Organic Setups, Oil Solids & 138 & 79 & $6 / 1 / 1968$ & $1 / 7 / 2014$ & $1 / 12 / 2014$ & $001600937 \mathrm{GBF}$ & 2,5 \\
\hline C & 10496164 & Yes & Organic Setups, Oil Solids & 113 & 54 & $6 / 1 / 1968$ & $1 / 25 / 2014$ & $2 / 1 / 2014$ & 001600959GBF & 2,5 \\
\hline C & 10496165 & Yes & Organic Setups, Oil Solids & 129 & 70 & 6/1/1968 & $1 / 24 / 2014$ & $1 / 28 / 2014$ & 001600956GBF & 2,5 \\
\hline C & 10496168 & Yes & Organic Setups, Oil Solids & 122 & 63 & $6 / 1 / 1968$ & $2 / 1 / 2014$ & & 001600969GBF & 2,5 \\
\hline c & 10496169 & Yes & Organic Setups, Oil Solids & 141 & 82 & $6 / 1 / 1968$ & $1 / 24 / 2014$ & $1 / 28 / 2014$ & $001600957 \mathrm{GBF}$ & 2,5 \\
\hline C & 10496171 & Yes & Organic Setups, Oil Solids & 119 & 60 & $6 / 1 / 1968$ & $1 / 25 / 2014$ & $2 / 1 / 2014$ & 001600959GBF & 2,5 \\
\hline C & 10496174 & Yes & Organic Setups, Oil Solids & 142 & 83 & $6 / 1 / 1968$ & $1 / 7 / 2014$ & $1 / 12 / 2014$ & $001600937 \mathrm{GBF}$ & 2,5 \\
\hline c & 10496176 & Yes & Organic Setups, Oil Solids & 127 & 68 & $6 / 1 / 1968$ & $1 / 16 / 2014$ & $1 / 24 / 2014$ & $001600944 G B F$ & 2,5 \\
\hline C & 10496177 & Yes & Organic Setups, Oil Solids & 134 & 75 & $6 / 1 / 1968$ & $1 / 24 / 2014$ & $1 / 28 / 2014$ & $001600957 \mathrm{GBF}$ & 2,5 \\
\hline C & 10496180 & Yes & Organic Setups, Oil Solids & 141 & 82 & $6 / 1 / 1968$ & $1 / 24 / 2014$ & $1 / 28 / 2014$ & 001600957GBF & 2,5 \\
\hline$C$ & 10496184 & Yes & Organic Setups, Oil Solids & 103 & 44 & $6 / 1 / 1968$ & $1 / 16 / 2014$ & $1 / 24 / 2014$ & 001600944GBF & 2,5 \\
\hline C & 10496185 & Yes & Organic Setups, Oil Solids & 126 & 67 & $6 / 1 / 1968$ & $1 / 7 / 2014$ & $1 / 12 / 2014$ & $001600937 \mathrm{GBF}$ & 2,5 \\
\hline C & 10496186 & Yes & Organic Setups, Oil Solids & 124 & 65 & $6 / 1 / 1968$ & $1 / 16 / 2014$ & $1 / 24 / 2014$ & 001600944GBF & 2,5 \\
\hline c & 10496187 & Yes & Organic Setups, Oil Solids & 111 & 52 & $6 / 1 / 1968$ & $1 / 24 / 2014$ & $1 / 28 / 2014$ & 001600956GBF & 2,5 \\
\hline C & 10496188 & Yes & Organic Setups, Oil Solids & 123 & 64 & $6 / 1 / 1968$ & $1 / 7 / 2014$ & $1 / 12 / 2014$ & $001600937 \mathrm{GBF}$ & 2,5 \\
\hline c & 10496190 & Yes & Organic Setups, Oil Solids & 110 & 51 & $6 / 1 / 1968$ & $1 / 24 / 2014$ & $1 / 28 / 2014$ & 001600957GBF & 2,5 \\
\hline 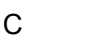 & 10496194 & Yes & Organic Setups, Oil Solids & 127 & 68 & $6 / 1 / 1968$ & $2 / 1 / 2014$ & & 001600969GBF & 2,5 \\
\hline
\end{tabular}

*A=Article; $C=$ Container; $A C=$ Article Container, $B W=B u l k$ Waste, $E=E q u i p m e n t$ 
Idaho National Laboratory

Advanced Mixed Waste Treatment Project (AMWTP)

PCB Waste Document Log

Removed from Service, Shipped and/or Disposed During Calendar Year 2014

Date of

Gross Net Removal

Radioactive

Type* Identification \#

$(\mathbf{Y} / \mathbf{N})$

Weight Weight from Transport Disposal Manifest

\begin{tabular}{lll}
10496272 & Yes & Sludge Repackage Project \\
10496273 & Yes & Sludge Repackage Project \\
10496274 & Yes & Sludge Repackage Project \\
10496275 & Yes & Sludge Repackage Project \\
10496276 & Yes & Sludge Repackage Project \\
10496277 & Yes & Sludge Repackage Project \\
10496278 & Yes & Sludge Repackage Project \\
10496279 & Yes & Sludge Repackage Project \\
10496280 & Yes & Sludge Repackage Project \\
10496281 & Yes & Sludge Repackage Project \\
10496282 & Yes & Sludge Repackage Project \\
10496283 & Yes & Sludge Repackage Project \\
10496285 & Yes & Organic Setups, Oil Solids \\
10496286 & Yes & Organic Setups, Oil Solids \\
10496287 & Yes & Organic Setups, Oil Solids \\
10496289 & Yes & Organic Setups, Oil Solids \\
10496290 & Yes & Organic Setups, Oil Solids \\
10496294 & Yes & Organic Setups, Oil Solids \\
10496295 & Yes & Organic Setups, Oil Solids \\
10496298 & Yes & Organic Setups, Oil Solids \\
10496299 & Yes & Organic Setups, Oil Solids \\
10496300 & Yes & Organic Setups, Oil Solids \\
10496301 & Yes & Organic Setups, Oil Solids \\
10496302 & Yes & Organic Setups, Oil Solids \\
10496303 & Yes & Organic Setups, Oil Solids \\
10496304 & Yes & Organic Setups, Oil Solids \\
10496305 & Yes & Organic Setups, Oil Solids \\
10496306 & Yes & Organic Setups, Oil Solids \\
10496307 & Yes & Organic Setups, Oil Solids \\
10496308 & Yes & Organic Setups, Oil Solids \\
10496309 & Yes & Organic Setups, Oil Solids \\
10496310 & Yes & Organic Setups, Oil Solids \\
10496314 & Yes & Organic Setups, Oil Solids \\
10496315 & Yes & Organic Setups, Oil Solids \\
10496316 & Yes & Organic Setups, Oil Solids \\
10496318 & Yes & Organic Setups, Oil Solids \\
10496322 & Yes & Organic Setups, Oil Solids \\
10496323 & & Organic Setups, Oil Solids \\
& & \\
\hline
\end{tabular}

(KGS) (KGS) Service

Date

Date Number Notes

$\begin{array}{lllllll}996 & 685 & 3 / 28 / 2013 & 7 / 20 / 2014 & 7 / 21 / 2014 & 001942723 G B F & 2\end{array}$

$\begin{array}{lllllll}932 & 621 & 3 / 19 / 2013 & 7 / 20 / 2014 & 7 / 21 / 2014 & 001942723 G B F & 2\end{array}$

$\begin{array}{lllllll}957 & 647 & 4 / 3 / 2013 & 7 / 20 / 2014 & 7 / 21 / 2014 & 001942723 G B F & 2\end{array}$

$\begin{array}{lllllll}910 & 604 & 5 / 30 / 2013 & 7 / 20 / 2014 & 7 / 21 / 2014 & 001942723 G B F & 2\end{array}$

$\begin{array}{lllllll}997 & 691 & 6 / 7 / 2013 & 7 / 20 / 2014 & 7 / 21 / 2014 & 001942724 G B F & 2\end{array}$

$\begin{array}{lllllll}1008 & 702 & 5 / 28 / 2013 & 7 / 20 / 2014 & 7 / 21 / 2014 & 001942724 G B F & 2\end{array}$

$\begin{array}{lllllll}917 & 605 & 5 / 7 / 2013 & 7 / 20 / 2014 & 7 / 21 / 2014 & 001942724 G B F & 2\end{array}$

$\begin{array}{lllllll} & 612 & 5 / 7 / 2013 & 7 / 20 / 2014 & 7 / 21 / 2014 & 001942724 G B F & 2\end{array}$

$866 \quad 560 \quad 6 / 7 / 2013 \quad 7 / 20 / 2014 \quad 7 / 21 / 2014 \quad 001942724$ GBF 2

$\begin{array}{lllllll}1048 & 742 & 6 / 7 / 2013 & 7 / 20 / 2014 & 7 / 21 / 2014 & 001942724 G B F & 2\end{array}$

$\begin{array}{lllllll}1038 & 732 & 5 / 22 / 2013 & 7 / 20 / 2014 & 7 / 21 / 2014 & 001942724 G B F & 2\end{array}$

$\begin{array}{lllllll}972 & 662 & 4 / 2 / 2013 & 7 / 20 / 2014 & 7 / 21 / 2014 & 001942724 G B F & 2\end{array}$

$\begin{array}{llllll}117 & 58 & 6 / 1 / 1968 & 1 / 20 / 2014 & 2 / 2 / 2014 & 001600950 G B F \\ 121,5\end{array}$

$121 \quad 62 \quad 6 / 1 / 1968 \quad 1 / 17 / 2014 \quad 1 / 26 / 2014 \quad 001600946 G B F \quad 2,5$

$117 \quad 58 \quad 6 / 1 / 1968 \quad 1 / 24 / 2014 \quad 2 / 1 / 2014 \quad 001600957$ GBF 2,5

$\begin{array}{llllll}113 & 54 & 6 / 1 / 1968 & 1 / 17 / 2014 & 1 / 26 / 2014 & 001600946 G B F \\ 2,5\end{array}$

$\begin{array}{lllllll}123 & 64 & 6 / 1 / 1968 & 1 / 20 / 2014 & 2 / 2 / 2014 & 001600950 G B F & 2,5 \\ 119 & 60 & 6 / 1 / 1968 & 1 / 18 / 2014 & 1 / 24 / 2014 & 001600947 G B F & 2,5\end{array}$

$\begin{array}{llllll}15 & 56 & 6 / 1 / 1968 & 1 / 14 / 2014 & 1 / 24 / 2014 & 001600941 G B F \\ 2,5\end{array}$

$1354 \quad 6 / 1 / 1968 \quad 1 / 24 / 2014 \quad 1 / 28 / 2014 \quad 001600957$ GBF 2, 5

$135 \quad 76 \quad 6 / 1 / 1968 \quad 1 / 14 / 2014 \quad 1 / 21 / 2014 \quad 001600941 \mathrm{GBF} \quad 2,5$

$1455 \quad 6 / 1 / 1968 \quad 1 / 20 / 2014 \quad 2 / 2 / 2014 \quad 001600950$ GBF 2,5

$\begin{array}{lllllll}114 & 55 & 6 / 1 / 1968 & 1 / 20 / 2014 & 2 / 2 / 2014 & 001600950 G B F & 2,5 \\ 116 & 57 & 6 / 1 / 1968 & 1 / 20 / 2014 & 2 / 2 / 2014 & 001600950 G B F & 2,5\end{array}$

$\begin{array}{lllllll}05 & 46 & 6 / 1 / 1968 & 1 / 17 / 2014 & 1 / 26 / 2014 & 001600946 G B F & 2,5\end{array}$

$\begin{array}{llllll}736 & 6 / 1 / 1968 & 1 / 14 / 2014 & 1 / 21 / 2014 & 001600941 G B F \quad 2,5\end{array}$

$141 \quad 82 \quad 6 / 1 / 1968 \quad 1 / 20 / 2014 \quad 2 / 2 / 2014 \quad 001600950$ GBF 2,5

$12465 \quad 6 / 1 / 1968 \quad 1 / 14 / 2014 \quad 1 / 21 / 2014 \quad 001600941$ GBF 2,5

$138 \quad 79 \quad 6 / 1 / 1968 \quad 1 / 20 / 2014 \quad 2 / 2 / 2014 \quad 001600950$ GBF 2,5

$11152 \quad 6 / 1 / 1968 \quad 1 / 14 / 2014 \quad 1 / 24 / 2014$ 001600941GBF 2, 5

$120 \quad 61 \quad 6 / 1 / 1968 \quad 1 / 16 / 2014 \quad 1 / 21 / 2014 \quad 001600943$ GBF 2,5

$129 \quad 70 \quad 6 / 1 / 1968 \quad 1 / 23 / 2014 \quad 1 / 26 / 2014$ 001600951GBF 2,5

$\begin{array}{lllll}27 & 68 & 6 / 1 / 1968 & 2 / 1 / 2014 & 001600969 G B F\end{array}$

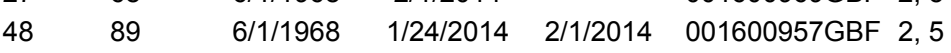

$\begin{array}{lllllll}138 & 79 & 6 / 1 / 1968 & 1 / 14 / 2014 & 1 / 24 / 2014 & 001600941 G B F & 2,5\end{array}$

$104 \quad 45 \quad 6 / 1 / 1968 \quad 1 / 18 / 2014 \quad 1 / 24 / 2014 \quad 001600947 G B F \quad 2,5$

$\begin{array}{lllllll}138 & 45 & 6 / 1 / 1968 & 1 / 23 / 2014 & 1 / 26 / 2014 & 001600951 G B F & 2,5\end{array}$

$15 \quad 56 \quad 6 / 1 / 1968 \quad 1 / 24 / 2014 \quad 1 / 28 / 2014 \quad 001600956$ GBF 2,5

$120 \quad 61 \quad 6 / 1 / 1968 \quad 1 / 24 / 2014 \quad 1 / 28 / 2014 \quad 001600957$ GBF 2,5

*A=Article; $C=$ Container; $A C=$ Article Container, $B W=B$ Bulk Waste, $E=$ Equipment 
Idaho National Laboratory

Advanced Mixed Waste Treatment Project (AMWTP)

PCB Waste Document Log

Removed from Service, Shipped and/or Disposed During Calendar Year 2014

Date of

Gross Net Removal

Radioactive

Type* Identification \# (Y/N)

Weight Weight from Transport Disposal Manifest

(KGS) (KGS) Service Date Date Number Notes

$10496324 \quad$ Yes $\quad$ Organic Setups, Oil Solids

$\begin{array}{lllllll}100 & 41 & 6 / 1 / 1968 & 1 / 23 / 2014 & 1 / 26 / 2014 & 001600951 G B F & 2,5\end{array}$

$10496327 \quad$ Yes Organic Setups, Oil Solids

$160 \quad 101 \quad 6 / 1 / 1968 \quad 1 / 24 / 2014 \quad 2 / 1 / 2014 \quad 001600957$ GBF 2,5

10496329 Yes Organic Setups, Oil Solids

$10496330 \quad$ Yes Organic Setups, Oil Solids

$10496331 \quad$ Yes Organic Setups, Oil Solids

$10496332 \quad$ Yes Organic Setups, Oil Solids

10496333 Yes Organic Setups, Oil Solids

$10496334 \quad$ Yes Organic Setups, Oil Solids

$10496335 \quad$ Yes Organic Setups, Oil Solids

$10496336 \quad$ Yes Organic Setups, Oil Solids

10496337 Yes Organic Setups, Oil Solids

$10496338 \quad$ Yes Organic Setups, Oil Solids

$10496339 \quad$ Yes Organic Setups, Oil Solids

10496342 Yes Organic Setups, Oil Solids

$10496343 \quad$ Yes Organic Setups, Oil Solids

$10496392 \quad$ Yes Organic Setups, Oil Solids

$10496394 \quad$ Yes Organic Setups, Oil Solids

$10496395 \quad$ Yes Organic Setups, Oil Solids

10496397 Yes Organic Setups, Oil Solids

$10496398 \quad$ Yes Organic Setups, Oil Solids

$10496399 \quad$ Yes Organic Setups, Oil Solids

$10496400 \quad$ Yes Organic Setups, Oil Solids

$10496401 \quad$ Yes Organic Setups, Oil Solids

$10496404 \quad$ Yes Organic Setups, Oil Solids

$10496405 \quad$ Yes Organic Setups, Oil Solids

$10496406 \quad$ Yes Organic Setups, Oil Solids

$10496411 \quad$ Yes Organic Setups, Oil Solids

$10496412 \quad$ Yes Organic Setups, Oil Solids

$10496413 \quad$ Yes Organic Setups, Oil Solids

$10496414 \quad$ Yes Organic Setups, Oil Solids

$10496415 \quad$ Yes Organic Setups, Oil Solids

10496416 Yes Organic Setups, Oil Solids

$10496417 \quad$ Yes Organic Setups, Oil Solids

$10496419 \quad$ Yes Organic Setups, Oil Solids

$10496422 \quad$ Yes Organic Setups, Oil Solids

$10496424 \quad$ Yes Organic Setups, Oil Solids

10496425

Yes Organic Setups, Oil Solids

$132 \quad 73 \quad 6 / 1 / 1968 \quad 1 / 24 / 2014 \quad 1 / 28 / 2014 \quad 001600956 G B F \quad 2,5$

$130 \quad 71 \quad 6 / 1 / 1968 \quad 1 / 14 / 2014 \quad 1 / 21 / 2014 \quad 001600941$ GBF 2, 5

$107 \quad 48 \quad 6 / 1 / 1968 \quad 1 / 20 / 2014 \quad 2 / 2 / 2014 \quad 001600950$ GBF 2,5

$10546 \quad 6 / 1 / 1968 \quad 1 / 20 / 2014 \quad 2 / 2 / 2014 \quad 001600950 G B F 2,5$

$96 \quad 37 \quad 6 / 1 / 1968 \quad 1 / 17 / 2014 \quad 1 / 26 / 2014 \quad 001600946$ GBF 2, 5

$\begin{array}{lllllll}104 & 45 & 6 / 1 / 1968 & 1 / 20 / 2014 & 2 / 2 / 2014 & 001600950 G B F & 2,5\end{array}$

$130 \quad 71 \quad 6 / 1 / 1968 \quad 1 / 23 / 2014 \quad 1 / 26 / 2014 \quad 001600951 G B F \quad 2,5$

$12364 \quad 6 / 1 / 1968 \quad 1 / 14 / 2014 \quad 1 / 17 / 2014 \quad 001600940$ GBF 2,5

$10950 \quad 6 / 1 / 1968 \quad 1 / 24 / 2014 \quad 1 / 28 / 2014 \quad 001600957 G B F \quad 2,5$

$117 \quad 58 \quad 6 / 1 / 1968 \quad 1 / 24 / 2014 \quad 1 / 28 / 2014 \quad 001600956$ GBF 2, 5

$144 \quad 85 \quad 6 / 1 / 1968 \quad 1 / 16 / 2014 \quad 1 / 24 / 2014 \quad 001600944$ GBF 2, 5

$134 \quad 75 \quad 6 / 1 / 1968 \quad 1 / 14 / 2014 \quad 1 / 17 / 2014 \quad 001600940$ GBF 2,5

$159 \quad 100 \quad 6 / 1 / 1968 \quad 1 / 14 / 2014 \quad 1 / 24 / 2014 \quad 001600941$ GBF 2,5

$122 \quad 63 \quad 6 / 1 / 1968 \quad 1 / 14 / 2014 \quad 1 / 19 / 2014 \quad 001600940 G B F \quad 2,5$

$147 \quad 88 \quad 6 / 1 / 1968 \quad 1 / 18 / 2014 \quad 1 / 24 / 2014 \quad 001600947$ GBF 2,5

$\begin{array}{lllllll}147 & 88 & 6 / 1 / 1968 & 1 / 18 / 2014 & 1 / 24 / 2014 & 001600947 G B F & 2,5 \\ 131 & 72 & 6 / 1 / 1968 & 1 / 16 / 2014 & 1 / 24 / 2014 & 001600944 G B F & 2,5\end{array}$

$12768 \quad 6 / 1 / 1968 \quad 2 / 1 / 2014 \quad$ 001600969GBF 2,5

$125 \quad 66 \quad 6 / 1 / 1968 \quad 1 / 18 / 2014 \quad 1 / 24 / 2014 \quad 001600947 \mathrm{GBF} 2,5$

$\begin{array}{lllllll}125 & 66 & 6 / 1 / 1968 & 1 / 18 / 2014 & 1 / 24 / 2014 & 001600947 G B F & 2,5 \\ 18 & 6 / 1 / 1968 & 1 / 18 / 2014 & 1 / 24 / 2014 & 001600947 G B F & 2,5\end{array}$

$11859 \quad 6 / 1 / 1968 \quad 1 / 4 / 2014 \quad 1 / 8 / 2014 \quad 001600933 G B F 2,5$

$94 \quad 35 \quad 6 / 1 / 1968 \quad 1 / 16 / 2014 \quad 1 / 24 / 2014 \quad 001600944 G B F \quad 2,5$

$\begin{array}{lllllll}46 & 87 & 6 / 1 / 1968 & 1 / 4 / 2014 & 1 / 8 / 2014 & 001600933 G B F & 2,5\end{array}$

$11152 \quad 6 / 1 / 1968 \quad 1 / 14 / 2014 \quad 1 / 21 / 2014 \quad 001600941$ GBF 2,5

$11253 \quad 6 / 1 / 1968 \quad 1 / 16 / 2014 \quad 1 / 24 / 2014 \quad 001600944$ GBF 2,5

$10647 \quad 6 / 1 / 1968 \quad 1 / 18 / 2014 \quad 1 / 24 / 2014 \quad 001600947$ GBF 2,5

$11253 \quad 6 / 1 / 1968 \quad 1 / 18 / 2014 \quad 1 / 24 / 2014$ 001600947GBF 2, 5

$94 \quad 35 \quad 6 / 1 / 1968 \quad 2 / 1 / 2014 \quad 001600969 G B F \quad 2,5$

6/1/1968 1/23/2014 1/26/2014 001600951 GBF 2,5

$145 \quad 86 \quad 6 / 1 / 1968 \quad 1 / 16 / 2014 \quad 1 / 21 / 2014 \quad 001600943 G B F \quad 2,5$

$135 \quad 76 \quad 6 / 1 / 1968 \quad 1 / 16 / 2014 \quad 1 / 21 / 2014 \quad 001600943 G B F 2,5$

$12061 \quad 6 / 1 / 1968 \quad 1 / 14 / 2014 \quad 1 / 21 / 2014 \quad 001600941$ GBF 2,5

$120 \quad 61 \quad 6 / 1 / 1968 \quad 1 / 14 / 2014 \quad 1 / 21 / 2014 \quad 001600941 G B F \quad 2,5$

$\begin{array}{llllll}101 & 42 & 6 / 1 / 1968 & 1 / 16 / 2014 & 1 / 21 / 2014 & 001600943 G B F \\ 2,5\end{array}$

$\begin{array}{ccccccc}101 & 42 & 6 / 1 / 1968 & 1 / 16 / 2014 & 1 / 21 / 2014 & 001600943 G B F & 2,5 \\ 98 & 39 & 6 / 1 / 1968 & 1 / 17 / 2014 & 1 / 26 / 2014 & 001600946 G B F & 2,5\end{array}$

$14990 \quad 6 / 1 / 1968 \quad 1 / 14 / 2014 \quad 1 / 21 / 2014 \quad 001600941 \mathrm{GBF} 2,5$

$120 \quad 61 \quad 6 / 1 / 1968 \quad 1 / 4 / 2014 \quad 1 / 17 / 2014 \quad 001600933$ GBF 2,5

* $A=$ Article; $C=$ Container AC=Article Container, $B W=B u l k$ Waste, $E=$ Equipment 
Idaho National Laboratory

Advanced Mixed Waste Treatment Project (AMWTP)

PCB Waste Document Log

Removed from Service, Shipped and/or Disposed During Calendar Year 2014

Date of

Gross Net Removal

Radioactive

\begin{tabular}{ll} 
Type* Identification \# & (Y/N) \\
\hline
\end{tabular}

Weight Weight from Transport Disposal Manifest

(KGS) (KGS) Service Date Date Number Notes

0496426

Yes

Description

$6 / 1 / 1968$

1/25/2014 1/28/2014 001600959GBF 2,5

$135 \quad 76 \quad 6 / 1 / 1968 \quad 1 / 4 / 2014 \quad 1 / 8 / 2014 \quad 001600933$ GBF 2,5

$10496428 \quad$ Yes Organic Setups, Oil Solids

$116 \quad 57$

Organic Setups, Oil Solids

$10496430 \quad$ Yes Organic Setups, Oil Solids

$10496431 \quad$ Yes Organic Setups, Oil Solids

$10496432 \quad$ Yes Organic Setups, Oil Solids

10496436

Organic Setups, Oil Solids
Organic Setups, Oil Solids

10496437

10496438

10496439

Organic Setups, Oil Solids

Organic Setups, Oil Solids

Organic Setups, Oil Solids

10496445

10496455

10496457

10496899

10496900

Organic Setups, Oil Solids

Organic Setups, Oil Solids

Organic Setups, Oil Solids

Sludge Repackage Project PCB Contaminated Debris Sludge Repackage Project PCB Contaminated Debris Sludge Repackage Project PCB Contaminated Debris Sludge Repackage Project PCB Contaminated Debris Sludge Repackage Project PCB Contaminated Debris

10496902

10496903 Sludge Repackage Project PCB Contaminated Debris Sludge Repackage Project PCB Contaminated Debris

10496905

10496906

10496907

10496908

Sludge Repackage Project PCB Contaminated Debris Sludge Repackage Project PCB Contaminated Debris Sludge Repackage Project PCB Contaminated Debris Sludge Repackage Project PCB Contaminated Debris Sludge Repackage Project PCB Contaminated Debris Sludge Repackage Project PCB Contaminated Debris

10496910 Sludge Repackage Project PCB Contaminated Debris Sludge Repackage Project PCB Contaminated Debris Sludge Repackage Project PCB Contaminated Debris Sludge Repackage Project PCB Contaminated Debris Sludge Repackage Project PCB Contaminated Debris Sludge Repackage Project PCB Contaminated Debris Sludge Repackage Project PCB Contaminated Debris Sludge Repackage Project PCB Contaminated Debris Sludge Repackage Project PCB Contaminated Debris Sludge Repackage Project PCB Contaminated Debris Sludge Repackage Project PCB Contaminated Debris 
Idaho National Laboratory

Advanced Mixed Waste Treatment Project (AMWTP)

PCB Waste Document Log

Removed from Service, Shipped and/or Disposed During Calendar Year 2014

Date of

Gross Net Removal

Radioactive

Type* Identification \#

adioactive

Weight Weight from

Yes Sludge Repackage Project PCB Contaminated Debris

10499085 Yes Sludge Repackage Project PCB Contaminated Debris

10499086

Sludge Repackage Project PCB Contaminated Debris

(KGS) (KGS) Service

Date Disposal Manifest Date Date Number Notes

$\begin{array}{lllllll}1120 & 808 & 5 / 9 / 2013 & 7 / 27 / 2014 & 7 / 28 / 2014 & 001942726 G B F & 2\end{array}$

$\begin{array}{lllllll}1046 & 737 & 7 / 1 / 2013 & 7 / 27 / 2014 & 7 / 28 / 2014 & 001942726 G B F & 2\end{array}$

10499087 Yes Sludge Repackage Project PCB Contaminated Debris

$10499088 \quad$ Yes Sludge Repackage Project PCB Contaminated Debris

10499089

Sludge Repackage Project PCB Contaminated Debris

10499090

10499091

Sludge Repackage Project PCB Contaminated Debris

10499092

Sludge Repackage Project PCB Contaminated Debris

10499093

10499094

Sludge Repackage Project PCB Contaminated Debris

10499958

10499959

10499960

10499961

10499962

10499963

10499964

10499965

10499966

10499967

10500844

10500845

10500846

10500847

10500848

10500849

10500850

10500851

10500852

10500853

10500854

10501555

10501556

10501557

10501558

10501559

Sludge Repackage Project PCB Contaminated Debris

Sludge Repackage Project PCB Contaminated Debris

Sludge Repackage Project PCB Contaminated Debris

Sludge Repackage Project PCB Contaminated Debris

Sludge Repackage Project PCB Contaminated Debris

Sludge Repackage Project PCB Contaminated Debris

Sludge Repackage Project PCB Contaminated Debris

Sludge Repackage Project PCB Contaminated Debris

Sludge Repackage Project PCB Contaminated Debris

Sludge Repackage Project PCB Contaminated Debris

Sludge Repackage Project PCB Contaminated Debris

Sludge Repackage Project PCB Contaminated Debris

Sludge Repackage Project PCB Contaminated Debris

Sludge Repackage Project PCB Contaminated Debris

Sludge Repackage Project PCB Contaminated Debris

Sludge Repackage Project PCB Contaminated Debris

Sludge Repackage Project PCB Contaminated Debris

Sludge Repackage Project PCB Contaminated Debris

Sludge Repackage Project PCB Contaminated Debris

Sludge Repackage Project PCB Contaminated Debris

Sludge Repackage Project PCB Contaminated Debris

Sludge Repackage Project PCB Contaminated Debris

Sludge Repackage Project PCB Contaminated Debris

Sludge Repackage Project PCB Contaminated Debris

Sludge Repackage Project PCB Contaminated Debris

Sludge Repackage Project PCB Contaminated Debris

Sludge Repackage Project PCB Contaminated Debris

Sludge Repackage Project PCB Contaminated Debris

10501560

Sludge Repackage Project PCB Contaminated Debris

$\begin{array}{llllllll}1073 & 767 & 6 / 3 / 2013 & 7 / 27 / 2014 & 7 / 28 / 2014 & 001942726 G B F & 2\end{array}$

$\begin{array}{lllllll}1015 & 709 & 6 / 7 / 2013 & 7 / 27 / 2014 & 7 / 28 / 2014 & 001942725 G B F & 2\end{array}$

$\begin{array}{lllllll} & 743 & 6 / 3 / 2013 & 7 / 27 / 2014 & 7 / 28 / 2014 & 001942725 G B F & 2\end{array}$

$\begin{array}{lllllll}1002 & 691 & 7 / 9 / 2013 & 7 / 27 / 2014 & 7 / 28 / 2014 & 001942725 G B F & 2\end{array}$

$\begin{array}{lllllll} & 1038 & 6 / 5 / 2013 & 7 / 27 / 2014 & 7 / 28 / 2014 & 001942725 G B F & 2\end{array}$

$\begin{array}{lllllll}931 & 621 & 4 / 15 / 2013 & 7 / 27 / 2014 & 7 / 28 / 2014 & 001942725 G B F & 2\end{array}$

$\begin{array}{lllllll}1087 & 776 & 7 / 11 / 2013 & 7 / 27 / 2014 & 7 / 28 / 2014 & 001942725 G B F & 2\end{array}$

$\begin{array}{lllllll}991 & 685 & 6 / 6 / 2013 & 7 / 27 / 2014 & 7 / 28 / 2014 & 001942726 G B F & 2\end{array}$

$\begin{array}{lllllll}915 & 604 & 7 / 9 / 2013 & 7 / 27 / 2014 & 7 / 28 / 2014 & 001942726 G B F & 2\end{array}$

$\begin{array}{lllllll}1071 & 764 & 6 / 20 / 2013 & 7 / 13 / 2014 & 7 / 14 / 2014 & 001942722 G B F & 2\end{array}$

$\begin{array}{lllllll}993 & 684 & 7 / 11 / 2013 & 7 / 13 / 2014 & 7 / 14 / 2014 & 001942722 \mathrm{GBF} & 2\end{array}$

$\begin{array}{lllllll}972 & 664 & 6 / 20 / 2013 & 7 / 13 / 2014 & 7 / 14 / 2014 & 001942722 G B F & 2\end{array}$

$\begin{array}{lllllll}1012 & 701 & 7 / 10 / 2013 & 7 / 27 / 2014 & 7 / 28 / 2014 & 001942725 G B F & 2\end{array}$

$\begin{array}{lllllll}981 & 670 & 7 / 15 / 2013 & 7 / 27 / 2014 & 7 / 28 / 2014 & 001942725 G B F & 2\end{array}$

$\begin{array}{lllllll}920 & 611 & 7 / 1 / 2013 & 7 / 27 / 2014 & 7 / 28 / 2014 & 001942725 G B F & 2\end{array}$

$\begin{array}{lllllll}939 & 631 & 7 / 16 / 2013 & 7 / 27 / 2014 & 7 / 28 / 2014 & 001942725 G B F & 2\end{array}$

$1087 \quad 781 \quad 6 / 14 / 2013 \quad 7 / 27 / 2014 \quad 7 / 28 / 2014 \quad 001942725 G B F$

$\begin{array}{lllllll}1060 & 749 & 7 / 10 / 2013 & 7 / 27 / 2014 & 7 / 28 / 2014 & 001942725 G B F & 2\end{array}$

$\begin{array}{lllllll}993 & 682 & 7 / 15 / 2013 & 7 / 13 / 2014 & 7 / 14 / 2014 & 001942722 \mathrm{GBF} & 2\end{array}$

$\begin{array}{lllllll}1061 & 750 & 7 / 12 / 2013 & 8 / 24 / 2014 & 8 / 25 / 2014 & 001942742 G B F & 2\end{array}$

$\begin{array}{lllllll}964 & 653 & 7 / 25 / 2013 & 8 / 24 / 2014 & 8 / 25 / 2014 & 001942742 G B F & 2\end{array}$

$\begin{array}{lllllll}1022 & 713 & 7 / 22 / 2013 & 7 / 20 / 2014 & 7 / 21 / 2014 & 001942724 G B F & 2\end{array}$

$\begin{array}{lllllll}1029 & 718 & 7 / 25 / 2013 & 7 / 20 / 2014 & 7 / 21 / 2014 & 001942724 G B F & 2\end{array}$

$\begin{array}{lllllll}944 & 633 & 7 / 23 / 2013 & 7 / 27 / 2014 & 7 / 28 / 2014 & 001942725 G B F & 2\end{array}$

$\begin{array}{lllllll}982 & 671 & 7 / 11 / 2013 & 7 / 27 / 2014 & 7 / 28 / 2014 & 001942725 G B F & 2\end{array}$

$\begin{array}{lllllll}977 & 669 & 7 / 22 / 2013 & 7 / 13 / 2014 & 7 / 14 / 2014 & 001942722 \mathrm{GBF} & 2\end{array}$

$\begin{array}{lllllll}979 & 668 & 7 / 18 / 2013 & 7 / 13 / 2014 & 7 / 14 / 2014 & 001942722 G B F & 2\end{array}$

$\begin{array}{lllllll}996 & 685 & 7 / 16 / 2013 & 7 / 13 / 2014 & 7 / 14 / 2014 & 001942722 \mathrm{GBF} & 2\end{array}$

$\begin{array}{lllllll}992 & 681 & 7 / 26 / 2013 & 7 / 13 / 2014 & 7 / 14 / 2014 & 001942722 \mathrm{GBF} & 2\end{array}$

$\begin{array}{lllllll}1040 & 732 & 7 / 12 / 2013 & 7 / 13 / 2014 & 7 / 14 / 2014 & 001942722 G B F & 2\end{array}$

$\begin{array}{lllllll} & 7079 & 7 / 29 / 2013 & 8 / 24 / 2014 & 8 / 25 / 2014 & 001942742 G B F & 2\end{array}$

$\begin{array}{lllllll}989 & 677 & 6 / 19 / 2013 & 8 / 24 / 2014 & 8 / 25 / 2014 & 001942743 G B F & 2\end{array}$

$\begin{array}{lllllll} & 1025 & 713 & 7 / 31 / 2013 & 9 / 7 / 2014 & 9 / 8 / 2014 & 001942748 G B F\end{array}$

$\begin{array}{lllllll}1123 & 817 & 6 / 10 / 2013 & 8 / 24 / 2014 & 8 / 25 / 2014 & 001942742 G B F & 2\end{array}$

$1108 \quad 796 \quad 7 / 31 / 2013 \quad 8 / 24 / 2014 \quad 8 / 25 / 2014 \quad 001942742 \mathrm{GBF} \quad 2$

$\begin{array}{lllllll}957 & 651 & 6 / 14 / 2013 & 8 / 24 / 2014 & 8 / 25 / 2014 & 001942742 G B F & 2\end{array}$

*A=Article; $C=$ Container; $A C=$ Article Container, $B W=$ Bulk Waste, $E=$ Equipment 
Idaho National Laboratory

Advanced Mixed Waste Treatment Project (AMWTP)

PCB Waste Document Log

Removed from Service, Shipped and/or Disposed During Calendar Year 2014

Date of

Gross Net Removal

Radioactive

Type* Identification \#

$(\mathbf{Y} / \mathbf{N})$

Weight Weight from Transport Disposal Manifest

\begin{tabular}{|c|c|c|}
\hline 10501561 & Yes & Sludge Repackage Project PCB Contaminated Debris \\
\hline 10501562 & Yes & Sludge Repackage Project PCB Contaminated Debris \\
\hline 10501563 & Yes & Sludge Repackage Project PCB Contaminated Debris \\
\hline 10501564 & Yes & Sludge Repackage Project PCB Contaminated Debris \\
\hline 10501565 & Yes & Sludge Repackage Project PCB Contaminated Debris \\
\hline 10501566 & Yes & Sludge Repackage Project PCB Contaminated Debris \\
\hline 10501934 & Yes & Organic Setups, Oil Solids \\
\hline 10502018 & Yes & Sludge Repackage Project PCB Contaminated Debris \\
\hline 10502019 & Yes & Sludge Repackage Project PCB Contaminated Debris \\
\hline 10502020 & Yes & Sludge Repackage Project PCB Contaminated Debris \\
\hline 10502021 & Yes & Sludge Repackage Project PCB Contaminated Debris \\
\hline 10502022 & Yes & Sludge Repackage Project PCB Contaminated Debris \\
\hline 10502023 & Yes & Sludge Repackage Project PCB Contaminated Debris \\
\hline 10502024 & Yes & Sludge Repackage Project PCB Contaminated Debris \\
\hline 10502025 & Yes & Sludge Repackage Project PCB Contaminated Debris \\
\hline 10502026 & Yes & Sludge Repackage Project PCB Contaminated Debris \\
\hline 10502027 & Yes & Sludge Repackage Project PCB Contaminated Debris \\
\hline 10502028 & Yes & Sludge Repackage Project PCB Contaminated Debris \\
\hline 10502029 & Yes & Sludge Repackage Project PCB Contaminated Debris \\
\hline 10502428 & Yes & Sludge Repackage Project PCB Contaminated Debris \\
\hline 10502429 & Yes & Sludge Repackage Project PCB Contaminated Debris \\
\hline 10502430 & Yes & Sludge Repackage Project PCB Contaminated Debris \\
\hline 10502431 & Yes & Sludge Repackage Project PCB Contaminated Debris \\
\hline 10502432 & Yes & Sludge Repackage Project PCB Contaminated Debris \\
\hline 10502433 & Yes & Sludge Repackage Project PCB Contaminated Debris \\
\hline 10502434 & Yes & Sludge Repackage Project PCB Contaminated Debris \\
\hline 10502815 & Yes & Organic Setups, Oil Solids \\
\hline 10502817 & Yes & Organic Setups, Oil Solids \\
\hline 10502818 & Yes & Organic Setups, Oil Solids \\
\hline 10502819 & Yes & Organic Setups, Oil Solids \\
\hline 10502821 & Yes & Organic Setups, Oil Solids \\
\hline 10502823 & Yes & Organic Setups, Oil Solids \\
\hline 10502825 & Yes & Organic Setups, Oil Solids \\
\hline 10502826 & Yes & Organic Setups, Oil Solids \\
\hline 10502829 & Yes & Organic Setups, Oil Solids \\
\hline 10502832 & Yes & Organic Setups, Oil Solids \\
\hline 10502833 & Yes & Organic Setups, Oil Solids \\
\hline 10502834 & Yes & Organic Setups, Oil Solids \\
\hline
\end{tabular}

(KGS) (KGS) Service

Date Date Number Notes

$\begin{array}{lllllll}951 & 639 & 7 / 30 / 2013 & 8 / 24 / 2014 & 8 / 25 / 2014 & 001942742 \mathrm{GBF} & 2\end{array}$

$\begin{array}{lllllll}1044 & 738 & 6 / 12 / 2013 & 8 / 24 / 2014 & 8 / 25 / 2014 & 001942742 \mathrm{GBF} & 2\end{array}$

$887578 \quad 6 / 19 / 2013 \quad 8 / 24 / 2014 \quad 8 / 25 / 2014 \quad 001942743 G B F \quad 2$

$\begin{array}{lllllll} & 1076 & 768 & 6 / 11 / 2013 & 9 / 7 / 2014 & 9 / 8 / 2014 & 001942748 G B F\end{array}$

$\begin{array}{cccccccc}1076 & 768 & 6 / 11 / 2013 & 9 / 7 / 2014 & 9 / 8 / 2014 & 001942748 \mathrm{GBF} & 2 \\ 878 & 570 & 6 / 17 / 2013 & 8 / 24 / 2014 & 8 / 25 / 2014 & 001942742 \mathrm{GBF} & 2\end{array}$

$\begin{array}{lllllll} & 665 & 654 & 7 / 29 / 2013 & 9 / 7 / 2014 & 9 / 8 / 2014 & 001942748 G B F\end{array}$

$124 \quad 65 \quad 6 / 1 / 1968 \quad 1 / 31 / 2014 \quad 2 / 4 / 2014 \quad 001600967$ GBF 2, 5

$\begin{array}{lllllll}1008 & 696 & 8 / 8 / 2013 & 8 / 20 / 2014 & 8 / 21 / 2014 & 001942737 G B F & 2\end{array}$

$\begin{array}{lllllll}922 & 610 & 8 / 5 / 2013 & 8 / 20 / 2014 & 8 / 21 / 2014 & 001942737 G B F & 2\end{array}$

$\begin{array}{lllllll}913 & 602 & 8 / 1 / 2013 & 8 / 20 / 2014 & 8 / 21 / 2014 & 001942737 G B F & 2\end{array}$

$\begin{array}{lllllll} & 7014 & 8 / 1 / 2013 & 8 / 20 / 2014 & 8 / 21 / 2014 & 001942737 \mathrm{GBF} & 2\end{array}$

$\begin{array}{lllllll}973 & 666 & 6 / 11 / 2013 & 8 / 20 / 2014 & 8 / 21 / 2014 & 001942737 \mathrm{GBF} & 2\end{array}$

$\begin{array}{llllllll}1025 & 713 & 8 / 7 / 2013 & 8 / 20 / 2014 & 8 / 21 / 2014 & 001942737 G B F & 2\end{array}$

$\begin{array}{lllllll}1012 & 705 & 8 / 12 / 2013 & 8 / 20 / 2014 & 8 / 21 / 2014 & 001942737 G B F & 2\end{array}$

$\begin{array}{llllllll}1012 & 701 & 8 / 1 / 2013 & 8 / 20 / 2014 & 8 / 21 / 2014 & 001942737 G B F & 2\end{array}$

$\begin{array}{lllllll}951 & 639 & 8 / 14 / 2013 & 8 / 20 / 2014 & 8 / 21 / 2014 & 001942737 G B F & 2\end{array}$

$\begin{array}{lllllll}867 & 560 & 8 / 13 / 2013 & 8 / 20 / 2014 & 8 / 21 / 2014 & 001942737 G B F & 2\end{array}$

$\begin{array}{lllllll}968 & 661 & 8 / 12 / 2013 & 8 / 20 / 2014 & 8 / 21 / 2014 & 001942737 \mathrm{GBF} & 2\end{array}$

$\begin{array}{lllllll}933 & 626 & 8 / 9 / 2013 & 8 / 17 / 2014 & 8 / 18 / 2014 & 001942736 G B F & 2\end{array}$

$\begin{array}{lllllll}1058 & 745 & 8 / 21 / 2013 & 8 / 17 / 2014 & 8 / 18 / 2014 & 001942736 G B F & 2\end{array}$

$\begin{array}{llllllll} & 1038 & 731 & 8 / 20 / 2013 & 8 / 17 / 2014 & 8 / 18 / 2014 & 001942736 G B F & 2\end{array}$

$\begin{array}{llllllll}1031 & 724 & 8 / 20 / 2013 & 8 / 17 / 2014 & 8 / 18 / 2014 & 001942736 G B F & 2\end{array}$

$\begin{array}{lllllll}1054 & 742 & 8 / 19 / 2013 & 8 / 17 / 2014 & 8 / 18 / 2014 & 001942736 G B F & 2\end{array}$

$\begin{array}{lllllll}1021 & 714 & 8 / 19 / 2013 & 8 / 17 / 2014 & 8 / 18 / 2014 & 001942736 G B F & 2\end{array}$

$\begin{array}{llllllll}1110 & 797 & 8 / 22 / 2013 & 8 / 17 / 2014 & 8 / 18 / 2014 & 001942736 G B F & 2 \\ 1048 & 741 & 8 / 20 / 2013 & 8 / 17 / 2014 & 8 / 18 / 2014 & 001942736 G B F & 2\end{array}$

$125 \quad 66 \quad 6 / 1 / 1968 \quad 2 / 1 / 2014 \quad 001600968$ GBF 2,5

$\begin{array}{llllll}151 & 92 & 6 / 1 / 1968 & 1 / 28 / 2014 & 2 / 1 / 2014 & 001600963 G B F \\ 1 & 2,5\end{array}$

$\begin{array}{llllll}126 & 67 & 6 / 1 / 1968 & 1 / 28 / 2014 & 1 / 31 / 2014 & 001600963 G B F \\ 155 & 2,5\end{array}$

$\begin{array}{lllllll}155 & 96 & 6 / 1 / 1968 & 2 / 1 / 2014 & & 001600968 G B F & 2,5 \\ 128 & 69 & 6 / 1 / 1968 & 1 / 28 / 2014 & 2 / 1 / 2014 & 001600963 G B F & 2,5\end{array}$

$119 \quad 60 \quad 6 / 1 / 1968 \quad 1 / 28 / 2014 \quad 2 / 1 / 2014 \quad 001600963 G B F 2,5$

$115 \quad 56 \quad 6 / 1 / 1968 \quad 1 / 23 / 2014 \quad 1 / 26 / 2014 \quad 001600954 G B F \quad, 5$

$\begin{array}{lllllll}115 & 56 & 6 / 1 / 1968 & 1 / 23 / 2014 & 1 / 26 / 2014 & 001600954 G B F & 2,5 \\ 137 & 78 & 6 / 1 / 1968 & 1 / 31 / 2014 & 2 / 4 / 2014 & 001600967 G B F & 2,5\end{array}$

$\begin{array}{llllll}146 & 87 & 6 / 1 / 1968 & 1 / 27 / 2014 & 1 / 31 / 2014 & 001600961 G B F \\ 130,5\end{array}$

$\begin{array}{lllllll}146 & 87 & 6 / 1 / 1968 & 1 / 27 / 2014 & 1 / 31 / 2014 & 001600961 G B F & 2,5 \\ 130 & 71 & 6 / 1 / 1968 & 1 / 28 / 2014 & 2 / 1 / 2014 & 001600962 G B F & 2,5\end{array}$

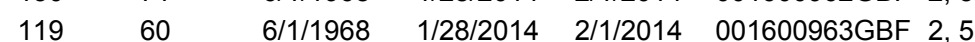

$13576 \quad 6 / 1 / 1968 \quad 1 / 28 / 2014 \quad 2 / 1 / 2014 \quad 001600963$ GBF 2,5 
Idaho National Laboratory

Advanced Mixed Waste Treatment Project (AMWTP)

PCB Waste Document Log

Removed from Service, Shipped and/or Disposed During Calendar Year 2014

Date of

Gross Net Removal

Radioactive

Type* Identification \# $\quad$ (Y/N)

Weight Weight from Transport Disposal Manifest

10502853

Yes

(KGS) (KGS) Service

Date Date

Number Notes

10502863

Organic Setups, Oil Solids

10502864

Organic Setups, Oil Solids

10503205

Organic Setups, Oil Solids

0503214

Organic Setups, Oil Solids

10503231

10503232

Organic Setups, Oil Solids

10503233

Organic Setups, Oil Solids

10503234

10503236

Organic Setups, Oil Solids

Organic Setups, Oil Solids

Organic Setups, Oil Solids

10503237

10503238

Organic Setups, Oil Solids

10503239

Organic Setups, Oil Solids

Organic Setups, Oil Solids

10503240

10503241

Organic Setups, Oil Solids

10503242

10503243

10503245

Setups, Oil Solids

Organic Setups, Oil Solids

Organic Setups, Oil Solids

10503246

10503252

Organic Setups, Oil Solids

Organic Setups, Oil Solids

Organic Setups, Oil Solids

10503255

10503256

10503257

Organic Setups, Oil Solids

Organic Setups, Oil Solids

Organic Setups, Oil Solids

10503260

10503261

Organic Setups, Oil Solids

10503262

Organic Setups, Oil Solids

10503263

10503265

Organic Setups, Oil Solids

Organic Setups, Oil Solids

Organic Setups, Oil Solids

Organic Setups, Oil Solids

10503266

10503267

10503268

Organic Setups, Oil Solids

Organic Setups, Oil Solids

Organic Setups, Oil Solids

10503303

Oil Sotups, Oil Solids

10503304

Organic Setups, Oil Solids

Organic Setups, Oil Solids

Organic Setups, Oil Solids

10503307

Organic Setups, Oil Solids

$148 \quad 89 \quad 6 / 1 / 1968$

$120 \quad 61$

$141 \quad 82$

$125 \quad 66$

$132 \quad 73$

15293

$133 \quad 74$

$138 \quad 79$

$126 \quad 67$

$144 \quad 85$

$121 \quad 62$

$122 \quad 63$

11152

$109 \quad 50$

$137 \quad 78$

$125 \quad 66$

$132 \quad 73$

$143 \quad 84$

$114 \quad 55$

$128 \quad 69$

$160 \quad 101$

$114 \quad 55$

$106 \quad 47$

$138 \quad 79$

$149 \quad 90$

$143 \quad 84$

$129 \quad 70$

$117 \quad 58$

$127 \quad 68$

$132 \quad 73$

$109 \quad 50$

$119 \quad 60$

14283

$143 \quad 84$

$158 \quad 99$

$153 \quad 94$

$140 \quad 81$

$139 \quad 80$
6/1/1968 1/28/2014

6/1/1968 2/1/2014

$6 / 1 / 1968$

$6 / 1 / 1968$

$6 / 1 / 1968$

$6 / 1 / 1968$

$6 / 1 / 1968$

6/1/1968

$6 / 1 / 1968$

$6 / 1 / 1968$

$6 / 1 / 1968$

$6 / 1 / 1968$

$6 / 1 / 1968$

$6 / 1 / 1968$

$6 / 1 / 1968$

6/1/1968

$6 / 1 / 1968$

$6 / 1 / 1968$

$6 / 1 / 1968$

$6 / 1 / 1968$

6/1/1968

$6 / 1 / 1968$

$6 / 1 / 1968$

6/1/1968

$6 / 1 / 1968$

$6 / 1 / 1968$

$6 / 1 / 1968$

6/1/1968

$6 / 1 / 1968$

$6 / 1 / 1968$

$6 / 1 / 1968$

6/1/1968

$6 / 1 / 1968$

$6 / 1 / 1968$

$6 / 1 / 1968$

$6 / 1 / 1968$

$6 / 1 / 1968$ $\begin{array}{ll}001600973 G B F & 2,5 \\ 001600968 G B F & 2,5\end{array}$

2/4/2014 001600967GBF 2,5

$1 / 31 / 2014 \quad 2 / 2 / 2014 \quad 001600966 G B F \quad 2,5$

$1 / 31 / 2014 \quad 2 / 2 / 2014 \quad 001600966 G B F \quad 2,5$

$1 / 31 / 2014 \quad 2 / 2 / 2014 \quad 001600966 G B F \quad 2,5$

$1 / 31 / 2014 \quad 2 / 2 / 2014 \quad 001600966 \mathrm{GBF} 2,5$

2/1/2014 001600968GBF 2, 5

$1 / 31 / 2014 \quad 2 / 2 / 2014 \quad 001600966 G B F \quad 2,5$

1/31/2014 2/2/2014 001600966GBF 2, 5

$1 / 31 / 2014 \quad 2 / 2 / 2014 \quad 001600966 G B F \quad 2,5$

$1 / 31 / 2014 \quad 2 / 2 / 2014 \quad 001600966$ GBF 2,5

$1 / 31 / 2014 \quad 2 / 2 / 2014 \quad 001600966$ GBF 2,5

2/4/2014 001600973GBF 2, 5

2/1/2014 001600968GBF 2,5

$1 / 31 / 2014 \quad 2 / 2 / 2014 \quad 001600966$ GBF 2,5

2/1/2014 001600968GBF 2, 5

001600968GBF 2, 5

1/31/2014 2/4/2014 001600967GBF 2,5

2/1/2014 001600968GBF 2, 5

1/31/2014 2/4/2014 001600967 GBF 2,5

1/31/2014 2/4/2014 001600967GBF 2, 5

2/4/2014 001600973GBF 2, 5

2/1/2014 001600968GBF 2, 5

1/31/2014 2/4/2014 001600967GBF 2, 5

1/31/2014 2/2/2014 001600966GBF 2,5

2/1/2014 001600968GBF 2, 5

2/1/2014 001600962GBF 2,5

2/4/2014 001600973GBF 2, 5

2/1/2014 001600968GBF 2, 5

001600968GBF 2, 5

1/31/2014 2/4/2014 001600967GBF 2,5

$1 / 31 / 2014 \quad 2 / 2 / 2014 \quad 001600966 G B F \quad 2,5$

$1 / 28 / 2014 \quad 2 / 1 / 2014 \quad 001600962 \mathrm{GBF} 2,5$

$1 / 31 / 2014 \quad 2 / 4 / 2014 \quad 001600967 G B F \quad 2,5$

1/31/2014 2/2/2014 001600966GBF 2,5

$1 / 31 / 2014 \quad 2 / 4 / 2014 \quad 001600967$ GBF 2,5 
Idaho National Laboratory

Advanced Mixed Waste Treatment Project (AMWTP)

PCB Waste Document Log

Removed from Service, Shipped and/or Disposed During Calendar Year 2014

Date of

Gross Net Removal

Radioactive

Type* Identification \# $\quad$ (Y/N)

Weight Weight from Transport Disposal Manifest

\begin{tabular}{lll}
10503309 & Yes & Organic Setups, Oil Solids \\
10503313 & Yes & Organic Setups, Oil Solids \\
10503316 & Yes & Organic Setups, Oil Solids \\
10503321 & Yes & Organic Setups, Oil Solids \\
10503322 & Yes & Organic Setups, Oil Solids \\
10503324 & Yes & Organic Setups, Oil Solids \\
10503325 & Yes & Organic Setups, Oil Solids \\
10503327 & Yes & Organic Setups, Oil Solids \\
10503329 & Yes & Organic Setups, Oil Solids \\
10503331 & Yes & Organic Setups, Oil Solids \\
10503341 & Yes & Organic Setups, Oil Solids \\
10503343 & Yes & Organic Setups, Oil Solids \\
10503344 & Yes & Organic Setups, Oil Solids \\
10503347 & Yes & Organic Setups, Oil Solids \\
10503350 & Yes & Organic Setups, Oil Solids \\
10503353 & Yes & Organic Setups, Oil Solids \\
10503356 & Yes & Organic Setups, Oil Solids \\
10503357 & Yes & Organic Setups, Oil Solids \\
10503363 & Yes & Organic Setups, Oil Solids \\
10503364 & Yes & Organic Setups, Oil Solids \\
10503366 & Yes & Organic Setups, Oil Solids \\
10503368 & Yes & Organic Setups, Oil Solids \\
10503369 & Yes & Organic Setups, Oil Solids \\
10503370 & Yes & Organic Setups, Oil Solids \\
10503372 & Yes & Organic Setups, Oil Solids \\
10503739 & Yes & Sludge Repackage Project PCB Contaminated Debris \\
10503740 & Yes & Sludge Repackage Project PCB Contaminated Debris \\
10503743 & Yes & Sludge Repackage Project PCB Contaminated Debris \\
10503744 & Yes & Sludge Repackage Project PCB Contaminated Debris \\
10503745 & Yes & Sludge Repackage Project PCB Contaminated Debris \\
10503746 & Yes & Sludge Repackage Project PCB Contaminated Debris \\
10503747 & Yes & Sludge Repackage Project PCB Contaminated Debris \\
10503748 & Yes & Sludge Repackage Project PCB Contaminated Debris \\
10503832 & Yes & Organic Setups, Oil Solids \\
10503834 & Yes & Organic Setups, Oil Solids \\
10503837 & Yes & Organic Setups, Oil Solids \\
10503840 & Organic Setups, Oil Solids \\
10503849 & Organic Setups, Oil Solids \\
\hline 10 & Yes &
\end{tabular}

(KGS) (KGS) Service

Date Date Number Notes

$\begin{array}{llllll}126 & 67 & 6 / 1 / 1968 & 1 / 31 / 2014 & 2 / 4 / 2014 & 001600967 G B F \\ 146 & 5\end{array}$

$\begin{array}{llllll}146 & 87 & 6 / 1 / 1968 & 1 / 31 / 2014 & 2 / 2 / 2014 & 001600966 G B F \\ 148,5\end{array}$

$148 \quad 89 \quad 6 / 1 / 1968 \quad 1 / 31 / 2014 \quad 2 / 2 / 2014 \quad 001600966 G B F \quad 2,5$

$\begin{array}{llllll}163 & 104 & 6 / 1 / 1968 & 1 / 28 / 2014 & 2 / 1 / 2014 & 001600962 G B F \\ 2,5\end{array}$

$\begin{array}{ccccccc}163 & 104 & 6 / 1 / 1968 & 1 / 28 / 2014 & 2 / 1 / 2014 & 001600962 \mathrm{GBF} & 2,5 \\ 111 & 52 & 6 / 1 / 1968 & 1 / 28 / 2014 & 2 / 1 / 2014 & 001600962 \mathrm{GBF} & 2,5\end{array}$

$\begin{array}{llllll}113 & 54 & 6 / 1 / 1968 & 1 / 31 / 2014 & 2 / 4 / 2014 & 001600967 G B F\end{array} 2,5$

$136 \quad 77 \quad 6 / 1 / 1968 \quad 1 / 31 / 2014 \quad 2 / 4 / 2014 \quad 001600967$ GBF 2,5

$\begin{array}{lccccc}136 & 77 & 6 / 1 / 1968 & 1 / 31 / 2014 & 2 / 4 / 2014 & 001600967 G B F 2,5 \\ 106 & 6 / 1 / 1968 & 1 / 31 / 2014 & 2 / 4 / 2014 & \text { 001600967GB 2, } 5\end{array}$

$\begin{array}{llllll}136 & 77 & 6 / 1 / 1968 & 1 / 31 / 2014 & 2 / 2 / 2014 & 001600966 G B F \quad 2,5\end{array}$

$146 \quad 87 \quad 6 / 1 / 1968 \quad 1 / 31 / 2014 \quad 2 / 4 / 2014 \quad 001600967$ GBF 2,5

$\begin{array}{llllll}149 & 90 & 6 / 1 / 1968 & 2 / 4 / 2014 & 001600973 G B F & 2,5\end{array}$

$14990 \quad 6 / 1 / 1968 \quad 1 / 28 / 2014 \quad 2 / 2 / 2014 \quad 001600962$ GBF 2, 5

$\begin{array}{lllllll}149 & 90 & 6 / 1 / 1968 & 1 / 28 / 2014 & 2 / 2 / 2014 & 001600962 G B F & 2,5 \\ 134 & 75 & 6 / 1 / 1968 & 1 / 28 / 2014 & 1 / 31 / 2014 & 001600963 G B F & 2,5\end{array}$

$\begin{array}{llllll}151 & 92 & 6 / 1 / 1968 & 1 / 28 / 2014 & 1 / 31 / 2014 & 001600963 G B F \\ 2,5\end{array}$

$113 \quad 54 \quad 6 / 1 / 1968 \quad 1 / 28 / 2014 \quad 2 / 2 / 2014 \quad 001600962$ GBF 2,5

$\begin{array}{llllll}128 & 69 & 6 / 1 / 1968 & 2 / 4 / 2014 & 001600973 G B F & 2,5\end{array}$

$152 \quad 93 \quad 6 / 1 / 1968 \quad 1 / 28 / 2014 \quad 2 / 2 / 2014 \quad 001600962$ GBF 2,5

$\begin{array}{ccccccc}152 & 93 & 6 / 1 / 1968 & 1 / 28 / 2014 & 2 / 2 / 2014 & 001600962 \mathrm{GBF} & 2,5 \\ 161 & 102 & 6 / 1 / 1968 & 1 / 28 / 2014 & 2 / 2 / 2014 & 001600962 \mathrm{GBF} & 2,5\end{array}$

$164 \quad 105 \quad 6 / 1 / 1968 \quad 1 / 28 / 2014 \quad 2 / 2 / 2014 \quad 001600962 G B F \quad 2,5$

$\begin{array}{llllll}145 & 86 & 6 / 1 / 1968 & 1 / 28 / 2014 & 2 / 2 / 2014 & 001600962 G B F \\ 155,5\end{array}$

$\begin{array}{lllllll}145 & 86 & 6 / 1 / 1968 & 1 / 28 / 2014 & 2 / 2 / 2014 & 001600962 \mathrm{GBF} & 2,5 \\ 155 & 96 & 6 / 1 / 1968 & 2 / 1 / 2014 & & 001600968 \mathrm{GBF} & 2,5\end{array}$

$123 \quad 64 \quad 6 / 1 / 1968 \quad 1 / 28 / 2014 \quad 2 / 1 / 2014 \quad 001600962 G B F \quad 2,5$

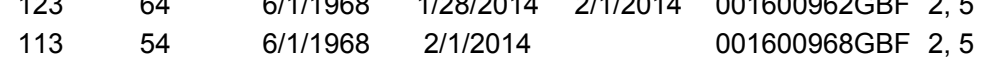

$12768 \quad 6 / 1 / 1968 \quad 2 / 1 / 2014 \quad 001600968$ GBF 2,5

$\begin{array}{llllll}136 & 77 & 6 / 1 / 1968 & 1 / 28 / 2014 & 2 / 1 / 2014 & 001600962 G B F \\ 2,5\end{array}$

$\begin{array}{lllllll}979 & 668 & 8 / 8 / 2013 & 8 / 17 / 2014 & 8 / 18 / 2014 & 001942736 G B F & 2\end{array}$

$\begin{array}{lllllll}1040 & 733 & 8 / 13 / 2013 & 8 / 17 / 2014 & 8 / 18 / 2014 & 001942736 G B F & 2\end{array}$

$\begin{array}{lllllll}855 & 546 & 12 / 11 / 2012 & 12 / 4 / 2014 & 12 / 18 / 2014 & 001942809 G B F & 2\end{array}$

$893584 \quad 12 / 17 / 2012 \quad 12 / 4 / 2014 \quad 12 / 18 / 2014 \quad 001942809 G B F \quad 2$

$\begin{array}{lllllll}6 & 384 & 11 / 29 / 2012 & 12 / 4 / 2014 & 12 / 18 / 2014 & 001942809 G B F & 2\end{array}$

$\begin{array}{lllllll} & 7012 & 8 / 8 / 2013 & 12 / 4 / 2014 & 12 / 18 / 2014 & 001942809 G B F & 2\end{array}$

$\begin{array}{lllllll}973 & 664 & 12 / 13 / 2012 & 12 / 4 / 2014 & 12 / 18 / 2014 & 001942809 G B F & 2\end{array}$

$\begin{array}{lllllll}1014 & 702 & 8 / 14 / 2013 & 8 / 17 / 2014 & 8 / 18 / 2014 & 001942736 G B F & 2\end{array}$

$\begin{array}{llllll}135 & 76 & 6 / 1 / 1968 & 1 / 31 / 2014 & 2 / 4 / 2014 & 001600967 G B F \\ 2,5\end{array}$

$\begin{array}{llllll}150 & 91 & 6 / 1 / 1968 & 1 / 31 / 2014 & 2 / 4 / 2014 & 001600967 G B F \\ 121,5\end{array}$

$\begin{array}{lllllll}150 & 91 & 6 / 1 / 1968 & 1 / 31 / 2014 & 2 / 4 / 2014 & 001600967 G B F & 2,5 \\ 121 & 62 & 6 / 1 / 1968 & 1 / 31 / 2014 & 2 / 4 / 2014 & 001600967 G B F & 2,5\end{array}$

$11253 \quad 6 / 1 / 1968 \quad 2 / 4 / 2014 \quad 001600973$ GBF 2,5

10503849 Yes Organic Setups, Oil Solids

11455

6/1/1968 1/31/2014 2/2/2014 001600966GBF 2, 5 
Idaho National Laboratory

Advanced Mixed Waste Treatment Project (AMWTP)

PCB Waste Document Log

Removed from Service, Shipped and/or Disposed During Calendar Year 2014

Date of

Gross Net Removal

Radioactive

Type* Identification \#

(Y/N)

Weight Weight from Transport Disposal Manifest

(KGS) (KGS) Service $\begin{gathered}\text { Date } \\ \text { Date }\end{gathered}$ Number Notes

C 10503852

Yes

$6 / 1 / 1968$

$1 / 31 / 2014 \quad 2 / 2 / 2014 \quad 001600966 \mathrm{GBF} 2,5$

$10503854 \quad$ Yes Organic Setups, Oil Solids

$10503858 \quad$ Yes Organic Setups, Oil Solids

$10503914 \quad$ Yes Sludge Repackage Project PCB Contaminated Debris

10503915 Yes Sludge Repackage Project PCB Contaminated Debris

10503916 Yes Sludge Repackage Project PCB Contaminated Debris

10503917 Yes Sludge Repackage Project PCB Contaminated Debris

10503918

10503919

Sludge Repackage Project PCB Contaminated Debris

Sludge Repackage Project PCB Contaminated Debris

10503920

10503922

Sludge Repackage Project PCB Contaminated Debris

Sludge Repackage Project PCB Contaminated Debris

10503923

10503924

10503925

10504587

10504588

10504589

10504590

10504592

10504593

10504594

10504595

10504596

10504597

10504598

10504874

10504875

10504876

10504877

10504878

10504879

10504880

10504881

10505306

10505307

10505308

10505309

Sludge Repackage Project PCB Contaminated Debris

Sludge Repackage Project PCB Contaminated Debris

Sludge Repackage Project PCB Contaminated Debris Sludge Repackage Project PCB Contaminated Debris Sludge Repackage Project PCB Contaminated Debris Sludge Repackage Project PCB Contaminated Debris Sludge Repackage Project PCB Contaminated Debris Sludge Repackage Project PCB Contaminated Debris Sludge Repackage Project PCB Contaminated Debris Sludge Repackage Project PCB Contaminated Debris Sludge Repackage Project PCB Contaminated Debris Sludge Repackage Project PCB Contaminated Debris Sludge Repackage Project PCB Contaminated Debris Sludge Repackage Project PCB Contaminated Debris Sludge Repackage Project PCB Contaminated Debris Sludge Repackage Project PCB Contaminated Debris Sludge Repackage Project PCB Contaminated Debris Sludge Repackage Project PCB Contaminated Debris Sludge Repackage Project PCB Contaminated Debris Sludge Repackage Project PCB Contaminated Debris Sludge Repackage Project PCB Contaminated Debris Sludge Repackage Project PCB Contaminated Debris Sludge Repackage Project PCB Contaminated Debris Sludge Repackage Project PCB Contaminated Debris Sludge Repackage Project PCB Contaminated Debris Sludge Repackage Project PCB Contaminated Debris

$121 \quad 62 \quad 6 / 1 / 1968 \quad 1 / 31 / 2014 \quad 2 / 2 / 2014 \quad 001600966 G B F \quad 2,5$

$11253 \quad 6 / 1 / 1968 \quad 1 / 31 / 2014 \quad 2 / 4 / 2014 \quad 001600967 G B F \quad 2,5$

$\begin{array}{lllllll}973 & 667 & 6 / 3 / 2013 & 12 / 4 / 2014 & 12 / 18 / 2014 & 001942809 G B F & 2\end{array}$

$\begin{array}{lllllll}1141 & 828 & 9 / 3 / 2013 & 8 / 17 / 2014 & 8 / 18 / 2014 & 001942736 G B F & 2\end{array}$

$\begin{array}{lllllll}1087 & 774 & 8 / 21 / 2013 & 8 / 17 / 2014 & 8 / 18 / 2014 & 001942735 G B F & 2\end{array}$

$\begin{array}{lllllll}975 & 662 & 8 / 23 / 2013 & 8 / 17 / 2014 & 8 / 18 / 2014 & 001942736 G B F & 2\end{array}$

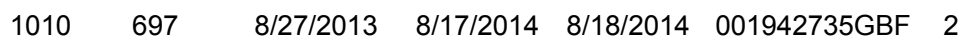

$\begin{array}{lllllll}1057 & 749 & 8 / 23 / 2013 & 8 / 17 / 2014 & 8 / 18 / 2014 & 001942736 G B F & 2\end{array}$

$\begin{array}{lllllll}1029 & 716 & 9 / 3 / 2013 & 8 / 17 / 2014 & 8 / 18 / 2014 & 001942735 G B F & 2\end{array}$

$\begin{array}{lllllll} & 7086 & 8 / 28 / 2013 & 8 / 17 / 2014 & 8 / 18 / 2014 & 001942735 G B F & 2\end{array}$

$\begin{array}{lllllll}991 & 678 & 9 / 5 / 2013 & 8 / 17 / 2014 & 8 / 18 / 2014 & 001942735 G B F & 2\end{array}$

$\begin{array}{lllllll} & 1055 & 742 & 9 / 4 / 2013 & 8 / 17 / 2014 & 8 / 18 / 2014 & 001942735 G B F\end{array}$

$\begin{array}{lllllll} & 963 & 650 & 8 / 27 / 2013 & 8 / 17 / 2014 & 8 / 18 / 2014 & 001942735 G B F\end{array}$

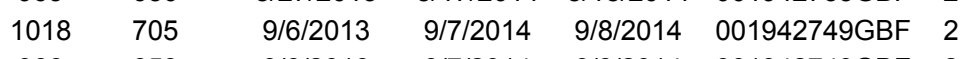

$\begin{array}{lllllll}966 & 653 & 9 / 6 / 2013 & 9 / 7 / 2014 & 9 / 8 / 2014 & 001942749 G B F & 2\end{array}$

$\begin{array}{lllllll} & 1095 & 9 / 4 / 2013 & 8 / 17 / 2014 & 8 / 18 / 2014 & 001942735 G B F & 2\end{array}$

$\begin{array}{lllllll}1040 & 727 & 9 / 11 / 2013 & 8 / 17 / 2014 & 8 / 18 / 2014 & 001942735 G B F & 2\end{array}$

$\begin{array}{lllllll}1127 & 820 & 9 / 10 / 2013 & 8 / 17 / 2014 & 8 / 18 / 2014 & 001942735 G B F & 2\end{array}$

$\begin{array}{lllllll}885 & 572 & 9 / 5 / 2013 & 9 / 7 / 2014 & 9 / 8 / 2014 & 001942749 G B F & 2\end{array}$

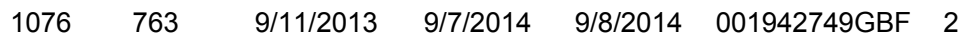

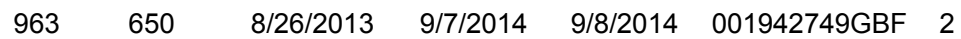

$\begin{array}{lllllll}1070 & 763 & 9 / 12 / 2013 & 9 / 7 / 2014 & 9 / 8 / 2014 & 001942749 G B F & 2\end{array}$

$\begin{array}{lllllll}897 & 584 & 9 / 16 / 2013 & 9 / 7 / 2014 & 9 / 8 / 2014 & 001942749 G B F & 2\end{array}$

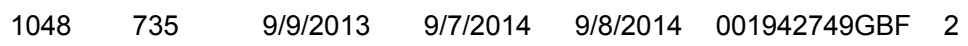

$\begin{array}{lllllll} & 7012 & 9 / 18 / 2013 & 8 / 20 / 2014 & 8 / 21 / 2014 & 001942738 G B F & 2\end{array}$

$\begin{array}{lllllll} & 1016 & 703 & 9 / 16 / 2013 & 8 / 20 / 2014 & 8 / 21 / 2014 & 001942738 G B F\end{array}$

$\begin{array}{lllllll} & 719 & 9 / 20 / 2013 & 8 / 24 / 2014 & 8 / 25 / 2014 & 001942743 G B F & 2\end{array}$

$\begin{array}{lllllll}1116 & 803 & 9 / 9 / 2013 & 8 / 24 / 2014 & 8 / 25 / 2014 & 001942743 G B F & 2\end{array}$

$\begin{array}{lllllll}1013 & 706 & 9 / 18 / 2013 & 8 / 24 / 2014 & 8 / 25 / 2014 & 001942743 G B F & 2\end{array}$

$\begin{array}{lllllll}950 & 643 & 9 / 19 / 2013 & 8 / 24 / 2014 & 8 / 25 / 2014 & 001942743 G B F & 2\end{array}$

$\begin{array}{lllllll}968 & 655 & 9 / 17 / 2013 & 8 / 24 / 2014 & 8 / 25 / 2014 & 001942743 G B F & 2\end{array}$

$\begin{array}{lllllll} & 1003 & 9 & 9 & & \end{array}$

$\begin{array}{lllllll}1075 & 768 & 9 / 23 / 2013 & 8 / 20 / 2014 & 8 / 21 / 2014 & 001942738 G B F & 2\end{array}$

$\begin{array}{lllllll}1026 & 718 & 9 / 24 / 2013 & 8 / 20 / 2014 & 8 / 21 / 2014 & 001942738 G B F & 2\end{array}$

$\begin{array}{lllllll}985 & 678 & 9 / 20 / 2013 & 8 / 20 / 2014 & 8 / 21 / 2014 & 001942738 G B F & 2\end{array}$

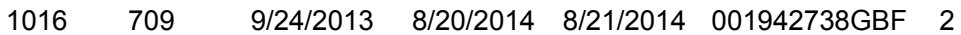

10505310

Yes Sludge Repackage Project PCB Contaminated Debris

1083773

$\begin{array}{lllll}5 / 22 / 2013 & 8 / 20 / 2014 & 8 / 21 / 2014 & 001942738 G B F & 2\end{array}$ 
Idaho National Laboratory

Advanced Mixed Waste Treatment Project (AMWTP)

PCB Waste Document Log

Removed from Service, Shipped and/or Disposed During Calendar Year 2014

Date of

Gross Net Removal

Radioactive

Type* Identification \#

$(\mathbf{Y} / \mathbf{N})$

Weight Weight from Transport Disposal Manifest (KGS) (KGS) Service Date Date Number Notes

\begin{tabular}{|c|c|}
\hline$C$ & 10505311 \\
\hline C & 10505778 \\
\hline C & 10505779 \\
\hline C & 10505780 \\
\hline C & 10505781 \\
\hline C & 10505782 \\
\hline C & 10505783 \\
\hline C & 10505784 \\
\hline C & 10505966 \\
\hline C & 10506244 \\
\hline C & 10506245 \\
\hline C & 10506246 \\
\hline C & 10506247 \\
\hline C & 10506248 \\
\hline C & 10506249 \\
\hline C & 10506250 \\
\hline C & 10506251 \\
\hline C & 10506252 \\
\hline C & 10506253 \\
\hline C & 10506254 \\
\hline C & 10506255 \\
\hline C & 10506689 \\
\hline C & 10506690 \\
\hline C & 10506691 \\
\hline C & 10506692 \\
\hline C & 10506693 \\
\hline C & 10506694 \\
\hline C & 10506695 \\
\hline C & 10507313 \\
\hline C & 10507314 \\
\hline C & 10507315 \\
\hline C & 10507316 \\
\hline C & 10507317 \\
\hline C & 10507318 \\
\hline C & 10507787 \\
\hline C & 10507788 \\
\hline C & 10507789 \\
\hline C & 10507790 \\
\hline
\end{tabular}

Sludge Repackage Project PCB Contaminated Debris Debris TSCA/PCB

Yes Sludge Repackage Project PCB Contaminated Debris Sludge Repackage Project PCB Contaminated Debris Sludge Repackage Project PCB Contaminated Debris Sludge Repackage Project PCB Contaminated Debris Sludge Repackage Project PCB Contaminated Debris Sludge Repackage Project PCB Contaminated Debris RFP Debris

Sludge Repackage Project PCB Contaminated Debris Sludge Repackage Project PCB Contaminated Debris Sludge Repackage Project PCB Contaminated Debris Sludge Repackage Project PCB Contaminated Debris Sludge Repackage Project PCB Contaminated Debris Sludge Repackage Project PCB Contaminated Debris Sludge Repackage Project PCB Contaminated Debris Sludge Repackage Project PCB Contaminated Debris Sludge Repackage Project PCB Contaminated Debris Sludge Repackage Project PCB Contaminated Debris Sludge Repackage Project PCB Contaminated Debris Sludge Repackage Project PCB Contaminated Debris Sludge Repackage Project PCB Contaminated Debris Sludge Repackage Project PCB Contaminated Debris Sludge Repackage Project PCB Contaminated Debris Sludge Repackage Project PCB Contaminated Debris Sludge Repackage Project PCB Contaminated Debris Sludge Repackage Project PCB Contaminated Debris Sludge Repackage Project PCB Contaminated Debris Sludge Repackage Project PCB Contaminated Debris Sludge Repackage Project PCB Contaminated Debris Sludge Repackage Project PCB Contaminated Debris Sludge Repackage Project PCB Contaminated Debris Sludge Repackage Project PCB Contaminated Debris Sludge Repackage Project PCB Contaminated Debris Sludge Repackage Project PCB Contaminated Debris Sludge Repackage Project PCB Contaminated Debris Sludge Repackage Project PCB Contaminated Debris Sludge Repackage Project PCB Contaminated Debris

\begin{tabular}{|c|c|c|c|c|c|c|}
\hline & כ & & $\int \angle U 14$ & $21 / 2014$ & $001942138 \mathrm{GBF}$ & 2 \\
\hline 89 & 53 & 2/6/2014 & & & & 8 \\
\hline 967 & 658 & $9 / 25 / 2013$ & $9 / 14 / 2014$ & $9 / 15 / 2014$ & 001942753GBF & 2 \\
\hline 1091 & 783 & $10 / 1 / 2013$ & $9 / 14 / 2014$ & $9 / 15 / 2014$ & 001942753GBF & 2 \\
\hline 1100 & 788 & $10 / 2 / 2013$ & $9 / 14 / 2014$ & $9 / 15 / 2014$ & 001942753GBF & 2 \\
\hline 1057 & 749 & $10 / 1 / 2013$ & $9 / 14 / 2014$ & $9 / 15 / 2014$ & 001942753GBF & 2 \\
\hline 953 & 644 & 9/26/2013 & 9/14/2014 & 9/15/2014 & $001942752 \mathrm{GBF}$ & 2 \\
\hline 1071 & 763 & 9/30/2013 & $9 / 14 / 2014$ & $9 / 15 / 2014$ & 001942753GBF & 2 \\
\hline 216 & 151 & 12/27/1971 & $12 / 10 / 2014$ & & 001942816GBF & 8 \\
\hline 1028 & 718 & $10 / 3 / 2013$ & 9/14/2014 & 9/15/2014 & $001942752 \mathrm{GBF}$ & 2 \\
\hline 1026 & 717 & $10 / 10 / 2013$ & 9/14/2014 & 9/15/2014 & 001942753GBF & 2 \\
\hline 1123 & 815 & $10 / 7 / 2013$ & $9 / 14 / 2014$ & $9 / 15 / 2014$ & 001942753GBF & 2 \\
\hline 1144 & 835 & $10 / 10 / 2013$ & 9/14/2014 & 9/15/2014 & 001942752GBF & 2 \\
\hline 1044 & 736 & $10 / 14 / 2013$ & 9/14/2014 & 9/15/2014 & 001942753GBF & 2 \\
\hline 1044 & 738 & $10 / 14 / 2013$ & 9/14/2014 & $9 / 15 / 2014$ & $001942752 \mathrm{GBF}$ & 2 \\
\hline 1095 & 787 & $10 / 9 / 2013$ & $9 / 14 / 2014$ & $9 / 15 / 2014$ & $001942753 \mathrm{GBF}$ & 2 \\
\hline 1056 & 749 & $10 / 14 / 2013$ & $9 / 14 / 2014$ & $9 / 15 / 2014$ & 001942753GBF & 2 \\
\hline 1012 & 704 & $10 / 9 / 2013$ & $9 / 14 / 2014$ & $9 / 15 / 2014$ & $001942752 \mathrm{GBF}$ & 2 \\
\hline 1059 & 750 & $10 / 7 / 2013$ & 9/14/2014 & $9 / 15 / 2014$ & $001942752 \mathrm{GBF}$ & 2 \\
\hline 1056 & 748 & $10 / 2 / 2013$ & $9 / 14 / 2014$ & $9 / 15 / 2014$ & 001942753GBF & 2 \\
\hline 961 & 652 & $10 / 3 / 2013$ & $9 / 14 / 2014$ & $9 / 15 / 2014$ & $001942752 \mathrm{GBF}$ & 2 \\
\hline 903 & 595 & $1 / 15 / 2013$ & 9/14/2014 & $9 / 15 / 2014$ & $001942752 \mathrm{GBF}$ & 2 \\
\hline 1232 & 925 & $10 / 17 / 2013$ & 9/14/2014 & $9 / 15 / 2014$ & $001942752 \mathrm{GBF}$ & 2 \\
\hline 1106 & 799 & $10 / 21 / 2013$ & 9/14/2014 & 9/15/2014 & $001942752 \mathrm{GBF}$ & 2 \\
\hline 1136 & 829 & $10 / 15 / 2013$ & $9 / 14 / 2014$ & 9/15/2014 & $001942752 \mathrm{GBF}$ & 2 \\
\hline 1128 & 819 & $10 / 17 / 2013$ & $9 / 14 / 2014$ & $9 / 15 / 2014$ & $001942752 \mathrm{GBF}$ & 2 \\
\hline 1134 & 827 & $10 / 16 / 2013$ & $9 / 7 / 2014$ & $9 / 8 / 2014$ & 001942749GBF & 2 \\
\hline 1149 & 841 & $10 / 16 / 2013$ & $9 / 7 / 2014$ & 9/8/2014 & 001942749GBF & 2 \\
\hline 1086 & 779 & $10 / 28 / 2013$ & $8 / 24 / 2014$ & $8 / 25 / 2014$ & $001942742 \mathrm{GBF}$ & 2 \\
\hline 1160 & 852 & $10 / 29 / 2013$ & $8 / 24 / 2014$ & $8 / 25 / 2014$ & $001942742 \mathrm{GBF}$ & 2 \\
\hline 1128 & 821 & $10 / 24 / 2013$ & $8 / 24 / 2014$ & $8 / 25 / 2014$ & $001942742 \mathrm{GBF}$ & 2 \\
\hline 1201 & 893 & $10 / 29 / 2013$ & $8 / 20 / 2014$ & $8 / 21 / 2014$ & 001942738GBF & 2 \\
\hline 1196 & 889 & $10 / 24 / 2013$ & 9/14/2014 & 9/15/2014 & $001942752 \mathrm{GBF}$ & 2 \\
\hline 1139 & 832 & 10/28/2013 & $9 / 14 / 2014$ & $9 / 15 / 2014$ & 001942752GBF & 2 \\
\hline 1030 & 723 & $10 / 23 / 2013$ & $11 / 23 / 2014$ & $11 / 24 / 2014$ & $001942767 \mathrm{GBF}$ & 2 \\
\hline 1173 & 865 & $10 / 29 / 2013$ & $11 / 23 / 2014$ & $11 / 24 / 2014$ & 001942767GBF & 2 \\
\hline 1233 & 926 & 10/21/2013 & $11 / 23 / 2014$ & $11 / 24 / 2014$ & 001942767GBF & 2 \\
\hline 1095 & 786 & $10 / 30 / 2013$ & $11 / 23 / 2014$ & $11 / 24 / 2014$ & 001942767GBF & 2 \\
\hline
\end{tabular}


Idaho National Laboratory

Advanced Mixed Waste Treatment Project (AMWTP)

PCB Waste Document Log

Removed from Service, Shipped and/or Disposed During Calendar Year 2014

Date of

Gross Net Removal

Radioactive

Type* Identification \#

$(\mathbf{Y} / \mathbf{N})$

Weight Weight from Transport Disposal Manifest

10507791

10507792

10508323

10508324

10508325

10508326

10508327

10508328

10508329

10508330

10508331

10508332

10508333

10508554

10508555

10508556

10508557

10508558

10508559

10508560

10509060

10509061

10509062

10509063

10509064

10509065

10509066

10509067

10509068

10509492

10509493

10509494

10509495

10509496

10509497

10509498

10509499

10509500
Yes Sludge Repackage Project PCB Contaminated Debris

Yes Sludge Repackage Project PCB Contaminated Debris

Yes Sludge Repackage Project PCB Contaminated Debris

Yes Sludge Repackage Project PCB Contaminated Debris

Yes Sludge Repackage Project PCB Contaminated Debris

Yes Sludge Repackage Project PCB Contaminated Debris

Yes Sludge Repackage Project PCB Contaminated Debris

Yes Sludge Repackage Project PCB Contaminated Debris

Yes Sludge Repackage Project PCB Contaminated Debris

Yes Sludge Repackage Project PCB Contaminated Debris

Yes Sludge Repackage Project PCB Contaminated Debris

Yes Sludge Repackage Project PCB Contaminated Debris

Yes Sludge Repackage Project PCB Contaminated Debris

Yes Sludge Repackage Project PCB Contaminated Debris

Yes Sludge Repackage Project PCB Contaminated Debris

Yes Sludge Repackage Project PCB Contaminated Debris

Yes Sludge Repackage Project PCB Contaminated Debris

Yes Sludge Repackage Project PCB Contaminated Debris

Yes Sludge Repackage Project PCB Contaminated Debris

Yes Sludge Repackage Project PCB Contaminated Debris

Yes Sludge Repackage Project PCB Contaminated Debris

Yes Sludge Repackage Project PCB Contaminated Debris

Yes Sludge Repackage Project PCB Contaminated Debris

Yes Sludge Repackage Project PCB Contaminated Debris

Yes Sludge Repackage Project PCB Contaminated Debris

Yes Sludge Repackage Project PCB Contaminated Debris

Yes Sludge Repackage Project PCB Contaminated Debris

Yes Sludge Repackage Project PCB Contaminated Debris

Yes Sludge Repackage Project PCB Contaminated Debris

Yes Sludge Repackage Project PCB Contaminated Debris

Yes Sludge Repackage Project PCB Contaminated Debris

Yes Sludge Repackage Project PCB Contaminated Debris

Yes Sludge Repackage Project PCB Contaminated Debris

Yes Sludge Repackage Project PCB Contaminated Debris

Yes Sludge Repackage Project PCB Contaminated Debris

Yes Sludge Repackage Project PCB Contaminated Debris

Yes Sludge Repackage Project PCB Contaminated Debris

Yes Sludge Repackage Project PCB Contaminated Debris
(KGS) (KGS) Service Date Date Number Notes

$\begin{array}{lllllll}1043 & 736 & 10 / 22 / 2013 & 11 / 23 / 2014 & 11 / 24 / 2014 & 001942767 G B F & 2\end{array}$

$1110801 \quad 10 / 30 / 2013 \quad 10 / 19 / 2014 \quad 10 / 20 / 2014$ 001942763GBF 2, 3

$1109797 \quad 11 / 12 / 2013 \quad 11 / 23 / 2014 \quad 11 / 24 / 2014 \quad 001942767 G B F \quad 2$

$\begin{array}{llllllll}1107 & 801 & 11 / 11 / 2013 & 11 / 23 / 2014 & 11 / 24 / 2014 & 001942767 G B F & 2\end{array}$

$\begin{array}{lllllll}1191 & 885 & 11 / 11 / 2013 & 10 / 19 / 2014 & 10 / 20 / 2014 & 001942764 G B F & 2\end{array}$

$1091779 \quad 11 / 12 / 2013 \quad 11 / 23 / 2014 \quad 11 / 24 / 2014 \quad 001942767 G B F \quad 2$

$\begin{array}{llllllll} & 816 & 116 & 11 / 8 / 2013 & 10 / 19 / 2014 & 10 / 20 / 2014 & 001942764 G B F & 2\end{array}$

$\begin{array}{llllllll}1095 & 788 & 11 / 6 / 2013 & 10 / 19 / 2014 & 10 / 20 / 2014 & 001942764 G B F & 2\end{array}$

$1020 \quad 712 \quad 11 / 11 / 2013 \quad 11 / 23 / 2014 \quad 11 / 24 / 2014 \quad 001942767 \mathrm{GBF} \quad 2$

$\begin{array}{llllllll} & 7674 & 11 / 8 / 2013 & 10 / 19 / 2014 & 10 / 20 / 2014 & 001942764 G B F & 2\end{array}$

$1048 \quad 738 \quad 10 / 31 / 2013 \quad 10 / 19 / 2014 \quad 10 / 20 / 2014$ 001942764GBF 2

$\begin{array}{llllllll} & 7101 & 11 / 5 / 2013 & 10 / 19 / 2014 & 10 / 20 / 2014 & 001942764 G B F & 2\end{array}$

$\begin{array}{llllllll}1125 & 816 \quad 11 / 5 / 2013 & 10 / 19 / 2014 & 10 / 20 / 2014 & 001942764 G B F & 2\end{array}$

$1202895 \quad 11 / 6 / 2013 \quad 10 / 19 / 2014 \quad 10 / 20 / 2014 \quad 001942764 G B F$

$906599 \quad 11 / 5 / 2013 \quad 10 / 19 / 2014 \quad 10 / 20 / 2014 \quad 001942764 G B F \quad 2$

$1028 \quad 719 \quad 11 / 7 / 2013 \quad 10 / 19 / 2014 \quad 10 / 20 / 2014$ 001942764GBF 2

$1143836 \quad 11 / 6 / 2013 \quad 10 / 19 / 2014 \quad 10 / 20 / 2014 \quad 001942763 G B F \quad 2$

$\begin{array}{llllllll} & 1083 & 11 / 14 / 2013 & 10 / 19 / 2014 & 10 / 20 / 2014 & 001942763 G B F & 2\end{array}$

$1136828 \quad 11 / 13 / 2013 \quad 10 / 19 / 2014 \quad 10 / 20 / 2014 \quad 001942763 G B F$

$\begin{array}{lllllll}900 & 590 \quad 11 / 13 / 2013 & 10 / 19 / 2014 & 10 / 20 / 2014 & 001942763 G B F & 2\end{array}$

$1065758 \quad 11 / 18 / 2013 \quad 10 / 19 / 2014 \quad 10 / 20 / 2014 \quad 001942763 G B F \quad 2$

$1171863 \quad 11 / 20 / 2013 \quad 10 / 19 / 2014 \quad 10 / 20 / 2014 \quad 001942763 G B F \quad 2$

$\begin{array}{llllllll}1073 & 763 & 11 / 14 / 2013 & 10 / 19 / 2014 & 10 / 20 / 2014 & 001942763 G B F & 2\end{array}$

$\begin{array}{lllllll}1150 & 838 & 11 / 18 / 2013 & 10 / 19 / 2014 & 10 / 20 / 2014 & 001942763 G B F & 2\end{array}$

$\begin{array}{llllllll}1093 & 783 & 11 / 21 / 2013 & 10 / 19 / 2014 & 10 / 20 / 2014 & 001942763 G B F & 2\end{array}$

$1111801 \quad 11 / 21 / 2013 \quad 10 / 19 / 2014 \quad 10 / 20 / 2014 \quad 001942763 G B F \quad 2$

$1122812 \quad 11 / 21 / 2013 \quad 10 / 19 / 2014 \quad 10 / 20 / 2014 \quad 001942764 G B F$

$1060750 \quad 11 / 25 / 2013 \quad 10 / 19 / 2014 \quad 10 / 20 / 2014$ 001942764GBF 2

$1165 \quad 855 \quad 11 / 25 / 2013 \quad 10 / 19 / 2014 \quad 10 / 20 / 2014 \quad 001942764 G B F \quad 2$

$\begin{array}{llllllll} & 716 & 12 / 4 / 2013 & 10 / 12 / 2014 & 10 / 13 / 2014 & 001942760 G B F & 2\end{array}$

$\begin{array}{llllllll}1218 & 910 & 12 / 2 / 2013 & 10 / 12 / 2014 & 10 / 13 / 2014 & 001942760 G B F & 2\end{array}$

$1051 \quad 743 \quad 12 / 3 / 2013 \quad 10 / 12 / 2014 \quad 10 / 13 / 2014 \quad 001942760 G B F$

$1059749 \quad 12 / 2 / 2013 \quad 10 / 12 / 2014 \quad 10 / 13 / 2014 \quad 001942760 G B F \quad 2$

$\begin{array}{llllllll}1113 & 805 & 12 / 5 / 2013 & 10 / 12 / 2014 & 10 / 13 / 2014 & 001942760 G B F & 2\end{array}$

$\begin{array}{lllllll}1131 & 823 & 12 / 3 / 2013 & 10 / 12 / 2014 & 10 / 13 / 2014 & 001942760 G B F & 2\end{array}$

$\begin{array}{llllllll} & 7673 \quad 12 / 3 / 2013 & 10 / 12 / 2014 & 10 / 13 / 2014 & 001942760 G B F & 2\end{array}$

$\begin{array}{lllllllll}1024 & 716 & 11 / 26 / 2013 & 10 / 12 / 2014 & 10 / 13 / 2014 & 001942760 G B F & 2\end{array}$

$\begin{array}{lllllll} & 847 & 1 & 12 / 5 / 2013 & 10 / 19 / 2014 & 10 / 20 / 2014 & 001942763 G B F\end{array}$ 
Idaho National Laboratory

Advanced Mixed Waste Treatment Project (AMWTP)

PCB Waste Document Log

Removed from Service, Shipped and/or Disposed During Calendar Year 2014

Date of

Gross Net Removal

Radioactive

Type* Identification \#

(Y/N)

Weight Weight from

\begin{tabular}{|c|c|}
\hline$C$ & 10509501 \\
\hline C & 10509502 \\
\hline C & 10509503 \\
\hline C & 10509804 \\
\hline C & 10510879 \\
\hline C & 10510915 \\
\hline C & 10511555 \\
\hline C & 10512038 \\
\hline C & 10512043 \\
\hline C & 10513518 \\
\hline C & 10514183 \\
\hline C & 10514448 \\
\hline C & 10515418 \\
\hline C & 10515420 \\
\hline C & 10515441 \\
\hline C & 10515442 \\
\hline C & 10515714 \\
\hline C & 10515765 \\
\hline C & 10515995 \\
\hline C & 10515996 \\
\hline C & 10515997 \\
\hline C & 10515998 \\
\hline C & 10515999 \\
\hline C & 10516000 \\
\hline C & 10516001 \\
\hline C & 10516002 \\
\hline$c$ & 10516003 \\
\hline$C$ & 10516004 \\
\hline c & 10516005 \\
\hline$c$ & 10516006 \\
\hline C & 10516813 \\
\hline C & 10516814 \\
\hline C & 10516815 \\
\hline c & 10516816 \\
\hline$C$ & 10516817 \\
\hline C & 10516818 \\
\hline C & 10516819 \\
\hline c & 10516820 \\
\hline
\end{tabular}

$\begin{array}{ll}\text { Yes } & \text { Sludge Repackage Project PCB Contaminated Debris } \\ \text { Yes } & \text { Sludge Repackage Project PCB Contaminated Debris }\end{array}$ (KGS) (KGS) Service Date Date Number Notes $\begin{array}{lllllll}1117 & 807 & 11 / 27 / 2013 & 10 / 19 / 2014 & 10 / 20 / 2014 & 001942763 G B F & 2\end{array}$

$\begin{array}{lllllll}1128 & 820 & 12 / 4 / 2013 & 10 / 19 / 2014 & 10 / 20 / 2014 & 001942763 G B F & 2 \\ 1053 & 743 & 11 / 26 / 2013 & 10 / 19 / 2014 & 10 / 20 / 2014 & 001942764 G B F & 2\end{array}$

Yes Sludge Repackage Project PCB Contaminated Debris

PCB Organic Homogeneous Solids

Second Stage Sludge

Second Stage Sludge

Yes Pad 1 Cells 1 and 2 Non-PCB Debris

Yes RFP Debris

Yes Absorbed Organic Liquids (Excluding Squeezants)

Yes Debris TSCA/PCB

Yes Pre-1980 INL-Exhumed SDA Homogeneous Solids

RFP Debris

WMF-676 PCB Contaminated Debris

WMF-676 PCB Contaminated Debris

WMF-676 PCB Contaminated Debris

WMF-676 PCB Contaminated Debris

RFP Debris

MLLW PCB Debris

Sludge Repackage Project PCB Contaminated Debris

Sludge Repackage Project PCB Contaminated Debris

Sludge Repackage Project PCB Contaminated Debris

Sludge Repackage Project PCB Contaminated Debris

Sludge Repackage Project PCB Contaminated Debris

Sludge Repackage Project PCB Contaminated Debris

Sludge Repackage Project PCB Contaminated Debris

Sludge Repackage Project PCB Contaminated Debris

Sludge Repackage Project PCB Contaminated Debris

Sludge Repackage Project PCB Contaminated Debris

Sludge Repackage Project PCB Contaminated Debris

Sludge Repackage Project PCB Contaminated Debris

Sludge Repackage Project PCB Contaminated Debris

Sludge Repackage Project PCB Contaminated Debris

Sludge Repackage Project PCB Contaminated Debris

Sludge Repackage Project PCB Contaminated Debris

Sludge Repackage Project PCB Contaminated Debris

Sludge Repackage Project PCB Contaminated Debris

Sludge Repackage Project PCB Contaminated Debris

$250 \quad 187 \quad 1 / 8 / 2014$

$305 \quad 235 \quad 1 / 27 / 2014$

$302 \quad 238 \quad 1 / 27 / 2014$

$1326 \quad 1136 \quad 2 / 5 / 2014$

$1256 \quad 1066 \quad 2 / 11 / 2014$

$33 \quad 6 \quad 2 / 11 / 2014$

$\begin{array}{lll}34 & 7 & 2 / 24 / 2014\end{array}$

$1849 \quad 1829 \quad 3 / 1 / 2014$

$1401 \quad 1211 \quad 3 / 3 / 2014$

$\begin{array}{lll}77 & 41 & 3 / 20 / 2014\end{array}$

$\begin{array}{lll}77 & 41 & 3 / 18 / 2014\end{array}$

$105 \quad 68 \quad 3 / 21 / 2014$

$\begin{array}{lll}112 & 74 & 3 / 21 / 2014\end{array}$

$1373 \quad 1183 \quad 3 / 23 / 2014$

$\begin{array}{ccc}1373 & 1183 & 3 / 23 / 2014 \\ 45 & 45 & 3 / 25 / 2014\end{array}$

$1087 \quad 778 \quad 6 / 1 / 1968$

$1092781 \quad 6 / 1 / 1968$

$1132 \quad 821 \quad 6 / 1 / 1968$

$1076767 \quad 6 / 1 / 1968$

$1118 \quad 809 \quad 6 / 1 / 1968$

$1116 \quad 805 \quad 6 / 1 / 1968$

$1117806 \quad 6 / 1 / 1968$

$1081 \quad 770 \quad 6 / 1 / 1968$

$1128 \quad 818-6 / 1 / 1968$

$1198 \quad 888 \quad 6 / 1 / 1968$

$1092781 \quad 6 / 1 / 1968$

$1050 \quad 742 \quad 6 / 1 / 1968$

$1248938 \quad 6 / 1 / 1968$

$1212901 \quad 6 / 1 / 1968$

$1026 \quad 718 \quad 6 / 1 / 1968$

$1127 \quad 817 \quad 6 / 1 / 1968$

$1022710 \quad 6 / 1 / 1968$

$985 \quad 673 \quad 6 / 1 / 1968$

$1176 \quad 865 \quad 6 / 1 / 1968$

$978 \quad 666 \quad 6 / 1 / 1968$

10/5/2014 10/6/2014 001942758GBF

10/5/2014 10/6/2014 001942758GBF 6

10/5/2014 10/6/2014 001942758GBF 6

10/5/2014 10/6/2014 001942758GBF 6

10/5/2014 10/6/2014 001942758GBF 6

10/5/2014 10/6/2014 001942758GBF 6

10/5/2014 10/6/2014 001942758GBF 6

10/1/2014 10/2/2014 001942757GBF 6

10/1/2014 10/2/2014 001942757GBF 6

10/1/2014 10/2/2014 001942757GBF 6

10/1/2014 10/2/2014 001942757GBF 6

10/1/2014 10/2/2014 001942757GBF 6

9/7/2014 9/8/2014 001942749GBF 6

9/7/2014 9/8/2014 001942748GBF 6

9/7/2014 9/8/2014 001942748GBF 6

9/7/2014 9/8/2014 001942748GBF 6

9/7/2014 9/8/2014 001942748GBF 6

8/24/2014 8/25/2014 001942743GBF 6

9/7/2014 9/8/2014 001942749GBF 6

Sludge Repackage Project PCB Contaminated Debris

9/7/2014 9/8/2014 001942749GBF

Article; $C=$ Container; $A C=$ Article Container, $B W=B$ Bulk Waste, $E=E q u i p m e n t$ 
Idaho National Laboratory

Advanced Mixed Waste Treatment Project (AMWTP)

PCB Waste Document Log

Removed from Service, Shipped and/or Disposed During Calendar Year 2014

Date of

Gross Net Removal

Radioactive

Type* Identification \#

adioactive

Weight Weight from

10516821

10516822

10516823

10516824

10516843

10516844

10516845

10516846

10516847

10516848

10516849

10516850

10516851

10516852

10516853

10516854

10517357

10517358

10517359

10517360

10517361

10517362

10517363

10517364

10517365

10517366

10517633

10518071

10518072

10518073

10518074

10518075

10518076

10518077

10518078

10518079

10518080

10518081
Yes Sludge Repackage Project PCB Contaminated Debris

Yes Sludge Repackage Project PCB Contaminated Debris

Yes Sludge Repackage Project PCB Contaminated Debris

Yes Sludge Repackage Project PCB Contaminated Debris

Yes Sludge Repackage Project PCB Contaminated Debris

Yes Sludge Repackage Project PCB Contaminated Debris

Yes Sludge Repackage Project PCB Contaminated Debris

Yes Sludge Repackage Project PCB Contaminated Debris

Yes Sludge Repackage Project PCB Contaminated Debris

Yes Sludge Repackage Project PCB Contaminated Debris

Yes Sludge Repackage Project PCB Contaminated Debris

Sludge Repackage Project PCB Contaminated Debris

Sludge Repackage Project PCB Contaminated Debris

Sludge Repackage Project PCB Contaminated Debris

Sludge Repackage Project PCB Contaminated Debris

Sludge Repackage Project PCB Contaminated Debris

Sludge Repackage Project PCB Contaminated Debris

Sludge Repackage Project PCB Contaminated Debris

Sludge Repackage Project PCB Contaminated Debris

Sludge Repackage Project PCB Contaminated Debris

Sludge Repackage Project PCB Contaminated Debris

Sludge Repackage Project PCB Contaminated Debris

Sludge Repackage Project PCB Contaminated Debris

Sludge Repackage Project PCB Contaminated Debris

Sludge Repackage Project PCB Contaminated Debris

Sludge Repackage Project PCB Contaminated Debris

Sludge Repackage Project PCB Contaminated Debris

Sludge Repackage Project PCB Contaminated Debris

Sludge Repackage Project PCB Contaminated Debris

Sludge Repackage Project PCB Contaminated Debris

Sludge Repackage Project PCB Contaminated Debris

Sludge Repackage Project PCB Contaminated Debris

Sludge Repackage Project PCB Contaminated Debris

Sludge Repackage Project PCB Contaminated Debris

Sludge Repackage Project PCB Contaminated Debris

Sludge Repackage Project PCB Contaminated Debris

Sludge Repackage Project PCB Contaminated Debris

Sludge Repackage Project PCB Contaminated Debris
(KGS) (KGS) Service Date

Number

$1111799 \quad 6 / 1 / 1968$

$1061 \quad 750 \quad 6 / 1 / 1968$

9/7/2014 9/8/2014 001942749GBF

$9 / 7 / 2014 \quad 9 / 8 / 2014 \quad 001942748 \mathrm{GBF} 6$

$\begin{array}{lllllll}1110 & 799 & 6 / 1 / 1968 & 9 / 7 / 2014 & 9 / 8 / 2014 & 001942748 G B F & 6\end{array}$

$\begin{array}{lllllll}1091 & 780 & 6 / 1 / 1968 & 9 / 7 / 2014 & 9 / 8 / 2014 & 001942748 \mathrm{GBF} & 6\end{array}$

$\begin{array}{lllllll} & 8119 & 6 / 1 / 1968 & 8 / 24 / 2014 & 8 / 25 / 2014 & 001942743 G B F & 6\end{array}$

$1228 \quad 917 \quad 6 / 1 / 1968 \quad 8 / 20 / 2014 \quad 8 / 21 / 2014 \quad 001942737$ GBF 6

$\begin{array}{lllllll}1143 \quad 833 & 6 / 1 / 1968 & 8 / 20 / 2014 & 8 / 21 / 2014 & 001942737 \mathrm{GBF} & 6\end{array}$

$\begin{array}{lllllll}1170 & 859 & 6 / 1 / 1968 & 8 / 20 / 2014 & 8 / 21 / 2014 & 001942737 G B F & 6\end{array}$

$\begin{array}{lllllll}1122 & 812 & 6 / 1 / 1968 & 8 / 20 / 2014 & 8 / 21 / 2014 & 001942738 \mathrm{GBF} & 6\end{array}$

$\begin{array}{llllllll}967 & 655 & 6 / 1 / 1968 & 8 / 20 / 2014 & 8 / 21 / 2014 & 001942738 G B F & 6\end{array}$

$\begin{array}{lllllll}1174 & 866 & 6 / 1 / 1968 & 8 / 20 / 2014 & 8 / 21 / 2014 & 001942738 \mathrm{GBF} & 6\end{array}$

$\begin{array}{lllllll}1152 & 841 & 6 / 1 / 1968 & 8 / 24 / 2014 & 8 / 25 / 2014 & 001942743 G B F & 6\end{array}$

$\begin{array}{lllllll}1073 & 763 & 6 / 1 / 1968 & 8 / 20 / 2014 & 8 / 21 / 2014 & 001942738 G B F & 6\end{array}$

$\begin{array}{lllllll}1199 & 889 & 6 / 1 / 1968 & 8 / 24 / 2014 & 8 / 25 / 2014 & 001942743 G B F & 6\end{array}$

$\begin{array}{lllllll}1098 & 788 & 6 / 1 / 1968 & 8 / 24 / 2014 & 8 / 25 / 2014 & 001942743 G B F & 6\end{array}$

$\begin{array}{lllllll}1152 & 841 & 6 / 1 / 1968 & 8 / 20 / 2014 & 8 / 21 / 2014 & 001942738 \mathrm{GBF} & 6\end{array}$

$\begin{array}{lllllll}986 & 678 & 6 / 1 / 1968 & 9 / 7 / 2014 & 9 / 8 / 2014 & 001942748 \mathrm{GBF} & 6\end{array}$

$\begin{array}{lllllll}1053 & 742 & 6 / 1 / 1968 & 9 / 7 / 2014 & 9 / 8 / 2014 & 001942748 G B F & 6\end{array}$

$1057 \quad 749 \quad 6 / 1 / 1968 \quad 8 / 24 / 2014 \quad 8 / 25 / 2014 \quad 001942742 \mathrm{GBF} \quad 6$

$\begin{array}{lllllll}975 & 664 & 6 / 1 / 1968 & 8 / 24 / 2014 & 8 / 25 / 2014 & 001942742 \mathrm{GBF} & 6\end{array}$

$\begin{array}{lllllll}1040 & 729 & 6 / 1 / 1968 & 8 / 24 / 2014 & 8 / 25 / 2014 & 001942743 G B F & 6\end{array}$

$\begin{array}{lllllll}1119 & 809 & 6 / 1 / 1968 & 10 / 1 / 2014 & 10 / 2 / 2014 & 001942757 \mathrm{GBF} & 6\end{array}$

$\begin{array}{lllllll}1097 & 786 & 6 / 1 / 1968 & 10 / 1 / 2014 & 10 / 2 / 2014 & 001942757 \mathrm{GBF} & 6\end{array}$

$\begin{array}{lllllll}1100 & 789 & 6 / 1 / 1968 & 10 / 1 / 2014 & 10 / 2 / 2014 & 001942757 G B F & 6\end{array}$

$\begin{array}{lllllll} & 1049 & 6 / 1 / 1968 & 9 / 7 / 2014 & 9 / 8 / 2014 & 001942748 \mathrm{GBF} & 6\end{array}$

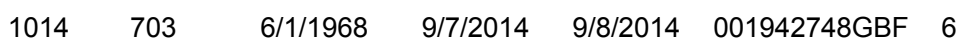

$\begin{array}{lllllll}1053 & 742 & 6 / 1 / 1968 & 10 / 1 / 2014 & 10 / 2 / 2014 & 001942757 G B F & 6\end{array}$

$1031 \quad 720 \quad 6 / 1 / 1968 \quad 10 / 12 / 2014 \quad 10 / 13 / 2014$ 001942759GBF 6

$1076 \quad 765 \quad 6 / 1 / 1968 \quad 10 / 1 / 2014 \quad 10 / 2 / 2014 \quad 001942757$ GBF 6

$\begin{array}{llllllll} & 876 & 6 / 1 / 1968 & 10 / 12 / 2014 & 10 / 13 / 2014 & 001942760 G B F & 6\end{array}$

$\begin{array}{lllllll}1070 & 759 & 6 / 1 / 1968 & 9 / 14 / 2014 & 9 / 15 / 2014 & 001942753 \mathrm{GBF} & 6\end{array}$

$\begin{array}{lllllll}1054 & 743 & 6 / 1 / 1968 & 9 / 14 / 2014 & 9 / 15 / 2014 & 001942753 G B F & 6\end{array}$

$\begin{array}{llllllll}978 & 667 & 6 / 1 / 1968 & 10 / 12 / 2014 & 10 / 13 / 2014 & 001942760 \mathrm{GBF} & 6\end{array}$

$\begin{array}{lllllll}1150 & 839 & 6 / 1 / 1968 & 9 / 14 / 2014 & 9 / 15 / 2014 & 001942753 G B F & 6\end{array}$

$1087 \quad 776 \quad 6 / 1 / 1968 \quad 10 / 12 / 2014 \quad 10 / 13 / 2014 \quad 001942759 G B F \quad 6$

$\begin{array}{lllllllll}1042 & 731 & 6 / 1 / 1968 & 10 / 12 / 2014 & 10 / 13 / 2014 & 001942759 G B F & 6\end{array}$

$1019708 \quad 6 / 1 / 1968 \quad 10 / 12 / 2014 \quad 10 / 13 / 2014 \quad 001942759$ GBF 6

$\begin{array}{llllll}1138 & 827 & 6 / 1 / 1968 & 10 / 1 / 2014 & 10 / 2 / 2014 & 001942757 G B F\end{array}$ 
Idaho National Laboratory

Advanced Mixed Waste Treatment Project (AMWTP)

PCB Waste Document Log

Removed from Service, Shipped and/or Disposed During Calendar Year 2014

Date of

Gross Net Removal

Radioactive

Type* Identification \#

\begin{tabular}{|c|c|c|c|c|c|c|c|c|c|c|}
\hline Гуре* & * Identification \# & $(\mathbf{Y} / \mathbf{N})$ & $\begin{array}{c}\text { Description } \\
\end{array}$ & (KGS) & (KGS) & Service & Date & Date & Number & Notes \\
\hline c & 10518082 & Yes & Sludge Repackage Project PCB Contaminated Debris & 1055 & 744 & $6 / 1 / 1968$ & $10 / 12 / 2014$ & $10 / 13 / 2014$ & 001942760GBF & 6 \\
\hline$c$ & 10518117 & Yes & Sludge Repackage Project РСВ Contaminated Debris & 1086 & 775 & $6 / 1 / 1968$ & $10 / 12 / 2014$ & $10 / 13 / 2014$ & $001942759 G B F$ & 6 \\
\hline c & 10518118 & Yes & Sludge Repackage Project РСВ Contaminated Debris & 1019 & 708 & 6/1/1968 & $10 / 12 / 2014$ & $10 / 13 / 2014$ & $001942759 G B F$ & 6 \\
\hline c & 10518119 & Yes & Sludge Repackage Project PCB Contaminated Debris & 1163 & 852 & $6 / 1 / 1968$ & $10 / 12 / 2014$ & $10 / 13 / 2014$ & 001942759GBF & 6 \\
\hline$c$ & 10518120 & Yes & Sludge Repackage Project PCB Contaminated Debris & 1075 & 764 & $6 / 1 / 1968$ & $10 / 12 / 2014$ & $10 / 13 / 2014$ & $001942760 G B F$ & 6 \\
\hline$c$ & 10518121 & Yes & Sludge Repackage Project РСВ Contaminated Debris & 1116 & 805 & 6/1/1968 & $10 / 1 / 2014$ & $10 / 2 / 2014$ & $001942757 G B F$ & 6 \\
\hline$c$ & 10518122 & Yes & Sludge Repackage Project PCB Contaminated Debris & 1148 & 837 & $6 / 1 / 1968$ & $10 / 12 / 2014$ & $10 / 13 / 2014$ & 001942759GBF & 6 \\
\hline$c$ & 10518123 & Yes & Sludge Repackage Project РСВ Contaminated Debris & 1173 & 862 & $6 / 1 / 1968$ & $10 / 12 / 2014$ & $10 / 13 / 2014$ & $001942760 G B F$ & 6 \\
\hline$c$ & 10518124 & Yes & Sludge Repackage Project PСВ Contaminated Debris & 1043 & 732 & $6 / 1 / 1968$ & $10 / 1 / 2014$ & $10 / 2 / 2014$ & $001942757 G B F$ & 6 \\
\hline$c$ & 10518125 & Yes & Sludge Repackage Project РСВ Contaminated Debris & 1039 & 728 & $6 / 1 / 1968$ & $10 / 12 / 2014$ & $10 / 13 / 2014$ & $001942759 G B F$ & 6 \\
\hline$c$ & 10518126 & Yes & Sludge Repackage Project PCB Contaminated Debris & 1069 & 758 & $6 / 1 / 1968$ & $10 / 12 / 2014$ & $10 / 13 / 2014$ & $001942760 \mathrm{GBF}$ & 6 \\
\hline c & 10518358 & Yes & Undefined Homogeneous Solids & 100 & 63 & $4 / 20 / 2014$ & & & & 8 \\
\hline$c$ & 10518360 & Yes & AMWTP Newly Generated Debris & 67 & 31 & $4 / 20 / 2014$ & & & & 8 \\
\hline$c$ & 10519131 & Yes & Sludge Repackage Project PCB Contaminated Debris & 1113 & 802 & 6/1/1968 & $10 / 5 / 2014$ & $10 / 6 / 2014$ & 001942758GBF & 6 \\
\hline c & 10519132 & Yes & Sludge Repackage Project РСВ Contaminated Debris & 1129 & 818 & $6 / 1 / 1968$ & $10 / 5 / 2014$ & $10 / 6 / 2014$ & 001942758GBF & 6 \\
\hline$c$ & 10519133 & Yes & Sludge Repackage Project PCB Contaminated Debris & 1216 & 905 & $6 / 1 / 1968$ & $10 / 5 / 2014$ & $10 / 6 / 2014$ & $001942758 \mathrm{GBF}$ & 6 \\
\hline$c$ & 10519134 & Yes & Sludge Repackage Project РСВ Contaminated Debris & 1115 & 804 & $6 / 1 / 1968$ & $10 / 5 / 2014$ & $10 / 6 / 2014$ & 001942758GBF & 6 \\
\hline c & 10519135 & Yes & Sludge Repackage Project РСВ Contaminated Debris & 945 & 633 & $6 / 1 / 1968$ & $10 / 5 / 2014$ & $10 / 6 / 2014$ & 001942758GBF & 6 \\
\hline$c$ & 10519136 & Yes & Sludge Repackage Project PCB Contaminated Debris & 1163 & 852 & $6 / 1 / 1968$ & $10 / 5 / 2014$ & $10 / 6 / 2014$ & $001942758 \mathrm{GBF}$ & 6 \\
\hline$c$ & 10519137 & Yes & Sludge Repackage Project РСВ Contaminated Debris & 1127 & 816 & $6 / 1 / 1968$ & $10 / 12 / 2014$ & $10 / 13 / 2014$ & $001942759 G B F$ & 6 \\
\hline c & 10519138 & Yes & Sludge Repackage Project РСВ Contaminated Debris & 1008 & 697 & $6 / 1 / 1968$ & $10 / 12 / 2014$ & $10 / 13 / 2014$ & $001942759 G B F$ & 6 \\
\hline$c$ & 10519139 & Yes & Sludge Repackage Project PCB Contaminated Debris & 1220 & 908 & $6 / 1 / 1968$ & $10 / 12 / 2014$ & $10 / 13 / 2014$ & $001942759 \mathrm{GBF}$ & 6 \\
\hline$c$ & 10519140 & Yes & Sludge Repackage Project PСВ Contaminated Debris & 1100 & 789 & $6 / 1 / 1968$ & $10 / 12 / 2014$ & $10 / 13 / 2014$ & $001942759 G B F$ & 6 \\
\hline$c$ & 10519142 & Yes & Sludge Repackage Project PCB Contaminated Debris & 1057 & 745 & 6/1/1968 & $10 / 5 / 2014$ & $10 / 6 / 2014$ & $001942758 \mathrm{GBF}$ & 6 \\
\hline$c$ & 10519616 & Yes & $\begin{array}{l}\text { CWI CH Debris from Re-packaging AMWTP RH Debris - RPT- } \\
\text { TRUW-83 IDCs }\end{array}$ & 666 & 664 & $3 / 25 / 2014$ & & & & 8 \\
\hline c & 10519623 & Yes & $\begin{array}{l}\text { CWI CH Homogenous Solids from Re-packaging AMWTP RH } \\
\text { Debris - WIPP Approved IDCs }\end{array}$ & 215 & 188 & $3 / 17 / 2014$ & & & & 8 \\
\hline$c$ & 10519632 & Yes & $\begin{array}{l}\text { CWI CH Homogenous Solids from Re-packaging AMWTP RH } \\
\text { Debris - WIPP Approved IDCs }\end{array}$ & 213 & 186 & $3 / 17 / 2014$ & & & & 8 \\
\hline$c$ & 10519634 & Yes & $\begin{array}{l}\text { CWI CH Homogenous Solids from Re-packaging AMWTP RH } \\
\text { Debris - WIPP Approved IDCs }\end{array}$ & 190 & 163 & $3 / 17 / 2014$ & & & & 8 \\
\hline z & 10519904 & Yes & Sludge Repackage Project PCB Contaminated Debris & 1089 & 777 & 6/1/1968 & $12 / 1 / 2014$ & $12 / 2 / 2014$ & 001942768GBF & 6 \\
\hline$c$ & 10519905 & Yes & Sludge Repackage Project PCB Contaminated Debris & 1131 & 819 & $6 / 1 / 1968$ & $12 / 1 / 2014$ & $12 / 2 / 2014$ & $001942768 \mathrm{GBF}$ & 6 \\
\hline$c$ & 10519906 & Yes & Sludge Repackage Project PCB Contaminated Debris & 1019 & 708 & $6 / 1 / 1968$ & $11 / 23 / 2014$ & $11 / 24 / 2014$ & $001942767 G B F$ & 6 \\
\hline 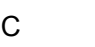 & 10519907 & Yes & Sludge Repackage Project PCB Contaminated Debris & 1206 & 894 & $6 / 1 / 1968$ & $12 / 1 / 2014$ & $12 / 2 / 2014$ & $001942768 \mathrm{GBF}$ & 6 \\
\hline 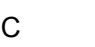 & 10519908 & Yes & Sludge Repackage Project РСВ Contaminated Debris & 1182 & 870 & $6 / 1 / 1968$ & $11 / 23 / 2014$ & $11 / 24 / 2014$ & $001942767 G B F$ & 6 \\
\hline c & 10519909 & Yes & Sludge Repackage Project PCB Contaminated Debris & 1124 & 813 & $6 / 1 / 1968$ & $11 / 23 / 2014$ & $11 / 24 / 2014$ & $001942767 G B F$ & 6 \\
\hline 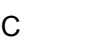 & 10519910 & Yes & Sludge Repackage Project PCB Contaminated Debris & 1097 & 786 & $6 / 1 / 1968$ & $11 / 23 / 2014$ & $11 / 24 / 2014$ & $001942767 G B F$ & 6 \\
\hline
\end{tabular}

Weight Weight from

$* A=$ Article; $C=$ Container; $A C=$ Article Container, $B W=B u l k$ Waste, $E=E q u i p m e n t$

Tuesday, March 24, 2015

Page 28 of 31 
Idaho National Laboratory

Advanced Mixed Waste Treatment Project (AMWTP)

PCB Waste Document Log

Removed from Service, Shipped and/or Disposed During Calendar Year 2014

Date of

Gross Net Removal

Radioactive

Type* Identification \#

(Y/N)

10519911

10519912

10519913

10519914

10519915

10521750

10521754

10521755

10521757

10521758

10522756

10522758

10523242

10523244

10523799

10523800

10523801

10523802

10523803

10523804

10523805

10523806

10524128

10524296

10524297

10524298

10524557

10524884

10524887

10524888

10525470

10525471

10525472

10525473

10525474

10525475

10525476

10525477
Sludge Repackage Project PCB Contaminated Debris

Sludge Repackage Project PCB Contaminated Debris

Sludge Repackage Project PCB Contaminated Debris

Sludge Repackage Project PCB Contaminated Debris

Sludge Repackage Project PCB Contaminated Debris

Sludge Repackage Project PCB Contaminated Debris

Sludge Repackage Project PCB Contaminated Debris

Sludge Repackage Project PCB Contaminated Debris

Sludge Repackage Project PCB Contaminated Debris

Sludge Repackage Project PCB Contaminated Debris

Sludge Repackage Project PCB Contaminated Debris

Sludge Repackage Project PCB Contaminated Debris

Sludge Repackage Project PCB Contaminated Debris

Sludge Repackage Project PCB Contaminated Debris Sludge Repackage Project PCB Contaminated Debris Sludge Repackage Project PCB Contaminated Debris Sludge Repackage Project PCB Contaminated Debris Sludge Repackage Project PCB Contaminated Debris Sludge Repackage Project PCB Contaminated Debris Sludge Repackage Project PCB Contaminated Debris Sludge Repackage Project PCB Contaminated Debris Sludge Repackage Project PCB Contaminated Debris RFP Debris

Sludge Repackage Project PCB Contaminated Debris Sludge Repackage Project PCB Contaminated Debris Sludge Repackage Project PCB Contaminated Debris MLLW Debris

Sludge Repackage Project PCB Contaminated Debris Sludge Repackage Project PCB Contaminated Debris Sludge Repackage Project PCB Contaminated Debris Sludge Repackage Project PCB Contaminated Debris Sludge Repackage Project PCB Contaminated Debris Sludge Repackage Project PCB Contaminated Debris Sludge Repackage Project PCB Contaminated Debris Sludge Repackage Project PCB Contaminated Debris Sludge Repackage Project PCB Contaminated Debris Sludge Repackage Project PCB Contaminated Debris Sludge Repackage Project PCB Contaminated Debris
Weight Weight from

(KGS) (KGS) Service

ansp Date Date

Date

Number

$\begin{array}{llllll}1281 & 969 & 6 / 1 / 1968 & 12 / 1 / 2014 & 12 / 2 / 2014 & 001942768 G B F\end{array}$

$1197 \quad 885-6 / 1 / 1968-12 / 1 / 2014 \quad 12 / 2 / 2014 \quad 001942768 G B F$

$1046 \quad 734 \quad 6 / 1 / 1968 \quad 11 / 23 / 2014 \quad 11 / 24 / 2014$ 001942767GBF 6

$\begin{array}{lllllll}1105 & 793 & 6 / 1 / 1968 & 12 / 1 / 2014 & 12 / 2 / 2014 & 001942768 G B F & 6\end{array}$

$\begin{array}{lllllll}1110 & 798 & 6 / 1 / 1968 & 12 / 1 / 2014 & 12 / 2 / 2014 & 001942768 G B F & 6\end{array}$

$\begin{array}{lllllll}1183 & 875 & 6 / 1 / 1968 & 12 / 7 / 2014 & 12 / 8 / 2014 & 001942810 \mathrm{GBF} & 6\end{array}$

$\begin{array}{lllllll}1237 & 925 & 6 / 1 / 1968 & 12 / 7 / 2014 & 12 / 8 / 2014 & 001942810 \mathrm{GBF} & 6\end{array}$

$\begin{array}{lllllll}1135 & 824 & 6 / 1 / 1968 & 12 / 7 / 2014 & 12 / 8 / 2014 & 001942810 G B F & 6\end{array}$

$\begin{array}{lllllll}1049 & 737 & 6 / 1 / 1968 & 12 / 7 / 2014 & 12 / 8 / 2014 & 001942810 \mathrm{GBF} & 6\end{array}$

$\begin{array}{lllllll}1052 & 742 & 6 / 1 / 1968 & 12 / 7 / 2014 & 12 / 8 / 2014 & 001942810 \mathrm{GBF} & 6\end{array}$

$\begin{array}{lllllll}1083 & 775 & 6 / 1 / 1968 & 12 / 7 / 2014 & 12 / 8 / 2014 & 001942810 G B F & 6\end{array}$

$\begin{array}{lllllll}1236 & 926 & 6 / 1 / 1968 & 12 / 7 / 2014 & 12 / 8 / 2014 & 001942810 \mathrm{GBF} & 6\end{array}$

$\begin{array}{lllllll}1121 & 813 & 6 / 1 / 1968 & 12 / 1 / 2014 & 12 / 2 / 2014 & 001942804 \mathrm{GBF} & 6\end{array}$

$1190 \quad 882 \quad 6 / 1 / 1968 \quad 12 / 1 / 2014 \quad 12 / 2 / 2014 \quad 001942804 \mathrm{GBF} \quad 6$

$\begin{array}{lllllll}1263 & 953 & 6 / 1 / 1968 & 12 / 1 / 2014 & 12 / 2 / 2014 & 001942804 \mathrm{GBF} & 6\end{array}$

$\begin{array}{lllllll}1122 & 812 & 6 / 1 / 1968 & 12 / 7 / 2014 & 12 / 8 / 2014 & 001942810 \mathrm{GBF} & 6\end{array}$

$\begin{array}{lllllll}1255 & 944 & 6 / 1 / 1968 & 12 / 1 / 2014 & 12 / 2 / 2014 & 001942804 \mathrm{GBF} & 6\end{array}$

$\begin{array}{lllllll}1210 & 900 & 6 / 1 / 1968 & 12 / 7 / 2014 & 12 / 8 / 2014 & 001942810 G B F & 6\end{array}$

$\begin{array}{lllllll}1185 & 878 & 6 / 1 / 1968 & 12 / 1 / 2014 & 12 / 2 / 2014 & 001942804 G B F & 6\end{array}$

$\begin{array}{lllllll}1133 & 821 & 6 / 1 / 1968 & 12 / 7 / 2014 & 12 / 8 / 2014 & 001942810 \mathrm{GBF} & 6\end{array}$

$\begin{array}{lllllll}1173 & 863 & 6 / 1 / 1968 & 12 / 1 / 2014 & 12 / 2 / 2014 & 001942804 \mathrm{GBF} & 6\end{array}$

$\begin{array}{lllllll}1275 & 965 & 6 / 1 / 1968 & 12 / 1 / 2014 & 12 / 2 / 2014 & 001942804 \mathrm{GBF} & 6\end{array}$

$\begin{array}{llllll}1559 & 1369 \quad 6 / 17 / 2014 & 12\end{array}$

$\begin{array}{lllllll}1179 & 871 & 6 / 1 / 1968 & 12 / 1 / 2014 & 12 / 2 / 2014 & 001942768 G B F & 6\end{array}$

$\begin{array}{lllllll}1305 & 995 & 6 / 1 / 1968 & 12 / 7 / 2014 & 12 / 8 / 2014 & 001942810 \mathrm{GBF} & 6\end{array}$

$\begin{array}{lllllll} & 916 & 6 / 1 / 1968 & 12 / 7 / 2014 & 12 / 8 / 2014 & 001942810 G B F & 6\end{array}$

$753 \quad 434 \quad 6 / 24 / 2014$

$\begin{array}{lllllll}1143 & 833 & 6 / 1 / 1968 & 12 / 7 / 2014 & 12 / 8 / 2014 & 001942810 G B F & 6\end{array}$

$1221909 \quad 6 / 1 / 1968 \quad 12 / 1 / 2014 \quad 12 / 2 / 2014 \quad 001942768 G B F \quad 6$

$\begin{array}{lllllll}1177 & 865 & 6 / 1 / 1968 & 12 / 7 / 2014 & 12 / 8 / 2014 & 001942810 G B F & 6\end{array}$

$\begin{array}{lllllll}1224 & 912 & 6 / 1 / 1968 & 12 / 1 / 2014 & 12 / 2 / 2014 & 001942804 G B F & 6\end{array}$

$\begin{array}{llllll}1116 & 804 & 6 / 1 / 1968 & 12 / 1 / 2014 & 12 / 2 / 2014 & 001942804 G B F\end{array}$

$\begin{array}{lllllll}1266 & 954 & 6 / 1 / 1968 & 12 / 1 / 2014 & 12 / 2 / 2014 & 001942804 \mathrm{GBF} & 6\end{array}$

$\begin{array}{lllllll}1304 & 994 & 6 / 1 / 1968 & 12 / 1 / 2014 & 12 / 2 / 2014 & 001942804 \mathrm{GBF} & 6\end{array}$

$\begin{array}{lllllll}1353 & 1042 & 6 / 1 / 1968 & 12 / 1 / 2014 & 12 / 2 / 2014 & 001942804 G B F & 6\end{array}$

$\begin{array}{lllllll}1171 & 859 & 6 / 1 / 1968 & 12 / 1 / 2014 & 12 / 2 / 2014 & 001942804 \mathrm{GBF} & 6\end{array}$

$\begin{array}{lllllll}1165 & 854 & 6 / 1 / 1968 & 12 / 1 / 2014 & 12 / 2 / 2014 & 001942768 \mathrm{GBF} & 6\end{array}$

$\begin{array}{lllllll}1234 & 923 & 6 / 1 / 1968 & 12 / 1 / 2014 & 12 / 2 / 2014 & 001942768 G B F & 6\end{array}$ 


\section{Idaho National Laboratory \\ Advanced Mixed Waste Treatment Project (AMWTP) \\ PCB Waste Document Log}

Removed from Service, Shipped and/or Disposed During Calendar Year 2014

Date of

Gross Net Removal

Radioactive

Type* Identification \#

Yes

$\begin{array}{lll}\text { Weight Weight } & \text { from } \\ \text { (KGS) } & \text { (KGS) } & \text { Service }\end{array}$

Transport Disposal Manifest

$\begin{array}{lllccccc}\text { KGS } & \text { (KGS) } & \text { Service } & \text { Date } & \text { Date } & \text { Number } & \text { Notes } \\ 1138 & 827 & 6 / 1 / 1968 & 12 / 1 / 2014 & 12 / 2 / 2014 & 001942804 \mathrm{GBF} & 6\end{array}$

Yes Sludge Repackage Project PCB Contaminated Debris

Sludge Repackage Project PCB Contaminated Debris

12/1/2014 12/2/2014 001942804GBF

$\begin{array}{lllllll}1208 & 897 & 6 / 1 / 1968 & 12 / 1 / 2014 & 12 / 2 / 2014 & 001942768 G B F & 6\end{array}$

$\begin{array}{lllllll}1210 & 900 & 6 / 1 / 1968 & 12 / 1 / 2014 & 12 / 2 / 2014 & 001942768 G B F & 6\end{array}$

10525481

10525589

10527413

Sludge Repackage Project PCB Contaminated Debris

$1180 \quad 870 \quad 6 / 1 / 1968$ MLLW PCB Debris

10527414

10528894

10528990

10528993

10529048

10530386

10530387

10530388

10530389

10530552

10530554

10531981

10532030

10532312

10533040

10533055

10534200

10534324

Sludge Repackage Project PCB Contaminated Debris Sludge Repackage Project PCB Contaminated Debris MLLW PCB Debris Generated from Offsite Waste

MLLW PCB Debris Generated from Offsite Waste

Sludge Repackage Project PCB Contaminated Debris

12/1/2014 12/2/2014 001942768GBF 6

$\begin{array}{llll}81 & 54 & 7 / 10 / 2014 & 10\end{array}$

$\begin{array}{lllllll}1317 & 1009 & 6 / 1 / 1968 & 12 / 4 / 2014 & 12 / 18 / 2014 & 001942809 G B F & 6\end{array}$

$\begin{array}{lllllll}1100 & 792 & 6 / 1 / 1968 & 12 / 4 / 2014 & 12 / 18 / 2014 & 001942809 G B F & 6\end{array}$

$\begin{array}{llll}540 & 221 & 9 / 3 / 2014 & 10\end{array}$

$549-230-9 / 4 / 2014$

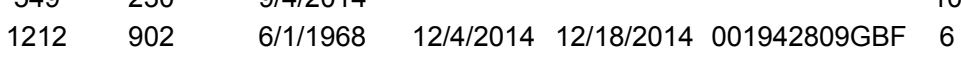

Yes RFP Debris

WMF-676 PCB Contaminated Debris

WMF-676 PCB Contaminated Debris

WMF-676 PCB Contaminated Debris

WMF-676 PCB Contaminated Debris

WMF-676 PCB Contaminated Debris

Undefined Homogeneous Solids

RFP Debris

WMF-676 PCB Contaminated Debris

RFP Debris

Pre-1980 INL-Exhumed SDA Soil

MLLW PCB Debris

Pre-1980 INL-Exhumed SDA Soil

RFP Debris

10534862

AMWT140010

RFP Debris

AMWTP Lab Packs

BN10533378

MLLW Supercompacted Debris

BN10533379

MLLW Supercompacted Debris

BN10534846

Yes

MLLW Supercompacted Debris

$1415 \quad 1224 \quad 9 / 17 / 2014$

$241 \quad 205 \quad 10 / 11 / 2014$

$125 \quad 89 \quad 10 / 11 / 2014$

$51 \quad 15 \quad 10 / 11 / 2014$

$79 \quad 43 \quad 10 / 11 / 2014$

$\begin{array}{lll}67 & 31 & 9 / 28 / 2014\end{array}$

$85 \quad 49 \quad 9 / 28 / 2014$

$1492 \quad 1301 \quad 10 / 9 / 2014$

$131 \quad 95 \quad 10 / 5 / 2014$

$1477 \quad 1287 \quad 10 / 18 / 2014$

$270 \quad 161 \quad 10 / 30 / 2014$

$549 \quad 230 \quad 10 / 31 / 2014$

$1593 \quad 1573 \quad 11 / 12 / 2014$

$1147 \quad 957 \quad 11 / 15 / 2014$

$\begin{array}{ccc}812 & 621 & 11 / 23 / 2014 \\ 4 & 2 & 1 / 22 / 2014\end{array}$

$202 \quad 145 \quad 11 / 2 / 2014$

$377 \quad 320 \quad 11 / 2 / 2014$

$401 \quad 344 \quad 11 / 22 / 2014$

2/20/2014 3/14/2014 001943013GBF

10

10 
Idaho National Laboratory

Advanced Mixed Waste Treatment Project (AMWTP)

PCB Waste Document Log

Removed from Service, Shipped and/or Disposed During Calendar Year 2014

Grand Total placed in storage in 2014 (out of service date in 2014)

Total number of Articles (A) placed in storage

Total number of Containers $(C)$ placed in storage

Total number of Article Containers (AC) placed in storage

Total number of Bulk Waste (BW) placed in storage

Total number of Equipment (E) placed in storage

Grand Total shipped, disposed, or removed from service

Grand Total placed in storage in 2014 and still in storage at end of 2014

Total number of Articles (A) in storage

Total number of Containers $(C)$ in storage

Total number of Article Containers (AC) in storage

Total number of Bulk Waste (BW) in storage

Total number of Equipment (E) in storage

Grand Total shipped for disposal in 2014 but not disposed at end of 2014

Total number of Articles (A) shipped

Total number of Containers (C) shipped

Total number of Article Containers (AC) shipped

Total number of Bulk Waste (BW) shipped

Total number of Equipment (E) shipped

Grand Total disposed in 2014

Total number of Articles (A) disposed

Total number of Containers (C) disposed

Total number of Article Containers (AC) disposed

Total number of Bulk Waste (BW) disposed

Total number of Equipment (E) disposed

$\begin{array}{rrr}46 & \text { Total Gross Weight : } & 24,085 \\ \text { 0 } & \text { Total Gross Weight : } & 0 \\ 46 & \text { Total Gross Weight : } & \mathbf{2 4 , 0 8 5} \\ \text { 0 } & \text { Total Gross Weight : } & 0 \\ 0 & \text { Total Gross Weight : } & 0 \\ 0 & \text { Total Gross Weight : } & 0\end{array}$

Total Net Weight : $\quad 19,715$

Total Net Weight :

Total Net Weight : $\quad 19,715$

Total Net Weight :

Total Net Weight :

Total Net Weight :

1128 Total Gross Weight : $560,087 \quad$ Total Net Weight : $\quad 385,480$

45 Total Gross Weight : $24,081 \quad$ Total Net Weight : 19,713

o Total Gross Weight:

45 Total Gross Weight : 24,081

Total Gross Weight :

T Total Gross Weight :

0 Total Gross Weight :

124 Total Gross Weight : $\quad 16,840$

( Total Gross Weight :

Total Net Weight :

19,713

Total Net Weight :

Total Net Weight :

Total Net Weight :

Total Net Weight :

Total Net Weight :

124 Total Gross Weight :

0 Total Gross Weight :

o Total Gross Weight :

0 Total Gross Weight :

959 Total Gross Weight : 519,166

0 Total Gross Weight :

959 Total Gross Weight : 519,166

0 Total Gross Weight :

o Total Gross Weight :

0 Total Gross Weight :

Total Net Weight :

Total Net Weight :

Total Net Weight :

Total Net Weight :

Total Net Weight : $\quad 356,303$

Total Net Weight :

Total Net Weight : $\quad 356,303$

Total Net Weight : $\quad 0$

Total Net Weight : $\quad 0$

Total Net Weight :

0
3
0
0
0
0
0
0
0
0
0
0
0
0

Total Weight. Weights are rounded to the nearest kilogram, except where the container weight is less than $0.5 \mathrm{Kg}$

Note 1: Container description updated from the previous report.

Note 2: Container net weight changed from the previous report.

Note 3: Container gross weight changed from the previous report.

Note 4: Date of removal from service was corrected from the date listed on the previous report to the oldest known date.

Note 5: The removal-from-service date listed on the shipping manifest for this container was incorrect. However, the removal-from-service date listed in this report for this container is correct.

Note 6: The waste in this container is comprised of secondary waste resulting from the repackaging operations performed in 2014 by the Accelerated Retrieval Project at the RWMC.

Note 7: This container resulted from sludge repackaging operations performed in 2014 by the Accelerated Retrieval Project at RMWC.

Note 8: Identified as a PCB Container during characterization performed during 2014.

Note 9: Identified as a PCB Container during characterization performed prior to 2014, but was inadvertantly omitted from the previous report.

Note 10: PCB Container contains waste generated in 2014 from the management of legacy PCB Wastes.

Note 11: Container was retrieved from the waste stack in 2014. Based on Acceptable Knowledge, a conservative removal-from-service date of 12/27/1971 was applied.

Note 12: Container was retrieved from the waste stack in 2014. Based on a lack of Acceptable Knowledge, the date of retrieval was applied as the removal-from-service date.

Note 13: Date of removal from service was taken from the original container during a repackaging operation performed in 2014.

NOTE: All of the above notes may not apply to this report. 
2.3 Waste Repackaged during Calendar Year 2014

The following table is included in order to document containers that were previously in inventory, but have been repackaged into another container.

This section is separated into two parts, INL without Advanced Mixed Waste Treatment Project (AMWTP) and AMWTP. 
Idaho National Laboratory

(excluding Advanced Mixed Waste Treatment Project [AMWTP])

PCB Waste Document Log

Repackaged in 2014

\begin{tabular}{|c|c|c|c|c|}
\hline Identification \# & $\begin{array}{c}\text { Radioactive } \\
\text { (Yes/No) }\end{array}$ & $\begin{array}{l}\text { Generating } \\
\text { Facility }\end{array}$ & Waste Name & $\begin{array}{l}\text { Receiving } \\
\text { Container(s) }\end{array}$ \\
\hline $05-12-291-006-\mathrm{F}$ & No & NRF & PCB Ballasts & NRF140042 \\
\hline 05-12-291-026-F & Yes & NRF & PCB Ballasts & NRF140047 \\
\hline 10015144 & Yes & AMWTP & ID-RF-S3114 Organic Sludge for Repackaging & see note 1 \\
\hline 10016120 & Yes & AMWTP & ID-RF-S3114 Organic Sludge for Repackaging & see note 1 \\
\hline 10018106 & Yes & AMWTP & ID-RF-S3114 Organic Sludge for Repackaging & see note 1 \\
\hline 10020657 & Yes & AMWTP & ID-RF-S3114 Organic Sludge for Repackaging & see note 1 \\
\hline 10020665 & Yes & AMWTP & ID-RF-S3114 Organic Sludge for Repackaging & see note 1 \\
\hline 10020695 & Yes & AMWTP & ID-RF-S3114 Organic Sludge for Repackaging & see note 1 \\
\hline 10020715 & Yes & AMWTP & ID-RF-S3114 Organic Sludge for Repackaging & see note 1 \\
\hline 10022163 & Yes & AMWTP & ID-RF-S3114 Organic Sludge for Repackaging & see note 1 \\
\hline 10023906 & Yes & AMWTP & ID-RF-S3114 Organic Sludge for Repackaging & see note 1 \\
\hline 10024322 & Yes & AMWTP & ID-RF-S3114 Organic Sludge for Repackaging & see note 1 \\
\hline 10024330 & Yes & AMWTP & ID-RF-S3114 Organic Sludge for Repackaging & see note 1 \\
\hline 10025099 & Yes & AMWTP & ID-RF-S3114 Organic Sludge for Repackaging & see note 1 \\
\hline 10025458 & Yes & AMWTP & ID-RF-S3114 Organic Sludge for Repackaging & see note 1 \\
\hline 10025523 & Yes & AMWTP & ID-RF-S3114 Organic Sludge for Repackaging & see note 1 \\
\hline 10073715 & Yes & AMWTP & ID-RF-S3114 Organic Sludge for Repackaging & see note 1 \\
\hline 10089783 & Yes & AMWTP & ID-RF-S3114 Organic Sludge for Repackaging & see note 1 \\
\hline 10107182 & Yes & AMWTP & ID-RF-S3114 Organic Sludge for Repackaging & see note 1 \\
\hline 10127011 & Yes & AMWTP & ID-RF-S3114 Organic Sludge for Repackaging & see note 1 \\
\hline 10144370 & Yes & AMWTP & ID-RF-S3114 Organic Sludge for Repackaging & see note 1 \\
\hline 10145339 & Yes & AMWTP & ID-RF-S3114 Organic Sludge for Repackaging & see note 1 \\
\hline 10146880 & Yes & AMWTP & ID-RF-S3114 Organic Sludge for Repackaging & see note 1 \\
\hline 10147195 & Yes & AMWTP & ID-RF-S3114 Organic Sludge for Repackaging & see note 1 \\
\hline 10151474 & Yes & AMWTP & ID-RF-S3114 Organic Sludge for Repackaging & see note 1 \\
\hline 10152960 & Yes & AMWTP & ID-RF-S3114 Organic Sludge for Repackaging & see note 1 \\
\hline 10153755 & Yes & AMWTP & ID-RF-S3114 Organic Sludge for Repackaging & see note 1 \\
\hline 10154789 & Yes & AMWTP & ID-RF-S3114 Organic Sludge for Repackaging & see note 1 \\
\hline 10158383 & Yes & AMWTP & ID-RF-S3114 Organic Sludge for Repackaging & see note 1 \\
\hline 10161218 & Yes & AMWTP & ID-RF-S3114 Organic Sludge for Repackaging & see note 1 \\
\hline 10162648 & Yes & AMWTP & ID-RF-S3114 Organic Sludge for Repackaging & see note 1 \\
\hline 10163761 & Yes & AMWTP & ID-RF-S3114 Organic Sludge for Repackaging & see note 1 \\
\hline 10167120 & Yes & AMWTP & ID-RF-S3114 Organic Sludge for Repackaging & see note 1 \\
\hline 10167830 & Yes & AMWTP & ID-RF-S3114 Organic Sludge for Repackaging & see note 1 \\
\hline 10177722 & Yes & AMWTP & ID-RF-S3114 Organic Sludge for Repackaging & see note 1 \\
\hline 10191983 & Yes & AMWTP & ID-RF-S3114 Organic Sludge for Repackaging & see note 1 \\
\hline 10196304 & Yes & AMWTP & ID-RF-S3114 Organic Sludge for Repackaging & see note 1 \\
\hline 10200318 & Yes & AMWTP & ID-RF-S3114 Organic Sludge for Repackaging & see note 1 \\
\hline 10221196 & Yes & AMWTP & ID-RF-S3114 Organic Sludge for Repackaging & see note 1 \\
\hline 10223349 & Yes & AMWTP & ID-RF-S3114 Organic Sludge for Repackaging & see note 1 \\
\hline 10223350 & Yes & AMWTP & ID-RF-S3114 Organic Sludge for Repackaging & see note 1 \\
\hline
\end{tabular}

Tuesday, May 12, 2015 
Idaho National Laboratory

(excluding Advanced Mixed Waste Treatment Project [AMWTP])

PCB Waste Document Log

Repackaged in 2014

Identification \# Radioactive Generating Waste Name Receiving

\begin{tabular}{|c|c|c|c|c|}
\hline 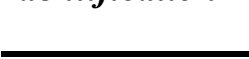 & $(\mathrm{Yes} / \mathrm{No})$ & Facility & & Container(s) \\
\hline 10242707 & Yes & AMWTP & ID-RF-S3114 Organic Sludge for Repackaging & see note 1 \\
\hline 10255791 & Yes & AMWTP & ID-RF-S3114 Organic Sludge for Repackaging & see note 1 \\
\hline 10268008 & Yes & AMWTP & ID-RF-S3114 Organic Sludge for Repackaging & see note 1 \\
\hline 10268227 & Yes & AMWTP & ID-RF-S3114 Organic Sludge for Repackaging & see note 1 \\
\hline 10288394 & Yes & AMWTP & ID-RF-S3114 Organic Sludge for Repackaging & see note 1 \\
\hline 10289864 & Yes & AMWTP & ID-RF-S3114 Organic Sludge for Repackaging & see note 1 \\
\hline 10291345 & Yes & AMWTP & ID-RF-S3114 Organic Sludge for Repackaging & see note 1 \\
\hline 10291351 & Yes & AMWTP & ID-RF-S3114 Organic Sludge for Repackaging & see note 1 \\
\hline 10301121 & Yes & AMWTP & ID-RF-S3114 Organic Sludge for Repackaging & see note 1 \\
\hline 10303225 & Yes & AMWTP & ID-RF-S3114 Organic Sludge for Repackaging & see note 1 \\
\hline 10305492 & Yes & AMWTP & ID-RF-S3114 Organic Sludge for Repackaging & see note 1 \\
\hline 10306568 & Yes & AMWTP & ID-RF-S3114 Organic Sludge for Repackaging & see note 1 \\
\hline 10309652 & Yes & AMWTP & ID-RF-S3114 Organic Sludge for Repackaging & see note 1 \\
\hline 10309676 & Yes & AMWTP & ID-RF-S3114 Organic Sludge for Repackaging & see note 1 \\
\hline 10310102 & Yes & AMWTP & ID-RF-S3114 Organic Sludge for Repackaging & see note 1 \\
\hline 10310143 & Yes & AMWTP & ID-RF-S3114 Organic Sludge for Repackaging & see note 1 \\
\hline 10310310 & Yes & AMWTP & ID-RF-S3114 Organic Sludge for Repackaging & see note 1 \\
\hline 10310412 & Yes & AMWTP & ID-RF-S3114 Organic Sludge for Repackaging & see note 1 \\
\hline 10310467 & Yes & AMWTP & ID-RF-S3114 Organic Sludge for Repackaging & see note 1 \\
\hline 10311047 & Yes & AMWTP & ID-RF-S3114 Organic Sludge for Repackaging & see note 1 \\
\hline 10311057 & Yes & AMWTP & ID-RF-S3114 Organic Sludge for Repackaging & see note 1 \\
\hline 10312126 & Yes & AMWTP & ID-RF-S3114 Organic Sludge for Repackaging & see note 1 \\
\hline 10313908 & Yes & AMWTP & ID-RF-S3114 Organic Sludge for Repackaging & see note 1 \\
\hline 10313910 & Yes & AMWTP & ID-RF-S3114 Organic Sludge for Repackaging & see note 1 \\
\hline 10313955 & Yes & AMWTP & ID-RF-S3114 Organic Sludge for Repackaging & see note 1 \\
\hline 10313957 & Yes & AMWTP & ID-RF-S3114 Organic Sludge for Repackaging & see note 1 \\
\hline 10313961 & Yes & AMWTP & ID-RF-S3114 Organic Sludge for Repackaging & see note 1 \\
\hline 10313967 & Yes & AMWTP & ID-RF-S3114 Organic Sludge for Repackaging & see note 1 \\
\hline 10314011 & Yes & AMWTP & ID-RF-S3114 Organic Sludge for Repackaging & see note 1 \\
\hline 10314021 & Yes & AMWTP & ID-RF-S3114 Organic Sludge for Repackaging & see note 1 \\
\hline 10320816 & Yes & AMWTP & ID-RF-S3114 Organic Sludge for Repackaging & see note 1 \\
\hline 10322758 & Yes & AMWTP & ID-RF-S3114 Organic Sludge for Repackaging & see note 1 \\
\hline 10325681 & Yes & AMWTP & ID-RF-S3114 Organic Sludge for Repackaging & see note 1 \\
\hline 10326220 & Yes & AMWTP & ID-RF-S3114 Organic Sludge for Repackaging & see note 1 \\
\hline 10326602 & Yes & AMWTP & ID-RF-S3114 Organic Sludge for Repackaging & see note 1 \\
\hline 10326608 & Yes & AMWTP & ID-RF-S3114 Organic Sludge for Repackaging & see note 1 \\
\hline 10326620 & Yes & AMWTP & ID-RF-S3114 Organic Sludge for Repackaging & see note 1 \\
\hline 10328089 & Yes & AMWTP & ID-RF-S3114 Organic Sludge for Repackaging & see note 1 \\
\hline 10330032 & Yes & AMWTP & ID-RF-S3114 Organic Sludge for Repackaging & see note 1 \\
\hline 10333901 & Yes & AMWTP & ID-RF-S3114 Organic Sludge for Repackaging & see note 1 \\
\hline 10335420 & Yes & AMWTP & ID-RF-S3114 Organic Sludge for Repackaging & see note 1 \\
\hline
\end{tabular}

Tuesday, May 12, 2015 
Idaho National Laboratory

(excluding Advanced Mixed Waste Treatment Project [AMWTP])

PCB Waste Document Log

Repackaged in 2014

Identification \# Radioactive Generating Waste Name Receiving

\begin{tabular}{|c|c|c|c|c|}
\hline 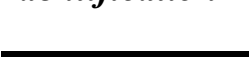 & $(\mathrm{Yes} / \mathrm{No})$ & Facility & & Container(s) \\
\hline 10335426 & Yes & AMWTP & ID-RF-S3114 Organic Sludge for Repackaging & see note 1 \\
\hline 10335428 & Yes & AMWTP & ID-RF-S3114 Organic Sludge for Repackaging & see note 1 \\
\hline 10336333 & Yes & AMWTP & ID-RF-S3114 Organic Sludge for Repackaging & see note 1 \\
\hline 10338175 & Yes & AMWTP & ID-RF-S3114 Organic Sludge for Repackaging & see note 1 \\
\hline 10339180 & Yes & AMWTP & ID-RF-S3114 Organic Sludge for Repackaging & see note 1 \\
\hline 10339210 & Yes & AMWTP & ID-RF-S3114 Organic Sludge for Repackaging & see note 1 \\
\hline 10340540 & Yes & AMWTP & ID-RF-S3114 Organic Sludge for Repackaging & see note 1 \\
\hline 10340593 & Yes & AMWTP & ID-RF-S3114 Organic Sludge for Repackaging & see note 1 \\
\hline 10341312 & Yes & AMWTP & ID-RF-S3114 Organic Sludge for Repackaging & see note 1 \\
\hline 10341327 & Yes & AMWTP & ID-RF-S3114 Organic Sludge for Repackaging & see note 1 \\
\hline 10341850 & Yes & AMWTP & ID-RF-S3114 Organic Sludge for Repackaging & see note 1 \\
\hline 10343659 & Yes & AMWTP & ID-RF-S3114 Organic Sludge for Repackaging & see note 1 \\
\hline 10344085 & Yes & AMWTP & ID-RF-S3114 Organic Sludge for Repackaging & see note 1 \\
\hline 10344124 & Yes & AMWTP & ID-RF-S3114 Organic Sludge for Repackaging & see note 1 \\
\hline 10345376 & Yes & AMWTP & ID-RF-S3114 Organic Sludge for Repackaging & see note 1 \\
\hline 10345434 & Yes & AMWTP & ID-RF-S3114 Organic Sludge for Repackaging & see note 1 \\
\hline 10351610 & Yes & AMWTP & ID-RF-S3114 Organic Sludge for Repackaging & see note 1 \\
\hline 10352470 & Yes & AMWTP & ID-RF-S3114 Organic Sludge for Repackaging & see note 1 \\
\hline 10355846 & Yes & AMWTP & ID-RF-S3114 Organic Sludge for Repackaging & see note 1 \\
\hline 10358141 & Yes & AMWTP & ID-RF-S3114 Organic Sludge for Repackaging & see note 1 \\
\hline 10359478 & Yes & AMWTP & ID-RF-S3114 Organic Sludge for Repackaging & see note 1 \\
\hline 10362266 & Yes & AMWTP & ID-RF-S3114 Organic Sludge for Repackaging & see note 1 \\
\hline 10366243 & Yes & AMWTP & ID-RF-S3114 Organic Sludge for Repackaging & see note 1 \\
\hline 10372284 & Yes & AMWTP & ID-RF-S3114 Organic Sludge for Repackaging & see note 1 \\
\hline 10388542 & Yes & AMWTP & ID-RF-S3114 Organic Sludge for Repackaging & see note 1 \\
\hline 10397078 & Yes & AMWTP & ID-RF-S3114 Organic Sludge for Repackaging & see note 1 \\
\hline 10402660 & Yes & AMWTP & ID-RF-S3114 Organic Sludge for Repackaging & see note 1 \\
\hline 10408222 & Yes & AMWTP & ID-RF-S3114 Organic Sludge for Repackaging & see note 1 \\
\hline 10414420 & Yes & AMWTP & ID-RF-S3114 Organic Sludge for Repackaging & see note 1 \\
\hline 10416208 & Yes & AMWTP & ID-RF-S3114 Organic Sludge for Repackaging & see note 1 \\
\hline 10416210 & Yes & AMWTP & ID-RF-S3114 Organic Sludge for Repackaging & see note 1 \\
\hline 10417151 & Yes & AMWTP & ID-RF-S3114 Organic Sludge for Repackaging & see note 1 \\
\hline 10418340 & Yes & AMWTP & ID-RF-S3114 Organic Sludge for Repackaging & see note 1 \\
\hline 10503128 & Yes & AMWTP & ID-RF-S3114 Organic Sludge for Repackaging & see note 1 \\
\hline 10503132 & Yes & AMWTP & ID-RF-S3114 Organic Sludge for Repackaging & see note 1 \\
\hline 10503133 & Yes & AMWTP & ID-RF-S3114 Organic Sludge for Repackaging & see note 1 \\
\hline 10504398 & Yes & AMWTP & ID-RF-S3114 Organic Sludge for Repackaging & see note 1 \\
\hline 10504407 & Yes & AMWTP & ID-RF-S3114 Organic Sludge for Repackaging & see note 1 \\
\hline 10504410 & Yes & AMWTP & ID-RF-S3114 Organic Sludge for Repackaging & see note 1 \\
\hline 10504974 & Yes & AMWTP & ID-RF-S3114 Organic Sludge for Repackaging & see note 1 \\
\hline 10505183 & Yes & AMWTP & ID-RF-S3114 Organic Sludge for Repackaging & see note 1 \\
\hline
\end{tabular}

Tuesday, May 12, 2015 
Idaho National Laboratory

(excluding Advanced Mixed Waste Treatment Project [AMWTP])

PCB Waste Document Log

Repackaged in 2014

Identification \# Radioactive Generating Waste Name Receiving

\begin{tabular}{|c|c|c|c|c|}
\hline 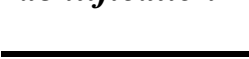 & $($ Yes/No) & Facility & & Container(s) \\
\hline 10505202 & Yes & AMWTP & ID-RF-S3114 Organic Sludge for Repackaging & see note 1 \\
\hline 10505620 & Yes & AMWTP & ID-RF-S3114 Organic Sludge for Repackaging & see note 1 \\
\hline 10506087 & Yes & AMWTP & ID-RF-S3114 Organic Sludge for Repackaging & see note 1 \\
\hline 10506092 & Yes & AMWTP & ID-RF-S3114 Organic Sludge for Repackaging & see note 1 \\
\hline 10506093 & Yes & AMWTP & ID-RF-S3114 Organic Sludge for Repackaging & see note 1 \\
\hline 10506094 & Yes & AMWTP & ID-RF-S3114 Organic Sludge for Repackaging & see note 1 \\
\hline 10506407 & Yes & AMWTP & ID-RF-S3114 Organic Sludge for Repackaging & see note 1 \\
\hline 10507793 & Yes & AMWTP & ID-RF-S3114 Organic Sludge for Repackaging & see note 1 \\
\hline 10507796 & Yes & AMWTP & ID-RF-S3114 Organic Sludge for Repackaging & see note 1 \\
\hline 10507797 & Yes & AMWTP & ID-RF-S3114 Organic Sludge for Repackaging & see note 1 \\
\hline 10507798 & Yes & AMWTP & ID-RF-S3114 Organic Sludge for Repackaging & see note 1 \\
\hline 10507799 & Yes & AMWTP & ID-RF-S3114 Organic Sludge for Repackaging & see note 1 \\
\hline 10507800 & Yes & AMWTP & ID-RF-S3114 Organic Sludge for Repackaging & see note 1 \\
\hline 10507802 & Yes & AMWTP & ID-RF-S3114 Organic Sludge for Repackaging & see note 1 \\
\hline 10507803 & Yes & AMWTP & ID-RF-S3114 Organic Sludge for Repackaging & see note 1 \\
\hline 10509352 & Yes & AMWTP & ID-RF-S3114 Organic Sludge for Repackaging & see note 1 \\
\hline 10509806 & Yes & AMWTP & ID-RF-S3114 Organic Sludge for Repackaging & see note 2 \\
\hline 10509863 & Yes & AMWTP & ID-RF-S3114 Organic Sludge for Repackaging & see note 2 \\
\hline 10510752 & Yes & AMWTP & ID-RF-S3114 Organic Sludge for Repackaging & see note 2 \\
\hline 10510753 & Yes & AMWTP & ID-RF-S3114 Organic Sludge for Repackaging & see note 2 \\
\hline 10510754 & Yes & AMWTP & ID-RF-S3114 Organic Sludge for Repackaging & see note 2 \\
\hline 10510756 & Yes & AMWTP & ID-RF-S3114 Organic Sludge for Repackaging & see note 2 \\
\hline 10510757 & Yes & AMWTP & ID-RF-S3114 Organic Sludge for Repackaging & see note 2 \\
\hline 10510762 & Yes & AMWTP & ID-RF-S3114 Organic Sludge for Repackaging & see note 2 \\
\hline 10510943 & Yes & AMWTP & ID-RF-S3114 Organic Sludge for Repackaging & see note 2 \\
\hline 10510947 & Yes & AMWTP & ID-RF-S3114 Organic Sludge for Repackaging & see note 2 \\
\hline 10511022 & Yes & AMWTP & ID-RF-S3114 Organic Sludge for Repackaging & see note 2 \\
\hline 10511023 & Yes & AMWTP & ID-RF-S3114 Organic Sludge for Repackaging & see note 2 \\
\hline 10511024 & Yes & AMWTP & ID-RF-S3114 Organic Sludge for Repackaging & see note 2 \\
\hline 10511025 & Yes & AMWTP & ID-RF-S3114 Organic Sludge for Repackaging & see note 2 \\
\hline 10512060 & Yes & AMWTP & ID-RF-S3114 Organic Sludge for Repackaging & see note 2 \\
\hline 10512061 & Yes & AMWTP & ID-RF-S3114 Organic Sludge for Repackaging & see note 2 \\
\hline 10512134 & Yes & AMWTP & ID-RF-S3114 Organic Sludge for Repackaging & see note 2 \\
\hline 10512156 & Yes & AMWTP & ID-RF-S3114 Organic Sludge for Repackaging & see note 2 \\
\hline 10512157 & Yes & AMWTP & ID-RF-S3114 Organic Sludge for Repackaging & see note 2 \\
\hline 10520179 & Yes & AMWTP & ID-RF-S3114 Organic Sludge for Repackaging & see note 1 \\
\hline 10520380 & Yes & AMWTP & ID-RF-S3114 Organic Sludge for Repackaging & see note 1 \\
\hline 10520381 & Yes & AMWTP & ID-RF-S3114 Organic Sludge for Repackaging & see note 1 \\
\hline 10520382 & Yes & AMWTP & ID-RF-S3114 Organic Sludge for Repackaging & see note 1 \\
\hline 10520383 & Yes & AMWTP & ID-RF-S3114 Organic Sludge for Repackaging & see note 1 \\
\hline 10520384 & Yes & AMWTP & ID-RF-S3114 Organic Sludge for Repackaging & see note 1 \\
\hline
\end{tabular}

Tuesday, May 12, 2015 
Idaho National Laboratory

(excluding Advanced Mixed Waste Treatment Project [AMWTP])

PCB Waste Document Log

Repackaged in 2014

\begin{tabular}{|c|c|c|c|c|}
\hline Identification \# & $\begin{array}{c}\text { Radioactive } \\
\text { (Yes/No) }\end{array}$ & $\begin{array}{l}\text { Generating } \\
\text { Facility }\end{array}$ & Waste Name & $\begin{array}{l}\text { Receiving } \\
\text { Container(s) }\end{array}$ \\
\hline 10520386 & Yes & AMWTP & ID-RF-S3114 Organic Sludge for Repackaging & see note 1 \\
\hline 10520387 & Yes & AMWTP & ID-RF-S3114 Organic Sludge for Repackaging & see note 1 \\
\hline 10520388 & Yes & AMWTP & ID-RF-S3114 Organic Sludge for Repackaging & see note 1 \\
\hline 10520389 & Yes & AMWTP & ID-RF-S3114 Organic Sludge for Repackaging & see note 1 \\
\hline 10520390 & Yes & AMWTP & ID-RF-S3114 Organic Sludge for Repackaging & see note 1 \\
\hline 10520391 & Yes & AMWTP & ID-RF-S3114 Organic Sludge for Repackaging & see note 1 \\
\hline 10520392 & Yes & AMWTP & ID-RF-S3114 Organic Sludge for Repackaging & see note 1 \\
\hline 10520393 & Yes & AMWTP & ID-RF-S3114 Organic Sludge for Repackaging & see note 1 \\
\hline 10520394 & Yes & AMWTP & ID-RF-S3114 Organic Sludge for Repackaging & see note 1 \\
\hline 10520395 & Yes & AMWTP & ID-RF-S3114 Organic Sludge for Repackaging & see note 1 \\
\hline 10520396 & Yes & AMWTP & ID-RF-S3114 Organic Sludge for Repackaging & see note 1 \\
\hline 10520397 & Yes & AMWTP & ID-RF-S3114 Organic Sludge for Repackaging & see note 1 \\
\hline 10520399 & Yes & AMWTP & ID-RF-S3114 Organic Sludge for Repackaging & see note 1 \\
\hline 10520400 & Yes & AMWTP & ID-RF-S3114 Organic Sludge for Repackaging & see note 1 \\
\hline 10520401 & Yes & AMWTP & ID-RF-S3114 Organic Sludge for Repackaging & see note 1 \\
\hline 10520402 & Yes & AMWTP & ID-RF-S3114 Organic Sludge for Repackaging & see note 1 \\
\hline 10520403 & Yes & AMWTP & ID-RF-S3114 Organic Sludge for Repackaging & see note 1 \\
\hline 10520404 & Yes & AMWTP & ID-RF-S3114 Organic Sludge for Repackaging & see note 1 \\
\hline 10520405 & Yes & AMWTP & ID-RF-S3114 Organic Sludge for Repackaging & see note 1 \\
\hline 10520406 & Yes & AMWTP & ID-RF-S3114 Organic Sludge for Repackaging & see note 1 \\
\hline 10520407 & Yes & AMWTP & ID-RF-S3114 Organic Sludge for Repackaging & see note 1 \\
\hline 10520408 & Yes & AMWTP & ID-RF-S3114 Organic Sludge for Repackaging & see note 1 \\
\hline 10520409 & Yes & AMWTP & ID-RF-S3114 Organic Sludge for Repackaging & see note 1 \\
\hline 10520436 & Yes & AMWTP & ID-RF-S3114 Organic Sludge for Repackaging & see note 1 \\
\hline 10520439 & Yes & AMWTP & ID-RF-S3114 Organic Sludge for Repackaging & see note 1 \\
\hline 10520440 & Yes & AMWTP & ID-RF-S3114 Organic Sludge for Repackaging & see note 1 \\
\hline 10520441 & Yes & AMWTP & ID-RF-S3114 Organic Sludge for Repackaging & see note 1 \\
\hline 10520442 & Yes & AMWTP & ID-RF-S3114 Organic Sludge for Repackaging & see note 1 \\
\hline 10520443 & Yes & AMWTP & ID-RF-S3114 Organic Sludge for Repackaging & see note 1 \\
\hline 10520444 & Yes & AMWTP & ID-RF-S3114 Organic Sludge for Repackaging & see note 1 \\
\hline 10520445 & Yes & AMWTP & ID-RF-S3114 Organic Sludge for Repackaging & see note 1 \\
\hline 10520447 & Yes & AMWTP & ID-RF-S3114 Organic Sludge for Repackaging & see note 1 \\
\hline 10520448 & Yes & AMWTP & ID-RF-S3114 Organic Sludge for Repackaging & see note 1 \\
\hline 10520449 & Yes & AMWTP & ID-RF-S3114 Organic Sludge for Repackaging & see note 1 \\
\hline 10520450 & Yes & AMWTP & ID-RF-S3114 Organic Sludge for Repackaging & see note 1 \\
\hline 10520451 & Yes & AMWTP & ID-RF-S3114 Organic Sludge for Repackaging & see note 1 \\
\hline 10520452 & Yes & AMWTP & ID-RF-S3114 Organic Sludge for Repackaging & see note 1 \\
\hline 10520453 & Yes & AMWTP & ID-RF-S3114 Organic Sludge for Repackaging & see note 1 \\
\hline 10520454 & Yes & AMWTP & ID-RF-S3114 Organic Sludge for Repackaging & see note 1 \\
\hline 10520455 & Yes & AMWTP & ID-RF-S3114 Organic Sludge for Repackaging & see note 1 \\
\hline 10520456 & Yes & AMWTP & ID-RF-S3114 Organic Sludge for Repackaging & see note 1 \\
\hline
\end{tabular}

Tuesday, May 12, 2015 
Idaho National Laboratory

(excluding Advanced Mixed Waste Treatment Project [AMWTP])

PCB Waste Document Log

Repackaged in 2014

\begin{tabular}{|c|c|c|c|c|}
\hline Identification \# & $\begin{array}{c}\text { Radioactive } \\
\text { (Yes/No) }\end{array}$ & $\begin{array}{l}\text { Generating } \\
\text { Facility }\end{array}$ & Waste Name & $\begin{array}{l}\text { Receiving } \\
\text { Container(s) }\end{array}$ \\
\hline 10520523 & Yes & AMWTP & ID-RF-S3114 Organic Sludge for Repackaging & see note 1 \\
\hline 10520524 & Yes & AMWTP & ID-RF-S3114 Organic Sludge for Repackaging & see note 1 \\
\hline 10520525 & Yes & AMWTP & ID-RF-S3114 Organic Sludge for Repackaging & see note 1 \\
\hline 10520526 & Yes & AMWTP & ID-RF-S3114 Organic Sludge for Repackaging & see note 1 \\
\hline 10520527 & Yes & AMWTP & ID-RF-S3114 Organic Sludge for Repackaging & see note 1 \\
\hline 10520529 & Yes & AMWTP & ID-RF-S3114 Organic Sludge for Repackaging & see note 1 \\
\hline 10520530 & Yes & AMWTP & ID-RF-S3114 Organic Sludge for Repackaging & see note 1 \\
\hline 10520531 & Yes & AMWTP & ID-RF-S3114 Organic Sludge for Repackaging & see note 1 \\
\hline 10520532 & Yes & AMWTP & ID-RF-S3114 Organic Sludge for Repackaging & see note 1 \\
\hline 10520533 & Yes & AMWTP & ID-RF-S3114 Organic Sludge for Repackaging & see note 1 \\
\hline 10520534 & Yes & AMWTP & ID-RF-S3114 Organic Sludge for Repackaging & see note 1 \\
\hline 10520540 & Yes & AMWTP & ID-RF-S3114 Organic Sludge for Repackaging & see note 1 \\
\hline 10520541 & Yes & AMWTP & ID-RF-S3114 Organic Sludge for Repackaging & see note 1 \\
\hline 10520542 & Yes & AMWTP & ID-RF-S3114 Organic Sludge for Repackaging & see note 1 \\
\hline 10520543 & Yes & AMWTP & ID-RF-S3114 Organic Sludge for Repackaging & see note 1 \\
\hline 10520544 & Yes & AMWTP & ID-RF-S3114 Organic Sludge for Repackaging & see note 1 \\
\hline 10520545 & Yes & AMWTP & ID-RF-S3114 Organic Sludge for Repackaging & see note 1 \\
\hline 10520546 & Yes & AMWTP & ID-RF-S3114 Organic Sludge for Repackaging & see note 1 \\
\hline 10520547 & Yes & AMWTP & ID-RF-S3114 Organic Sludge for Repackaging & see note 1 \\
\hline 10520548 & Yes & AMWTP & ID-RF-S3114 Organic Sludge for Repackaging & see note 1 \\
\hline 10520549 & Yes & AMWTP & ID-RF-S3114 Organic Sludge for Repackaging & see note 1 \\
\hline 10520550 & Yes & AMWTP & ID-RF-S3114 Organic Sludge for Repackaging & see note 1 \\
\hline 10520551 & Yes & AMWTP & ID-RF-S3114 Organic Sludge for Repackaging & see note 1 \\
\hline 10520552 & Yes & AMWTP & ID-RF-S3114 Organic Sludge for Repackaging & see note 1 \\
\hline 10520553 & Yes & AMWTP & ID-RF-S3114 Organic Sludge for Repackaging & see note 1 \\
\hline 10520554 & Yes & AMWTP & ID-RF-S3114 Organic Sludge for Repackaging & see note 1 \\
\hline 10520555 & Yes & AMWTP & ID-RF-S3114 Organic Sludge for Repackaging & see note 1 \\
\hline 10520556 & Yes & AMWTP & ID-RF-S3114 Organic Sludge for Repackaging & see note 1 \\
\hline 10520557 & Yes & AMWTP & ID-RF-S3114 Organic Sludge for Repackaging & see note 1 \\
\hline 10520558 & Yes & AMWTP & ID-RF-S3114 Organic Sludge for Repackaging & see note 1 \\
\hline 10520559 & Yes & AMWTP & ID-RF-S3114 Organic Sludge for Repackaging & see note 1 \\
\hline 10520560 & Yes & AMWTP & ID-RF-S3114 Organic Sludge for Repackaging & see note 1 \\
\hline 10520561 & Yes & AMWTP & ID-RF-S3114 Organic Sludge for Repackaging & see note 1 \\
\hline 10520562 & Yes & AMWTP & ID-RF-S3114 Organic Sludge for Repackaging & see note 1 \\
\hline 10520563 & Yes & AMWTP & ID-RF-S3114 Organic Sludge for Repackaging & see note 1 \\
\hline 10520637 & Yes & AMWTP & ID-RF-S3114 Organic Sludge for Repackaging & see note 1 \\
\hline 10520638 & Yes & AMWTP & ID-RF-S3114 Organic Sludge for Repackaging & see note 1 \\
\hline 10520639 & Yes & AMWTP & ID-RF-S3114 Organic Sludge for Repackaging & see note 1 \\
\hline 10520640 & Yes & AMWTP & ID-RF-S3114 Organic Sludge for Repackaging & see note 1 \\
\hline 10520641 & Yes & AMWTP & ID-RF-S3114 Organic Sludge for Repackaging & see note 1 \\
\hline 10520642 & Yes & AMWTP & ID-RF-S3114 Organic Sludge for Repackaging & see note 1 \\
\hline
\end{tabular}

Tuesday, May 12, 2015 
Idaho National Laboratory

(excluding Advanced Mixed Waste Treatment Project [AMWTP])

PCB Waste Document Log

Repackaged in 2014

\begin{tabular}{|c|c|c|c|c|}
\hline Identification \# & $\begin{array}{c}\text { Radioactive } \\
\text { (Yes/No) }\end{array}$ & $\begin{array}{l}\text { Generating } \\
\text { Facility }\end{array}$ & Waste Name & $\begin{array}{l}\text { Receiving } \\
\text { Container(s) }\end{array}$ \\
\hline 10520650 & Yes & AMWTP & ID-RF-S3114 Organic Sludge for Repackaging & see note 1 \\
\hline 10520651 & Yes & AMWTP & ID-RF-S3114 Organic Sludge for Repackaging & see note 1 \\
\hline 10520652 & Yes & AMWTP & ID-RF-S3114 Organic Sludge for Repackaging & see note 1 \\
\hline 10520653 & Yes & AMWTP & ID-RF-S3114 Organic Sludge for Repackaging & see note 1 \\
\hline 10520654 & Yes & AMWTP & ID-RF-S3114 Organic Sludge for Repackaging & see note 1 \\
\hline 10520656 & Yes & AMWTP & ID-RF-S3114 Organic Sludge for Repackaging & see note 1 \\
\hline 10520657 & Yes & AMWTP & ID-RF-S3114 Organic Sludge for Repackaging & see note 1 \\
\hline 10520658 & Yes & AMWTP & ID-RF-S3114 Organic Sludge for Repackaging & see note 1 \\
\hline 10520659 & Yes & AMWTP & ID-RF-S3114 Organic Sludge for Repackaging & see note 1 \\
\hline 10520660 & Yes & AMWTP & ID-RF-S3114 Organic Sludge for Repackaging & see note 1 \\
\hline 10520661 & Yes & AMWTP & ID-RF-S3114 Organic Sludge for Repackaging & see note 1 \\
\hline 10520662 & Yes & AMWTP & ID-RF-S3114 Organic Sludge for Repackaging & see note 1 \\
\hline 10520663 & Yes & AMWTP & ID-RF-S3114 Organic Sludge for Repackaging & see note 1 \\
\hline 10520664 & Yes & AMWTP & ID-RF-S3114 Organic Sludge for Repackaging & see note 1 \\
\hline 10520665 & Yes & AMWTP & ID-RF-S3114 Organic Sludge for Repackaging & see note 1 \\
\hline 10520787 & Yes & AMWTP & ID-RF-S3114 Organic Sludge for Repackaging & see note 1 \\
\hline 10520788 & Yes & AMWTP & ID-RF-S3114 Organic Sludge for Repackaging & see note 1 \\
\hline 10520789 & Yes & AMWTP & ID-RF-S3114 Organic Sludge for Repackaging & see note 1 \\
\hline 10520790 & Yes & AMWTP & ID-RF-S3114 Organic Sludge for Repackaging & see note 1 \\
\hline 10520792 & Yes & AMWTP & ID-RF-S3114 Organic Sludge for Repackaging & see note 1 \\
\hline 10520793 & Yes & AMWTP & ID-RF-S3114 Organic Sludge for Repackaging & see note 1 \\
\hline 10520794 & Yes & AMWTP & ID-RF-S3114 Organic Sludge for Repackaging & see note 1 \\
\hline 10520795 & Yes & AMWTP & ID-RF-S3114 Organic Sludge for Repackaging & see note 1 \\
\hline 10520796 & Yes & AMWTP & ID-RF-S3114 Organic Sludge for Repackaging & see note 1 \\
\hline 10520797 & Yes & AMWTP & ID-RF-S3114 Organic Sludge for Repackaging & see note 1 \\
\hline 10520798 & Yes & AMWTP & ID-RF-S3114 Organic Sludge for Repackaging & see note 1 \\
\hline 10520799 & Yes & AMWTP & ID-RF-S3114 Organic Sludge for Repackaging & see note 1 \\
\hline 10520800 & Yes & AMWTP & ID-RF-S3114 Organic Sludge for Repackaging & see note 1 \\
\hline 10520801 & Yes & AMWTP & ID-RF-S3114 Organic Sludge for Repackaging & see note 1 \\
\hline 10520802 & Yes & AMWTP & ID-RF-S3114 Organic Sludge for Repackaging & see note 1 \\
\hline 10520869 & Yes & AMWTP & ID-RF-S3114 Organic Sludge for Repackaging & see note 1 \\
\hline 10520870 & Yes & AMWTP & ID-RF-S3114 Organic Sludge for Repackaging & see note 1 \\
\hline 10520871 & Yes & AMWTP & ID-RF-S3114 Organic Sludge for Repackaging & see note 1 \\
\hline 10520872 & Yes & AMWTP & ID-RF-S3114 Organic Sludge for Repackaging & see note 1 \\
\hline 10520873 & Yes & AMWTP & ID-RF-S3114 Organic Sludge for Repackaging & see note 1 \\
\hline 10520874 & Yes & AMWTP & ID-RF-S3114 Organic Sludge for Repackaging & see note 1 \\
\hline 10520875 & Yes & AMWTP & ID-RF-S3114 Organic Sludge for Repackaging & see note 1 \\
\hline 10520876 & Yes & AMWTP & ID-RF-S3114 Organic Sludge for Repackaging & see note 1 \\
\hline 10520877 & Yes & AMWTP & ID-RF-S3114 Organic Sludge for Repackaging & see note 1 \\
\hline 10520878 & Yes & AMWTP & ID-RF-S3114 Organic Sludge for Repackaging & see note 1 \\
\hline 10520879 & Yes & AMWTP & ID-RF-S3114 Organic Sludge for Repackaging & see note 1 \\
\hline
\end{tabular}

Tuesday, May 12, 2015 
Idaho National Laboratory

(excluding Advanced Mixed Waste Treatment Project [AMWTP])
PCB Waste Document Log

Repackaged in 2014

\begin{tabular}{|c|c|c|c|c|}
\hline Identification \# & $\begin{array}{c}\text { Radioactive } \\
\text { (Yes/No) }\end{array}$ & $\begin{array}{l}\text { Generating } \\
\text { Facility }\end{array}$ & Waste Name & $\begin{array}{l}\text { Receiving } \\
\text { Container(s) }\end{array}$ \\
\hline 10520880 & Yes & AMWTP & ID-RF-S3114 Organic Sludge for Repackaging & see note 1 \\
\hline 20-11-298-015-F & No & NRF & PCB Spill Cleanup Material & NRF140062 \\
\hline $30-11-311-028-F$ & Yes & NRF & PCB Debris & NRF140034 \\
\hline ATRX140085 & No & ATRX & INL ATR Complex TSCA Regulated Hazardous Waste Debris & ATRX140116 \\
\hline SRS130421 & Yes & RWMC & LDR compliant, PCB regulated, AMWTP sludge repack secondary waste to NNSS & SRS140500 \\
\hline SRS130424 & Yes & RWMC & LDR compliant, PCB regulated, AMWTP sludge repack secondary waste to NNSS & SRS140499 \\
\hline SRS130425 & Yes & RWMC & LDR compliant, PCB regulated, AMWTP sludge repack secondary waste to NNSS & SRS140499 \\
\hline SRS130435 & Yes & RWMC & LDR compliant, PCB regulated, AMWTP sludge repack secondary waste to NNSS & SRS140499 \\
\hline SRS130437 & Yes & RWMC & LDR compliant, PCB regulated, AMWTP sludge repack secondary waste to NNSS & SRS140499 \\
\hline SRS130442 & Yes & RWMC & LDR compliant, PCB regulated, AMWTP sludge repack secondary waste to NNSS & SRS140500 \\
\hline SRS130443 & Yes & RWMC & LDR compliant, PCB regulated, AMWTP sludge repack secondary waste to NNSS & SRS140500 \\
\hline SRS130446 & Yes & RWMC & LDR compliant, PCB regulated, AMWTP sludge repack secondary waste to NNSS & SRS140500 \\
\hline \multicolumn{5}{|c|}{$\begin{array}{l}\text { Note 1: Repackaged drums of organic sludge ID-RF-S3114 from AMWTP that does not correlate to one specific parent container (reported in the } 2013 \text { AMWTP report) due to comingling of sludge from numerous parent } \\
\text { containers during processing. Repackaged drums returned to AMWTP during } 2014 \text {. }\end{array}$} \\
\hline
\end{tabular}


Idaho National Laboratory

Advanced Mixed Waste Treatment Project (AMWTP)

PCB Waste Document Log

Repackaged in 2014

Identification \# Radioactive Generating Facility (Yes/No)

\begin{tabular}{lll}
\hline 10000833 & Yes & Rocky Flats Plant \\
10000963 & Yes & Rocky Flats Plant \\
10000973 & Yes & Rocky Flats Plant \\
10002049 & Yes & Rocky Flats Plant \\
10002050 & Yes & Rocky Flats Plant \\
10002065 & Yes & Rocky Flats Plant \\
10002715 & Yes & Rocky Flats Plant \\
10007611 & Yes & Rocky Flats Plant \\
10007614 & Yes & Rocky Flats Plant \\
10007626 & Yes & Rocky Flats Plant \\
10007652 & Yes & Rocky Flats Plant \\
10007669 & Yes & Rocky Flats Plant \\
10007738 & Yes & Rocky Flats Plant \\
10007787 & Yes & Rocky Flats Plant \\
10007803 & Yes & Rocky Flats Plant \\
10007922 & Yes & Rocky Flats Plant \\
10007926 & Yes & Rocky Flats Plant \\
10007930 & Yes & Rocky Flats Plant \\
10007996 & Yes & Rocky Flats Plant \\
10008187 & Yes & Rocky Flats Plant \\
10008215 & Yes & Rocky Flats Plant \\
10008955 & Yes & Rocky Flats Plant \\
10015917 & Yes & Rocky Flats Plant \\
10017799 & Yes & Rocky Flats Plant \\
10018921 & Yes & Rocky Flats Plant \\
10019643 & Yes & Rocky Flats Plant \\
10020581 & Yes & Rocky Flats Plant \\
10020587 & Yes & Rocky Flats Plant \\
10021004 & Yes & Rocky Flats Plant \\
10021063 & Yes & Rocky Flats Plant \\
10021069 & Yes & Rocky Flats Plant \\
10022741 & Yes & Rocky Flats Plant \\
10023153 & Yes & Rocky Flats Plant \\
10023291 & Yes & Rocky Flats Plant \\
10023317 & Yes & Rocky Flats Plant \\
10023580 & Rocky Flats Plant \\
10023663 & Rocky Flats Plant \\
10024528 & Rocky Flats Plant
\end{tabular}

\section{Waste Name}

Organic Setups, Oil Solids

Organic Setups, Oil Solids

Organic Setups, Oil Solids

Organic Setups, Oil Solids

Organic Setups, Oil Solids

Organic Setups, Oil Solids

Organic Setups, Oil Solids

Organic Setups, Oil Solids

Organic Setups, Oil Solids

Organic Setups, Oil Solids

Organic Setups, Oil Solids

Organic Setups, Oil Solids

Organic Setups, Oil Solids

Organic Setups, Oil Solids

Organic Setups, Oil Solids

Organic Setups, Oil Solids

Organic Setups, Oil Solids

Organic Setups, Oil Solids

Organic Setups, Oil Solids

Organic Setups, Oil Solids

Organic Setups, Oil Solids

Organic Setups, Oil Solids

Organic Setups, Oil Solids

Organic Setups, Oil Solids

Organic Setups, Oil Solids

Organic Setups, Oil Solids

Organic Setups, Oil Solids

Organic Setups, Oil Solids

Organic Setups, Oil Solids

Organic Setups, Oil Solids

Organic Setups, Oil Solids

Organic Setups, Oil Solids

Organic Setups, Oil Solids

Organic Setups, Oil Solids

Organic Setups, Oil Solids

Organic Setups, Oil Solids

Organic Setups, Oil Solids

Organic Setups, Oil Solids
Receiving Notes

Container(s)

10520638 a

10520787

10520454

10520650

10520561

10520652

10520444

10520406

10520661

10520439

10520528

10520800

10520450

10520870

10520403

10520456

10520390

10520544

10520527

10520556

10520401

10520664

10520657

10520663

10520637

10520384

10520543

10520559

10520388

10520402

10520797

10520796

10520533

10520531

10520662

10520540

10520397

10520789 a

a

a

a

a

a

a

a

a

a

a

a

a

a

a

a

a

a

a

a

a

a

a

a

a

a

a

$a$
$a$ 
Idaho National Laboratory

Advanced Mixed Waste Treatment Project (AMWTP)

PCB Waste Document Log

Repackaged in 2014

\begin{tabular}{|c|c|c|c|c|c|}
\hline Identification \# & $\begin{array}{c}\text { Radioactive } \\
\text { (Yes/No) }\end{array}$ & Generating Facility & Waste Name & $\begin{array}{l}\text { Receiving } \\
\text { Container(s) }\end{array}$ & Notes \\
\hline 10025283 & Yes & Rocky Flats Plant & Organic Setups, Oil Solids & 10520542 & a \\
\hline 10025929 & Yes & Rocky Flats Plant & Organic Setups, Oil Solids & 10520640 & a \\
\hline 10026038 & Yes & Rocky Flats Plant & Organic Setups, Oil Solids & 10520443 & a \\
\hline 10027460 & Yes & Rocky Flats Plant & Organic Setups, Oil Solids & 10520877 & a \\
\hline 10027899 & Yes & Rocky Flats Plant & Organic Setups, Oil Solids & 10520653 & a \\
\hline 10030093 & Yes & Rocky Flats Plant & Organic Setups, Oil Solids & 10520534 & a \\
\hline 10030563 & Yes & Rocky Flats Plant & Organic Setups, Oil Solids & 10520558 & a \\
\hline 10033020 & Yes & Rocky Flats Plant & Organic Setups, Oil Solids & 10520452 & a \\
\hline 10036517 & Yes & Rocky Flats Plant & Organic Setups, Oil Solids & 10520547 & a \\
\hline 10036791 & Yes & Rocky Flats Plant & Organic Setups, Oil Solids & 10520874 & a \\
\hline 10038324 & Yes & Rocky Flats Plant & Organic Setups, Oil Solids & 10520524 & a \\
\hline 10038449 & Yes & Rocky Flats Plant & Organic Setups, Oil Solids & 10520407 & a \\
\hline 10040243 & Yes & Rocky Flats Plant & Organic Setups, Oil Solids & 10520802 & a \\
\hline 10043605 & Yes & Rocky Flats Plant & Organic Setups, Oil Solids & 10520391 & a \\
\hline 10052372 & Yes & Rocky Flats Plant & Organic Setups, Oil Solids & 10520447 & a \\
\hline 10060968 & Yes & Rocky Flats Plant & Organic Setups, Oil Solids & 10520392 & $a$ \\
\hline 10078775 & Yes & Rocky Flats Plant & Organic Setups, Oil Solids & 10520389 & $a$ \\
\hline 10079487 & Yes & Rocky Flats Plant & Organic Setups, Oil Solids & 10520875 & a \\
\hline 10079493 & Yes & Rocky Flats Plant & Organic Setups, Oil Solids & 10520405 & a \\
\hline 10079501 & Yes & Rocky Flats Plant & Organic Setups, Oil Solids & 10520869 & a \\
\hline 10079508 & Yes & Rocky Flats Plant & Organic Setups, Oil Solids & 10520878 & a \\
\hline 10083179 & Yes & Rocky Flats Plant & Organic Setups, Oil Solids & 10520448 & a \\
\hline 10085099 & Yes & Rocky Flats Plant & Organic Setups, Oil Solids & 10520880 & a \\
\hline 10086292 & Yes & Rocky Flats Plant & Organic Setups, Oil Solids & 10520641 & a \\
\hline 10086728 & Yes & Rocky Flats Plant & Organic Setups, Oil Solids & 10520548 & a \\
\hline 10086739 & Yes & Rocky Flats Plant & Organic Setups, Oil Solids & 10520529 & a \\
\hline 10086759 & Yes & Rocky Flats Plant & Organic Setups, Oil Solids & 10520551 & a \\
\hline 10086846 & Yes & Rocky Flats Plant & Organic Setups, Oil Solids & 10520550 & a \\
\hline 10086878 & Yes & Rocky Flats Plant & Organic Setups, Oil Solids & 10520879 & a \\
\hline 10086922 & Yes & Rocky Flats Plant & Organic Setups, Oil Solids & 10520665 & a \\
\hline 10086926 & Yes & Rocky Flats Plant & Organic Setups, Oil Solids & 10520655 & \\
\hline 10086927 & Yes & Rocky Flats Plant & Organic Setups, Oil Solids & 10520393 & a \\
\hline 10086941 & Yes & Rocky Flats Plant & Organic Setups, Oil Solids & 10520451 & a \\
\hline 10087004 & Yes & Rocky Flats Plant & Organic Setups, Oil Solids & 10520557 & a \\
\hline 10087290 & Yes & Rocky Flats Plant & Organic Setups, Oil Solids & 10520554 & a \\
\hline 10087359 & Yes & Rocky Flats Plant & Organic Setups, Oil Solids & 10520873 & a \\
\hline 10087399 & Yes & Rocky Flats Plant & Organic Setups, Oil Solids & 10520399 & a \\
\hline 10087417 & Yes & Rocky Flats Plant & Organic Setups, Oil Solids & 10520792 & a \\
\hline
\end{tabular}


Idaho National Laboratory

Advanced Mixed Waste Treatment Project (AMWTP)

PCB Waste Document Log

Repackaged in 2014

\begin{tabular}{|c|c|c|c|c|c|}
\hline Identification \# & $\begin{array}{c}\text { Radioactive } \\
\text { (Yes/No) }\end{array}$ & Generating Facility & Waste Name & $\begin{array}{l}\text { Receiving } \\
\text { Container(s) }\end{array}$ & Notes \\
\hline 10087463 & Yes & Rocky Flats Plant & Organic Setups, Oil Solids & 10520876 & a \\
\hline 10087594 & Yes & Rocky Flats Plant & Organic Setups, Oil Solids & 10520446 & \\
\hline 10092398 & Yes & Rocky Flats Plant & Organic Setups, Oil Solids & 10520793 & a \\
\hline 10092420 & Yes & Rocky Flats Plant & Organic Setups, Oil Solids & 10520658 & a \\
\hline 10092445 & Yes & Rocky Flats Plant & Organic Setups, Oil Solids & 10520660 & a \\
\hline 10092460 & Yes & Rocky Flats Plant & Organic Setups, Oil Solids & 10520545 & a \\
\hline 10092461 & Yes & Rocky Flats Plant & Organic Setups, Oil Solids & 10520449 & a \\
\hline 10092476 & Yes & Rocky Flats Plant & Organic Setups, Oil Solids & 10520440 & a \\
\hline 10092836 & Yes & Rocky Flats Plant & Organic Setups, Oil Solids & 10520530 & a \\
\hline 10100939 & Yes & Rocky Flats Plant & Organic Setups, Oil Solids & 10520790 & a \\
\hline 10100941 & Yes & Rocky Flats Plant & Organic Setups, Oil Solids & 10520523 & a \\
\hline 10101018 & Yes & Rocky Flats Plant & Organic Setups, Oil Solids & 10520546 & a \\
\hline 10101076 & Yes & Rocky Flats Plant & Organic Setups, Oil Solids & 10520872 & a \\
\hline 10101993 & Yes & Rocky Flats Plant & Organic Setups, Oil Solids & 10520871 & a \\
\hline 10102198 & Yes & Rocky Flats Plant & Organic Setups, Oil Solids & 10520442 & a \\
\hline 10104761 & Yes & Rocky Flats Plant & Organic Setups, Oil Solids & 10520656 & $a$ \\
\hline 10105597 & Yes & Rocky Flats Plant & Organic Setups, Oil Solids & 10520436 & $a$ \\
\hline 10106815 & Yes & Rocky Flats Plant & Organic Setups, Oil Solids & 10520639 & a \\
\hline 10107104 & Yes & Rocky Flats Plant & Organic Setups, Oil Solids & 10520383 & a \\
\hline 10108278 & Yes & Rocky Flats Plant & Organic Setups, Oil Solids & 10520526 & a \\
\hline 10116539 & Yes & Rocky Flats Plant & Organic Setups, Oil Solids & 10520560 & a \\
\hline 10116959 & Yes & Rocky Flats Plant & Organic Setups, Oil Solids & 10520455 & a \\
\hline 10117546 & Yes & Rocky Flats Plant & Organic Setups, Oil Solids & 10520387 & a \\
\hline 10120613 & Yes & Rocky Flats Plant & Organic Setups, Oil Solids & 10520555 & a \\
\hline 10129877 & Yes & Rocky Flats Plant & Organic Setups, Oil Solids & 10520788 & a \\
\hline 10130111 & Yes & Rocky Flats Plant & Organic Setups, Oil Solids & 10520799 & a \\
\hline 10135232 & Yes & Rocky Flats Plant & Organic Setups, Oil Solids & 10520445 & a \\
\hline 10136360 & Yes & Rocky Flats Plant & Organic Setups, Oil Solids & 10520380 & a \\
\hline 10136866 & Yes & Rocky Flats Plant & Organic Setups, Oil Solids & 10520381 & a \\
\hline 10137096 & Yes & Rocky Flats Plant & Organic Setups, Oil Solids & 10520562 & a \\
\hline 10140319 & Yes & Rocky Flats Plant & Organic Setups, Oil Solids & 10520525 & a \\
\hline 10140664 & Yes & Rocky Flats Plant & Organic Setups, Oil Solids & 10520386 & a \\
\hline 10163771 & Yes & Rocky Flats Plant & Organic Setups, Oil Solids & 10520179 & a \\
\hline 10163788 & Yes & Rocky Flats Plant & Organic Setups, Oil Solids & 10520532 & a \\
\hline 10168802 & Yes & Rocky Flats Plant & Organic Setups, Oil Solids & 10520553 & a \\
\hline 10168898 & Yes & Rocky Flats Plant & Organic Setups, Oil Solids & 10520400 & a \\
\hline 10185922 & Yes & Rocky Flats Plant & Organic Setups, Oil Solids & 10520795 & a \\
\hline 10185938 & Yes & Rocky Flats Plant & Organic Setups, Oil Solids & 10520651 & a \\
\hline
\end{tabular}


Idaho National Laboratory

Advanced Mixed Waste Treatment Project (AMWTP)

PCB Waste Document Log

Repackaged in 2014

\begin{tabular}{|c|c|c|c|c|c|}
\hline Identification \# & $\begin{array}{c}\text { Radioactive } \\
\text { (Yes/No) }\end{array}$ & Generating Facility & Waste Name & $\begin{array}{l}\text { Receiving } \\
\text { Container(s) }\end{array}$ & Notes \\
\hline 10186098 & Yes & Rocky Flats Plant & Organic Setups, Oil Solids & 10520794 & $a$ \\
\hline 10186380 & Yes & Rocky Flats Plant & Organic Setups, Oil Solids & 10520382 & a \\
\hline 10191625 & Yes & Rocky Flats Plant & Organic Setups, Oil Solids & 10520441 & a \\
\hline 10198265 & Yes & Rocky Flats Plant & Organic Setups, Oil Solids & 10520552 & a \\
\hline 10200141 & Yes & Rocky Flats Plant & Organic Setups, Oil Solids & 10520453 & a \\
\hline 10200185 & Yes & Rocky Flats Plant & Organic Setups, Oil Solids & 10520549 & a \\
\hline 10200654 & Yes & Rocky Flats Plant & Organic Setups, Oil Solids & 10520394 & a \\
\hline 10200655 & Yes & Rocky Flats Plant & Organic Setups, Oil Solids & 10498099 & \\
\hline 10206802 & Yes & Rocky Flats Plant & Organic Setups, Oil Solids & 10520659 & a \\
\hline 10219805 & Yes & Rocky Flats Plant & Organic Setups, Oil Solids & 10520642 & a \\
\hline 10222998 & Yes & Rocky Flats Plant & Organic Setups, Oil Solids & 10520801 & a \\
\hline 10291379 & Yes & Rocky Flats Plant & Pits 11 \& 12 Organic Setups & 10520798 & a \\
\hline 10305217 & Yes & Unknown Generator & Undefined Homogeneous Solids & 10535743 & \\
\hline 10308701 & Yes & Unknown Generator & Undefined Homogeneous Solids & 10536346 & \\
\hline 10308879 & Yes & Rocky Flats Plant & Organic Setups, Oil Solids & 10520541 & a \\
\hline 10309601 & Yes & Unknown Generator & Undefined Homogeneous Solids & 10536345 & \\
\hline 10315823 & Yes & Rocky Flats Plant & Pits 11 and 12 Cargos and Bins & 10535115 & \\
\hline 10320598 & Yes & Unknown Generator & Undefined Homogeneous Solids & 10514499 & \\
\hline 10407548 & Yes & Rocky Flats Plant & Organic Setups, Oil Solids & 10520408 & a \\
\hline 10408608 & Yes & Rocky Flats Plant & Organic Setups, Oil Solids & 10520404 & a \\
\hline 10408625 & Yes & Rocky Flats Plant & Organic Setups, Oil Solids & 10520395 & a \\
\hline 10413854 & Yes & Rocky Flats Plant & Organic Setups, Oil Solids & 10520654 & a \\
\hline 10415417 & Yes & Rocky Flats Plant & Organic Setups, Oil Solids & 10520563 & a \\
\hline 10415942 & Yes & Rocky Flats Plant & Organic Setups, Oil Solids & 10520409 & a \\
\hline 10416151 & Yes & Rocky Flats Plant & Organic Setups, Oil Solids & 10520396 & a \\
\hline 10438330 & Yes & $\begin{array}{l}\text { INL Advanced Mixed Waste } \\
\text { Treatment Facility (formerly called } \\
\text { BNFL) }\end{array}$ & WMF-676 PCB Contaminated Debris & 10511831 & \\
\hline 10438341 & Yes & $\begin{array}{l}\text { INL Advanced Mixed Waste } \\
\text { Treatment Facility (formerly called } \\
\text { BNFL) }\end{array}$ & WMF-676 PCB Contaminated Debris & 10515443 & \\
\hline
\end{tabular}




\section{$2.4 \quad$ Notes on 2014 Report}

The following table is included in order to document containers that were on the 2013 report but are not on the 2014 report and other information related to the 2014 report.

This section is separated into two parts, INL without Advanced Mixed Waste Treatment Project (AMWTP) and AMWTP. 


\section{Idaho National Laboratory \\ (excluding Advanced Mixed Waste Treatment Project [AMWTP]) \\ PCB Waste Document Log \\ Notes on 2014 Report}

Identification \# 02-12-222-033-F

PCB Bulk Product

16-11-297-015-F

PCB Debris

\section{0-11-311-030-F $\quad$ PCB Debris}

ATRX140085 INL ATR Complex TSCA Regulated Hazardous Waste Debris

INTC130120 Non-leaking/Suspect-leaking PCB light ballasts and capacitors

SRP19496

SRP19497

Repackaged combined RCRA TRU sludge to AMWTP ID-SRP-S3000

SRP19498

SRP19514

SRP19515

SRP19517

SRP19519

SRP19521

SRP19523

SRP19535

SRP19536

SRP19537

SRP19538

SRP19539

SRP19540

Description
Weight

(kg)

\section{Note}

Rad

2 This container was listed on the 2013 report but is not listed on the 2014 report because it was disposed in the CFA Landfill in 2014 as bulk product waste.

22 This container is located in a PCB storage area. The container is periodically emptied but is not removed from the storage area. This container was listed in the 2013 reports but was empty as of $12 / 31 / 2014$

20 This non-radioactive container was erroneously reported as radioactive in the 2013 No report.

Waste transferred from this accumulation container and appears in this report under No ATRX140116

Waste transferred from this accumulation container and appears in this report under No INTC140040

177 This container was in storage at RWMC after repackaging in 2013. During 2014 it Yes was transferred back to AMWTP and appears on their report as barcode 10509725.

160 This container was in storage at RWMC after repackaging in 2013. During 2014 it Yes was transferred back to AMWTP and appears on their report as barcode 10510008 .

175 This container was in storage at RWMC after repackaging in 2013. During 2014 it Yes was transferred back to AMWTP and appears on their report as barcode 10509980.

154 This container was in storage at RWMC after repackaging in 2013. During 2014 it Yes was transferred back to AMWTP and appears on their report as barcode 10509997.

182 This container was in storage at RWMC after repackaging in 2013. During 2014 it Yes was transferred back to AMWTP and appears on their report as barcode 10509992 .

162 This container was in storage at RWMC after repackaging in 2013. During 2014 it Yes was transferred back to AMWTP and appears on their report as barcode 10510059.

131 This container was in storage at RWMC after repackaging in 2013. During 2014 it Yes was transferred back to AMWTP and appears on their report as barcode 10510002 .

164 This container was in storage at RWMC after repackaging in 2013. During 2014 it Yes was transferred back to AMWTP and appears on their report as barcode 10510058.

160 This container was in storage at RWMC after repackaging in 2013. During 2014 it Yes was transferred back to AMWTP and appears on their report as barcode 10509965.

143 This container was in storage at RWMC after repackaging in 2013. During 2014 it Yes was transferred back to AMWTP and appears on their report as barcode 10509962 .

164 This container was in storage at RWMC after repackaging in 2013. During 2014 it Yes was transferred back to AMWTP and appears on their report as barcode 10509999.

153 This container was in storage at RWMC after repackaging in 2013. During 2014 it Yes was transferred back to AMWTP and appears on their report as barcode 10509969.

172 This container was in storage at RWMC after repackaging in 2013. During 2014 it Yes was transferred back to AMWTP and appears on their report as barcode 10510009 .

160 This container was in storage at RWMC after repackaging in 2013. During 2014 it Yes was transferred back to AMWTP and appears on their report as barcode 10509973.

145 This container was in storage at RWMC after repackaging in 2013. During 2014 it Yes was transferred back to AMWTP and appears on their report as barcode 10509996. 


\section{Idaho National Laboratory \\ (excluding Advanced Mixed Waste Treatment Project [AMWTP]) \\ PCB Waste Document Log \\ Notes on 2014 Report}

Identification \#

SRP19541

SRP19542

SRP19543

SRP19544

SRP19545

SRP19546

SRP19547

SRP19548

SRP19549

SRP19550

SRP19551

SRP19552

SRP19553

SRP19554

SRP19555

SRP19556

SRP19557

SRP19558

SRP19559

SRP19560

SRP19561
Description

\section{Weight}

(kg)

\section{Note}

Rad

Repackaged combined RCRA TRU sludge to AMWTP ID-SRP-S3000

Repackaged combined RCRA TRU sludge to AMWTP ID-SRP-S3000

Repackaged combined RCRA TRU sludge to AMWTP ID-SRP-S3000

Repackaged combined RCRA TRU sludge to AMWTP ID-SRP-S3000

Repackaged combined RCRA TRU sludge to AMWTP ID-SRP-S3000

Repackaged combined RCRA TRU sludge to AMWTP ID-SRP-S3000

Repackaged combined RCRA TRU sludge to AMWTP ID-SRP-S3000

Repackaged combined RCRA TRU sludge to AMWTP ID-SRP-S3000

Repackaged combined RCRA TRU sludge to AMWTP ID-SRP-S3000

Repackaged combined RCRA TRU sludge to AMWTP ID-SRP-S3000

Repackaged combined RCRA TRU sludge to AMWTP ID-SRP-S3000

Repackaged combined RCRA TRU sludge to AMWTP ID-SRP-S3000

Repackaged combined RCRA TRU sludge to AMWTP ID-SRP-S3000

Repackaged combined RCRA TRU sludge to AMWTP ID-SRP-S3000

Repackaged combined RCRA TRU sludge to AMWTP ID-SRP-S3000

Repackaged combined RCRA TRU sludge to AMWTP ID-SRP-S3000

Repackaged combined RCRA TRU sludge to AMWTP ID-SRP-S3000

Repackaged combined RCRA TRU sludge to AMWTP ID-SRP-S3000

Repackaged combined RCRA TRU sludge to AMWTP ID-SRP-S3000

Repackaged combined RCRA TRU sludge to AMWTP ID-SRP-S3000

Repackaged combined RCRA TRU sludge to AMWTP ID-SRP-S3000
167 This container was in storage at RWMC after repackaging in 2013. During 2014 it Yes was transferred back to AMWTP and appears on their report as barcode 10510007.

136 This container was in storage at RWMC after repackaging in 2013. During 2014 it Yes was transferred back to AMWTP and appears on their report as barcode 10509774.

182 This container was in storage at RWMC after repackaging in 2013. During 2014 it Yes was transferred back to AMWTP and appears on their report as barcode 10509966. was transferred back to AMWTP and appears on their report as barcode 10510005.

140 This container was in storage at RWMC after repackaging in 2013. During 2014 it Yes was transferred back to AMWTP and appears on their report as barcode 10509755.

136 This container was in storage at RWMC after repackaging in 2013. During 2014 it Yes was transferred back to AMWTP and appears on their report as barcode 10509967.

137 This container was in storage at RWMC after repackaging in 2013. During 2014 it Yes was transferred back to AMWTP and appears on their report as barcode 10509984.

125 This container was in storage at RWMC after repackaging in 2013. During 2014 it Yes was transferred back to AMWTP and appears on their report as barcode 10509987.

139 This container was in storage at RWMC after repackaging in 2013. During 2014 it Yes was transferred back to AMWTP and appears on their report as barcode 10509983.

146 This container was in storage at RWMC after repackaging in 2013. During 2014 it Yes was transferred back to AMWTP and appears on their report as barcode 10509964.

155 This container was in storage at RWMC after repackaging in 2013. During 2014 it Yes was transferred back to AMWTP and appears on their report as barcode 10510004.

139 This container was in storage at RWMC after repackaging in 2013. During 2014 it Yes was transferred back to AMWTP and appears on their report as barcode 10509990.

147 This container was in storage at RWMC after repackaging in 2013. During 2014 it Yes was transferred back to AMWTP and appears on their report as barcode 10509961.

179 This container was in storage at RWMC after repackaging in 2013. During 2014 it Yes was transferred back to AMWTP and appears on their report as barcode 10509767.

150 This container was in storage at RWMC after repackaging in 2013. During 2014 it Yes was transferred back to AMWTP and appears on their report as barcode 10510001.

192 This container was in storage at RWMC after repackaging in 2013. During 2014 it Yes was transferred back to AMWTP and appears on their report as barcode 10509970 .

137 This container was in storage at RWMC after repackaging in 2013. During 2014 it Yes was transferred back to AMWTP and appears on their report as barcode 10509775.

163 This container was in storage at RWMC after repackaging in 2013. During 2014 it Yes was transferred back to AMWTP and appears on their report as barcode 10509977.

166 This container was in storage at RWMC after repackaging in 2013. During 2014 it Yes was transferred back to AMWTP and appears on their report as barcode 10509985 .

146 This container was in storage at RWMC after repackaging in 2013. During 2014 it Yes was transferred back to AMWTP and appears on their report as barcode 10510003.

157 This container was in storage at RWMC after repackaging in 2013. During 2014 it Yes was transferred back to AMWTP and appears on their report as barcode 10510000 .
159 This container was in storage at RWMC after repackaging in 2013. During 2014 it Yes 


\section{Idaho National Laboratory \\ (excluding Advanced Mixed Waste Treatment Project [AMWTP]) \\ PCB Waste Document Log \\ Notes on 2014 Report}

Identification \#

SRP19562

SRP19563

SRP19564

SRP19565

SRP19566

SRP19567

SRP19568

SRP19569

SRP19570

SRP19571

SRP19572

SRP19573

SRP19574

SRP19575

SRP19576

SRP19577

SRP19578

SRP19579

SRP19580

SRP19581

SRP19582
Description

Repackaged combined RCRA TRU sludge to AMWTP ID-SRP-S3000

(kg)

Note

Rad

147 This container was in storage at RWMC after repackaging in 2013. During 2014 it Yes was transferred back to AMWTP and appears on their report as barcode 10509995.

164 This container was in storage at RWMC after repackaging in 2013. During 2014 it Yes was transferred back to AMWTP and appears on their report as barcode 10509971.

151 This container was in storage at RWMC after repackaging in 2013. During 2014 it Yes was transferred back to AMWTP and appears on their report as barcode 10509976.

158 This container was in storage at RWMC after repackaging in 2013. During 2014 it Yes was transferred back to AMWTP and appears on their report as barcode 10509978.

177 This container was in storage at RWMC after repackaging in 2013. During 2014 it Yes was transferred back to AMWTP and appears on their report as barcode 10509988 .

162 This container was in storage at RWMC after repackaging in 2013. During 2014 it Yes was transferred back to AMWTP and appears on their report as barcode 10509766.

101 This container was in storage at RWMC after repackaging in 2013. During 2014 it Yes was transferred back to AMWTP and appears on their report as barcode 10509979.

185 This container was in storage at RWMC after repackaging in 2013. During 2014 it Yes was transferred back to AMWTP and appears on their report as barcode 10509764.

178 This container was in storage at RWMC after repackaging in 2013. During 2014 it Yes was transferred back to AMWTP and appears on their report as barcode 10509972.

159 This container was in storage at RWMC after repackaging in 2013. During 2014 it Yes was transferred back to AMWTP and appears on their report as barcode 10509720

154 This container was in storage at RWMC after repackaging in 2013. During 2014 it Yes was transferred back to AMWTP and appears on their report as barcode 10509994.

158 This container was in storage at RWMC after repackaging in 2013. During 2014 it Yes was transferred back to AMWTP and appears on their report as barcode 10509975.

162 This container was in storage at RWMC after repackaging in 2013. During 2014 it Yes was transferred back to AMWTP and appears on their report as barcode 10509960

162 This container was in storage at RWMC after repackaging in 2013. During 2014 it Yes was transferred back to AMWTP and appears on their report as barcode 10509986.

174 This container was in storage at RWMC after repackaging in 2013. During 2014 it Yes was transferred back to AMWTP and appears on their report as barcode 10509727.

128 This container was in storage at RWMC after repackaging in 2013. During 2014 it Yes

166 This container was in storage at RWMC after repackaging in 2013. During 2014 it Yes was transferred back to AMWTP and appears on their report as barcode 10509991.

155 This container was in storage at RWMC after repackaging in 2013. During 2014 it Yes was transferred back to AMWTP and appears on their report as barcode 10509974 .

179 This container was in storage at RWMC after repackaging in 2013. During 2014 it Yes was transferred back to AMWTP and appears on their report as barcode 10509998.

189 This container was in storage at RWMC after repackaging in 2013. During 2014 it Yes was transferred back to AMWTP and appears on their report as barcode 10509736 .

177 This container was in storage at RWMC after repackaging in 2013. During 2014 it Yes was transferred back to AMWTP and appears on their report as barcode 10509715 . 


\section{Idaho National Laboratory \\ (excluding Advanced Mixed Waste Treatment Project [AMWTP]) \\ PCB Waste Document Log \\ Notes on 2014 Report}

Identification \#

SRP19583

SRP19584

SRP19585

SRP19586

SRP19587

SRP19589

SRP19590

SRP19591

SRP19592

SRP19593

SRP19594

SRP19595

SRP19596

SRP19597

SRP19598

SRP19599

SRP19601

SRP19602

SRP19603

SRP19604

SRP19605
Description

Repackaged combined RCRA TRU sludge to AMWTP ID-SRP-S3000

(kg)

\section{Note}

Rad

163 This container was in storage at RWMC after repackaging in 2013. During 2014 it Yes was transferred back to AMWTP and appears on their report as barcode 10509968.

148 This container was in storage at RWMC after repackaging in 2013. During 2014 it Yes was transferred back to AMWTP and appears on their report as barcode 10509963.

171 This container was in storage at RWMC after repackaging in 2013. During 2014 it Yes was transferred back to AMWTP and appears on their report as barcode 10509714 .

124 This container was in storage at RWMC after repackaging in 2013. During 2014 it Yes was transferred back to AMWTP and appears on their report as barcode 10510006 .

151 This container was in storage at RWMC after repackaging in 2013. During 2014 it Yes was transferred back to AMWTP and appears on their report as barcode 10509739.

181 This container was in storage at RWMC after repackaging in 2013. During 2014 it Yes was transferred back to AMWTP and appears on their report as barcode 10509753.

199 This container was in storage at RWMC after repackaging in 2013. During 2014 it Yes was transferred back to AMWTP and appears on their report as barcode 10509742.

155 This container was in storage at RWMC after repackaging in 2013. During 2014 it Yes was transferred back to AMWTP and appears on their report as barcode 10509778 .

184 This container was in storage at RWMC after repackaging in 2013. During 2014 it Yes was transferred back to AMWTP and appears on their report as barcode 10509731 .

194 This container was in storage at RWMC after repackaging in 2013. During 2014 it Yes was transferred back to AMWTP and appears on their report as barcode 10509762.

153 This container was in storage at RWMC after repackaging in 2013. During 2014 it Yes was transferred back to AMWTP and appears on their report as barcode 10509763 .

131 This container was in storage at RWMC after repackaging in 2013. During 2014 it Yes was transferred back to AMWTP and appears on their report as barcode 10509765.

136 This container was in storage at RWMC after repackaging in 2013. During 2014 it Yes was transferred back to AMWTP and appears on their report as barcode 10509728.

167 This container was in storage at RWMC after repackaging in 2013. During 2014 it Yes was transferred back to AMWTP and appears on their report as barcode 10509718 .

176 This container was in storage at RWMC after repackaging in 2013. During 2014 it Yes was transferred back to AMWTP and appears on their report as barcode 10509729.

171 This container was in storage at RWMC after repackaging in 2013. During 2014 it Yes was transferred back to AMWTP and appears on their report as barcode 10509721.

166 This container was in storage at RWMC after repackaging in 2013. During 2014 it Yes was transferred back to AMWTP and appears on their report as barcode 10509732.

188 This container was in storage at RWMC after repackaging in 2013. During 2014 it Yes was transferred back to AMWTP and appears on their report as barcode 10509734 .

213 This container was in storage at RWMC after repackaging in 2013. During 2014 it Yes was transferred back to AMWTP and appears on their report as barcode 10509716.

160 This container was in storage at RWMC after repackaging in 2013. During 2014 it Yes was transferred back to AMWTP and appears on their report as barcode 10509760.

152 This container was in storage at RWMC after repackaging in 2013. During 2014 it Yes was transferred back to AMWTP and appears on their report as barcode 10509744 . 


\section{Idaho National Laboratory \\ (excluding Advanced Mixed Waste Treatment Project [AMWTP]) \\ PCB Waste Document Log \\ Notes on 2014 Report}

Identification \#

SRP19606

SRP19607

SRP19608

SRP19609

SRP19610

SRP19611

SRP19612

SRP19613

SRP19614

SRP19615

SRP19616

SRP19617

SRP19618

SRP19619

SRP19620

SRP19621

SRP19622

SRP19623

SRP19624

SRP19626

SRP19627
Description

\section{Weight}

(kg)

\section{Note}

Rad

Repackaged combined RCRA TRU sludge to AMWTP ID-SRP-S3000

Repackaged combined RCRA TRU sludge to AMWTP ID-SRP-S3000

Repackaged combined RCRA TRU sludge to AMWTP ID-SRP-S3000

Repackaged combined RCRA TRU sludge to AMWTP ID-SRP-S3000

Repackaged combined RCRA TRU sludge to AMWTP ID-SRP-S3000

Repackaged combined RCRA TRU sludge to AMWTP ID-SRP-S3000

Repackaged combined RCRA TRU sludge to AMWTP ID-SRP-S3000

Repackaged combined RCRA TRU sludge to AMWTP ID-SRP-S3000

Repackaged combined RCRA TRU sludge to AMWTP ID-SRP-S3000

Repackaged combined RCRA TRU sludge to AMWTP ID-SRP-S3000

Repackaged combined RCRA TRU sludge to AMWTP ID-SRP-S3000

Repackaged combined RCRA TRU sludge to AMWTP ID-SRP-S3000

Repackaged combined RCRA TRU sludge to AMWTP ID-SRP-S3000

Repackaged combined RCRA TRU sludge to AMWTP ID-SRP-S3000

Repackaged combined RCRA TRU sludge to AMWTP ID-SRP-S3000

Repackaged combined RCRA TRU sludge to AMWTP ID-SRP-S3000

Repackaged combined RCRA TRU sludge to AMWTP ID-SRP-S3000

Repackaged combined RCRA TRU sludge to AMWTP ID-SRP-S3000

Repackaged combined RCRA TRU sludge to AMWTP ID-SRP-S3000

Repackaged combined RCRA TRU sludge to AMWTP ID-SRP-S3000

Repackaged combined RCRA TRU sludge to AMWTP ID-SRP-S3000
139 This container was in storage at RWMC after repackaging in 2013. During 2014 it was transferred back to AMWTP and appears on their report as barcode 10509771.

131 This container was in storage at RWMC after repackaging in 2013. During 2014 it Yes was transferred back to AMWTP and appears on their report as barcode 10509780.

182 This container was in storage at RWMC after repackaging in 2013. During 2014 it Yes was transferred back to AMWTP and appears on their report as barcode 10509712 .

154 This container was in storage at RWMC after repackaging in 2013. During 2014 it Yes was transferred back to AMWTP and appears on their report as barcode 10509761.

157 This container was in storage at RWMC after repackaging in 2013. During 2014 it Yes was transferred back to AMWTP and appears on their report as barcode 10509713.

182 This container was in storage at RWMC after repackaging in 2013. During 2014 it Yes was transferred back to AMWTP and appears on their report as barcode 10509722.

150 This container was in storage at RWMC after repackaging in 2013. During 2014 it Yes was transferred back to AMWTP and appears on their report as barcode 10509733.

170 This container was in storage at RWMC after repackaging in 2013. During 2014 it Yes was transferred back to AMWTP and appears on their report as barcode 10509781.

162 This container was in storage at RWMC after repackaging in 2013. During 2014 it Yes was transferred back to AMWTP and appears on their report as barcode 10509730.

137 This container was in storage at RWMC after repackaging in 2013. During 2014 it Yes was transferred back to AMWTP and appears on their report as barcode 10509769.

130 This container was in storage at RWMC after repackaging in 2013. During 2014 it Yes was transferred back to AMWTP and appears on their report as barcode 10509768 .

138 This container was in storage at RWMC after repackaging in 2013. During 2014 it Yes was transferred back to AMWTP and appears on their report as barcode 10509993.

167 This container was in storage at RWMC after repackaging in 2013. During 2014 it Yes was transferred back to AMWTP and appears on their report as barcode 10509719.

180 This container was in storage at RWMC after repackaging in 2013. During 2014 it Yes was transferred back to AMWTP and appears on their report as barcode 10509770.

175 This container was in storage at RWMC after repackaging in 2013. During 2014 it Yes was transferred back to AMWTP and appears on their report as barcode 10509724.

153 This container was in storage at RWMC after repackaging in 2013. During 2014 it Yes was transferred back to AMWTP and appears on their report as barcode 10509723.

115 This container was in storage at RWMC after repackaging in 2013. During 2014 it Yes was transferred back to AMWTP and appears on their report as barcode 10509735.

161 This container was in storage at RWMC after repackaging in 2013. During 2014 it Yes was transferred back to AMWTP and appears on their report as barcode 10509751.

189 This container was in storage at RWMC after repackaging in 2013. During 2014 it Yes was transferred back to AMWTP and appears on their report as barcode 10509758 .

179 This container was in storage at RWMC after repackaging in 2013. During 2014 it Yes was transferred back to AMWTP and appears on their report as barcode 10509743.

174 This container was in storage at RWMC after repackaging in 2013. During 2014 it Yes was transferred back to AMWTP and appears on their report as barcode 10509747. 


\section{Idaho National Laboratory \\ (excluding Advanced Mixed Waste Treatment Project [AMWTP]) \\ PCB Waste Document Log \\ Notes on 2014 Report}

Identification \#

SRP19628

SRP19629

SRP19630

SRP19631

SRP19632

SRP19634

SRP19635

SRP19636

SRP19637

SRP19638

SRP19639

SRP19640

SRP19641

SRP19642

SRP19643

SRP19644

SRP19645

SRP19646

SRP19647

SRP19648

SRP19649
Description

\section{Weight}

(kg)

\section{Note}

Rad

Repackaged combined RCRA TRU sludge to AMWTP ID-SRP-S3000

Repackaged combined RCRA TRU sludge to AMWTP ID-SRP-S3000

Repackaged combined RCRA TRU sludge to AMWTP ID-SRP-S3000

Repackaged combined RCRA TRU sludge to AMWTP ID-SRP-S3000

Repackaged combined RCRA TRU sludge to AMWTP ID-SRP-S3000

Repackaged combined RCRA TRU sludge to AMWTP ID-SRP-S3000

Repackaged combined RCRA TRU sludge to AMWTP ID-SRP-S3000

Repackaged combined RCRA TRU sludge to AMWTP ID-SRP-S3000

Repackaged combined RCRA TRU sludge to AMWTP ID-SRP-S3000

Repackaged combined RCRA TRU sludge to AMWTP ID-SRP-S3000

Repackaged combined RCRA TRU sludge to AMWTP ID-SRP-S3000

Repackaged combined RCRA TRU sludge to AMWTP ID-SRP-S3000

Repackaged combined RCRA TRU sludge to AMWTP ID-SRP-S3000

Repackaged combined RCRA TRU sludge to AMWTP ID-SRP-S3000

Repackaged combined RCRA TRU sludge to AMWTP ID-SRP-S3000

Repackaged combined RCRA TRU sludge to AMWTP ID-SRP-S3000

Repackaged combined RCRA TRU sludge to AMWTP ID-SRP-S3000

Repackaged combined RCRA TRU sludge to AMWTP ID-SRP-S3000

Repackaged combined RCRA TRU sludge to AMWTP ID-SRP-S3000

Repackaged combined RCRA TRU sludge to AMWTP ID-SRP-S3000

Repackaged combined RCRA TRU sludge to AMWTP ID-SRP-S3000
184 This container was in storage at RWMC after repackaging in 2013. During 2014 it was transferred back to AMWTP and appears on their report as barcode 10509748.

175 This container was in storage at RWMC after repackaging in 2013. During 2014 it Yes was transferred back to AMWTP and appears on their report as barcode 10509741.

169 This container was in storage at RWMC after repackaging in 2013. During 2014 it Yes was transferred back to AMWTP and appears on their report as barcode 10509772.

143 This container was in storage at RWMC after repackaging in 2013. During 2014 it Yes was transferred back to AMWTP and appears on their report as barcode 10509773.

157 This container was in storage at RWMC after repackaging in 2013. During 2014 it Yes was transferred back to AMWTP and appears on their report as barcode 10509783.

200 This container was in storage at RWMC after repackaging in 2013. During 2014 it Yes was transferred back to AMWTP and appears on their report as barcode 10509746.

166 This container was in storage at RWMC after repackaging in 2013. During 2014 it Yes was transferred back to AMWTP and appears on their report as barcode 10509749.

175 This container was in storage at RWMC after repackaging in 2013. During 2014 it Yes was transferred back to AMWTP and appears on their report as barcode 10509757.

196 This container was in storage at RWMC after repackaging in 2013. During 2014 it Yes was transferred back to AMWTP and appears on their report as barcode 10509737.

193 This container was in storage at RWMC after repackaging in 2013. During 2014 it Yes was transferred back to AMWTP and appears on their report as barcode 10509726.

164 This container was in storage at RWMC after repackaging in 2013. During 2014 it Yes was transferred back to AMWTP and appears on their report as barcode 10509717.

142 This container was in storage at RWMC after repackaging in 2013. During 2014 it Yes was transferred back to AMWTP and appears on their report as barcode 10509989.

184 This container was in storage at RWMC after repackaging in 2013. During 2014 it Yes was transferred back to AMWTP and appears on their report as barcode 10509750.

167 This container was in storage at RWMC after repackaging in 2013. During 2014 it Yes was transferred back to AMWTP and appears on their report as barcode 10509756.

147 This container was in storage at RWMC after repackaging in 2013. During 2014 it Yes was transferred back to AMWTP and appears on their report as barcode 10509740.

165 This container was in storage at RWMC after repackaging in 2013. During 2014 it Yes was transferred back to AMWTP and appears on their report as barcode 10509745.

174 This container was in storage at RWMC after repackaging in 2013. During 2014 it Yes was transferred back to AMWTP and appears on their report as barcode 10509759.

194 This container was in storage at RWMC after repackaging in 2013. During 2014 it Yes was transferred back to AMWTP and appears on their report as barcode 10509777.

155 This container was in storage at RWMC after repackaging in 2013. During 2014 it Yes was transferred back to AMWTP and appears on their report as barcode 10509779 .

198 This container was in storage at RWMC after repackaging in 2013. During 2014 it Yes was transferred back to AMWTP and appears on their report as barcode 10509782 .

194 This container was in storage at RWMC after repackaging in 2013. During 2014 it Yes was transferred back to AMWTP and appears on their report as barcode 10509752. 


\section{Idaho National Laboratory \\ (excluding Advanced Mixed Waste Treatment Project [AMWTP]) \\ PCB Waste Document Log \\ Notes on 2014 Report}

Identification \#

SRP19696

SRP19698

SRP19699

SRS12032

SRS12036

SRS130007

SRS130101

SRS130103

SRS130104

SRS130120

SRS130124

SRS130125

SRS130132

SRS130133

SRS130134

SRS130141

SRS130142

SRS130143

SRS130150

SRS130251

SRS130267
Description

\section{Weight}

(kg)

\section{Note}

Rad

Repackaged combined RCRA TRU sludge to AMWTP ID-SRP-S3000

Repackaged combined RCRA TRU sludge to AMWTP ID-SRP-S3000

Repackaged combined RCRA TRU sludge to AMWTP ID-SRP-S3000

152 This container was in storage at RWMC after repackaging in 2013. During 2014 it was transferred back to AMWTP and appears on their report as barcode 10509754.

163 This container was in storage at RWMC after repackaging in 2013. During 2014 it Yes was transferred back to AMWTP and appears on their report as barcode 10509776.

196 This container was in storage at RWMC after repackaging in 2013. During 2014 it Yes was transferred back to AMWTP and appears on their report as barcode 10509738 . This container, that appeared in the 2013 report, is an accumulation container that contained no waste at the end of 2014 while the ARP SRP was in warm standby. This container, that appeared in the 2013 report, is an accumulation container that contained no waste at the end of 2014 while the ARP SRP was in warm standby.

This container, that appeared in the 2013 report, is an accumulation container that contained no waste at the end of 2014 while the ARP SRP was in warm standby.

963 This container was in storage at RWMC after repackaging in 2013. During 2014 it Yes was transferred back to AMWTP and appears on their report as barcode 1051239 .

1045 This container was in storage at RWMC after repackaging in 2013. During 2014 it Yes was transferred back to AMWTP and appears on their report as barcode 10512877.

901 This container was in storage at RWMC after repackaging in 2013. During 2014 it Yes was transferred back to AMWTP and appears on their report as barcode 10512397.

941 This container was in storage at RWMC after repackaging in 2013. During 2014 it Yes was transferred back to AMWTP and appears on their report as barcode 10512392.

919 This container was in storage at RWMC after repackaging in 2013. During 2014 it was transferred back to AMWTP and appears on their report as barcode 10512391.

1064 This container was in storage at RWMC after repackaging in 2013. During 2014 it was transferred back to AMWTP and appears on their report as barcode 10512394 .

988 This container was in storage at RWMC after repackaging in 2013. During 2014 it was transferred back to AMWTP and appears on their report as barcode 10512880 .

946 This container was in storage at RWMC after repackaging in 2013. During 2014 it Yes was transferred back to AMWTP and appears on their report as barcode 10512390.

1077 This container was in storage at RWMC after repackaging in 2013. During 2014 it Yes was transferred back to AMWTP and appears on their report as barcode 10512881.

852 This container was in storage at RWMC after repackaging in 2013. During 2014 it Yes was transferred back to AMWTP and appears on their report as barcode 10512389.

1019 This container was in storage at RWMC after repackaging in 2013. During 2014 it Yes was transferred back to AMWTP and appears on their report as barcode 10512386.

1065 This container was in storage at RWMC after repackaging in 2013. During 2014 it Yes was transferred back to AMWTP and appears on their report as barcode 10512396.

1130 This container was in storage at RWMC after repackaging in 2013. During 2014 it Yes was transferred back to AMWTP and appears on their report as barcode 10512875 .

1061 This container was in storage at RWMC after repackaging in 2013. During 2014 it Yes was transferred back to AMWTP and appears on their report as barcode 10512876.

1066 This container was in storage at RWMC after repackaging in 2013. During 2014 it Yes was transferred back to AMWTP and appears on their report as barcode 10512879 . 


\section{Idaho National Laboratory \\ (excluding Advanced Mixed Waste Treatment Project [AMWTP]) \\ PCB Waste Document Log \\ Notes on 2014 Report}

Identification \#

SRS130268

SRS130272

SRS130310

SRS130337

SRS130353

SRS130426

SRS130436

SRS130438

SRS130439

SRS130440

SRS130441

SRS130444

SRS130445
Description

LDR compliant, PCB AMWTP repack secondary waste

LDR compliant, PCB AMWTP repack secondary waste

LDR compliant, PCB AMWTP repack secondary waste

LDR compliant, PCB AMWTP repack secondary waste

LDR compliant, PCB AMWTP repack secondary waste-combined sludge

LDR compliant, PCB AMWTP repack secondary waste-combined sludge

LDR compliant, PCB AMWTP repack secondary waste-combined sludge

LDR compliant, PCB AMWTP repack secondary waste-combined sludge

LDR compliant, PCB AMWTP repack secondary waste-combined sludge

LDR compliant, PCB AMWTP repack secondary waste-combined sludge

LDR compliant, PCB AMWTP repack secondary waste-combined sludge

LDR compliant, PCB AMWTP repack secondary waste-combined sludge

LDR compliant, PCB AMWTP repack secondary waste-combined sludge

\section{Weight}

(kg)

Note

Rad

1026 This container was in storage at RWMC after repackaging in 2013. During 2014 it Yes was transferred back to AMWTP and appears on their report as barcode 10512878 .

1031 This container was in storage at RWMC after repackaging in 2013. During 2014 it Yes was transferred back to AMWTP and appears on their report as barcode 10512387.

1007 This container was in storage at RWMC after repackaging in 2013. During 2014 it Yes was transferred back to AMWTP and appears on their report as barcode 10512395.

1117 This container was in storage at RWMC after repackaging in 2013. During 2014 it Yes was transferred back to AMWTP and appears on their report as barcode 10512388. This container, that appeared in the 2013 report, is an accumulation container that contained no waste at the end of 2014 while the ARP SRP was in warm standby.

1072 This container was in storage at RWMC after repackaging in 2013. During 2014 it Yes was transferred back to AMWTP and appears on their report as barcode 10521371.

1118 This container was in storage at RWMC after repackaging in 2013. During 2014 it Yes was transferred back to AMWTP and appears on their report as barcode 10515999.

1087 This container was in storage at RWMC after repackaging in 2013. During 2014 it Yes was transferred back to AMWTP and appears on their report as barcode 10515995.

1076 This container was in storage at RWMC after repackaging in 2013. During 2014 it Yes was transferred back to AMWTP and appears on their report as barcode 10515998.

1139 This container was in storage at RWMC after repackaging in 2013. During 2014 it Yes was transferred back to AMWTP and appears on th

1169 This container was in storage at RWMC after repackaging in 2013. During 2014 it Yes was transferred back to AMWTP and appears on their report as barcode 10521368 .

1117 This container was in storage at RWMC after repackaging in 2013. During 2014 it Yes was transferred back to AMWTP and appears on their report as barcode 10516001 .

1092 This container was in storage at RWMC after repackaging in 2013. During 2014 it Yes was transferred back to AMWTP and appears on their report as barcode 10516005. 


\section{Idaho National Laboratory \\ Advanced Mixed Waste Treatment Project (AMWTP) \\ PCB Waste Document Log \\ Notes on 2014 Report}

\begin{tabular}{ll} 
Identification \# & \multicolumn{1}{c}{ Description } \\
\hline 10007920 & Undefined Debris \\
10015144 & Organic Setups, Oil Solids \\
10016120 & Unknown \\
10018106 & Organic Setups, Oil Solids \\
10020657 & Organic Setups, Oil Solids \\
10020665 & Organic Setups, Oil Solids \\
10020695 & Organic Setups, Oil Solids \\
10020715 & Organic Setups, Oil Solids \\
10022163 & Organic Setups, Oil Solids \\
10023906 & Organic Setups, Oil Solids \\
10024322 & Unknown \\
10024330 & Organic Setups, Oil Solids \\
10025099 & Organic Setups, Oil Solids \\
10025458 & Organic Setups, Oil Solids \\
10025523 & Organic Setups, Oil Solids \\
10027931 & Paper, Cloth, Metals, Glass \\
10033755 & Solidified Organics \\
10056342 & Undefined Homogeneous Solids \\
10073715 & Organic Setups, Oil Solids \\
10085518 & Non-special Source Metal \\
10089783 & Organic Setups, Oil Solids \\
10105628 & Paper and Rags-Moist \\
10107182 & Organic Setups, Oil Solids \\
10113538 & Undefined Homogeneous Solids \\
10113552 & Undefined Homogeneous Solids \\
10127011 & Organic Setups, Oil Solids \\
10136777 & Undefined Homogeneous Solids \\
10140650 & Non-special Source Metal \\
10140764 & Undefined Homogeneous Solids \\
10141041 & Undefined Homogeneous Solids \\
10141062 & Undefined Homogeneous Solids \\
10144343 & Undefined Homogeneous Solids \\
10144370 & its 11 \& 12 Organic Setups \\
10145296 & Undefined Homogeneous Solids
\end{tabular}

Weight

(kg)

Note

Rad

77 Determined not to contain PCBs during characterization performed in 2014

246 This container was transferred to the Accelerated Retrieval Project at RWMC for the Sludge Repackaging Project.

237 This container was transferred to the Accelerated Retrieval Project at RWMC for the Sludge Repackaging Project.

249 This container was transferred to the Accelerated Retrieval Project at RWMC for the Sludge Repackaging Project.

232 This container was transferred to the Accelerated Retrieval Project at RWMC for the Sludge Repackaging Project.

257 This container was transferred to the Accelerated Retrieval Project at RWMC for the Sludge Repackaging Project.

229 This container was transferred to the Accelerated Retrieval Project at RWMC for the Sludge Repackaging Project.

242 This container was transferred to the Accelerated Retrieval Project at RWMC for the Sludge Repackaging Project.

225 This container was transferred to the Accelerated Retrieval Project at RWMC for the Sludge Repackaging Project.

235 This container was transferred to the Accelerated Retrieval Project at RWMC for the Sludge Repackaging Project.

238 This container was transferred to the Accelerated Retrieval Project at RWMC for the Sludge Repackaging Project.

236 This container was transferred to the Accelerated Retrieval Project at RWMC for the Sludge Repackaging Project.

226 This container was transferred to the Accelerated Retrieval Project at RWMC for the Sludge Repackaging Project.

303 This container was transferred to the Accelerated Retrieval Project at RWMC for the Sludge Repackaging Project.

303 This container was transferred to the Accelerated Retrieval Project at RWMC for the Sludge Repackaging Project.

202 Determined not to contain PCBs during characterization performed in 2014

285 Determined not to contain PCBs during characterization performed in 2014

80 Container erroneously listed as containing PCB waste in previous report.

作

150 Determined not to contain PCBs during characterization performed in 2014

300 This container was transferred to the Accelerated Retrieval Project at RWMC for the Sludge Repackaging Project.

102 Container erroneously listed as containing PCB waste in previous report.

304 This container was transferred to the Accelerated Retrieval Project at RWMC for the Sludge Repackaging Project.

1034 Determined not to contain PCBs during characterization performed in 2014

1034 Determined not to contain PCBs during characterization performed in 2014

291 This container was transferred to the Accelerated Retrieval Project at RWMC for the Sludge Repackaging Project.

125 Determined not to contain PCBs during characterization performed in 2014

143 Determined not to contain PCBs during characterization performed in 2014.

1034 Determined not to contain PCBs during characterization performed in 2014

1034 Determined not to contain PCBs during characterization performed in 2014

1034 Determined not to contain PCBs during characterization performed in 2014

1034 Determined not to contain PCBs during characterization performed in 2014

249 This container was transferred to the Accelerated Retrieval Project at RWMC for the Sludge Repackaging Project. Yes

1034 Container erroneously listed as containing PCB waste in previous report. 


\section{Idaho National Laboratory \\ Advanced Mixed Waste Treatment Project (AMWTP) \\ PCB Waste Document Log \\ Notes on 2014 Report}

\begin{tabular}{|c|c|c|c|c|}
\hline Identification \# & Description & $\begin{array}{c}\text { Weight } \\
\text { (kg) }\end{array}$ & Note & Rad \\
\hline 10145339 & Pits $11 \& 12$ Organic Setups & 249 & This container was transferred to the Accelerated Retrieval Project at RWMC for the Sludge Repackaging Project. & Yes \\
\hline 10146880 & Organic Setups, Oil Solids & 284 & This container was transferred to the Accelerated Retrieval Project at RWMC for the Sludge Repackaging Project. & Yes \\
\hline 10147195 & Organic Setups, Oil Solids & 304 & This container was transferred to the Accelerated Retrieval Project at RWMC for the Sludge Repackaging Project. & Yes \\
\hline 10151474 & Organic Setups, Oil Solids & 312 & This container was transferred to the Accelerated Retrieval Project at RWMC for the Sludge Repackaging Project. & Yes \\
\hline 10152960 & Organic Setups, Oil Solids & 233 & This container was transferred to the Accelerated Retrieval Project at RWMC for the Sludge Repackaging Project. & Yes \\
\hline 10153755 & Organic Setups, Oil Solids & 364 & This container was transferred to the Accelerated Retrieval Project at RWMC for the Sludge Repackaging Project. & Yes \\
\hline 10154789 & Organic Setups, Oil Solids & 318 & This container was transferred to the Accelerated Retrieval Project at RWMC for the Sludge Repackaging Project. & Yes \\
\hline 10158383 & Organic Setups, Oil Solids & 253 & This container was transferred to the Accelerated Retrieval Project at RWMC for the Sludge Repackaging Project. & Yes \\
\hline 10161218 & Organic Setups, Oil Solids & 295 & This container was transferred to the Accelerated Retrieval Project at RWMC for the Sludge Repackaging Project. & Yes \\
\hline 10162648 & Organic Setups, Oil Solids & 287 & This container was transferred to the Accelerated Retrieval Project at RWMC for the Sludge Repackaging Project. & Yes \\
\hline 10163761 & Organic Setups, Oil Solids & 283 & This container was transferred to the Accelerated Retrieval Project at RWMC for the Sludge Repackaging Project. & Yes \\
\hline 10167120 & Organic Setups, Oil Solids & 276 & This container was transferred to the Accelerated Retrieval Project at RWMC for the Sludge Repackaging Project. & Yes \\
\hline 10167830 & Organic Setups, Oil Solids & 267 & This container was transferred to the Accelerated Retrieval Project at RWMC for the Sludge Repackaging Project. & Yes \\
\hline 10177722 & Organic Setups, Oil Solids & 311 & This container was transferred to the Accelerated Retrieval Project at RWMC for the Sludge Repackaging Project. & Yes \\
\hline 10191983 & Organic Setups, Oil Solids & 255 & This container was transferred to the Accelerated Retrieval Project at RWMC for the Sludge Repackaging Project. & Yes \\
\hline 10196304 & Organic Setups, Oil Solids & 349 & This container was transferred to the Accelerated Retrieval Project at RWMC for the Sludge Repackaging Project. & Yes \\
\hline 10200318 & Organic Setups, Oil Solids & 248 & This container was transferred to the Accelerated Retrieval Project at RWMC for the Sludge Repackaging Project. & Yes \\
\hline 10205964 & Undefined Homogeneous Solids & 199 & Determined not to contain PCBs during characterization performed in 2014. & Yes \\
\hline 10206179 & Miscellaneous Radionuclide Sources & 51 & Container erroneously listed as containing PCB waste in previous report. & Yes \\
\hline 10221196 & Organic Setups, Oil Solids & 302 & This container was transferred to the Accelerated Retrieval Project at RWMC for the Sludge Repackaging Project. & Yes \\
\hline 10223349 & Organic Setups, Oil Solids & 304 & This container was transferred to the Accelerated Retrieval Project at RWMC for the Sludge Repackaging Project. & Yes \\
\hline 10223350 & Organic Setups, Oil Solids & 274 & This container was transferred to the Accelerated Retrieval Project at RWMC for the Sludge Repackaging Project. & Yes \\
\hline 10242707 & Organic Setups, Oil Solids & 307 & This container was transferred to the Accelerated Retrieval Project at RWMC for the Sludge Repackaging Project. & Yes \\
\hline 10242932 & Undefined Homogeneous Solids & 685 & Determined not to contain PCBs during characterization performed in 2014. & Yes \\
\hline 10255791 & Organic Setups, Oil Solids & 241 & This container was transferred to the Accelerated Retrieval Project at RWMC for the Sludge Repackaging Project. & Yes \\
\hline 10264250 & Pits 11 \& 12 Debris & 127 & Determined not to contain PCBs during characterization performed in 2014. & Yes \\
\hline 10264480 & Pits 11 and 12 Cargos and Bins & 6085 & Determined not to contain PCBs during characterization performed in 2014. & Yes \\
\hline 10264629 & Pits 11 and 12 Cargos and Bins with Roaster Oxide & 13107 & Determined not to contain PCBs during characterization performed in 2014. & Yes \\
\hline 10264633 & Pits 11 and 12 Cargos and Bins & 9521 & Determined not to contain PCBs during characterization performed in 2014. & Yes \\
\hline 10264636 & Pits 11 and 12 Cargos and Bins & 11570 & Determined not to contain PCBs during characterization performed in 2014. & Yes \\
\hline 10268008 & Pits $11 \& 12$ Organic Setups & 249 & This container was transferred to the Accelerated Retrieval Project at RWMC for the Sludge Repackaging Project. & Yes \\
\hline 10268128 & Undefined Homogeneous Solids & 371 & Container erroneously listed as containing PCB waste in previous report. & Yes \\
\hline 10268227 & Pits 11 \& 12 Organic Setups & 306 & This container was transferred to the Accelerated Retrieval Project at RWMC for the Sludge Repackaging Project. & Yes \\
\hline 10268412 & Undefined Homogeneous Solids & 1034 & Determined not to contain PCBs during characterization performed in 2014. & Yes \\
\hline
\end{tabular}




\section{Idaho National Laboratory \\ Advanced Mixed Waste Treatment Project (AMWTP) \\ PCB Waste Document Log \\ Notes on 2014 Report}

\begin{tabular}{|c|c|c|c|c|}
\hline Identification \# & Description & $\begin{array}{l}\text { Weight } \\
\text { (kg) }\end{array}$ & Note & Rad \\
\hline 10268434 & Undefined Homogeneous Solids & 1034 & Determined not to contain PCBs during characterization performed in 2014. & Yes \\
\hline 10268537 & Undefined Homogeneous Solids & 1034 & Determined not to contain PCBs during characterization performed in 2014. & Yes \\
\hline 10272861 & Undefined Homogeneous Solids & 114 & Determined not to contain PCBs during characterization performed in 2014. & Yes \\
\hline 10286691 & Undefined Homogeneous Solids & 122 & Determined not to contain PCBs during characterization performed in 2014. & Yes \\
\hline 10287849 & Undefined Homogeneous Solids & 117 & Determined not to contain PCBs during characterization performed in 2014. & Yes \\
\hline 10288394 & Pits $11 \& 12$ Organic Setups & 249 & This container was transferred to the Accelerated Retrieval Project at RWMC for the Sludge Repackaging Project. & Yes \\
\hline 10289408 & Undefined Homogeneous Solids & 226 & Determined not to contain PCBs during characterization performed in 2014. & Yes \\
\hline 10289864 & Organic Setups, Oil Solids & 252 & This container was transferred to the Accelerated Retrieval Project at RWMC for the Sludge Repackaging Project. & Yes \\
\hline 10291345 & Pits $11 \& 12$ Organic Setups & 287 & This container was transferred to the Accelerated Retrieval Project at RWMC for the Sludge Repackaging Project. & Yes \\
\hline 10291351 & Pits $11 \& 12$ Organic Setups & 299 & This container was transferred to the Accelerated Retrieval Project at RWMC for the Sludge Repackaging Project. & Yes \\
\hline 10291933 & Pits 11 and 12 Cargos and Bins & 6440 & Determined not to contain PCBs during characterization performed in 2014. & Yes \\
\hline 10292011 & Pits 11 and 12 Cargos and Bins with Roaster Oxide & 5213 & Determined not to contain PCBs during characterization performed in 2014. & Yes \\
\hline 10293768 & Pits $11 \& 12$ Debris & 96 & Determined not to contain PCBs during characterization performed in 2014. & Yes \\
\hline 10301121 & Pits $11 \& 12$ Organic Setups & 246 & This container was transferred to the Accelerated Retrieval Project at RWMC for the Sludge Repackaging Project. & Yes \\
\hline 10303225 & Pits $11 \& 12$ Organic Setups & 250 & This container was transferred to the Accelerated Retrieval Project at RWMC for the Sludge Repackaging Project. & Yes \\
\hline 10305492 & Pits $11 \& 12$ Organic Setups & 189 & This container was transferred to the Accelerated Retrieval Project at RWMC for the Sludge Repackaging Project. & Yes \\
\hline 10306568 & Pits $11 \& 12$ Organic Setups & 194 & This container was transferred to the Accelerated Retrieval Project at RWMC for the Sludge Repackaging Project. & Yes \\
\hline 10309652 & Pits $11 \& 12$ Organic Setups & 247 & This container was transferred to the Accelerated Retrieval Project at RWMC for the Sludge Repackaging Project. & Yes \\
\hline 10309676 & Pits $11 \& 12$ Organic Setups & 250 & This container was transferred to the Accelerated Retrieval Project at RWMC for the Sludge Repackaging Project. & Yes \\
\hline 10310102 & Pits $11 \& 12$ Organic Setups & 227 & This container was transferred to the Accelerated Retrieval Project at RWMC for the Sludge Repackaging Project. & Yes \\
\hline 10310143 & Pits $11 \& 12$ Organic Setups & 178 & This container was transferred to the Accelerated Retrieval Project at RWMC for the Sludge Repackaging Project. & Yes \\
\hline 10310310 & Pits $11 \& 12$ Organic Setups & 201 & This container was transferred to the Accelerated Retrieval Project at RWMC for the Sludge Repackaging Project. & Yes \\
\hline 10310412 & Undefined Homogeneous Solids & 203 & This container was transferred to the Accelerated Retrieval Project at RWMC for the Sludge Repackaging Project. & Yes \\
\hline 10310467 & Pits $11 \& 12$ Organic Setups & 248 & This container was transferred to the Accelerated Retrieval Project at RWMC for the Sludge Repackaging Project. & Yes \\
\hline 10311047 & Pits $11 \& 12$ Organic Setups & 245 & This container was transferred to the Accelerated Retrieval Project at RWMC for the Sludge Repackaging Project. & Yes \\
\hline 10311057 & Pits $11 \& 12$ Organic Setups & 184 & This container was transferred to the Accelerated Retrieval Project at RWMC for the Sludge Repackaging Project. & Yes \\
\hline 10312126 & Pits $11 \& 12$ Organic Setups & 232 & This container was transferred to the Accelerated Retrieval Project at RWMC for the Sludge Repackaging Project. & Yes \\
\hline 10313908 & Pits $11 \& 12$ Organic Setups & 233 & This container was transferred to the Accelerated Retrieval Project at RWMC for the Sludge Repackaging Project. & Yes \\
\hline 10313910 & Pits $11 \& 12$ Organic Setups & 259 & This container was transferred to the Accelerated Retrieval Project at RWMC for the Sludge Repackaging Project. & Yes \\
\hline 10313955 & Pits $11 \& 12$ Organic Setups & 250 & This container was transferred to the Accelerated Retrieval Project at RWMC for the Sludge Repackaging Project. & Yes \\
\hline 10313957 & Pits $11 \& 12$ Organic Setups & 287 & This container was transferred to the Accelerated Retrieval Project at RWMC for the Sludge Repackaging Project. & Yes \\
\hline 10313961 & Pits $11 \& 12$ Organic Setups & 236 & This container was transferred to the Accelerated Retrieval Project at RWMC for the Sludge Repackaging Project. & Yes \\
\hline 10313967 & Pits $11 \& 12$ Organic Setups & 210 & This container was transferred to the Accelerated Retrieval Project at RWMC for the Sludge Repackaging Project. & Yes \\
\hline 10314011 & Pits $11 \& 12$ Organic Setups & 258 & This container was transferred to the Accelerated Retrieval Project at RWMC for the Sludge Repackaging Project. & Yes \\
\hline
\end{tabular}




\section{Idaho National Laboratory \\ Advanced Mixed Waste Treatment Project (AMWTP) \\ PCB Waste Document Log \\ Notes on 2014 Report}

Identification \#

10314021

10315868

10315888

10315896

10316067

10316070

10316082

10316092

10316110

10316111

10320816

10322758

10325681

10326220

10326602

10326608

10326620

10328089

10328889

10330032

10331220

10331229

10331230

10331232

10331445

10331454

10331467

10332273

10333901

10335420

10335426

10335428

10336333

10338175
Description

Pits $11 \& 12$ Organic Setups

Pre-1980 INL-Exhumed SDA Heterogeneous Debris Pre-1980 INL-Exhumed SDA Heterogeneous Debris Pre-1980 INL-Exhumed SDA Heterogeneous Debris Pits 11 and 12 Cargos and Bins with Roaster Oxide Pits 11 and 12 Cargos and Bins with Roaster Oxide Pits 11 and 12 Cargos and Bins with Roaster Oxide Pits 11 and 12 Cargos and Bins with Roaster Oxide Pits 11 and 12 Cargos and Bins with Roaster Oxide Pits 11 and 12 Cargos and Bins with Roaster Oxide Pits 11 \& 12 Organic Setups Organic Setups, Oil Solids Pits 11 \& 12 Organic Setups Pits $11 \& 12$ Organic Setups Pits $11 \& 12$ Organic Setups Pits $11 \& 12$ Organic Setups Pits $11 \& 12$ Organic Setups Pits $11 \& 12$ Organic Setups Undefined Homogeneous Solids Organic Setups, Oil Solids

Pits 11 and 12 Cargos and Bins with Roaster Oxide Pits 11 and 12 Cargos and Bins with Roaster Oxide Pits 11 and 12 Cargos and Bins with Roaster Oxide Pits 11 and 12 Cargos and Bins with Roaster Oxide Pits 11 and 12 Cargos and Bins with Roaster Oxide Pits 11 and 12 Cargos and Bins with Roaster Oxide Pits 11 and 12 Cargos and Bins with Roaster Oxide Pits 11 and 12 Cargos and Bins with Roaster Oxide Pits 11 \& 12 Organic Setup Organic Setups, Oil Solids Organic Setups, Oil Solids Organic Setups, Oil Solids Pits $11 \& 12$ Organic Setups Pits $11 \& 12$ Organic Setups
Weight

(kg)

Note

Rad

202 This container was transferred to the Accelerated Retrieval Project at RWMC for the Sludge Repackaging Project.

943 Determined not to contain PCBs during characterization performed in 2014

1346 Determined not to contain PCBs during characterization performed in 2014.

1023 Determined not to contain PCBs during characterization performed in 2014

1082 Determined not to contain PCBs during characterization performed in 2014.

1558 Determined not to contain PCBs during characterization performed in 2014

923 Determined not to contain PCBs during characterization performed in 2014

855 Determined not to contain PCBs during characterization performed in 2014.

653 Determined not to contain PCBs during characterization performed in 2014

986 Determined not to contain PCBs during characterization performed in 2014

249 This container was transferred to the Accelerated Retrieval Project at RWMC for the Sludge Repackaging Project.

255 This container was transferred to the Accelerated Retrieval Project at RWMC for the Sludge Repackaging Project.

204 This container was transferred to the Accelerated Retrieval Project at RWMC for the Sludge Repackaging Project.

264 This container was transferred to the Accelerated Retrieval Project at RWMC for the Sludge Repackaging Project.

205 This container was transferred to the Accelerated Retrieval Project at RWMC for the Sludge Repackaging Project.

272 This container was transferred to the Accelerated Retrieval Project at RWMC for the Sludge Repackaging Project.

249 This container was transferred to the Accelerated Retrieval Project at RWMC for the Sludge Repackaging Project.

249 This container was transferred to the Accelerated Retrieval Project at RWMC for the Sludge Repackaging Project.

257 Determined not to contain PCBs during characterization performed in 2014

315 This container was transferred to the Accelerated Retrieval Project at RWMC for the Sludge Repackaging Project.

1385 Determined not to contain PCBs during characterization performed in 2014

1002 Determined not to contain PCBs during characterization performed in 2014

1483 Determined not to contain PCBs during characterization performed in 2014

1354 Determined not to contain PCBs during characterization performed in 2014

1439 Determined not to contain PCBs during characterization performed in 2014

1455 Determined not to contain PCBs during characterization performed in 2014

761 Determined not to contain PCBs during characterization performed in 2014

1209 Determined not to contain PCBs during characterization performed in 2014

232 This container was transferred to the Accelerated Retrieval Project at RWMC for the Sludge Repackaging Project.

317 This container was transferred to the Accelerated Retrieval Project at RWMC for the Sludge Repackaging Project.

299 This container was transferred to the Accelerated Retrieval Project at RWMC for the Sludge Repackaging Project.

295 This container was transferred to the Accelerated Retrieval Project at RWMC for the Sludge Repackaging Project.

249 This container was transferred to the Accelerated Retrieval Project at RWMC for the Sludge Repackaging Project.

249 This container was transferred to the Accelerated Retrieval Project at RWMC for the Sludge Repackaging Project. 


\section{Idaho National Laboratory \\ Advanced Mixed Waste Treatment Project (AMWTP) \\ PCB Waste Document Log \\ Notes on 2014 Report}

Identification \#

10338234

10338237

10338243

10339180

10339210

10339555

10340540

10340593

10341312

10341327

10341850

10343659

10344085

10344124

10345376

10345434

10351610

10352470

10355846

10358141

10359478

10362266

10364192

10366243

10367013

10368500

10368506

10372284

10388542

10397078

10402660

10408222

10411387

10414420
Description

Pits $11 \& 12$ Debris

Pits $11 \& 12$ Debri

Pits $11 \& 12$ Debris

Organic Setups, Oil Solids

Organic Setups, Oil Solids

Non-special Source Metal

Organic Setups, Oil Solids

Pits $11 \& 12$ Organic Setups

Organic Setups, Oil Solids

Organic Setups, Oil Solids

Organic Setups, Oil Solids

Organic Setups, Oil Solids

Pits 11 \& 12 Organic Setups

Organic Setups, Oil Solids

Organic Setups, Oil Solids

Pits $11 \& 12$ Organic Setups

Pits 11 \& 12 Organic Setups

Organic Setups, Oil Solids

Pits $11 \& 12$ Organic Setups

Pits 11 \& 12 Organic Setups

Organic Setups, Oil Solids

Organic Setups, Oil Solids

LSA Metals, Glass, etc.

Organic Setups, Oil Solids

Paper and Rags-Dry

Non-special Source Metal

LSA Metals, Glass, etc.

Organic Setups, Oil Solids

Organic Setups, Oil Solids

Organic Setups, Oil Solids

Organic Setups, Oil Solids

Organic Setups, Oil Solids

Debris TSCA/PCB

Organic Setups, Oil Solids
Weight

(kg)

Note

Rad

132 Determined not to contain PCBs during characterization performed in 2014.

112 Determined not to contain PCBs during characterization performed in 2014

121 Determined not to contain PCBs during characterization performed in 2014

296 This container was transferred to the Accelerated Retrieval Project at RWMC for the Sludge Repackaging Project.

252 This container was transferred to the Accelerated Retrieval Project at RWMC for the Sludge Repackaging Project.

87 Determined not to contain PCBs during characterization performed in 2014

300 This container was transferred to the Accelerated Retrieval Project at RWMC for the Sludge Repackaging Project.

275 This container was transferred to the Accelerated Retrieval Project at RWMC for the Sludge Repackaging Project.

292 This container was transferred to the Accelerated Retrieval Project at RWMC for the Sludge Repackaging Project.

289 This container was transferred to the Accelerated Retrieval Project at RWMC for the Sludge Repackaging Project.

268 This container was transferred to the Accelerated Retrieval Project at RWMC for the Sludge Repackaging Project.

285 This container was transferred to the Accelerated Retrieval Project at RWMC for the Sludge Repackaging Project.

217 This container was transferred to the Accelerated Retrieval Project at RWMC for the Sludge Repackaging Project.

262 This container was transferred to the Accelerated Retrieval Project at RWMC for the Sludge Repackaging Project.

287 This container was transferred to the Accelerated Retrieval Project at RWMC for the Sludge Repackaging Project.

188 This container was transferred to the Accelerated Retrieval Project at RWMC for the Sludge Repackaging Project.

272 This container was transferred to the Accelerated Retrieval Project at RWMC for the Sludge Repackaging Project.

297 This container was transferred to the Accelerated Retrieval Project at RWMC for the Sludge Repackaging Project.

289 This container was transferred to the Accelerated Retrieval Project at RWMC for the Sludge Repackaging Project.

242 This container was transferred to the Accelerated Retrieval Project at RWMC for the Sludge Repackaging Project.

250 This container was transferred to the Accelerated Retrieval Project at RWMC for the Sludge Repackaging Project.

292 This container was transferred to the Accelerated Retrieval Project at RWMC for the Sludge Repackaging Project.

77 Determined not to contain PCBs during characterization performed in 2014

240 This container was transferred to the Accelerated Retrieval Project at RWMC for the Sludge Repackaging Project.

59 Container erroneously listed as containing PCB waste in previous report.

114 Determined not to contain PCBs during characterization performed in 2014

107 Determined not to contain PCBs during characterization performed in 2014

247 This container was transferred to the Accelerated Retrieval Project at RWMC for the Sludge Repackaging Project.

287 This container was transferred to the Accelerated Retrieval Project at RWMC for the Sludge Repackaging Project.

241 This container was transferred to the Accelerated Retrieval Project at RWMC for the Sludge Repackaging Project.

272 This container was transferred to the Accelerated Retrieval Project at RWMC for the Sludge Repackaging Project.

241 This container was transferred to the Accelerated Retrieval Project at RWMC for the Sludge Repackaging Project.

33 Determined not to contain PCBs during characterization performed in 2014

251 This container was transferred to the Accelerated Retrieval Project at RWMC for the Sludge Repackaging Project.
Yes

Yes

Yes

Yes

Yes

Yes

Yes

Yes

Yes

Yes

Yes

Yes

Yes

Yes

Yes

Yes

Yes

Yes

Yes

Yes

Yes

Yes

Yes

Yes

Yes

Yes

Yes

Yes

Yes

Yes

Yes

Yes

Yes 


\section{Idaho National Laboratory \\ Advanced Mixed Waste Treatment Project (AMWTP) \\ PCB Waste Document Log \\ Notes on 2014 Report}

Identification \#

10416208

10416210

10417151

10418340

10455741

10457122

10459572

10463299

10465835

10465836

10472391

10501180

10501642

10503128

10503132

10503133

10504398

10504407

10504410

10504974

10505183

10505202

10505620

10505869

10506087

10506092

10506093

10506094

10506407

10507793

10507796

10507797

10507798

10507799
Description

Organic Setups, Oil Solids

Organic Setups, Oil Solids

Organic Setups, Oil Solids

Organic Setups, Oil Solids

Debris SDOP to Supercompactor

Debris SDOP to Supercompactor

Debris SDOP to Supercompactor

Debris SDOP to Supercompactor

Debris SDOP to Supercompactor

Debris SDOP to Supercompactor

Pad 1 Cells 1 and 2 RFP Debris

Evaporator Salts

Non-special Source Metal

Organic Setups, Oil Solids

Organic Setups, Oil Solids

Organic Setups, Oil Solids

Organic Setups, Oil Solids

Organic Setups, Oil Solids

Organic Setups, Oil Solids

Organic Setups, Oil Solids

Organic Setups, Oil Solids

Organic Setups, Oil Solids

Organic Setups, Oil Solids

TRU SDOP to Supercompactor

Organic Setups, Oil Solids

Organic Setups, Oil Solids

Organic Setups, Oil Solids

Organic Setups, Oil Solids

Organic Setups, Oil Solids

Organic Setups, Oil Solids

Organic Setups, Oil Solids

Organic Setups, Oil Solids

Organic Setups, Oil Solids

Organic Setups, Oil Solids
Weight

(kg)

Note

Rad

258 This container was transferred to the Accelerated Retrieval Project at RWMC for the Sludge Repackaging Project.

272 This container was transferred to the Accelerated Retrieval Project at RWMC for the Sludge Repackaging Project.

219 This container was transferred to the Accelerated Retrieval Project at RWMC for the Sludge Repackaging Project.

281 This container was transferred to the Accelerated Retrieval Project at RWMC for the Sludge Repackaging Project.

1103 Determined not to contain PCBs during characterization performed in 2014

1044 Determined not to contain PCBs during characterization performed in 2014

676 Container erroneously listed as containing PCB waste in previous report.

848 Container erroneously listed as containing PCB waste in previous report.

771 Container erroneously listed as containing PCB waste in previous report.

785 Container erroneously listed as containing PCB waste in previous report.

102 Determined not to contain PCBs during characterization performed in 2014.

194 Determined not to contain PCBs during characterization performed in 2014

875 Determined not to contain PCBs during characterization performed in 2014

275 This container was transferred to the Accelerated Retrieval Project at RWMC for the Sludge Repackaging Project.

259 This container was transferred to the Accelerated Retrieval Project at RWMC for the Sludge Repackaging Project.

294 This container was transferred to the Accelerated Retrieval Project at RWMC for the Sludge Repackaging Project.

237 This container was transferred to the Accelerated Retrieval Project at RWMC for the Sludge Repackaging Project.

257 This container was transferred to the Accelerated Retrieval Project at RWMC for the Sludge Repackaging Project.

270 This container was transferred to the Accelerated Retrieval Project at RWMC for the Sludge Repackaging Project.

305 This container was transferred to the Accelerated Retrieval Project at RWMC for the Sludge Repackaging Project.

276 This container was transferred to the Accelerated Retrieval Project at RWMC for the Sludge Repackaging Project.

243 This container was transferred to the Accelerated Retrieval Project at RWMC for the Sludge Repackaging Project.

289 This container was transferred to the Accelerated Retrieval Project at RWMC for the Sludge Repackaging Project.

866 Determined not to contain PCBs during characterization performed in 2014

288 This container was transferred to the Accelerated Retrieval Project at RWMC for the Sludge Repackaging Project.

307 This container was transferred to the Accelerated Retrieval Project at RWMC for the Sludge Repackaging Project.

283 This container was transferred to the Accelerated Retrieval Project at RWMC for the Sludge Repackaging Project.

241 This container was transferred to the Accelerated Retrieval Project at RWMC for the Sludge Repackaging Project.

224 This container was transferred to the Accelerated Retrieval Project at RWMC for the Sludge Repackaging Project.

187 This container was transferred to the Accelerated Retrieval Project at RWMC for the Sludge Repackaging Project.

283 This container was transferred to the Accelerated Retrieval Project at RWMC for the Sludge Repackaging Project.

278 This container was transferred to the Accelerated Retrieval Project at RWMC for the Sludge Repackaging Project.

292 This container was transferred to the Accelerated Retrieval Project at RWMC for the Sludge Repackaging Project.

290 This container was transferred to the Accelerated Retrieval Project at RWMC for the Sludge Repackaging Project. 
Idaho National Laboratory

Advanced Mixed Waste Treatment Project (AMWTP)

PCB Waste Document Log

Notes on 2014 Report

Identification \#

10507800

10507802

10507803

10509352
Description

Organic Setups, Oil Solids

Organic Setups, Oil Solids

Organic Setups, Oil Solid

Organic Setups, Oil Solids
Weight

(kg)

Rad

299 This container was transferred to the Accelerated Retrieval Project at RWMC for the Sludge Repackaging Project.

295 This container was transferred to the Accelerated Retrieval Project at RWMC for the Sludge Repackaging Project.

232 This container was transferred to the Accelerated Retrieval Project at RWMC for the Sludge Repackaging Project.

302 This container was transferred to the Accelerated Retrieval Project at RWMC for the Sludge Repackaging Project.
Yes

Yes

Yes

Yes 


\subsection{PCB ANNUAL RECORDS}

The PCB annual records contains detailed data in compliance with 40 CFR 761.180(a)(1) as follows

3.1 Manifests generated during calendar year 2014 that received a certificate of disposal/destruction during calendar year 2014 (see Appendix 1).

3.2 Manifests generated during calendar year 2014 that did not receive a certificate of disposal/destruction during calendar year 2014 (see Appendix 2).

3.3 Manifests generated during calendar year 2013 that received a certificate of disposal/destruction during calendar year 2014 (see Appendix 3)

3.4 Records of inspections and cleanups performed in accordance with 40 CFR 761.65(c)(5). These records are available from the facilities upon request. 


\section{APPENDIX 1}

Manifests Generated during Calendar Year 2014 that received a Certificate of Disposal/Destruction during Calendar Year 2014 (manifests and certificates of disposal on following pages)

\begin{tabular}{|c|c|c|c|}
\hline Item No. & Manifest No. & Item No. & Manifest No. \\
\hline 1 & $000372275 \mathrm{JJK}$ & 42 & $001942725 \mathrm{GBF}^{*}$ \\
\hline 2 & $000372278 \mathrm{JJK} * *$ & 43 & 001942726GBF* \\
\hline 3 & 000372416JJK & 44 & 001942729GBF* \\
\hline 4 & $000372422 \mathrm{JJK}$ & 45 & 001942730GBF* \\
\hline 5 & 000372433JJK & 46 & $001942731 \mathrm{GBF}^{*}$ \\
\hline 6 & $000372447 \mathrm{JJK}$ & 47 & 001942733GBF* \\
\hline 7 & 000372451JJK & 48 & 001942734GBF* \\
\hline 8 & 000372452JJK & 49 & 001942735GBF* \\
\hline 9 & 000372458JJK & 50 & 001942736GBF* \\
\hline 10 & 000372465JJK & 51 & 001942737GBF* \\
\hline 11 & 000372466JJK & 52 & 001942738GBF* \\
\hline 12 & 000372483JJK & 53 & 001942742GBF* \\
\hline 13 & 000372489JJK & 54 & 001942743GBF* \\
\hline 14 & 000372494JJK & 55 & 001942748GBF* \\
\hline 15 & $001600933 \mathrm{GBF}^{*}$ & 56 & 001942749GBF* \\
\hline 16 & 001600934GBF* & 57 & 001942752GBF* \\
\hline 17 & $001600936 \mathrm{GBF}^{*}$ & 58 & 001942753GBF* \\
\hline 18 & $001600937 \mathrm{GBF}^{*}$ & 59 & 001942757GBF* \\
\hline 19 & $001600938 \mathrm{GBF}^{*}$ & 60 & 001942758GBF* \\
\hline 20 & 001600940GBF* & 61 & 001942759GBF* \\
\hline 21 & $001600941 \mathrm{GBF}^{*}$ & 62 & 001942760GBF* \\
\hline 22 & $001600942 \mathrm{GBF}^{*}$ & 63 & $001942763 \mathrm{GBF}^{*}$ \\
\hline 23 & $001600943 \mathrm{GBF}^{*}$ & 64 & 001942764GBF* \\
\hline 24 & $001600944 \mathrm{GBF}^{*}$ & 65 & $001942767 \mathrm{GBF}^{*}$ \\
\hline 25 & $001600946 \mathrm{GBF}^{*}$ & 66 & 001942768GBF* \\
\hline 26 & $001600947 \mathrm{GBF}^{*}$ & 67 & 001942804GBF* \\
\hline 27 & $001600950 \mathrm{GBF}^{*}$ & 68 & 001942809GBF* \\
\hline 28 & $001600951 \mathrm{GBF}^{*}$ & 69 & 001942810GBF* \\
\hline 29 & $001600952 \mathrm{GBF}^{*}$ & 70 & 001943013GBF* \\
\hline 30 & $001600954 \mathrm{GBF}^{*}$ & 71 & 002907736FLE \\
\hline 31 & $001600956 \mathrm{GBF}^{*}$ & 72 & 002907737FLE \\
\hline 32 & $001600957 \mathrm{GBF}^{*}$ & 73 & 002907740FLE \\
\hline 33 & $001600959 \mathrm{GBF}^{*}$ & 74 & 002907742FLE \\
\hline 34 & $001600961 \mathrm{GBF}^{*}$ & 75 & 002907759FLE \\
\hline 35 & $001600962 \mathrm{GBF}^{*}$ & 76 & 002907760FLE** \\
\hline 36 & $001600963 \mathrm{GBF}^{*}$ & 77 & 002907761FLE \\
\hline 37 & $001600966 \mathrm{GBF}^{*}$ & 78 & 002907769FLE \\
\hline 38 & $001600967 \mathrm{GBF}^{*}$ & 79 & 002907772FLE \\
\hline 39 & $001942722 \mathrm{GBF}^{*}$ & 80 & 002909439FLE \\
\hline 40 & $001942723 \mathrm{GBF}^{*}$ & 81 & 002911379FLE \\
\hline 41 & 001942724GBF* & 82 & 002911381FLE \\
\hline
\end{tabular}




\section{APPENDIX 1}

Manifests Generated during Calendar Year 2014 that received a Certificate of Disposal/Destruction during Calendar Year 2014

(manifests and certificates of disposal on following pages)

\begin{tabular}{|c|l|c|r|}
\hline Item No. & Manifest No. & Item No. & Manifest No. \\
\hline 83 & 002911388FLE & 87 & 002911406FLE \\
\hline 84 & 002911392FLE & 88 & 006155106FLE \\
\hline 85 & 002911398FLE & 89 & 006155128FLE \\
\hline 86 & 002911402FLE & & \\
\hline
\end{tabular}

* Indicates AMWTP manifests

** only one of the containers on the manifest received a certificate of disposal/destruction during 2014 


\section{AMWTP Repackaged Shipping Container Cross Reference 2014}

\begin{tabular}{|c|c|c|c|}
\hline Manifest & Container & Historical ID & Shipping Package \\
\hline $001600933 \mathrm{GBF}$ & 10485072 & SRP13142 & BN10503786 \\
\hline $001600933 \mathrm{GBF}$ & 10485082 & SRP13092 & BN10503786 \\
\hline $001600933 \mathrm{GBF}$ & 10485084 & SRP13117 & BN10503786 \\
\hline $001600933 \mathrm{GBF}$ & 10485085 & SRP13110 & BN10503786 \\
\hline $001600933 \mathrm{GBF}$ & 10485309 & SRP13170 & BN10503786 \\
\hline $001600933 \mathrm{GBF}$ & 10486608 & SRP13421 & BN10503786 \\
\hline $001600933 \mathrm{GBF}$ & 10486617 & SRP13418 & BN10503786 \\
\hline $001600933 \mathrm{GBF}$ & 10486985 & SRP13455 & BN10503786 \\
\hline $001600933 \mathrm{GBF}$ & 10486991 & SRP13588 & BN10503786 \\
\hline $001600933 \mathrm{GBF}$ & 10489234 & SRP13815 & BN10503781 \\
\hline $001600933 \mathrm{GBF}$ & 10491430 & SRP14468 & BN10503781 \\
\hline $001600933 \mathrm{GBF}$ & 10495839 & SRP15642 & BN10503781 \\
\hline $001600933 \mathrm{GBF}$ & 10495843 & SRP15651 & BN10503781 \\
\hline $001600933 \mathrm{GBF}$ & 10496149 & SRP15777 & BN10503781 \\
\hline $001600933 \mathrm{GBF}$ & 10496160 & SRP15661 & BN10503781 \\
\hline $001600933 \mathrm{GBF}$ & 10496399 & SRP15843 & BN10503781 \\
\hline $001600933 \mathrm{GBF}$ & 10496401 & SRP15898 & BN10503781 \\
\hline $001600933 \mathrm{GBF}$ & 10496425 & SRP15936 & BN10503786 \\
\hline $001600933 \mathrm{GBF}$ & 10496427 & SRP15836 & BN10503781 \\
\hline $001600933 \mathrm{GBF}$ & 10496439 & SRP15899 & BN10503781 \\
\hline $001600934 \mathrm{GBF}$ & 10481278 & SRP12698 & BN10490916 \\
\hline $001600934 \mathrm{GBF}$ & 10481290 & SRP12638 & BN10490916 \\
\hline $001600934 \mathrm{GBF}$ & 10481304 & SRP12629 & BN10490916 \\
\hline $001600934 \mathrm{GBF}$ & 10482150 & SRP12770 & BN10490916 \\
\hline $001600934 \mathrm{GBF}$ & 10483958 & SRP13002 & BN10490916 \\
\hline $001600934 \mathrm{GBF}$ & 10484017 & SRP12951 & BN10490916 \\
\hline $001600934 \mathrm{GBF}$ & 10484040 & SRP13011 & BN10490916 \\
\hline $001600934 \mathrm{GBF}$ & 10486190 & SRP13229 & BN10490916 \\
\hline $001600934 \mathrm{GBF}$ & 10486200 & SRP13297 & BN10490916 \\
\hline $001600934 \mathrm{GBF}$ & 10486244 & SRP13316 & BN10490916 \\
\hline $001600934 \mathrm{GBF}$ & 10494429 & SRP15343 & BN10501231 \\
\hline $001600934 \mathrm{GBF}$ & 10494435 & SRP15320 & BN10501231 \\
\hline $001600934 \mathrm{GBF}$ & 10494438 & SRP15306 & BN10501231 \\
\hline $001600934 \mathrm{GBF}$ & 10494439 & SRP15310 & BN10501231 \\
\hline $001600934 \mathrm{GBF}$ & 10494624 & SRP15386 & BN10501231 \\
\hline $001600934 \mathrm{GBF}$ & 10494630 & SRP15245 & BN10501231 \\
\hline $001600934 \mathrm{GBF}$ & 10494645 & SRP15378 & BN10501231 \\
\hline $001600934 \mathrm{GBF}$ & 10494653 & SRP15370 & BN10501231 \\
\hline 001600934GBF & 10494825 & SRP15444 & BN10501231 \\
\hline $001600934 \mathrm{GBF}$ & 10494851 & SRP15448 & BN10501231 \\
\hline $001600936 \mathrm{GBF}$ & 10491720 & SRP14558 & BN10501238 \\
\hline $001600936 \mathrm{GBF}$ & 10491740 & SRP14533 & BN10501238 \\
\hline $001600936 \mathrm{GBF}$ & 10491742 & SRP14598 & BN10501238 \\
\hline $001600936 \mathrm{GBF}$ & 10491996 & SRP14692 & BN10501238 \\
\hline $001600936 \mathrm{GBF}$ & 10491997 & SRP14690 & BN10501238 \\
\hline $001600936 \mathrm{GBF}$ & 10493578 & SRP15041 & BN10500615 \\
\hline $001600936 \mathrm{GBF}$ & 10493735 & SRP15144 & BN10501238 \\
\hline $001600936 \mathrm{GBF}$ & 10493736 & SRP15145 & BN10501238 \\
\hline $001600936 \mathrm{GBF}$ & 10493751 & SRP15088 & BN10501238 \\
\hline $001600936 \mathrm{GBF}$ & 10493895 & SRP15167 & BN10500615 \\
\hline $001600936 \mathrm{GBF}$ & 10494163 & SRP15268 & BN10501238 \\
\hline $001600936 \mathrm{GBF}$ & 10494168 & SRP15252 & BN10500615 \\
\hline $001600936 \mathrm{GBF}$ & 10494181 & SRP15260 & BN10501238 \\
\hline $001600936 \mathrm{GBF}$ & 10494182 & SRP15301 & BN10500615 \\
\hline $001600936 \mathrm{GBF}$ & 10494428 & SRP15342 & BN10500615 \\
\hline $001600936 \mathrm{GBF}$ & 10494434 & SRP15228 & BN10500615 \\
\hline $001600936 \mathrm{GBF}$ & 10494436 & SRP15345 & BN10500615 \\
\hline $001600936 \mathrm{GBF}$ & 10494452 & SRP15307 & BN10500615 \\
\hline
\end{tabular}




\section{AMWTP Repackaged Shipping Container Cross Reference 2014}

\begin{tabular}{|c|c|c|c|}
\hline Manifest & Container & Historical ID & Shipping Package \\
\hline $001600936 G B F$ & 10494595 & SRP15316 & BN10500615 \\
\hline 001600936GBF & 10494621 & SRP15406 & BN10500615 \\
\hline $001600937 \mathrm{GBF}$ & 10482496 & SRP12795 & BN10503780 \\
\hline $001600937 \mathrm{GBF}$ & 10493749 & SRP15103 & BN10501234 \\
\hline $001600937 \mathrm{GBF}$ & 10493879 & SRP15150 & BN10501234 \\
\hline $001600937 G B F$ & 10493880 & SRP15169 & BN10501234 \\
\hline $001600937 G B F$ & 10493882 & SRP15163 & BN10501234 \\
\hline $001600937 \mathrm{GBF}$ & 10494109 & SRP15231 & BN10501234 \\
\hline $001600937 \mathrm{GBF}$ & 10494110 & SRP15225 & BN10501234 \\
\hline $001600937 \mathrm{GBF}$ & 10494427 & SRP15331 & BN10501234 \\
\hline $001600937 \mathrm{GBF}$ & 10494430 & SRP15351 & BN10501234 \\
\hline $001600937 \mathrm{GBF}$ & 10494433 & SRP15288 & BN10501234 \\
\hline $001600937 \mathrm{GBF}$ & 10494647 & SRP15369 & BN10501234 \\
\hline $001600937 \mathrm{GBF}$ & 10495833 & SRP15687 & BN10503780 \\
\hline $001600937 \mathrm{GBF}$ & 10495849 & SRP15631 & BN10503780 \\
\hline $001600937 \mathrm{GBF}$ & 10495870 & SRP15471 & BN10503780 \\
\hline $001600937 \mathrm{GBF}$ & 10496150 & SRP15763 & BN10503780 \\
\hline $001600937 \mathrm{GBF}$ & 10496162 & SRP15660 & BN10503780 \\
\hline $001600937 \mathrm{GBF}$ & 10496163 & SRP15729 & BN10503780 \\
\hline $001600937 \mathrm{GBF}$ & 10496174 & SRP15756 & BN10503780 \\
\hline $001600937 \mathrm{GBF}$ & 10496185 & SRP15755 & BN10503780 \\
\hline $001600937 \mathrm{GBF}$ & 10496188 & SRP15772 & BN10503780 \\
\hline $001600938 \mathrm{GBF}$ & 10480760 & SRP12559 & BN10490915 \\
\hline $001600938 \mathrm{GBF}$ & 10481295 & SRP12683 & BN10490915 \\
\hline $001600938 \mathrm{GBF}$ & 10482136 & SRP12645 & BN10490915 \\
\hline $001600938 \mathrm{GBF}$ & 10482147 & SRP12678 & BN10490915 \\
\hline $001600938 \mathrm{GBF}$ & 10484065 & SRP13005 & BN10490915 \\
\hline $001600938 \mathrm{GBF}$ & 10484492 & SRP12991 & BN10490915 \\
\hline $001600938 \mathrm{GBF}$ & 10484495 & SRP13031 & BN10490915 \\
\hline $001600938 \mathrm{GBF}$ & 10486199 & SRP13247 & BN10490915 \\
\hline $001600938 \mathrm{GBF}$ & 10486995 & SRP13491 & BN10490915 \\
\hline $001600938 \mathrm{GBF}$ & 10487001 & SRP13579 & BN10490915 \\
\hline $001600938 \mathrm{GBF}$ & 10488673 & SRP13724 & BN10503782 \\
\hline $001600938 \mathrm{GBF}$ & 10488846 & SRP13802 & BN10503782 \\
\hline $001600938 \mathrm{GBF}$ & 10490526 & SRP14235 & BN10503782 \\
\hline $001600938 \mathrm{GBF}$ & 10490850 & SRP14317 & BN10503782 \\
\hline $001600938 \mathrm{GBF}$ & 10490857 & SRP14303 & BN10503782 \\
\hline $001600938 \mathrm{GBF}$ & 10490859 & SRP14304 & BN10503782 \\
\hline $001600938 \mathrm{GBF}$ & 10491055 & SRP14326 & BN10503782 \\
\hline $001600938 \mathrm{GBF}$ & 10495840 & SRP15677 & BN10503782 \\
\hline $001600938 \mathrm{GBF}$ & 10496431 & SRP15882 & BN10503782 \\
\hline $001600938 G B F$ & 10496438 & SRP15883 & BN10503782 \\
\hline $001600940 \mathrm{GBF}$ & 10486996 & SRP13494 & BN10505064 \\
\hline $001600940 \mathrm{GBF}$ & 10487007 & SRP13442 & BN10505064 \\
\hline $001600940 \mathrm{GBF}$ & 10495058 & SRP15561 & BN10505065 \\
\hline $001600940 \mathrm{GBF}$ & 10495059 & SRP15547 & BN10505065 \\
\hline $001600940 \mathrm{GBF}$ & 10495066 & SRP15518 & BN10505064 \\
\hline $001600940 \mathrm{GBF}$ & 10495068 & SRP15522 & BN10505065 \\
\hline $001600940 \mathrm{GBF}$ & 10495070 & SRP15430 & BN10505065 \\
\hline $001600940 \mathrm{GBF}$ & 10495071 & SRP15494 & BN10505065 \\
\hline $001600940 \mathrm{GBF}$ & 10495127 & SRP15465 & BN10505065 \\
\hline $001600940 \mathrm{GBF}$ & 10495129 & SRP15512 & BN10505064 \\
\hline $001600940 G B F$ & 10495131 & SRP15497 & BN10505064 \\
\hline $001600940 \mathrm{GBF}$ & 10495140 & SRP15457 & BN10505065 \\
\hline $001600940 \mathrm{GBF}$ & 10495306 & SRP15617 & BN10505064 \\
\hline $001600940 \mathrm{GBF}$ & 10495314 & SRP15610 & BN10505064 \\
\hline $001600940 \mathrm{GBF}$ & 10495316 & SRP15597 & BN10505064 \\
\hline $001600940 \mathrm{GBF}$ & 10495355 & SRP15577 & BN10505064 \\
\hline
\end{tabular}




\section{AMWTP Repackaged Shipping Container Cross Reference 2014}

\begin{tabular}{|c|c|c|c|}
\hline Manifest & Container & Historical ID & Shipping Package \\
\hline $001600940 \mathrm{GBF}$ & 10495847 & SRP15554 & BN10505065 \\
\hline $001600940 \mathrm{GBF}$ & 10496335 & SRP15829 & BN10505065 \\
\hline $001600940 \mathrm{GBF}$ & 10496339 & SRP15824 & BN10505065 \\
\hline $001600940 \mathrm{GBF}$ & 10496343 & SRP15867 & BN10505064 \\
\hline $001600941 \mathrm{GBF}$ & 10487503 & SRP13620 & BN10505054 \\
\hline $001600941 \mathrm{GBF}$ & 10495367 & SRP15601 & BN10505055 \\
\hline $001600941 \mathrm{GBF}$ & 10495374 & SRP15629 & BN10505055 \\
\hline $001600941 \mathrm{GBF}$ & 10495832 & SRP15556 & BN10505055 \\
\hline $001600941 \mathrm{GBF}$ & 10495851 & SRP15572 & BN10505055 \\
\hline $001600941 \mathrm{GBF}$ & 10496142 & SRP15552 & BN10505055 \\
\hline $001600941 \mathrm{GBF}$ & 10496143 & SRP15555 & BN10505055 \\
\hline $001600941 \mathrm{GBF}$ & 10496295 & SRP15812 & BN10505055 \\
\hline $001600941 \mathrm{GBF}$ & 10496299 & SRP15783 & BN10505054 \\
\hline $001600941 \mathrm{GBF}$ & 10496303 & SRP15801 & BN10505054 \\
\hline $001600941 \mathrm{GBF}$ & 10496305 & SRP15806 & BN10505054 \\
\hline $001600941 \mathrm{GBF}$ & 10496307 & SRP15808 & BN10505055 \\
\hline $001600941 \mathrm{GBF}$ & 10496315 & SRP15594 & BN10505055 \\
\hline $001600941 \mathrm{GBF}$ & 10496329 & SRP15823 & BN10505054 \\
\hline $001600941 \mathrm{GBF}$ & 10496342 & SRP15815 & BN10505055 \\
\hline $001600941 \mathrm{GBF}$ & 10496404 & SRP15904 & BN10505054 \\
\hline $001600941 \mathrm{GBF}$ & 10496416 & SRP15835 & BN10505054 \\
\hline $001600941 \mathrm{GBF}$ & 10496417 & SRP15846 & BN10505054 \\
\hline $001600941 \mathrm{GBF}$ & 10496424 & SRP15915 & BN10505054 \\
\hline $001600941 \mathrm{GBF}$ & 10496437 & SRP15785 & BN10505054 \\
\hline $001600942 \mathrm{GBF}$ & 10476923 & SRP12209 & BN10490912 \\
\hline $001600942 \mathrm{GBF}$ & 10476964 & SRP12216 & BN10490912 \\
\hline $001600942 \mathrm{GBF}$ & 10476983 & SRP12107 & BN10490912 \\
\hline $001600942 \mathrm{GBF}$ & 10478047 & SRP12274 & BN10490911 \\
\hline $001600942 \mathrm{GBF}$ & 10478076 & SRP12229 & BN10490912 \\
\hline $001600942 \mathrm{GBF}$ & 10479387 & SRP12320 & BN10490912 \\
\hline $001600942 \mathrm{GBF}$ & 10479403 & SRP12373 & BN10490912 \\
\hline $001600942 \mathrm{GBF}$ & 10480194 & SRP12508 & BN10490911 \\
\hline $001600942 \mathrm{GBF}$ & 10480472 & SRP12523 & BN10490911 \\
\hline $001600942 \mathrm{GBF}$ & 10480473 & SRP12541 & BN10490912 \\
\hline $001600942 \mathrm{GBF}$ & 10480486 & SRP12531 & BN10490911 \\
\hline $001600942 \mathrm{GBF}$ & 10480489 & SRP12526 & BN10490912 \\
\hline $001600942 \mathrm{GBF}$ & 10480769 & SRP12631 & BN10490912 \\
\hline $001600942 \mathrm{GBF}$ & 10480770 & SRP12632 & BN10490911 \\
\hline $001600942 \mathrm{GBF}$ & 10480800 & SRP12555 & BN10490911 \\
\hline $001600942 \mathrm{GBF}$ & 10483681 & SRP12910 & BN10490911 \\
\hline $001600942 \mathrm{GBF}$ & 10484021 & SRP12949 & BN10490911 \\
\hline $001600942 \mathrm{GBF}$ & 10484061 & SRP12967 & BN10490911 \\
\hline $001600942 \mathrm{GBF}$ & 10486185 & SRP13077 & BN10490912 \\
\hline $001600943 \mathrm{GBF}$ & 10485067 & SRP13131 & BN10505057 \\
\hline $001600943 \mathrm{GBF}$ & 10485069 & SRP13129 & BN10505057 \\
\hline $001600943 \mathrm{GBF}$ & 10485081 & SRP13039 & BN10505057 \\
\hline $001600943 \mathrm{GBF}$ & 10485350 & SRP13187 & BN10505057 \\
\hline $001600943 G B F$ & 10485640 & SRP13060 & BN10505057 \\
\hline $001600943 \mathrm{GBF}$ & 10485642 & SRP13241 & BN10505057 \\
\hline $001600943 \mathrm{GBF}$ & 10485937 & SRP13254 & BN10505057 \\
\hline $001600943 G B F$ & 10486984 & SRP13461 & BN10505057 \\
\hline $001600943 \mathrm{GBF}$ & 10487502 & SRP13574 & BN10505057 \\
\hline $001600943 \mathrm{GBF}$ & 10487627 & SRP13636 & BN10505057 \\
\hline $001600943 \mathrm{GBF}$ & 10495063 & SRP15492 & BN10505066 \\
\hline $001600943 \mathrm{GBF}$ & 10495065 & SRP15536 & BN10505066 \\
\hline $001600943 \mathrm{GBF}$ & 10495830 & SRP15704 & BN10505066 \\
\hline $001600943 \mathrm{GBF}$ & 10496308 & SRP15799 & BN10505066 \\
\hline $001600943 \mathrm{GBF}$ & 10496414 & SRP15841 & BN10505066 \\
\hline
\end{tabular}




\section{AMWTP Repackaged Shipping Container Cross Reference 2014}

\begin{tabular}{|c|c|c|c|}
\hline Manifest & Container & Historical ID & Shipping Package \\
\hline $001600943 G B F$ & 10496415 & SRP15910 & BN10505066 \\
\hline $001600943 \mathrm{GBF}$ & 10496419 & SRP15903 & BN10505066 \\
\hline $001600943 \mathrm{GBF}$ & 10496445 & SRP15909 & BN10505066 \\
\hline $001600943 \mathrm{GBF}$ & 10496455 & SRP15896 & BN10505066 \\
\hline $001600943 G B F$ & 10496457 & SRP15788 & BN10505066 \\
\hline $001600944 \mathrm{GBF}$ & 10489139 & SRP13861 & BN10503788 \\
\hline $001600944 \mathrm{GBF}$ & 10489228 & SRP13874 & BN10505059 \\
\hline $001600944 \mathrm{GBF}$ & 10492994 & SRP14755 & BN10505059 \\
\hline $001600944 \mathrm{GBF}$ & 10495135 & SRP15510 & BN10503788 \\
\hline $001600944 G B F$ & 10495136 & SRP15483 & BN10503788 \\
\hline $001600944 G B F$ & 10495307 & SRP15628 & BN10505059 \\
\hline $001600944 G B F$ & 10495312 & SRP15608 & BN10505059 \\
\hline $001600944 G B F$ & 10495369 & SRP15603 & BN10503788 \\
\hline $001600944 G B F$ & 10495377 & SRP15623 & BN10505059 \\
\hline $001600944 G B F$ & 10495838 & SRP15682 & BN10505059 \\
\hline $001600944 \mathrm{GBF}$ & 10496144 & SRP15559 & BN10503788 \\
\hline $001600944 \mathrm{GBF}$ & 10496148 & SRP15810 & BN10503788 \\
\hline $001600944 G B F$ & 10496151 & SRP15779 & BN10503788 \\
\hline $001600944 \mathrm{GBF}$ & 10496176 & SRP15736 & BN10503788 \\
\hline $001600944 G B F$ & 10496184 & SRP15765 & BN10503788 \\
\hline $001600944 \mathrm{GBF}$ & 10496186 & SRP15771 & BN10505059 \\
\hline $001600944 G B F$ & 10496338 & SRP15822 & BN10505059 \\
\hline $001600944 \mathrm{GBF}$ & 10496394 & SRP15845 & BN10503788 \\
\hline $001600944 \mathrm{GBF}$ & 10496400 & SRP15901 & BN10505059 \\
\hline $001600944 G B F$ & 10496405 & SRP15891 & BN10505059 \\
\hline $001600946 \mathrm{GBF}$ & 10485075 & SRP13119 & BN10505058 \\
\hline $001600946 \mathrm{GBF}$ & 10485078 & SRP13122 & BN10505058 \\
\hline $001600946 \mathrm{GBF}$ & 10485079 & SRP13111 & BN10505058 \\
\hline $001600946 \mathrm{GBF}$ & 10485080 & SRP13099 & BN10505058 \\
\hline $001600946 \mathrm{GBF}$ & 10485318 & SRP13210 & BN10505058 \\
\hline $001600946 \mathrm{GBF}$ & 10487632 & SRP13602 & BN10505058 \\
\hline $001600946 \mathrm{GBF}$ & 10487646 & SRP13624 & BN10505058 \\
\hline $001600946 \mathrm{GBF}$ & 10495138 & SRP15377 & BN10505058 \\
\hline $001600946 \mathrm{GBF}$ & 10495352 & SRP15578 & BN10505058 \\
\hline $001600946 \mathrm{GBF}$ & 10496145 & SRP15745 & BN10505058 \\
\hline $001600946 \mathrm{GBF}$ & 10496286 & SRP15859 & BN10505062 \\
\hline $001600946 \mathrm{GBF}$ & 10496289 & SRP15872 & BN10505062 \\
\hline $001600946 \mathrm{GBF}$ & 10496302 & SRP15826 & BN10505062 \\
\hline $001600946 \mathrm{GBF}$ & 10496332 & SRP15821 & BN10505062 \\
\hline $001600946 \mathrm{GBF}$ & 10496422 & SRP15930 & BN10505062 \\
\hline $001600946 \mathrm{GBF}$ & 10496428 & SRP15890 & BN10505062 \\
\hline $001600946 \mathrm{GBF}$ & 10496429 & SRP15881 & BN10505062 \\
\hline $001600946 \mathrm{GBF}$ & 10496430 & SRP15837 & BN10505062 \\
\hline $001600946 \mathrm{GBF}$ & 10496432 & SRP15902 & BN10505062 \\
\hline $001600946 \mathrm{GBF}$ & 10496436 & SRP15869 & BN10505062 \\
\hline $001600947 \mathrm{GBF}$ & 10490474 & SRP14250 & BN10503760 \\
\hline $001600947 \mathrm{GBF}$ & 10490536 & SRP14220 & BN10503760 \\
\hline $001600947 \mathrm{GBF}$ & 10491550 & SRP14589 & BN10503760 \\
\hline $001600947 \mathrm{GBF}$ & 10491579 & SRP14544 & BN10503760 \\
\hline $001600947 \mathrm{GBF}$ & 10491990 & SRP14682 & BN10503775 \\
\hline $001600947 G B F$ & 10493569 & SRP15060 & BN10503760 \\
\hline $001600947 \mathrm{GBF}$ & 10493577 & SRP13906 & BN10503760 \\
\hline $001600947 \mathrm{GBF}$ & 10493769 & SRP15151 & BN10503760 \\
\hline $001600947 \mathrm{GBF}$ & 10493863 & SRP15165 & BN10503760 \\
\hline $001600947 \mathrm{GBF}$ & 10493890 & SRP15195 & BN10503760 \\
\hline $001600947 \mathrm{GBF}$ & 10493897 & SRP15114 & BN10503760 \\
\hline $001600947 \mathrm{GBF}$ & 10495829 & SRP15695 & BN10503775 \\
\hline $001600947 \mathrm{GBF}$ & 10495835 & SRP15670 & BN10503775 \\
\hline
\end{tabular}




\section{AMWTP Repackaged Shipping Container Cross Reference 2014}

\begin{tabular}{|c|c|c|c|}
\hline Manifest & Container & Historical ID & Shipping Package \\
\hline $001600947 \mathrm{GBF}$ & 10496294 & SRP15850 & BN10503775 \\
\hline $001600947 \mathrm{GBF}$ & 10496316 & SRP15856 & BN10503775 \\
\hline $001600947 \mathrm{GBF}$ & 10496392 & SRP15911 & BN10503775 \\
\hline $001600947 \mathrm{GBF}$ & 10496397 & SRP15907 & BN10503775 \\
\hline $001600947 \mathrm{GBF}$ & 10496398 & SRP15940 & BN10503775 \\
\hline $001600947 \mathrm{GBF}$ & 10496406 & SRP15905 & BN10503775 \\
\hline $001600947 \mathrm{GBF}$ & 10496411 & SRP15782 & BN10503775 \\
\hline $001600950 \mathrm{GBF}$ & 10486992 & SRP13492 & BN10505063 \\
\hline $001600950 \mathrm{GBF}$ & 10491998 & SRP14700 & BN10501246 \\
\hline $001600950 \mathrm{GBF}$ & 10493766 & SRP15100 & BN10501246 \\
\hline $001600950 \mathrm{GBF}$ & 10493899 & SRP15109 & BN10501246 \\
\hline $001600950 \mathrm{GBF}$ & 10494075 & SRP15214 & BN10501246 \\
\hline $001600950 \mathrm{GBF}$ & 10494097 & SRP15210 & BN10501246 \\
\hline $001600950 \mathrm{GBF}$ & 10494171 & SRP15265 & BN10501246 \\
\hline $001600950 \mathrm{GBF}$ & 10494190 & SRP15272 & BN10501246 \\
\hline $001600950 \mathrm{GBF}$ & 10494195 & SRP15266 & BN10501246 \\
\hline $001600950 \mathrm{GBF}$ & 10494828 & SRP15399 & BN10501246 \\
\hline $001600950 \mathrm{GBF}$ & 10494836 & SRP15436 & BN10501246 \\
\hline $001600950 \mathrm{GBF}$ & 10496285 & SRP15857 & BN10505063 \\
\hline $001600950 \mathrm{GBF}$ & 10496290 & SRP15871 & BN10505063 \\
\hline $001600950 \mathrm{GBF}$ & 10496300 & SRP15827 & BN10505063 \\
\hline $001600950 \mathrm{GBF}$ & 10496301 & SRP15830 & BN10505063 \\
\hline $001600950 \mathrm{GBF}$ & 10496304 & SRP15805 & BN10505063 \\
\hline $001600950 \mathrm{GBF}$ & 10496306 & SRP15803 & BN10505063 \\
\hline $001600950 \mathrm{GBF}$ & 10496330 & SRP15800 & BN10505063 \\
\hline $001600950 \mathrm{GBF}$ & 10496331 & SRP15816 & BN10505063 \\
\hline $001600950 \mathrm{GBF}$ & 10496333 & SRP15809 & BN10505063 \\
\hline $001600951 \mathrm{GBF}$ & 10480178 & SRP12448 & BN10503777 \\
\hline $001600951 \mathrm{GBF}$ & 10480185 & SRP12496 & BN10503777 \\
\hline $001600951 \mathrm{GBF}$ & 10489124 & SRP13913 & BN10503777 \\
\hline $001600951 \mathrm{GBF}$ & 10491972 & SRP14673 & BN10500612 \\
\hline $001600951 \mathrm{GBF}$ & 10494425 & SRP15341 & BN10500612 \\
\hline $001600951 \mathrm{GBF}$ & 10494635 & SRP15381 & BN10500612 \\
\hline $001600951 \mathrm{GBF}$ & 10494827 & SRP15433 & BN10500612 \\
\hline $001600951 \mathrm{GBF}$ & 10494831 & SRP15387 & BN10500612 \\
\hline $001600951 \mathrm{GBF}$ & 10494832 & SRP15409 & BN10500612 \\
\hline $001600951 \mathrm{GBF}$ & 10494841 & SRP15414 & BN10500612 \\
\hline $001600951 \mathrm{GBF}$ & 10494845 & SRP15445 & BN10500612 \\
\hline $001600951 \mathrm{GBF}$ & 10494857 & SRP15361 & BN10500612 \\
\hline $001600951 \mathrm{GBF}$ & 10494861 & SRP15456 & BN10500612 \\
\hline $001600951 \mathrm{GBF}$ & 10496157 & SRP15769 & BN10503777 \\
\hline $001600951 \mathrm{GBF}$ & 10496158 & SRP15762 & BN10503777 \\
\hline $001600951 \mathrm{GBF}$ & 10496309 & SRP15853 & BN10503777 \\
\hline $001600951 \mathrm{GBF}$ & 10496318 & SRP15819 & BN10503777 \\
\hline $001600951 \mathrm{GBF}$ & 10496324 & SRP15820 & BN10503777 \\
\hline $001600951 \mathrm{GBF}$ & 10496334 & SRP15818 & BN10503777 \\
\hline $001600951 \mathrm{GBF}$ & 10496413 & SRP15662 & BN10503777 \\
\hline $001600952 \mathrm{GBF}$ & 10488520 & SRP13705 & BN10509616 \\
\hline $001600952 \mathrm{GBF}$ & 10491619 & SRP14499 & BN10509615 \\
\hline $001600952 \mathrm{GBF}$ & 10493562 & SRP15049 & BN10509615 \\
\hline $001600952 \mathrm{GBF}$ & 10493572 & SRP15048 & BN10509616 \\
\hline $001600952 \mathrm{GBF}$ & 10493859 & SRP15171 & BN10509616 \\
\hline $001600952 \mathrm{GBF}$ & 10493861 & SRP15172 & BN10509616 \\
\hline $001600952 \mathrm{GBF}$ & 10493867 & SRP15162 & BN10509615 \\
\hline $001600952 \mathrm{GBF}$ & 10493869 & SRP15079 & BN10509615 \\
\hline $001600952 \mathrm{GBF}$ & 10494061 & SRP15040 & BN10509615 \\
\hline $001600952 \mathrm{GBF}$ & 10494063 & SRP15208 & BN10509616 \\
\hline $001600952 \mathrm{GBF}$ & 10494067 & SRP15207 & BN10509616 \\
\hline
\end{tabular}




\section{AMWTP Repackaged Shipping Container Cross Reference 2014}

\begin{tabular}{|c|c|c|c|}
\hline Manifest & Container & Historical ID & Shipping Package \\
\hline 001600952GBF & 10494069 & SRP15297 & BN10509615 \\
\hline 001600952GBF & 10494070 & SRP15194 & BN10509615 \\
\hline 001600952GBF & 10494102 & SRP15209 & BN10509616 \\
\hline $001600952 \mathrm{GBF}$ & 10494104 & SRP15294 & BN10509615 \\
\hline $001600952 \mathrm{GBF}$ & 10494105 & SRP15293 & BN10509616 \\
\hline $001600952 \mathrm{GBF}$ & 10494629 & SRP15276 & BN10509616 \\
\hline $001600952 \mathrm{GBF}$ & 10494848 & SRP15464 & BN10509616 \\
\hline $001600952 \mathrm{GBF}$ & 10495938 & SRP15701 & BN10509615 \\
\hline $001600952 \mathrm{GBF}$ & 10495940 & SRP15699 & BN10509615 \\
\hline $001600954 \mathrm{GBF}$ & 10491093 & SRP14372 & BN10509688 \\
\hline $001600954 \mathrm{GBF}$ & 10491218 & SRP14335 & BN10509688 \\
\hline $001600954 G B F$ & 10491624 & SRP14517 & BN10509618 \\
\hline $001600954 \mathrm{GBF}$ & 10493481 & SRP14962 & BN10509688 \\
\hline $001600954 \mathrm{GBF}$ & 10493516 & SRP15024 & BN10509618 \\
\hline $001600954 \mathrm{GBF}$ & 10493517 & SRP15035 & BN10509618 \\
\hline $001600954 \mathrm{GBF}$ & 10493594 & SRP15095 & BN10509618 \\
\hline $001600954 \mathrm{GBF}$ & 10494082 & SRP15072 & BN10509618 \\
\hline 001600954GBF & 10494597 & SRP15317 & BN10509688 \\
\hline $001600954 G B F$ & 10494608 & SRP15403 & BN10509618 \\
\hline $001600954 \mathrm{GBF}$ & 10494611 & SRP15391 & BN10509618 \\
\hline $001600954 \mathrm{GBF}$ & 10494617 & SRP15363 & BN10509618 \\
\hline $001600954 \mathrm{GBF}$ & 10494623 & SRP15348 & BN10509618 \\
\hline $001600954 G B F$ & 10494631 & SRP15371 & BN10509688 \\
\hline $001600954 \mathrm{GBF}$ & 10494655 & SRP15355 & BN10509618 \\
\hline $001600954 \mathrm{GBF}$ & 10494672 & SRP15330 & BN10509688 \\
\hline $001600954 \mathrm{GBF}$ & 10495051 & SRP15527 & BN10509688 \\
\hline $001600954 \mathrm{GBF}$ & 10495073 & SRP15499 & BN10509688 \\
\hline $001600954 \mathrm{GBF}$ & 10495078 & SRP15481 & BN10509688 \\
\hline $001600954 \mathrm{GBF}$ & 10502825 & SRP16642 & BN10509688 \\
\hline $001600956 \mathrm{GBF}$ & 10480187 & SRP12506 & BN10503774 \\
\hline $001600956 \mathrm{GBF}$ & 10490478 & SRP14276 & BN10503774 \\
\hline $001600956 \mathrm{GBF}$ & 10490498 & SRP14265 & BN10503774 \\
\hline $001600956 \mathrm{GBF}$ & 10491626 & SRP14525 & BN10509606 \\
\hline $001600956 \mathrm{GBF}$ & 10493515 & SRP14997 & BN10509606 \\
\hline $001600956 \mathrm{GBF}$ & 10493521 & SRP14954 & BN10509606 \\
\hline $001600956 \mathrm{GBF}$ & 10493559 & SRP15066 & BN10509606 \\
\hline $001600956 \mathrm{GBF}$ & 10494089 & SRP15295 & BN10509606 \\
\hline $001600956 \mathrm{GBF}$ & 10494640 & SRP15360 & BN10509606 \\
\hline $001600956 \mathrm{GBF}$ & 10494804 & SRP15420 & BN10509606 \\
\hline $001600956 \mathrm{GBF}$ & 10495047 & SRP15532 & BN10509606 \\
\hline $001600956 \mathrm{GBF}$ & 10495844 & SRP15633 & BN10503774 \\
\hline $001600956 \mathrm{GBF}$ & 10495945 & SRP15718 & BN10509606 \\
\hline $001600956 \mathrm{GBF}$ & 10495953 & SRP15719 & BN10503774 \\
\hline $001600956 \mathrm{GBF}$ & 10496153 & SRP15775 & BN10503774 \\
\hline $001600956 \mathrm{GBF}$ & 10496165 & SRP15746 & BN10503774 \\
\hline $001600956 \mathrm{GBF}$ & 10496187 & SRP15781 & BN10503774 \\
\hline $001600956 \mathrm{GBF}$ & 10496322 & SRP15811 & BN10503774 \\
\hline $001600956 \mathrm{GBF}$ & 10496327 & SRP15804 & BN10509606 \\
\hline $001600956 \mathrm{GBF}$ & 10496337 & SRP15814 & BN10503774 \\
\hline $001600957 G B F$ & 10488684 & SRP13795 & BN10509611 \\
\hline $001600957 G B F$ & 10489221 & SRP13938 & BN10501248 \\
\hline $001600957 G B F$ & 10491432 & SRP14454 & BN10501248 \\
\hline $001600957 \mathrm{GBF}$ & 10494663 & SRP15258 & BN10509611 \\
\hline $001600957 \mathrm{GBF}$ & 10495055 & SRP15545 & BN10509611 \\
\hline $001600957 \mathrm{GBF}$ & 10495964 & SRP15726 & BN10509611 \\
\hline $001600957 \mathrm{GBF}$ & 10495969 & SRP15725 & BN10509611 \\
\hline $001600957 \mathrm{GBF}$ & 10495971 & SRP15733 & BN10509611 \\
\hline $001600957 \mathrm{GBF}$ & 10495973 & SRP15717 & BN10509611 \\
\hline
\end{tabular}




\section{AMWTP Repackaged Shipping Container Cross Reference 2014}

\begin{tabular}{|c|c|c|c|}
\hline Manifest & Container & Historical ID & Shipping Package \\
\hline $001600957 G B F$ & 10496169 & SRP15739 & BN10501248 \\
\hline $001600957 \mathrm{GBF}$ & 10496177 & SRP15732 & BN10501248 \\
\hline $001600957 \mathrm{GBF}$ & 10496180 & SRP15802 & BN10501248 \\
\hline $001600957 \mathrm{GBF}$ & 10496190 & SRP15760 & BN10501248 \\
\hline $001600957 \mathrm{GBF}$ & 10496287 & SRP15863 & BN10509611 \\
\hline $001600957 \mathrm{GBF}$ & 10496298 & SRP15825 & BN10501248 \\
\hline $001600957 \mathrm{GBF}$ & 10496314 & SRP15858 & BN10509611 \\
\hline $001600957 \mathrm{GBF}$ & 10496323 & SRP15813 & BN10501248 \\
\hline $001600957 \mathrm{GBF}$ & 10496326 & SRP15664 & BN10509611 \\
\hline $001600957 \mathrm{GBF}$ & 10496336 & SRP15834 & BN10501248 \\
\hline $001600959 G B F$ & 10495089 & SRP15503 & BN10505061 \\
\hline $001600959 \mathrm{GBF}$ & 10495308 & SRP15614 & BN10505061 \\
\hline $001600959 \mathrm{GBF}$ & 10495309 & SRP15576 & BN10505060 \\
\hline $001600959 G B F$ & 10495313 & SRP15625 & BN10505061 \\
\hline $001600959 G B F$ & 10495315 & SRP15599 & BN10505061 \\
\hline $001600959 \mathrm{GBF}$ & 10495317 & SRP15621 & BN10505060 \\
\hline $001600959 G B F$ & 10495319 & SRP15606 & BN10505060 \\
\hline $001600959 \mathrm{GBF}$ & 10495336 & SRP15568 & BN10505061 \\
\hline $001600959 \mathrm{GBF}$ & 10495354 & SRP15580 & BN10505061 \\
\hline $001600959 \mathrm{GBF}$ & 10495356 & SRP15605 & BN10505060 \\
\hline $001600959 \mathrm{GBF}$ & 10495357 & SRP15582 & BN10505060 \\
\hline $001600959 \mathrm{GBF}$ & 10495368 & SRP15607 & BN10505060 \\
\hline $001600959 G B F$ & 10495372 & SRP15622 & BN10505061 \\
\hline $001600959 \mathrm{GBF}$ & 10495834 & SRP15684 & BN10505060 \\
\hline $001600959 \mathrm{GBF}$ & 10495837 & SRP15676 & BN10505061 \\
\hline $001600959 G B F$ & 10495842 & SRP15646 & BN10505061 \\
\hline $001600959 \mathrm{GBF}$ & 10496141 & SRP15759 & BN10505060 \\
\hline $001600959 \mathrm{GBF}$ & 10496164 & SRP15663 & BN10505060 \\
\hline $001600959 \mathrm{GBF}$ & 10496171 & SRP15773 & BN10505060 \\
\hline $001600959 \mathrm{GBF}$ & 10496426 & SRP15895 & BN10505061 \\
\hline $001600961 \mathrm{GBF}$ & 10488565 & SRP13695 & BN10509601 \\
\hline $001600961 \mathrm{GBF}$ & 10490275 & SRP14120 & BN10509601 \\
\hline $001600961 \mathrm{GBF}$ & 10490276 & SRP14166 & BN10509601 \\
\hline $001600961 \mathrm{GBF}$ & 10490487 & SRP14266 & BN10509682 \\
\hline $001600961 \mathrm{GBF}$ & 10491197 & SRP14412 & BN10509682 \\
\hline $001600961 \mathrm{GBF}$ & 10491205 & SRP14401 & BN10509682 \\
\hline $001600961 \mathrm{GBF}$ & 10491206 & SRP14413 & BN10509682 \\
\hline $001600961 \mathrm{GBF}$ & 10491207 & SRP14408 & BN10509682 \\
\hline $001600961 \mathrm{GBF}$ & 10493524 & SRP15031 & BN10509601 \\
\hline $001600961 \mathrm{GBF}$ & 10493525 & SRP14849 & BN10509682 \\
\hline $001600961 \mathrm{GBF}$ & 10493527 & SRP15028 & BN10509601 \\
\hline $001600961 \mathrm{GBF}$ & 10493528 & SRP15038 & BN10509601 \\
\hline $001600961 \mathrm{GBF}$ & 10493530 & SRP15036 & BN10509682 \\
\hline $001600961 \mathrm{GBF}$ & 10493533 & SRP14861 & BN10509601 \\
\hline $001600961 \mathrm{GBF}$ & 10493535 & SRP15010 & BN10509601 \\
\hline $001600961 \mathrm{GBF}$ & 10493537 & SRP15011 & BN10509601 \\
\hline $001600961 \mathrm{GBF}$ & 10493540 & SRP15014 & BN10509682 \\
\hline $001600961 \mathrm{GBF}$ & 10493541 & SRP15013 & BN10509601 \\
\hline $001600961 \mathrm{GBF}$ & 10493542 & SRP14943 & BN10509682 \\
\hline $001600961 \mathrm{GBF}$ & 10502829 & SRP16790 & BN10509682 \\
\hline $001600962 \mathrm{GBF}$ & 10480188 & SRP12414 & BN10509687 \\
\hline $001600962 \mathrm{GBF}$ & 10489832 & SRP14121 & BN10509687 \\
\hline $001600962 \mathrm{GBF}$ & 10490277 & SRP14122 & BN10509687 \\
\hline $001600962 \mathrm{GBF}$ & 10491190 & SRP14426 & BN10507549 \\
\hline $001600962 \mathrm{GBF}$ & 10491199 & SRP14402 & BN10507549 \\
\hline $001600962 \mathrm{GBF}$ & 10491201 & SRP14399 & BN10507549 \\
\hline $001600962 \mathrm{GBF}$ & 10491221 & SRP14381 & BN10507549 \\
\hline $001600962 \mathrm{GBF}$ & 10502832 & SRP16671 & BN10509687 \\
\hline
\end{tabular}




\section{AMWTP Repackaged Shipping Container Cross Reference 2014}

\begin{tabular}{|c|c|c|c|}
\hline Manifest & Container & Historical ID & Shipping Package \\
\hline $001600962 \mathrm{GBF}$ & 10503265 & SRP17219 & BN10509687 \\
\hline $001600962 \mathrm{GBF}$ & 10503304 & SRP17339 & BN10509687 \\
\hline $001600962 \mathrm{GBF}$ & 10503321 & SRP17139 & BN10509687 \\
\hline $001600962 \mathrm{GBF}$ & 10503322 & SRP17270 & BN10509687 \\
\hline $001600962 \mathrm{GBF}$ & 10503343 & SRP17308 & BN10507549 \\
\hline $001600962 \mathrm{GBF}$ & 10503350 & SRP17328 & BN10507549 \\
\hline $001600962 \mathrm{GBF}$ & 10503356 & SRP17319 & BN10507549 \\
\hline $001600962 \mathrm{GBF}$ & 10503357 & SRP17344 & BN10507549 \\
\hline $001600962 \mathrm{GBF}$ & 10503363 & SRP17299 & BN10507549 \\
\hline $001600962 \mathrm{GBF}$ & 10503364 & SRP17251 & BN10507549 \\
\hline $001600962 \mathrm{GBF}$ & 10503368 & SRP17234 & BN10509687 \\
\hline $001600962 \mathrm{GBF}$ & 10503372 & SRP17254 & BN10509687 \\
\hline $001600963 \mathrm{GBF}$ & 10480223 & SRP12438 & BN10509599 \\
\hline $001600963 \mathrm{GBF}$ & 10482501 & SRP12786 & BN10509599 \\
\hline $001600963 \mathrm{GBF}$ & 10488582 & SRP13715 & BN10509599 \\
\hline $001600963 \mathrm{GBF}$ & 10491186 & SRP14417 & BN10507550 \\
\hline $001600963 \mathrm{GBF}$ & 10491187 & SRP14423 & BN10507550 \\
\hline $001600963 \mathrm{GBF}$ & 10491189 & SRP14414 & BN10507550 \\
\hline $001600963 \mathrm{GBF}$ & 10491198 & SRP14406 & BN10507550 \\
\hline $001600963 \mathrm{GBF}$ & 10491203 & SRP14411 & BN10507550 \\
\hline $001600963 \mathrm{GBF}$ & 10491204 & SRP14248 & BN10507550 \\
\hline $001600963 \mathrm{GBF}$ & 10491212 & SRP14446 & BN10507550 \\
\hline $001600963 \mathrm{GBF}$ & 10491214 & SRP14445 & BN10509599 \\
\hline $001600963 \mathrm{GBF}$ & 10502817 & SRP17167 & BN10509599 \\
\hline $001600963 \mathrm{GBF}$ & 10502818 & SRP17224 & BN10507550 \\
\hline $001600963 \mathrm{GBF}$ & 10502821 & SRP16644 & BN10509599 \\
\hline $001600963 \mathrm{GBF}$ & 10502823 & SRP16637 & BN10509599 \\
\hline $001600963 \mathrm{GBF}$ & 10502833 & SRP16795 & BN10509599 \\
\hline $001600963 \mathrm{GBF}$ & 10502834 & SRP16787 & BN10509599 \\
\hline $001600963 \mathrm{GBF}$ & 10502853 & SRP17206 & BN10509599 \\
\hline $001600963 \mathrm{GBF}$ & 10503344 & SRP17323 & BN10507550 \\
\hline $001600963 \mathrm{GBF}$ & 10503347 & SRP17373 & BN10507550 \\
\hline $001600965 \mathrm{GBF}$ & 10485651 & SRP13225 & BN10509608 \\
\hline $001600965 \mathrm{GBF}$ & 10488566 & SRP13756 & BN10509608 \\
\hline $001600965 \mathrm{GBF}$ & 10488567 & SRP13753 & BN10509600 \\
\hline $001600965 \mathrm{GBF}$ & 10488569 & SRP13764 & BN10509600 \\
\hline $001600965 \mathrm{GBF}$ & 10488574 & SRP13752 & BN10509600 \\
\hline $001600965 \mathrm{GBF}$ & 10488579 & SRP13699 & BN10509600 \\
\hline $001600965 \mathrm{GBF}$ & 10488581 & SRP13746 & BN10509608 \\
\hline $001600965 \mathrm{GBF}$ & 10493531 & SRP15008 & BN10509600 \\
\hline $001600965 \mathrm{GBF}$ & 10493536 & SRP14860 & BN10509608 \\
\hline $001600965 \mathrm{GBF}$ & 10493538 & SRP14857 & BN10509608 \\
\hline $001600965 \mathrm{GBF}$ & 10493539 & SRP14859 & BN10509608 \\
\hline $001600965 \mathrm{GBF}$ & 10493586 & SRP15083 & BN10509600 \\
\hline $001600965 \mathrm{GBF}$ & 10493613 & SRP14858 & BN10509600 \\
\hline $001600965 \mathrm{GBF}$ & 10493615 & SRP14862 & BN10509608 \\
\hline $001600965 \mathrm{GBF}$ & 10493616 & SRP15039 & BN10509608 \\
\hline $001600965 \mathrm{GBF}$ & 10493617 & SRP13851 & BN10509608 \\
\hline $001600965 \mathrm{GBF}$ & 10493620 & SRP13889 & BN10509608 \\
\hline $001600965 \mathrm{GBF}$ & 10493621 & SRP14883 & BN10509600 \\
\hline $001600965 \mathrm{GBF}$ & 10493622 & SRP15055 & BN10509600 \\
\hline $001600965 \mathrm{GBF}$ & 10493623 & SRP13877 & BN10509600 \\
\hline $001600966 \mathrm{GBF}$ & 10485094 & SRP13106 & BN10507553 \\
\hline $001600966 \mathrm{GBF}$ & 10503205 & SRP17226 & BN10507553 \\
\hline $001600966 \mathrm{GBF}$ & 10503214 & SRP17218 & BN10507553 \\
\hline $001600966 \mathrm{GBF}$ & 10503231 & SRP17168 & BN10507553 \\
\hline $001600966 \mathrm{GBF}$ & 10503232 & SRP17159 & BN10507557 \\
\hline $001600966 \mathrm{GBF}$ & 10503234 & SRP17227 & BN10507553 \\
\hline
\end{tabular}




\section{AMWTP Repackaged Shipping Container Cross Reference 2014}

\begin{tabular}{|c|c|c|c|}
\hline Manifest & Container & Historical ID & Shipping Package \\
\hline $001600966 \mathrm{GBF}$ & 10503236 & SRP17241 & BN10507557 \\
\hline $001600966 \mathrm{GBF}$ & 10503237 & SRP17238 & BN10507557 \\
\hline $001600966 \mathrm{GBF}$ & 10503238 & SRP17263 & BN10507557 \\
\hline $001600966 \mathrm{GBF}$ & 10503239 & SRP17253 & BN10507557 \\
\hline $001600966 \mathrm{GBF}$ & 10503242 & SRP17301 & BN10507557 \\
\hline $001600966 \mathrm{GBF}$ & 10503262 & SRP17156 & BN10507557 \\
\hline $001600966 \mathrm{GBF}$ & 10503303 & SRP17165 & BN10507553 \\
\hline $001600966 \mathrm{GBF}$ & 10503306 & SRP17307 & BN10507557 \\
\hline $001600966 \mathrm{GBF}$ & 10503313 & SRP17295 & BN10507553 \\
\hline $001600966 \mathrm{GBF}$ & 10503316 & SRP17306 & BN10507557 \\
\hline $001600966 \mathrm{GBF}$ & 10503329 & SRP17268 & BN10507557 \\
\hline $001600966 \mathrm{GBF}$ & 10503849 & SRP17415 & BN10507553 \\
\hline $001600966 \mathrm{GBF}$ & 10503852 & SRP17427 & BN10507553 \\
\hline $001600966 \mathrm{GBF}$ & 10503854 & SRP17416 & BN10507553 \\
\hline $001600967 \mathrm{GBF}$ & 10491216 & SRP14429 & BN10507554 \\
\hline $001600967 \mathrm{GBF}$ & 10501934 & SRP16991 & BN10507554 \\
\hline $001600967 \mathrm{GBF}$ & 10502826 & SRP16794 & BN10507554 \\
\hline $001600967 \mathrm{GBF}$ & 10502864 & SRP17142 & BN10507554 \\
\hline $001600967 \mathrm{GBF}$ & 10503246 & SRP17258 & BN10507555 \\
\hline $001600967 \mathrm{GBF}$ & 10503255 & SRP17271 & BN10507554 \\
\hline $001600967 \mathrm{GBF}$ & 10503256 & SRP17267 & BN10507555 \\
\hline $001600967 \mathrm{GBF}$ & 10503261 & SRP17274 & BN10507555 \\
\hline $001600967 \mathrm{GBF}$ & 10503302 & SRP17322 & BN10507555 \\
\hline $001600967 \mathrm{GBF}$ & 10503305 & SRP17275 & BN10507555 \\
\hline $001600967 \mathrm{GBF}$ & 10503307 & SRP17278 & BN10507555 \\
\hline $001600967 \mathrm{GBF}$ & 10503309 & SRP17311 & BN10507555 \\
\hline $001600967 \mathrm{GBF}$ & 10503324 & SRP17243 & BN10507554 \\
\hline $001600967 \mathrm{GBF}$ & 10503325 & SRP17289 & BN10507555 \\
\hline $001600967 \mathrm{GBF}$ & 10503327 & SRP17151 & BN10507555 \\
\hline $001600967 \mathrm{GBF}$ & 10503331 & SRP17264 & BN10507555 \\
\hline $001600967 \mathrm{GBF}$ & 10503832 & SRP17356 & BN10507554 \\
\hline $001600967 \mathrm{GBF}$ & 10503834 & SRP17445 & BN10507554 \\
\hline $001600967 \mathrm{GBF}$ & 10503837 & SRP17441 & BN10507554 \\
\hline $001600967 \mathrm{GBF}$ & 10503858 & SRP17464 & BN10507554 \\
\hline 001600968GBF & 10480204 & SRP12446 & BN10509686 \\
\hline $001600968 \mathrm{GBF}$ & 10480228 & SRP12481 & BN10509686 \\
\hline $001600968 \mathrm{GBF}$ & 10490496 & SRP14274 & BN10509686 \\
\hline $001600968 \mathrm{GBF}$ & 10491200 & SRP14409 & BN10509686 \\
\hline 001600968GBF & 10493598 & SRP15064 & BN10509604 \\
\hline $001600968 \mathrm{GBF}$ & 10502815 & SRP17201 & BN10509604 \\
\hline $001600968 \mathrm{GBF}$ & 10502819 & SRP17208 & BN10509604 \\
\hline $001600968 \mathrm{GBF}$ & 10502863 & SRP17146 & BN10509604 \\
\hline $001600968 \mathrm{GBF}$ & 10503233 & SRP17158 & BN10509604 \\
\hline $001600968 \mathrm{GBF}$ & 10503241 & SRP17262 & BN10509686 \\
\hline $001600968 \mathrm{GBF}$ & 10503243 & SRP17252 & BN10509604 \\
\hline $001600968 \mathrm{GBF}$ & 10503245 & SRP17231 & BN10509686 \\
\hline $001600968 \mathrm{GBF}$ & 10503252 & SRP17229 & BN10509686 \\
\hline $001600968 \mathrm{GBF}$ & 10503260 & SRP17272 & BN10509686 \\
\hline 001600968GBF & 10503263 & SRP17237 & BN10509604 \\
\hline $001600968 \mathrm{GBF}$ & 10503267 & SRP17236 & BN10509604 \\
\hline $001600968 \mathrm{GBF}$ & 10503268 & SRP17171 & BN10509604 \\
\hline $001600968 \mathrm{GBF}$ & 10503366 & SRP17290 & BN10509686 \\
\hline $001600968 \mathrm{GBF}$ & 10503369 & SRP17302 & BN10509686 \\
\hline $001600968 \mathrm{GBF}$ & 10503370 & SRP17232 & BN10509604 \\
\hline $001600969 \mathrm{GBF}$ & 10489120 & SRP13921 & BN10503776 \\
\hline $001600969 \mathrm{GBF}$ & 10492983 & SRP14916 & BN10503776 \\
\hline $001600969 \mathrm{GBF}$ & 10492993 & SRP14801 & BN10503776 \\
\hline $001600969 \mathrm{GBF}$ & 10494620 & SRP15247 & BN10509684 \\
\hline
\end{tabular}




\section{AMWTP Repackaged Shipping Container Cross Reference 2014}

\begin{tabular}{|c|c|c|c|}
\hline Manifest & Container & Historical ID & Shipping Package \\
\hline $001600969 \mathrm{GBF}$ & 10494661 & SRP15315 & BN10509684 \\
\hline $001600969 \mathrm{GBF}$ & 10494674 & SRP15340 & BN10509684 \\
\hline $001600969 \mathrm{GBF}$ & 10495822 & SRP15624 & BN10503776 \\
\hline $001600969 \mathrm{GBF}$ & 10495823 & SRP15632 & BN10503776 \\
\hline $001600969 \mathrm{GBF}$ & 10495944 & SRP15723 & BN10509684 \\
\hline $001600969 \mathrm{GBF}$ & 10495947 & SRP15724 & BN10509684 \\
\hline $001600969 \mathrm{GBF}$ & 10495954 & SRP15698 & BN10509684 \\
\hline $001600969 \mathrm{GBF}$ & 10495955 & SRP15720 & BN10509684 \\
\hline $001600969 \mathrm{GBF}$ & 10495956 & SRP15751 & BN10509684 \\
\hline $001600969 \mathrm{GBF}$ & 10495957 & SRP15749 & BN10509684 \\
\hline $001600969 \mathrm{GBF}$ & 10495976 & SRP15696 & BN10509684 \\
\hline $001600969 \mathrm{GBF}$ & 10496168 & SRP15761 & BN10503776 \\
\hline $001600969 \mathrm{GBF}$ & 10496194 & SRP15754 & BN10503776 \\
\hline $001600969 \mathrm{GBF}$ & 10496310 & SRP15852 & BN10503776 \\
\hline $001600969 \mathrm{GBF}$ & 10496395 & SRP15932 & BN10503776 \\
\hline $001600969 \mathrm{GBF}$ & 10496412 & SRP15862 & BN10503776 \\
\hline $001600972 \mathrm{GBF}$ & 10483112 & SRP12876 & BN10509602 \\
\hline $001600972 \mathrm{GBF}$ & 10488876 & SRP13799 & BN10509602 \\
\hline $001600972 \mathrm{GBF}$ & 10489237 & SRP13903 & BN10509602 \\
\hline $001600972 \mathrm{GBF}$ & 10490477 & SRP14259 & BN10509602 \\
\hline $001600972 \mathrm{GBF}$ & 10490488 & SRP14290 & BN10509602 \\
\hline $001600972 \mathrm{GBF}$ & 10490541 & SRP13740 & BN10509603 \\
\hline $001600972 \mathrm{GBF}$ & 10491183 & SRP14400 & BN10509603 \\
\hline $001600972 \mathrm{GBF}$ & 10491208 & SRP14404 & BN10509603 \\
\hline $001600972 \mathrm{GBF}$ & 10491219 & SRP14336 & BN10509603 \\
\hline $001600972 \mathrm{GBF}$ & 10493484 & SRP14942 & BN10509603 \\
\hline $001600972 \mathrm{GBF}$ & 10493529 & SRP15027 & BN10509603 \\
\hline $001600972 \mathrm{GBF}$ & 10493534 & SRP14957 & BN10509603 \\
\hline $001600972 \mathrm{GBF}$ & 10493543 & SRP15033 & BN10509603 \\
\hline $001600972 \mathrm{GBF}$ & 10493575 & SRP15068 & BN10509603 \\
\hline $001600972 \mathrm{GBF}$ & 10493587 & SRP15091 & BN10509602 \\
\hline $001600972 \mathrm{GBF}$ & 10493599 & SRP13572 & BN10509602 \\
\hline $001600972 \mathrm{GBF}$ & 10493611 & SRP15050 & BN10509602 \\
\hline $001600972 \mathrm{GBF}$ & 10493618 & SRP13870 & BN10509602 \\
\hline $001600972 \mathrm{GBF}$ & 10493619 & SRP15052 & BN10509602 \\
\hline $001600972 \mathrm{GBF}$ & 10495950 & SRP15752 & BN10509603 \\
\hline $001600973 \mathrm{GBF}$ & 10480205 & SRP12477 & BN10507558 \\
\hline $001600973 \mathrm{GBF}$ & 10480225 & SRP12427 & BN10507558 \\
\hline $001600973 \mathrm{GBF}$ & 10491188 & SRP14425 & BN10507558 \\
\hline $001600973 \mathrm{GBF}$ & 10491211 & SRP14430 & BN10507558 \\
\hline $001600973 \mathrm{GBF}$ & 10493478 & SRP14953 & BN10507558 \\
\hline $001600973 \mathrm{GBF}$ & 10493523 & SRP15025 & BN10507558 \\
\hline $001600973 \mathrm{GBF}$ & 10493552 & SRP15090 & BN10507545 \\
\hline $001600973 \mathrm{GBF}$ & 10493747 & SRP15117 & BN10507545 \\
\hline $001600973 G B F$ & 10493779 & SRP14842 & BN10507545 \\
\hline $001600973 \mathrm{GBF}$ & 10494178 & SRP15300 & BN10507545 \\
\hline $001600973 \mathrm{GBF}$ & 10494654 & SRP15372 & BN10507545 \\
\hline $001600973 \mathrm{GBF}$ & 10494660 & SRP15319 & BN10507545 \\
\hline $001600973 \mathrm{GBF}$ & 10495952 & SRP15744 & BN10507558 \\
\hline $001600973 \mathrm{GBF}$ & 10502860 & SRP16228 & BN10507545 \\
\hline $001600973 \mathrm{GBF}$ & 10503240 & SRP17324 & BN10507558 \\
\hline $001600973 \mathrm{GBF}$ & 10503257 & SRP17169 & BN10507558 \\
\hline $001600973 \mathrm{GBF}$ & 10503266 & SRP17217 & BN10507558 \\
\hline $001600973 \mathrm{GBF}$ & 10503341 & SRP17283 & BN10507545 \\
\hline $001600973 \mathrm{GBF}$ & 10503353 & SRP17309 & BN10507545 \\
\hline $001600973 \mathrm{GBF}$ & 10503840 & SRP17444 & BN10507545 \\
\hline $001942718 \mathrm{GBF}$ & 10004014 & & 10519027 \\
\hline $001942718 \mathrm{GBF}$ & 10004809 & & 10519027 \\
\hline
\end{tabular}




\section{AMWTP Repackaged Shipping Container Cross Reference 2014}

\begin{tabular}{|c|c|c|c|}
\hline Manifest & Container & Historical ID & Shipping Package \\
\hline 001942718GBF & 10020386 & & 10519027 \\
\hline 001942718GBF & 10027705 & & 10519027 \\
\hline 001942718GBF & 10033436 & & 10519027 \\
\hline 001942718GBF & 10033444 & & 10519027 \\
\hline 001942718GBF & 10033445 & & 10519027 \\
\hline 001942718GBF & 10036797 & & 10519027 \\
\hline 001942718GBF & 10094744 & & 10519027 \\
\hline 001942718GBF & 10097393 & & 10519027 \\
\hline 001942718GBF & 10098916 & & 10519027 \\
\hline 001942718GBF & 10100134 & & 10519027 \\
\hline 001942718GBF & 10163211 & & 10519027 \\
\hline 001942718GBF & 10166762 & & 10519027 \\
\hline 001942718GBF & 10174234 & & 10519027 \\
\hline 001942718GBF & 10215834 & & 10519027 \\
\hline 001942718GBF & 10217940 & & 10519027 \\
\hline 001942718GBF & 10218422 & & 10519027 \\
\hline 001942718GBF & 10230714 & & 10519027 \\
\hline 001942718GBF & 10268013 & & 10519028 \\
\hline 001942718GBF & 10268414 & & 10519028 \\
\hline 001942718GBF & 10291155 & & 10519028 \\
\hline 001942718GBF & 10291543 & & 10519028 \\
\hline 001942718GBF & 10293756 & & 10519028 \\
\hline 001942718GBF & 10299577 & & 10519028 \\
\hline 001942718GBF & 10299587 & & 10519028 \\
\hline 001942718GBF & 10301265 & & 10519027 \\
\hline 001942718GBF & 10305146 & & 10519028 \\
\hline 001942718GBF & 10305486 & & 10519028 \\
\hline 001942718GBF & 10308389 & & 10519027 \\
\hline 001942718GBF & 10309548 & & 10519028 \\
\hline 001942718GBF & 10310252 & & 10519028 \\
\hline 001942718GBF & 10310268 & & 10519028 \\
\hline 001942718GBF & 10311055 & & 10519028 \\
\hline 001942718GBF & 10311118 & & 10519028 \\
\hline 001942718GBF & 10312442 & & 10519028 \\
\hline 001942718GBF & 10314986 & & 10519028 \\
\hline 001942718GBF & 10323328 & & 10519028 \\
\hline 001942718GBF & 10324458 & & 10519028 \\
\hline 001942718GBF & 10325058 & & 10519028 \\
\hline 001942718GBF & 10327901 & & 10519028 \\
\hline 001942718GBF & 10328284 & & 10519028 \\
\hline 001942718GBF & 10330095 & & 10519028 \\
\hline 001942718GBF & 10333701 & & 10519028 \\
\hline 001942718GBF & 10342925 & & 10519027 \\
\hline 001942718GBF & 10352439 & & 10519027 \\
\hline 001942718GBF & 10356127 & & 10519027 \\
\hline 001942718GBF & 10362580 & & 10519027 \\
\hline 001942718GBF & 10367221 & & 10519027 \\
\hline 001942718GBF & 10369054 & & 10519027 \\
\hline 001942718GBF & 10370319 & & 10519027 \\
\hline 001942718GBF & 10370406 & & 10519027 \\
\hline 001942718GBF & 10443336 & & 10519028 \\
\hline 001942722GBF & 10497539 & SRS130206 & \\
\hline 001942722GBF & 10497545 & SRS130197 & \\
\hline $001942722 \mathrm{GBF}$ & 10497546 & SRS130191 & \\
\hline $001942722 \mathrm{GBF}$ & 10497547 & SRS130192 & \\
\hline $001942722 \mathrm{GBF}$ & 10497548 & SRS130207 & \\
\hline $001942722 \mathrm{GBF}$ & 10499958 & SRS130183 & \\
\hline 001942722GBF & 10499959 & SRS130215 & \\
\hline
\end{tabular}




\section{AMWTP Repackaged Shipping Container Cross Reference 2014}

\begin{tabular}{|c|c|c|c|}
\hline Manifest & Container & Historical ID & Shipping Package \\
\hline $001942722 \mathrm{GBF}$ & 10499960 & SRS130184 & \\
\hline $001942722 \mathrm{GBF}$ & 10499967 & SRS130223 & \\
\hline $001942722 \mathrm{GBF}$ & 10500850 & SRS130227 & \\
\hline $001942722 \mathrm{GBF}$ & 10500851 & SRS130226 & \\
\hline $001942722 \mathrm{GBF}$ & 10500852 & SRS130224 & \\
\hline $001942722 \mathrm{GBF}$ & 10500853 & SRS130236 & \\
\hline $001942722 \mathrm{GBF}$ & 10500854 & SRS130219 & \\
\hline $001942723 \mathrm{GBF}$ & 10496272 & SRS130071 & \\
\hline $001942723 \mathrm{GBF}$ & 10496273 & SRS130058 & \\
\hline $001942723 \mathrm{GBF}$ & 10496274 & SRS130075 & \\
\hline $001942723 \mathrm{GBF}$ & 10496275 & SRS130148 & \\
\hline $001942723 \mathrm{GBF}$ & 10496908 & SRS130169 & \\
\hline $001942723 \mathrm{GBF}$ & 10496909 & SRS130177 & \\
\hline $001942723 \mathrm{GBF}$ & 10496910 & SRS130186 & \\
\hline $001942723 \mathrm{GBF}$ & 10497540 & SRS130201 & \\
\hline $001942723 \mathrm{GBF}$ & 10497541 & SRS130151 & \\
\hline $001942723 \mathrm{GBF}$ & 10497542 & SRS130204 & \\
\hline $001942723 \mathrm{GBF}$ & 10497543 & SRS130202 & \\
\hline $001942723 \mathrm{GBF}$ & 10497544 & SRS130200 & \\
\hline $001942723 \mathrm{GBF}$ & 10497549 & SRS130196 & \\
\hline $001942723 \mathrm{GBF}$ & 10497550 & SRS130195 & \\
\hline $001942724 G B F$ & 10496047 & SRS130160 & \\
\hline $001942724 \mathrm{GBF}$ & 10496048 & SRS130131 & \\
\hline $001942724 G B F$ & 10496049 & SRS130089 & \\
\hline $001942724 G B F$ & 10496050 & SRS130130 & \\
\hline $001942724 \mathrm{GBF}$ & 10496276 & SRS130159 & \\
\hline $001942724 G B F$ & 10496277 & SRS130140 & \\
\hline $001942724 G B F$ & 10496278 & SRS130113 & \\
\hline $001942724 G B F$ & 10496279 & SRS130112 & \\
\hline $001942724 \mathrm{GBF}$ & 10496280 & SRS130162 & \\
\hline 001942724GBF & 10496281 & SRS130161 & \\
\hline $001942724 \mathrm{GBF}$ & 10496282 & SRS130137 & \\
\hline 001942724GBF & 10496283 & SRS130074 & \\
\hline 001942724GBF & 10500846 & SRS130228 & \\
\hline 001942724GBF & 10500847 & SRS130231 & \\
\hline $001942725 \mathrm{GBF}$ & 10499087 & SRS130163 & \\
\hline $001942725 \mathrm{GBF}$ & 10499088 & SRS130145 & \\
\hline $001942725 G B F$ & 10499089 & SRS130208 & \\
\hline $001942725 \mathrm{GBF}$ & 10499090 & SRS130149 & \\
\hline $001942725 \mathrm{GBF}$ & 10499091 & SRS130087 & \\
\hline $001942725 \mathrm{GBF}$ & 10499092 & SRS130216 & \\
\hline $001942725 \mathrm{GBF}$ & 10499961 & SRS130211 & \\
\hline $001942725 \mathrm{GBF}$ & 10499962 & SRS130221 & \\
\hline $001942725 \mathrm{GBF}$ & 10499963 & SRS130203 & \\
\hline 001942725GBF & 10499964 & SRS130222 & \\
\hline $001942725 \mathrm{GBF}$ & 10499965 & SRS130173 & \\
\hline $001942725 G B F$ & 10499966 & SRS130210 & \\
\hline $001942725 \mathrm{GBF}$ & 10500848 & SRS130232 & \\
\hline $001942725 G B F$ & 10500849 & SRS130217 & \\
\hline $001942726 \mathrm{GBF}$ & 10496899 & SRS130138 & \\
\hline $001942726 \mathrm{GBF}$ & 10496900 & SRS130182 & \\
\hline $001942726 \mathrm{GBF}$ & 10496901 & SRS130178 & \\
\hline $001942726 \mathrm{GBF}$ & 10496902 & SRS130185 & \\
\hline $001942726 \mathrm{GBF}$ & 10496903 & SRS130174 & \\
\hline $001942726 \mathrm{GBF}$ & 10496904 & SRS130108 & \\
\hline $001942726 \mathrm{GBF}$ & 10496905 & SRS130187 & \\
\hline $001942726 \mathrm{GBF}$ & 10496906 & SRS130188 & \\
\hline $001942726 \mathrm{GBF}$ & 10496907 & SRS130190 & \\
\hline
\end{tabular}




\section{AMWTP Repackaged Shipping Container Cross Reference 2014}

\begin{tabular}{|c|c|c|c|}
\hline Manifest & Container & Historical ID & Shipping Package \\
\hline $001942726 \mathrm{GBF}$ & 10499084 & SRS130118 & \\
\hline $001942726 \mathrm{GBF}$ & 10499085 & SRS130205 & \\
\hline $001942726 \mathrm{GBF}$ & 10499086 & SRS130147 & \\
\hline $001942726 \mathrm{GBF}$ & 10499093 & SRS130152 & \\
\hline $001942726 \mathrm{GBF}$ & 10499094 & SRS130212 & \\
\hline $001942729 \mathrm{GBF}$ & 10494514 & SRS130114 & \\
\hline $001942729 \mathrm{GBF}$ & 10494515 & SRS130116 & \\
\hline $001942729 \mathrm{GBF}$ & 10494787 & SRS130109 & \\
\hline $001942729 \mathrm{GBF}$ & 10494790 & SRS130119 & \\
\hline $001942729 \mathrm{GBF}$ & 10494791 & SRS130111 & \\
\hline $001942729 \mathrm{GBF}$ & 10494793 & SRS130099 & \\
\hline $001942729 \mathrm{GBF}$ & 10496043 & SRS130135 & \\
\hline $001942729 \mathrm{GBF}$ & 10496044 & SRS130091 & \\
\hline $001942729 \mathrm{GBF}$ & 10496045 & SRS130094 & \\
\hline $001942729 \mathrm{GBF}$ & 10496046 & SRS130126 & \\
\hline $001942729 \mathrm{GBF}$ & 10496051 & SRS130127 & \\
\hline $001942729 \mathrm{GBF}$ & 10496052 & SRS130128 & \\
\hline $001942729 \mathrm{GBF}$ & 10496053 & SRS130093 & \\
\hline $001942729 \mathrm{GBF}$ & 10496054 & SRS130129 & \\
\hline $001942730 \mathrm{GBF}$ & 10493124 & SRS130061 & \\
\hline 001942730GBF & 10493125 & SRS130000 & \\
\hline 001942730GBF & 10493127 & SRS130072 & \\
\hline $001942730 \mathrm{GBF}$ & 10493128 & SRS130068 & \\
\hline 001942730GBF & 10493129 & SRS130081 & \\
\hline 001942730GBF & 10493130 & SRS130065 & \\
\hline 001942730GBF & 10493131 & SRS130066 & \\
\hline 001942730GBF & 10493132 & SRS130069 & \\
\hline $001942730 \mathrm{GBF}$ & 10493133 & SRS130083 & \\
\hline 001942730GBF & 10493134 & SRS130062 & \\
\hline 001942730GBF & 10493135 & SRS130076 & \\
\hline 001942730GBF & 10494516 & SRS130117 & \\
\hline $001942730 \mathrm{GBF}$ & 10494517 & SRS130095 & \\
\hline 001942730GBF & 10494519 & SRS130096 & \\
\hline $001942731 \mathrm{GBF}$ & 10493126 & SRS130070 & \\
\hline $001942731 \mathrm{GBF}$ & 10493248 & SRS130057 & \\
\hline $001942731 \mathrm{GBF}$ & 10493249 & SRS130047 & \\
\hline $001942731 \mathrm{GBF}$ & 10493250 & SRS130038 & \\
\hline $001942731 \mathrm{GBF}$ & 10493251 & SRS130037 & \\
\hline $001942731 \mathrm{GBF}$ & 10493252 & SRS130030 & \\
\hline $001942731 \mathrm{GBF}$ & 10493253 & SRS130054 & \\
\hline $001942731 \mathrm{GBF}$ & 10493254 & SRS130059 & \\
\hline $001942731 \mathrm{GBF}$ & 10493255 & SRS130056 & \\
\hline $001942731 \mathrm{GBF}$ & 10493256 & SRS130029 & \\
\hline $001942731 \mathrm{GBF}$ & 10493257 & SRS130006 & \\
\hline $001942731 \mathrm{GBF}$ & 10493258 & SRS130046 & \\
\hline $001942731 \mathrm{GBF}$ & 10493259 & SRS130048 & \\
\hline $001942731 \mathrm{GBF}$ & 10494788 & SRS130080 & \\
\hline 001942733GBF & 10492740 & SRS130053 & \\
\hline $001942733 G B F$ & 10492741 & SRS130051 & \\
\hline $001942733 G B F$ & 10492742 & SRS130052 & \\
\hline $001942733 G B F$ & 10492743 & SRS130050 & \\
\hline 001942733GBF & 10492744 & SRS130008 & \\
\hline $001942733 G B F$ & 10492746 & SRS130009 & \\
\hline 001942733GBF & 10494518 & SRS130086 & \\
\hline 001942733GBF & 10494520 & SRS130115 & \\
\hline 001942733GBF & 10494521 & SRS130088 & \\
\hline 001942733GBF & 10494522 & SRS130097 & \\
\hline $001942733 \mathrm{GBF}$ & 10494523 & SRS130084 & \\
\hline
\end{tabular}




\section{AMWTP Repackaged Shipping Container Cross Reference 2014}

\begin{tabular}{|c|c|c|c|}
\hline Manifest & Container & Historical ID & Shipping Package \\
\hline 001942733GBF & 10494789 & SRS130078 & \\
\hline $001942733 \mathrm{GBF}$ & 10494792 & SRS130107 & \\
\hline 001942733GBF & 10494794 & SRS130100 & \\
\hline 001942734GBF & 10492247 & SRS130018 & \\
\hline 001942734GBF & 10492248 & SRS12035 & \\
\hline $001942734 \mathrm{GBF}$ & 10492249 & SRS130022 & \\
\hline $001942734 \mathrm{GBF}$ & 10492252 & SRS130016 & \\
\hline $001942734 \mathrm{GBF}$ & 10492253 & SRS130036 & \\
\hline $001942734 \mathrm{GBF}$ & 10492255 & SRS130020 & \\
\hline $001942734 \mathrm{GBF}$ & 10492256 & SRS130021 & \\
\hline $001942734 \mathrm{GBF}$ & 10492257 & SRS130017 & \\
\hline $001942734 \mathrm{GBF}$ & 10492745 & SRS130012 & \\
\hline $001942734 \mathrm{GBF}$ & 10492747 & SRS130011 & \\
\hline $001942734 \mathrm{GBF}$ & 10492748 & SRS130049 & \\
\hline $001942734 \mathrm{GBF}$ & 10492749 & SRS130028 & \\
\hline $001942734 \mathrm{GBF}$ & 10492750 & SRS130013 & \\
\hline $001942734 \mathrm{GBF}$ & 10492751 & SRS130025 & \\
\hline $001942735 \mathrm{GBF}$ & 10492246 & SRS12034 & \\
\hline $001942735 \mathrm{GBF}$ & 10492250 & SRS130031 & \\
\hline $001942735 \mathrm{GBF}$ & 10492251 & SRS130033 & \\
\hline $001942735 \mathrm{GBF}$ & 10492254 & SRS130019 & \\
\hline $001942735 \mathrm{GBF}$ & 10503916 & SRS130280 & \\
\hline $001942735 \mathrm{GBF}$ & 10503918 & SRS130285 & \\
\hline $001942735 \mathrm{GBF}$ & 10503920 & SRS130290 & \\
\hline $001942735 \mathrm{GBF}$ & 10503922 & SRS130284 & \\
\hline $001942735 \mathrm{GBF}$ & 10503923 & SRS130302 & \\
\hline $001942735 \mathrm{GBF}$ & 10503924 & SRS130301 & \\
\hline $001942735 \mathrm{GBF}$ & 10503925 & SRS130286 & \\
\hline $001942735 \mathrm{GBF}$ & 10504589 & SRS130289 & \\
\hline $001942735 G B F$ & 10504590 & SRS130314 & \\
\hline $001942735 G B F$ & 10504592 & SRS130309 & \\
\hline $001942736 \mathrm{GBF}$ & 10502029 & SRS130264 & \\
\hline $001942736 \mathrm{GBF}$ & 10502428 & SRS130279 & \\
\hline $001942736 \mathrm{GBF}$ & 10502429 & SRS130277 & \\
\hline $001942736 \mathrm{GBF}$ & 10502430 & SRS130275 & \\
\hline $001942736 \mathrm{GBF}$ & 10502431 & SRS130270 & \\
\hline $001942736 \mathrm{GBF}$ & 10502432 & SRS130271 & \\
\hline $001942736 \mathrm{GBF}$ & 10502433 & SRS130278 & \\
\hline $001942736 \mathrm{GBF}$ & 10502434 & SRS130276 & \\
\hline $001942736 \mathrm{GBF}$ & 10503739 & SRS130258 & \\
\hline $001942736 \mathrm{GBF}$ & 10503740 & SRS130263 & \\
\hline 001942736GBF & 10503748 & SRS130269 & \\
\hline $001942736 \mathrm{GBF}$ & 10503915 & SRS130288 & \\
\hline $001942736 \mathrm{GBF}$ & 10503917 & SRS130282 & \\
\hline 001942736GBF & 10503919 & SRS130283 & \\
\hline $001942737 \mathrm{GBF}$ & 10502018 & SRS130256 & \\
\hline $001942737 \mathrm{GBF}$ & 10502019 & SRS130253 & \\
\hline $001942737 \mathrm{GBF}$ & 10502020 & SRS130249 & \\
\hline $001942737 \mathrm{GBF}$ & 10502021 & SRS130248 & \\
\hline $001942737 \mathrm{GBF}$ & 10502022 & SRS130165 & \\
\hline $001942737 \mathrm{GBF}$ & 10502023 & SRS130252 & \\
\hline $001942737 G B F$ & 10502024 & SRS130261 & \\
\hline $001942737 \mathrm{GBF}$ & 10502025 & SRS130250 & \\
\hline $001942737 G B F$ & 10502026 & SRS130266 & \\
\hline $001942737 G B F$ & 10502027 & SRS130265 & \\
\hline $001942737 \mathrm{GBF}$ & 10502028 & SRS130262 & \\
\hline $001942737 \mathrm{GBF}$ & 10516844 & SRS130454 & \\
\hline $001942737 \mathrm{GBF}$ & 10516845 & SRS140014 & \\
\hline
\end{tabular}




\section{AMWTP Repackaged Shipping Container Cross Reference 2014}

\begin{tabular}{|c|c|c|c|}
\hline Manifest & Container & Historical ID & Shipping Package \\
\hline $001942737 \mathrm{GBF}$ & 10516846 & SRS140023 & \\
\hline 001942738GBF & 10504874 & SRS130317 & \\
\hline 001942738GBF & 10504875 & SRS130315 & \\
\hline $001942738 \mathrm{GBF}$ & 10505306 & SRS130325 & \\
\hline 001942738GBF & 10505307 & SRS130323 & \\
\hline 001942738GBF & 10505308 & SRS130320 & \\
\hline 001942738GBF & 10505309 & SRS130324 & \\
\hline $001942738 \mathrm{GBF}$ & 10505310 & SRS130139 & \\
\hline $001942738 \mathrm{GBF}$ & 10505311 & SRS130334 & \\
\hline 001942738GBF & 10507316 & SRS130366 & \\
\hline $001942738 \mathrm{GBF}$ & 10516847 & SRS140006 & \\
\hline $001942738 \mathrm{GBF}$ & 10516848 & SRS140032 & \\
\hline $001942738 \mathrm{GBF}$ & 10516849 & SRS140025 & \\
\hline $001942738 \mathrm{GBF}$ & 10516851 & SRS140009 & \\
\hline $001942738 \mathrm{GBF}$ & 10516854 & SRS140024 & \\
\hline $001942742 \mathrm{GBF}$ & 10500844 & SRS130220 & \\
\hline $001942742 \mathrm{GBF}$ & 10500845 & SRS130230 & \\
\hline $001942742 \mathrm{GBF}$ & 10501555 & SRS130238 & \\
\hline $001942742 \mathrm{GBF}$ & 10501558 & SRS130164 & \\
\hline $001942742 \mathrm{GBF}$ & 10501559 & SRS130241 & \\
\hline $001942742 \mathrm{GBF}$ & 10501560 & SRS130175 & \\
\hline $001942742 \mathrm{GBF}$ & 10501561 & SRS130240 & \\
\hline $001942742 \mathrm{GBF}$ & 10501562 & SRS130170 & \\
\hline $001942742 \mathrm{GBF}$ & 10501565 & SRS130176 & \\
\hline $001942742 \mathrm{GBF}$ & 10507313 & SRS130370 & \\
\hline $001942742 \mathrm{GBF}$ & 10507314 & SRS130368 & \\
\hline $001942742 \mathrm{GBF}$ & 10507315 & SRS130369 & \\
\hline $001942742 \mathrm{GBF}$ & 10517359 & SRS140028 & \\
\hline $001942742 \mathrm{GBF}$ & 10517360 & SRS140036 & \\
\hline $001942743 \mathrm{GBF}$ & 10501556 & SRS130180 & \\
\hline 001942743GBF & 10501563 & SRS130181 & \\
\hline $001942743 \mathrm{GBF}$ & 10504876 & SRS130322 & \\
\hline $001942743 \mathrm{GBF}$ & 10504877 & SRS130305 & \\
\hline 001942743GBF & 10504878 & SRS130318 & \\
\hline $001942743 G B F$ & 10504879 & SRS130321 & \\
\hline $001942743 G B F$ & 10504880 & SRS130319 & \\
\hline $001942743 \mathrm{GBF}$ & 10504881 & SRS130313 & \\
\hline $001942743 \mathrm{GBF}$ & 10516818 & SRS140035 & \\
\hline 001942743GBF & 10516843 & SRS140012 & \\
\hline $001942743 G B F$ & 10516850 & SRS140001 & \\
\hline 001942743GBF & 10516852 & SRS140003 & \\
\hline 001942743GBF & 10516853 & SRS140022 & \\
\hline $001942743 G B F$ & 10517361 & SRS140044 & \\
\hline 001942748GBF & 10501557 & SRS130242 & \\
\hline 001942748GBF & 10501564 & SRS130168 & \\
\hline $001942748 \mathrm{GBF}$ & 10501566 & SRS130237 & \\
\hline $001942748 G B F$ & 10516814 & SRS130453 & \\
\hline 001942748GBF & 10516815 & SRS140029 & \\
\hline $001942748 G B F$ & 10516816 & SRS140013 & \\
\hline $001942748 G B F$ & 10516817 & SRS140033 & \\
\hline $001942748 G B F$ & 10516822 & SRS140040 & \\
\hline 001942748GBF & 10516823 & SRS130456 & \\
\hline $001942748 G B F$ & 10516824 & SRS140002 & \\
\hline 001942748GBF & 10517357 & SRS140030 & \\
\hline 001942748GBF & 10517358 & SRS140045 & \\
\hline 001942748GBF & 10517365 & SRS140042 & \\
\hline 001942748GBF & 10517366 & SRS140053 & \\
\hline $001942749 \mathrm{GBF}$ & 10504587 & SRS130306 & \\
\hline
\end{tabular}




\section{AMWTP Repackaged Shipping Container Cross Reference 2014}

\begin{tabular}{|c|c|c|c|}
\hline Manifest & Container & Historical ID & Shipping Package \\
\hline 001942749GBF & 10504588 & SRS130307 & \\
\hline $001942749 \mathrm{GBF}$ & 10504593 & SRS130303 & \\
\hline 001942749GBF & 10504594 & SRS130312 & \\
\hline $001942749 G B F$ & 10504595 & SRS130281 & \\
\hline 001942749GBF & 10504596 & SRS130311 & \\
\hline $001942749 G B F$ & 10504597 & SRS130316 & \\
\hline $001942749 \mathrm{GBF}$ & 10504598 & SRS130308 & \\
\hline $001942749 \mathrm{GBF}$ & 10506694 & SRS130357 & \\
\hline $001942749 \mathrm{GBF}$ & 10506695 & SRS130358 & \\
\hline $001942749 \mathrm{GBF}$ & 10516813 & SRS130460 & \\
\hline $001942749 \mathrm{GBF}$ & 10516819 & SRS130455 & \\
\hline $001942749 \mathrm{GBF}$ & 10516820 & SRS140031 & \\
\hline $001942749 \mathrm{GBF}$ & 10516821 & SRS140034 & \\
\hline $001942752 \mathrm{GBF}$ & 10505783 & SRS130335 & \\
\hline $001942752 \mathrm{GBF}$ & 10506244 & SRS130344 & \\
\hline $001942752 \mathrm{GBF}$ & 10506247 & SRS130351 & \\
\hline $001942752 \mathrm{GBF}$ & 10506249 & SRS130356 & \\
\hline $001942752 \mathrm{GBF}$ & 10506252 & SRS130347 & \\
\hline $001942752 \mathrm{GBF}$ & 10506253 & SRS130343 & \\
\hline $001942752 \mathrm{GBF}$ & 10506255 & SRS130345 & \\
\hline $001942752 \mathrm{GBF}$ & 10506689 & SRS130005 & \\
\hline $001942752 \mathrm{GBF}$ & 10506690 & SRS130360 & \\
\hline $001942752 \mathrm{GBF}$ & 10506691 & SRS130361 & \\
\hline $001942752 \mathrm{GBF}$ & 10506692 & SRS130354 & \\
\hline $001942752 \mathrm{GBF}$ & 10506693 & SRS130359 & \\
\hline $001942752 \mathrm{GBF}$ & 10507317 & SRS130365 & \\
\hline $001942752 \mathrm{GBF}$ & 10507318 & SRS130371 & \\
\hline $001942753 \mathrm{GBF}$ & 10505779 & SRS130336 & \\
\hline $001942753 \mathrm{GBF}$ & 10505780 & SRS130339 & \\
\hline $001942753 \mathrm{GBF}$ & 10505781 & SRS130340 & \\
\hline 001942753GBF & 10505782 & SRS130342 & \\
\hline $001942753 \mathrm{GBF}$ & 10505784 & SRS130338 & \\
\hline $001942753 \mathrm{GBF}$ & 10506245 & SRS130350 & \\
\hline $001942753 \mathrm{GBF}$ & 10506246 & SRS130348 & \\
\hline $001942753 \mathrm{GBF}$ & 10506248 & SRS130349 & \\
\hline 001942753GBF & 10506250 & SRS130346 & \\
\hline 001942753GBF & 10506251 & SRS130355 & \\
\hline 001942753GBF & 10506254 & SRS130341 & \\
\hline 001942753GBF & 10518074 & SRS140049 & \\
\hline 001942753GBF & 10518075 & SRS140047 & \\
\hline 001942753GBF & 10518077 & SRS140066 & \\
\hline $001942757 \mathrm{GBF}$ & 10516002 & SRS130458 & \\
\hline $001942757 G B F$ & 10516003 & SRS140011 & \\
\hline $001942757 G B F$ & 10516004 & SRS140007 & \\
\hline $001942757 \mathrm{GBF}$ & 10516005 & SRS130445 & \\
\hline $001942757 \mathrm{GBF}$ & 10516006 & SRS140026 & \\
\hline $001942757 G B F$ & 10517362 & SRS140008 & \\
\hline $001942757 G B F$ & 10517363 & SRS140043 & \\
\hline $001942757 G B F$ & 10517364 & SRS140041 & \\
\hline $001942757 \mathrm{GBF}$ & 10517633 & SRS140048 & \\
\hline $001942757 G B F$ & 10518072 & SRS140070 & \\
\hline $001942757 G B F$ & 10518081 & SRS140051 & \\
\hline $001942757 G B F$ & 10518121 & SRS140084 & \\
\hline $001942757 G B F$ & 10518124 & SRS140061 & \\
\hline 001942758GBF & 10515995 & SRS130438 & \\
\hline 001942758GBF & 10515996 & SRS130449 & \\
\hline 001942758GBF & 10515997 & SRS130450 & \\
\hline $001942758 \mathrm{GBF}$ & 10515998 & SRS130439 & \\
\hline
\end{tabular}




\section{AMWTP Repackaged Shipping Container Cross Reference 2014}

\begin{tabular}{|c|c|c|c|}
\hline Manifest & Container & Historical ID & Shipping Package \\
\hline $001942758 \mathrm{GBF}$ & 10515999 & SRS130436 & \\
\hline 001942758GBF & 10516000 & SRS130447 & \\
\hline 001942758GBF & 10516001 & SRS130444 & \\
\hline $001942758 \mathrm{GBF}$ & 10519131 & SRS140056 & \\
\hline 001942758GBF & 10519132 & SRS140089 & \\
\hline $001942758 \mathrm{GBF}$ & 10519133 & SRS140091 & \\
\hline $001942758 \mathrm{GBF}$ & 10519134 & SRS140088 & \\
\hline $001942758 \mathrm{GBF}$ & 10519135 & SRS140097 & \\
\hline $001942758 \mathrm{GBF}$ & 10519136 & SRS140090 & \\
\hline $001942758 \mathrm{GBF}$ & 10519142 & SRS140095 & \\
\hline 001942759GBF & 10518071 & SRS140050 & \\
\hline 001942759GBF & 10518078 & SRS140052 & \\
\hline $001942759 G B F$ & 10518079 & SRS140057 & \\
\hline 001942759GBF & 10518080 & SRS140060 & \\
\hline 001942759GBF & 10518117 & SRS140074 & \\
\hline 001942759GBF & 10518118 & SRS140068 & \\
\hline 001942759GBF & 10518119 & SRS140085 & \\
\hline 001942759GBF & 10518122 & SRS140071 & \\
\hline 001942759GBF & 10518125 & SRS140072 & \\
\hline 001942759GBF & 10519137 & SRS140086 & \\
\hline 001942759GBF & 10519138 & SRS140059 & \\
\hline 001942759GBF & 10519139 & SRS140087 & \\
\hline 001942759GBF & 10519140 & SRS140058 & \\
\hline 001942760GBF & 10509492 & SRS130419 & \\
\hline $001942760 G B F$ & 10509493 & SRS130417 & \\
\hline 001942760GBF & 10509494 & SRS130416 & \\
\hline 001942760GBF & 10509495 & SRS130413 & \\
\hline $001942760 \mathrm{GBF}$ & 10509496 & SRS130422 & \\
\hline 001942760GBF & 10509497 & SRS130415 & \\
\hline 001942760GBF & 10509498 & SRS130418 & \\
\hline 001942760GBF & 10509499 & SRS130414 & \\
\hline 001942760GBF & 10518073 & SRS140069 & \\
\hline 001942760GBF & 10518076 & SRS140054 & \\
\hline 001942760GBF & 10518082 & SRS140055 & \\
\hline 001942760GBF & 10518120 & SRS140082 & \\
\hline 001942760GBF & 10518123 & SRS140073 & \\
\hline 001942760GBF & 10518126 & SRS140063 & \\
\hline 001942763GBF & 10507792 & SRS130372 & \\
\hline 001942763GBF & 10508557 & SRS130387 & \\
\hline 001942763GBF & 10508558 & SRS130402 & \\
\hline 001942763GBF & 10508559 & SRS130397 & \\
\hline $001942763 \mathrm{GBF}$ & 10508560 & SRS130401 & \\
\hline $001942763 \mathrm{GBF}$ & 10509060 & SRS130403 & \\
\hline $001942763 \mathrm{GBF}$ & 10509061 & SRS130405 & \\
\hline 001942763GBF & 10509062 & SRS130400 & \\
\hline 001942763GBF & 10509063 & SRS130404 & \\
\hline $001942763 G B F$ & 10509064 & SRS130407 & \\
\hline $001942763 \mathrm{GBF}$ & 10509065 & SRS130406 & \\
\hline 001942763GBF & 10509500 & SRS130423 & \\
\hline $001942763 G B F$ & 10509501 & SRS130412 & \\
\hline $001942763 G B F$ & 10509502 & SRS130420 & \\
\hline 001942764GBF & 10508325 & SRS130394 & \\
\hline $001942764 G B F$ & 10508327 & SRS130391 & \\
\hline 001942764GBF & 10508328 & SRS130389 & \\
\hline 001942764GBF & 10508330 & SRS130392 & \\
\hline 001942764GBF & 10508331 & SRS130373 & \\
\hline 001942764GBF & 10508332 & SRS130386 & \\
\hline $001942764 G B F$ & 10508333 & SRS130384 & \\
\hline
\end{tabular}




\section{AMWTP Repackaged Shipping Container Cross Reference 2014}

\begin{tabular}{|c|c|c|c|}
\hline Manifest & Container & Historical ID & Shipping Package \\
\hline $001942764 G B F$ & 10508554 & SRS130388 & \\
\hline 001942764GBF & 10508555 & SRS130385 & \\
\hline $001942764 G B F$ & 10508556 & SRS130393 & \\
\hline 001942764GBF & 10509066 & SRS130408 & \\
\hline 001942764GBF & 10509067 & SRS130410 & \\
\hline $001942764 \mathrm{GBF}$ & 10509068 & SRS130411 & \\
\hline $001942764 \mathrm{GBF}$ & 10509503 & SRS130409 & \\
\hline $001942767 \mathrm{GBF}$ & 10507787 & SRS130364 & \\
\hline $001942767 \mathrm{GBF}$ & 10507788 & SRS130367 & \\
\hline $001942767 \mathrm{GBF}$ & 10507789 & SRS130362 & \\
\hline $001942767 \mathrm{GBF}$ & 10507790 & SRS130374 & \\
\hline $001942767 \mathrm{GBF}$ & 10507791 & SRS130363 & \\
\hline $001942767 \mathrm{GBF}$ & 10508323 & SRS130398 & \\
\hline $001942767 \mathrm{GBF}$ & 10508324 & SRS130395 & \\
\hline $001942767 \mathrm{GBF}$ & 10508326 & SRS130399 & \\
\hline $001942767 \mathrm{GBF}$ & 10508329 & SRS130396 & \\
\hline $001942767 \mathrm{GBF}$ & 10519906 & SRS140064 & \\
\hline $001942767 \mathrm{GBF}$ & 10519908 & SRS140092 & \\
\hline $001942767 \mathrm{GBF}$ & 10519909 & SRS140065 & \\
\hline $001942767 \mathrm{GBF}$ & 10519910 & SRS140062 & \\
\hline $001942767 G B F$ & 10519913 & SRS140106 & \\
\hline 001942768GBF & 10519904 & SRS140093 & \\
\hline $001942768 \mathrm{GBF}$ & 10519905 & SRS140102 & \\
\hline 001942768GBF & 10519907 & SRS140105 & \\
\hline 001942768GBF & 10519911 & SRS140094 & \\
\hline 001942768GBF & 10519912 & SRS140104 & \\
\hline 001942768GBF & 10519914 & SRS140101 & \\
\hline 001942768GBF & 10519915 & SRS140103 & \\
\hline 001942768GBF & 10524296 & SRS140129 & \\
\hline 001942768GBF & 10524887 & SRS140147 & \\
\hline 001942768GBF & 10525476 & SRS140167 & \\
\hline 001942768GBF & 10525477 & SRS140169 & \\
\hline 001942768GBF & 10525479 & SRS140170 & \\
\hline 001942768GBF & 10525480 & SRS140166 & \\
\hline 001942768GBF & 10525481 & SRS140168 & \\
\hline $001942804 \mathrm{GBF}$ & 10523242 & SRS140124 & \\
\hline $001942804 \mathrm{GBF}$ & 10523244 & SRS140131 & \\
\hline $001942804 \mathrm{GBF}$ & 10523799 & SRS140136 & \\
\hline $001942804 G B F$ & 10523801 & SRS140139 & \\
\hline $001942804 \mathrm{GBF}$ & 10523803 & SRS140133 & \\
\hline $001942804 \mathrm{GBF}$ & 10523805 & SRS140137 & \\
\hline $001942804 \mathrm{GBF}$ & 10523806 & SRS140138 & \\
\hline $001942804 \mathrm{GBF}$ & 10525470 & SRS140177 & \\
\hline $001942804 G B F$ & 10525471 & SRS140176 & \\
\hline 001942804GBF & 10525472 & SRS140175 & \\
\hline $001942804 \mathrm{GBF}$ & 10525473 & SRS140172 & \\
\hline $001942804 G B F$ & 10525474 & SRS140173 & \\
\hline $001942804 G B F$ & 10525475 & SRS140174 & \\
\hline 001942804GBF & 10525478 & SRS140171 & \\
\hline 001942809GBF & 10503743 & SRS12026 & \\
\hline $001942809 \mathrm{GBF}$ & 10503744 & SRS12033 & \\
\hline $001942809 \mathrm{GBF}$ & 10503745 & SRS120003 & \\
\hline $001942809 \mathrm{GBF}$ & 10503746 & SRS130257 & \\
\hline 001942809GBF & 10503747 & SRS12027 & \\
\hline $001942809 \mathrm{GBF}$ & 10503914 & SRS130146 & \\
\hline $001942809 \mathrm{GBF}$ & 10527413 & SRS140194 & \\
\hline $001942809 \mathrm{GBF}$ & 10527414 & SRS140195 & \\
\hline 001942809GBF & 10528993 & SRS140162 & \\
\hline
\end{tabular}




\section{AMWTP Repackaged Shipping Container Cross Reference 2014}

\begin{tabular}{|c|c|c|c|}
\hline Manifest & Container & Historical ID & Shipping Package \\
\hline 001942810GBF & 10521750 & SRS140110 & \\
\hline 001942810GBF & 10521754 & SRS140098 & \\
\hline 001942810GBF & 10521755 & SRS140075 & \\
\hline 001942810GBF & 10521757 & SRS140100 & \\
\hline 001942810GBF & 10521758 & SRS140108 & \\
\hline 001942810GBF & 10522756 & SRS140119 & \\
\hline 001942810GBF & 10522758 & SRS140121 & \\
\hline 001942810GBF & 10523800 & SRS140144 & \\
\hline 001942810GBF & 10523802 & SRS140142 & \\
\hline 001942810GBF & 10523804 & SRS140146 & \\
\hline 001942810GBF & 10524297 & SRS140157 & \\
\hline 001942810GBF & 10524298 & SRS140155 & \\
\hline 001942810GBF & 10524884 & SRS140161 & \\
\hline 001942810GBF & 10524888 & SRS140149 & \\
\hline 001942816GBF & 10141087 & & 10532107 \\
\hline 001942816GBF & 10145188 & & 10532107 \\
\hline 001942816GBF & 10227060 & & 10532107 \\
\hline 001942816GBF & 10268531 & & 10532107 \\
\hline 001942816GBF & 10270823 & & 10532107 \\
\hline 001942816GBF & 10272421 & & 10532107 \\
\hline 001942816GBF & 10288488 & & 10532107 \\
\hline 001942816GBF & 10291381 & & 10532107 \\
\hline 001942816GBF & 10295844 & & 10532107 \\
\hline 001942816GBF & 10302522 & & 10532107 \\
\hline 001942816GBF & 10303995 & & 10532107 \\
\hline 001942816GBF & 10305954 & & 10532107 \\
\hline 001942816GBF & 10306562 & & 10532107 \\
\hline 001942816GBF & 10307413 & & 10532107 \\
\hline 001942816GBF & 10308175 & & 10532107 \\
\hline 001942816GBF & 10309591 & & 10532107 \\
\hline 001942816GBF & 10309608 & & 10532107 \\
\hline $001942816 \mathrm{GBF}$ & 10310233 & & 10532107 \\
\hline 001942816GBF & 10313213 & & 10532107 \\
\hline 001942816GBF & 10319462 & & 10532107 \\
\hline 001942816GBF & 10333747 & & 10532107 \\
\hline 001942816GBF & 10349170 & & 10532107 \\
\hline 001942816GBF & 10459538 & & 10532107 \\
\hline 001942816GBF & 10505966 & & 10532107 \\
\hline $001943013 \mathrm{GBF}$ & AMWT140010 & & \\
\hline
\end{tabular}


Please print or type. (Form designed for use on elite (12-pitch) typewriter.)

\begin{tabular}{|c|c|c|c|c|}
\hline $\begin{array}{c}\text { UNIFORM HAZARDOUS } \\
\text { WASTE MANIFEST }\end{array}$ & $\begin{array}{c}1 \text { Generator ID Number } \\
\text { ID4890008952 }\end{array}$ & $\begin{array}{c}\text { 2. Pags } 1 \text { of } \\
1\end{array}$ & \\
\hline 5. Generator's Name and Mailling Address &
\end{tabular}

Idaho National Iaboratory, v.s. Department of

Energy, 1580 sawtelle street, MB-9226, Idaho

Fallas ID 83402

6. Transportier 1 Company Name

Fri state Motor Mransit

7. Transporler 2 Company Name
(209) $533-3377$

(800) 234 -8768

Form Approved. OMB No. 2050-0039

8. Designated Facility Name and Site Address

Emergency Response Phon

(208) 526-1515

Generator's Sile Address (il different than mailing address)

Idaho Nationel Iaboratory

Bcoville, ID

63415

TRK 47006 U.S. EPAID Number

met 648701 mopogso38998

IT: U.S. EPAID Number

TR:

U.S. EPAID Number

Ensxgysolutions, IIC

Us-I80 Exit 19 Toosle County

Facilitifisinge, UH B4029

9a. 9 b. U.S. DOT Description (Including Proper Shipping Name, Hazard Class, ID Number,

HM and Packing Group (if any))

$\mathrm{x}$ (1.) UN2910, Radioactive material, excepted package-limited quantity of material, 7 Contains dobris with PCBs $>50 \mathrm{~mm}$ og

- 03f24f2014, BRGEl161, BC-KRRF140077

$03 / 12 / 2014$

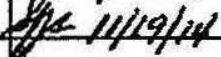

(435) $\quad$ 684-0.1.55

\begin{tabular}{|c|c|c|c|c|}
\hline $884-1$ & & & 0982. & 398 \\
\hline & & 11. Total & 12. Unit & 13. Waste Codes \\
\hline No. & Type & Quantity & WLNol. & \\
\hline 1 & CYY & 755 & $\pi$ & \\
\hline & & & & \\
\hline & & & & \\
\hline & & & & \\
\hline & & & & \\
\hline & & & & \\
\hline & & & & \\
\hline
\end{tabular}

14. Special Handling Instructions and Addilional Inlormation

Retuxn signed oxiginal within 30 days to CWI for U.8. DOE, Attn: Cynthia Mahlum, MS 9226. Prepared under Contract No. DE-AC07-05ID14516. Comp 27644189. Bhipment No.

9113-19-0034 EXCLUSIVE USE SAIPMEATI.

15. GENERATOR'S/OFFEROR'S CERTIFICATION: I heraby declare that the contents of this consigniment are fully and accuratefy described above by the proper shipping name, and are classified, packaged, marked and labeled/placarded, and are In all respects in proper condition for transport according lo applicable intermational and nabional govemmental regulations. If export shipment and I am the Primary

Exporter, I certify that the contents of this consignment conform to the lems of the atlached EPAAcknowledgment of Consent.

I certify that the waste minimization statement ldentified in 40 CFR 262.27(a) (if I am a large quentily generalor) or (b) (itsam a small quantity generator) is true.

Generator's/Offero's Prinled/Typed Name

Stephen Keating

16. International Shipments $\quad \square$ Impart to U.S.

Transporter signature (for exports only):
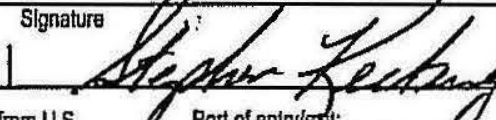

Port of enirylext: Date leaving U.S:

17. Transporter Acknowledgment of Receipt of Materials

Fred fofmeister

Transporter 2 Printed/Typed Name

$\square$ Export from U.S.
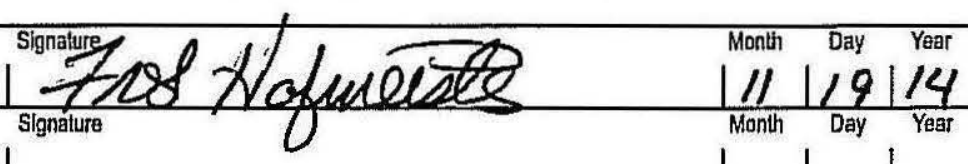

18. Discrepancy

. $\square_{\text {Type }}$

$\square_{\text {Residua }}$

$\square_{\text {Partial Rejection }}$

$\square_{\text {Full Rejection }}$

Manilest Relerence Number.
U.S. EPA ID Number

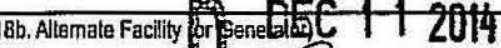

Facility's Phone:

BY.

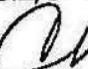

n

I.

U.S. EPA ID Number

18c. Signalure of Alternate Facility (or Generalor)

19. Hazardous Wasle Report Managemenl Method Codes (i.e., codes for hazardous wasta treatment, disposal, and recycling systems)

1132

$\left.\right|^{2}$

4.

20. Designated Facility Owner or Operator. Certificalion of recelpt of hazardous materials covered by the manifest except as ndad In ltem 18a

Albert Gums

EPA Form 8700-22 (Rev. 3-05) Previous editions are obsolele.

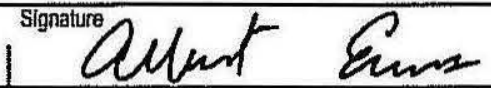

Month Day Year 


\section{CERTIFICATE OF DISPOSAL}

3 inies South Exit 49. 1-80

Chive. Utah 84029

EPA ID UTD982598898

CH2M-WG Idaho of USA DOE, Idaho Falls

This cerlificale acknowledges that the following manifested shipments have been disposed of as listed below

$\begin{array}{llllll}\text { Shloment } & \text { Manifest } & \text { Disposal Date } & \text { Volume(CulFu } & \text { Rrocess } & \text { DisposalLocation } \\ 911307-0103 & 72494 & 11 / 20 / 2014 & 40 & \text { Landfil } & \text { Mixed Waste } \\ 9113-19-0034 & 72275 & 11 / 2412914 & 450 & \text { Landill } & \text { Mixed Wasle }\end{array}$

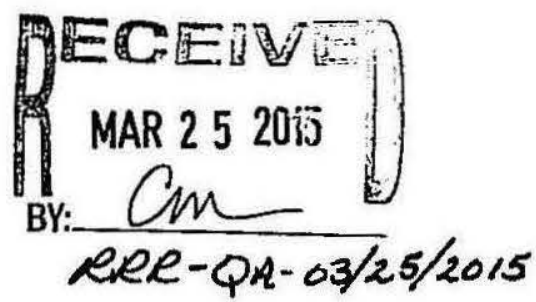

The total volume above represents the cubic feet of waste disposed of at EnergySolutions' Disposal Facility Landfill Disposal is subject to EnergySolutıons' Radioactive Material License, all other applicable licenses. permits and regulations, and Ihe Disposal Agreement

Under crvil and criminal penatties ol law for the making or submission of lalse or traudulant statemants or reprasentations (18 U S C 1001 and 15 U S C 2615 ) t canify that the information contained in or accompanying this documant is irue accurate and complete As lo the identification sactionts) of this dacument for which I cannol personally venly tnuth and accuracy l certify as tha company official having supervisory responsibility for the parsons who acting under my direct instructions made the ventication that this intormahon is true accurate and complefe

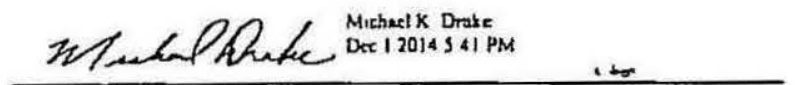

Michael Drake

Manager Wasle Disposat Operations
$12-1-14$
Dale 
Please print or type. (F̈̈rm designed for use on elite (12-pitch) lypewriter.)

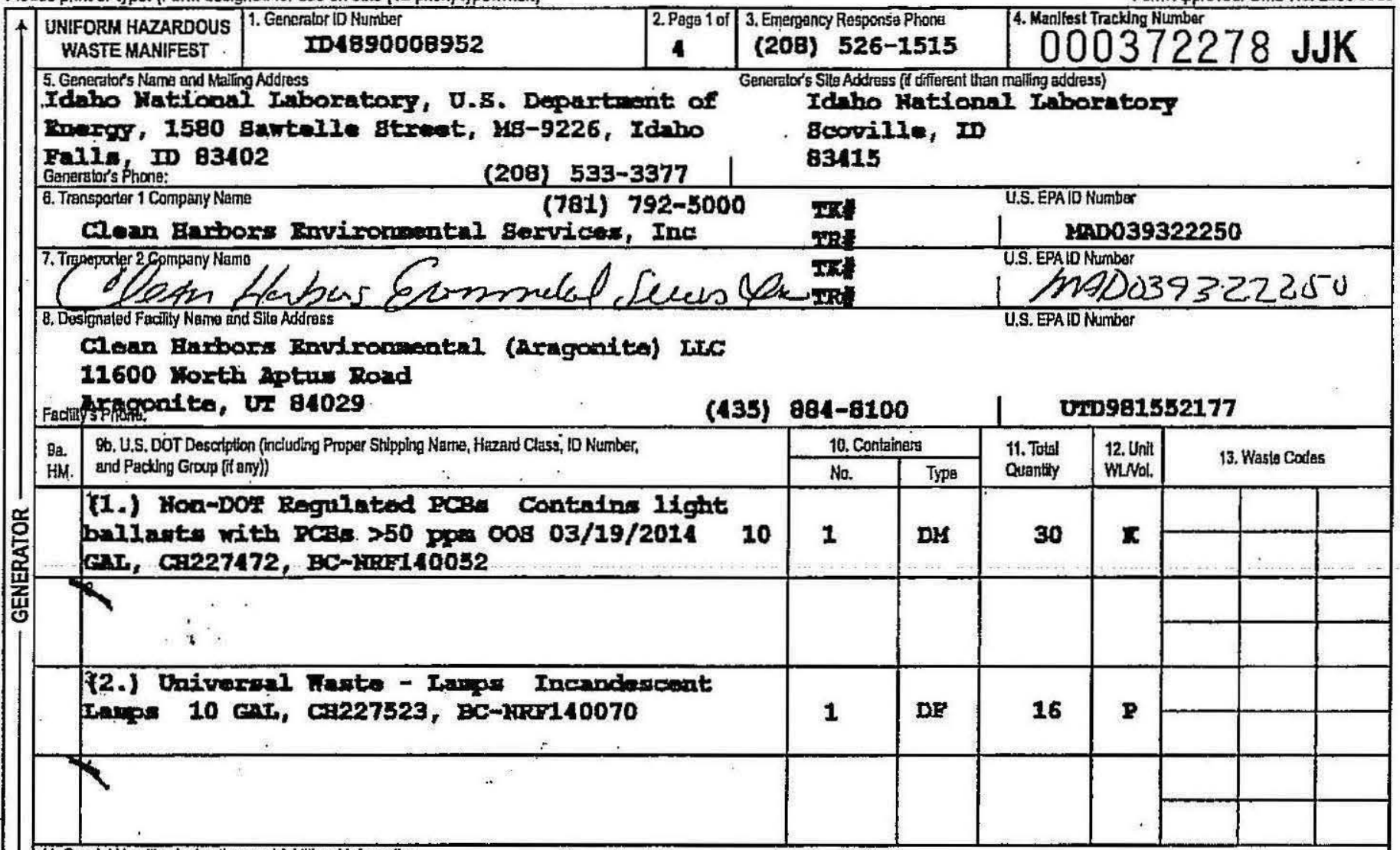

14. Special Handling Instructions and Addilional Infortiation

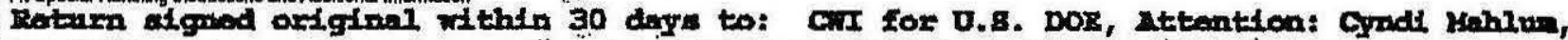

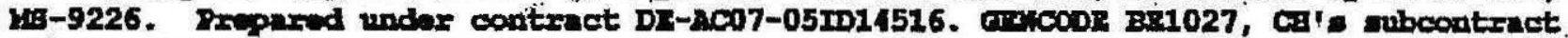

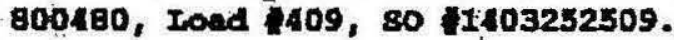

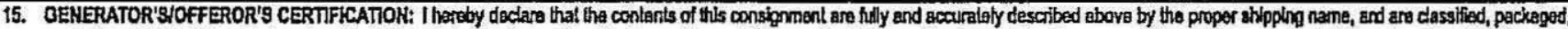

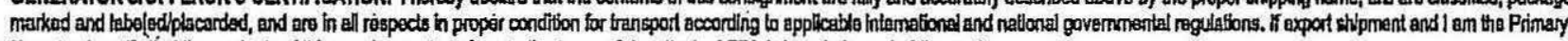

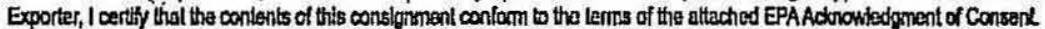

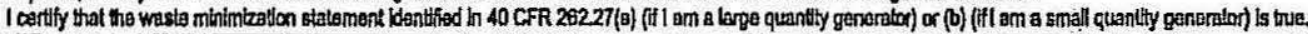

Generalo's : Ofero's Prinled/yped Name

Inatbar I Bhphond

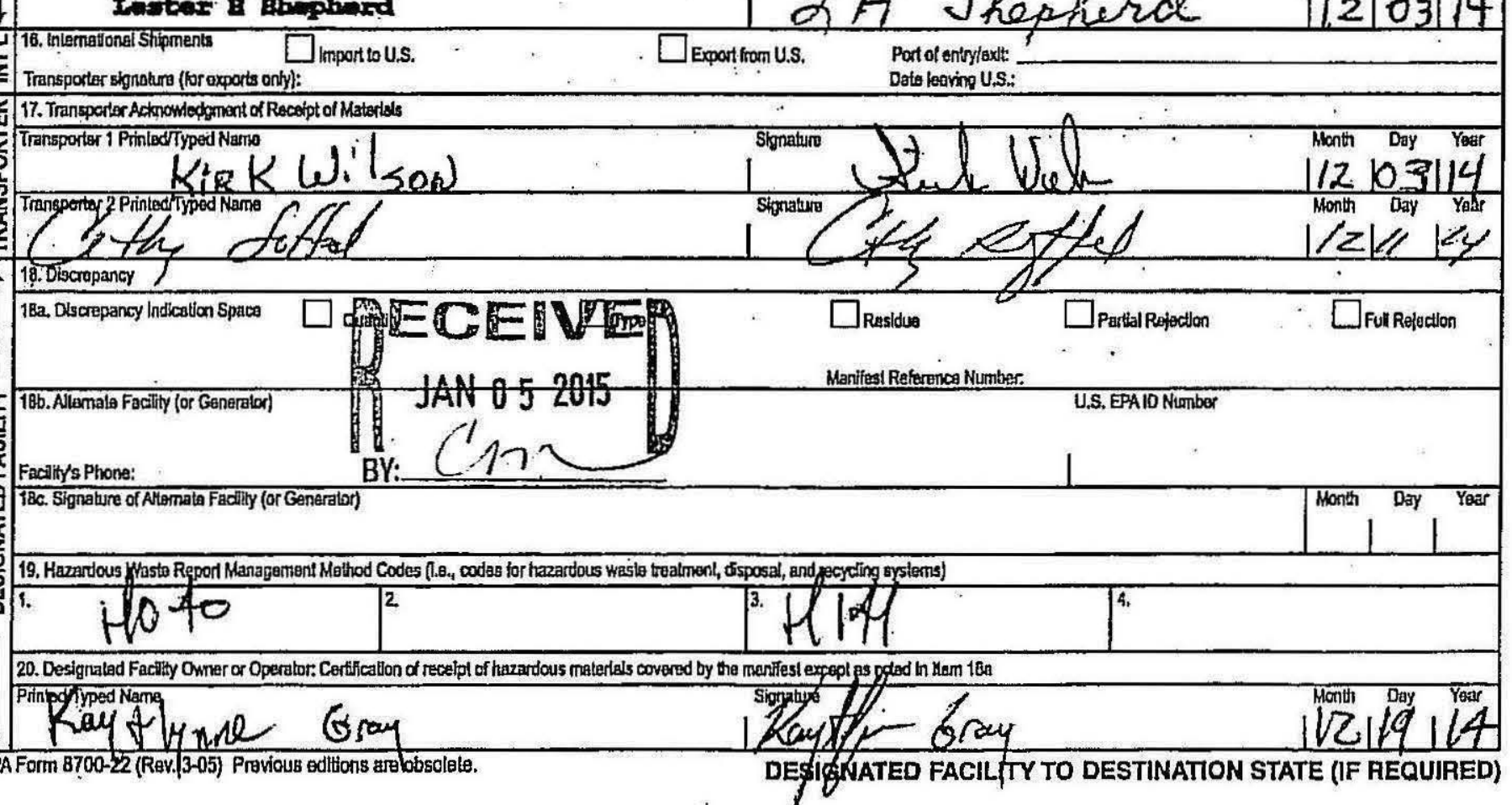

EPAForm 8700-22 (R日v. (3-05) Pravious aditions arelobsolete. 
Pleese print or type. (Form designed for use on elite (12-pitch) typewriter.)

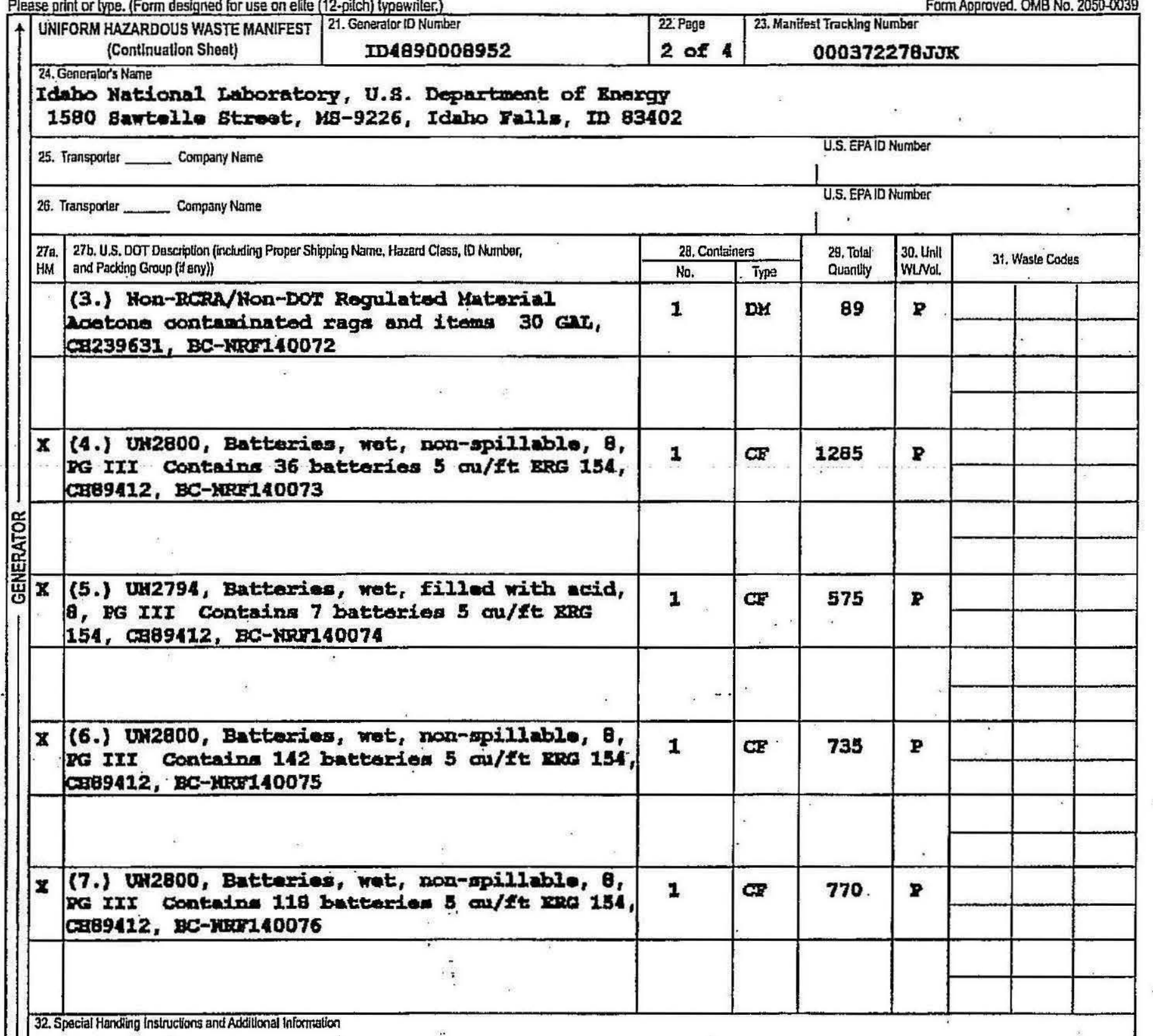

32. Special Handing Instructions and Addritlonal Information

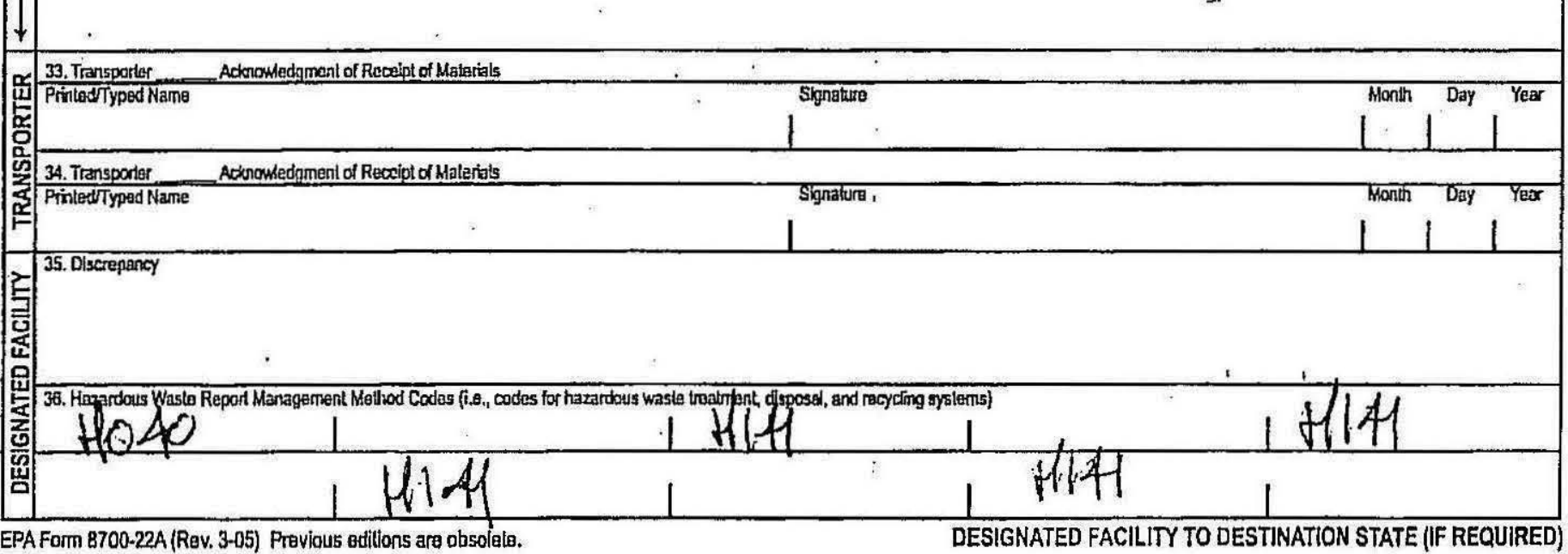


Please print or type. (Form desioned for use on elite (12-pitch) typewriler.)

(Continuation Sheet)

ID4890008952

3 of 4

23. Nanllest Tracking Number

Form Approved. OMB No. 2050-0039 24. Generalor's Name

Idaho Kational Iuboratory, U.S. Departmant of Bnargy 1580 santelle 8treot, MB-9226, Idabo Fa11s, ID 83402

\begin{tabular}{l|l} 
25. Transporter __ Company Name & U.S. EPAID Numbar \\
\hline 26. Transporter __ Company Name & U.S. EPAID Number
\end{tabular}

27a. 27 b. U.S. Dor Desciplion (ind luxing Proper Shipping Name, Hazard Class, ID Number.

HM and Packing Group (if any))

Ma (B.) Un1993, Wasto Fla...ble liquids, n.0.s. (Aromaticic Eydrocarbons, H-butylacetate), 3, PG

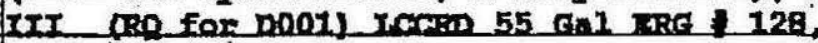
Ca51997IR1, BC-XIRE140078

$x$ (9.) Un1993, Fiate Hlanable Iiquids, n.o.s. (d-Ifimenene, Pxopylene glyool wothyl etbar), 3,

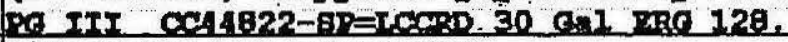
Cx51997LP1, BC-KLiY140079

(10.) Mon-DOI Regallated PCBs Conitain: Debris with PCases $>30$ ppm $00804 / 16 / 201430$ car, ca227451, $\mathrm{BC}-\mathrm{NrR2} 40080$

26 (11.) Ma3077, gazerdous waste, wolid, n.0.5., 9, PG III Contains Dobelis with PCBs > 50 Ppe

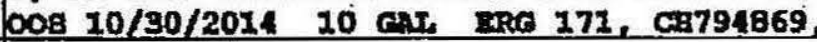
DC-KIRE110081

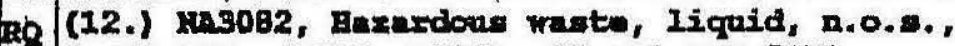
9, PE III (D007, D011) $85 \mathrm{Gal}$ MRT 171 ,

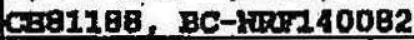

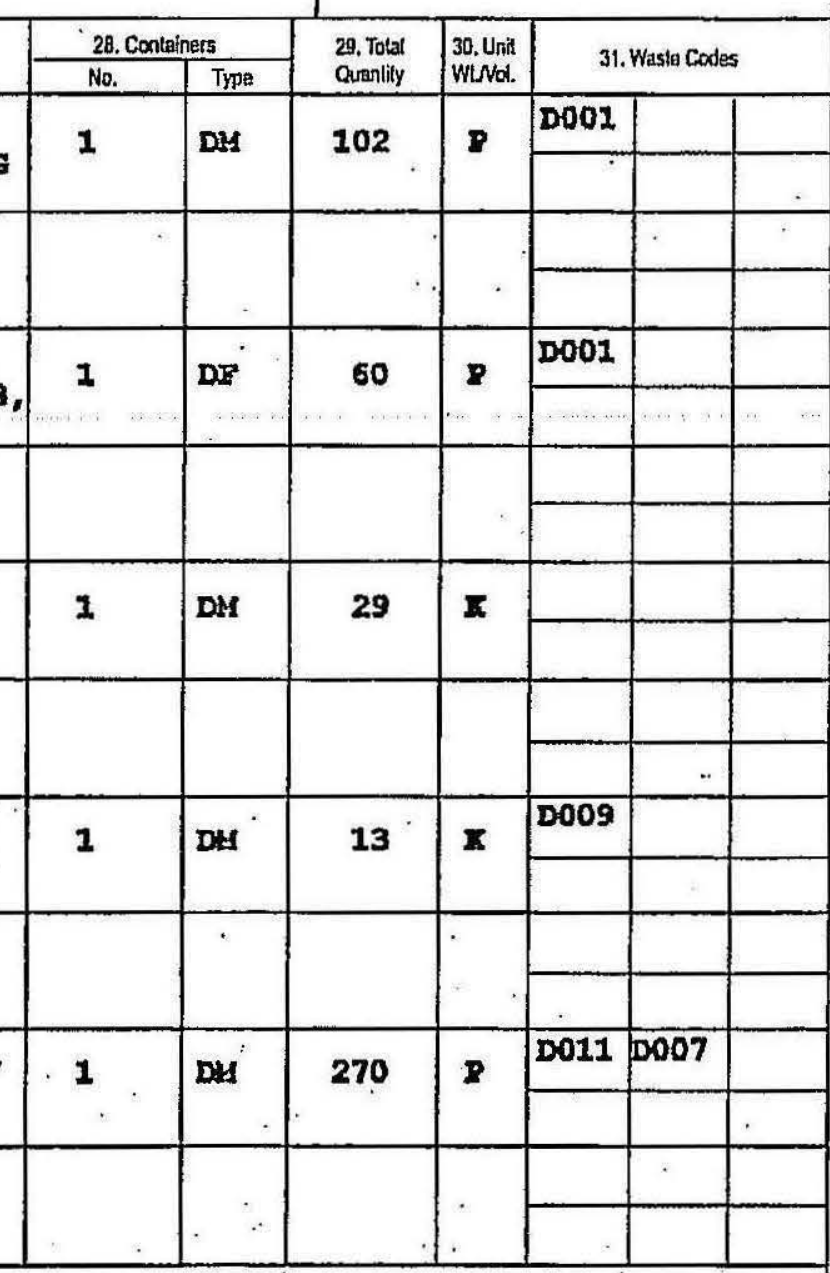

32 Speciai Handing instructions end Additional linlormalion

33. Transporter Aclerowlodgment of Receipl af Materials

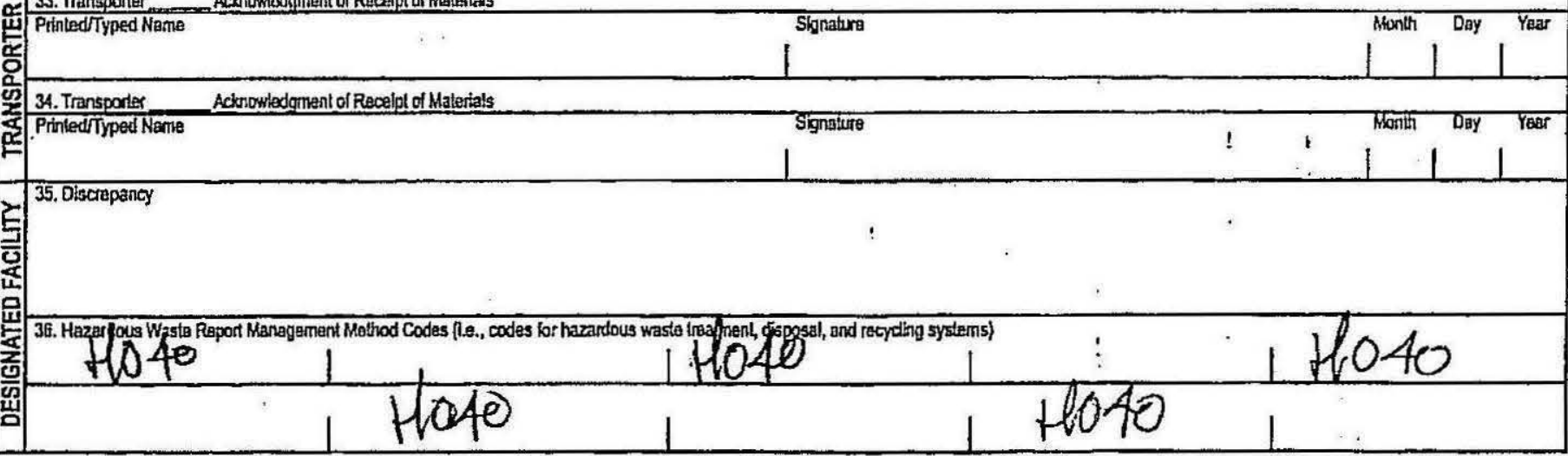


Please prinl or type. (Form designed for use on elile (12-pilch) typewriter.)

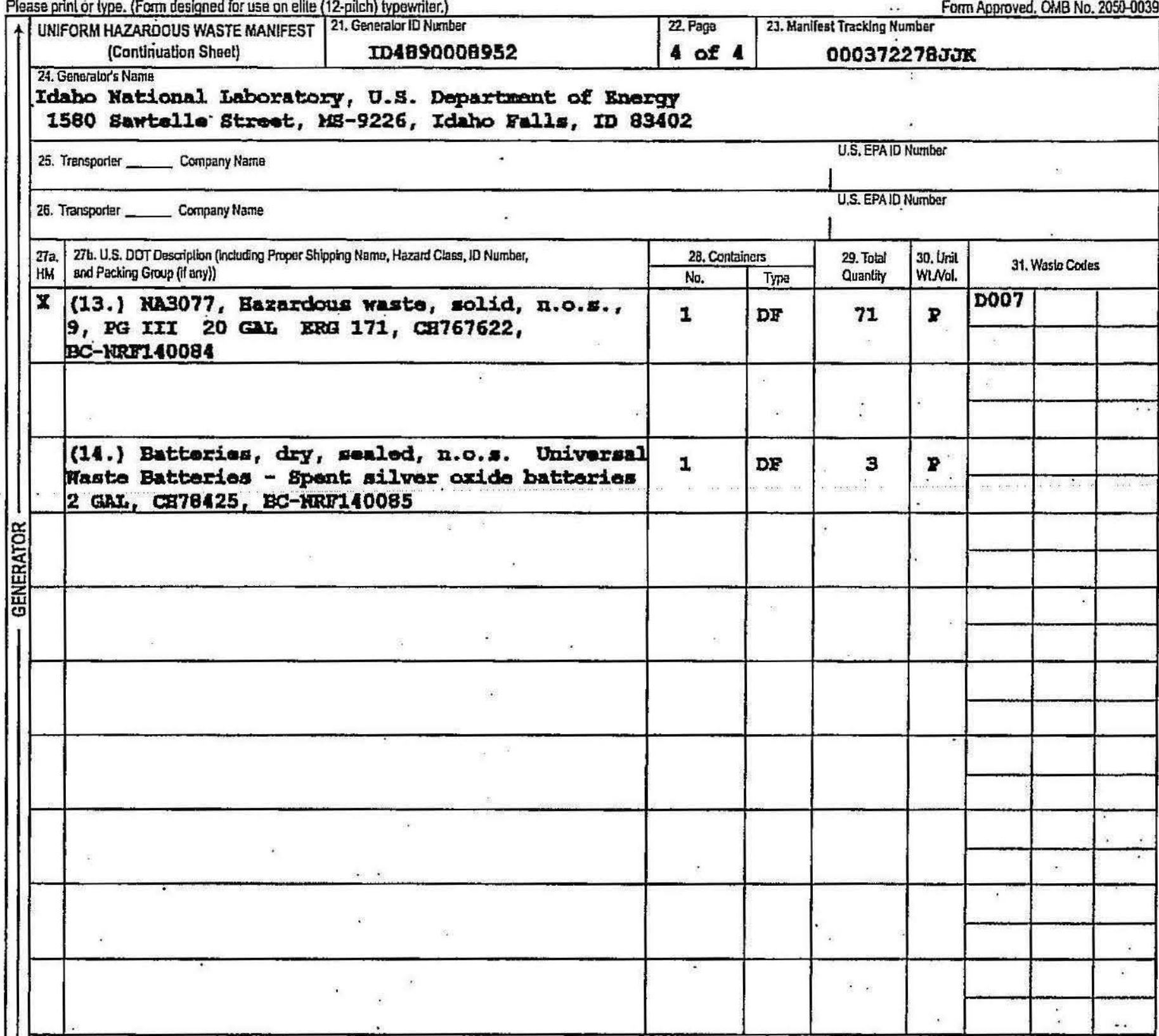

32. Spedal Hendling Instruclions and Addilional Information

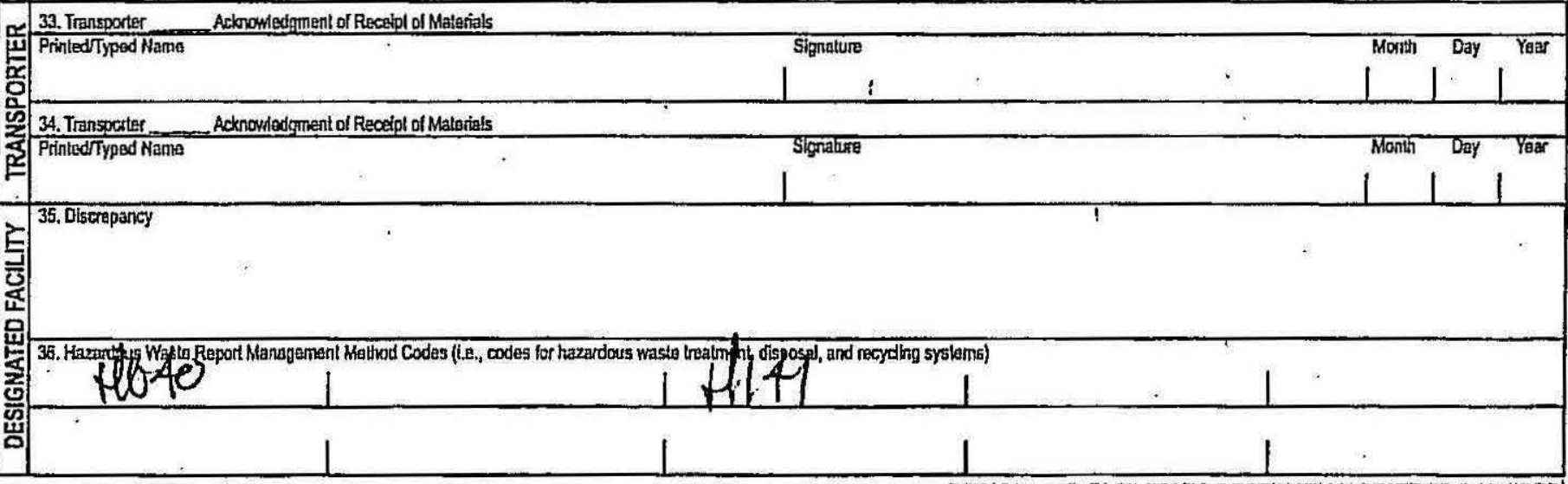


000372278JJK COD

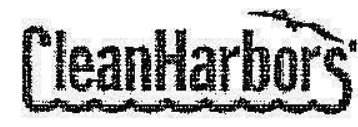

\author{
Clean Harbors Aragonite LLC \\ 11600 North Aptus Road \\ Grantsville UT, 84029 \\ UTD981552177 \\ (435) $884-8100$
}

CERTIFICATE OF DISPOSAL

Generator Facility Name:

Generator Address:
CH2M-WG Idaho LLC

PO Box 2010 MS 9226

1580 Sawlelle Street

Idaho Falls, ID, 83403
Sales OrderH: $\quad 1403252509$

Date Received: $\quad$ 12/19/2014

Generator Contact Name:

\begin{tabular}{|c|c|c|c|c|c|c|c|}
\hline \multirow{2}{*}{\multicolumn{2}{|c|}{ Generator EPA ID: }} & \multirow{2}{*}{\multicolumn{2}{|c|}{ NONEREQUIRED }} & & \multirow{2}{*}{\multicolumn{2}{|c|}{$\begin{array}{l}\text { Load \#: } \\
\text { Manifest \#: }\end{array}$}} & 70941 \\
\hline & & & & & & & $000372278 \mathrm{JJK}$ \\
\hline $\begin{array}{l}\text { Original } \\
\mathrm{CH} \text { ID \# }\end{array}$ & $\begin{array}{l}\text { Date Removed } \\
\text { From Service }\end{array}$ & $\begin{array}{l}\text { Unit } \\
\text { Type }\end{array}$ & $\begin{array}{c}\text { Serial \#/ } \\
\text { Customer ID }\end{array}$ & $\begin{array}{c}\text { Material } \\
\text { Description }\end{array}$ & $\begin{array}{l}\text { Disposal } \\
\text { Date }\end{array}$ & $\begin{array}{l}\text { Method of } \\
\text { Disposal }\end{array}$ & Disposal Facility \\
\hline 42280967 & $10 / 30 / 2014$ & DM & NRF140081/ & PCB Solids For Incineration & $12 / 30 / 2014$ & Incineration & Araganite, UT Facillty \\
\hline
\end{tabular}

Under Civil and Criminal Penalties of Law for the making or submission of false or fraudulent statements or representations (18 U.S.C. 1001 and 15 U.S.C. 2615), I certify that the Informatlon contained in or accompanying this document is true, accurate, and complete. As to the identified section(s) of this document for which I cannot personally verify truth and accuracy, I certify as the company official having supervisory responsibility for the persons who, acting under my direct instructions, made the verification that this information is true, accurate, and complete.

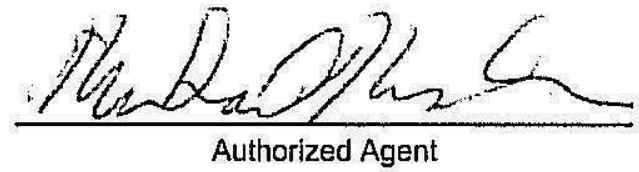

Authorized Agent
Wednesday, April 01, 2015

Date

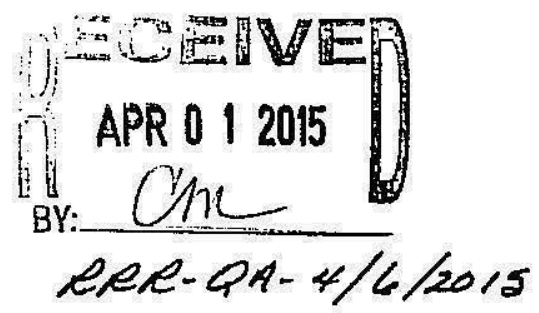


Please print or type, (Form designed for use on elite (12-pitch) typewtiter.)

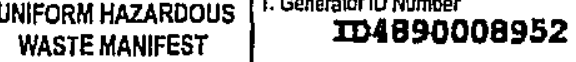
2. Pags 1 of 3. Emergency Response Phone
5.Genaglo's Name and Malling Address
1 (208) 526-1515
$000372416 \mathrm{JJK}$
Inevgy, 1580 sintelle streot, Mis-9226, Idaho
Fallo, ID 83402
Generalor't Phona:
(208) $533-3377$
Gencrator's Sile Address (if dillesent than mailing address)
Idaho Hationel Ioboratory
Bcoville, ID
83415

Form Approved. OMB No. 2050-0039

6. Transporder 1 Company Name

Iri state Notor Irangit

7. Transpotter 2 Cornpany Nama

(800) 234-8768

B. Designated Fachity Nante and Site Addres5

Bnergy Balutions, IrC

us-I80 Rrit 49 rooele county

Gtva, IT 84029

9a. 9b. U.S, Dot Destription fincluding Propar Shipping Nanze, Hazand Class, ID Number,

HM and Packing Group (Il any))

(1.) KA3077, Barardon: wasto, solid, n.0.6.

\section{9, PO III Containg traco mounts of} radionuclides, Contatis paint ohipg with PCBs

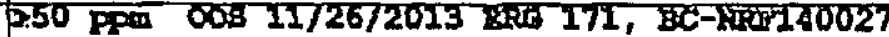

(435) $884-0135$

\begin{tabular}{|c|c|}
\hline $\operatorname{2x} 47006$ & U.S. EPAID Numbar \\
\hline IR 453702 & 1200095038998 \\
\hline Tht & U.S. EPAD Number \\
\hline
\end{tabular}

(1)

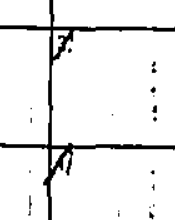

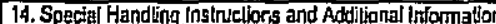

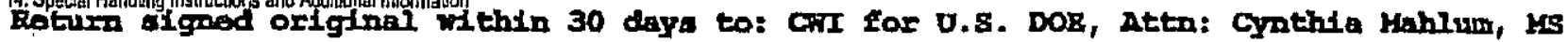

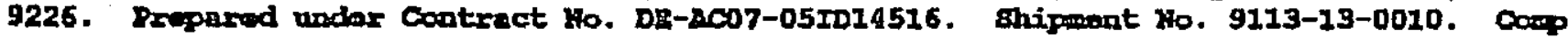

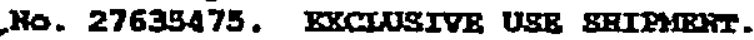

PMO 1658

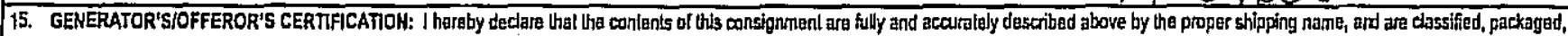

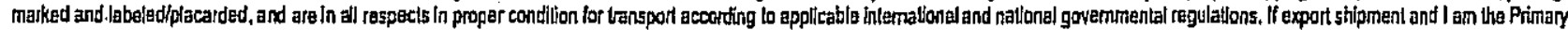

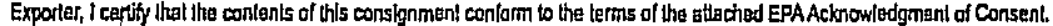

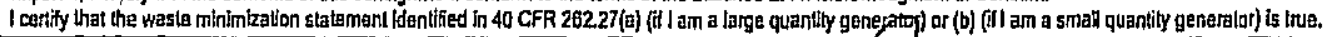

Generator's/Oferoj's Prinled/Typed Name Gritbia Yahlum

16. Internallanal Shiprnenls $\square$ Import to U.S.

Transporter signature (tor exporis ondy):

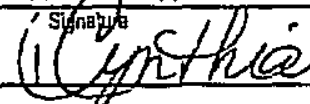

$\square$ Equert fien U.

Port of anirylexit: Dalo leaving U.S:

17. Transporter Acknowledgment of Recaipl ol Maletrials

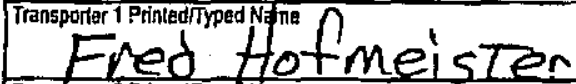

Trensponter 2 Prinked yyped Name

18. Discrapancy

18a. Discrepancy Indication Space $\square$

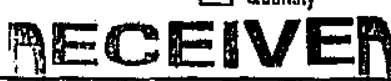

1ab. Altemale Fachit (or Generalor)

APR 15 2014

Facilly's Phane:

19. Hazardous Wasta Report Managamant Method Codes (i.e., codes for hazardous waste tratment, disposal, and recycling 5ystems)

413?

20. Designated Facilly Owner or Operalor: Cortification of recelpt ol hazardous materials covered by the manifest excepl as nded in leam $16 a$

Printedriyped Narde

Albort froms

EFAForm 8700-22 (Rey. 3.05) Prevlous adilions are obsolete.

Stgralure

Qunip Em

Silonth Day Year

$3 \mid 20,14$

DESIGNATED FACILITY TO DESTINATION STATE (IF REQUIRED) 


\section{IENERGI SOLUTIONS}

\section{CERTIFICATE OF DISPOSAL}

3 mules South, $\Gamma x \mathrm{tt} 49,1-80$

Clive. Utah 84029

LPA ID UTD 982598898

\section{CH2M-WG Idaho of USA DOE, Idaho Falls}

This certificate acknowledges that the following manifested shipments have been disposed of as listed below

$\begin{array}{llllll}\text { Shipment } & \text { Manifost } & \text { Dispesal Date } & \text { Volume(CulEU } & \text { Process } & \text { DigresalLecation } \\ 9113-01-0393 & 72415 & 04 / 24 / 2014 & 114 & \text { Landfill } & \text { Mixed Waste } \\ 9113-130010 & 72416 & 04 / 24 / 2014 & 07 & \text { Landfill } & \text { Mixed Waste }\end{array}$

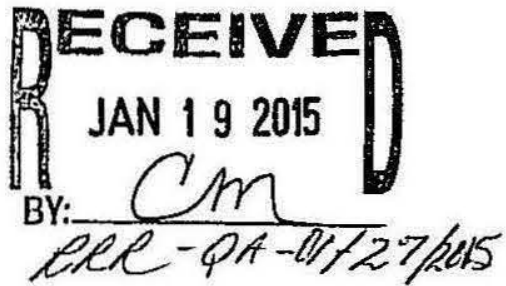

The total volume above represents the cubic feet of waste disposed of at EnergySolutions' Disposal Facility Landfill Disposal is subject to EnergySolutions' Radioactive Matenal License, all other applicable licenses, permits and regulations, and the Disposal Agreement

Under crvil and crimingl penalties of law for the making or submission of false or fraudulent statements or represantations (18 U S C 1001 and 15 U S C 2615 ) I certify that the information contained in or accompanying this document is irue accurate and complete As to the identification section(s) of this document for which I cannot personally venfy truth and accuracy I certify as the company official having supervisary responsibutity for the persons who, acting undor my diract instructions, made the venficalion that this information is true, accurale and complate

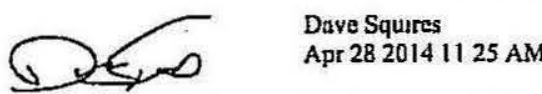

David Squires

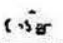

Manager Wasle Disposal Operations 
$=2 \because \because \frac{1}{2}=$

Please print or type. (Form designed for use on elile (12-pitch) typawiter.)

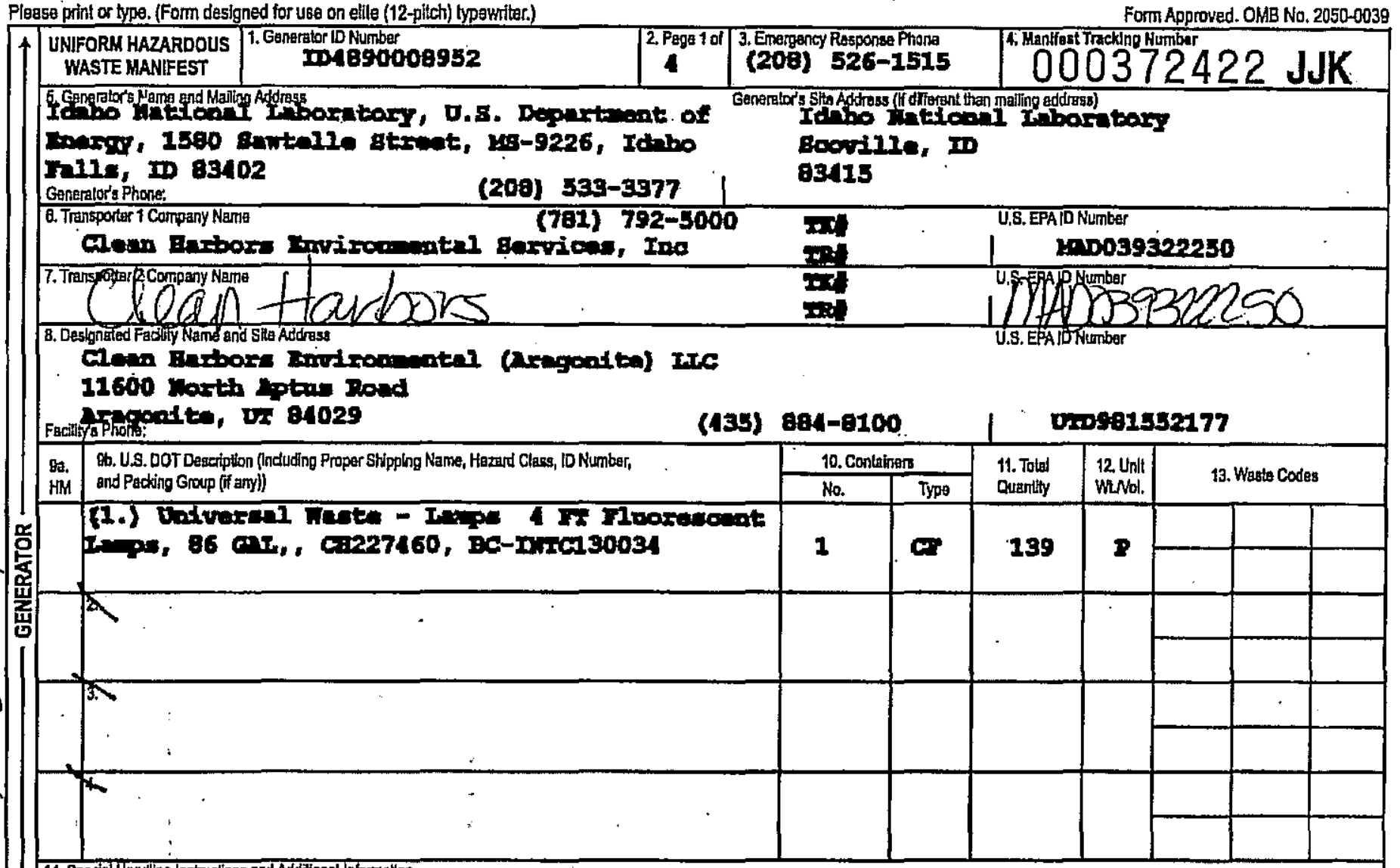

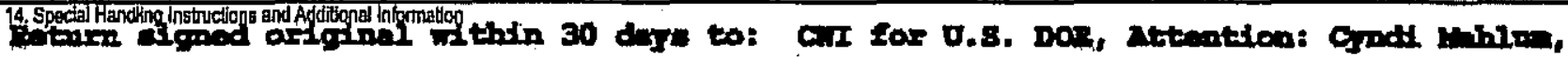

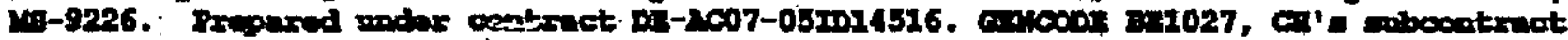

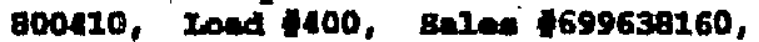

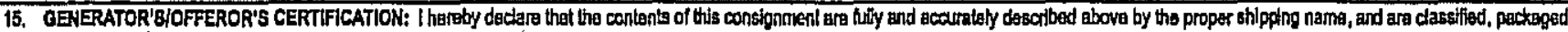

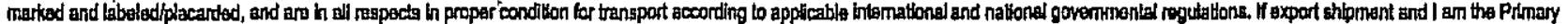

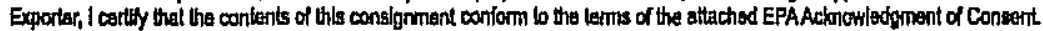

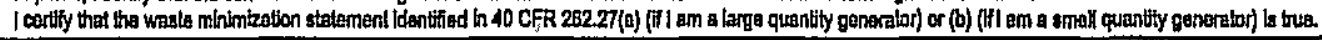

Generator's Orferor's Finted/Typed Name

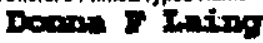

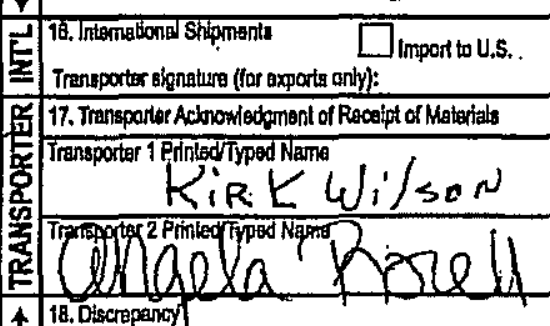

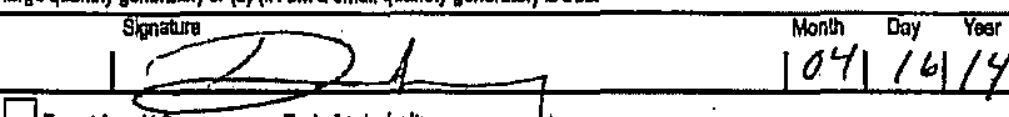

18a. Discrepancy lofication Space

18b. Alemato Facility (or Generator)
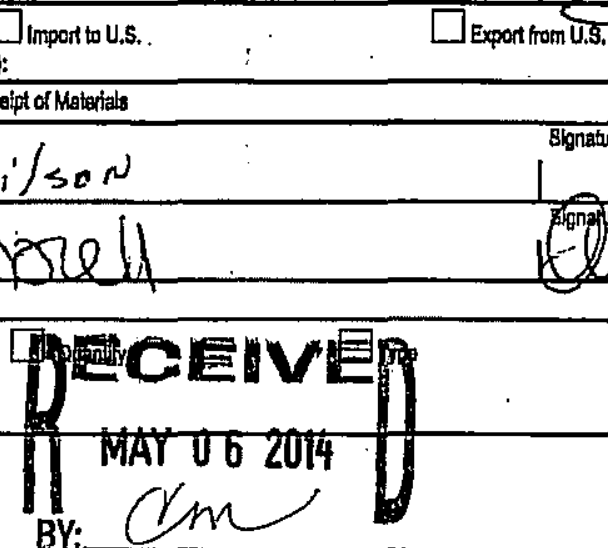

Port of entrylade

Dato loaving U.8.5.

$+$

$+2$

sonatura kelulich

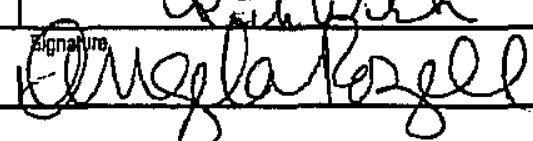

Wonth Day Year

Facititys Phons:

BY:

$\square_{\text {Residue }}$

$\square$ Partal Rejaction

$104116 \quad 14$

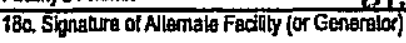

Manifest Raterenos Numbar.

U.S. EPAID Number

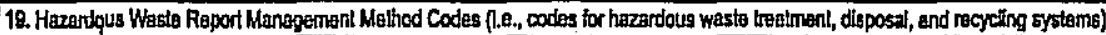

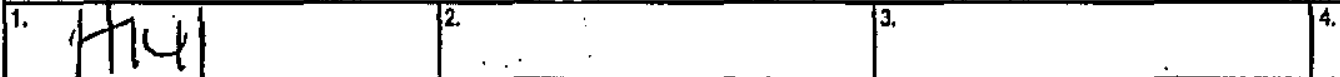

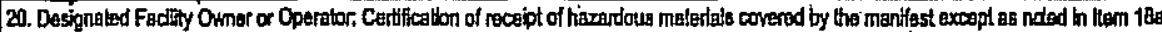

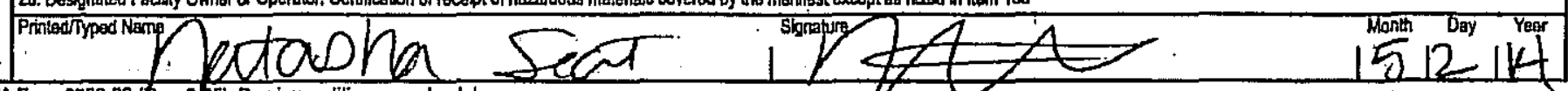

EPAForm 8700-22 (Rov. 3-05) Praviouts edtions are obsoletita. 
Please print or type. (Form designed for use on elite (12-pilchi iypewriter.)

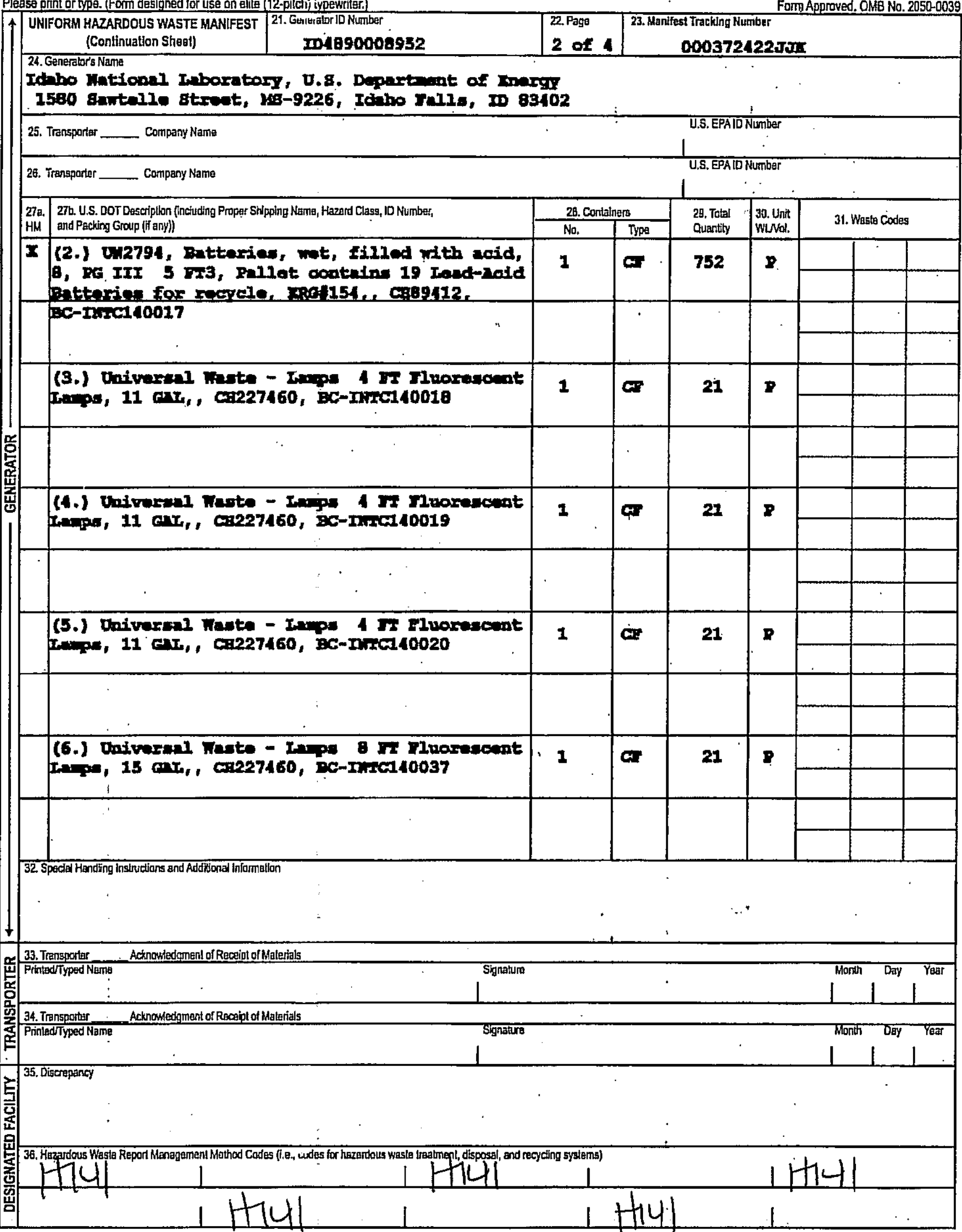




\section{JJK}

Please print or type. (Fom designed for use on ellite (12-plich) typewriter.)

21. Genaralor ID Number

(Continuation Sheet)

ID489000a952

22. Page

23. Manifest Tracking Number

24. Generabo's Name

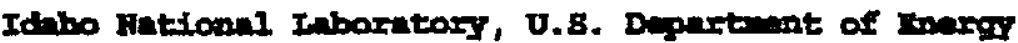

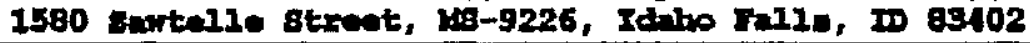

25. Transporter Company Name

26. Transporter Company Name

3 of 4 $000372423 \pi 5$.

Form Approved. OMB No. 2050-0039

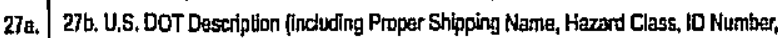
HM. and Packing Group (if any))

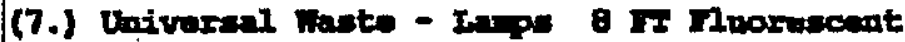

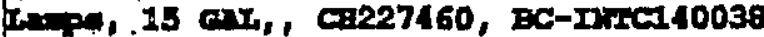

(B.) Mon-DOr Beralated PCis Contains 5 fallante, 1 aprattar with pose $>50$ pR, cos

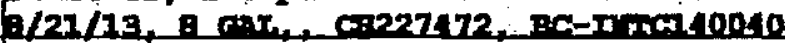

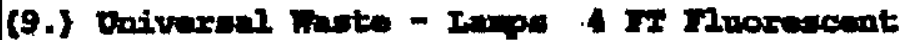

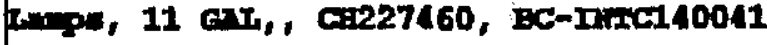

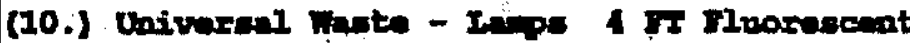
Ene, 11 ert, co227460, EC-Drict40042

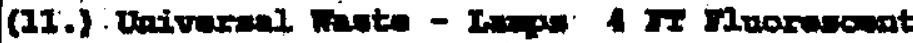

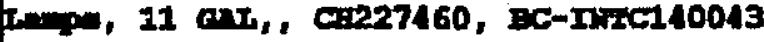

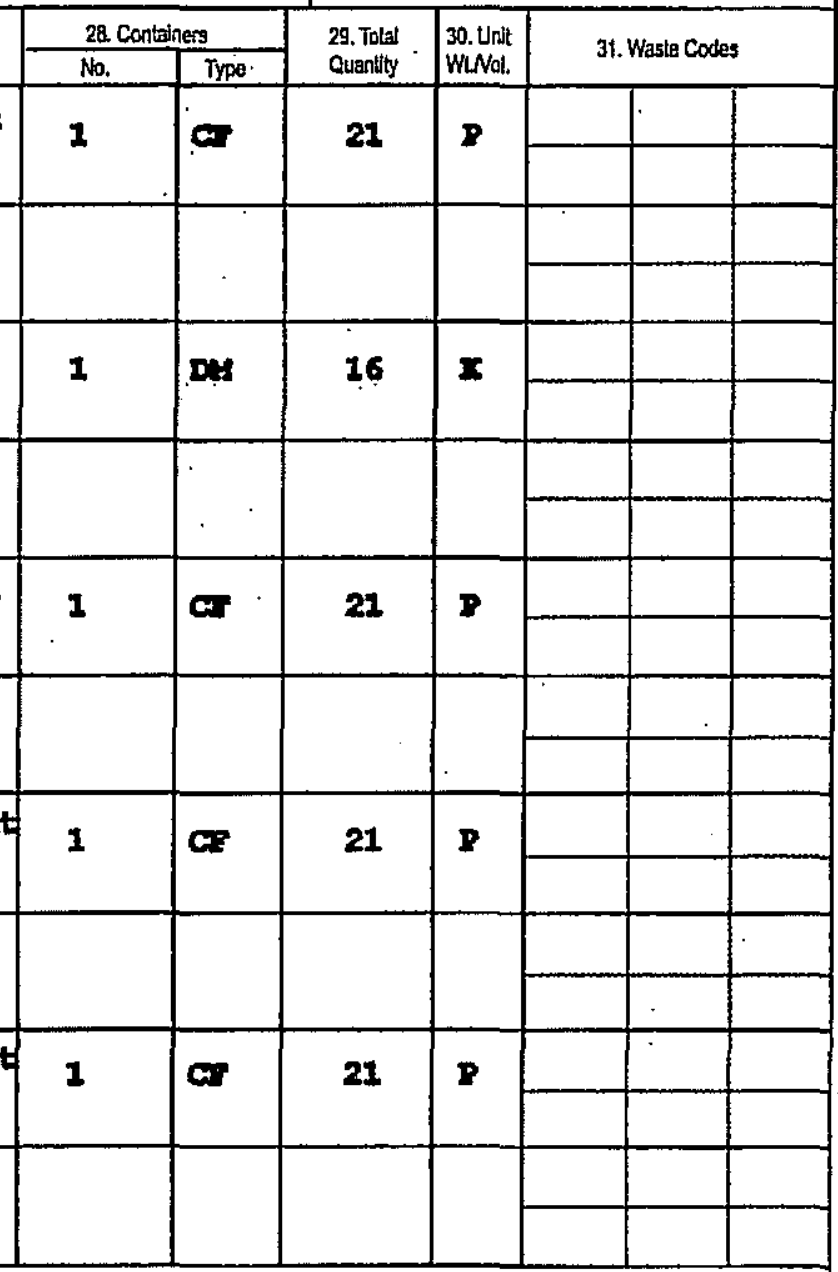

32. Special Handing Instructlons and Add ditonal Information

$+$

20. 33. Transpoitar Acknowiadgment of Recelpl of Materlats

Hi Ptintedryped Name

Acknomiledgrment of Roceipl of Matarilals

U.S. EPA ID Number

Number 
Plaase print or lype. (Fom designed for use on elite (12-pitch) typewriter.)

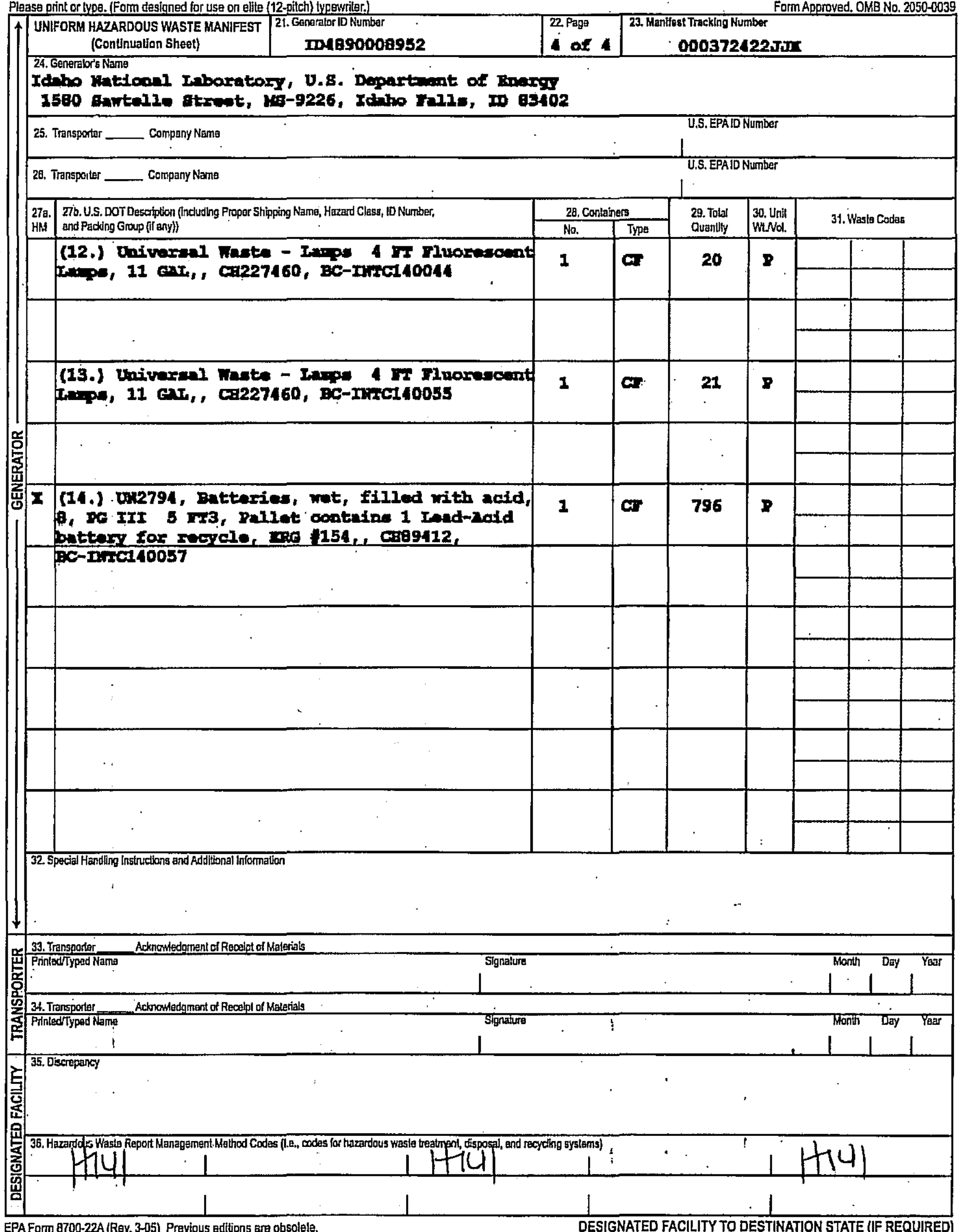




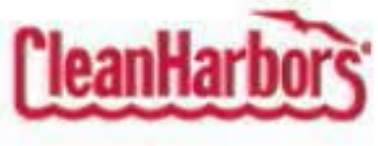
Clean Harbors Aragonite LLC
11600 North Aptus Road
Grantsville UT, 84029
UTD981552177
(435) $884-8100$

\section{CERTIFICATE OF DISPOSAL}

\begin{tabular}{|c|c|c|c|c|c|c|c|}
\hline Generator $F$ acility Name: & Idaho & National Laborat & US Department of Energy & Sal & rder\#: & & 160 \\
\hline Generator Address & $\mathrm{CH}_{2} \mathrm{~N}$ & A-MG Idaho, LLC & an Haley - MS 9226 & Dat & seived: & & \\
\hline & POB & $0 \times 2010$ & & & & & \\
\hline & Idaho & Falls, ID, 83415 & & & & & \\
\hline Generator Contad Name: & & & & & & & \\
\hline Generator EPAID: & CESO & & & Los & & 67 & \\
\hline & & & & $\mathrm{Ma}$ & & 00 & $422 . J J K$ \\
\hline $\begin{array}{l}\text { Original Date Removed } \\
\text { CHID \# From Service }\end{array}$ & $\begin{array}{l}\text { Unit } \\
\text { Type }\end{array}$ & $\begin{array}{c}\text { Serial \#i } \\
\text { Customer ID }\end{array}$ & $\begin{array}{c}\text { Material } \\
\text { Description }\end{array}$ & $\begin{array}{l}\text { Disposal } \\
\text { Date }\end{array}$ & $\begin{array}{l}\text { Metho } \\
\text { Dispo }\end{array}$ & & Disposal Facility \\
\hline $8 / 21 / 2013$ & DM & BC-INTC140040 & PCB Solids For Incineration & $6 / / 2014$ & Inciner & & Aragonite, UT Facility \\
\hline
\end{tabular}

Under Civil and Crimina Penalties of Law for the making or sukmission of false or fraudulent statements or representations (18 U.S.C. 1001 and 15 U.S.C. 2615), I certify that the information contained in or acompanying this document is true, accurate, and complete. As to the identified section(s) of this document for which I cannot personally verify truth and accuracy, I certify as the company official having supervisory responsibility for the persons who, ading under my dired instructions, made the verification that this information is true, acourate, and complete.

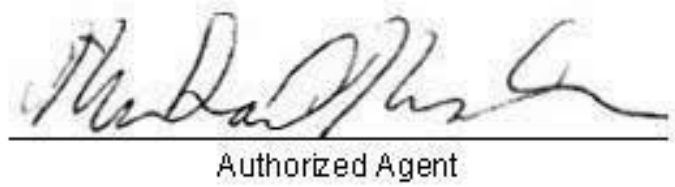

Tuesday, June 03, 2014

Date 
Please print or type. (Form designed for use on elite (12-pilch) bypewriter.)

4 UNIFORM HAZARDOUS 1 . Generalon ID Number

WASTE MANIFEST

5. Generator's Narne and Mailing Addrass

Idaho National Iaboratory, U.g. Departaent of

Frargy, 1580 8awtallo Btwet, MS-9226, Edaho

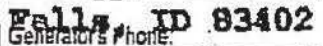

6. Transporter 1 Company Nama

seri. stentin Motor Mrinsit.

7. Transporter 2 Companty Name

8. Designated Facility Naime and. Sike Ad d dtess

Form Approved. ONAB No. 2050.0039

\section{Inargysolitione, ItC \\ US-I80 Iseit 49 rooel. Corunty}

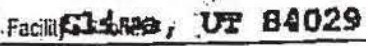

9a. 9b.U.S. Dot Dascription fincluxing Proper Shipping Name, Hazard Class, tD Number,

(208) $533-3377$

HM End Packing Gtoup (if any)\}

x (1.) Wi2910, Radionative material, eroepted pachagre-limited gantity of matorial, 7

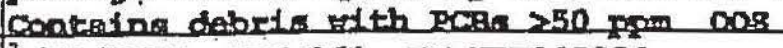

9/11/2013 IRRC 161, EC-STR140034

(800) $230-8769$

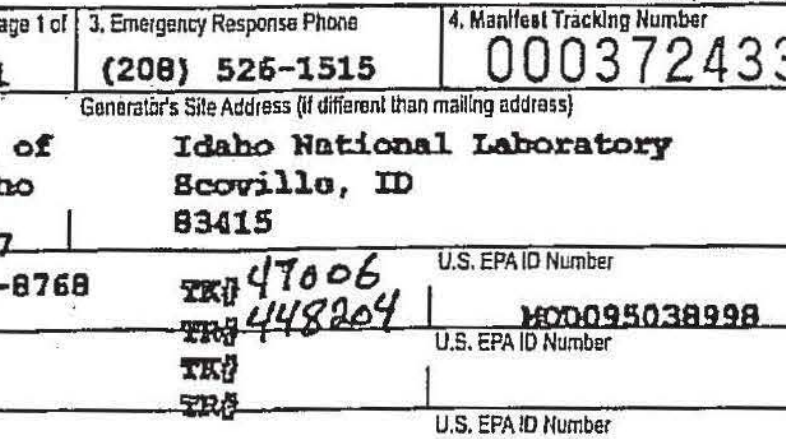

14. Spedial Handling Ins Iructions and Additonal Information

Raturn algnad ariglnal within 30 days to: CWI for U.8. DOB, Attn: Cyathia Mahlum, MS

9226. Propored undar Contract $\$ 0$. Dz-MC07-051011516. Bhipmast 170. 9119-19-0031. Cousp

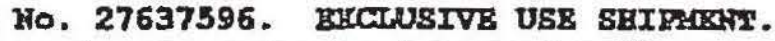

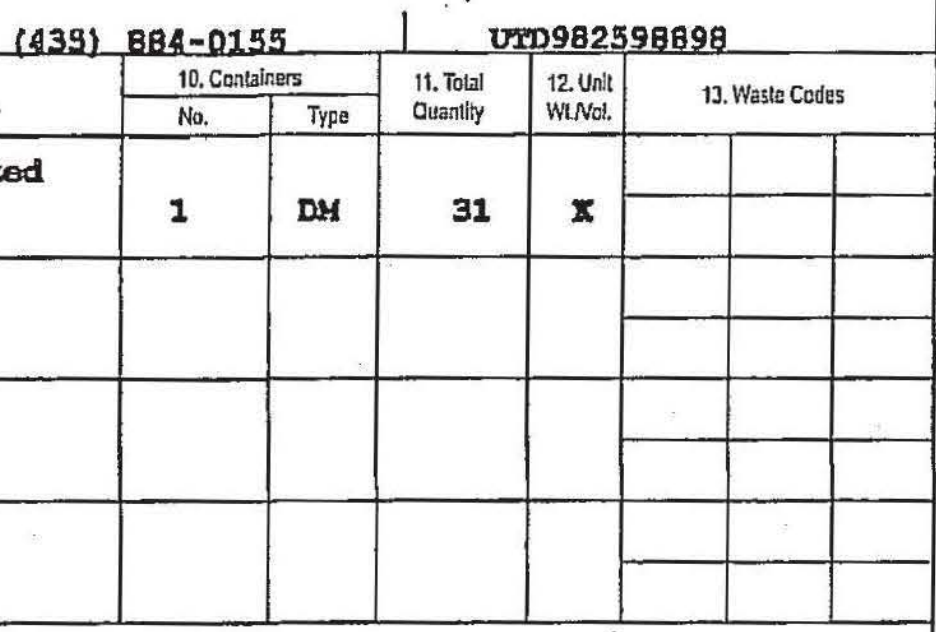

15. GENERATOR'SJOFFEROR'S CERTIFICATION: I hereby deciare that the conlents of this consignment are hully and accuralely described above by the proper shipping namte, and are classilied, patkagad,

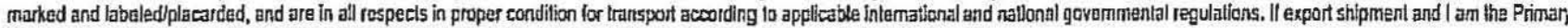
Expotter, I certify that the contenls of this consignmient canlarm to the terms of the attachad EFAAcknowiledgment of Consent.

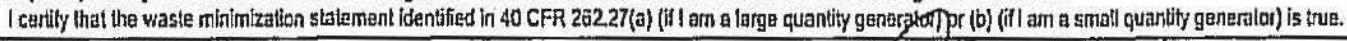

Generator'siofiero's Prinledi/yped Name

Cyathio Mablum

16. Intametional Shipmenls $\square$ Import is U.S.

Transporter signature |lor exports only\}:

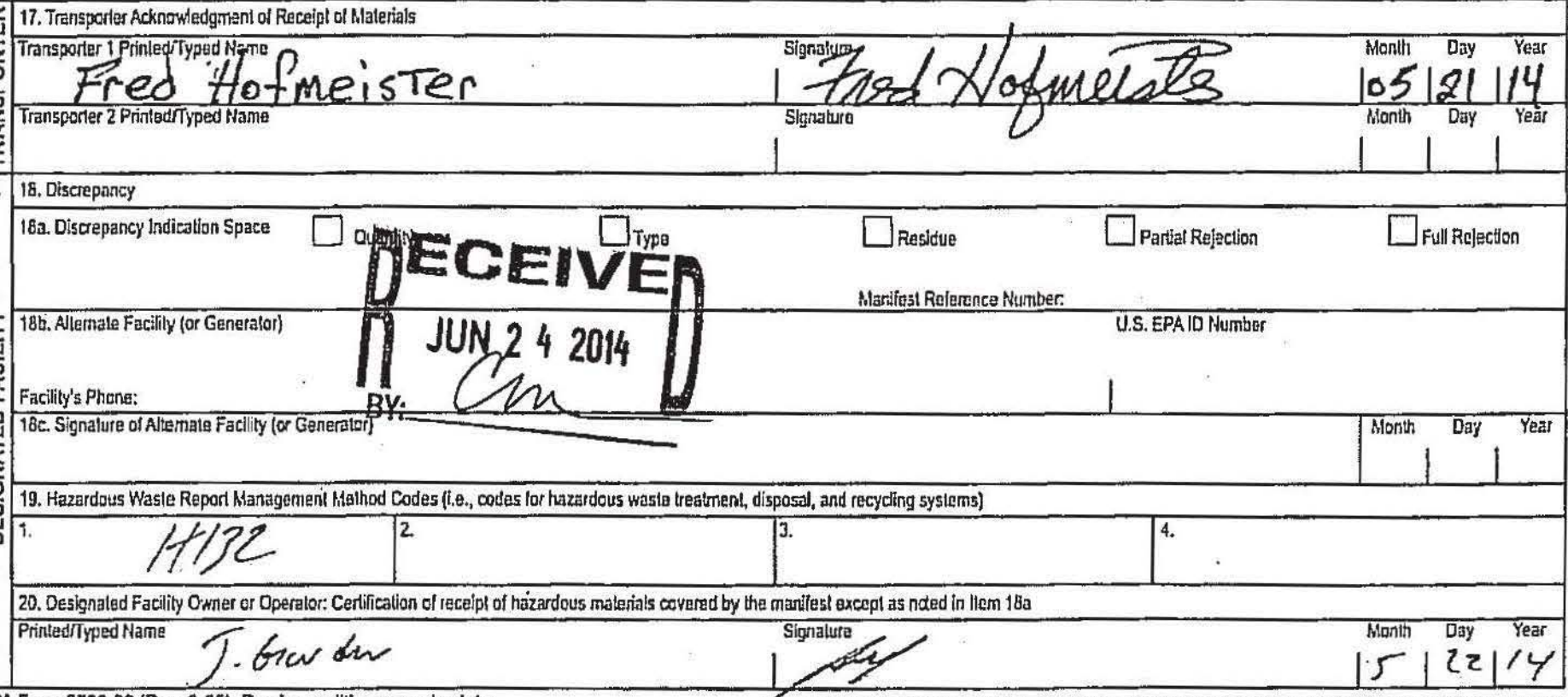

EPA Form 8700-22 (Rev. 3-05) Previous editions are obsolele. 


\title{
CERTIFICATE OF DISPOSAL
}

\author{
3 miles South, Exit 49, I-80 \\ Clive, Utah 84029 \\ EPA ID: UTD982598898
}

\section{CH2M-WG Idaho of USA DOE, Idaho Falis}

This certificate acknowledges that the following manifested shipments have been disposed of as listed below:

\begin{tabular}{|c|c|c|c|c|c|}
\hline$\frac{\text { Shipment }}{9113-19-0031}$ & $\frac{\text { Manlfest }}{72433}$ & $\frac{\text { Dispogal Qate }}{06 / 13 / 2014}$ & $\frac{\text { Volume (Cu/Ft) }}{4.0}$ & $\begin{array}{l}\text { Procas.5 } \\
\text { Landfill }\end{array}$ & $\begin{array}{l}\text { Disposal Location } \\
\text { Mlxed Wasle }\end{array}$ \\
\hline
\end{tabular}

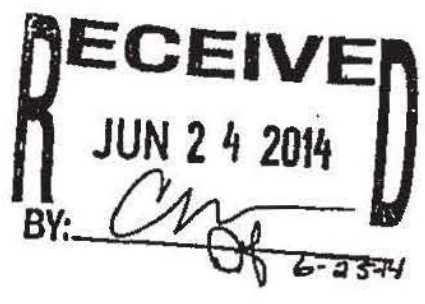

The total volume above represents the cubic feet of waste disposed of at EnergySolutions' Disposal Facility Landfill. Disposal is subjecl to EnergySolutions' Radioactlve Material License, all other applicable licenses, permits and regulations, and the Disposal Agreement.

Undar civil and criminal ponalies of law for the making or submission of false or fraudulent stalements or rapresentalions (18 U.S.C 1001 and 15 U.S.C. 2615) I certify that the information contained in or accompanying this document is true, accurale and complete. As to the identification section(s) of this document for which I cannot personally verify inth and accuracy, l cerlify as the company official having suporvisory responsibility for the parsons who, acling undar my direct instructions, made tho verification that inis information is irve, accurale and complete.

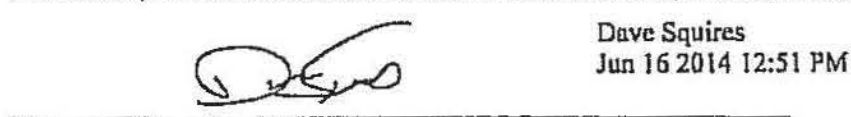

Jun 162014 12:51 PM 
Please print or type. (Form designed for use on elite (12-pitch) typewriter.)

\begin{tabular}{|c|c|}
\hline $\begin{array}{l}\text { UNIFORM HAZARDOUS } \\
\text { WASTE MANIFEST }\end{array}$ & $\begin{array}{l}\text { 1. Generator ID Number } \\
\text { ID } 1 \text { a90008952 }\end{array}$ \\
\hline
\end{tabular}

5. Gengrator's Name and Malling Address

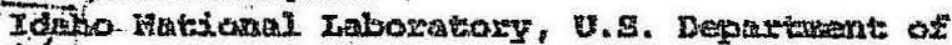

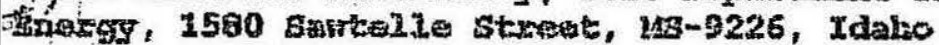

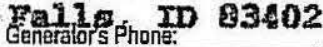

6. Transporler 1 Company Name

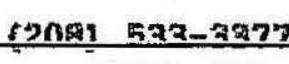

(781) $792-5000$

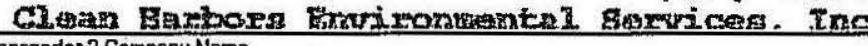
7. Transporter,2. Company Narne

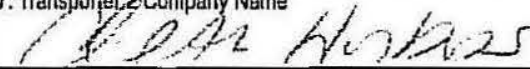

8. Deslgnaled Facility Name and Site Address

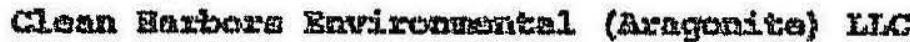

31600 Joxth Aptas word

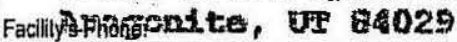

9a. 9b. U.S. DOT Description (Including Proper Shipping Name, Hazard Class, ID Number,

HM and Packing Group (if any))

11.) Ha3077, Baxtaxclonss yastre, solid, n.0.f5.,

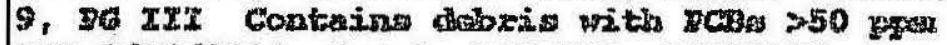

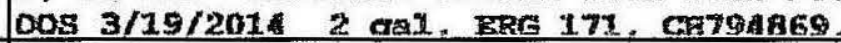
2e-jtrin140039
Form Approved. OMB №. 2050-0039 \begin{tabular}{l|l|l} 
(203) $5265-15: 5$ & 000 \\
\hline Generator's Sit Address (if different than malling address)
\end{tabular}

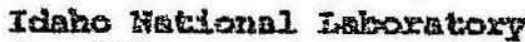

Beovi119; 20

BaA15

\begin{tabular}{l|l} 
U.S. EPAID Number \\
U.S. EPAID Number \\
U.S. EPAID Number
\end{tabular}

(435) ละด 9100

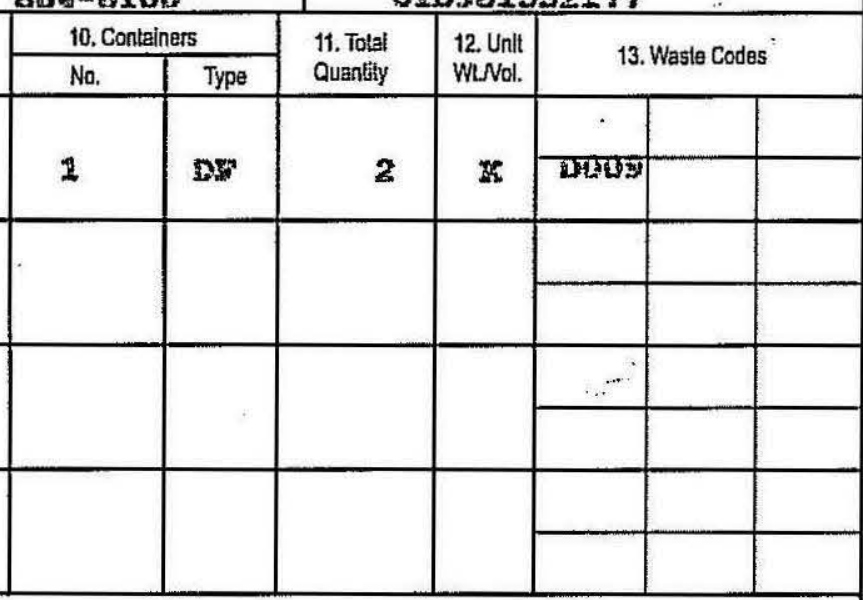

14. Speclar Hendling Instructions and Adedilional Information

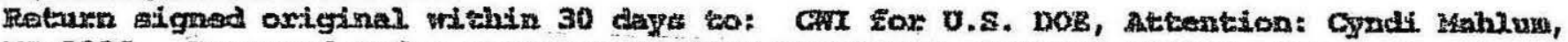

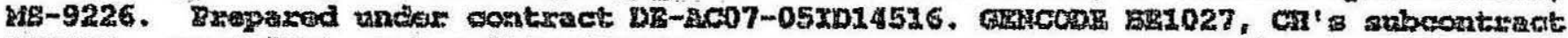

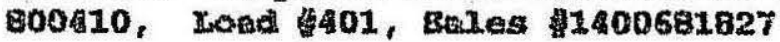

15, GENERATOR'SIOFFEROR'S CERTIFICATION: I hareby declara that tha contents of this consignment are fully and accurately described above by tha proper shipplng name, and are classlified, packaged, marked and labeled/placardad, and are in all respects in proper condition for transport according to appllcabla intemational and natlonal governmental regulations. If export shlpment and I am the Primary Exporter, I certily that the contents of thls consignment confom to the terms of the atteched EPAAcknowledgment of Consent.

I certify that the waste minimizatlon statement identfied in 40 CFR 262.27(a) (If I am a large quantity generator) or (b) (ifl a am a small quanitity generator) Is true.

Generalo's s/oferor's Prinled/Typed Name

Leater I 50 orohem

16. International Shipments $\square$ import lo U.S

Transporter signature (for exporits only):

$|x| 4 \mid$

Exportifin U.S.

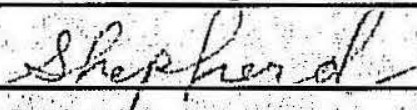

Port of entrylexit: Date leaving U.S.:

\section{Transporter Acknowledgment of Receipt of Materials.}

Transportar 1:Prinjed Typed Name

RIAK leitson

Transportes 2 Printed/Typed Name

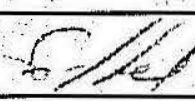

18. Discrepancy $f$

Ba. Discrepency Indication Spaco

De...

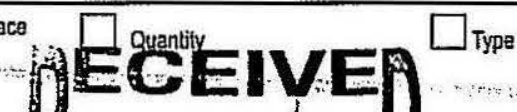

$\square_{\text {Type }} \quad \square_{\text {Resldue }}$

Hath Wiln

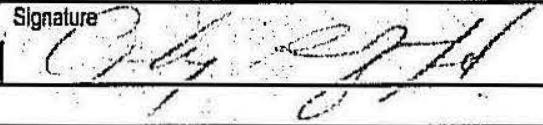

$\square$ Partial Rejection

Month Day Year

18b. Altemate Facilly (or Generalo

Facility's Phone:

\section{JUL 072014}

Mänlfést Relerence Number:-

U.S. EPAID Nurnber

18c. Signature of Altemsle Facility (of tefmerator

19. Hazardous Waste Report Managernen! Mathod Codes (i.e., codes for hazardous waste trealment, disposal, and recycling systems)

$\left.\left.\mid \int(1)(1)^{2}\right]^{3}\right)^{4}$

20. Designated Facilty Owner ar Operator. Certification of receipt of hazardous materials covered by the manffest except as nded in-ltem.18a

Printed/Typed Name: 


\section{res.}

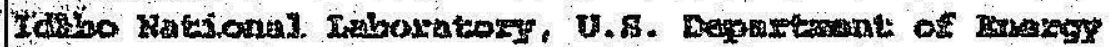

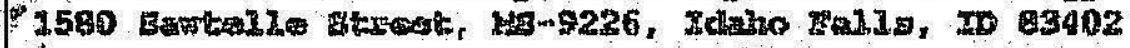

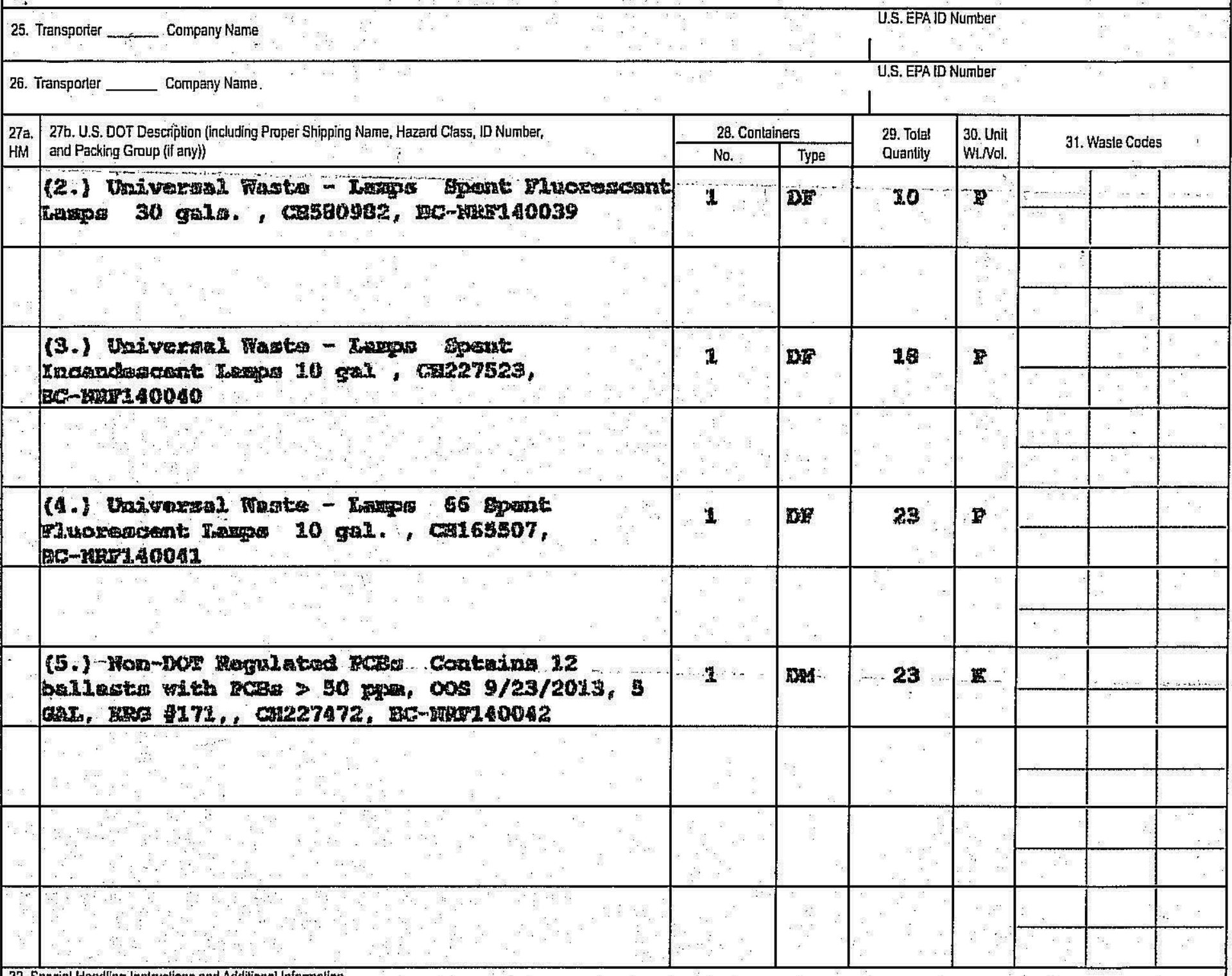

32. Special Handling Insirtuctions and Addisonal Infermation

000372 A $477 \mathrm{mx}$ 


\title{
000372447JJK COD
}

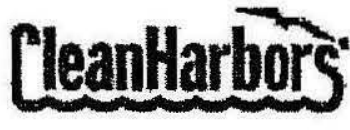

\author{
Clean Harbors Aragonite LLC \\ 11600 North Aptus Road \\ Grantsville UT, 84029 \\ UTD981552177 \\ (435) $884-8100$
}

\section{CERTIFICATE OF DISPOSAL}

Generator Facility Name:

Generator Address:
Idaho National Laboratory US Department of Energy

CH2M-WG Idaho, LLC- Dan Haley - MS 9226

PO Box 2010

idaho Falls, JD, 83415
Sales Order\#: $\quad 1400681828$

Date Received: $\quad$ 6/24/2014

Generator Contact Name:

\begin{tabular}{|c|c|c|c|c|c|c|c|}
\hline \multirow{2}{*}{\multicolumn{2}{|c|}{ Generator EPA ID: }} & \multirow{2}{*}{\multicolumn{2}{|c|}{ CESQG }} & & \multicolumn{2}{|c|}{ Load \#: } & 68731 \\
\hline & & & & & Mar & & 447JJKK \\
\hline $\begin{array}{l}\text { Original } \\
\mathrm{CH} \text { ID \# }\end{array}$ & $\begin{array}{l}\text { Date Removed } \\
\text { From Service }\end{array}$ & $\begin{array}{l}\text { Unit } \\
\text { Type }\end{array}$ & $\begin{array}{c}\text { Serial \# I } \\
\text { Customer ID }\end{array}$ & $\begin{array}{c}\text { Material } \\
\text { Description }\end{array}$ & $\begin{array}{l}\text { Disposal } \\
\text { Date }\end{array}$ & $\begin{array}{l}\text { Method of } \\
\text { Disposal }\end{array}$ & Disposal Facility \\
\hline 38673853 & $9 / 23 / 2013$ & DM & none $l$ & PCB Solids For Incineratlon & $7 / 2 / 2014$ & Incineration & Aragonite, UT Facility \\
\hline
\end{tabular}

Under Civil and Criminal Penalties of Law for the making or submission of false or fraudulent statements or representations (18 U.S.C. 1001 and 15 U.S.C. 2615), I certify that the Information contained in or accompanying this document is true, accurate, and complete. As to the Identifted sectlon(s) of this document for which I cannot personally verify truth and accuracy, I certify as the company official having supervisory responsibility for the persons who, acling under my direct instructions, made the verification that this information is true, accurate, and complete.

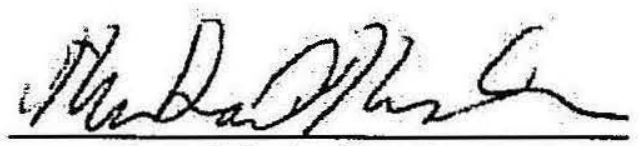

Authorized Agent
Monday, July 14, 2014

\section{Date}

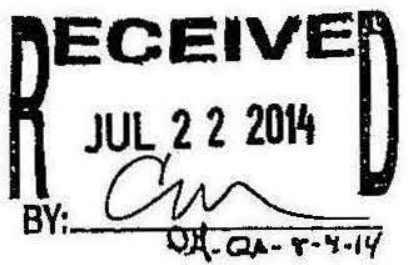

Page 1 of 1 


\section{JJK COD}

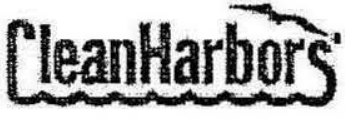

\author{
Clean Harbors Aragonite LLC \\ 11600 North Aptus Road \\ Grantsville UT, 84029 \\ UTD981552177 \\ (435) $884-8100$
}

\section{CERTIFICATE OF DISPOSAL}

Generator Facility Name:

Generator Address:
Idaho National Laboratory US Department of Energy

CH2M-WG Idaho, LLC- Dan Haley - MS 9226

PO Box 2010

Idaho Falls, ID, 83415

\section{Sales OrderH: \\ 1400681828 \\ Date Received:}

Generator Contact Name:

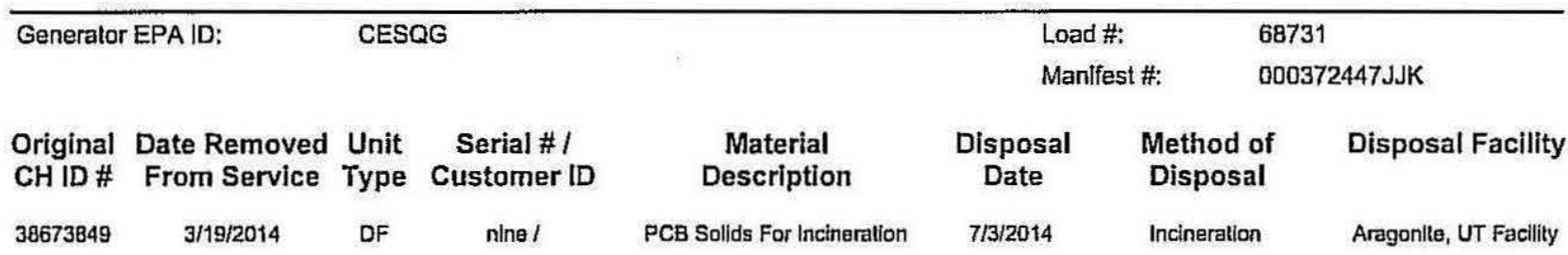

Under Clvil and Criminal Penalties of Law for the making or submission of false or fraudulent statements or representalions (18 U.S.C. 1001 and 15 U.S.C. 2615), I certify that the informalion contalned In or accompanying this document is true, accurate, and complete. As to the identified section(s) of this document for which I cannot personally verify truth and accuracy, I certify as the company official having supervisory responsibility for the persons who, acting under my direct instructions, made the verification that this information is true, accurate, and complete.

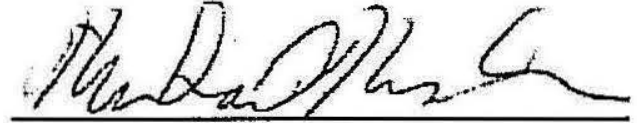

Authorized Agent
Monday, July 14, 2014

Date

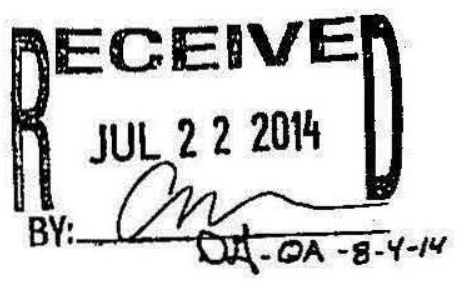

Page 1 of 1 
Please print or type. (Form designed for use on elite (12-pilch) typewriter.)

$000372451 \mathbf{J}$.

Form Approved. OMB No. 2050-0039

\begin{tabular}{|c|c|}
\hline $\begin{array}{l}\text { UNIFORM HAZARDOUS } \\
\text { WASTE MANIFEST }\end{array}$ & $\begin{array}{l}\text { 1. Generalor lD Number } \\
\text { ID4890008952 }\end{array}$ \\
\hline
\end{tabular}

Idaho kational Iaboratory, U.s. Department of

EnexgY, 1580 Bartelle Streat, MB-9226, Idaho

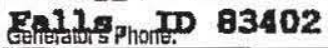

6. Transparter 1 Company Name

Tri state Motor Mransit

7. Transporter 2 Company Name

8. Designated Facility Name and Sile Address

2. Page 1 of 3. Emergency Response Phone

Form Approver

Generaior's Site Address (ii different than maliing address)

$000372451 \mathrm{JJK}$

Idaho Mational Imboratory

Scoville, ID

83415

(200) $-533-3377$

(800) 234-8768

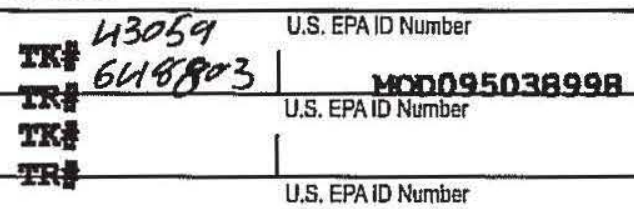

Energysolutions, Irc

Us-I80 Exit 49 Tooele County

Facilitchitive, UT 84029

9a. $9 b$. U.S. Dot Description (including Proper Shipping Name, Hazard Class, ID Number,

HM and Packing Group (if any))

x (1.) un2910, Waste Radioactive material, excepted package-1.imited quantity of material, 7 Contains dehris with PCBs $>50$ mpm oos $10 / 23 / 2013$, BC-NRF140046

14. Special Handling Instructions and Addifional Information

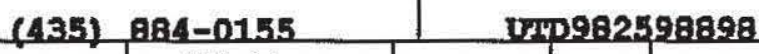

\begin{tabular}{|c|c|c|c|c|c|c|}
\hline \multicolumn{2}{|c|}{ 10. Contalners } & \multirow{2}{*}{$\begin{array}{l}\text { 11. Total } \\
\text { Quanlity }\end{array}$} & \multirow{2}{*}{$\begin{array}{l}\text { 12. Unlt } \\
\text { W.Nol. }\end{array}$} & \multirow{2}{*}{\multicolumn{3}{|c|}{ 13. Waste Cades }} \\
\hline No. & Type & & & & & \\
\hline 1 & DM & 33 & $\mathbf{x}$ & $\begin{array}{l}\text { Doos } \\
\text { D008 }\end{array}$ & $\begin{array}{l}\text { D006 } \\
\text { D009 }\end{array}$ & $\begin{array}{l}0007 \\
0010\end{array}$ \\
\hline & & & & & & \\
\hline & & & & & & \\
\hline & & & & & & \\
\hline & & & & & & \\
\hline & & & & & & \\
\hline & & & & & & \\
\hline
\end{tabular}

Return signed original within 30 days to CWI for U.s. DOz, Attn: Cynthia Mahlum, Ms 9226. Prepared under Contract No. DE-AC07-05ID14516. Bhipwent No. 9113-07-0102. ERT 161.

Comp No. 27638960. EXCLUSIVB USE SBIPABAI.

15. GENERATOR'S/OFFEROR'S CERTIFICATION: I hereby declara that the conlents of this consignnent are fully and accurately described above by the proper shippling narne, and are classified, packaged, marked and labeled/placarded, and are in all respects In proper conditlon for transport according to applicable intemational and natlonal govemmental regulations. If export shipment and I am the Primary

Exporter, I cerlify that the contents of this conslgnment conform to the termis of the attached EPAAcknowladgment of Consent.

I certify that the waste minimization stalement identified in 40 CFR 262.27(a) (if I am a large quantity gengratioy) or (b) (iil am a small quantily generalor) Is true.

Ganerator's/Offero's Printed/Typed Nemi

Crnthia Yahlum

16. International Shipments $\square$ import to U.S.

Transporter slgnalure (for exports only):

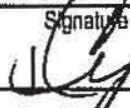

ivt/a

Maheum)

Monih Day Yea

17.

Transporter 1 Printed/Typed Name

Jorey Fouler

Transporter 2 Pinled/Typed Name

Port of entryiaxi:

Dato leaving U.S.:

18. Discrepancy

18a. Discrepancy Ind $\square_{\text {Type }} \quad \square_{\text {Residus }} \quad \square$ Partial Rejection

18b. Allernale Facilit (19 Gendidit 1720 2014

Facility's Phone:

BY:

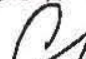

U.S. EPAID Number

18c. Slgnature of Altarnate Facility (or Generator)

19. Hazardous Waste Report Management Method Codes (i.e., codes for hazardous waste treatment, disposal, and recycling systems)

$H-112$

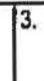

4.

20. Designated Facility Owner or Operatar. Cerlification of recelpt of hazardous materials covered by the masifest except as nded In Hem $18 \mathrm{a}$

Printed/Typed Name

I J4MFí

Kafift

EPA Form 8700-22 (Rev. 3-05) Previous edilions are obsolete.

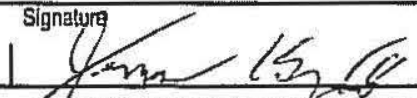

Month Day Year 


\section{CERTIFICATE OF DISPOSAL}

3 miles Suth, Exit 49, I-80

Clive. Utah 84029

EPA ID: UTD982598898

CH2M-WG Idaho of USA DOE, Idaho Falis

This certificate acknowledges that the following manifested shipments have been disposed of as listed below:

$\begin{array}{lllll}\text { Shhipment } & \text { Manifest } & \text { DIsposal Dato } & \text { Volumo(Cu/Ft) } & \text { Process } \\ \text { 9113-01-0394 } & 72435 & 07 / 21 / 2014 & 4 B .8 & \text { Lendfill } \\ 9113-01-0395 & 72450 & 07 / 21 / 2014 & 22.1 & \text { Landfill } \\ 9113-07-0102 & 72451 & 07 / 17 / 2014 & 2.7 & \text { Landfill } \\ 9113-19-0032 & 72452 & 07 / 1812014 & 0.7 & \end{array}$

Disposal Location

Mixed Wasle

Mixed Waste

Mixed Waste

Mllxed Waste

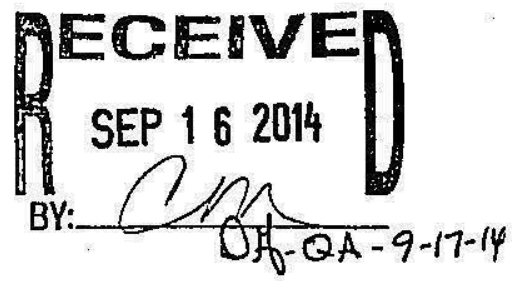

The total volume above represents the cubic feet of waste disposed of at EnergySolutions' Disposal Facility Landill. Disposal is subject to EnergySolutions' Radioactive Malerial License, all other applicable licenses, permits and regulations, and the Disposal Agreement.

Under civil and criminal penallies of law for the making or submission of false or fraudulent slatements or rapresentations (18 U.S.C 1001 and 15 U.S.C. 2615) I cerify that the information canteined in or accompanying this document is true, accurate and complete. As to the idenithication stectian(5) of thls document for which I cannot personally verify inth and accuracy, I certify as the company olficlal having supervisory respansibilly for tha parsons who, acting under my direct insiructions, mate the verificalion that this informaltan is true, accurate and complete.

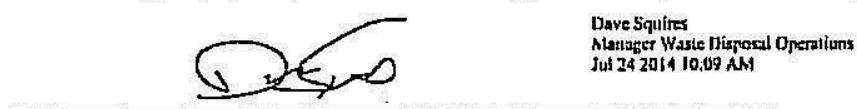

David Squires

Manager Wasle Disposal Operatlons

Date \\ Date}


Please print or type. (Form designed for use on elite (12-pitch) typewriter.)

$$
\text { 000372452JJK }
$$

Form Approved. OMB No. 2050-0039

\section{UNIFORM HAZARDOUS 1 1. Generator ID Number WASTE MANIFEST \\ ID4890008952 \\ 5. Generator's Name and Mailing Address \\ Fal1s ID 63402 \\ 6. Transporter 1 Company Name \\ Tri state Motor Transit \\ 7. Transporter 2 Company Name}

Idaho Nationai Iaboratory, U.S. Department of

Finergy, 1580 Sawtelle street, MS-9226, Idaho

8. Designaled Facility Name and Sile Addrass

\section{Page 1 of 3. Emergency Response Phone \\ (208) 526-1515 \\ 4. Manifest Tracking Number $00372452 \mathrm{JJK}$}

\section{Energysolutions, IrC}

U8-I80 Exit 49 Tooele County

Facliffiphixise, UT 84029

9a. Gb. U.S. DOT Descriplion (including Proper Shipping Name, Hazard Class, ID Number,

HM and Packing Group (ff any)\}

(1.) UN2910, Radioactive material, excepted package-limited quantity of material, 7 Contains ballast with PCBe $>50 \mathrm{ppm}$ oos $10 / 15 / 2013$, BC-NRE140047

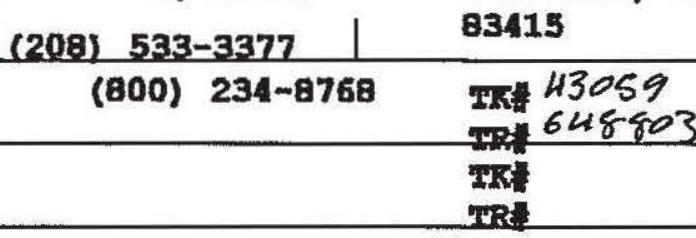

Idaho National Inaboratoxy

Bcovilile, ID

3415

U.S. EPA ID Number
MOD095038998

U.S. EPAID Number

U.S. EPAID Number

(435) $884-0155$

UTD982598898

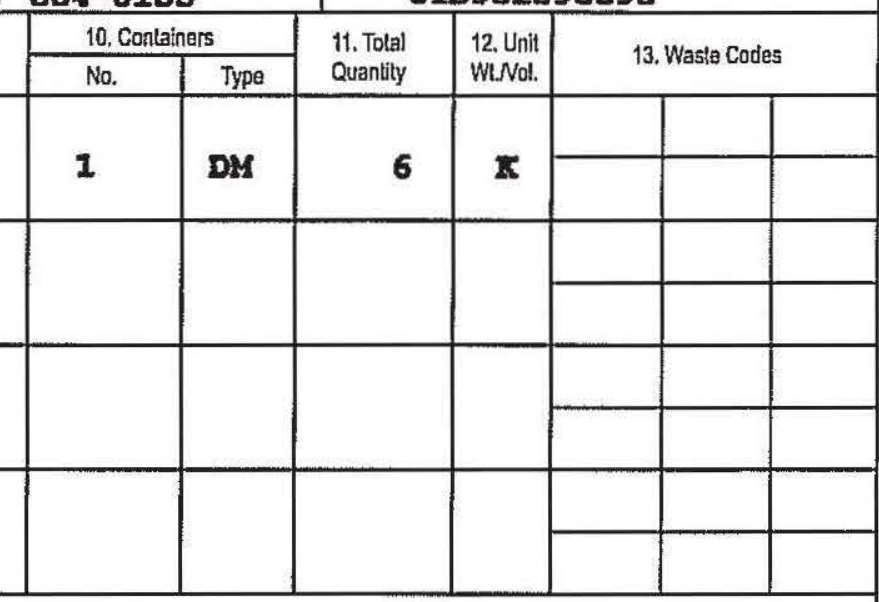

14. Special Handling Instructlons and Additional Informetion

Return signed original within 30 days to Cix for U.S. DOz, Attn: Cymthia Mahlum, MS 9226. Prepined under Contract No. DI-AC07-05ID14516. Bhipment No. 9113-19-0032. FRC 161. Comp No. 27638960. EXCIUSIVE USE SAIPMANT.

15. GENERATOR'S/OFFEROR'S CERTIFICATION: I heraby declare that the contents of thls consignmenl are fully and accurately described above by the proper shipping name, ard are ciassiffed, packaged, marked and labeled/placarded, and are in all respects in proper condition for transport according to appllcable International and national govemmental regulations, If export shipment and I am the Primery Exparter, I certify that the contents of this consigniment conform to the terms of the altached EPAAcknowledgment of Consent.

I certify that the waste minimizalion statement identified in 40 CFR 262.27(a) (fif I am a large quantity generatg) or (b) (ifl am a small quantity generator) Is true.

\section{Generalor's/Offerơ's Printed/Typed Name}

\section{Cynthia Mahlum}

\section{Intermational Shipments $\quad \square$ Import to U.S. \\ Transporter signatura (Ior exporls only): \\ 17. Transporter Acknowledgment of Receipl of Materials \\ Transporter 1 Prinled/Typed Name \\ Transporter 2 Prinled/Typed Name

\author{
-
}

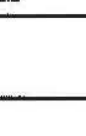

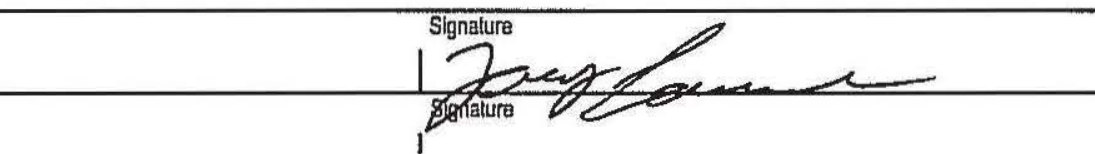

Port of entry/ext: Date leaving U.S.

18. Discrepancy

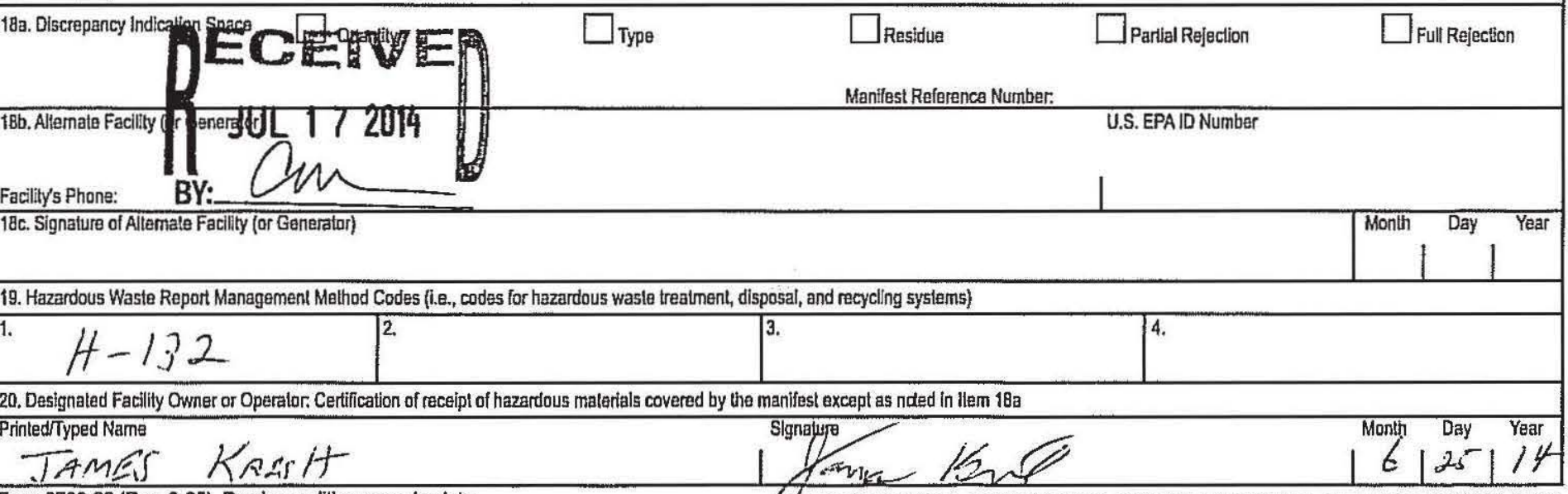
EPA Form 8700-22 (Rev. 3-05) Previous editions are obsolete. 


\title{
CERTIFICATE OF DISPOSAL
}

\author{
3 milus Suth, Exit $49,1-80$ \\ Clive. Uinh 84029 \\ EPA ID: UTD982508898
}

\section{CH2M-WG Idaho of USA DOE, Idaho Falis}

This certificate acknowiedges that the following manifested shipments have been disposed of as listed below:

\begin{tabular}{|c|c|c|c|c|c|}
\hline Şhipment & Manifest & Dispgasal Dato & \multicolumn{2}{|c|}{ Voluma (cu/Ft) } & Process \\
\hline $9113-01-0394$ & 72435 & $07 / 21 / 2014$ & 48.8 & & Landfill \\
\hline 9113-01-0395 & 72450 & $07 / 21 / 2014$ & 22.1 & - & Landfill \\
\hline $9113-07-0102$ & 72451 & $07 / 17 / 2014$ & 2.7 & - & Landffll \\
\hline $9113-19-0032$ & 72452 & $07 / 18 / 2014$ & 0.7 & & Landfill \\
\hline
\end{tabular}

Disepsal bocation

Mixad Waste

Mlxed Wasle

Mixed Wasle

Mlxed Waste

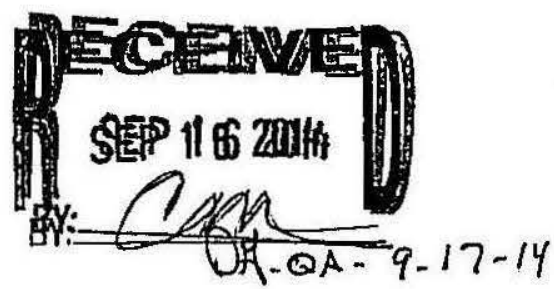

The total volume above represents the cubic feet of waste disposed of at EnergySolutions' Disposal Facility Landfill. Disposal is subject to EnergySolutions' Radioactive Material License, all other applicable licenses, permits and regulations, and the Disposal Agreement.

Under civil and criminal penallies of law lor the making or submission of false or fraudulent statements or representations (18 U.S.C 1001 and 15 U.S.C. 2615) I certify that the information contained in or accompanying this document is true, atcurate and complete. As to the identification section(s) of this document for which I cannot personally verify truth and accuracy, I centify as the company oflicial having supervisory responsibility for the persons who, acting under my dirbet instruclions, mats the verificalion that this informallon is true, accurale and complete.

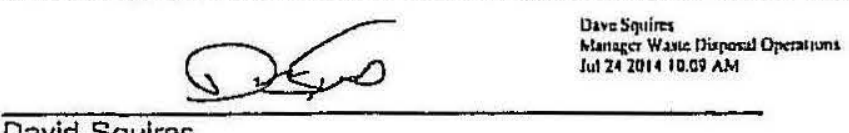

David Squires

Date

Manager Waslo Disposal Operatlons 
Plesse pint or type. (Form designed for use on eltip (12-pitch) typewititer.)
1 UNIFORH HAZARDOUS 1. Genarator DT Nurmber
HASTE MANIFEST 1 I01890008952
5. Generato's Nams and Mialling Address

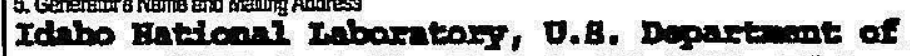

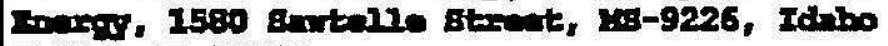

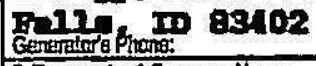
6. Trerspouter 1 Conpany Name
(208) $593=3972 \quad \mid$

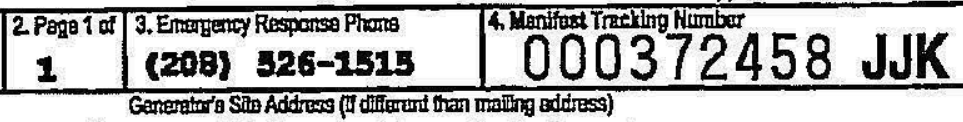

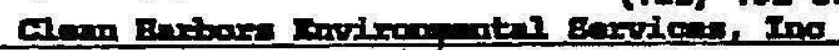

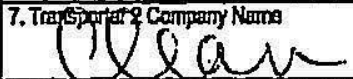

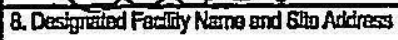

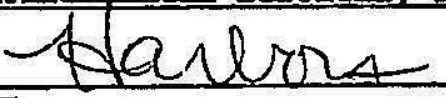

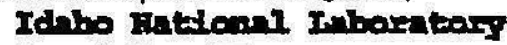
goorille, 10
83115

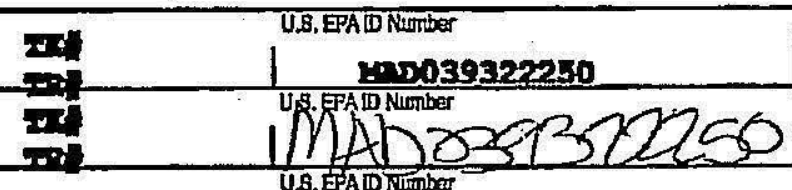

Form Approved. OMB No. 2050-0039

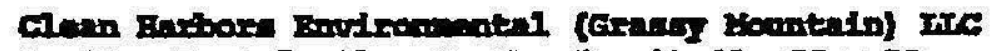

3 ile Int 7 dien worth of edt 19 off I-80

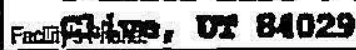

(135) 8g1-8915

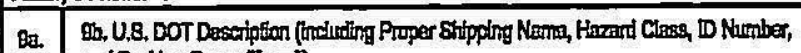

His and Packing Group (f any))

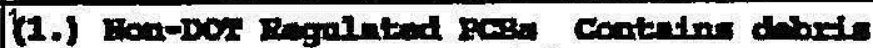
with pas 250 ppom 009 11/7/2013 10 en,

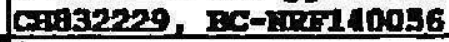

\begin{tabular}{|c|c|c|c|}
\hline \multicolumn{2}{|c|}{ Bge-Bg15 } & \multicolumn{2}{|c|}{ OzOD99130 } \\
\hline \multicolumn{2}{|c|}{ 10. Containgrs } & \multirow{2}{*}{ 11. Total } & \multirow{2}{*}{$\begin{array}{l}12 \text { unl } \\
\text { WU NaL. }\end{array}$} \\
\hline No. & Typo & & \\
\hline 1 & E:4 & 18 & $\pi$ \\
\hline & & & \\
\hline & & & \\
\hline & & & \\
\hline & & & \\
\hline & & & \\
\hline & & & \\
\hline
\end{tabular}

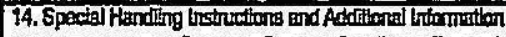

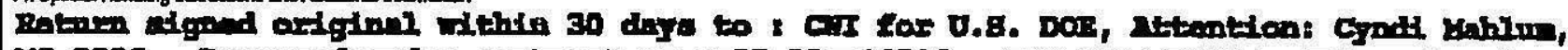

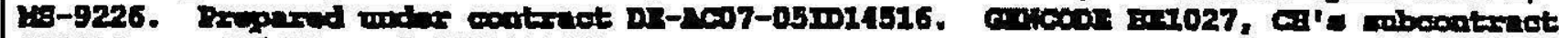
800110, Iand 103, 80) 1401189664

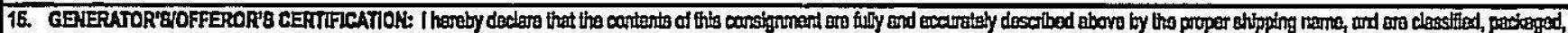

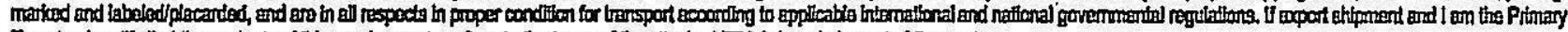

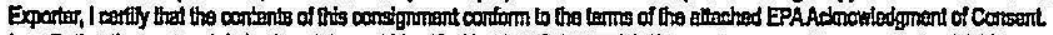

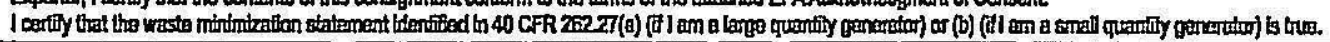

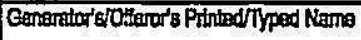

ratax $\mathbf{E}$ ghephad

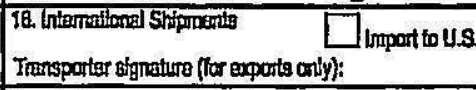

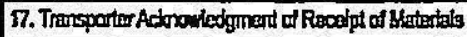

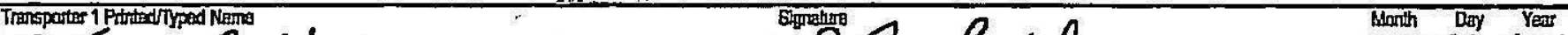

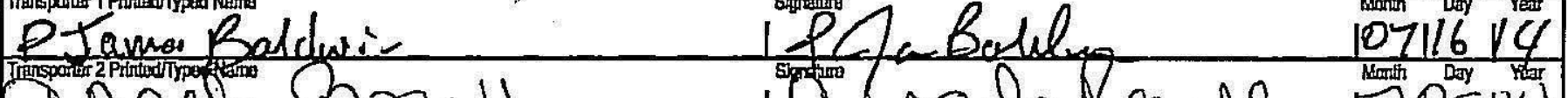

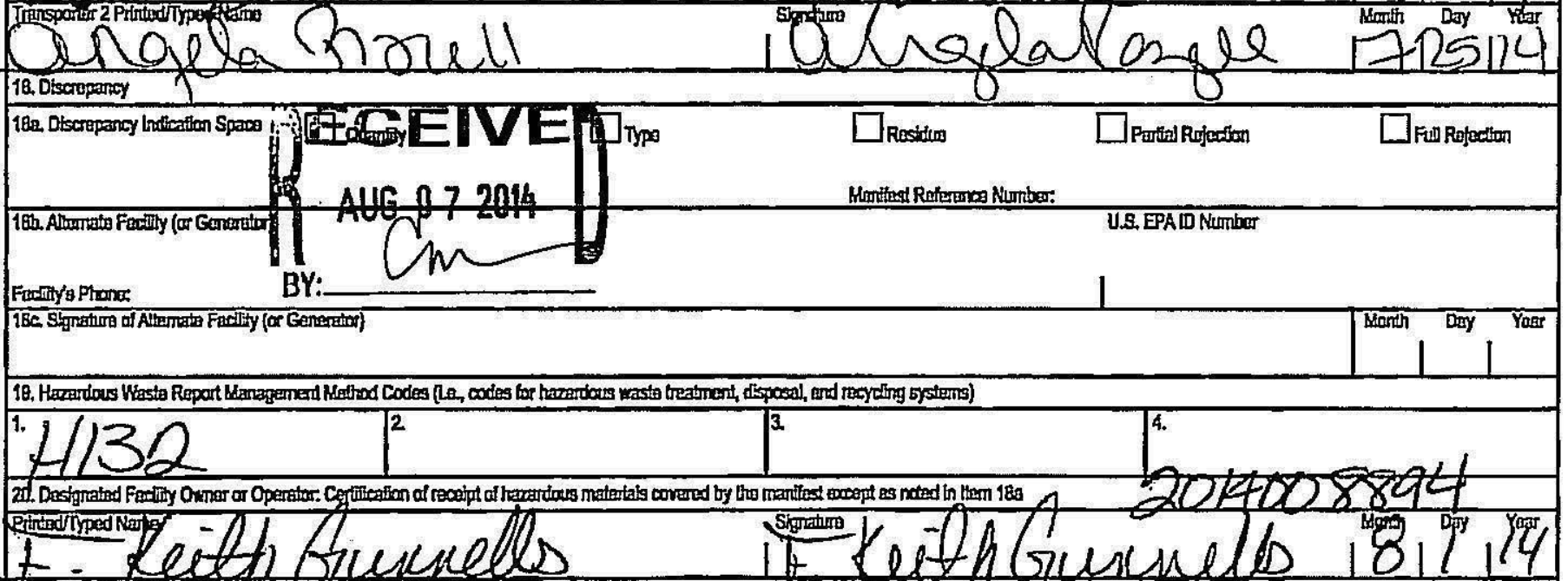

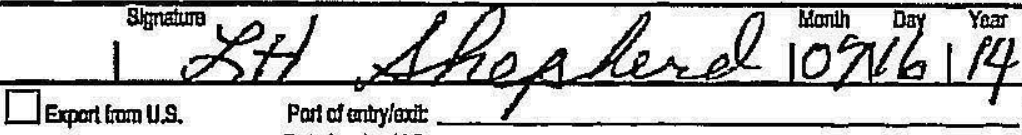

Porf of entity/arit Dade lesving U.S: 


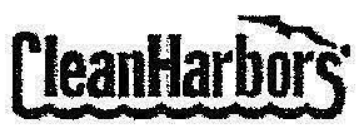

Clean Harbors Grassy Mountain LLC

3 Miles East 7 Miles North of Knolls

Grantsville UT, 84029

UTD991301748

(435) $884-8900$

\section{CERTIFICATE OF DISPOSAL}

Generator Facility Name:

Generator Address:
Idaho National Laboratory US Department of Energy

CH2M-WG Idaho, LLC-Dan Haley - MS 9226

PO Box 2010

Idaho Falls, ID, 83415 $\begin{array}{ll}\text { Sales Order\#: } & 1401189665 \\ \text { Date Received: } & 8 / 1 / 2014\end{array}$

Generator Contact Name:

\begin{tabular}{|c|c|c|c|c|c|c|c|}
\hline \multirow{2}{*}{\multicolumn{2}{|c|}{ Generator EPA ID: }} & \multirow{2}{*}{\multicolumn{2}{|c|}{ CESQG }} & & \multicolumn{2}{|c|}{ Load \#: } & 14008894 \\
\hline & & & & & Mat & & 2458.JJK \\
\hline $\begin{array}{l}\text { Original } \\
\mathrm{CH} \text { ID \# }\end{array}$ & $\begin{array}{l}\text { Date Removed } \\
\text { From Service }\end{array}$ & $\begin{array}{l}\text { Unit } \\
\text { Type }\end{array}$ & $\begin{array}{c}\text { Serial \# I } \\
\text { Customer ID }\end{array}$ & $\begin{array}{c}\text { Material } \\
\text { Description }\end{array}$ & $\begin{array}{l}\text { Disposal } \\
\text { Date }\end{array}$ & $\begin{array}{l}\text { Method of } \\
\text { Disposal }\end{array}$ & Disposal Facility \\
\hline 39754035 & $11 / 7 / 2013$ & DM & $1401189664 /$ & PCB Sollds For Landfill & $8 / 6 / 2014$ & Landîll & $\begin{array}{l}\text { Grassy Mountaln, UT } \\
\text { Facllity }\end{array}$ \\
\hline
\end{tabular}

Under Civil and Criminal Penallies of Law for the making or submission of false or fraudulent statements or representations (18 U.S.C. 1001 and 15 U.S.C. 2615), I certify that the Information contained in or accompanying this document is true, accurate, and complete. As to the identified section(s) of this document for which I cannot personally verify truth and accuracy, I cerlify as the company ofiicial having supervisory responsibility for the persons who, actlng under my direct instructions, made the verification that this information is true, accurate, and complete.

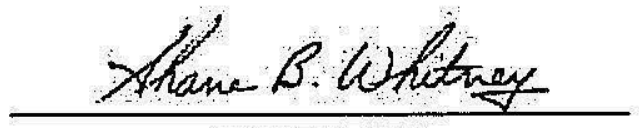

Authorized Agent
Thursday, August 07, 2014

Date

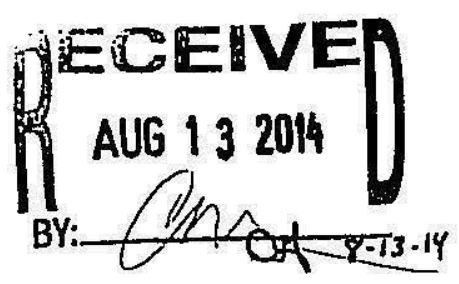

Page 1 of 1 
Please prinl or type. (Form designed for use on elite (12-pitch) typewriter.)

UNIFORM HAZARDOUS 1. Generalor ID Number

WASTE MANIFEST

ID4890008952

Form Approved. OMB No. 2050-0039

5. Generator's Name and Maling Address

Iduho Kational Imboratory, u.8. Departinent of

Tyexgy, 1580 gawtelle Btwet, MB-9226, Idiho

Fe. 13.5 in 83102

6. Transporter 1 Company Name

(209) $533-3377$

Fri State Mator Trannit.

(B00) 234-8768

7. Transporter 2 Company Nams

8. Designated Facilly Name and Sile Addrass

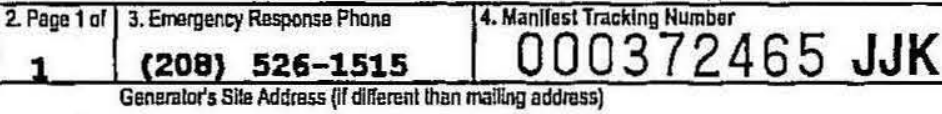

Idiho Intional Imboratory

Bcoville, ID

83415

IXI: 96020 U.S. EPAID Number

Kational Seomed ty Teahnologies, IrC

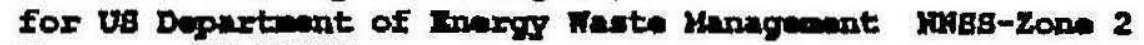
Facilitermanis, iv 89023

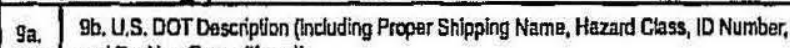

HM and Packing Group (II any)

(1.) UN2915, Warte Radiosotive material, Type A puakrge, 7, A-241 pu-239, molid avide

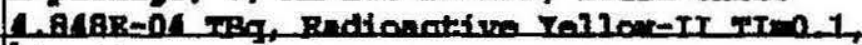
Finsile Ircepted, PCB container >50 pro, 008 06/01/1968, (ER for PCB), KRE 163, BC- 9 Rs140500 F

f.

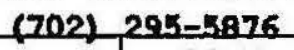

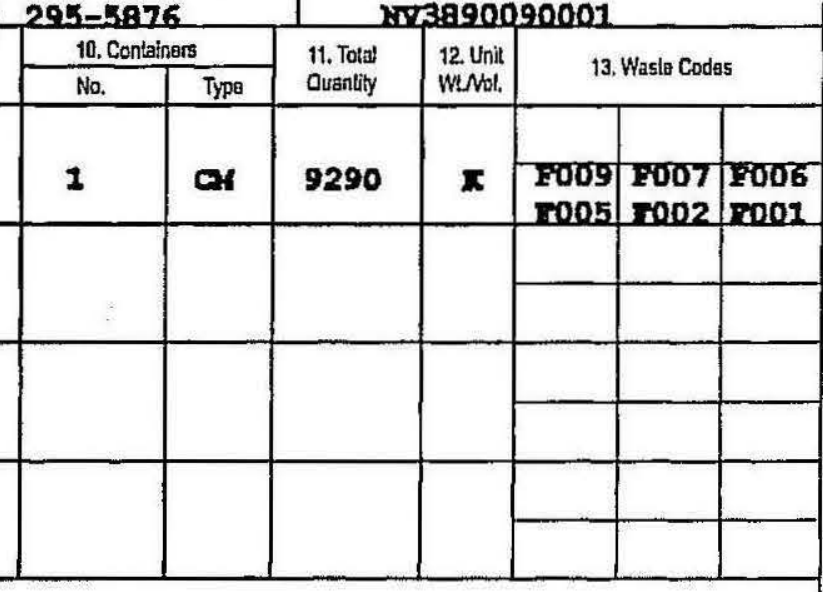

14. Spectal Handling Instructions and Additoral Informalion

Raturn aignad originnl within 30 days to: C.I for U.8. Dos, Attn: Cynthia Mahlum, Ms

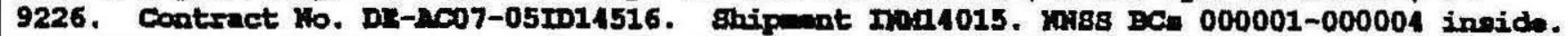

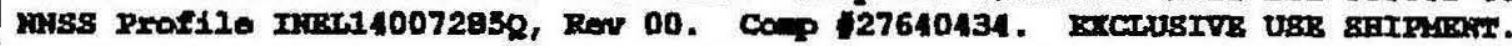

15. GENERATOR'S/OFFEROR'S CERTIFICATION: I hereby declare that the contents of thls consignment are fully and socurately described above by the proper stipping name, and are classified, packaged, marked and labeled/placarded, and are in all respects In proper condlion for transport according to sppilcable internalional and national governmental regulalions. If export shipment and I am the Primary Exporter, I cartly that the contents of thls consignment conform to the termis of the stlached EPAAcknowiedgnent of Consent.

I certify that the wasłe minimizalion statement identified in 40 CFR 262.27(a) (if I am a large quantity generaly) or (b) (ifl am a small quantity ganerator) is tua.

Generator's/OReror's Prisled/Typed Name

\section{Crathic Yahlus}

16. Intemalional Shipments
Transporter signature (for exports only):

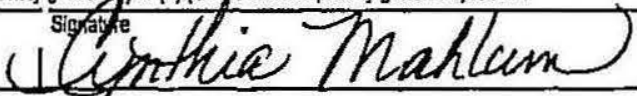

Ulemthie Malcum

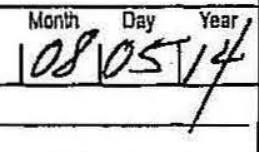

17. Transporter Acknowledgment of Recelpt of Materials

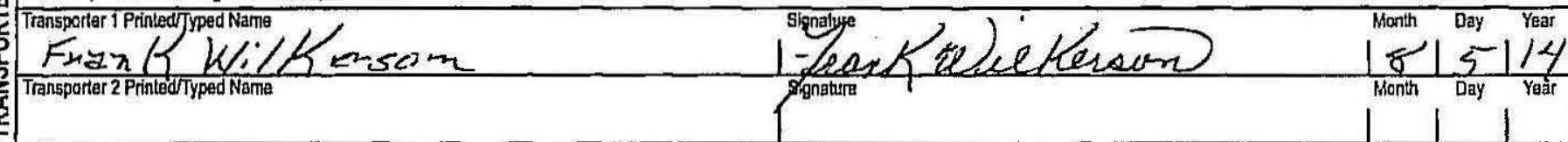

$\uparrow$ to. Discrepancy

18a. Discrepancy finf filduspate

$\square_{\text {Type }}$

$\square$ Partial Rejection

$\square$ Full Rejection

d

Manilest Reforence Number:

Facilly's Phone: BY:
18c. Signature of Alternate Faclity (or Generator)

Part of entrylexit: Date leaving U.S.:

19. Hazardous Waste Report Manzgement Mathod Codes (l.en, codes for hazardous wasta treatmenh, disposal, and recycling systemis)

\begin{tabular}{|l|l|l|l|l|l}
\hline 132 & 2 & 3. & \\
\hline
\end{tabular}

20. Designated Facillty Owner or Operator: Certificaton of Fecaipl ol hezardous materials covered by the manifest except as nded in ltem 1 Ba

EDOWIN TACAHASIV

EPA Form 8700-22 (Rev. 3-05) Previous editions are obsolete.

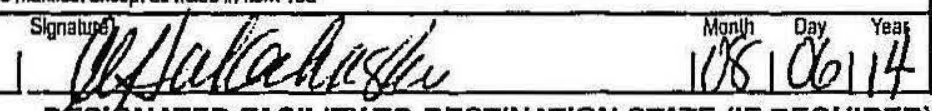

DESIGNATED FACILITY TO DESTINATION STATE (IF REQUIRED) 
National Security Technologiesuc

H000-PA-14-0116

August 11, 2014

Stuart D. Gerard

Waste Certification Official

CH2M $\bullet$ WG Idaho, LLC

P.O. Box 1625, MS 5306

Idaho Falls, ID 83415

Subject: CERTIFICATE OF DISPOSAL FOR POLYCHLORINATED BIPHENYL (PCB) WASTE AT THE NEVADA NATIONAL SECURITY SITE RADIOACTIVE WASTE MANAGEMENT SITE (RWMS)

Enclosed is the certificate acknowledging disposal of manifested PCB shipment INM14015 in the Mixed Waste Disposal Unit, at the Nevada National Security Site RWMS.

If you have any questions, please contact me at 702-295-2261.

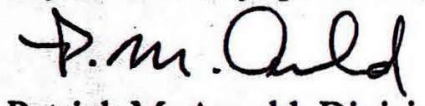

Patrick M. Arnold, Division Manager

Environmental Management

LBG:saq

Enclosure: as stated

cc w/enc.

Correspondence Control

EWO Correspondence

J. T. Carilli, NNSA/NFO

R. C. Denton, NSTec

R. G. Geisinger, NSTec

L. B. Gregory, NSTec

M. Libidinsky, NNSA/NFO

C. P. Moke, NSTec

K. M. Small, NNSA/NFO

K. C. Tanaka, NSTec

A. V. Tauber, NNSA/NFO

R. A. Wagner, NSTec 


\section{National Security Technologies uc \\ For U.S. Department of Energy \\ Waste Management \\ Nevada National Security Site - Zone 2 \\ Mercury, NV 89028}

EPA ID NV3890090001

This Certificate acknowledges that the following shipment(s) of manifested

POLYCHLORINATED BIPHENYL (PCB) waste have been disposed at the Nevada National Security Site Radioactive Waste Management Site.

\begin{tabular}{|c|c|c|c|c|}
\hline $\begin{array}{c}\text { Shipment } \\
\text { Number }\end{array}$ & $\begin{array}{c}\text { Uniform Hazardous Waste } \\
\text { Manifest Number }\end{array}$ & Date(s) of Disposal & Volume $\mathbf{F t}^{\mathbf{3}}\left(\mathbf{m}^{\mathbf{3}}\right)$ & Disposal Process \\
\hline INM14015 & $000372465 J J K$ & $08 / 06 / 2014$ & $324.05(9.18)$ & Landfill \\
\hline & & & & \\
\hline & & & & \\
\hline & & & & \\
\hline
\end{tabular}

Under clvil and criminal penalties of law for the making or submission of false or fraudulent statements or representations (18 U.S.C. 1001 and 15 U.S.C. 2615), I certify that the information contained in or accompanying this document is true, accurate, and complete.

As to the identified section(s) of this document for which I cannot personally verify truth and accuracy, I certify as the company official having supervisory responsibility for the persons who, acting under my direct instructions, made the verification that this information is true, accurate, and complete.

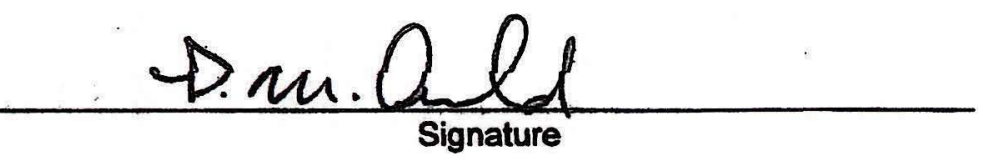

Signature

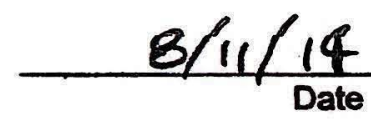

Division Manager, Environmental Management Title

Instructions:

Shipment Number - enter shipment number from LWIS database.

Uniform Hazardous Waste Manifest Number - enter number from UHWM provided by generator.

Date of Disposal - enter date waste was placed in disposal cell.

Volume - enter shipment volume in cubic feet and equivalent cubic meters in parenthesis.

Disposal Process - enter Landfill.

National Security Technologies, LLC

Vision • Service - Partnership

MSTRacom

P.O. Box 98521, Las Vegas, NV 89193-8521

2621 Losee Road, N. Las Vegas, NV 89030-4129 
Please prinl or type. (Form designed for use on elile (12-pitch) lypewriter.)

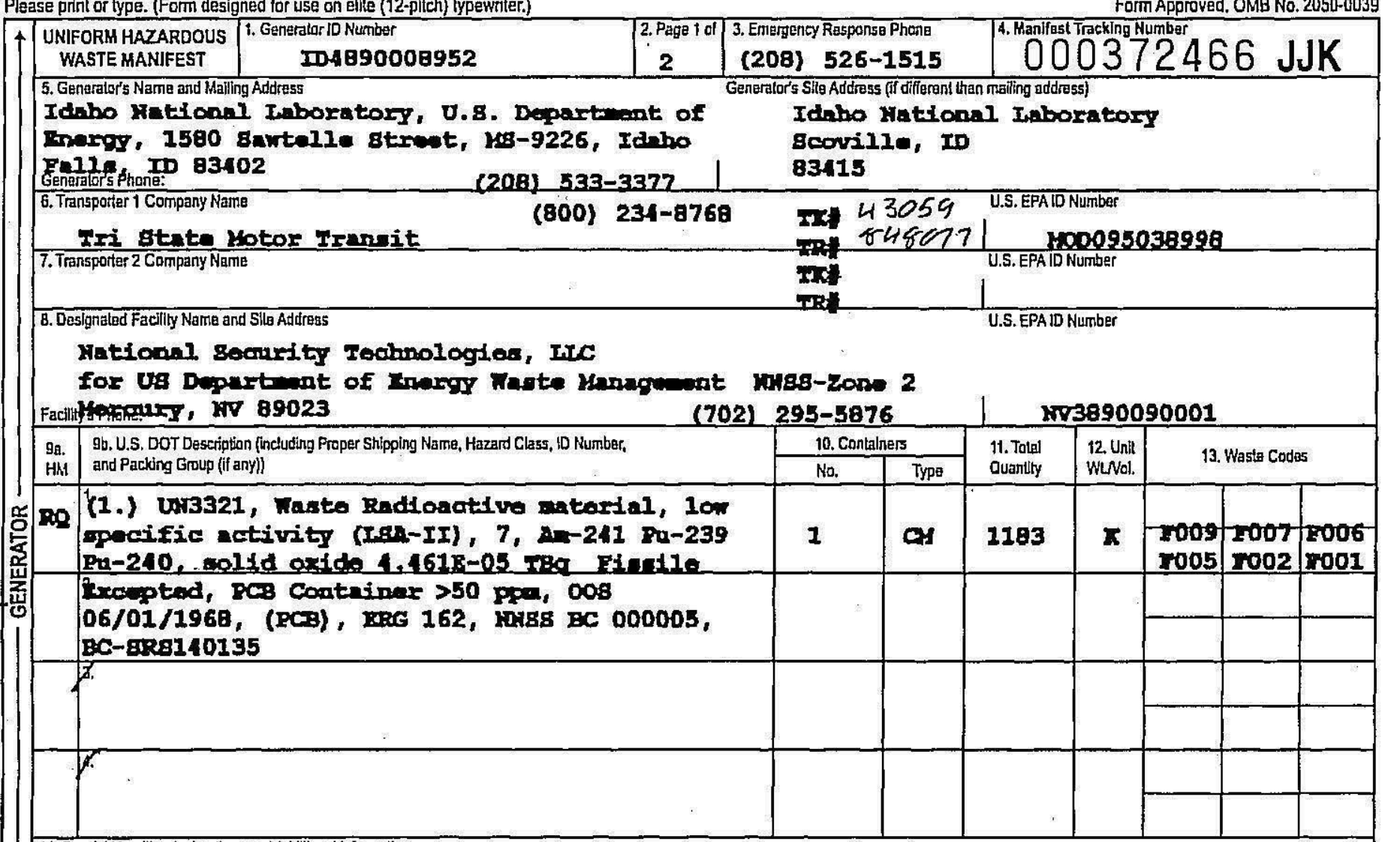

14. Spectal Handling Instructions and Additional Infomation

Raturn signed original within 30 days to: CrI for v.g. poz, Atto: Crnthia Mahlus, Ms

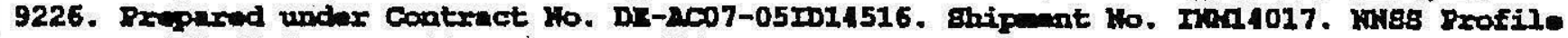

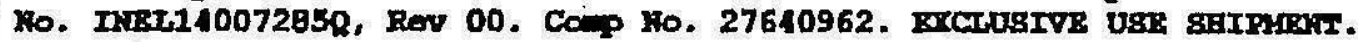

15. GENERATOR'SJOFFEROR'S CERTIFICATION: Theseby dedare that the contents of this constgniment are fully and accurately described above by the proper stipping name, and are classilied, packaged,

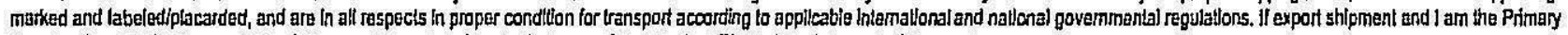
Exporter, I certity that tha contents of this consignument conform to the terms of the altached EPAAcknowiedgrnent of Consent.

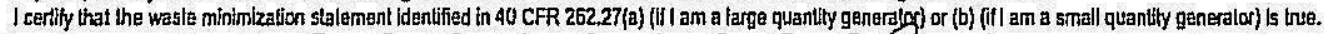

Generalor'b/OIferor's Printed/Typed Name Cynthie Mhlus:

16. Intamational Shipments $\square$ Import to U.S.

Transporter signature (for exports only):

$\square_{\text {Impart to U.S. } \quad \square \text { Export from U.S. }}$

signiof Daka laaving U.S.:

17. Transporter Acknowfedgmant of Receipt of Mlateials

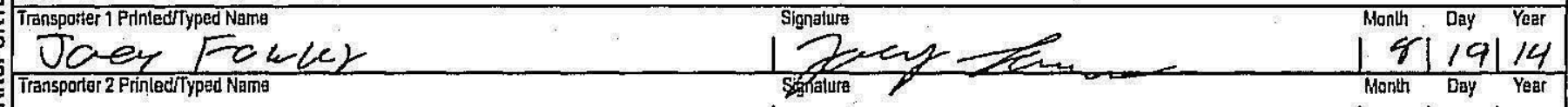

18. Discrepangy

16в. Discrepancy Indication Spac

tab. Altemale Facility (or Ganeratif)

A 202014

Faciitit's Phone:

BY:

$C$

18c. Signature of Altemale Facility (or Generalor)

19. Hazarogus Waste Repart Management Method Codes (1.en, codes for hazardous wasla traatment, disposal, and recycling systems)

1. H[32 $]^{2}$

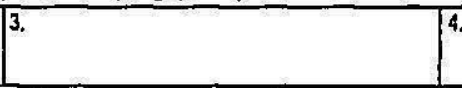

20. Designated Facillty Owner or Operalar. Certification of receipt of hazartous materials covered by the manilest oxpept as nded in ltem 18a 
Please print or type. (Form designed for use on elite (12-pitch) typewriter.)

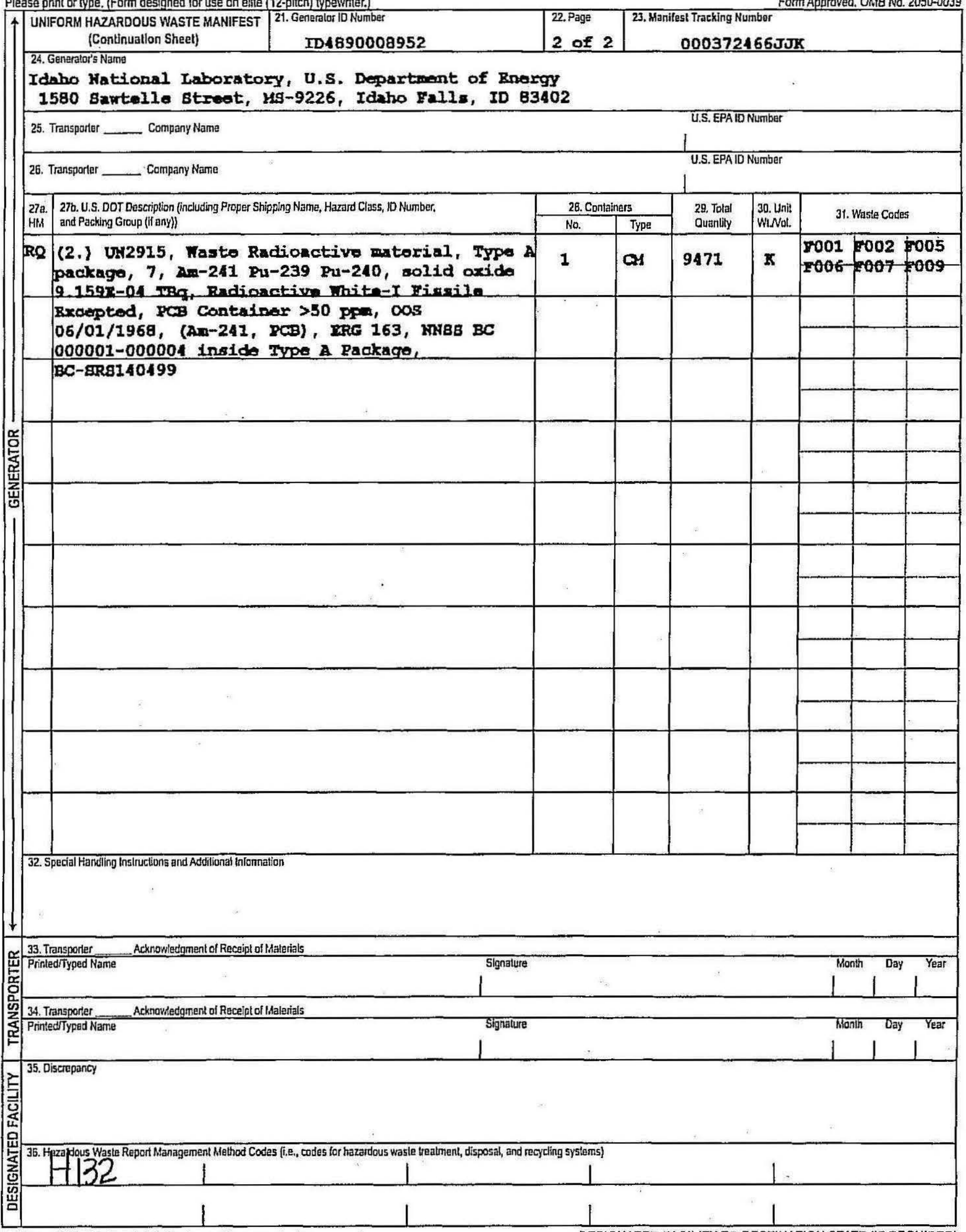




\section{National Security Technologies LLC}

H000-PA-14-0125

August 25, 2014

Stuart D. Gerard

Waste Certification Official

$\mathrm{CH} 2 \mathrm{M} \diamond \mathrm{WG}$ Idaho, LLC

1580 Sawtelle St., MS 9226

Idaho Falls, ID 83402

\section{Subject: CERTIFICATE OF DISPOSAL FOR POLYCHLORINATED BIPHENYL WASTE AT THE NEVADA NATIONAL SECURITY SITE RADIOACTIVE WASTE MANAGEMENT SITE (RWMS)}

Enclosed is the certificate acknowledging disposal of manifested PCB shipment INM14017 in the Mixed Waste Disposal Unit, at the Nevada National Security Site RWMS.

If you have any questions, please contact me at 702-295-2261.

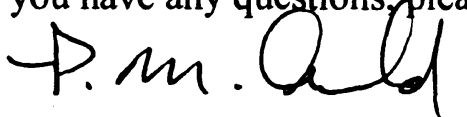

Patrick M. Arnold, Division Manager

Environmental Management

LBG:saq

Enclosure: as stated

cc w/enc.

Correspondence Control

EWO Correspondence

J. T. Carilli, NNSANFO

R. C. Denton, NSTec

R. G. Geisinger, NSTec

L. B. Gregory, NSTec

M. Libidinsky, NNSA/NFO

C. P. Moke, NSTec

K. M. Small, NNSA/NFO

K. C. Tanaka, NSTec

A. V. Tauber, NNSA/NFO

R. A. Wagner, NSTec

\section{National Security Technologies, LLC Vision - Service - Partnership wuw.NSTeC.Com}


NSTec

Form

National Security Technologies LLC

For U.S. Department of Energy

Waste Management

Nevada National Security Site - Zone 2

Mercury, NV 89023

EPA ID NV3890090001

This Certificate acknowledges that the following shipment(s) of manifested POLYCHLORINATED BIPHENYL (PCB) waste have been disposed at the Nevada National Security Site Radioactive Waste Management Site.

\begin{tabular}{|c|c|c|c|c|}
\hline $\begin{array}{c}\text { Shipment } \\
\text { Number }\end{array}$ & $\begin{array}{c}\text { Uniform Hazardous Waste } \\
\text { Manifest Number }\end{array}$ & Date(s) of Disposal & Volume $\mathbf{F t}^{\mathbf{3}}\left(\mathbf{m}^{\mathbf{3}}\right)$ & Disposal Process \\
\hline INM14017 & $000372466 J J K$ & $08 / 20 / 2014$ & $405.06(11.47)$ & Landfill \\
\hline & & & & \\
\hline & & & & \\
\hline & & & & \\
\hline
\end{tabular}

Under civil and criminal penalties of law for the making or submission of false or fraudulent statements or representations (18 U.S.C. 1001 and 15 U.S.C. 2615), I certify that the information contained in or accompanying this document is true, accurate, and complete.

As to the identified section(s) of this document for which I cannot personally verify truth and accuracy, I certify as the company official having supervisory responsibility for the persons who, acting under my direct instructions, made the verification that this information is true, accurate, and complete.
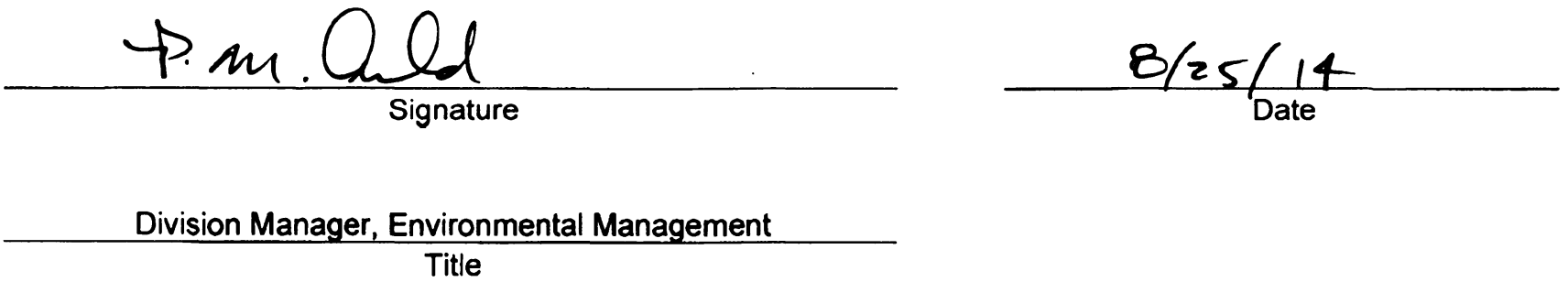

\section{Instructions:}

Shipment Number - enter shipment number from LWIS database.

Uniform Hazardous Waste Manifest Number - enter number from UHWM provided by generator.

Date of Disposal - enter date waste was placed in disposal cell.

Volume - enter shipment volume in cubic feet and equivalent cubic meters in parenthesis.

Disposal Process - enter Landfill.

National Security Technologies, LLC

Vision - Service - Partnership

www.NSTec.com

P.O. Box 98521, Las Vegas, NV 89193-8521

2621 Losee Road, N. Las Vegas, NV 89030-4129 


\section{$\sqrt{1}$}

Please print or type. (Form designed for use on elite (12-pilch) typewiter.)

4 UNIFORM HAZARDOUS 1 . Generalor ID Number

WASTE MANIFEST

ID4890000952

5. Generalor's Name and Maling Address

Idabo National Inboratory, U.8. Departant of

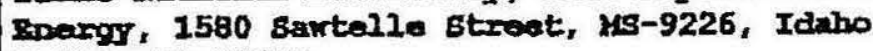

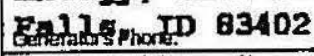

6. Trensporler 1 Company Name

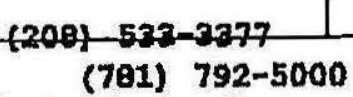

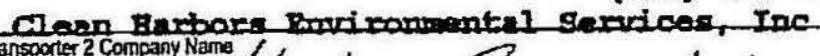

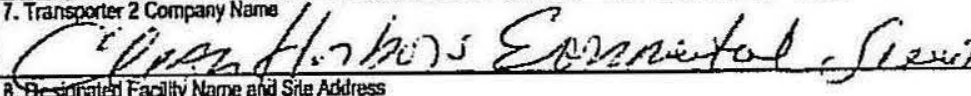

(208) 526-1515

000372483 JJK Gencrator's Sia Address (d ditlerent tratan maling address)

Idaho Hational tuboratory

Bcoville, ID

83115

Clean Barbors Burimonneal (Grasay Kountain) HC

3 miles zest 7 wiles North of axit 19 off I-80 Facititelinive, OS 84029

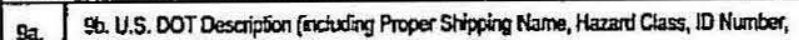
HM and Pading Group (il anyi)

(1.) Hon-RCRN/Kon-DOr Regulated Materiul

Urureod Gronse 20 CAI, Ca118077, BC-KREF140061

(135) $684-8915$

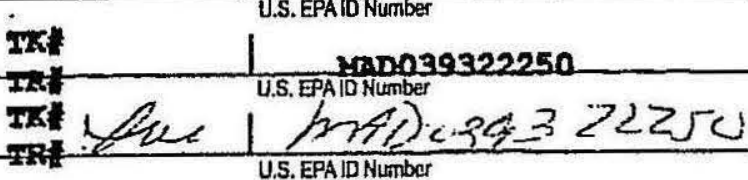

\section{(2.) Kon-DOr Regrilated PCBB Contane Dehris} with PCBs >50 Fpom 008 03/19/2014 $55 \mathrm{car}$, CORL 330 月, BC-KREL1 10062

tro

3.

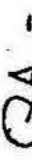

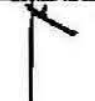

14. Special Handing Instructions and Additonal Inlonnation

Retarn signed original within 30 days to: Cir for U.S. DOs, Attention: Crndi Kahlun,

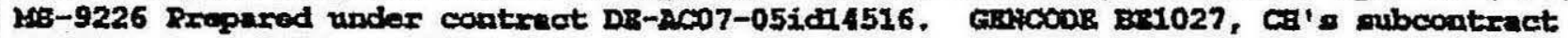
800480 , Loud $406,80 \div 1402206423$.

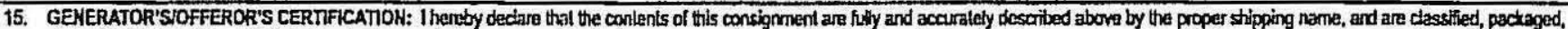

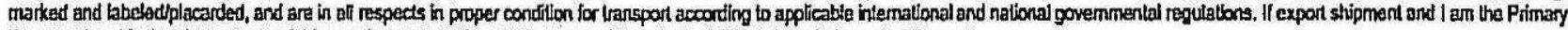
Exporter, I certify that the contents of this consignment conform to the terms of the attached EPA Acknowledgment of Consent.

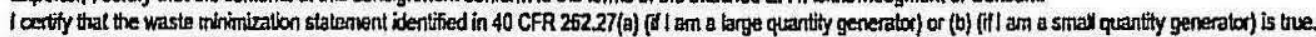

Generalor's Offero's's Printedryped Nane

Iester $\mathrm{B}$ Bhewherd

16. Intemsitoral Shipoments $\square$ import io U.S.

Transporter sigrature (for exports only):

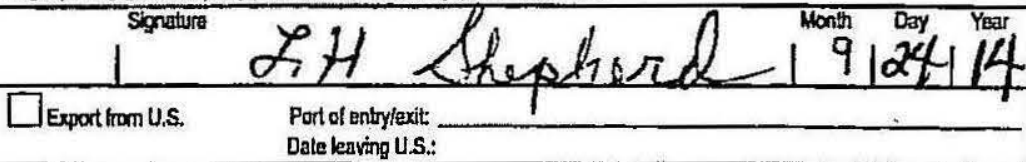

17. Transpoter Acknowledgment of Recelpl of Maletials

(18b. Aliernalo Faciaty (or Generator) 


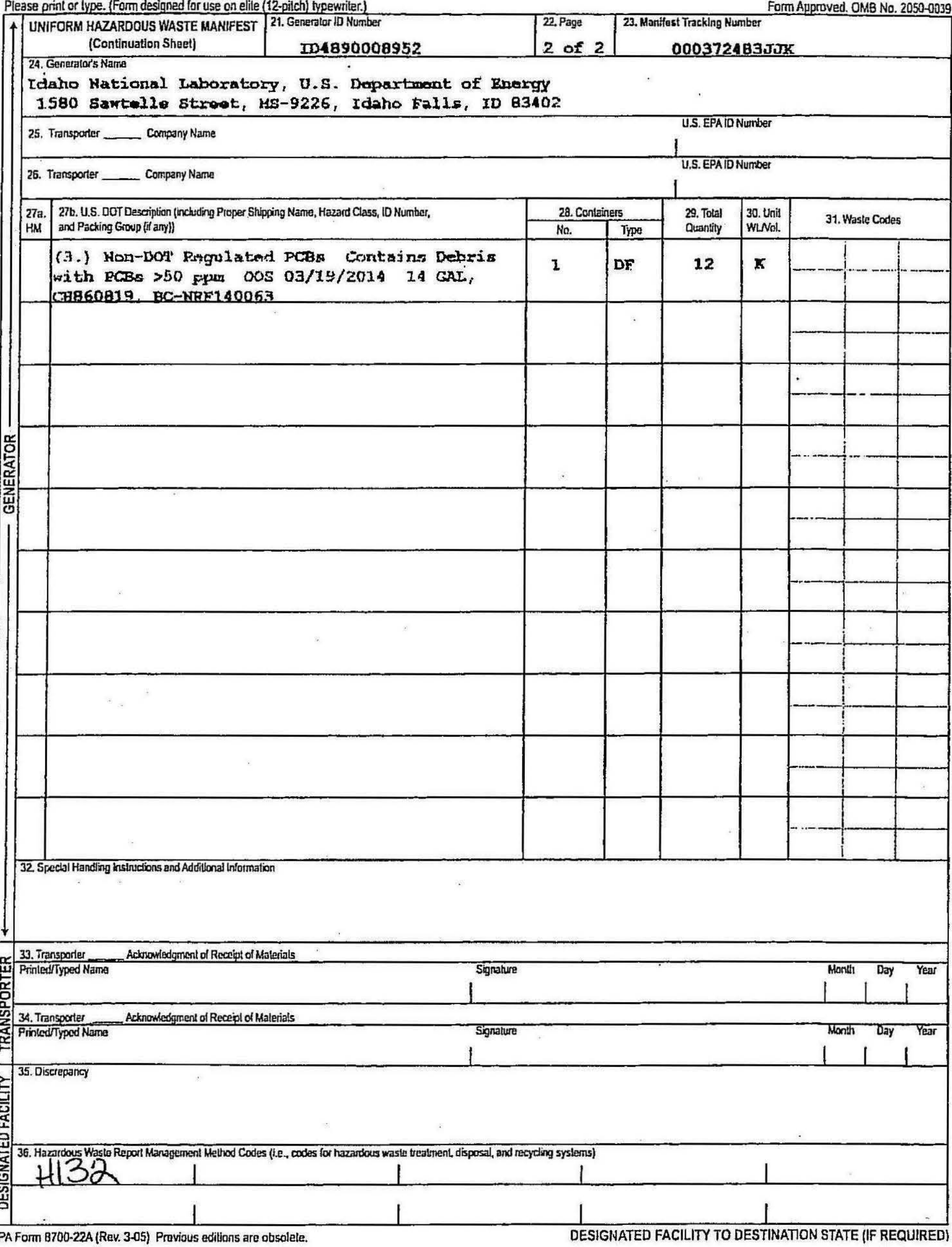




\section{JJK COD}

Cleantarbors'

Clean Harbors Grassy Mountain LLC

3 Miles East 7 Miles North of Knolls

Grantsville UT, 84029

UTD991301748

(435) $884-8900$

CERTIFICATE OF DISPOSAL

Generator Facility Name:

Generator Address:

CH2M-WG Idaho LLC

PO Box 2010 MS 9226

1580 Sawtelle Street

Idaho Falls, ID, 83403
Sales Order\#: $\quad 1402206423$

Date Received: $\quad$ 10/10/2014

Generator Contact Name:

\begin{tabular}{|c|c|c|c|}
\hline \multirow{2}{*}{ Generalor EPA ID: } & NONEREQUIRED & Load \#: & 14011491 \\
\hline & & Manifest \#: & $000372483 \mathrm{JJK}$ \\
\hline
\end{tabular}

\section{Original Date Removed Unit Serial \#/ \\ CHID \# From Service Type Customer ID}

40933208 3/19/2014 DM BC-NRF140062 I

\section{Material Description}

PCB Solids For Landfill
Disposal
Date

$10 / 21 / 2014$
Disposal Facility

Disposal

Landfill
Grassy Mountain, UT Facllity

Under Civil and Criminal Penalties of Law for the making or submission of false or fraudulent statements or representatlons (18 U.S.C. 1001 and 15 U.S.C. 2615), I certify that the information contained in or accompanying this document Is true, accurate, and complete. As to the identified section(s) of this document for which I cannot personally verify truth and accuracy, I certify as the company officlal having supervisory responsiblity for the persons who, acting under my drect Instructions, made the verificalion that this information Is true, accurale, and complete.

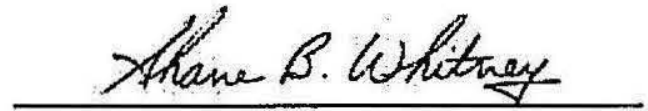

Authorized Agent
Wednesday, October 22, 2014

Date

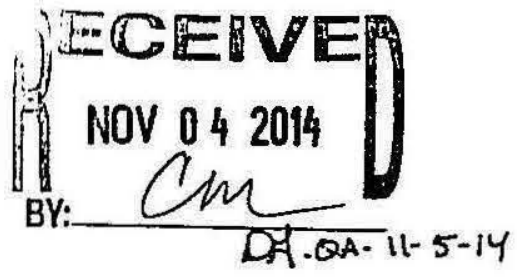

Page 1 of 1 
000372483JJK COD

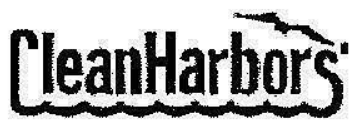

Clean Harbors Grassy Mountain LLC

3 Miles East 7 Miles North of Knolls

Grantsville UT, 84029

UTD991301748

(435) $884-8900$

\section{CERTIFICATE OF DISPOSAL}

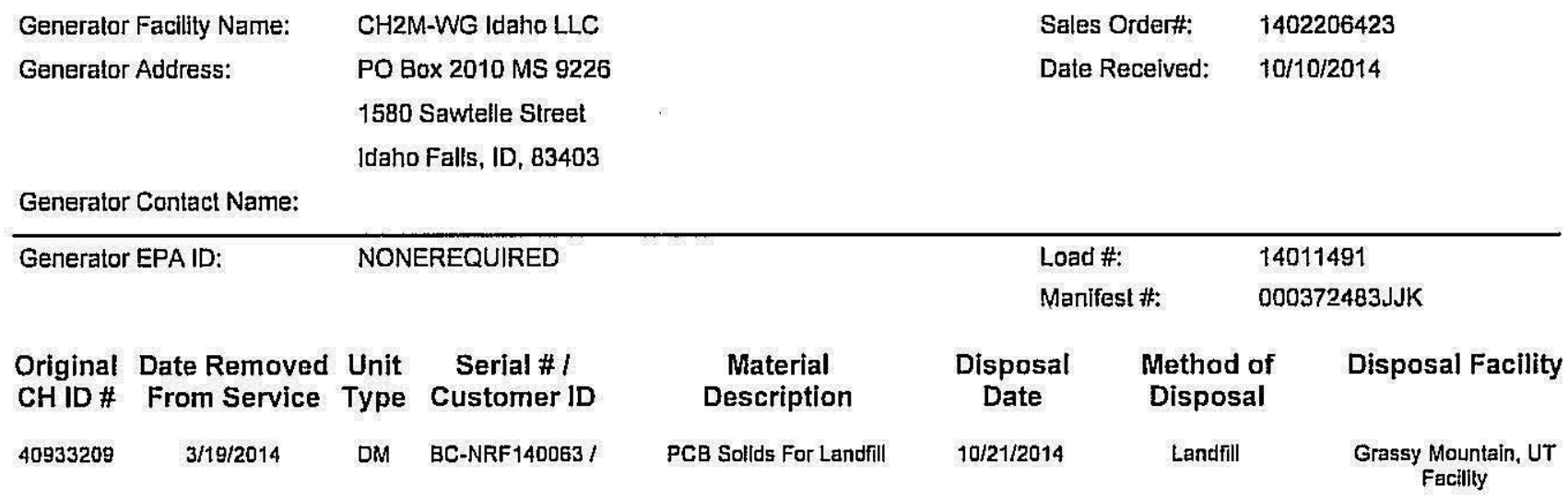

Under Civil and Criminal Penalties of Law for the making or submission of faise or fraudulent statements or representations (18 U.S.C. 1001 and 15 U.S.C. 2615), I certify that the Information contained in or accompanying this document is true, accurate, and complete. As to the identified section(s) of this document for which I cannot personally verify truth and accuracy, I certlfy as the company official having supervisory responsibllity for the persons who, acting under my direct instructlons, made the verification that thls informalton is true, accurate, and complele.

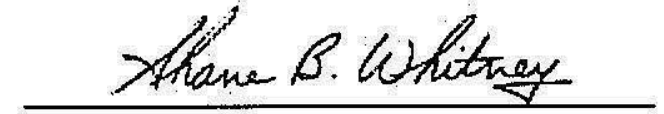

Authorized Agent
Wednesday, October 22, 2014

Date

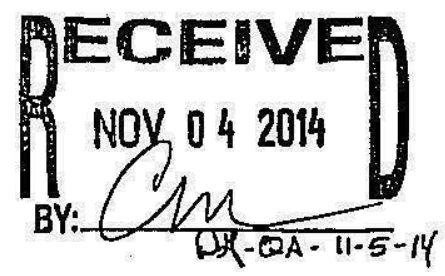

Page 1 of 1 
Please print or type. (Fom designed for use on elite (12-pitch) typewriter.)

\begin{tabular}{|c|c|}
\hline $\begin{array}{l}\text { UNIFORM HAZARDOUS } \\
\text { WASTE MANIFEST }\end{array}$ & $\begin{array}{l}\text { 1. Generator id Number } \\
\text { ID\&890008952 }\end{array}$ \\
\hline
\end{tabular}

5. Generatar's Name and Mailling Address

Idaho Hational Imboratory, 0.3. Department of

Inergy, 1580 sawtelle street, MS-9226, Idaho

Fa1.18 Th 83402

6. Transporter 1 Company Name

rei state Motor rransit

7. Transporter 2 Company Name

8. Designated Faclity Name and Slte Address
2. Page 1 of 3 3. Emergency Response Phone

1 (208) 526-1515

Generator's SlleAddress (if difierent than meiling addrass)

4. Manliest Trackjng Number

Idaho Mationul Iraboratory

Ecoville, ID

83415

(200)-5a2-2077

(600) 234-8768

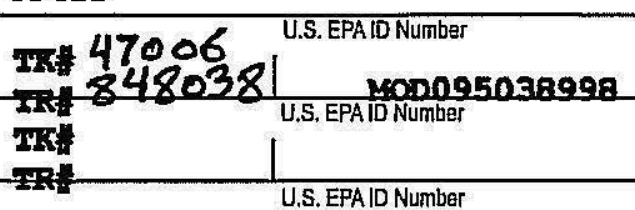

Energysolutions, IIC

US-I80 Exit 49 Tooele County

Facilitghinve, Ur 84029

9a. 9b. U.S. DOT Description (including Proper Shipping Neme, Hazard Class, ID Number,

HM and Packing Group (if any))

x (1.) Uw2910, Radioactive material, excepted package-limited quantity of material, 7

Contal ins PGB bellestes > 500 ppu 0.0 .5

07/14/2014, ERCF 161, BC-MDD140023

(435) $884-0155$

uтp982599898

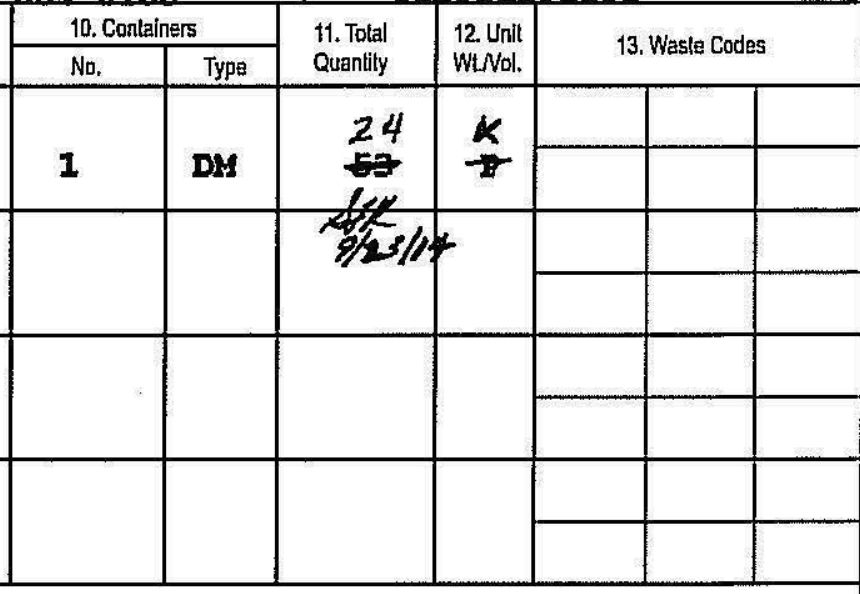

14. Special Handlling Instructicns and Additional Information

Return signed original within 30 dnys to CFI for u.s. DOE, Attn: Cynthia Mahlum, MS 9226. Prepared undor Contract No. DE-AC07-05ID14516. Coup 27642211. 9113-19-0033 EXCGLUSIVE USE BAIPATMT.

Shimanent No.

PRossol

15. GENERATOR'SIOFFEROR'S CERTIFICATION: I hereby declare thal the contents of this conslgnment are fully and accuralely described above by the proper shipping name, and are classified, packaged, marked and labeled/placarded, and are In all respects in proper conditon for transport according to appllcable intemational and national governmenial regulalions. If export shipment and I am the Primary Exporter, I certify that the contents of this consignment conform to the terms of the aitached EPAAcknowtedgment of Consent.

I certify that the wasle minimlzation stalement Identified in 40 CFR 262.27(a) (III Im a lange quantity generator) or (b) (it] an a small quently generator) is true.

Generato's/Offeror's Printed/Typed Name

Stephen Keating

16. International Shipments $\square$ Import to U.S.

Transportar signature (for exporits only):

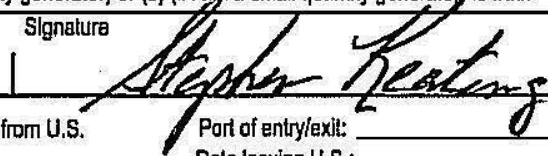

$\square$ Export from U.S.

Date leaving U.S.:

17. Transporter Acknowledgment of Receipt of Materials

Transpoter 1 Printed/Typed Name

Transporler 2 Pinled/Typed Name

Fred Hofmeister

iB, Discrepancy

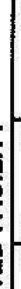

tBa. DIscrepancy In

18b. Alternate Faclity of Gentêf 212014

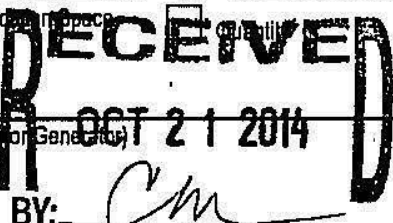

$\square_{\text {Type }}$

$\square$ Residue

Partal Rejection

Month Day Year

Facilliy's Phone:

BY:

U.S. EPAID Number

19. Hazerdous Waste Report Managemenl Method Codes (i.e,, codes for hazardous waste treatmenl, disposal, and recycling systems)

$\mathrm{H} 132$

20. Deslunaled Facility Owner or Operator. Certification of receipt of hazardous materials coverad by the manifast excepl as noted in liem $18 \mathrm{a}$

Printed/yped Name

SIgnature

Monith Day Year

Thomas Wright

$12 \Omega$

$\log |25| 14$

EPAForm 8700-22 (Rev. 3-(fo) Previous editions are obsolete.

DESIGNATED FACILITY TO DESTINATION STATE (IF REQUIRED) 


\title{
000372489JJK COD
}

\section{EMETGI SOL UTIONS}

\section{CERTIFICATE OF DISPOSAL}

\author{
3 miles South, Erit 49 1-80 \\ Clive, Utah 84029 \\ EPA ID UTD 982598898
}

CH2M-WG Idaho of USA DOE, Idaho Falls

This certificate acknowledges that the following manifested shipments have been disposed of as listed below

$\begin{array}{ll}\text { Shipment } & \text { Manilest } \\ \text { 9113 01-0397 } & 72469 \\ 9113-01-0398 & 72479 \\ 9113-18-0061 & 72460 \\ 9113-18-0062 & 72473 \\ 9113190033 & 72489 \\ 911328-0017 & 72453\end{array}$

$\begin{array}{ll}\text { Disposal Date } & \text { Volume (CulE) } \\ 09 / 29 / 2014 & 294 \\ 09 / 29 / 2014 & 12914 \\ 09 / 30 / 2014 & 358 \\ 09 / 30 / 2014 & 53 \\ 09 / 30 / 2014 & 13 \\ 09 / 22 / 2014 & 53\end{array}$

Progess
Landfill
Landfill
Landfitl
Landfill
Landfill
Landiil

DIsposal Locintıpn

Mixed Wasle

Mixed Waste

Mixed Wasle

Mixed Wasle

Mixed Wasle

Mixed Wasle

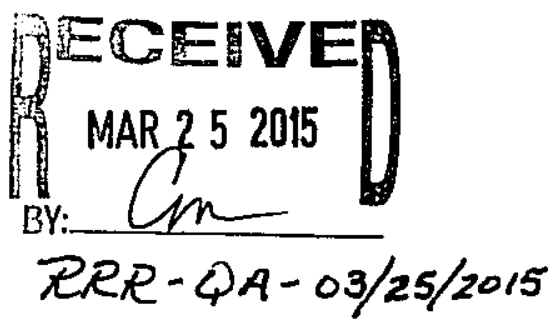

The total volume above represents the cubic feet of waste disposed of at EnergySolutions' Disposal Facilty Landfill Disposal is subject to EnergySolutions' Radioactive Material License, all other applicable licenses, permits and regulations, and the Disposal Agreement

Under civil and criminal penalies of law for the making or submussion of taise or fraudutent statements or representaltons (18 USC 1001 and 15 U S C 2615) I certify that the in/ormation contained in or accompenying this document is true accurate and complete As to the idenification section(s) of this document for which I cannot personally venty truth and accuracy, I certify as the company official having supervisory responsibitity for the persons who acting under my direct instructions, made the verification that this information is true accurate and complete

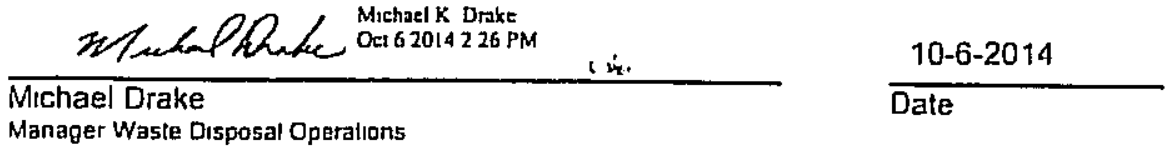




\section{RECORD INFORMATION}

Document ID: $\quad 000372489 J J K ~ C O D$ Revision ID: NA Project Number: 24513

Title/Description: Certificate of Disposal for PCB Container from EnergySolutions

Alternate ID:

Document

Author(s)/Creator(s): $\quad$ Cyndi Mahlum

Document Owner: $\quad$ Travis Myers

Organization Name: $\quad$ P\&T
Date of Record

or Effective Date: 10/6/2014

Date Range From:

(if applicable): To:

\section{RECORDS MANAGEMENT REQUIREMENTS}

Uniform File Code(s): 7252

Disposition Authority: ENV2-d-3

Keywords: $\quad$ COD, PCB container MDD140023, manifest 000372489JJK, 9113-19-0033

Controlled Unclassified Record (Sensitive)

\section{QA RECORD VALIDATION}

Only required for QA records where no other method of validation (signature, initials, etc.) is available on the record itself

Cyndi Mahlum

Validator Print/Type Name

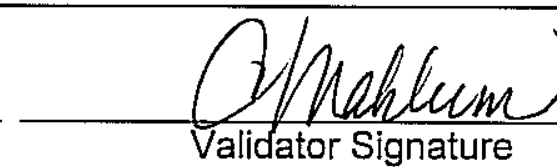

4. SEND/RECEIVE
Name/Date as

Sender:

Acceptance/

Receipt:

\begin{tabular}{|c|c|}
\hline Cyndi Mahlum & $3 / 25 / 15$ \\
\hline Sender Print/Type Name & Date \\
\hline
\end{tabular}




\section{E.YLRG I SOLUTIONS}

\section{CERTIFICATE OF DISPOSAL}

3 iniles South Exit 49, I-80

Clive, Utah 84029

EPA ID UTD982598898

\section{CH2M-WG Idaho of USA DOE, Idaho Falts}

This certıficate acknowledges that the following manifested shipments have been disposed of as listed below

$\begin{array}{llllll}\text { Shlpment } & \text { Manifest } & \text { Disposal.Date } & \text { Volume/Cu/Fu } & \text { Procass } & \text { DisposalLocation } \\ 911307-0103 & 72494 & 11 / 20 / 2014 & 40 & \text { Landfill } & \text { Mixed Waste } \\ 9113-19-0034 & 72275 & 11 / 24 / 2014 & 450 & \text { Landfil } & \text { Mixed Wasle }\end{array}$

40

Landfil
Mixed Waste

Mixed Wasle

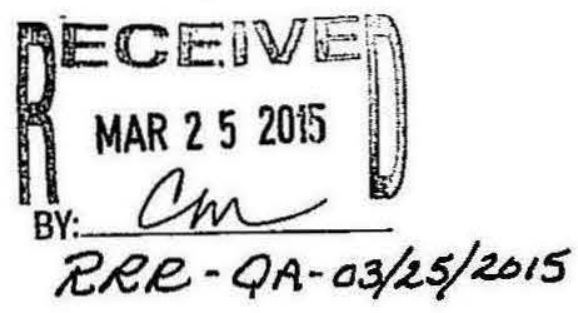

The tolal volume above represents the cubic feet of waste disposed of at EnergySolutions' Disposal Facility Landfill Disposal is subject to EnergySolutions' Radioactive Material License, all other applicable licenses, permits and regulations, and the Disposal Agreement

Under crvil and cruminal penalties of law for the making or submission of false or fraudulent statements or reprasentations (18 U S C 1001 and 15 U S C 2615) I certify that the information conlained in or accompanying this document is inve accurale and complefe As fo the identification section(s) of this document for which I cannot personally venly truth and accuracy i certify as the company official having supervisory responsibility for lhe parsons who acting under my direct instructions made the venlication that this information is true accurate and complete

HTuhal Ahufec Meris $12014541 \mathrm{PM}$
$\begin{aligned} & \text { Michael Drake } \\ & \text { Manager Wasle Disposal Operations }\end{aligned}$$\frac{12-1-14}{\text { Dale }}$




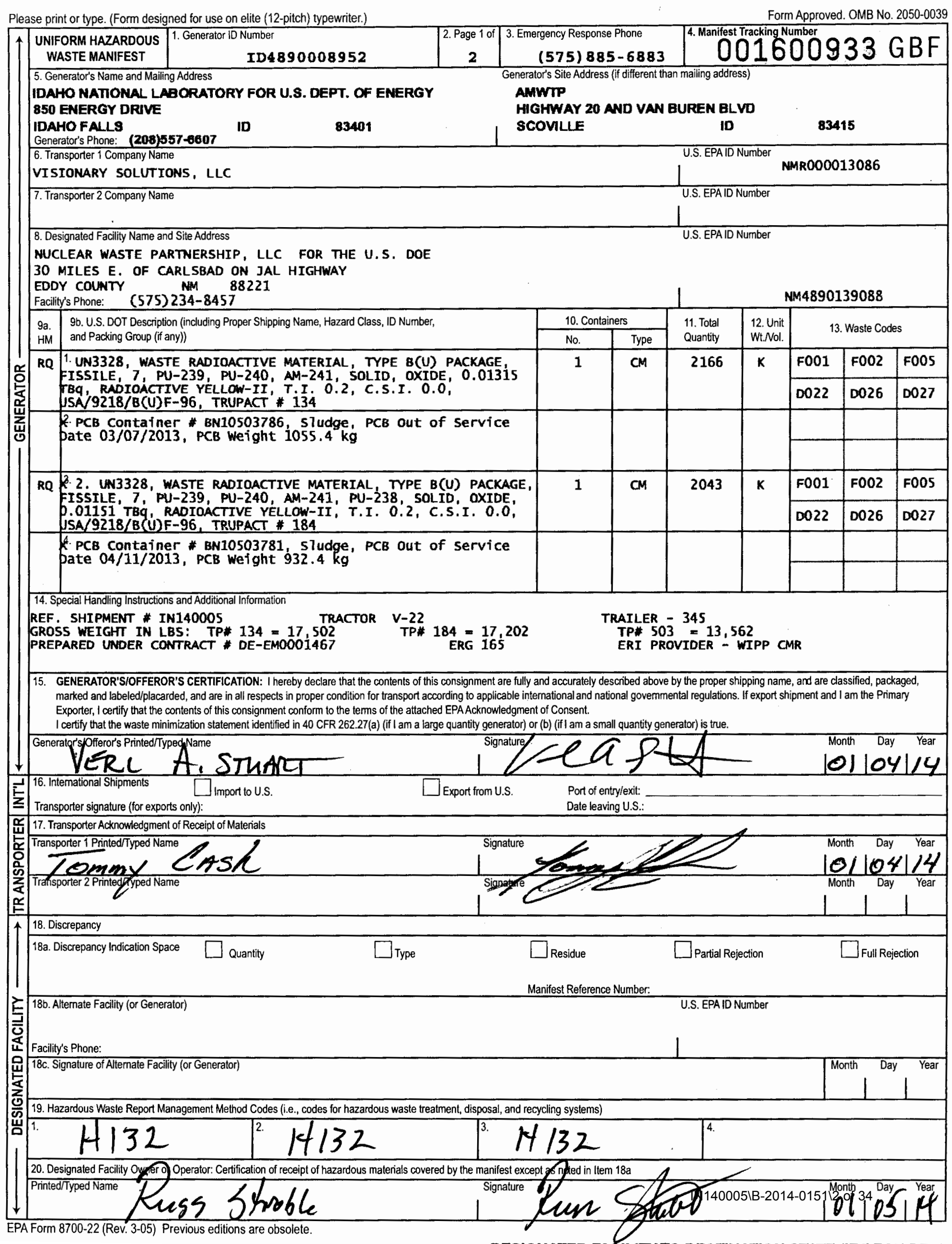


Please print or type. (Form designed for use on elite (12-pitch) typewriter.)

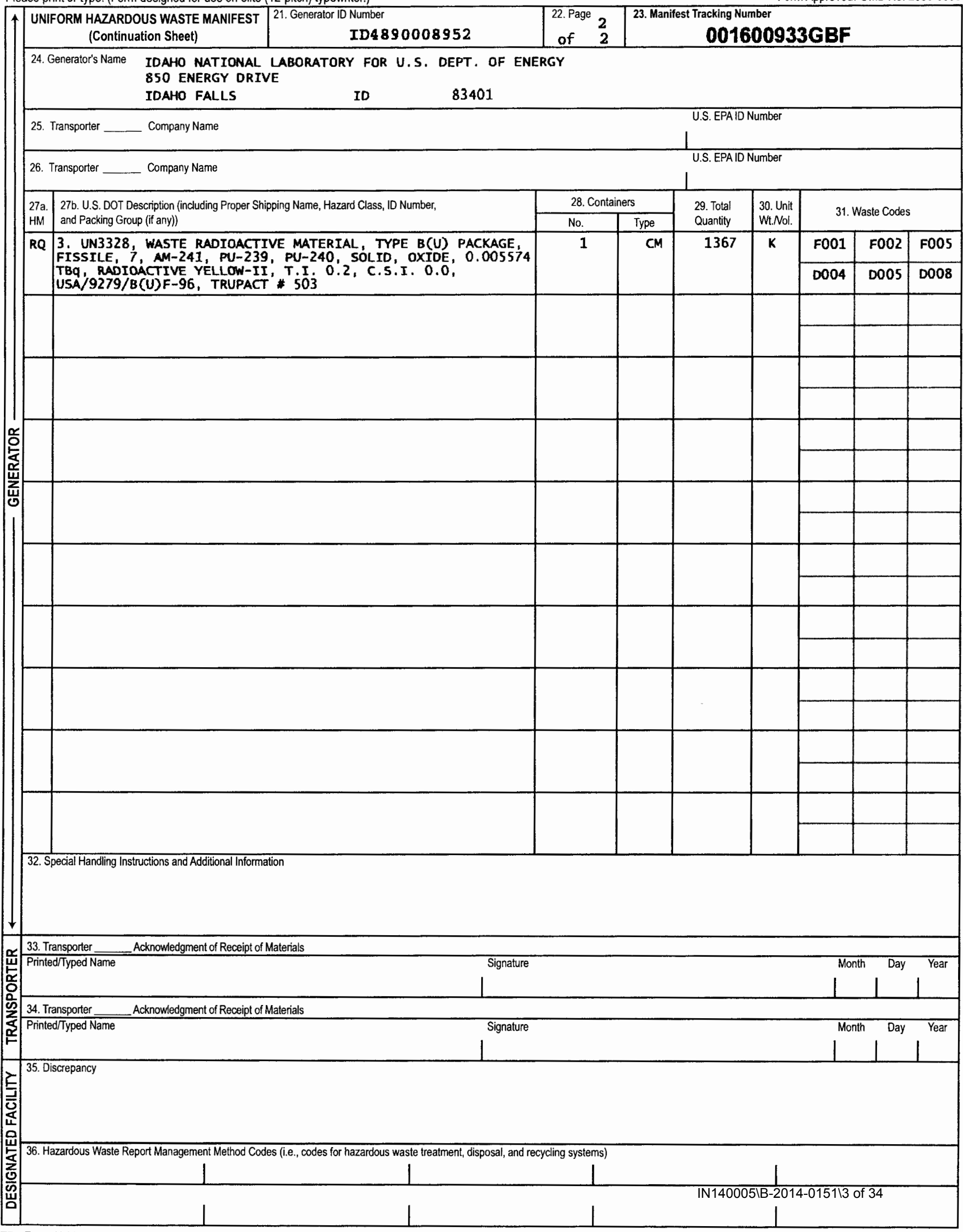




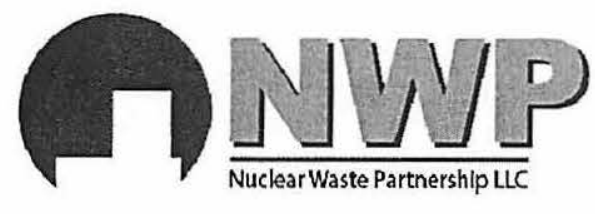

CP:14:02004

UFC:5822.00

AURS-led partnership with B\&W and AREVA

January 24,2014

Ms. R. Hubler, Transportation Manager

Advanced Mixed Waste Treatment Plant/ITG

Idaho National Laboratory

850 Energy Drive, Suite 100

Idaho Falls, ID 83401

SUBJECT: CERTIFICATE OF DISPOSAL FOR POLYCHLORINATED BIPHENYL BEARING WASTE SHIPMENT NUMBERS IN140005, IN140006, IN140008, IN140009, IN140010, IN140012 AND IN140015 EMPLACED AT THE WASTE ISOLATION PILOT PLANT

Dear Ms. Hubler:

In compliance with Title 40 Code of Federal Regulations, Part 761.218 , I certify that the following Polychlorinated Biphenyl (PCB) wastes from your facility have been disposed by emplacement 2,150 feet underground in the Waste Isolation Pilot Plant waste repository.

Disposal Facility:

Waste Isolation Pilot Plant

30 Miles SE of Carlsbad, New Mexico

Eddy County, New Mexico 88220

Environmental Protection Agency (EPA) Identification Number (ID): $\underline{\text { NM4890139088 }}$

Shipping Site's EPA ID: ID4890008952

\begin{tabular}{|c|c|c|c|}
\hline $\begin{array}{c}\text { Shipment } \\
\text { Number }\end{array}$ & $\begin{array}{c}\text { Manifest Tracking } \\
\text { Number }\end{array}$ & $\begin{array}{c}\text { Container } \\
\text { Number }\end{array}$ & $\begin{array}{c}\text { Emplacement } \\
\text { Date }\end{array}$ \\
\hline IN140005 & $001600933 G B F$ & BN10503786 & $1 / 17 / 2014$ \\
\hline IN140005 & $001600933 G B F$ & BN10503781 & $1 / 8 / 2014$ \\
\hline IN140006 & $001600934 G B F$ & BN10501231 & $1 / 10 / 2014$ \\
\hline IN140006 & $001600934 G B F$ & BN10490916 & $1 / 17 / 2014$ \\
\hline IN140008 & $001600936 G B F$ & BN10500615 & $1 / 15 / 2014$ \\
\hline IN140008 & $001600936 G B F$ & BN10501238 & $1 / 15 / 2014$ \\
\hline IN140009 & $001600937 G B F$ & BN10501234 & $1 / 12 / 2014$ \\
\hline IN140009 & $001600937 G B F$ & BN10503780 & $1 / 12 / 2014$ \\
\hline IN140010 & $001600938 G B F$ & $B N 10490915$ & $1 / 12 / 2014$ \\
\hline IN140010 & $001600938 G B F$ & $B N 10503782$ & $1 / 17 / 2014$ \\
\hline IN140012 & $001600940 G B F$ & BN10505064 & $1 / 19 / 2014$ \\
\hline IN140012 & $001600940 G B F$ & BN10505065 & $1 / 17 / 2014$ \\
\hline
\end{tabular}




\begin{tabular}{|c|c|c|c|}
\hline $\begin{array}{c}\text { Shipment } \\
\text { Number }\end{array}$ & $\begin{array}{c}\text { Manifest Tracking } \\
\text { Number }\end{array}$ & $\begin{array}{c}\text { Container } \\
\text { Number }\end{array}$ & $\begin{array}{c}\text { Emplacement } \\
\text { Date }\end{array}$ \\
\hline IN140015 & $001600943 \mathrm{GBF}$ & $\mathrm{BN} 10505057$ & $1 / 21 / 2014$ \\
\hline IN140015 & $001600943 \mathrm{GBF}$ & $\mathrm{BN} 10505066$ & $1 / 21 / 2014$ \\
\hline
\end{tabular}

Under civil and criminal penalties of law for the making or submission of false or fraudulent statements or representations (18 U.S.C. 1001 and 15 U.S.C. 2615), I certify that the information contained in or accompanying this document is true, accurate, and complete.

As to the identified section(s) of this document for which I cannot personally verify truth and accuracy, I certify as the company official having supervisory responsibility for the persons who, acting under my direct instructions, made the verification that this information is true, accurate, and complete.

Should you require further information concerning this certificate of disposal, please contact Mr. R. S. (Bob) Nieman at (575) 234-8141.

Sincerely,

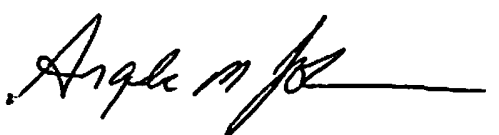

A. M. Johnson, Manager

Transportation Management

RSN/rsn

cc: Shipment portfolio for shipments IN140005, IN140006, IN140008, IN140009, IN140010, IN140012 and IN140015. 
bcc: NWP Distribution
A. M. Johnson
ED
R. U. Carrasco
ED
K. G. Darrah
ED
R. S. Nieman
ED
J.P. Smith
ED

\section{RES Distribution}

S. L. Travis, RES ED 


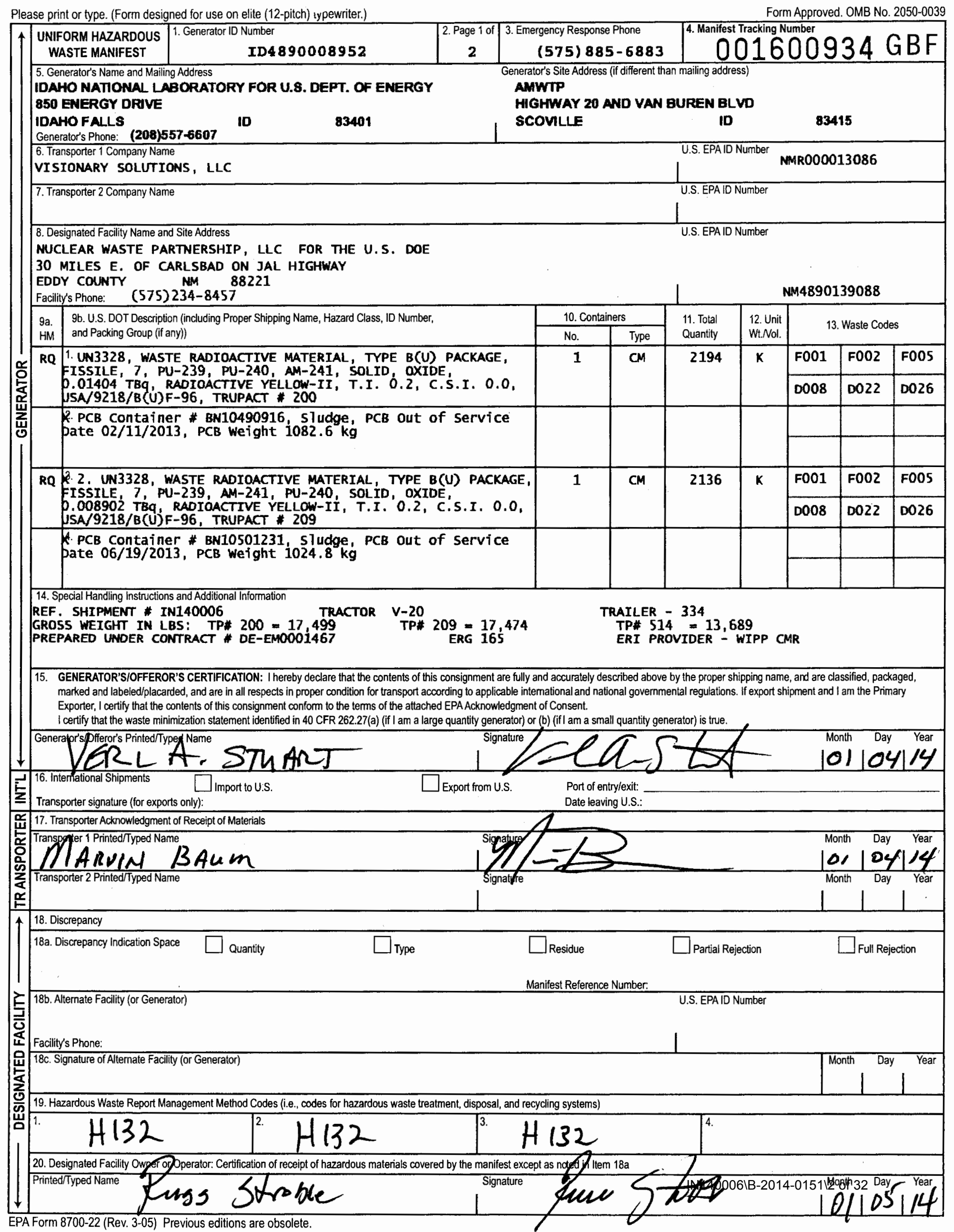


Please print or type. (Form designed for use on elite (12-pitch) typewriter.)

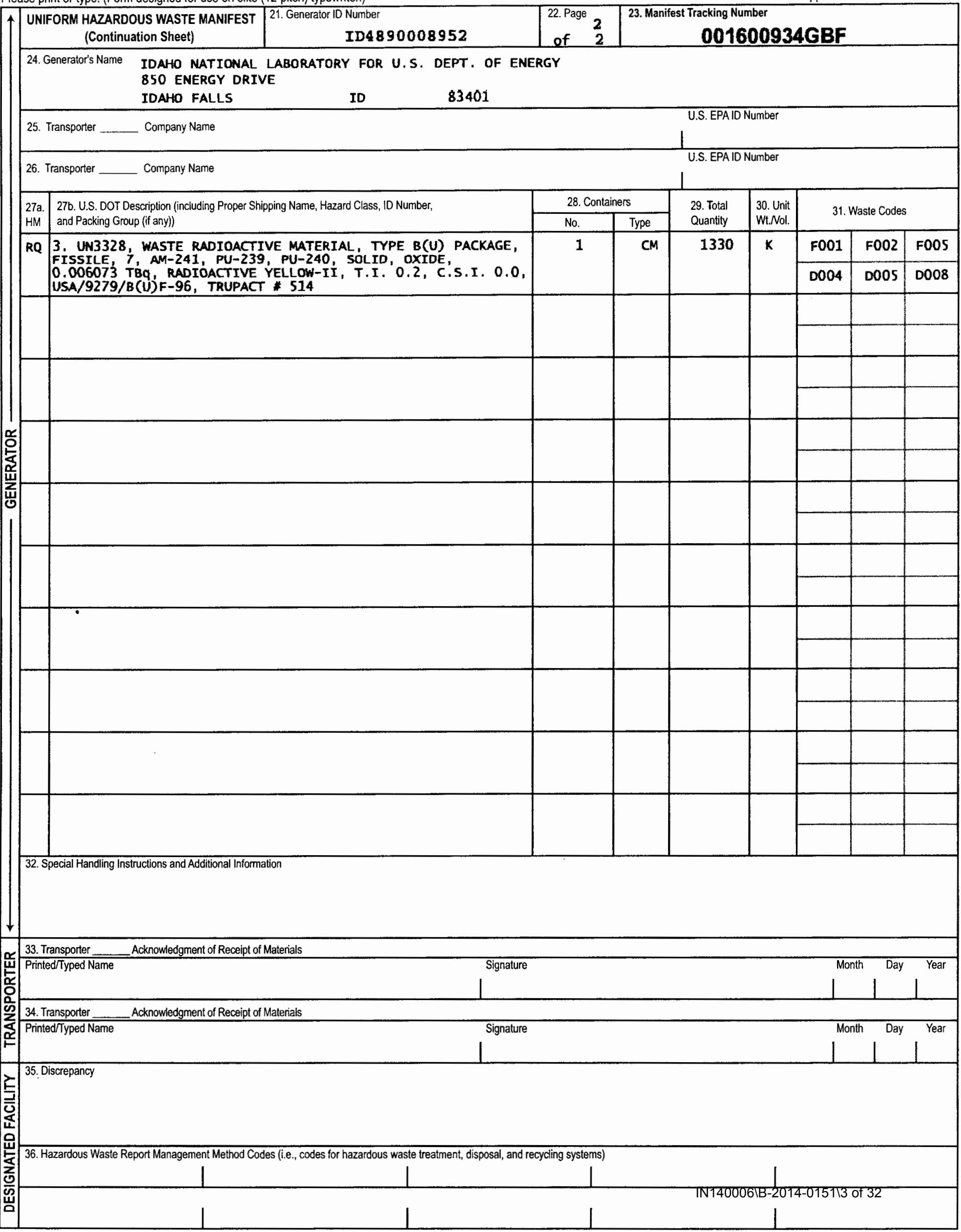




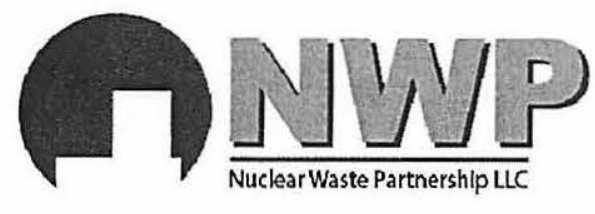

CP:14:02004

UFC:5822.00

AURS-led partnership with B\&W and AREVA

January 24,2014

Ms. R. Hubler, Transportation Manager

Advanced Mixed Waste Treatment Plant/ITG

Idaho National Laboratory

850 Energy Drive, Suite 100

Idaho Falls, ID 83401

SUBJECT: CERTIFICATE OF DISPOSAL FOR POLYCHLORINATED BIPHENYL BEARING WASTE SHIPMENT NUMBERS IN140005, IN140006, IN140008, IN140009, IN140010, IN140012 AND IN140015 EMPLACED AT THE WASTE ISOLATION PILOT PLANT

Dear Ms. Hubler:

In compliance with Title 40 Code of Federal Regulations, Part 761.218 , I certify that the following Polychlorinated Biphenyl (PCB) wastes from your facility have been disposed by emplacement 2,150 feet underground in the Waste Isolation Pilot Plant waste repository.

Disposal Facility:

Waste Isolation Pilot Plant

30 Miles SE of Carlsbad, New Mexico

Eddy County, New Mexico 88220

Environmental Protection Agency (EPA) Identification Number (ID): $\underline{\text { NM4890139088 }}$

Shipping Site's EPA ID: ID4890008952

\begin{tabular}{|c|c|c|c|}
\hline $\begin{array}{c}\text { Shipment } \\
\text { Number }\end{array}$ & $\begin{array}{c}\text { Manifest Tracking } \\
\text { Number }\end{array}$ & $\begin{array}{c}\text { Container } \\
\text { Number }\end{array}$ & $\begin{array}{c}\text { Emplacement } \\
\text { Date }\end{array}$ \\
\hline IN140005 & $001600933 G B F$ & BN10503786 & $1 / 17 / 2014$ \\
\hline IN140005 & $001600933 G B F$ & BN10503781 & $1 / 8 / 2014$ \\
\hline IN140006 & $001600934 G B F$ & BN10501231 & $1 / 10 / 2014$ \\
\hline IN140006 & $001600934 G B F$ & BN10490916 & $1 / 17 / 2014$ \\
\hline IN140008 & $001600936 G B F$ & BN10500615 & $1 / 15 / 2014$ \\
\hline IN140008 & $001600936 G B F$ & BN10501238 & $1 / 15 / 2014$ \\
\hline IN140009 & $001600937 G B F$ & BN10501234 & $1 / 12 / 2014$ \\
\hline IN140009 & $001600937 G B F$ & BN10503780 & $1 / 12 / 2014$ \\
\hline IN140010 & $001600938 G B F$ & $B N 10490915$ & $1 / 12 / 2014$ \\
\hline IN140010 & $001600938 G B F$ & $B N 10503782$ & $1 / 17 / 2014$ \\
\hline IN140012 & $001600940 G B F$ & BN10505064 & $1 / 19 / 2014$ \\
\hline IN140012 & $001600940 G B F$ & BN10505065 & $1 / 17 / 2014$ \\
\hline
\end{tabular}




\begin{tabular}{|c|c|c|c|}
\hline $\begin{array}{c}\text { Shipment } \\
\text { Number }\end{array}$ & $\begin{array}{c}\text { Manifest Tracking } \\
\text { Number }\end{array}$ & $\begin{array}{c}\text { Container } \\
\text { Number }\end{array}$ & $\begin{array}{c}\text { Emplacement } \\
\text { Date }\end{array}$ \\
\hline IN140015 & $001600943 \mathrm{GBF}$ & $\mathrm{BN} 10505057$ & $1 / 21 / 2014$ \\
\hline IN140015 & $001600943 \mathrm{GBF}$ & $\mathrm{BN} 10505066$ & $1 / 21 / 2014$ \\
\hline
\end{tabular}

Under civil and criminal penalties of law for the making or submission of false or fraudulent statements or representations (18 U.S.C. 1001 and 15 U.S.C. 2615), I certify that the information contained in or accompanying this document is true, accurate, and complete.

As to the identified section(s) of this document for which I cannot personally verify truth and accuracy, I certify as the company official having supervisory responsibility for the persons who, acting under my direct instructions, made the verification that this information is true, accurate, and complete.

Should you require further information concerning this certificate of disposal, please contact Mr. R. S. (Bob) Nieman at (575) 234-8141.

Sincerely,

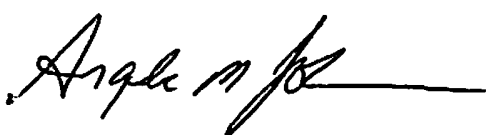

A. M. Johnson, Manager

Transportation Management

RSN/rsn

cc: Shipment portfolio for shipments IN140005, IN140006, IN140008, IN140009, IN140010, IN140012 and IN140015. 
bcc: NWP Distribution
A. M. Johnson
ED
R. U. Carrasco
ED
K. G. Darrah
ED
R. S. Nieman
ED
J.P. Smith
ED

\section{RES Distribution}

S. L. Travis, RES ED 
Please print or type. (Form designed for use on elite (12-pitch) typewriter.)

$\uparrow$\begin{tabular}{l|l|l|}
$\begin{array}{l}\text { UNIFORM HAZARDOUS } \\
\text { WASTE MANIFEST }\end{array}$ & $\begin{array}{l}\text { 1. Generator ID Number } \\
\text { ID4890008952 }\end{array}$ \\
\hline $\begin{array}{l}\text { 5. Generato's Name and Mailing Address } \\
\text { IOAHO NATIONAL LABORATORY FOR U.8. DEPT. OF ENERGY } \\
\text { 850 ENERGY DRIVE } \\
\text { IDAHOFALL8 }\end{array}$ & ID
\end{tabular}

Generator's Phone: (208)557-6607

6. Transporter 1 Company Name

CAST SPECIALTY TRANSPORTATION INC.

7. Transporter 2 Company Name

\begin{tabular}{l|c|c|}
\hline 2. Page 1 of & $\begin{array}{c}\text { 3. Emergency Response Phone } \\
(575) 885-6883\end{array}$ & 4. Manifest Trac \\
Generator's Site Address fif different than mailing address) \\
AMWTP \\
HIGHWAY 20 AND VAN BUREN BLVD \\
SCOVLLE
\end{tabular}

Form Approved. OMB №. 2050-0039

8. Designated Facility Name and Site Aodress

NUCLEAR WASTE PARTNERSHIP, LLC, FOR THE U.S. DOE

30 MILES E. OF CARLSBAD ON JAL HIGHWAY

EDDY COUNTY NM 88221

Facility's Phone: (575) 234-8457

\begin{tabular}{|c|c|c|}
\hline ga. & $9 b$. U.S. DOT Description (including Proper Shipping Name, Hazard Class, ID Number, \\
\hline
\end{tabular}

HM and Packing Group (if any))

RQ 1. UN3328، WASTE RADTOACTIVE MATERIAL, TYPE B(U) PACKAGE

EISSILE, 7, PU-239, AM-241, PU-240, SOLID, OXIDE, 0.007391

rBq, RADIOACTIVE YELLOW-II, T.I. 0.2, C.S.I. 0.0,

$15{ }^{\prime} / 9218 / B(U)$ F-96, TRUPACT * 157

2. PCB container *, BN10501238, sludge, PCB out of service pate 05/13/2013, PCB Weight $1052.2 \mathrm{~kg}$

RQ 2. 2. UN3328, WASTE RADTOACTIVE MATERIAL, TYPE B(U) PACKAGE EISSILE, 7, PU-239, AM-241, PU-240, SOLID, OXIDE, 0.007801 Bq, RADTOACTIVE YELLON-II, T.I. 0.2, C.S.I, 0.0, USA/9218/B(U)F-96, TRUPACT * 166

4. PCB Container \#, BN10500615 5iudge, PCB out of service pate 06/06/2013," РCB Welght $996.8 \mathrm{~kg}$

14. Special Handling instructions and Additional Information

SHIPMENT * IN140008 TRACTOR - C - 32

GROSS WEIGHT IN LBS:

PREPARED UNDER CONTRACT * DE-EM0001467

\author{
TRAILER - 358 \\ TP\# $166=17,476$
}

ERG - 165

\begin{tabular}{|c|c|c|c|c|c|c|}
\hline & & \multicolumn{5}{|c|}{ MM4890139088 } \\
\hline \multicolumn{2}{|c|}{ 10. Containers } & \multirow{2}{*}{$\begin{array}{l}\text { 11. Total } \\
\text { Quantity }\end{array}$} & \multirow{2}{*}{$\begin{array}{l}\text { 12. Unit } \\
\text { Wi. } \mathrm{Nol} \text {. }\end{array}$} & \multirow{2}{*}{\multicolumn{3}{|c|}{ 13. Waste Codes }} \\
\hline No. & Type & & & & & \\
\hline \multirow[t]{2}{*}{1} & \multirow[t]{2}{*}{$\mathrm{CM}$} & \multirow[t]{2}{*}{2163} & \multirow[t]{2}{*}{$K$} & F001 & F002 & FOOS \\
\hline & & & & 0022 & 0026 & $\mathrm{D} 027$ \\
\hline & & & & & & \\
\hline & & & & & & \\
\hline \multirow[t]{2}{*}{1} & \multirow[t]{2}{*}{ CM } & \multirow[t]{2}{*}{2108} & \multirow[t]{2}{*}{$k$} & F001 & F002 & F005 \\
\hline & & & & D022 & D026 & D027 \\
\hline & & & & & & \\
\hline & & & & & & \\
\hline
\end{tabular}

$\left.\right|_{\text {U.S. EPAID Number }} ^{\text {U.S. EPAID Number COR000206722 }}$

83415

1600936 G B F SCOVLLE

ID

TP* $507=13,613$

ERI PROVIDER - WIPP CMR

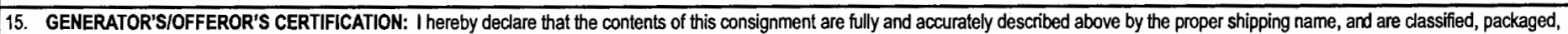
marked and labeled/placarded, and are in all respects in proper condition for transport according to applicable intemational and national governmental regulations. If export shipment and I am the Primary Exporter, I certify that the contents of this consignment conform to the terms of the attached EPAAcknowledgment of Consent.

I certify that the waste minimization statement identified in 40 CFR 262.27(a) (if I am a large quantity generator) or (b) (if I am a small quantity generator) is true.

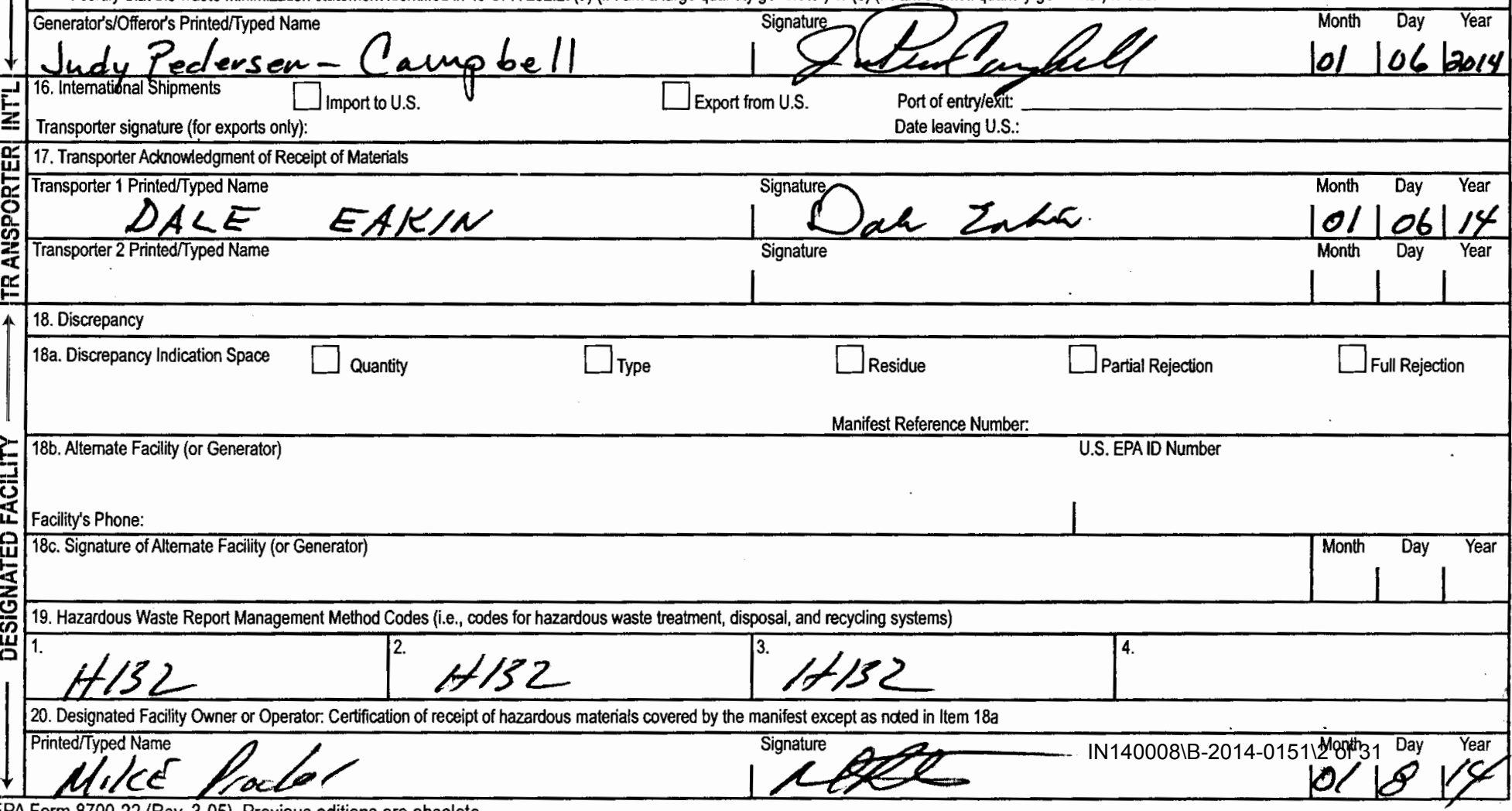


Please print or type. (Form designed for use on elite (12-pitch) typewriter.)

Form Approved. OMB No. 2050-0039

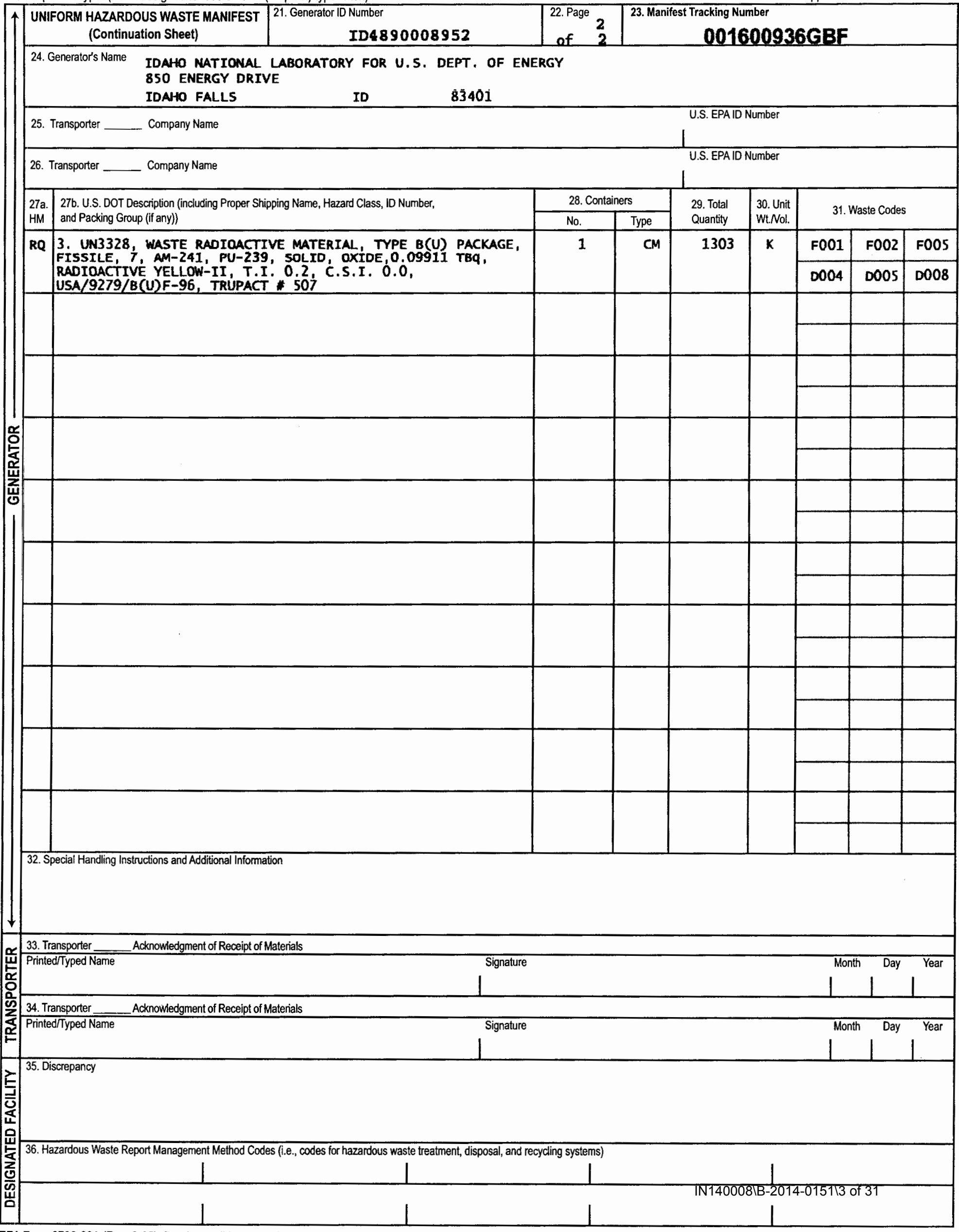




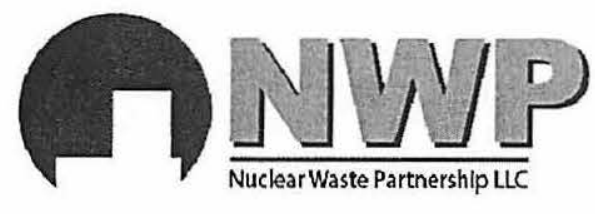

CP:14:02004

UFC:5822.00

AURS-led partnership with B\&W and AREVA

January 24,2014

Ms. R. Hubler, Transportation Manager

Advanced Mixed Waste Treatment Plant/ITG

Idaho National Laboratory

850 Energy Drive, Suite 100

Idaho Falls, ID 83401

SUBJECT: CERTIFICATE OF DISPOSAL FOR POLYCHLORINATED BIPHENYL BEARING WASTE SHIPMENT NUMBERS IN140005, IN140006, IN140008, IN140009, IN140010, IN140012 AND IN140015 EMPLACED AT THE WASTE ISOLATION PILOT PLANT

Dear Ms. Hubler:

In compliance with Title 40 Code of Federal Regulations, Part 761.218 , I certify that the following Polychlorinated Biphenyl (PCB) wastes from your facility have been disposed by emplacement 2,150 feet underground in the Waste Isolation Pilot Plant waste repository.

Disposal Facility:

Waste Isolation Pilot Plant

30 Miles SE of Carlsbad, New Mexico

Eddy County, New Mexico 88220

Environmental Protection Agency (EPA) Identification Number (ID): $\underline{\text { NM4890139088 }}$

Shipping Site's EPA ID: ID4890008952

\begin{tabular}{|c|c|c|c|}
\hline $\begin{array}{c}\text { Shipment } \\
\text { Number }\end{array}$ & $\begin{array}{c}\text { Manifest Tracking } \\
\text { Number }\end{array}$ & $\begin{array}{c}\text { Container } \\
\text { Number }\end{array}$ & $\begin{array}{c}\text { Emplacement } \\
\text { Date }\end{array}$ \\
\hline IN140005 & $001600933 G B F$ & BN10503786 & $1 / 17 / 2014$ \\
\hline IN140005 & $001600933 G B F$ & BN10503781 & $1 / 8 / 2014$ \\
\hline IN140006 & $001600934 G B F$ & BN10501231 & $1 / 10 / 2014$ \\
\hline IN140006 & $001600934 G B F$ & BN10490916 & $1 / 17 / 2014$ \\
\hline IN140008 & $001600936 G B F$ & BN10500615 & $1 / 15 / 2014$ \\
\hline IN140008 & $001600936 G B F$ & BN10501238 & $1 / 15 / 2014$ \\
\hline IN140009 & $001600937 G B F$ & BN10501234 & $1 / 12 / 2014$ \\
\hline IN140009 & $001600937 G B F$ & BN10503780 & $1 / 12 / 2014$ \\
\hline IN140010 & $001600938 G B F$ & $B N 10490915$ & $1 / 12 / 2014$ \\
\hline IN140010 & $001600938 G B F$ & $B N 10503782$ & $1 / 17 / 2014$ \\
\hline IN140012 & $001600940 G B F$ & BN10505064 & $1 / 19 / 2014$ \\
\hline IN140012 & $001600940 G B F$ & BN10505065 & $1 / 17 / 2014$ \\
\hline
\end{tabular}




\begin{tabular}{|c|c|c|c|}
\hline $\begin{array}{c}\text { Shipment } \\
\text { Number }\end{array}$ & $\begin{array}{c}\text { Manifest Tracking } \\
\text { Number }\end{array}$ & $\begin{array}{c}\text { Container } \\
\text { Number }\end{array}$ & $\begin{array}{c}\text { Emplacement } \\
\text { Date }\end{array}$ \\
\hline IN140015 & $001600943 \mathrm{GBF}$ & $\mathrm{BN} 10505057$ & $1 / 21 / 2014$ \\
\hline IN140015 & $001600943 \mathrm{GBF}$ & $\mathrm{BN} 10505066$ & $1 / 21 / 2014$ \\
\hline
\end{tabular}

Under civil and criminal penalties of law for the making or submission of false or fraudulent statements or representations (18 U.S.C. 1001 and 15 U.S.C. 2615), I certify that the information contained in or accompanying this document is true, accurate, and complete.

As to the identified section(s) of this document for which I cannot personally verify truth and accuracy, I certify as the company official having supervisory responsibility for the persons who, acting under my direct instructions, made the verification that this information is true, accurate, and complete.

Should you require further information concerning this certificate of disposal, please contact Mr. R. S. (Bob) Nieman at (575) 234-8141.

Sincerely,

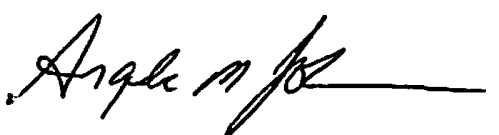

A. M. Johnson, Manager

Transportation Management

RSN/rsn

cc: Shipment portfolio for shipments IN140005, IN140006, IN140008, IN140009, IN140010, IN140012 and IN140015. 
bcc: NWP Distribution
A. M. Johnson
ED
R. U. Carrasco
ED
K. G. Darrah
ED
R. S. Nieman
ED
J.P. Smith
ED

\section{RES Distribution}

S. L. Travis, RES ED 
Please print or type. (Form designed for use on elite (12-pitch) typewriter.)

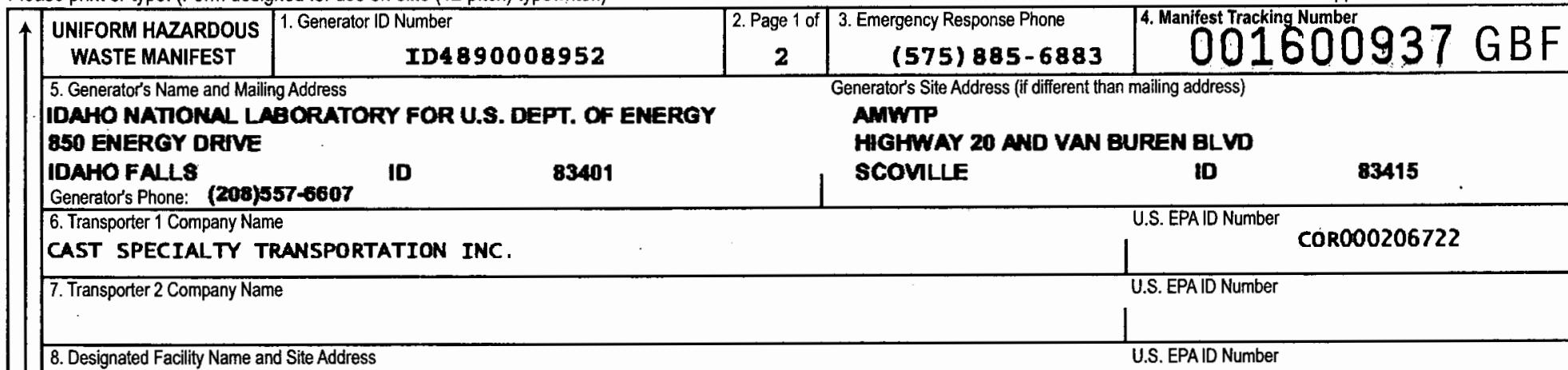

MUCLEAR WASTE PARTNERSHIP, LLC FOR THE U.S. DOE

30 MILES E. OF CARLSBAD ON JAL HIGHWAY

EDDY COUNTY AM BB221

Facility's Phone: (575) 234-8457

9a. 96. U.S. DOT Description (including Proper Shipping Name, Hazard Class, ID Number,

HM and Packing Group (if any))

RQ 1. UA3328, WASTE RADIOACTIVE MATERIAL, TYPE B(U) PACKAGE, =ISSILE, 7, PU-239, AM-241, PU-240, SOLID, OXIDE,

0.008085 TBq, RADIOACTIVE YELLOW-II, T.I. 0.2, C.S.I.0.0 ISA $9218 / B(U) F-96$, TRUPACT\# 136

2. PCB Contalner \# BN10501234, sludge, PCB out of service late $06 / 10 / 2013$, PCB wefght $1028 \mathrm{~kg}$

RQ 3.2. UN3328, WASTE RADIOACTIVE MATERIAL, TYPE B(U) PACKAGE, ISSILE, 7, PU-239, AM-241, PU-240, PU-238, SOLID, OXIDE, 0.02099 TBg RADTOACTIVE YELLOW-II, T.I. 0.2, C.S.I. 0.0. 15A/9218/B(U)F-96, TRUPACT\# 193

4. PCB Container \# BN10503780, sludge, PCB out of service date $02 / 20 / 2013$, РСB weight $981.6 \mathrm{~kg}$

14. Special Handling Instructions and Additional Information

SHIPMENT \# IN140009 TRAC - C - 40

GROSS WEIGHT IN LBS: TP* $136=17,947$

PREPARED UNDER CONTRACT * DE-EMOOO1467

TP\# $193=17,360^{\text {TRLR }}-325$ TP* $513=13,543$

ERG * 165 ERI PROVIDER - WIPP CMR

NM4890139088

\begin{tabular}{|c|c|c|c|c|c|c|}
\hline & & \multicolumn{5}{|c|}{ NM4890139088 } \\
\hline \multicolumn{2}{|c|}{ 10. Containers } & 11. Total & 12. Un & \multirow{2}{*}{\multicolumn{3}{|c|}{ 13. Waste Codes }} \\
\hline No. & Type & Quantity & Wt:No & & & \\
\hline \multirow[t]{2}{*}{1} & \multirow[t]{2}{*}{$\mathrm{CM}$} & \multirow[t]{2}{*}{2139} & \multirow[t]{2}{*}{ K } & F001 & F002 & F005 \\
\hline & & & & D008 & D022 & D026 \\
\hline & & & & & & \\
\hline \multirow[t]{2}{*}{1} & \multirow[t]{2}{*}{$\mathrm{CM}$} & \multirow[t]{2}{*}{2093} & \multirow[t]{2}{*}{ K } & F001 & F002 & F005 \\
\hline & & & & 0008 & D022 & 0026 \\
\hline & & & & & & \\
\hline & & & & & & \\
\hline
\end{tabular}

15. GENERATOR'S/OFFEROR'S CERTIFICATION: I hereby declare that the contents of this consignment are fully and accurately described above by the proper shipping name, and are classified, packaged marked and labeled/placarded, and are in all respects in proper condition for transport according to applicable international and national governmental regulations. If export shipment and I am the Primary

Exporter, I certify that the contents of this consignment conform to the terms of the attached EPAAcknowledgment of Consent.

I certify that the waste minimization statement identified in 40 CFR 262.27(a) (if I am a large quantity generator) or (b) (if I am a small quantity generator) is true.

Generator's/Offero's's Printed/Typed Name

Richard A. NeSmith

16. International Shipments
Transporter signature (for exports only):

Signature

A.

it:

Port of entrylexit:

17. Transporter Acknowledgment of Receipt of Materials

Transporter 1 Printed/Typed Name

Lewaed temendses

Transporter 2 Printed/Typed Name

$\square$ Export from U.S.

18. Discrepancy

18a. Discrepancy Indication Space

$\square$ Quantity $\quad \square$ Type

$\square$ Residue

Partial Rejection

Month Day Year

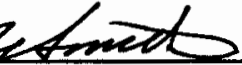

$011071 / 4$

18b. Alternate Facility (or Generator)

Manifest Reference Number:

Facility's Phone:

18c. Signature of Alternate Facility (or Generator)

19. Hazardous Waste Report Management Method Codes (i.e., codes for hazardous waste treatment, disposal, and recycling systems)
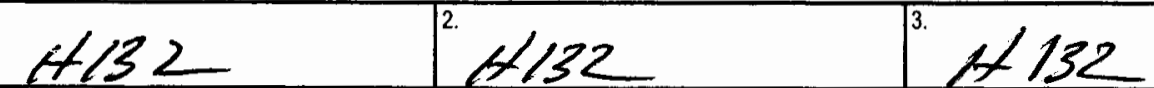

\section{4}

20. Designated Facility Owner or Operator: Certification of receipt of hazardous materials covered by the manifest except as noted in ltem 18 a 
Please print or type. (Form designed for use on elite (12-pilch) typewriter.)

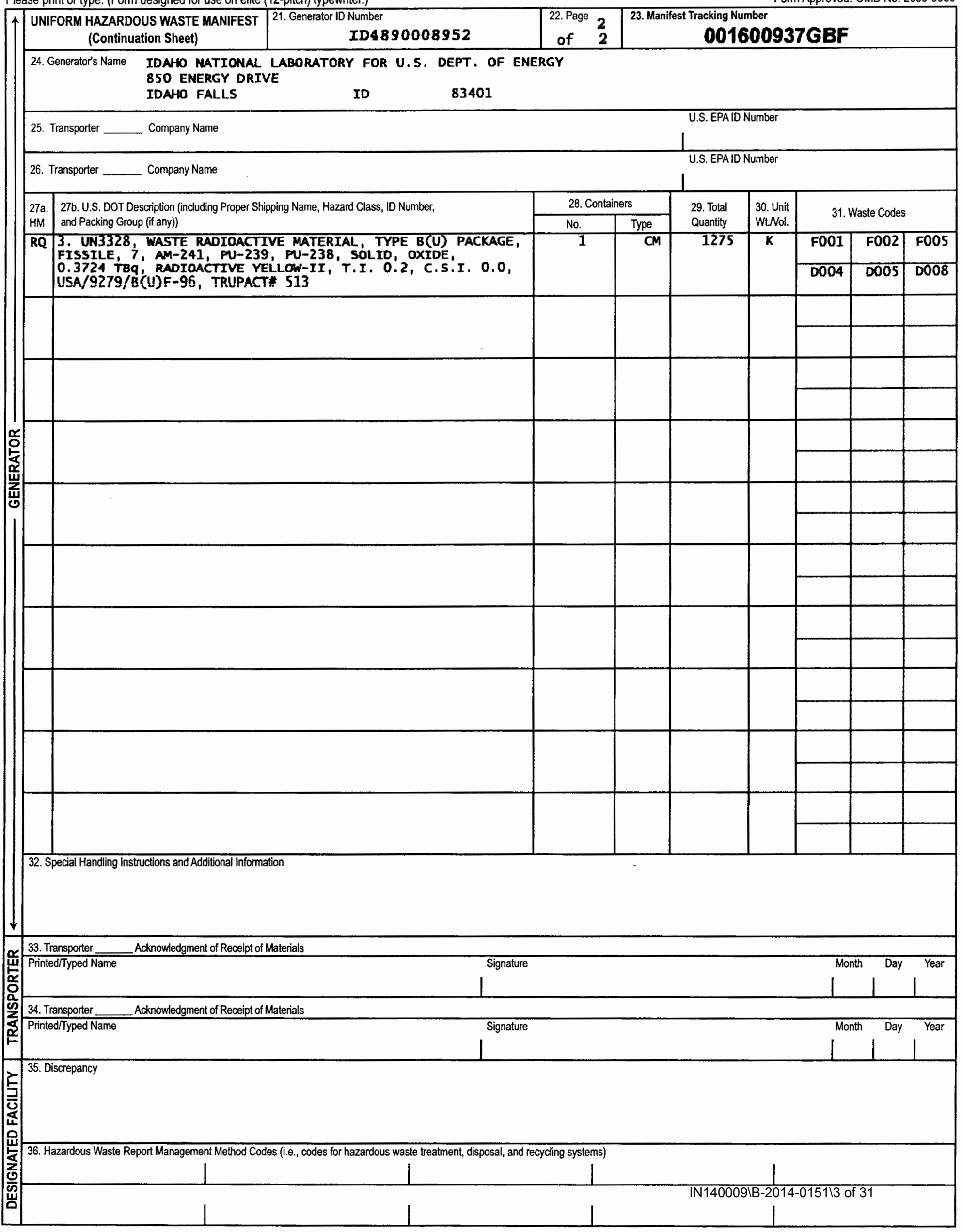




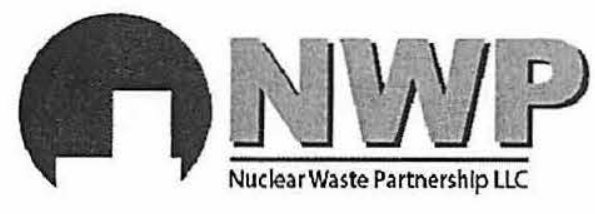

CP:14:02004

UFC:5822.00

AURS-led partnership with B\&W and AREVA

January 24,2014

Ms. R. Hubler, Transportation Manager

Advanced Mixed Waste Treatment Plant/ITG

Idaho National Laboratory

850 Energy Drive, Suite 100

Idaho Falls, ID 83401

SUBJECT: CERTIFICATE OF DISPOSAL FOR POLYCHLORINATED BIPHENYL BEARING WASTE SHIPMENT NUMBERS IN140005, IN140006, IN140008, IN140009, IN140010, IN140012 AND IN140015 EMPLACED AT THE WASTE ISOLATION PILOT PLANT

Dear Ms. Hubler:

In compliance with Title 40 Code of Federal Regulations, Part 761.218 , I certify that the following Polychlorinated Biphenyl (PCB) wastes from your facility have been disposed by emplacement 2,150 feet underground in the Waste Isolation Pilot Plant waste repository.

Disposal Facility:

Waste Isolation Pilot Plant

30 Miles SE of Carlsbad, New Mexico

Eddy County, New Mexico 88220

Environmental Protection Agency (EPA) Identification Number (ID): $\underline{\text { NM4890139088 }}$

Shipping Site's EPA ID: ID4890008952

\begin{tabular}{|c|c|c|c|}
\hline $\begin{array}{c}\text { Shipment } \\
\text { Number }\end{array}$ & $\begin{array}{c}\text { Manifest Tracking } \\
\text { Number }\end{array}$ & $\begin{array}{c}\text { Container } \\
\text { Number }\end{array}$ & $\begin{array}{c}\text { Emplacement } \\
\text { Date }\end{array}$ \\
\hline IN140005 & $001600933 G B F$ & BN10503786 & $1 / 17 / 2014$ \\
\hline IN140005 & $001600933 G B F$ & BN10503781 & $1 / 8 / 2014$ \\
\hline IN140006 & $001600934 G B F$ & BN10501231 & $1 / 10 / 2014$ \\
\hline IN140006 & $001600934 G B F$ & BN10490916 & $1 / 17 / 2014$ \\
\hline IN140008 & $001600936 G B F$ & BN10500615 & $1 / 15 / 2014$ \\
\hline IN140008 & $001600936 G B F$ & BN10501238 & $1 / 15 / 2014$ \\
\hline IN140009 & $001600937 G B F$ & BN10501234 & $1 / 12 / 2014$ \\
\hline IN140009 & $001600937 G B F$ & BN10503780 & $1 / 12 / 2014$ \\
\hline IN140010 & $001600938 G B F$ & $B N 10490915$ & $1 / 12 / 2014$ \\
\hline IN140010 & $001600938 G B F$ & $B N 10503782$ & $1 / 17 / 2014$ \\
\hline IN140012 & $001600940 G B F$ & BN10505064 & $1 / 19 / 2014$ \\
\hline IN140012 & $001600940 G B F$ & BN10505065 & $1 / 17 / 2014$ \\
\hline
\end{tabular}




\begin{tabular}{|c|c|c|c|}
\hline $\begin{array}{c}\text { Shipment } \\
\text { Number }\end{array}$ & $\begin{array}{c}\text { Manifest Tracking } \\
\text { Number }\end{array}$ & $\begin{array}{c}\text { Container } \\
\text { Number }\end{array}$ & $\begin{array}{c}\text { Emplacement } \\
\text { Date }\end{array}$ \\
\hline IN140015 & $001600943 \mathrm{GBF}$ & $\mathrm{BN} 10505057$ & $1 / 21 / 2014$ \\
\hline IN140015 & $001600943 \mathrm{GBF}$ & $\mathrm{BN} 10505066$ & $1 / 21 / 2014$ \\
\hline
\end{tabular}

Under civil and criminal penalties of law for the making or submission of false or fraudulent statements or representations (18 U.S.C. 1001 and 15 U.S.C. 2615), I certify that the information contained in or accompanying this document is true, accurate, and complete.

As to the identified section(s) of this document for which I cannot personally verify truth and accuracy, I certify as the company official having supervisory responsibility for the persons who, acting under my direct instructions, made the verification that this information is true, accurate, and complete.

Should you require further information concerning this certificate of disposal, please contact Mr. R. S. (Bob) Nieman at (575) 234-8141.

Sincerely,

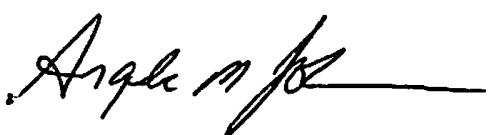

A. M. Johnson, Manager

Transportation Management

RSN/rsn

cc: Shipment portfolio for shipments IN140005, IN140006, IN140008, IN140009, IN140010, IN140012 and IN140015. 
bcc: NWP Distribution
A. M. Johnson
ED
R. U. Carrasco
ED
K. G. Darrah
ED
R. S. Nieman
ED
J.P. Smith
ED

\section{RES Distribution}

S. L. Travis, RES ED 
Please print or type. (Form designed for use on elite (12-pitch) Iypewriter.)

Form Approved. OMB No. 2050-0039

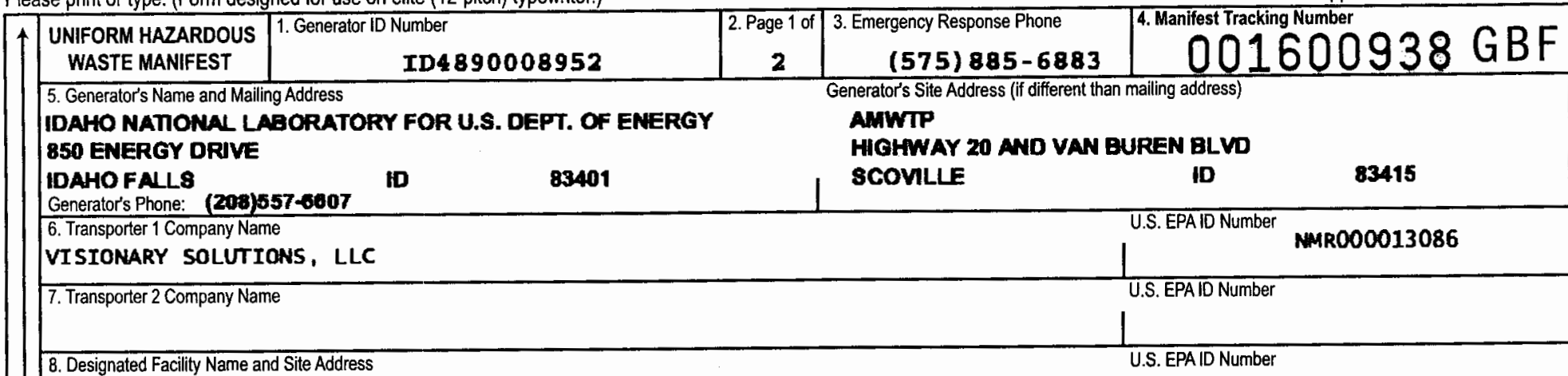

NUCLEAR WASTE PARTNERSHIP, LLC FOR THE U.S. DOE

30 MILES E. OF CARLSBAD ON JAL. HIGHWAY

EDDY COUNTY NM 88221

\begin{tabular}{ll|l|l} 
Facility's Phone: & (575) 234-8457 & NM4890139088
\end{tabular}

9a. 96. U.S. DOT Description (including Proper Shipping Name, Hazard Class, ID Number,

HM and Packing Group (if any))

RQ 1. UN3328, WASTE RADIOACTIVE MATERIAL, TYPE B(U) PACKAGE,

RQ 1 UN3328, WASTE RADIOACTIVE MATERIAL, TYPE 8CU) PACKAGE,

TBq, RADIOACTIVE YELLOW-II, T.I. 0.2, C.S.I. 0.0,

USA/9218/B(U)F-96, TRUPACT 129

2. PCB contafiner \# BN10490915, sludge, PCB out of service pate $02 / 06 / 2013$, PCB weight $1068.8 \mathrm{~kg}$

3. 2. UN3328, WASTE RADTOACTIVE MATERIAL, TYPE B(U) PACKAGE, FISSILE, 7, PU-239, PU-240, AM-241, SOLID, OXIDE, 0.02572 TBG RADIOACTIVE YELLOW-II, T.I. 0.2, C.S.I. 0.0, USA/9218/B(U)F-96, TRUPACT * 206

A. PCB container * BN10503782 sludge, PCB out of service pate 04/09/2013, РСВ weight $1043.8 \mathrm{~kg}$

14. Special Handling Instructions and Additional Information

SHIPMENT * IN140010

GROSS WETGHT

PREPARED UNDER CONTRACT * DE-EMOOO1467
$\mathbf{V}-27$

TP* $206=17,608$

ERG 165

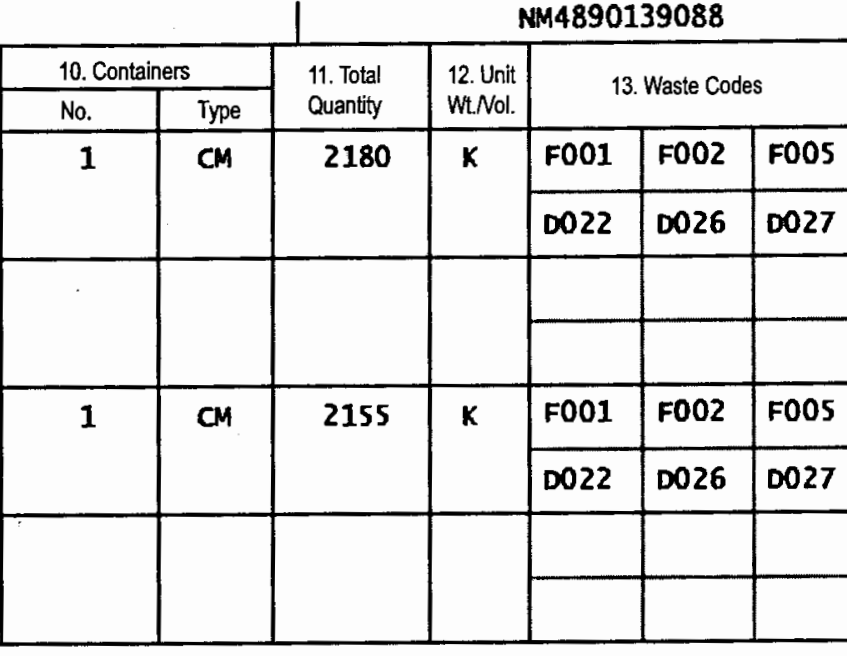

TRATLER - $36 ?$

TP* $504=13,321$

ERI PROVIDER - WIPP GMP

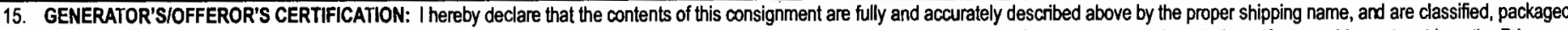
marked and labeled/placarded, and are in all respects in proper condition for transport according to applicable international and national governmental regulations. If export shipment and I am the Primary Exporter, I certify that the contents of this consignment conform to the terms of the attached EPAAcknowledgment of Consent.

I certify that the waste minimization statement identified in 40 CFR 262.27(a) (if I am a large quantity generator) or (b) (if I am a small quantity generator) is irue. Generator's/Offeror's Printed/Typed Name

\section{Richard A. NeSmith}

\section{$\square$ Import tous.}

Lin:
Transporter signature (for exports only):

17. Transporter Acknowledgment of Receipt of Materials
Signature

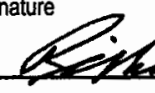

$\square$ Export from U.S. Port of entryexit: Date leaving U.S.

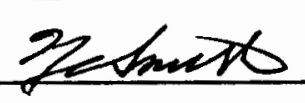

Month Day Year

$01|07| 14$

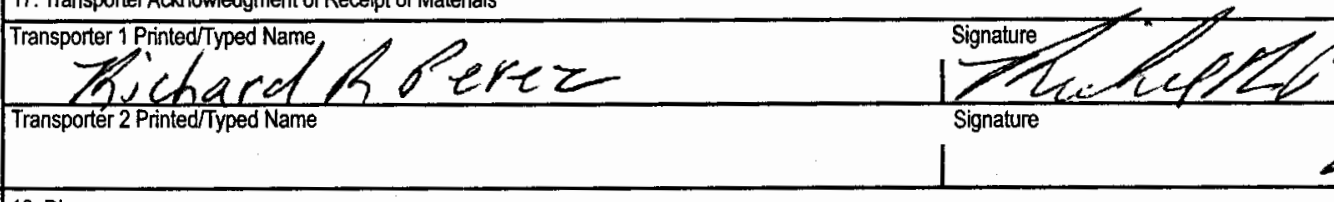

18. Discrepancy

18a. Discrepancy Indication Space $\square$ Quantity $\square$ Type

$\square_{\text {Type }} \quad \square_{\text {Residue }}$

$\square$ Patial Rejection

18b. Alternate Facility (or Generator)

Manifest Reference Number:

Facility's Phone:

18c. Signature of Altemate Facility (or Generator)

19. Hazardous Waste Report Management Method Codes (i.e., codes for hazardous waste treatment, disposal, and recycling systems)

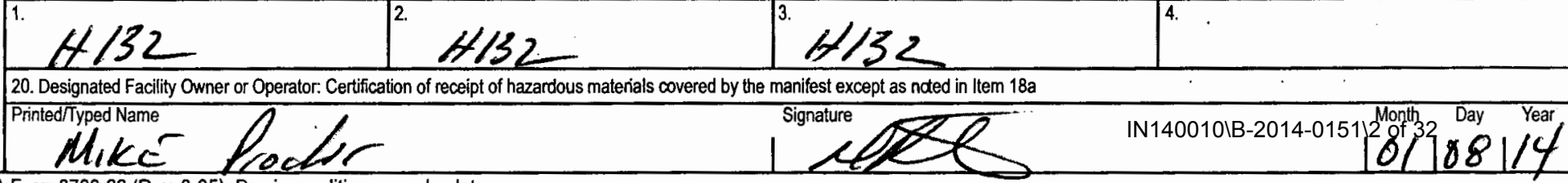


Please print or type. (Form designed for use on elite (12-pitch) typewriter.)

Form Approved. OMB №. 2050-0039

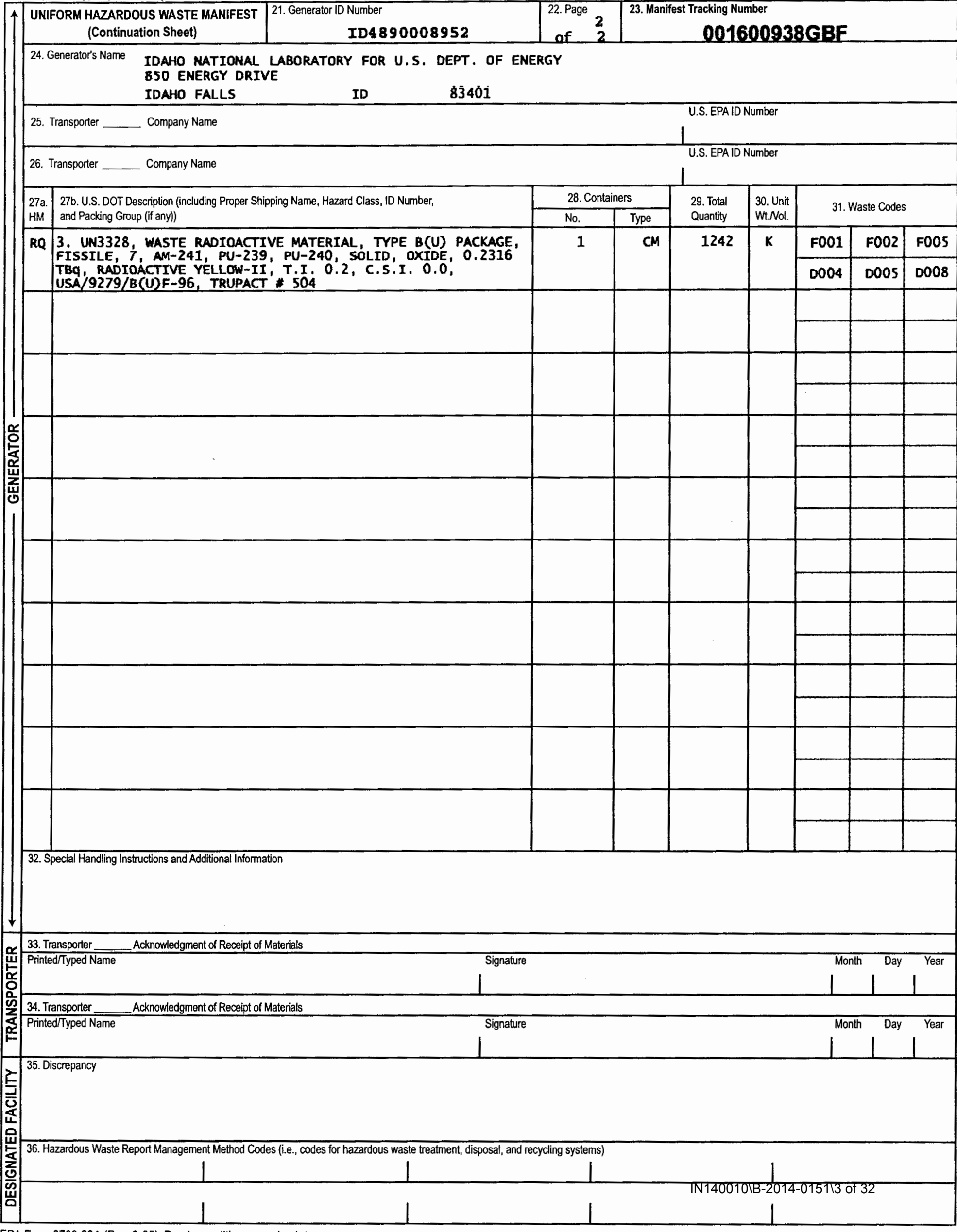




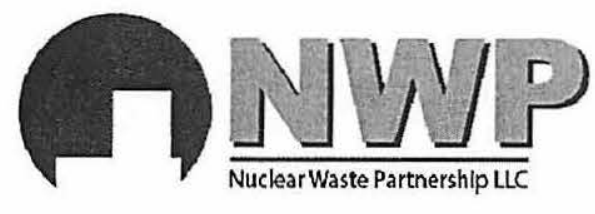

CP:14:02004

UFC:5822.00

AURS-led partnership with B\&W and AREVA

January 24,2014

Ms. R. Hubler, Transportation Manager

Advanced Mixed Waste Treatment Plant/ITG

Idaho National Laboratory

850 Energy Drive, Suite 100

Idaho Falls, ID 83401

SUBJECT: CERTIFICATE OF DISPOSAL FOR POLYCHLORINATED BIPHENYL BEARING WASTE SHIPMENT NUMBERS IN140005, IN140006, IN140008, IN140009, IN140010, IN140012 AND IN140015 EMPLACED AT THE WASTE ISOLATION PILOT PLANT

Dear Ms. Hubler:

In compliance with Title 40 Code of Federal Regulations, Part 761.218 , I certify that the following Polychlorinated Biphenyl (PCB) wastes from your facility have been disposed by emplacement 2,150 feet underground in the Waste Isolation Pilot Plant waste repository.

Disposal Facility:

Waste Isolation Pilot Plant

30 Miles SE of Carlsbad, New Mexico

Eddy County, New Mexico 88220

Environmental Protection Agency (EPA) Identification Number (ID): $\underline{\text { NM4890139088 }}$

Shipping Site's EPA ID: ID4890008952

\begin{tabular}{|c|c|c|c|}
\hline $\begin{array}{c}\text { Shipment } \\
\text { Number }\end{array}$ & $\begin{array}{c}\text { Manifest Tracking } \\
\text { Number }\end{array}$ & $\begin{array}{c}\text { Container } \\
\text { Number }\end{array}$ & $\begin{array}{c}\text { Emplacement } \\
\text { Date }\end{array}$ \\
\hline IN140005 & $001600933 G B F$ & BN10503786 & $1 / 17 / 2014$ \\
\hline IN140005 & $001600933 G B F$ & BN10503781 & $1 / 8 / 2014$ \\
\hline IN140006 & $001600934 G B F$ & BN10501231 & $1 / 10 / 2014$ \\
\hline IN140006 & $001600934 G B F$ & BN10490916 & $1 / 17 / 2014$ \\
\hline IN140008 & $001600936 G B F$ & BN10500615 & $1 / 15 / 2014$ \\
\hline IN140008 & $001600936 G B F$ & BN10501238 & $1 / 15 / 2014$ \\
\hline IN140009 & $001600937 G B F$ & BN10501234 & $1 / 12 / 2014$ \\
\hline IN140009 & $001600937 G B F$ & BN10503780 & $1 / 12 / 2014$ \\
\hline IN140010 & $001600938 G B F$ & $B N 10490915$ & $1 / 12 / 2014$ \\
\hline IN140010 & $001600938 G B F$ & $B N 10503782$ & $1 / 17 / 2014$ \\
\hline IN140012 & $001600940 G B F$ & BN10505064 & $1 / 19 / 2014$ \\
\hline IN140012 & $001600940 G B F$ & BN10505065 & $1 / 17 / 2014$ \\
\hline
\end{tabular}




\begin{tabular}{|c|c|c|c|}
\hline $\begin{array}{c}\text { Shipment } \\
\text { Number }\end{array}$ & $\begin{array}{c}\text { Manifest Tracking } \\
\text { Number }\end{array}$ & $\begin{array}{c}\text { Container } \\
\text { Number }\end{array}$ & $\begin{array}{c}\text { Emplacement } \\
\text { Date }\end{array}$ \\
\hline IN140015 & $001600943 \mathrm{GBF}$ & $\mathrm{BN} 10505057$ & $1 / 21 / 2014$ \\
\hline IN140015 & $001600943 \mathrm{GBF}$ & $\mathrm{BN} 10505066$ & $1 / 21 / 2014$ \\
\hline
\end{tabular}

Under civil and criminal penalties of law for the making or submission of false or fraudulent statements or representations (18 U.S.C. 1001 and 15 U.S.C. 2615), I certify that the information contained in or accompanying this document is true, accurate, and complete.

As to the identified section(s) of this document for which I cannot personally verify truth and accuracy, I certify as the company official having supervisory responsibility for the persons who, acting under my direct instructions, made the verification that this information is true, accurate, and complete.

Should you require further information concerning this certificate of disposal, please contact Mr. R. S. (Bob) Nieman at (575) 234-8141.

Sincerely,

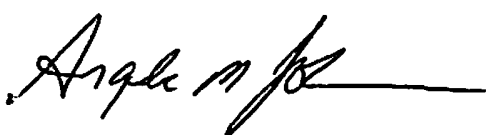

A. M. Johnson, Manager

Transportation Management

RSN/rsn

cc: Shipment portfolio for shipments IN140005, IN140006, IN140008, IN140009, IN140010, IN140012 and IN140015. 
bcc: NWP Distribution
A. M. Johnson
ED
R. U. Carrasco
ED
K. G. Darrah
ED
R. S. Nieman
ED
J.P. Smith
ED

\section{RES Distribution}

S. L. Travis, RES ED 
Please print or type. (Form designed for use on elite (12-pitch) ıyuewriter.)

Form Approved. OMB №. 2050-0039

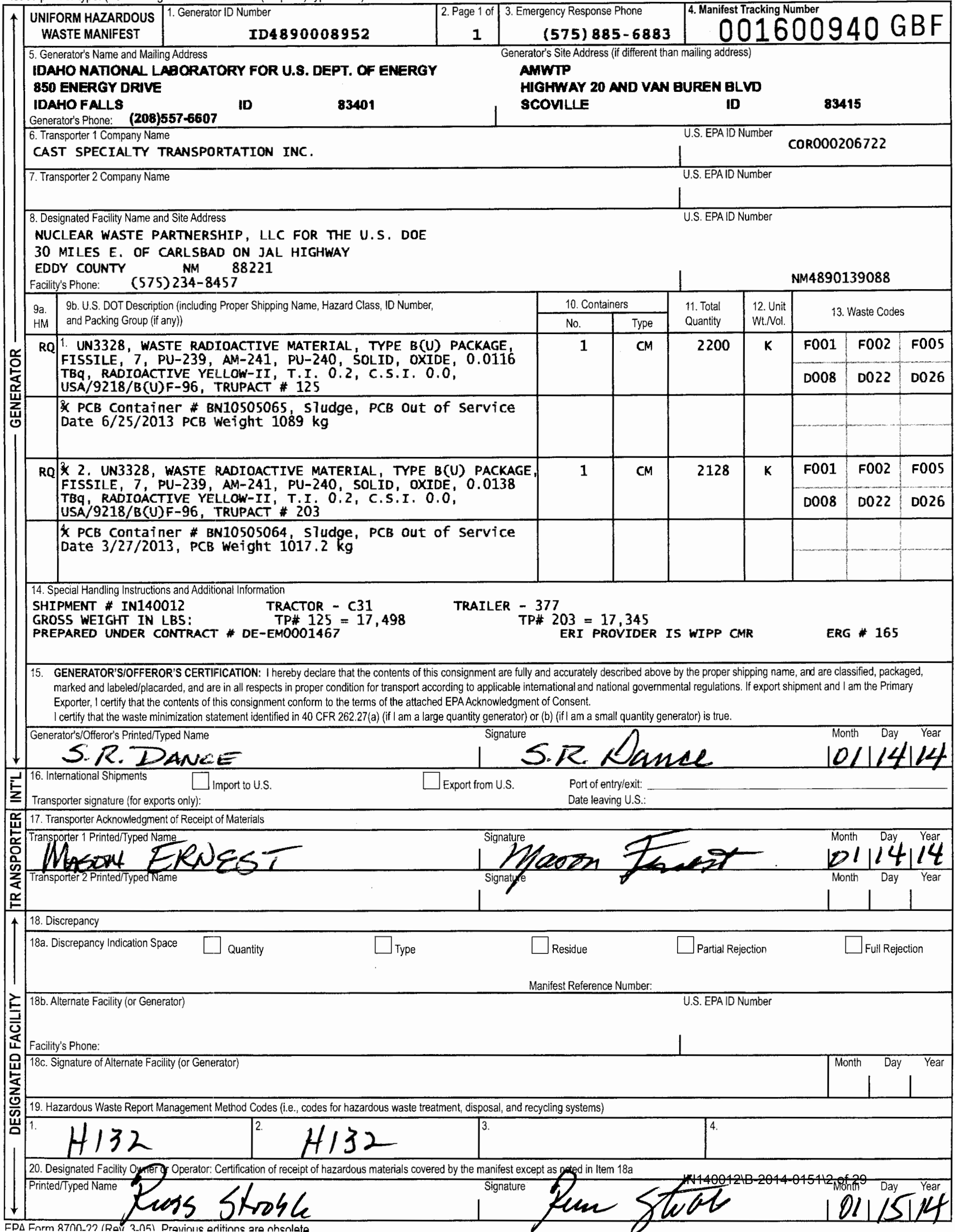




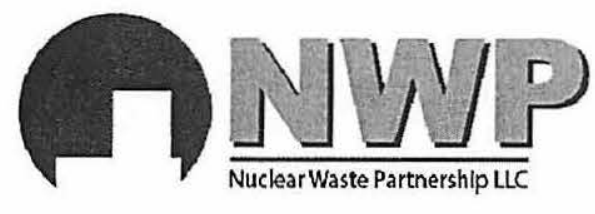

CP:14:02004

UFC:5822.00

AURS-led partnership with B\&W and AREVA

January 24,2014

Ms. R. Hubler, Transportation Manager

Advanced Mixed Waste Treatment Plant/ITG

Idaho National Laboratory

850 Energy Drive, Suite 100

Idaho Falls, ID 83401

SUBJECT: CERTIFICATE OF DISPOSAL FOR POLYCHLORINATED BIPHENYL BEARING WASTE SHIPMENT NUMBERS IN140005, IN140006, IN140008, IN140009, IN140010, IN140012 AND IN140015 EMPLACED AT THE WASTE ISOLATION PILOT PLANT

Dear Ms. Hubler:

In compliance with Title 40 Code of Federal Regulations, Part 761.218 , I certify that the following Polychlorinated Biphenyl (PCB) wastes from your facility have been disposed by emplacement 2,150 feet underground in the Waste Isolation Pilot Plant waste repository.

Disposal Facility:

Waste Isolation Pilot Plant

30 Miles SE of Carlsbad, New Mexico

Eddy County, New Mexico 88220

Environmental Protection Agency (EPA) Identification Number (ID): $\underline{\text { NM4890139088 }}$

Shipping Site's EPA ID: ID4890008952

\begin{tabular}{|c|c|c|c|}
\hline $\begin{array}{c}\text { Shipment } \\
\text { Number }\end{array}$ & $\begin{array}{c}\text { Manifest Tracking } \\
\text { Number }\end{array}$ & $\begin{array}{c}\text { Container } \\
\text { Number }\end{array}$ & $\begin{array}{c}\text { Emplacement } \\
\text { Date }\end{array}$ \\
\hline IN140005 & $001600933 G B F$ & BN10503786 & $1 / 17 / 2014$ \\
\hline IN140005 & $001600933 G B F$ & BN10503781 & $1 / 8 / 2014$ \\
\hline IN140006 & $001600934 G B F$ & BN10501231 & $1 / 10 / 2014$ \\
\hline IN140006 & $001600934 G B F$ & BN10490916 & $1 / 17 / 2014$ \\
\hline IN140008 & $001600936 G B F$ & BN10500615 & $1 / 15 / 2014$ \\
\hline IN140008 & $001600936 G B F$ & BN10501238 & $1 / 15 / 2014$ \\
\hline IN140009 & $001600937 G B F$ & BN10501234 & $1 / 12 / 2014$ \\
\hline IN140009 & $001600937 G B F$ & BN10503780 & $1 / 12 / 2014$ \\
\hline IN140010 & $001600938 G B F$ & $B N 10490915$ & $1 / 12 / 2014$ \\
\hline IN140010 & $001600938 G B F$ & $B N 10503782$ & $1 / 17 / 2014$ \\
\hline IN140012 & $001600940 G B F$ & BN10505064 & $1 / 19 / 2014$ \\
\hline IN140012 & $001600940 G B F$ & BN10505065 & $1 / 17 / 2014$ \\
\hline
\end{tabular}




\begin{tabular}{|c|c|c|c|}
\hline $\begin{array}{c}\text { Shipment } \\
\text { Number }\end{array}$ & $\begin{array}{c}\text { Manifest Tracking } \\
\text { Number }\end{array}$ & $\begin{array}{c}\text { Container } \\
\text { Number }\end{array}$ & $\begin{array}{c}\text { Emplacement } \\
\text { Date }\end{array}$ \\
\hline IN140015 & $001600943 \mathrm{GBF}$ & $\mathrm{BN} 10505057$ & $1 / 21 / 2014$ \\
\hline IN140015 & $001600943 \mathrm{GBF}$ & $\mathrm{BN} 10505066$ & $1 / 21 / 2014$ \\
\hline
\end{tabular}

Under civil and criminal penalties of law for the making or submission of false or fraudulent statements or representations (18 U.S.C. 1001 and 15 U.S.C. 2615), I certify that the information contained in or accompanying this document is true, accurate, and complete.

As to the identified section(s) of this document for which I cannot personally verify truth and accuracy, I certify as the company official having supervisory responsibility for the persons who, acting under my direct instructions, made the verification that this information is true, accurate, and complete.

Should you require further information concerning this certificate of disposal, please contact Mr. R. S. (Bob) Nieman at (575) 234-8141.

Sincerely,

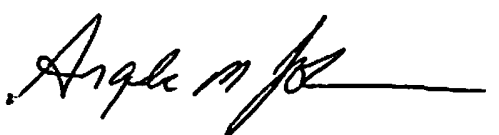

A. M. Johnson, Manager

Transportation Management

RSN/rsn

cc: Shipment portfolio for shipments IN140005, IN140006, IN140008, IN140009, IN140010, IN140012 and IN140015. 
bcc: NWP Distribution
A. M. Johnson
ED
R. U. Carrasco
ED
K. G. Darrah
ED
R. S. Nieman
ED
J.P. Smith
ED

\section{RES Distribution}

S. L. Travis, RES ED 
Piease print or type. (Form designed for use on elite (12-pitch) typewriter.)

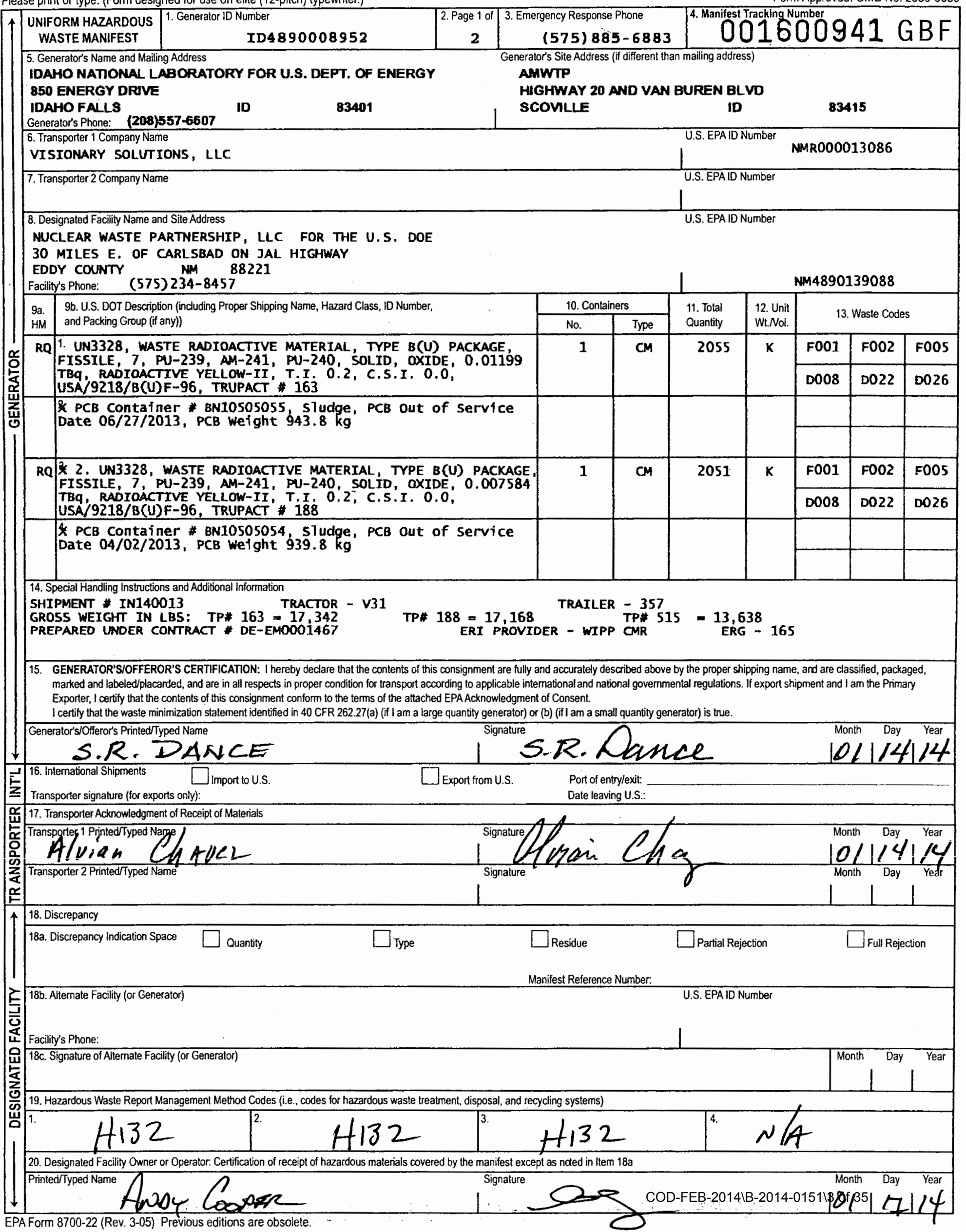




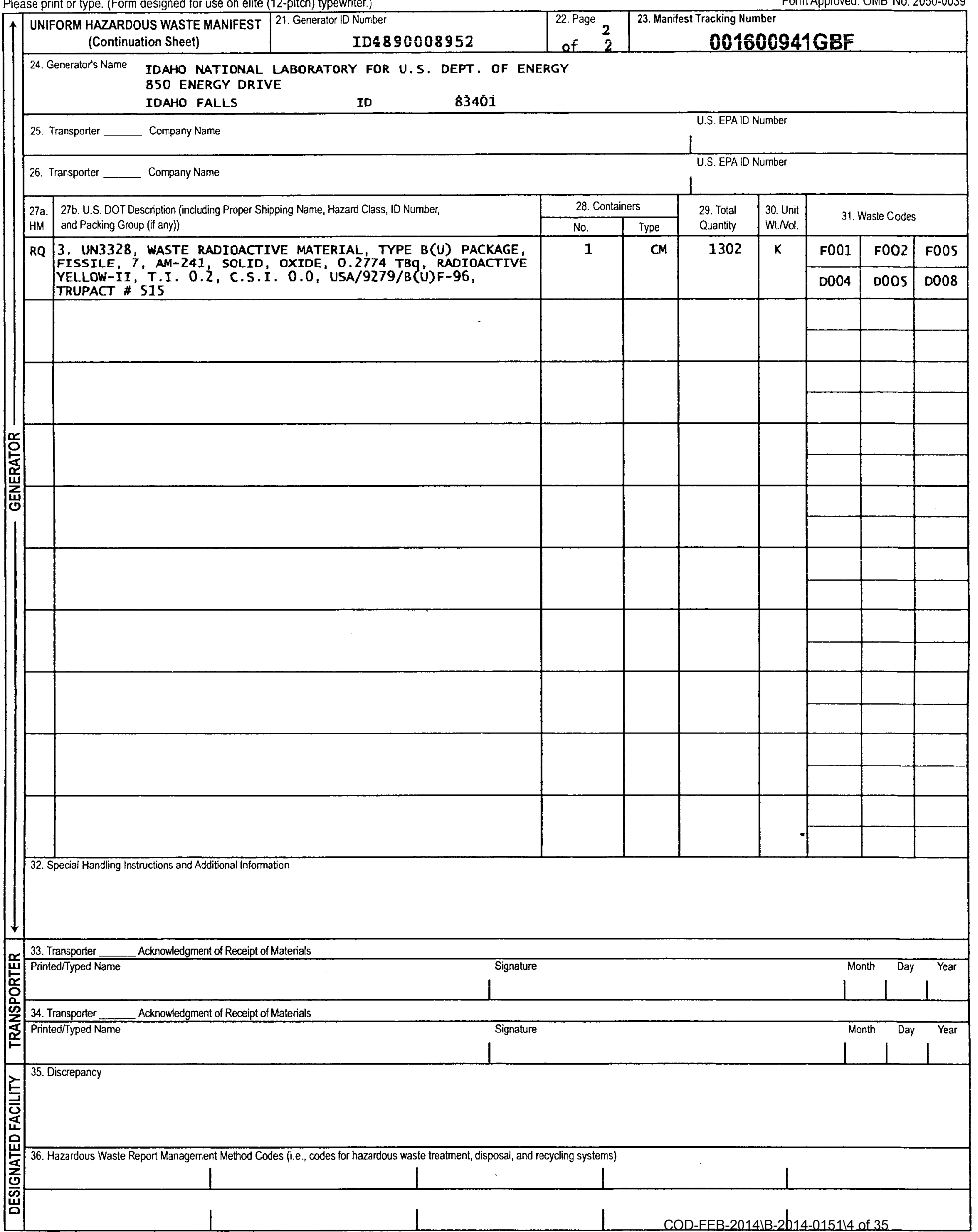




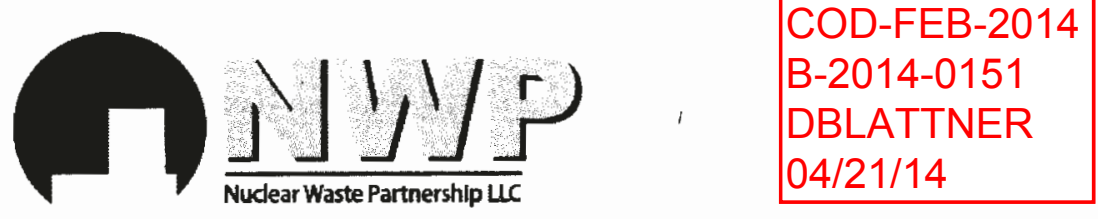

CP:14:02012

UFC:5822.00

A URS-led partnership with B\&W and AREVA

February 12, 2014

Ms. R. Hubler, Transportation Manager

Advanced Mixed Waste Treatment Plant/ITG

Idaho National Laboratory

850 Energy Drive, Suite 100

Idaho Falls, ID 83401

SUBJECT: CERTIFICATE OF DISPOSAL FOR POLYCHLORINATED BIPHENYL BEARING WASTE SHIPMENT NUMBERS IN140013, IN140014, IN140016, IN140018, IN140019, IN140022, IN140023, IN140024, IN140026, IN140028, IN140029, IN140031, IN140033, IN140034, IN140035, IN140038 AND IN140039 EMPLACED AT THE WASTE ISOLATION PILOT PLANT

Dear Ms. Hubler:

In compliance with Title 40 Code of Federal Regulations, Part 761.218 , I certify that the following Polychlorinated Biphenyl (PCB) wastes from your facility have been disposed by emplacement 2,150 feet underground in the Waste Isolation Pilot Plant waste repository.

Disposal Facility:

Waste Isolation Pilot Plant

30 Miles SE of Carlsbad, New Mexico

Eddy County, New Mexico 88220

Environmental Protection Agency (EPA) Identification Number (ID): NM4890139088

Shipping Site's EPA ID: ID4890008952

\begin{tabular}{|c|c|c|c|}
\hline $\begin{array}{c}\text { Shipment } \\
\text { Number }\end{array}$ & $\begin{array}{c}\text { Manifest Tracking } \\
\text { Number }\end{array}$ & $\begin{array}{c}\text { Container } \\
\text { Number }\end{array}$ & $\begin{array}{c}\text { Emplacement } \\
\text { Date }\end{array}$ \\
\hline IN140013 & $001600941 \mathrm{GBF}$ & BN10505055 & $1 / 24 / 2014$ \\
\hline IN140013 & $001600941 \mathrm{GBF}$ & BN10505054 & $1 / 21 / 2014$ \\
\hline IN140014 & $001600942 \mathrm{GBF}$ & BN10490911 & $1 / 25 / 2014$ \\
\hline IN140014 & $001600942 \mathrm{GBF}$ & BN10490912 & $1 / 25 / 2014$ \\
\hline IN140016 & $001600944 \mathrm{GBF}$ & BN10505059 & $1 / 24 / 2014$ \\
\hline IN140016 & $001600944 \mathrm{GBF}$ & BN10503788 & $1 / 24 / 2014$ \\
\hline IN140018 & $001600946 \mathrm{GBF}$ & BN10505058 & $1 / 26 / 2014$ \\
\hline IN140018 & $001600946 \mathrm{GBF}$ & BN10505062 & $1 / 26 / 2014$ \\
\hline IN140019 & $001600947 \mathrm{GBF}$ & BN10503775 & $1 / 24 / 2014$ \\
\hline IN140019 & $001600947 \mathrm{GBF}$ & BN10503760 & $1 / 24 / 2014$ \\
\hline IN140022 & 001600950GBF & BN10505063 & $2 / 2 / 2014$ \\
\hline
\end{tabular}




\begin{tabular}{|c|c|c|c|}
\hline $\begin{array}{l}\text { Shipment } \\
\text { Number }\end{array}$ & $\begin{array}{c}\text { Manifest Tracking } \\
\text { Number }\end{array}$ & $\begin{array}{l}\text { Container } \\
\text { Number }\end{array}$ & $\begin{array}{c}\text { Emplacement } \\
\text { Date }\end{array}$ \\
\hline IN140022 & $001600950 \mathrm{GBF}$ & BN10501246 & $1 / 24 / 2014$ \\
\hline IN140023 & $001600951 \mathrm{GBF}$ & BN10500612 & $1 / 30 / 2014$ \\
\hline IN140023 & $001600951 \mathrm{GBF}$ & BN10503777 & $1 / 26 / 2014$ \\
\hline IN140024 & $001600952 \mathrm{GBF}$ & BN10509616 & $1 / 24 / 2014$ \\
\hline IN140024 & $001600952 \mathrm{GBF}$ & BN10509615 & $2 / 2 / 2014$ \\
\hline IN140026 & $001600954 \mathrm{GBF}$ & BN10509688 & $1 / 26 / 2014$ \\
\hline IN140026 & $001600954 \mathrm{GBF}$ & BN10509618 & $1 / 28 / 2014$ \\
\hline IN140028 & $001600956 \mathrm{GBF}$ & BN10503774 & $1 / 28 / 2014$ \\
\hline IN140028 & $001600956 \mathrm{GBF}$ & BN10509606 & $1 / 28 / 2014$ \\
\hline IN140029 & $001600957 \mathrm{GBF}$ & BN10501248 & $1 / 28 / 2014$ \\
\hline IN140029 & $001600957 \mathrm{GBF}$ & BN10509611 & $2 / 1 / 2014$ \\
\hline IN140031 & $001600959 \mathrm{GBF}$ & BN10505060 & $2 / 1 / 2014$ \\
\hline IN140031 & 001600959GBF & BN10505061 & $1 / 28 / 2014$ \\
\hline IN140033 & $001600961 \mathrm{GBF}$ & BN10509682 & $1 / 31 / 2014$ \\
\hline IN140033 & $001600961 \mathrm{GBF}$ & BN10509601 & $1 / 31 / 2014$ \\
\hline IN140034 & $001600962 \mathrm{GBF}$ & BN10507549 & $2 / 2 / 2014$ \\
\hline IN140034 & $001600962 \mathrm{GBF}$ & BN10509687 & $2 / 1 / 2014$ \\
\hline IN140035 & $001600963 \mathrm{GBF}$ & BN10507550 & $1 / 31 / 2014$ \\
\hline IN140035 & $001600963 \mathrm{GBF}$ & BN10509599 & $2 / 1 / 2014$ \\
\hline IN140038 & $001600966 \mathrm{GBF}$ & BN10507553 & $2 / 2 / 2014$ \\
\hline IN140038 & $001600966 \mathrm{GBF}$ & BN10507557 & $2 / 2 / 2014$ \\
\hline IN140039 & $001600967 \mathrm{GBF}$ & BN10507555 & $2 / 4 / 2014$ \\
\hline IN140039 & $001600967 \mathrm{GBF}$ & BN10507554 & $2 / 4 / 2014$ \\
\hline
\end{tabular}

Under civil and criminal penalties of law for the making or submission of false or fraudulent statements or representations (18 U.S.C. 1001 and 15 U.S.C. 2615), I certify that the information contained in or accompanying this document is true, accurate, and complete.

As to the identified section(s) of this document for which I cannot personally verify truth and accuracy, I certify as the company official having supervisory responsibility for the persons who, acting under my direct instructions, made the verification that this information is true, accurate, and complete.

Should you require further information concerning this certificate of disposal, please contact Mr. R. S. (Bob) Nieman at (575) 234-8141.

Sincerely,

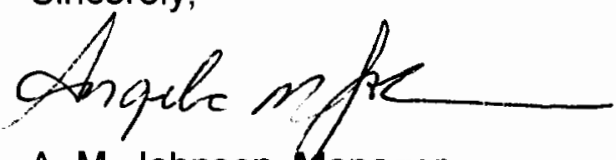

A. M. Johnson, Manager

Transportation Management

RSN/rsn

cc: Shipment portfolio for shipments IN140013, IN140014, IN140016, IN140018, IN140019, IN140022, IN140023, IN140024, IN140026, IN140028, IN140029, IN140031, IN140033, IN140034, IN140035, IN140038 and IN140039. 
Please print or type. (Form designed for use on elite (12-pitch) typewriter.)

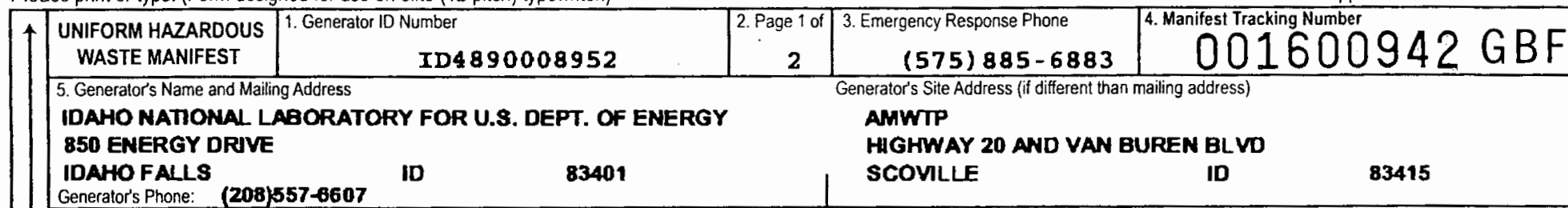

6. Transporter 1 Company Name

CAST SPECIALTY TRANSPORTATION INC.

COR000206722

7. Transporter 2 Company Name

U.S. EPA ID Number

8. Designated Facility Name and Site Address

L

NUCLEAR WASTE PARTNERSHIP, LLC FOR THE U.S. DOE

30 MILES E. OF CARLSBAD ON JAL HIGHWAY

EDOY COUNTY 88221

Facility's Phone: (575) 234-8457

\begin{tabular}{l|l}
\hline $9 a$ & $9 b$. U.S. DOT Description (including Proper Shipping Name, Hazard Class, ID Number,
\end{tabular}

HM and Packing Group (if any))

RQ 1. UN3328, WASTE RADIOACTIVE MATERIAL, TYPE B(U) PACKAGE,

FISSILE, 7, PU-239, PU-240, AM-241, PU-238, SOLID, OXIDE

$0.007739 \mathrm{TBq}$, RADIOACTIVE YELLOW-II, T.I. 0.2, C.S.I. 0.0, USA/9218/B(U)F-96, TRUPACT \# 191

* PCB Container \#BN10490912, Sludge, PCB out of Service

Date $12 / 17 / 2012$, PCB Weight $884.8 \mathrm{~kg}$

RQ $*$ 2. UN3328, WASTE RADTOACTIVE MATERIAL, TYPE B(U) PACKAGE

FISSILE, 7, PU-239, PU-240, AM-241, SOLID, OXIDE, 0.006799

TBQ, RADIOACTIVE YELLOW-II, T.I. 0.2, C.S.I. 0.0,

USA $/ 9218 / B(U) F-96$, TRUPACT \# 131

* PCB Container \# BN10490911, sludge, PCB out of service Date 01/10/2013, PCB weight $945.0 \mathrm{~kg}$

14. Speciai Handling Instructions and Additional information
SHIPMENT * IN140014
TRACTOR - C30
GROSS WEIGHT IN LBS: TP\# $191=16,902$
PREPARED UNDER CONTRACT \# DE-EMO001467

TRAILER - 351

TP\# $131=17,242 \quad$ TP\# $502=13,689$

ERI PROVIDER IS WIPP CMR

ERG * 165

15. GENERATOR'SIOFFEROR'S CERTIFICATION: I hereby dectare that the contents of this consignment are fully and accurately described above by the proper shipping name, and are classified, packaged, marked and labeled/placarded, and are in all respects in proper condition for transport according to applicable intemational and national govemmental regulations. If export shipment and I am the Primary Exporter, I certify that the contents of this consignment conform to the terns of the attached EPA Acknowtedgment of Consent.

I certify that the waste minimization statement identified in 40 CFR 262.27(a) (if I am a large quantity generator) or (b) (if I am a small quantity generator) is true.

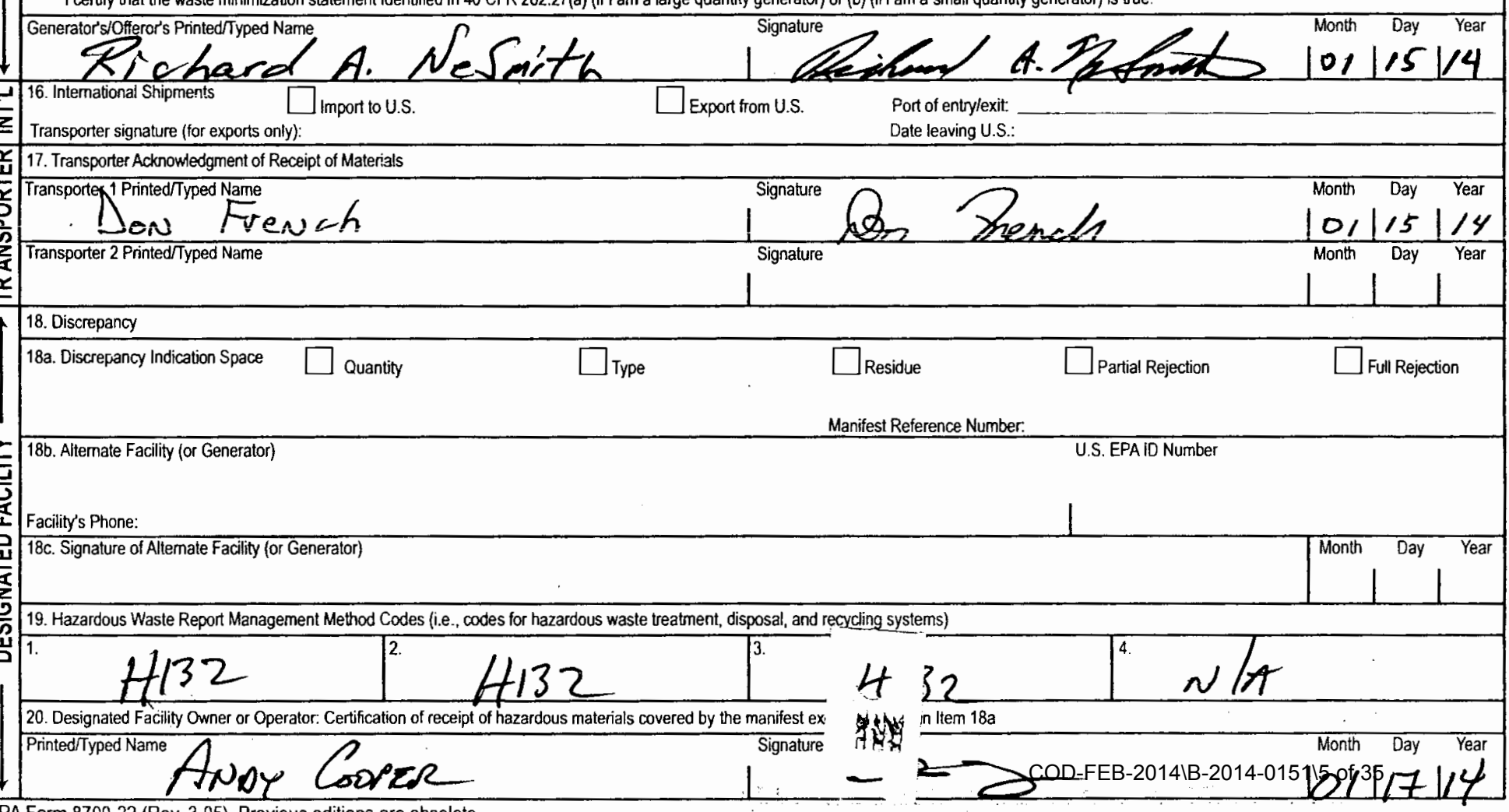


Please print or type. (Form designed for use on elite (12-pitch) typewriter.)

Form Approved. OMB No. $2050-0039$

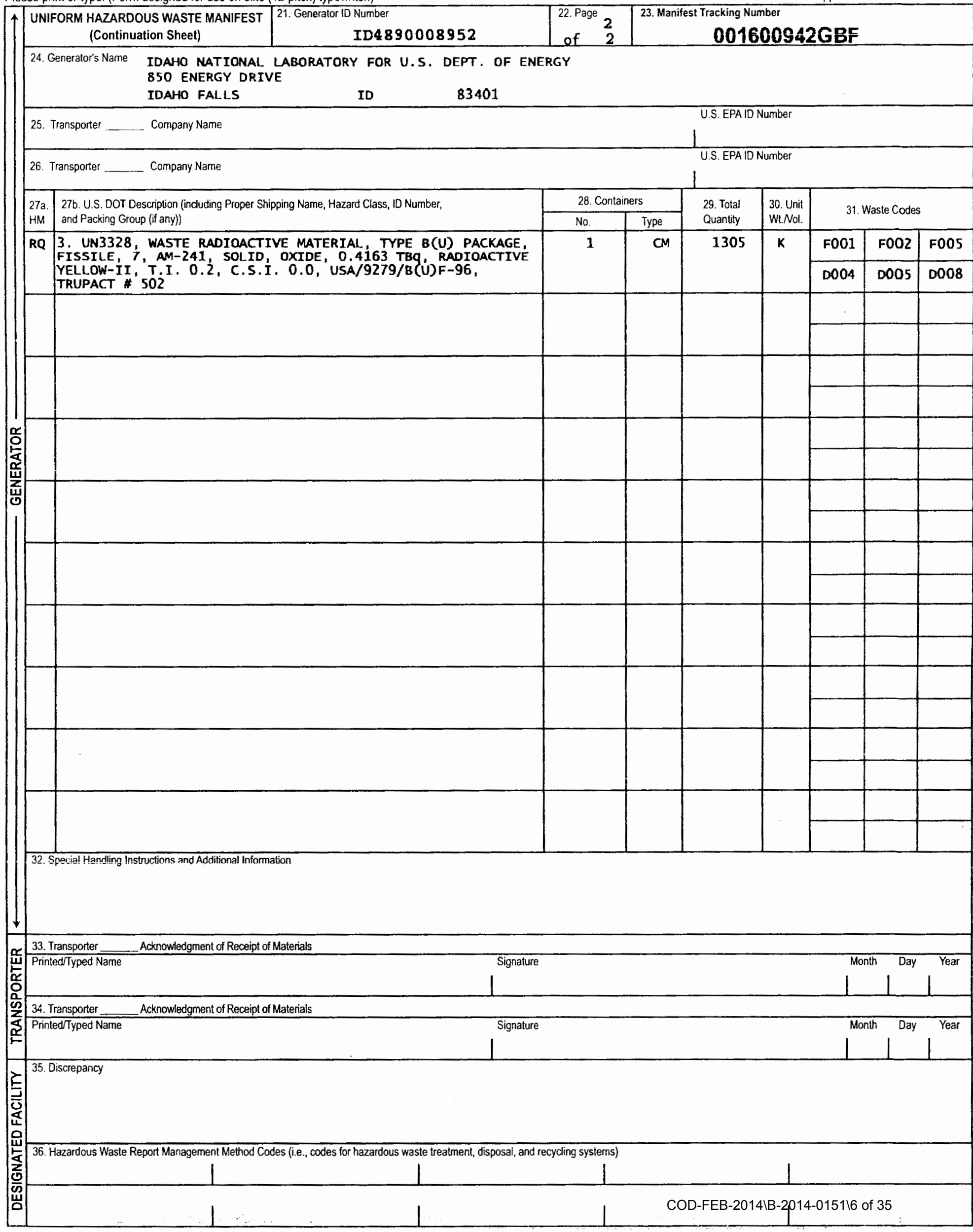




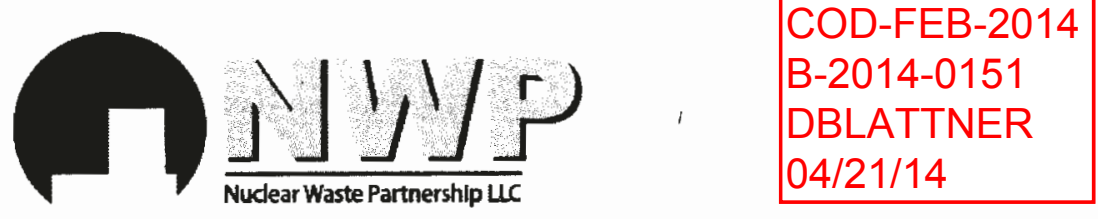

CP:14:02012

UFC:5822.00

A URS-led partnership with B\&W and AREVA

February 12, 2014

Ms. R. Hubler, Transportation Manager

Advanced Mixed Waste Treatment Plant/ITG

Idaho National Laboratory

850 Energy Drive, Suite 100

Idaho Falls, ID 83401

SUBJECT: CERTIFICATE OF DISPOSAL FOR POLYCHLORINATED BIPHENYL BEARING WASTE SHIPMENT NUMBERS IN140013, IN140014, IN140016, IN140018, IN140019, IN140022, IN140023, IN140024, IN140026, IN140028, IN140029, IN140031, IN140033, IN140034, IN140035, IN140038 AND IN140039 EMPLACED AT THE WASTE ISOLATION PILOT PLANT

Dear Ms. Hubler:

In compliance with Title 40 Code of Federal Regulations, Part 761.218 , I certify that the following Polychlorinated Biphenyl (PCB) wastes from your facility have been disposed by emplacement 2,150 feet underground in the Waste Isolation Pilot Plant waste repository.

Disposal Facility:

Waste Isolation Pilot Plant

30 Miles SE of Carlsbad, New Mexico

Eddy County, New Mexico 88220

Environmental Protection Agency (EPA) Identification Number (ID): NM4890139088

Shipping Site's EPA ID: ID4890008952

\begin{tabular}{|c|c|c|c|}
\hline $\begin{array}{c}\text { Shipment } \\
\text { Number }\end{array}$ & $\begin{array}{c}\text { Manifest Tracking } \\
\text { Number }\end{array}$ & $\begin{array}{c}\text { Container } \\
\text { Number }\end{array}$ & $\begin{array}{c}\text { Emplacement } \\
\text { Date }\end{array}$ \\
\hline IN140013 & $001600941 \mathrm{GBF}$ & BN10505055 & $1 / 24 / 2014$ \\
\hline IN140013 & $001600941 \mathrm{GBF}$ & BN10505054 & $1 / 21 / 2014$ \\
\hline IN140014 & $001600942 \mathrm{GBF}$ & BN10490911 & $1 / 25 / 2014$ \\
\hline IN140014 & $001600942 \mathrm{GBF}$ & BN10490912 & $1 / 25 / 2014$ \\
\hline IN140016 & $001600944 \mathrm{GBF}$ & BN10505059 & $1 / 24 / 2014$ \\
\hline IN140016 & $001600944 \mathrm{GBF}$ & BN10503788 & $1 / 24 / 2014$ \\
\hline IN140018 & $001600946 \mathrm{GBF}$ & BN10505058 & $1 / 26 / 2014$ \\
\hline IN140018 & $001600946 \mathrm{GBF}$ & BN10505062 & $1 / 26 / 2014$ \\
\hline IN140019 & $001600947 \mathrm{GBF}$ & BN10503775 & $1 / 24 / 2014$ \\
\hline IN140019 & $001600947 \mathrm{GBF}$ & BN10503760 & $1 / 24 / 2014$ \\
\hline IN140022 & 001600950GBF & BN10505063 & $2 / 2 / 2014$ \\
\hline
\end{tabular}




\begin{tabular}{|c|c|c|c|}
\hline $\begin{array}{l}\text { Shipment } \\
\text { Number }\end{array}$ & $\begin{array}{c}\text { Manifest Tracking } \\
\text { Number }\end{array}$ & $\begin{array}{l}\text { Container } \\
\text { Number }\end{array}$ & $\begin{array}{c}\text { Emplacement } \\
\text { Date }\end{array}$ \\
\hline IN140022 & $001600950 \mathrm{GBF}$ & BN10501246 & $1 / 24 / 2014$ \\
\hline IN140023 & $001600951 \mathrm{GBF}$ & BN10500612 & $1 / 30 / 2014$ \\
\hline IN140023 & $001600951 \mathrm{GBF}$ & BN10503777 & $1 / 26 / 2014$ \\
\hline IN140024 & $001600952 \mathrm{GBF}$ & BN10509616 & $1 / 24 / 2014$ \\
\hline IN140024 & $001600952 \mathrm{GBF}$ & BN10509615 & $2 / 2 / 2014$ \\
\hline IN140026 & $001600954 \mathrm{GBF}$ & BN10509688 & $1 / 26 / 2014$ \\
\hline IN140026 & $001600954 \mathrm{GBF}$ & BN10509618 & $1 / 28 / 2014$ \\
\hline IN140028 & $001600956 \mathrm{GBF}$ & BN10503774 & $1 / 28 / 2014$ \\
\hline IN140028 & $001600956 \mathrm{GBF}$ & BN10509606 & $1 / 28 / 2014$ \\
\hline IN140029 & $001600957 \mathrm{GBF}$ & BN10501248 & $1 / 28 / 2014$ \\
\hline IN140029 & $001600957 \mathrm{GBF}$ & BN10509611 & $2 / 1 / 2014$ \\
\hline IN140031 & $001600959 \mathrm{GBF}$ & BN10505060 & $2 / 1 / 2014$ \\
\hline IN140031 & 001600959GBF & BN10505061 & $1 / 28 / 2014$ \\
\hline IN140033 & $001600961 \mathrm{GBF}$ & BN10509682 & $1 / 31 / 2014$ \\
\hline IN140033 & $001600961 \mathrm{GBF}$ & BN10509601 & $1 / 31 / 2014$ \\
\hline IN140034 & $001600962 \mathrm{GBF}$ & BN10507549 & $2 / 2 / 2014$ \\
\hline IN140034 & $001600962 \mathrm{GBF}$ & BN10509687 & $2 / 1 / 2014$ \\
\hline IN140035 & $001600963 \mathrm{GBF}$ & BN10507550 & $1 / 31 / 2014$ \\
\hline IN140035 & $001600963 \mathrm{GBF}$ & BN10509599 & $2 / 1 / 2014$ \\
\hline IN140038 & $001600966 \mathrm{GBF}$ & BN10507553 & $2 / 2 / 2014$ \\
\hline IN140038 & $001600966 \mathrm{GBF}$ & BN10507557 & $2 / 2 / 2014$ \\
\hline IN140039 & $001600967 \mathrm{GBF}$ & BN10507555 & $2 / 4 / 2014$ \\
\hline IN140039 & $001600967 \mathrm{GBF}$ & BN10507554 & $2 / 4 / 2014$ \\
\hline
\end{tabular}

Under civil and criminal penalties of law for the making or submission of false or fraudulent statements or representations (18 U.S.C. 1001 and 15 U.S.C. 2615), I certify that the information contained in or accompanying this document is true, accurate, and complete.

As to the identified section(s) of this document for which I cannot personally verify truth and accuracy, I certify as the company official having supervisory responsibility for the persons who, acting under my direct instructions, made the verification that this information is true, accurate, and complete.

Should you require further information concerning this certificate of disposal, please contact Mr. R. S. (Bob) Nieman at (575) 234-8141.

Sincerely,

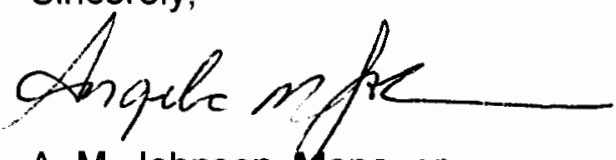

A. M. Johnson, Manager

Transportation Management

RSN/rsn

cc: Shipment portfolio for shipments IN140013, IN140014, IN140016, IN140018, IN140019, IN140022, IN140023, IN140024, IN140026, IN140028, IN140029, IN140031, IN140033, IN140034, IN140035, IN140038 and IN140039. 
Please print or type. (Form designed for use on elite (12-pitch) typewriter.)

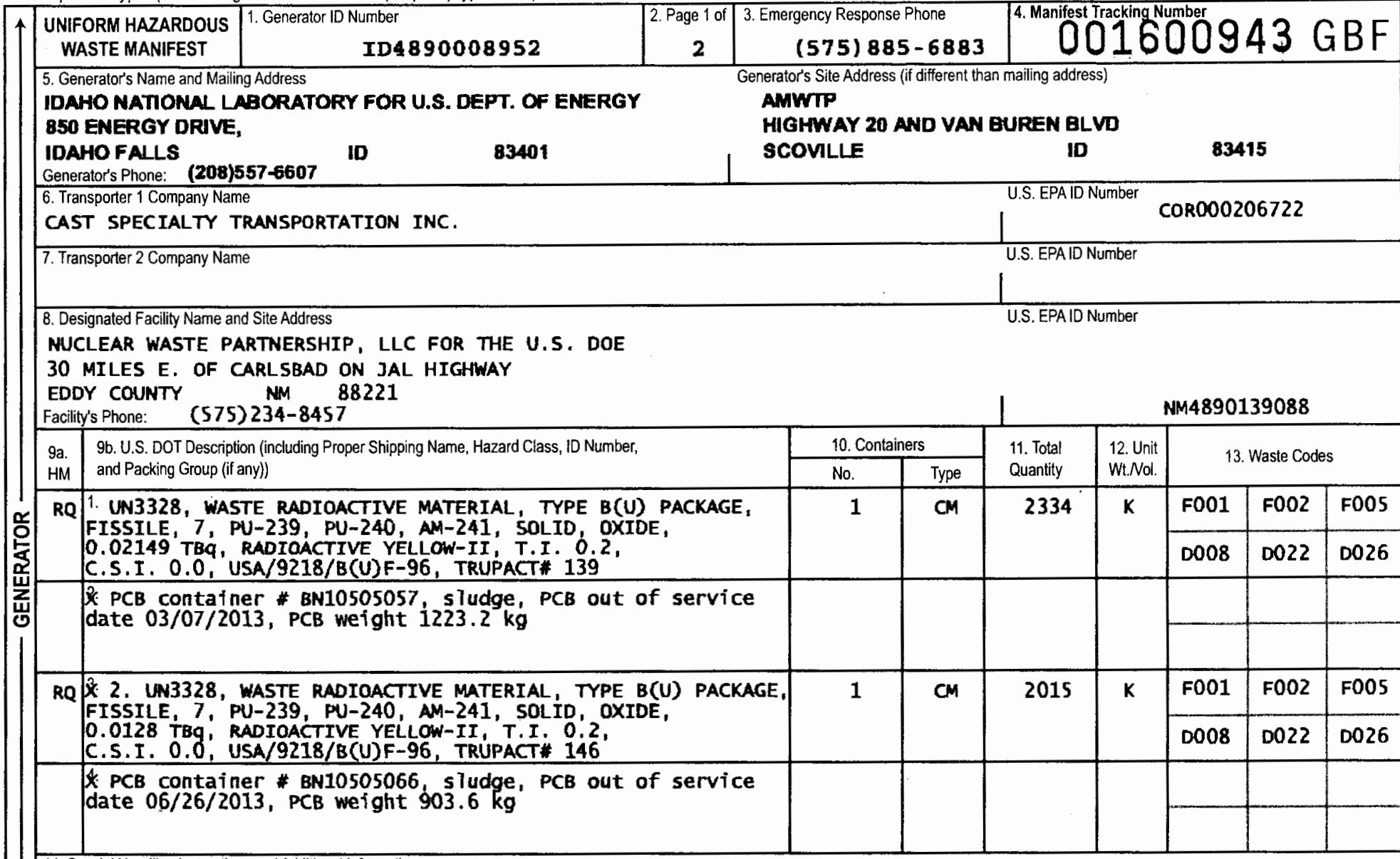

14. Special Handling Instructions and Additionai Information

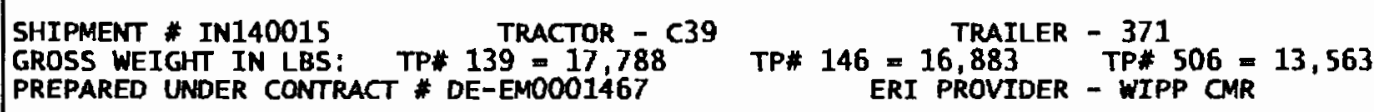

\section{ERI PROVIDER - WIPP CMR ERG * 165}

15. GENERATOR'S/OFFEROR'S CERTIFICATION: I hereby declare that the contents of this consignment are fully and accurately described above by the proper shipping name, and are classified, packaged, marked and labeled/placarded, and are in all respects in proper condition for transport according to applicable international and national govemmental regulations. If export shipment and I am the Primary

Exporter, I certify that the contents of this consignment conform to the terms of the attached EPAAcknowledgment of Consent.

I certify that the waste minimization statement identified in 40 CFR 262.27(a) (if I am a large quantily generator) or (b) (ifl am a small quantity generator) is true.

Generator's/Offeror's Printed/Typed Name

$$
\text { S.R. } 24 \times 1 \times
$$

\section{International Shipments $\square$ import to U.S. \\ Transporter signature (for exports only): \\ 17. Transporter Acknowledgment of Receipt of Materials}

Signature

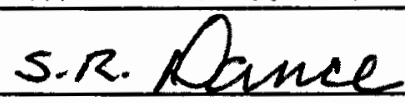

StEPHEN M EAsBoN

18. Discrepancy

18a. Discrepancy Indication Space $\square$ Quantity $\quad \square_{\text {Type }} \quad \square$ Residue $\quad \square$ Partial Rejection $\square_{\text {Full Rejection }}$

18b. Alternate Facility (or Generator)

Manifest Reference Number: 
Please print or type. (Form designed for use on elite (12-pitch) typewriter.)

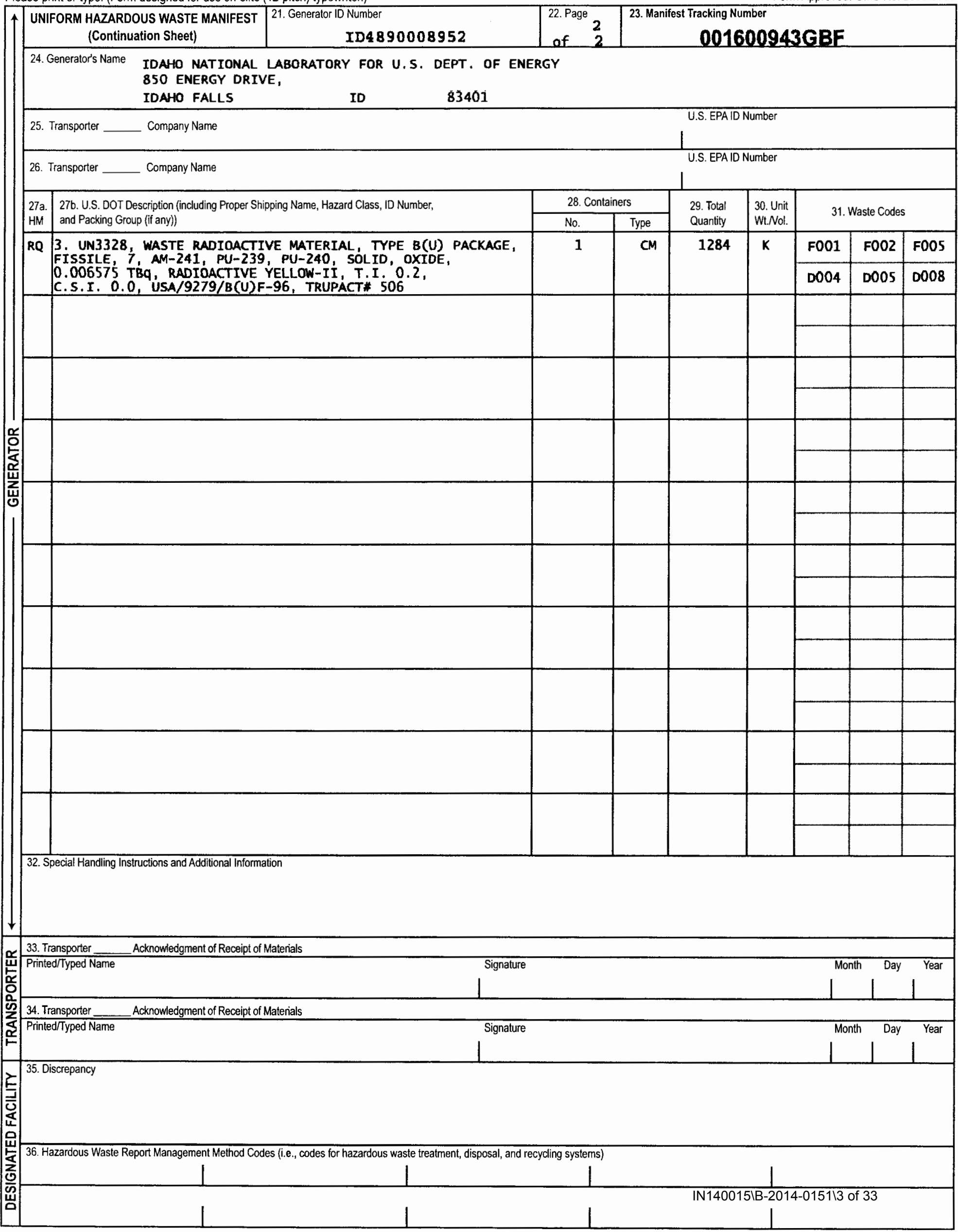




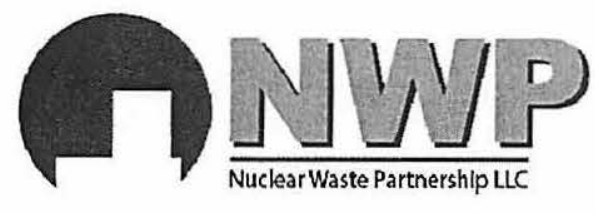

CP:14:02004

UFC:5822.00

AURS-led partnership with B\&W and AREVA

January 24,2014

Ms. R. Hubler, Transportation Manager

Advanced Mixed Waste Treatment Plant/ITG

Idaho National Laboratory

850 Energy Drive, Suite 100

Idaho Falls, ID 83401

SUBJECT: CERTIFICATE OF DISPOSAL FOR POLYCHLORINATED BIPHENYL BEARING WASTE SHIPMENT NUMBERS IN140005, IN140006, IN140008, IN140009, IN140010, IN140012 AND IN140015 EMPLACED AT THE WASTE ISOLATION PILOT PLANT

Dear Ms. Hubler:

In compliance with Title 40 Code of Federal Regulations, Part 761.218 , I certify that the following Polychlorinated Biphenyl (PCB) wastes from your facility have been disposed by emplacement 2,150 feet underground in the Waste Isolation Pilot Plant waste repository.

Disposal Facility:

Waste Isolation Pilot Plant

30 Miles SE of Carlsbad, New Mexico

Eddy County, New Mexico 88220

Environmental Protection Agency (EPA) Identification Number (ID): $\underline{\text { NM4890139088 }}$

Shipping Site's EPA ID: ID4890008952

\begin{tabular}{|c|c|c|c|}
\hline $\begin{array}{c}\text { Shipment } \\
\text { Number }\end{array}$ & $\begin{array}{c}\text { Manifest Tracking } \\
\text { Number }\end{array}$ & $\begin{array}{c}\text { Container } \\
\text { Number }\end{array}$ & $\begin{array}{c}\text { Emplacement } \\
\text { Date }\end{array}$ \\
\hline IN140005 & $001600933 G B F$ & BN10503786 & $1 / 17 / 2014$ \\
\hline IN140005 & $001600933 G B F$ & BN10503781 & $1 / 8 / 2014$ \\
\hline IN140006 & $001600934 G B F$ & BN10501231 & $1 / 10 / 2014$ \\
\hline IN140006 & $001600934 G B F$ & BN10490916 & $1 / 17 / 2014$ \\
\hline IN140008 & $001600936 G B F$ & BN10500615 & $1 / 15 / 2014$ \\
\hline IN140008 & $001600936 G B F$ & BN10501238 & $1 / 15 / 2014$ \\
\hline IN140009 & $001600937 G B F$ & BN10501234 & $1 / 12 / 2014$ \\
\hline IN140009 & $001600937 G B F$ & BN10503780 & $1 / 12 / 2014$ \\
\hline IN140010 & $001600938 G B F$ & $B N 10490915$ & $1 / 12 / 2014$ \\
\hline IN140010 & $001600938 G B F$ & $B N 10503782$ & $1 / 17 / 2014$ \\
\hline IN140012 & $001600940 G B F$ & BN10505064 & $1 / 19 / 2014$ \\
\hline IN140012 & $001600940 G B F$ & BN10505065 & $1 / 17 / 2014$ \\
\hline
\end{tabular}




\begin{tabular}{|c|c|c|c|}
\hline $\begin{array}{c}\text { Shipment } \\
\text { Number }\end{array}$ & $\begin{array}{c}\text { Manifest Tracking } \\
\text { Number }\end{array}$ & $\begin{array}{c}\text { Container } \\
\text { Number }\end{array}$ & $\begin{array}{c}\text { Emplacement } \\
\text { Date }\end{array}$ \\
\hline IN140015 & $001600943 \mathrm{GBF}$ & $\mathrm{BN} 10505057$ & $1 / 21 / 2014$ \\
\hline IN140015 & $001600943 \mathrm{GBF}$ & $\mathrm{BN} 10505066$ & $1 / 21 / 2014$ \\
\hline
\end{tabular}

Under civil and criminal penalties of law for the making or submission of false or fraudulent statements or representations (18 U.S.C. 1001 and 15 U.S.C. 2615), I certify that the information contained in or accompanying this document is true, accurate, and complete.

As to the identified section(s) of this document for which I cannot personally verify truth and accuracy, I certify as the company official having supervisory responsibility for the persons who, acting under my direct instructions, made the verification that this information is true, accurate, and complete.

Should you require further information concerning this certificate of disposal, please contact Mr. R. S. (Bob) Nieman at (575) 234-8141.

Sincerely,

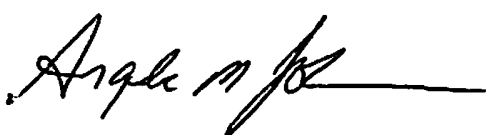

A. M. Johnson, Manager

Transportation Management

RSN/rsn

cc: Shipment portfolio for shipments IN140005, IN140006, IN140008, IN140009, IN140010, IN140012 and IN140015. 
bcc: NWP Distribution
A. M. Johnson
ED
R. U. Carrasco
ED
K. G. Darrah
ED
R. S. Nieman
ED
J.P. Smith
ED

\section{RES Distribution}

S. L. Travis, RES ED 
Please print or type. (Form designed for use on elite (12-pitch) typewriter.)

Form Approved. OMB No. 2050-0039

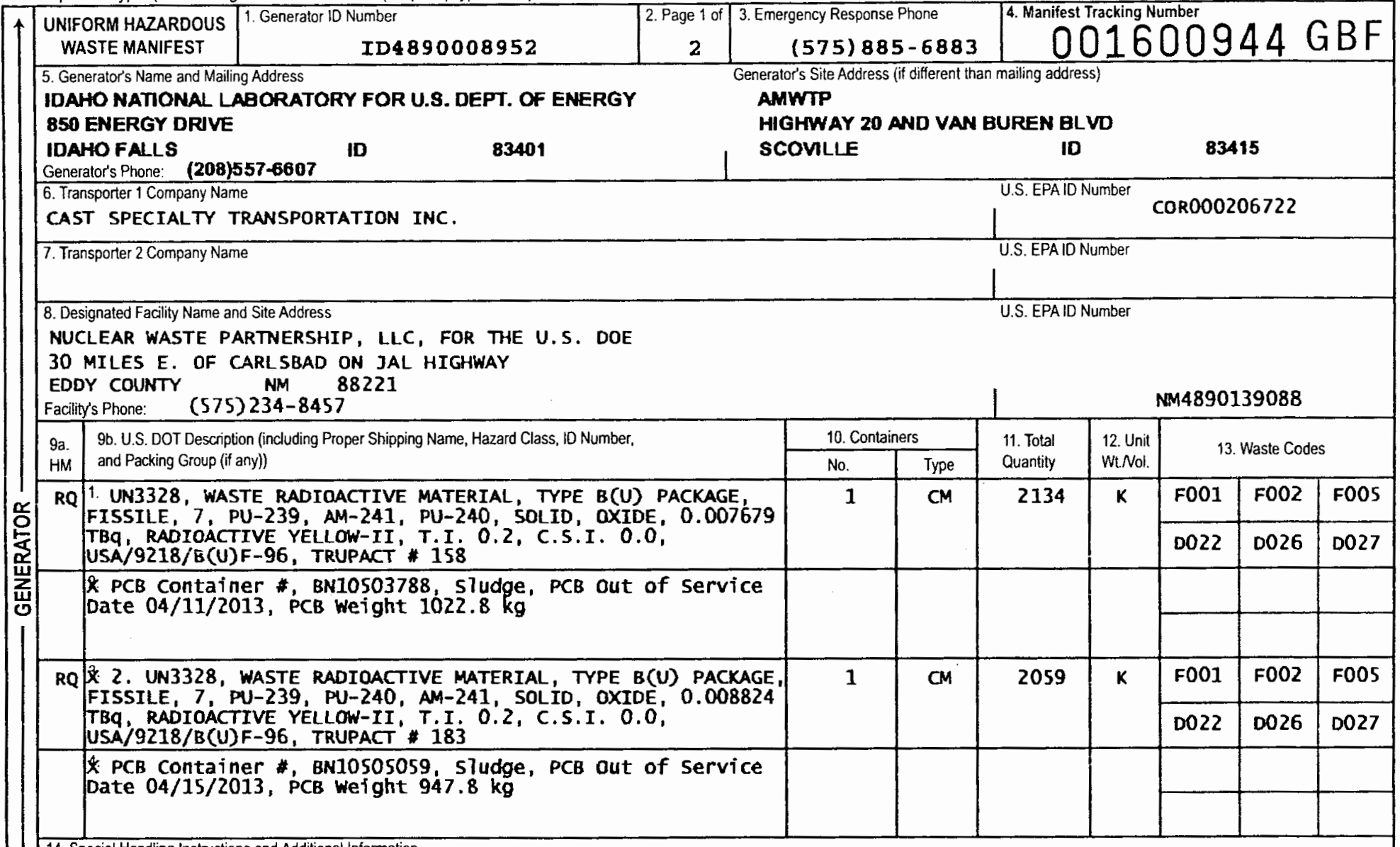

14. Special Handling Instructions and Additional Information

SHIPMENT \# IN140016 TRACTOR - C - $35 \quad$ TRAILER - 327

GROSS WEIGHT IN LBS: TP\# $158=17,321$ TP\# $183=17,356$ TP\# S01 = 13,587

PREPARED UNDER CONTRACT \# DE-EM0001467 ERG - 165 TO

15. GENERATOR'S/OFFEROR'S CERTIFICATION: I hereby declare that the contents of this consignment are fully and accurately described above by the proper shipping name, and are classified, packaged, marked and labelediplacarded, and are in all respects in proper condition for transport according to applicable international and national governmental regulations. If export shipment and I am the Primary Exporter, f certify that the contents of this consignment conform to the terms of the attached EPA Acknowledgment of Consent.

I certify that the waste minimization statement identified in 40 CFR 262.27 (a) (if I am a large quantity generator) or (b) (ifl am a small quantity generator) is true.

Generator's/Offero's Printed/fyped Name

S.R. D ANCE

$\vec{E}$ 16. International Shipments $\square$ import to U.S.

Transporter signature (for exports onity):

Signature

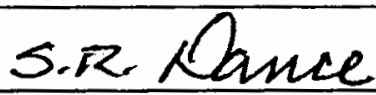

17. Transporter Acknowledgment of Receipt of Materials

Thsporter 1 Printed/Typed Name

Steinmen

Bnyan

Ned Name

$\square$ Expont from U.S.

Por of entry/exit:

Date leaving U.S

18. Discrepancy

18a. Discrepancy Indication Space $\quad \square$ Quantity

$\square_{\text {Type }}$

$\square$ Residue

$[$ Partial Rejection

$\square$ Full Rejection

Manifest Reference Number:

18b. Alternate Facility (or Generator)

U.S. EPA ID Number

Facility's Phone:

18c. Signature of Alternate Facility (or Generator)

99. Hazardous Waste Report Management Methad Codes (i.e., codes for hazardous waste treatment, disposal, and recycling systems)

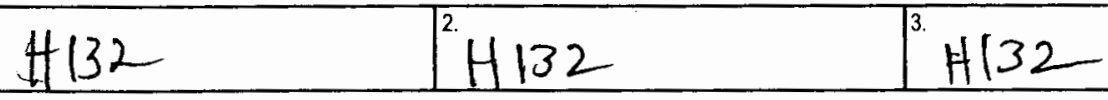

20. Designated Facility Owner or Operator: Certification of receipt of hazardous materials covered by the manifest except as nded in ltem 18a 


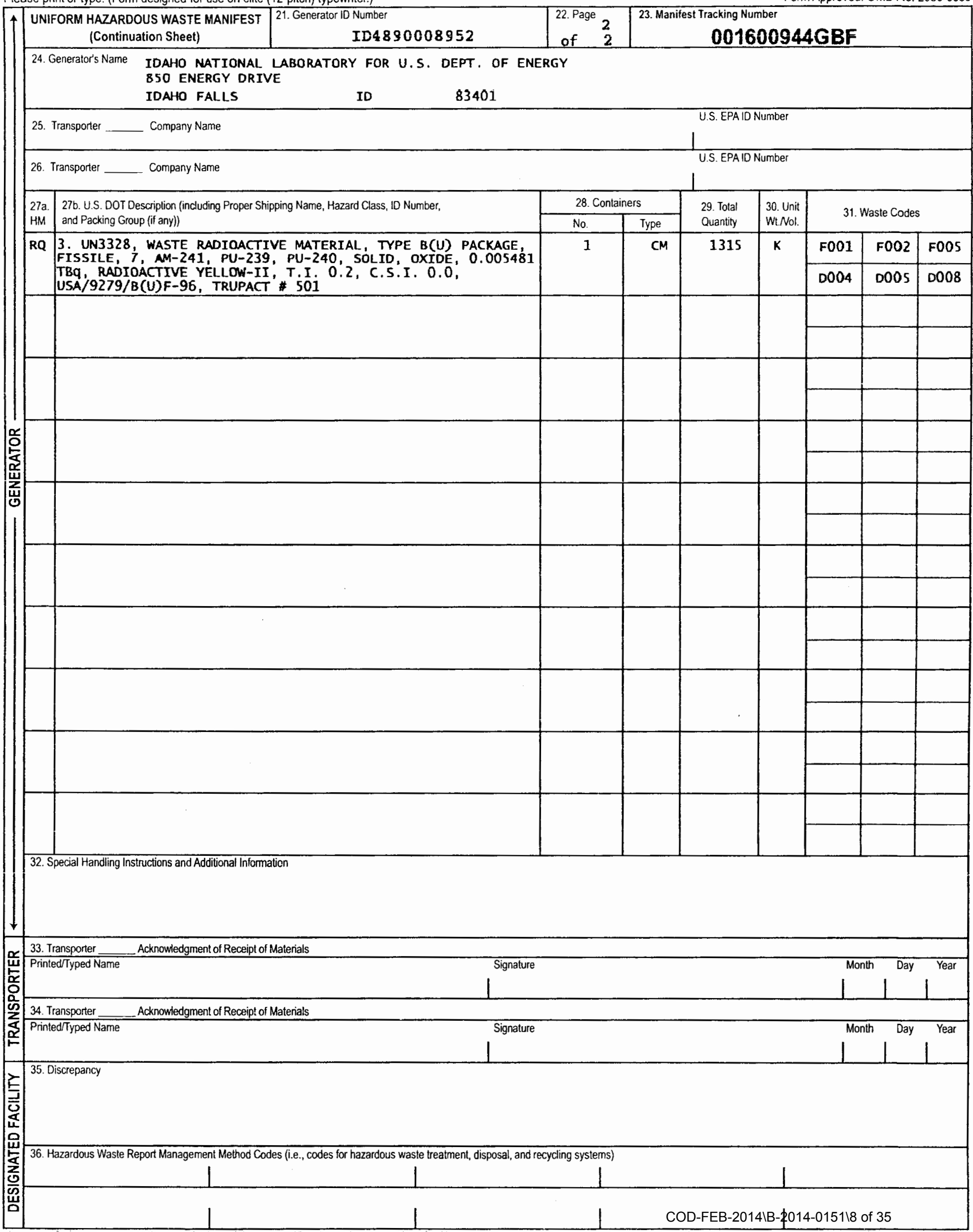




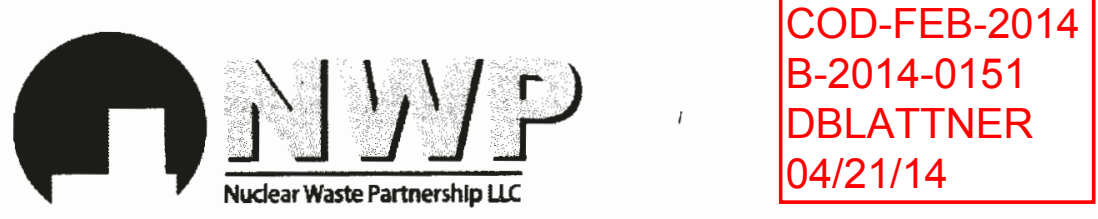

CP:14:02012

UFC:5822.00

A URS-led partnership with B\&W and AREVA

February 12, 2014

Ms. R. Hubler, Transportation Manager

Advanced Mixed Waste Treatment Plant/ITG

Idaho National Laboratory

850 Energy Drive, Suite 100

Idaho Falls, ID 83401

SUBJECT: CERTIFICATE OF DISPOSAL FOR POLYCHLORINATED BIPHENYL BEARING WASTE SHIPMENT NUMBERS IN140013, IN140014, IN140016, IN140018, IN140019, IN140022, IN140023, IN140024, IN140026, IN140028, IN140029, IN140031, IN140033, IN140034, IN140035, IN140038 AND IN140039 EMPLACED AT THE WASTE ISOLATION PILOT PLANT

Dear Ms. Hubler:

In compliance with Title 40 Code of Federal Regulations, Part 761.218 , I certify that the following Polychlorinated Biphenyl (PCB) wastes from your facility have been disposed by emplacement 2,150 feet underground in the Waste Isolation Pilot Plant waste repository.

Disposal Facility:

Waste Isolation Pilot Plant

30 Miles SE of Carlsbad, New Mexico

Eddy County, New Mexico 88220

Environmental Protection Agency (EPA) Identification Number (ID): NM4890139088

Shipping Site's EPA ID: ID4890008952

\begin{tabular}{|c|c|c|c|}
\hline $\begin{array}{c}\text { Shipment } \\
\text { Number }\end{array}$ & $\begin{array}{c}\text { Manifest Tracking } \\
\text { Number }\end{array}$ & $\begin{array}{c}\text { Container } \\
\text { Number }\end{array}$ & $\begin{array}{c}\text { Emplacement } \\
\text { Date }\end{array}$ \\
\hline IN140013 & $001600941 \mathrm{GBF}$ & BN10505055 & $1 / 24 / 2014$ \\
\hline IN140013 & $001600941 \mathrm{GBF}$ & BN10505054 & $1 / 21 / 2014$ \\
\hline IN140014 & $001600942 \mathrm{GBF}$ & BN10490911 & $1 / 25 / 2014$ \\
\hline IN140014 & $001600942 \mathrm{GBF}$ & BN10490912 & $1 / 25 / 2014$ \\
\hline IN140016 & $001600944 \mathrm{GBF}$ & BN10505059 & $1 / 24 / 2014$ \\
\hline IN140016 & $001600944 \mathrm{GBF}$ & BN10503788 & $1 / 24 / 2014$ \\
\hline IN140018 & $001600946 \mathrm{GBF}$ & BN10505058 & $1 / 26 / 2014$ \\
\hline IN140018 & $001600946 \mathrm{GBF}$ & BN10505062 & $1 / 26 / 2014$ \\
\hline IN140019 & $001600947 \mathrm{GBF}$ & BN10503775 & $1 / 24 / 2014$ \\
\hline IN140019 & $001600947 \mathrm{GBF}$ & BN10503760 & $1 / 24 / 2014$ \\
\hline IN140022 & 001600950GBF & BN10505063 & $2 / 2 / 2014$ \\
\hline
\end{tabular}




\begin{tabular}{|c|c|c|c|}
\hline $\begin{array}{l}\text { Shipment } \\
\text { Number }\end{array}$ & $\begin{array}{c}\text { Manifest Tracking } \\
\text { Number }\end{array}$ & $\begin{array}{l}\text { Container } \\
\text { Number }\end{array}$ & $\begin{array}{c}\text { Emplacement } \\
\text { Date }\end{array}$ \\
\hline IN140022 & $001600950 \mathrm{GBF}$ & BN10501246 & $1 / 24 / 2014$ \\
\hline IN140023 & $001600951 \mathrm{GBF}$ & BN10500612 & $1 / 30 / 2014$ \\
\hline IN140023 & $001600951 \mathrm{GBF}$ & BN10503777 & $1 / 26 / 2014$ \\
\hline IN140024 & $001600952 \mathrm{GBF}$ & BN10509616 & $1 / 24 / 2014$ \\
\hline IN140024 & $001600952 \mathrm{GBF}$ & BN10509615 & $2 / 2 / 2014$ \\
\hline IN140026 & $001600954 \mathrm{GBF}$ & BN10509688 & $1 / 26 / 2014$ \\
\hline IN140026 & $001600954 \mathrm{GBF}$ & BN10509618 & $1 / 28 / 2014$ \\
\hline IN140028 & $001600956 \mathrm{GBF}$ & BN10503774 & $1 / 28 / 2014$ \\
\hline IN140028 & $001600956 \mathrm{GBF}$ & BN10509606 & $1 / 28 / 2014$ \\
\hline IN140029 & $001600957 \mathrm{GBF}$ & BN10501248 & $1 / 28 / 2014$ \\
\hline IN140029 & $001600957 \mathrm{GBF}$ & BN10509611 & $2 / 1 / 2014$ \\
\hline IN140031 & $001600959 \mathrm{GBF}$ & BN10505060 & $2 / 1 / 2014$ \\
\hline IN140031 & 001600959GBF & BN10505061 & $1 / 28 / 2014$ \\
\hline IN140033 & $001600961 \mathrm{GBF}$ & BN10509682 & $1 / 31 / 2014$ \\
\hline IN140033 & $001600961 \mathrm{GBF}$ & BN10509601 & $1 / 31 / 2014$ \\
\hline IN140034 & $001600962 \mathrm{GBF}$ & BN10507549 & $2 / 2 / 2014$ \\
\hline IN140034 & $001600962 \mathrm{GBF}$ & BN10509687 & $2 / 1 / 2014$ \\
\hline IN140035 & $001600963 \mathrm{GBF}$ & BN10507550 & $1 / 31 / 2014$ \\
\hline IN140035 & $001600963 \mathrm{GBF}$ & BN10509599 & $2 / 1 / 2014$ \\
\hline IN140038 & $001600966 \mathrm{GBF}$ & BN10507553 & $2 / 2 / 2014$ \\
\hline IN140038 & $001600966 \mathrm{GBF}$ & BN10507557 & $2 / 2 / 2014$ \\
\hline IN140039 & $001600967 \mathrm{GBF}$ & BN10507555 & $2 / 4 / 2014$ \\
\hline IN140039 & $001600967 \mathrm{GBF}$ & BN10507554 & $2 / 4 / 2014$ \\
\hline
\end{tabular}

Under civil and criminal penalties of law for the making or submission of false or fraudulent statements or representations (18 U.S.C. 1001 and 15 U.S.C. 2615), I certify that the information contained in or accompanying this document is true, accurate, and complete.

As to the identified section(s) of this document for which I cannot personally verify truth and accuracy, I certify as the company official having supervisory responsibility for the persons who, acting under my direct instructions, made the verification that this information is true, accurate, and complete.

Should you require further information concerning this certificate of disposal, please contact Mr. R. S. (Bob) Nieman at (575) 234-8141.

Sincerely,

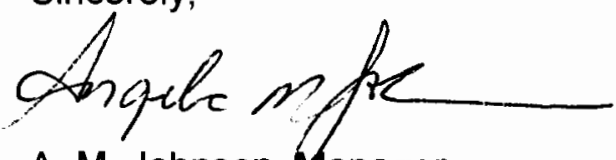

A. M. Johnson, Manager

Transportation Management

RSN/rsn

cc: Shipment portfolio for shipments IN140013, IN140014, IN140016, IN140018, IN140019, IN140022, IN140023, IN140024, IN140026, IN140028, IN140029, IN140031, IN140033, IN140034, IN140035, IN140038 and IN140039. 
Please print or type. (Form designed for use on elite (12-pitch; ypewriter.)

Form Approved. OMB No. 2050-0039

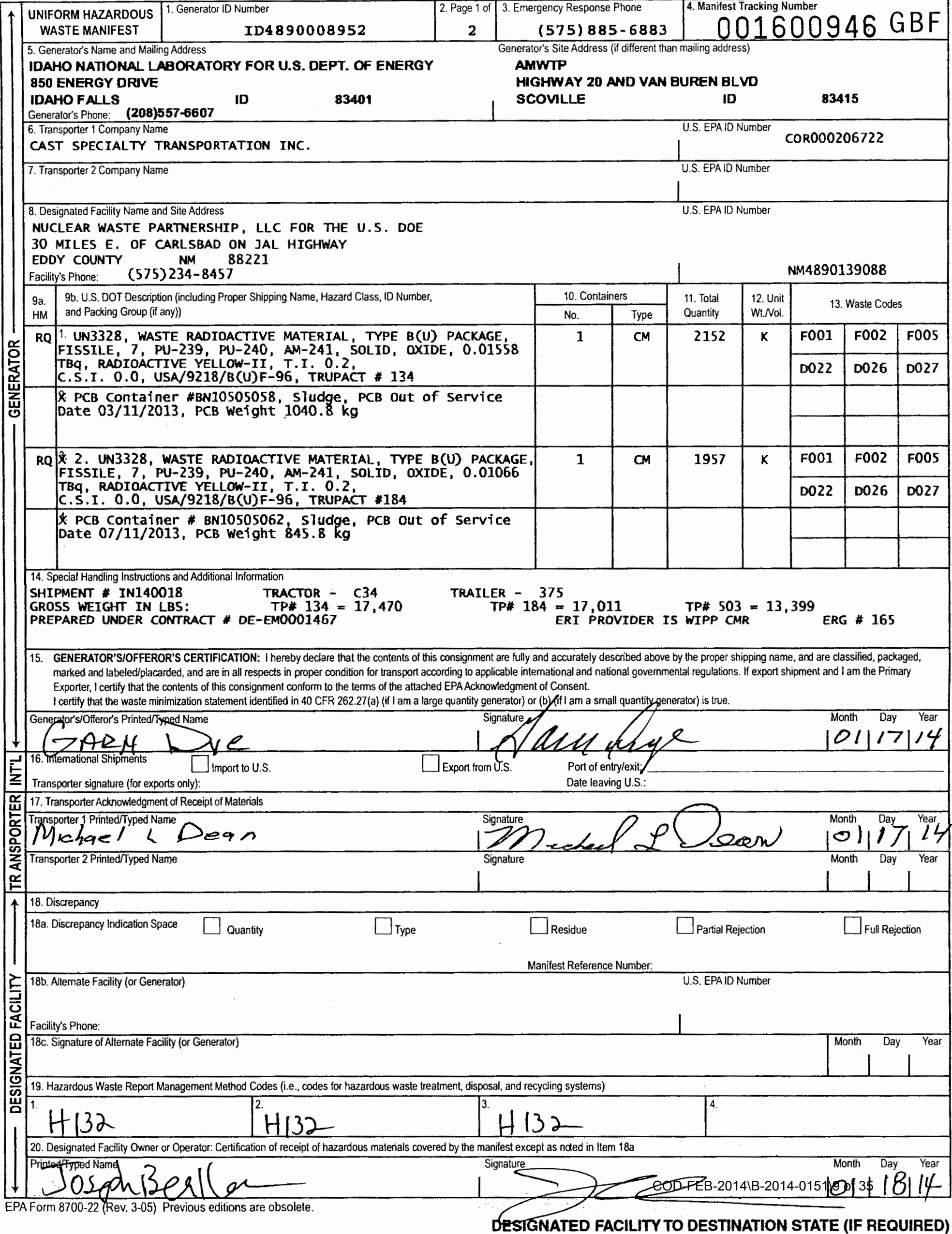


Please print or type. (Form designed for use on elite (12-pitch) typewriter.)

Form Approved. OMB No. 2050-0039

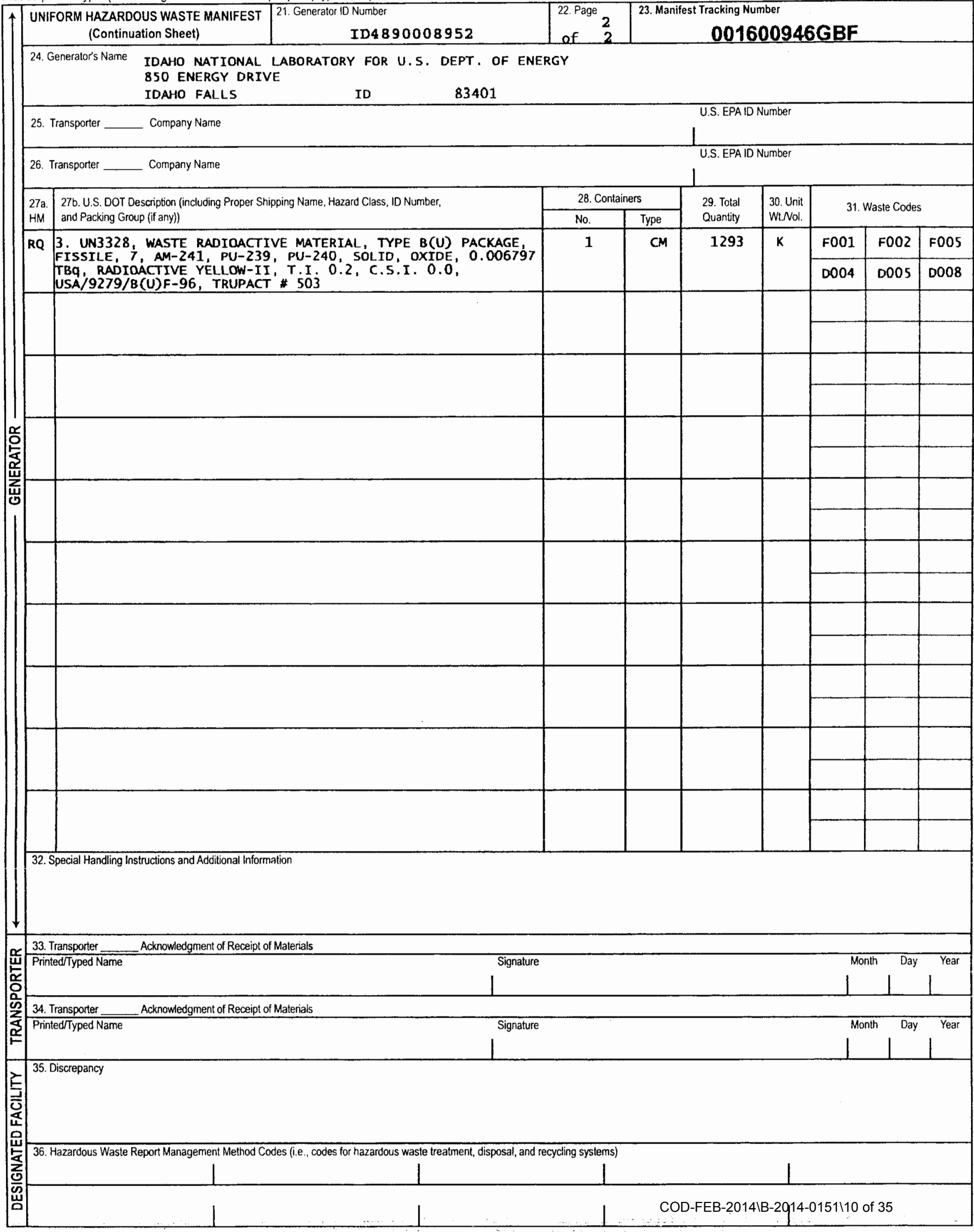




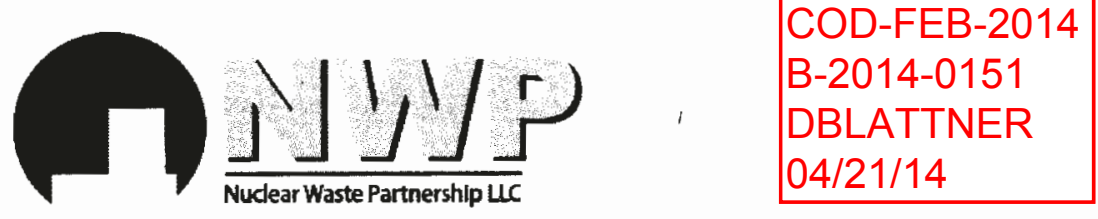

CP:14:02012

UFC:5822.00

A URS-led partnership with B\&W and AREVA

February 12, 2014

Ms. R. Hubler, Transportation Manager

Advanced Mixed Waste Treatment Plant/ITG

Idaho National Laboratory

850 Energy Drive, Suite 100

Idaho Falls, ID 83401

SUBJECT: CERTIFICATE OF DISPOSAL FOR POLYCHLORINATED BIPHENYL BEARING WASTE SHIPMENT NUMBERS IN140013, IN140014, IN140016, IN140018, IN140019, IN140022, IN140023, IN140024, IN140026, IN140028, IN140029, IN140031, IN140033, IN140034, IN140035, IN140038 AND IN140039 EMPLACED AT THE WASTE ISOLATION PILOT PLANT

Dear Ms. Hubler:

In compliance with Title 40 Code of Federal Regulations, Part 761.218 , I certify that the following Polychlorinated Biphenyl (PCB) wastes from your facility have been disposed by emplacement 2,150 feet underground in the Waste Isolation Pilot Plant waste repository.

Disposal Facility:

Waste Isolation Pilot Plant

30 Miles SE of Carlsbad, New Mexico

Eddy County, New Mexico 88220

Environmental Protection Agency (EPA) Identification Number (ID): NM4890139088

Shipping Site's EPA ID: ID4890008952

\begin{tabular}{|c|c|c|c|}
\hline $\begin{array}{c}\text { Shipment } \\
\text { Number }\end{array}$ & $\begin{array}{c}\text { Manifest Tracking } \\
\text { Number }\end{array}$ & $\begin{array}{c}\text { Container } \\
\text { Number }\end{array}$ & $\begin{array}{c}\text { Emplacement } \\
\text { Date }\end{array}$ \\
\hline IN140013 & $001600941 \mathrm{GBF}$ & BN10505055 & $1 / 24 / 2014$ \\
\hline IN140013 & $001600941 \mathrm{GBF}$ & BN10505054 & $1 / 21 / 2014$ \\
\hline IN140014 & $001600942 \mathrm{GBF}$ & BN10490911 & $1 / 25 / 2014$ \\
\hline IN140014 & $001600942 \mathrm{GBF}$ & BN10490912 & $1 / 25 / 2014$ \\
\hline IN140016 & $001600944 \mathrm{GBF}$ & BN10505059 & $1 / 24 / 2014$ \\
\hline IN140016 & $001600944 \mathrm{GBF}$ & BN10503788 & $1 / 24 / 2014$ \\
\hline IN140018 & $001600946 \mathrm{GBF}$ & BN10505058 & $1 / 26 / 2014$ \\
\hline IN140018 & $001600946 \mathrm{GBF}$ & BN10505062 & $1 / 26 / 2014$ \\
\hline IN140019 & $001600947 \mathrm{GBF}$ & BN10503775 & $1 / 24 / 2014$ \\
\hline IN140019 & $001600947 \mathrm{GBF}$ & BN10503760 & $1 / 24 / 2014$ \\
\hline IN140022 & 001600950GBF & BN10505063 & $2 / 2 / 2014$ \\
\hline
\end{tabular}




\begin{tabular}{|c|c|c|c|}
\hline $\begin{array}{l}\text { Shipment } \\
\text { Number }\end{array}$ & $\begin{array}{c}\text { Manifest Tracking } \\
\text { Number }\end{array}$ & $\begin{array}{l}\text { Container } \\
\text { Number }\end{array}$ & $\begin{array}{c}\text { Emplacement } \\
\text { Date }\end{array}$ \\
\hline IN140022 & $001600950 \mathrm{GBF}$ & BN10501246 & $1 / 24 / 2014$ \\
\hline IN140023 & $001600951 \mathrm{GBF}$ & BN10500612 & $1 / 30 / 2014$ \\
\hline IN140023 & $001600951 \mathrm{GBF}$ & BN10503777 & $1 / 26 / 2014$ \\
\hline IN140024 & $001600952 \mathrm{GBF}$ & BN10509616 & $1 / 24 / 2014$ \\
\hline IN140024 & $001600952 \mathrm{GBF}$ & BN10509615 & $2 / 2 / 2014$ \\
\hline IN140026 & $001600954 \mathrm{GBF}$ & BN10509688 & $1 / 26 / 2014$ \\
\hline IN140026 & $001600954 \mathrm{GBF}$ & BN10509618 & $1 / 28 / 2014$ \\
\hline IN140028 & $001600956 \mathrm{GBF}$ & BN10503774 & $1 / 28 / 2014$ \\
\hline IN140028 & $001600956 \mathrm{GBF}$ & BN10509606 & $1 / 28 / 2014$ \\
\hline IN140029 & $001600957 \mathrm{GBF}$ & BN10501248 & $1 / 28 / 2014$ \\
\hline IN140029 & $001600957 \mathrm{GBF}$ & BN10509611 & $2 / 1 / 2014$ \\
\hline IN140031 & $001600959 \mathrm{GBF}$ & BN10505060 & $2 / 1 / 2014$ \\
\hline IN140031 & 001600959GBF & BN10505061 & $1 / 28 / 2014$ \\
\hline IN140033 & $001600961 \mathrm{GBF}$ & BN10509682 & $1 / 31 / 2014$ \\
\hline IN140033 & $001600961 \mathrm{GBF}$ & BN10509601 & $1 / 31 / 2014$ \\
\hline IN140034 & $001600962 \mathrm{GBF}$ & BN10507549 & $2 / 2 / 2014$ \\
\hline IN140034 & $001600962 \mathrm{GBF}$ & BN10509687 & $2 / 1 / 2014$ \\
\hline IN140035 & $001600963 \mathrm{GBF}$ & BN10507550 & $1 / 31 / 2014$ \\
\hline IN140035 & $001600963 \mathrm{GBF}$ & BN10509599 & $2 / 1 / 2014$ \\
\hline IN140038 & $001600966 \mathrm{GBF}$ & BN10507553 & $2 / 2 / 2014$ \\
\hline IN140038 & $001600966 \mathrm{GBF}$ & BN10507557 & $2 / 2 / 2014$ \\
\hline IN140039 & $001600967 \mathrm{GBF}$ & BN10507555 & $2 / 4 / 2014$ \\
\hline IN140039 & $001600967 \mathrm{GBF}$ & BN10507554 & $2 / 4 / 2014$ \\
\hline
\end{tabular}

Under civil and criminal penalties of law for the making or submission of false or fraudulent statements or representations (18 U.S.C. 1001 and 15 U.S.C. 2615), I certify that the information contained in or accompanying this document is true, accurate, and complete.

As to the identified section(s) of this document for which I cannot personally verify truth and accuracy, I certify as the company official having supervisory responsibility for the persons who, acting under my direct instructions, made the verification that this information is true, accurate, and complete.

Should you require further information concerning this certificate of disposal, please contact Mr. R. S. (Bob) Nieman at (575) 234-8141.

Sincerely,

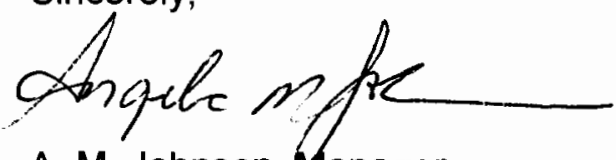

A. M. Johnson, Manager

Transportation Management

RSN/rsn

cc: Shipment portfolio for shipments IN140013, IN140014, IN140016, IN140018, IN140019, IN140022, IN140023, IN140024, IN140026, IN140028, IN140029, IN140031, IN140033, IN140034, IN140035, IN140038 and IN140039. 
Please print or type. (Form designed for use on elite (12-pitch) typewriter.)

Form Approved. OMB No. 2050-0039

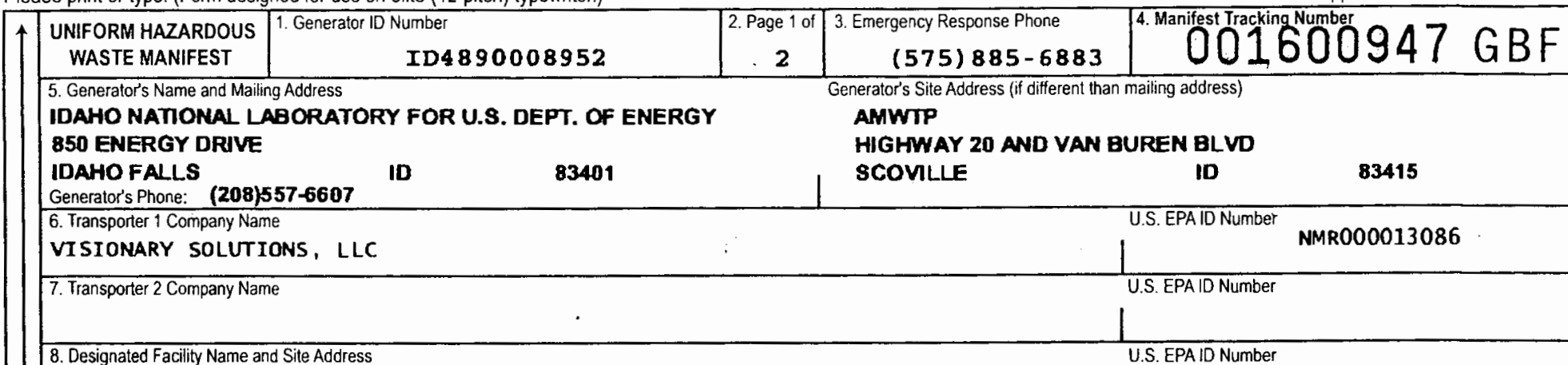

NUCLEAR WASTE PARTNERSHIP, LLC FOR THE U.S. DOE

30 MILES E. OF CARLSBAD ON JAL HIGHWAY

EDDY COUNTY NM 88221

Facility's Phone: (575) 234-8457

9a. 9b. U.S. DOT Description (including Proper Shipping Name, Hazard Class, ID Number,

HM and Packing Group (if anyi)

RQ 1. UN3328, WASTE RADIOACTIVE MATERTAL, TYPE B(U) PACKAGE FISSILE, 7, PU-239, AM-241, PU-240, SOLID, OXIDE, 0.00908

TBq, RADIOACTIVE YELLOW-II, T.I. 0.2, C.S.Y. 0.0,

USA' $/ 9218 / B(U) F-96$, TRUPACT \# 200

2. PCB Container \# BN10503760, sludge, PCB out of service

bate $04 / 29 / 2013$, $P C B$ Weight $1028.8 \mathrm{~kg}$

RQ 2. UN3328, WASTE RADIOACTIVE MATERIAL, TYPE B(U) PACKAGE,

FISSILE, 7, PU-239, AM-241, PU-240, PU-238, SOLID, OXIDE,

0.01603 TBq, RADTOACTIVE YELLOW-II, T.I. 0.2, C.S.I. 0.0, USA $/ 9218 / B(U)$ F-96, TRUPACT \# 209

* PCB Container \# BN10503775, sludge, PCB out of service pate $05 / 15 / 2013$, PCB Weight $929.8 \mathrm{~kg}$

14. Special Handling Instructions and Additional Information

SHIPMENT * IN140019 TRACTOR - V - 27

GROSS WEIGHT IN LBS: TP\# $200=17,380$
PREPARED UNDER CONTRACT \# DE-EMOOO1467

15. GENERATOR'S/OFFEROR'S CERTIFICATION: I hereby declare that the contents of this consignment are fully and accurately described above by the proper shipping name, and are classified, packaged, marked and labeled'placarded, and are in all respects in proper condition for transport according to applicable international and national govemmental regulations. If export shipment and I am the Primary

Exporter, I certity that the contents of this consignment conform to the terms of the attached EPAAcknowledgment of Consent.

$I$ cerrity that the waste minimization statement identified in 40 CFR 262.27 (a) (if I am a large quantity generator) or (b) (if I am a small quantity generator) is true,

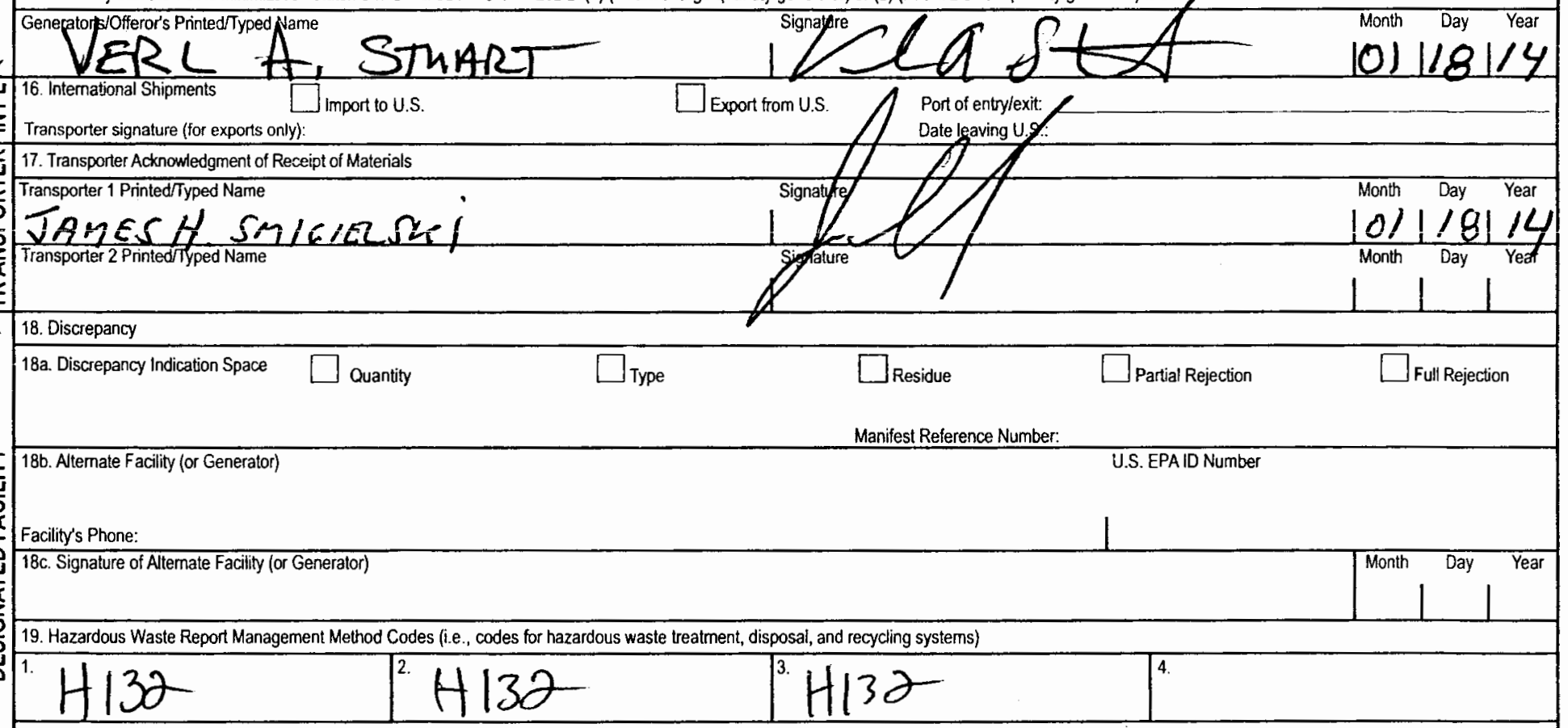

20. Designated Facility Owner or Operator: Certification of receipt of hazardous matenals covered by the manifest except as noded in ltem 18a

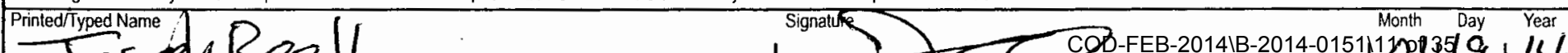


Please print or type. (Form designed for use on elite (12-pitch) typewriter)

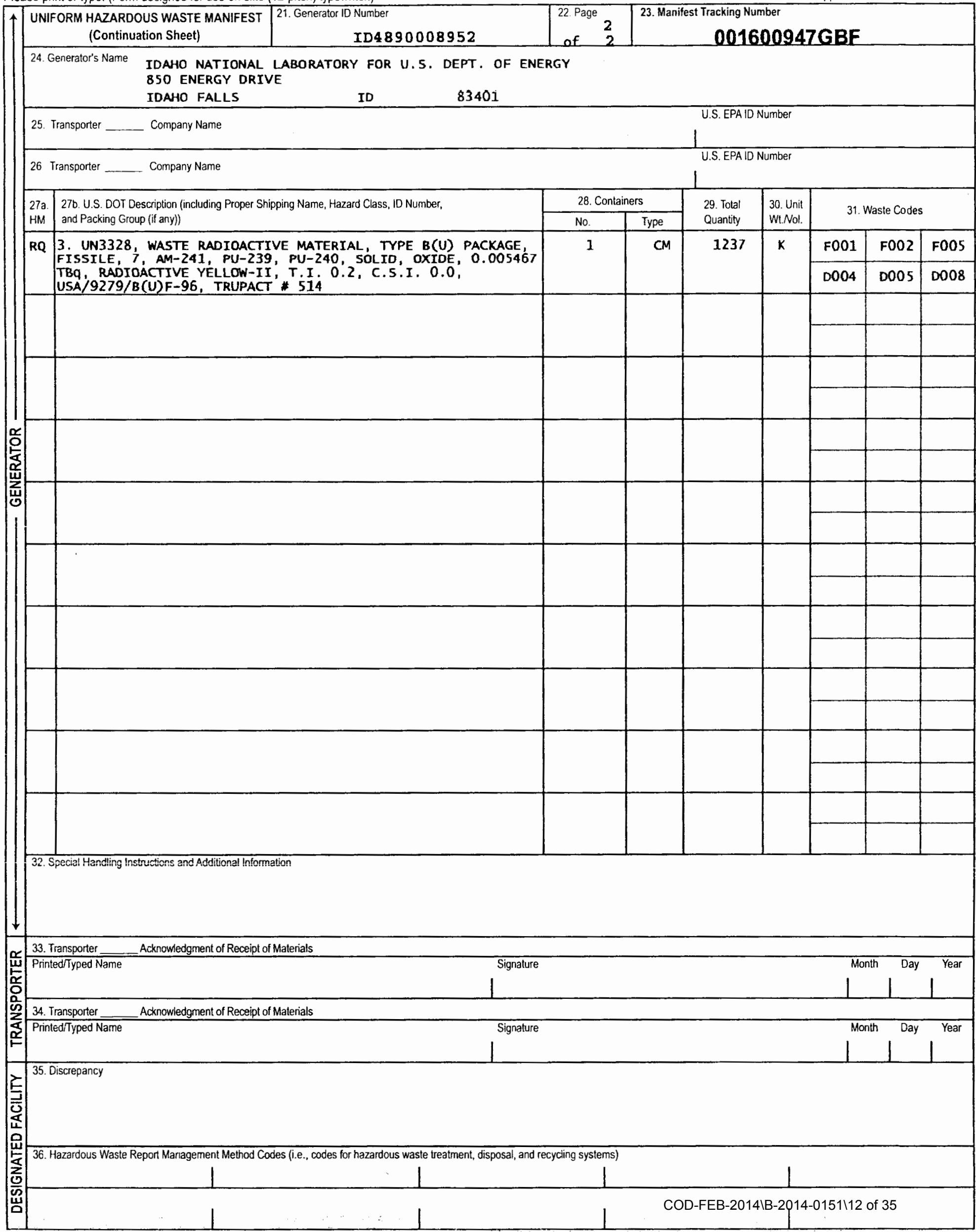




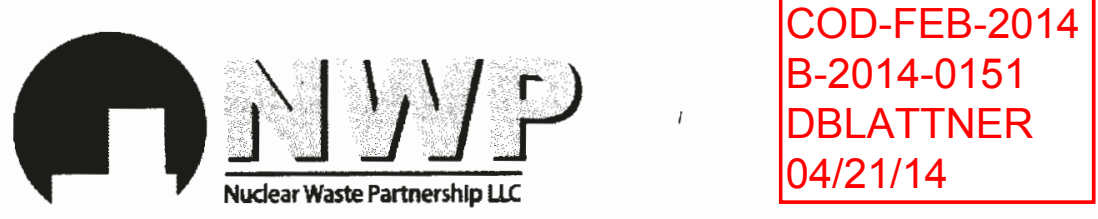

CP:14:02012

UFC:5822.00

A URS-led partnership with B\&W and AREVA

February 12, 2014

Ms. R. Hubler, Transportation Manager

Advanced Mixed Waste Treatment Plant/ITG

Idaho National Laboratory

850 Energy Drive, Suite 100

Idaho Falls, ID 83401

SUBJECT: CERTIFICATE OF DISPOSAL FOR POLYCHLORINATED BIPHENYL BEARING WASTE SHIPMENT NUMBERS IN140013, IN140014, IN140016, IN140018, IN140019, IN140022, IN140023, IN140024, IN140026, IN140028, IN140029, IN140031, IN140033, IN140034, IN140035, IN140038 AND IN140039 EMPLACED AT THE WASTE ISOLATION PILOT PLANT

Dear Ms. Hubler:

In compliance with Title 40 Code of Federal Regulations, Part 761.218 , I certify that the following Polychlorinated Biphenyl (PCB) wastes from your facility have been disposed by emplacement 2,150 feet underground in the Waste Isolation Pilot Plant waste repository.

Disposal Facility:

Waste Isolation Pilot Plant

30 Miles SE of Carlsbad, New Mexico

Eddy County, New Mexico 88220

Environmental Protection Agency (EPA) Identification Number (ID): NM4890139088

Shipping Site's EPA ID: ID4890008952

\begin{tabular}{|c|c|c|c|}
\hline $\begin{array}{c}\text { Shipment } \\
\text { Number }\end{array}$ & $\begin{array}{c}\text { Manifest Tracking } \\
\text { Number }\end{array}$ & $\begin{array}{c}\text { Container } \\
\text { Number }\end{array}$ & $\begin{array}{c}\text { Emplacement } \\
\text { Date }\end{array}$ \\
\hline IN140013 & $001600941 \mathrm{GBF}$ & BN10505055 & $1 / 24 / 2014$ \\
\hline IN140013 & $001600941 \mathrm{GBF}$ & BN10505054 & $1 / 21 / 2014$ \\
\hline IN140014 & $001600942 \mathrm{GBF}$ & BN10490911 & $1 / 25 / 2014$ \\
\hline IN140014 & $001600942 \mathrm{GBF}$ & BN10490912 & $1 / 25 / 2014$ \\
\hline IN140016 & $001600944 \mathrm{GBF}$ & BN10505059 & $1 / 24 / 2014$ \\
\hline IN140016 & $001600944 \mathrm{GBF}$ & BN10503788 & $1 / 24 / 2014$ \\
\hline IN140018 & $001600946 \mathrm{GBF}$ & BN10505058 & $1 / 26 / 2014$ \\
\hline IN140018 & $001600946 \mathrm{GBF}$ & BN10505062 & $1 / 26 / 2014$ \\
\hline IN140019 & $001600947 \mathrm{GBF}$ & BN10503775 & $1 / 24 / 2014$ \\
\hline IN140019 & $001600947 \mathrm{GBF}$ & BN10503760 & $1 / 24 / 2014$ \\
\hline IN140022 & 001600950GBF & BN10505063 & $2 / 2 / 2014$ \\
\hline
\end{tabular}




\begin{tabular}{|c|c|c|c|}
\hline $\begin{array}{l}\text { Shipment } \\
\text { Number }\end{array}$ & $\begin{array}{c}\text { Manifest Tracking } \\
\text { Number }\end{array}$ & $\begin{array}{l}\text { Container } \\
\text { Number }\end{array}$ & $\begin{array}{c}\text { Emplacement } \\
\text { Date }\end{array}$ \\
\hline IN140022 & $001600950 \mathrm{GBF}$ & BN10501246 & $1 / 24 / 2014$ \\
\hline IN140023 & $001600951 \mathrm{GBF}$ & BN10500612 & $1 / 30 / 2014$ \\
\hline IN140023 & $001600951 \mathrm{GBF}$ & BN10503777 & $1 / 26 / 2014$ \\
\hline IN140024 & $001600952 \mathrm{GBF}$ & BN10509616 & $1 / 24 / 2014$ \\
\hline IN140024 & $001600952 \mathrm{GBF}$ & BN10509615 & $2 / 2 / 2014$ \\
\hline IN140026 & $001600954 \mathrm{GBF}$ & BN10509688 & $1 / 26 / 2014$ \\
\hline IN140026 & $001600954 \mathrm{GBF}$ & BN10509618 & $1 / 28 / 2014$ \\
\hline IN140028 & $001600956 \mathrm{GBF}$ & BN10503774 & $1 / 28 / 2014$ \\
\hline IN140028 & $001600956 \mathrm{GBF}$ & BN10509606 & $1 / 28 / 2014$ \\
\hline IN140029 & $001600957 \mathrm{GBF}$ & BN10501248 & $1 / 28 / 2014$ \\
\hline IN140029 & $001600957 \mathrm{GBF}$ & BN10509611 & $2 / 1 / 2014$ \\
\hline IN140031 & $001600959 \mathrm{GBF}$ & BN10505060 & $2 / 1 / 2014$ \\
\hline IN140031 & 001600959GBF & BN10505061 & $1 / 28 / 2014$ \\
\hline IN140033 & $001600961 \mathrm{GBF}$ & BN10509682 & $1 / 31 / 2014$ \\
\hline IN140033 & $001600961 \mathrm{GBF}$ & BN10509601 & $1 / 31 / 2014$ \\
\hline IN140034 & $001600962 \mathrm{GBF}$ & BN10507549 & $2 / 2 / 2014$ \\
\hline IN140034 & $001600962 \mathrm{GBF}$ & BN10509687 & $2 / 1 / 2014$ \\
\hline IN140035 & $001600963 \mathrm{GBF}$ & BN10507550 & $1 / 31 / 2014$ \\
\hline IN140035 & $001600963 \mathrm{GBF}$ & BN10509599 & $2 / 1 / 2014$ \\
\hline IN140038 & $001600966 \mathrm{GBF}$ & BN10507553 & $2 / 2 / 2014$ \\
\hline IN140038 & $001600966 \mathrm{GBF}$ & BN10507557 & $2 / 2 / 2014$ \\
\hline IN140039 & $001600967 \mathrm{GBF}$ & BN10507555 & $2 / 4 / 2014$ \\
\hline IN140039 & $001600967 \mathrm{GBF}$ & BN10507554 & $2 / 4 / 2014$ \\
\hline
\end{tabular}

Under civil and criminal penalties of law for the making or submission of false or fraudulent statements or representations (18 U.S.C. 1001 and 15 U.S.C. 2615), I certify that the information contained in or accompanying this document is true, accurate, and complete.

As to the identified section(s) of this document for which I cannot personally verify truth and accuracy, I certify as the company official having supervisory responsibility for the persons who, acting under my direct instructions, made the verification that this information is true, accurate, and complete.

Should you require further information concerning this certificate of disposal, please contact Mr. R. S. (Bob) Nieman at (575) 234-8141.

Sincerely,

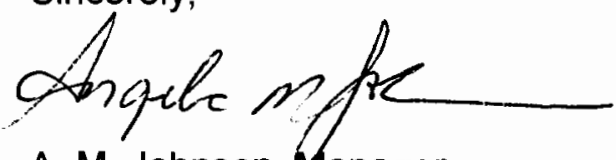

A. M. Johnson, Manager

Transportation Management

RSN/rsn

cc: Shipment portfolio for shipments IN140013, IN140014, IN140016, IN140018, IN140019, IN140022, IN140023, IN140024, IN140026, IN140028, IN140029, IN140031, IN140033, IN140034, IN140035, IN140038 and IN140039. 
Please print or type. (Form designed for use on elite (12-pitch) typewriter.)

Form Approved. OMB No. 2050-0039

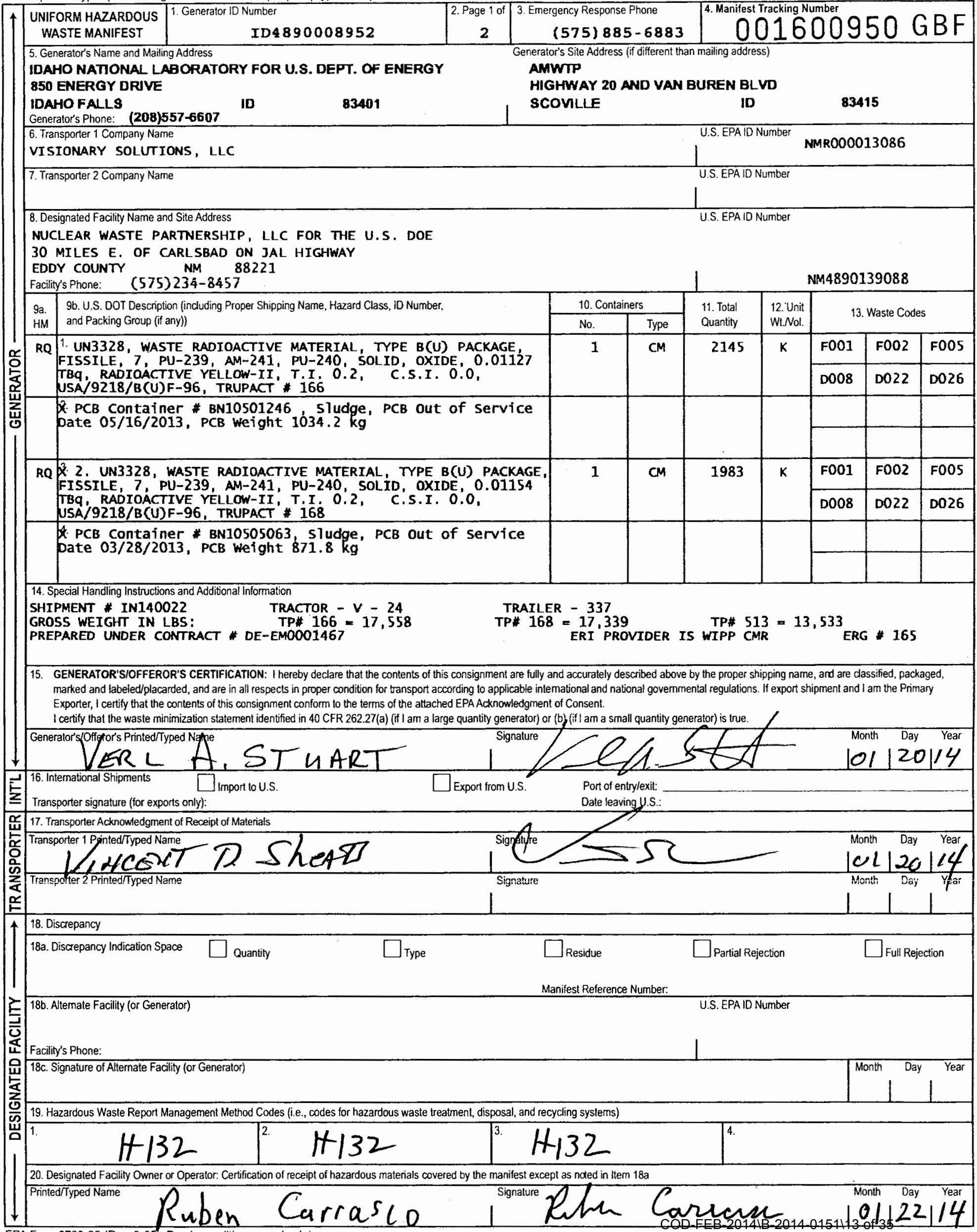




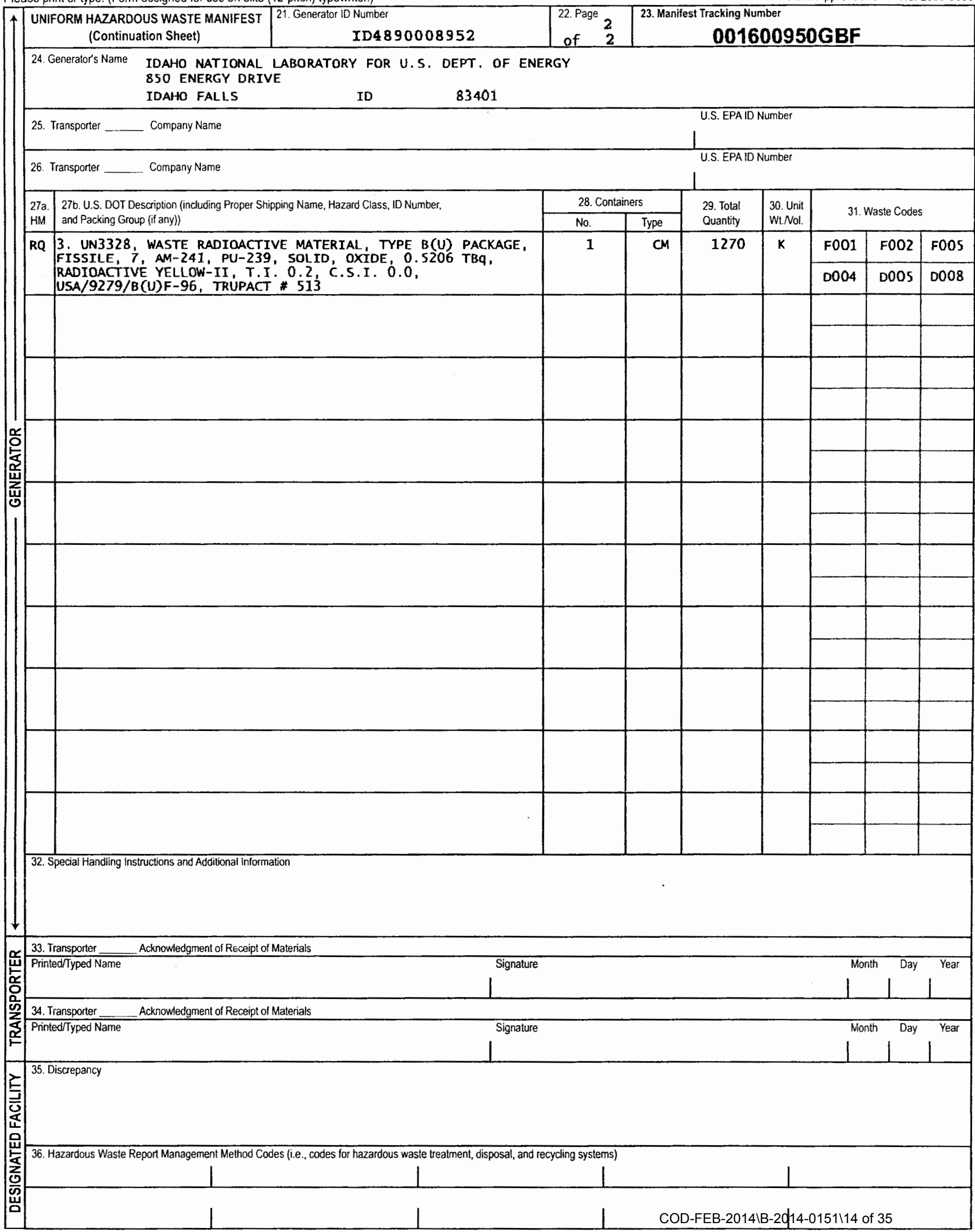




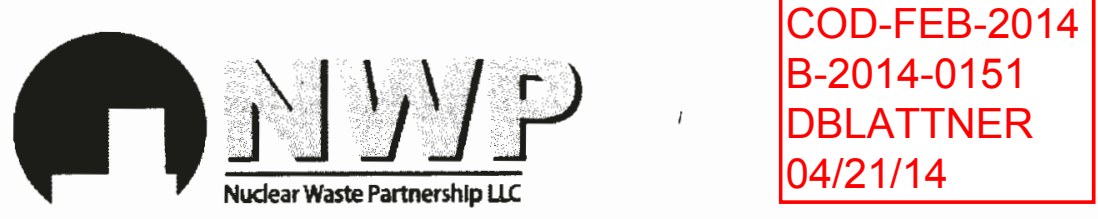

CP:14:02012

UFC:5822.00

A URS-led partnership with B\&W and AREVA

February 12, 2014

Ms. R. Hubler, Transportation Manager

Advanced Mixed Waste Treatment Plant/ITG

Idaho National Laboratory

850 Energy Drive, Suite 100

Idaho Falls, ID 83401

SUBJECT: CERTIFICATE OF DISPOSAL FOR POLYCHLORINATED BIPHENYL BEARING WASTE SHIPMENT NUMBERS IN140013, IN140014, IN140016, IN140018, IN140019, IN140022, IN140023, IN140024, IN140026, IN140028, IN140029, IN140031, IN140033, IN140034, IN140035, IN140038 AND IN140039 EMPLACED AT THE WASTE ISOLATION PILOT PLANT

Dear Ms. Hubler:

In compliance with Title 40 Code of Federal Regulations, Part 761.218 , I certify that the following Polychlorinated Biphenyl (PCB) wastes from your facility have been disposed by emplacement 2,150 feet underground in the Waste Isolation Pilot Plant waste repository.

Disposal Facility:

Waste Isolation Pilot Plant

30 Miles SE of Carlsbad, New Mexico

Eddy County, New Mexico 88220

Environmental Protection Agency (EPA) Identification Number (ID): NM4890139088

Shipping Site's EPA ID: ID4890008952

\begin{tabular}{|c|c|c|c|}
\hline $\begin{array}{c}\text { Shipment } \\
\text { Number }\end{array}$ & $\begin{array}{c}\text { Manifest Tracking } \\
\text { Number }\end{array}$ & $\begin{array}{c}\text { Container } \\
\text { Number }\end{array}$ & $\begin{array}{c}\text { Emplacement } \\
\text { Date }\end{array}$ \\
\hline IN140013 & $001600941 \mathrm{GBF}$ & BN10505055 & $1 / 24 / 2014$ \\
\hline IN140013 & $001600941 \mathrm{GBF}$ & BN10505054 & $1 / 21 / 2014$ \\
\hline IN140014 & $001600942 \mathrm{GBF}$ & BN10490911 & $1 / 25 / 2014$ \\
\hline IN140014 & $001600942 \mathrm{GBF}$ & BN10490912 & $1 / 25 / 2014$ \\
\hline IN140016 & $001600944 \mathrm{GBF}$ & BN10505059 & $1 / 24 / 2014$ \\
\hline IN140016 & $001600944 \mathrm{GBF}$ & BN10503788 & $1 / 24 / 2014$ \\
\hline IN140018 & $001600946 \mathrm{GBF}$ & BN10505058 & $1 / 26 / 2014$ \\
\hline IN140018 & $001600946 \mathrm{GBF}$ & BN10505062 & $1 / 26 / 2014$ \\
\hline IN140019 & $001600947 \mathrm{GBF}$ & BN10503775 & $1 / 24 / 2014$ \\
\hline IN140019 & $001600947 \mathrm{GBF}$ & BN10503760 & $1 / 24 / 2014$ \\
\hline IN140022 & 001600950GBF & BN10505063 & $2 / 2 / 2014$ \\
\hline
\end{tabular}




\begin{tabular}{|c|c|c|c|}
\hline $\begin{array}{l}\text { Shipment } \\
\text { Number }\end{array}$ & $\begin{array}{c}\text { Manifest Tracking } \\
\text { Number }\end{array}$ & $\begin{array}{l}\text { Container } \\
\text { Number }\end{array}$ & $\begin{array}{c}\text { Emplacement } \\
\text { Date }\end{array}$ \\
\hline IN140022 & $001600950 \mathrm{GBF}$ & BN10501246 & $1 / 24 / 2014$ \\
\hline IN140023 & $001600951 \mathrm{GBF}$ & BN10500612 & $1 / 30 / 2014$ \\
\hline IN140023 & $001600951 \mathrm{GBF}$ & BN10503777 & $1 / 26 / 2014$ \\
\hline IN140024 & $001600952 \mathrm{GBF}$ & BN10509616 & $1 / 24 / 2014$ \\
\hline IN140024 & $001600952 \mathrm{GBF}$ & BN10509615 & $2 / 2 / 2014$ \\
\hline IN140026 & $001600954 \mathrm{GBF}$ & BN10509688 & $1 / 26 / 2014$ \\
\hline IN140026 & $001600954 \mathrm{GBF}$ & BN10509618 & $1 / 28 / 2014$ \\
\hline IN140028 & $001600956 \mathrm{GBF}$ & BN10503774 & $1 / 28 / 2014$ \\
\hline IN140028 & $001600956 \mathrm{GBF}$ & BN10509606 & $1 / 28 / 2014$ \\
\hline IN140029 & $001600957 \mathrm{GBF}$ & BN10501248 & $1 / 28 / 2014$ \\
\hline IN140029 & $001600957 \mathrm{GBF}$ & BN10509611 & $2 / 1 / 2014$ \\
\hline IN140031 & $001600959 \mathrm{GBF}$ & BN10505060 & $2 / 1 / 2014$ \\
\hline IN140031 & 001600959GBF & BN10505061 & $1 / 28 / 2014$ \\
\hline IN140033 & $001600961 \mathrm{GBF}$ & BN10509682 & $1 / 31 / 2014$ \\
\hline IN140033 & $001600961 \mathrm{GBF}$ & BN10509601 & $1 / 31 / 2014$ \\
\hline IN140034 & $001600962 \mathrm{GBF}$ & BN10507549 & $2 / 2 / 2014$ \\
\hline IN140034 & $001600962 \mathrm{GBF}$ & BN10509687 & $2 / 1 / 2014$ \\
\hline IN140035 & $001600963 \mathrm{GBF}$ & BN10507550 & $1 / 31 / 2014$ \\
\hline IN140035 & $001600963 \mathrm{GBF}$ & BN10509599 & $2 / 1 / 2014$ \\
\hline IN140038 & $001600966 \mathrm{GBF}$ & BN10507553 & $2 / 2 / 2014$ \\
\hline IN140038 & $001600966 \mathrm{GBF}$ & BN10507557 & $2 / 2 / 2014$ \\
\hline IN140039 & $001600967 \mathrm{GBF}$ & BN10507555 & $2 / 4 / 2014$ \\
\hline IN140039 & $001600967 \mathrm{GBF}$ & BN10507554 & $2 / 4 / 2014$ \\
\hline
\end{tabular}

Under civil and criminal penalties of law for the making or submission of false or fraudulent statements or representations (18 U.S.C. 1001 and 15 U.S.C. 2615), I certify that the information contained in or accompanying this document is true, accurate, and complete.

As to the identified section(s) of this document for which I cannot personally verify truth and accuracy, I certify as the company official having supervisory responsibility for the persons who, acting under my direct instructions, made the verification that this information is true, accurate, and complete.

Should you require further information concerning this certificate of disposal, please contact Mr. R. S. (Bob) Nieman at (575) 234-8141.

Sincerely,

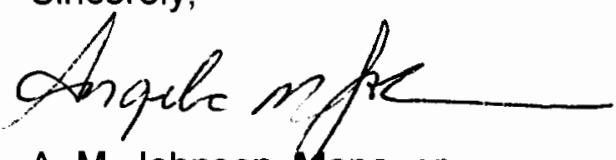

A. M. Johnson, Manager

Transportation Management

RSN/rsn

cc: Shipment portfolio for shipments IN140013, IN140014, IN140016, IN140018, IN140019, IN140022, IN140023, IN140024, IN140026, IN140028, IN140029, IN140031, IN140033, IN140034, IN140035, IN140038 and IN140039. 
Please print or type. (Form designed for use on elite (12-pitch) rypewriter.)

Form Approved. OMB №. 2050-0039

$\uparrow$\begin{tabular}{|l|l|l}
\hline $\begin{array}{c}\text { UNIFORM HAZARDOUS } \\
\text { WASTE MANIFEST }\end{array}$ & $\begin{array}{r}\text { 1. Generator ID Number } \\
\text { ID48900089.52 }\end{array}$ \\
\cline { 2 - 3 } 5. Generator's Name and Mailing Address &
\end{tabular}

IDAHO NATIONAL LABCRATORY FOR U.S. DEPT. OF ENERGY 850 ENERGY DRIVE

\section{IDAHO FALLS}

Generator's Phone: (208) $557-6607$

6. Transporter 1 Company Name

CAST SPECIALTY TRANSPORTATION INC.

7. Transporter 2 Company Name

\section{1}

$\mid \begin{gathered}\text { 2. Page } 1 \text { of } \\ 2\end{gathered}$

(575) $885-6883$ Generator's Site Address (if different than mailing address)

$001600951 \mathrm{GBF}$

\section{AMWTP}

HIGHWAY 20 AND VAN BUREN BLVO SCOVILE

83415

COR000206722

8. Designated Facility Name and Site Address

NUCLEAR WASTE PARTNERSHIP, LLC FOR THE U.S. DOE

30 MILES E. OF CARLSBAD ON JAL HIGHWAY

EDDY COUNTY NM 88221

Facility's Phone: (575) 234-8457

9a. 96. U.S. Dot Description (induding Proper Shipping Name, Hazard Class, ID Number

HM and Packing Group (if any))

RQ 1. UN3328, WASTE RADIOACTIVE MATERIAL, TYPE B(U) PACKAGE FISSILE, 7, PU-239, AM-241, PU-240, SOLID, OXIDE, 0.008188 TBQ, RADIOACTIVE YELLOW-II, T.I. 0.2, C.S.I. 0.0, USA/9218/B(U)F-96, TRUPACT \# 185

2. PCB container \# BN10500612, Sludge, PCB out of service bate 05/15/2013, PCB Weight $991.2 \mathrm{~kg}$

RQ 2. UN3328, WASTE RADIOACTIVE MATERIAL, TYPE $B(U)$ PACKAGE FISSILE; 7, PU-239, AM-241, PU-240, SOLID, OXIDE, 0.01905 TBq, RADIOACTIVE YELLOW-II, T.I. O.2, C.S.I. 0.0 USA/9218/B(U)F-96, TRUPACT \# 141

4. PCB container \# BN10503777, sludge, PCB out of service pate $01 / 29 / 2013$, РCB Weight $953.4 \mathrm{~kg}$

14. Special Handling Instructions and Additional intormation

SHIPMENT \# IN140023 TRACTOR C-31

GROSS WEIGHT IN LBS: TP\# 185 = 17,331

PREPARED UNDER CONTRACT \# DE-EMDOO1467

$C-31$ TP\# $141=17,118$

ERG 165
NM4890139088

\begin{tabular}{|c|c|c|c|c|c|c|}
\hline & & \multicolumn{5}{|c|}{ NM4890139088 } \\
\hline \multicolumn{2}{|c|}{ 10. Containers } & \multirow{2}{*}{$\begin{array}{l}\text { 11. Total } \\
\text { Quantity }\end{array}$} & \multirow{2}{*}{$\begin{array}{l}\text { 12. Unit } \\
\text { Wt. Nol. }\end{array}$} & \multirow{2}{*}{\multicolumn{3}{|c|}{ 13. Waste Codes }} \\
\hline No. & Type & & & & & \\
\hline \multirow[t]{2}{*}{1} & \multirow[t]{2}{*}{$C M$} & \multirow[t]{2}{*}{2102} & \multirow[t]{2}{*}{$\mathbf{K}$} & F001 & $\mathrm{FOO2}$ & F005 \\
\hline & & & & D022 & D026 & $\mathrm{D} 027$ \\
\hline & & & & & & \\
\hline \multirow[t]{2}{*}{1} & \multirow[t]{2}{*}{$C M$} & \multirow[t]{2}{*}{2064} & \multirow[t]{2}{*}{ K } & F001 & $\mathrm{F} 002$ & F00S \\
\hline & & & & $\mathrm{D} 022$ & D026 & $\mathrm{D} 027$ \\
\hline & & & & & & \\
\hline & & & & & & \\
\hline
\end{tabular}

TRAILER - 348 TP\# $507=13,456$

ERI PROVIDER - WIPP GMR

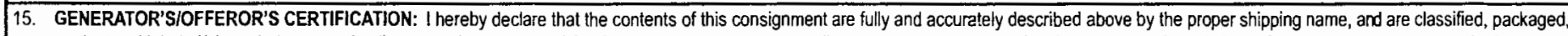
marked and labeled/placarded, and are in all respects in proper condition for transport according to applicable international and national governmental regulations. If export shipment and I am the Primary Exporter, I certify that the contents of this consignment conform to the terms of the attached EPAAcknowledgment of Consent.

I certify that the waste minimization statement identified in 40 CFR 262.27(a) (if I am a large quantity generator) or (b) (if I am a small quantily generator) is true.

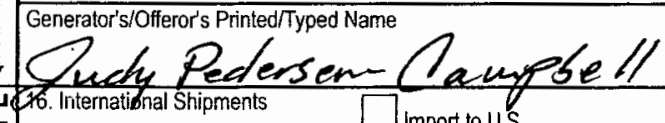

Transporter signature (for exports only):

17. Transporter Acknowledgment of Receipt of Materiais Transporter 1 Printed/Typed Name
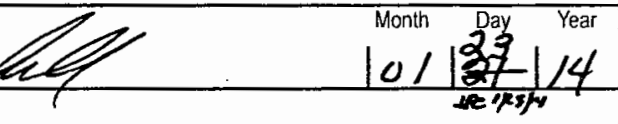

18. Discrepancy

18a. Discrepancy Indication Space

20. Designated Facility Owner or Operator: Certification of receipt of hazardous materials covered by the manifest except as noted in Item 18a 
Please print or type. (Form designed for use on elite (12-pitch) typewriter.)

Form Approved. OMB No. 2050-0039

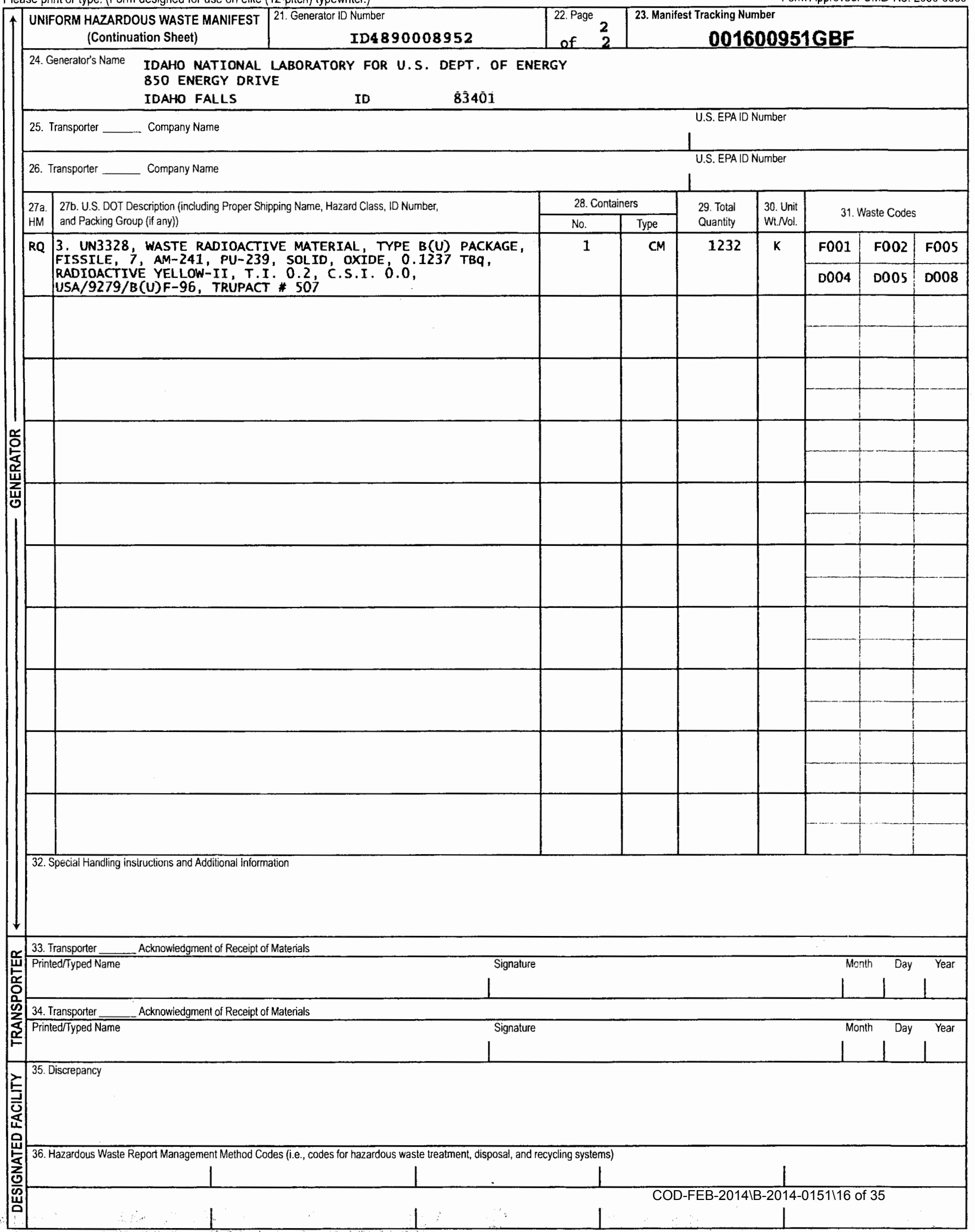




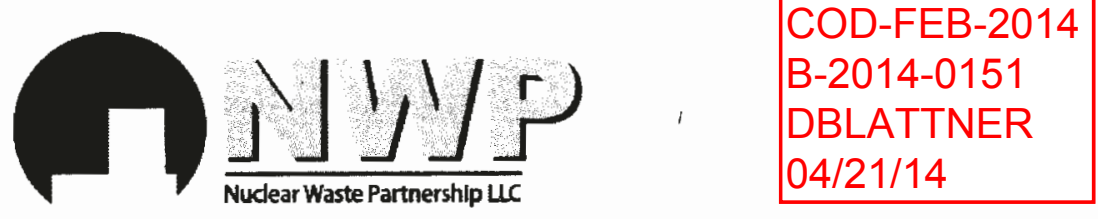

CP:14:02012

UFC:5822.00

A URS-led partnership with B\&W and AREVA

February 12, 2014

Ms. R. Hubler, Transportation Manager

Advanced Mixed Waste Treatment Plant/ITG

Idaho National Laboratory

850 Energy Drive, Suite 100

Idaho Falls, ID 83401

SUBJECT: CERTIFICATE OF DISPOSAL FOR POLYCHLORINATED BIPHENYL BEARING WASTE SHIPMENT NUMBERS IN140013, IN140014, IN140016, IN140018, IN140019, IN140022, IN140023, IN140024, IN140026, IN140028, IN140029, IN140031, IN140033, IN140034, IN140035, IN140038 AND IN140039 EMPLACED AT THE WASTE ISOLATION PILOT PLANT

Dear Ms. Hubler:

In compliance with Title 40 Code of Federal Regulations, Part 761.218 , I certify that the following Polychlorinated Biphenyl (PCB) wastes from your facility have been disposed by emplacement 2,150 feet underground in the Waste Isolation Pilot Plant waste repository.

Disposal Facility:

Waste Isolation Pilot Plant

30 Miles SE of Carlsbad, New Mexico

Eddy County, New Mexico 88220

Environmental Protection Agency (EPA) Identification Number (ID): NM4890139088

Shipping Site's EPA ID: ID4890008952

\begin{tabular}{|c|c|c|c|}
\hline $\begin{array}{c}\text { Shipment } \\
\text { Number }\end{array}$ & $\begin{array}{c}\text { Manifest Tracking } \\
\text { Number }\end{array}$ & $\begin{array}{c}\text { Container } \\
\text { Number }\end{array}$ & $\begin{array}{c}\text { Emplacement } \\
\text { Date }\end{array}$ \\
\hline IN140013 & $001600941 \mathrm{GBF}$ & BN10505055 & $1 / 24 / 2014$ \\
\hline IN140013 & $001600941 \mathrm{GBF}$ & BN10505054 & $1 / 21 / 2014$ \\
\hline IN140014 & $001600942 \mathrm{GBF}$ & BN10490911 & $1 / 25 / 2014$ \\
\hline IN140014 & $001600942 \mathrm{GBF}$ & BN10490912 & $1 / 25 / 2014$ \\
\hline IN140016 & $001600944 \mathrm{GBF}$ & BN10505059 & $1 / 24 / 2014$ \\
\hline IN140016 & $001600944 \mathrm{GBF}$ & BN10503788 & $1 / 24 / 2014$ \\
\hline IN140018 & $001600946 \mathrm{GBF}$ & BN10505058 & $1 / 26 / 2014$ \\
\hline IN140018 & $001600946 \mathrm{GBF}$ & BN10505062 & $1 / 26 / 2014$ \\
\hline IN140019 & $001600947 \mathrm{GBF}$ & BN10503775 & $1 / 24 / 2014$ \\
\hline IN140019 & $001600947 \mathrm{GBF}$ & BN10503760 & $1 / 24 / 2014$ \\
\hline IN140022 & 001600950GBF & BN10505063 & $2 / 2 / 2014$ \\
\hline
\end{tabular}




\begin{tabular}{|c|c|c|c|}
\hline $\begin{array}{l}\text { Shipment } \\
\text { Number }\end{array}$ & $\begin{array}{c}\text { Manifest Tracking } \\
\text { Number }\end{array}$ & $\begin{array}{l}\text { Container } \\
\text { Number }\end{array}$ & $\begin{array}{c}\text { Emplacement } \\
\text { Date }\end{array}$ \\
\hline IN140022 & $001600950 \mathrm{GBF}$ & BN10501246 & $1 / 24 / 2014$ \\
\hline IN140023 & $001600951 \mathrm{GBF}$ & BN10500612 & $1 / 30 / 2014$ \\
\hline IN140023 & $001600951 \mathrm{GBF}$ & BN10503777 & $1 / 26 / 2014$ \\
\hline IN140024 & $001600952 \mathrm{GBF}$ & BN10509616 & $1 / 24 / 2014$ \\
\hline IN140024 & $001600952 \mathrm{GBF}$ & BN10509615 & $2 / 2 / 2014$ \\
\hline IN140026 & $001600954 \mathrm{GBF}$ & BN10509688 & $1 / 26 / 2014$ \\
\hline IN140026 & $001600954 \mathrm{GBF}$ & BN10509618 & $1 / 28 / 2014$ \\
\hline IN140028 & $001600956 \mathrm{GBF}$ & BN10503774 & $1 / 28 / 2014$ \\
\hline IN140028 & $001600956 \mathrm{GBF}$ & BN10509606 & $1 / 28 / 2014$ \\
\hline IN140029 & $001600957 \mathrm{GBF}$ & BN10501248 & $1 / 28 / 2014$ \\
\hline IN140029 & $001600957 \mathrm{GBF}$ & BN10509611 & $2 / 1 / 2014$ \\
\hline IN140031 & $001600959 \mathrm{GBF}$ & BN10505060 & $2 / 1 / 2014$ \\
\hline IN140031 & 001600959GBF & BN10505061 & $1 / 28 / 2014$ \\
\hline IN140033 & $001600961 \mathrm{GBF}$ & BN10509682 & $1 / 31 / 2014$ \\
\hline IN140033 & $001600961 \mathrm{GBF}$ & BN10509601 & $1 / 31 / 2014$ \\
\hline IN140034 & $001600962 \mathrm{GBF}$ & BN10507549 & $2 / 2 / 2014$ \\
\hline IN140034 & $001600962 \mathrm{GBF}$ & BN10509687 & $2 / 1 / 2014$ \\
\hline IN140035 & $001600963 \mathrm{GBF}$ & BN10507550 & $1 / 31 / 2014$ \\
\hline IN140035 & $001600963 \mathrm{GBF}$ & BN10509599 & $2 / 1 / 2014$ \\
\hline IN140038 & $001600966 \mathrm{GBF}$ & BN10507553 & $2 / 2 / 2014$ \\
\hline IN140038 & $001600966 \mathrm{GBF}$ & BN10507557 & $2 / 2 / 2014$ \\
\hline IN140039 & $001600967 \mathrm{GBF}$ & BN10507555 & $2 / 4 / 2014$ \\
\hline IN140039 & $001600967 \mathrm{GBF}$ & BN10507554 & $2 / 4 / 2014$ \\
\hline
\end{tabular}

Under civil and criminal penalties of law for the making or submission of false or fraudulent statements or representations (18 U.S.C. 1001 and 15 U.S.C. 2615), I certify that the information contained in or accompanying this document is true, accurate, and complete.

As to the identified section(s) of this document for which I cannot personally verify truth and accuracy, I certify as the company official having supervisory responsibility for the persons who, acting under my direct instructions, made the verification that this information is true, accurate, and complete.

Should you require further information concerning this certificate of disposal, please contact Mr. R. S. (Bob) Nieman at (575) 234-8141.

Sincerely,

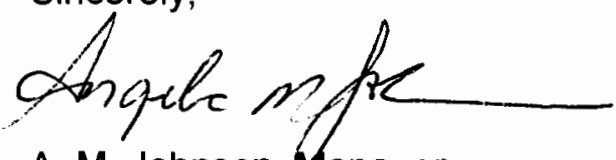

A. M. Johnson, Manager

Transportation Management

RSN/rsn

cc: Shipment portfolio for shipments IN140013, IN140014, IN140016, IN140018, IN140019, IN140022, IN140023, IN140024, IN140026, IN140028, IN140029, IN140031, IN140033, IN140034, IN140035, IN140038 and IN140039. 
Please print or type. (Form designed for use on elite (12-pitch) typewriter.)

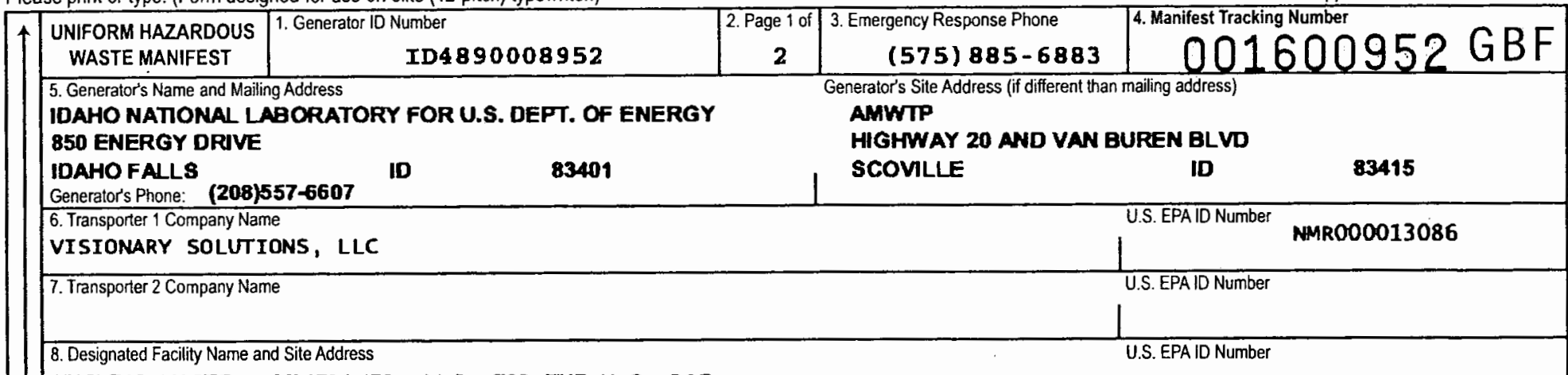

NUCLEAR WASTE PARTNERSHIP, LLC, FOR THE U.S. DOE

30 MILES E. OF CARL SBAD ON JAL HIGHWAY

EDDY COUNTY $\mathrm{NM} 88221$

Facility's Phone: (575) 234-8457

9a. 9 b. U.S. DOT Description (including Proper Shipping Name, Hazard Class, ID Number,

HM and Packing Group (if any))

RQ 1. UN3328, WASTE RADIOACTIVE MATERIAL, TYPE B(V) PACKAGE,

FISSILE, 7, PU-239, AM-241, PU-240, SOLID, OXIDE, 0.00906

TBQ , RADIOACTIVE YELLOW-II, T.I. 0.2, C.S.I. 0.0,

USA/9218/B(U)F-96, TRUPACT * 189

X. PCB Container \#, BN10509615 sludge, PCB out of service pate 05/09/2013, РСB weight $1216.2 \mathrm{~kg}$

RQ 2. UN3328, WASTE RADIOACTIVE MATERIAL, TYPE B(U) PACKAGE FISSILE, 7, PU-239, AM-241, PU-240, SOLID, OXIDE, 0.008238 TBq. RADIOACTIVE YELLOW-II, T.I. 0.2, C.S.I. 0.0,

USA $9218 / B(U) F-96$, TRUPACT * 161

A. PCB Container *, BN10509616, Sludge, PCB out of service pate $04 / 04 / 2013$, PCB Welght $1181.0 \mathrm{~kg}$

14. Special Handling instructions and Additional Information

SHIPMENT * IN140024 TRACTOR - V - 015 TRAILER - 366

GROSS WEIGH IN LBS: TP* $189=17,582$ TP\# $161=17,830$ TP\# $504=13,541$

PREPARED UNDER CONTRACT * DE-EMO001467 ERG - 165 ERI PROVIDER - WTPP CMR

15. GENERATOR'SIOFFEROR'S CERTIFICATION: I hereby declare that the contents of this onsignment are fully and accurately described above by the proper shipping name, and are classified, packaged, marked and labeled/placarded, and are in all respects in proper condition for transport according to applicable international and national governmental regulations. If export shipment and I am the Primary Exporter, I certify that the contents of this consignment conform to the terms of the attached EPA Acknowiedgment of Consent.

I certify that the waste minimization statement identified in 40 CFR 262.27(a) (it I am a large quantity generator) or (b) (ifl am a snall quantity generator) is (rue.

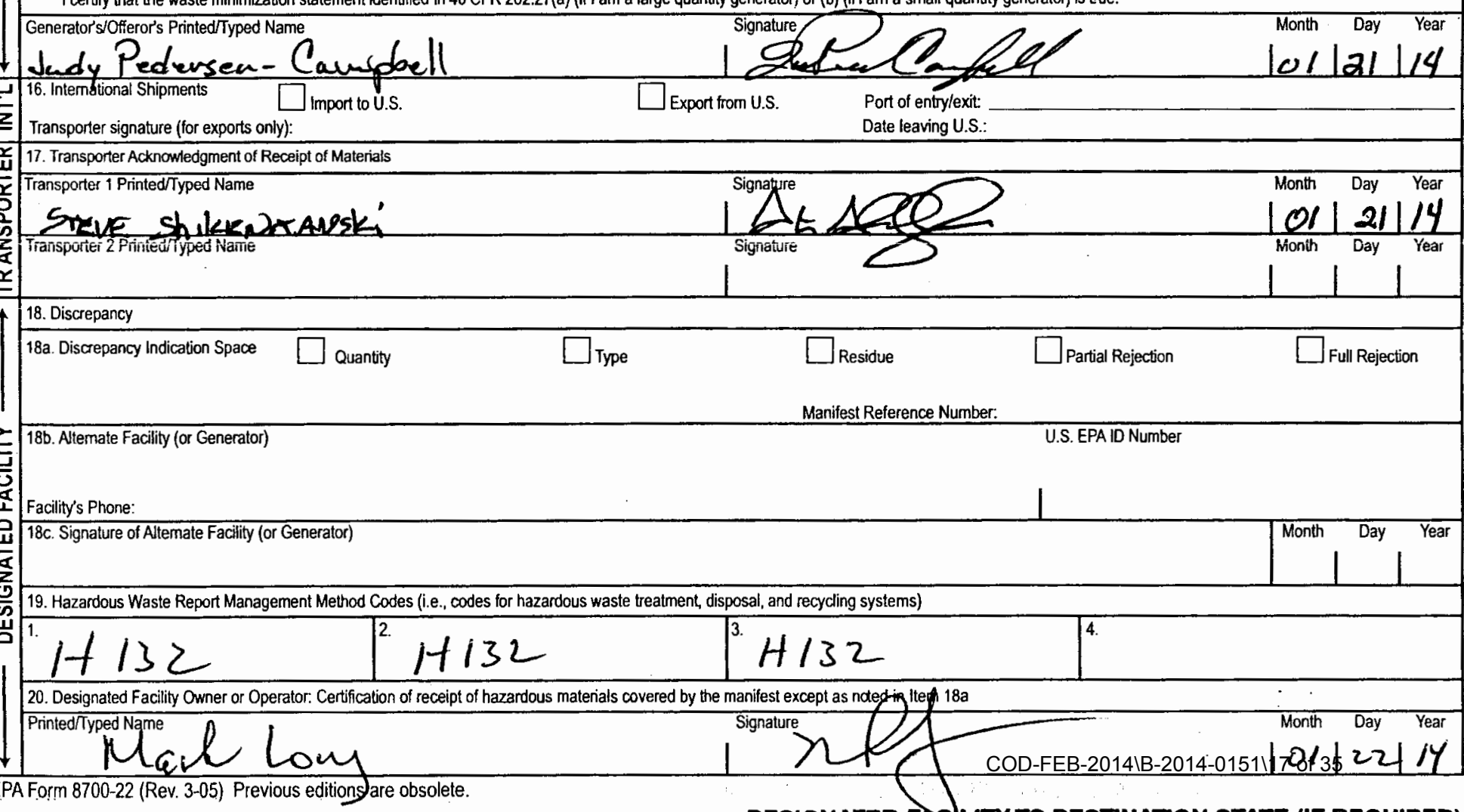




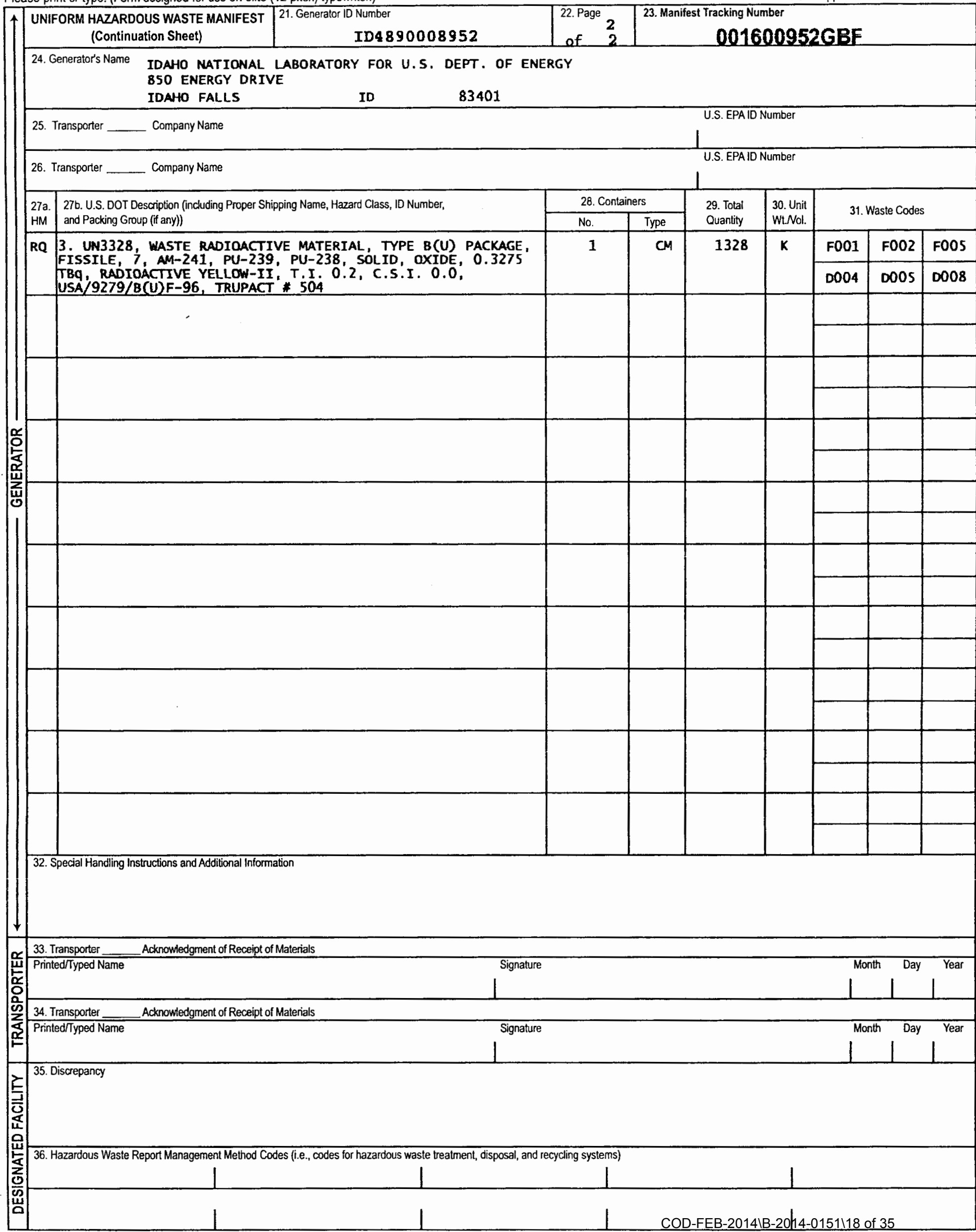




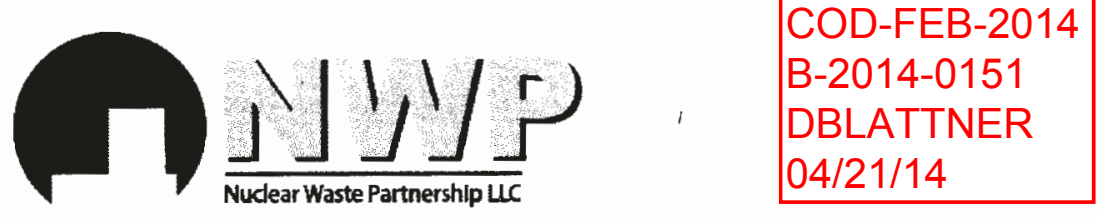

CP:14:02012

UFC:5822.00

A URS-led partnership with B\&W and AREVA

February 12, 2014

Ms. R. Hubler, Transportation Manager

Advanced Mixed Waste Treatment Plant/ITG

Idaho National Laboratory

850 Energy Drive, Suite 100

Idaho Falls, ID 83401

SUBJECT: CERTIFICATE OF DISPOSAL FOR POLYCHLORINATED BIPHENYL BEARING WASTE SHIPMENT NUMBERS IN140013, IN140014, IN140016, IN140018, IN140019, IN140022, IN140023, IN140024, IN140026, IN140028, IN140029, IN140031, IN140033, IN140034, IN140035, IN140038 AND IN140039 EMPLACED AT THE WASTE ISOLATION PILOT PLANT

Dear Ms. Hubler:

In compliance with Title 40 Code of Federal Regulations, Part 761.218 , I certify that the following Polychlorinated Biphenyl (PCB) wastes from your facility have been disposed by emplacement 2,150 feet underground in the Waste Isolation Pilot Plant waste repository.

Disposal Facility:

Waste Isolation Pilot Plant

30 Miles SE of Carlsbad, New Mexico

Eddy County, New Mexico 88220

Environmental Protection Agency (EPA) Identification Number (ID): NM4890139088

Shipping Site's EPA ID: ID4890008952

\begin{tabular}{|c|c|c|c|}
\hline $\begin{array}{c}\text { Shipment } \\
\text { Number }\end{array}$ & $\begin{array}{c}\text { Manifest Tracking } \\
\text { Number }\end{array}$ & $\begin{array}{c}\text { Container } \\
\text { Number }\end{array}$ & $\begin{array}{c}\text { Emplacement } \\
\text { Date }\end{array}$ \\
\hline IN140013 & $001600941 \mathrm{GBF}$ & BN10505055 & $1 / 24 / 2014$ \\
\hline IN140013 & $001600941 \mathrm{GBF}$ & BN10505054 & $1 / 21 / 2014$ \\
\hline IN140014 & $001600942 \mathrm{GBF}$ & BN10490911 & $1 / 25 / 2014$ \\
\hline IN140014 & $001600942 \mathrm{GBF}$ & BN10490912 & $1 / 25 / 2014$ \\
\hline IN140016 & $001600944 \mathrm{GBF}$ & BN10505059 & $1 / 24 / 2014$ \\
\hline IN140016 & $001600944 \mathrm{GBF}$ & BN10503788 & $1 / 24 / 2014$ \\
\hline IN140018 & $001600946 \mathrm{GBF}$ & BN10505058 & $1 / 26 / 2014$ \\
\hline IN140018 & $001600946 \mathrm{GBF}$ & BN10505062 & $1 / 26 / 2014$ \\
\hline IN140019 & $001600947 \mathrm{GBF}$ & BN10503775 & $1 / 24 / 2014$ \\
\hline IN140019 & $001600947 \mathrm{GBF}$ & BN10503760 & $1 / 24 / 2014$ \\
\hline IN140022 & 001600950GBF & BN10505063 & $2 / 2 / 2014$ \\
\hline
\end{tabular}




\begin{tabular}{|c|c|c|c|}
\hline $\begin{array}{l}\text { Shipment } \\
\text { Number }\end{array}$ & $\begin{array}{c}\text { Manifest Tracking } \\
\text { Number }\end{array}$ & $\begin{array}{l}\text { Container } \\
\text { Number }\end{array}$ & $\begin{array}{c}\text { Emplacement } \\
\text { Date }\end{array}$ \\
\hline IN140022 & $001600950 \mathrm{GBF}$ & BN10501246 & $1 / 24 / 2014$ \\
\hline IN140023 & $001600951 \mathrm{GBF}$ & BN10500612 & $1 / 30 / 2014$ \\
\hline IN140023 & $001600951 \mathrm{GBF}$ & BN10503777 & $1 / 26 / 2014$ \\
\hline IN140024 & $001600952 \mathrm{GBF}$ & BN10509616 & $1 / 24 / 2014$ \\
\hline IN140024 & $001600952 \mathrm{GBF}$ & BN10509615 & $2 / 2 / 2014$ \\
\hline IN140026 & $001600954 \mathrm{GBF}$ & BN10509688 & $1 / 26 / 2014$ \\
\hline IN140026 & $001600954 \mathrm{GBF}$ & BN10509618 & $1 / 28 / 2014$ \\
\hline IN140028 & $001600956 \mathrm{GBF}$ & BN10503774 & $1 / 28 / 2014$ \\
\hline IN140028 & $001600956 \mathrm{GBF}$ & BN10509606 & $1 / 28 / 2014$ \\
\hline IN140029 & $001600957 \mathrm{GBF}$ & BN10501248 & $1 / 28 / 2014$ \\
\hline IN140029 & $001600957 \mathrm{GBF}$ & BN10509611 & $2 / 1 / 2014$ \\
\hline IN140031 & $001600959 \mathrm{GBF}$ & BN10505060 & $2 / 1 / 2014$ \\
\hline IN140031 & 001600959GBF & BN10505061 & $1 / 28 / 2014$ \\
\hline IN140033 & $001600961 \mathrm{GBF}$ & BN10509682 & $1 / 31 / 2014$ \\
\hline IN140033 & $001600961 \mathrm{GBF}$ & BN10509601 & $1 / 31 / 2014$ \\
\hline IN140034 & $001600962 \mathrm{GBF}$ & BN10507549 & $2 / 2 / 2014$ \\
\hline IN140034 & $001600962 \mathrm{GBF}$ & BN10509687 & $2 / 1 / 2014$ \\
\hline IN140035 & $001600963 \mathrm{GBF}$ & BN10507550 & $1 / 31 / 2014$ \\
\hline IN140035 & $001600963 \mathrm{GBF}$ & BN10509599 & $2 / 1 / 2014$ \\
\hline IN140038 & $001600966 \mathrm{GBF}$ & BN10507553 & $2 / 2 / 2014$ \\
\hline IN140038 & $001600966 \mathrm{GBF}$ & BN10507557 & $2 / 2 / 2014$ \\
\hline IN140039 & $001600967 \mathrm{GBF}$ & BN10507555 & $2 / 4 / 2014$ \\
\hline IN140039 & $001600967 \mathrm{GBF}$ & BN10507554 & $2 / 4 / 2014$ \\
\hline
\end{tabular}

Under civil and criminal penalties of law for the making or submission of false or fraudulent statements or representations (18 U.S.C. 1001 and 15 U.S.C. 2615), I certify that the information contained in or accompanying this document is true, accurate, and complete.

As to the identified section(s) of this document for which I cannot personally verify truth and accuracy, I certify as the company official having supervisory responsibility for the persons who, acting under my direct instructions, made the verification that this information is true, accurate, and complete.

Should you require further information concerning this certificate of disposal, please contact Mr. R. S. (Bob) Nieman at (575) 234-8141.

Sincerely,

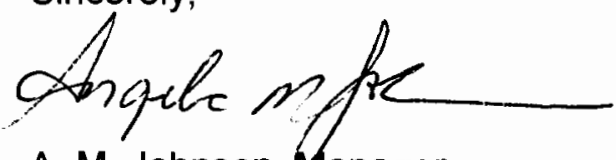

A. M. Johnson, Manager

Transportation Management

RSN/rsn

cc: Shipment portfolio for shipments IN140013, IN140014, IN140016, IN140018, IN140019, IN140022, IN140023, IN140024, IN140026, IN140028, IN140029, IN140031, IN140033, IN140034, IN140035, IN140038 and IN140039. 
Please print or type. (Form designed for use on elite (12-pitch) typewriter.)

Form Approved. OMB No. 2050-0039

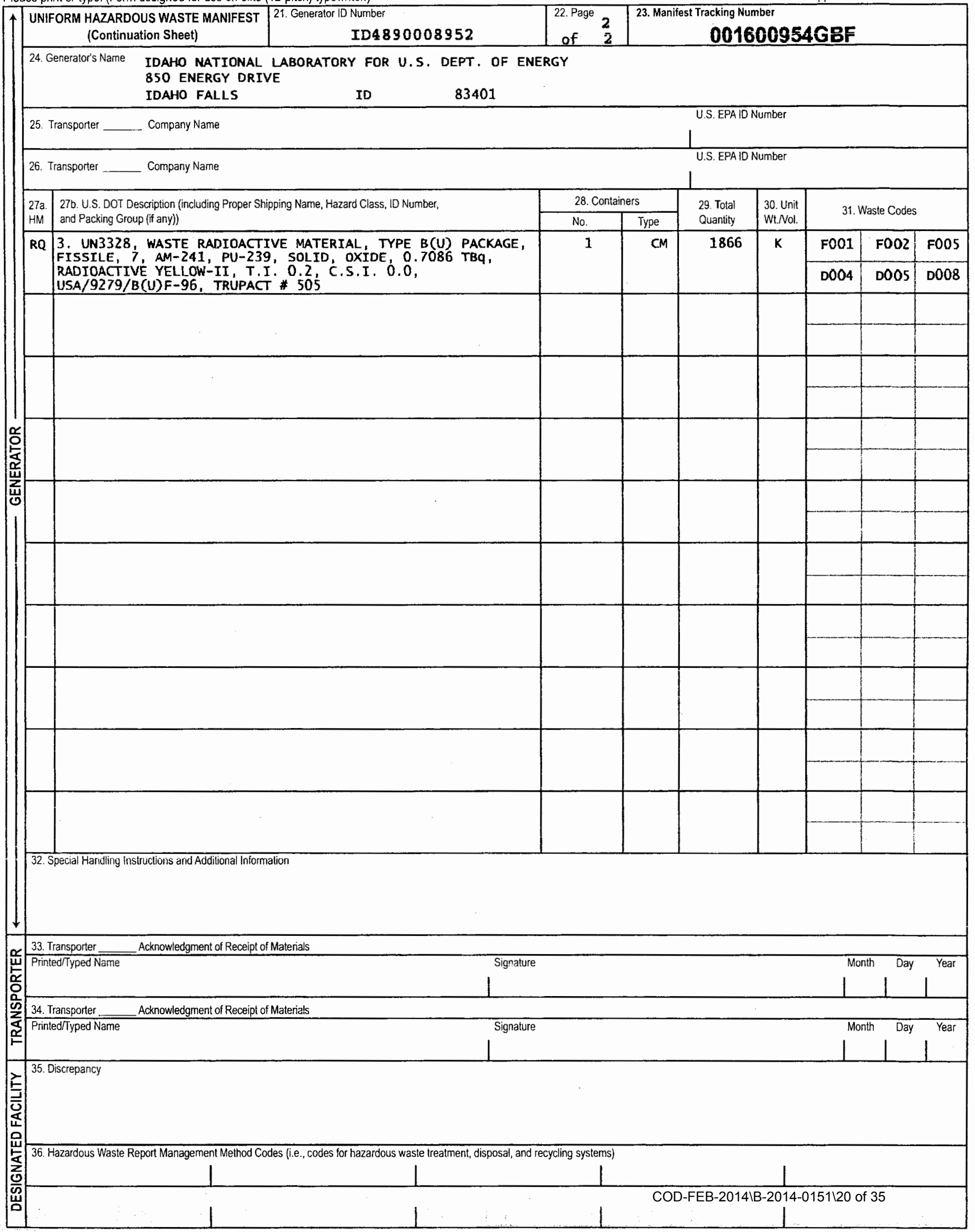




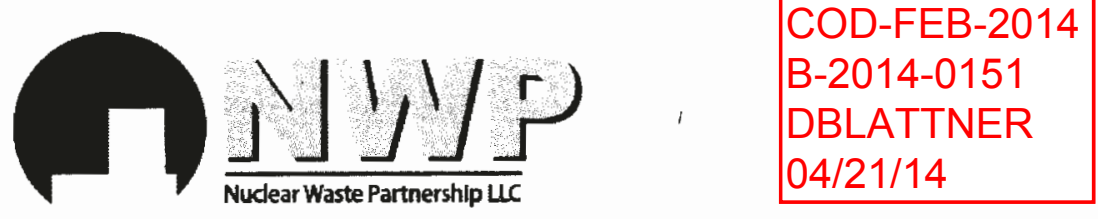

CP:14:02012

UFC:5822.00

A URS-led partnership with B\&W and AREVA

February 12, 2014

Ms. R. Hubler, Transportation Manager

Advanced Mixed Waste Treatment Plant/ITG

Idaho National Laboratory

850 Energy Drive, Suite 100

Idaho Falls, ID 83401

SUBJECT: CERTIFICATE OF DISPOSAL FOR POLYCHLORINATED BIPHENYL BEARING WASTE SHIPMENT NUMBERS IN140013, IN140014, IN140016, IN140018, IN140019, IN140022, IN140023, IN140024, IN140026, IN140028, IN140029, IN140031, IN140033, IN140034, IN140035, IN140038 AND IN140039 EMPLACED AT THE WASTE ISOLATION PILOT PLANT

Dear Ms. Hubler:

In compliance with Title 40 Code of Federal Regulations, Part 761.218 , I certify that the following Polychlorinated Biphenyl (PCB) wastes from your facility have been disposed by emplacement 2,150 feet underground in the Waste Isolation Pilot Plant waste repository.

Disposal Facility:

Waste Isolation Pilot Plant

30 Miles SE of Carlsbad, New Mexico

Eddy County, New Mexico 88220

Environmental Protection Agency (EPA) Identification Number (ID): NM4890139088

Shipping Site's EPA ID: ID4890008952

\begin{tabular}{|c|c|c|c|}
\hline $\begin{array}{c}\text { Shipment } \\
\text { Number }\end{array}$ & $\begin{array}{c}\text { Manifest Tracking } \\
\text { Number }\end{array}$ & $\begin{array}{c}\text { Container } \\
\text { Number }\end{array}$ & $\begin{array}{c}\text { Emplacement } \\
\text { Date }\end{array}$ \\
\hline IN140013 & $001600941 \mathrm{GBF}$ & BN10505055 & $1 / 24 / 2014$ \\
\hline IN140013 & $001600941 \mathrm{GBF}$ & BN10505054 & $1 / 21 / 2014$ \\
\hline IN140014 & $001600942 \mathrm{GBF}$ & BN10490911 & $1 / 25 / 2014$ \\
\hline IN140014 & $001600942 \mathrm{GBF}$ & BN10490912 & $1 / 25 / 2014$ \\
\hline IN140016 & $001600944 \mathrm{GBF}$ & BN10505059 & $1 / 24 / 2014$ \\
\hline IN140016 & $001600944 \mathrm{GBF}$ & BN10503788 & $1 / 24 / 2014$ \\
\hline IN140018 & $001600946 \mathrm{GBF}$ & BN10505058 & $1 / 26 / 2014$ \\
\hline IN140018 & $001600946 \mathrm{GBF}$ & BN10505062 & $1 / 26 / 2014$ \\
\hline IN140019 & $001600947 \mathrm{GBF}$ & BN10503775 & $1 / 24 / 2014$ \\
\hline IN140019 & $001600947 \mathrm{GBF}$ & BN10503760 & $1 / 24 / 2014$ \\
\hline IN140022 & 001600950GBF & BN10505063 & $2 / 2 / 2014$ \\
\hline
\end{tabular}




\begin{tabular}{|c|c|c|c|}
\hline $\begin{array}{l}\text { Shipment } \\
\text { Number }\end{array}$ & $\begin{array}{c}\text { Manifest Tracking } \\
\text { Number }\end{array}$ & $\begin{array}{l}\text { Container } \\
\text { Number }\end{array}$ & $\begin{array}{c}\text { Emplacement } \\
\text { Date }\end{array}$ \\
\hline IN140022 & $001600950 \mathrm{GBF}$ & BN10501246 & $1 / 24 / 2014$ \\
\hline IN140023 & $001600951 \mathrm{GBF}$ & BN10500612 & $1 / 30 / 2014$ \\
\hline IN140023 & $001600951 \mathrm{GBF}$ & BN10503777 & $1 / 26 / 2014$ \\
\hline IN140024 & $001600952 \mathrm{GBF}$ & BN10509616 & $1 / 24 / 2014$ \\
\hline IN140024 & $001600952 \mathrm{GBF}$ & BN10509615 & $2 / 2 / 2014$ \\
\hline IN140026 & $001600954 \mathrm{GBF}$ & BN10509688 & $1 / 26 / 2014$ \\
\hline IN140026 & $001600954 \mathrm{GBF}$ & BN10509618 & $1 / 28 / 2014$ \\
\hline IN140028 & $001600956 \mathrm{GBF}$ & BN10503774 & $1 / 28 / 2014$ \\
\hline IN140028 & $001600956 \mathrm{GBF}$ & BN10509606 & $1 / 28 / 2014$ \\
\hline IN140029 & $001600957 \mathrm{GBF}$ & BN10501248 & $1 / 28 / 2014$ \\
\hline IN140029 & $001600957 \mathrm{GBF}$ & BN10509611 & $2 / 1 / 2014$ \\
\hline IN140031 & $001600959 \mathrm{GBF}$ & BN10505060 & $2 / 1 / 2014$ \\
\hline IN140031 & 001600959GBF & BN10505061 & $1 / 28 / 2014$ \\
\hline IN140033 & $001600961 \mathrm{GBF}$ & BN10509682 & $1 / 31 / 2014$ \\
\hline IN140033 & $001600961 \mathrm{GBF}$ & BN10509601 & $1 / 31 / 2014$ \\
\hline IN140034 & $001600962 \mathrm{GBF}$ & BN10507549 & $2 / 2 / 2014$ \\
\hline IN140034 & $001600962 \mathrm{GBF}$ & BN10509687 & $2 / 1 / 2014$ \\
\hline IN140035 & $001600963 \mathrm{GBF}$ & BN10507550 & $1 / 31 / 2014$ \\
\hline IN140035 & $001600963 \mathrm{GBF}$ & BN10509599 & $2 / 1 / 2014$ \\
\hline IN140038 & $001600966 \mathrm{GBF}$ & BN10507553 & $2 / 2 / 2014$ \\
\hline IN140038 & $001600966 \mathrm{GBF}$ & BN10507557 & $2 / 2 / 2014$ \\
\hline IN140039 & $001600967 \mathrm{GBF}$ & BN10507555 & $2 / 4 / 2014$ \\
\hline IN140039 & $001600967 \mathrm{GBF}$ & BN10507554 & $2 / 4 / 2014$ \\
\hline
\end{tabular}

Under civil and criminal penalties of law for the making or submission of false or fraudulent statements or representations (18 U.S.C. 1001 and 15 U.S.C. 2615), I certify that the information contained in or accompanying this document is true, accurate, and complete.

As to the identified section(s) of this document for which I cannot personally verify truth and accuracy, I certify as the company official having supervisory responsibility for the persons who, acting under my direct instructions, made the verification that this information is true, accurate, and complete.

Should you require further information concerning this certificate of disposal, please contact Mr. R. S. (Bob) Nieman at (575) 234-8141.

Sincerely,

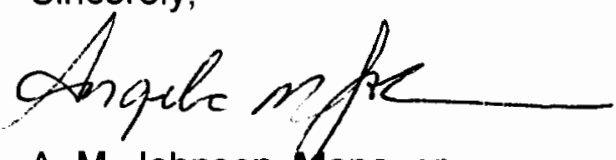

A. M. Johnson, Manager

Transportation Management

RSN/rsn

cc: Shipment portfolio for shipments IN140013, IN140014, IN140016, IN140018, IN140019, IN140022, IN140023, IN140024, IN140026, IN140028, IN140029, IN140031, IN140033, IN140034, IN140035, IN140038 and IN140039. 
Please print or type. (Form designed for use on elite (12-pucn) typewriter.)

Form Approved. OMB №. 2050-0039

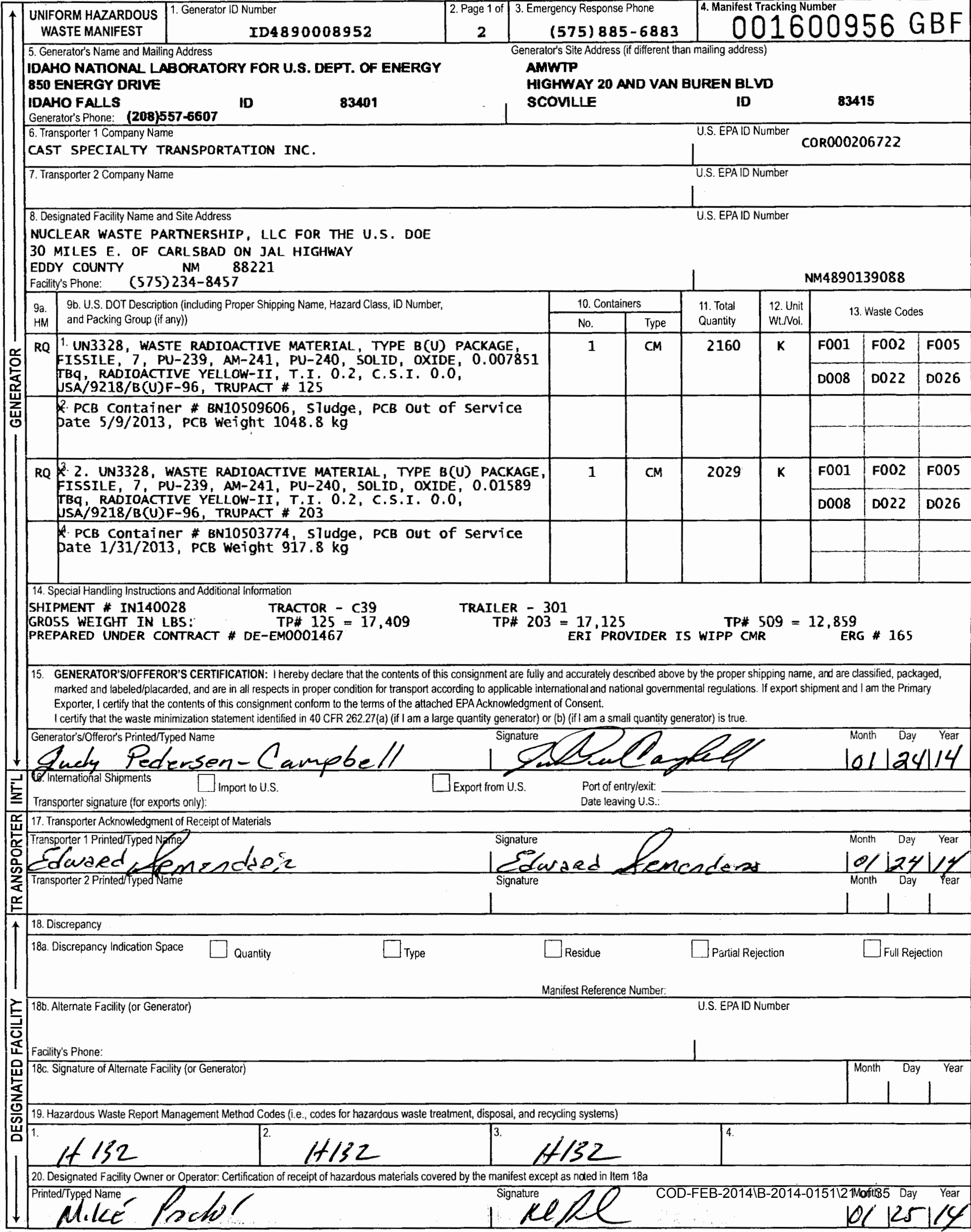


Please print or type. (Form designed for use on elite (12-pitch) typewriter.)

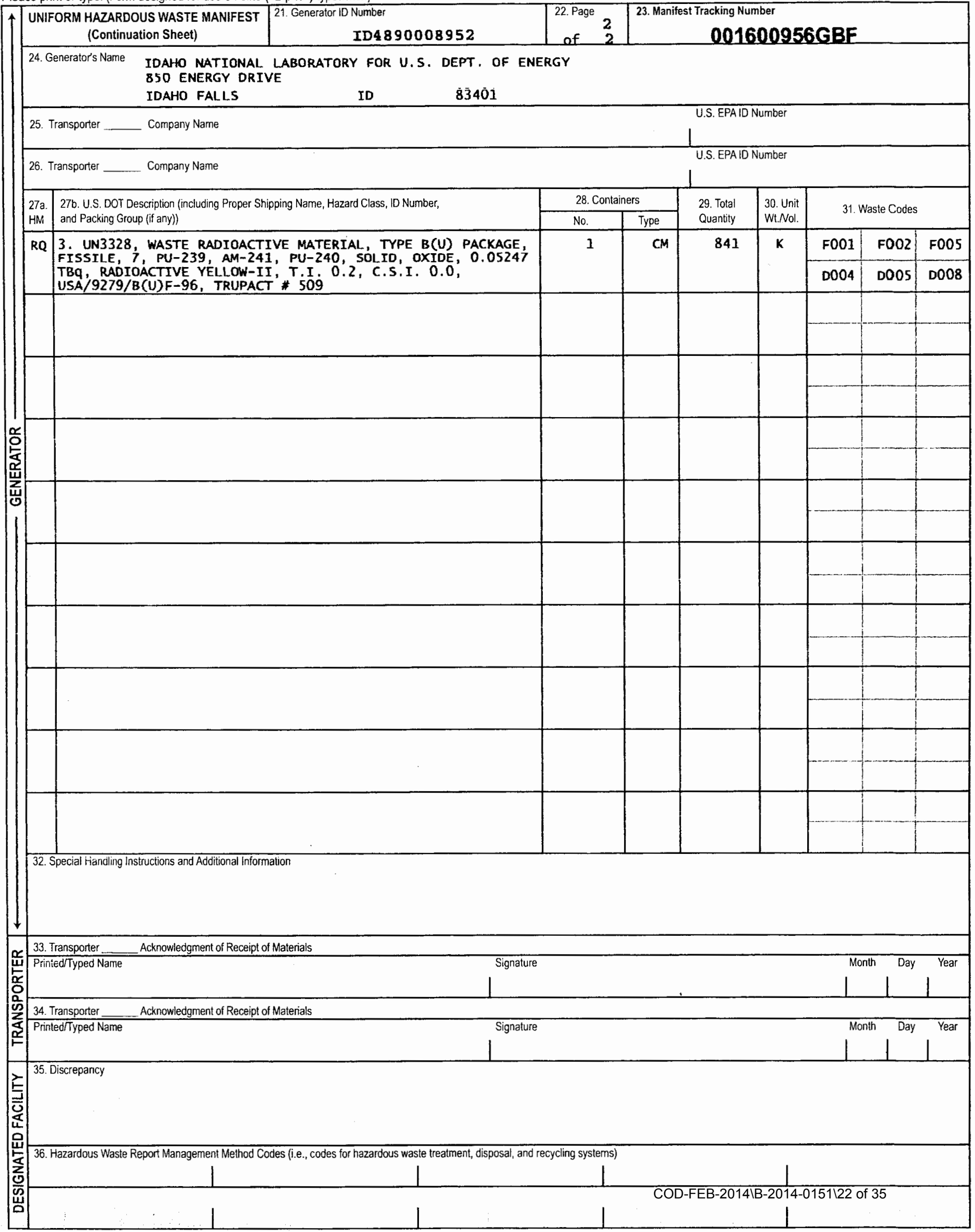




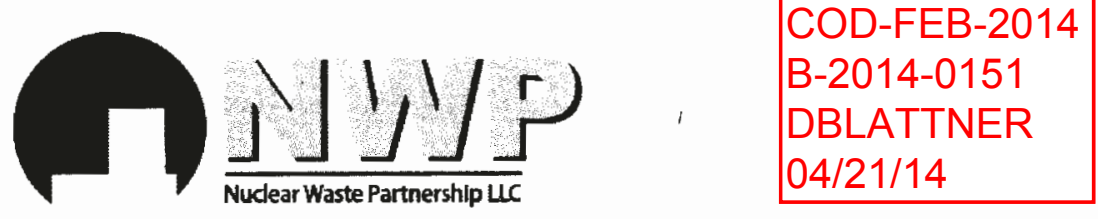

CP:14:02012

UFC:5822.00

A URS-led partnership with B\&W and AREVA

February 12, 2014

Ms. R. Hubler, Transportation Manager

Advanced Mixed Waste Treatment Plant/ITG

Idaho National Laboratory

850 Energy Drive, Suite 100

Idaho Falls, ID 83401

SUBJECT: CERTIFICATE OF DISPOSAL FOR POLYCHLORINATED BIPHENYL BEARING WASTE SHIPMENT NUMBERS IN140013, IN140014, IN140016, IN140018, IN140019, IN140022, IN140023, IN140024, IN140026, IN140028, IN140029, IN140031, IN140033, IN140034, IN140035, IN140038 AND IN140039 EMPLACED AT THE WASTE ISOLATION PILOT PLANT

Dear Ms. Hubler:

In compliance with Title 40 Code of Federal Regulations, Part 761.218 , I certify that the following Polychlorinated Biphenyl (PCB) wastes from your facility have been disposed by emplacement 2,150 feet underground in the Waste Isolation Pilot Plant waste repository.

Disposal Facility:

Waste Isolation Pilot Plant

30 Miles SE of Carlsbad, New Mexico

Eddy County, New Mexico 88220

Environmental Protection Agency (EPA) Identification Number (ID): NM4890139088

Shipping Site's EPA ID: ID4890008952

\begin{tabular}{|c|c|c|c|}
\hline $\begin{array}{c}\text { Shipment } \\
\text { Number }\end{array}$ & $\begin{array}{c}\text { Manifest Tracking } \\
\text { Number }\end{array}$ & $\begin{array}{c}\text { Container } \\
\text { Number }\end{array}$ & $\begin{array}{c}\text { Emplacement } \\
\text { Date }\end{array}$ \\
\hline IN140013 & $001600941 \mathrm{GBF}$ & BN10505055 & $1 / 24 / 2014$ \\
\hline IN140013 & $001600941 \mathrm{GBF}$ & BN10505054 & $1 / 21 / 2014$ \\
\hline IN140014 & $001600942 \mathrm{GBF}$ & BN10490911 & $1 / 25 / 2014$ \\
\hline IN140014 & $001600942 \mathrm{GBF}$ & BN10490912 & $1 / 25 / 2014$ \\
\hline IN140016 & $001600944 \mathrm{GBF}$ & BN10505059 & $1 / 24 / 2014$ \\
\hline IN140016 & $001600944 \mathrm{GBF}$ & BN10503788 & $1 / 24 / 2014$ \\
\hline IN140018 & $001600946 \mathrm{GBF}$ & BN10505058 & $1 / 26 / 2014$ \\
\hline IN140018 & $001600946 \mathrm{GBF}$ & BN10505062 & $1 / 26 / 2014$ \\
\hline IN140019 & $001600947 \mathrm{GBF}$ & BN10503775 & $1 / 24 / 2014$ \\
\hline IN140019 & $001600947 \mathrm{GBF}$ & BN10503760 & $1 / 24 / 2014$ \\
\hline IN140022 & 001600950GBF & BN10505063 & $2 / 2 / 2014$ \\
\hline
\end{tabular}




\begin{tabular}{|c|c|c|c|}
\hline $\begin{array}{l}\text { Shipment } \\
\text { Number }\end{array}$ & $\begin{array}{c}\text { Manifest Tracking } \\
\text { Number }\end{array}$ & $\begin{array}{l}\text { Container } \\
\text { Number }\end{array}$ & $\begin{array}{c}\text { Emplacement } \\
\text { Date }\end{array}$ \\
\hline IN140022 & $001600950 \mathrm{GBF}$ & BN10501246 & $1 / 24 / 2014$ \\
\hline IN140023 & $001600951 \mathrm{GBF}$ & BN10500612 & $1 / 30 / 2014$ \\
\hline IN140023 & $001600951 \mathrm{GBF}$ & BN10503777 & $1 / 26 / 2014$ \\
\hline IN140024 & $001600952 \mathrm{GBF}$ & BN10509616 & $1 / 24 / 2014$ \\
\hline IN140024 & $001600952 \mathrm{GBF}$ & BN10509615 & $2 / 2 / 2014$ \\
\hline IN140026 & $001600954 \mathrm{GBF}$ & BN10509688 & $1 / 26 / 2014$ \\
\hline IN140026 & $001600954 \mathrm{GBF}$ & BN10509618 & $1 / 28 / 2014$ \\
\hline IN140028 & $001600956 \mathrm{GBF}$ & BN10503774 & $1 / 28 / 2014$ \\
\hline IN140028 & $001600956 \mathrm{GBF}$ & BN10509606 & $1 / 28 / 2014$ \\
\hline IN140029 & $001600957 \mathrm{GBF}$ & BN10501248 & $1 / 28 / 2014$ \\
\hline IN140029 & $001600957 \mathrm{GBF}$ & BN10509611 & $2 / 1 / 2014$ \\
\hline IN140031 & $001600959 \mathrm{GBF}$ & BN10505060 & $2 / 1 / 2014$ \\
\hline IN140031 & 001600959GBF & BN10505061 & $1 / 28 / 2014$ \\
\hline IN140033 & $001600961 \mathrm{GBF}$ & BN10509682 & $1 / 31 / 2014$ \\
\hline IN140033 & $001600961 \mathrm{GBF}$ & BN10509601 & $1 / 31 / 2014$ \\
\hline IN140034 & $001600962 \mathrm{GBF}$ & BN10507549 & $2 / 2 / 2014$ \\
\hline IN140034 & $001600962 \mathrm{GBF}$ & BN10509687 & $2 / 1 / 2014$ \\
\hline IN140035 & $001600963 \mathrm{GBF}$ & BN10507550 & $1 / 31 / 2014$ \\
\hline IN140035 & $001600963 \mathrm{GBF}$ & BN10509599 & $2 / 1 / 2014$ \\
\hline IN140038 & $001600966 \mathrm{GBF}$ & BN10507553 & $2 / 2 / 2014$ \\
\hline IN140038 & $001600966 \mathrm{GBF}$ & BN10507557 & $2 / 2 / 2014$ \\
\hline IN140039 & $001600967 \mathrm{GBF}$ & BN10507555 & $2 / 4 / 2014$ \\
\hline IN140039 & $001600967 \mathrm{GBF}$ & BN10507554 & $2 / 4 / 2014$ \\
\hline
\end{tabular}

Under civil and criminal penalties of law for the making or submission of false or fraudulent statements or representations (18 U.S.C. 1001 and 15 U.S.C. 2615), I certify that the information contained in or accompanying this document is true, accurate, and complete.

As to the identified section(s) of this document for which I cannot personally verify truth and accuracy, I certify as the company official having supervisory responsibility for the persons who, acting under my direct instructions, made the verification that this information is true, accurate, and complete.

Should you require further information concerning this certificate of disposal, please contact Mr. R. S. (Bob) Nieman at (575) 234-8141.

Sincerely,

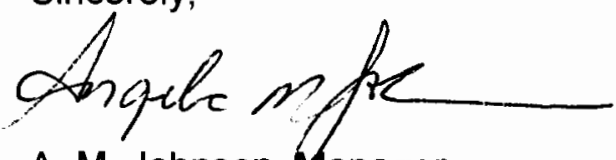

A. M. Johnson, Manager

Transportation Management

RSN/rsn

cc: Shipment portfolio for shipments IN140013, IN140014, IN140016, IN140018, IN140019, IN140022, IN140023, IN140024, IN140026, IN140028, IN140029, IN140031, IN140033, IN140034, IN140035, IN140038 and IN140039. 
Please print or type. (Form designed for use on elite (12-pitch) typewriter.)

Form Approved. OMB №. 2050-0039

$\uparrow$\begin{tabular}{|c|c|}
\hline $\begin{array}{c}\text { UNIFORM HAZARDOUS } \\
\text { WASTE MANIFEST }\end{array}$ & $\begin{array}{c}\text { 1. Generator ID Number } \\
\text { ID489 } 80008952\end{array}$ \\
\cline { 2 - 3 } 5. Generator's Name and Mailing Address &
\end{tabular}

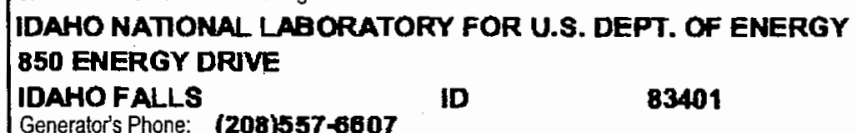

Generator's Phone: (208)557-6607

6. Transporter 1 Company Name

CAST SPECIALTY TRANSPORTATION INC.

7. Transpoiter 2 Company Name

2. Page 1 of 3 3. Emergency Response Phone

2

(575) $885-6883$ 4. Manifest Tracking Number $950 \mathrm{GBF}$ Generator's Site Address (if different thar maling address)

\section{AMWTP}

HHGHWAY 20 AND VAN BUREN BLVD SCOVLLE

83415

COR000206722

8. Designated Facility Name and Site Address

NUCLEAR WASTE PARTNERSHIP, LLC FOR THE U.5. DOE

30 MILES E. OF CARLSBAD ON JAL HIGHWAY

EDDY COUNTY NM 88221

Facility's Phone: (575) 234-8457

\begin{tabular}{l|l} 
9a. & 9b. U.S. DOT Description (including Proper Shipping Name, Hazard Class, ID Number,
\end{tabular}

$\mathrm{HM}$ and Packing Group (if any))

RQ 1. UN3328, WASTE RADIOACTIVE MATERIAL, TYPE B(U) PACKAGE FI55ILE, 7, PU-239, PU-240, AM-241, 5OLID, OXIDE, 0.008281 FBq, RADIOACTIVE YÉLLOW-II, T.I. 0.2, C.S.I. 0.0, USA/9218/B(U)F-96, TRUPACT \# 132

2. PCB Container \#BN10509611, Sludge, PCB out of service pate 04/09/2013, PCB Weight $1108.8 \mathrm{~kg}$

RQ 3. 2. UN3328, WASTE RADIOACTIVE MATERIAL, TYPE B(U) PACKAGE, EISSILE, 7, PU-239, PU-240, AM-241, SOLID, OXIDE, 0.007265 PBq, RADIOACTIVE YELLOW-II, T.I. 0.2, C.S.I. 0.0, USA/9218/B(U)F-96, TRUPACT \# 136

4. PCB container \#BN10501248, 57udge, PCB out of service pate $04 / 15 / 2013$, PCB weight $803.2 \mathrm{~kg}$

14. Special Handling Instructions and Additional information

SHIPMENT \# IN140029

GROSS WEIGHT IN LBS:

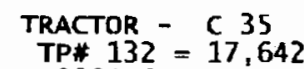

TRACTOR - C 35

TP\# $132=17,642$

PREPARED UNDER CONTRACT \# DE-EMO001467

TRAILER -321

TP\# $136=17,440$ ERI PROVIDER IS WIPP CMR
NM4890139088

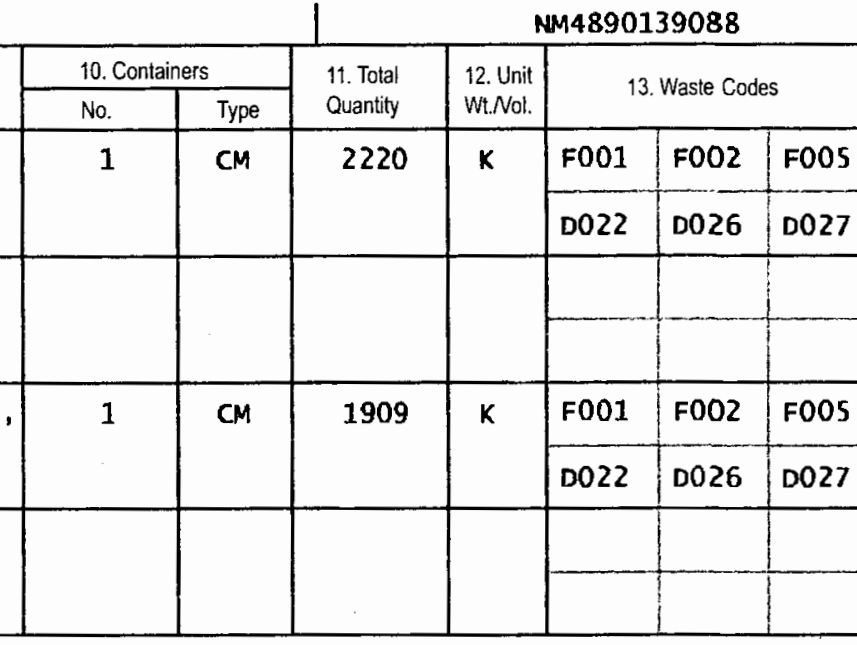

ERG \# 165

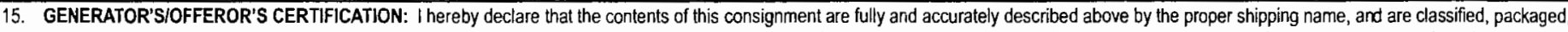
marked and labeled/placarded, and are in all respects in proper condition for transport according to applicable internationaiand national governmental regulations. If export shipment and I am the Primary

Exporter, 1 certify that the contents of this consignment conform to the terms of the attached EPAAcknowiedgment of Consent.

I certify that the waste minimization statement identified in 40 CFR 262.27(a) (if I am a large quantity generator) or (b) (if I am a small quantity generator) is true

Generator's/Offeror's PrintedTyped Name $]_{\text {dy }}$ Pedersen-(aun pbe /)

Transporter signature (for exports only): import to U.S
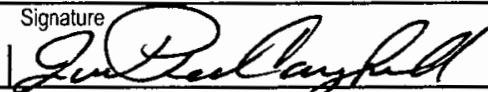

Month Day Year

$\square$ Export from U.S. Port of entrylexit:

17. Transporter Acknowledgment of Receipt of Materials

Ifarmoporter 1 Printed/Typed tame

Dran Steinman

Transporter 2 P Tintedityped Name

$\simeq$

18. Discrepancy

18a. Discrepancy Indication Space

$\square$ Quaritity

[]$_{\text {Type }}$

$\square$ Residue

$\square$ Partial Rejection

\begin{tabular}{cc} 
Month Day & Year \\
$10,124 \mid$ & 14 \\
\hline Monih & $24 y$ \\
\hline Day
\end{tabular}

$\uparrow 8 \mathrm{~b}$. Alternate Facility (or Generator)

Manifest Reference Number

Facility's Phone:

18c. Signature of Alternate Facility (or Generator)

19. Hazardous Waste Report Management Method Codes (i.e., codes for hazardous waste treatment, disposal, and recycling systems)

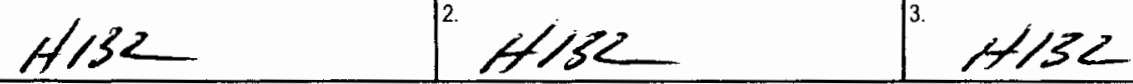

20. Designated Facility Owner or Operator: Certification of receipt of hazardous materials covered by the manifest except as nded in ltem $18 \mathrm{~B}$

Printed/Typed Nam

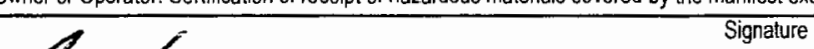

Signature

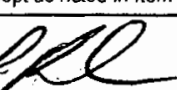


Please print or type. (Form designed for use on elite (12-pitch) typewriter.)

Form Approved. OMB No. 2050-0039

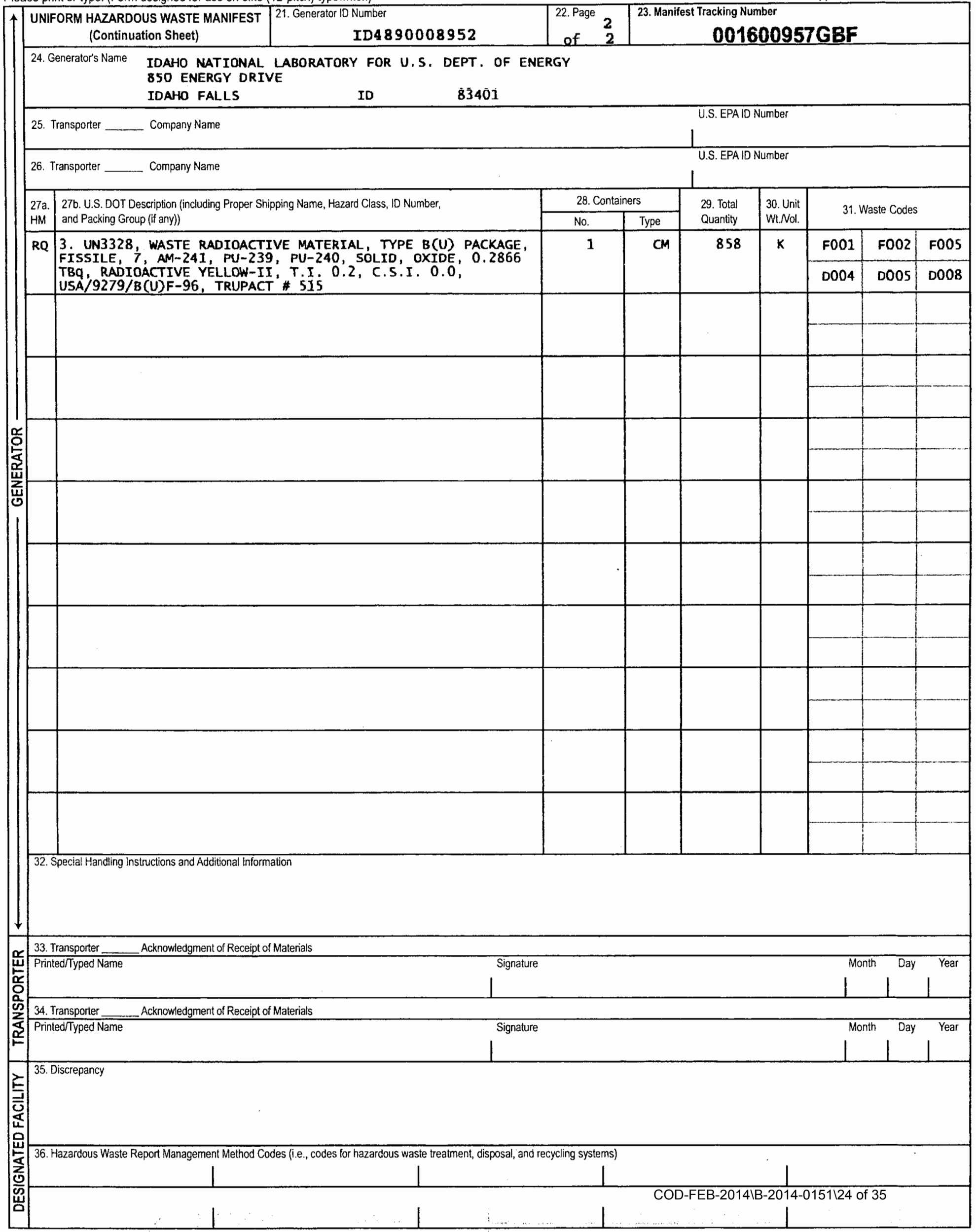




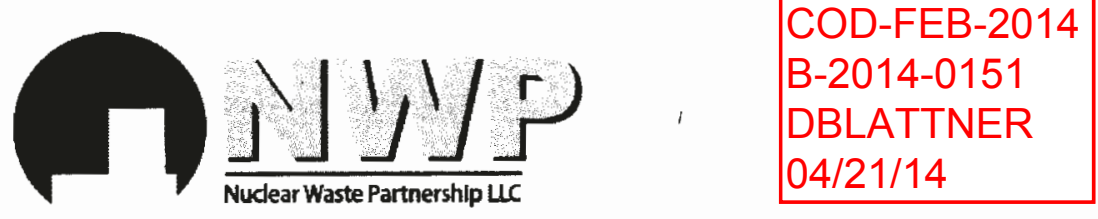

CP:14:02012

UFC:5822.00

A URS-led partnership with B\&W and AREVA

February 12, 2014

Ms. R. Hubler, Transportation Manager

Advanced Mixed Waste Treatment Plant/ITG

Idaho National Laboratory

850 Energy Drive, Suite 100

Idaho Falls, ID 83401

SUBJECT: CERTIFICATE OF DISPOSAL FOR POLYCHLORINATED BIPHENYL BEARING WASTE SHIPMENT NUMBERS IN140013, IN140014, IN140016, IN140018, IN140019, IN140022, IN140023, IN140024, IN140026, IN140028, IN140029, IN140031, IN140033, IN140034, IN140035, IN140038 AND IN140039 EMPLACED AT THE WASTE ISOLATION PILOT PLANT

Dear Ms. Hubler:

In compliance with Title 40 Code of Federal Regulations, Part 761.218 , I certify that the following Polychlorinated Biphenyl (PCB) wastes from your facility have been disposed by emplacement 2,150 feet underground in the Waste Isolation Pilot Plant waste repository.

Disposal Facility:

Waste Isolation Pilot Plant

30 Miles SE of Carlsbad, New Mexico

Eddy County, New Mexico 88220

Environmental Protection Agency (EPA) Identification Number (ID): NM4890139088

Shipping Site's EPA ID: ID4890008952

\begin{tabular}{|c|c|c|c|}
\hline $\begin{array}{c}\text { Shipment } \\
\text { Number }\end{array}$ & $\begin{array}{c}\text { Manifest Tracking } \\
\text { Number }\end{array}$ & $\begin{array}{c}\text { Container } \\
\text { Number }\end{array}$ & $\begin{array}{c}\text { Emplacement } \\
\text { Date }\end{array}$ \\
\hline IN140013 & $001600941 \mathrm{GBF}$ & BN10505055 & $1 / 24 / 2014$ \\
\hline IN140013 & $001600941 \mathrm{GBF}$ & BN10505054 & $1 / 21 / 2014$ \\
\hline IN140014 & $001600942 \mathrm{GBF}$ & BN10490911 & $1 / 25 / 2014$ \\
\hline IN140014 & $001600942 \mathrm{GBF}$ & BN10490912 & $1 / 25 / 2014$ \\
\hline IN140016 & $001600944 \mathrm{GBF}$ & BN10505059 & $1 / 24 / 2014$ \\
\hline IN140016 & $001600944 \mathrm{GBF}$ & BN10503788 & $1 / 24 / 2014$ \\
\hline IN140018 & $001600946 \mathrm{GBF}$ & BN10505058 & $1 / 26 / 2014$ \\
\hline IN140018 & $001600946 \mathrm{GBF}$ & BN10505062 & $1 / 26 / 2014$ \\
\hline IN140019 & $001600947 \mathrm{GBF}$ & BN10503775 & $1 / 24 / 2014$ \\
\hline IN140019 & $001600947 \mathrm{GBF}$ & BN10503760 & $1 / 24 / 2014$ \\
\hline IN140022 & 001600950GBF & BN10505063 & $2 / 2 / 2014$ \\
\hline
\end{tabular}




\begin{tabular}{|c|c|c|c|}
\hline $\begin{array}{l}\text { Shipment } \\
\text { Number }\end{array}$ & $\begin{array}{c}\text { Manifest Tracking } \\
\text { Number }\end{array}$ & $\begin{array}{l}\text { Container } \\
\text { Number }\end{array}$ & $\begin{array}{c}\text { Emplacement } \\
\text { Date }\end{array}$ \\
\hline IN140022 & $001600950 \mathrm{GBF}$ & BN10501246 & $1 / 24 / 2014$ \\
\hline IN140023 & $001600951 \mathrm{GBF}$ & BN10500612 & $1 / 30 / 2014$ \\
\hline IN140023 & $001600951 \mathrm{GBF}$ & BN10503777 & $1 / 26 / 2014$ \\
\hline IN140024 & $001600952 \mathrm{GBF}$ & BN10509616 & $1 / 24 / 2014$ \\
\hline IN140024 & $001600952 \mathrm{GBF}$ & BN10509615 & $2 / 2 / 2014$ \\
\hline IN140026 & $001600954 \mathrm{GBF}$ & BN10509688 & $1 / 26 / 2014$ \\
\hline IN140026 & $001600954 \mathrm{GBF}$ & BN10509618 & $1 / 28 / 2014$ \\
\hline IN140028 & $001600956 \mathrm{GBF}$ & BN10503774 & $1 / 28 / 2014$ \\
\hline IN140028 & $001600956 \mathrm{GBF}$ & BN10509606 & $1 / 28 / 2014$ \\
\hline IN140029 & $001600957 \mathrm{GBF}$ & BN10501248 & $1 / 28 / 2014$ \\
\hline IN140029 & $001600957 \mathrm{GBF}$ & BN10509611 & $2 / 1 / 2014$ \\
\hline IN140031 & $001600959 \mathrm{GBF}$ & BN10505060 & $2 / 1 / 2014$ \\
\hline IN140031 & 001600959GBF & BN10505061 & $1 / 28 / 2014$ \\
\hline IN140033 & $001600961 \mathrm{GBF}$ & BN10509682 & $1 / 31 / 2014$ \\
\hline IN140033 & $001600961 \mathrm{GBF}$ & BN10509601 & $1 / 31 / 2014$ \\
\hline IN140034 & $001600962 \mathrm{GBF}$ & BN10507549 & $2 / 2 / 2014$ \\
\hline IN140034 & $001600962 \mathrm{GBF}$ & BN10509687 & $2 / 1 / 2014$ \\
\hline IN140035 & $001600963 \mathrm{GBF}$ & BN10507550 & $1 / 31 / 2014$ \\
\hline IN140035 & $001600963 \mathrm{GBF}$ & BN10509599 & $2 / 1 / 2014$ \\
\hline IN140038 & $001600966 \mathrm{GBF}$ & BN10507553 & $2 / 2 / 2014$ \\
\hline IN140038 & $001600966 \mathrm{GBF}$ & BN10507557 & $2 / 2 / 2014$ \\
\hline IN140039 & $001600967 \mathrm{GBF}$ & BN10507555 & $2 / 4 / 2014$ \\
\hline IN140039 & $001600967 \mathrm{GBF}$ & BN10507554 & $2 / 4 / 2014$ \\
\hline
\end{tabular}

Under civil and criminal penalties of law for the making or submission of false or fraudulent statements or representations (18 U.S.C. 1001 and 15 U.S.C. 2615), I certify that the information contained in or accompanying this document is true, accurate, and complete.

As to the identified section(s) of this document for which I cannot personally verify truth and accuracy, I certify as the company official having supervisory responsibility for the persons who, acting under my direct instructions, made the verification that this information is true, accurate, and complete.

Should you require further information concerning this certificate of disposal, please contact Mr. R. S. (Bob) Nieman at (575) 234-8141.

Sincerely,

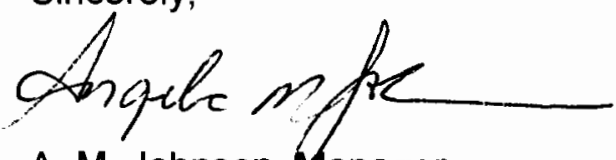

A. M. Johnson, Manager

Transportation Management

RSN/rsn

cc: Shipment portfolio for shipments IN140013, IN140014, IN140016, IN140018, IN140019, IN140022, IN140023, IN140024, IN140026, IN140028, IN140029, IN140031, IN140033, IN140034, IN140035, IN140038 and IN140039. 
Please print or type. (Form designed for use on elite (12-pitch) typewriter.)

Form Approved. OMB No. 2050-0039 UNIFORM HAZARDOUS 1 . Generator ID Number WASTE MANIFEST

ID4890008952

5. Generator's Name and Mailing Address

IDAHO NATIONAL LABORATORY FOR U.S. DEPT. OF ENERGY

850 ENERGY DRIVE

IDAHO FALLS

10

ID 83401

Generator's Phone: (208)557-6607

6. Transporter 1 Company Name

VISIONARY SOLUTIONS, LLC

7. Transporter 2 Company Name

8. Designated Facility Name and Site Address

NUCLEAR WASTE PARTNERSHIP, LLC FOR THE U.S. DOE

30 MILES E. OF CARLSBAD ON JAL HIGHWAY

EDDY COUNTY NM 88221

Facility's Phone: (575) 234-8457

9a. $9 \mathrm{~b}$. U.S. DOT Description (including Proper Shipping Name, Hazard Class, ID Number,

HM and Packing Group (if any))

RQ 1. UN3328, WASTE RADIOACTIVE MATERIAL, TYPE B(U) PACKAGE FISSILE, 7, PU-239, AM-241, PU-240, SOLID, OXIDE, 0.01296 TBq, RADIOACTIVE YELLOW-II, T.I. 0.2, C.5.I. 0.0, USA /9218/B(U)F-96, TRUPACT \# 191

R. PCB Container \#BN10505061, 57udge, PCB out of service pate 06/25/2013, PCB Weight $986.6 \mathrm{~kg}$

RQ 2. 2, UN3328, WASTE RADIOACTIVE MATERIAL, TYPE B(U) PACKAGE, FISSILE, 7, PU-239, AM-241, PU-240, SOLID, OXIDE, 0.01583 TBQ, RADIOACTIVE YELLOW-II, T.I. 0.2, C.S.I. 0.0, USA/9218/B(U)F-96, TRUPACT * 163 4. PCB Container \#BN10505060, s7udge, PCB out of service pate 06/27/2013, PCB weight $971.2 \mathrm{~kg}$

14. Special Handling Instructions and Additional Information

SHIPMENT * IN140031

GROS5 WEIGHT IN LBS:

TRACTOR - V 31

TP\# 191=17,126

PREPARED UNDER CONTRACT * DE-EMO001467

TRAILER - 358

TP\# $16 \overline{3}=17,402 \quad$ TP\# $501=13,144$

N4890139088

(575) 885-6883 OO1600959 GBF Generator's Site Address (if different than mailing address)

AMWTP

HIGHWAY 20 AND VAN BUREN BLVD

SCOVLLE ID

83415

NMR000013086

U.S. EPAIC Number

U.S. EPAID Number

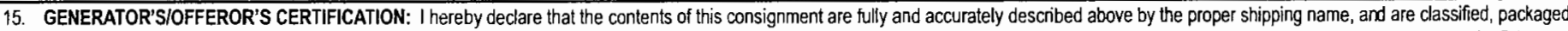
marked and labeled/placarded, and are in all respects in proper condition for transport according to applicable intemational and national governmental regulations. If export shipment and I am the Primary

Exporter, I certify that the contents of this consignment conform to the terms of the attached EPA Acknowledgment of Consent.

I certify that the waste minimization statement identified in 40 CFR 262.27(a) (if I am a large quantity generator) or (b) (if I am a small quantity generator) is true.

$\downarrow$ LOA NEV A

Transporter signature (for exports only):

$\square$ Import to U.S.

17. Transporter Acknowledgment of Receipt of Materials

${ }_{10} \mathrm{O}$

Transporter 2 Printed/Typed Nát

18. Discrepancy

18a. Discrepancy Indication Space

$\square$ Quantity

$\square_{\text {Type }}$

$\square$ Residue

$\square$ Partial Rejection

Month Day Year

$18 \mathrm{~b}$. Ailernate Faciility (or Gererator)

Manifest Reference Number:

Facility's Phone:

18c. Signature of Alternate Facility (or Generator)

$\square$ Export from U.S.

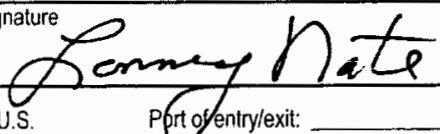

$0 /|25| 14$

19. Hazardous Waste Report Management Method Codes (i.e., codes for hazardous waste treatment, disposal, and recycling systems)
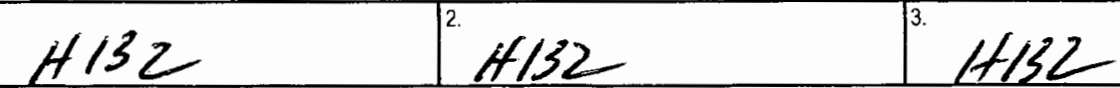

20. Designated Facility Owner or Operator: Certification of receipt of hazardous materials covered by the manifest except as noted in item 18a 
Please print or type. (Form designed for use on elite (12-pitch) typewriter.)

Form Approved. OMB No. 2050-0039

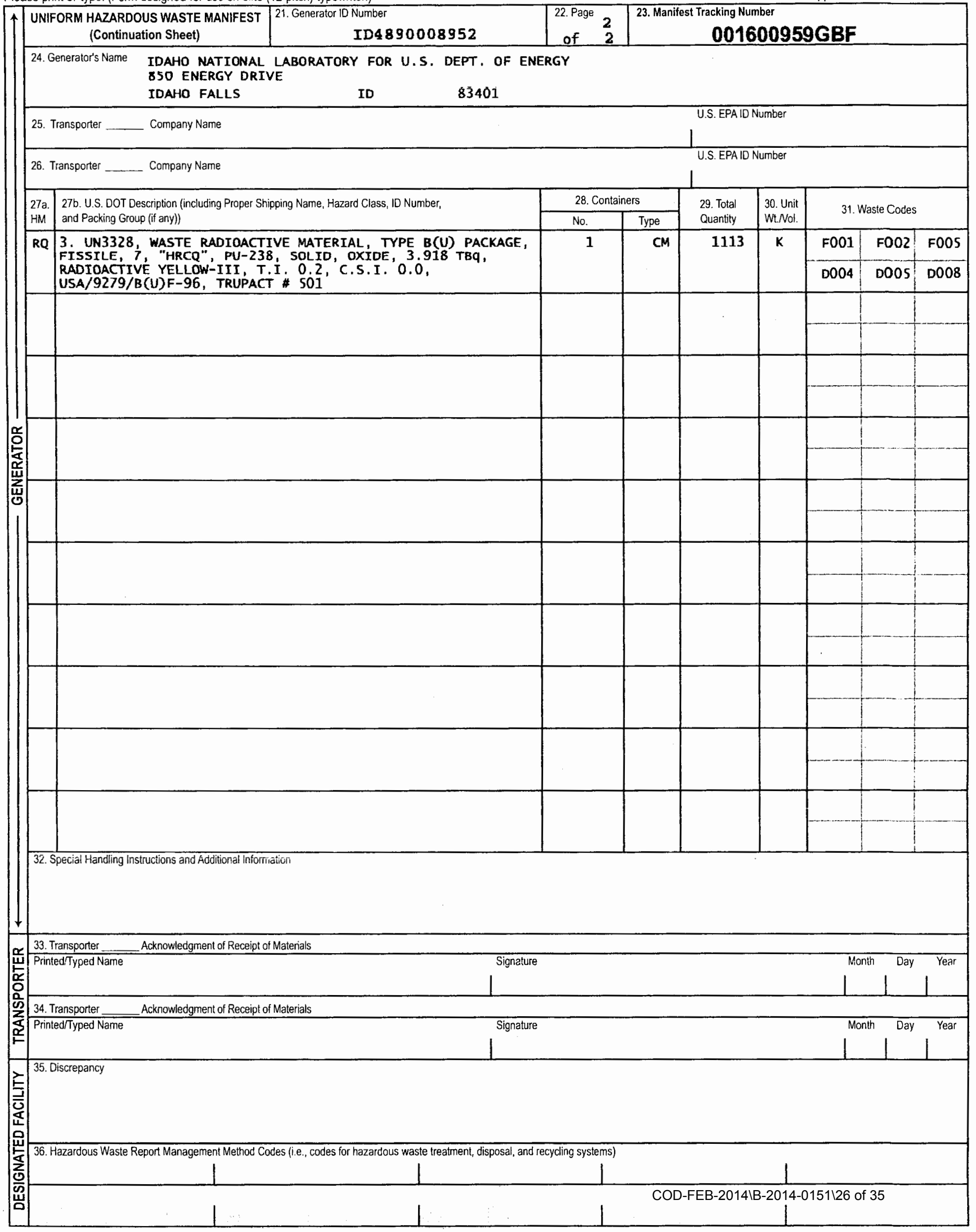




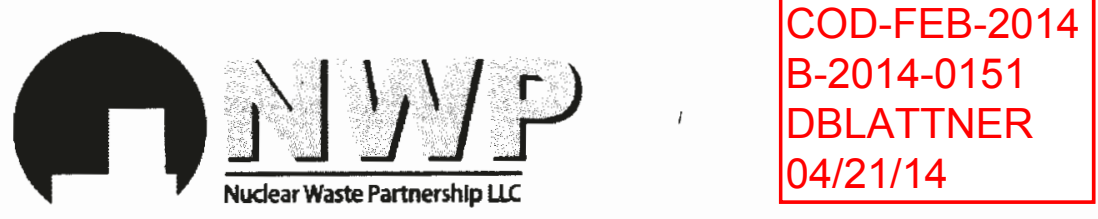

CP:14:02012

UFC:5822.00

A URS-led partnership with B\&W and AREVA

February 12, 2014

Ms. R. Hubler, Transportation Manager

Advanced Mixed Waste Treatment Plant/ITG

Idaho National Laboratory

850 Energy Drive, Suite 100

Idaho Falls, ID 83401

SUBJECT: CERTIFICATE OF DISPOSAL FOR POLYCHLORINATED BIPHENYL BEARING WASTE SHIPMENT NUMBERS IN140013, IN140014, IN140016, IN140018, IN140019, IN140022, IN140023, IN140024, IN140026, IN140028, IN140029, IN140031, IN140033, IN140034, IN140035, IN140038 AND IN140039 EMPLACED AT THE WASTE ISOLATION PILOT PLANT

Dear Ms. Hubler:

In compliance with Title 40 Code of Federal Regulations, Part 761.218 , I certify that the following Polychlorinated Biphenyl (PCB) wastes from your facility have been disposed by emplacement 2,150 feet underground in the Waste Isolation Pilot Plant waste repository.

Disposal Facility:

Waste Isolation Pilot Plant

30 Miles SE of Carlsbad, New Mexico

Eddy County, New Mexico 88220

Environmental Protection Agency (EPA) Identification Number (ID): NM4890139088

Shipping Site's EPA ID: ID4890008952

\begin{tabular}{|c|c|c|c|}
\hline $\begin{array}{c}\text { Shipment } \\
\text { Number }\end{array}$ & $\begin{array}{c}\text { Manifest Tracking } \\
\text { Number }\end{array}$ & $\begin{array}{c}\text { Container } \\
\text { Number }\end{array}$ & $\begin{array}{c}\text { Emplacement } \\
\text { Date }\end{array}$ \\
\hline IN140013 & $001600941 \mathrm{GBF}$ & BN10505055 & $1 / 24 / 2014$ \\
\hline IN140013 & $001600941 \mathrm{GBF}$ & BN10505054 & $1 / 21 / 2014$ \\
\hline IN140014 & $001600942 \mathrm{GBF}$ & BN10490911 & $1 / 25 / 2014$ \\
\hline IN140014 & $001600942 \mathrm{GBF}$ & BN10490912 & $1 / 25 / 2014$ \\
\hline IN140016 & $001600944 \mathrm{GBF}$ & BN10505059 & $1 / 24 / 2014$ \\
\hline IN140016 & $001600944 \mathrm{GBF}$ & BN10503788 & $1 / 24 / 2014$ \\
\hline IN140018 & $001600946 \mathrm{GBF}$ & BN10505058 & $1 / 26 / 2014$ \\
\hline IN140018 & $001600946 \mathrm{GBF}$ & BN10505062 & $1 / 26 / 2014$ \\
\hline IN140019 & $001600947 \mathrm{GBF}$ & BN10503775 & $1 / 24 / 2014$ \\
\hline IN140019 & $001600947 \mathrm{GBF}$ & BN10503760 & $1 / 24 / 2014$ \\
\hline IN140022 & 001600950GBF & BN10505063 & $2 / 2 / 2014$ \\
\hline
\end{tabular}




\begin{tabular}{|c|c|c|c|}
\hline $\begin{array}{l}\text { Shipment } \\
\text { Number }\end{array}$ & $\begin{array}{c}\text { Manifest Tracking } \\
\text { Number }\end{array}$ & $\begin{array}{l}\text { Container } \\
\text { Number }\end{array}$ & $\begin{array}{c}\text { Emplacement } \\
\text { Date }\end{array}$ \\
\hline IN140022 & $001600950 \mathrm{GBF}$ & BN10501246 & $1 / 24 / 2014$ \\
\hline IN140023 & $001600951 \mathrm{GBF}$ & BN10500612 & $1 / 30 / 2014$ \\
\hline IN140023 & $001600951 \mathrm{GBF}$ & BN10503777 & $1 / 26 / 2014$ \\
\hline IN140024 & $001600952 \mathrm{GBF}$ & BN10509616 & $1 / 24 / 2014$ \\
\hline IN140024 & $001600952 \mathrm{GBF}$ & BN10509615 & $2 / 2 / 2014$ \\
\hline IN140026 & $001600954 \mathrm{GBF}$ & BN10509688 & $1 / 26 / 2014$ \\
\hline IN140026 & $001600954 \mathrm{GBF}$ & BN10509618 & $1 / 28 / 2014$ \\
\hline IN140028 & $001600956 \mathrm{GBF}$ & BN10503774 & $1 / 28 / 2014$ \\
\hline IN140028 & $001600956 \mathrm{GBF}$ & BN10509606 & $1 / 28 / 2014$ \\
\hline IN140029 & $001600957 \mathrm{GBF}$ & BN10501248 & $1 / 28 / 2014$ \\
\hline IN140029 & $001600957 \mathrm{GBF}$ & BN10509611 & $2 / 1 / 2014$ \\
\hline IN140031 & $001600959 \mathrm{GBF}$ & BN10505060 & $2 / 1 / 2014$ \\
\hline IN140031 & 001600959GBF & BN10505061 & $1 / 28 / 2014$ \\
\hline IN140033 & $001600961 \mathrm{GBF}$ & BN10509682 & $1 / 31 / 2014$ \\
\hline IN140033 & $001600961 \mathrm{GBF}$ & BN10509601 & $1 / 31 / 2014$ \\
\hline IN140034 & $001600962 \mathrm{GBF}$ & BN10507549 & $2 / 2 / 2014$ \\
\hline IN140034 & $001600962 \mathrm{GBF}$ & BN10509687 & $2 / 1 / 2014$ \\
\hline IN140035 & $001600963 \mathrm{GBF}$ & BN10507550 & $1 / 31 / 2014$ \\
\hline IN140035 & $001600963 \mathrm{GBF}$ & BN10509599 & $2 / 1 / 2014$ \\
\hline IN140038 & $001600966 \mathrm{GBF}$ & BN10507553 & $2 / 2 / 2014$ \\
\hline IN140038 & $001600966 \mathrm{GBF}$ & BN10507557 & $2 / 2 / 2014$ \\
\hline IN140039 & $001600967 \mathrm{GBF}$ & BN10507555 & $2 / 4 / 2014$ \\
\hline IN140039 & $001600967 \mathrm{GBF}$ & BN10507554 & $2 / 4 / 2014$ \\
\hline
\end{tabular}

Under civil and criminal penalties of law for the making or submission of false or fraudulent statements or representations (18 U.S.C. 1001 and 15 U.S.C. 2615), I certify that the information contained in or accompanying this document is true, accurate, and complete.

As to the identified section(s) of this document for which I cannot personally verify truth and accuracy, I certify as the company official having supervisory responsibility for the persons who, acting under my direct instructions, made the verification that this information is true, accurate, and complete.

Should you require further information concerning this certificate of disposal, please contact Mr. R. S. (Bob) Nieman at (575) 234-8141.

Sincerely,

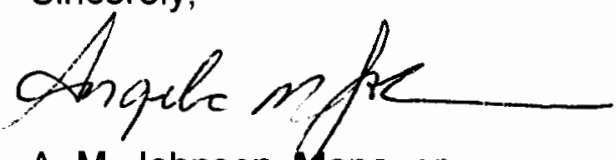

A. M. Johnson, Manager

Transportation Management

RSN/rsn

cc: Shipment portfolio for shipments IN140013, IN140014, IN140016, IN140018, IN140019, IN140022, IN140023, IN140024, IN140026, IN140028, IN140029, IN140031, IN140033, IN140034, IN140035, IN140038 and IN140039. 
Please print or type. (Form designed for use on elite (12-pitch) typewriter.)

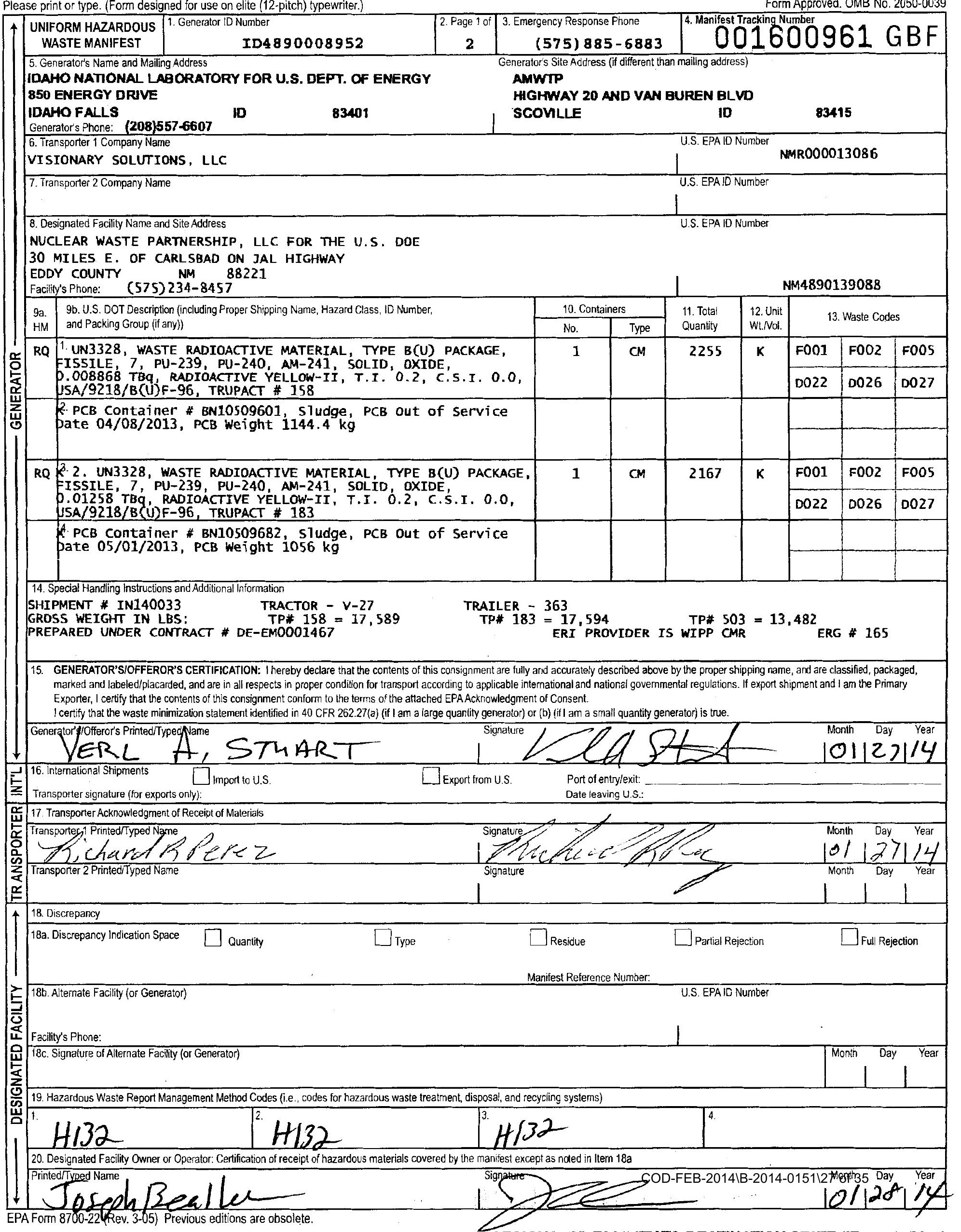


Please print or type. (Form designed for use on elite (12-pitch) typewriter.)

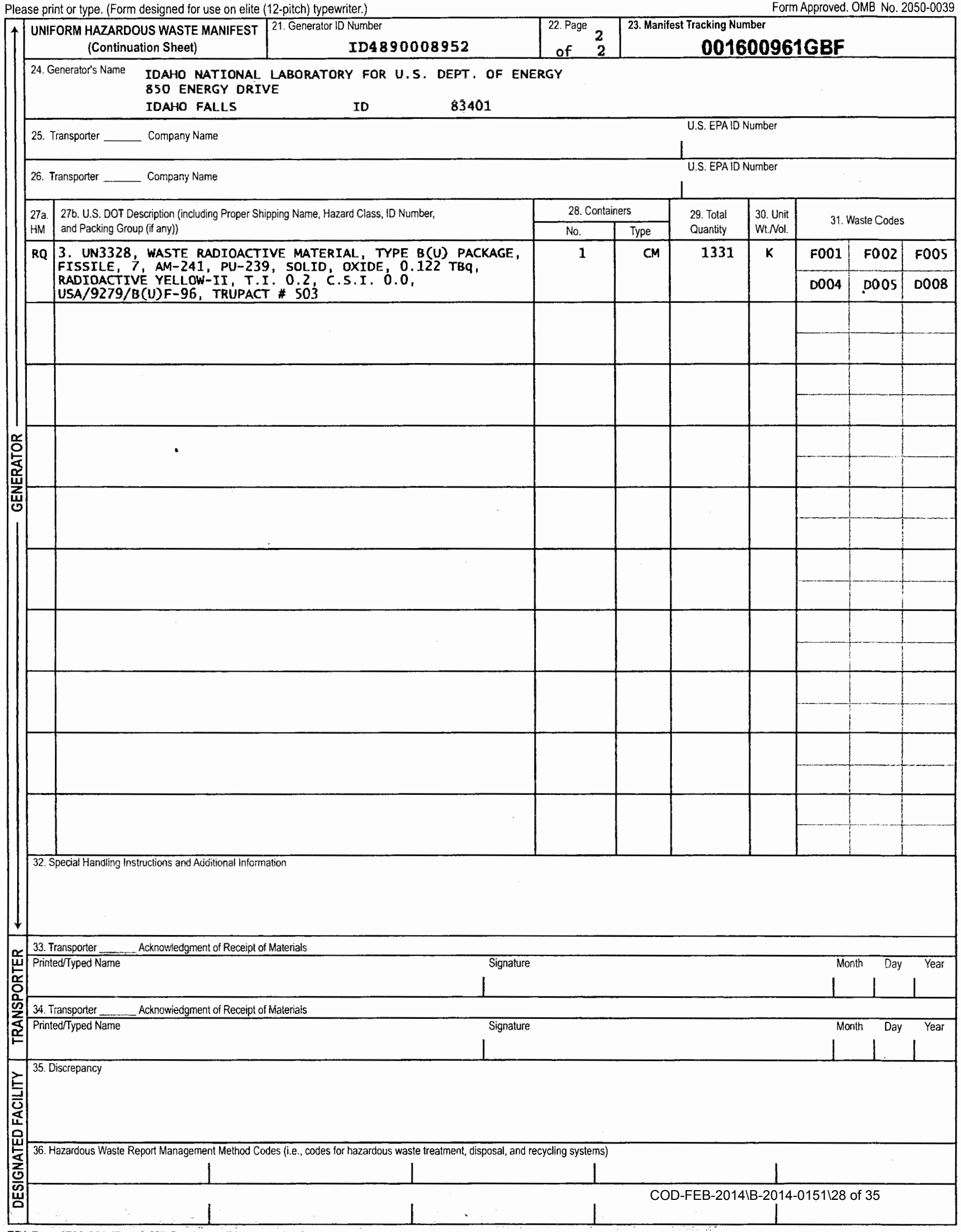

EPA Form 8700-22A (Rev. 3-05) Previous editions are obsolete. 


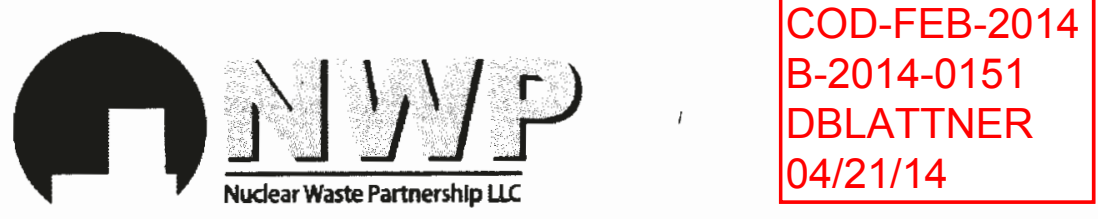

CP:14:02012

UFC:5822.00

A URS-led partnership with B\&W and AREVA

February 12, 2014

Ms. R. Hubler, Transportation Manager

Advanced Mixed Waste Treatment Plant/ITG

Idaho National Laboratory

850 Energy Drive, Suite 100

Idaho Falls, ID 83401

SUBJECT: CERTIFICATE OF DISPOSAL FOR POLYCHLORINATED BIPHENYL BEARING WASTE SHIPMENT NUMBERS IN140013, IN140014, IN140016, IN140018, IN140019, IN140022, IN140023, IN140024, IN140026, IN140028, IN140029, IN140031, IN140033, IN140034, IN140035, IN140038 AND IN140039 EMPLACED AT THE WASTE ISOLATION PILOT PLANT

Dear Ms. Hubler:

In compliance with Title 40 Code of Federal Regulations, Part 761.218 , I certify that the following Polychlorinated Biphenyl (PCB) wastes from your facility have been disposed by emplacement 2,150 feet underground in the Waste Isolation Pilot Plant waste repository.

Disposal Facility:

Waste Isolation Pilot Plant

30 Miles SE of Carlsbad, New Mexico

Eddy County, New Mexico 88220

Environmental Protection Agency (EPA) Identification Number (ID): NM4890139088

Shipping Site's EPA ID: ID4890008952

\begin{tabular}{|c|c|c|c|}
\hline $\begin{array}{c}\text { Shipment } \\
\text { Number }\end{array}$ & $\begin{array}{c}\text { Manifest Tracking } \\
\text { Number }\end{array}$ & $\begin{array}{c}\text { Container } \\
\text { Number }\end{array}$ & $\begin{array}{c}\text { Emplacement } \\
\text { Date }\end{array}$ \\
\hline IN140013 & $001600941 \mathrm{GBF}$ & BN10505055 & $1 / 24 / 2014$ \\
\hline IN140013 & $001600941 \mathrm{GBF}$ & BN10505054 & $1 / 21 / 2014$ \\
\hline IN140014 & $001600942 \mathrm{GBF}$ & BN10490911 & $1 / 25 / 2014$ \\
\hline IN140014 & $001600942 \mathrm{GBF}$ & BN10490912 & $1 / 25 / 2014$ \\
\hline IN140016 & $001600944 \mathrm{GBF}$ & BN10505059 & $1 / 24 / 2014$ \\
\hline IN140016 & $001600944 \mathrm{GBF}$ & BN10503788 & $1 / 24 / 2014$ \\
\hline IN140018 & $001600946 \mathrm{GBF}$ & BN10505058 & $1 / 26 / 2014$ \\
\hline IN140018 & $001600946 \mathrm{GBF}$ & BN10505062 & $1 / 26 / 2014$ \\
\hline IN140019 & $001600947 \mathrm{GBF}$ & BN10503775 & $1 / 24 / 2014$ \\
\hline IN140019 & $001600947 \mathrm{GBF}$ & BN10503760 & $1 / 24 / 2014$ \\
\hline IN140022 & 001600950GBF & BN10505063 & $2 / 2 / 2014$ \\
\hline
\end{tabular}




\begin{tabular}{|c|c|c|c|}
\hline $\begin{array}{l}\text { Shipment } \\
\text { Number }\end{array}$ & $\begin{array}{c}\text { Manifest Tracking } \\
\text { Number }\end{array}$ & $\begin{array}{l}\text { Container } \\
\text { Number }\end{array}$ & $\begin{array}{c}\text { Emplacement } \\
\text { Date }\end{array}$ \\
\hline IN140022 & $001600950 \mathrm{GBF}$ & BN10501246 & $1 / 24 / 2014$ \\
\hline IN140023 & $001600951 \mathrm{GBF}$ & BN10500612 & $1 / 30 / 2014$ \\
\hline IN140023 & $001600951 \mathrm{GBF}$ & BN10503777 & $1 / 26 / 2014$ \\
\hline IN140024 & $001600952 \mathrm{GBF}$ & BN10509616 & $1 / 24 / 2014$ \\
\hline IN140024 & $001600952 \mathrm{GBF}$ & BN10509615 & $2 / 2 / 2014$ \\
\hline IN140026 & $001600954 \mathrm{GBF}$ & BN10509688 & $1 / 26 / 2014$ \\
\hline IN140026 & $001600954 \mathrm{GBF}$ & BN10509618 & $1 / 28 / 2014$ \\
\hline IN140028 & $001600956 \mathrm{GBF}$ & BN10503774 & $1 / 28 / 2014$ \\
\hline IN140028 & $001600956 \mathrm{GBF}$ & BN10509606 & $1 / 28 / 2014$ \\
\hline IN140029 & $001600957 \mathrm{GBF}$ & BN10501248 & $1 / 28 / 2014$ \\
\hline IN140029 & $001600957 \mathrm{GBF}$ & BN10509611 & $2 / 1 / 2014$ \\
\hline IN140031 & $001600959 \mathrm{GBF}$ & BN10505060 & $2 / 1 / 2014$ \\
\hline IN140031 & 001600959GBF & BN10505061 & $1 / 28 / 2014$ \\
\hline IN140033 & $001600961 \mathrm{GBF}$ & BN10509682 & $1 / 31 / 2014$ \\
\hline IN140033 & $001600961 \mathrm{GBF}$ & BN10509601 & $1 / 31 / 2014$ \\
\hline IN140034 & $001600962 \mathrm{GBF}$ & BN10507549 & $2 / 2 / 2014$ \\
\hline IN140034 & $001600962 \mathrm{GBF}$ & BN10509687 & $2 / 1 / 2014$ \\
\hline IN140035 & $001600963 \mathrm{GBF}$ & BN10507550 & $1 / 31 / 2014$ \\
\hline IN140035 & $001600963 \mathrm{GBF}$ & BN10509599 & $2 / 1 / 2014$ \\
\hline IN140038 & $001600966 \mathrm{GBF}$ & BN10507553 & $2 / 2 / 2014$ \\
\hline IN140038 & $001600966 \mathrm{GBF}$ & BN10507557 & $2 / 2 / 2014$ \\
\hline IN140039 & $001600967 \mathrm{GBF}$ & BN10507555 & $2 / 4 / 2014$ \\
\hline IN140039 & $001600967 \mathrm{GBF}$ & BN10507554 & $2 / 4 / 2014$ \\
\hline
\end{tabular}

Under civil and criminal penalties of law for the making or submission of false or fraudulent statements or representations (18 U.S.C. 1001 and 15 U.S.C. 2615), I certify that the information contained in or accompanying this document is true, accurate, and complete.

As to the identified section(s) of this document for which I cannot personally verify truth and accuracy, I certify as the company official having supervisory responsibility for the persons who, acting under my direct instructions, made the verification that this information is true, accurate, and complete.

Should you require further information concerning this certificate of disposal, please contact Mr. R. S. (Bob) Nieman at (575) 234-8141.

Sincerely,

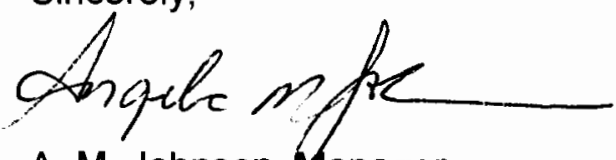

A. M. Johnson, Manager

Transportation Management

RSN/rsn

cc: Shipment portfolio for shipments IN140013, IN140014, IN140016, IN140018, IN140019, IN140022, IN140023, IN140024, IN140026, IN140028, IN140029, IN140031, IN140033, IN140034, IN140035, IN140038 and IN140039. 
Please print or type. (Form designed for use on elite (12-pitch) typewriter.)

Form Approved. OMB No. 2050-0039

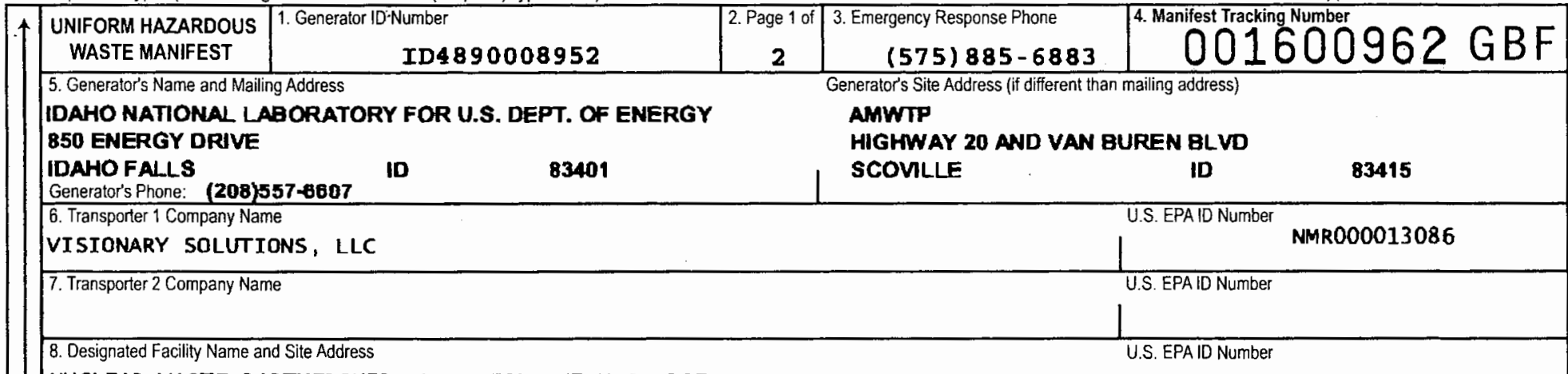

NUCLEAR WASTE PARTNERSHIP, LLC FOR THE U.S. DOE

30 MILES E. OF CARL.SBAD ON JAL HIGHWAY

EDDY COUNTY NM 88221

\begin{tabular}{ll|l|l} 
Facility's Phone: $\quad(575) 234-8457$ & NM4890139088
\end{tabular}

9a. 9 b. U.S. DOT Description fincluding Proper Shipping Name, Hazard Class, ID Number,

$\mathrm{HM}$ and Packing Group (if any))

RQ 1. UN3328, WASTE RADIOACTIVE MATERIAL, TYPE B(U) PACKAGE

FIS5ILE, 7, PU-239, AM-241, PU-240, SOLID, OXIDE, 0.01164

TBG, RADTOACTIVE YELLOW-II, T.I. 0.2, C.S.I. 0.0,

15A/9218/B(U)F-96, TRUPACT \# 134

2. PCB container \# BN10507549, s7udge, PCB out of service

pate $05 / 07 / 2013$, PCB Weight $1137.2 \mathrm{~kg}$

2. UN3328, WASTE RADIOACTIVE MATERTAL, TYPE B(U) PACKAGE

FISSILE, 7, PU-239, AM-241, PU-240, SOLID, OXIDE, 0.008226

FBG, RADIOÁCTIVE YELLOW-II, T.I. O.'2, C.S.I. 0.0,

JSA/9218/B (U)F-96, TRUPACT \# 184

4. PCB Container \# BN10509687, s7udge, PCB out of service

pate $01 / 31 / 2013$, $P C B$ Weight $1050.4 \mathrm{~kg}$

14. Special Handling Instructions and Additional Information

SHIPMENT \# IN140034

TRACTOR

GROSS WEIGHT IN LBS: TP\# $134=17,682$

PREPARED UNDER CONTRACT \# DE-EMOOO 1467 $v-32$

\section{$T P \# 184=17,462$ ERG 165}

TRAILER - 357
TP\# $514=13,657$
ERT PROVIDER - WIPP CMR

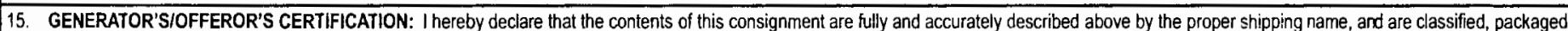
marked and labeled/placarded, and are in all respects in proper condition for transport according to applicable international and national governmental regulations. If export shipment and I am: the Primary Exporter, I certify that the contents of this consignment conform to the terms of the attached EPA Acknowledgment of Consent.

I certify that the waste minimization statement identified in 40 CFR 262.27 (a) (if I am a large quantity generator) or (b) (if $I$ am a small grandity generator) is true.

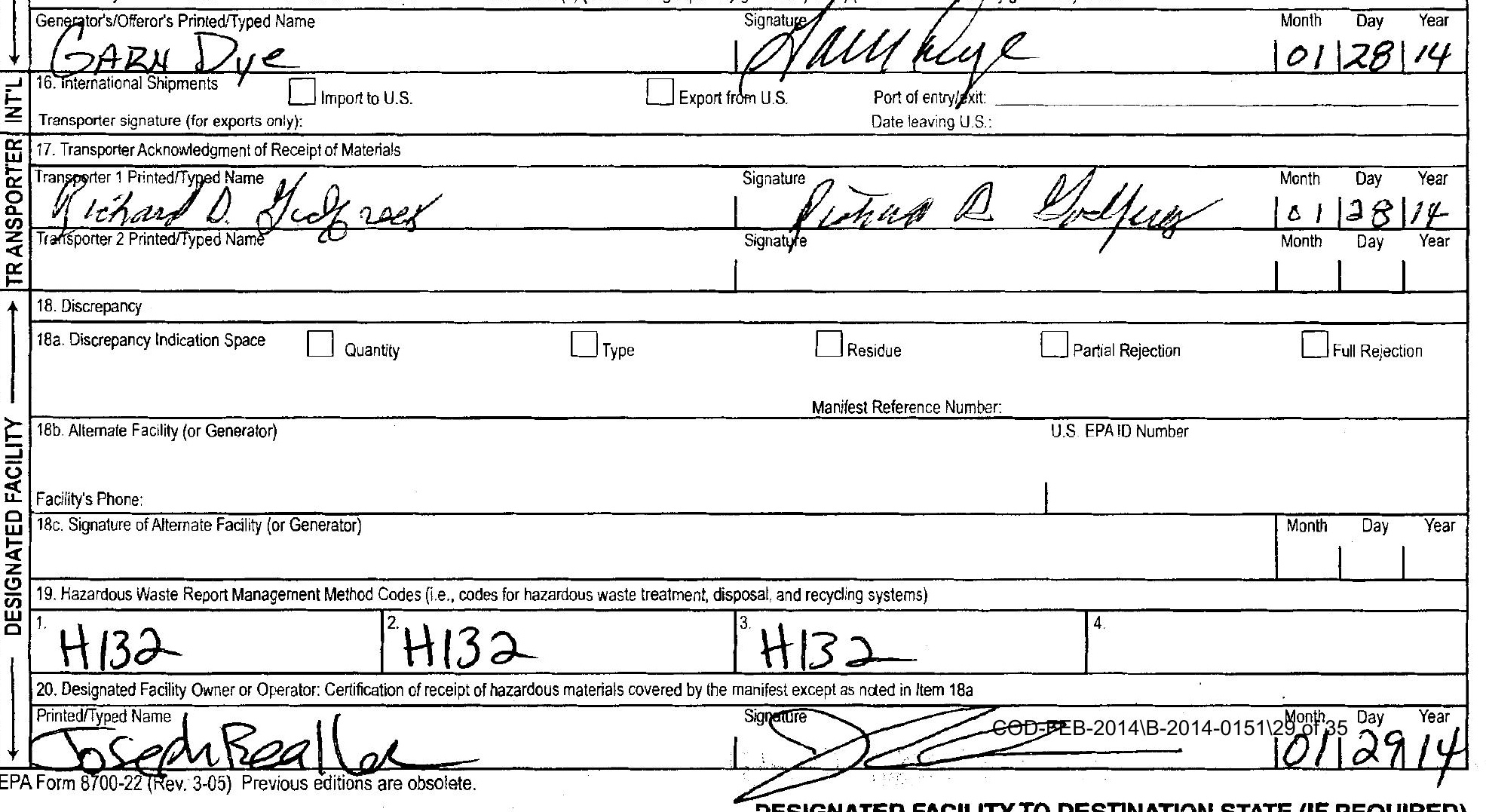


Please print or type. (Form designed for use on elite (12-pitch) typewriter.)

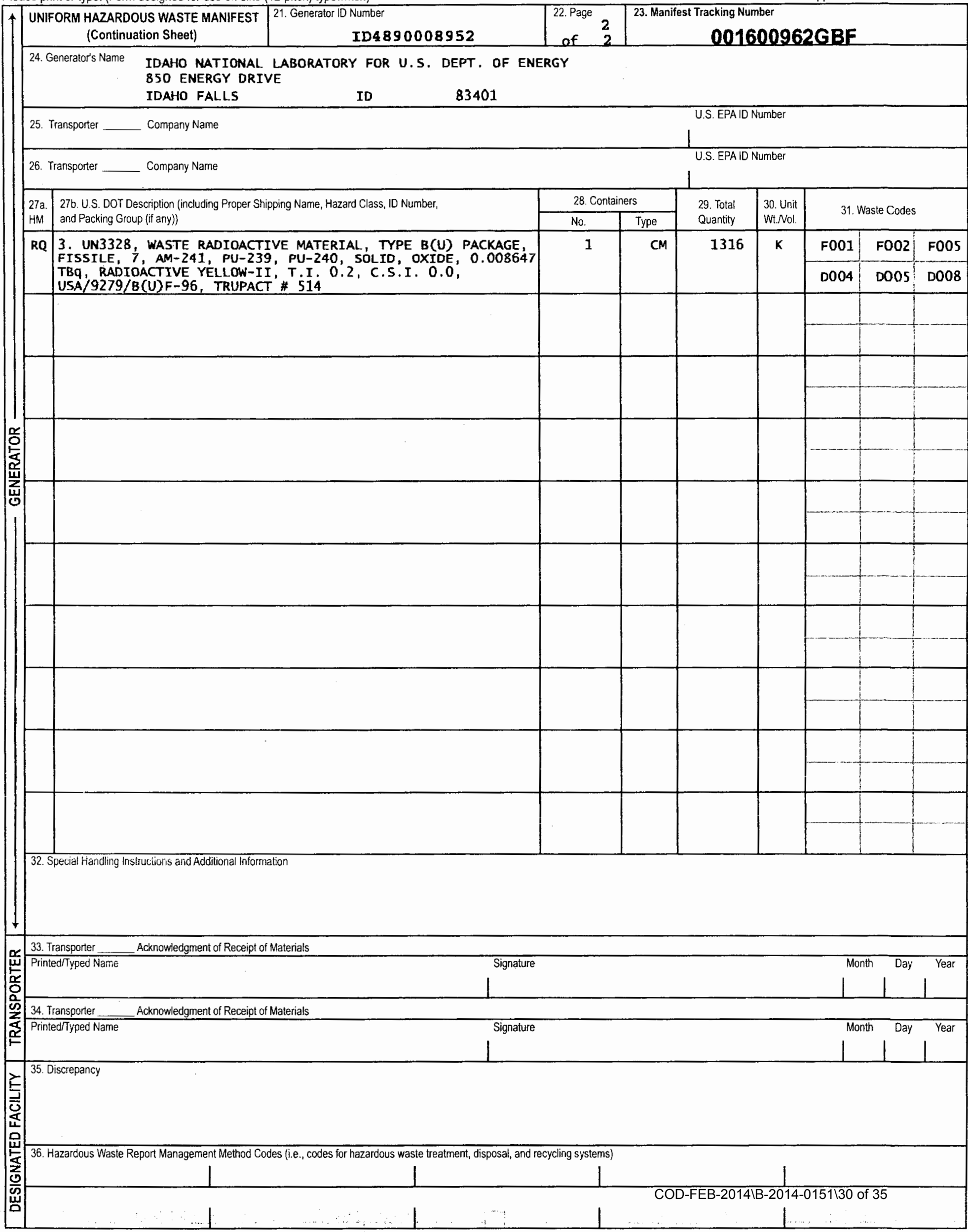




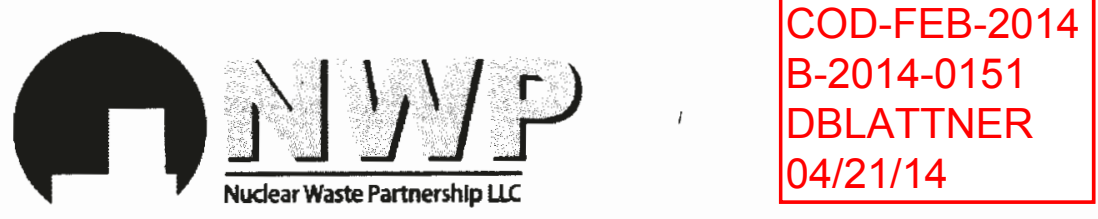

CP:14:02012

UFC:5822.00

A URS-led partnership with B\&W and AREVA

February 12, 2014

Ms. R. Hubler, Transportation Manager

Advanced Mixed Waste Treatment Plant/ITG

Idaho National Laboratory

850 Energy Drive, Suite 100

Idaho Falls, ID 83401

SUBJECT: CERTIFICATE OF DISPOSAL FOR POLYCHLORINATED BIPHENYL BEARING WASTE SHIPMENT NUMBERS IN140013, IN140014, IN140016, IN140018, IN140019, IN140022, IN140023, IN140024, IN140026, IN140028, IN140029, IN140031, IN140033, IN140034, IN140035, IN140038 AND IN140039 EMPLACED AT THE WASTE ISOLATION PILOT PLANT

Dear Ms. Hubler:

In compliance with Title 40 Code of Federal Regulations, Part 761.218 , I certify that the following Polychlorinated Biphenyl (PCB) wastes from your facility have been disposed by emplacement 2,150 feet underground in the Waste Isolation Pilot Plant waste repository.

Disposal Facility:

Waste Isolation Pilot Plant

30 Miles SE of Carlsbad, New Mexico

Eddy County, New Mexico 88220

Environmental Protection Agency (EPA) Identification Number (ID): NM4890139088

Shipping Site's EPA ID: ID4890008952

\begin{tabular}{|c|c|c|c|}
\hline $\begin{array}{c}\text { Shipment } \\
\text { Number }\end{array}$ & $\begin{array}{c}\text { Manifest Tracking } \\
\text { Number }\end{array}$ & $\begin{array}{c}\text { Container } \\
\text { Number }\end{array}$ & $\begin{array}{c}\text { Emplacement } \\
\text { Date }\end{array}$ \\
\hline IN140013 & $001600941 \mathrm{GBF}$ & BN10505055 & $1 / 24 / 2014$ \\
\hline IN140013 & $001600941 \mathrm{GBF}$ & BN10505054 & $1 / 21 / 2014$ \\
\hline IN140014 & $001600942 \mathrm{GBF}$ & BN10490911 & $1 / 25 / 2014$ \\
\hline IN140014 & $001600942 \mathrm{GBF}$ & BN10490912 & $1 / 25 / 2014$ \\
\hline IN140016 & $001600944 \mathrm{GBF}$ & BN10505059 & $1 / 24 / 2014$ \\
\hline IN140016 & $001600944 \mathrm{GBF}$ & BN10503788 & $1 / 24 / 2014$ \\
\hline IN140018 & $001600946 \mathrm{GBF}$ & BN10505058 & $1 / 26 / 2014$ \\
\hline IN140018 & $001600946 \mathrm{GBF}$ & BN10505062 & $1 / 26 / 2014$ \\
\hline IN140019 & $001600947 \mathrm{GBF}$ & BN10503775 & $1 / 24 / 2014$ \\
\hline IN140019 & $001600947 \mathrm{GBF}$ & BN10503760 & $1 / 24 / 2014$ \\
\hline IN140022 & 001600950GBF & BN10505063 & $2 / 2 / 2014$ \\
\hline
\end{tabular}




\begin{tabular}{|c|c|c|c|}
\hline $\begin{array}{l}\text { Shipment } \\
\text { Number }\end{array}$ & $\begin{array}{c}\text { Manifest Tracking } \\
\text { Number }\end{array}$ & $\begin{array}{l}\text { Container } \\
\text { Number }\end{array}$ & $\begin{array}{c}\text { Emplacement } \\
\text { Date }\end{array}$ \\
\hline IN140022 & $001600950 \mathrm{GBF}$ & BN10501246 & $1 / 24 / 2014$ \\
\hline IN140023 & $001600951 \mathrm{GBF}$ & BN10500612 & $1 / 30 / 2014$ \\
\hline IN140023 & $001600951 \mathrm{GBF}$ & BN10503777 & $1 / 26 / 2014$ \\
\hline IN140024 & $001600952 \mathrm{GBF}$ & BN10509616 & $1 / 24 / 2014$ \\
\hline IN140024 & $001600952 \mathrm{GBF}$ & BN10509615 & $2 / 2 / 2014$ \\
\hline IN140026 & $001600954 \mathrm{GBF}$ & BN10509688 & $1 / 26 / 2014$ \\
\hline IN140026 & $001600954 \mathrm{GBF}$ & BN10509618 & $1 / 28 / 2014$ \\
\hline IN140028 & $001600956 \mathrm{GBF}$ & BN10503774 & $1 / 28 / 2014$ \\
\hline IN140028 & $001600956 \mathrm{GBF}$ & BN10509606 & $1 / 28 / 2014$ \\
\hline IN140029 & $001600957 \mathrm{GBF}$ & BN10501248 & $1 / 28 / 2014$ \\
\hline IN140029 & $001600957 \mathrm{GBF}$ & BN10509611 & $2 / 1 / 2014$ \\
\hline IN140031 & $001600959 \mathrm{GBF}$ & BN10505060 & $2 / 1 / 2014$ \\
\hline IN140031 & 001600959GBF & BN10505061 & $1 / 28 / 2014$ \\
\hline IN140033 & $001600961 \mathrm{GBF}$ & BN10509682 & $1 / 31 / 2014$ \\
\hline IN140033 & $001600961 \mathrm{GBF}$ & BN10509601 & $1 / 31 / 2014$ \\
\hline IN140034 & $001600962 \mathrm{GBF}$ & BN10507549 & $2 / 2 / 2014$ \\
\hline IN140034 & $001600962 \mathrm{GBF}$ & BN10509687 & $2 / 1 / 2014$ \\
\hline IN140035 & $001600963 \mathrm{GBF}$ & BN10507550 & $1 / 31 / 2014$ \\
\hline IN140035 & $001600963 \mathrm{GBF}$ & BN10509599 & $2 / 1 / 2014$ \\
\hline IN140038 & $001600966 \mathrm{GBF}$ & BN10507553 & $2 / 2 / 2014$ \\
\hline IN140038 & $001600966 \mathrm{GBF}$ & BN10507557 & $2 / 2 / 2014$ \\
\hline IN140039 & $001600967 \mathrm{GBF}$ & BN10507555 & $2 / 4 / 2014$ \\
\hline IN140039 & $001600967 \mathrm{GBF}$ & BN10507554 & $2 / 4 / 2014$ \\
\hline
\end{tabular}

Under civil and criminal penalties of law for the making or submission of false or fraudulent statements or representations (18 U.S.C. 1001 and 15 U.S.C. 2615), I certify that the information contained in or accompanying this document is true, accurate, and complete.

As to the identified section(s) of this document for which I cannot personally verify truth and accuracy, I certify as the company official having supervisory responsibility for the persons who, acting under my direct instructions, made the verification that this information is true, accurate, and complete.

Should you require further information concerning this certificate of disposal, please contact Mr. R. S. (Bob) Nieman at (575) 234-8141.

Sincerely,

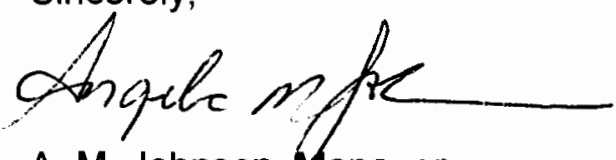

A. M. Johnson, Manager

Transportation Management

RSN/rsn

cc: Shipment portfolio for shipments IN140013, IN140014, IN140016, IN140018, IN140019, IN140022, IN140023, IN140024, IN140026, IN140028, IN140029, IN140031, IN140033, IN140034, IN140035, IN140038 and IN140039. 
Please print or type. (Form designed for use on elite (12-pitch) typewriter.)

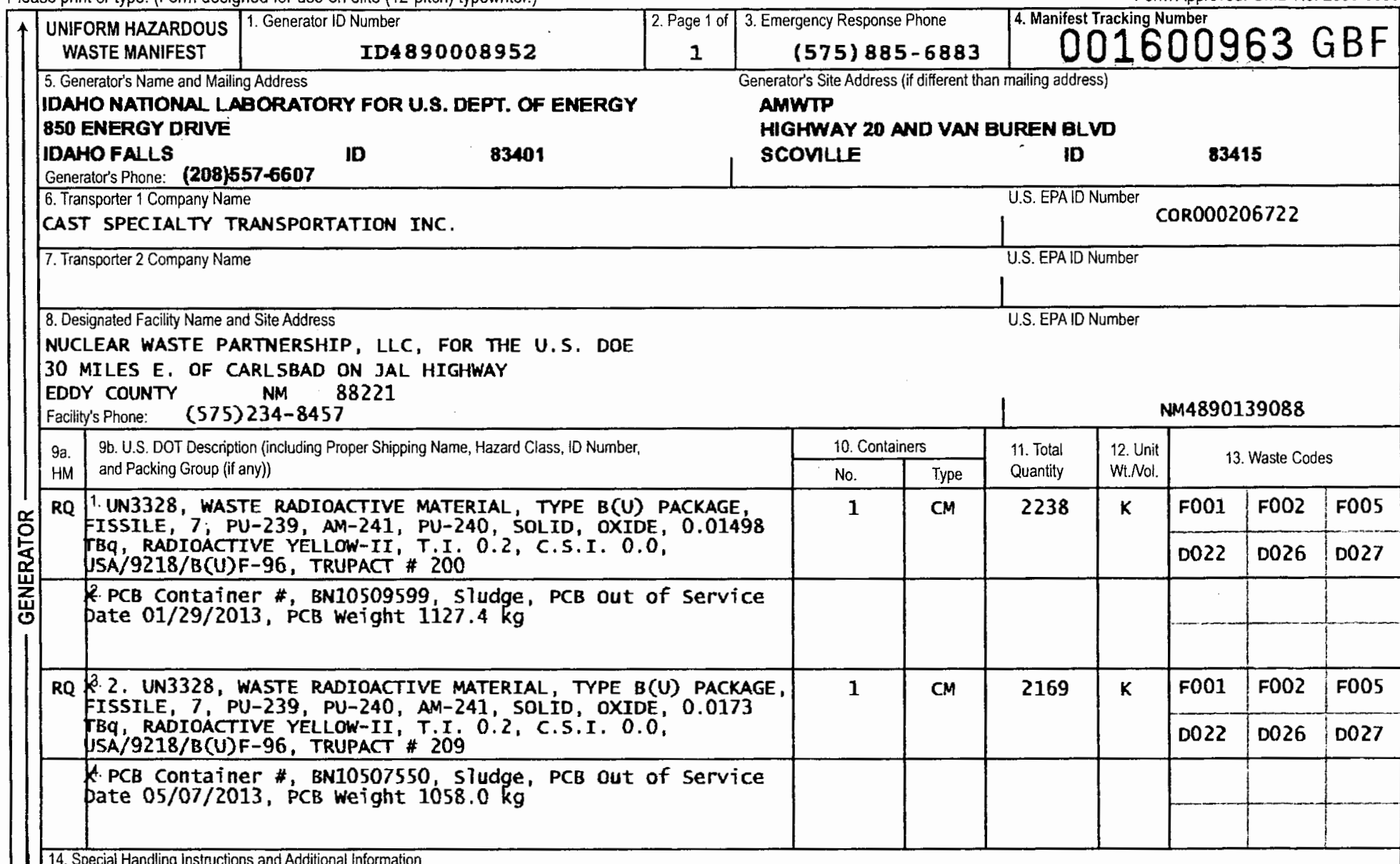

14. Special Handling Instructions and Additional Information

SHIPMENT \# IN140035 TRACTOR - C - 37 TRAILER - 340

GROSS WEIGHT IN LBS: TP\# $200=17,598$ TP\# $209=17,548$

PREPARED UNDER CONTRACT \# DE-EMO001467 TER - 165 ERI PROVIDER - WIPP CMR

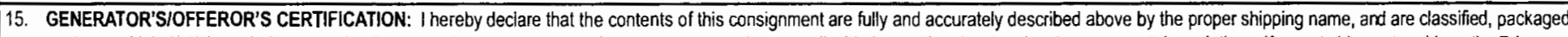
marked and labeled/placarded, and are in all respects in proper condition for transport according to applicable international and national governmental regulations. If export shipment and I am the Primary Exporter, I certify that the contents of this consignment conform to the terms of the attached EPA Acknowledgment of Consent.

I certify that the waste minimization statement identified in 40 CFR 262.27(a) (if I am a large quantity generator) or $(6)$ (if I am a smaly gantity generator) is true.

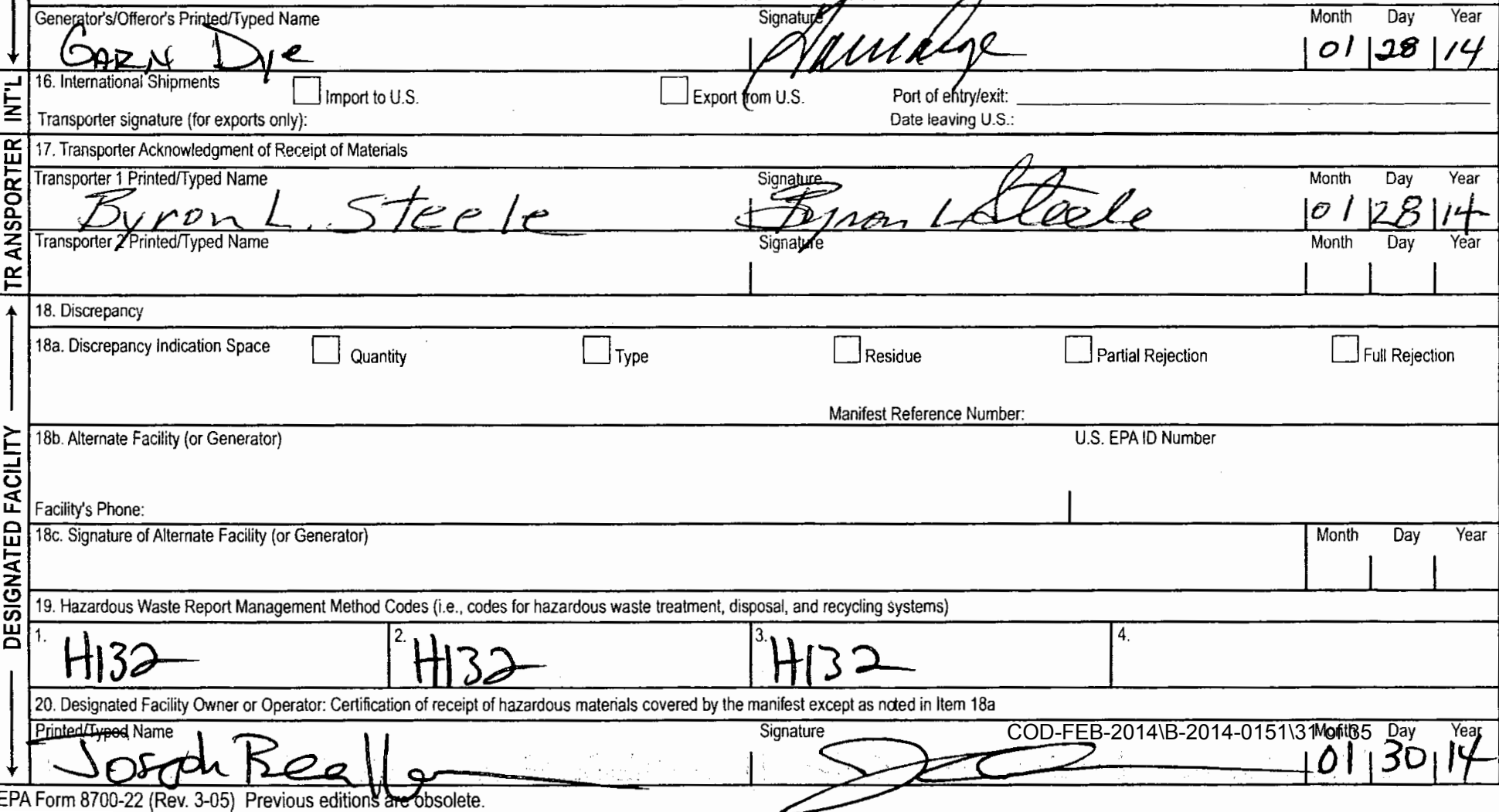




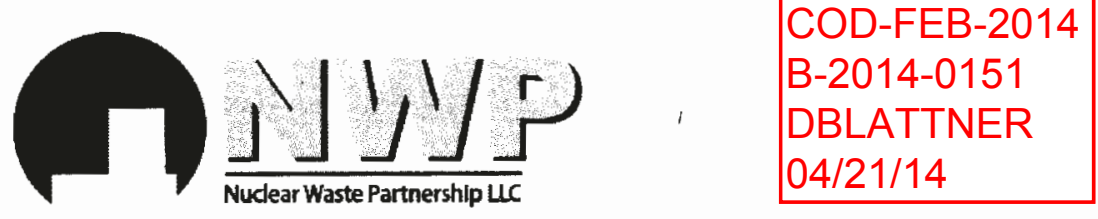

CP:14:02012

UFC:5822.00

A URS-led partnership with B\&W and AREVA

February 12, 2014

Ms. R. Hubler, Transportation Manager

Advanced Mixed Waste Treatment Plant/ITG

Idaho National Laboratory

850 Energy Drive, Suite 100

Idaho Falls, ID 83401

SUBJECT: CERTIFICATE OF DISPOSAL FOR POLYCHLORINATED BIPHENYL BEARING WASTE SHIPMENT NUMBERS IN140013, IN140014, IN140016, IN140018, IN140019, IN140022, IN140023, IN140024, IN140026, IN140028, IN140029, IN140031, IN140033, IN140034, IN140035, IN140038 AND IN140039 EMPLACED AT THE WASTE ISOLATION PILOT PLANT

Dear Ms. Hubler:

In compliance with Title 40 Code of Federal Regulations, Part 761.218 , I certify that the following Polychlorinated Biphenyl (PCB) wastes from your facility have been disposed by emplacement 2,150 feet underground in the Waste Isolation Pilot Plant waste repository.

Disposal Facility:

Waste Isolation Pilot Plant

30 Miles SE of Carlsbad, New Mexico

Eddy County, New Mexico 88220

Environmental Protection Agency (EPA) Identification Number (ID): NM4890139088

Shipping Site's EPA ID: ID4890008952

\begin{tabular}{|c|c|c|c|}
\hline $\begin{array}{c}\text { Shipment } \\
\text { Number }\end{array}$ & $\begin{array}{c}\text { Manifest Tracking } \\
\text { Number }\end{array}$ & $\begin{array}{c}\text { Container } \\
\text { Number }\end{array}$ & $\begin{array}{c}\text { Emplacement } \\
\text { Date }\end{array}$ \\
\hline IN140013 & $001600941 \mathrm{GBF}$ & BN10505055 & $1 / 24 / 2014$ \\
\hline IN140013 & $001600941 \mathrm{GBF}$ & BN10505054 & $1 / 21 / 2014$ \\
\hline IN140014 & $001600942 \mathrm{GBF}$ & BN10490911 & $1 / 25 / 2014$ \\
\hline IN140014 & $001600942 \mathrm{GBF}$ & BN10490912 & $1 / 25 / 2014$ \\
\hline IN140016 & $001600944 \mathrm{GBF}$ & BN10505059 & $1 / 24 / 2014$ \\
\hline IN140016 & $001600944 \mathrm{GBF}$ & BN10503788 & $1 / 24 / 2014$ \\
\hline IN140018 & $001600946 \mathrm{GBF}$ & BN10505058 & $1 / 26 / 2014$ \\
\hline IN140018 & $001600946 \mathrm{GBF}$ & BN10505062 & $1 / 26 / 2014$ \\
\hline IN140019 & $001600947 \mathrm{GBF}$ & BN10503775 & $1 / 24 / 2014$ \\
\hline IN140019 & $001600947 \mathrm{GBF}$ & BN10503760 & $1 / 24 / 2014$ \\
\hline IN140022 & 001600950GBF & BN10505063 & $2 / 2 / 2014$ \\
\hline
\end{tabular}




\begin{tabular}{|c|c|c|c|}
\hline $\begin{array}{l}\text { Shipment } \\
\text { Number }\end{array}$ & $\begin{array}{c}\text { Manifest Tracking } \\
\text { Number }\end{array}$ & $\begin{array}{l}\text { Container } \\
\text { Number }\end{array}$ & $\begin{array}{c}\text { Emplacement } \\
\text { Date }\end{array}$ \\
\hline IN140022 & $001600950 \mathrm{GBF}$ & BN10501246 & $1 / 24 / 2014$ \\
\hline IN140023 & $001600951 \mathrm{GBF}$ & BN10500612 & $1 / 30 / 2014$ \\
\hline IN140023 & $001600951 \mathrm{GBF}$ & BN10503777 & $1 / 26 / 2014$ \\
\hline IN140024 & $001600952 \mathrm{GBF}$ & BN10509616 & $1 / 24 / 2014$ \\
\hline IN140024 & $001600952 \mathrm{GBF}$ & BN10509615 & $2 / 2 / 2014$ \\
\hline IN140026 & $001600954 \mathrm{GBF}$ & BN10509688 & $1 / 26 / 2014$ \\
\hline IN140026 & $001600954 \mathrm{GBF}$ & BN10509618 & $1 / 28 / 2014$ \\
\hline IN140028 & $001600956 \mathrm{GBF}$ & BN10503774 & $1 / 28 / 2014$ \\
\hline IN140028 & $001600956 \mathrm{GBF}$ & BN10509606 & $1 / 28 / 2014$ \\
\hline IN140029 & $001600957 \mathrm{GBF}$ & BN10501248 & $1 / 28 / 2014$ \\
\hline IN140029 & $001600957 \mathrm{GBF}$ & BN10509611 & $2 / 1 / 2014$ \\
\hline IN140031 & $001600959 \mathrm{GBF}$ & BN10505060 & $2 / 1 / 2014$ \\
\hline IN140031 & 001600959GBF & BN10505061 & $1 / 28 / 2014$ \\
\hline IN140033 & $001600961 \mathrm{GBF}$ & BN10509682 & $1 / 31 / 2014$ \\
\hline IN140033 & $001600961 \mathrm{GBF}$ & BN10509601 & $1 / 31 / 2014$ \\
\hline IN140034 & $001600962 \mathrm{GBF}$ & BN10507549 & $2 / 2 / 2014$ \\
\hline IN140034 & $001600962 \mathrm{GBF}$ & BN10509687 & $2 / 1 / 2014$ \\
\hline IN140035 & $001600963 \mathrm{GBF}$ & BN10507550 & $1 / 31 / 2014$ \\
\hline IN140035 & $001600963 \mathrm{GBF}$ & BN10509599 & $2 / 1 / 2014$ \\
\hline IN140038 & $001600966 \mathrm{GBF}$ & BN10507553 & $2 / 2 / 2014$ \\
\hline IN140038 & $001600966 \mathrm{GBF}$ & BN10507557 & $2 / 2 / 2014$ \\
\hline IN140039 & $001600967 \mathrm{GBF}$ & BN10507555 & $2 / 4 / 2014$ \\
\hline IN140039 & $001600967 \mathrm{GBF}$ & BN10507554 & $2 / 4 / 2014$ \\
\hline
\end{tabular}

Under civil and criminal penalties of law for the making or submission of false or fraudulent statements or representations (18 U.S.C. 1001 and 15 U.S.C. 2615), I certify that the information contained in or accompanying this document is true, accurate, and complete.

As to the identified section(s) of this document for which I cannot personally verify truth and accuracy, I certify as the company official having supervisory responsibility for the persons who, acting under my direct instructions, made the verification that this information is true, accurate, and complete.

Should you require further information concerning this certificate of disposal, please contact Mr. R. S. (Bob) Nieman at (575) 234-8141.

Sincerely,

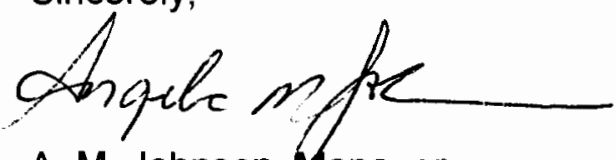

A. M. Johnson, Manager

Transportation Management

RSN/rsn

cc: Shipment portfolio for shipments IN140013, IN140014, IN140016, IN140018, IN140019, IN140022, IN140023, IN140024, IN140026, IN140028, IN140029, IN140031, IN140033, IN140034, IN140035, IN140038 and IN140039. 
Please print or type. (Form designed for use on elite (12-pitch) typewriter.)

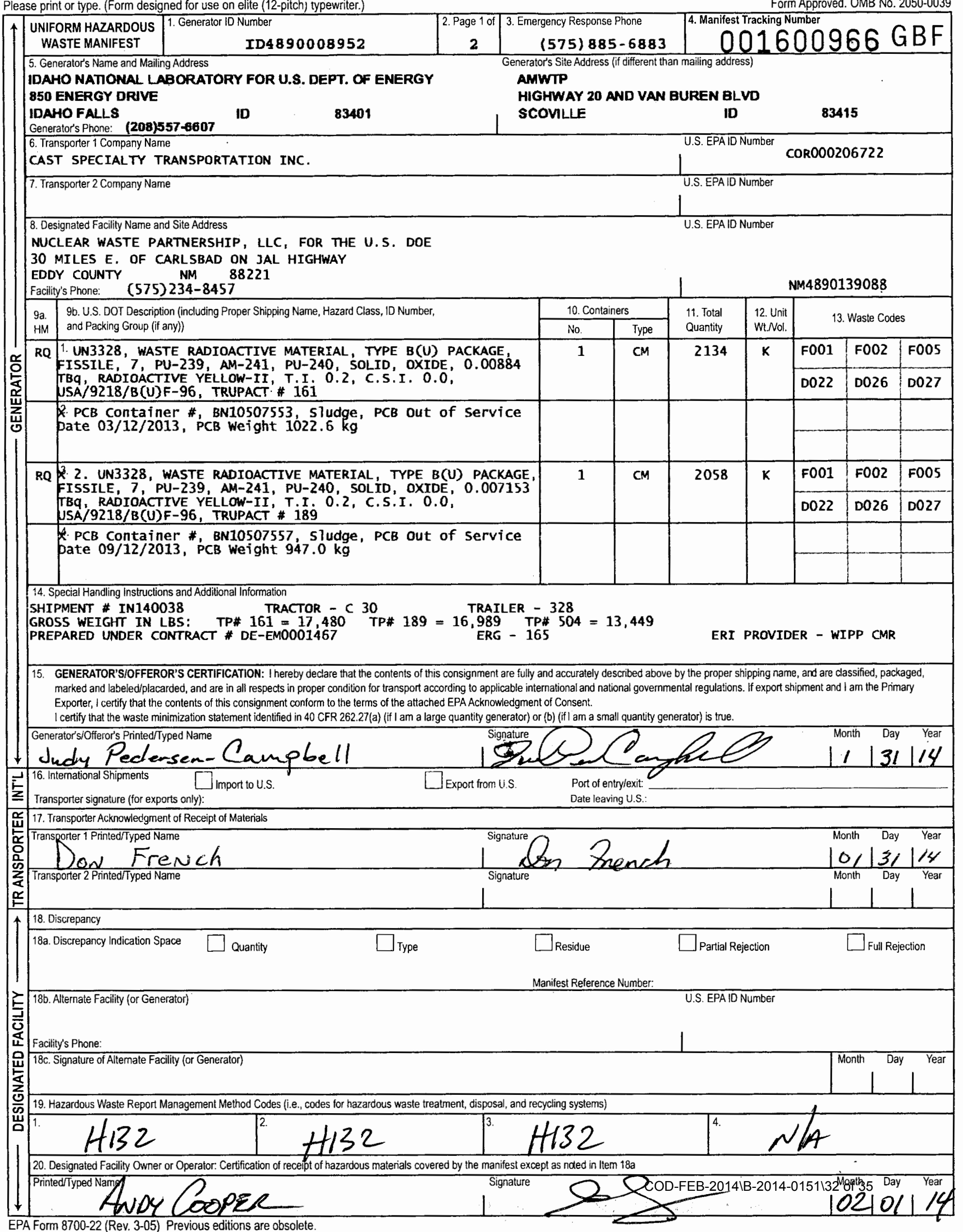


Please print or type. (Form designed for use on elite (12-pitch) typewriter.)

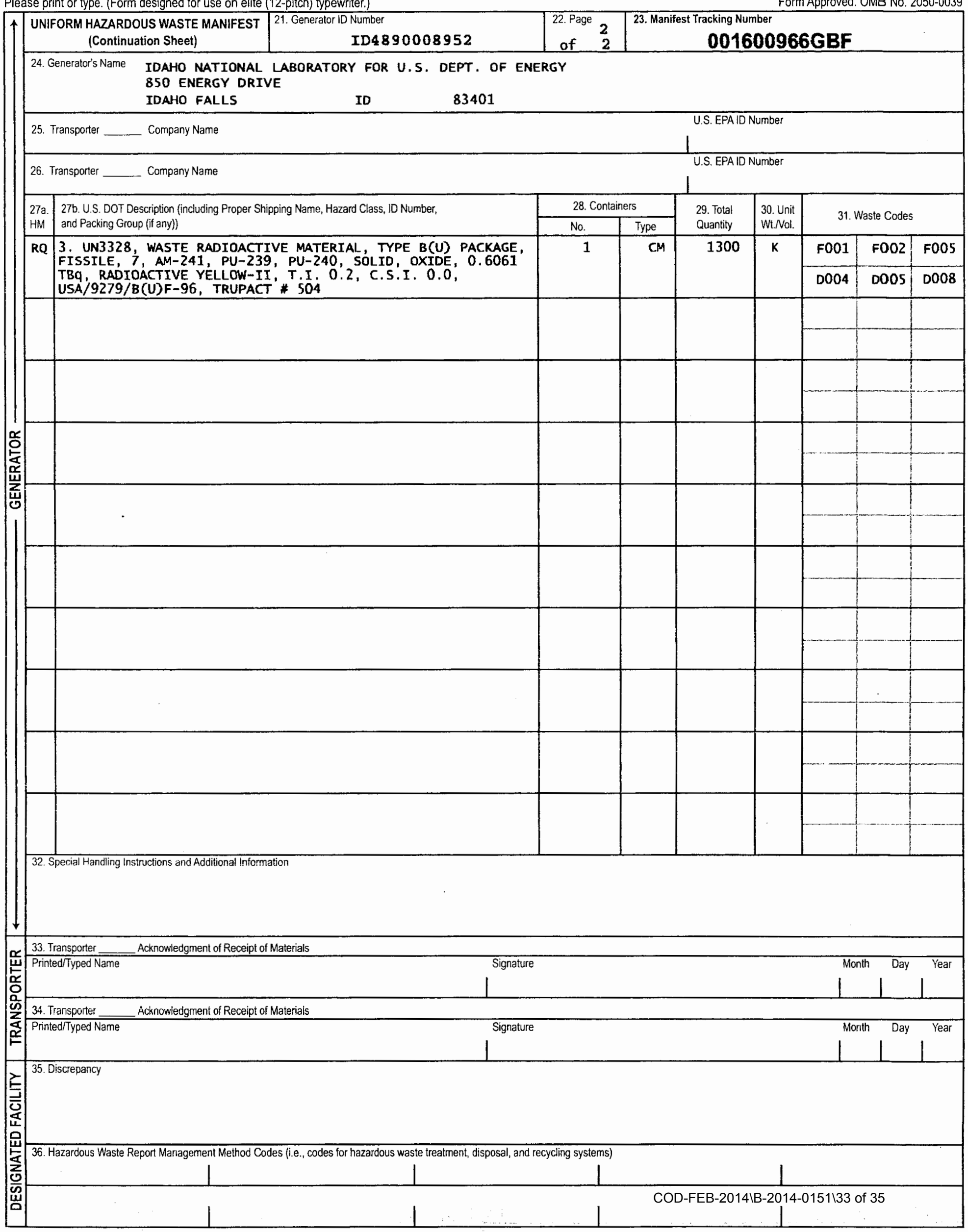




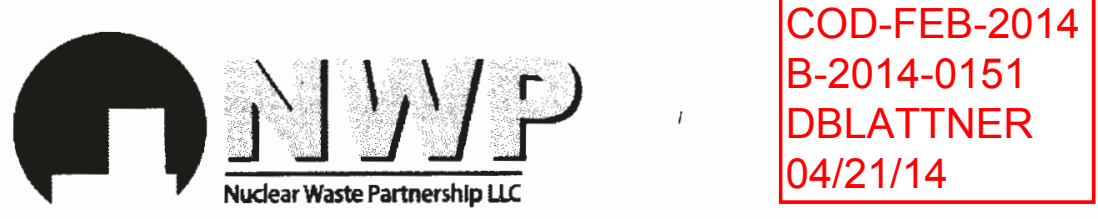

CP:14:02012

UFC:5822.00

A URS-led partnership with B\&W and AREVA

February 12, 2014

Ms. R. Hubler, Transportation Manager

Advanced Mixed Waste Treatment Plant/ITG

Idaho National Laboratory

850 Energy Drive, Suite 100

Idaho Falls, ID 83401

SUBJECT: CERTIFICATE OF DISPOSAL FOR POLYCHLORINATED BIPHENYL BEARING WASTE SHIPMENT NUMBERS IN140013, IN140014, IN140016, IN140018, IN140019, IN140022, IN140023, IN140024, IN140026, IN140028, IN140029, IN140031, IN140033, IN140034, IN140035, IN140038 AND IN140039 EMPLACED AT THE WASTE ISOLATION PILOT PLANT

Dear Ms. Hubler:

In compliance with Title 40 Code of Federal Regulations, Part 761.218 , I certify that the following Polychlorinated Biphenyl (PCB) wastes from your facility have been disposed by emplacement 2,150 feet underground in the Waste Isolation Pilot Plant waste repository.

Disposal Facility:

Waste Isolation Pilot Plant

30 Miles SE of Carlsbad, New Mexico

Eddy County, New Mexico 88220

Environmental Protection Agency (EPA) Identification Number (ID): NM4890139088

Shipping Site's EPA ID: ID4890008952

\begin{tabular}{|c|c|c|c|}
\hline $\begin{array}{c}\text { Shipment } \\
\text { Number }\end{array}$ & $\begin{array}{c}\text { Manifest Tracking } \\
\text { Number }\end{array}$ & $\begin{array}{c}\text { Container } \\
\text { Number }\end{array}$ & $\begin{array}{c}\text { Emplacement } \\
\text { Date }\end{array}$ \\
\hline IN140013 & $001600941 \mathrm{GBF}$ & BN10505055 & $1 / 24 / 2014$ \\
\hline IN140013 & $001600941 \mathrm{GBF}$ & BN10505054 & $1 / 21 / 2014$ \\
\hline IN140014 & $001600942 \mathrm{GBF}$ & BN10490911 & $1 / 25 / 2014$ \\
\hline IN140014 & $001600942 \mathrm{GBF}$ & BN10490912 & $1 / 25 / 2014$ \\
\hline IN140016 & $001600944 \mathrm{GBF}$ & BN10505059 & $1 / 24 / 2014$ \\
\hline IN140016 & $001600944 \mathrm{GBF}$ & BN10503788 & $1 / 24 / 2014$ \\
\hline IN140018 & $001600946 \mathrm{GBF}$ & BN10505058 & $1 / 26 / 2014$ \\
\hline IN140018 & $001600946 \mathrm{GBF}$ & BN10505062 & $1 / 26 / 2014$ \\
\hline IN140019 & $001600947 \mathrm{GBF}$ & BN10503775 & $1 / 24 / 2014$ \\
\hline IN140019 & $001600947 \mathrm{GBF}$ & BN10503760 & $1 / 24 / 2014$ \\
\hline IN140022 & 001600950GBF & BN10505063 & $2 / 2 / 2014$ \\
\hline
\end{tabular}




\begin{tabular}{|c|c|c|c|}
\hline $\begin{array}{l}\text { Shipment } \\
\text { Number }\end{array}$ & $\begin{array}{c}\text { Manifest Tracking } \\
\text { Number }\end{array}$ & $\begin{array}{l}\text { Container } \\
\text { Number }\end{array}$ & $\begin{array}{c}\text { Emplacement } \\
\text { Date }\end{array}$ \\
\hline IN140022 & $001600950 \mathrm{GBF}$ & BN10501246 & $1 / 24 / 2014$ \\
\hline IN140023 & $001600951 \mathrm{GBF}$ & BN10500612 & $1 / 30 / 2014$ \\
\hline IN140023 & $001600951 \mathrm{GBF}$ & BN10503777 & $1 / 26 / 2014$ \\
\hline IN140024 & $001600952 \mathrm{GBF}$ & BN10509616 & $1 / 24 / 2014$ \\
\hline IN140024 & $001600952 \mathrm{GBF}$ & BN10509615 & $2 / 2 / 2014$ \\
\hline IN140026 & $001600954 \mathrm{GBF}$ & BN10509688 & $1 / 26 / 2014$ \\
\hline IN140026 & $001600954 \mathrm{GBF}$ & BN10509618 & $1 / 28 / 2014$ \\
\hline IN140028 & $001600956 \mathrm{GBF}$ & BN10503774 & $1 / 28 / 2014$ \\
\hline IN140028 & $001600956 \mathrm{GBF}$ & BN10509606 & $1 / 28 / 2014$ \\
\hline IN140029 & $001600957 \mathrm{GBF}$ & BN10501248 & $1 / 28 / 2014$ \\
\hline IN140029 & $001600957 \mathrm{GBF}$ & BN10509611 & $2 / 1 / 2014$ \\
\hline IN140031 & $001600959 \mathrm{GBF}$ & BN10505060 & $2 / 1 / 2014$ \\
\hline IN140031 & 001600959GBF & BN10505061 & $1 / 28 / 2014$ \\
\hline IN140033 & $001600961 \mathrm{GBF}$ & BN10509682 & $1 / 31 / 2014$ \\
\hline IN140033 & $001600961 \mathrm{GBF}$ & BN10509601 & $1 / 31 / 2014$ \\
\hline IN140034 & $001600962 \mathrm{GBF}$ & BN10507549 & $2 / 2 / 2014$ \\
\hline IN140034 & $001600962 \mathrm{GBF}$ & BN10509687 & $2 / 1 / 2014$ \\
\hline IN140035 & $001600963 \mathrm{GBF}$ & BN10507550 & $1 / 31 / 2014$ \\
\hline IN140035 & $001600963 \mathrm{GBF}$ & BN10509599 & $2 / 1 / 2014$ \\
\hline IN140038 & $001600966 \mathrm{GBF}$ & BN10507553 & $2 / 2 / 2014$ \\
\hline IN140038 & $001600966 \mathrm{GBF}$ & BN10507557 & $2 / 2 / 2014$ \\
\hline IN140039 & $001600967 \mathrm{GBF}$ & BN10507555 & $2 / 4 / 2014$ \\
\hline IN140039 & $001600967 \mathrm{GBF}$ & BN10507554 & $2 / 4 / 2014$ \\
\hline
\end{tabular}

Under civil and criminal penalties of law for the making or submission of false or fraudulent statements or representations (18 U.S.C. 1001 and 15 U.S.C. 2615), I certify that the information contained in or accompanying this document is true, accurate, and complete.

As to the identified section(s) of this document for which I cannot personally verify truth and accuracy, I certify as the company official having supervisory responsibility for the persons who, acting under my direct instructions, made the verification that this information is true, accurate, and complete.

Should you require further information concerning this certificate of disposal, please contact Mr. R. S. (Bob) Nieman at (575) 234-8141.

Sincerely,

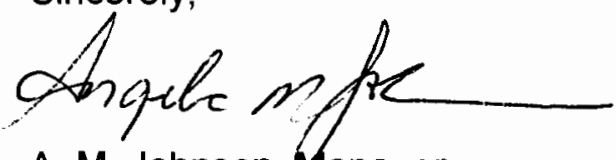

A. M. Johnson, Manager

Transportation Management

RSN/rsn

cc: Shipment portfolio for shipments IN140013, IN140014, IN140016, IN140018, IN140019, IN140022, IN140023, IN140024, IN140026, IN140028, IN140029, IN140031, IN140033, IN140034, IN140035, IN140038 and IN140039. 
Please print or type. (Form designed for use on elite (12-pitch) typewriter.)

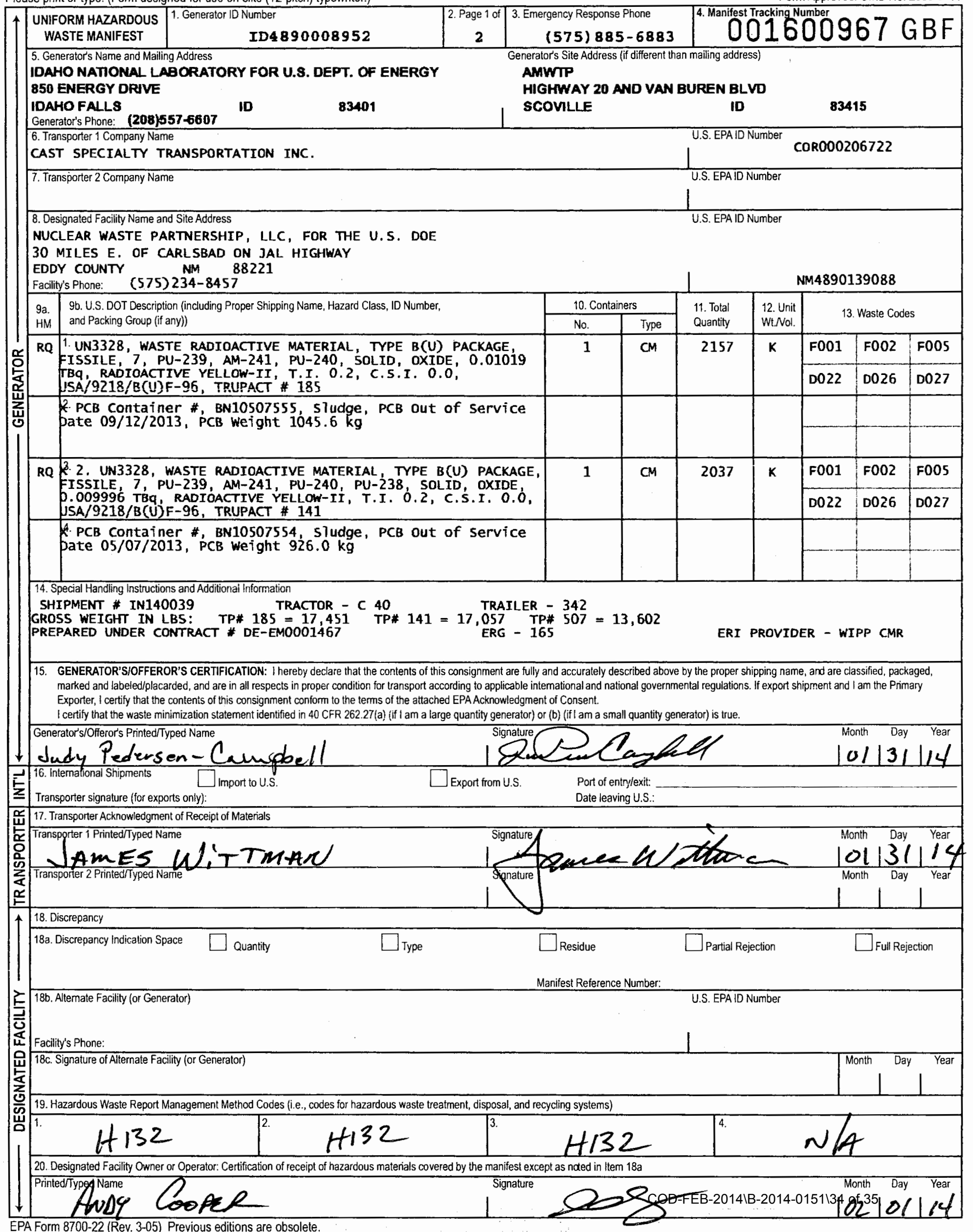


Please print or type. (Form designed for use on elite (12-pitch) typewriter.)

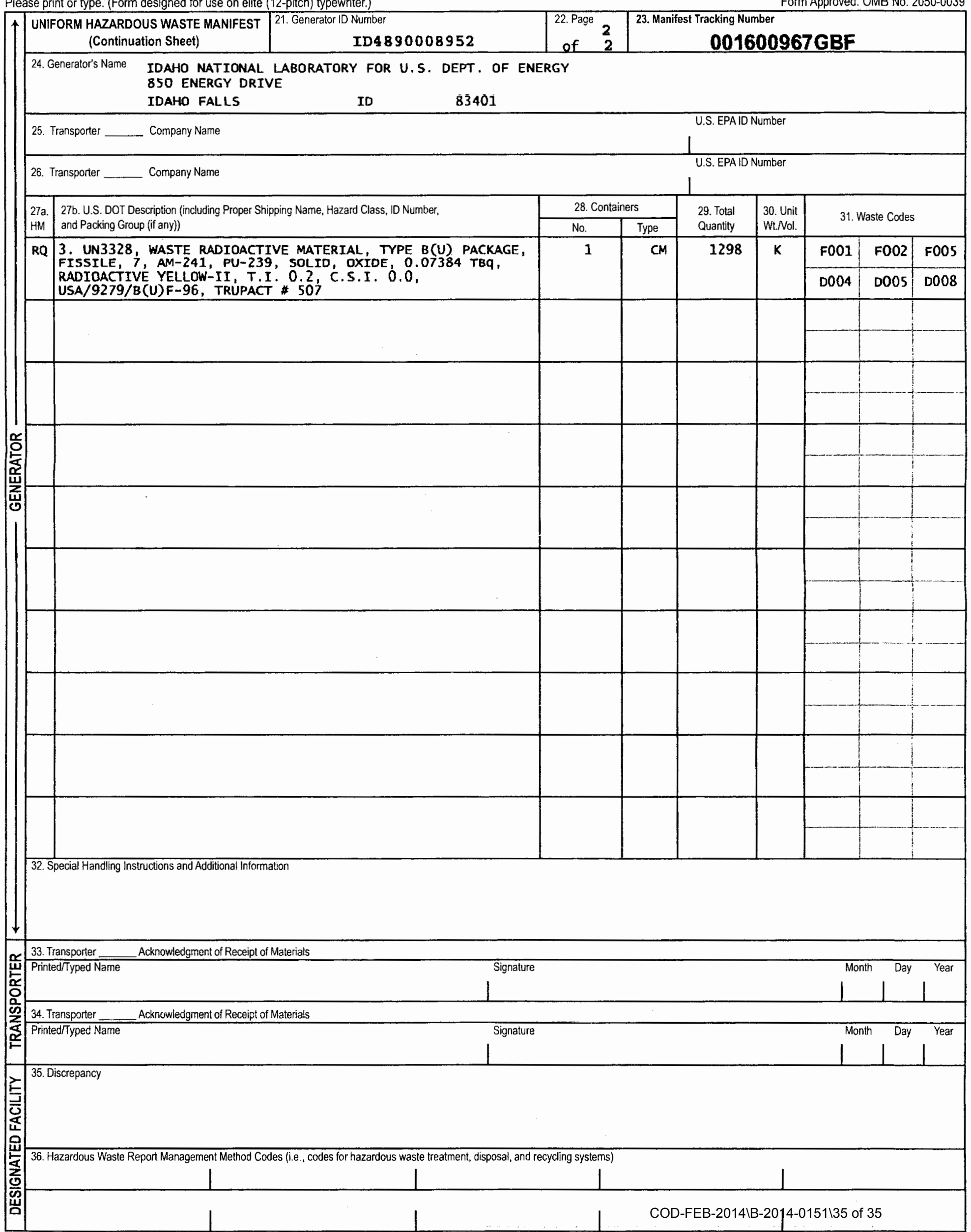




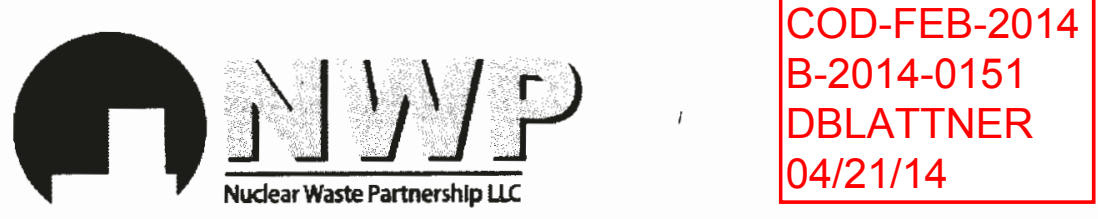

CP:14:02012

UFC:5822.00

A URS-led partnership with B\&W and AREVA

February 12, 2014

Ms. R. Hubler, Transportation Manager

Advanced Mixed Waste Treatment Plant/ITG

Idaho National Laboratory

850 Energy Drive, Suite 100

Idaho Falls, ID 83401

SUBJECT: CERTIFICATE OF DISPOSAL FOR POLYCHLORINATED BIPHENYL BEARING WASTE SHIPMENT NUMBERS IN140013, IN140014, IN140016, IN140018, IN140019, IN140022, IN140023, IN140024, IN140026, IN140028, IN140029, IN140031, IN140033, IN140034, IN140035, IN140038 AND IN140039 EMPLACED AT THE WASTE ISOLATION PILOT PLANT

Dear Ms. Hubler:

In compliance with Title 40 Code of Federal Regulations, Part 761.218 , I certify that the following Polychlorinated Biphenyl (PCB) wastes from your facility have been disposed by emplacement 2,150 feet underground in the Waste Isolation Pilot Plant waste repository.

Disposal Facility:

Waste Isolation Pilot Plant

30 Miles SE of Carlsbad, New Mexico

Eddy County, New Mexico 88220

Environmental Protection Agency (EPA) Identification Number (ID): NM4890139088

Shipping Site's EPA ID: ID4890008952

\begin{tabular}{|c|c|c|c|}
\hline $\begin{array}{c}\text { Shipment } \\
\text { Number }\end{array}$ & $\begin{array}{c}\text { Manifest Tracking } \\
\text { Number }\end{array}$ & $\begin{array}{c}\text { Container } \\
\text { Number }\end{array}$ & $\begin{array}{c}\text { Emplacement } \\
\text { Date }\end{array}$ \\
\hline IN140013 & $001600941 \mathrm{GBF}$ & BN10505055 & $1 / 24 / 2014$ \\
\hline IN140013 & $001600941 \mathrm{GBF}$ & BN10505054 & $1 / 21 / 2014$ \\
\hline IN140014 & $001600942 \mathrm{GBF}$ & BN10490911 & $1 / 25 / 2014$ \\
\hline IN140014 & $001600942 \mathrm{GBF}$ & BN10490912 & $1 / 25 / 2014$ \\
\hline IN140016 & $001600944 \mathrm{GBF}$ & BN10505059 & $1 / 24 / 2014$ \\
\hline IN140016 & $001600944 \mathrm{GBF}$ & BN10503788 & $1 / 24 / 2014$ \\
\hline IN140018 & $001600946 \mathrm{GBF}$ & BN10505058 & $1 / 26 / 2014$ \\
\hline IN140018 & $001600946 \mathrm{GBF}$ & BN10505062 & $1 / 26 / 2014$ \\
\hline IN140019 & $001600947 \mathrm{GBF}$ & BN10503775 & $1 / 24 / 2014$ \\
\hline IN140019 & $001600947 \mathrm{GBF}$ & BN10503760 & $1 / 24 / 2014$ \\
\hline IN140022 & 001600950GBF & BN10505063 & $2 / 2 / 2014$ \\
\hline
\end{tabular}




\begin{tabular}{|c|c|c|c|}
\hline $\begin{array}{l}\text { Shipment } \\
\text { Number }\end{array}$ & $\begin{array}{c}\text { Manifest Tracking } \\
\text { Number }\end{array}$ & $\begin{array}{l}\text { Container } \\
\text { Number }\end{array}$ & $\begin{array}{c}\text { Emplacement } \\
\text { Date }\end{array}$ \\
\hline IN140022 & $001600950 \mathrm{GBF}$ & BN10501246 & $1 / 24 / 2014$ \\
\hline IN140023 & $001600951 \mathrm{GBF}$ & BN10500612 & $1 / 30 / 2014$ \\
\hline IN140023 & $001600951 \mathrm{GBF}$ & BN10503777 & $1 / 26 / 2014$ \\
\hline IN140024 & $001600952 \mathrm{GBF}$ & BN10509616 & $1 / 24 / 2014$ \\
\hline IN140024 & $001600952 \mathrm{GBF}$ & BN10509615 & $2 / 2 / 2014$ \\
\hline IN140026 & $001600954 \mathrm{GBF}$ & BN10509688 & $1 / 26 / 2014$ \\
\hline IN140026 & $001600954 \mathrm{GBF}$ & BN10509618 & $1 / 28 / 2014$ \\
\hline IN140028 & $001600956 \mathrm{GBF}$ & BN10503774 & $1 / 28 / 2014$ \\
\hline IN140028 & $001600956 \mathrm{GBF}$ & BN10509606 & $1 / 28 / 2014$ \\
\hline IN140029 & $001600957 \mathrm{GBF}$ & BN10501248 & $1 / 28 / 2014$ \\
\hline IN140029 & $001600957 \mathrm{GBF}$ & BN10509611 & $2 / 1 / 2014$ \\
\hline IN140031 & $001600959 \mathrm{GBF}$ & BN10505060 & $2 / 1 / 2014$ \\
\hline IN140031 & 001600959GBF & BN10505061 & $1 / 28 / 2014$ \\
\hline IN140033 & $001600961 \mathrm{GBF}$ & BN10509682 & $1 / 31 / 2014$ \\
\hline IN140033 & $001600961 \mathrm{GBF}$ & BN10509601 & $1 / 31 / 2014$ \\
\hline IN140034 & $001600962 \mathrm{GBF}$ & BN10507549 & $2 / 2 / 2014$ \\
\hline IN140034 & $001600962 \mathrm{GBF}$ & BN10509687 & $2 / 1 / 2014$ \\
\hline IN140035 & $001600963 \mathrm{GBF}$ & BN10507550 & $1 / 31 / 2014$ \\
\hline IN140035 & $001600963 \mathrm{GBF}$ & BN10509599 & $2 / 1 / 2014$ \\
\hline IN140038 & $001600966 \mathrm{GBF}$ & BN10507553 & $2 / 2 / 2014$ \\
\hline IN140038 & $001600966 \mathrm{GBF}$ & BN10507557 & $2 / 2 / 2014$ \\
\hline IN140039 & $001600967 \mathrm{GBF}$ & BN10507555 & $2 / 4 / 2014$ \\
\hline IN140039 & $001600967 \mathrm{GBF}$ & BN10507554 & $2 / 4 / 2014$ \\
\hline
\end{tabular}

Under civil and criminal penalties of law for the making or submission of false or fraudulent statements or representations (18 U.S.C. 1001 and 15 U.S.C. 2615), I certify that the information contained in or accompanying this document is true, accurate, and complete.

As to the identified section(s) of this document for which I cannot personally verify truth and accuracy, I certify as the company official having supervisory responsibility for the persons who, acting under my direct instructions, made the verification that this information is true, accurate, and complete.

Should you require further information concerning this certificate of disposal, please contact Mr. R. S. (Bob) Nieman at (575) 234-8141.

Sincerely,

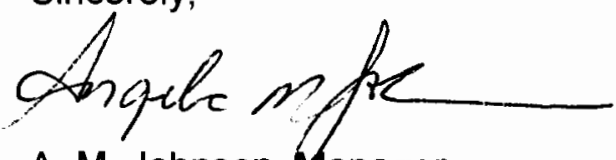

A. M. Johnson, Manager

Transportation Management

RSN/rsn

cc: Shipment portfolio for shipments IN140013, IN140014, IN140016, IN140018, IN140019, IN140022, IN140023, IN140024, IN140026, IN140028, IN140029, IN140031, IN140033, IN140034, IN140035, IN140038 and IN140039. 
Please print or type. (Form designed for use on elite (12-pitch) typewriter.)

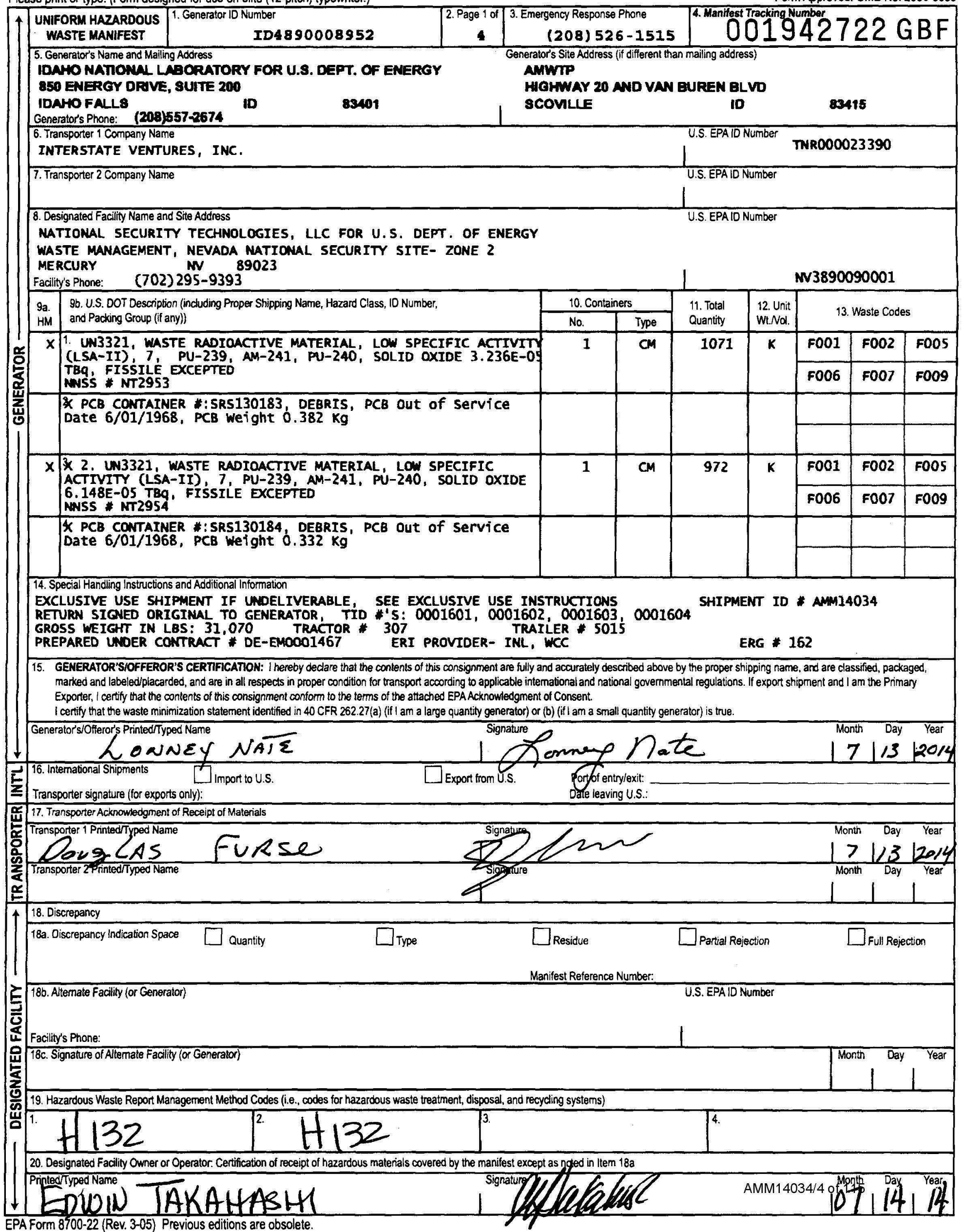


Please print or type. (Form designed for use on elite (12-pitch) typewriter.)

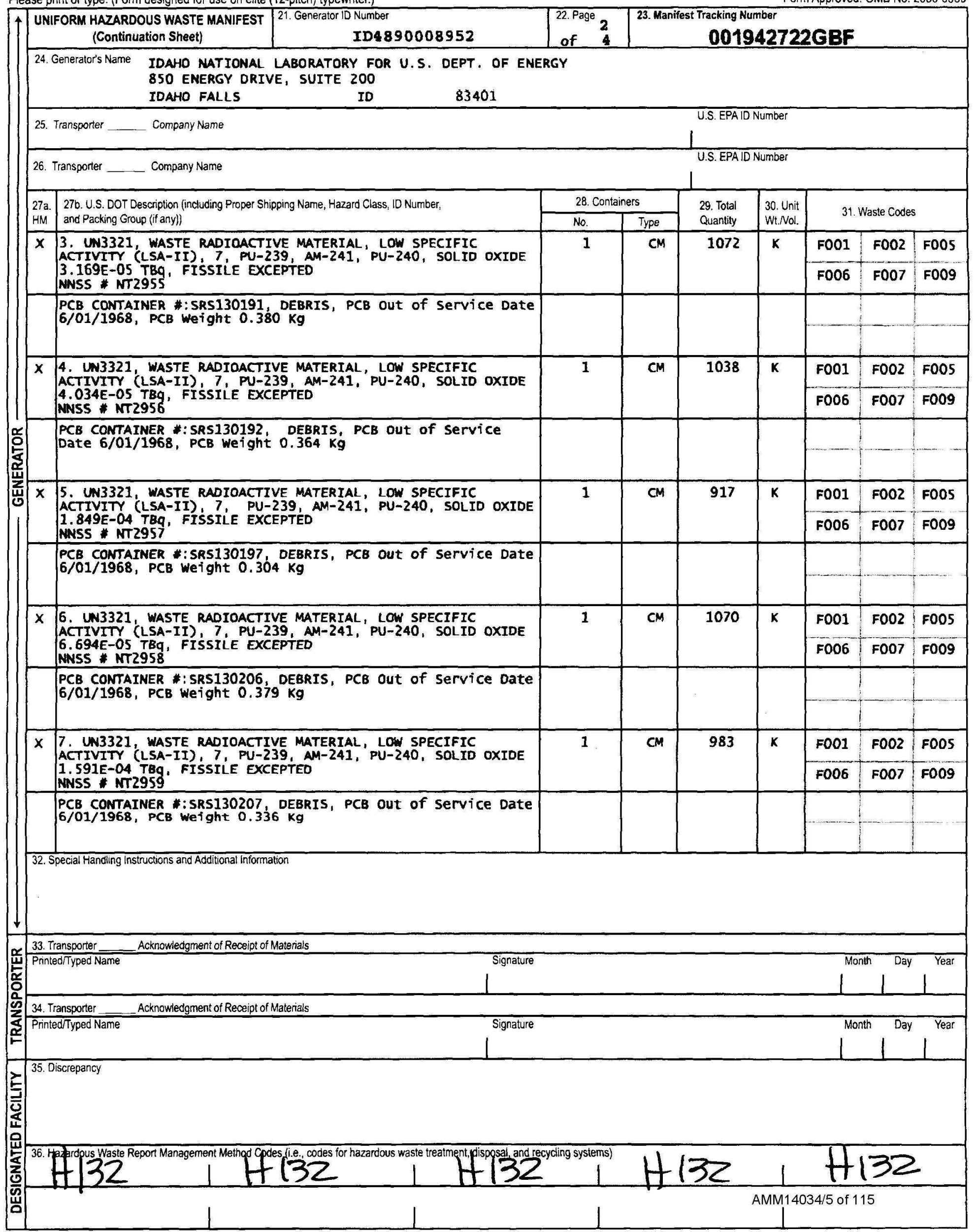


Please print or type. (Form designed for use on elite (12-pitch) typewriter.)

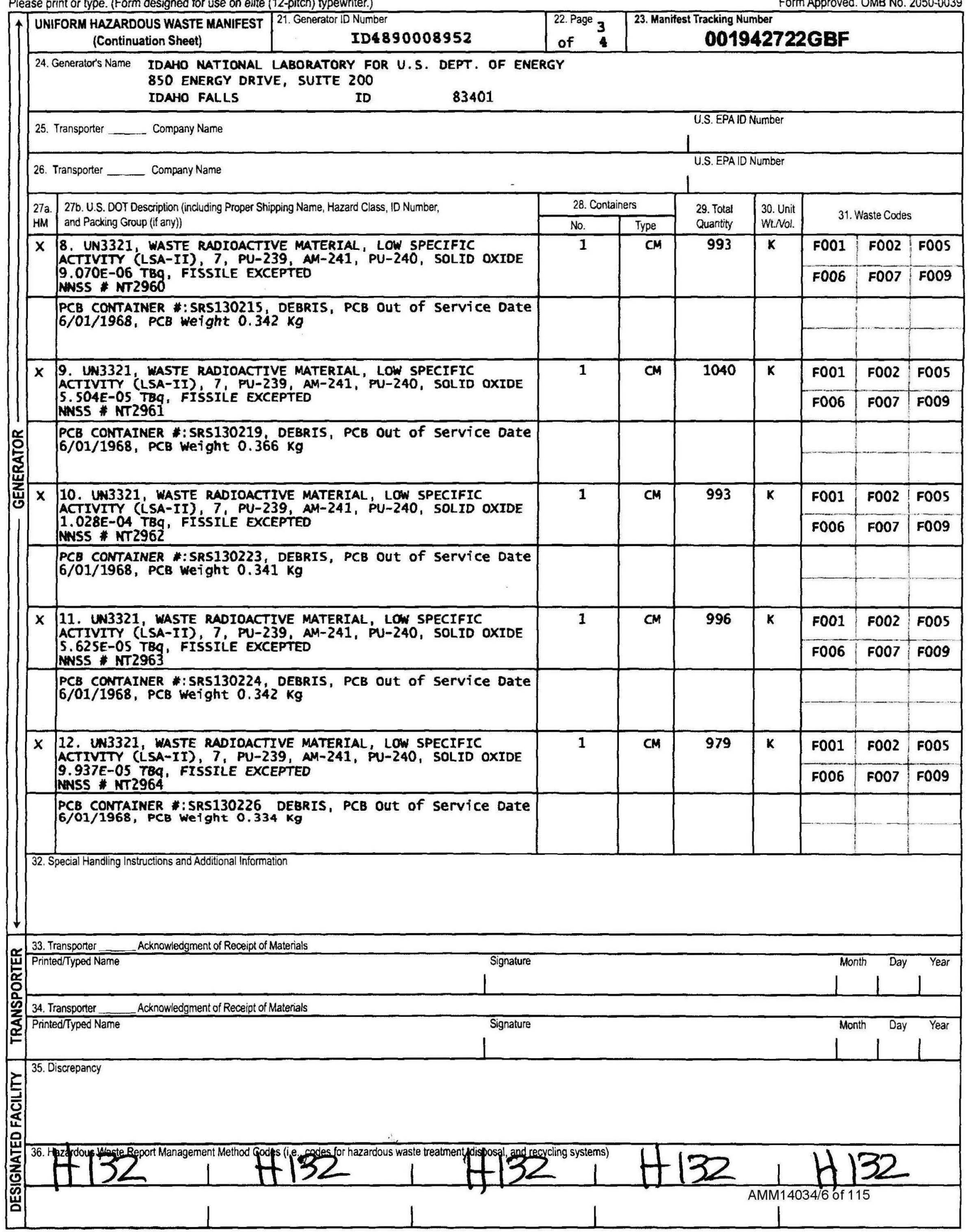




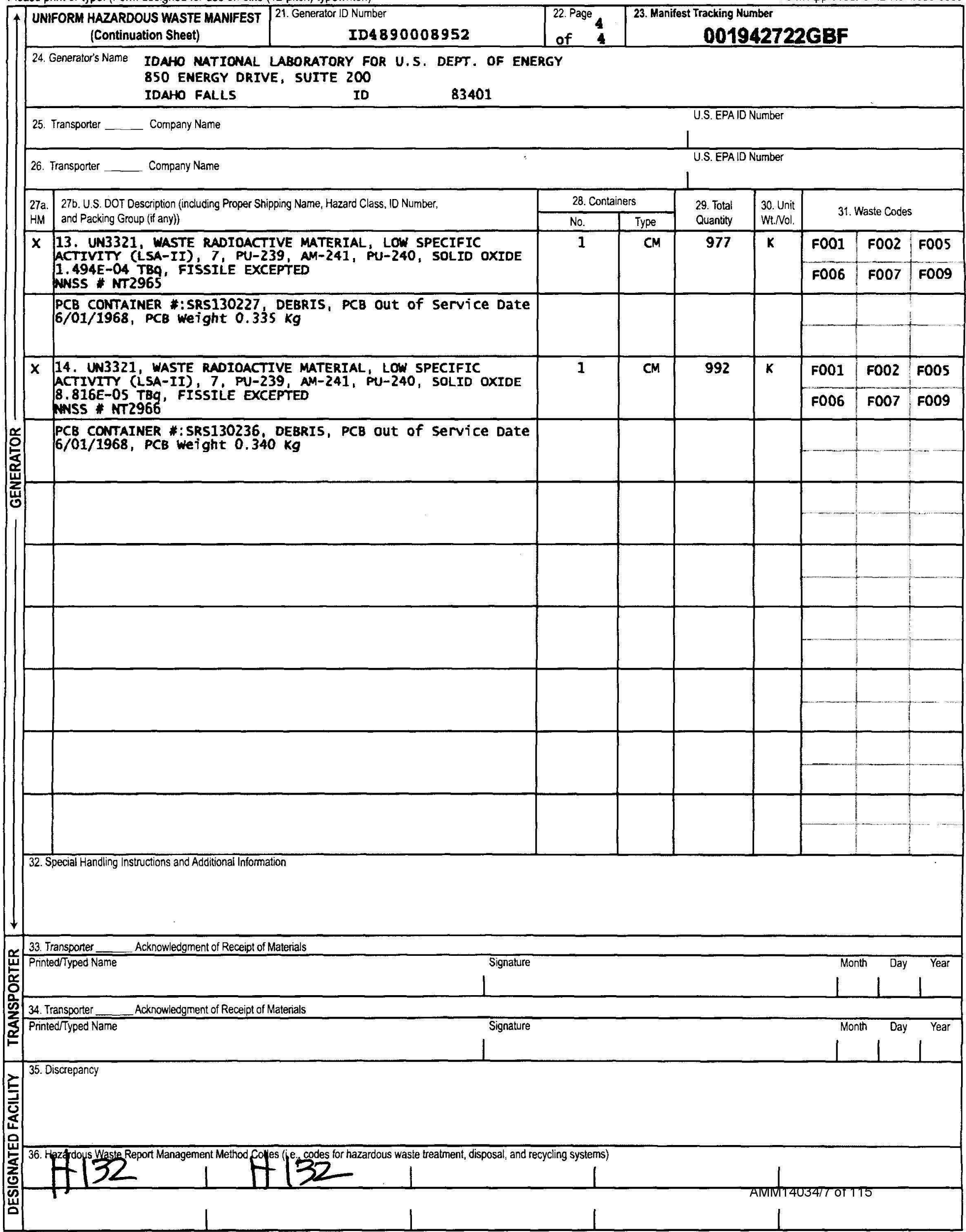


National Security Technologies LLc

Vision - Service - Partnership

H100-PA-14-0109

July 21,2014

Jared Dominick

Waste Certification Official

Idaho Treatment Group, LLC

850 Energy Drive, Suite 100

Idaho Falls, ID 83401-1502

Subject: CERTIFICATE OF DISPOSAL FOR POLYCHLORINATED BIPHENYL (PCB) WASTE AT THE NEVADA NATIONAL SECURITY SITE RADIOACTIVE WASTE MANAGEMENT SITE (RWMS)

Enclosed is the courtesy certificate acknowledging disposal of shipment AMM14034 in the Mixed Waste Disposal Unit, at the Nevada National Security Site RWMS.

If you have any questions, please contact me at 702-295-2261.<smiles>[124IH]</smiles><smiles>CCC(=C1CCCCC1)C(C)=C(C)C</smiles>

Patrick M. Arnold, Division Manager

Environmental Management

RCD:saq

Enclosure: as stated

cc w/enc.

Correspondence Control

EWO Correspondence

J. T. Carilli, NNSA/NFO

R. C. Denton, NSTec

R. G. Geisinger, NSTec

M. Libidinsky, NNSA/NFO

C. P. Moke, NSTec

K. M. Small, NNSA/NFO

K. C. Tanaka, NSTec

A. V. Tauber, NNSA/NFO

R. A. Wagner, NSTec 
National Security Technologies LLC

For U.S. Department of Energy

Waste Management

Nevada National Security Site - Zone 2

Mercury, NV 89023

EPA ID NV3890090001

This Certificate acknowledges that the following shipment(s) of manifested POLYCHLORINATED BIPHENYL (PCB) waste have been disposed at the Nevada National Security Site Radioactive Waste Management Site.

\begin{tabular}{|c|c|c|c|c|}
\hline $\begin{array}{c}\text { Shipment } \\
\text { Number }\end{array}$ & $\begin{array}{c}\text { Uniform Hazardous Waste } \\
\text { Manifest Number }\end{array}$ & Date(s) of Disposal & Volume $\mathbf{F t}^{\mathbf{3}}\left(\mathbf{m}^{\mathbf{3}}\right)$ & Disposal Process \\
\hline AMM14034 & $001942722 \mathrm{GBF}$ & $07 / 14 / 2014$ & $1,259.76(35.67)$ & Landfill \\
\hline & & & & \\
\hline & & & & \\
\hline & & & & \\
\hline
\end{tabular}

Under civil and criminal penalties of law for the making or submission of false or fraudulent statements or representations (18 U.S.C. 1001 and 15 U.S.C. 2615), I certify that the information contained in or accompanying this document is true, accurate, and complete.

As to the identified section(s) of this document for which I cannot personally verify truth and accuracy, I certify as the company official having supervisory responsibility for the persons who, acting under my direct instructions, made the verification that this information is true, accurate, and complete.
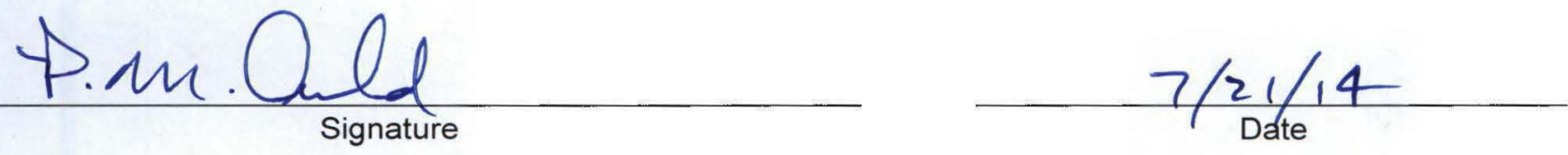

Division Manager, Environmental Management

Title

Instructions:

Shipment Number - enter shipment number from LWIS database.

Uniform Hazardous Waste Manifest Number - enter number from UHWM provided by generator.

Date of Disposal - enter date waste was placed in disposal cell.

Volume - enter shipment volume in cubic feet and equivalent cubic meters in parenthesis.

Disposal Process - enter Landfill.

National Security Technologies, LLC

Vision • Service • Partnership

WWW.NSTEC.com

P.O. Box 98521, Las Vegas, NV 89193-8521

2621 Losee Road, N. Las Vegas, NV 89030-4129 
Please print or type. (Form designed for use on elite (12-pitch) typewriter.)

Form Approved. OMB №. 2050-0039

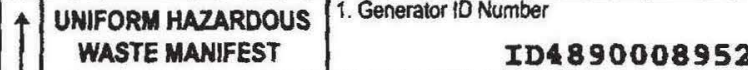 \\ 5. Generator's Name and Mailing Address}

IOAHO MATONAL LABORATORY FOR U.S. DEPT. OF ENERGY 250 ENEROY DFVE SUITE 100

IDAHO FALL8
Generator's Phone:
(208)557-6607

ID $\mathbf{8 3 4 0 1}$

2. Page 1 of
-

Generator's Site Address (if different than mailing address)

AMwTP

MOMNAY 20 AND VAN BUREN BLVD

SCOVLLE

10
U.S. EPAID Number

$\left.\right|_{U \text { U.S. EPAID Number }} ^{\text {U.S. EPAID Number }}$ TNR000023390

8. Designated facility Name and Site Address

NATIONAL SECURITY TECHNOLOGIES, LLC FOR U.S. DEPT, OF ENERGY

WASTE MANAGEMENT, NEVADA NATIONAL SECURITY SITE- ZONE 2

MERCURY NV 89023

\begin{tabular}{l|l} 
Facility's Phone: $\quad$ (702) $295-9393$ \\
\hline 9 ab. U.S. DoT Description (including Prope
\end{tabular}

INTERSTATE VENTURES, INC.

INTERSTATE VENTURES, INK. 9023

9a. 96. U.S. DOT Description (induding Proper Shipping Name, Hazard Class, ID Number,

HM and Packing Group (if any))

$X$ 1. UN3321, WASTE, RADIOACTIVE MATERIAL, LOW SPECIFIC ACTIVITY (LSA-II), 7, PU-239, AM-241, PU-240, SOLID
OXIDE, 2.260E-04 TBq, FISSILE EXCEPTED, NNSS * NT2967 2X PCB CONTATNER : SRS130058, DEBRIS, PCB OUt of SEVICe Date $6 / 01 / 1968$, PCB weight $0.311 \mathrm{Kg}$

$\times$ 2. UN3321, WASTE, RADIOACTIVE MATERIAL, LOW SPECIFIC ACTIVITY (LSA-II), 7, PU-239, AM-241, PU-240, SOLIO, OXIDE, 3.537E-04 TBq, FISSILE EXCEPTED, NNSS * NT2968

X PCB CONTAINER :SRS130071, DEBRIS, PCB Out of Service Date 6/01/1968, PCB weight $0.343 \mathrm{~kg}$

\begin{tabular}{|c|c|c|c|c|c|c|}
\hline & & & \multicolumn{4}{|c|}{ NV3890090001 } \\
\hline & 10. Containers & \multirow{2}{*}{$\begin{array}{l}\text { 11. Total } \\
\text { Quantity }\end{array}$} & \multirow{2}{*}{$\begin{array}{l}\text { 12. Unit } \\
\text { Wt.Nol. }\end{array}$} & \multirow{2}{*}{\multicolumn{3}{|c|}{ 13. Waste Codes }} \\
\hline No. & Type & & & & & \\
\hline 1 & \multirow[t]{2}{*}{ DF } & \multirow[t]{2}{*}{932} & \multirow[t]{2}{*}{$k$} & F001 & $\mathrm{FOO2}$ & FOOS \\
\hline & & & & F006 & F007 & FoOg \\
\hline \multicolumn{7}{|l|}{ ce } \\
\hline \multirow[t]{2}{*}{1} & \multirow[t]{2}{*}{ DF } & \multirow[t]{2}{*}{996} & \multirow[t]{2}{*}{ K } & F001 & $\mathrm{FOO2}$ & FOOS \\
\hline & & & & F006 & F007 & F009 \\
\hline \multicolumn{7}{|l|}{ ce } \\
\hline & & & & & & \\
\hline
\end{tabular}

14. Special Handling Instructions and Additional Information

EXCLUSTVE USE SHTPMENT IF UNDEL TVERABLE, SEE EXCLUSTVE USE INSTRUCTIONS SHIPMEMT ID * AMM1403S

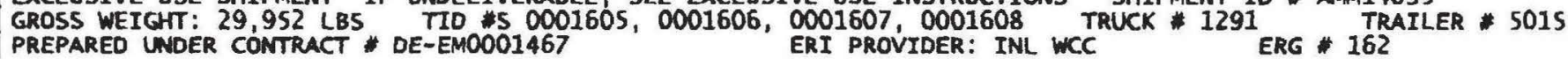

15. GENERATOR'SJOFFEROR'S CERTIFICATION: I hereby declare that the contents of this consignment are fully and accurately described above by the proper shipping name, and are classified, packaged,

marked and labelediplacarded, and are in all respects in proper condition for transport according to applicable international and national governmental regulations. If export shipment and I am the Primary

Exporter, I certify that the contents of this consignment conform to the terms of the attached EPA Acknowledgment of Consent.

I certify that the waste minimization statement identified in 40 CFR 262.27(a) (if I am a large quantity generator) or (b) (if I am a small quantity generator) is true.

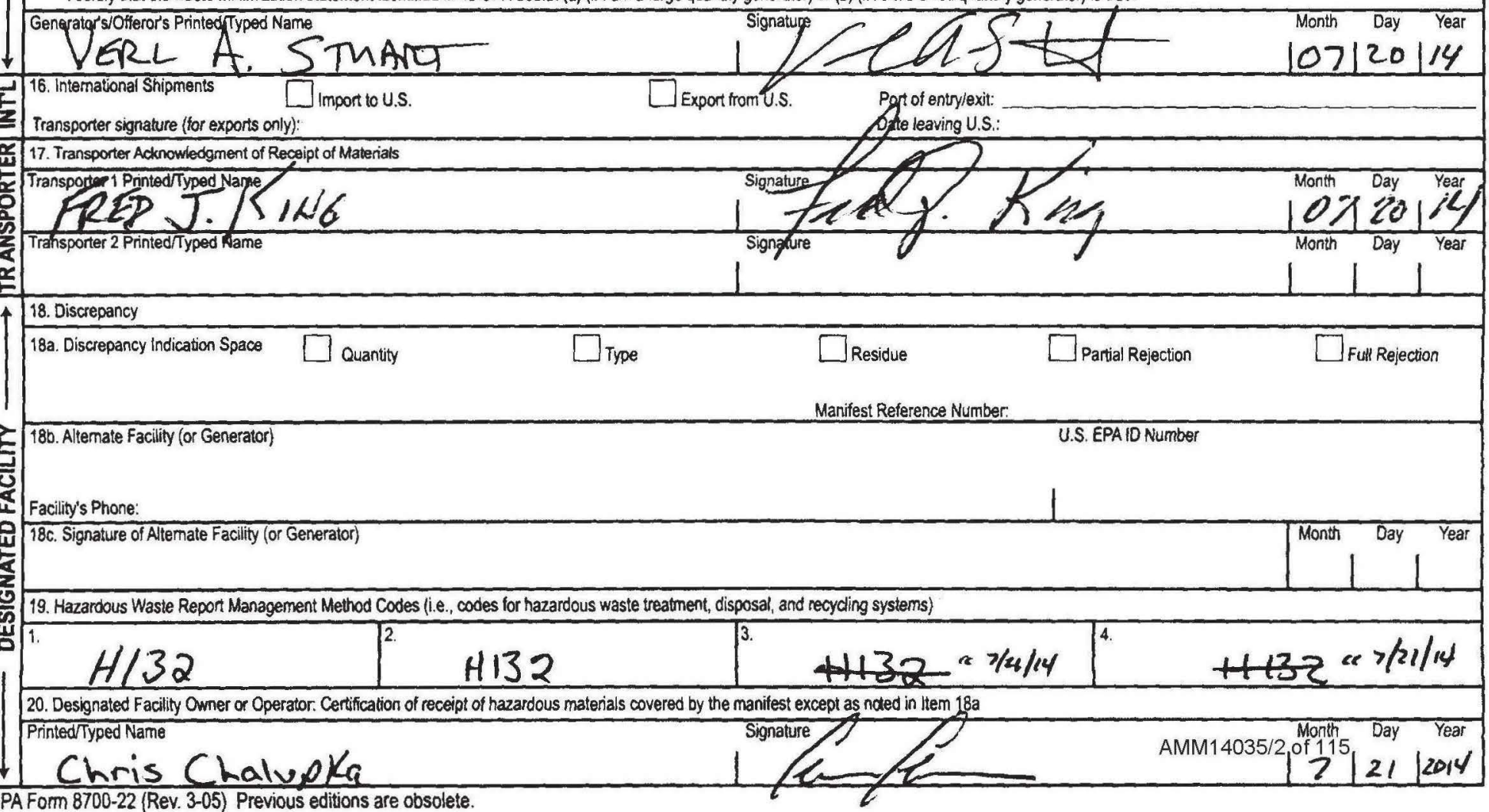


Please print or type. (Form designed for use on elite (12-pitch) typewriter.)

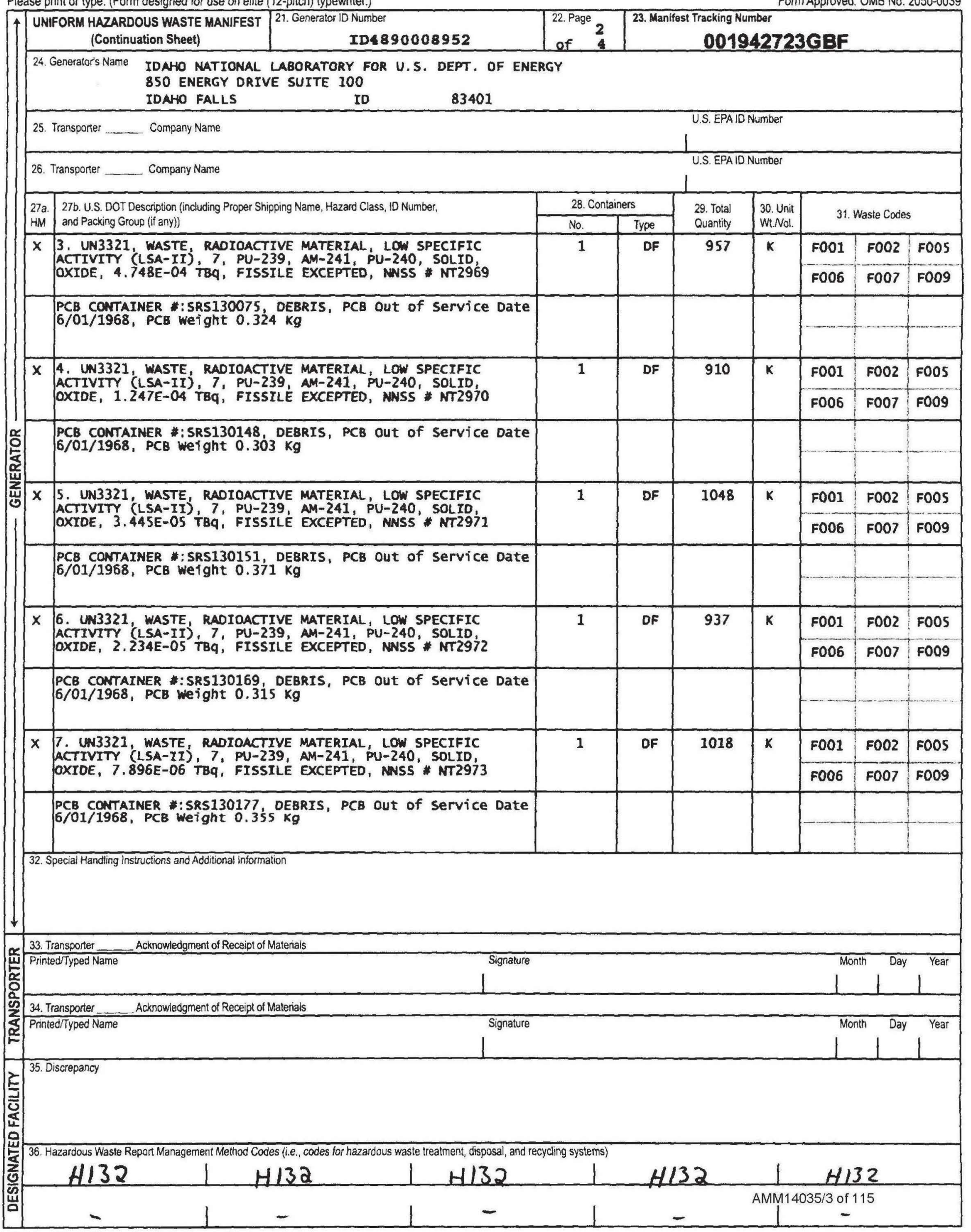




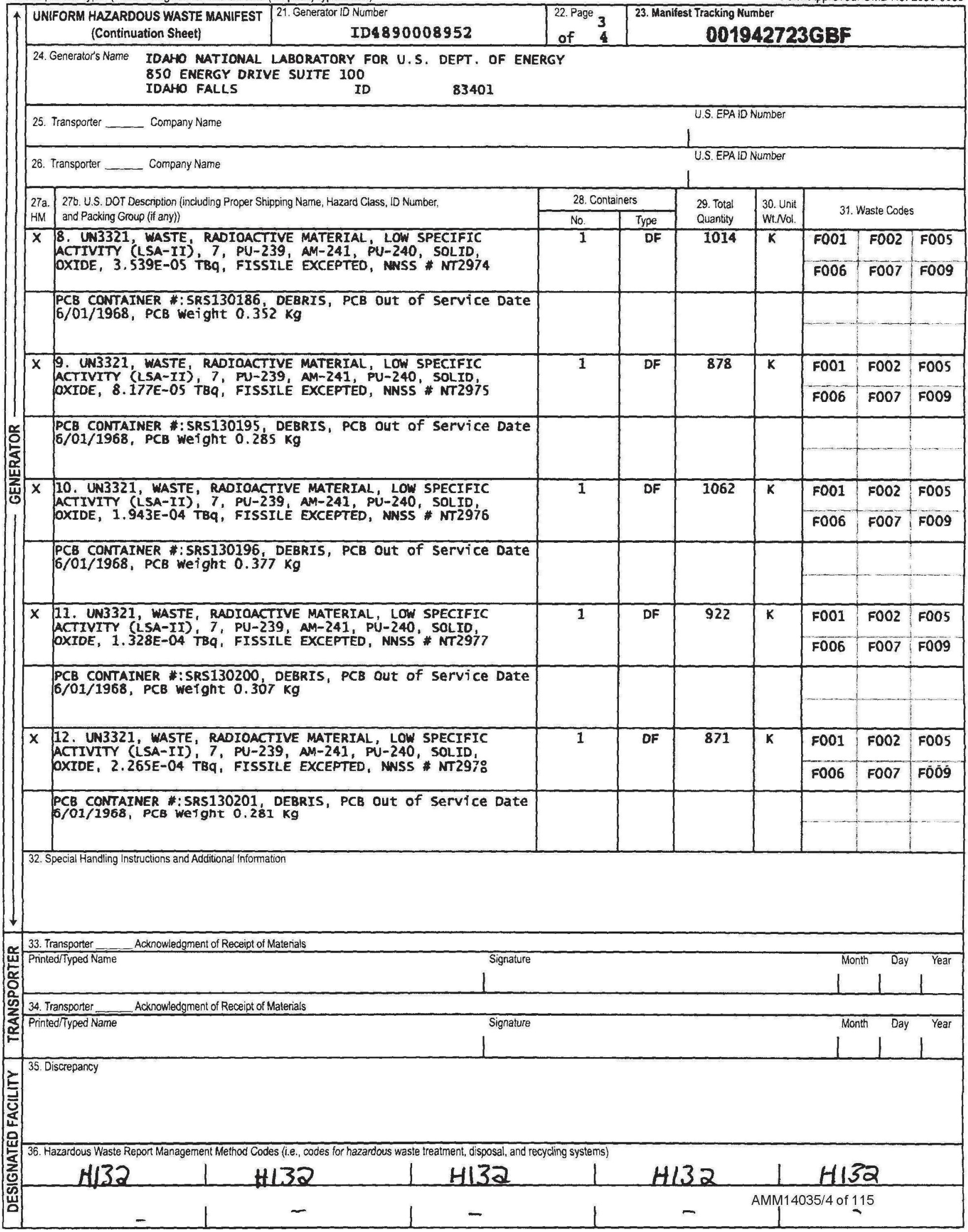




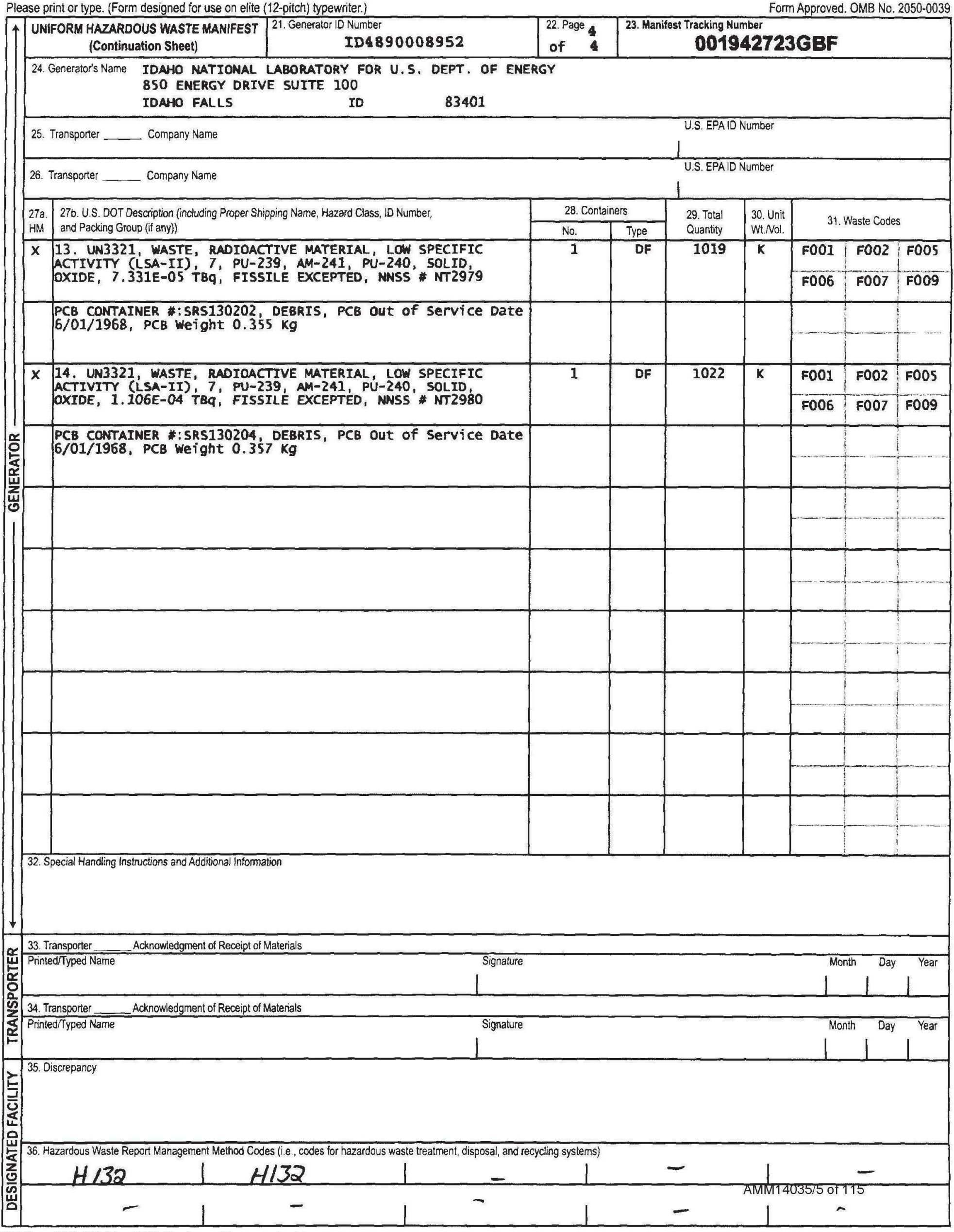


$\underset{\substack{\text { National Security Techice. Parnorship } \\ \text { Vision }}}{\text { Technologiesuc }}$

H000-PA-14-0111

July 28,2014

Jared Dominick

Waste Certification Official

Idaho Treatment Group

850 Energy Drive, Suite 100

Idaho Falls, ID 83401

Subject: CERTIFICATE OF DISPOSAL FOR POLYCHLORINATED BIPHENYL (PCB) WASTE AT THE NEVADA NATIONAL SECURITY SITE RADIOACTIVE WASTE MANAGEMENT SITE (RWMS)

Enclosed is the certificate acknowledging disposal of manifested PCB shipments AMM14035 and AMM14036 (per 40 CFR 761.218), in the Mixed Waste Disposal Unit at the Nevada National Security Site RWMS.

If you have any questions, please contact me at 702-295-2261.

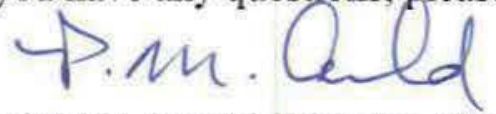

Patrick M. Arnold, Division Manager

Environmental Management

RCD:saq

Enclosure: as stated

cc w/enc.

Correspondence Control

EWO Correspondence

J. T. Carilli, NNSA/NFO

R. C. Denton, NSTec

R. G. Geisinger, NSTec

M. Libidinsky, NNSA/NFO

C. P. Moke, NSTec

K. M. Small, NNSA/NFO

K. C. Tanaka, NSTec

A. V. Tauber, NNSA/NFO

R. A. Wagner, NSTec

National Security Technologies, LLC

Vision • Service • Partnership

WWW.NSTEC.COM

P.O. Box 98521, Las Vegas, NV 89193-8521

2621 Losee Road, N. Las Vegas, NV 89030-4129 
National Security Technologies LLC

For U.S. Department of Energy

Waste Management

Nevada National Security Site - Zone 2

Mercury, NV 89023

EPA ID NV3890090001

This Certificate acknowledges that the following shipment(s) of manifested POLYCHLORINATED BIPHENYL (PCB) waste have been disposed at the Nevada National Security Site Radioactive Waste Management Site.

\begin{tabular}{|c|c|c|c|c|}
\hline $\begin{array}{c}\text { Shipment } \\
\text { Number }\end{array}$ & $\begin{array}{c}\text { Uniform Hazardous Waste } \\
\text { Manifest Number }\end{array}$ & Date(s) of Disposal & Volume $\mathrm{Ft}^{\mathbf{3}}\left(\mathrm{m}^{\mathbf{3}}\right)$ & Disposal Process \\
\hline AMM14035 & $001942723 \mathrm{GBF}$ & $07 / 21 / 2014$ & $1,259.76(35.67)$ & Landfill \\
\hline AMM14036 & $001942724 \mathrm{GBF}$ & $07 / 21 / 2014$ & $1,259.83(35.67)$ & Landfill \\
\hline & & & & \\
\hline & & & & \\
\hline
\end{tabular}

Under civil and criminal penalties of law for the making or submission of false or fraudulent statements or representations (18 U.S.C. 1001 and 15 U.S.C. 2615), I certify that the information contained in or accompanying this document is true, accurate, and complete.

As to the identified section(s) of this document for which I cannot personally verify truth and accuracy, I certify as the company official having supervisory responsibility for the persons who, acting under my direct instructions, made the verification that this information is true, accurate, and complete.
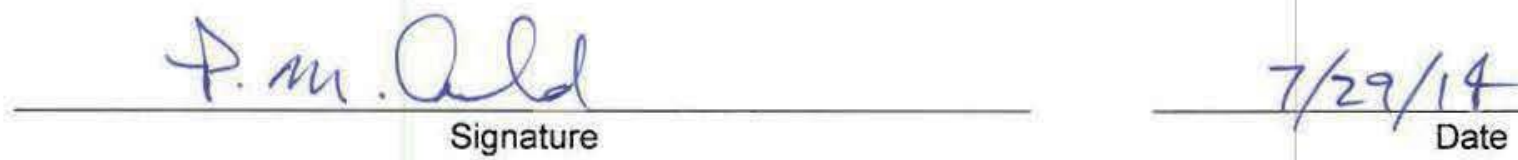

Division Manager, Environmental Management

$$
\text { Title }
$$

Instructions:

Shipment Number - enter shipment number from LWIS database.

Uniform Hazardous Waste Manifest Number - enter number from UHWM provided by generator.

Date of Disposal - enter date waste was placed in disposal cell.

Volume - enter shipment volume in cubic feet and equivalent cubic meters in parenthesis.

Disposal Process - enter Landfill. 
Please print or type. (Form designed for use on elite (12-pitch) typewriter.)

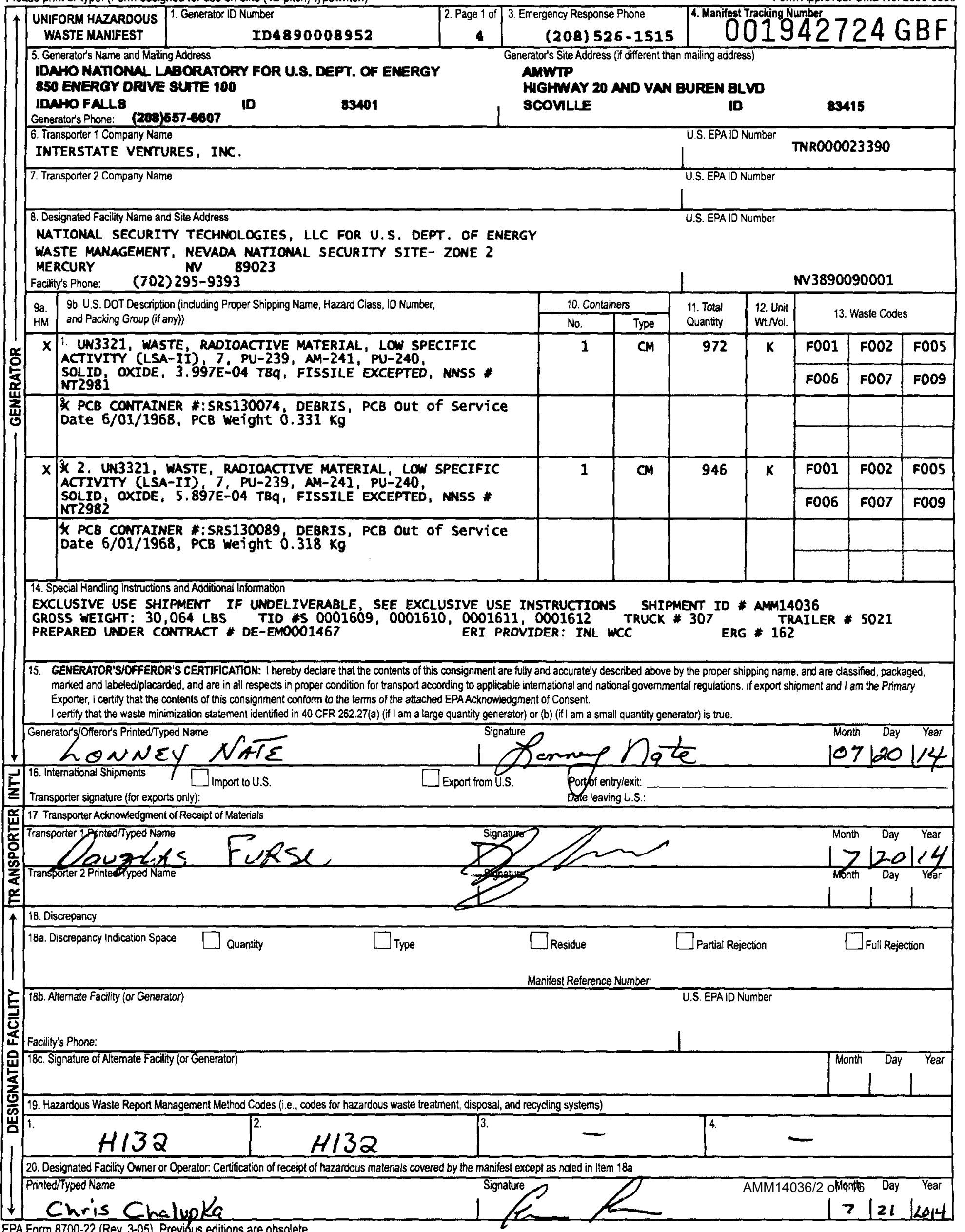


Please print or type. (Form designed for use on elite (12-pitch) typewriter.)

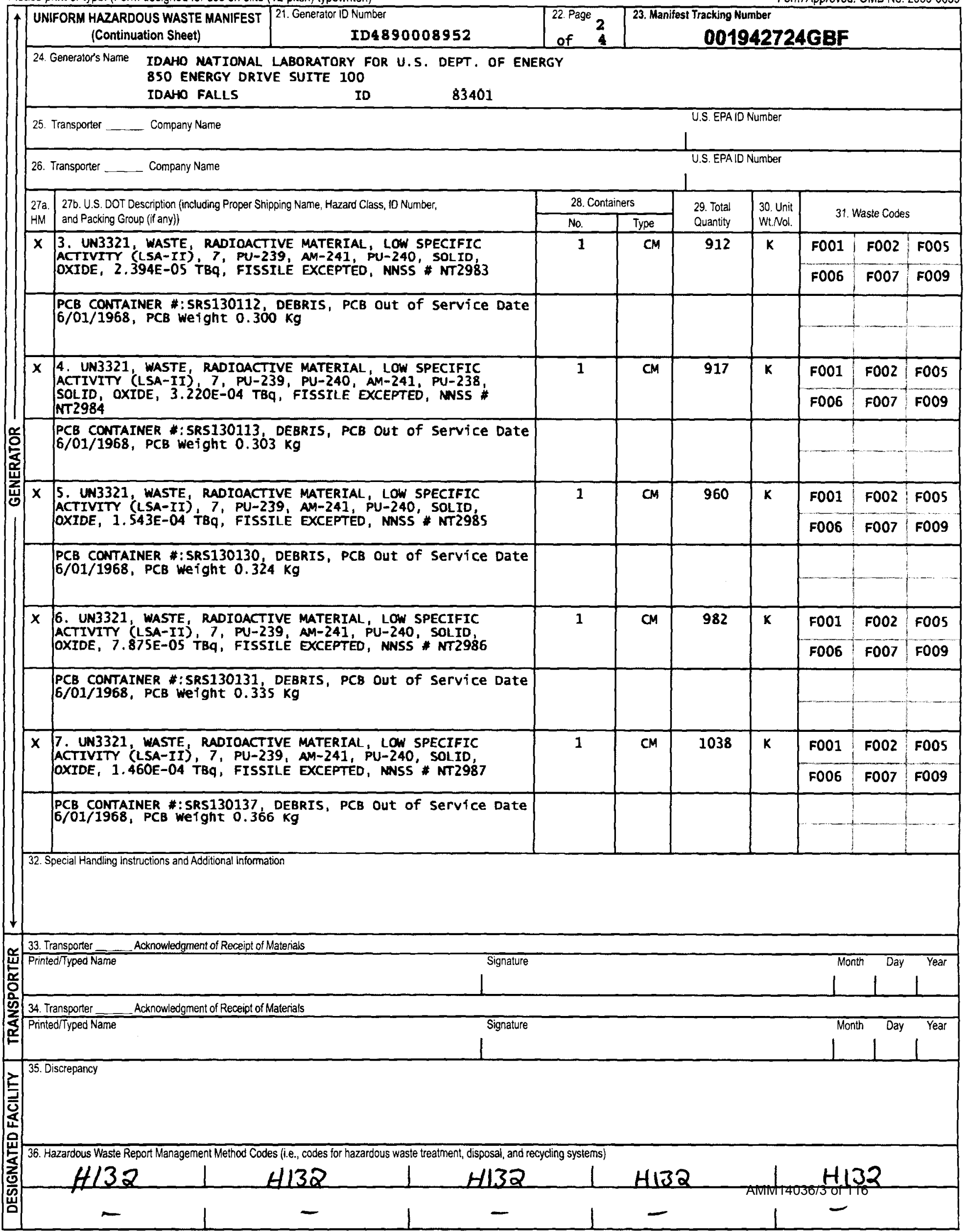


Please print or type. (Form designed for use on elite (12-pitch) typewriter.)

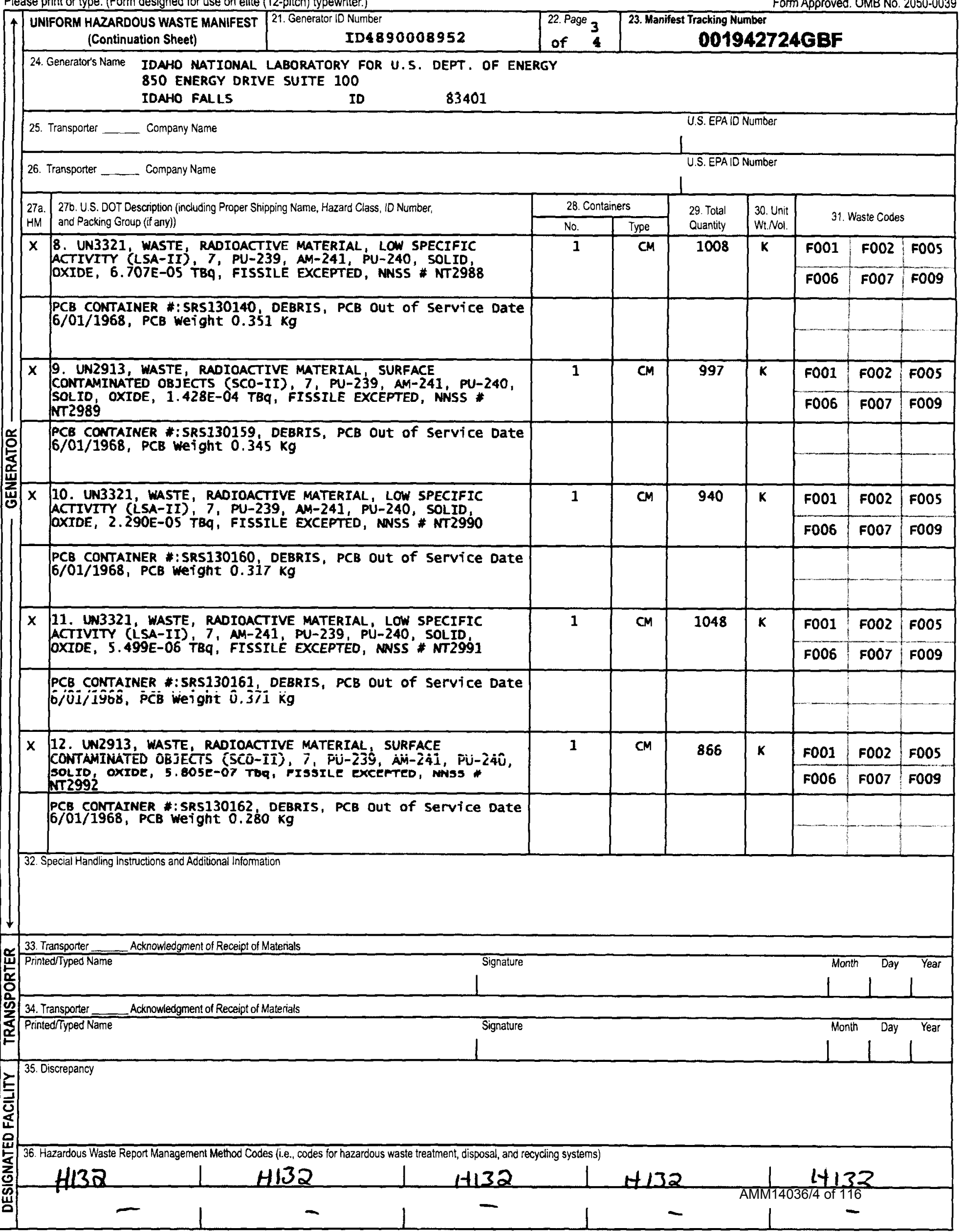


Please print or type. (Form designed for use on elite (12-pitch) typewriter.)

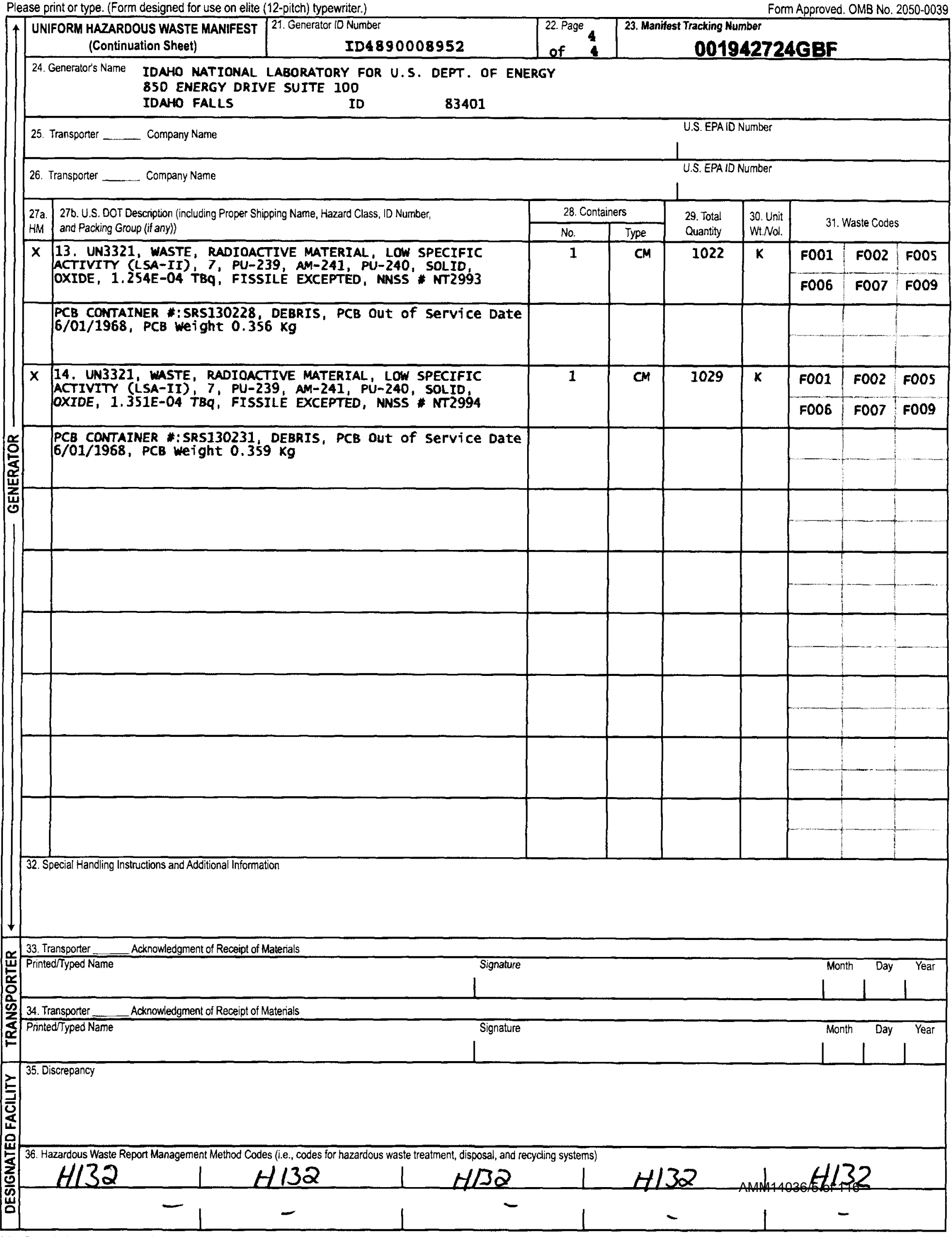


$\underset{\substack{\text { National Security Technologiesuc } \\ \text { Vision. Senice. Parnorship }}}{\text { Tech }}$

H000-PA-14-0111

July 28,2014

Jared Dominick

Waste Certification Official

Idaho Treatment Group

850 Energy Drive, Suite 100

Idaho Falls, ID 83401

Subject: CERTIFICATE OF DISPOSAL FOR POLYCHLORINATED BIPHENYL (PCB) WASTE AT THE NEVADA NATIONAL SECURITY SITE RADIOACTIVE WASTE MANAGEMENT SITE (RWMS)

Enclosed is the certificate acknowledging disposal of manifested PCB shipments AMM14035 and AMM14036 (per 40 CFR 761.218), in the Mixed Waste Disposal Unit at the Nevada National Security Site RWMS.

If you have any questions, please contact me at 702-295-2261.

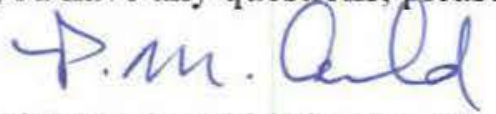

Patrick M. Arnold, Division Manager

Environmental Management

RCD:saq

Enclosure: as stated

cc w/enc.

Correspondence Control

EWO Correspondence

J. T. Carilli, NNSA/NFO

R. C. Denton, NSTec

R. G. Geisinger, NSTec

M. Libidinsky, NNSA/NFO

C. P. Moke, NSTec

K. M. Small, NNSA/NFO

K. C. Tanaka, NSTec

A. V. Tauber, NNSA/NFO

R. A. Wagner, NSTec

National Security Technologies, LLC

Vision • Service • Partnership

WWW.NSTEC.COM

P.O. Box 98521, Las Vegas, NV 89193-8521

2621 Losee Road, N. Las Vegas, NV 89030-4129 
National Security Technologies LLC

For U.S. Department of Energy

Waste Management

Nevada National Security Site - Zone 2

Mercury, NV 89023

EPA ID NV3890090001

This Certificate acknowledges that the following shipment(s) of manifested POLYCHLORINATED BIPHENYL (PCB) waste have been disposed at the Nevada National Security Site Radioactive Waste Management Site.

\begin{tabular}{|c|c|c|c|c|}
\hline $\begin{array}{c}\text { Shipment } \\
\text { Number }\end{array}$ & $\begin{array}{c}\text { Uniform Hazardous Waste } \\
\text { Manifest Number }\end{array}$ & Date(s) of Disposal & Volume $\mathrm{Ft}^{3}\left(\mathrm{~m}^{3}\right)$ & Disposal Process \\
\hline AMM14035 & $001942723 \mathrm{GBF}$ & $07 / 21 / 2014$ & $1,259.76(35.67)$ & Landfill \\
\hline AMM14036 & $001942724 \mathrm{GBF}$ & $07 / 21 / 2014$ & $1,259.83(35.67)$ & Landfill \\
\hline & & & & \\
\hline & & & & \\
\hline
\end{tabular}

Under civil and criminal penalties of law for the making or submission of false or fraudulent statements or representations (18 U.S.C. 1001 and 15 U.S.C. 2615), I certify that the information contained in or accompanying this document is true, accurate, and complete.

As to the identified section(s) of this document for which I cannot personally verify truth and accuracy, I certify as the company official having supervisory responsibility for the persons who, acting under my direct instructions, made the verification that this information is true, accurate, and complete.
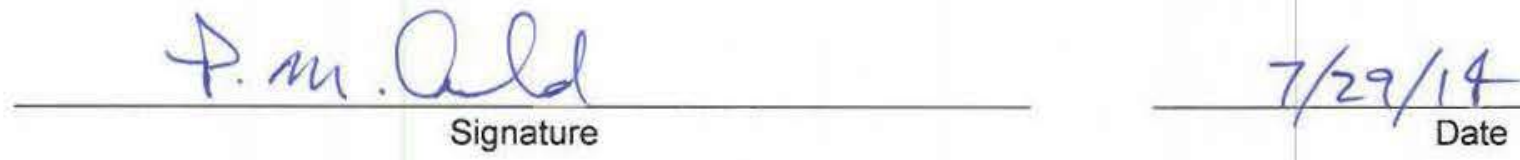

Division Manager, Environmental Management

$$
\text { Title }
$$

\section{Instructions:}

Shipment Number - enter shipment number from LWIS database.

Uniform Hazardous Waste Manifest Number - enter number from UHWM provided by generator.

Date of Disposal - enter date waste was placed in disposal cell.

Volume - enter shipment volume in cubic feet and equivalent cubic meters in parenthesis.

Disposal Process - enter Landfill. 
Please print or type. (Form designed for use on elite (12-pitch) typewriter.)

Form Approved. OMB No. 2050-0039

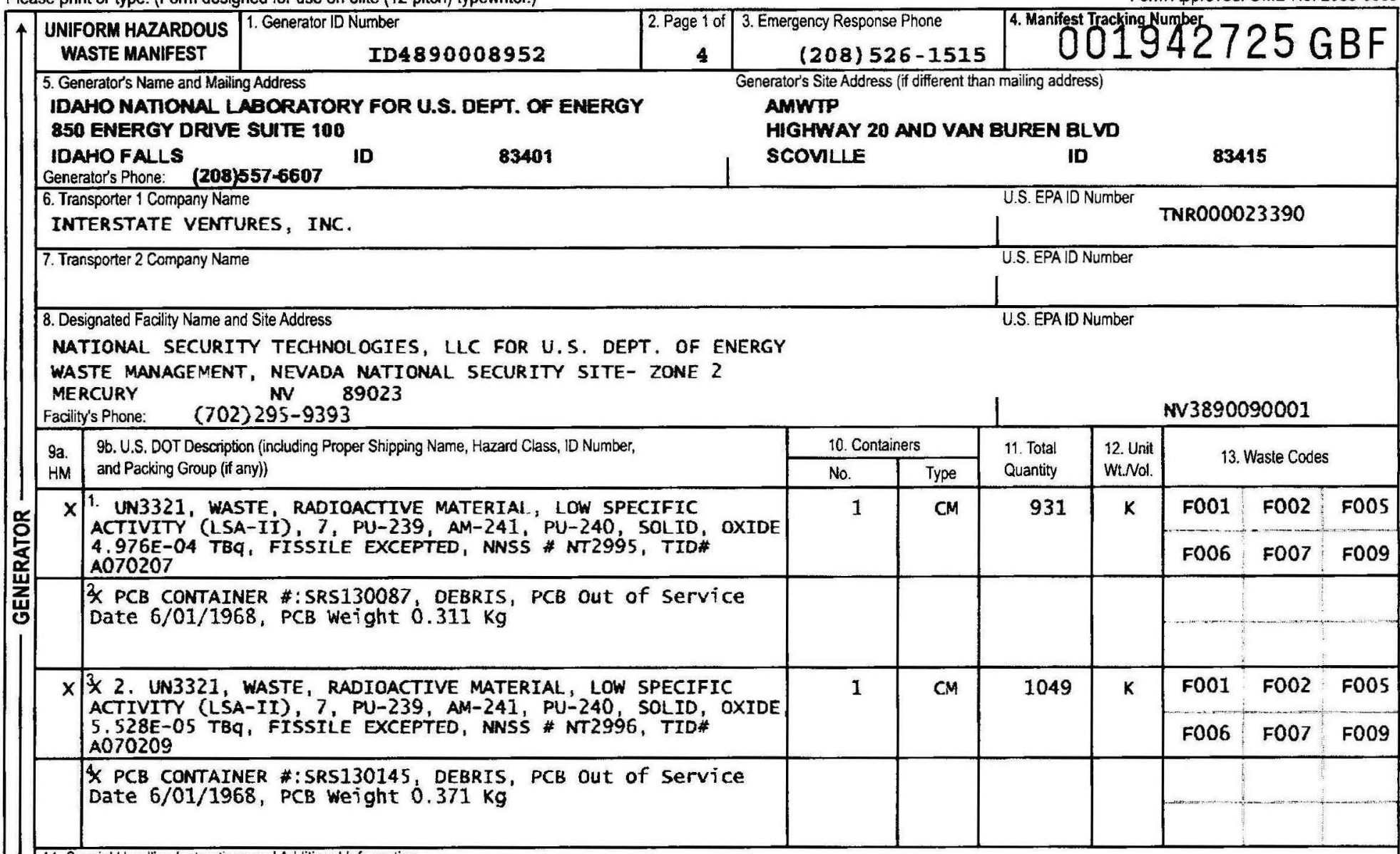

14. Special Handling Instructions and Additional Information

EXCLUSTVE USE SHIPMENT IF UNDELIVERABLE, SEE EXCLUSTVE USE INSTRUCTIONS

RETURN SIGNED ORIGINAL TO GENERATOR,

GROSS WEIGHT: 30,968 LBS

TRUCK \# 307

PREPARED UNDER CONTRACT \# DE-EMO001467

\section{ERT PROVIDER: INL WCC ERG \# 162}

TRAILER \# 1012

15. GENERATOR'S/OFFEROR'S CERTIFICATION: I hereby declare that the contents of this consignment are fully and accurately described above by the proper shipping name, and are classified, packaged, marked and labeled/placarded, and are in all respects in proper condition for transport according to applicable international and national governmental regulations. If export shipment and I am the Primary

Exporter, I certify that the contents of this consignment conform to the terms of the attached EPA Acknowledgment of Consent.

I certify that the waste minimization statement identified in 40 CFR 262.27 (a) (if 1 am a large quantity generator) or (b) (if I am a small quantity generator) is true.

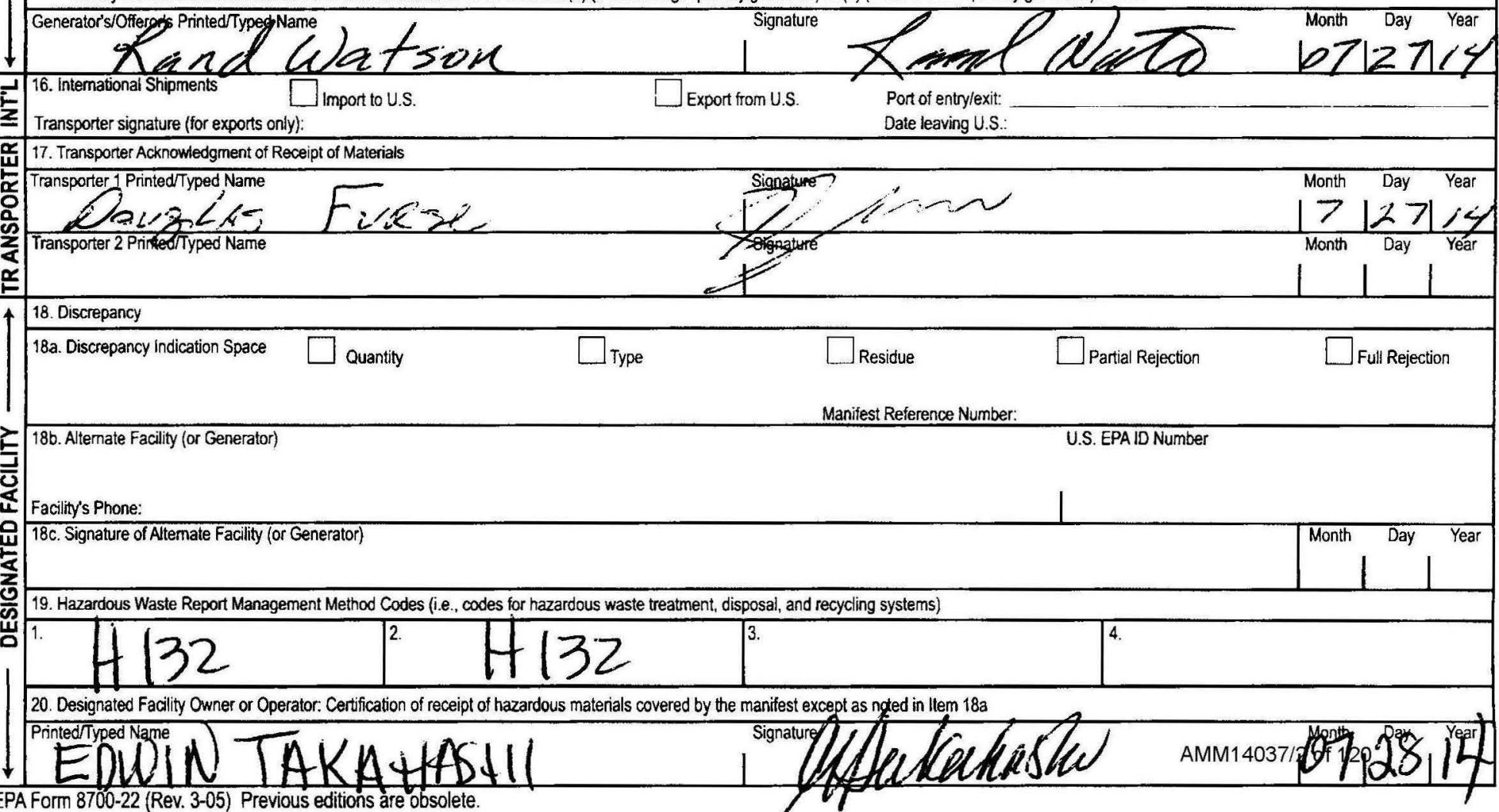




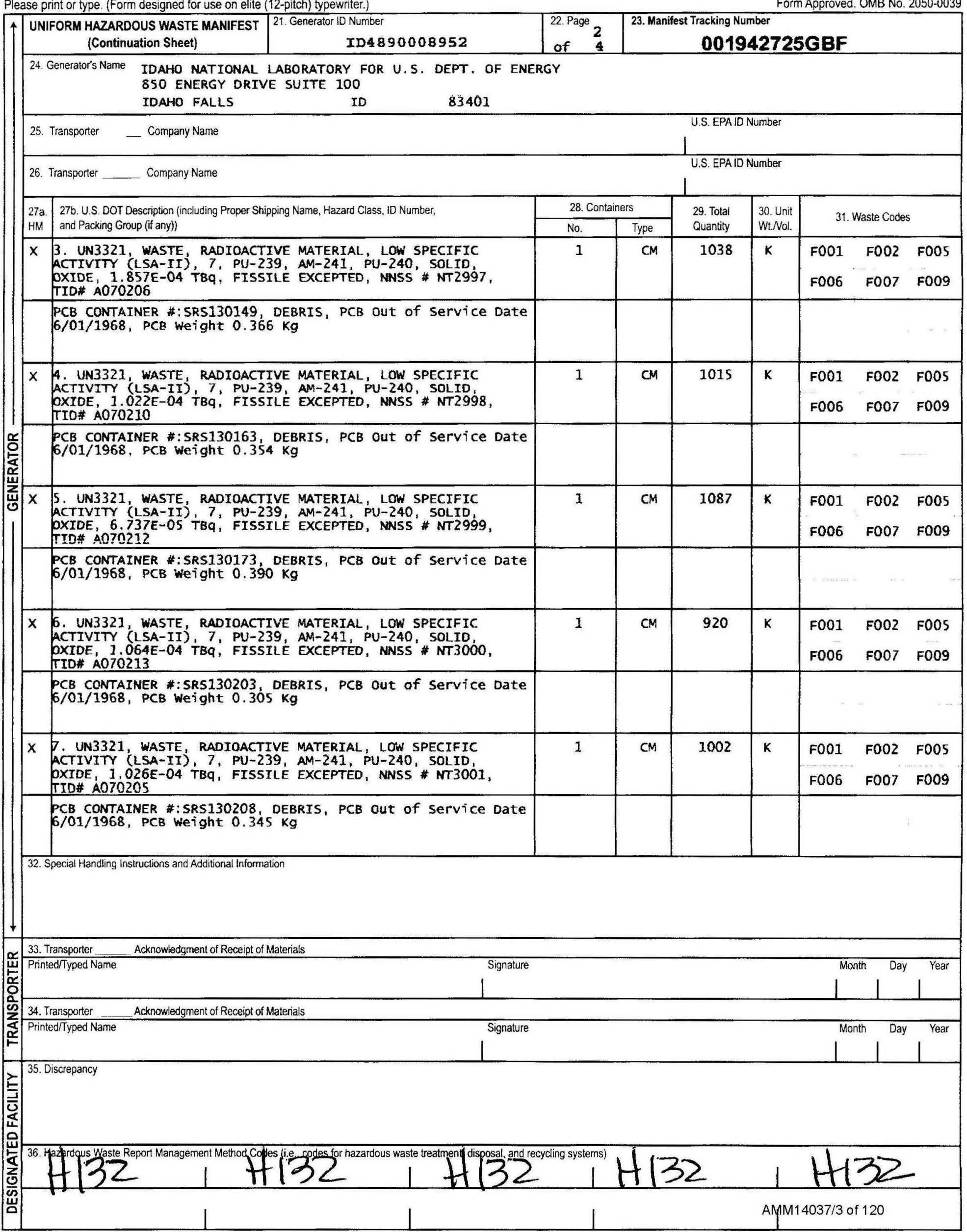




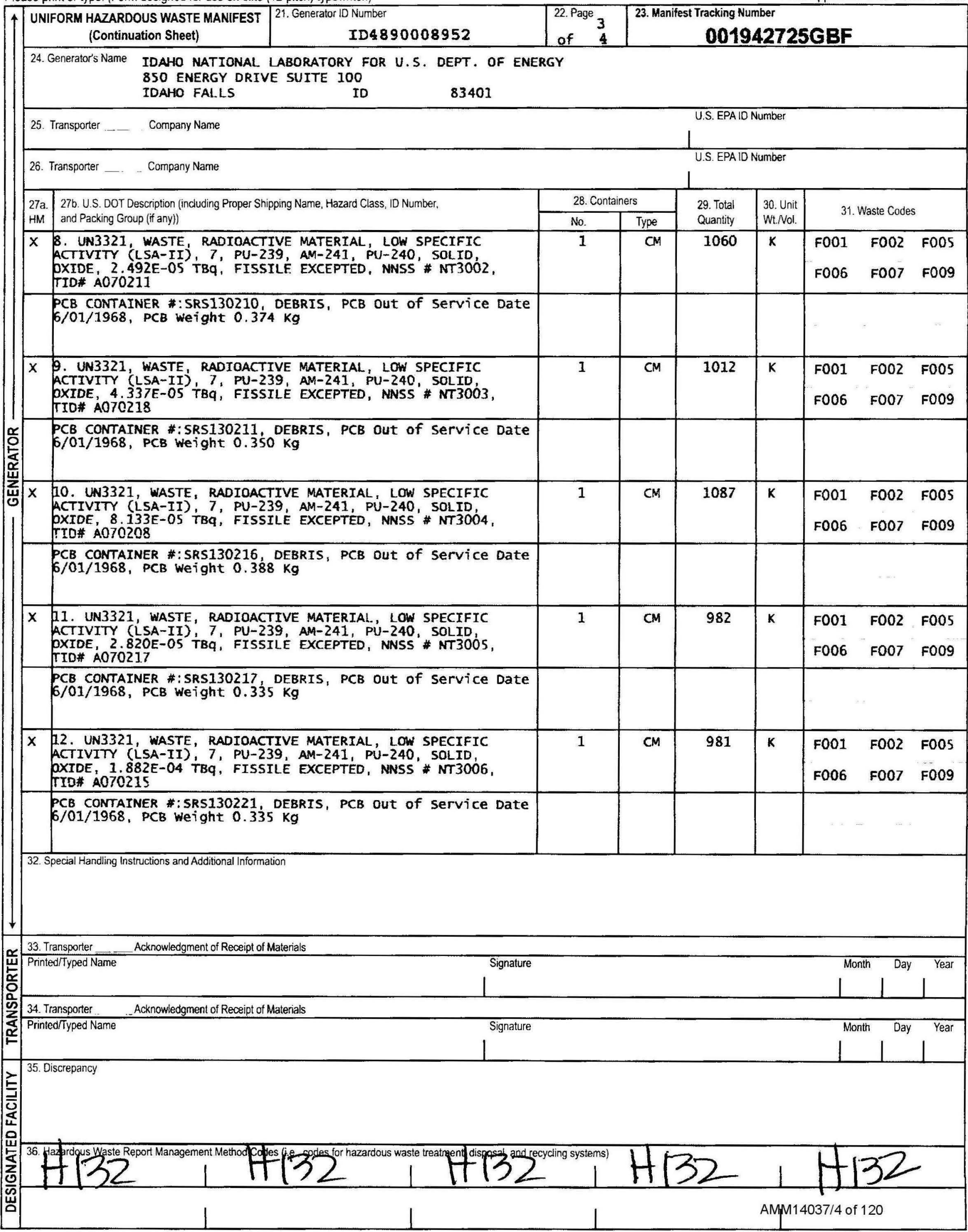


Please print or type. (Form designed for use on elite (12-pitch) typewriter.)

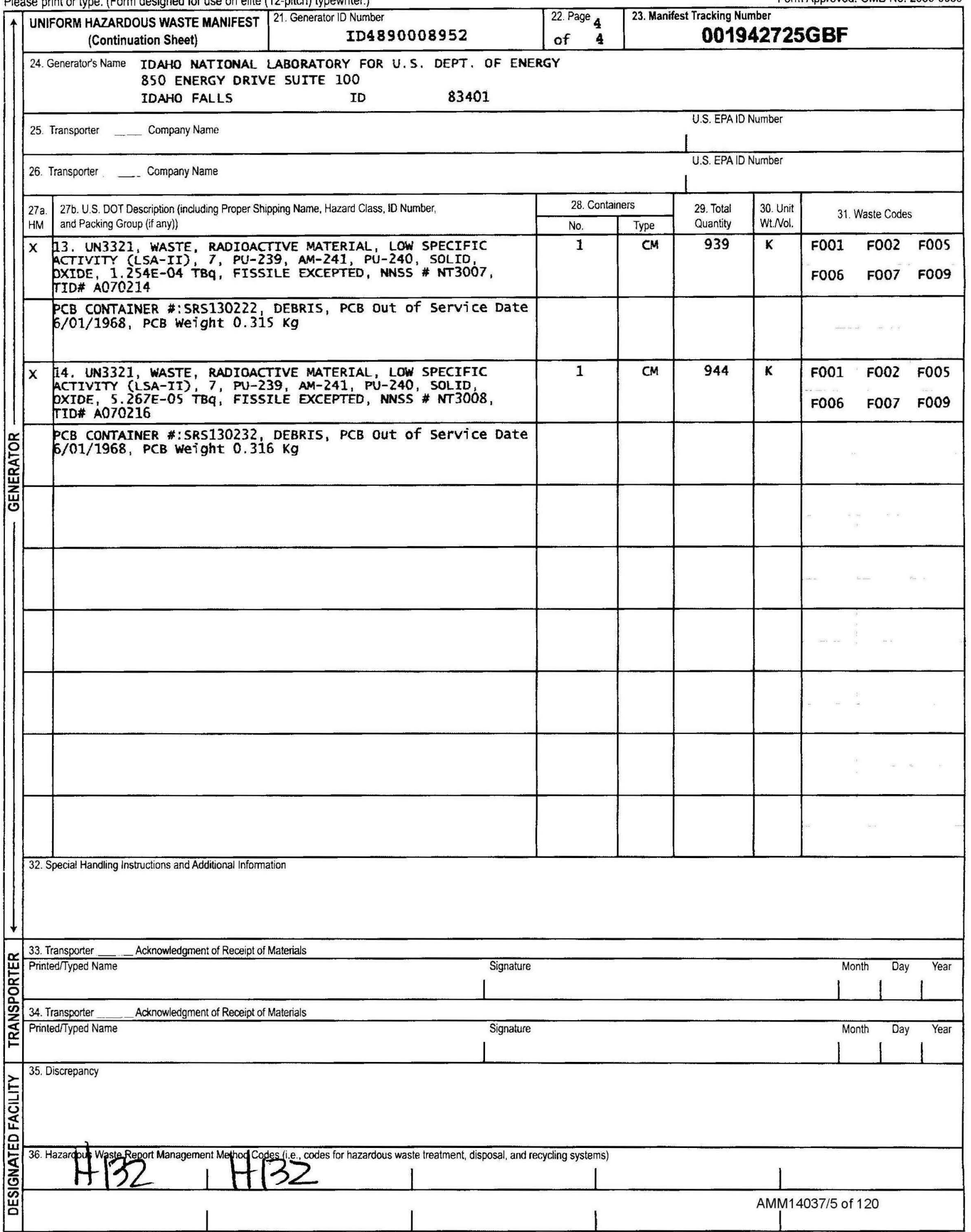


$\underset{\substack{\text { Nision. Senvice. Partnershio } \\ \text { Naty }}}{\text { Technologies LLc }}$

H000-PA-14-0113

August 4, 2014

Jared Dominick

Waste Certification Official

Idaho Treatment Group

850 Energy Drive, Suite 100

Idaho Falls, ID 83401

\section{Subject: CERTIFICATE OF DISPOSAL FOR POLYCHLORINATED} BIPHENYL (PCB) WASTE AT THE NEVADA NATIONAL SECURITY SITE RADIOACTIVE WASTE MANAGEMENT SITE (RWMS)

Enclosed is the certificate acknowledging disposal of manifested PCB shipments AMM14037 and AMM14038 in the Mixed Waste Disposal Unit, at the Nevada National Security Site RWMS.

If you have any questions, please contact me at 702-295-2261.<smiles>[Y10]C1CC12CC2</smiles><smiles>C=CC(=C)C1CCCC1</smiles>

Patrick M. Arnold, Division Manager

Environmental Management

RCD:saq

Enclosure: as stated

cc w/enc.

Correspondence Control

EWO Correspondence

J. T. Carilli, NNSA/NFO

R. C. Denton, NSTec

R. G. Geisinger, NSTec

M. Libidinsky, NNSA/NFO

C. P. Moke, NSTec

K. M. Small, NNSA/NFO

K. C. Tanaka, NSTec

A. V. Tauber, NNSA/NFO

R. A. Wagner, NSTec

National Security Technologies, LLC

Vision • Service - Partnership

WwW.NSTec.com

P.O. Box 98521, Las Vegas, NV 89193-8521

2621 Losee Road, N. Las Vegas, NV 89030-4129 
National Security Technologies LLC

For U.S. Department of Energy

Waste Management

Nevada National Security Site - Zone 2

Mercury, NV 89023

EPA ID NV3890090001

This Certificate acknowledges that the following shipment(s) of manifested

POLYCHLORINATED BIPHENYL (PCB) waste have been disposed at the Nevada National Security Site Radioactive Waste Management Site.

\begin{tabular}{|c|c|c|c|c|}
\hline $\begin{array}{c}\text { Shipment } \\
\text { Number }\end{array}$ & $\begin{array}{c}\text { Uniform Hazardous Waste } \\
\text { Manifest Number }\end{array}$ & Date(s) of Disposal & Volume $\mathbf{F t}^{\mathbf{3}}\left(\mathbf{m}^{\mathbf{3}}\right)$ & Disposal Process \\
\hline AMM14037 & $001942725 \mathrm{GBF}$ & $07 / 28 / 2014$ & $1,259.76(35.67)$ & Landfill \\
\hline AMM14038 & $001942726 \mathrm{GBF}$ & $07 / 28 / 2014$ & $1,259.79(35.67)$ & Landfill \\
\hline & & & & \\
\hline & & & & \\
\hline
\end{tabular}

Under civil and criminal penalties of law for the making or submission of false or fraudulent statements or representations (18 U.S.C. 1001 and 15 U.S.C. 2615), I certify that the information contained in or accompanying this document is true, accurate, and complete.

As to the identified section(s) of this document for which I cannot personally verify truth and accuracy, I certify as the company official having supervisory responsibility for the persons who, acting under my direct instructions, made the verification that this information is true, accurate, and complete.
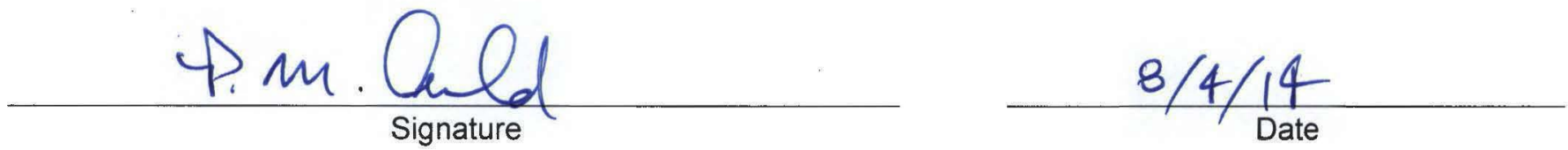

Division Manager, Environmental Management

$$
\text { Title }
$$

\section{Instructions:}

Shipment Number - enter shipment number from LWIS database.

Uniform Hazardous Waste Manifest Number - enter number from UHWM provided by generator.

Date of Disposal - enter date waste was placed in disposal cell.

Volume - enter shipment volume in cubic feet and equivalent cubic meters in parenthesis.

Disposal Process - enter Landfill. 
Please print or type. (Form designed for use on elite (12-pitch) typewriter.)

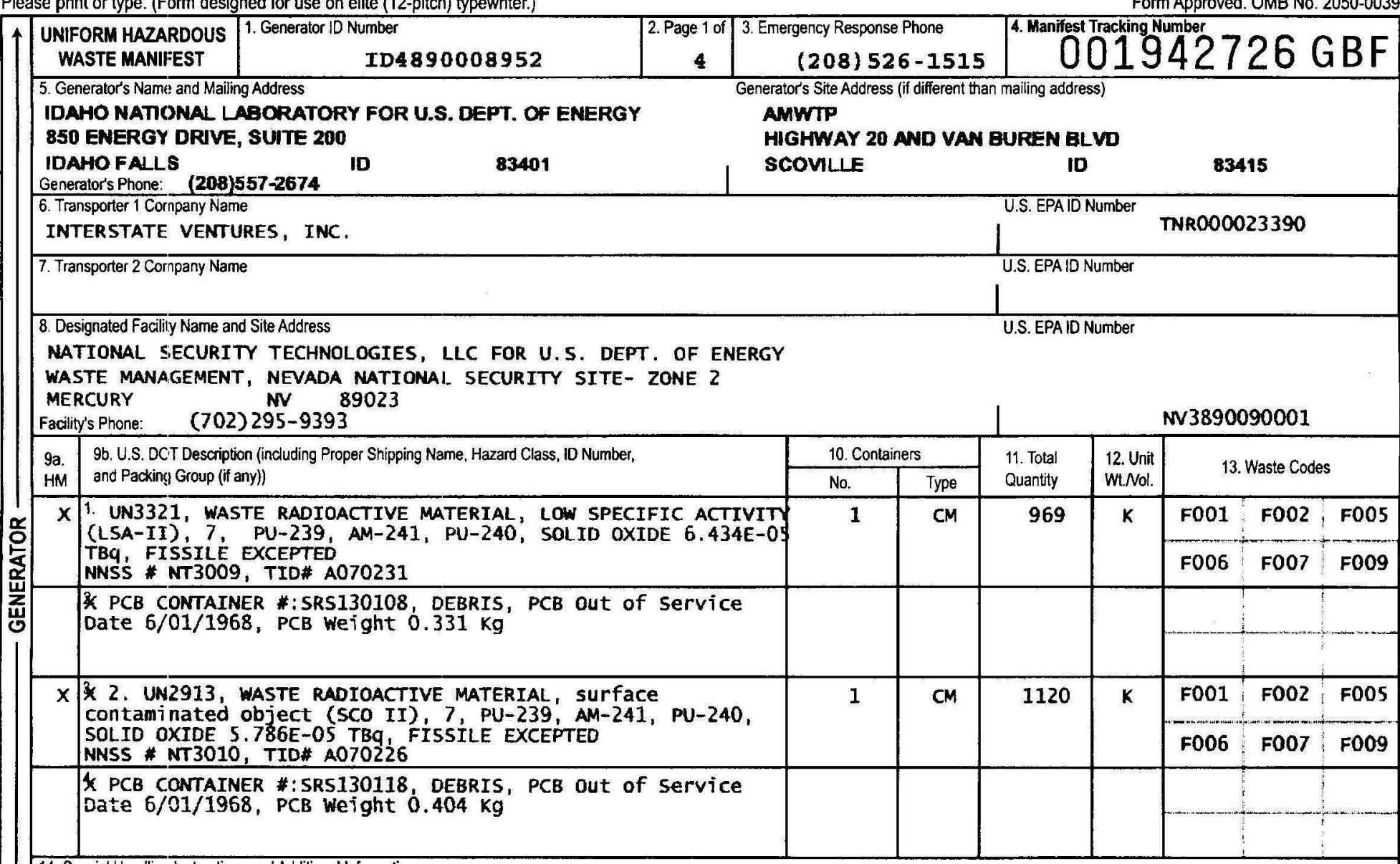

14. Special Handling Instructions and Additional Information

EXCLUSIVE USE SHIPMENT IF UNDELIVERABLE, SEE EXCLUSTVE USE INSTRUCTIONS

RETURN SIGNED ORIGINAL TO GENERATOR,

GROSS WEIGHT IN LBS: 30,093 TRACTOR \#1291 TRAILER \# 1013

PREPARED UNTER CONTRACT * DE-EM0001467

ERI PROVIDER- INL, WCC

SHIPMENT ID \# AMM14038

15. GENERATOR'S/OFFEROR'S CERTIFICATION: I hereby declare that the contents of this consignment are fully and accurately described above by the proper shipping name, and are classified, packaged, marked and lateled/placarded, and are in all respects in proper condition for transport according to applicable international and national governmental regulations. If export shipment and I am the Primary Exporter, I certify that the contents of this consignment conform to the terms of the attached EPAAcknowledgment of Consent.

I certify that the waste minimization statement identified in 40 CFR 262.27 (a) (if I am a large quantity generator) or (b) (if I am a small quantity generator) is true.

Generator's/Offerar's Printed/yped Name

Undy Pedersen - Camplied!

Transporter signature (for exports only):

17. Transporter Acknowledgment of Receipt of Materials

\section{Transpacter T Printed/Typed Name \\ RED

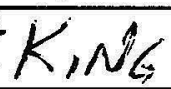

Transporter 2 Printed $/$ Typed Name

18. Discrepancy

18a. Discrepancy Inclication Space

$\square$ Quantity

$\square_{\text {Type }}$

$\square$ Residue

$\square$ Partial Rejection

Gull Rejection

8b. Alternate Facility (or Generator)

Manifest Reference Number

Month Day Year

Facility's Phone:

18c. Signature of Atternate Facility (or Generator)

$\square$ Export from U.S. Port of entrylexit:

Port of entrylexit:
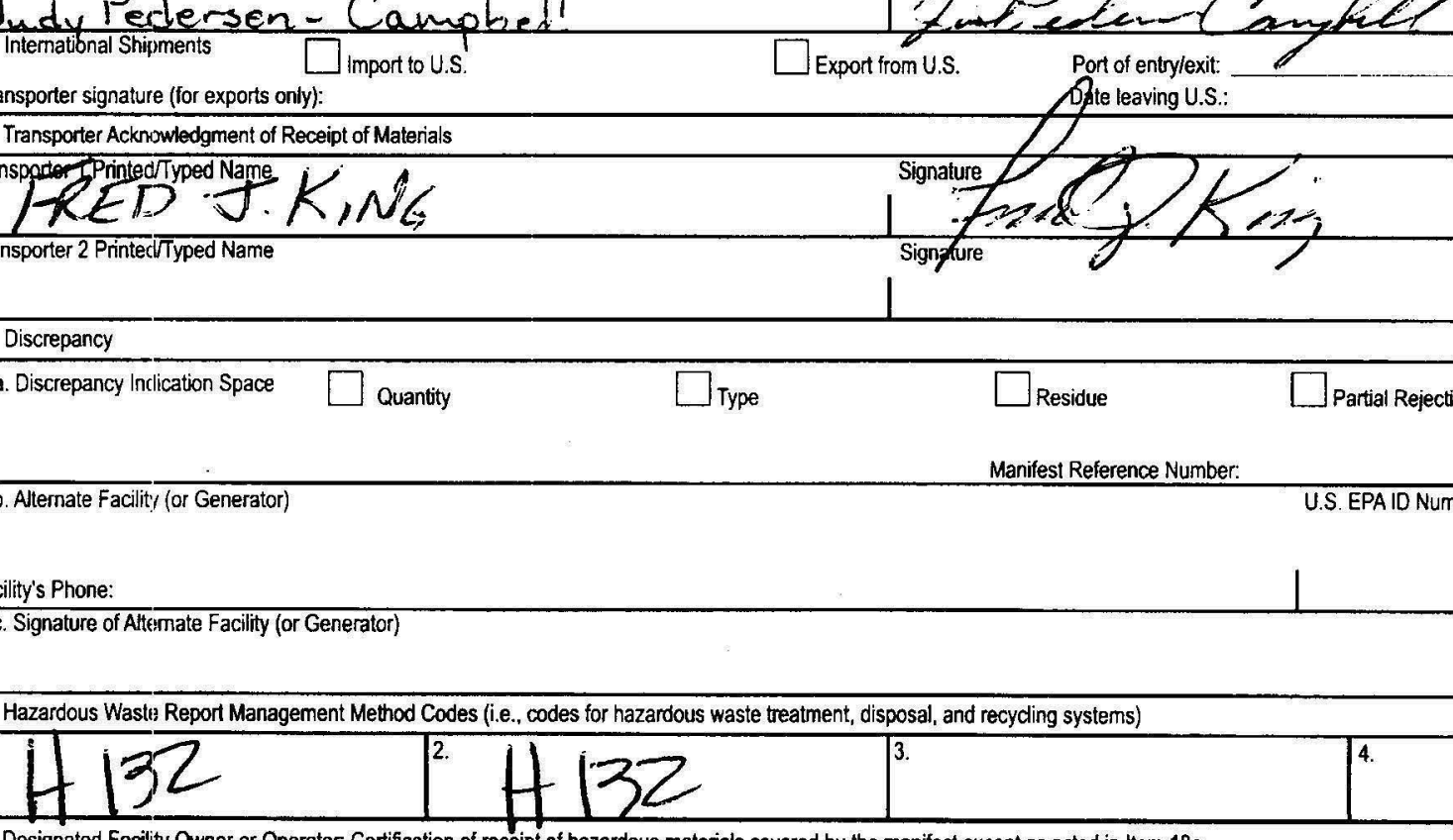

\begin{tabular}{|c|c|}
4 & \\
\hline
\end{tabular}

20. Designated Facility Owner or Operator. Certification of receipt of hazardous materials covered by the manifest except as nded in Item $18 \mathrm{a}$

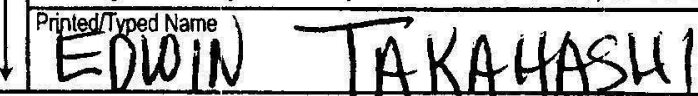

EPA Form 8700-22 (Rev. 3-05) Previous editions are obsolete.

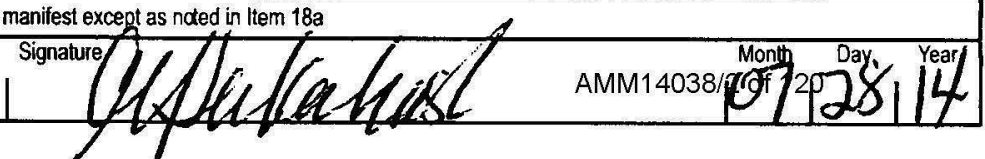




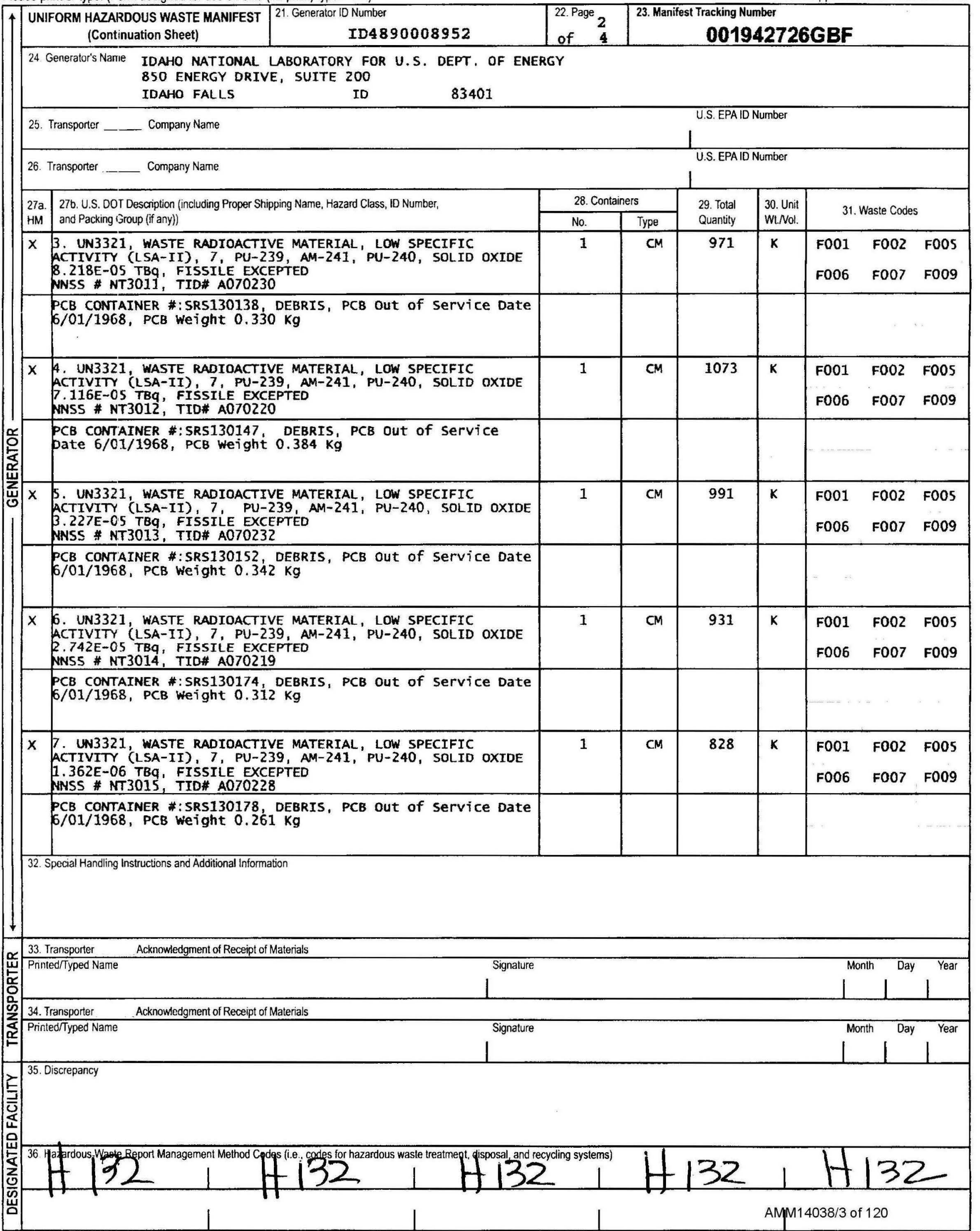




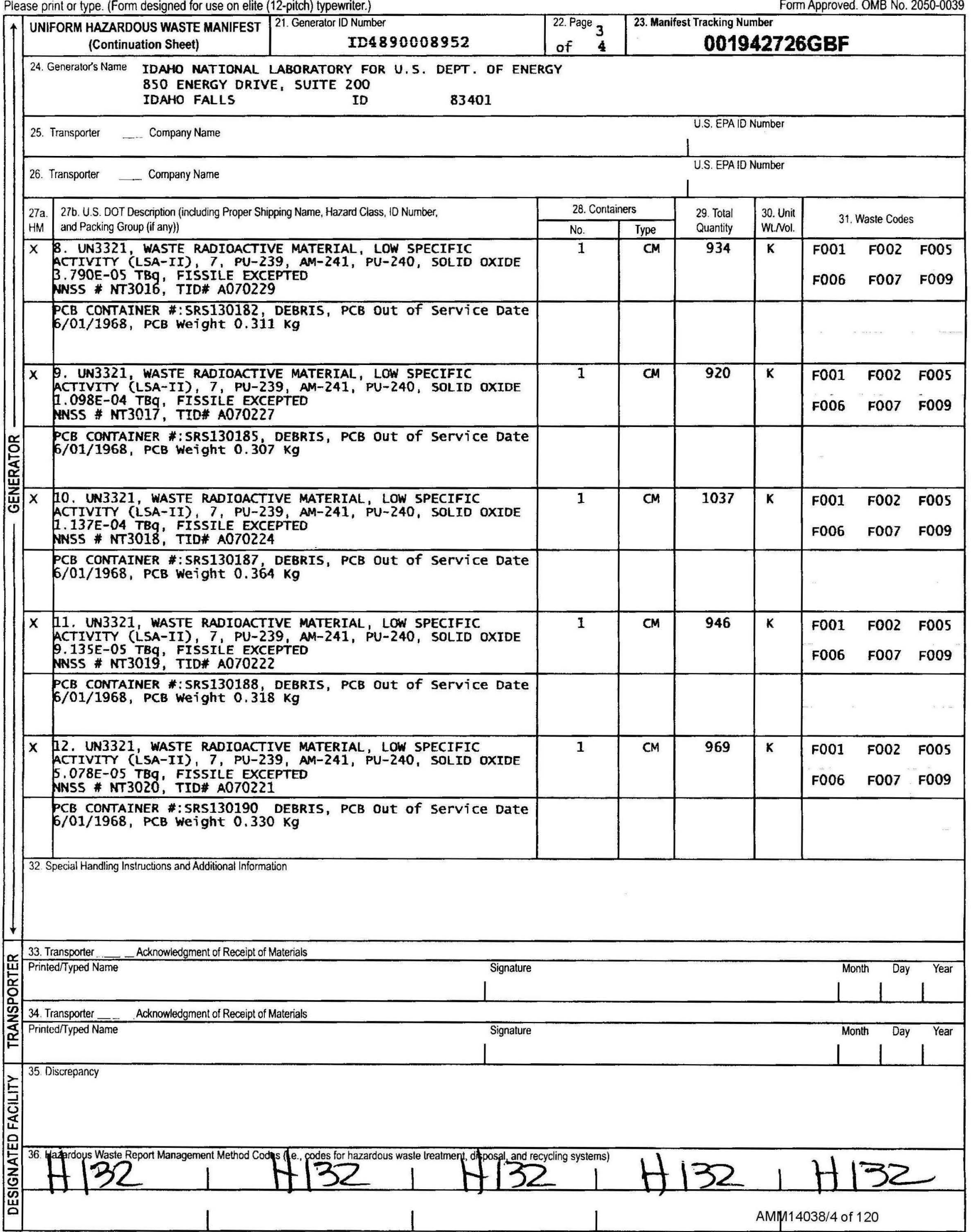


Please print or type. (Form designed for use on elite (12-pitch) typewriter.)

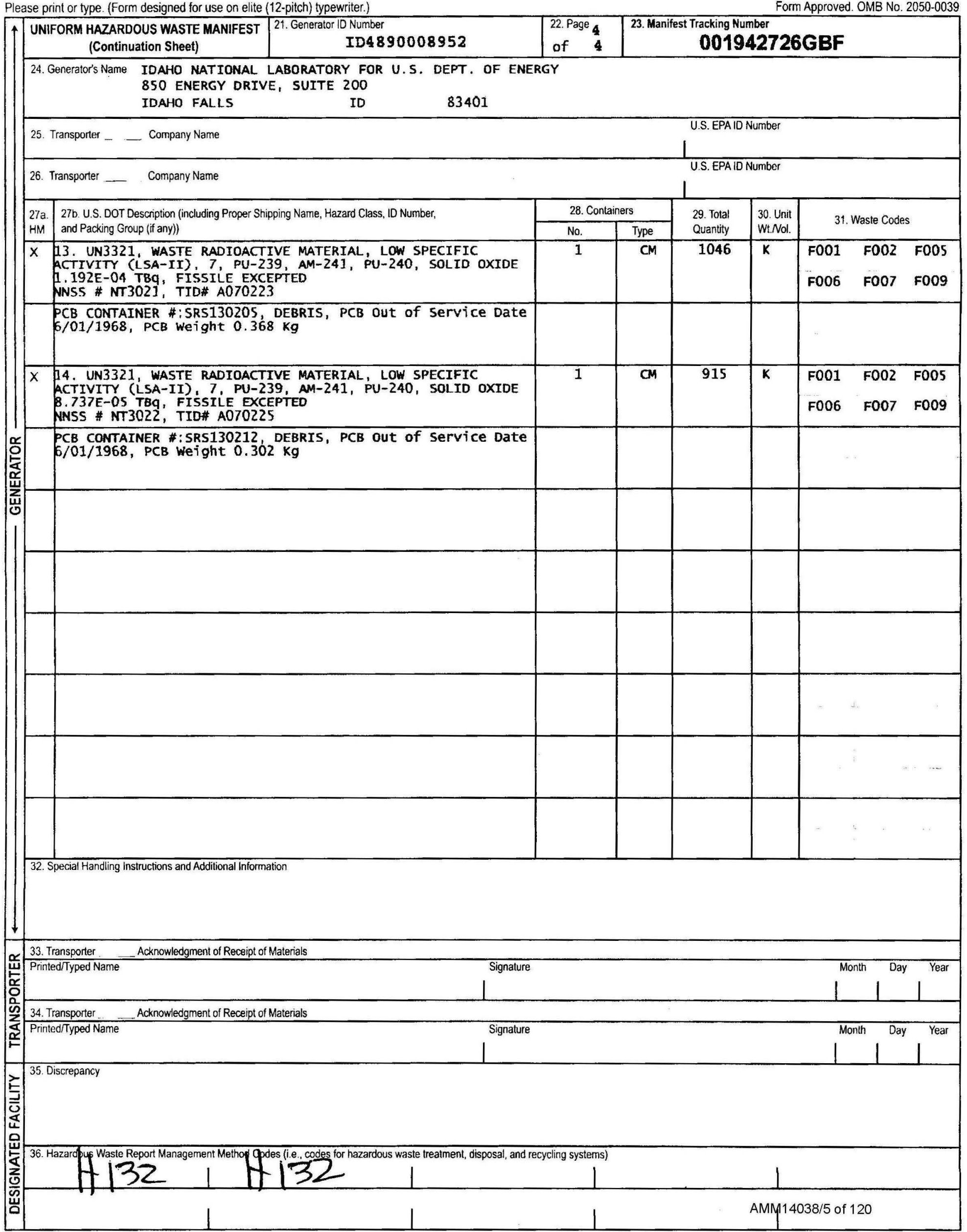


$\underset{\substack{\text { Nision. Senvice. Partnershio } \\ \text { Naty }}}{\text { Technologies LLc }}$

H000-PA-14-0113

August 4, 2014

Jared Dominick

Waste Certification Official

Idaho Treatment Group

850 Energy Drive, Suite 100

Idaho Falls, ID 83401

\section{Subject: CERTIFICATE OF DISPOSAL FOR POLYCHLORINATED} BIPHENYL (PCB) WASTE AT THE NEVADA NATIONAL SECURITY SITE RADIOACTIVE WASTE MANAGEMENT SITE (RWMS)

Enclosed is the certificate acknowledging disposal of manifested PCB shipments AMM14037 and AMM14038 in the Mixed Waste Disposal Unit, at the Nevada National Security Site RWMS.

If you have any questions, please contact me at 702-295-2261.<smiles>[Y10]C1CC12CC2</smiles><smiles>C=CC(=C)C1CCCC1</smiles>

Patrick M. Arnold, Division Manager

Environmental Management

RCD:saq

Enclosure: as stated

cc w/enc.

Correspondence Control

EWO Correspondence

J. T. Carilli, NNSA/NFO

R. C. Denton, NSTec

R. G. Geisinger, NSTec

M. Libidinsky, NNSA/NFO

C. P. Moke, NSTec

K. M. Small, NNSA/NFO

K. C. Tanaka, NSTec

A. V. Tauber, NNSA/NFO

R. A. Wagner, NSTec

National Security Technologies, LLC

Vision • Service - Partnership

WwW.NSTec.com

P.O. Box 98521, Las Vegas, NV 89193-8521

2621 Losee Road, N. Las Vegas, NV 89030-4129 
National Security Technologies LLC

For U.S. Department of Energy

Waste Management

Nevada National Security Site - Zone 2

Mercury, NV 89023

EPA ID NV3890090001

This Certificate acknowledges that the following shipment(s) of manifested

POLYCHLORINATED BIPHENYL (PCB) waste have been disposed at the Nevada National Security Site Radioactive Waste Management Site.

\begin{tabular}{|c|c|c|c|c|}
\hline $\begin{array}{c}\text { Shipment } \\
\text { Number }\end{array}$ & $\begin{array}{c}\text { Uniform Hazardous Waste } \\
\text { Manifest Number }\end{array}$ & Date(s) of Disposal & Volume $\mathbf{F t}^{\mathbf{3}}\left(\mathbf{m}^{\mathbf{3}}\right)$ & Disposal Process \\
\hline AMM14037 & $001942725 \mathrm{GBF}$ & $07 / 28 / 2014$ & $1,259.76(35.67)$ & Landfill \\
\hline AMM14038 & $001942726 \mathrm{GBF}$ & $07 / 28 / 2014$ & $1,259.79(35.67)$ & Landfill \\
\hline & & & & \\
\hline & & & & \\
\hline
\end{tabular}

Under civil and criminal penalties of law for the making or submission of false or fraudulent statements or representations (18 U.S.C. 1001 and 15 U.S.C. 2615), I certify that the information contained in or accompanying this document is true, accurate, and complete.

As to the identified section(s) of this document for which I cannot personally verify truth and accuracy, I certify as the company official having supervisory responsibility for the persons who, acting under my direct instructions, made the verification that this information is true, accurate, and complete.
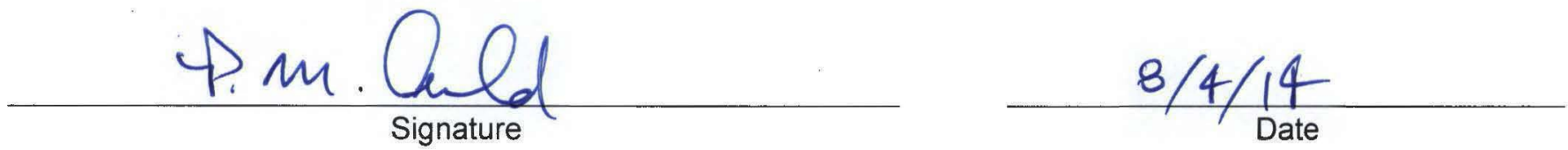

Division Manager, Environmental Management

$$
\text { Title }
$$

\section{Instructions:}

Shipment Number - enter shipment number from LWIS database.

Uniform Hazardous Waste Manifest Number - enter number from UHWM provided by generator.

Date of Disposal - enter date waste was placed in disposal cell.

Volume - enter shipment volume in cubic feet and equivalent cubic meters in parenthesis.

Disposal Process - enter Landfill. 
Please print or type. (Form designed for use on elite (12-pitch) typewriter.)

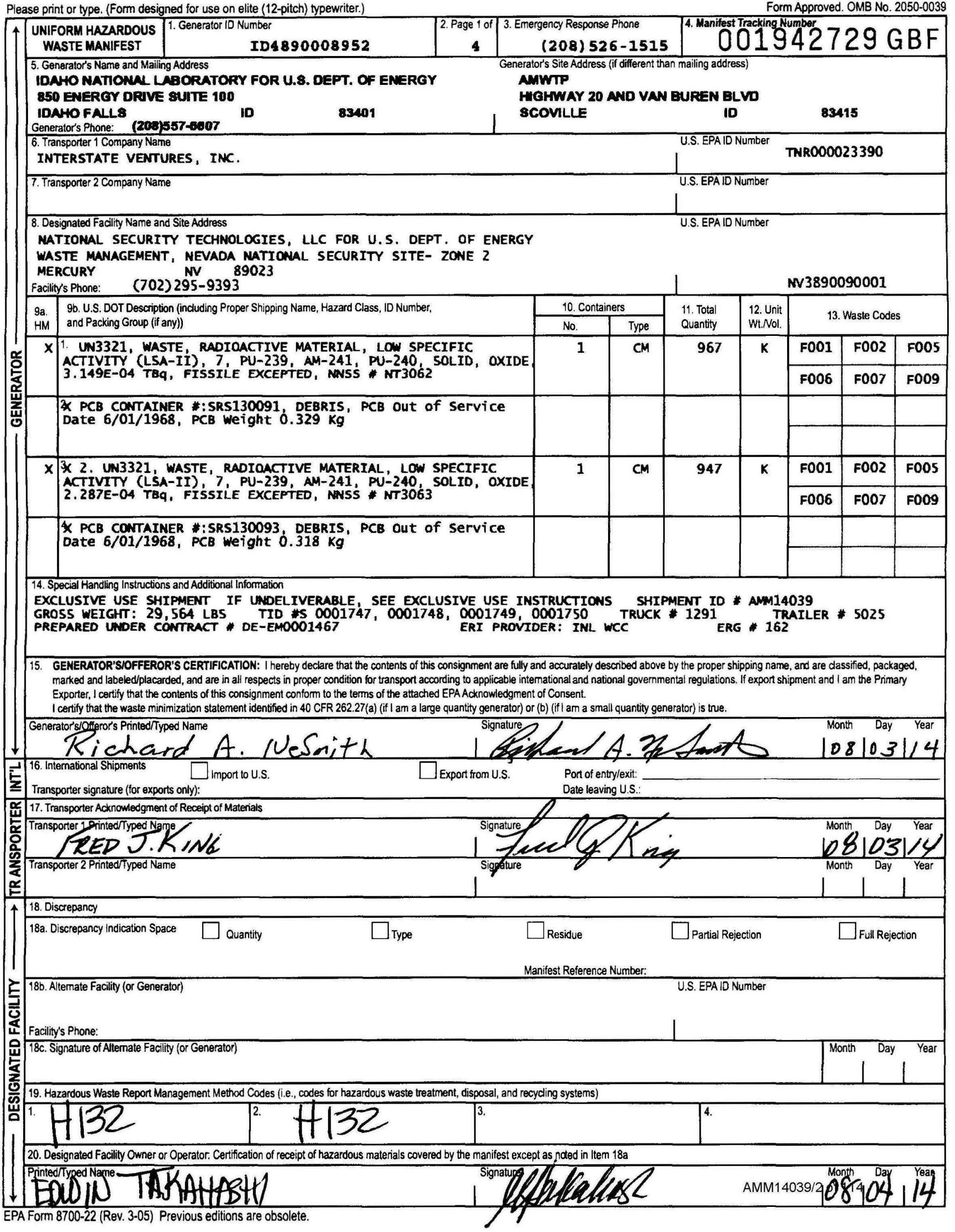


Please print or type. (Form designed for use on elite (12-pitch) typewriter.)

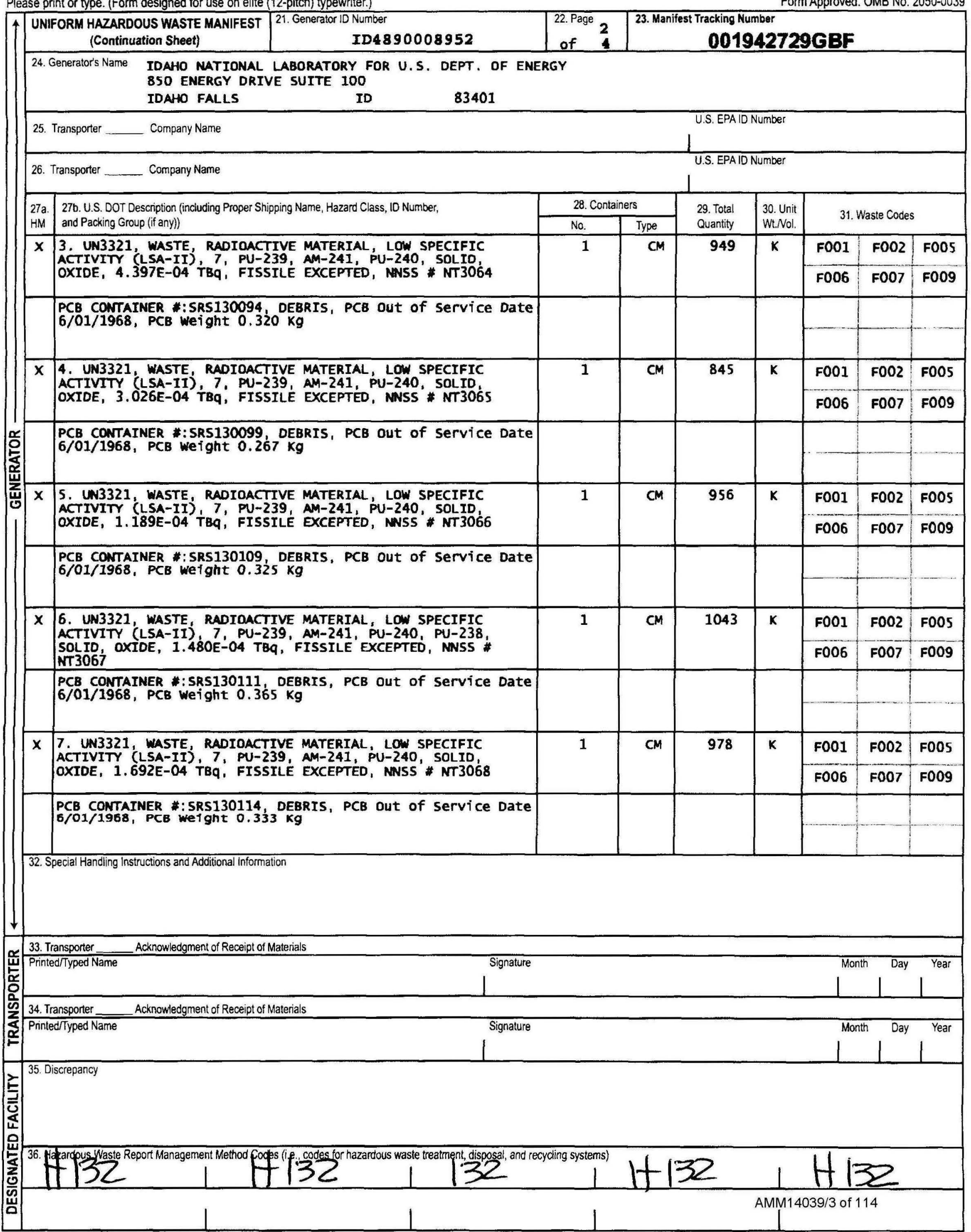


Please print or type. (Form designed for use on elite (12-pitch) typewriter.)

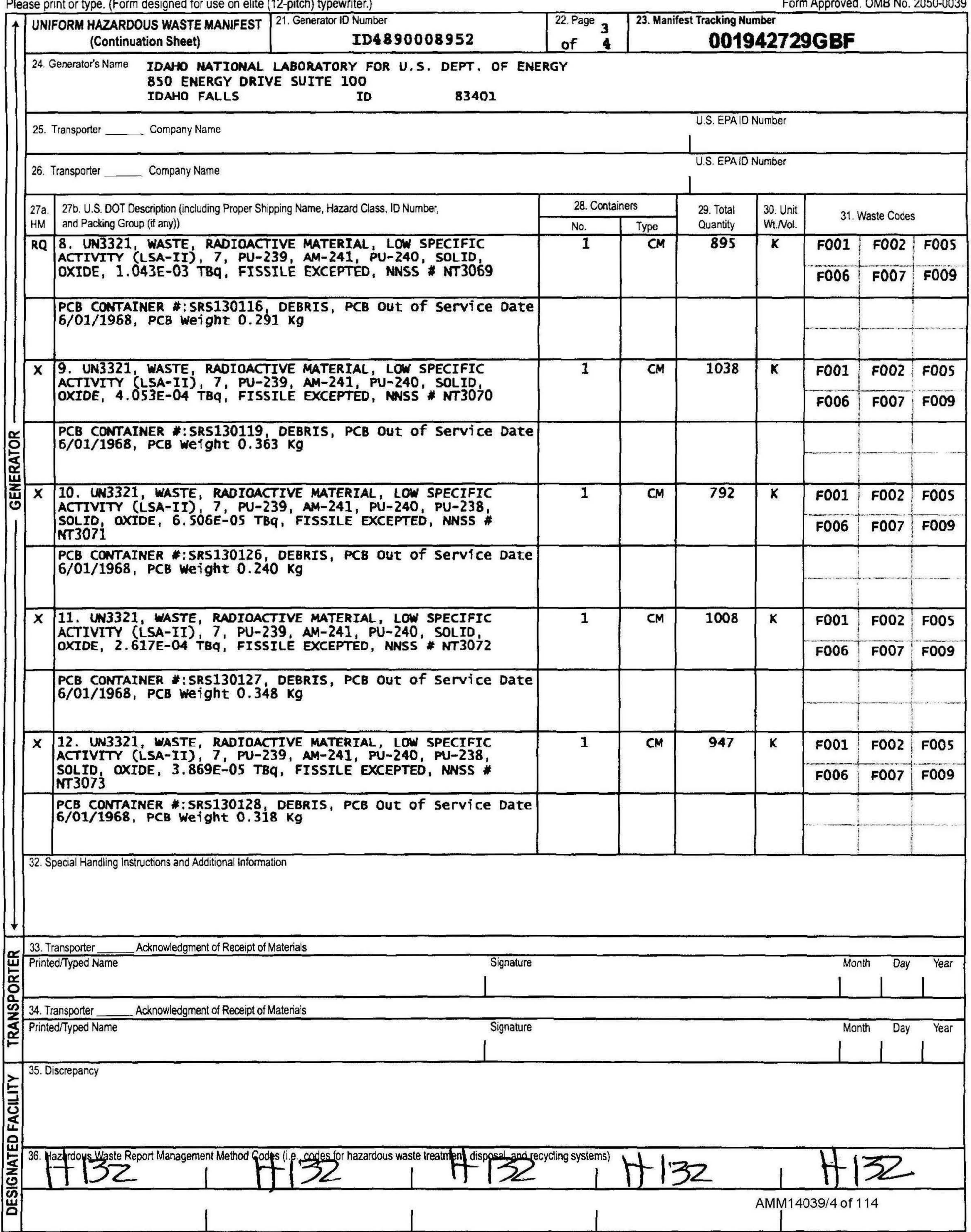


Please print or type. (Form designed for use on elite (12-pitch) typewriter.)

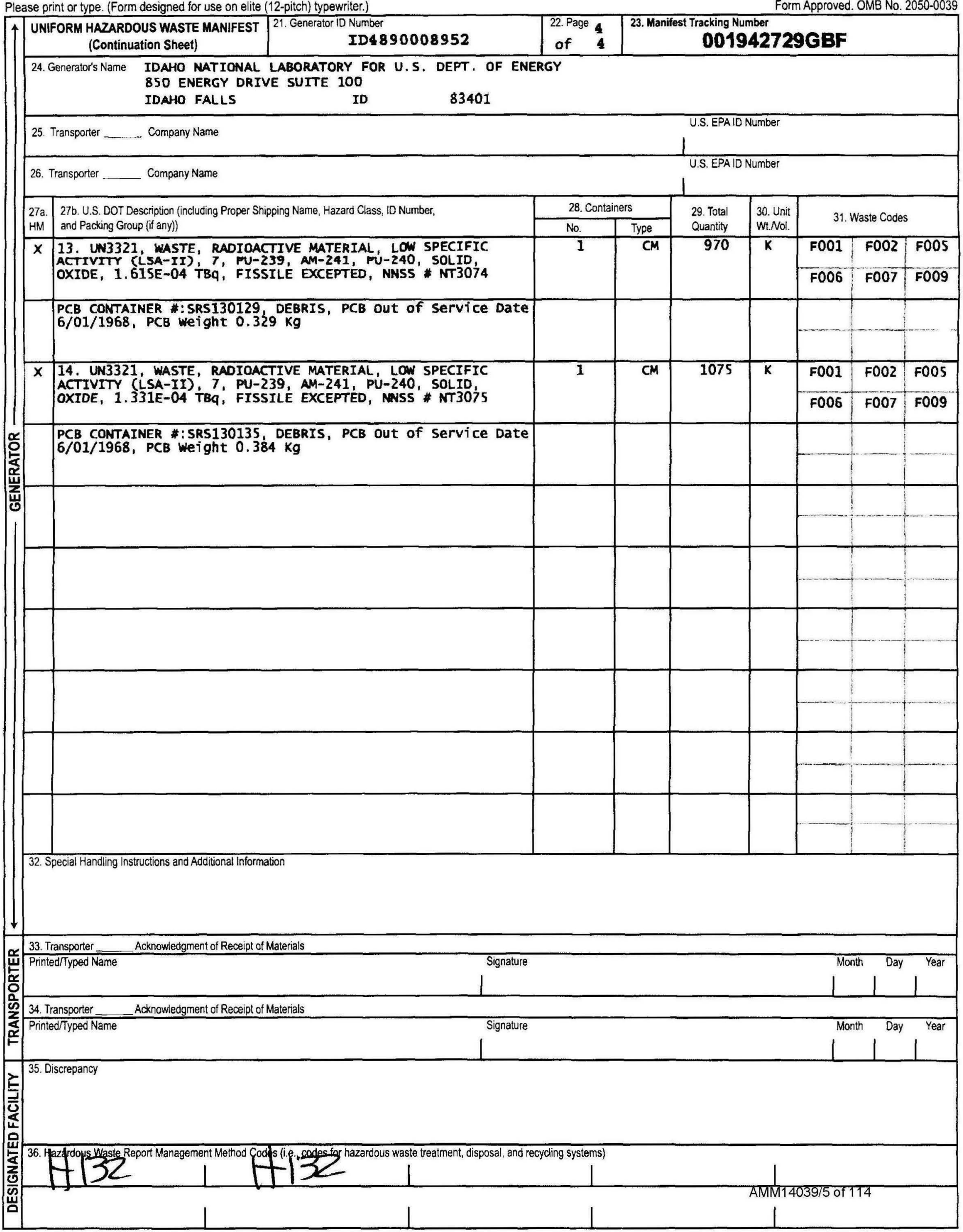


National Security Technologies LLe

Vision. Service - Partnership

H000-PA-14-0119

August 11, 2014

Jared Dominick

Waste Certification Official

Idaho Treatment Group

850 Energy Drive, Suite 100

Idaho Falls, ID 83401-1502

Subject: CERTIFICATE OF DISPOSAL FOR POLYCHLORINATED BIPHENYL (PCB) WASTE AT THE NEVADA NATIONAL SECURITY SITE RADIOACTIVE WASTE MANAGEMENT SITE (RWMS)

Enclosed is the certificate acknowledging disposal of manifested PCB shipments AMM14039, AMM14040 and AMM14041 in the Mixed Waste Disposal Unit, at the Nevada National Security Site RWMS.

If you have any questions, please contact me at 702-295-2261.<smiles>CC1(CCCCC2CC2(C)C)CC1</smiles><smiles>CC(CC1CCCCC1)CC1CCCCC1C</smiles>

Patrick M. Arnold, Division Manager

Environmental Management

LBG:saq

Enclosure: as stated

cc w/enc.

Correspondence Control

EWO Correspondence

J. T. Carilli, NNSA/NFO

R. C. Denton, NSTec

R. G. Geisinger, NSTec

L. B. Gregory, NSTec

M. Libidinsky, NNSA/NFO

C. P. Moke, NSTec

K. M. Small, NNSA/NFO

K. C. Tanaka, NSTec

A. V. Tauber, NNSA/NFO

R. A. Wagner, NSTec

National Security Technologies, LLC

Vision - Service - Partnership

www.NSTeC.com

P.O. Box 98521, Las Vegas, NV 89193-8521

2621 Losee Road, N. Las Vegas, NV 89030-4129 
National Security Technologies LLC

For U.S. Department of Energy

Waste Management

Nevada National Security Site - Zone 2

Mercury, NV 89023

EPA ID NV3890090001

This Certificate acknowledges that the following shipment(s) of manifested POLYCHLORINATED BIPHENYL (PCB) waste have been disposed at the Nevada National Security Site Radioactive Waste Management Site.

\begin{tabular}{|c|c|c|c|c|}
\hline $\begin{array}{c}\text { Shipment } \\
\text { Number }\end{array}$ & $\begin{array}{c}\text { Uniform Hazardous Waste } \\
\text { Manifest Number }\end{array}$ & Date(s) of Disposal & Volume $\mathbf{F t}^{\mathbf{3}}\left(\mathbf{m}^{\mathbf{3}}\right)$ & Disposal Process \\
\hline AMM14039 & $001942729 \mathrm{GBF}$ & $08 / 04 / 2014$ & $1,259.76(35.67)$ & Landfill \\
\hline AMM14040 & $001942730 \mathrm{GBF}$ & $08 / 07 / 2014$ & $1,259.76(35.67)$ & Landfill \\
\hline AMM14041 & $001942731 \mathrm{GBF}$ & $08 / 04 / 2014$ & $1,259.76(35.67)$ & Landfill \\
\hline & & & & \\
\hline
\end{tabular}

Under civil and criminal penalties of law for the making or submission of false or fraudulent statements or representations (18 U.S.C. 1001 and 15 U.S.C. 2615), I certify that the information contained in or accompanying this document is true, accurate, and complete.

As to the identified section(s) of this document for which I cannot personally verify truth and accuracy, I certify as the company official having supervisory responsibility for the persons who, acting under my direct instructions, made the verification that this information is true, accurate, and complete.
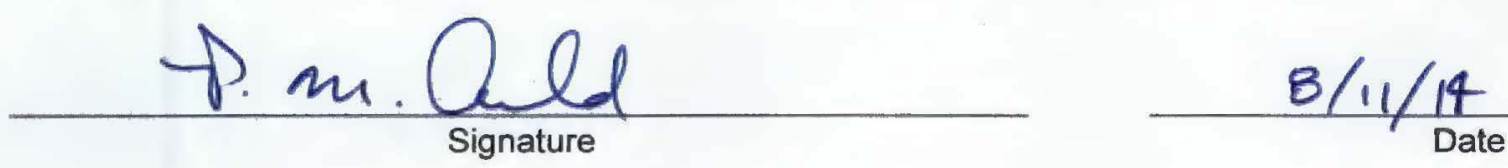

Division Manager, Environmental Management

Title

Instructions:

Shipment Number - enter shipment number from LWIS database.

Uniform Hazardous Waste Manifest Number - enter number from UHWM provided by generator.

Date of Disposal - enter date waste was placed in disposal cell.

Volume - enter shipment volume in cubic feet and equivalent cubic meters in parenthesis.

Disposal Process - enter Landfill.

National Security Technologies, LLC

Vision - Service - Partnership

mWw.NSTEC.COm.

P.O. Box 98521, Las Vegas, NV 89193-8521

2621 Losee Road, N. Las Vegas, NV 89030-4129 
Please print or type. (Form designed for use on elite (12-pitch) typewriter.)

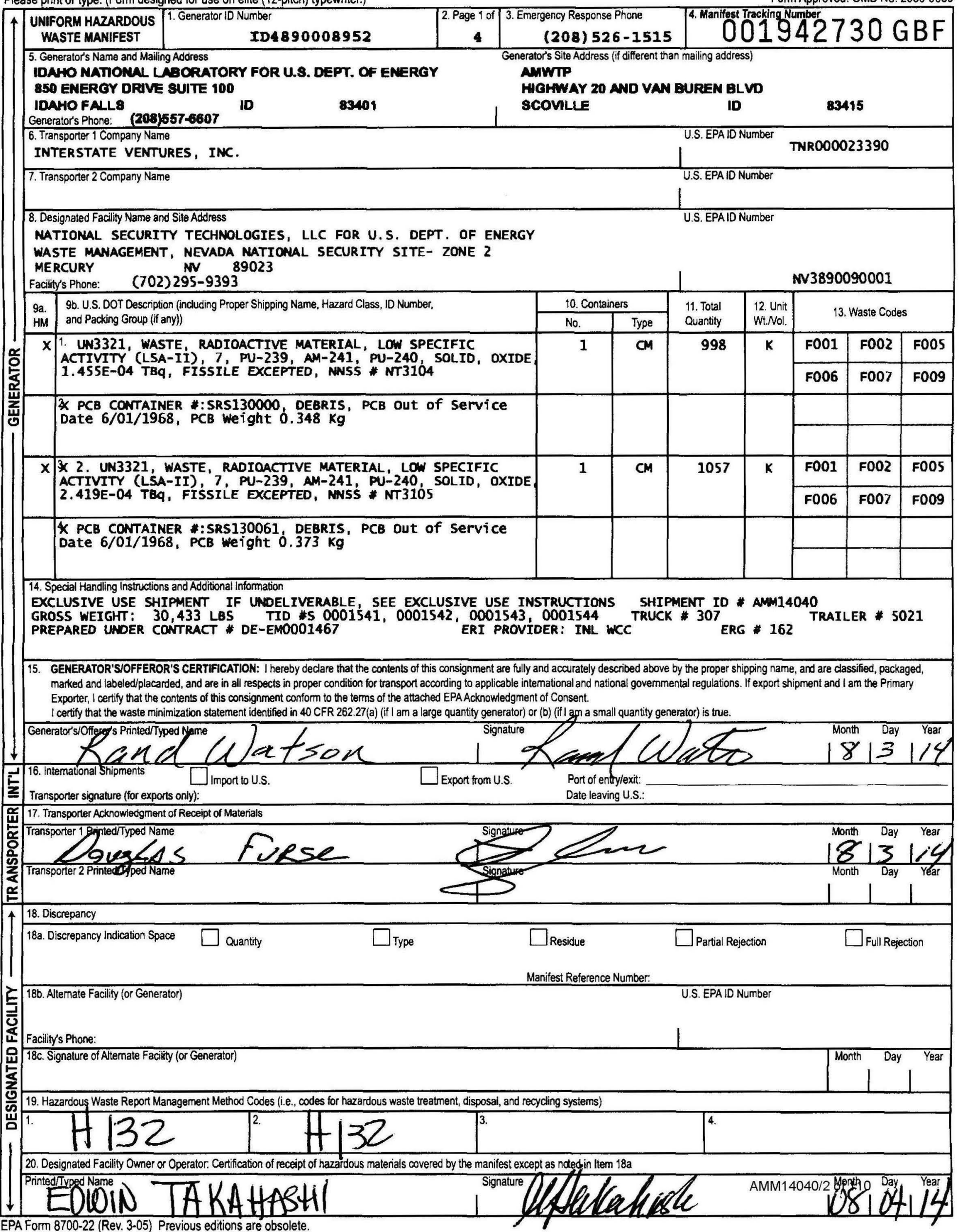




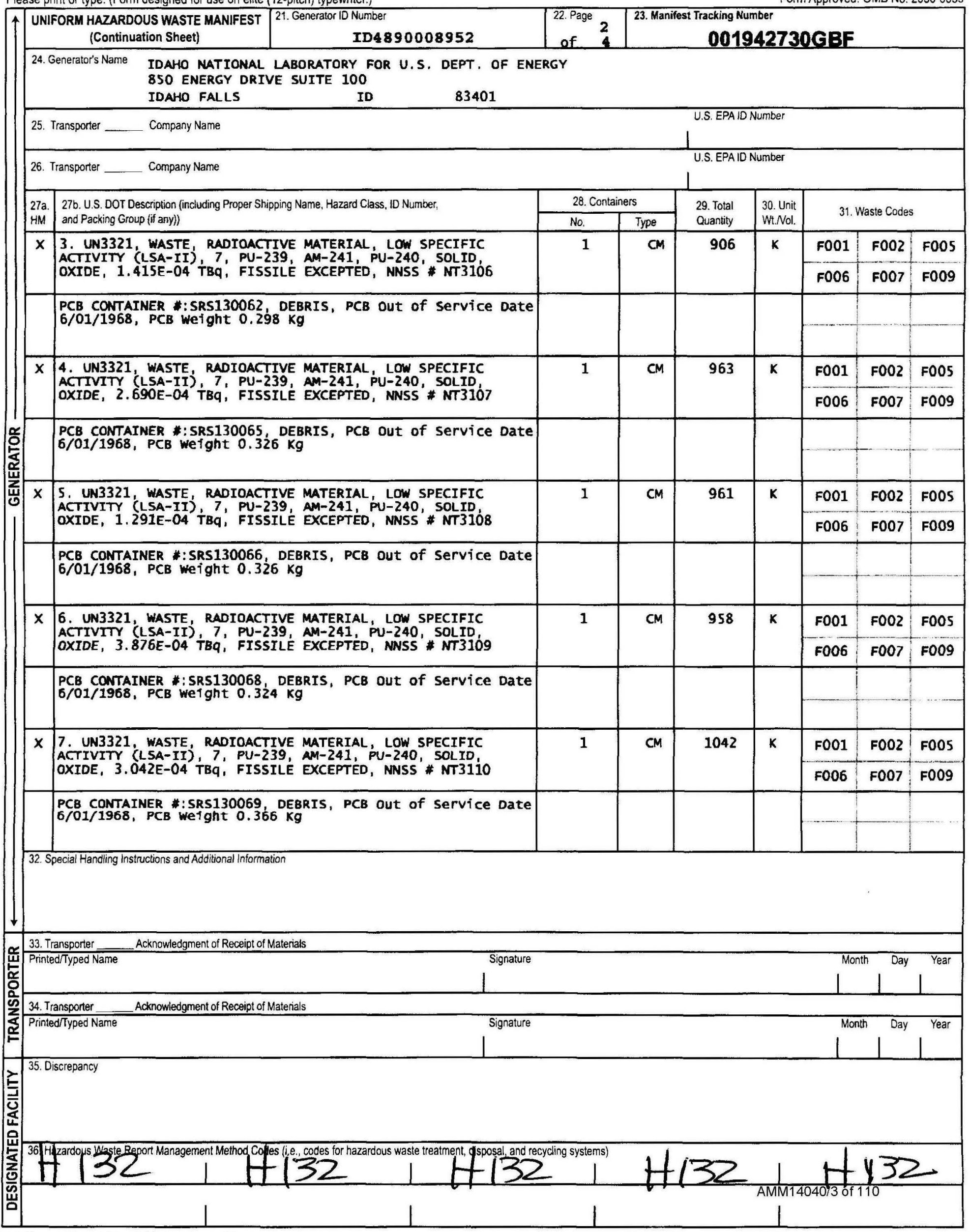


Please print or type. (Form designed for use on elite (12-pitch) typewriter.)

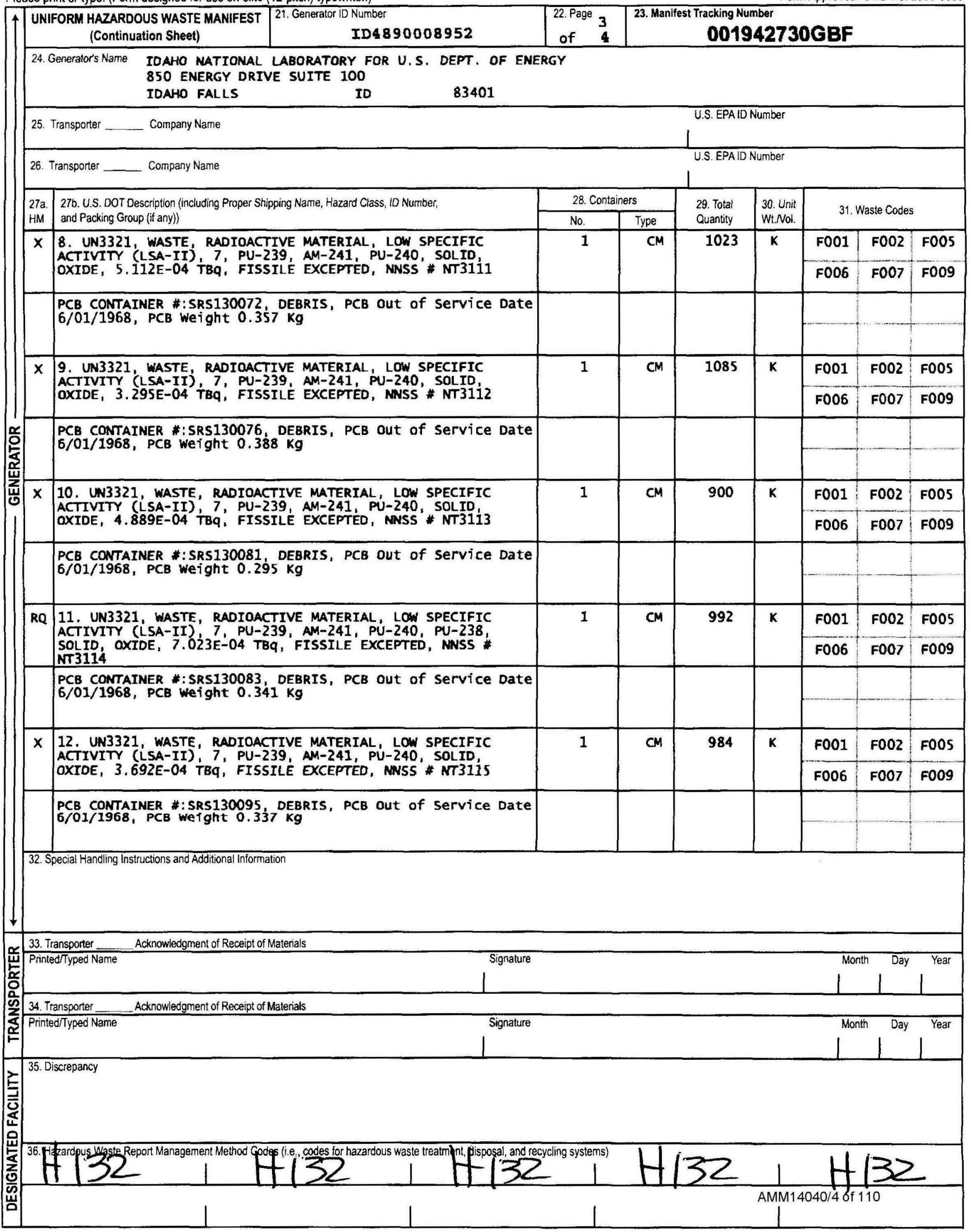


Please print or type. (Form designed for use on elite (12-pitch) typewriter.)

Form Approved. OMB No. 2050-0039

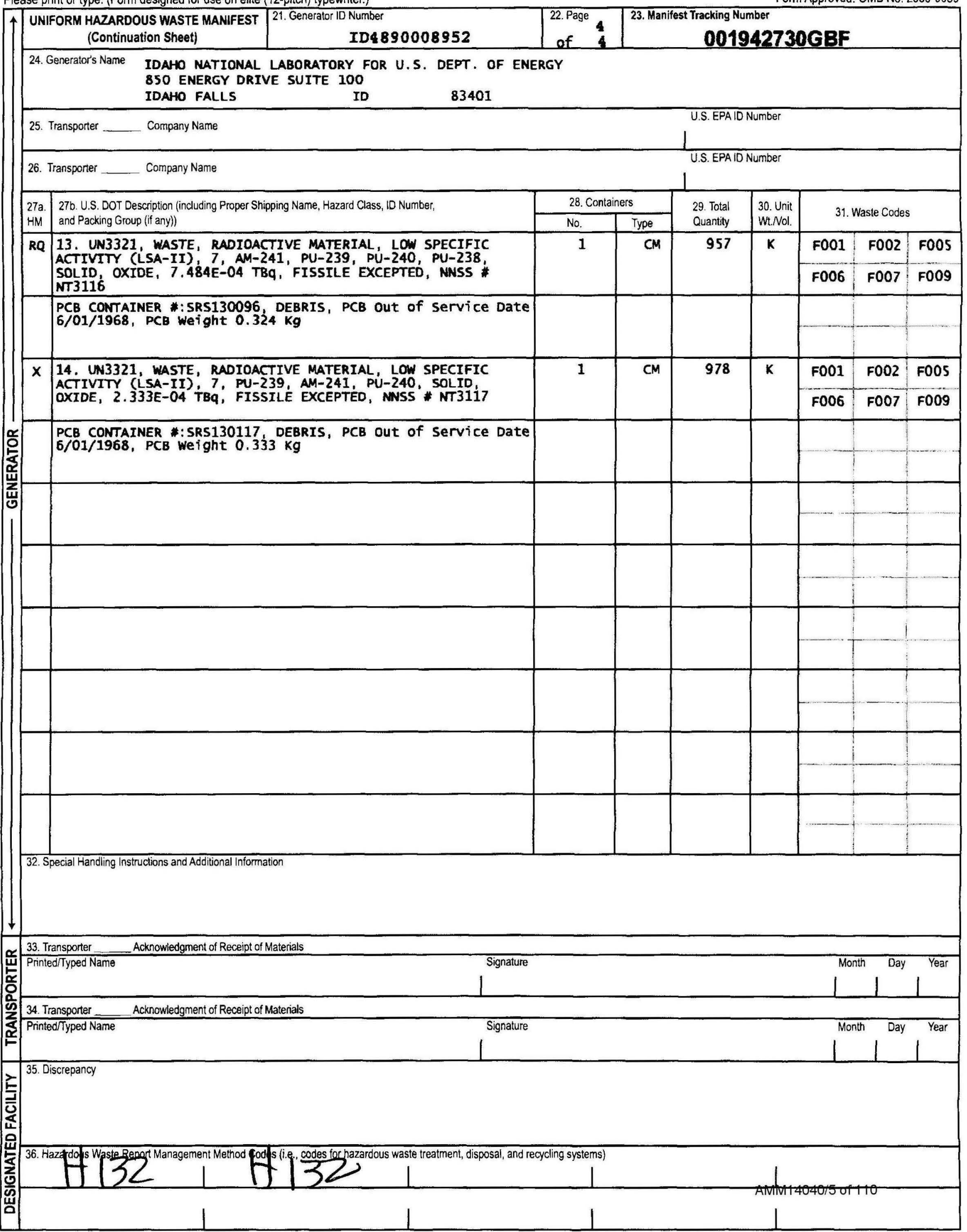


National Security Technologies LLe

Vision. Service - Partnership

H000-PA-14-0119

August 11, 2014

Jared Dominick

Waste Certification Official

Idaho Treatment Group

850 Energy Drive, Suite 100

Idaho Falls, ID 83401-1502

Subject: CERTIFICATE OF DISPOSAL FOR POLYCHLORINATED BIPHENYL (PCB) WASTE AT THE NEVADA NATIONAL SECURITY SITE RADIOACTIVE WASTE MANAGEMENT SITE (RWMS)

Enclosed is the certificate acknowledging disposal of manifested PCB shipments AMM14039, AMM14040 and AMM14041 in the Mixed Waste Disposal Unit, at the Nevada National Security Site RWMS.

If you have any questions, please contact me at 702-295-2261.<smiles>CC1(CCCCC2CC2(C)C)CC1</smiles><smiles>CC(CC1CCCCC1)CC1CCCCC1C</smiles>

Patrick M. Arnold, Division Manager

Environmental Management

LBG:saq

Enclosure: as stated

cc w/enc.

Correspondence Control

EWO Correspondence

J. T. Carilli, NNSA/NFO

R. C. Denton, NSTec

R. G. Geisinger, NSTec

L. B. Gregory, NSTec

M. Libidinsky, NNSA/NFO

C. P. Moke, NSTec

K. M. Small, NNSA/NFO

K. C. Tanaka, NSTec

A. V. Tauber, NNSA/NFO

R. A. Wagner, NSTec

National Security Technologies, LLC

Vision - Service - Partnership

www.NSTeC.com

P.O. Box 98521, Las Vegas, NV 89193-8521

2621 Losee Road, N. Las Vegas, NV 89030-4129 
National Security Technologies LLC

For U.S. Department of Energy

Waste Management

Nevada National Security Site - Zone 2

Mercury, NV 89023

EPA ID NV3890090001

This Certificate acknowledges that the following shipment(s) of manifested POLYCHLORINATED BIPHENYL (PCB) waste have been disposed at the Nevada National Security Site Radioactive Waste Management Site.

\begin{tabular}{|c|c|c|c|c|}
\hline $\begin{array}{c}\text { Shipment } \\
\text { Number }\end{array}$ & $\begin{array}{c}\text { Uniform Hazardous Waste } \\
\text { Manifest Number }\end{array}$ & Date(s) of Disposal & Volume $\mathbf{F t}^{\mathbf{3}}\left(\mathbf{m}^{\mathbf{3}}\right)$ & Disposal Process \\
\hline AMM14039 & $001942729 \mathrm{GBF}$ & $08 / 04 / 2014$ & $1,259.76(35.67)$ & Landfill \\
\hline AMM14040 & $001942730 \mathrm{GBF}$ & $08 / 07 / 2014$ & $1,259.76(35.67)$ & Landfill \\
\hline AMM14041 & $001942731 \mathrm{GBF}$ & $08 / 04 / 2014$ & $1,259.76(35.67)$ & Landfill \\
\hline & & & & \\
\hline
\end{tabular}

Under civil and criminal penalties of law for the making or submission of false or fraudulent statements or representations (18 U.S.C. 1001 and 15 U.S.C. 2615), I certify that the information contained in or accompanying this document is true, accurate, and complete.

As to the identified section(s) of this document for which I cannot personally verify truth and accuracy, I certify as the company official having supervisory responsibility for the persons who, acting under my direct instructions, made the verification that this information is true, accurate, and complete.
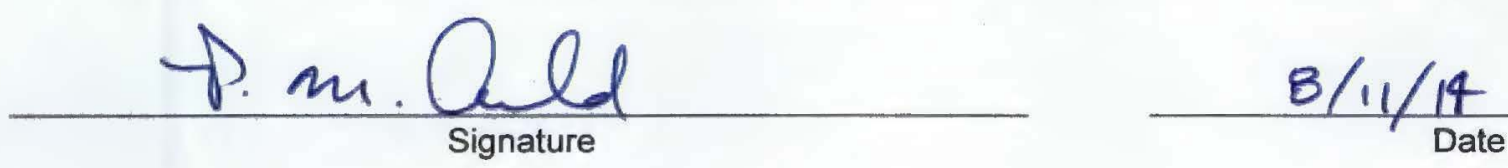

Division Manager, Environmental Management

Title

Instructions:

Shipment Number - enter shipment number from LWIS database.

Uniform Hazardous Waste Manifest Number - enter number from UHWM provided by generator.

Date of Disposal - enter date waste was placed in disposal cell.

Volume - enter shipment volume in cubic feet and equivalent cubic meters in parenthesis.

Disposal Process - enter Landfill.

National Security Technologies, LLC

Vision - Service - Partnership

mWw.NSTEC.COm.

P.O. Box 98521, Las Vegas, NV 89193-8521

2621 Losee Road, N. Las Vegas, NV 89030-4129 
Please print or type. (Form designed for use on elite (12-pitch) typewriter.)

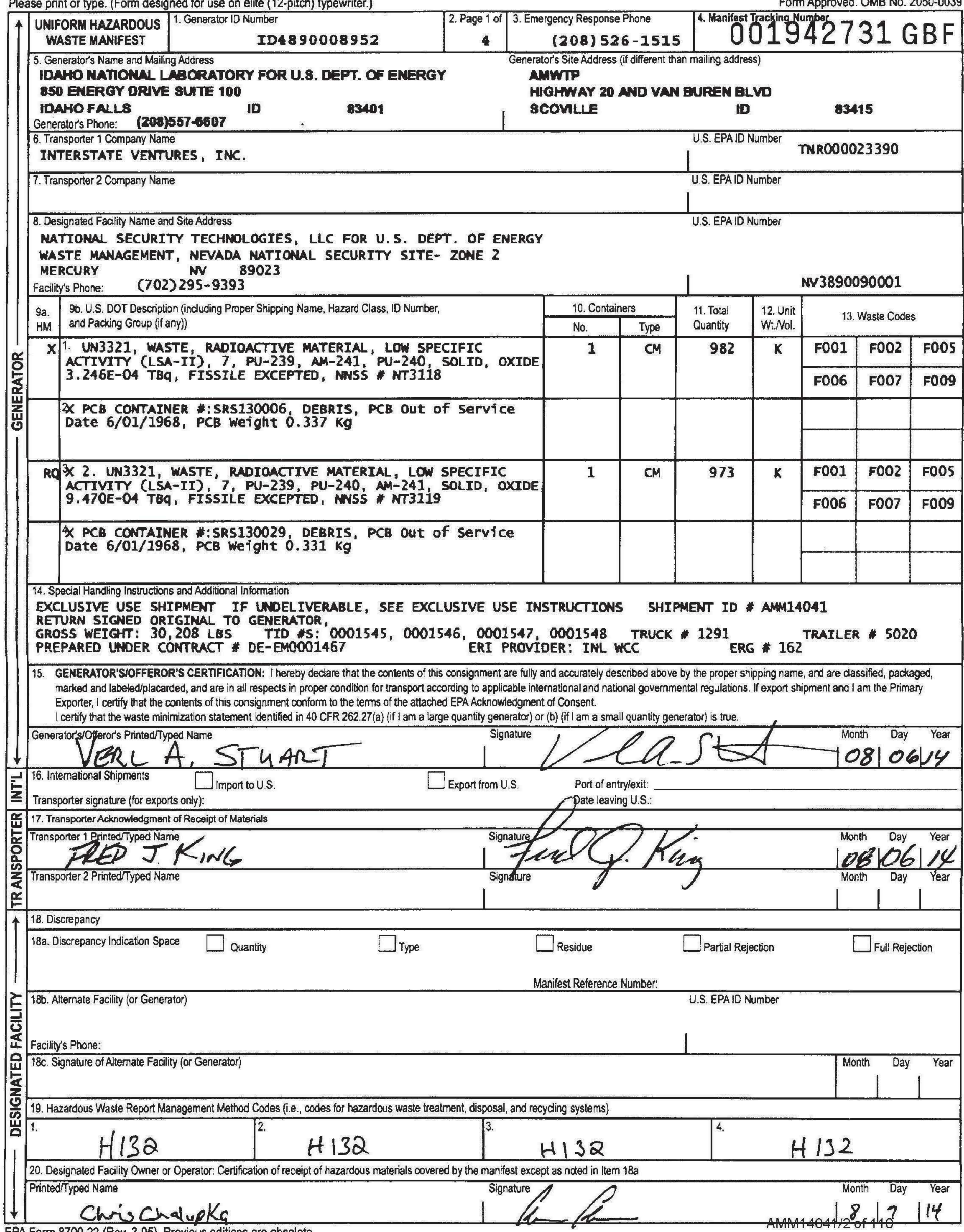

EPA Form 8700-22 (Rev. 3-05) Previous editions are obsolete. 
Please print or type. (Form designed for use on elite (12-pitch) typewriter.)

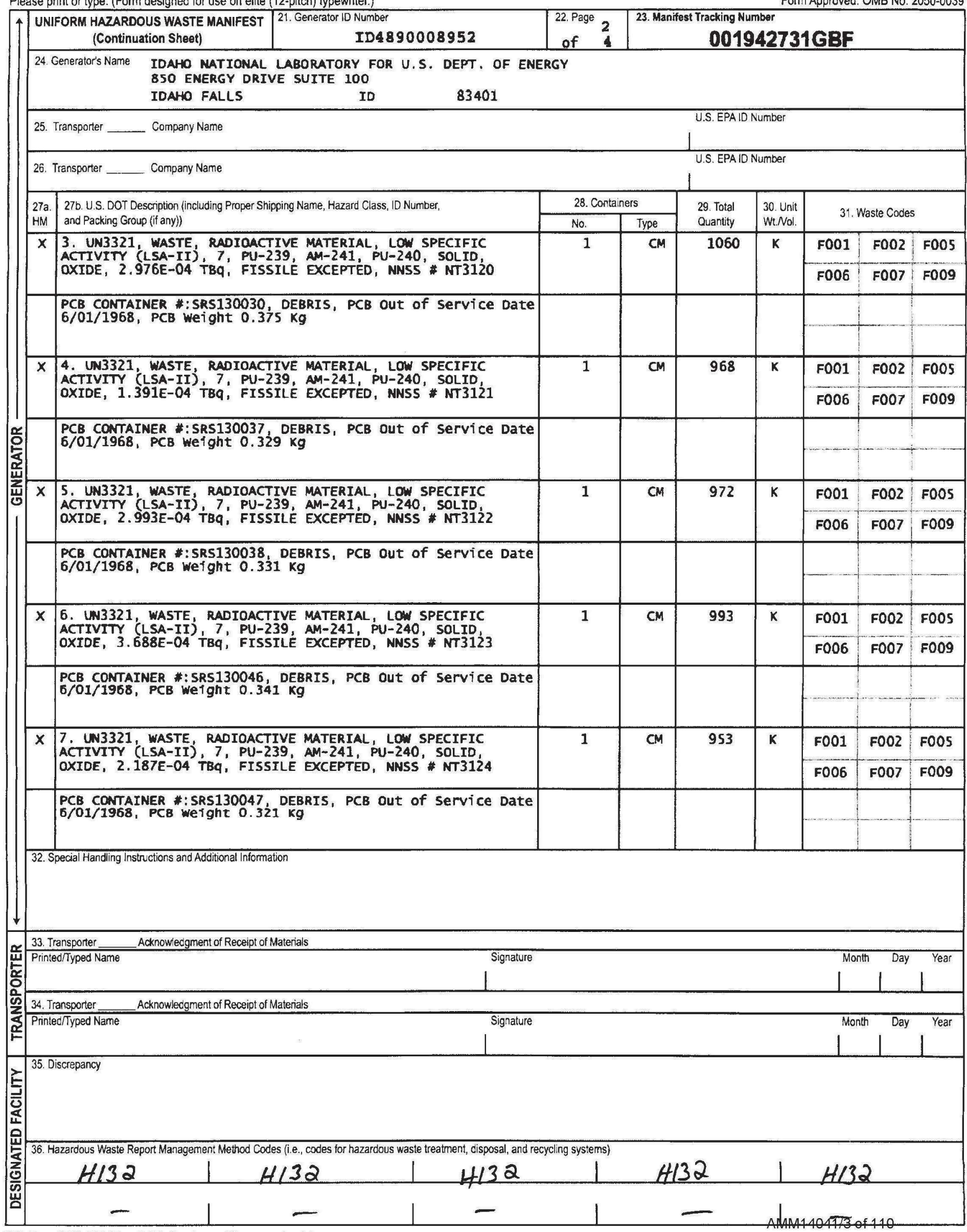


Please print or type. (Form designed for use on elite (12-pitch) typewriter.)

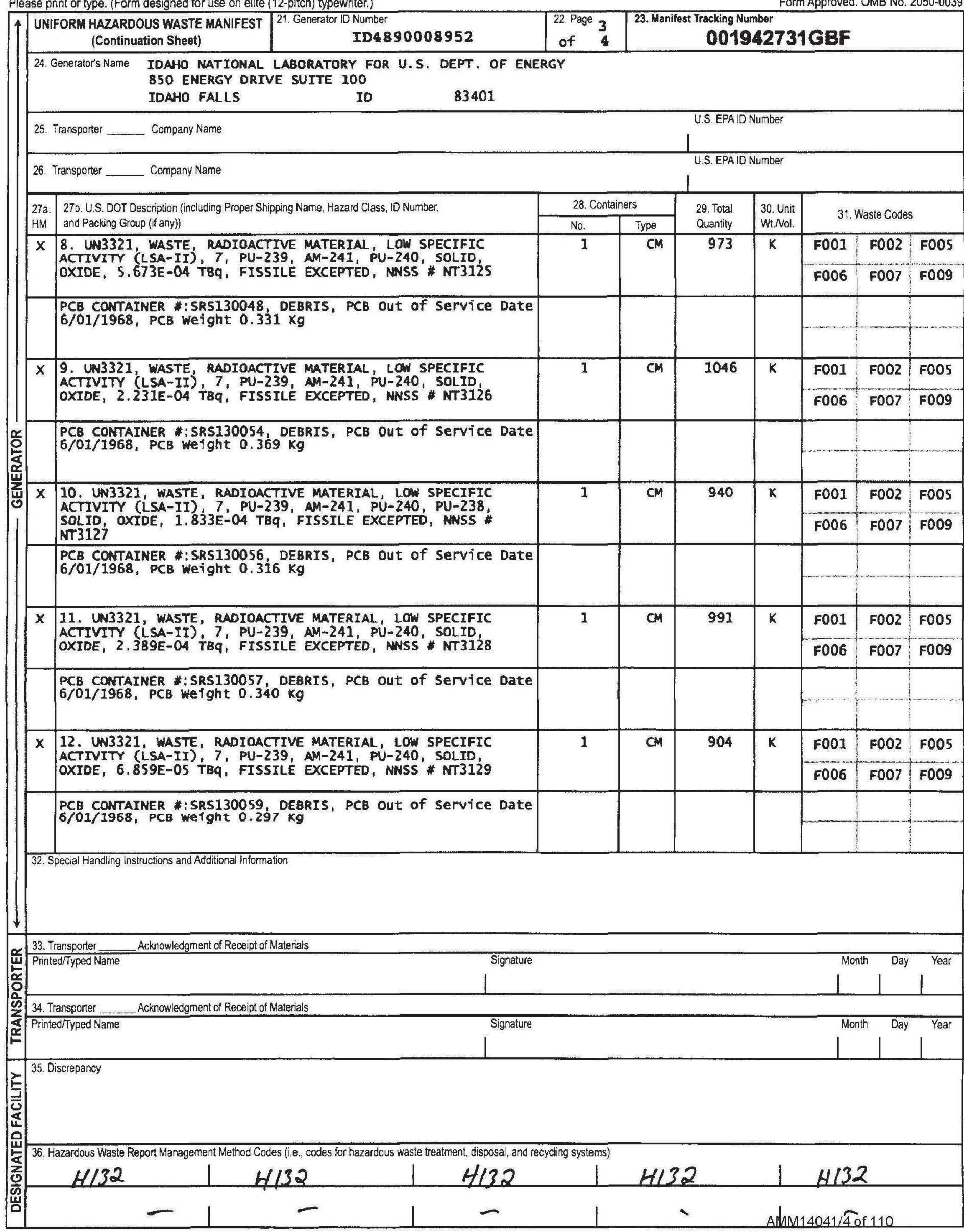


Please print or type. (Form designed for use on elite (12-pitch) typewriter.)

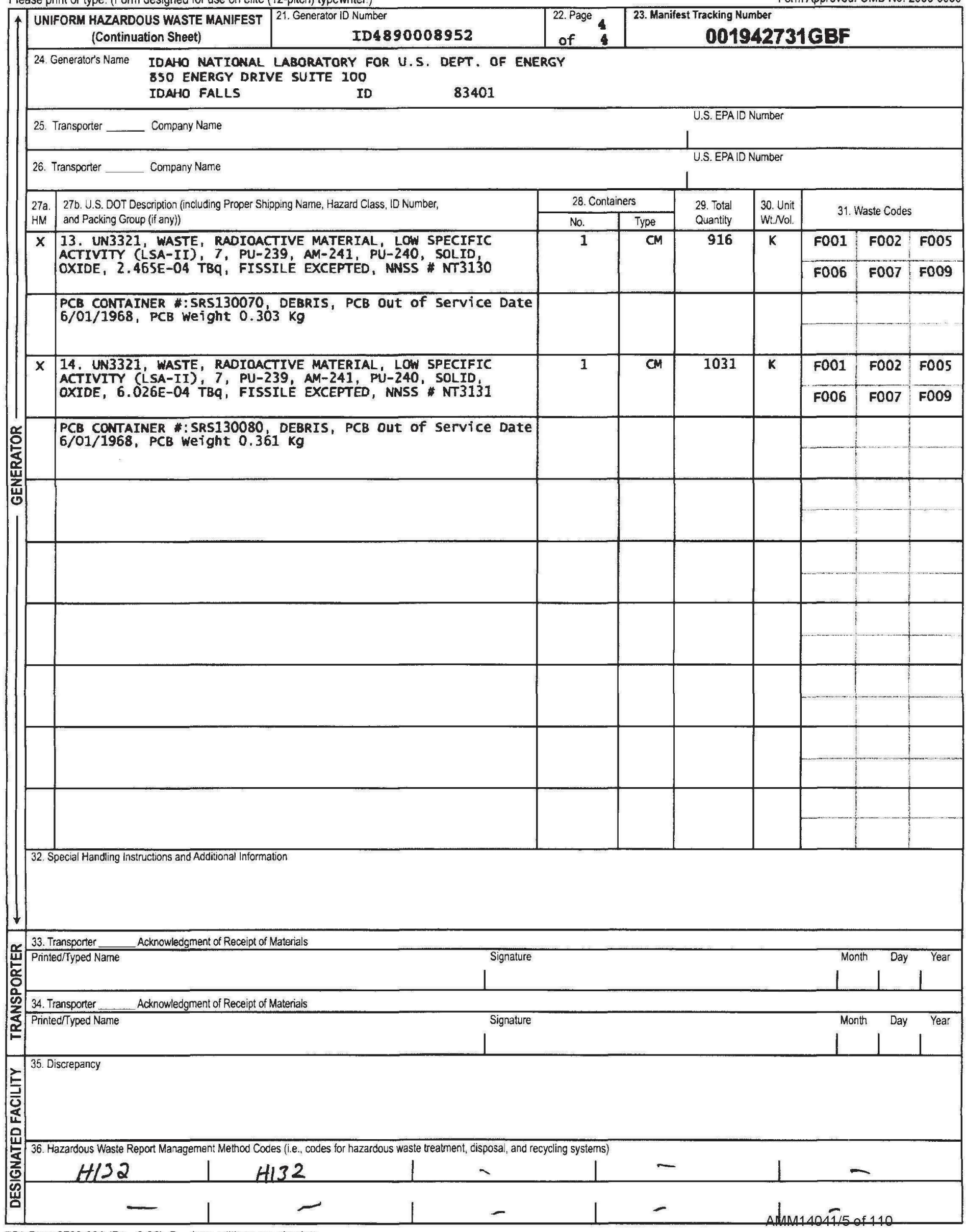




\section{National Security Technologies LLc}

Vision. Service - Partnership

H000-PA-14-0119

August 11, 2014

Jared Dominick

Waste Certification Official

Idaho Treatment Group

850 Energy Drive, Suite 100

Idaho Falls, ID 83401-1502

\section{Subject: CERTIFICATE OF DISPOSAL FOR POLYCHLORINATED BIPHENYL (PCB) WASTE AT THE NEVADA NATIONAL SECURITY SITE RADIOACTIVE WASTE MANAGEMENT SITE (RWMS)}

Enclosed is the certificate acknowledging disposal of manifested PCB shipments AMM14039, AMM14040 and AMM14041 in the Mixed Waste Disposal Unit, at the Nevada National Security Site RWMS.

If you have any questions, please contact me at 702-295-2261.

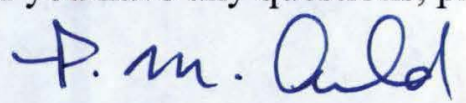

Patrick M. Arnold, Division Manager

Environmental Management

LBG:saq

Enclosure: as stated

cc w/enc.

Correspondence Control

EWO Correspondence

J. T. Carilli, NNSA/NFO

R. C. Denton, NSTec

R. G. Geisinger, NSTec

L. B. Gregory, NSTec

M. Libidinsky, NNSA/NFO

C. P. Moke, NSTec

K. M. Small, NNSA/NFO

K. C. Tanaka, NSTec

A. V. Tauber, NNSA/NFO

R. A. Wagner, NSTec

National Security Technologies, LLC

Vision - Service $\cdot$ Partnership

www.NSTec.com

P.O. Box 98521 , Las Vegas, NV 89193-8521

2621 Losee Road, N. Las Vegas, NV 89030-4129 
National Security Technologies LLC

For U.S. Department of Energy

Waste Management

Nevada National Security Site - Zone 2

Mercury, NV 89023

EPA ID NV3890090001

This Certificate acknowledges that the following shipment(s) of manifested POLYCHLORINATED BIPHENYL (PCB) waste have been disposed at the Nevada National Security Site Radioactive Waste Management Site.

\begin{tabular}{|c|c|c|c|c|}
\hline $\begin{array}{c}\text { Shipment } \\
\text { Number }\end{array}$ & $\begin{array}{c}\text { Uniform Hazardous Waste } \\
\text { Manifest Number }\end{array}$ & Date(s) of Disposal & Volume $\mathbf{F t}^{\mathbf{3}}\left(\mathbf{m}^{\mathbf{3}}\right)$ & Disposal Process \\
\hline AMM14039 & $001942729 \mathrm{GBF}$ & $08 / 04 / 2014$ & $1,259.76(35.67)$ & Landfill \\
\hline AMM14040 & $001942730 \mathrm{GBF}$ & $08 / 07 / 2014$ & $1,259.76(35.67)$ & Landfill \\
\hline AMM14041 & $001942731 \mathrm{GBF}$ & $08 / 04 / 2014$ & $1,259.76(35.67)$ & Landfill \\
\hline & & & & \\
\hline
\end{tabular}

Under civil and criminal penalties of law for the making or submission of false or fraudulent statements or representations (18 U.S.C. 1001 and 15 U.S.C. 2615), I certify that the information contained in or accompanying this document is true, accurate, and complete.

As to the identified section(s) of this document for which I cannot personally verify truth and accuracy, I certify as the company official having supervisory responsibility for the persons who, acting under my direct instructions, made the verification that this information is true, accurate, and complete.
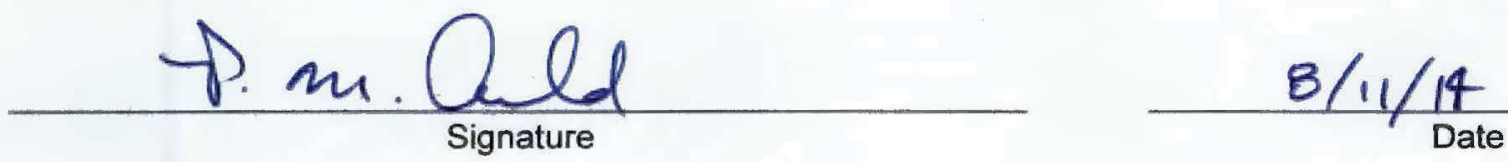

Division Manager, Environmental Management

Title

Instructions:

Shipment Number - enter shipment number from LWIS database.

Uniform Hazardous Waste Manifest Number - enter number from UHWM provided by generator.

Date of Disposal - enter date waste was placed in disposal cell.

Volume - enter shipment volume in cubic feet and equivalent cubic meters in parenthesis.

Disposal Process - enter Landfill.

National Security Technologies, LLC

Vision - Service - Partnership

unw.NSTeC.com

P.O. Box 98521, Las Vegas, NV 89193-8521

2621 Losee Road, N. Las Vegas, NV 89030-4129 
Please print or type. (Form designed for use on elite (12-pitch) typewriter.)

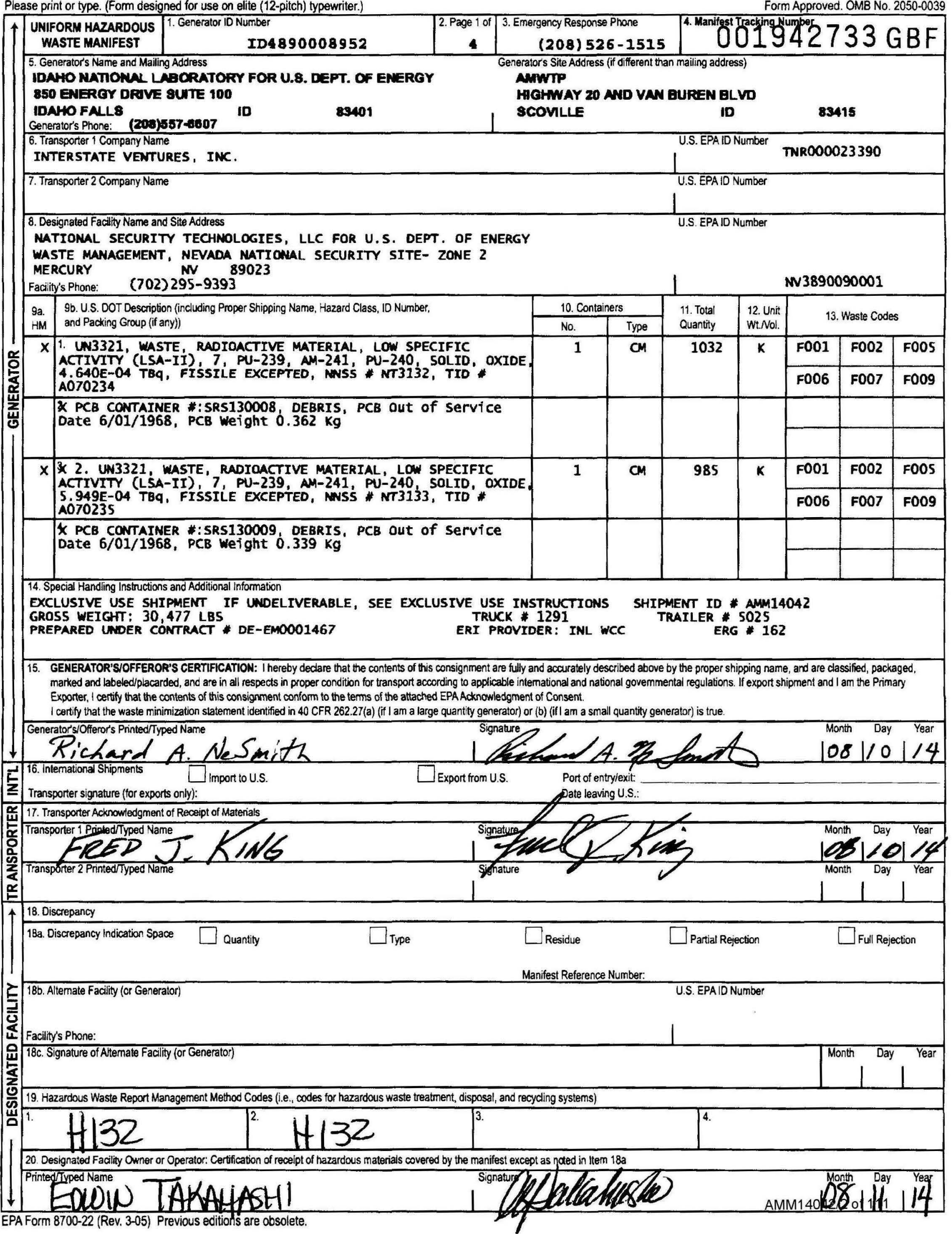


Please print or type. (Form designed for use on elite (12-pitch) typewriter.)

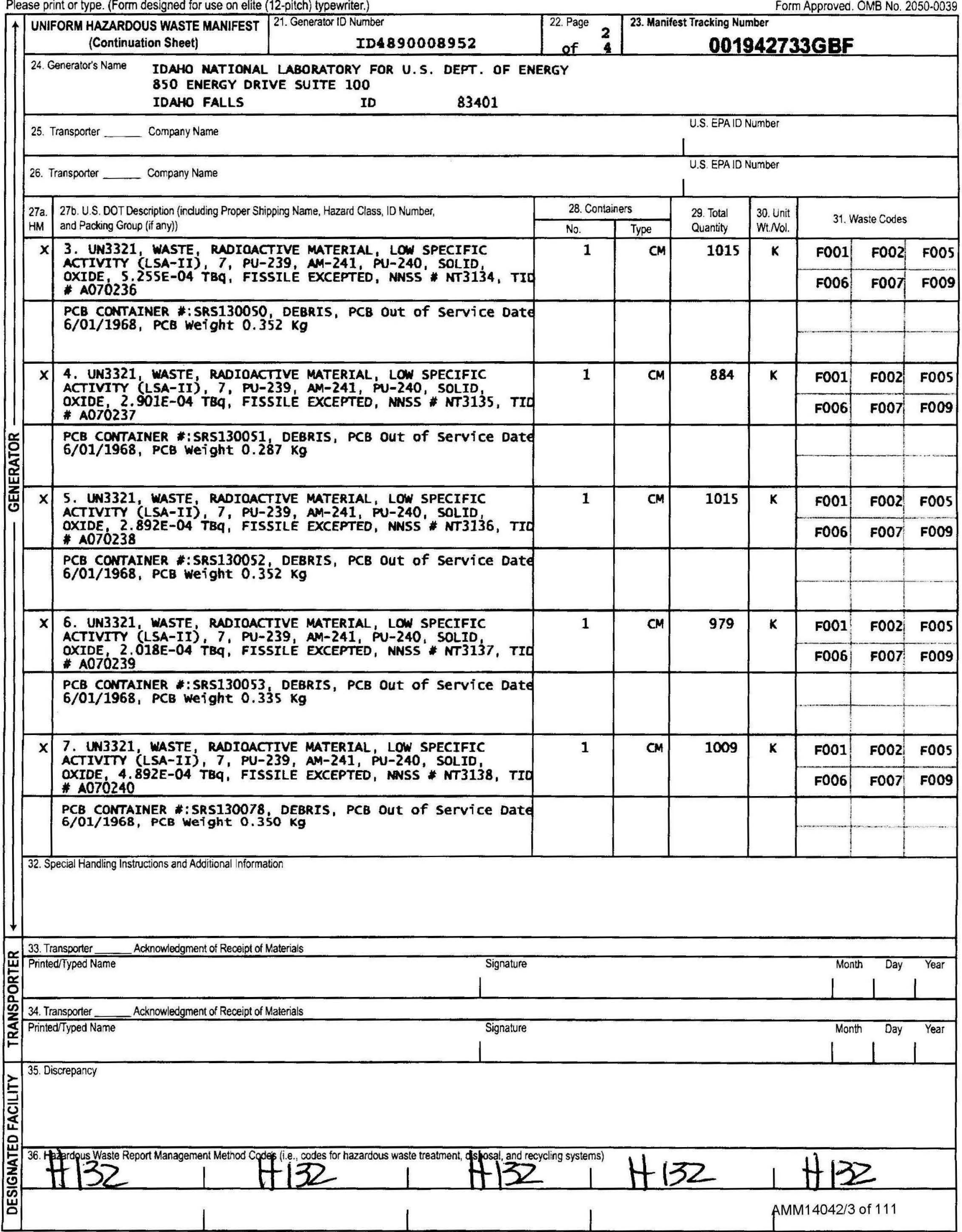


Please print or type. (Form designed for use on elite (12-pitch) typewriter.)

Form Approved. OMB №. 2050-0039

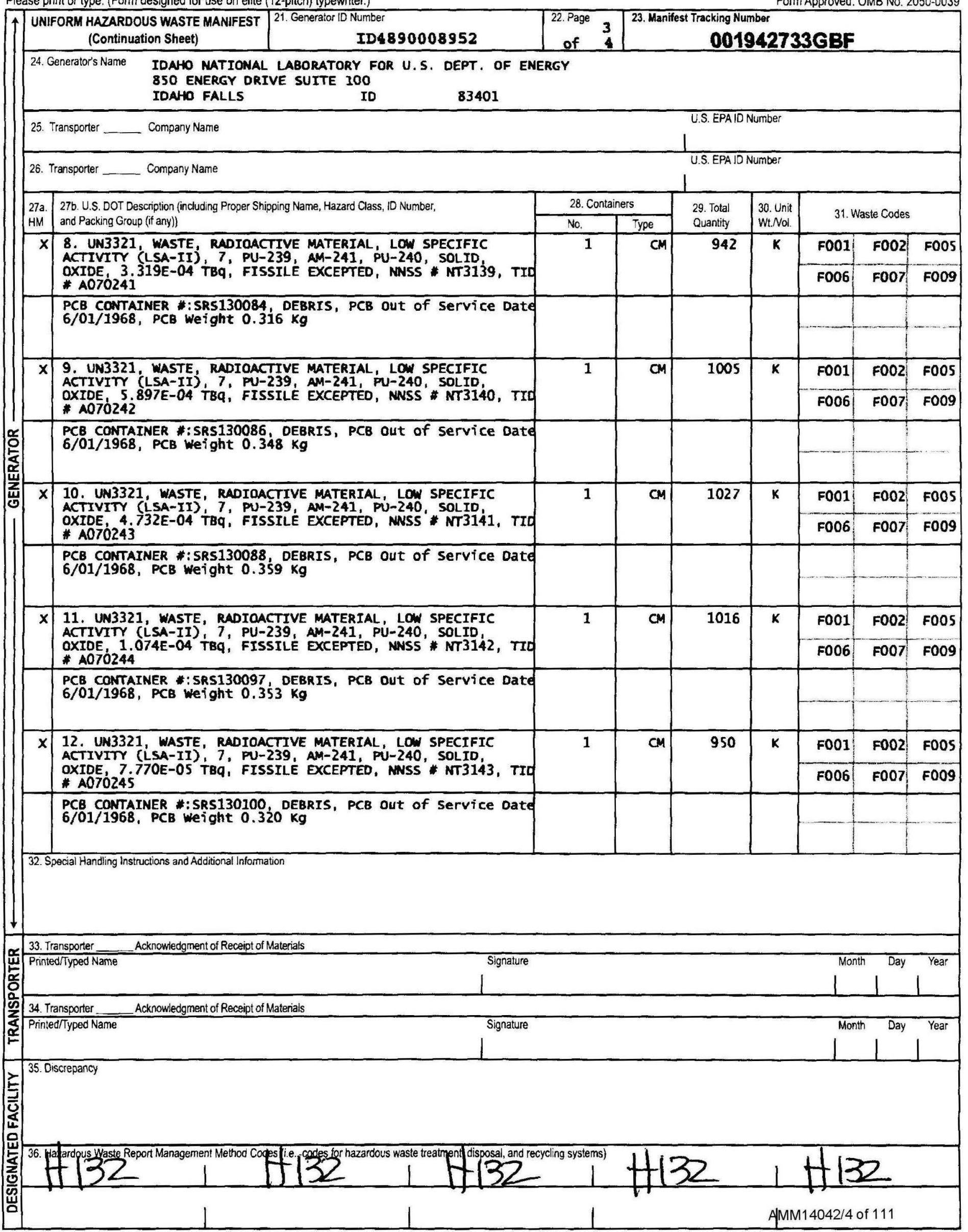


Please print or type. (Form designed for use on elite (12-pitch) typewriter.)

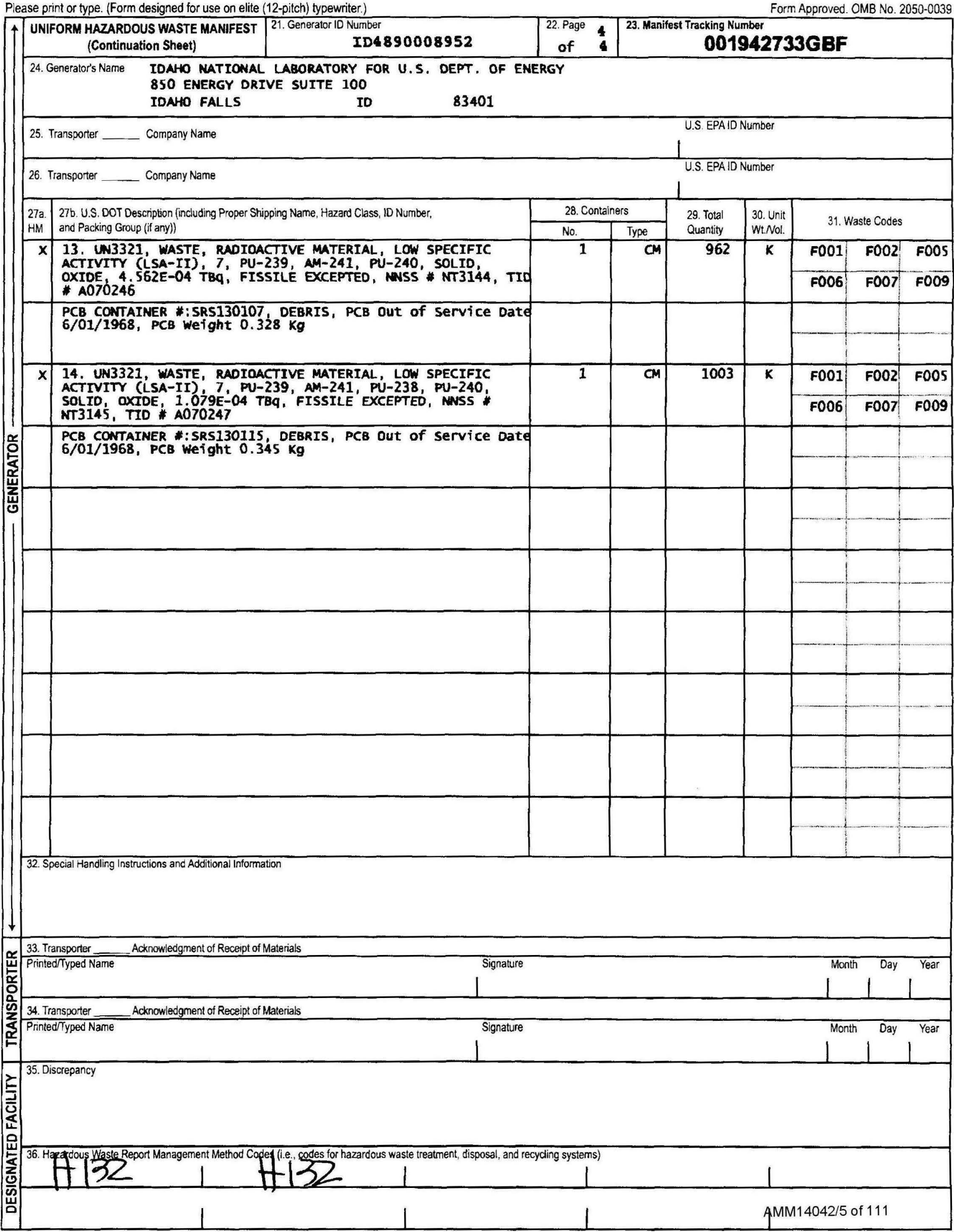


National Security Technologies $L L c$

H000-PA-14-0121

August 18, 2014

Jared Dominick

Waste Certification Official

Idaho Treatment Group

850 Energy Drive, Suite 100

Idaho Falls, ID 83401-1502

Subject: CERTIFICATE OF DISPOSAL FOR POLYCHLORINATED BIPHENYL (PCB) WASTE AT THE NEVADA NATIONAL SECURITY SITE RADIOACTIVE WASTE MANAGEMENT SITE (RWMS)

Enclosed is the certificate acknowledging disposal of manifested PCB shipments AMM14042 and AMM14043 in the Mixed Waste Disposal Unit, at the Nevada National Security Site RWMS.

If you have any questions, please contact me at 702-295-2261.

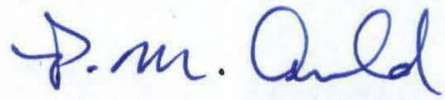

Patrick M. Arnold, Division Manager

Environmental Management

RCD:saq

Enclosure: as stated

cc w/enc.

Correspondence Control

EWO Correspondence

J. T. Carilli, NNSA/NFO

R. C. Denton, NSTec

R. G. Geisinger, NSTec

M. Libidinsky, NNSA/NFO

C. P. Moke, NSTec

K. M. Small, NNSA/NFO

K. C. Tanaka, NSTec

A. V. Tauber, NNSA/NFO

R. A. Wagner, NSTec 


\section{National Security Technologies LLC \\ For U.S. Department of Energy \\ Waste Management \\ Nevada National Security Site - Zone 2 \\ Mercury, NV 89023}

EPA ID NV3890090001

This Certificate acknowledges that the following shipment(s) of manifested POLYCHLORINATED BIPHENYL (PCB) waste have been disposed at the Nevada National Security Site Radioactive Waste Management Site.

\begin{tabular}{|c|c|c|c|c|}
\hline $\begin{array}{c}\text { Shipment } \\
\text { Number }\end{array}$ & $\begin{array}{c}\text { Uniform Hazardous Waste } \\
\text { Manifest Number }\end{array}$ & Date(s) of Disposal & Volume $\left.\mathbf{F t}^{\mathbf{3}} \mathbf{( m}^{\mathbf{3}}\right)$ & Disposal Process \\
\hline AMM14042 & $001942733 \mathrm{GBF}$ & $08 / 11 / 2014$ & $1,259.76(35.67)$ & Landfill \\
\hline AMM14043 & $001942734 \mathrm{GBF}$ & $08 / 11 / 2014$ & $1,259.83(35.67)$ & Landfill \\
\hline & & & & \\
\hline & & & & \\
\hline
\end{tabular}

Under civil and criminal penalties of law for the making or submission of false or fraudulent statements or representations (18 U.S.C. 1001 and 15 U.S.C. 2615), I certify that the information contained in or accompanying this document is true, accurate, and complete.

As to the identified section(s) of this document for which I cannot personally verify truth and accuracy, I certify as the company official having supervisory responsibility for the persons who, acting under my direct instructions, made the verification that this information is true, accurate, and complete.
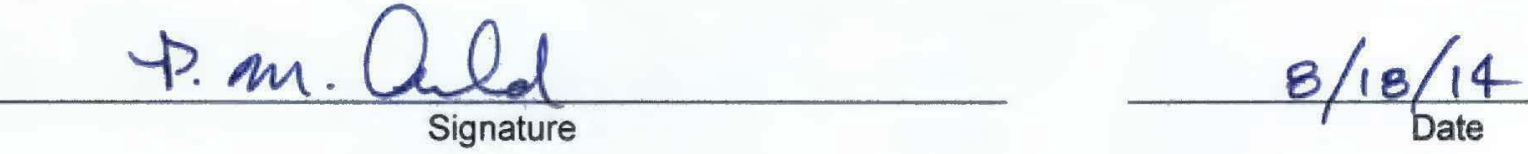

Division Manager, Environmental Management

Title

Instructions:

Shipment Number - enter shipment number from LWIS database.

Uniform Hazardous Waste Manifest Number - enter number from UHWM provided by generator.

Date of Disposal - enter date waste was placed in disposal cell.

Volume - enter shipment volume in cubic feet and equivalent cubic meters in parenthesis.

Disposal Process - enter Landfill.

National Security Technologies, LLC

Vision • Service • Partnership

Wuw. NSTEC.com

P.O. Box 98521 , Las Vegas, NV 89193-8521

2621 Losee Road, N. Las Vegas, NV 89030-4129 


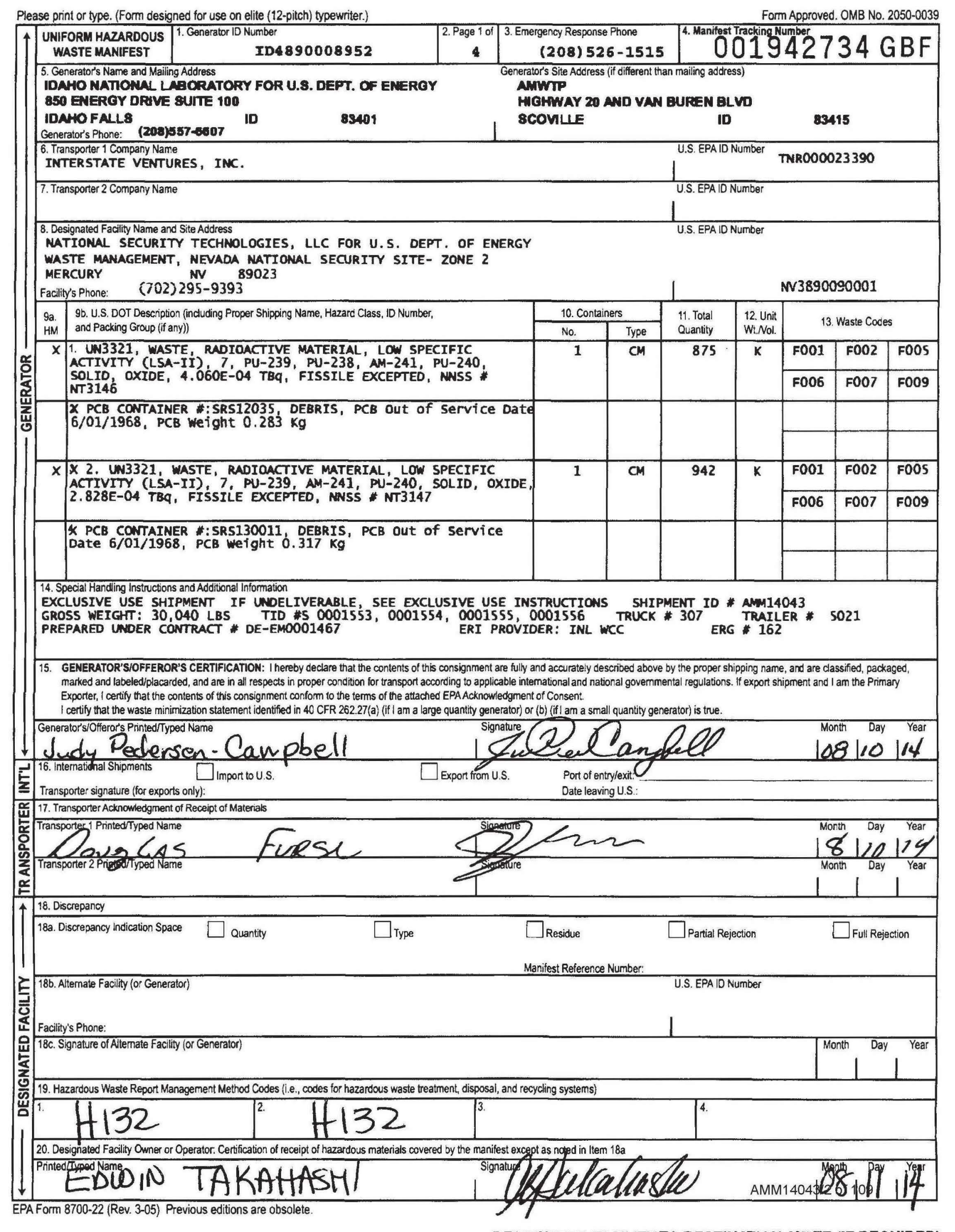


Please print or type. (Form designed for use on elite (12-pitch) typewriter.)

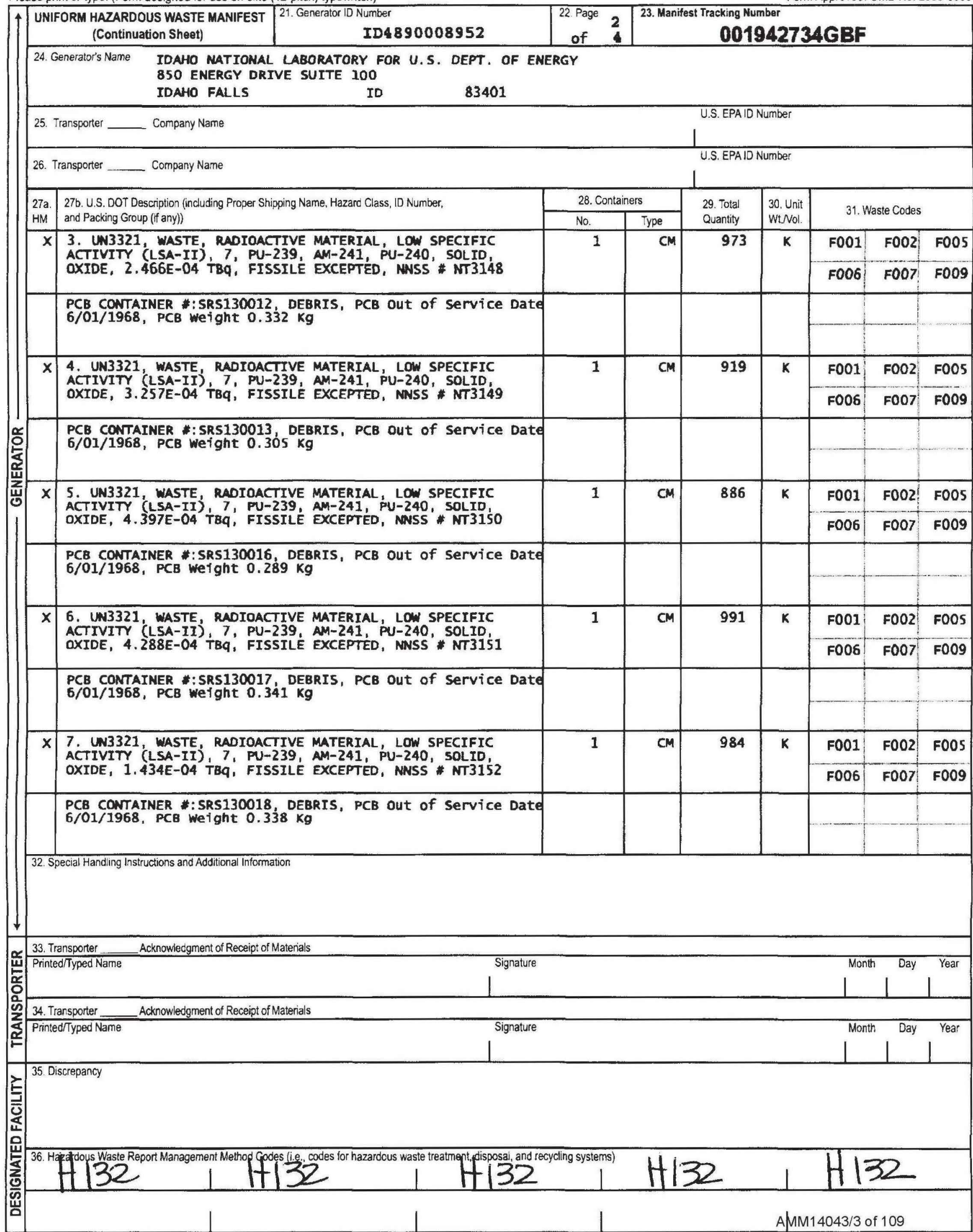


Please print or type. (Form designed for use on elite (12-pitch) typewriter.)

Form Approved. OMB No. 2050-0039

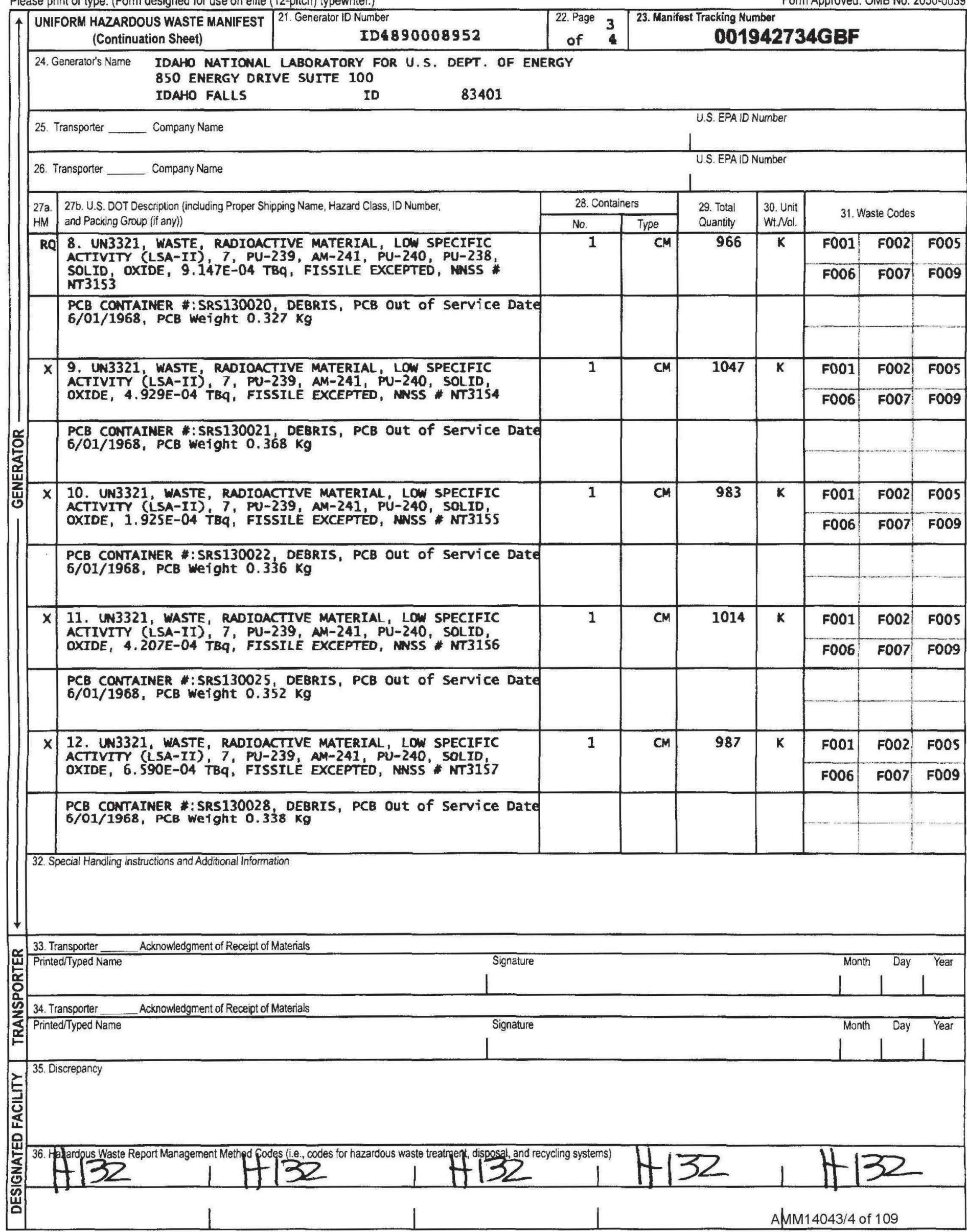


Please print or type. (Form designed for use on elite (12-pitch) typewriter.)

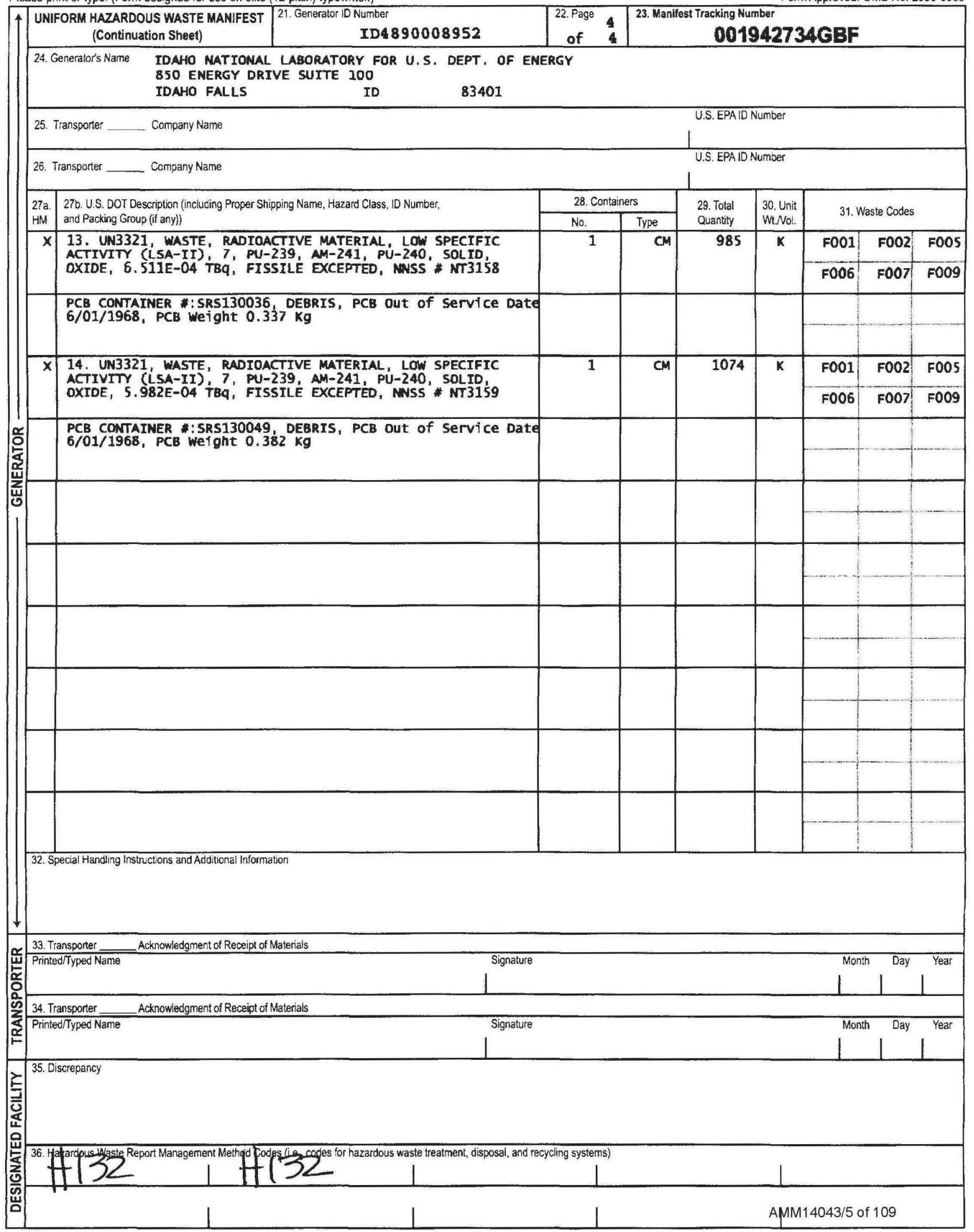


National Security Technologies LLc

H000-PA-14-0121

August 18, 2014

Jared Dominick

Waste Certification Official

Idaho Treatment Group

850 Energy Drive, Suite 100

Idaho Falls, ID 83401-1502

Subject: CERTIFICATE OF DISPOSAL FOR POLYCHLORINATED BIPHENYL (PCB) WASTE AT THE NEVADA NATIONAL SECURITY SITE RADIOACTIVE WASTE MANAGEMENT SITE (RWMS)

Enclosed is the certificate acknowledging disposal of manifested PCB shipments AMM14042 and AMM14043 in the Mixed Waste Disposal Unit, at the Nevada National Security Site RWMS.

If you have any questions, please contact me at 702-295-2261.<smiles>CC(C)=C(C)C(=O)c1ccccc1</smiles>

Patrick M. Arnold, Division Manager

Environmental Management

RCD:saq

Enclosure: as stated

cc w/enc.

Correspondence Control

EWO Correspondence

J. T. Carilli, NNSA/NFO

R. C. Denton, NSTec

R. G. Geisinger, NSTec

M. Libidinsky, NNSA/NFO

C. P. Moke, NSTec

K. M. Small, NNSA/NFO

K. C. Tanaka, NSTec

A. V. Tauber, NNSA/NFO

R. A. Wagner, NSTec 


\section{National Security Technologies LLC \\ For U.S. Department of Energy \\ Waste Management \\ Nevada National Security Site - Zone 2 \\ Mercury, NV 89023}

EPA ID NV3890090001

This Certificate acknowledges that the following shipment(s) of manifested

POLYCHLORINATED BIPHENYL (PCB) waste have been disposed at the Nevada National

Security Site Radioactive Waste Management Site.

\begin{tabular}{|c|c|c|c|c|}
\hline $\begin{array}{c}\text { Shipment } \\
\text { Number }\end{array}$ & $\begin{array}{c}\text { Uniform Hazardous Waste } \\
\text { Manifest Number }\end{array}$ & Date(s) of Disposal & Volume $\left.\mathbf{F t}^{\mathbf{3}} \mathbf{( m}^{\mathbf{3}}\right)$ & Disposal Process \\
\hline AMM14042 & $001942733 \mathrm{GBF}$ & $08 / 11 / 2014$ & $1,259.76(35.67)$ & Landfill \\
\hline AMM14043 & $001942734 \mathrm{GBF}$ & $08 / 11 / 2014$ & $1,259.83(35.67)$ & Landfill \\
\hline & & & & \\
\hline & & & & \\
\hline
\end{tabular}

Under civil and criminal penalties of law for the making or submission of false or fraudulent statements or representations (18 U.S.C. 1001 and 15 U.S.C. 2615), I certify that the information contained in or accompanying this document is true, accurate, and complete.

As to the identified section(s) of this document for which I cannot personally verify truth and accuracy, I certify as the company official having supervisory responsibility for the persons who, acting under my direct instructions, made the verification that this information is true, accurate, and complete.
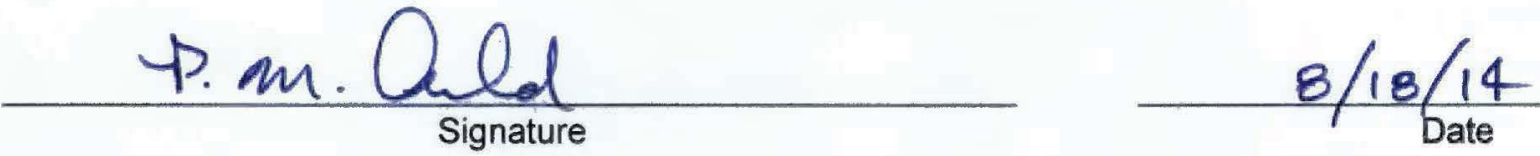

Division Manager, Environmental Management

Title

Instructions:

Shipment Number - enter shipment number from LWIS database.

Uniform Hazardous Waste Manifest Number - enter number from UHWM provided by generator.

Date of Disposal - enter date waste was placed in disposal cell.

Volume - enter shipment volume in cubic feet and equivalent cubic meters in parenthesis.

Disposal Process - enter Landfill.

National Security Technologies, LLC

Vision • Service - Partnership

www.NSTeC.com

P.O. Box 98521 , Las Vegas, NV 89193-8521

2621 Losee Road, N. Las Vegas, NV 89030-4129 
Please print or type. (Form designed for use on elite (12-pitch) typewriter.)

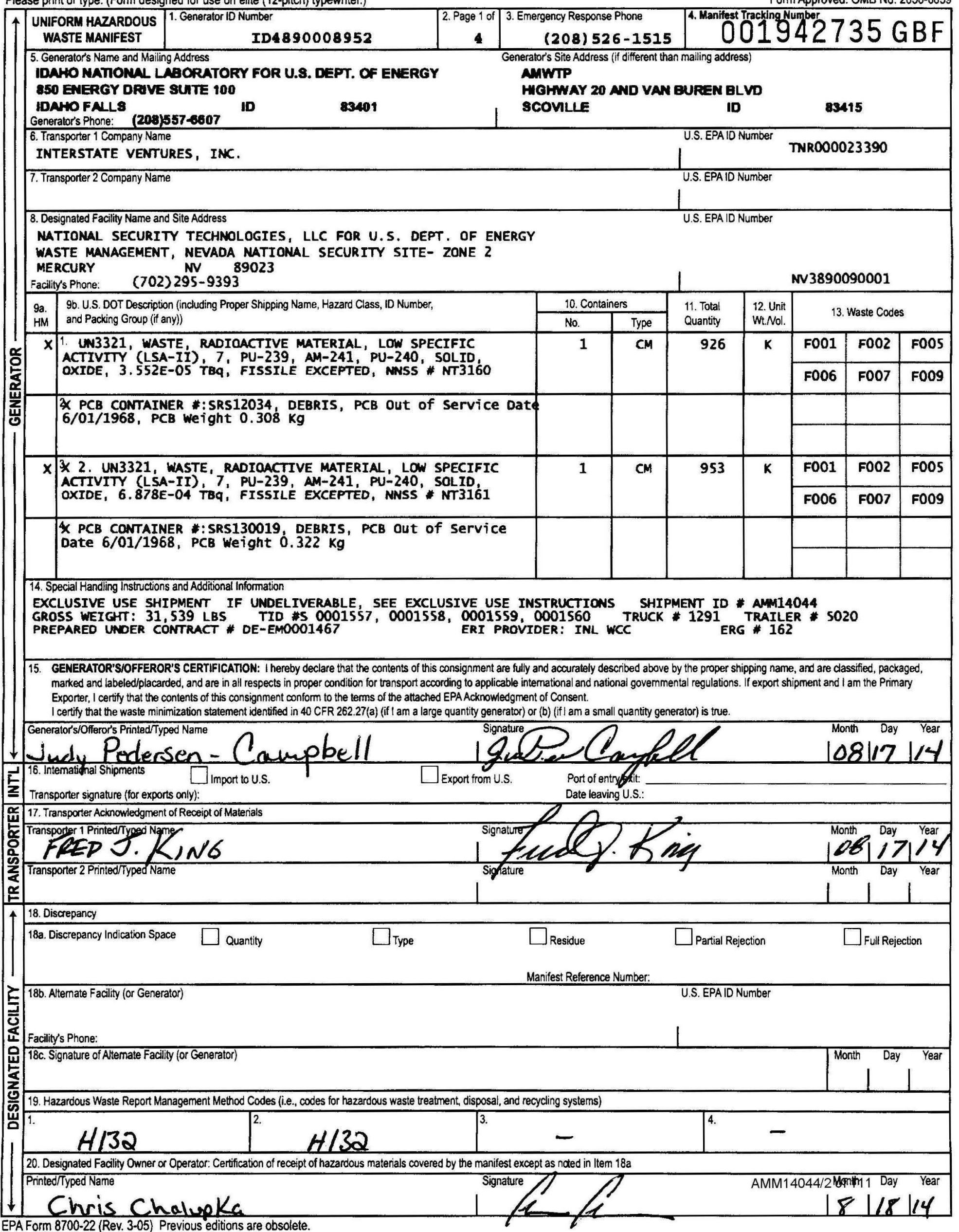


Please print or type. (Form designed for use on elite (12-pitch) typewriter.)

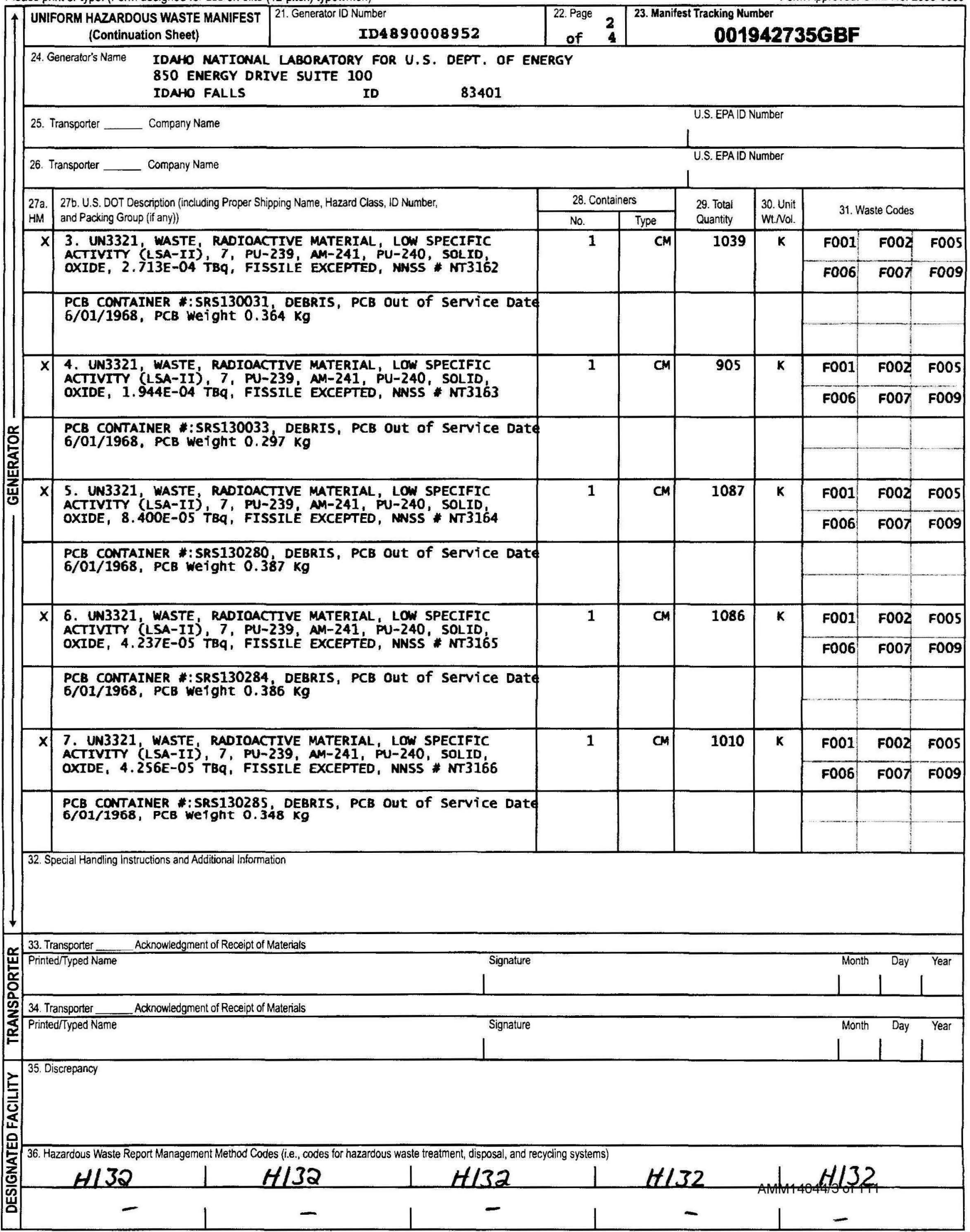


Please print or type. (Form designed for use on elite (12-pitch) typewriter.)

Form Approved. OMB №. 2050-0039

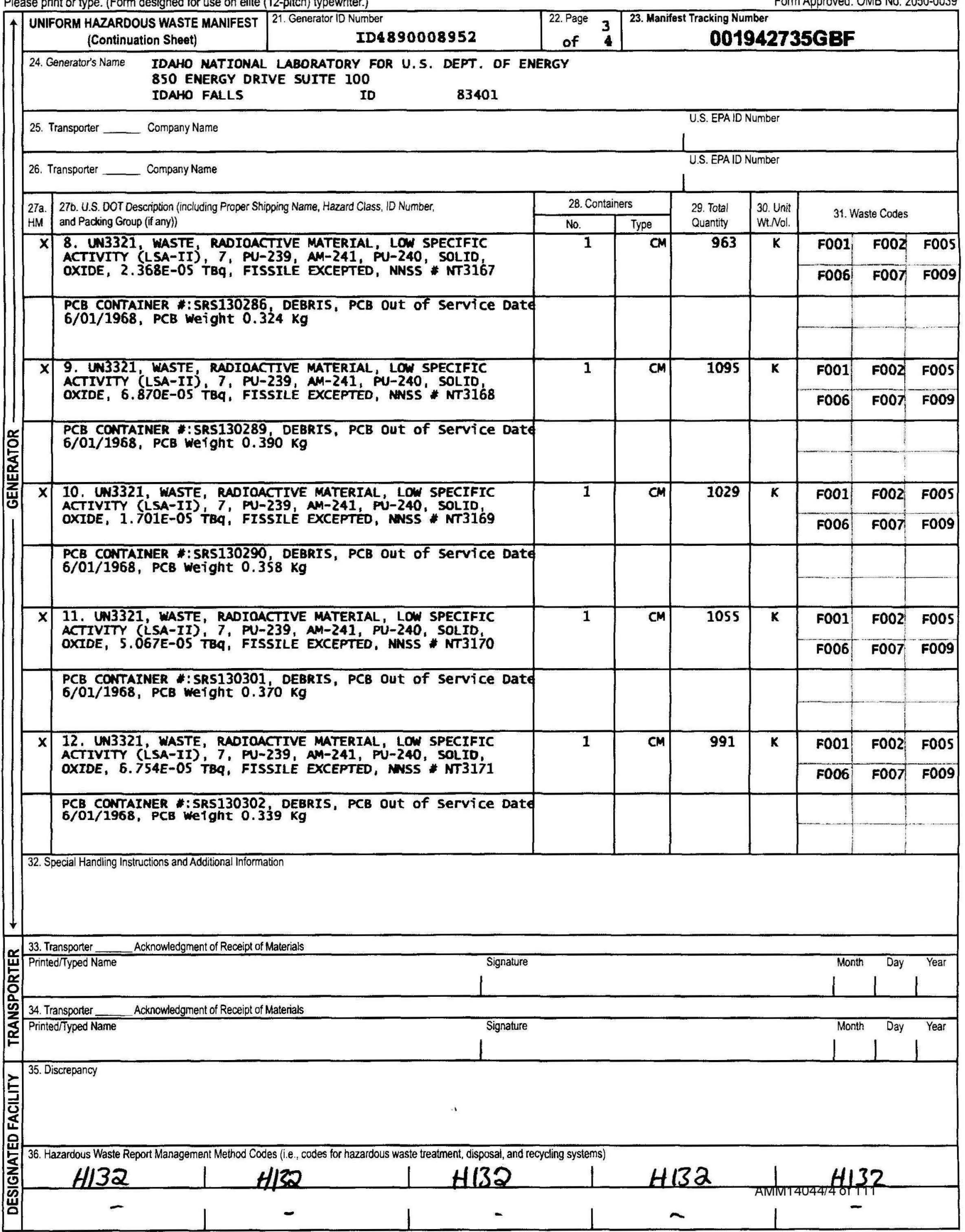


Please print or type. (Form designed for use on elite (12-pitch) typewriter.)

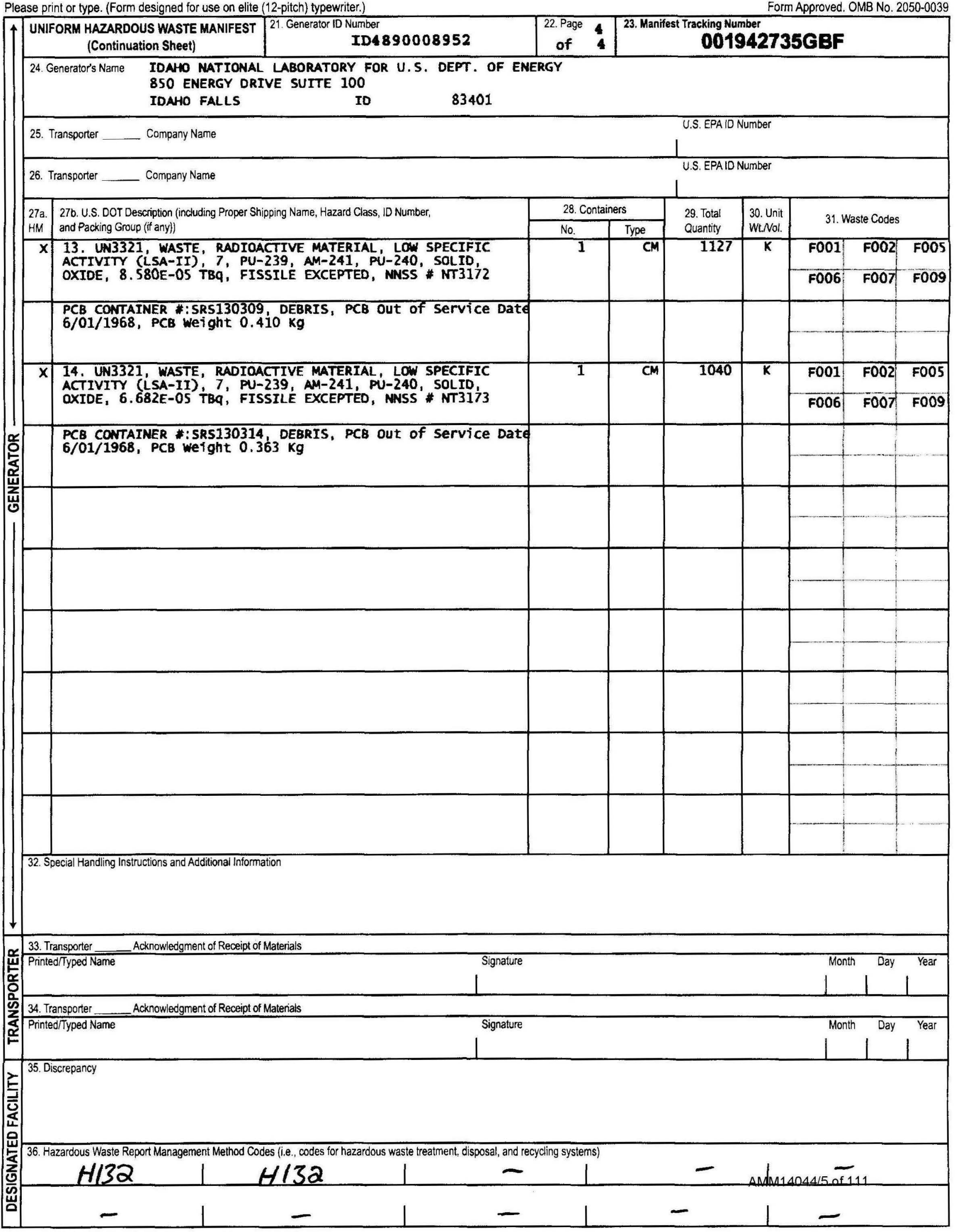


$\underset{\text { Nision. Senvice. Partnership }}{\text { Naty Technologies Luc }}$

H000-PA-14-0124

August 25, 2014

Jared Dominick

Waste Certification Official

Idaho Treatment Group

850 Energy Drive, Suite 100

Idaho Falls, ID 83401-1502

Subject: CERTIFICATE OF DISPOSAL FOR POLYCHLORINATED

BIPHENYL (PCB) WASTE AT THE NEVADA NATIONAL SECURITY SITE RADIOACTIVE WASTE MANAGEMENT SITE (RWMS)

Enclosed is the certificate acknowledging disposal of manifested PCB shipments AMM14044, AMM14045, AMM14046, and AMM14047 in the Mixed Waste Disposal Unit, at the Nevada National Security Site RWMS.

If you have any questions, please contact me at 702-295-2261.<smiles>CC(C)CC(O)CC(C)C(C)C</smiles>

Patrick M. Arnold, Division Manager

Environmental Management

LBG:saq

Enclosure: as stated

cc w/enc.

Correspondence Control

EWO Correspondence

J. T. Carilli, NNSA/NFO

R. C. Denton, NSTec

R. G. Geisinger, NSTec

L. B. Gregory, NSTec

M. Libidinsky, NNSA/NFO

C. P. Moke, NSTec

K. M. Small, NNSA/NFO

K. C. Tanaka, NSTec

A. V. Tauber, NNSA/NFO

R. A. Wagner, NSTec

National Security Technologies, LLC

Vision - Service - Partnership

www.NSTec.com

P.O. Box 98521, Las Vegas, NV 89193-8521

2621 Losee Road, N. Las Vegas, NV 89030-4129 


\section{National Security Technologies LLC \\ For U.S. Department of Energy \\ Waste Management \\ Nevada National Security Site - Zone 2 \\ Mercury, NV 89023}

EPA ID NV3890090001

This Certificate acknowledges that the following shipment(s) of manifested POLYCHLORINATED BIPHENYL (PCB) waste have been disposed at the Nevada National Security Site Radioactive Waste Management Site.

\begin{tabular}{|c|c|c|c|c|}
\hline $\begin{array}{c}\text { Shipment } \\
\text { Number }\end{array}$ & $\begin{array}{c}\text { Uniform Hazardous Waste } \\
\text { Manifest Number }\end{array}$ & Date(s) of Disposal & Volume $\mathbf{F t}^{3}\left(\mathbf{m}^{3}\right)$ & Disposal Process \\
\hline AMM14044 & $001942735 G B F$ & $08 / 18 / 2014$ & $1,259.76(35.67)$ & Landfill \\
\hline AMM14045 & $001942736 \mathrm{GBF}$ & $08 / 18 / 2014$ & $1,259.76(35.67)$ & Landfill \\
\hline AMM14046 & $001942737 G B F$ & $08 / 21 / 2014$ & $1,259.76(35.67)$ & Landfill \\
\hline AMM14047 & $001942738 G B F$ & $08 / 21 / 2014$ & $1,259.76(35.67)$ & Landfill \\
\hline
\end{tabular}

Under civil and criminal penalties of law for the making or submission of false or fraudulent statements or representations (18 U.S.C. 1001 and 15 U.S.C. 2615), I certify that the information contained in or accompanying this document is true, accurate, and complete.

As to the identified section(s) of this document for which I cannot personally verify truth and accuracy, I certify as the company official having supervisory responsibility for the persons who, acting under my direct instructions, made the verification that this information is true, accurate, and complete.
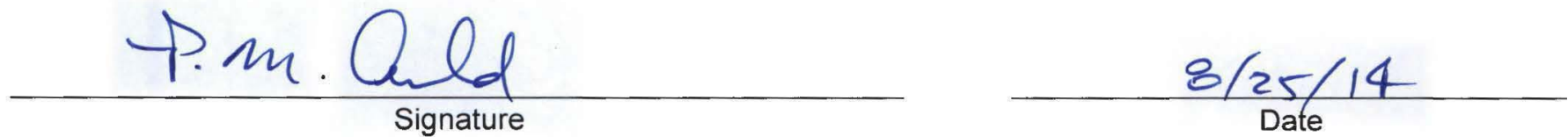

Division Manager, Environmental Management

Title

Instructions:

Shipment Number - enter shipment number from LWIS database.

Uniform Hazardous Waste Manifest Number - enter number from UHWM provided by generator.

Date of Disposal - enter date waste was placed in disposal cell.

Volume - enter shipment volume in cubic feet and equivalent cubic meters in parenthesis.

Disposal Process - enter Landfill.

\section{National Security Technologies, LLC}

Vision - Service $\cdot$ Partnership

www.NSTec.com

P.O. Box 98521, Las Vegas, NV 89193-8521

2621 Losee Road, N. Las Vegas, NV 89030-4129 
Please print or type. (Form designed for use on elite (12-pitch) typewriter.)

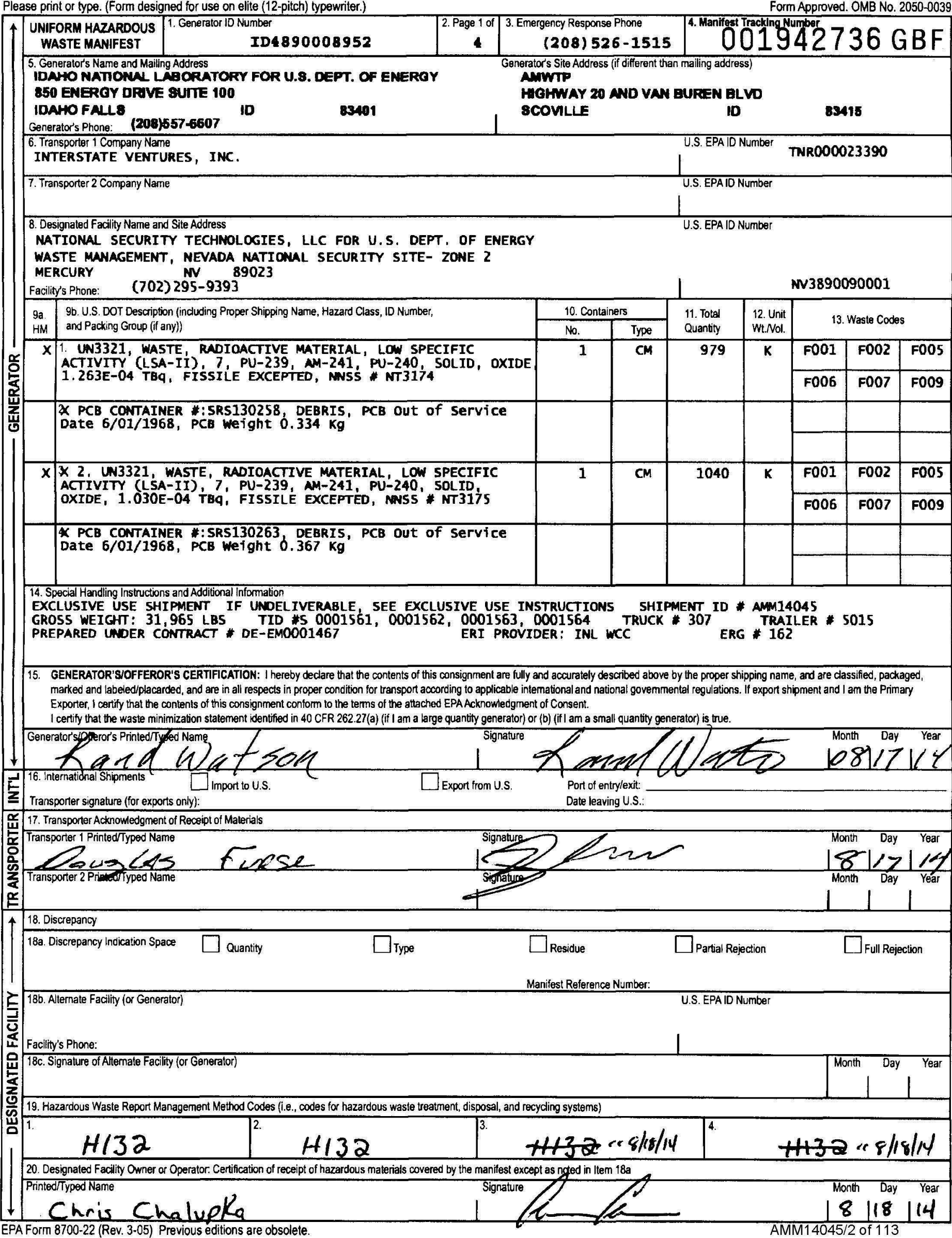


Please print or type. (Form designed for use on elite (12-pitch) typewriter.)

Form Approved. OMB No. 2050-0039

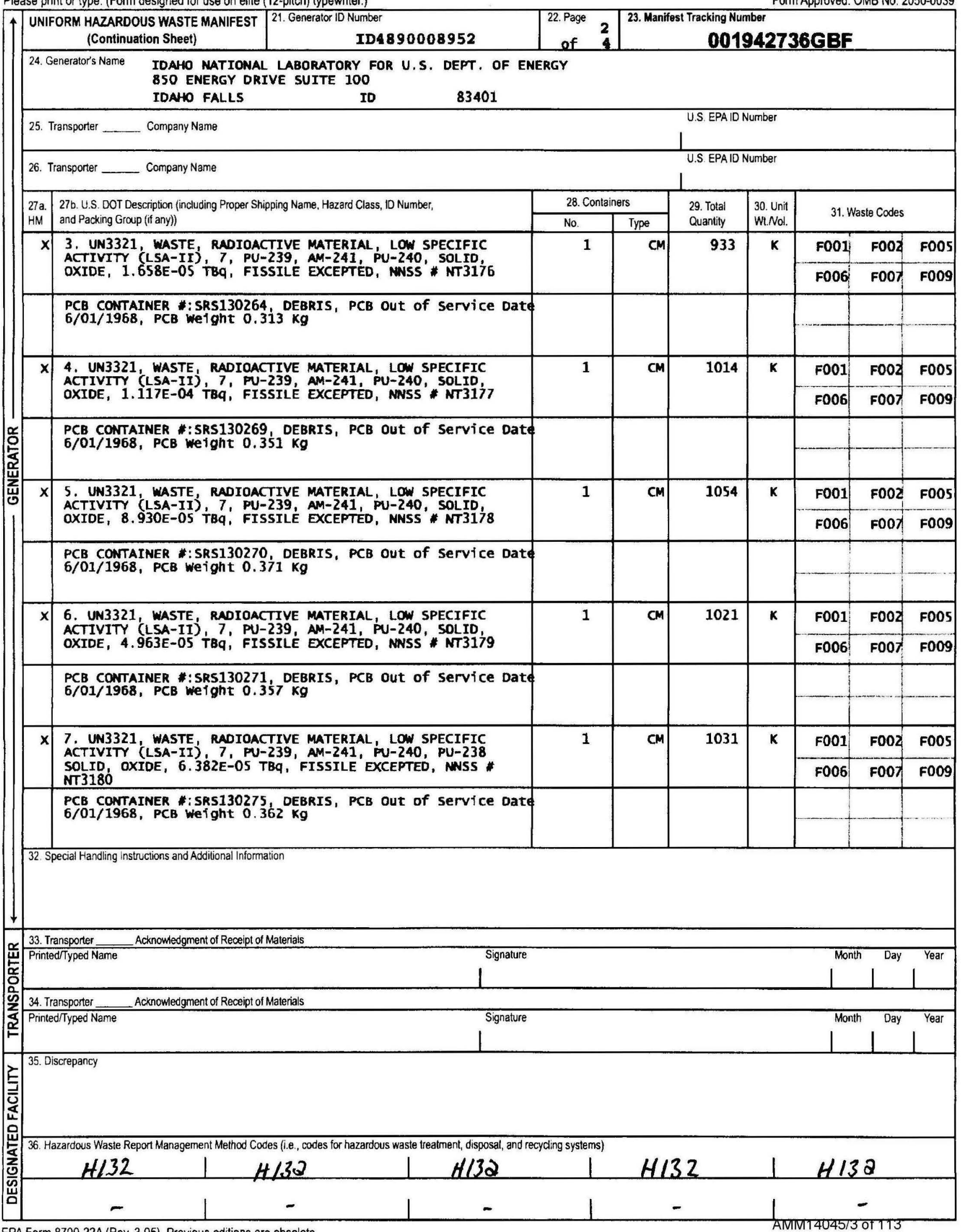

EPA Form 8700-22A (Rev. 3-05) Previous editions are obsolete. 
Please print or type. (Form designed for use on elite (12-pitch) typewriter.)

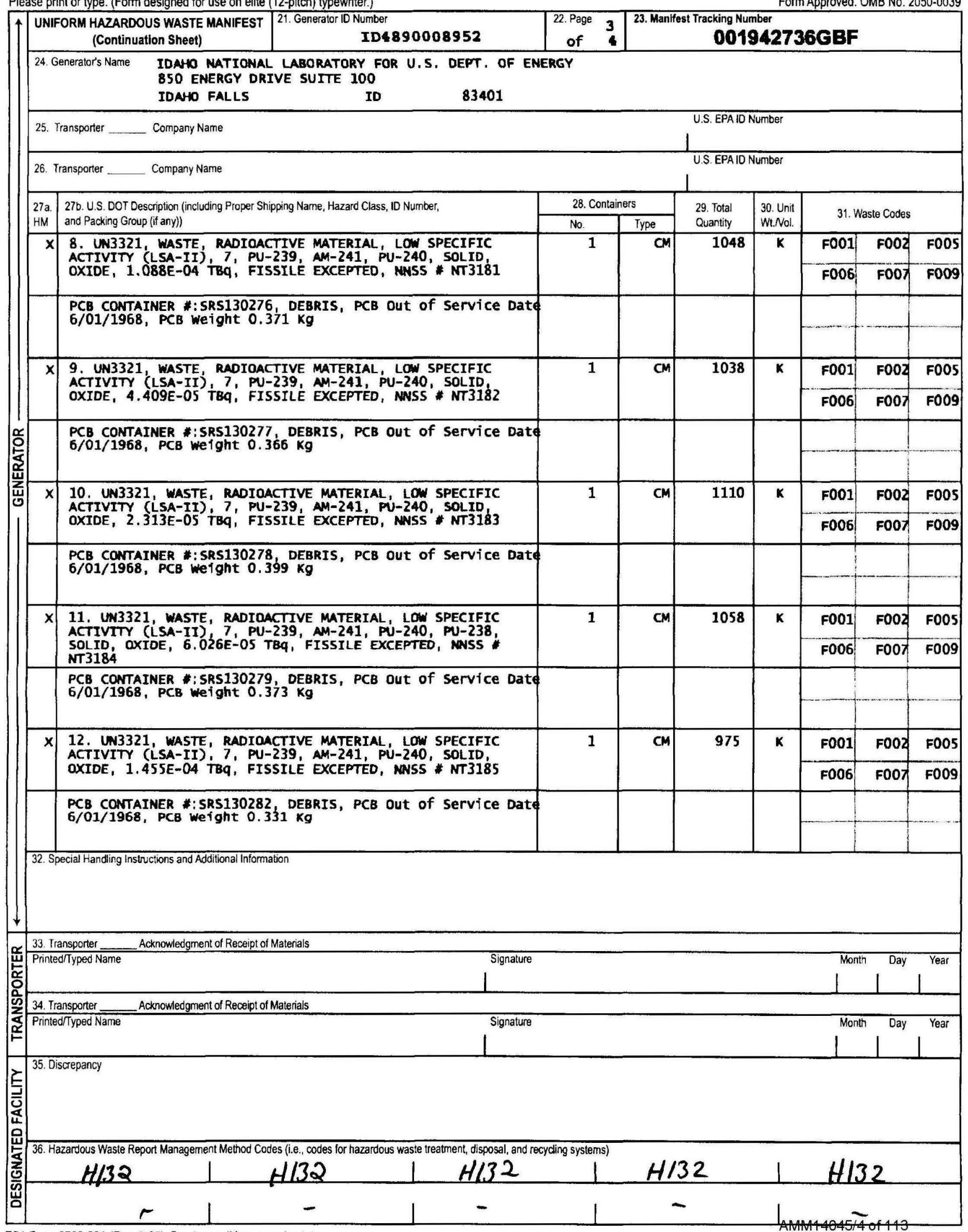


Please print or type. (Form designed for use on elite (12-pitch) typewriter.)

Form Approved. OMB No. 2050-0039

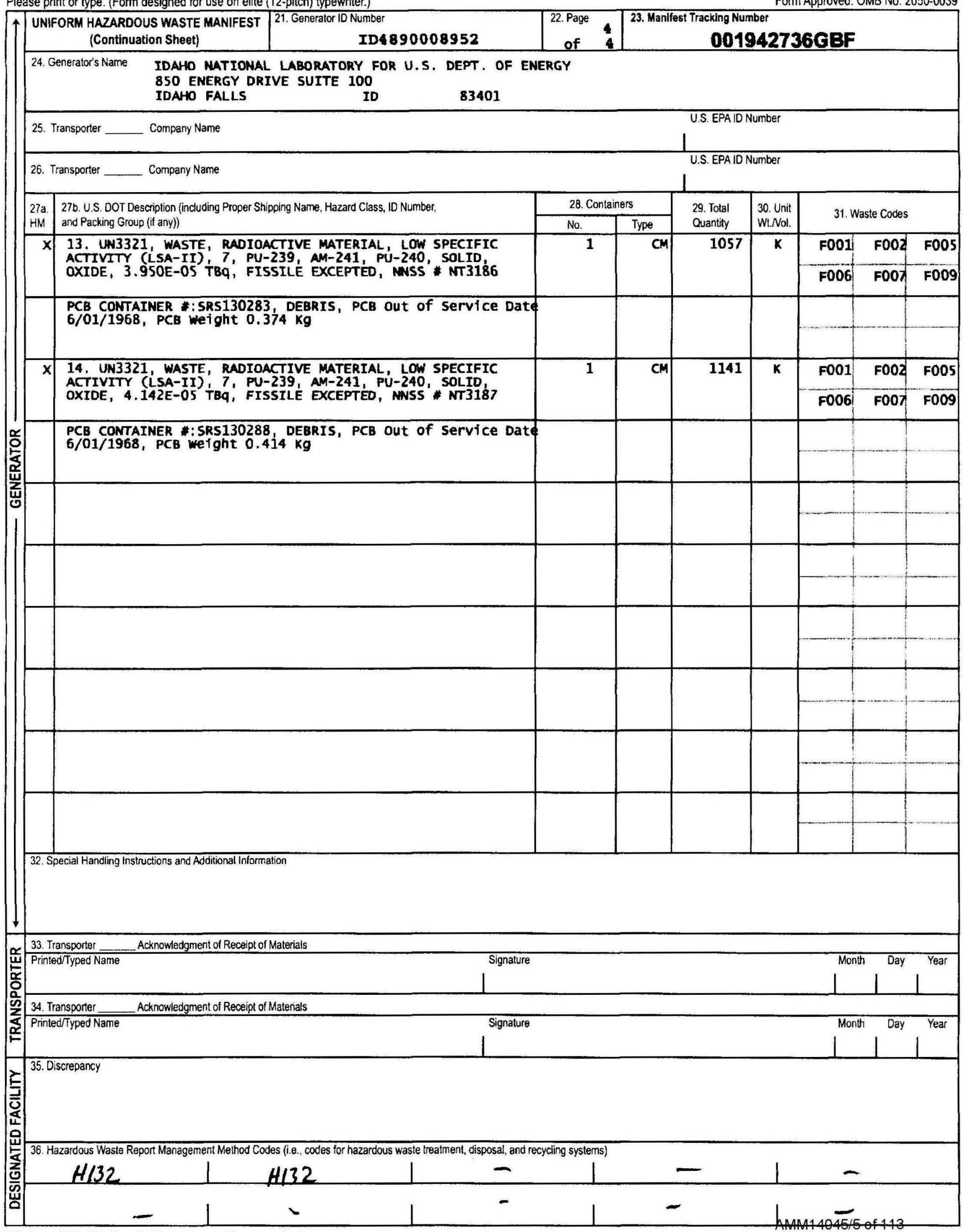


$\underset{\text { Nision. Senvice. Partnership }}{\text { Naty Technologies Luc }}$

H000-PA-14-0124

August 25, 2014

Jared Dominick

Waste Certification Official

Idaho Treatment Group

850 Energy Drive, Suite 100

Idaho Falls, ID 83401-1502

Subject: CERTIFICATE OF DISPOSAL FOR POLYCHLORINATED

BIPHENYL (PCB) WASTE AT THE NEVADA NATIONAL SECURITY SITE RADIOACTIVE WASTE MANAGEMENT SITE (RWMS)

Enclosed is the certificate acknowledging disposal of manifested PCB shipments AMM14044, AMM14045, AMM14046, and AMM14047 in the Mixed Waste Disposal Unit, at the Nevada National Security Site RWMS.

If you have any questions, please contact me at 702-295-2261.<smiles>CC(C)CC(O)CC(C)C(C)C</smiles>

Patrick M. Arnold, Division Manager

Environmental Management

LBG:saq

Enclosure: as stated

cc w/enc.

Correspondence Control

EWO Correspondence

J. T. Carilli, NNSA/NFO

R. C. Denton, NSTec

R. G. Geisinger, NSTec

L. B. Gregory, NSTec

M. Libidinsky, NNSA/NFO

C. P. Moke, NSTec

K. M. Small, NNSA/NFO

K. C. Tanaka, NSTec

A. V. Tauber, NNSA/NFO

R. A. Wagner, NSTec

National Security Technologies, LLC

Vision - Service - Partnership

www.NSTec.com

P.O. Box 98521, Las Vegas, NV 89193-8521

2621 Losee Road, N. Las Vegas, NV 89030-4129 


\section{National Security Technologies LLC \\ For U.S. Department of Energy \\ Waste Management \\ Nevada National Security Site - Zone 2 \\ Mercury, NV 89023}

EPA ID NV3890090001

This Certificate acknowledges that the following shipment(s) of manifested POLYCHLORINATED BIPHENYL (PCB) waste have been disposed at the Nevada National Security Site Radioactive Waste Management Site.

\begin{tabular}{|c|c|c|c|c|}
\hline $\begin{array}{c}\text { Shipment } \\
\text { Number }\end{array}$ & $\begin{array}{c}\text { Uniform Hazardous Waste } \\
\text { Manifest Number }\end{array}$ & Date(s) of Disposal & Volume $\mathbf{F t}^{3}\left(\mathbf{m}^{3}\right)$ & Disposal Process \\
\hline AMM14044 & $001942735 G B F$ & $08 / 18 / 2014$ & $1,259.76(35.67)$ & Landfill \\
\hline AMM14045 & $001942736 \mathrm{GBF}$ & $08 / 18 / 2014$ & $1,259.76(35.67)$ & Landfill \\
\hline AMM14046 & $001942737 G B F$ & $08 / 21 / 2014$ & $1,259.76(35.67)$ & Landfill \\
\hline AMM14047 & $001942738 G B F$ & $08 / 21 / 2014$ & $1,259.76(35.67)$ & Landfill \\
\hline
\end{tabular}

Under civil and criminal penalties of law for the making or submission of false or fraudulent statements or representations (18 U.S.C. 1001 and 15 U.S.C. 2615), I certify that the information contained in or accompanying this document is true, accurate, and complete.

As to the identified section(s) of this document for which I cannot personally verify truth and accuracy, I certify as the company official having supervisory responsibility for the persons who, acting under my direct instructions, made the verification that this information is true, accurate, and complete.
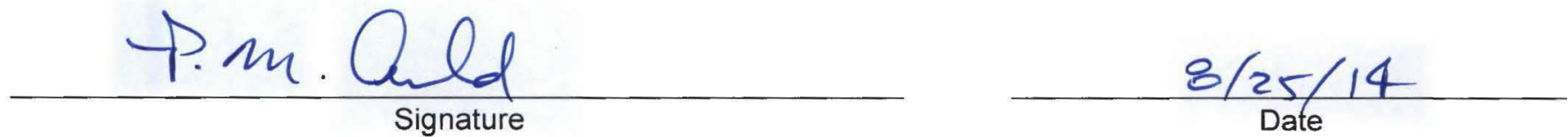

Division Manager, Environmental Management

Title

Instructions:

Shipment Number - enter shipment number from LWIS database.

Uniform Hazardous Waste Manifest Number - enter number from UHWM provided by generator.

Date of Disposal - enter date waste was placed in disposal cell.

Volume - enter shipment volume in cubic feet and equivalent cubic meters in parenthesis.

Disposal Process - enter Landfill.

\section{National Security Technologies, LLC}

Vision - Service $\cdot$ Partnership

www.NSTec.com

P.O. Box 98521, Las Vegas, NV 89193-8521

2621 Losee Road, N. Las Vegas, NV 89030-4129 
Please print or type. (Form designed for use on elite (12-pitch) typewriter.)

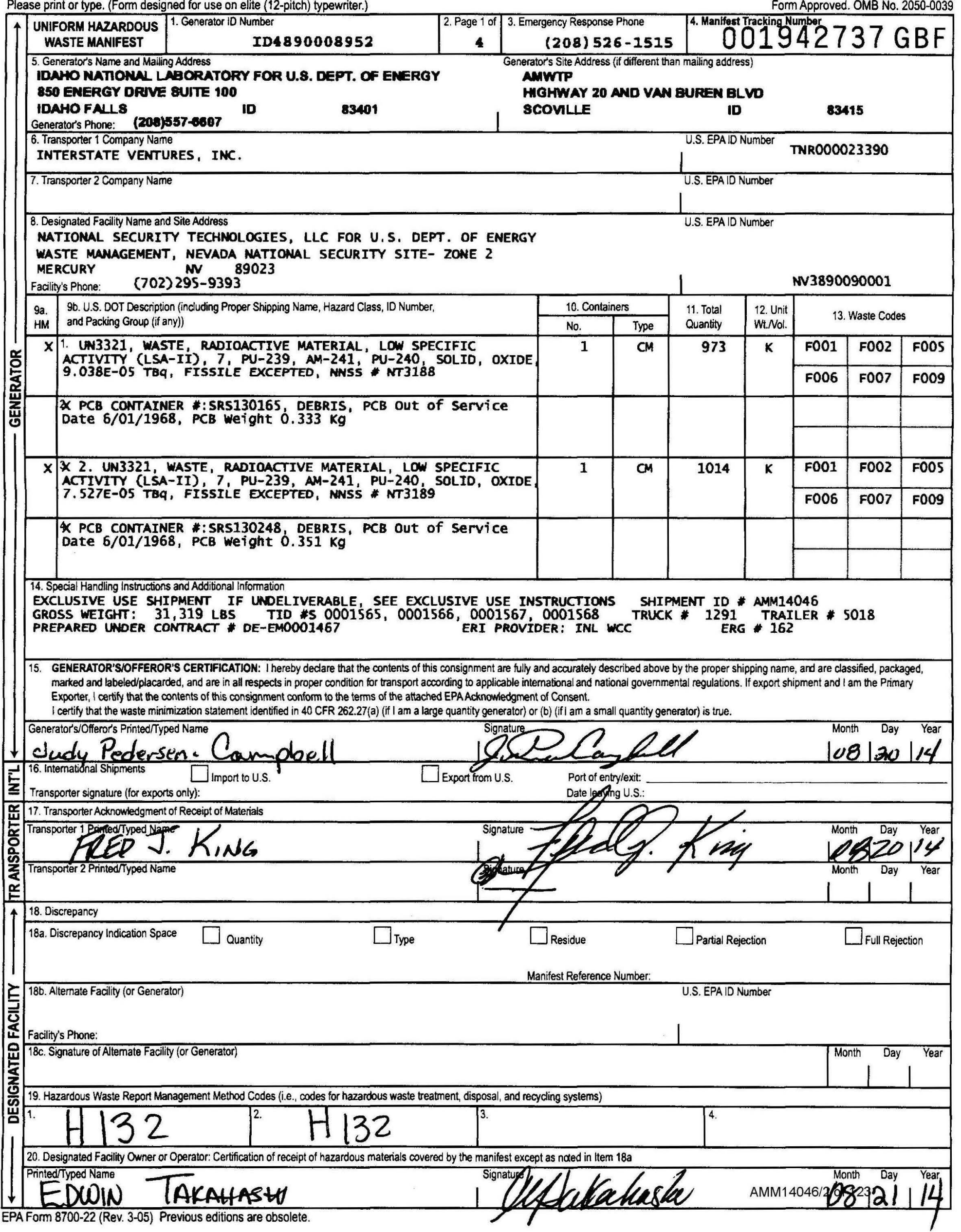


Please print or type. (Form designed for use on elite (12-pitch) typewriter.)

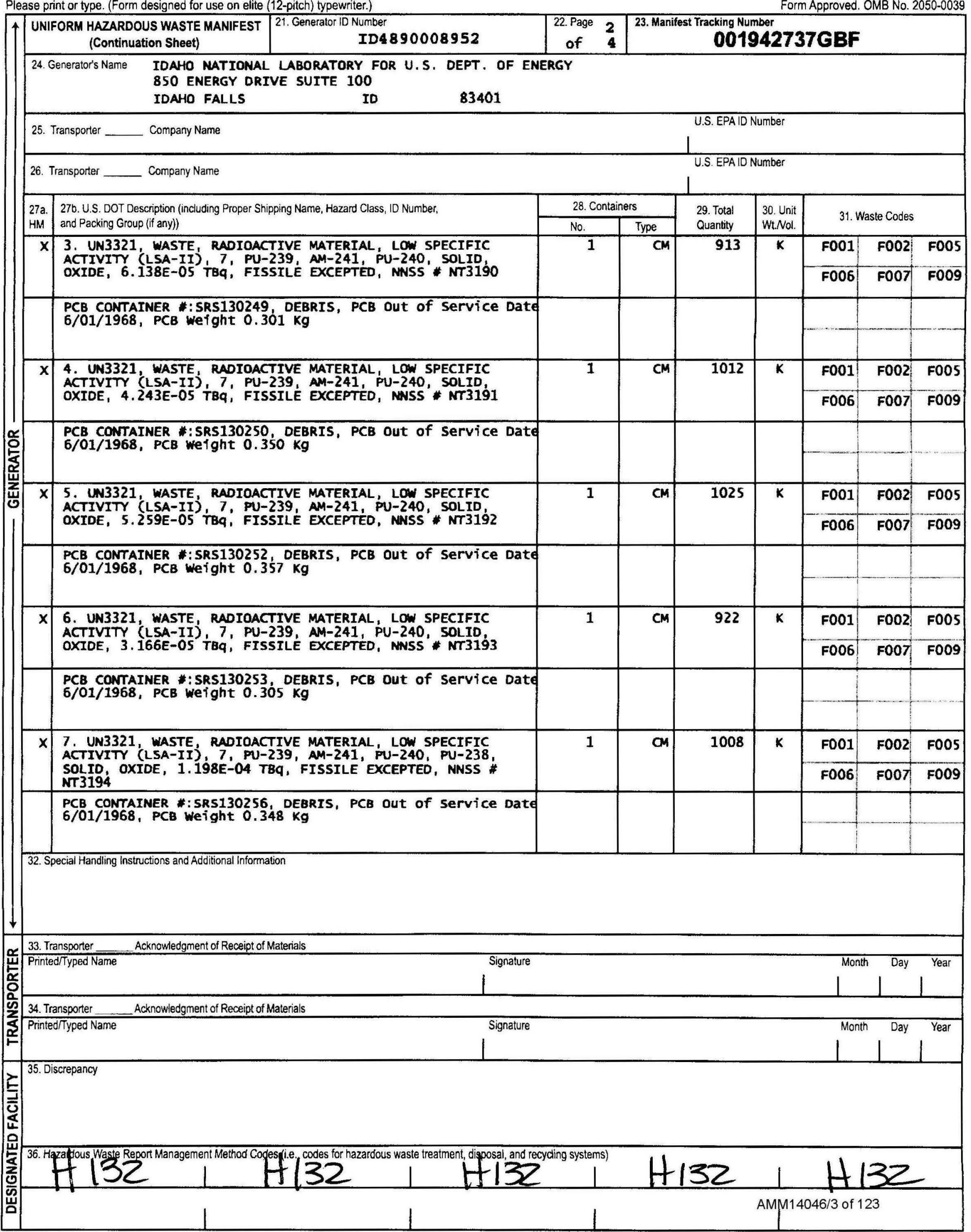


Please print or type. (Form designed for use on elite (12-pitch) typewriter.)

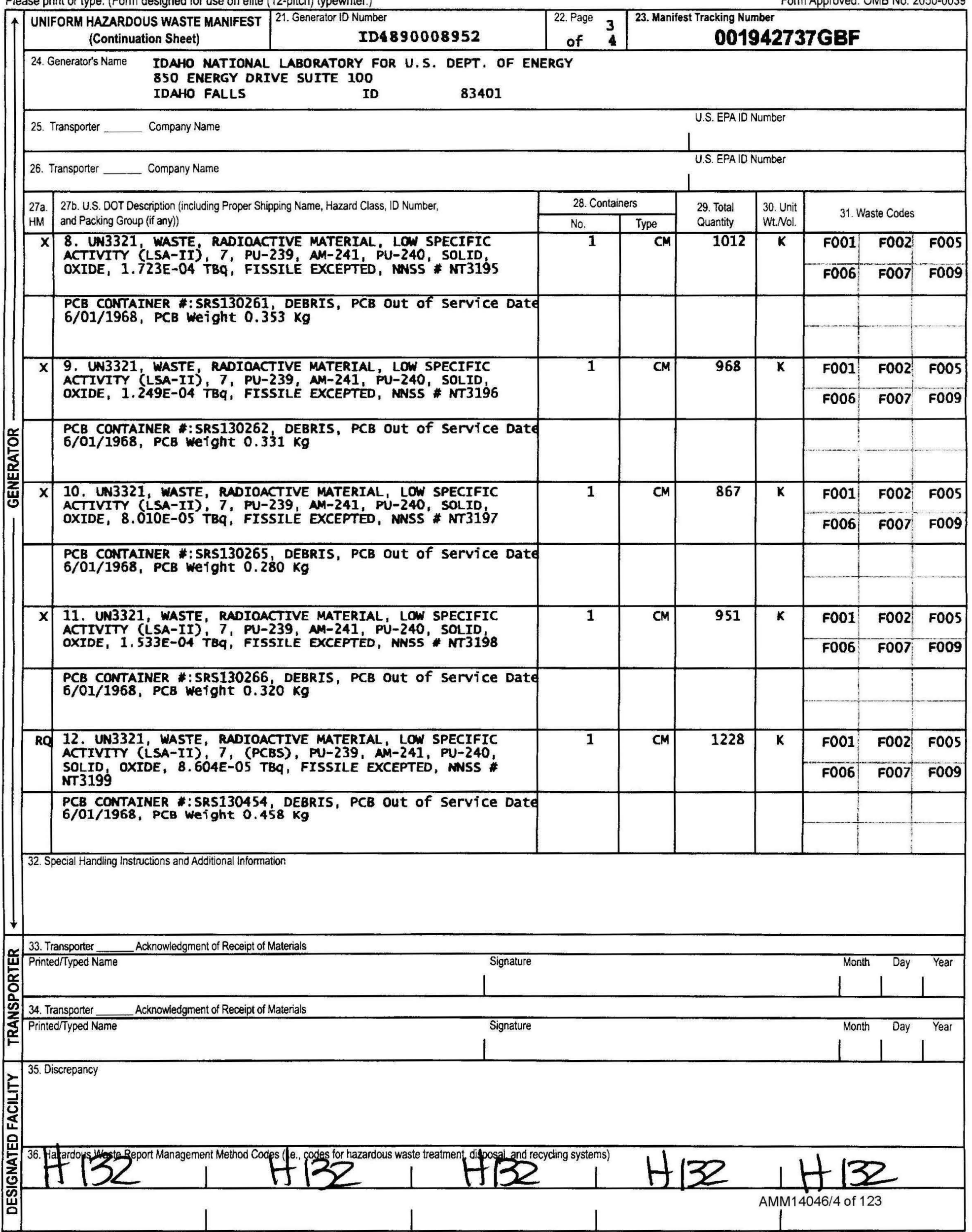


Please print or type. (Form designed for use on elite (12-pitch) typewriter.)

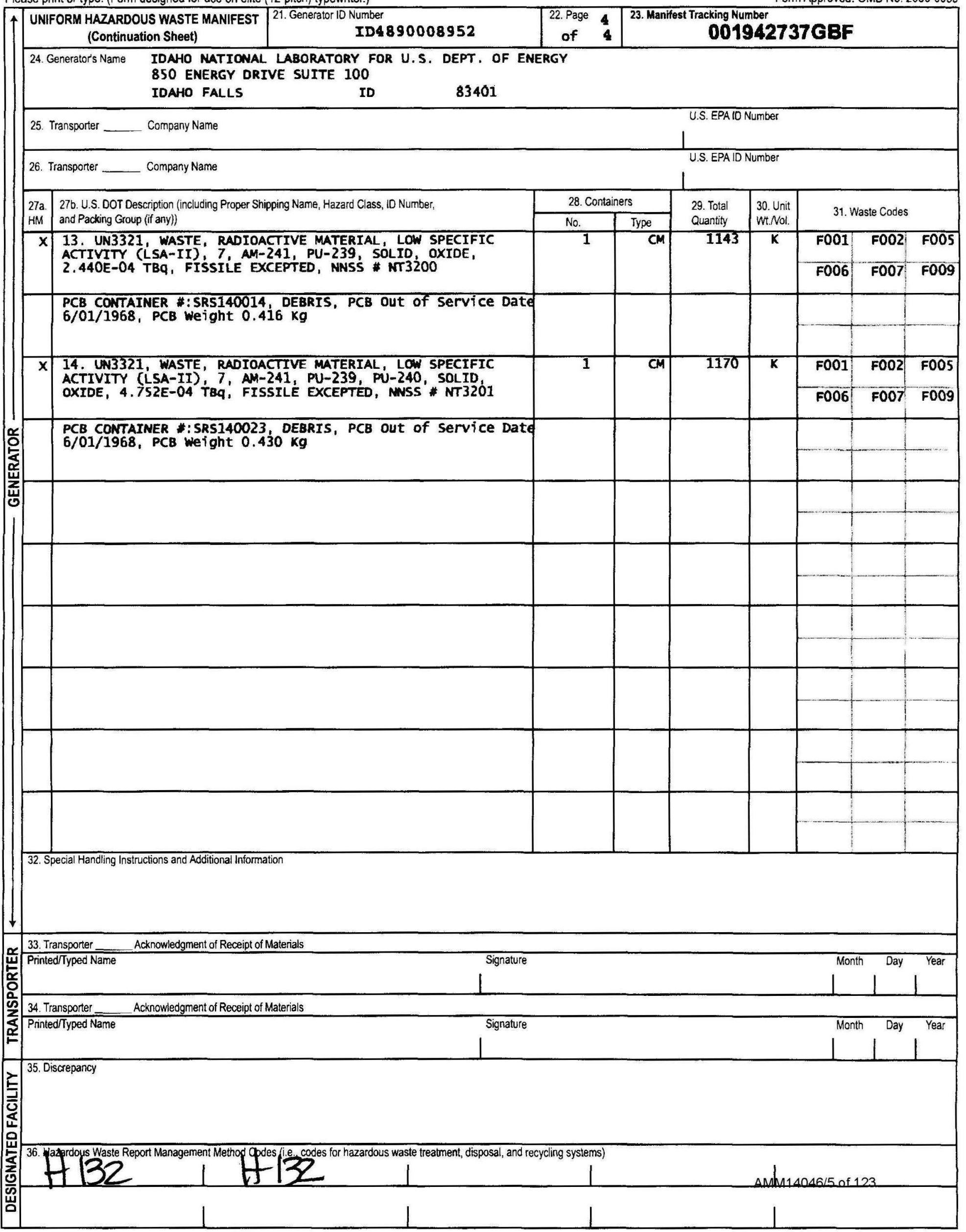


$\underset{\text { Nision. Senvice. Partnership }}{\text { Naty Technologies Luc }}$

H000-PA-14-0124

August 25, 2014

Jared Dominick

Waste Certification Official

Idaho Treatment Group

850 Energy Drive, Suite 100

Idaho Falls, ID 83401-1502

Subject: CERTIFICATE OF DISPOSAL FOR POLYCHLORINATED

BIPHENYL (PCB) WASTE AT THE NEVADA NATIONAL SECURITY SITE RADIOACTIVE WASTE MANAGEMENT SITE (RWMS)

Enclosed is the certificate acknowledging disposal of manifested PCB shipments AMM14044, AMM14045, AMM14046, and AMM14047 in the Mixed Waste Disposal Unit, at the Nevada National Security Site RWMS.

If you have any questions, please contact me at 702-295-2261.<smiles>CC(C)CC(O)CC(C)C(C)C</smiles>

Patrick M. Arnold, Division Manager

Environmental Management

LBG:saq

Enclosure: as stated

cc w/enc.

Correspondence Control

EWO Correspondence

J. T. Carilli, NNSA/NFO

R. C. Denton, NSTec

R. G. Geisinger, NSTec

L. B. Gregory, NSTec

M. Libidinsky, NNSA/NFO

C. P. Moke, NSTec

K. M. Small, NNSA/NFO

K. C. Tanaka, NSTec

A. V. Tauber, NNSA/NFO

R. A. Wagner, NSTec

National Security Technologies, LLC

Vision - Service - Partnership

www.NSTec.com

P.O. Box 98521, Las Vegas, NV 89193-8521

2621 Losee Road, N. Las Vegas, NV 89030-4129 


\section{National Security Technologies LLC \\ For U.S. Department of Energy \\ Waste Management \\ Nevada National Security Site - Zone 2 \\ Mercury, NV 89023}

EPA ID NV3890090001

This Certificate acknowledges that the following shipment(s) of manifested POLYCHLORINATED BIPHENYL (PCB) waste have been disposed at the Nevada National Security Site Radioactive Waste Management Site.

\begin{tabular}{|c|c|c|c|c|}
\hline $\begin{array}{c}\text { Shipment } \\
\text { Number }\end{array}$ & $\begin{array}{c}\text { Uniform Hazardous Waste } \\
\text { Manifest Number }\end{array}$ & Date(s) of Disposal & Volume $\mathbf{F t}^{3}\left(\mathbf{m}^{3}\right)$ & Disposal Process \\
\hline AMM14044 & $001942735 G B F$ & $08 / 18 / 2014$ & $1,259.76(35.67)$ & Landfill \\
\hline AMM14045 & $001942736 \mathrm{GBF}$ & $08 / 18 / 2014$ & $1,259.76(35.67)$ & Landfill \\
\hline AMM14046 & $001942737 G B F$ & $08 / 21 / 2014$ & $1,259.76(35.67)$ & Landfill \\
\hline AMM14047 & $001942738 G B F$ & $08 / 21 / 2014$ & $1,259.76(35.67)$ & Landfill \\
\hline
\end{tabular}

Under civil and criminal penalties of law for the making or submission of false or fraudulent statements or representations (18 U.S.C. 1001 and 15 U.S.C. 2615), I certify that the information contained in or accompanying this document is true, accurate, and complete.

As to the identified section(s) of this document for which I cannot personally verify truth and accuracy, I certify as the company official having supervisory responsibility for the persons who, acting under my direct instructions, made the verification that this information is true, accurate, and complete.
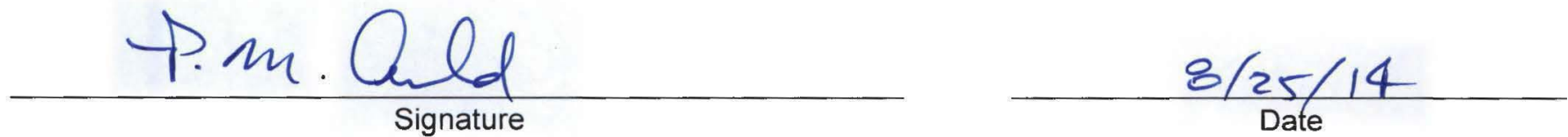

Division Manager, Environmental Management

Title

Instructions:

Shipment Number - enter shipment number from LWIS database.

Uniform Hazardous Waste Manifest Number - enter number from UHWM provided by generator.

Date of Disposal - enter date waste was placed in disposal cell.

Volume - enter shipment volume in cubic feet and equivalent cubic meters in parenthesis.

Disposal Process - enter Landfill.

\section{National Security Technologies, LLC}

Vision - Service $\cdot$ Partnership

www.NSTec.com

P.O. Box 98521, Las Vegas, NV 89193-8521

2621 Losee Road, N. Las Vegas, NV 89030-4129 
Please print or type. (Form designed for use on elite (12-pitch) typewriter.)

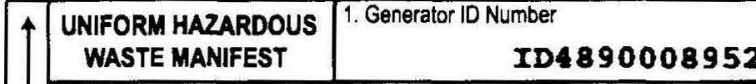 \\ 5. Generator's Name and Mailing Address} 850 ENEROY DRUVE SUITE 100

IDAHO FALL8

ID

83401
IDAHO MATIONAL LABORATORY FOR U.S. DEPT. OF ENERGY

Form Approved. OMB NNo. 2050-0039

(2085576607

6. Transporter 1 Company Name

INTERSTATE VENTURES, INC.

7. Transporter 2 Company Name
2. Page 10

1

${ }_{\text {Genera }}^{3}$

(if different than mailing address)

\section{AMWTP}

HOHWAY 20 NND VAN BUREN BLVD

SCOVLLE

TNR000023390

U.S. EPAID Number

8. Designated Facility Name and Site Address

NATIONAL SECURITY TECHNOLOGIES, LLC FOR U.S. DEPT. OF ENERGY

U.S. EPA ID Number

WASTE MANAGEMENT, NEVADA NATIONAL SECURITY SITE- ZONE 2

MERCURY NN 89023

Facility's Phone: (702) 295-9393

9a. 9 b. U.S. DOT Description (including Proper Shipping Name, Hazard Class, ID Number,

HM and Packing Group (if any))

$\times$ 1. UN3321, WASTE, RADIOACTIVE MATERIAL, LOW SPECIFIC

吅 ACTIVITY' (LSA-II), 7, PU-239, AM-241, PU-240, SOLID, OXIDE

1.895E-04 TBQ, FISSTLE EXCEPTED, NNSS * NT3202

\begin{tabular}{|c|c|c|c|}
\hline \multicolumn{2}{|c|}{ 10. Containers } & \multirow{2}{*}{$\begin{array}{l}\text { 11. Total } \\
\text { Quantity }\end{array}$} & \multirow{2}{*}{$\begin{array}{l}\text { 12. Unit } \\
\text { W. Nol. }\end{array}$} \\
\hline No. & Type & & \\
\hline 1 & $\mathrm{CM}$ & 1083 & K \\
\hline & & & \\
\hline 1 & $\mathrm{CM}$ & 1016 & $k$ \\
\hline & & & \\
\hline & & & \\
\hline & & & \\
\hline
\end{tabular}

NV3890090001

13. Waste Codes

\begin{tabular}{|l|l|l|}
\hline$F 001$ & $F 002$ & $F 005$ \\
\hline$F 006$ & $F 007$ & $F 009$ \\
\hline
\end{tabular}

2X PCB CONTAINER *:SR5130139, DEBRIS, PCB Out of service

Date $6 / 01 / 1968$, PCB weight $0.387 \mathrm{Kg}$

$X$ 3. 2. UN3321, WASTE, RADTOACTIVE MATERIAL, LOW SPECIFIC

ACTIVITY (LSA-II), 7, PU-239, AM-241, PU-240, SOLID, OXIDE

2.564E-05 TBQ, FISSTLE EXCEPTED, MSS * NT3203

4 PCB CONTAINER *:SRS130315, DEBRIS, PCB out of service Date 6/01/1968, PCB weight $0.351 \mathrm{~kg}$

14. Special Handling Instructions and Additional Information

EXCLUSTVE USE SHIPMENT IF UNDELIVERABLE, SEE EXCLUSIVE USE INSTRUCTTONS SHIPMENT ID * AMM14047

GROSS WEIGHT: 32,564 LBS TID \#S 0001569, 0001570,0001571, 0001572 TRUCK *307

PREPARED UNDER CONTRACT * DE-EMO001467

ERI PROVIDER: INL WCC

ERG * 162

TRAILER \# 5021

15. GENERATOR'S/OFFEROR'S CERTIFICATION: I hereby declare that the contents of this consignment are fully and accurately described above by the proper shipping name, and are classified, packaged, marked and labeled/placarded, and are in all respects in proper condition for transport according to applicable intemational and national governmental regulations. If export shipment and I am the Primary Exporter, I certify that the contents of this consignment conform to the terms of the attached EPA Acknowledgment of Consent.

I certify that the waste minimization statement identified in 40 CFR 262.27(a) (if I am a large quantity generator) or (b) (if I am a small quantity generator) is true.

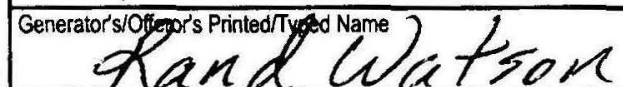

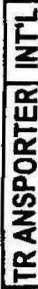

Transporter signature (for exports only):

$\square$ import to U.S

17. Transporter Acknowledgment of Receipt of Materials

Transpgra 1 Printed/Typed Name

love cas

Transporter 2 Pfítied/Typed Name

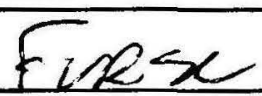

Signature

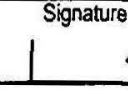

Export from U.S

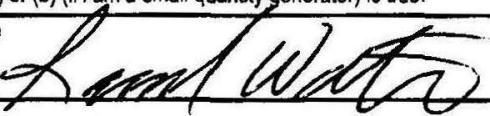

Port of entrylexit:

Date leaving U.S

\begin{tabular}{|l|l|l|} 
& & \\
\hline$F 001$ & $F 002$ & $F 005$ \\
\hline$F 006$ & $F 007$ & $F 009$ \\
\hline & & \\
\hline
\end{tabular}

18. Discrepancy

18a. Discrepancy indication Space

$\square$ Quantity

$\square$ Type

$\square$ Residue

Partial Rejection

$181201 / 4$

Dareloang
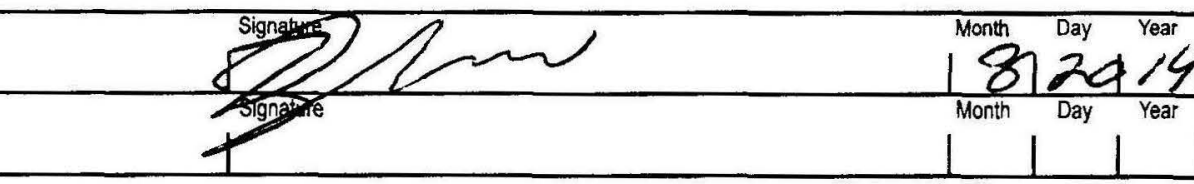

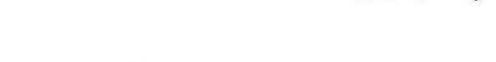

18b. Alternate Facility (or Generator)

Manifest Reference Number:

Facility's Phone:

18c. Signature of Alternate Facility (or Generator)

19. Hazardous Waste Report Management Method Codes (i.e., codes for hazardous waste treatment, disposal, and recycling systems)

岂 1 .

\section{$H 132$ \\ 4132}

20. Designated Facility Owner or Operator: Certification of receipt of hazardous materials covered by the manifest except as nuted in Item $18 \mathrm{a}$

Printed/Typed Name

Chris Chaluokg

EPA Form 8700-22 (Rev. 3-05) Previous editions are obsolete.

U.S. EPA ID Number

\begin{tabular}{|l|l|l|l|l|}
\hline Signature & Lear \\
\hline
\end{tabular}




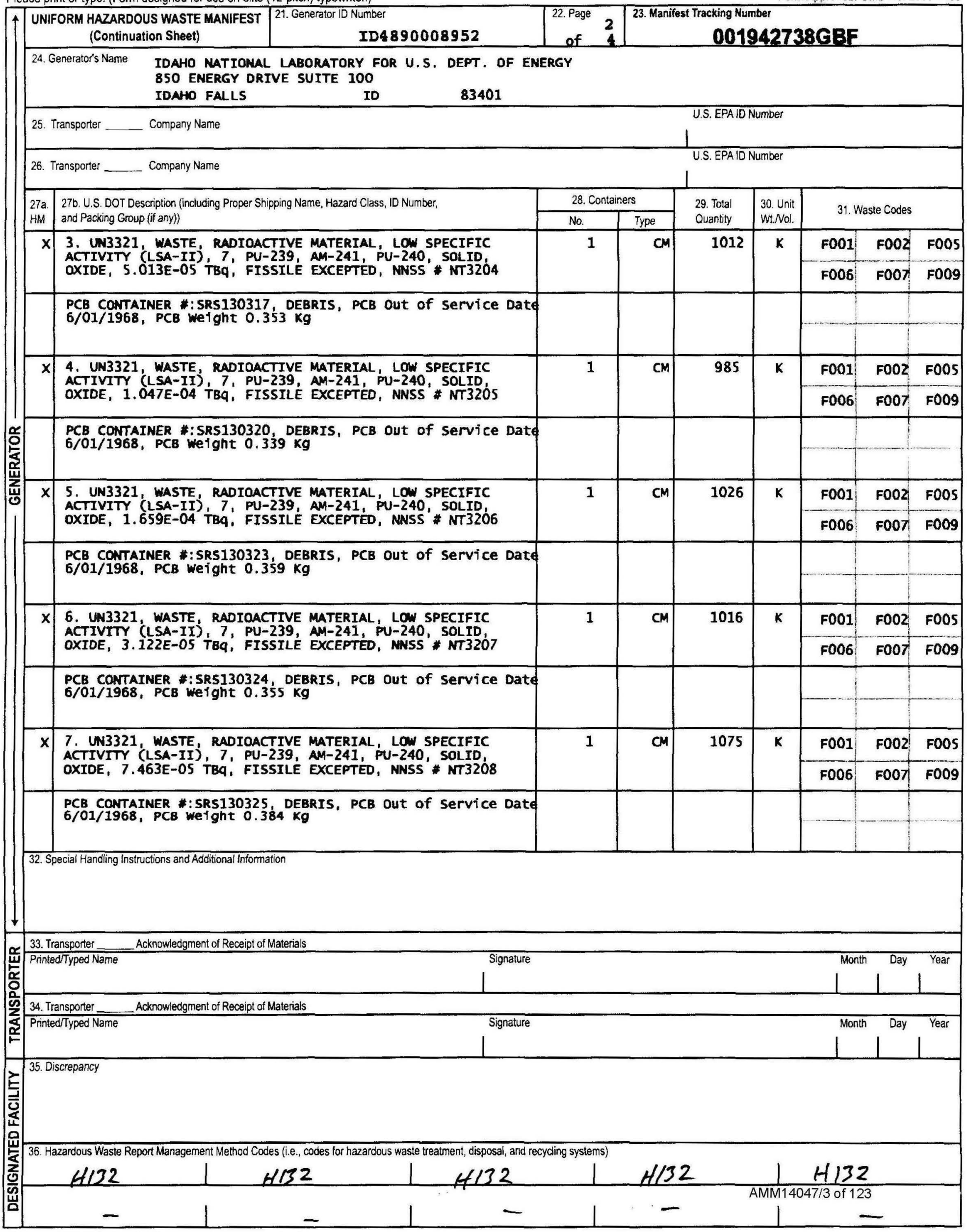


Please print or type. (Form designed for use on elite (12-pitch) typewriter.)

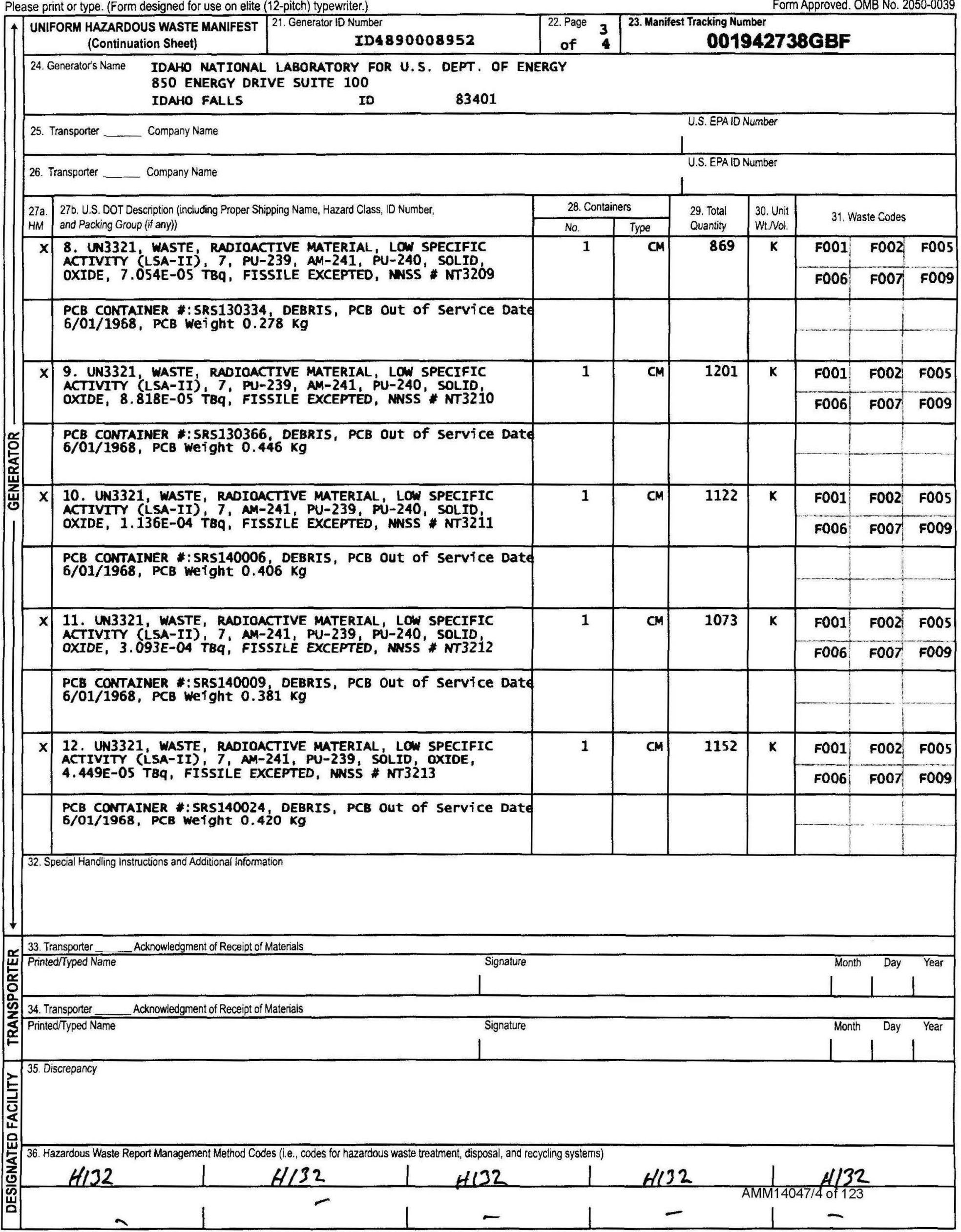




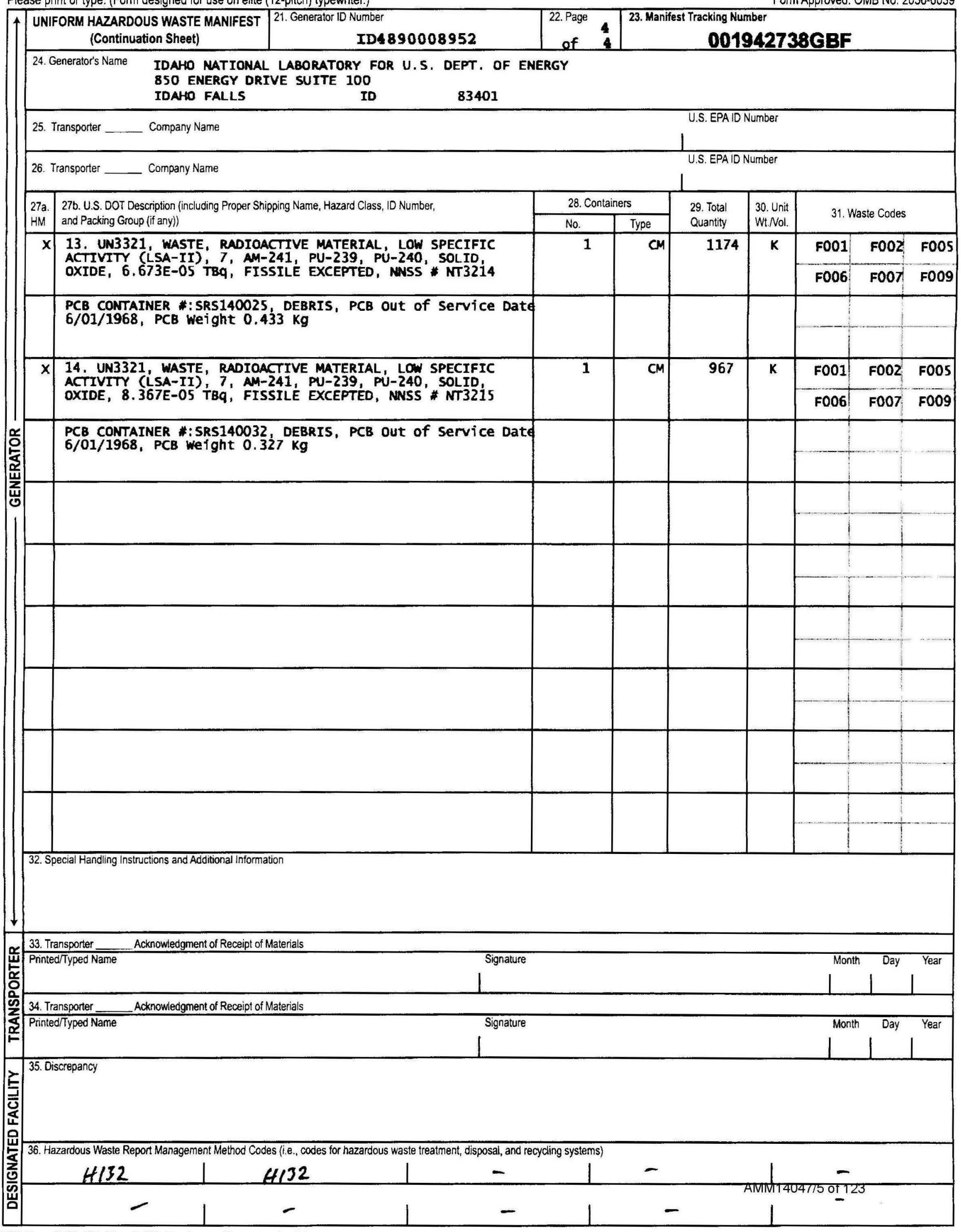


$\underset{\text { Nision. Senvice. Partnership }}{\text { Naty Technologies Luc }}$

H000-PA-14-0124

August 25, 2014

Jared Dominick

Waste Certification Official

Idaho Treatment Group

850 Energy Drive, Suite 100

Idaho Falls, ID 83401-1502

Subject: CERTIFICATE OF DISPOSAL FOR POLYCHLORINATED

BIPHENYL (PCB) WASTE AT THE NEVADA NATIONAL SECURITY SITE RADIOACTIVE WASTE MANAGEMENT SITE (RWMS)

Enclosed is the certificate acknowledging disposal of manifested PCB shipments AMM14044, AMM14045, AMM14046, and AMM14047 in the Mixed Waste Disposal Unit, at the Nevada National Security Site RWMS.

If you have any questions, please contact me at 702-295-2261.<smiles>CC(C)CC(O)CC(C)C(C)C</smiles>

Patrick M. Arnold, Division Manager

Environmental Management

LBG:saq

Enclosure: as stated

cc w/enc.

Correspondence Control

EWO Correspondence

J. T. Carilli, NNSA/NFO

R. C. Denton, NSTec

R. G. Geisinger, NSTec

L. B. Gregory, NSTec

M. Libidinsky, NNSA/NFO

C. P. Moke, NSTec

K. M. Small, NNSA/NFO

K. C. Tanaka, NSTec

A. V. Tauber, NNSA/NFO

R. A. Wagner, NSTec

National Security Technologies, LLC

Vision - Service - Partnership

www.NSTec.com

P.O. Box 98521, Las Vegas, NV 89193-8521

2621 Losee Road, N. Las Vegas, NV 89030-4129 


\section{National Security Technologies LLC \\ For U.S. Department of Energy \\ Waste Management \\ Nevada National Security Site - Zone 2 \\ Mercury, NV 89023}

EPA ID NV3890090001

This Certificate acknowledges that the following shipment(s) of manifested POLYCHLORINATED BIPHENYL (PCB) waste have been disposed at the Nevada National Security Site Radioactive Waste Management Site.

\begin{tabular}{|c|c|c|c|c|}
\hline $\begin{array}{c}\text { Shipment } \\
\text { Number }\end{array}$ & $\begin{array}{c}\text { Uniform Hazardous Waste } \\
\text { Manifest Number }\end{array}$ & Date(s) of Disposal & Volume $\mathbf{F t}^{3}\left(\mathbf{m}^{3}\right)$ & Disposal Process \\
\hline AMM14044 & $001942735 G B F$ & $08 / 18 / 2014$ & $1,259.76(35.67)$ & Landfill \\
\hline AMM14045 & $001942736 \mathrm{GBF}$ & $08 / 18 / 2014$ & $1,259.76(35.67)$ & Landfill \\
\hline AMM14046 & $001942737 G B F$ & $08 / 21 / 2014$ & $1,259.76(35.67)$ & Landfill \\
\hline AMM14047 & $001942738 G B F$ & $08 / 21 / 2014$ & $1,259.76(35.67)$ & Landfill \\
\hline
\end{tabular}

Under civil and criminal penalties of law for the making or submission of false or fraudulent statements or representations (18 U.S.C. 1001 and 15 U.S.C. 2615), I certify that the information contained in or accompanying this document is true, accurate, and complete.

As to the identified section(s) of this document for which I cannot personally verify truth and accuracy, I certify as the company official having supervisory responsibility for the persons who, acting under my direct instructions, made the verification that this information is true, accurate, and complete.
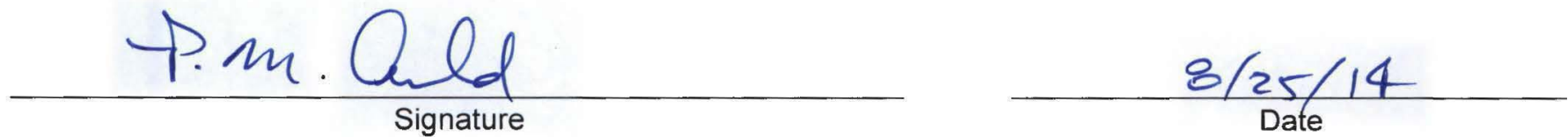

Division Manager, Environmental Management

Title

Instructions:

Shipment Number - enter shipment number from LWIS database.

Uniform Hazardous Waste Manifest Number - enter number from UHWM provided by generator.

Date of Disposal - enter date waste was placed in disposal cell.

Volume - enter shipment volume in cubic feet and equivalent cubic meters in parenthesis.

Disposal Process - enter Landfill.

\section{National Security Technologies, LLC}

Vision - Service $\cdot$ Partnership

www.NSTec.com

P.O. Box 98521, Las Vegas, NV 89193-8521

2621 Losee Road, N. Las Vegas, NV 89030-4129 
Please print or type. (Form designed for use on elite (12-pitch) typewriter.)

$\uparrow$\begin{tabular}{|c|c|c|}
$\begin{array}{c}\text { UNIFORM HAZARDOUS } \\
\text { WASTE MANIFEST }\end{array}$ & $\begin{array}{c}1 . \text { Generator ID Number } \\
\text { ID4 } 890008952\end{array}$ \\
\hline 5. Generator's Name and Mailing Address &
\end{tabular}

IDAHO NATIONAL LABORATORY FOR U.S. DEPT. OF ENERGY 850 ENERGY DRIVE SUITE 100

IDAHO FALLS

Generator's Phone: (208)557-6607

6. Transporter 1 Company Name

INTERSTATE VENTURES, INC.

7. Transporter 2 Company Name

ID $\mathbf{8 3 4 0 1}$
Form Approved. OMB №. 2050-0039

\begin{tabular}{|c|c|c|c|}
\hline $\begin{array}{c}\text { 2. Page } 1 \text { of } \\
4\end{array}$ & $\begin{array}{c}\text { 3. Emergency Response Phone } \\
\text { (208) } 52.6-1515\end{array}$ & $001942742 \mathrm{GBF}$ \\
\hline
\end{tabular}

ANWTP

HIGHWAY 20 AND VAN BUREN BLVD

SCOVLLE
ID

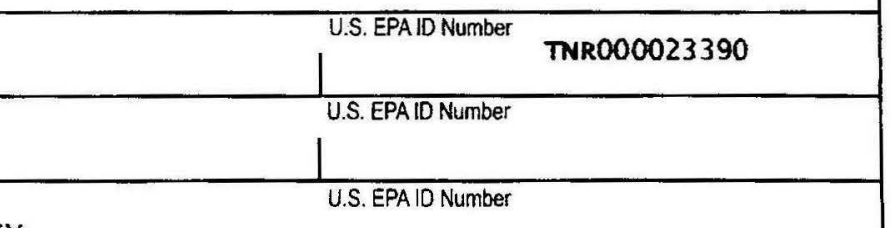

8. Designated Facility Name and Site Address

NATIONAL SECURITY TECHNOLOGIES, LLC FOR U.S. DEPT. OF ENERGY

WASTE MANAGEMENT, NEVADA NATIONAL SECURITY SITE- ZONE 2

MERCURY NV 89023

Facility's Phone: (702) 295-9393

1

9a. 9b. U.S. Dor Description (induding Proper Shipping Name, Hazard Class, ID Number,

HM and Packing Group (if any))

$x$ 1. UN3321, WASTE, RADIOACTTVE MATERIAL, LOW SPECIFIC ACTIVITY (LSA-II), 7, PU-239, AM-241, PU-240, SOLID, OXIDE 7.180E-0S TBq, FISSILE EXCEPTED, NNSS \# NT3216

2x PCB CONTAINER \#:SRS130164, DEBRIS, PCB out of service Date 6/01/1968, PCB Weight $0.409 \mathrm{~kg}$

$x$ 33 2. UN3321, WASTE, RADIOACTIVE MATERTAL, LOW SPECIFIC ACTIVITY (LSA-II), 7, PU-239, AM-241, PU-240, SOLID, OXIDE 1.383E-04 TBQ, FISSTLE EXCEPTED, NNSS \# NT3217

$4 \times$ PCB CONTAINER \#:SRS130170, DEBRIS, PCB out of service oate $6 / 01 / 1968$, PCB Weight $0.369 \mathrm{~kg}$

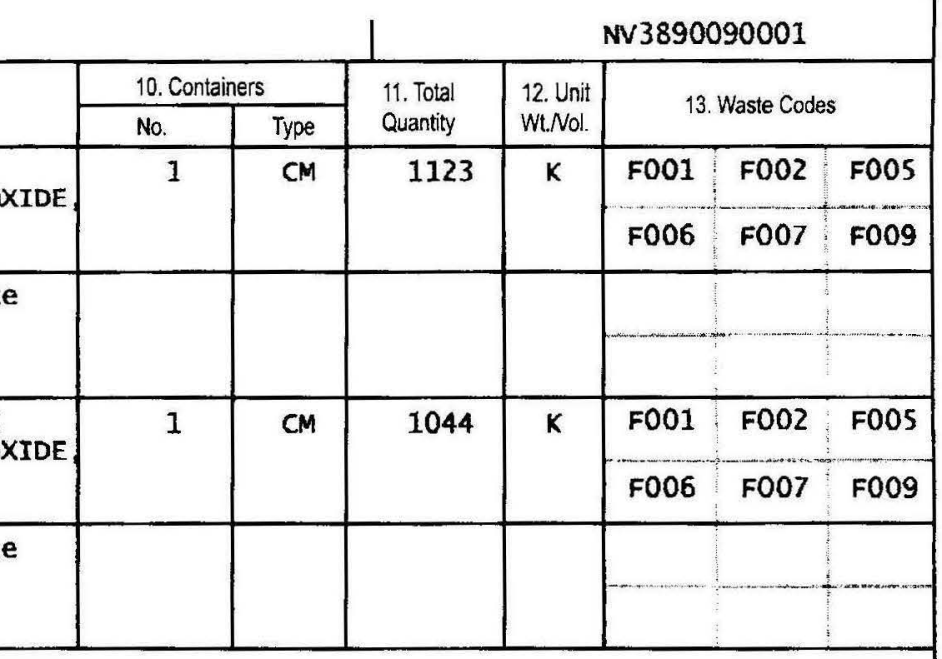

14. Special Handling Instructions and Additional Information

EXCLUSIVE USE SHIPMENT IF UNDELIVERABLE, SEE EXCLUSIVE USE INSTRUCTIONS

RETURN SIGNED ORIGINAL TO GENERATOR,

GROSS WEIGHT: 32,124 LBS TID \#S 0001617, 0001618, 0001619,0001620

PREPARED UNDER CONTRACT \# DE-EM0001467

ERT PROVIDER: INL WCC

SHTPMENT ID \# AMM14048

TRUCK * 1291 TRAILER \# SO2S

ERG \# 162

15. GENERATOR'S/OFFEROR'S CERTIFICATION: I hereby declare that the contents of this consignment are fully and accurately described above by the proper shipping name, and are classified, packaged, marked and labeled/placarced, and are in all respects in proper condition for transport according to applicable international and national governmental regulations. If export shipment and 1 am the Primary Exporter, I certify that the contents of this consignment conform to the terms of the attached EPAAcknowledgment of Consent.

I certify that the waste minimization statement identified in 40 CFR 262.27 (a) (if I am a large quantity generator) or (b) (if I am a small quantity generator) is true.

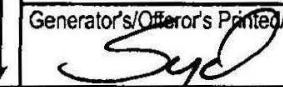

16. International Shipments

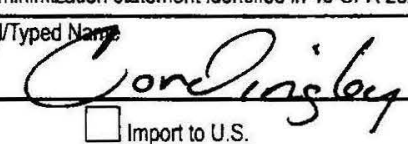

Transporter signature (for exports only):

17. 17. Transporter Acknowledgment of Receipt of Materials

18. Discrepancy

18a. Discrepancy indication Space $\square$ Quantity $\square$ Type

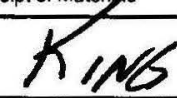

ansporter 2 Printed/lyped Name

orter 1 ginted/Typed Name

18b. Alternate Facility (or Generator)

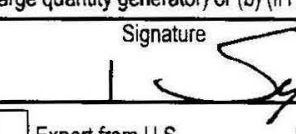

$\square$ Export from U.S. Port of entrylexit:

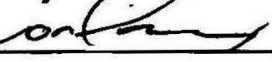

Datreayng U.S

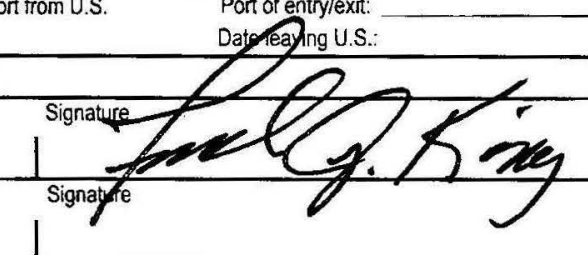

$\square$ Residue

Partial Rejection

Month Day Year

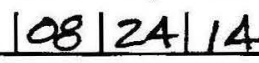

U.S. EPAID Number

Facility's Phone

18c. Signature of Alternate Facility (or Generator)

19. Hazardous Waste Report Management Method Codes (i.e., codes for hazardous waste treatment, disposal, and recycling systems)
$H 132$
$\mathrm{H} 132$

3.

20. Designated Facility Owner or Operator: Certification of receipt of hazardous materials covered by the manifest except as noted in ltem $18 \mathrm{a}$

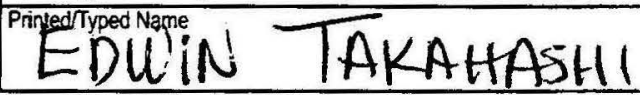

EPA Form 8700-22 (Rev. 3-05) Previous editions are obsolete.

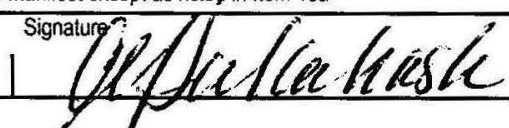


Please print or type. (Form designed for use on elite (12-pitch) typewriter.)

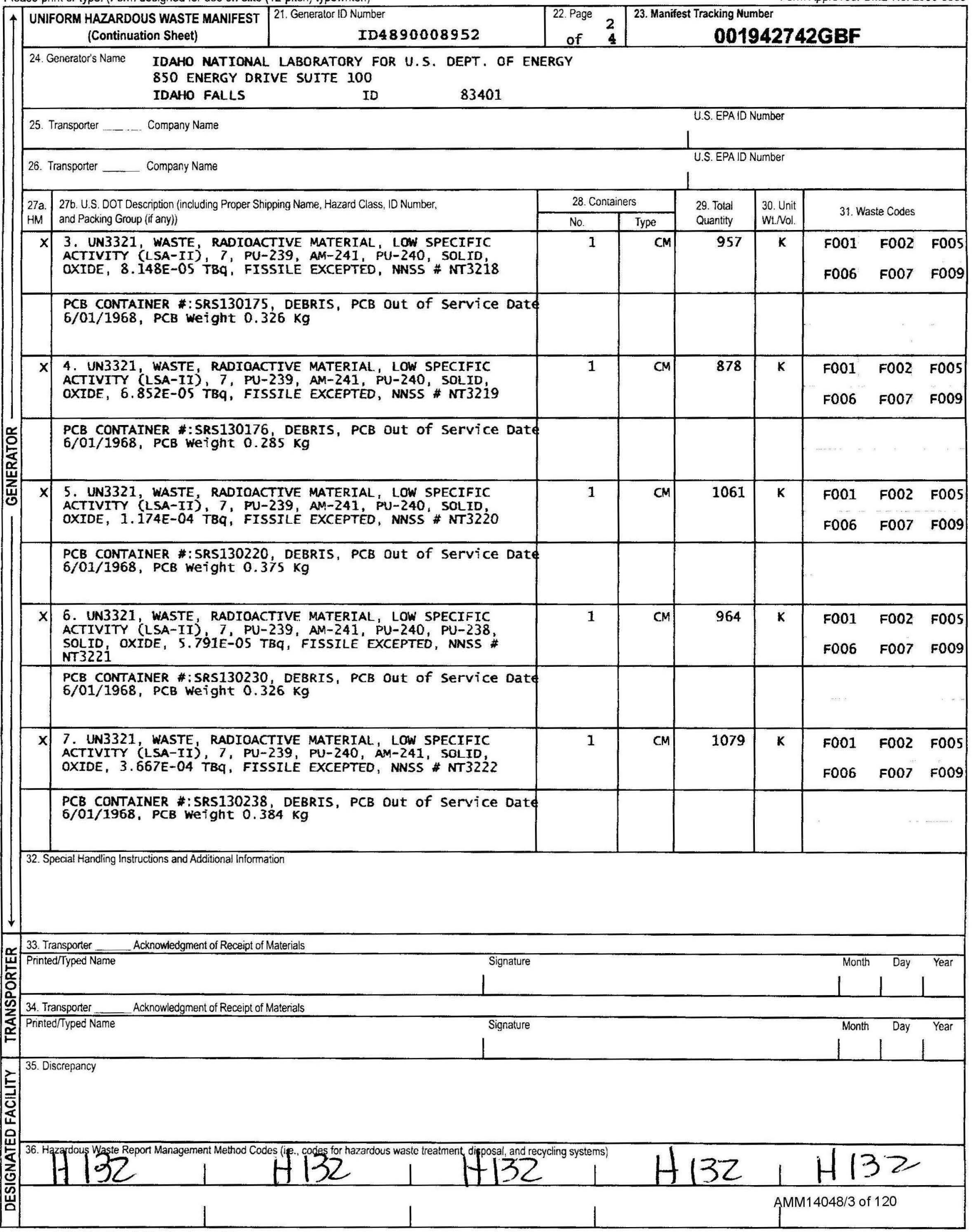


Please print or type. (Form designed for use on elite (12-pitch) typewriter.)

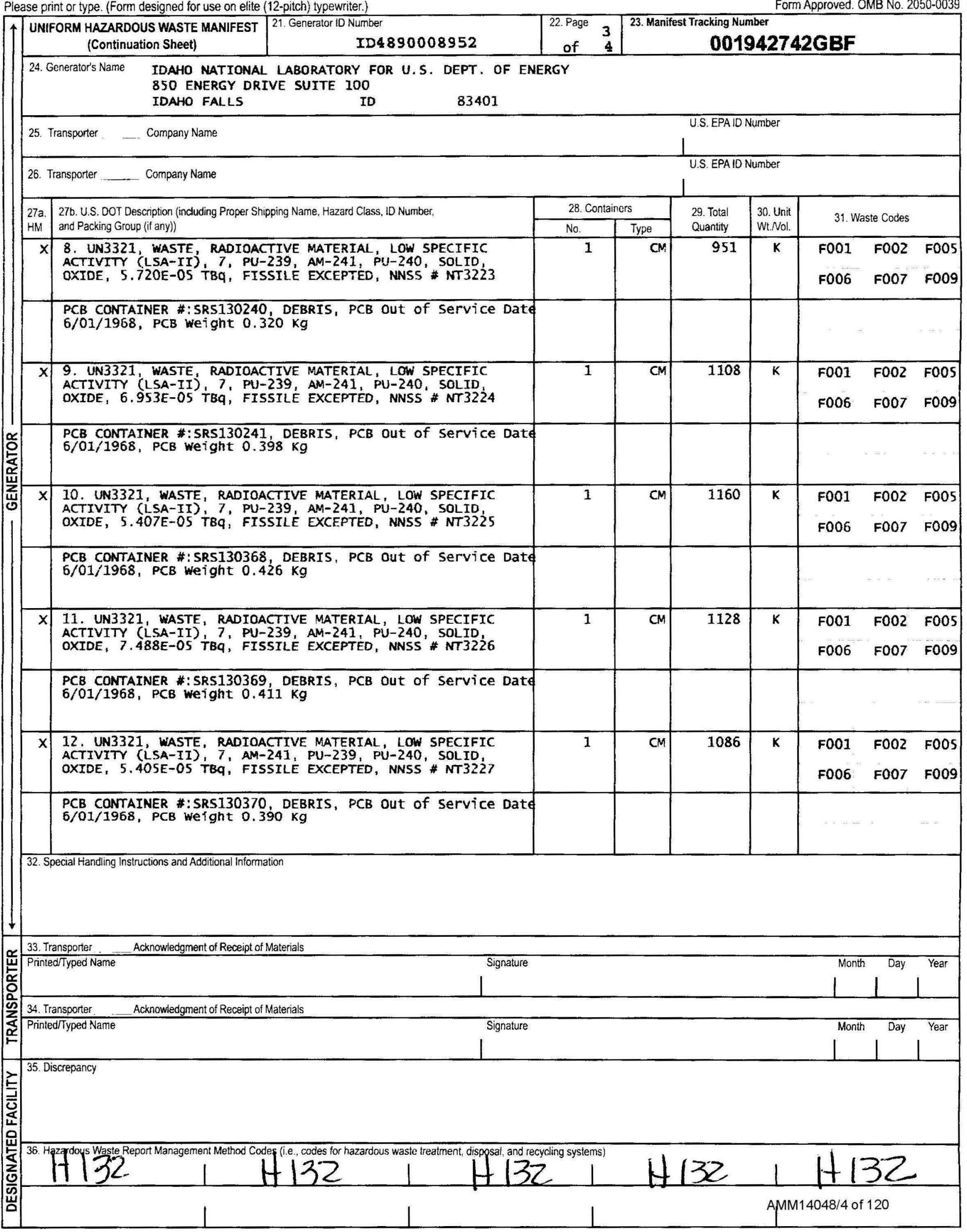


Please print or type. (Form designed for use on elite (12-pitch) typewriter.)

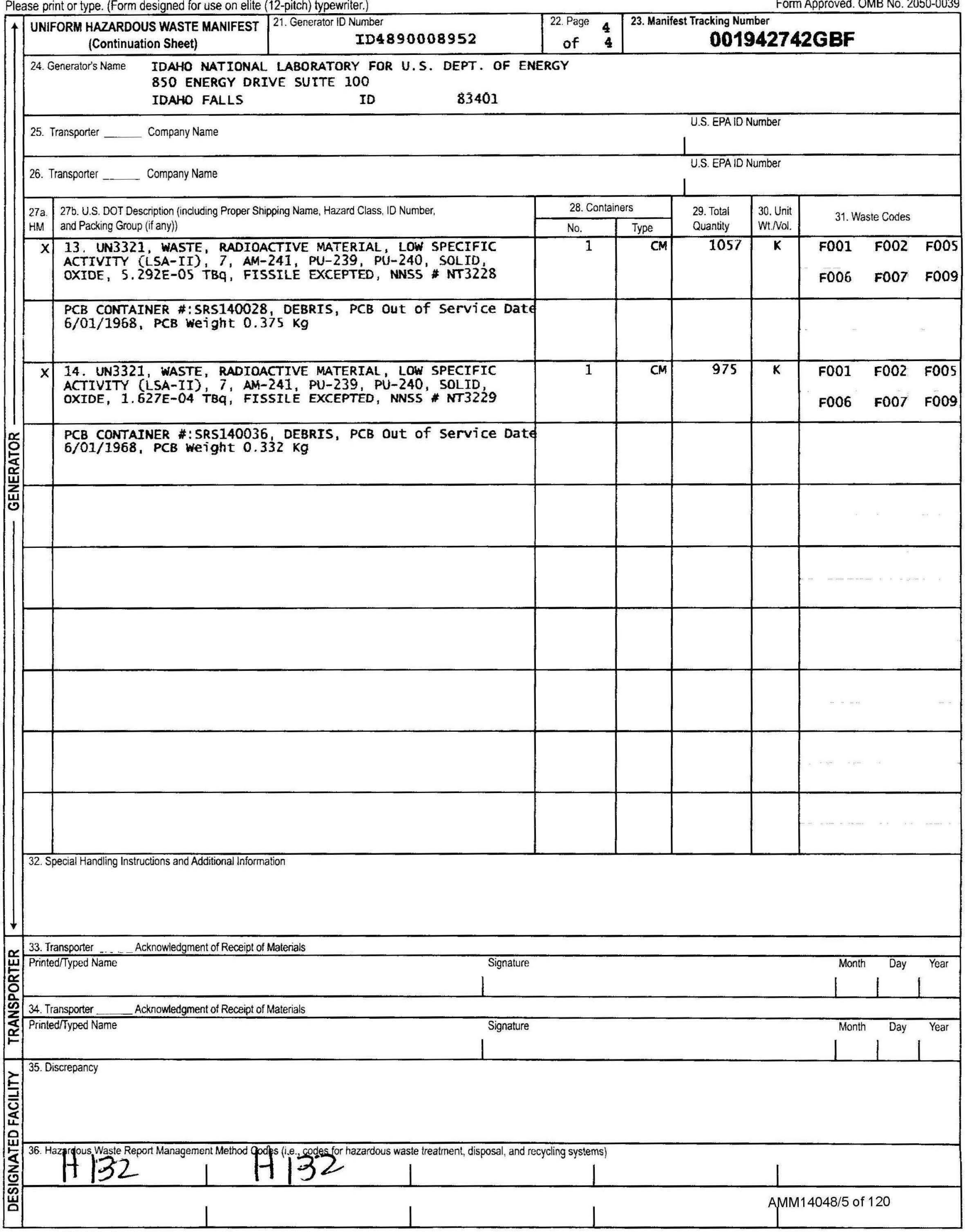


National Security Technologies Lc

Vision-Service - Partnership

H000-PA-14-0126

September 2, 2014

Jared Dominick

Waste Certification Official

Idaho Treatment Group

850 Energy Drive, Suite 100

Idaho Falls, ID 83401-1502

\section{Subject: CERTIFICATE OF DISPOSAL FOR POLYCHLORINATED BIPHENYL (PCB) WASTE AT THE NEVADA NATIONAL SECURITY SITE RADIOACTIVE WASTE MANAGEMENT SITE (RWMS)}

Enclosed is the certificate acknowledging disposal of manifested PCB shipments AMM14048, and AMM14049 in the Mixed Waste Disposal Unit, at the Nevada National Security Site RWMS.

If you have any questions, please contact me at 702-295-2261.

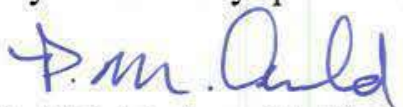

Patrick M. Arnold, Division Manager

Environmental Management

LBG:saq

Enclosure: as stated

cc w/enc.

Correspondence Control

EWO Correspondence

J. T. Carilli, NNSA/NFO

R. C. Denton, NSTec

R. G. Geisinger, NSTec

L. B. Gregory, NSTec

M. Libidinsky, NNSA/NFO

C. P. Moke, NSTec

K. M. Small, NNSA/NFO

K. C. Tanaka, NSTec

A. V. Tauber, NNSA/NFO

R. A. Wagner, NSTec

National Security Technologies, LLC

Vision • Service • Partnership

www.NSTec.com

P.O. Box 98521, Las Vegas, NV 89193-8521

2621 Losee Road, N. Las Vegas, NV 89030-4129 
National Security Technologies LLC

For U.S. Department of Energy

Waste Management

Nevada National Security Site - Zone 2

Mercury, NV 89023

EPA ID NV3890090001

This Certificate acknowledges that the following shipment(s) of manifested POLYCHLORINATED BIPHENYL (PCB) waste have been disposed at the Nevada National Security Site Radioactive Waste Management Site.

\begin{tabular}{|c|c|c|c|c|}
\hline $\begin{array}{c}\text { Shipment } \\
\text { Number }\end{array}$ & $\begin{array}{c}\text { Uniform Hazardous Waste } \\
\text { Manifest Number }\end{array}$ & Date(s) of Disposal & Volume $\mathrm{Ft}^{3}\left(\mathbf{m}^{3}\right)$ & Disposal Process \\
\hline AMM14048 & $001942742 \mathrm{GBF}$ & $08 / 25 / 2014$ & $1,259.76(35.67)$ & Landfill \\
\hline AMM14049 & $001942743 \mathrm{GBF}$ & $08 / 25 / 2014$ & $1,259.76(35.67)$ & Landfill \\
\hline
\end{tabular}

Under civil and criminal penalties of law for the making or submission of false or fraudulent statements or representations (18 U.S.C. 1001 and 15 U.S.C. 2615), I certify that the information contained in or accompanying this document is true, accurate, and complete.

As to the identified section(s) of this document for which I cannot personally verify truth and accuracy, I certify as the company official having supervisory responsibility for the persons who, acting under my direct instructions, made the verification that this information is true, accurate, and complete.

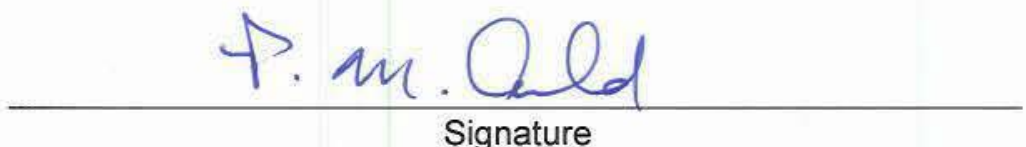

Division Manager, Environmental Management

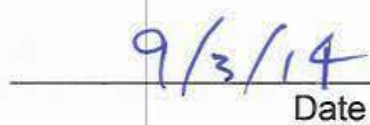

Date

\section{Title}

\section{Instructions:}

Shipment Number - enter shipment number from LWIS database.

Uniform Hazardous Waste Manifest Number - enter number from UHWM provided by generator.

Date of Disposal - enter date waste was placed in disposal cell.

Volume - enter shipment volume in cubic feet and equivalent cubic meters in parenthesis.

Disposal Process - enter Landfill. 
Please print or type. (Form designed for use an elite (12-pitch) typewriter.)

Form Approved. OMB No. 2050-0039

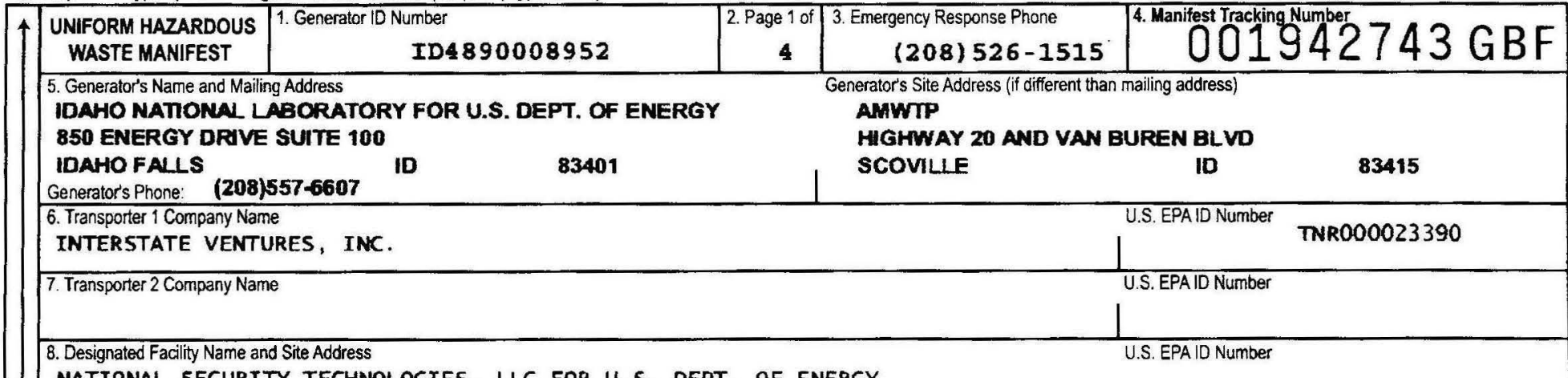

MATIONAL SECURITY TECHNOLOGIES, LLC FOR U.S. DEPT, OF ENERGY

WASTE MANAGEMENT, NEVADA NATIONAL SECURTTY SITE- ZONE 2

MERCURY NV 89023

Facility's Phone: (702) $295-9393$

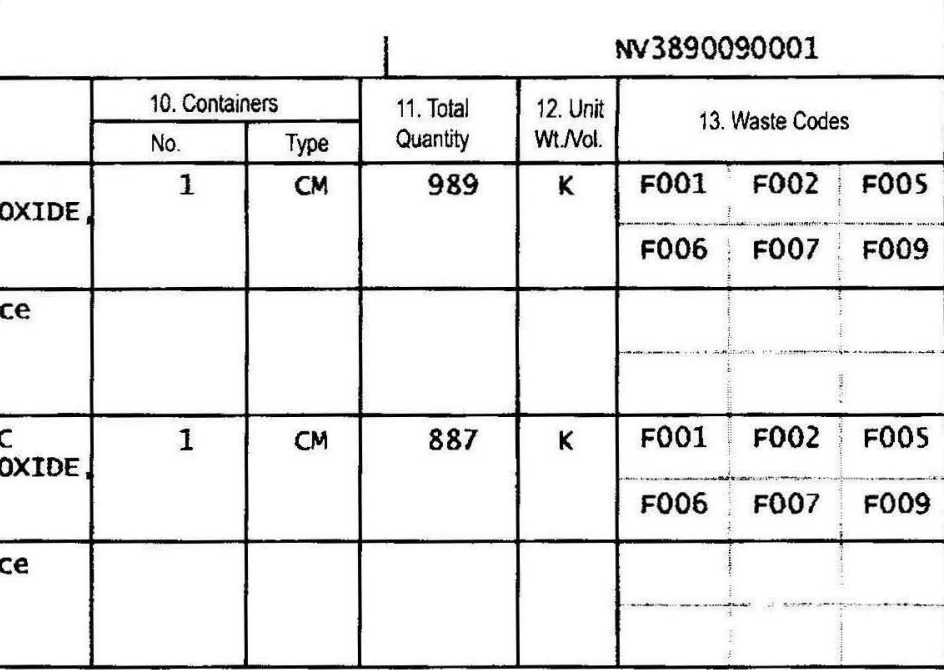

14. Special Handling Instuctions and Additional Information

EXCLUSIVE USE SHIPMENT IF UNDELIVERABLE, SEE EXCLUSIVE USE INSTRUCTIONS SHIPMENT ID \# AMM14049

GROSS WEIGHT: 32,066 LBS TID \#S 0001741, 0001742,0001743,0001744 TRUCK\#307

PREPARED UNDER CONTRACT \# DE-EM0001467 ERT PROVIDER: INL WCC TRCK \#307 ERG \# 162

15. GENERATOR'S/OFFEROR'S CERTIFICATION: I hereby declare that the contents of this consignment are fully and accurately described above by the proper shipping name, and are classified, packaged, marked and labeled/placarded, and are in all respecis in proper condition for transport according to applicable international and national governmental regulations. If export shipment and I am the Primary Exporter, I certify that the contents of this consignment conform to the terms of the attached EPAAcknowledgment of Consent.

I cerrify that the waste minimization statement identified in 40 CFR 262.27(a) (ff I am a large quantity generator) or (b) (if I am a small quantity generator) is true.

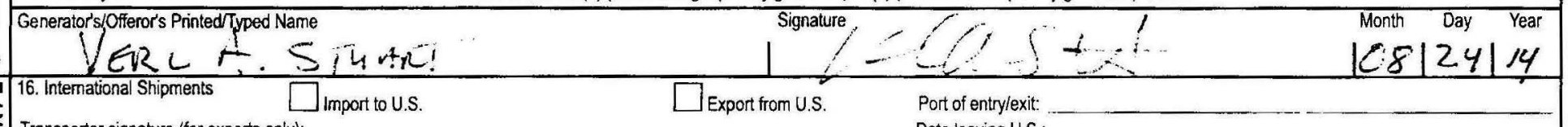

Transporter signature (for exports only): Date leaving U.S.

17. Transporter Acknowledgment of Receipt of Materials

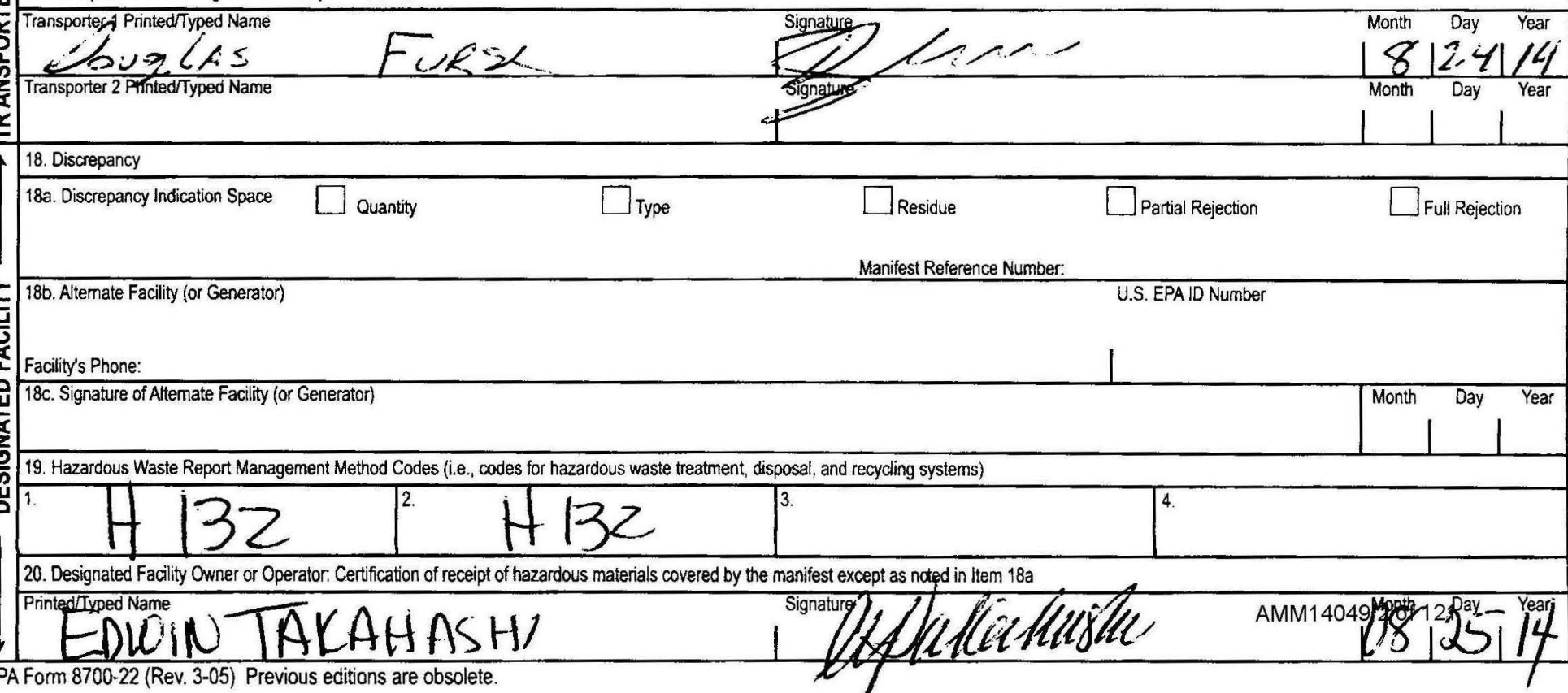


Please print or type. (Form designed for use on elite (12-pitch) typewriter.)

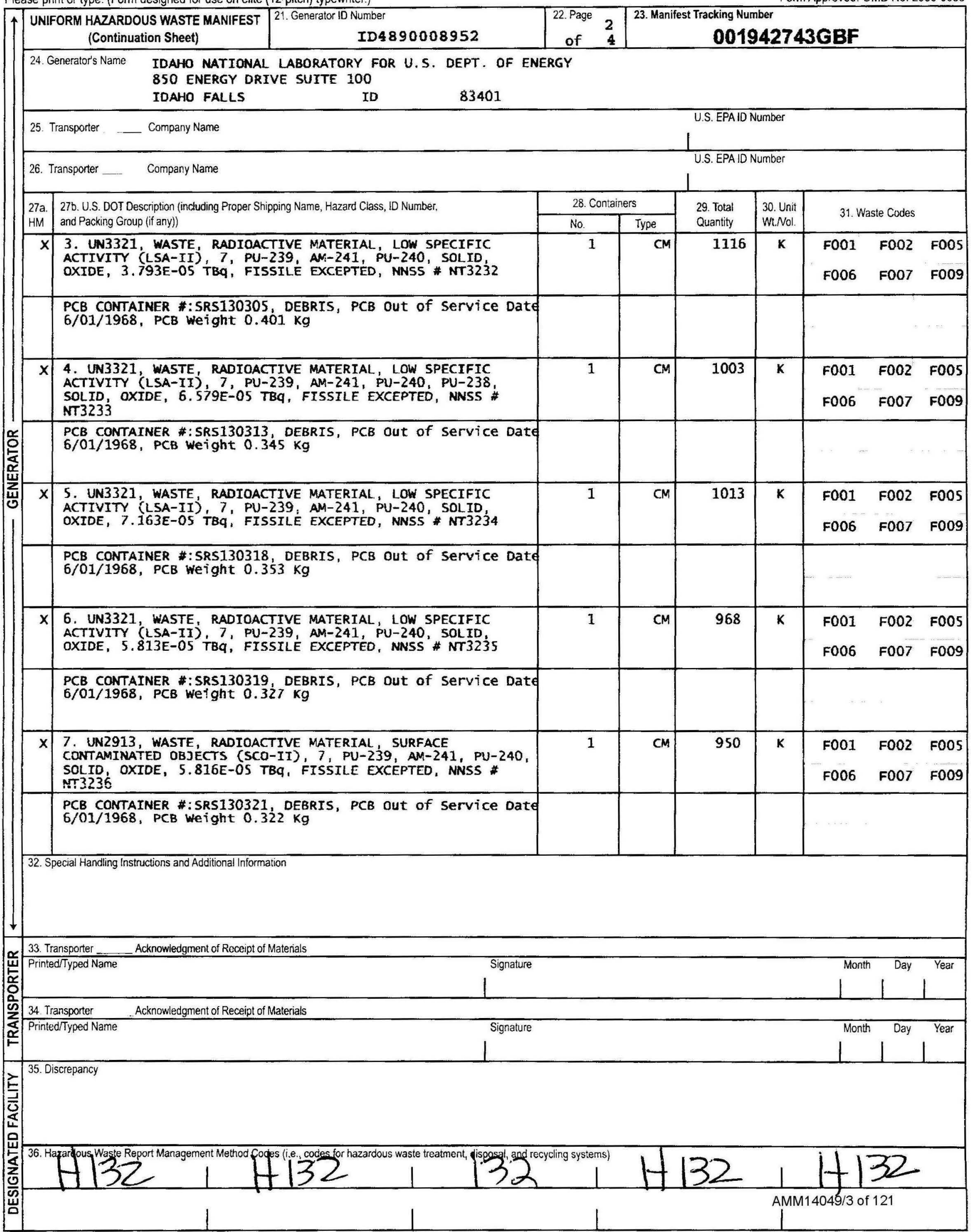


Please print or type. (Form designed for use on elite (12-pitch) typewriter.)

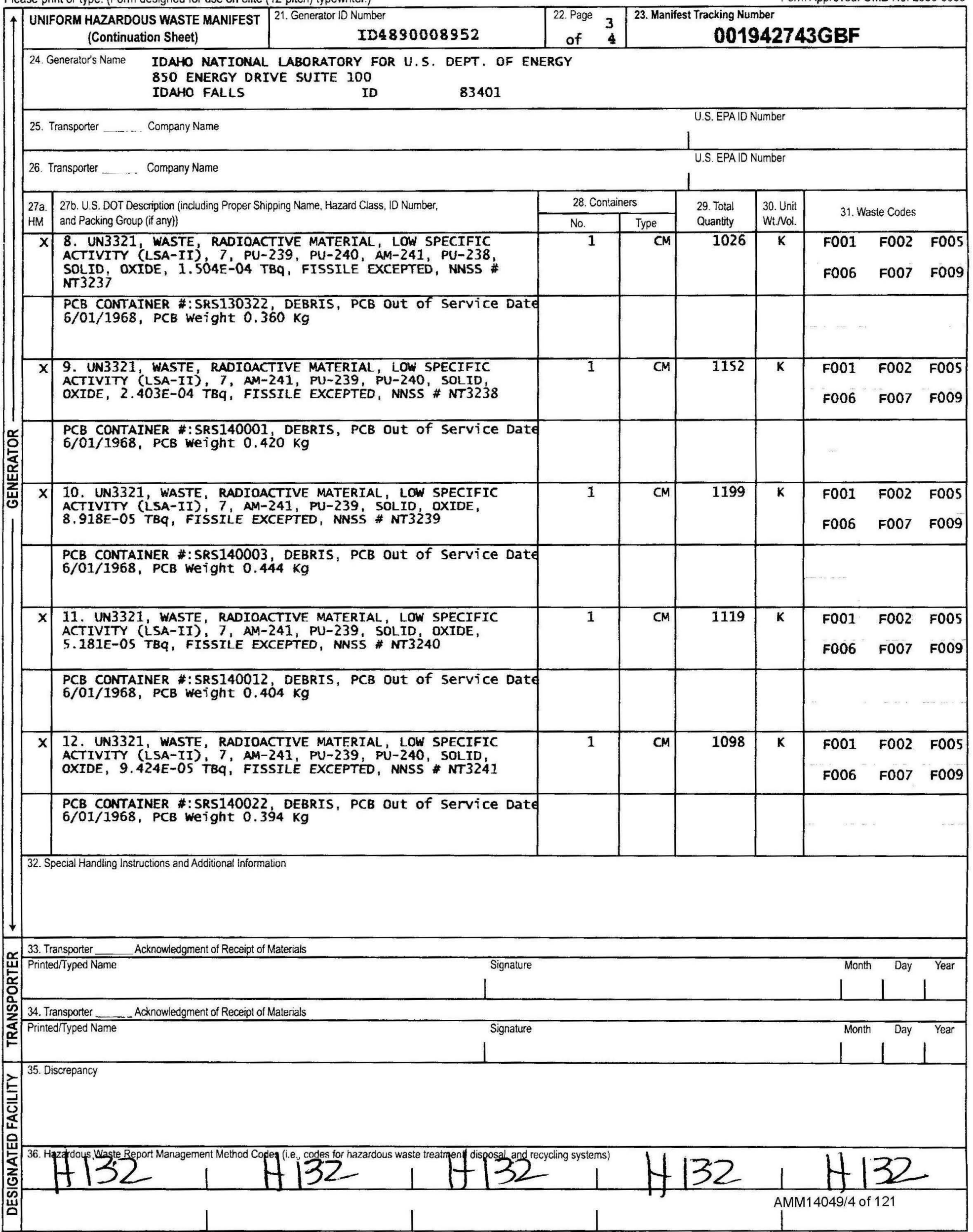


Please print or type. (Form designed for use on elite (12-pitch) typewriter.)

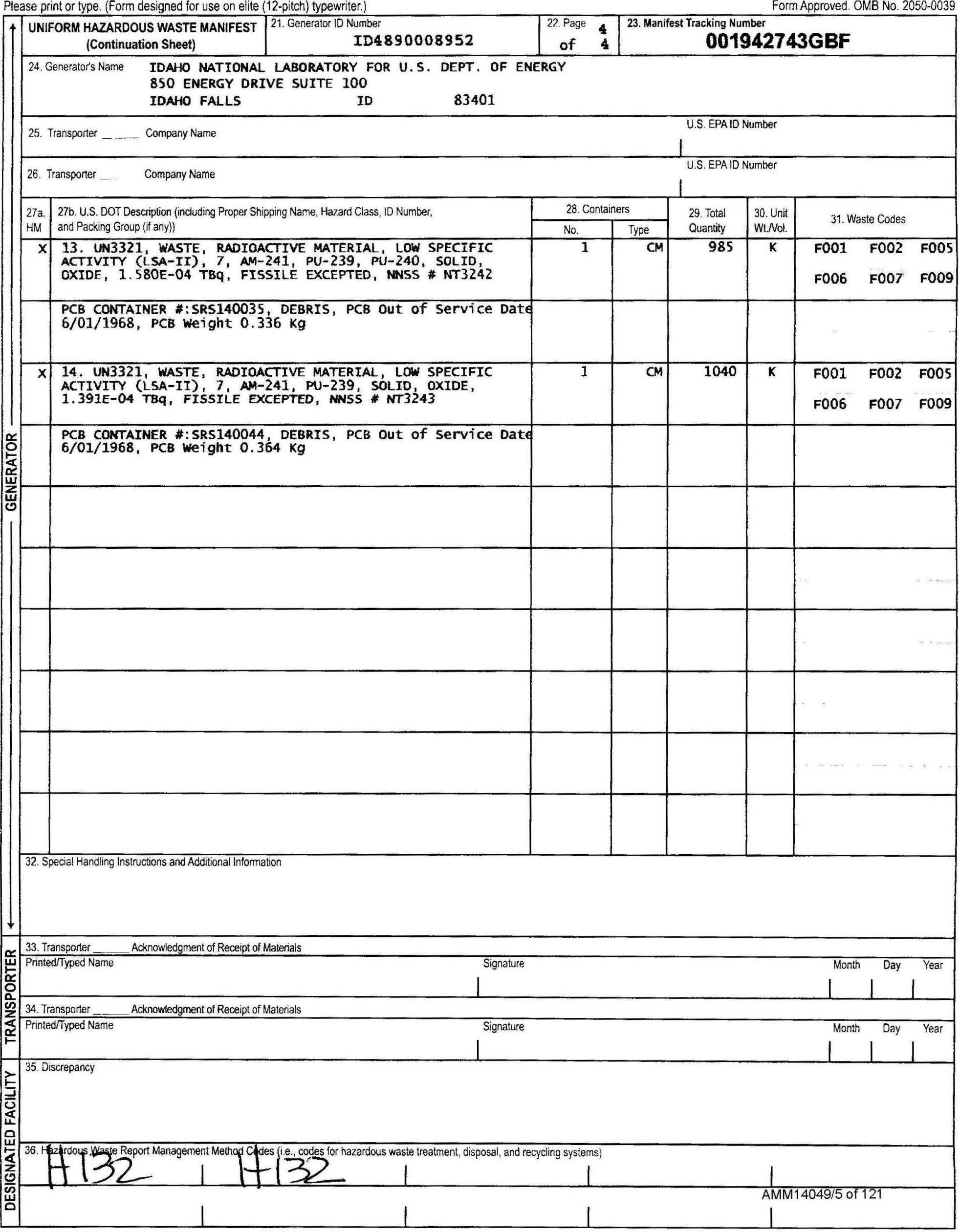


National Security Technologies Lc

Vision-Service - Partnership

H000-PA-14-0126

September 2, 2014

Jared Dominick

Waste Certification Official

Idaho Treatment Group

850 Energy Drive, Suite 100

Idaho Falls, ID 83401-1502

\section{Subject: CERTIFICATE OF DISPOSAL FOR POLYCHLORINATED BIPHENYL (PCB) WASTE AT THE NEVADA NATIONAL SECURITY SITE RADIOACTIVE WASTE MANAGEMENT SITE (RWMS)}

Enclosed is the certificate acknowledging disposal of manifested PCB shipments AMM14048, and AMM14049 in the Mixed Waste Disposal Unit, at the Nevada National Security Site RWMS.

If you have any questions, please contact me at 702-295-2261.

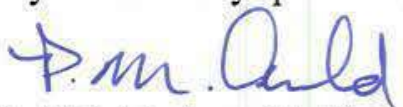

Patrick M. Arnold, Division Manager

Environmental Management

LBG:saq

Enclosure: as stated

cc w/enc.

Correspondence Control

EWO Correspondence

J. T. Carilli, NNSA/NFO

R. C. Denton, NSTec

R. G. Geisinger, NSTec

L. B. Gregory, NSTec

M. Libidinsky, NNSA/NFO

C. P. Moke, NSTec

K. M. Small, NNSA/NFO

K. C. Tanaka, NSTec

A. V. Tauber, NNSA/NFO

R. A. Wagner, NSTec

National Security Technologies, LLC

Vision • Service • Partnership

www.NSTec.com

P.O. Box 98521, Las Vegas, NV 89193-8521

2621 Losee Road, N. Las Vegas, NV 89030-4129 
National Security Technologies LLC

For U.S. Department of Energy

Waste Management

Nevada National Security Site - Zone 2

Mercury, NV 89023

EPA ID NV3890090001

This Certificate acknowledges that the following shipment(s) of manifested POLYCHLORINATED BIPHENYL (PCB) waste have been disposed at the Nevada National Security Site Radioactive Waste Management Site.

\begin{tabular}{|c|c|c|c|c|}
\hline $\begin{array}{c}\text { Shipment } \\
\text { Number }\end{array}$ & $\begin{array}{c}\text { Uniform Hazardous Waste } \\
\text { Manifest Number }\end{array}$ & Date(s) of Disposal & Volume $\mathrm{Ft}^{3}\left(\mathbf{m}^{3}\right)$ & Disposal Process \\
\hline AMM14048 & $001942742 \mathrm{GBF}$ & $08 / 25 / 2014$ & $1,259.76(35.67)$ & Landfill \\
\hline AMM14049 & $001942743 \mathrm{GBF}$ & $08 / 25 / 2014$ & $1,259.76(35.67)$ & Landfill \\
\hline
\end{tabular}

Under civil and criminal penalties of law for the making or submission of false or fraudulent statements or representations (18 U.S.C. 1001 and 15 U.S.C. 2615), I certify that the information contained in or accompanying this document is true, accurate, and complete.

As to the identified section(s) of this document for which I cannot personally verify truth and accuracy, I certify as the company official having supervisory responsibility for the persons who, acting under my direct instructions, made the verification that this information is true, accurate, and complete.

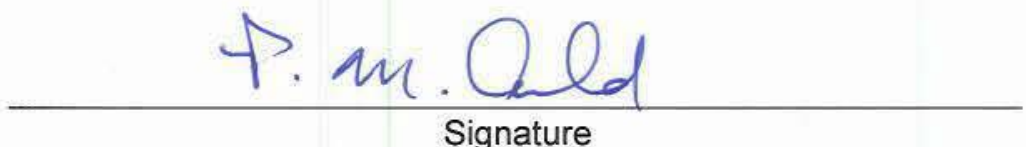

Division Manager, Environmental Management

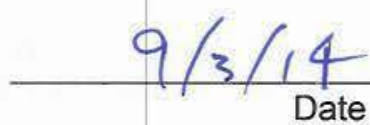

Date

\section{Title}

\section{Instructions:}

Shipment Number - enter shipment number from LWIS database.

Uniform Hazardous Waste Manifest Number - enter number from UHWM provided by generator.

Date of Disposal - enter date waste was placed in disposal cell.

Volume - enter shipment volume in cubic feet and equivalent cubic meters in parenthesis.

Disposal Process - enter Landfill. 


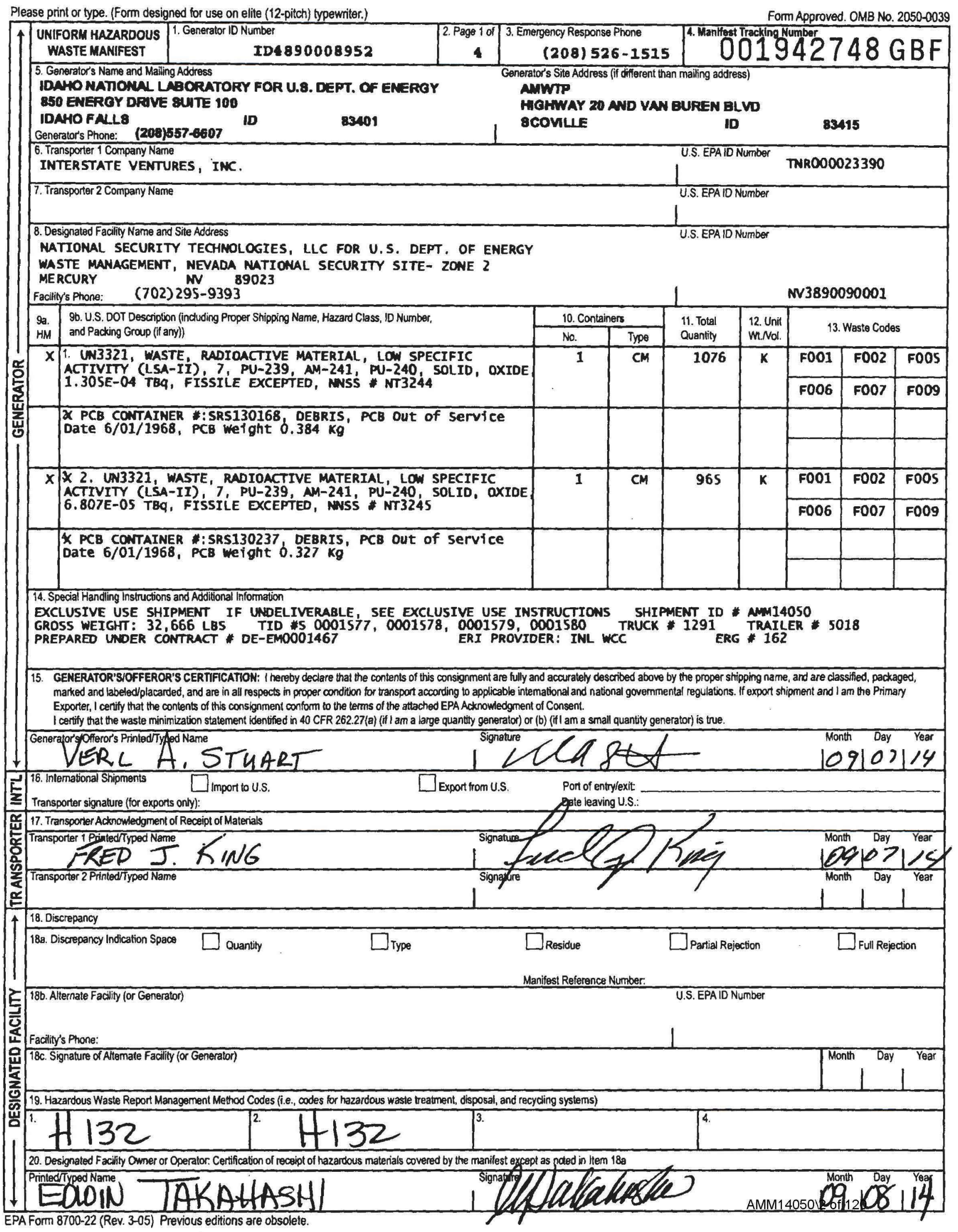


Please print or type. (Form designed for use on elite (12-pitch) typewriter.)

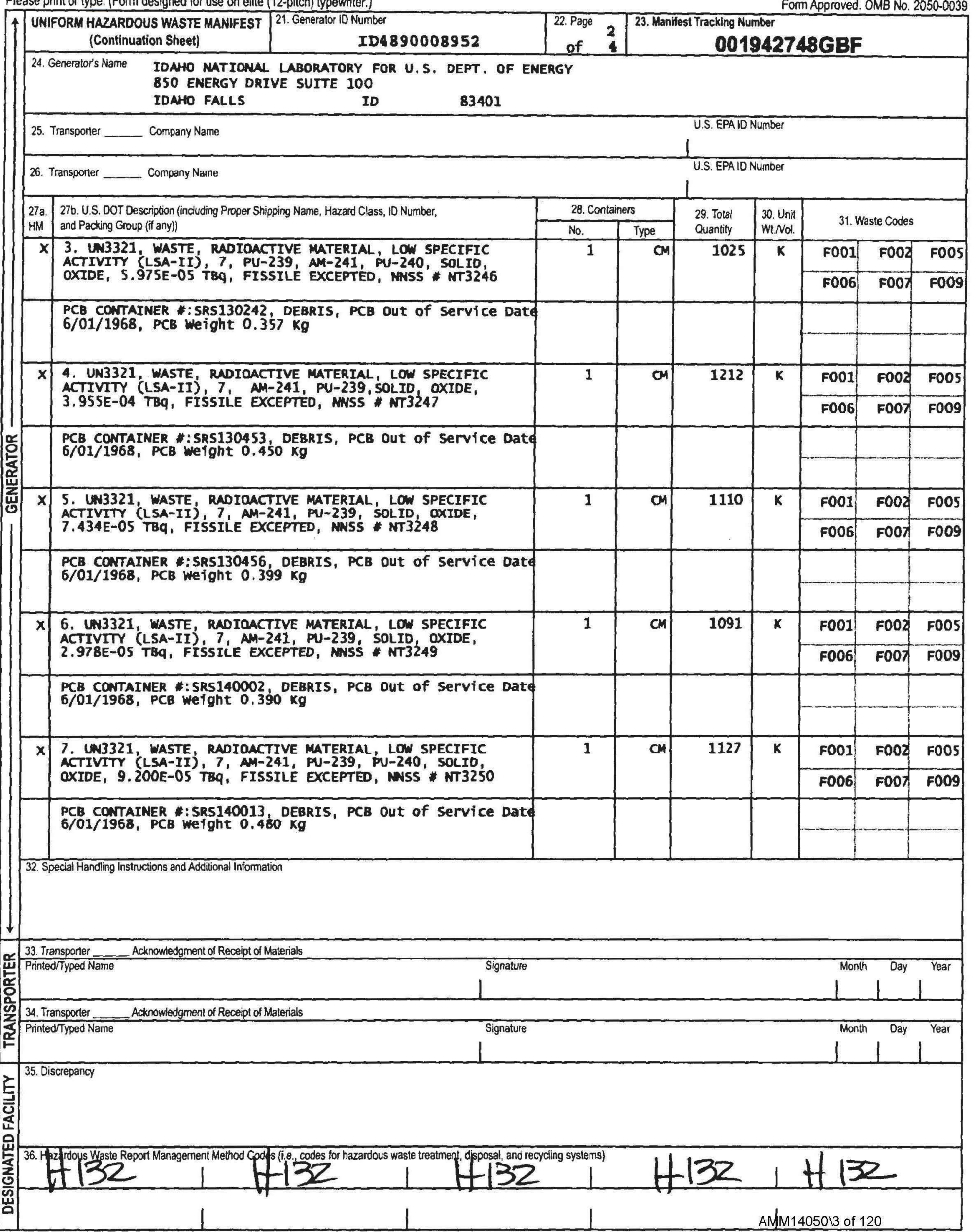




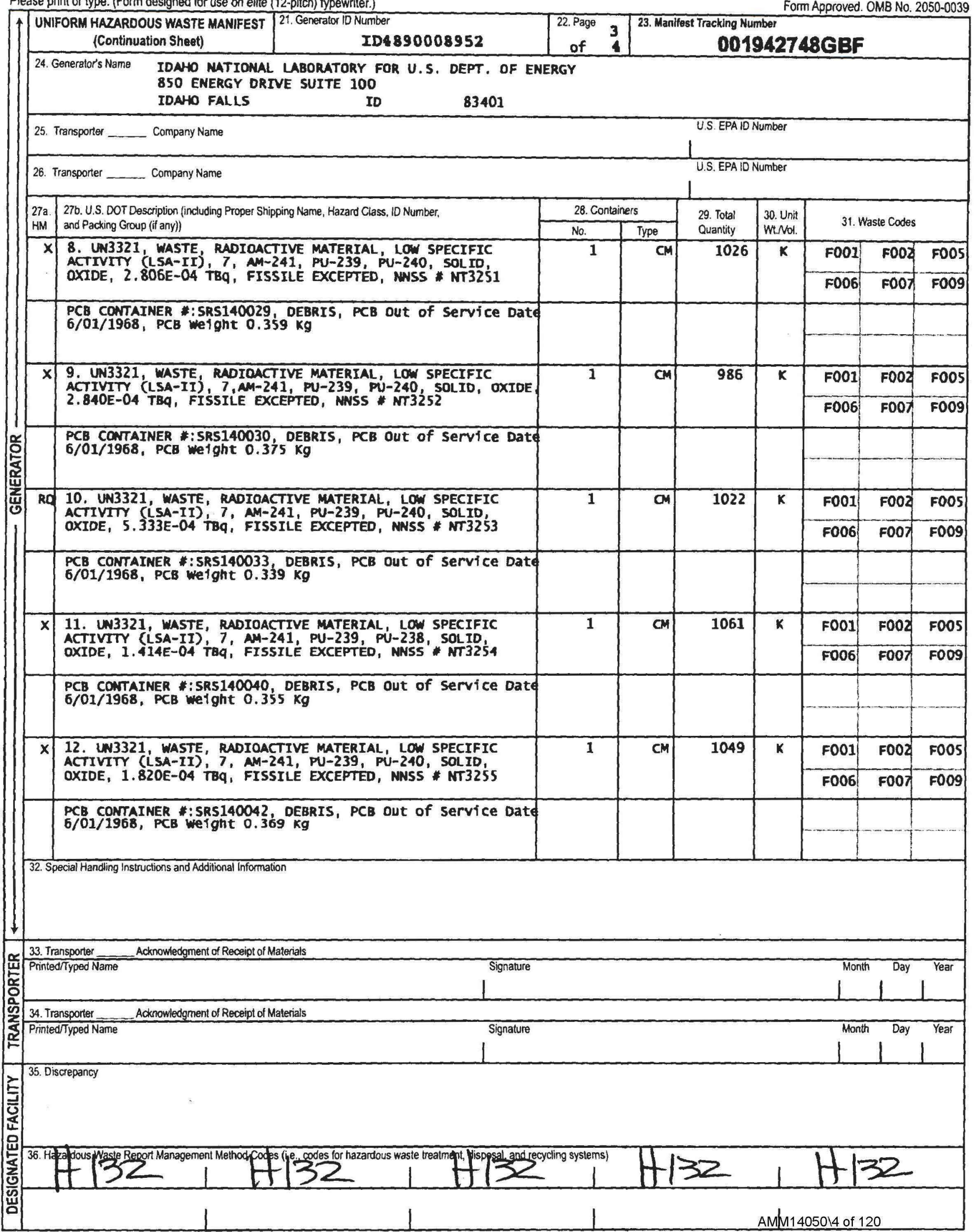


Please print or type. (Form designed for use on elite (12-pitch) typewriter.)

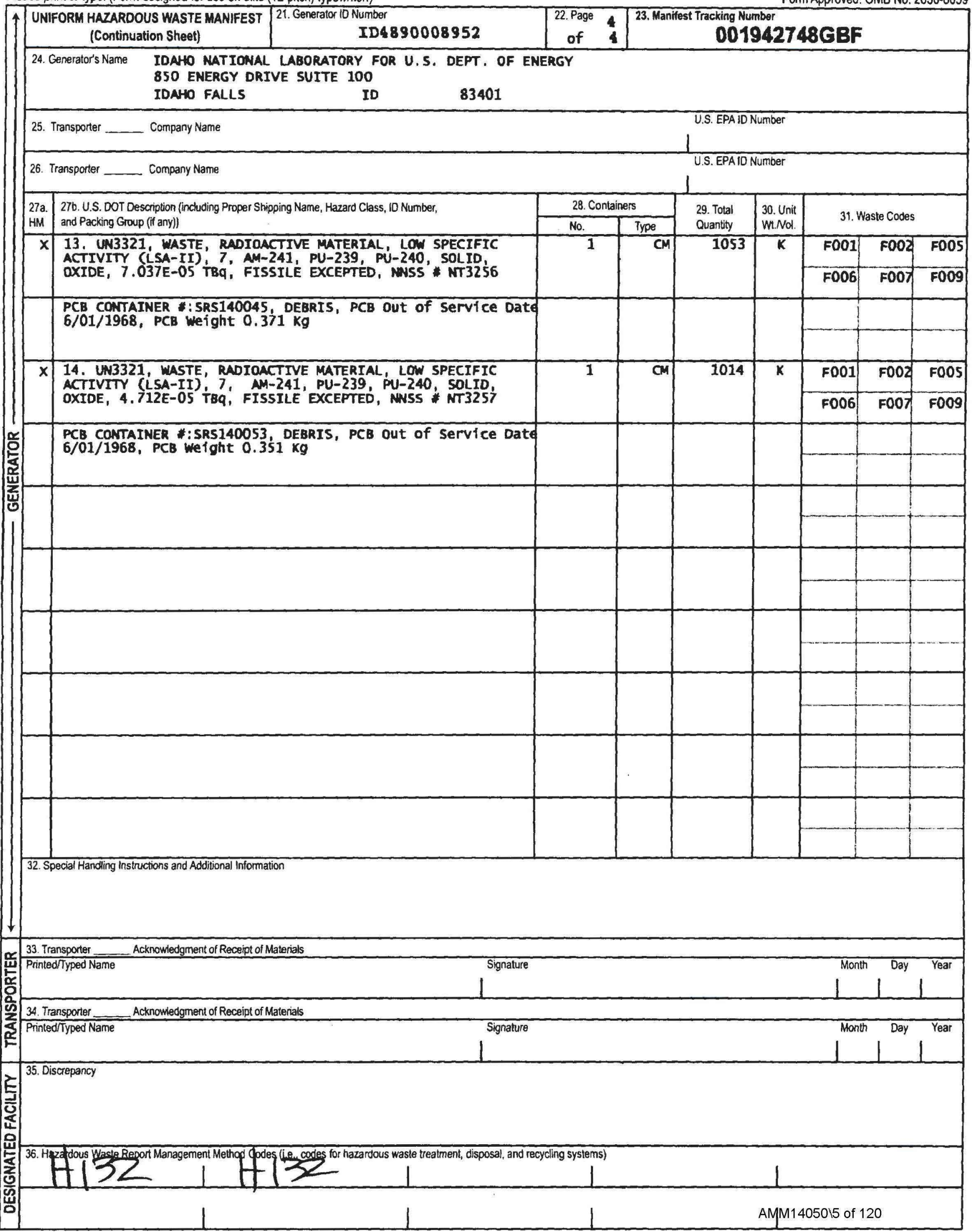


National Security Technologies Luc
Vision. Senice: Parnership

H000-PA-14-0129

September 15,2014

Jared Dominick

Waste Certification Official

Idaho Treatment Group

850 Energy Drive, Suite 100

Idaho Falls, ID 83401- 1502

Subject: CERTIFICATE OF DISPOSAL FOR POLYCHLORINATED

BIPHENYL (PCB) WASTE AT THE NEVADA NATIONAL SECURITY SITE RADIOACTIVE WASTE MANAGEMENT SITE (RWMS)

Enclosed is the certificate acknowledging disposal of manifested PCB shipments AMM14050 and AMM14051 in the Mixed Waste Disposal Unit, at the Nevada National Security Site RWMS.

If you have any questions, please contact me at 702-295-2261.<smiles>CC(C)C1=CC1(C)C</smiles><smiles>CC(C)CC(C)CC1CCCCC1</smiles>

Patrick M. Arnold, Division Manager

Environmental Management

LBG:saq

Enclosure: as stated

cc w/enc.

Correspondence Control

EWO Correspondence

J. T. Carilli, NNSA/NFO

R. C. Denton, NSTec

R. G. Geisinger, NSTec

L. B. Gregory, NSTec

M. Libidinsky, NNSA/NFO

C. P. Moke, NSTec

K. M. Small, NNSA/NFO

K. C. Tanaka, NSTec

A. V. Tauber, NNSA/NFO

R. A. Wagner, NSTec

National Security Technologies, LLC

Vision • Service $\cdot$ Partnership

WWW.NSTEC.Com

P.O. Box 98521, Las Vegas, NV 89193-8521

2621 Losee Road, N. Las Vegas, NV 89030-4129 
National Security Technologies LLC

For U.S. Department of Energy

Waste Management

Nevada National Security Site - Zone 2

Mercury, NV 89023

This Certificate acknowledges that the following shipment(s) of manifested POLYCHLORINATED BIPHENYL (PCB) waste have been disposed at the Nevada National Security Site Radioactive Waste Management Site.

\begin{tabular}{|c|c|c|c|c|}
\hline $\begin{array}{c}\text { Shipment } \\
\text { Number }\end{array}$ & $\begin{array}{c}\text { Uniform Hazardous Waste } \\
\text { Manifest Number }\end{array}$ & Date(s) of Disposal & Volume $\mathrm{Ft}^{3}\left(\mathbf{m}^{3}\right)$ & Disposal Process \\
\hline AMM14050 & $001942748 \mathrm{GBF}$ & $09 / 08 / 2014$ & $1,259.76(35.67)$ & Landfill \\
\hline AMM14051 & $001942749 \mathrm{GBF}$ & $09 / 08 / 2014$ & $1,259.79(35.67)$ & Landfill \\
\hline
\end{tabular}

Under civil and criminal penalties of law for the making or submission of false or fraudulent statements or representations (18 U.S.C. 1001 and 15 U.S.C. 2615), I certify that the information contained in or accompanying this document is true, accurate, and complete.

As to the identified section(s) of this document for which I cannot personally verify truth and accuracy, I certify as the company official having supervisory responsibility for the persons who, acting under my direct instructions, made the verification that this information is true, accurate, and complete.

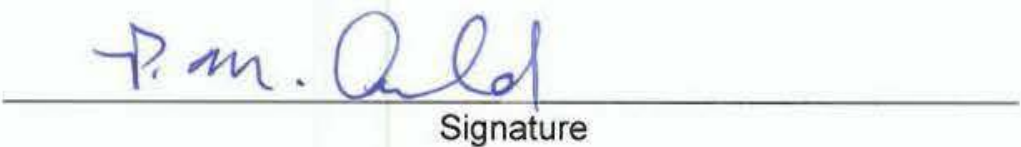

Division Manager, Environmental Management

Title

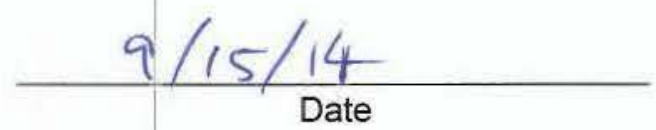

Instructions:

Shipment Number - enter shipment number from LWIS database.

Uniform Hazardous Waste Manifest Number - enter number from UHWM provided by generator.

Date of Disposal - enter date waste was placed in disposal cell.

Volume - enter shipment volume in cubic feet and equivalent cubic meters in parenthesis.

Disposal Process - enter Landfill.

National Security Technologies, LLC

Vision • Service • Partnership

WwW.NSTEC.COM

P.O. Box 98521, Las Vegas, NV 89193-8521

2621 Losee Road, N. Las Vegas, NV 89030-4129 
Please print or type. (Form designed for use on elite (12-pitch) typewriter.)

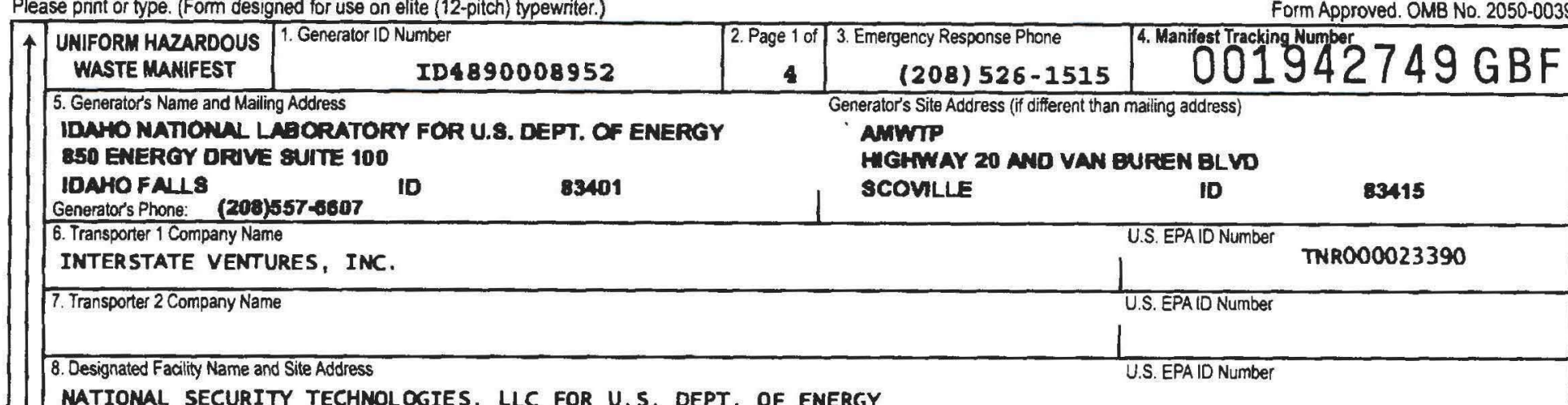

MATIONAL SECURITY TECHNOLOGIES, LLC FOR U.5. DEPT. OF ENERGY

WASTE MANAGEMENT, NEVADA NATIONAL SECURITY SITE- ZONE 2

MERCURY NV 89023

Facility's Phone: (702)295-9393

9a. 96. U.S. DOT Description (including Proper Shipping Name, Hazard Class, ID Number,

HM and Packing Group (if any))

$x$ 1. UN3321, WASTE, RADTOACTIVE MATERIAL, LOW SPECIFTC

ACTIVITY (LSA-II), 7, PU-239, AM-241, PU-240, SOLID, OXIDE

3.863E-OS TBQ, FISSTLE EXCEPTED, NNSS NT325B

X PCB CONTAINER : SRS130281, DEBRIS, PCB Out of Service Date 6/01/1968, PCB weight $0.325 \mathrm{Kg}$

$X$ 3. 2. UN3321, WASTE, RADTOACTIVE MATERIAL, LOW SPECIFIC ACTIVITY (LSA-II), 7, PU-239, AM-241, PU-240, SOLID, OXIDE 8.833E-06 TBq, FISSILE EXCEPTED, NNSS * NT3259

$X$ PCB CONTAINER \#:SRS130303, DEBRIS, PCB Out of Service Date $6 / 01 / 1968$, PCB weight $0.286 \mathrm{Kg}$

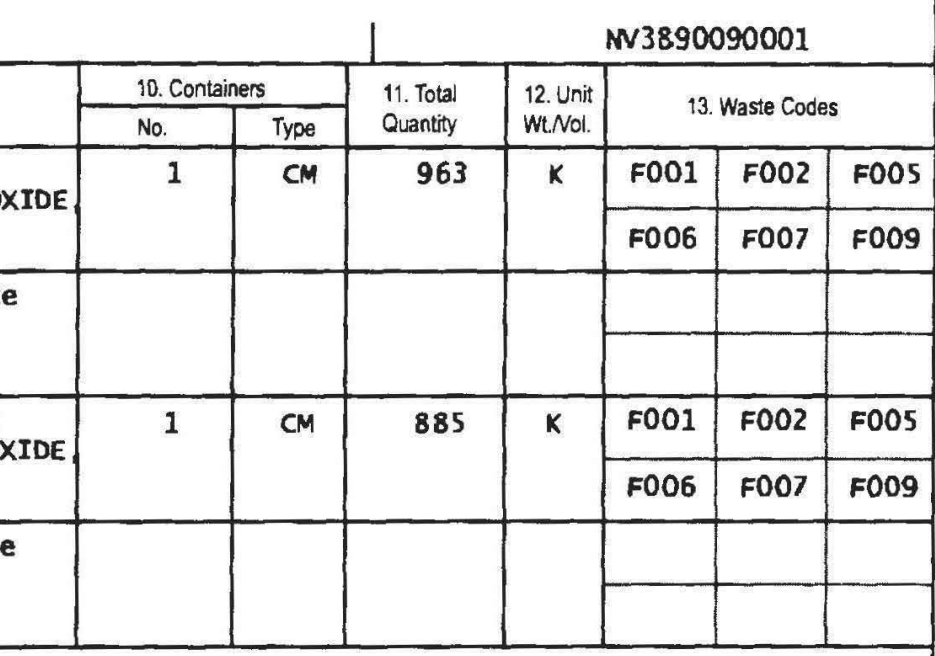

14. Special Handling Instructions and Additional Information

EXCLUSIVE USE SHIPMENT IF UNDELTVERABLE, SEE EXCLUSIVE USE INSTRUCTIONS SHIPMENT ID * AMM14051

RETURN SIGNED ORIGINAL TO GENERATOR. TID $\# S$ : $0001755,0001756,0001757,0001758$

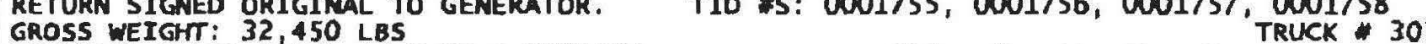

PREPARED UNDER CONTRACT * DE-EM0001467 ERI PROVIOER: INL WCC

15. GEMERATOR'SJOFFEROR'S CERTIFICATION: I hereby decdare that the contents of this consignment are fully and accurately described above by the proper shipping name, and are classified, packaged, marked and labeled/placarded, and are in all respects in proper condition for transport according to applicable international and national governmental regulations. If export shipment and I am the Primary

Exporter, I cartify that the contents of this consignment conform to the terns of the attached EPA Acknowiedgment of Consent.

I certify that the waste minimization statement identified in 40 CFR 262.27 (a) (if I am a iarge quantity generator) or (b) (if I am a small quantity generator) is true.

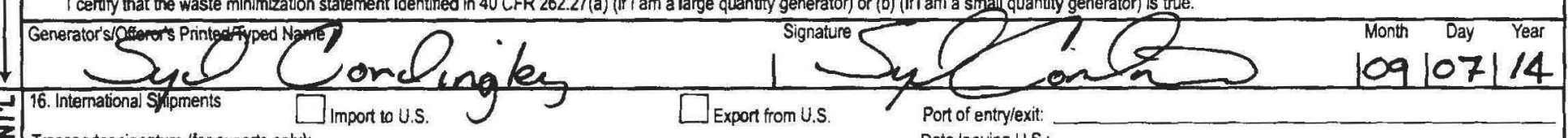

Transporter signature (for exports only):

Date leavin

舀 17. Transporter Acknowiedgment of Receipt of Materials

Transporter 1 p pinted/yped Name

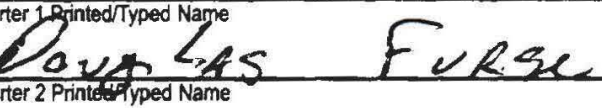

Transporter 2 Printet yped Name

18. Discrepancy

18a. Discrepancy Indication Space $\square$ auntity $\square$

$\square$ Type

$\square$ Residue

$\square$ Partial Rejection

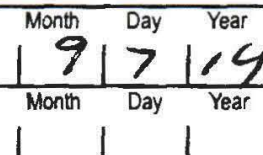

$+$

18b. Alternate Facility (or Generator)

Manifest Reference Number:

Facility's Phone:

18c. Signature of Alternate Facility (or Generator)

19. Hazardous Waste Report Management Method Codes (i.e., codes for hazandous waste treatment, disposal, and recycling systems)
H132
H132.
4.

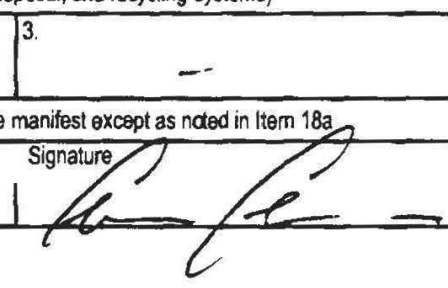

20. Designated Facility Owner or Operator: Cerrification of receipt of hazarcous materials covered by the manifest excopt as noted in liern 18a

Printed Typed Name

Chris Chalu of a

EPA Form 8700-22 (Rev. 3-05) Previous editions are obsolete. 
Please print or type. (Form designed for use on elite (12-pitch) typewriter.)

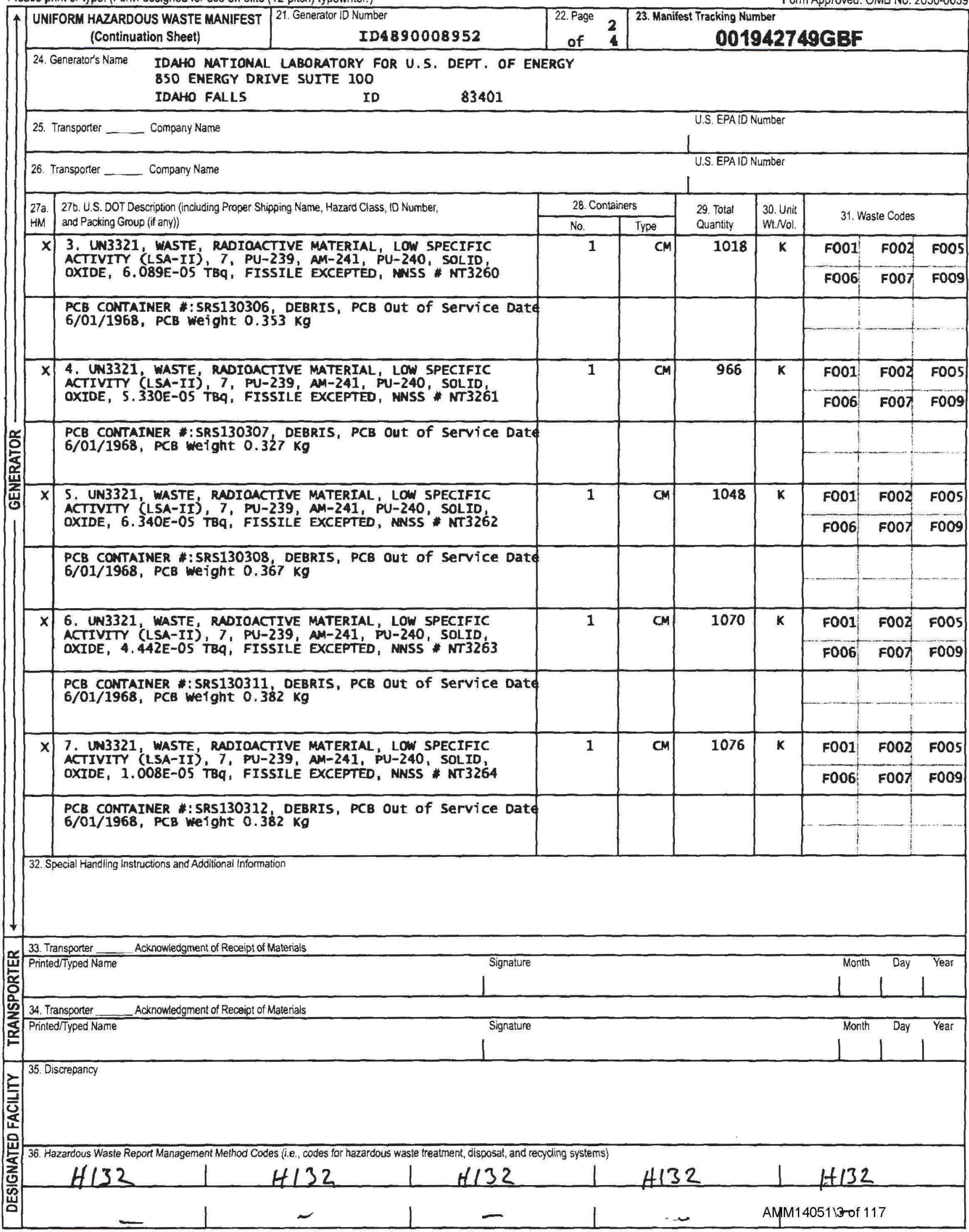


Please print or type. (Form designed for use on elite (12-pitch) typewriter.)

Form Approved. OMB No. 2050-0039

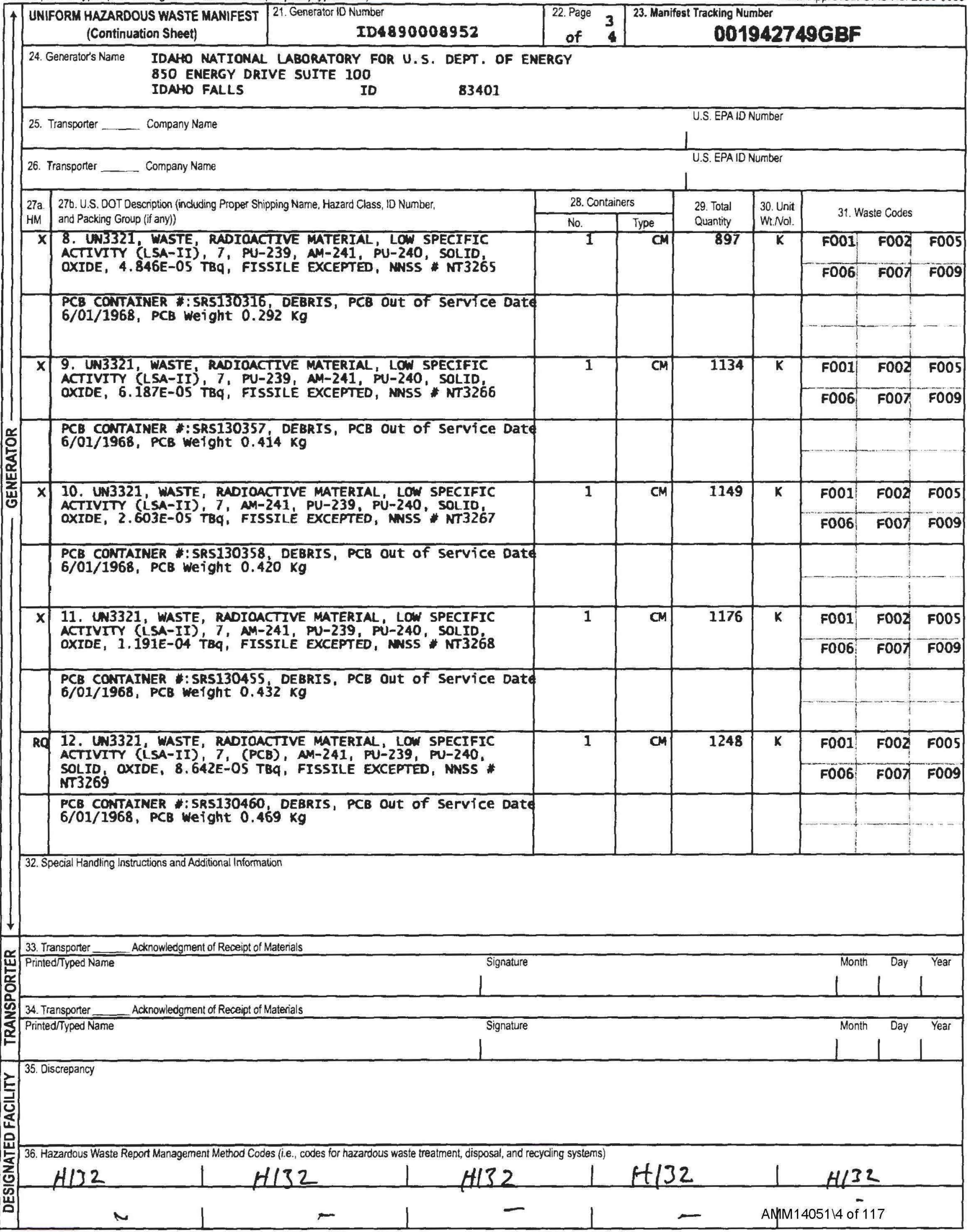


Please print or type. (Form designed for use on elite (12-pitch) typewriter.)

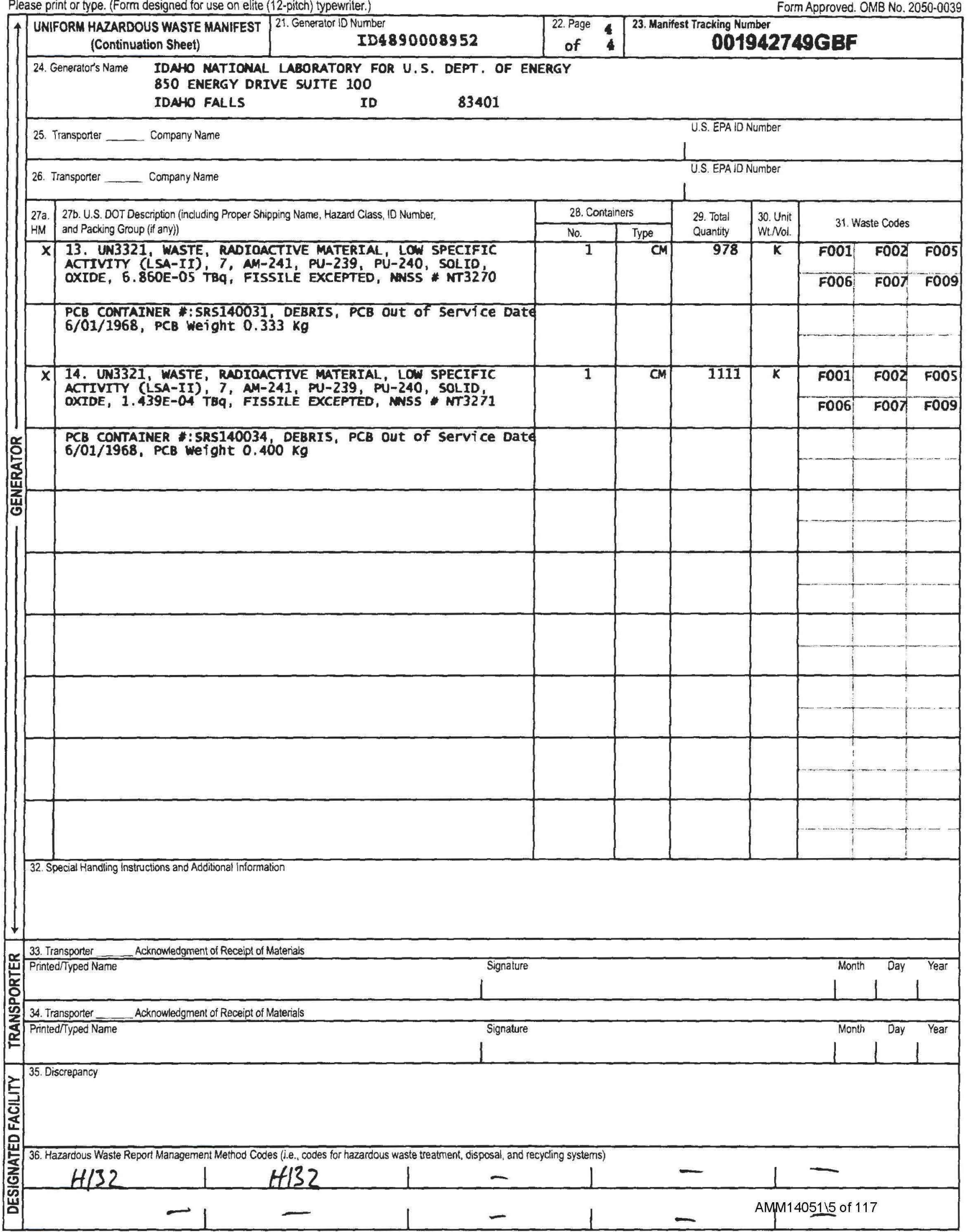


National Security Technologies Luc
Vision. Senice: Parnership

H000-PA-14-0129

September 15,2014

Jared Dominick

Waste Certification Official

Idaho Treatment Group

850 Energy Drive, Suite 100

Idaho Falls, ID 83401- 1502

Subject: CERTIFICATE OF DISPOSAL FOR POLYCHLORINATED

BIPHENYL (PCB) WASTE AT THE NEVADA NATIONAL SECURITY SITE RADIOACTIVE WASTE MANAGEMENT SITE (RWMS)

Enclosed is the certificate acknowledging disposal of manifested PCB shipments AMM14050 and AMM14051 in the Mixed Waste Disposal Unit, at the Nevada National Security Site RWMS.

If you have any questions, please contact me at 702-295-2261.<smiles>CC(C)C1=CC1(C)C</smiles><smiles>CC(C)CC(C)CC1CCCCC1</smiles>

Patrick M. Arnold, Division Manager

Environmental Management

LBG:saq

Enclosure: as stated

cc w/enc.

Correspondence Control

EWO Correspondence

J. T. Carilli, NNSA/NFO

R. C. Denton, NSTec

R. G. Geisinger, NSTec

L. B. Gregory, NSTec

M. Libidinsky, NNSA/NFO

C. P. Moke, NSTec

K. M. Small, NNSA/NFO

K. C. Tanaka, NSTec

A. V. Tauber, NNSA/NFO

R. A. Wagner, NSTec

National Security Technologies, LLC

Vision • Service $\cdot$ Partnership

WWW.NSTEC.Com

P.O. Box 98521, Las Vegas, NV 89193-8521

2621 Losee Road, N. Las Vegas, NV 89030-4129 
National Security Technologies LLC

For U.S. Department of Energy

Waste Management

Nevada National Security Site - Zone 2

Mercury, NV 89023

This Certificate acknowledges that the following shipment(s) of manifested POLYCHLORINATED BIPHENYL (PCB) waste have been disposed at the Nevada National Security Site Radioactive Waste Management Site.

\begin{tabular}{|c|c|c|c|c|}
\hline $\begin{array}{c}\text { Shipment } \\
\text { Number }\end{array}$ & $\begin{array}{c}\text { Uniform Hazardous Waste } \\
\text { Manifest Number }\end{array}$ & Date(s) of Disposal & Volume $\mathrm{Ft}^{3}\left(\mathbf{m}^{3}\right)$ & Disposal Process \\
\hline AMM14050 & $001942748 \mathrm{GBF}$ & $09 / 08 / 2014$ & $1,259.76(35.67)$ & Landfill \\
\hline AMM14051 & $001942749 \mathrm{GBF}$ & $09 / 08 / 2014$ & $1,259.79(35.67)$ & Landfill \\
\hline
\end{tabular}

Under civil and criminal penalties of law for the making or submission of false or fraudulent statements or representations (18 U.S.C. 1001 and 15 U.S.C. 2615), I certify that the information contained in or accompanying this document is true, accurate, and complete.

As to the identified section(s) of this document for which I cannot personally verify truth and accuracy, I certify as the company official having supervisory responsibility for the persons who, acting under my direct instructions, made the verification that this information is true, accurate, and complete.

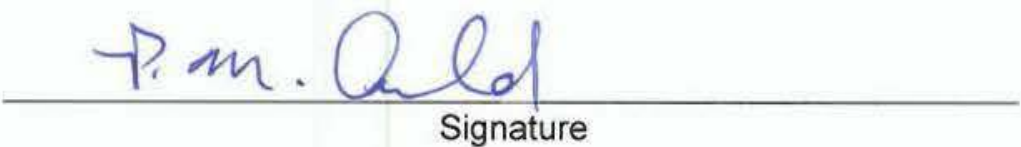

Division Manager, Environmental Management

Title

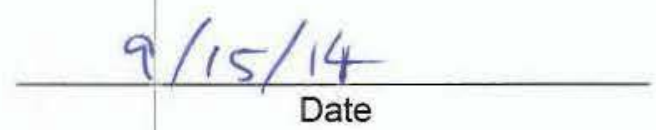

Instructions:

Shipment Number - enter shipment number from LWIS database.

Uniform Hazardous Waste Manifest Number - enter number from UHWM provided by generator.

Date of Disposal - enter date waste was placed in disposal cell.

Volume - enter shipment volume in cubic feet and equivalent cubic meters in parenthesis.

Disposal Process - enter Landfill.

National Security Technologies, LLC

Vision • Service • Partnership

WwW.NSTEC.COM

P.O. Box 98521, Las Vegas, NV 89193-8521

2621 Losee Road, N. Las Vegas, NV 89030-4129 
Please print ar type. (Form designed for use on elth (12-pitch) typewriter.)

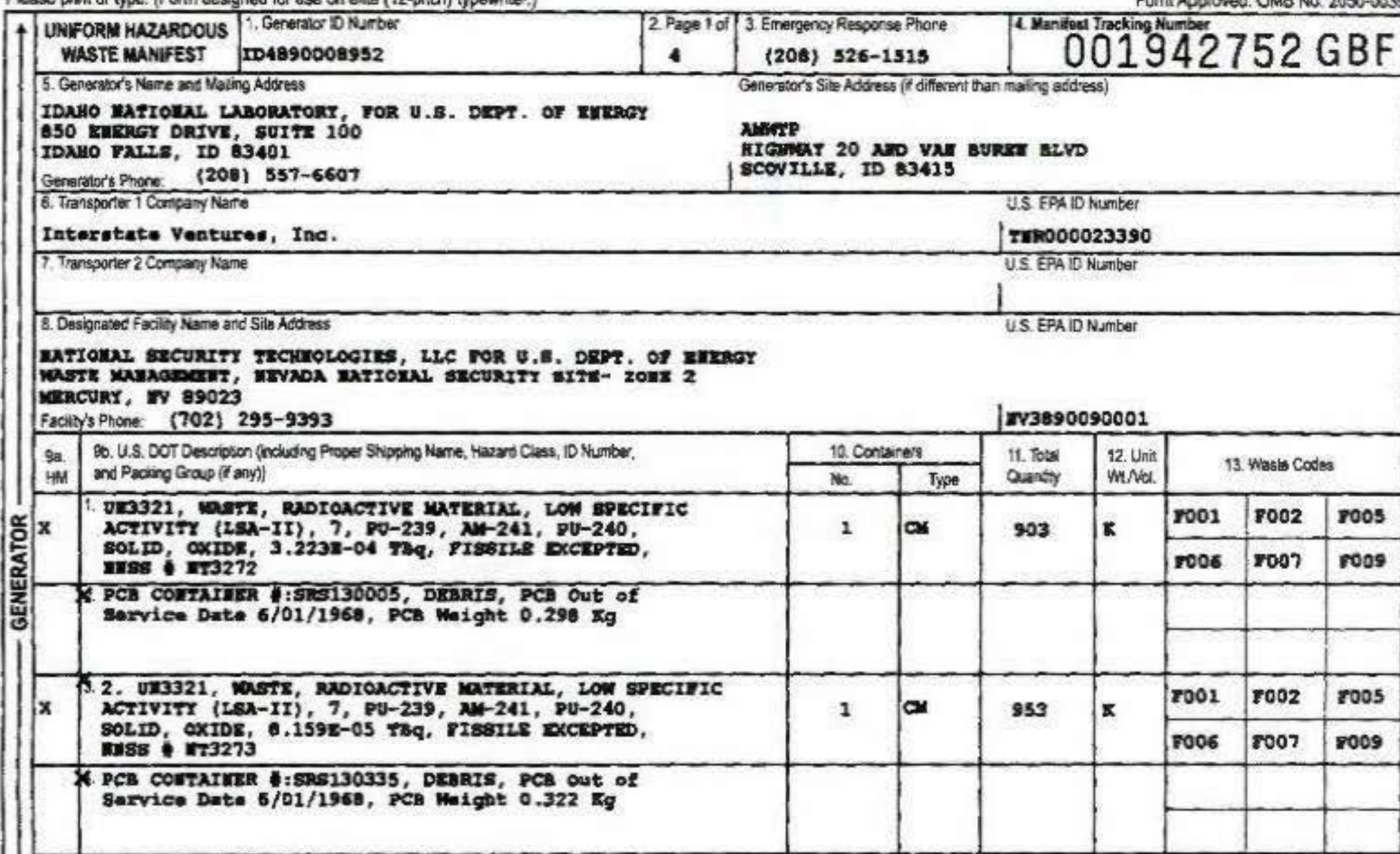

U. Spedal Handing lasivetiors and toditions hiomator:

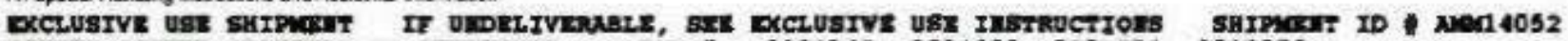

REFUR SIGID ORIGIUN TO GIERATOR. TID Aa: 0001549, 0001550, 0001551, 0001552

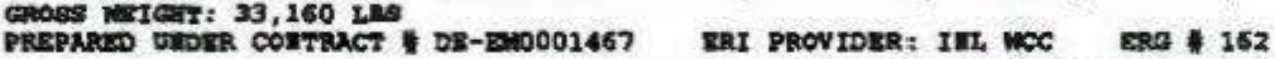

TRvCR 1291 IRATLER 3020

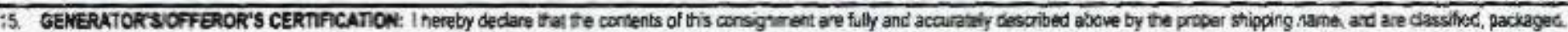

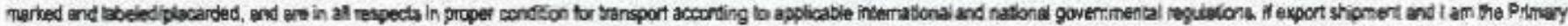

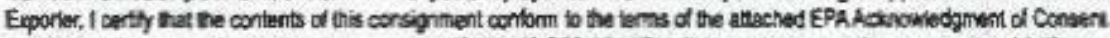

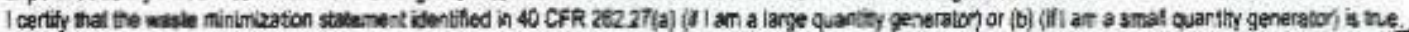

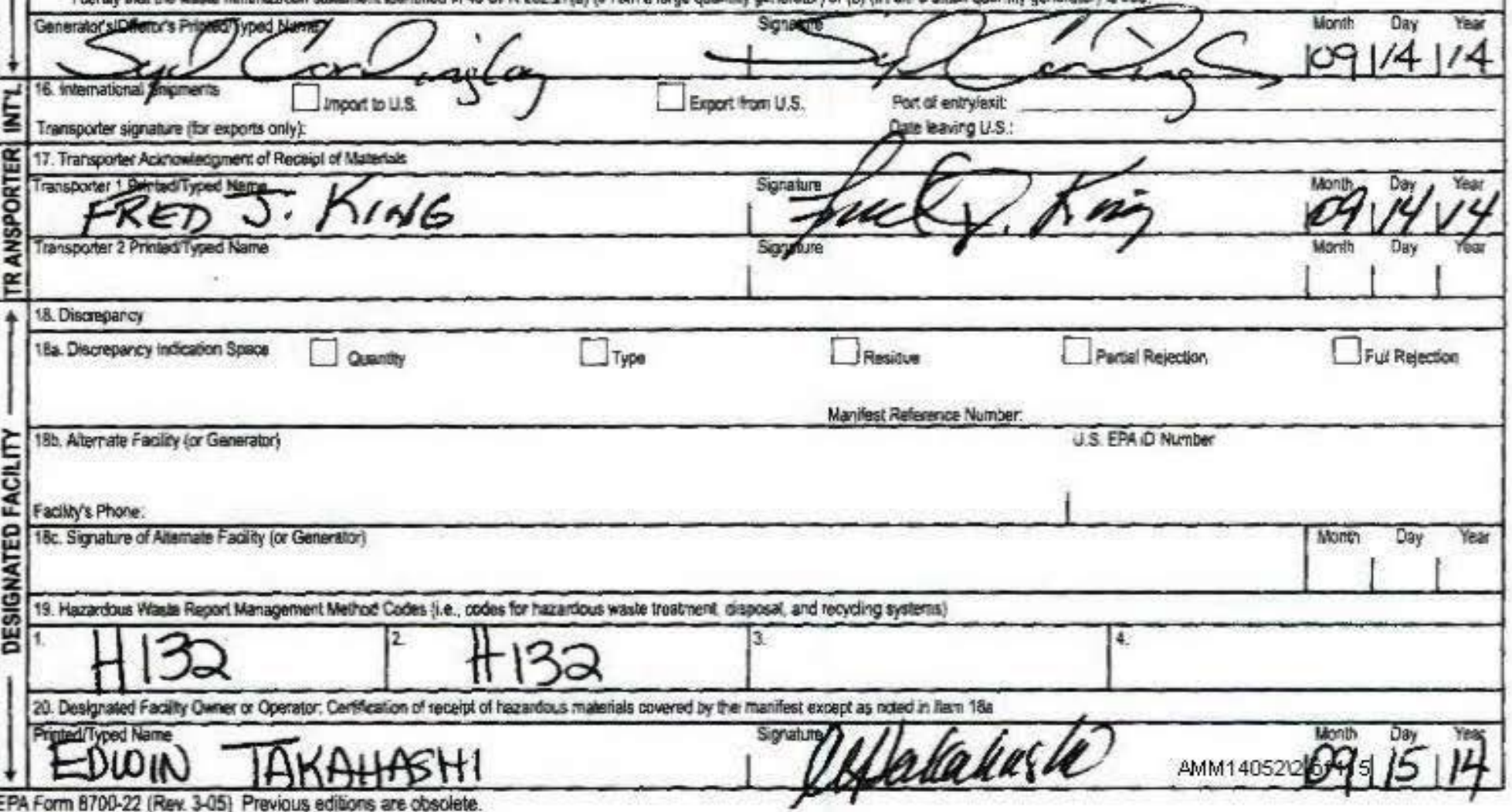


Please print or type. (Form designed for use on elite (12-pitch) typewriter.)

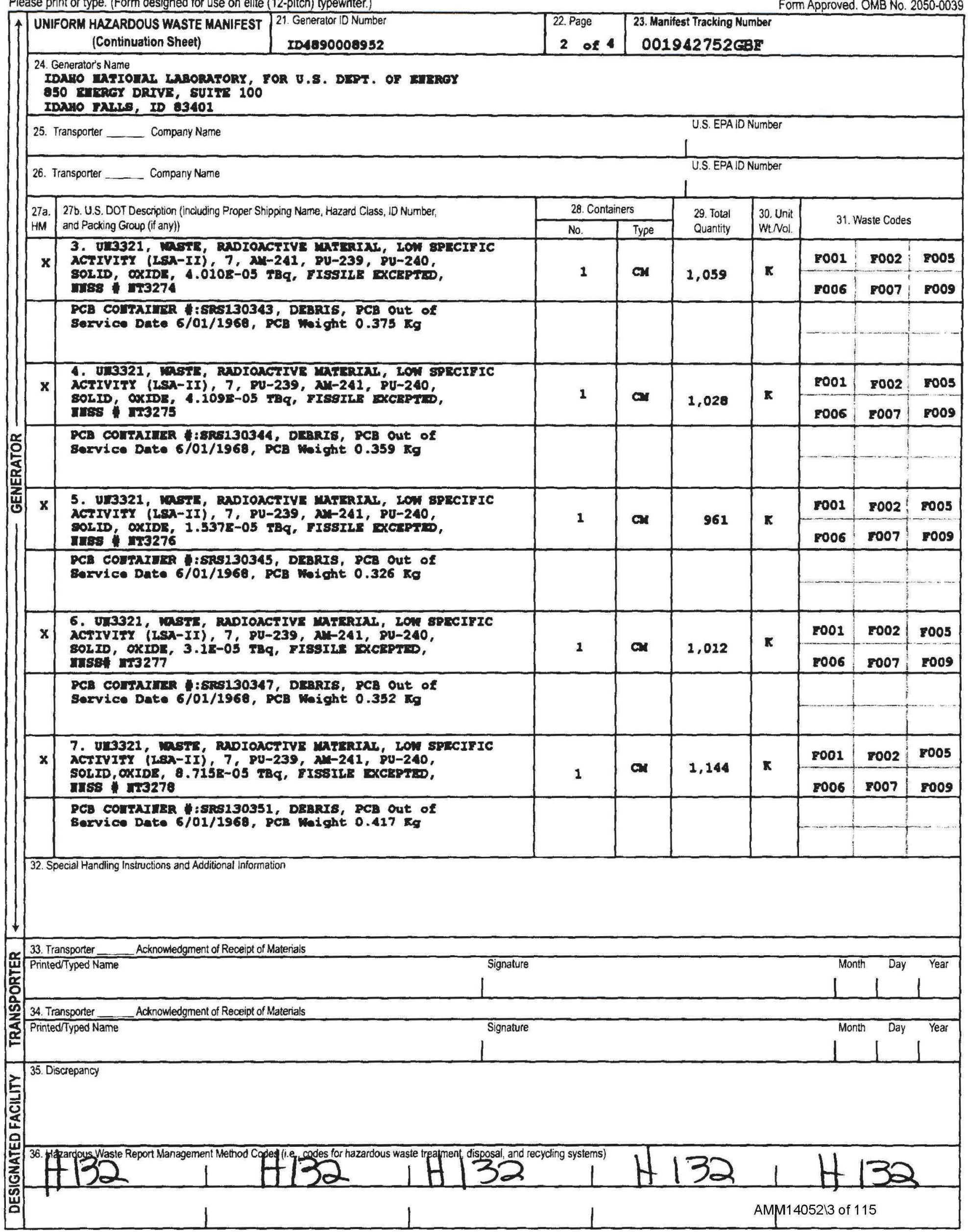

EPA Form 8700-22A (Rev. 3-05) Previous editions are obsolete. 
Please print or type. (Form designed for use on elite (12-pitch) typewriter.)

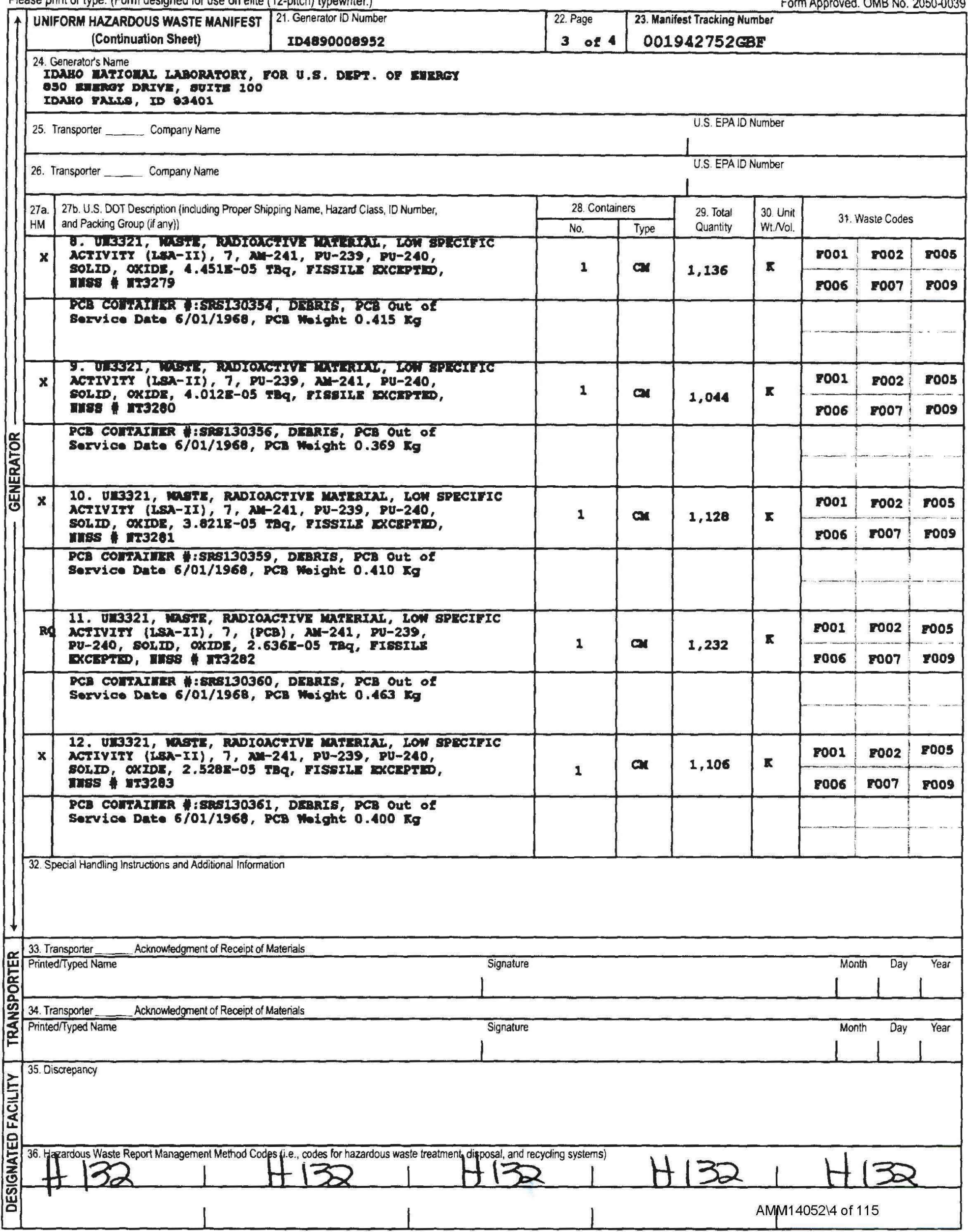


Please print or type. (Form designed for use on elite (12-pitch) typewriter.)

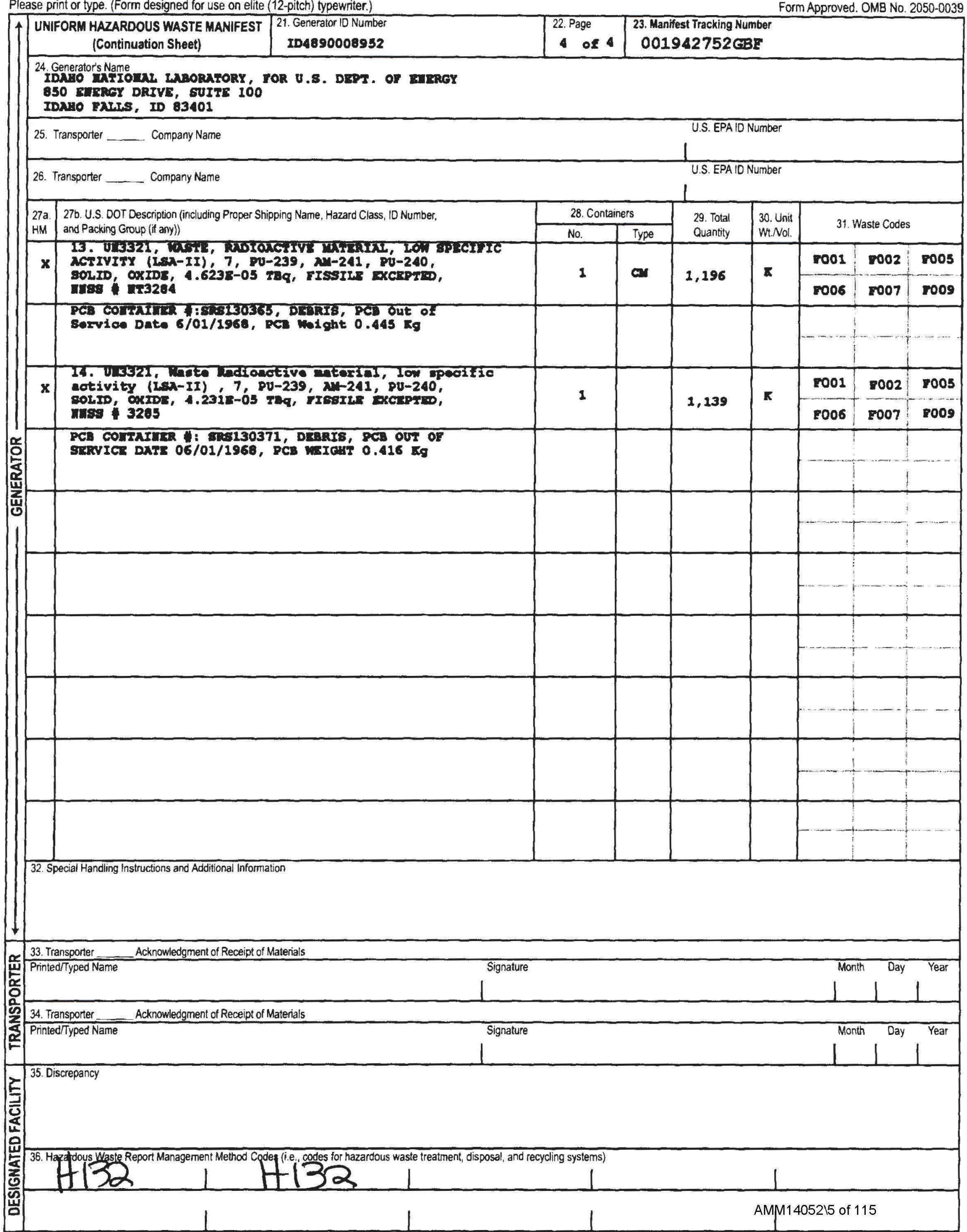




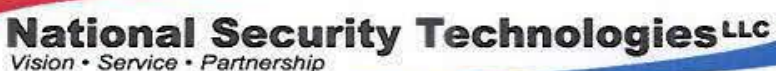

H000-PA-14-0131

September 22, 2014

Jared Dominick

Waste Certification Official

Idaho Treatment Group

850 Energy Drive, Suite 100

Idaho Falls, ID 83401-1502

Subject: CERTIFICATE OF DISPOSAL FOR POLYCHLORINATED BIPHENYL (PCB) WASTE AT THE NEVADA NATIONAL SECURITY SITE
RADIOACTIVE WASTE MANAGEMENT SITE (RWMS)

Enclosed is the certificate acknowledging disposal of manifested PCB shipments AMM14052 and AMM14053 in the Mixed Waste Disposal Unit, at the Nevada National Security Site RWMS.

If you have any questions, please contact me at 702-295-2261.

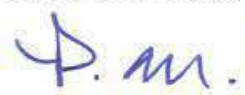<smiles>C=C(C)CC(C)C1CCCCC1</smiles>

Patrick M. Arnold, Division Manager

Environmental Management

RCD:saq

Enclosure: as stated

cc w/enc.

Correspondence Control

EWO Correspondence

J. T. Carilli, NNSA/NFO

R. C. Denton, NSTec

R. G. Geisinger, NSTec

L. B. Gregory, NSTec

M. Libidinsky, NNSA/NFO

C. P. Moke, NSTec

K. M. Small, NNSA/NFO

K. C. Tanaka, NSTec

A. V. Tauber, NNSA/NFO

R. A. Wagner, NSTec

National Security Technologies, LLC

Vision - Service $\cdot$ Partnership

WwW.NSTeC.com 
National Security Technologies LLC

For U.S. Department of Energy

Waste Management

Nevada National Security Site - Zone 2

Mercury, NV 89023

EPA ID NV3890090001

This Certificate acknowledges that the following shipment(s) of manifested

POLYCHLORINATED BIPHENYL (PCB) waste have been disposed at the Nevada National Security Site Radioactive Waste Management Site.

\begin{tabular}{|c|c|c|c|c|}
\hline $\begin{array}{c}\text { Shipment } \\
\text { Number }\end{array}$ & $\begin{array}{c}\text { Uniform Hazardous Waste } \\
\text { Manifest Number }\end{array}$ & Date(s) of Disposal & Volume $\mathbf{F t}^{3}\left(\mathbf{m}^{3}\right)$ & Disposal Process \\
\hline AMM14052 & 001942752 GBF & $09 / 15 / 2014$ & $1,259.79(35.67)$ & Landfill \\
\hline AMM14053 & $001942753 G B F$ & $09 / 15 / 2014$ & $1,259.76(35.67)$ & Landfill \\
\hline
\end{tabular}

Under civil and criminal penalties of law for the making or submission of false or fraudulent statements or representations (18 U.S.C. 1001 and 15 U.S.C. 2615), I certify that the information contained in or accompanying this document is true, accurate, and complete.

As to the identified section(s) of this document for which I cannot personally verify truth and accuracy, I certify as the company official having supervisory responsibility for the persons who, acting under my direct instructions, made the verification that this information is true, accurate, and complete.
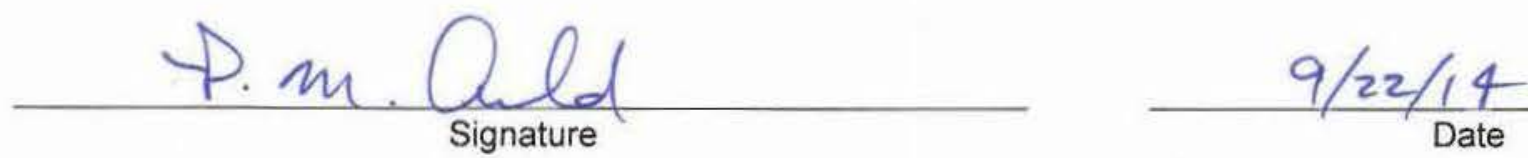

Division Manager, Environmental Management

Title

Instructions:

Shipment Number - enter shipment number from LWIS database.

Uniform Hazardous Waste Manifest Number - enter number from UHWM provided by generator.

Date of Disposal - enter date waste was placed in disposal cell.

Volume - enter shipment volume in cubic feet and equivalent cubic meters in parenthesis.

Disposal Process - enter Landfill.

National Security Technologies, LLC

Vision - Service • Partnership

WWW.NSTEC.com

P.O. Box 98521, Las Vegas, NV 89193-8521

2621 Losee Road, N. Las Vegas, NV 89030-4129 
Please print or type. (Form designed for use on elite (12-pitch) typewriter.)

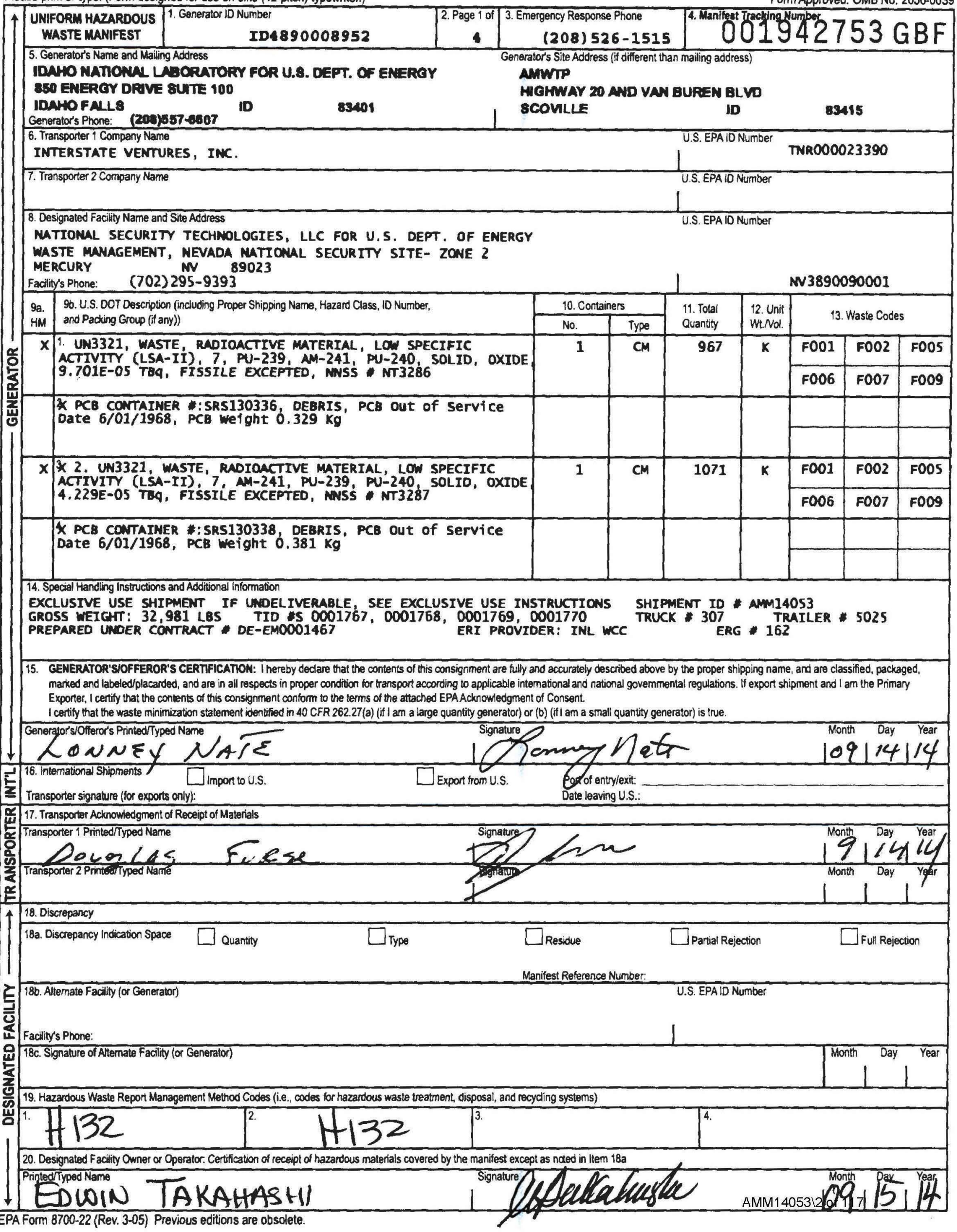


Please print or type. (Fom designed for use on elite (12-pitch) typewriter.)

Form Approved. OMB No. 2050-0039

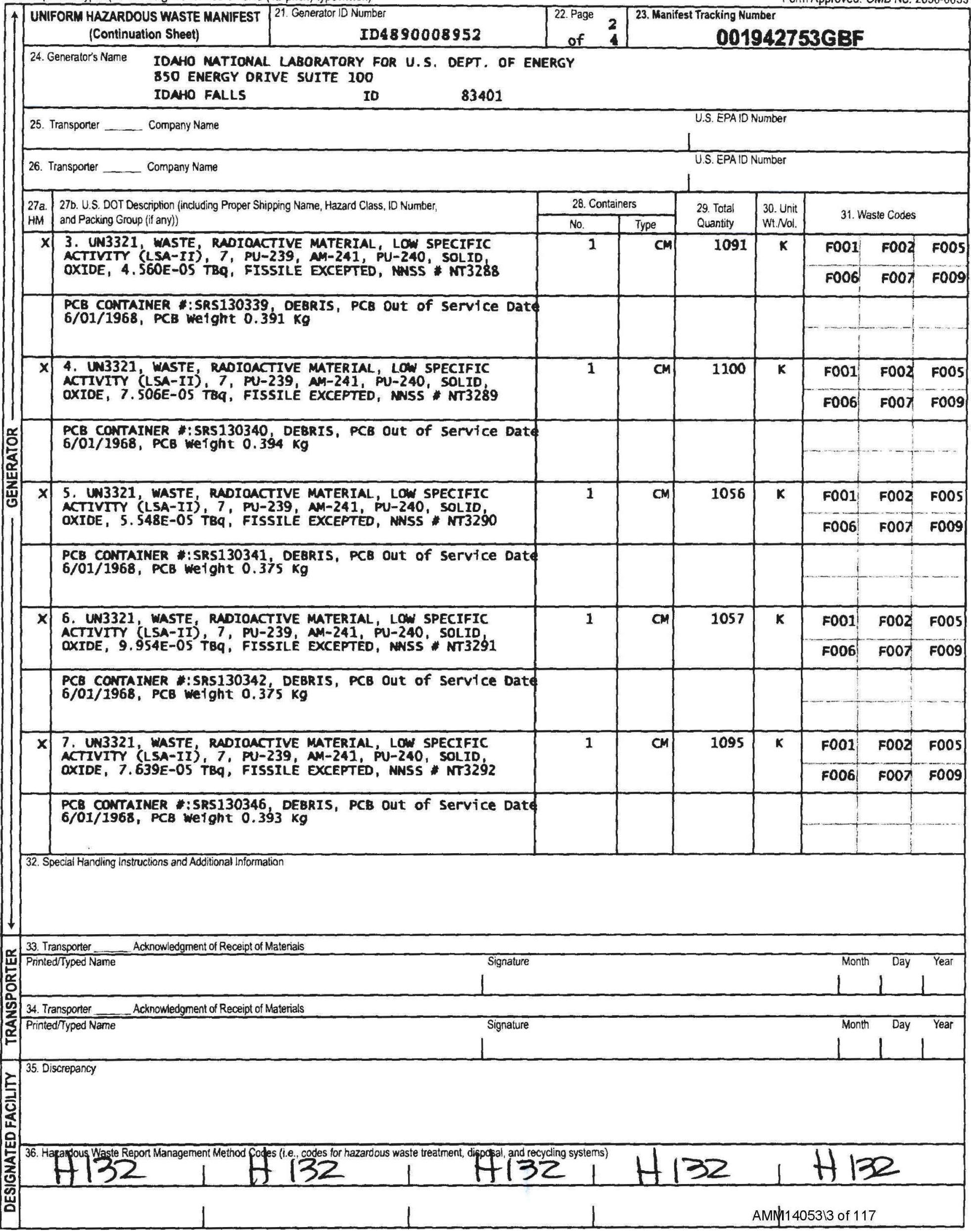


Please print or type. (Form designed for use on elite (12-pitch) typewriter.)

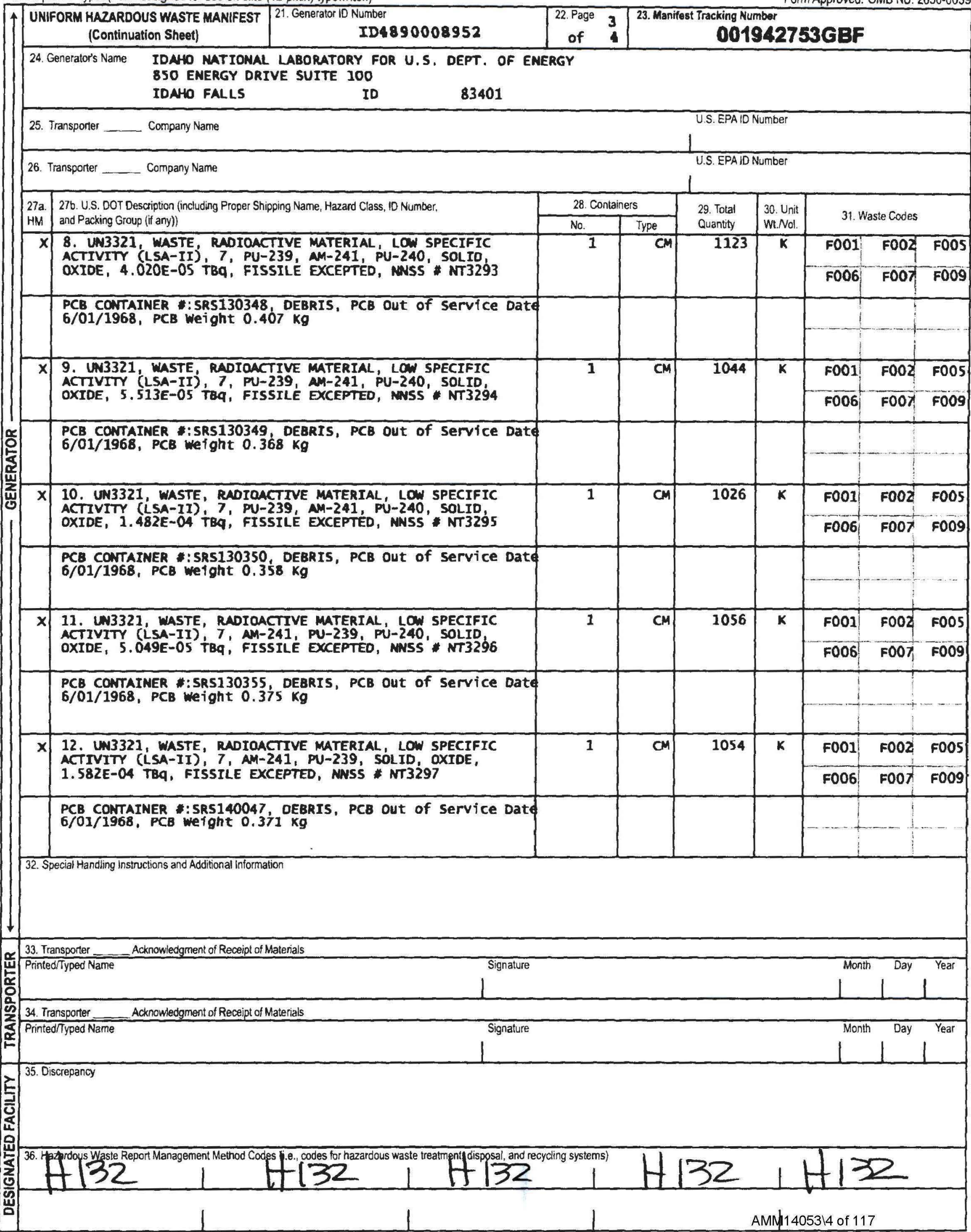




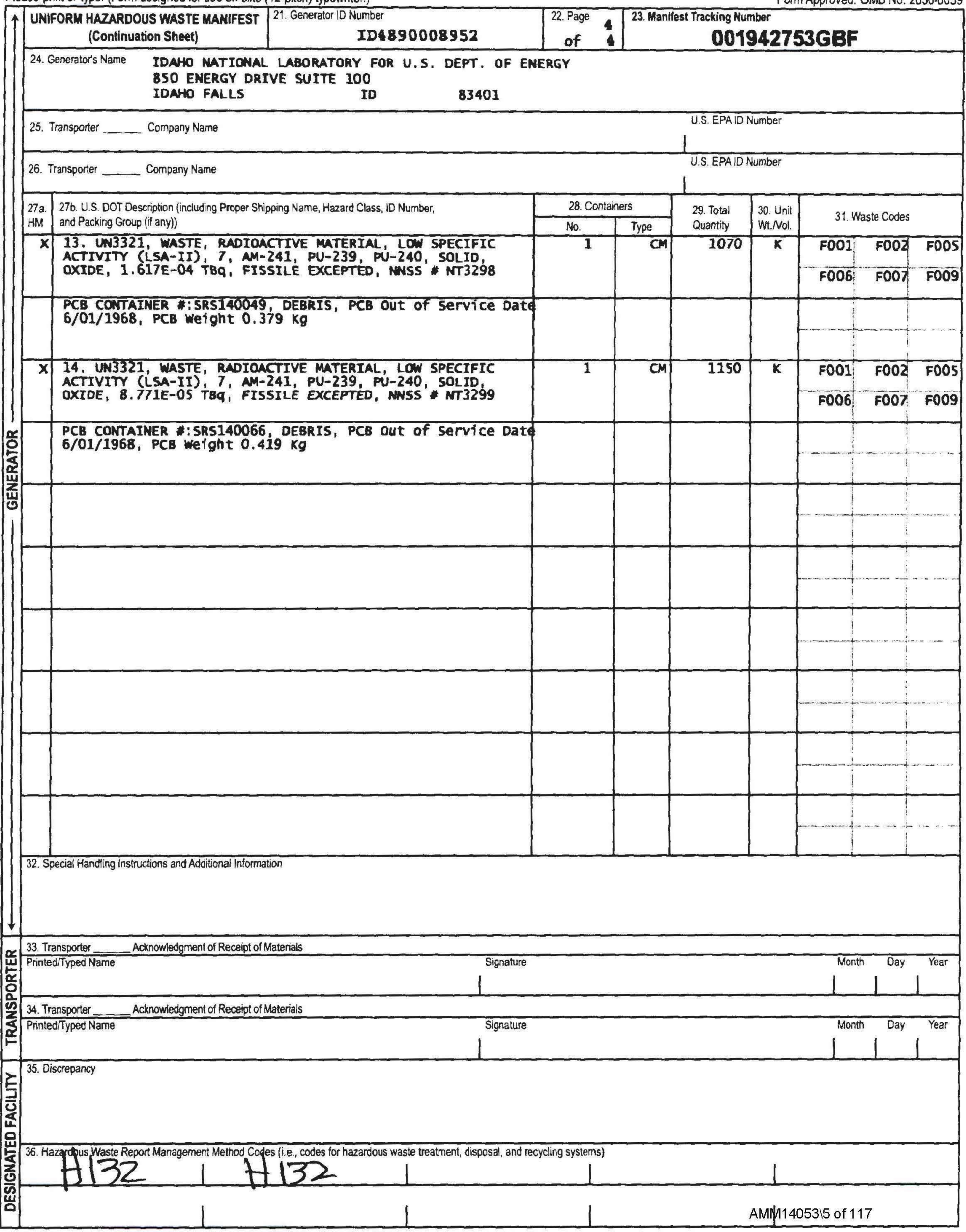




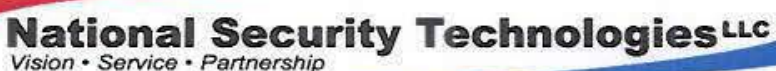

H000-PA-14-0131

September 22, 2014

Jared Dominick

Waste Certification Official

Idaho Treatment Group

850 Energy Drive, Suite 100

Idaho Falls, ID 83401-1502

Subject: CERTIFICATE OF DISPOSAL FOR POLYCHLORINATED BIPHENYL (PCB) WASTE AT THE NEVADA NATIONAL SECURITY SITE
RADIOACTIVE WASTE MANAGEMENT SITE (RWMS)

Enclosed is the certificate acknowledging disposal of manifested PCB shipments AMM14052 and AMM14053 in the Mixed Waste Disposal Unit, at the Nevada National Security Site RWMS.

If you have any questions, please contact me at 702-295-2261.

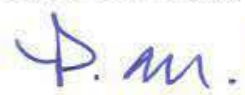<smiles>C=C(C)CC(C)C1CCCCC1</smiles>

Patrick M. Arnold, Division Manager

Environmental Management

RCD:saq

Enclosure: as stated

cc w/enc.

Correspondence Control

EWO Correspondence

J. T. Carilli, NNSA/NFO

R. C. Denton, NSTec

R. G. Geisinger, NSTec

L. B. Gregory, NSTec

M. Libidinsky, NNSA/NFO

C. P. Moke, NSTec

K. M. Small, NNSA/NFO

K. C. Tanaka, NSTec

A. V. Tauber, NNSA/NFO

R. A. Wagner, NSTec

National Security Technologies, LLC

Vision - Service $\cdot$ Partnership

WwW.NSTeC.com 
National Security Technologies LLC

For U.S. Department of Energy

Waste Management

Nevada National Security Site - Zone 2

Mercury, NV 89023

EPA ID NV3890090001

This Certificate acknowledges that the following shipment(s) of manifested

POLYCHLORINATED BIPHENYL (PCB) waste have been disposed at the Nevada National Security Site Radioactive Waste Management Site.

\begin{tabular}{|c|c|c|c|c|}
\hline $\begin{array}{c}\text { Shipment } \\
\text { Number }\end{array}$ & $\begin{array}{c}\text { Uniform Hazardous Waste } \\
\text { Manifest Number }\end{array}$ & Date(s) of Disposal & Volume $\mathbf{F t}^{3}\left(\mathbf{m}^{3}\right)$ & Disposal Process \\
\hline AMM14052 & 001942752 GBF & $09 / 15 / 2014$ & $1,259.79(35.67)$ & Landfill \\
\hline AMM14053 & $001942753 G B F$ & $09 / 15 / 2014$ & $1,259.76(35.67)$ & Landfill \\
\hline
\end{tabular}

Under civil and criminal penalties of law for the making or submission of false or fraudulent statements or representations (18 U.S.C. 1001 and 15 U.S.C. 2615), I certify that the information contained in or accompanying this document is true, accurate, and complete.

As to the identified section(s) of this document for which I cannot personally verify truth and accuracy, I certify as the company official having supervisory responsibility for the persons who, acting under my direct instructions, made the verification that this information is true, accurate, and complete.
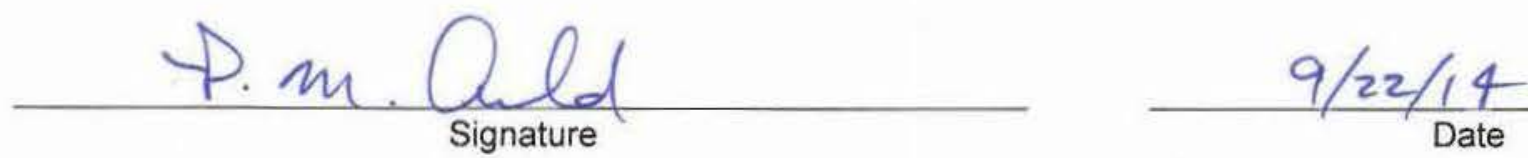

Division Manager, Environmental Management

Title

Instructions:

Shipment Number - enter shipment number from LWIS database.

Uniform Hazardous Waste Manifest Number - enter number from UHWM provided by generator.

Date of Disposal - enter date waste was placed in disposal cell.

Volume - enter shipment volume in cubic feet and equivalent cubic meters in parenthesis.

Disposal Process - enter Landfill.

National Security Technologies, LLC

Vision - Service • Partnership

WWW.NSTEC.com

P.O. Box 98521, Las Vegas, NV 89193-8521

2621 Losee Road, N. Las Vegas, NV 89030-4129 
Please print or type. (Form designed for use on elite (12-pitch) typewriter.)

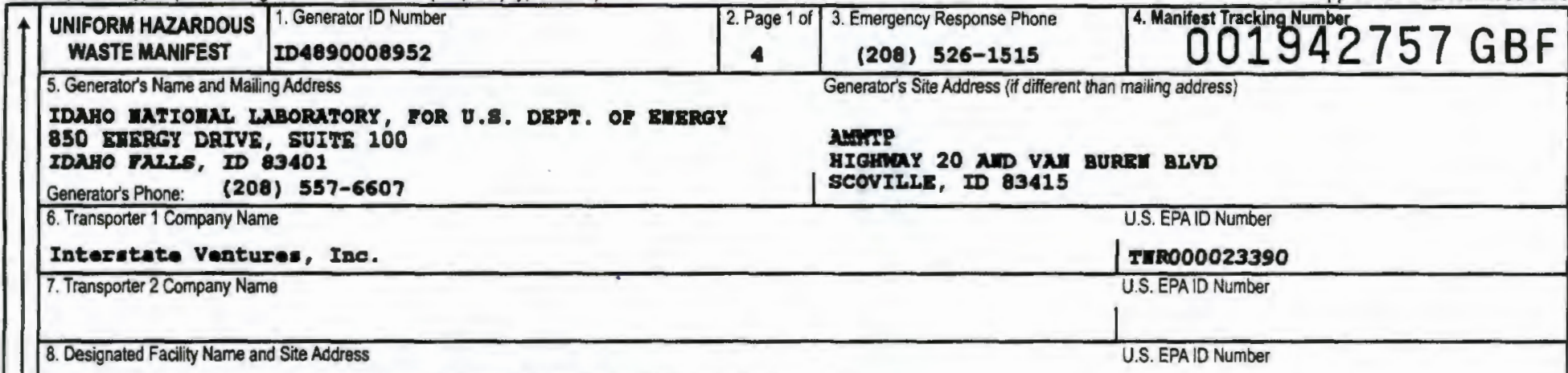

MATOMNL SECURITY TECHYLOCIES, LLC TOR U.8. DLPT. OF EURRGY

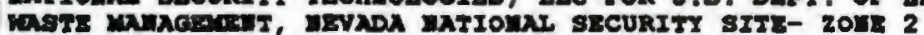

ITRCURY, IN 89023

Facility's Phone: (702) 295-9393

9a. 96. U.S. DOT Description (including Proper Shipping Name, Hazard Class, ID Number,

HM and Packing Group (fi any))

1. U13321, WSTE, RXIONCTIVE MTERIN, LON SPECIFIC

으 XCTIVITY (LSA-II), 7, AN-241, PU-239,

DOLID, OXIDE, 5.2615-05 FAg, FIOETLE EXCRPTID,

IIIS8 * Era334

7. PCB COITAIEER : SRS130445, DERRIS, PCB OUt of

Service Date $6 / 01 / 1968$, PCB Moight $0.390 \mathrm{~kg}$

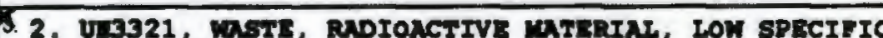

ACTIVITY (LSA-II) $7, X N-241$, PU-239, PU-240,

SOLID, OXIDE, 5.399E-05 TBq, FISSILE EXCEPTW,

zuss * mrass

7 PCB COTFXIMER : :SRS130458, DEBRIS, PCB Out of

Service Date 6/01/1968, PCl Moight $0.385 \mathrm{~kg}$

14. Special Handing Instructions and Additional Information

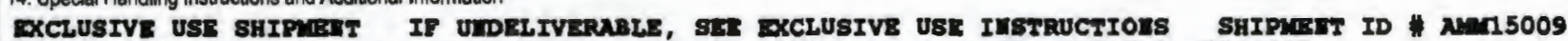

RETURA SIGID ORIGIEAL TO GRERRTTR. TID He: 0001624, 0001625, 0001626, 0001627

GROBg WICHT: 31,506 LAS

PREPARSD ULDER CONTRAT DE-EMD001467 ERI PROVIDER: IIL NCC ERG 162

15. GEMERATOR'SOFFEROR'S CERTIFICATION: I hereby deciare that the contents of this consignment are fully and accurately described above by the proper shipping name, and are classified, packaged,

marked and labeled/placarded, and are in all respects in proper condition for transport according to applicable intemational and national governmental regulations. If export stipment and I am the Primany

Exporter, I certily that the contents of this consignment contorm to the terms of the attached EPAAcknowledgment of Consent.

I certity that the wasse minimization statement identified in 40 CFR 262.27 (a) (if I am a large quantity generator) or (b) (ifl am a small quantity generator) is tue.

Generator's/ Ofieror's Printed Typed Name

Lonney L. NATE

Transporter signature (for exports only):

[import to U.S.

1 Pommal $\alpha$. Nate Month Day Year

17. Transponter Ackonowledgment of Receipt of Matenials

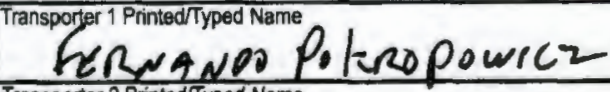

Transporter 2 Printedrityped Name

18. Discrepancy

189. Discrepancy Indication Space $\square$ cuantity

$\square$ Type

$\square$ Export rom U.S.

Polol entry/exit: Date leaving U.S.

xv3890090001 
Please print or type. (Form designed for use on elite (12-pitch) typewriter.)

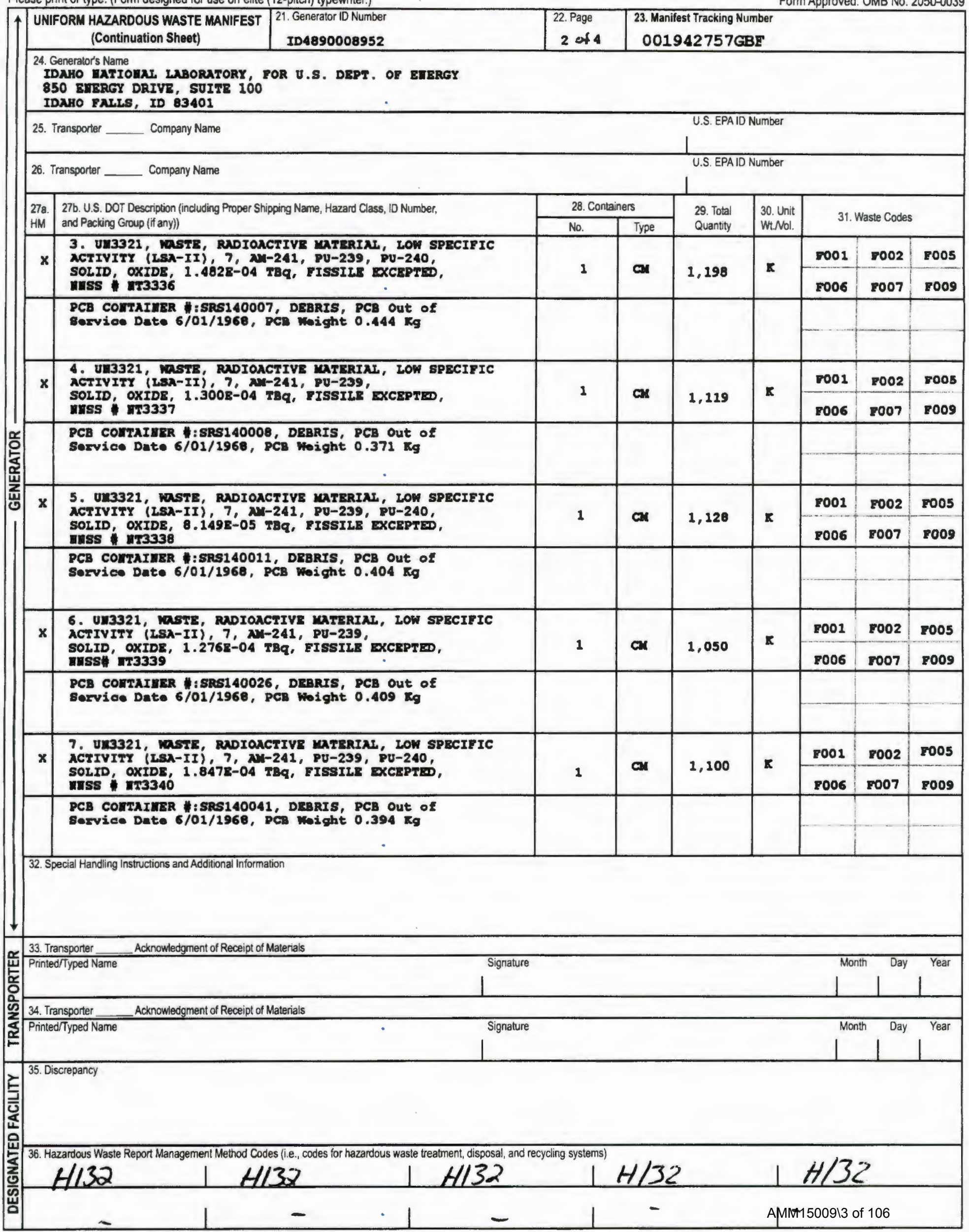

EPA Form 8700-22A (Rev. 3-05) Previous editions are obsolete. 
Please print or type. (Form designed for use on elite (12-pitch) typewriter.)

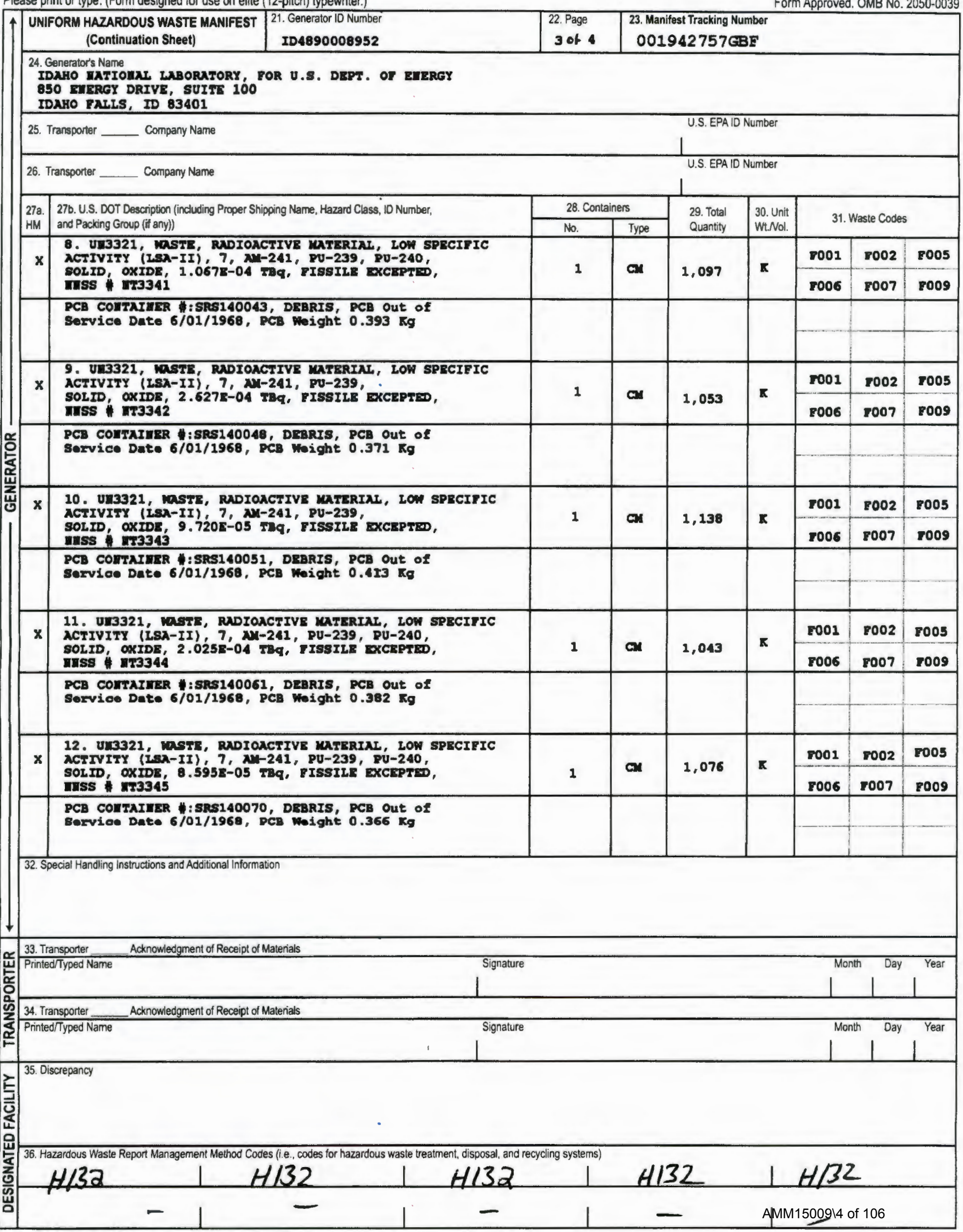


Please print or type. (Form designed for use on elite (12-pitch) typewriter.)

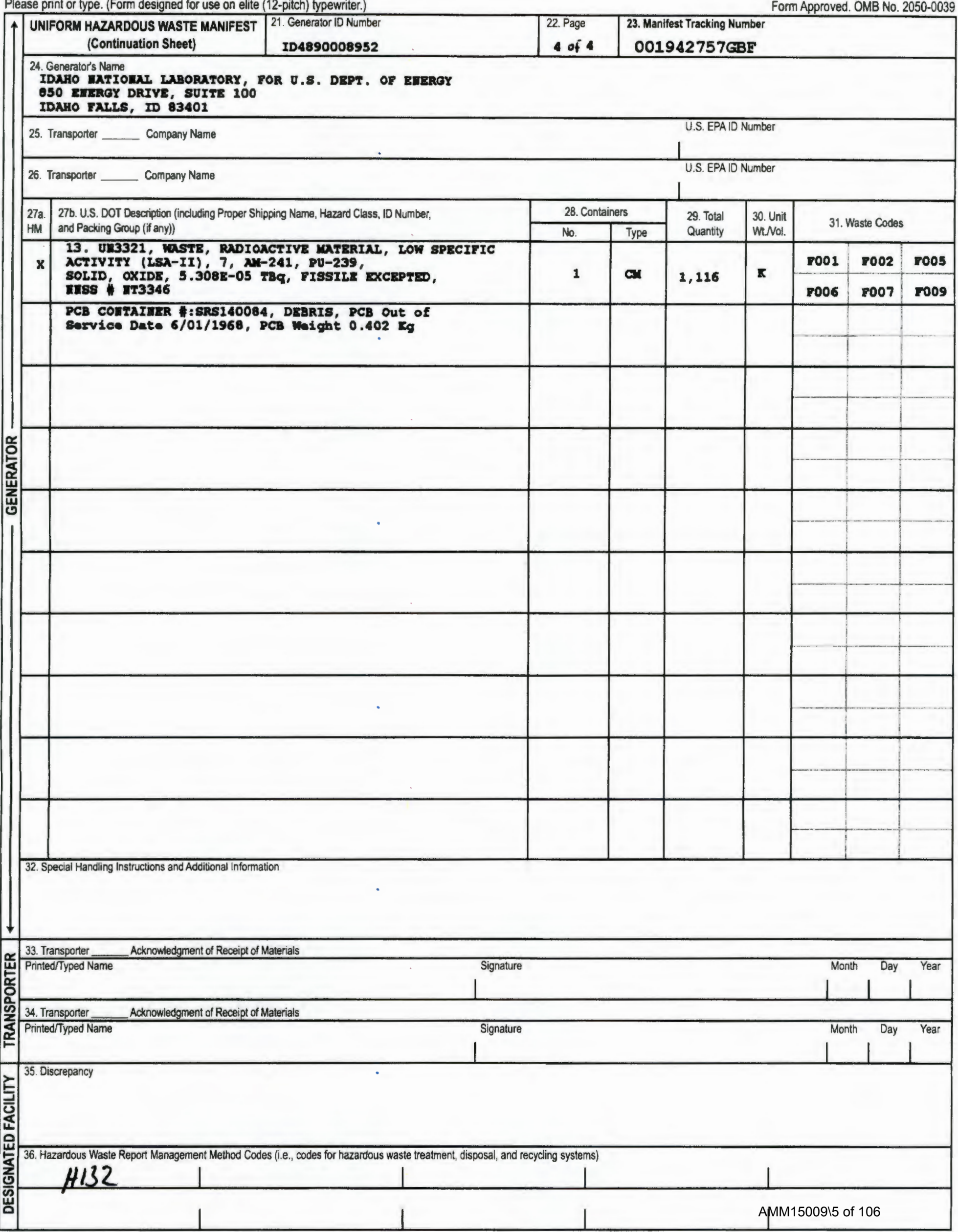


H000-PA-15-0002

October 6, 2014

Jared Dominick

Waste Certification Official

Idaho Treatment Group

850 Energy Drive, Suite 100

Idaho Falls, ID 83401-1502

Subject: CERTIFICATE OF DISPOSAL FOR POL YCHLORINATED BIPHENYL (PCB) WASTE AT THE NEVADA NATIONAL SECURITY SITE RADIOACTIVE WASTE MANAGEMENT SITE (RWMS)

Enclosed is the certificate acknowledging disposal of manifested PCB shipment AMM15009 in the Mixed Waste Disposal Unit, at the Nevada National Security Site RWMS.

If you have any questions, please contact me at 702-295-2261.<smiles>CC(C)(C)PC1(C)CC1</smiles><smiles>CCCC12CCCC1C21CCCC1</smiles>

Patrick M. Arnold, Division Manager

Environmental Management

RCD:saq

Enclosure: as stated

cc w/enc.

Correspondence Control

EWO Correspondence

J. T. Carilli, NNSA/NFO

R. C. Denton, NSTec

R. G. Geisinger, NSTec

L. B. Gregory, NSTec

M. Libidinsky, NNSA/NFO

C. P. Moke, NSTec

K. M. Small, NNSA/NFO

K. C. Tanaka, NSTec

A. V. Tauber, NNSANFO

R. A. Wagner, NSTec 
National Security Techmologles LLC

For U.S. Department of Energy

Naste Management

Nevada Nationa! Security Site - Zone 2

Mercury, MY 89023

EPA ID NV3890090001

This Certificate acknowledges that the following shipment(s) of manifested

POLYCHLORINATED BIPHENYL (PCB) waste have been disposed at the Nevada National Security Site Radioactive Waste Management Site.

\begin{tabular}{|c|c|c|c|c|}
\hline $\begin{array}{c}\text { Shipment } \\
\text { Number }\end{array}$ & $\begin{array}{c}\text { Uniform Hazardous Waste } \\
\text { Manifest Number }\end{array}$ & Date(s) of Disposal & Volume $\mathbf{F t}^{\mathbf{3}}\left(\mathbf{m}^{\mathbf{3}}\right)$ & Disposal Process \\
\hline AMM15009 & $001942757 \mathrm{GBF}$ & $10 / 02 / 2014$ & $1,169.77(33.12)$ & Landfill \\
\hline & & & & \\
\hline & & & & \\
\hline & & & & \\
\hline
\end{tabular}

Under civil and criminal penalties of law for the making or submission of false or fraudiulent statements or representations (18 U.S.C. 1001 and 15 U.S.C. 2615), I certify that the information contained in or accompanying this document is true, accurate, and complete.

As to the identified section(s) of this document for which I cannot personally verify truth and accuracy, I certify as the company official having supervisory responsibility for the persons who, acting under my direct instructions, made the verification that this information is true, accurate, and complete.
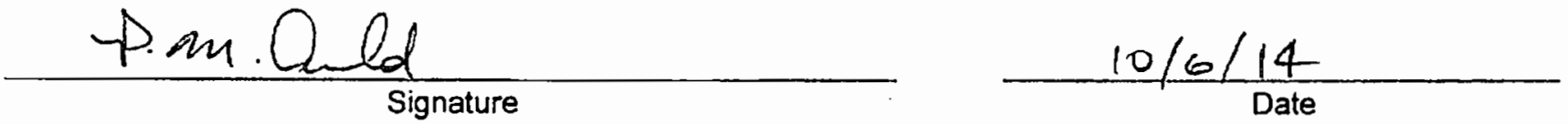

Division Manager, Environmental Management

Title

Instructions:

Shipment Number - enter shipment number from LWIS database.

Uniform Hazardous Waste Manifest Number - enter number from UHWM provided by generator.

Date of Disposal - enter date waste was placed in disposal cell.

Volume - enter shipment volume in cubic feet and equivalent cubic meters in parenthesis.

Disposal Process - enter Landfill.

National Securily Techonologies, LLC

Vision - Senvice - Partnership

WWW.NSTEC.COM

P.O. Box 98521, Las Vegas, NV 89193-8521

2621 Losee Road, N. Las Vegas, NV 89030-4129 
Please print or type. (Form designed for use on elite (12-pitch) typewriter.)

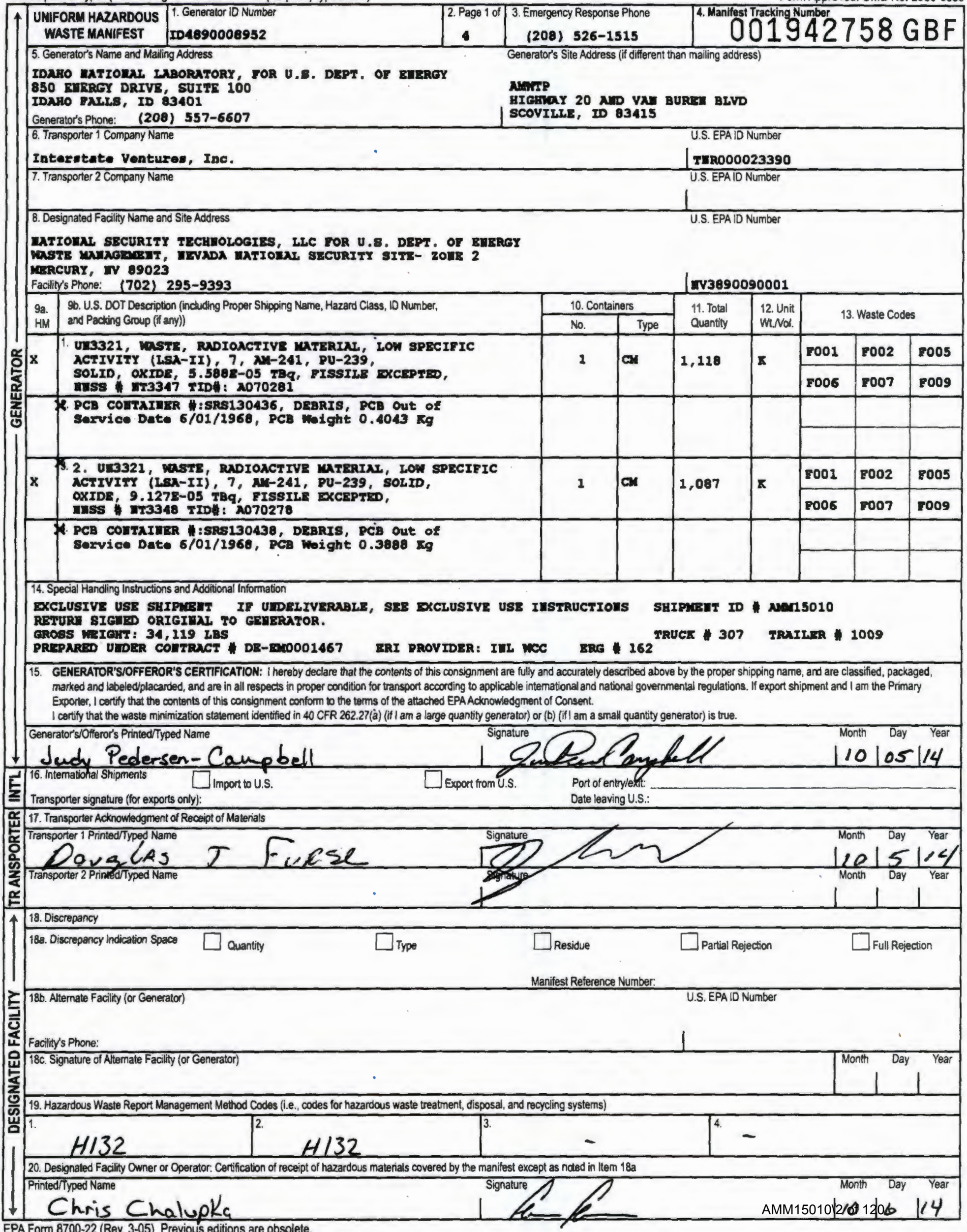


Please print or type. (Form designed for use on elite (12-pitch) typewriter.)

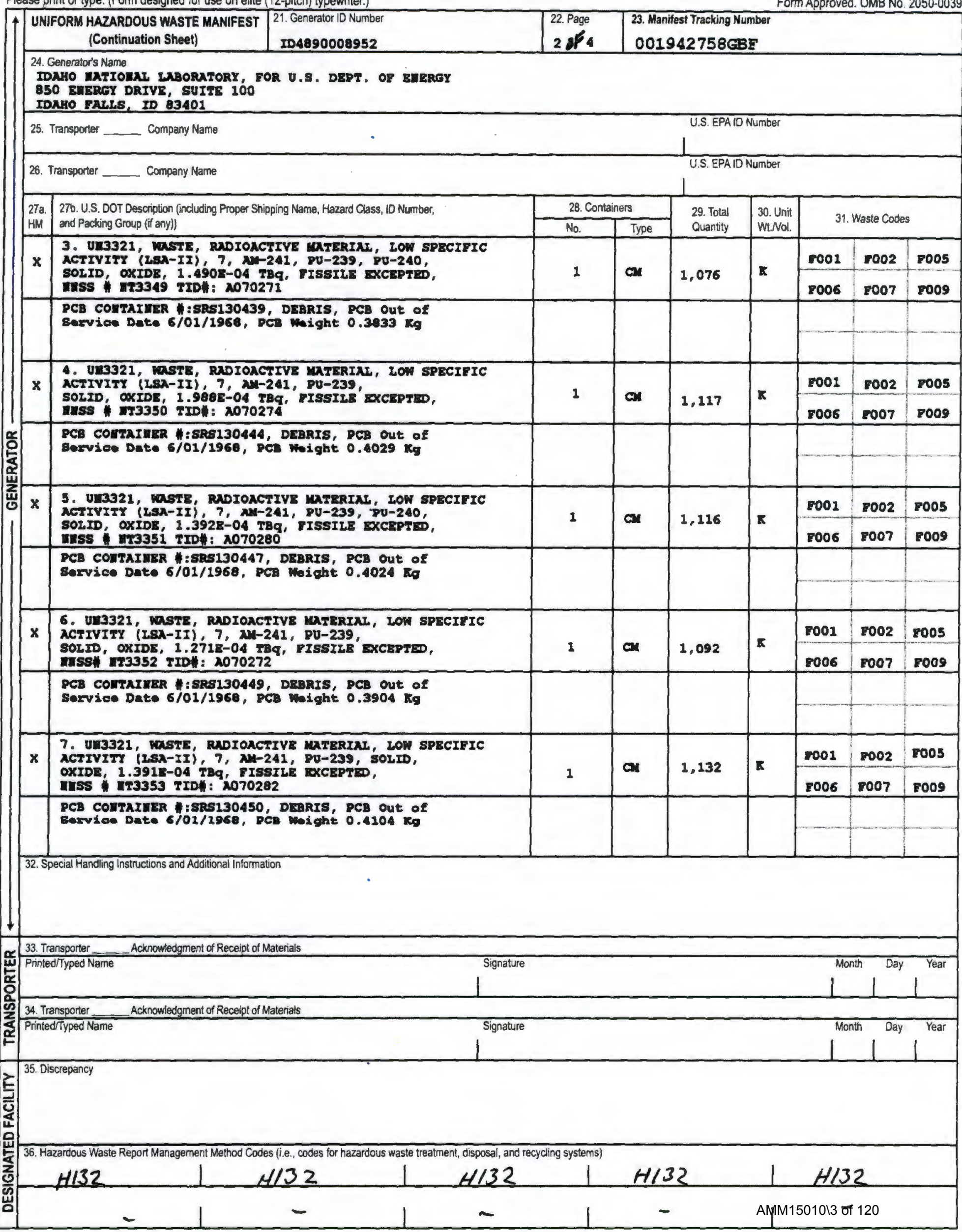

EPA Form 8700-22A (Rev. 3-05) Previous editions are obsolete. 
Please print or type. (Form designed for use on elite (12-pitch) typewriter.)

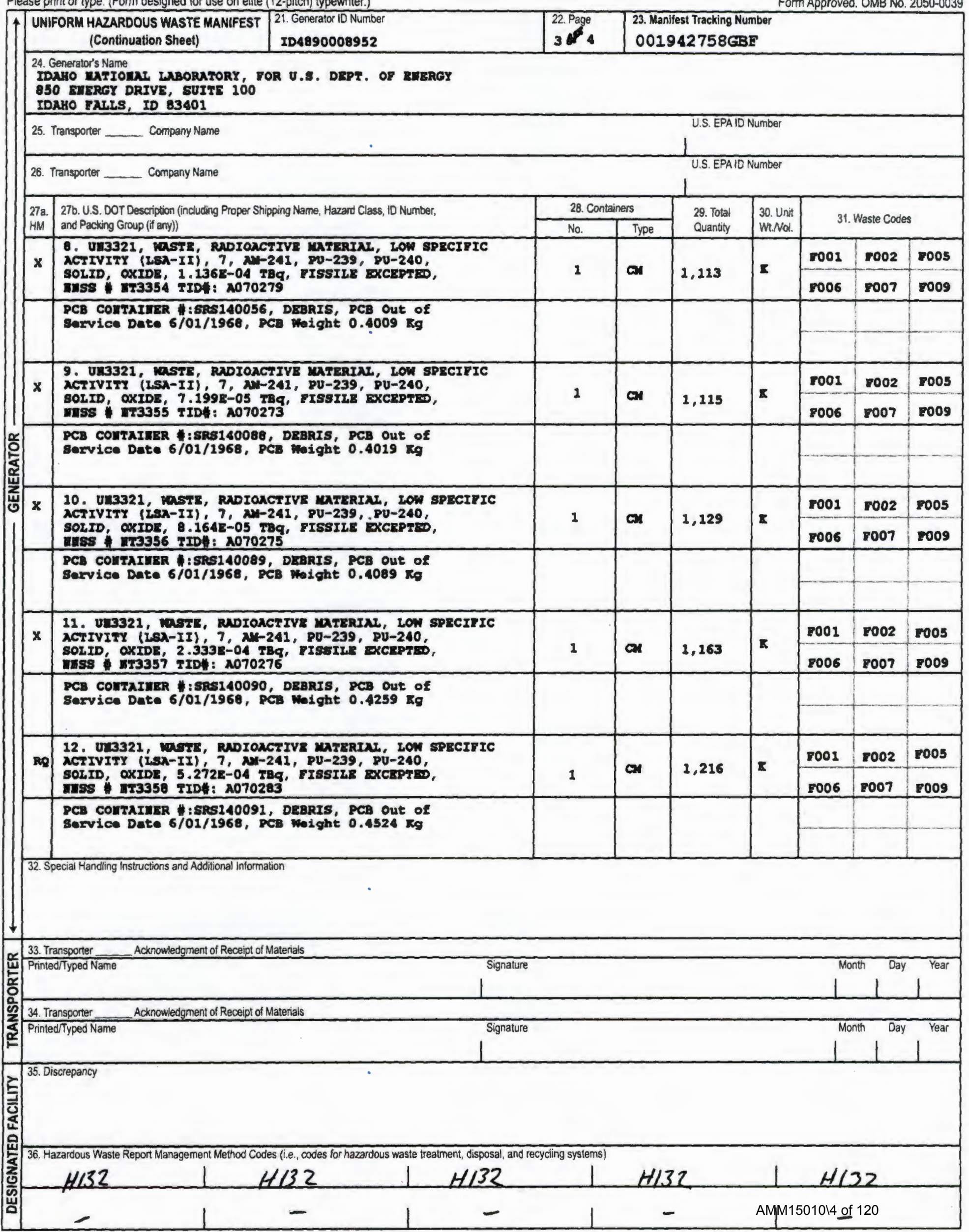


Please print or type. (Form designed for use on elite (12-pitch) typewriter.)

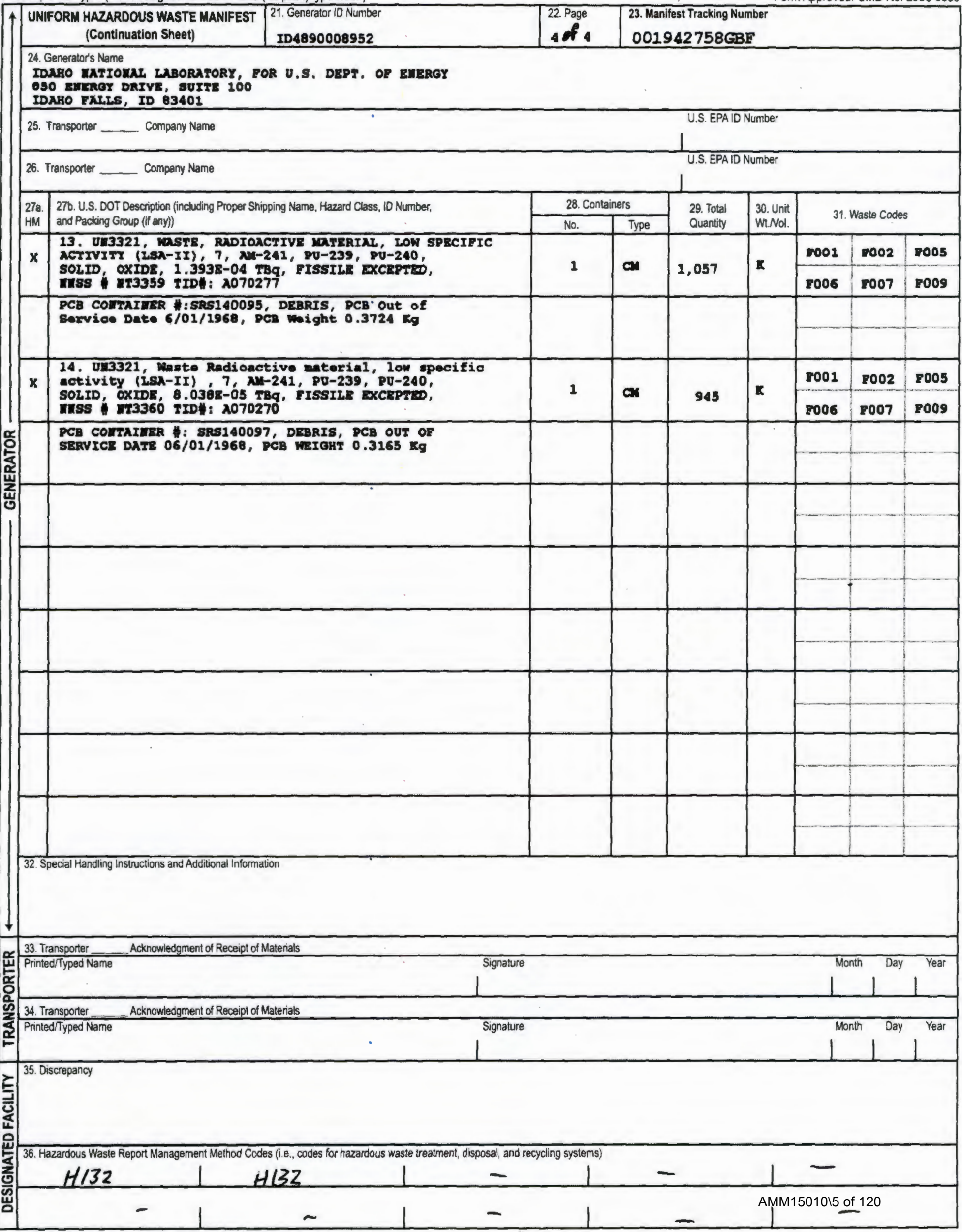


H000-PA-15-0007

October 13, 2014

Jared Dominick

Waste Certification Official

Idaho Treatment Group

850 Energy Drive, Suite 100

Idaho Falls, ID 83401 - 1502

Subject: CERTIFICATE OF DISPOSAL FOR POLYCHLORINATED BIPHENYL (PCB) WASTE AT THE NEVADA NATIONAL SECURITY SITE RADIOACTIVE WASTE MANAGEMENT SITE (RWMS)

Enclosed is the certificate acknowledging disposal of manifested PCB shipment AMM15010 in the Mixed Waste Disposal Unit, at the Nevada National Security Site RWMS.

If you have any questions, please contact me at 702-295-2261.

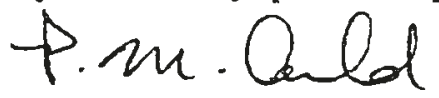

Patrick M. Arnold, Division Manager

Environmental Management

LBG:saq

Enclosure: as stated

cc w/enc.

Correspondence Control

EWO Correspondence

J. T. Carilli, NNSA/NFO

R. C. Denton, NSTec

R. G. Geisinger, NSTec

L. B. Gregory, NSTec

M. Libidinsky, NNSA/NFO

C. P. Moke, NSTec

K. M. Small, NNSA/NFO

K. C. Tanaka, NSTec

A. V. Tauber, NNSA/NFO

R. A. Wagner, NSTec

Nationai Security Technologies, LrC

Vision - Service - Partnership

unww.NSTeC.COm

P.O. Box 98521, Las Vegas, NV 89193-8521

2621 Losee Road, N. Las Vegas, NV 89030-4129 
Naḱional Security Technologies LLC

For U.S. Department of Energy

Waste Management

Nevada National Security Site - Zone 2

Mercury, NY 89023

EPA ID NV3890090001

This Certificate acknowledges that the following shipment(s) of manifested POLYCHLORINATED BIPHENYL (PCB) waste have been disposed at the Nevada National Security Site Radioactive Waste Management Site.

\begin{tabular}{|c|c|c|c|c|}
\hline $\begin{array}{c}\text { Shipment } \\
\text { Number }\end{array}$ & $\begin{array}{c}\text { Uniform Hazardous Waste } \\
\text { Mhanifest Number }\end{array}$ & Date(s) of Disposal & Volume $\mathrm{Fi}^{3}\left(\mathrm{~m}^{3}\right)$ & Disposal Process \\
\hline AMM15010 & $001942758 \mathrm{GBF}$ & $10 / 08 / 2014$ & $1.259 .76(35.67)$ & Landfill \\
\hline & & & & \\
\hline & & & & \\
\hline & & & & \\
\hline
\end{tabular}

Under civil and criminal penalties of law for the making or submission of false or fraudulent statements or representations ( 18 U.S.C. 1001 and 15 U.S.C. 2615), I certify that the information contained in or accompanying this document is true, accurate, and complete.

As to the identified section(s) of this document for which I cannot personally verify truth and accuracy, I certify as the company official having supervisory responsibility for the persons who, acting under my direct instructions, made the verification that this information is true, accurate, and complete.
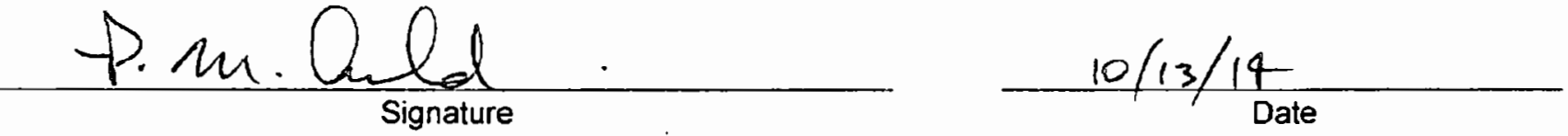

Division Manager, Environmental Management

Title

\section{Instragctions:}

Shipment Number - enter shipment number from LWIS database.

Uniform I-lazardous Waste Manifest Number - enter number from UHWM provided by generator.

Date of Disposal - enter date waste was placed in disposal cell.

Volume - enter shipment volume in cubic feet and equivalent cubic meters in parenthesis.

Disposal Process - enter Landfill. 
Please print or type. (Form designed for use on eiite (12-pitch) typewriter.)

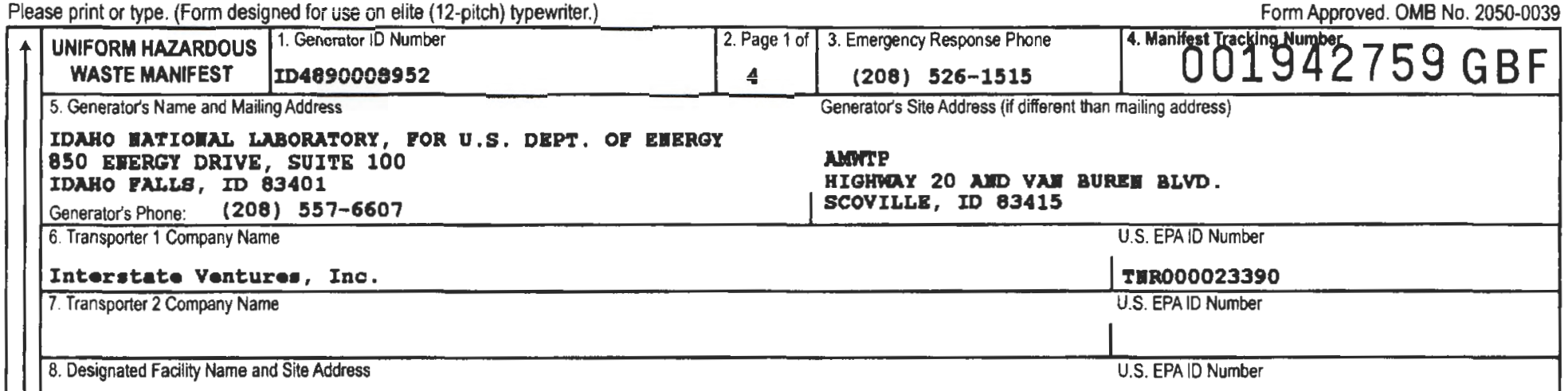

MATIOIAL BECURITY TECHEOLOGIES, LLC FOR U.s. DEPT. OF EMERGY

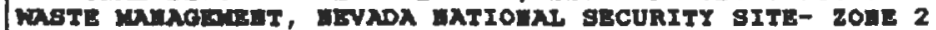

MERCURY, IV 89023

Facility's Phone: (702) 295-9393

\begin{tabular}{l|l} 
9a. & 96. U.S. DOT Description (induding Proper Shipping Name, Hazard Class, ID Number,
\end{tabular}

HM and Packing Group (if any))

o 1 Un3321, wete Radioactive materiel, low upecific

$\mathrm{O}$ aativity (LSA-II), 7, $\operatorname{An}-241, \mathrm{Pu}-239, \mathrm{Pu}-240$,

olid, oxide, 1.050B-04 TBq, Fimile Excopted, unss

2. PCB Container sas140050, Debris, PCB out of Service Date $6 / 01 / 1968$, PCB Woight $0.360 \mathrm{~kg}$

3. 2 ve3321, Maste Redionctive meterial, lou apecific

$\mathrm{x}$ activity (LGA-II), 7, Mn-241, Pu-239, Pu-240, olid, oxide, 1.139E-04 TEq, Fiesile Excepted, 4 m8s 173364

PCB Container sRs140052, Debrie, PCB Out of Servioe Date 6/01/1968, PCB Woight $0.388 \mathrm{~kg}$

14. Special Handling Instructions and Additional Information

EXCLUSTVE USE SHIPAEHT IF UMDELIVERABLE, SEE EXCLUSIVE USE IMSTRUCTIOMS SHIPAEHT ID * NA15012

RETURI SIGEED ORIGIWAL TO GEIERATOR.

OROBg

PREPARED ULDER COATRACT \# DE-BLDO01467, ERI PROYIDER: IUL MCC

TRUCE 307 TRAILER 5018

ERG 162

15. GENERATOR'S/OFFEROR'S CERTIFICATION: I hereby declare that the contents of this consignment are fully and accurately described above by the proper shipoing name, and are classified, packaged, marked and labeled/placarded, and are in all respects in proper condition for transport according to applicable intemational and national governmental regulations. If export shipment and I am the Primary Exporter, I certify that the contents of this consignment conform to the terms of the attached EPAAcknowledgment of Consent.

I certify that the waste minimization statement identified in 40 CFR 262.27(a) (ii I am a large quantity generator) or (b) (if I am a small quantity generalor) is true.

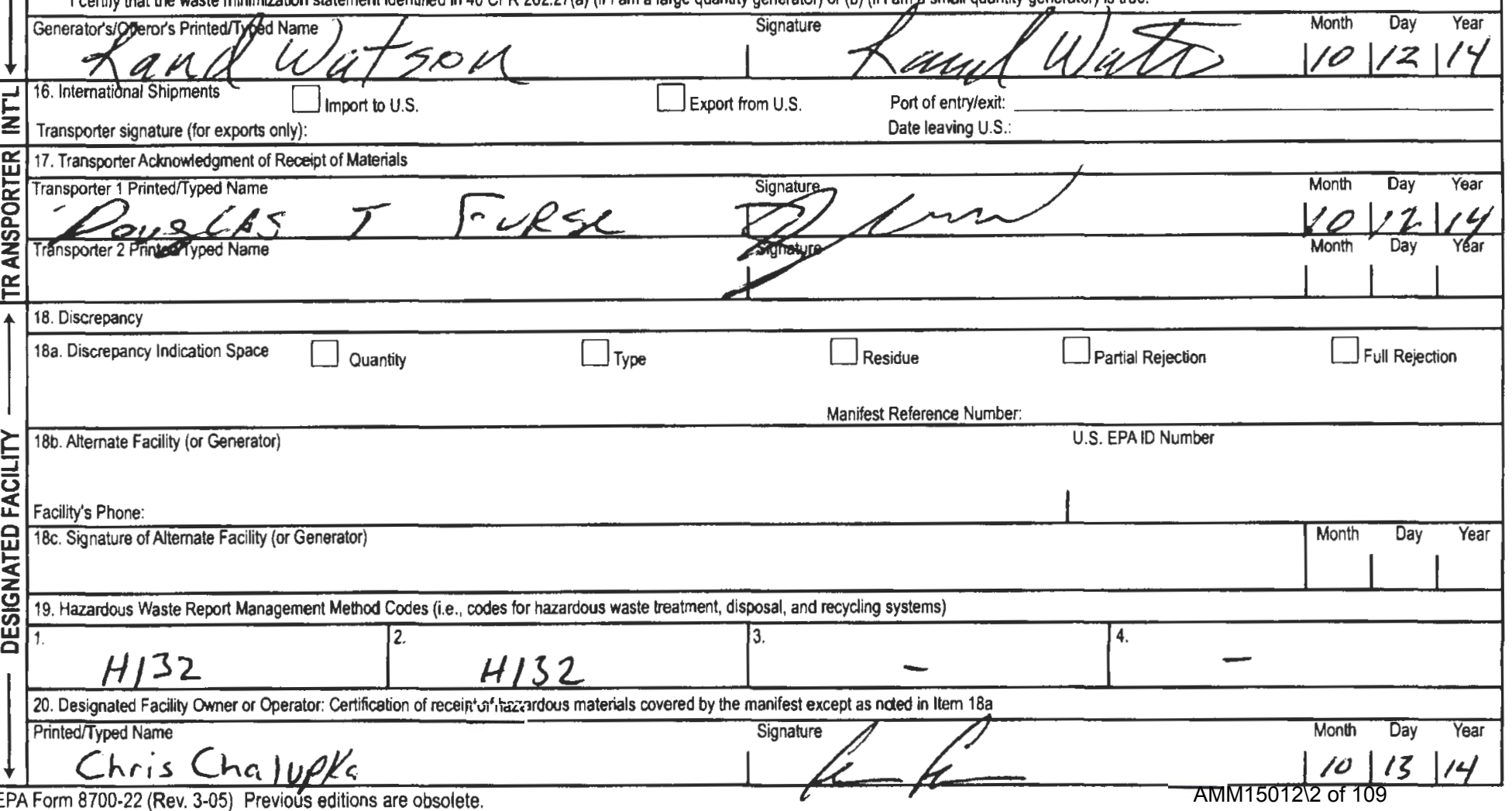


Please print or type. (Form designed for use on elite (12-pitch) typewriter.)

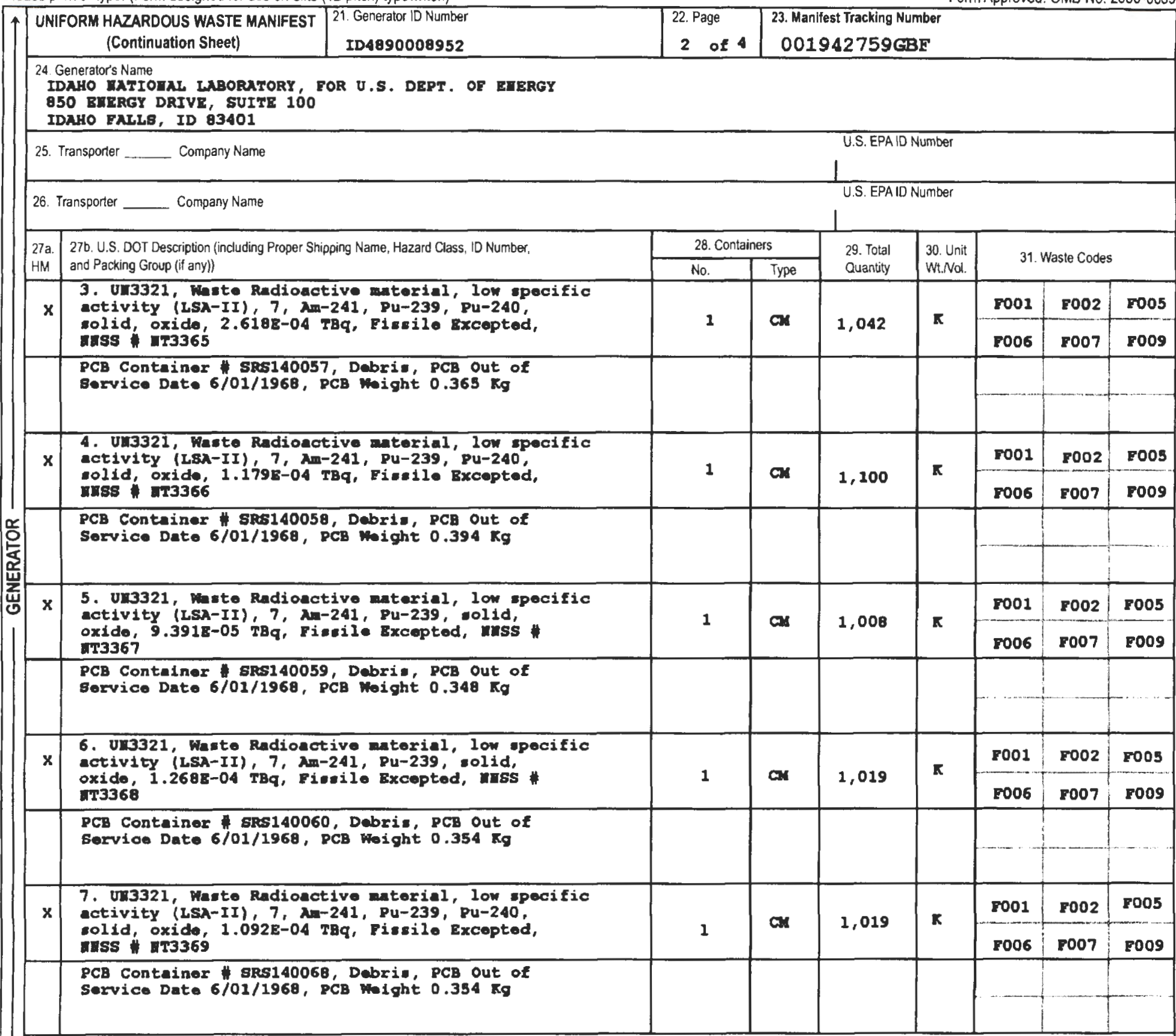

32. Special Handling Instructions and Additional Information

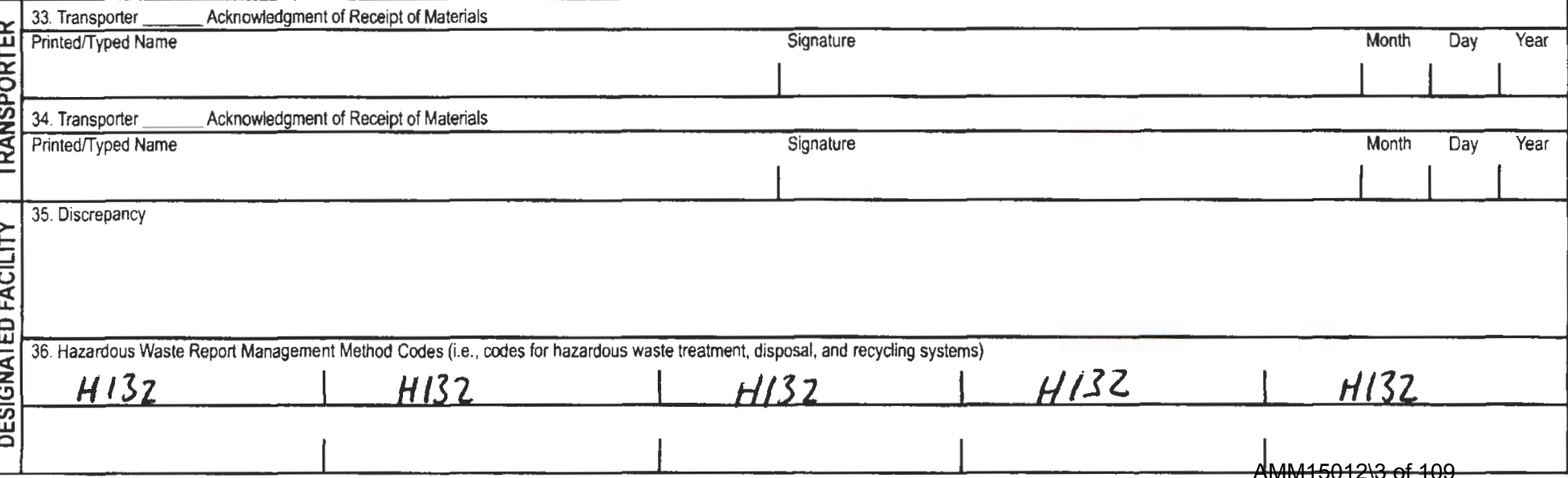




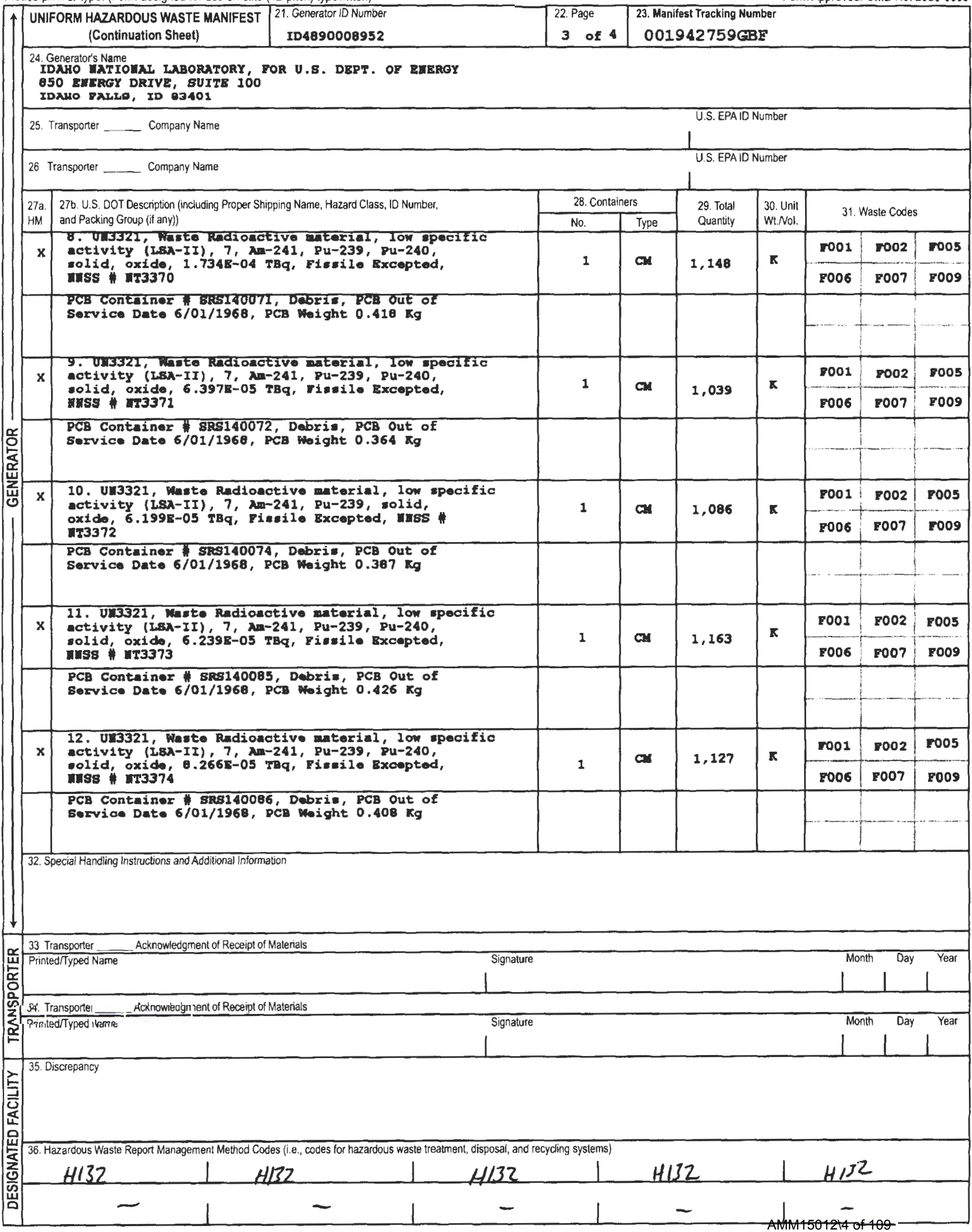


Please print or type. (Form designed for use on elite (12-pitch) typewriter.)

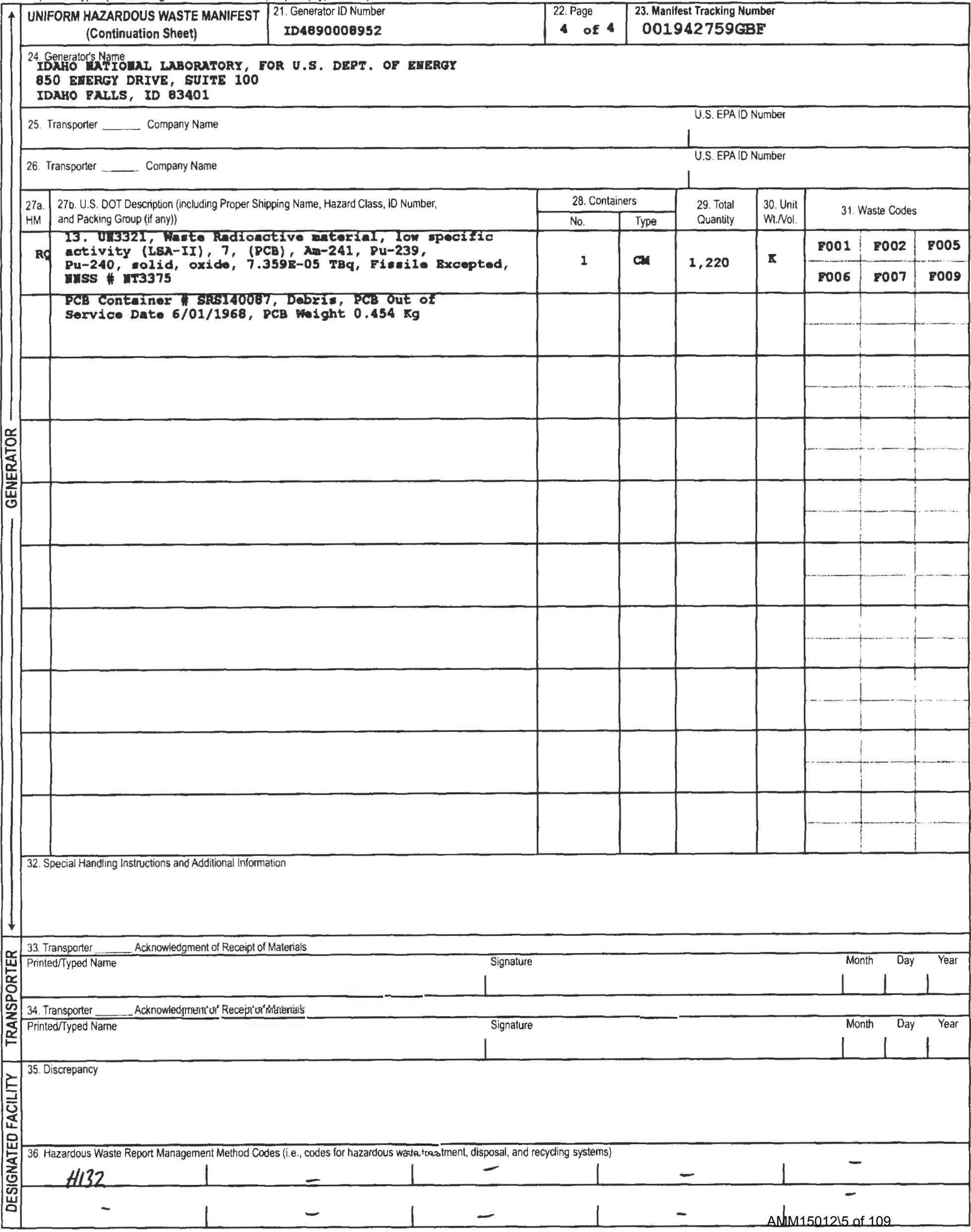


H000-PA-15-0011

October 20,2014

Jared Dominick

Waste Certification Official

Idaho Treatment Group

850 Energy Drive, Suite 100

Idaho Falls, ID $83401-1502$

\section{Subject: CERTIFICATE OF DISPOSAL FOR POLYCHLORINATED BIPHENYL (PCB) WASTE AT THE NEVADA NATIONAL SECURITY SITE RADIOACTIVE WASTE MANAGEMENT SITE (RWMS)}

Enclosed is the certificate acknowledging disposal of manifested PCB shipments AMM15012 and AMM15013 in the Mixed Waste Disposal Unit, at the Nevada National Security Site RWMS.

If you have any questions, please contact me at 702-295-2261.

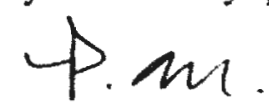<smiles>CC(C)[C@H](C)C(C)C1CCCC1</smiles>

Patrick M. Arnold, Division Manager

Environmental Management

RCD:saq

Enclosure: as stated

cc w/enc.

Correspondence Control

EWO Correspondence

J. T. Carilli, NNSA/NFO

R. C. Denton, NSTec

R. G. Geisinger, NS'lec

L. B. Gregory, NSTec

M. L ibidinsky, NNSA/NFO

C. P. Moke, NSTec

K. M. Small, NNSANFO

K. C. Tanaka, NSTec

A. V. Tauber, NNSA/NFO

R. A. Wagner, NSTec 
NSTec

Form

National Security Technologies uc

For U.S. Department of Energy

Waste Management

Nevada National Security Site - Zone 2

Mercury, NV 89023

EPA ID NV3890090001

This Certificate acknowledges that the following shipment(s) of manifested POLYCHLORINATED BIPHENYL (PCB) waste have been disposed at the Nevada National Security Site Radioactive Waste Management Site.

\begin{tabular}{|c|c|c|c|c|}
\hline $\begin{array}{c}\text { Shipment } \\
\text { Number }\end{array}$ & $\begin{array}{c}\text { Uniform Hazardous Waste } \\
\text { Manifest Number }\end{array}$ & Date(s) of Disposal & Volume $\mathbf{F t}^{3}\left(\mathbf{m}^{3}\right)$ & Disposal Process \\
\hline AMM15012 & $001942759 G B F$ & $10 / 13 / 2014$ & $1,169.77(33.12)$ & Landfill \\
\hline AMM15013 & $001942760 G B F$ & $10 / 13 / 2014$ & $1,259.76(35.67)$ & Landfill \\
\hline & & & & \\
\hline & & & & \\
\hline
\end{tabular}

Under civil and criminal penalties of law for the making or submission of false or fraudulent statements or representations (18 U.S.C. 1001 and 15 U.S.C. 2615), I certify that the information contained in or accompanying this document is true, accurate, and complete.

As to the identified section(s) of this document for which I cannot personally verify truth and accuracy, I certify as the company official having supervisory responsibility for the persons who, acting under my direct instructions, made the verification that this information is true, accurate, and complete.
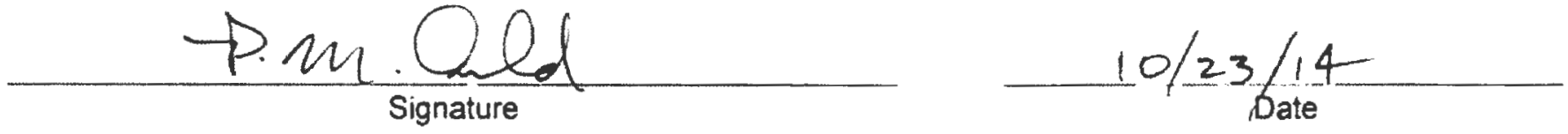

Division Manager, Environmental Management

Title

\section{Instructions:}

Shipment Number - enter shipment number from LWIS database.

Uniform Hazardous Waste Manifest Number - enter number from UHWM provided by generator.

Date of Disposal - enter date waste was placed in disposal cell.

Volume - enter shipment volume in cubic feet and equivalent cubic meters in parenthesis.

Disposal Process - enter Landfill. 
Please print or type. (Form designed for use on elite (12-pitch) typewriter.)

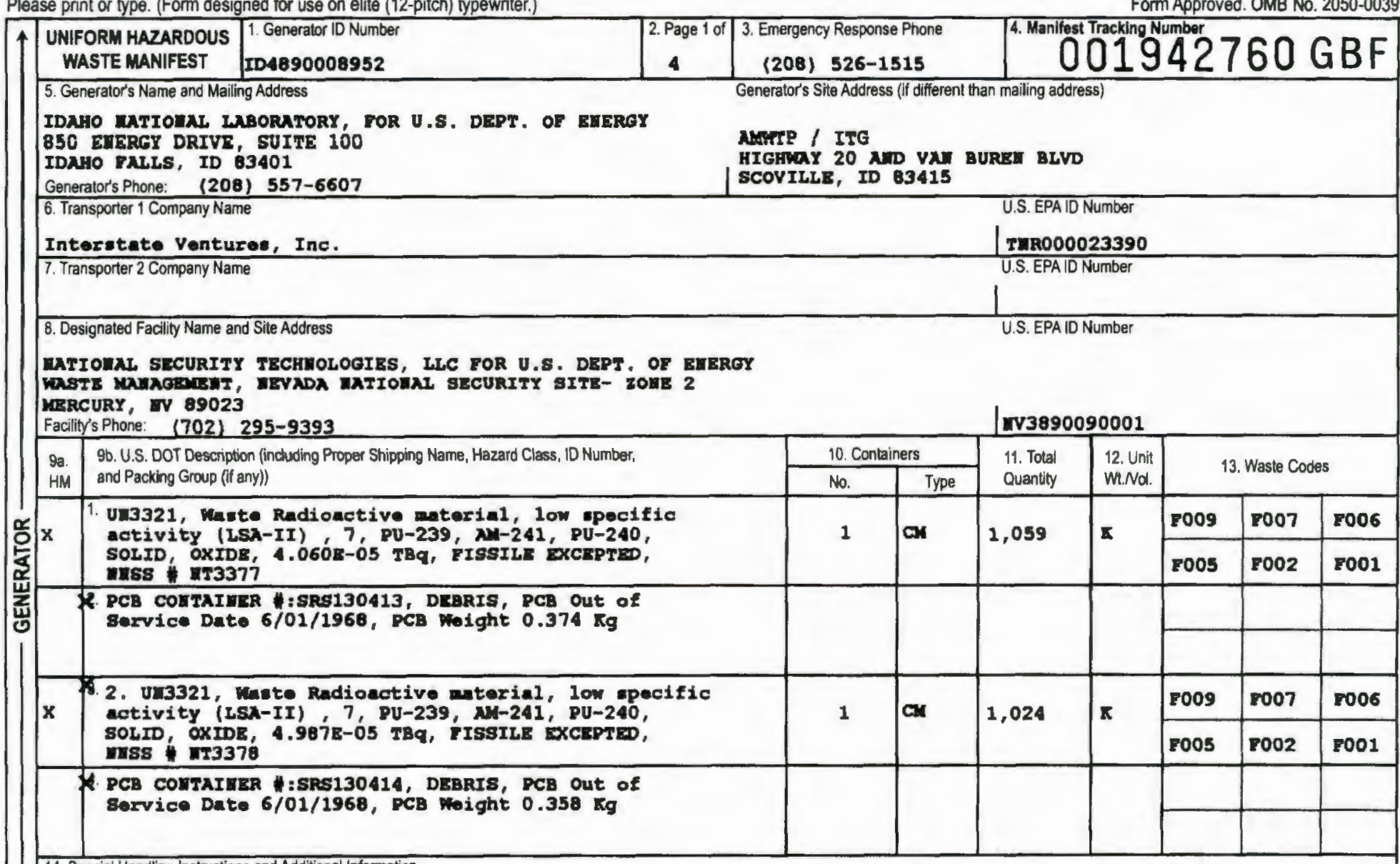

14 Special Handling Instructions and Additional Information

EXCLUSIVE USE SHIPURET IF UIDELIVERABLE, SEE EXCLUSIVE USE IESTRUCTIONS SHIPMEET ID ANO15013

RETURS SIGEED ORIGIMA TO GEERATOR. TID HE: 0001772, 0001773, 0001774, 0001775

GROSS NEICHT: 33,576 LBS

PREPNRED UEDER COETRACT \# DE-E:30001467 ERI PROVIDER: IIL WCC

TRAILER 5021

15. GENERATOR'S/OFFEROR'S CERTFICATION: I hereby declare that the contents of this consignment are fully and accurately described above by the proper shipping name, and are classified, packaged marked and labeled/placarded, and are in all respects in proper condition for transport according to applicable intemational and national governmental regulations. If export shipment and I am the Primary

Exporter, I certify that the contents of this consignment conform to the terms of the attached EPA Acknowledgment of Consent.

I certify that the waste minimization statement identifled in 40 CFR 262.27(a) (if I am a large quantity generator) or (b) (if I am a small quantity generator) is true.

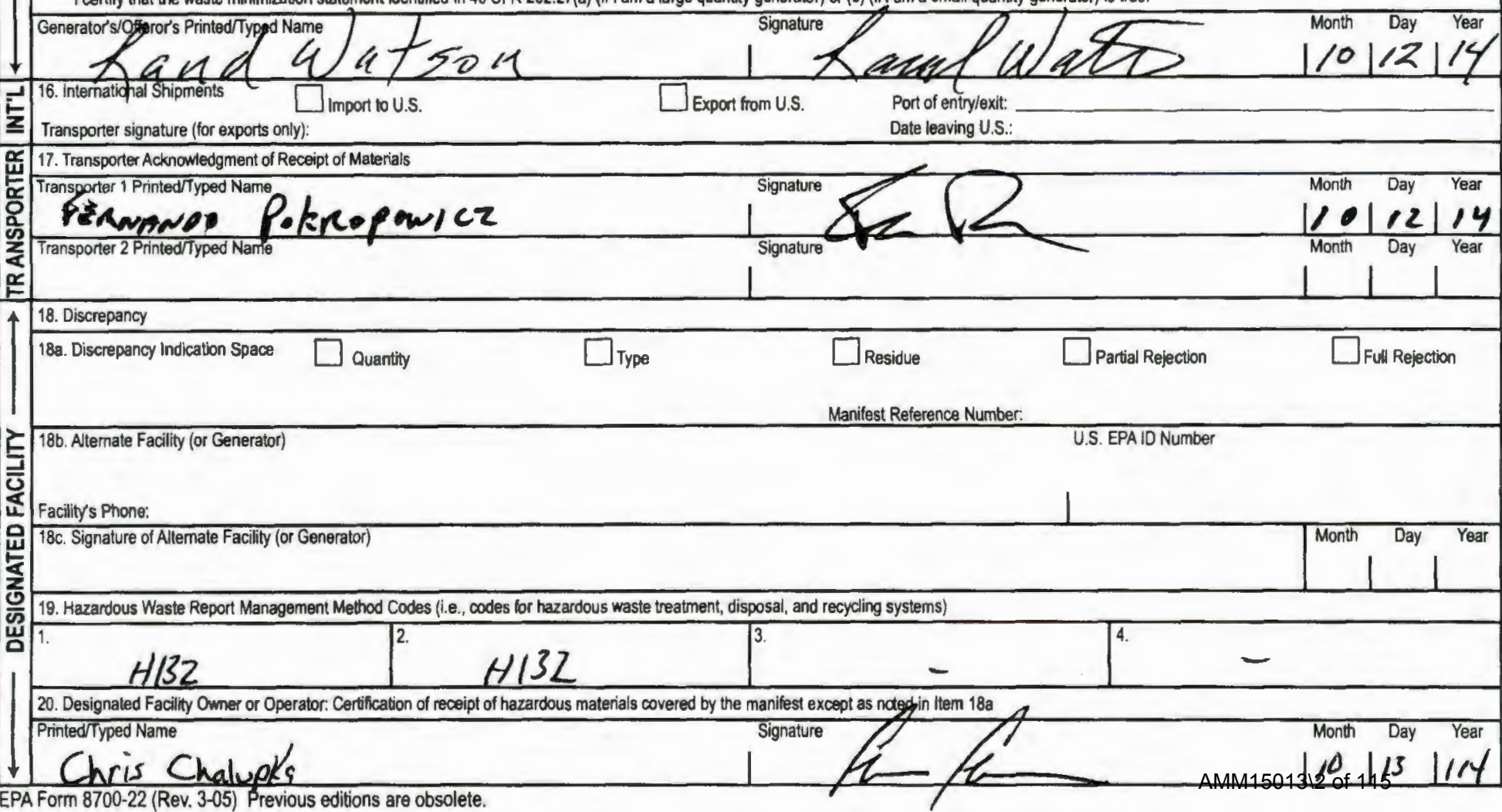


Please print or type. (Form designed for use on elite (12-pitch) typewriter.)

Form Approved. OMB No. 2050-0039

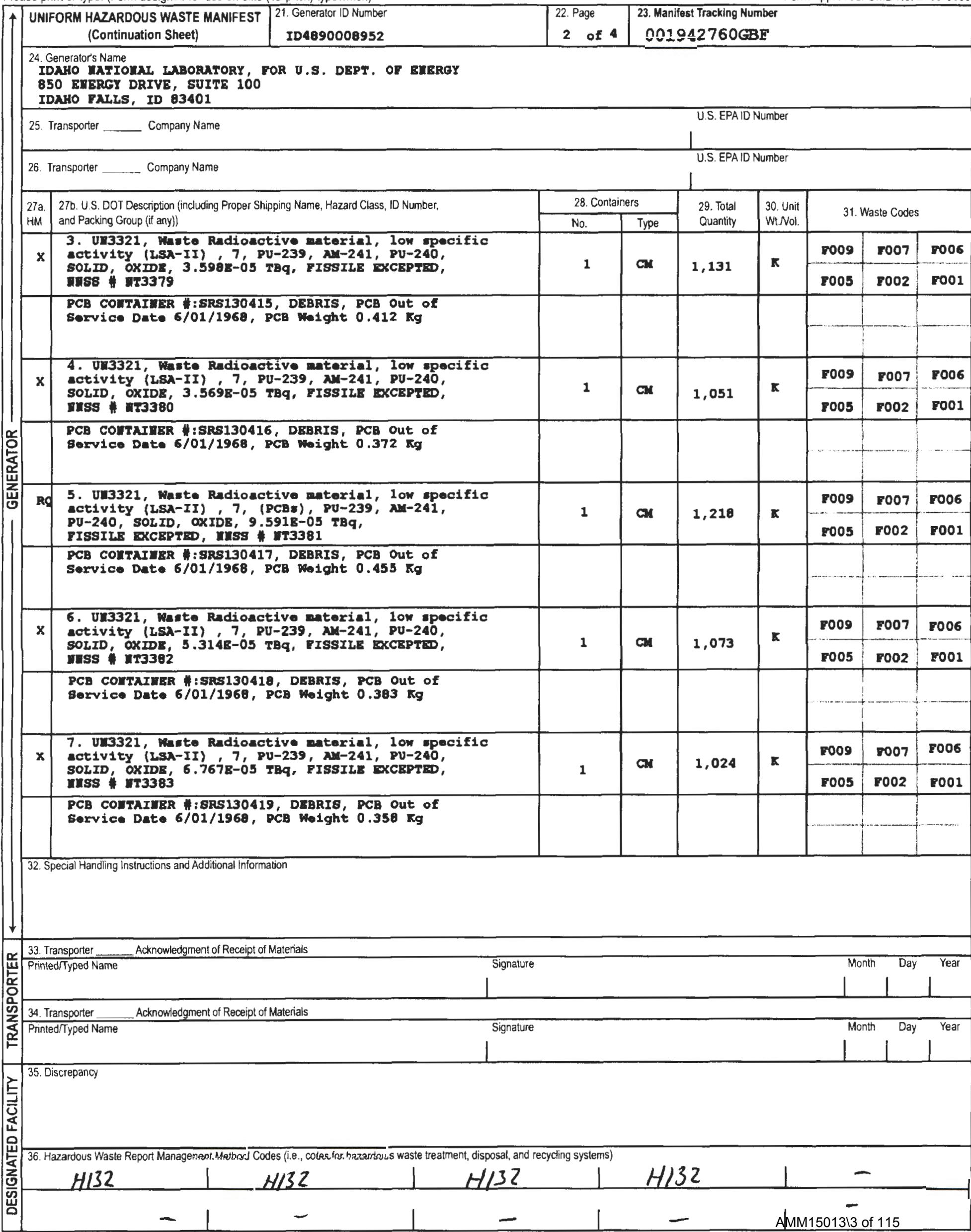

EPA Form 8700-22A (Rev. 3-05) Previous editions are obsolete. 
Please print or type. (Form designed for use on elite (12-pitch) typewriter.)

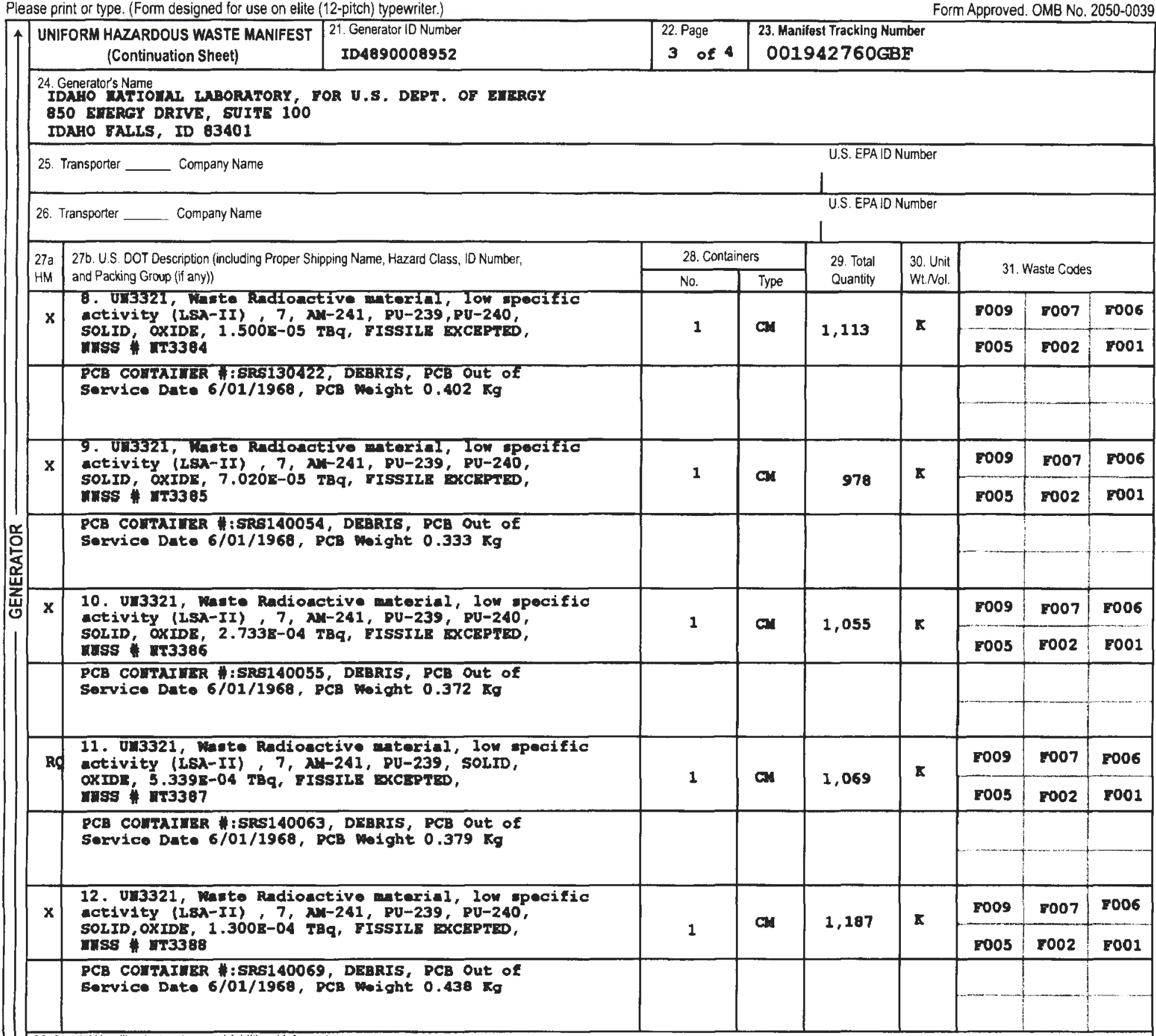

32. Special Handling Instuctions and Additional Information

33. Transporter Acknowledgment of Receipt of Matenals

34. Transporter

Acknowledgment of Receipt of Matenals

Printed/Typed Name

IDAHO WATIOHAL INBORATORY, FOR U.S. DEPT. OF EITRRY

IDAHO FALLS, ID 83401

276. U.S. DOT Description (including Proper Shipping Name, Hazard Class, ID Number,

Ion apecitic

PCB COTTAITR : :ERS130422, DFBRI $\mathrm{PU}-240$ SOLID, OXIDE, 7.020E-0S TBQ, FISSILE EXCEPTED, PCB COTTAIIER : SRg140054, DEARIS, PCB Out of

35. Discrepancy

||$^{\text {Signature }}$

36. Hazardous Waste Report Management Method Codes (i.e., codes for hazardous waste treatment, disposal, and recycling systems)

$4 / 32$

$H / 32$

4132

HISZ

$4 / 32$

EPA Form 8700-22A (Rev. 3-05) Previous editions are obsolete. 
Please print or type. (Form designed for use on elite (12-pitch) typewriter.)

Form Approved. OMB No. 2050-0039

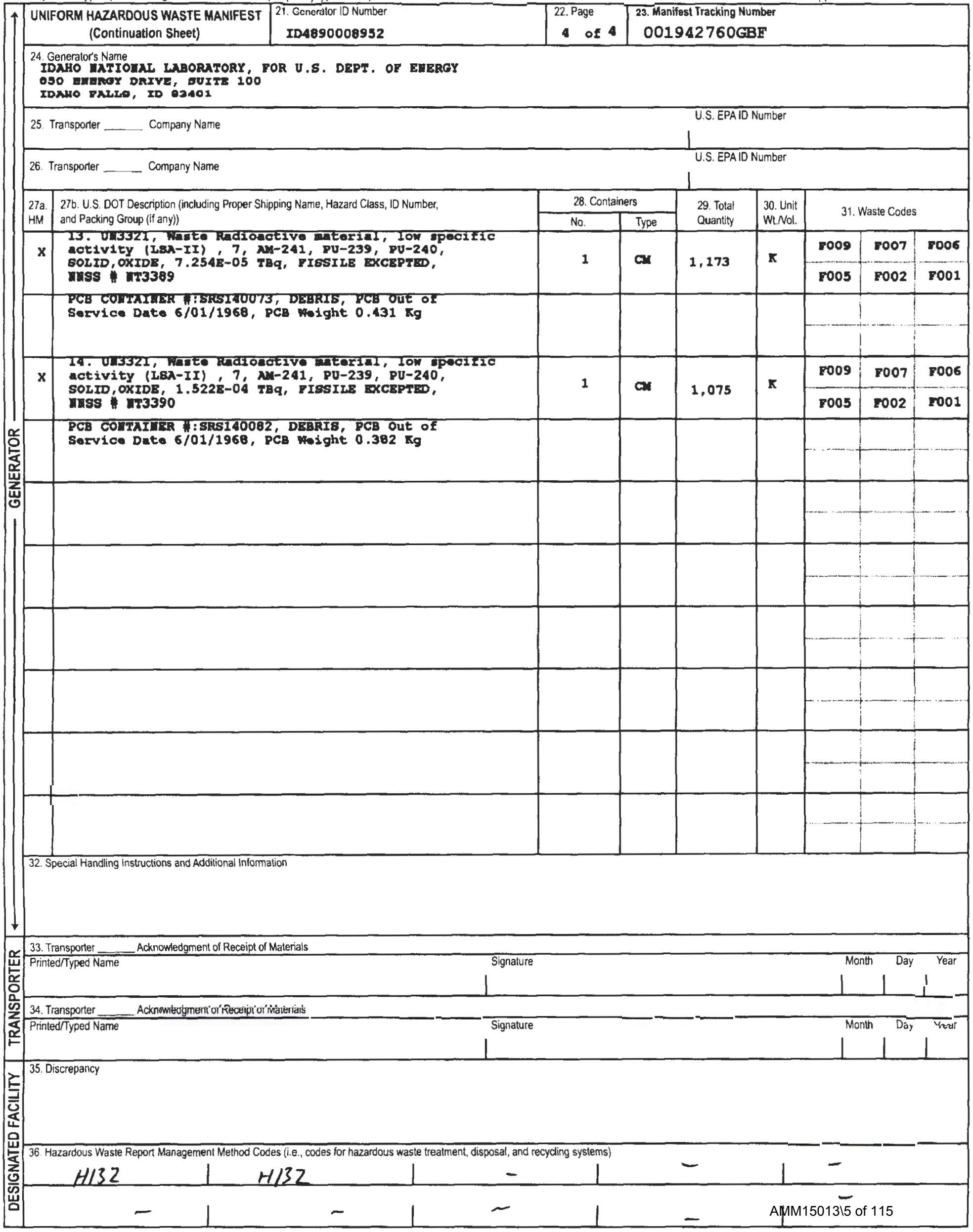


H000-PA-15-0011

October 20,2014

Jared Dominick

Waste Certification Official

Idaho Treatment Group

850 Energy Drive, Suite 100

Idaho Falls, ID $83401-1502$

\section{Subject: CERTIFICATE OF DISPOSAL FOR POLYCHLORINATED BIPHENYL (PCB) WASTE AT THE NEVADA NATIONAL SECURITY SITE RADIOACTIVE WASTE MANAGEMENT SITE (RWMS)}

Enclosed is the certificate acknowledging disposal of manifested PCB shipments AMM15012 and AMM15013 in the Mixed Waste Disposal Unit, at the Nevada National Security Site RWMS.

If you have any questions, please contact me at 702-295-2261.

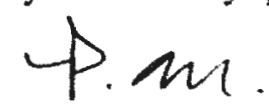<smiles>CC(C)[C@H](C)C(C)C1CCCC1</smiles>

Patrick M. Arnold, Division Manager

Environmental Management

RCD:saq

Enclosure: as stated

cc w/enc.

Correspondence Control

EWO Correspondence

J. T. Carilli, NNSA/NFO

R. C. Denton, NSTec

R. G. Geisinger, NS'lec

L. B. Gregory, NSTec

M. L ibidinsky, NNSA/NFO

C. P. Moke, NSTec

K. M. Small, NNSANFO

K. C. Tanaka, NSTec

A. V. Tauber, NNSA/NFO

R. A. Wagner, NSTec 
NSTec

Form

National Security Technologies uc

For U.S. Department of Energy

Waste Management

Nevada National Security Site - Zone 2

Mercury, NV 89023

EPA ID NV3890090001

This Certificate acknowledges that the following shipment(s) of manifested POLYCHLORINATED BIPHENYL (PCB) waste have been disposed at the Nevada National Security Site Radioactive Waste Management Site.

\begin{tabular}{|c|c|c|c|c|}
\hline $\begin{array}{c}\text { Shipment } \\
\text { Number }\end{array}$ & $\begin{array}{c}\text { Uniform Hazardous Waste } \\
\text { Manifest Number }\end{array}$ & Date(s) of Disposal & Volume $\mathbf{F t}^{3}\left(\mathbf{m}^{3}\right)$ & Disposal Process \\
\hline AMM15012 & $001942759 G B F$ & $10 / 13 / 2014$ & $1,169.77(33.12)$ & Landfill \\
\hline AMM15013 & $001942760 G B F$ & $10 / 13 / 2014$ & $1,259.76(35.67)$ & Landfill \\
\hline & & & & \\
\hline & & & & \\
\hline
\end{tabular}

Under civil and criminal penalties of law for the making or submission of false or fraudulent statements or representations (18 U.S.C. 1001 and 15 U.S.C. 2615), I certify that the information contained in or accompanying this document is true, accurate, and complete.

As to the identified section(s) of this document for which I cannot personally verify truth and accuracy, I certify as the company official having supervisory responsibility for the persons who, acting under my direct instructions, made the verification that this information is true, accurate, and complete.
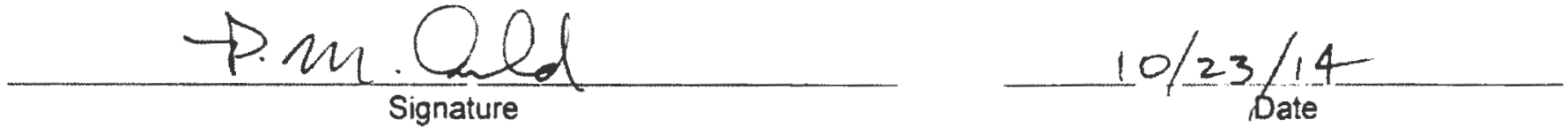

Division Manager, Environmental Management

Title

\section{Instructions:}

Shipment Number - enter shipment number from LWIS database.

Uniform Hazardous Waste Manifest Number - enter number from UHWM provided by generator.

Date of Disposal - enter date waste was placed in disposal cell.

Volume - enter shipment volume in cubic feet and equivalent cubic meters in parenthesis.

Disposal Process - enter Landfill. 
Please print or type. (Form designed for use on elite (12-pitch) typewriter.)

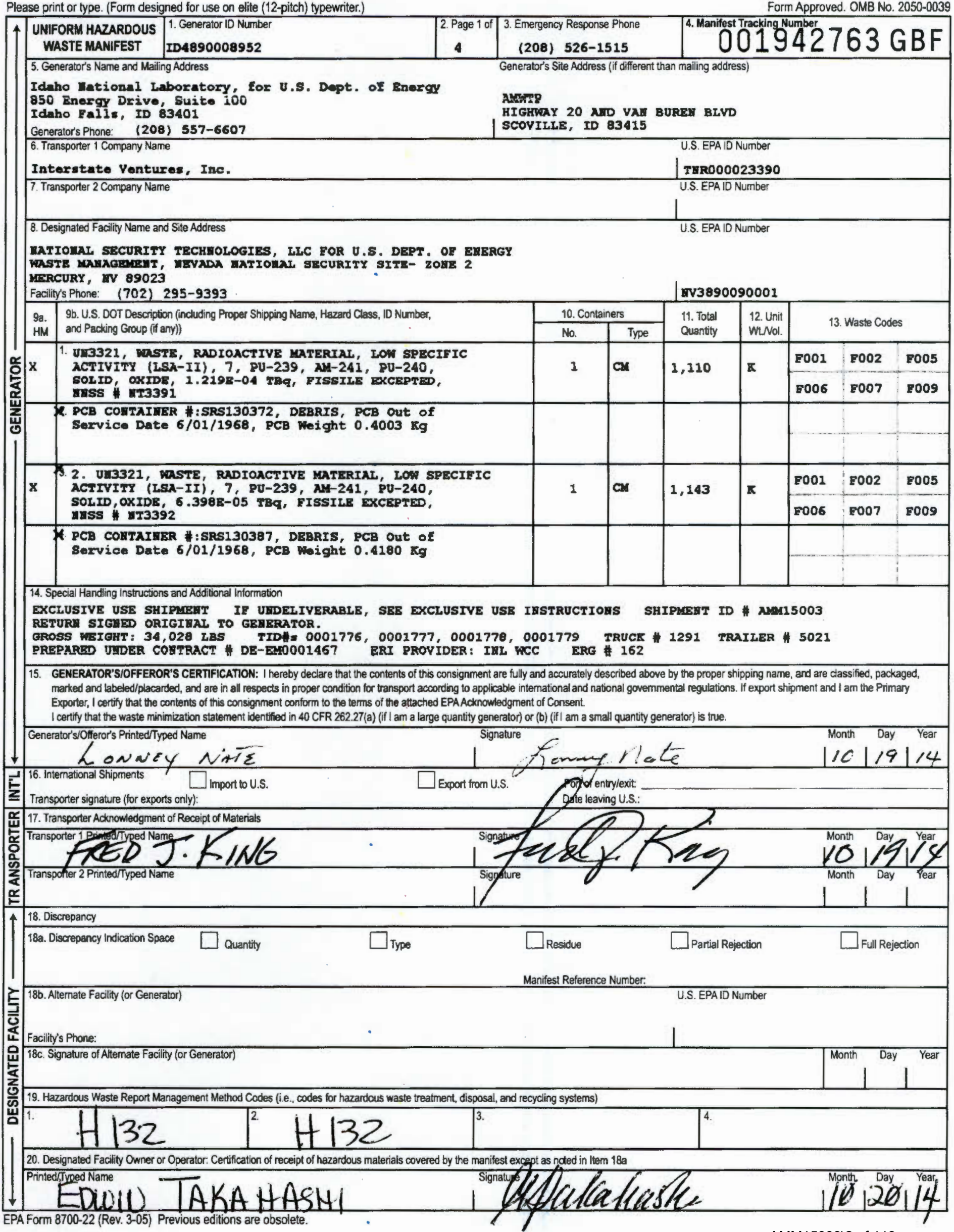


Please print or type. (Form designed for use on elite (12-pitch) typewriter.)

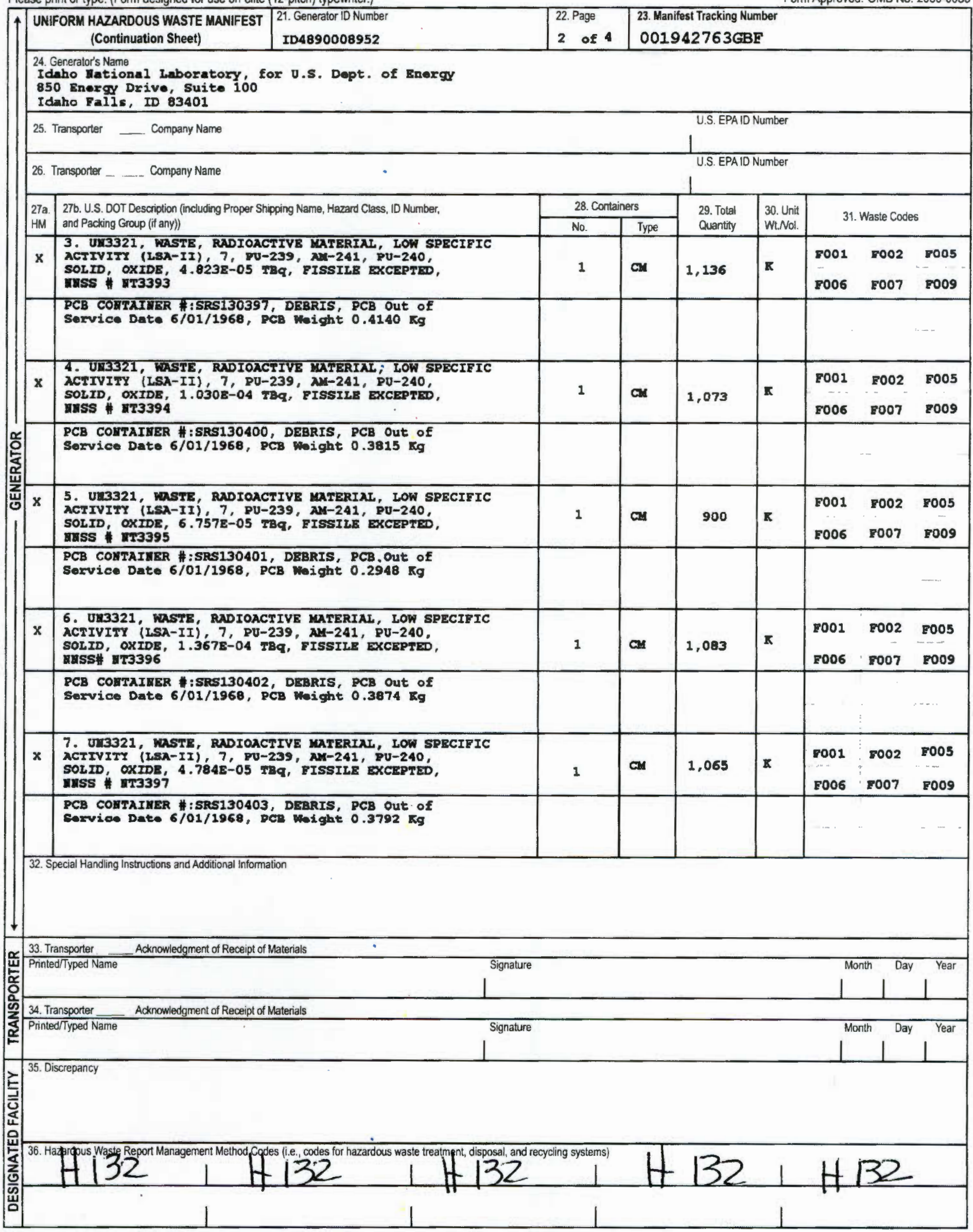


Please print or type. (Form designed for use on elite (12-pitch) typewriter.)

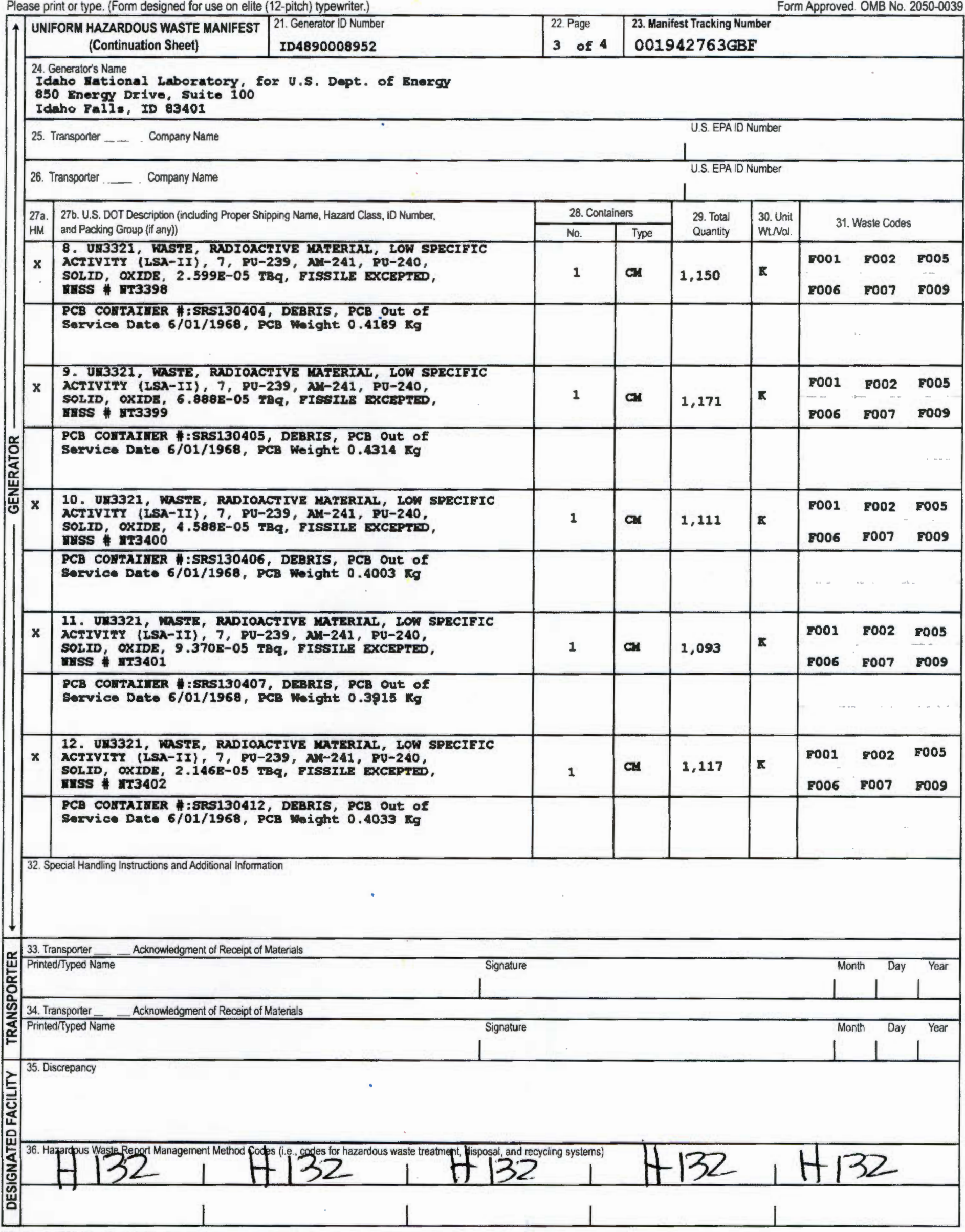


Please print or type. (Form designed for use on elite (12-pitch) typewriter.)

Form Approved. OMB No. 2050-0039

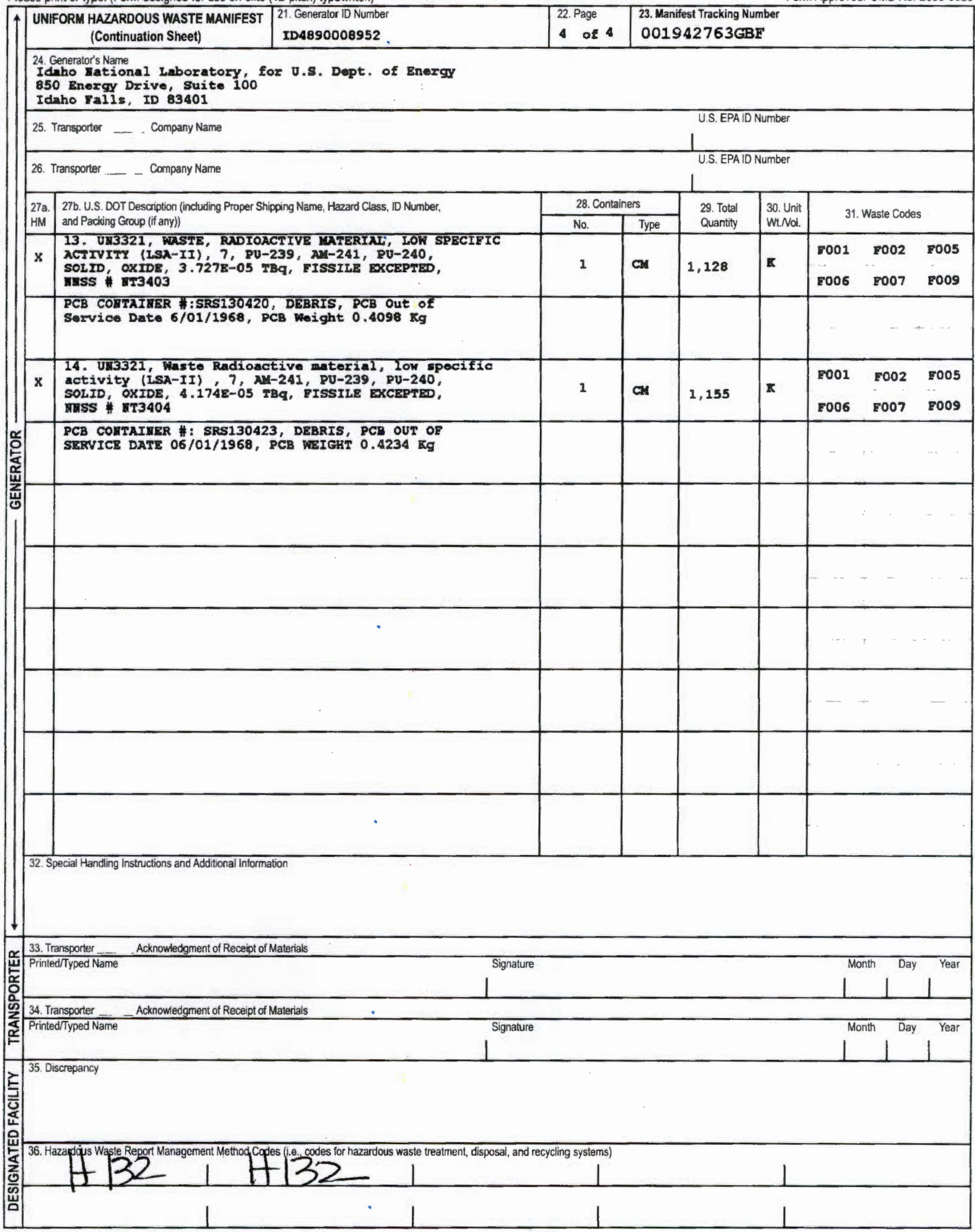


H000-PA-15-0012

October 27, 2014

Jared Dominick

Waste Certification Official

Idaho Treatment Group

850 Energy Drive, Suite 100

Idaho Falls, ID $83401-1502$

Subject: CERTIFICATE OF DISPOSAL FOR POLYCHLORINATED BIPHENYL (PCB) WASTE AT THE NEVADA NATIONAL SECURITY SITE RADIOACTIVE WASTE MANAGEMENT SITE (RWMS)

Enclosed is the certificate acknowledging disposal of manifested PCB shipments AMM15003 and AMM15004 in the Mixed Waste Disposal Unit, at the Nevada National Security Site RWMS.

If you have any questions, please contact me at 702-295-2261.<smiles>CC(C)(C)C1CC1</smiles>

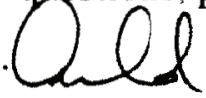

Patrick M. Arnold, Division Manager

Environmental Management

LBG:saq

Enclosure: as stated

cc w/enc.

Correspondence Control

EWO Correspondence

J. T. Carilli, NNSA/NFO

R. C. Denton, NSTec

R. G. Geisinger, NSTec

L. B. Gregory, NSTec

M. Libidinsky, NNSA/NFO

C. P. Moke, NSTec

K. M. Small, NNSA/NFO

K. C. Tanaka, NSTec

A. V. Tauber, NNSA/NFO

R. A. Wagner, NSTec 


\author{
National Security Technologies LLC \\ For U.S. Department of Energy \\ Waste Management \\ Nevada National Security Site - Zone 2 \\ Mercury, NV 89023
}

\title{
EPA ID NV3890090001
}

This Certificate acknowledges that the following shipment(s) of manifested POLYCHLORINATED BIPHENYL (PCB) waste have been disposed at the Nevada National Security Site Radioactive Waste Management Site.

\begin{tabular}{|c|c|c|c|c|}
\hline $\begin{array}{c}\text { Shipment } \\
\text { Number }\end{array}$ & $\begin{array}{c}\text { Uniform Hazardous Waste } \\
\text { Manifest Number }\end{array}$ & Date(s) of Disposal & Volume $\mathrm{Fi}^{\mathbf{3}}\left(\mathbf{m}^{3}\right)$ & Disposal Process \\
\hline AMM15003 & $001942763 \mathrm{GBF}$ & $10 / 20 / 2014$ & $1,259.76(35.67)$ & Landfill \\
\hline AMM15004 & $001942764 \mathrm{GBF}$ & $10 / 20 / 2014$ & $1,259.76(35.67)$ & Landfill \\
\hline & & & & \\
\hline & & & & \\
\hline
\end{tabular}

Under civil and criminal penalties of law for the making or submission of false or fraudulent statements or representations (18 U.S.C. 1001 and 15 U.S.C. 2615), I certify that the information contained in or accompanying this document is true, accurate, and complete.

As to the identified section(s) of this document for which I cannot personally verify truth and accuracy, I certify as the company official having supervisory responsibility for the persons who, acting under my direct instructions, made the verification that this information is true, accurate, and complete.
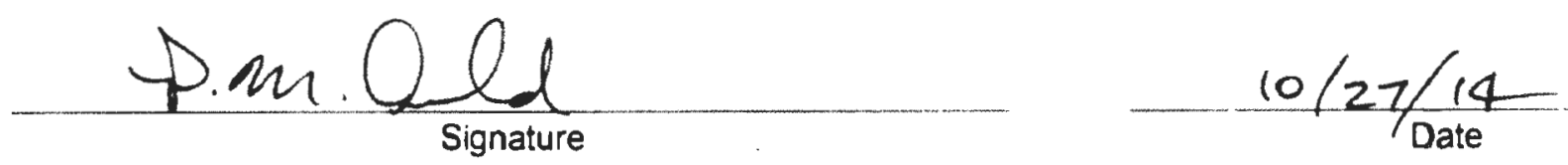

Division Manager, Environmental Management

Title

Instructions:

Shipment Number - enter shipment number from LWIS database.

Uniform Hazardous Waste Manifest Number - enter number from UHWM provided by generator.

Date of Disposal - enter date waste was placed in disposal cell.

Volume - enter shipment volume in cubic feet and equivalent cubic meters in parenthesis.

Disposal Process - enter Landfill.

\section{National Security Technologies, LLC}

Vision - Service - Partnership

muw. NSTEC.Com

P.O. Box 98521, Las Vegas, NV 89193-8521

2621 Losee Road, N. Las Vegas, NV 89030-4129 
Please print or type. (Form designed for use on elite (12-pitch) typewriter.) *

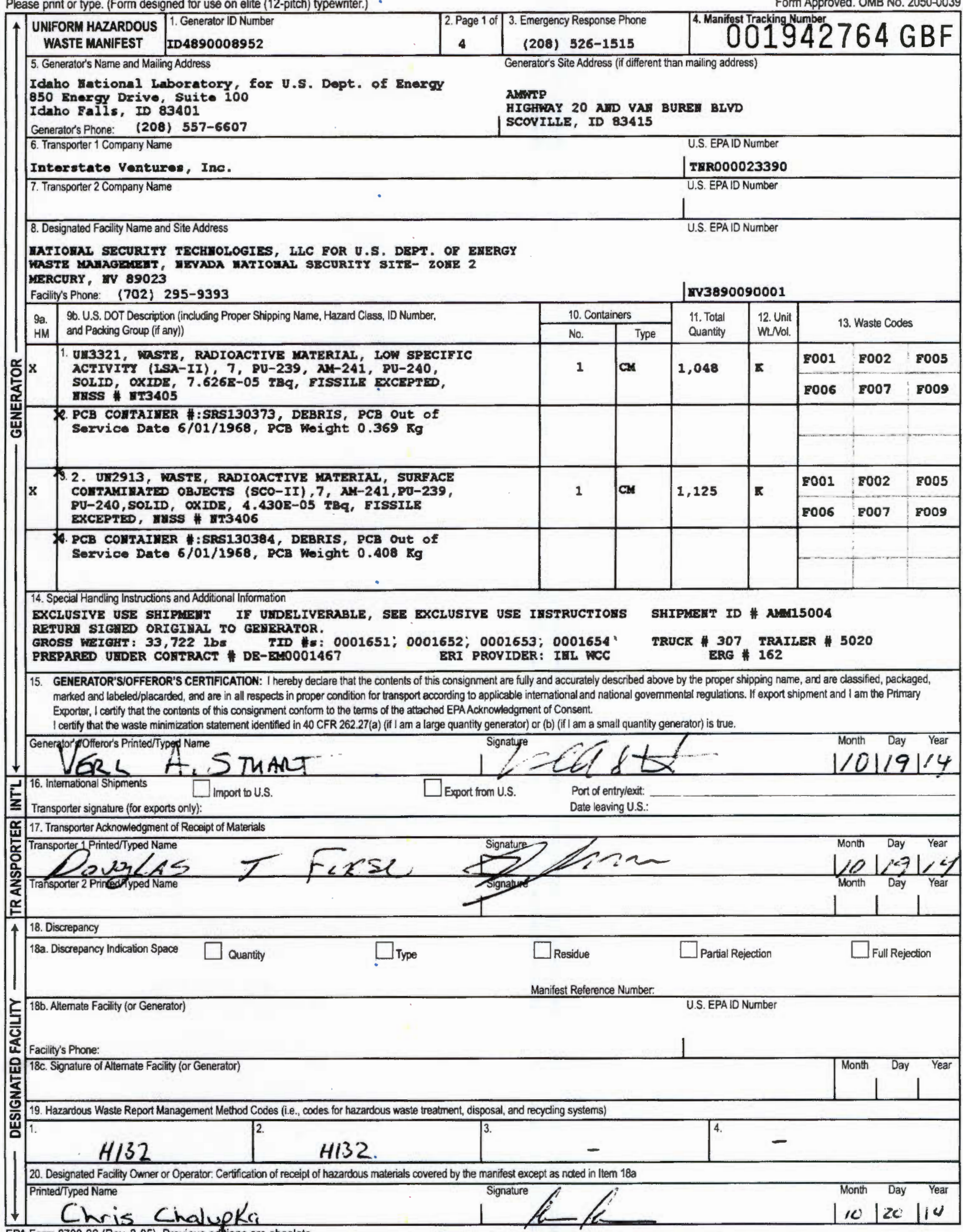


Please print or type. (Form designed for use on elite (12-pitch) typewriter.)

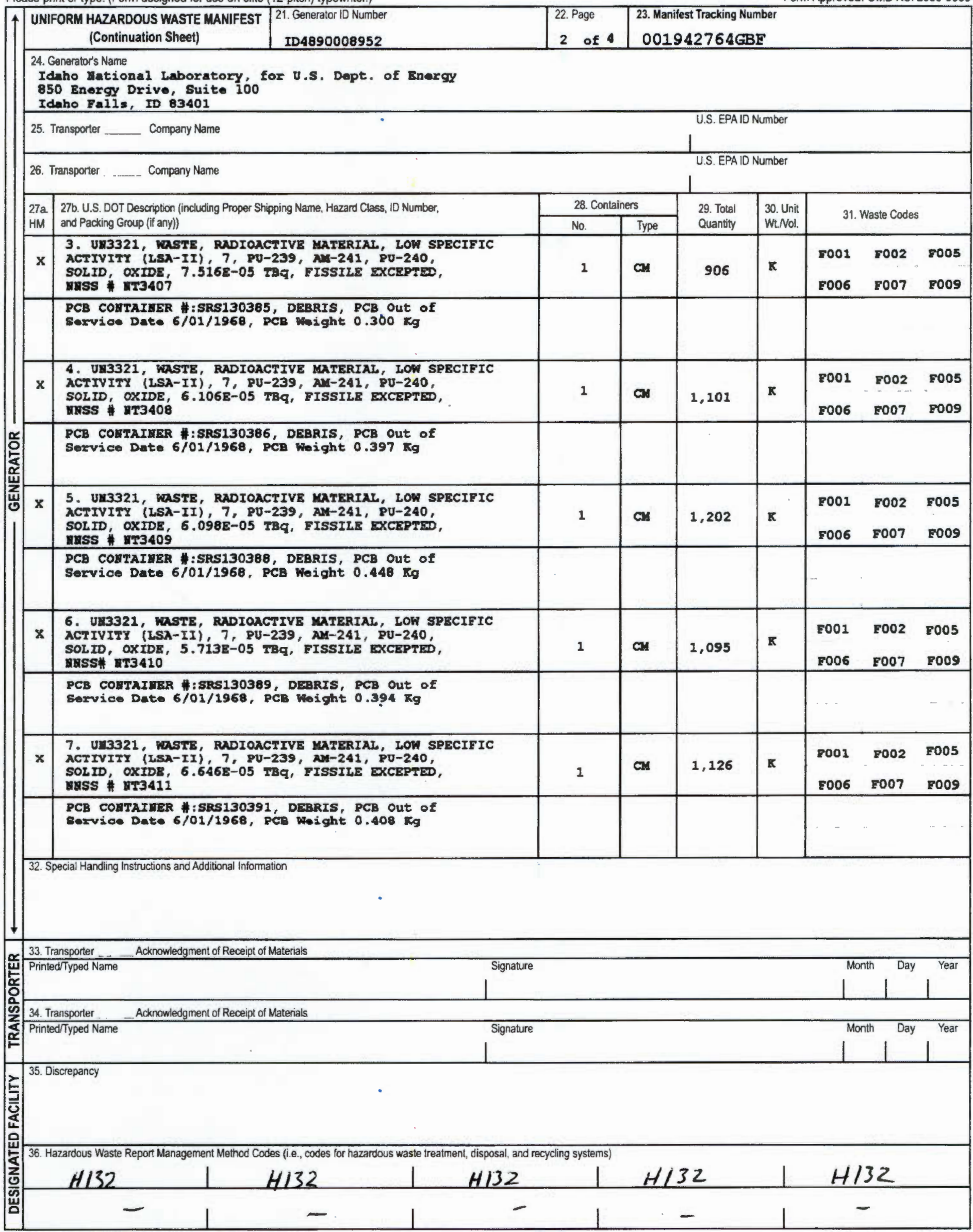


Please print or type. (Form designed for use on elite (12-pitch) typewriter.)

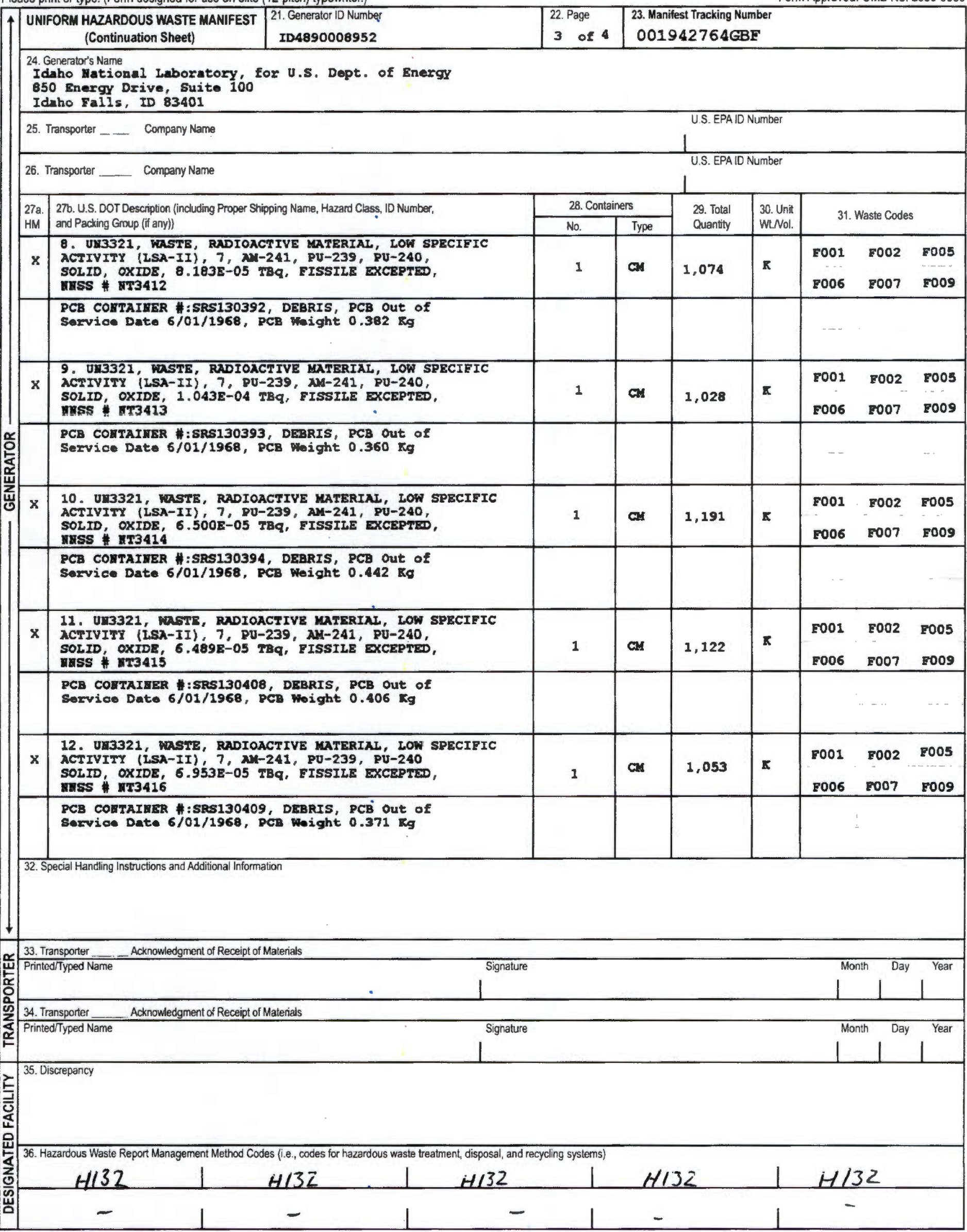


Please print or type. (Form designed for use on elite (12-pitch) typewriter.)

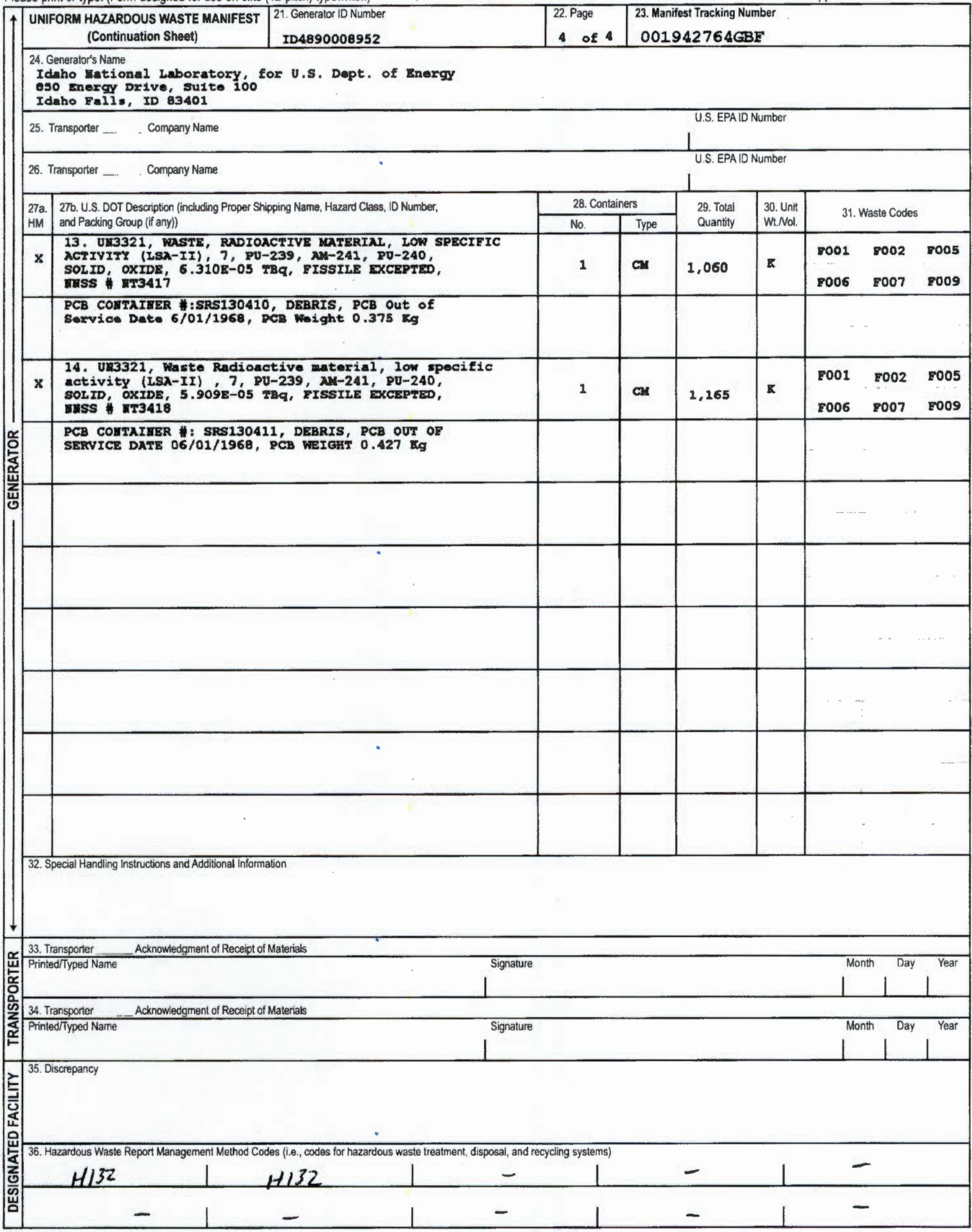


H000-PA-15-0012

October 27, 2014

Jared Dominick

Waste Certification Official

Idaho Treatment Group

850 Energy Drive, Suite 100

Idaho Falls, ID $83401-1502$

Subject: CERTIFICATE OF DISPOSAL FOR POLYCHLORINATED BIPHENYL (PCB) WASTE AT THE NEVADA NATIONAL SECURITY SITE RADIOACTIVE WASTE MANAGEMENT SITE (RWMS)

Enclosed is the certificate acknowledging disposal of manifested PCB shipments AMM15003 and AMM15004 in the Mixed Waste Disposal Unit, at the Nevada National Security Site RWMS.

If you have any questions, please contact me at 702-295-2261.<smiles>CC(C)(C)C1CC1</smiles>

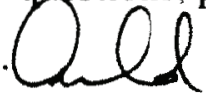

Patrick M. Arnold, Division Manager

Environmental Management

LBG:saq

Enclosure: as stated

cc w/enc.

Correspondence Control

EWO Correspondence

J. T. Carilli, NNSA/NFO

R. C. Denton, NSTec

R. G. Geisinger, NSTec

L. B. Gregory, NSTec

M. Libidinsky, NNSA/NFO

C. P. Moke, NSTec

K. M. Small, NNSA/NFO

K. C. Tanaka, NSTec

A. V. Tauber, NNSA/NFO

R. A. Wagner, NSTec 


\author{
National Security Technologies LLC \\ For U.S. Department of Energy \\ Waste Management \\ Nevada National Security Site - Zone 2 \\ Mercury, NV 89023
}

\title{
EPA ID NV3890090001
}

This Certificate acknowledges that the following shipment(s) of manifested POLYCHLORINATED BIPHENYL (PCB) waste have been disposed at the Nevada National Security Site Radioactive Waste Management Site.

\begin{tabular}{|c|c|c|c|c|}
\hline $\begin{array}{c}\text { Shipment } \\
\text { Number }\end{array}$ & $\begin{array}{c}\text { Uniform Hazardous Waste } \\
\text { Manifest Number }\end{array}$ & Date(s) of Disposal & Volume $\mathrm{Fi}^{\mathbf{3}}\left(\mathbf{m}^{3}\right)$ & Disposal Process \\
\hline AMM15003 & $001942763 \mathrm{GBF}$ & $10 / 20 / 2014$ & $1,259.76(35.67)$ & Landfill \\
\hline AMM15004 & $001942764 \mathrm{GBF}$ & $10 / 20 / 2014$ & $1,259.76(35.67)$ & Landfill \\
\hline & & & & \\
\hline & & & & \\
\hline
\end{tabular}

Under civil and criminal penalties of law for the making or submission of false or fraudulent statements or representations (18 U.S.C. 1001 and 15 U.S.C. 2615), I certify that the information contained in or accompanying this document is true, accurate, and complete.

As to the identified section(s) of this document for which I cannot personally verify truth and accuracy, I certify as the company official having supervisory responsibility for the persons who, acting under my direct instructions, made the verification that this information is true, accurate, and complete.
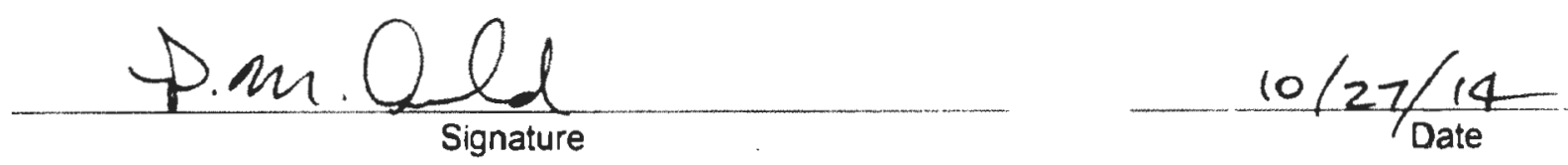

Division Manager, Environmental Management

Title

Instructions:

Shipment Number - enter shipment number from LWIS database.

Uniform Hazardous Waste Manifest Number - enter number from UHWM provided by generator.

Date of Disposal - enter date waste was placed in disposal cell.

Volume - enter shipment volume in cubic feet and equivalent cubic meters in parenthesis.

Disposal Process - enter Landfill.

\section{National Security Technologies, LLC}

Vision - Service - Partnership

muw. NSTEC.Com

P.O. Box 98521, Las Vegas, NV 89193-8521

2621 Losee Road, N. Las Vegas, NV 89030-4129 
Pleâse pổnt or type. (Form designed for use on elite (12-pitch) typewriter.)

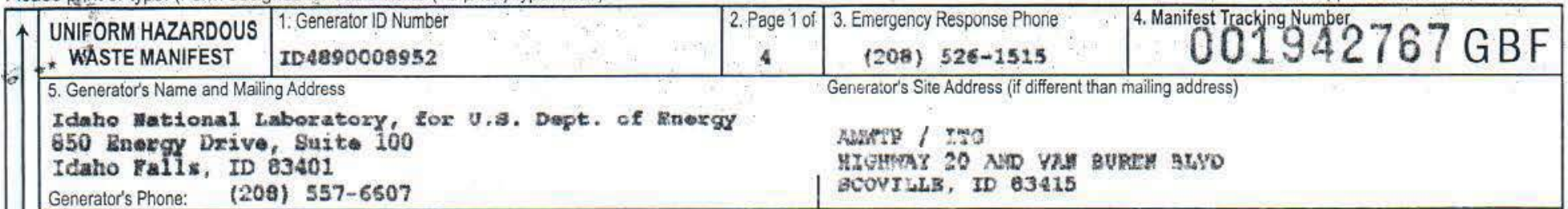

Generator's Phone: (200) 557-6507

Interstate ventures, Inc.

7. Transporter 2 Company Name

TMRO0002.3390

U.S. EPA ID Number

8. Designated Facility Name and Site Address

U.S. EPAID Number

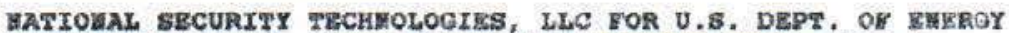

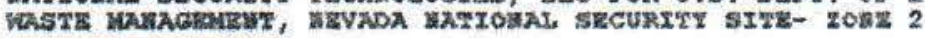

UERCURY, IV 89023

Facility's Phone: (702) 295-9393

9a. $9 \mathrm{~b}$. U.S. DOT Description (including Proper Shipping Name, Hazard Class, ID Number, HM and Packing Group (if any))

UH3321, Wasto Radiometive naterial, lon spocific activity (LSA-II), 7, (PCBS), RU-239, AM-241, PU-240, DOL,ID, OXIDE, 6.365E-05 Fin,

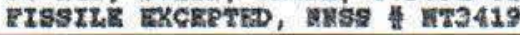

Z PCB CCAKAIMER " SRS130362, DEBRTS, PCB Out of Service Data $6 / 01 / 1968$, PCB Waight $0.463 \mathrm{~kg}$

3. 2. Ux3321, Masto Radioactive natioria1, low spect.fitc

$\mathrm{x}$ activity (LSN-II) $7,8 U-239, \mathrm{NH}-241, \mathrm{PU}-240$,

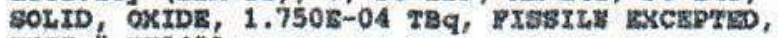

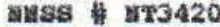

X PCB COMTATERR W : SRS130363, DERRIS, PGB Out of Service Date 6/01/2968, PCB Weight $0.368 \mathrm{~kg}$

14. Special Handling Instructions and Additional Information

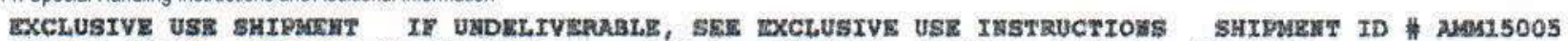

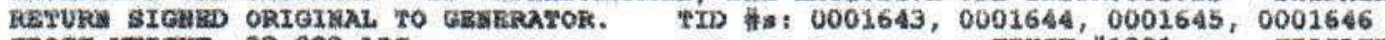

GRoss werGs:; 33,633 Las

PREPARED VRDER COKTRACT

15. GENERATOR'SIOFFEROR'S CERTIFICATION: I hereby declare that the contents of this consignment are fully and accurately described above by the proper shipping name, and are classified, packaged, marked and labeled/placarded, and are in all respects in proper condition for transport according to applicable international and national governmental regulations. If export shipment and I am the Primary Exporter, I certify that the contents of this consignment conform to the terms of the attached EPAAcknowledgment of Consent.

I certify that the waste minimization statement identified in 40 CFR 262.27 (a) (if I am a large quantity generator) or (b) (ifl am a small quantity generator) is true.

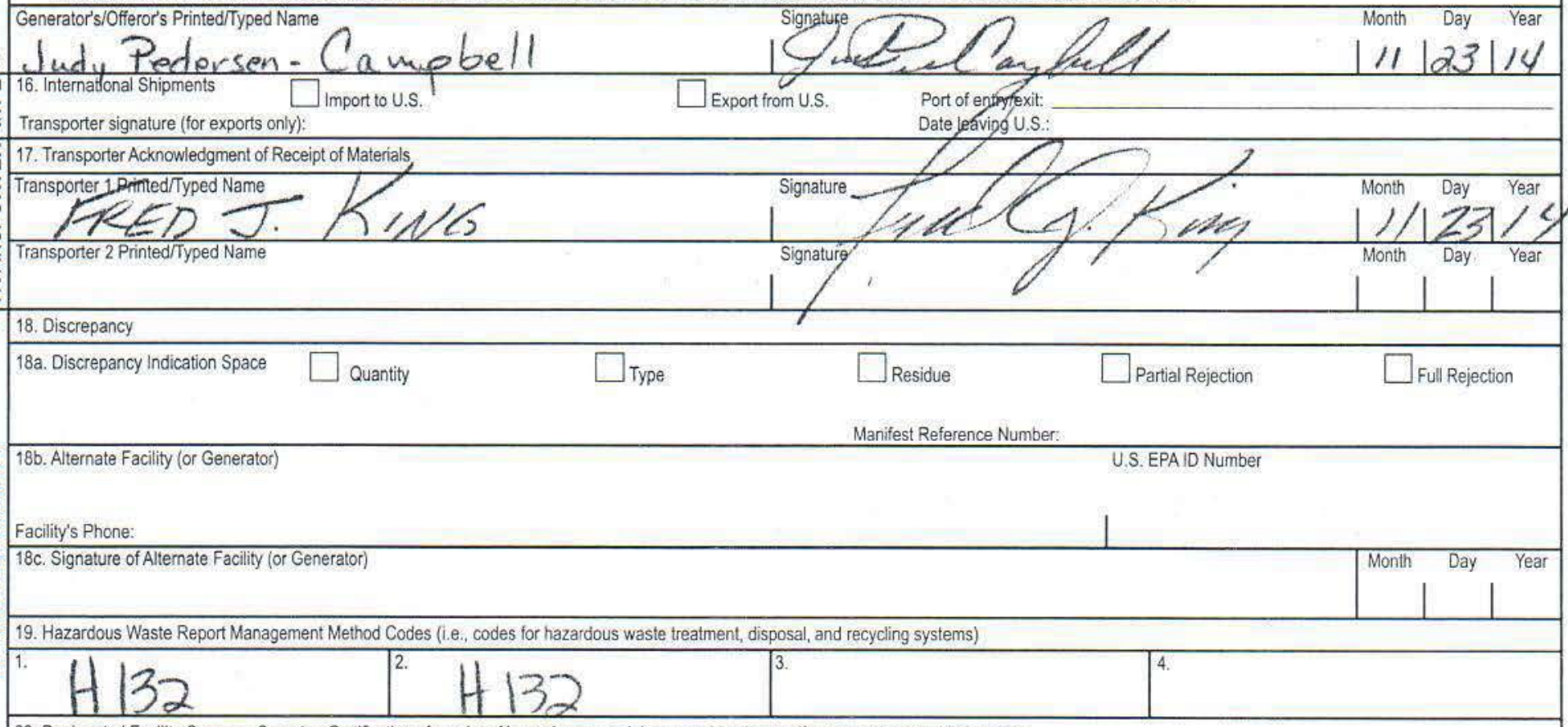

20. Designated Facility Owner or Operator: Certification of receipt of hazardous materials covered by the manifest except as noded in Item 18a

Printed/Typed Name

$\downarrow E D W W$

TAKAHASHII

EPA Form 8700-22 (Rev. 3-05) Previous editions are obsolete.

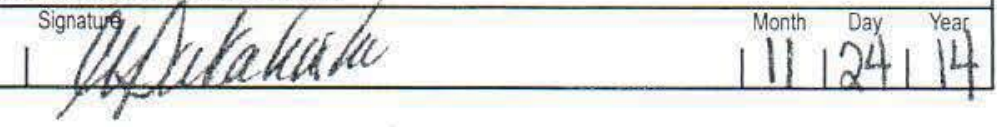


t

Please print or type. (Form designed for use on elite (12-pitch) typewriter.)

Form Approved. OMB No, 2050-0039

\begin{tabular}{|c|c|c|c|c}
\hline $\begin{array}{l}\text { UNIFORM HAZARDOUS WASTE MANIFEST } \\
\text { (Continuation Sheet) }\end{array}$ & $\begin{array}{c}21 . \text { Generator ID Number } \\
\text { ID } 4890008952\end{array}$ & $\begin{array}{c}\text { 22. Page } \\
2 \text { of } 4\end{array}$ & $\begin{array}{c}\text { 23. Manifest Tracking Number } \\
00194276763 \mathrm{Y}\end{array}$ \\
\hline
\end{tabular}

24. Generator's Name

Idaho Mational Laboratozy, for U.S. Dept. of Bnercy

650 Easrgy Drive, Suite 100

Idaho FaIle, iD 93401

25. Transporter __ Company Name

26. Transporter __ Company Name

Q US. EPAID Number

1

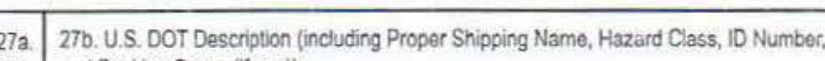

HM and Packing Group (if any))

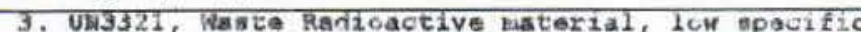

$\mathrm{X}$ aotivity (LSA-II), 7, PV-239, NN-241, PU-240,

SOLTD, OXIDE, $8.682 \mathrm{E}-05 \mathrm{TBq}$, EISSILE EXCEPTZD,

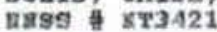

PCB CQW FAIMER \#!SRS130364, DERTIS, PCB DUE of

Service Date $6 / 01 / 1968$, PCB Woight $0.362 \mathrm{~kg}$

4. Ux3321, Waste Radionctive waterial, Iow spocizio

$x$ activity (ISA-II) $7, P U-239,2 M-241, P U-240$,

SOLID, OXIDE, $1.466 \mathrm{E}-04 \mathrm{FBg}$, FISSILE EXCLPTID, UNSS \#

$\propto$ PCB COHTAIMER H: :SRS130367, DEBRIS, PCB Out of

Service Date $6 / 01 / 1968$, PCB Weight $0.432 \mathrm{~kg}$

$x$ 5, UX3321, Waste Radioactive material, low ppecific activity (LBA-II), $7, \lambda M-241, P U-239, P U-240$, SOLID, OKIDE, 8.9468-05 TBq, TISSILE EXCEPTED, nuss $\operatorname{sr} 3423$

PCB COHTAIMSR Fi:SRS130374, DEARIS, PCB Out of Servioe Date 6/01/1968, PCB Weight $0.393 \mathrm{~kg}$

6. UN3321, Waste Radioactivs maturial, low specifio

$x$ activity (LgX-II), 7, $P U-239, \lambda M-241, P V-240$,

SOLID, OXIDE, $6.991 \mathrm{E}-05 \mathrm{TBq}, \mathrm{FISSTLE}$ EXCEPTED, MISS * 353424

PCB CO\&TAYMER : SRS130395, DEBRIS, PCB Out of

Bervico Date $6 / 01 / 1968$, PCs Woight $0.400 \mathrm{~kg}$

7. U13321, Naste Radioactive material, low specific

$x$ sotivity (LSA-II), 7, PU-239, NM 241, PU-240,

SOLID, OXIDE, $1.514 \mathrm{E}-04$ TAq, EISSILE EXCEPTED, suss \# Mr3425

PCB COMTATBER E : SRS130396, DEBRIS, PCB Out of

Sorvice Date $6 / 01 / 1968$, PCB Woight $0.356 \mathrm{~kg}$

32. Special Handling Instructions and Additional Iniomation

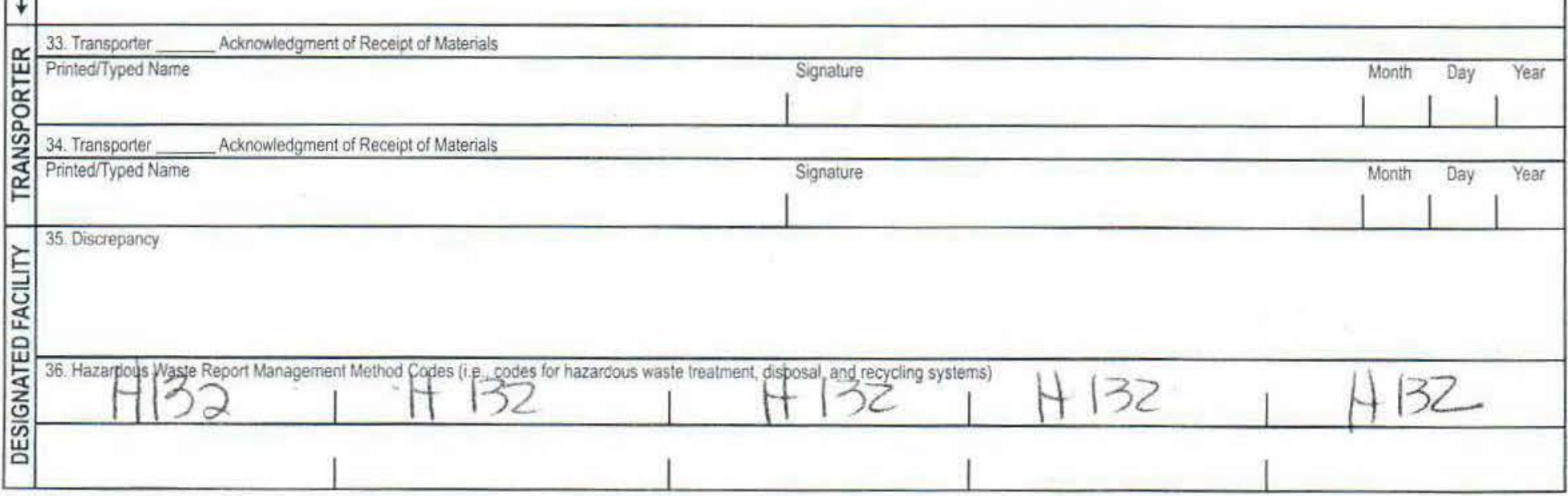


Form Approved, OMB No. 2050-0039 4 UNIFORY HAZARDOUS WASTE MANIFEST (Continuation Sheet) 104890000952

\begin{tabular}{|c|c|}
\hline 22. Page & 23. Manifest Tracking Number \\
3 of 4 & $001942767 \mathrm{Gs} E$
\end{tabular}

24. Generator's Name

Idaho yational Laboratory, for V.S. Dapt. of Irergy

950 Enexgy Drive, Buite 100

Idaho Falin, ID 93401

\begin{tabular}{|c|c|c|}
\hline 25. Transporter & Company Name & U.S. EPAID Number \\
\hline
\end{tabular}

27a. 27b. U.S. DOT Description (including Proper Shipping Name, Hazard Class, ID Number,

HM and Packing Group (if any))

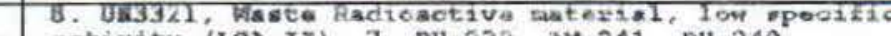

activity (LSA-II), 7, PU-239, A4-241, PU-240, SOLTD, OXIDE, 2.917R-OS TBq, FISSILE EXCEN"ID, inass 1 vT3426

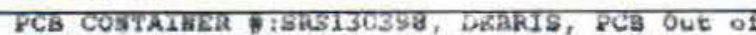

Service Date $5 / 01 / 1968$, PCB Weight $0.399 \mathrm{Kg}$

$X$ activity (LSA-II), 7, PU-239, AM-241, $P U-240$,

SOLID, OXIDE, 3.406E-05 TBq, FISSIIE EXCEPFED, NESS H Mr3427

PCA COMTAISER I\$RS130399, DEBRIS, PCB Out of Service Date $6 / 01 / 1968$, PCB weight $0.389 \mathrm{Kg}$

x 10. Uz3321, Waste Radioactive material, low specific activity (LSA-II), 7, 2M-24I, PU-239, PU-240, SOZID, OXIDE, $1.645 \mathrm{~g}-04 \mathrm{TBq}$, PISSILE EXCEPTED, MESS

PCB CONTAINER \#:SRS140062, DEBRIS, PCB Out of Service Date $6 / 01 / 1968$, PCB Weight $0.393 \mathrm{Kg}$

11. Ur3321, Waste Radioactive matorial, Lov specific

$X$ activity (LSA-II) $7, \lambda$, $241, \mathrm{PU}-239, \mathrm{PU}-240$ SOLID, OXIDE, 5.681E-05 TBq, FISSILE EXCEPTED, urss PCB COHTXIKEF औ Servico Date $6 / 01 / 1968$, pCB Woight $0.354 \mathrm{~kg}$

12. U⿴囗十321, Waste Radioactive naterial, low specifio

$x$ activity (LSA-II), 7, AM-241, PU-239, PU-240, SOLID, OXIDE, 1.104E-04 TBq, FISSILE EXCEPTED, ENSS \&

PCB COSTAIMER 萑:SR8140065, DERRIS, PCB Out of Service Date $6 / 01 / 1968$, PCB Weight $0.406 \mathrm{Kg}$

32. Special Handling Instructions and Additional information

33. Transporter__Acknowledgment of Receipt of Materials

34. Transporter__Acknowledgment of Receipt of Materials

35. Discrepancy

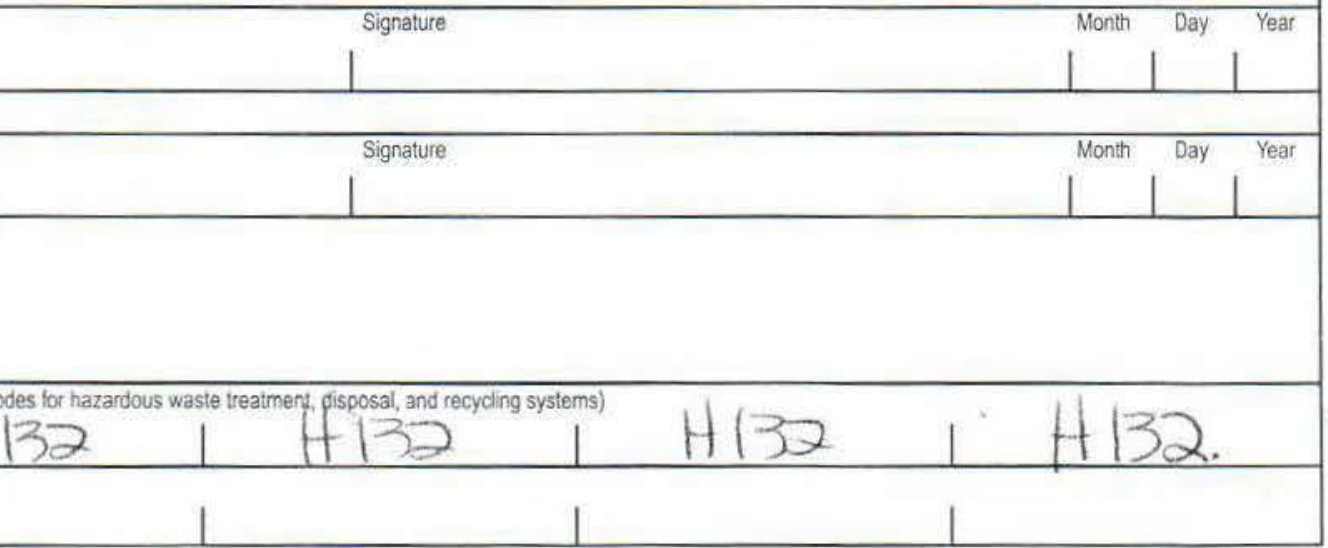




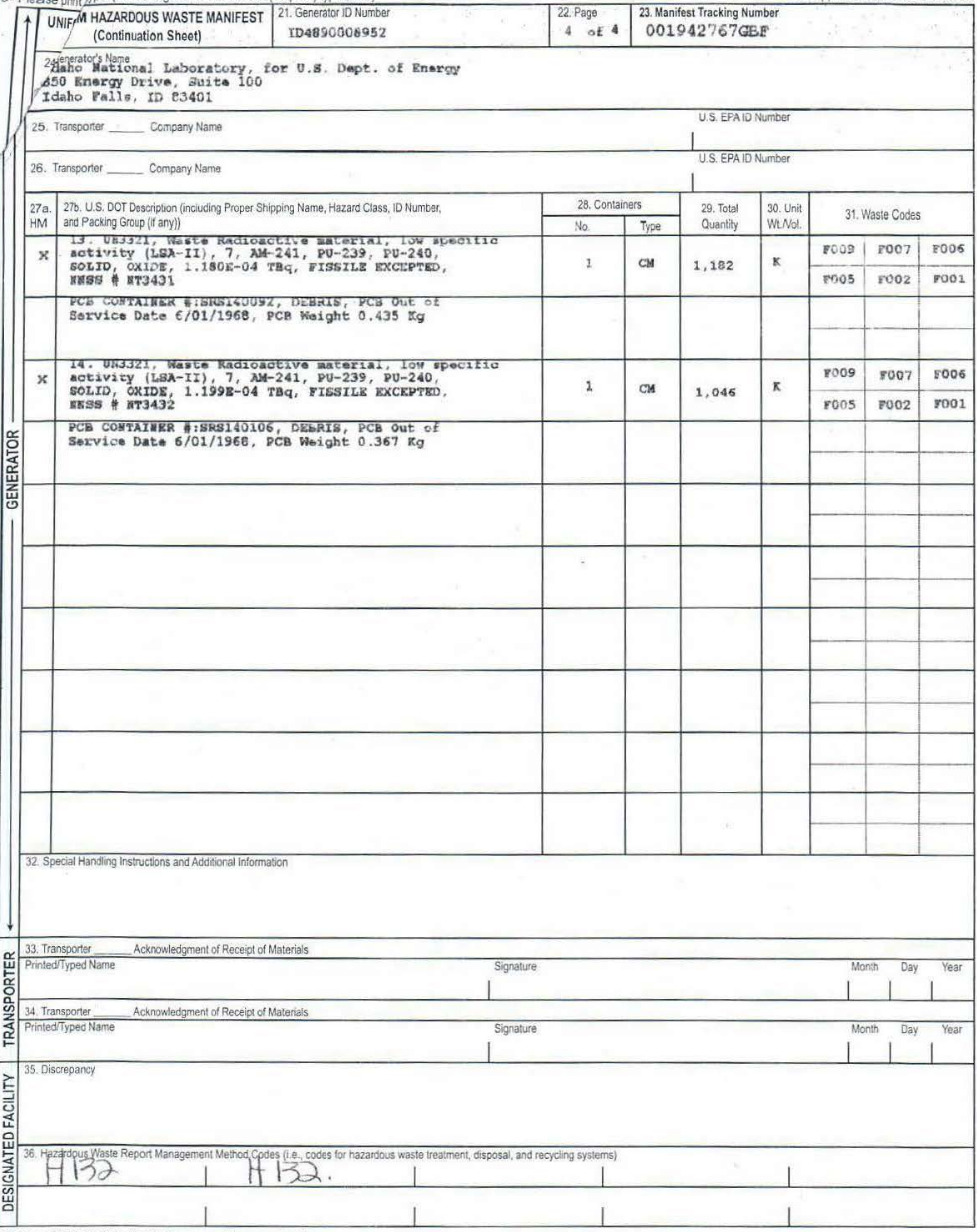


H000-PA-15-0022

December 1, 2014

Jared Dominick

Waste Certification Official

Idaho Treatment Group

850 Energy Drive, Suite 100

Idaho Falls. ID 83401-1502

\section{Subject: CERTIFICATE OF DISPOSAL FOR POLYCHLORINATED BIPHENYL (PCB) WASTE AT THE NEVADA NATIONAL SECURITY SITE RADIOACTIVE WASTE MANAGEMENT SITE (RWMS)}

Enclosed is the certificate acknowledging disposal of manifested PCB shipment AMM15005 in the Mixed Waste Disposal Unit, at the Nevada National Security Site RWMS.

If you have any questions, please contact me at 702-295-2261.

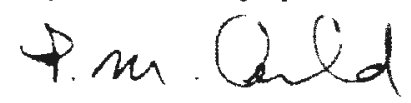

Patrick M. Arnold, Division Manager

Environmental Management

RCD:saq

Fnclosure: as stated

cc w/enc.

Correspondence Management

EWO Correspondence

J. T. Carilli, NNSANFO

R. C. Denton, NSTec

R. G. Geisinger, NSTec

L. B. Gregory, NSTec

M. Libidinsky, NNSA/NFO

C. P. Moke, NSTec

K. M. Small, NNSANFO

K. C. Tanaka, NSTec

A. V. Tauber, NNSA/NFO

R. A. Wagner, NSTec

National Security Technologies, LLC

Vision - Service - Partnership

Mirw NSTeC com

P.O. Box 98521, Las Vegas, NV 89193-8521

2621 Losee Road, N. Las Vegas, NV 89030-4129 
National Security Technologies Lc

For U.S. Department of Energy

Wasto Management

Nevada National Security Site - Zone 2

Mercury, NV 88023

EPA ID NV3890090001

This Certificate acknowledges that the following shipment(s) of manifested POLYCHLORINATED BIPHENYL (PCB) waste have been disposed at the Nevada National Security Site Radioactive Waste Management Site.

\begin{tabular}{|c|c|c|c|c|}
\hline $\begin{array}{c}\text { Shipment } \\
\text { Number }\end{array}$ & $\begin{array}{c}\text { Uniform Hazardous Waste } \\
\text { Manifest Number }\end{array}$ & Date(s) of Disposal & Volume $\mathbf{F t}^{\mathbf{3}}\left(\mathbf{m}^{\mathbf{3}}\right)$ & Disposal Process \\
\hline AMM15005 & $001942767 \mathrm{GBF}$ & $11 / 24 / 2014$ & $1,259.76(35.67)$ & Landfill \\
\hline & & & & \\
\hline & & & & \\
\hline
\end{tabular}

Under civil and criminal penalties of law for the making or submission of false or fraudulent statements or representations (18 U.S.C. 1001 and 15 U.S.C. 2615), I certify that the information contained in or accompanying this document is true, accurate, and complete.

As to the identified section(s) of this document for which I cannot personally verify truth and accuracy, I certify as the company official having supervisory responsibility for the persons who, acting under my direct instructions, made the verification that this information is true, accurate, and complete.
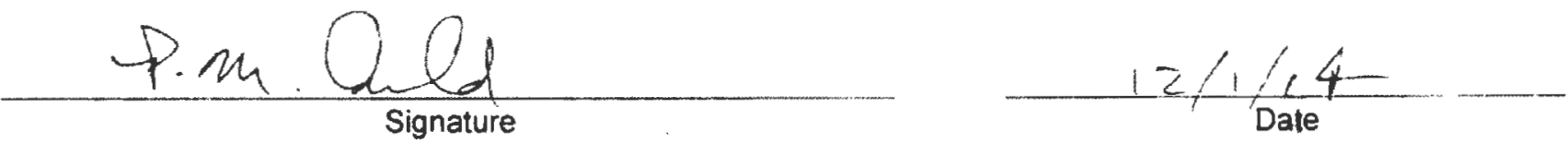

Division Manager, Environmental Management

$$
\text { Title }
$$

Instructions:

Shipment Number - enter shipment number from LWIS database.

Uniform Hazardous Waste Manifest Number - enter number from UHWM provided by generator.

Date of Disposal - enter date waste was placed in disposal cell.

Volume - enter shipment volume in cubic feet and equivalent cubic meters in parenthesis.

Disposal Process - enter Landfill. 
Please print or type. (Form designed for usegon elite (12-pitch) typewriter.)

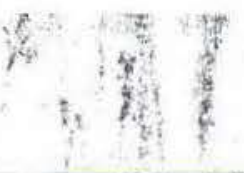

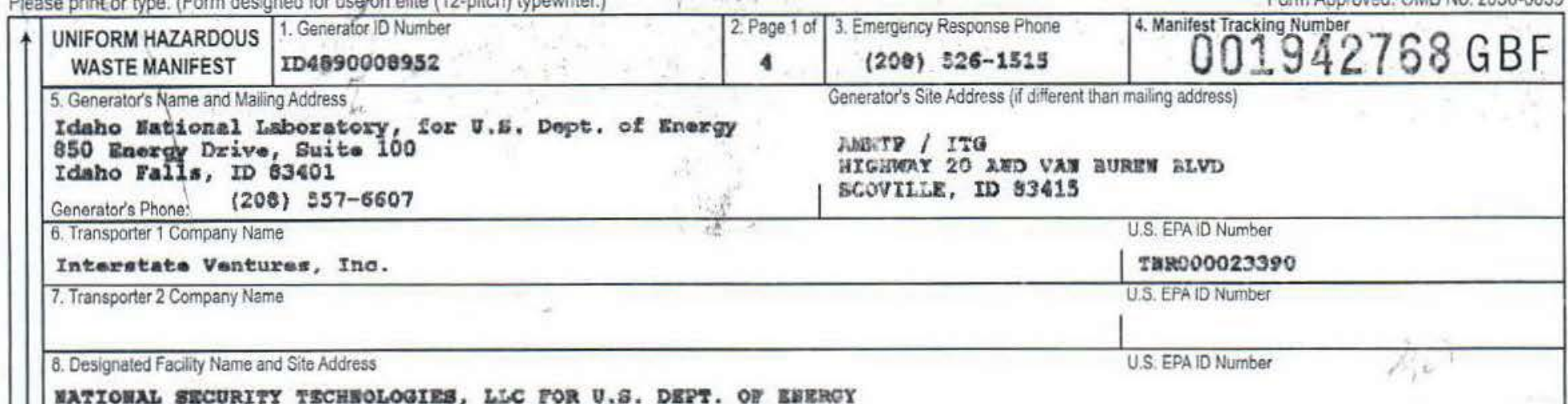

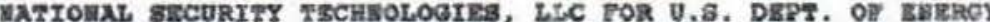

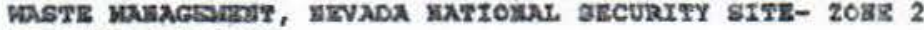

WERCURY, IN 89023

Facility's Phone: (702) 295-9393

9a. 9b. U.S. DOT Description (including Proper Shipping Name, Hazard Class, ID Number,

HM. and Packing Group (f any))

1. UH3321, Nate Radioactive material, low spocific

등 activity (LSA-II), 7, AM-242, $\mathrm{PU-239,} P U-240$,

SOLID, OXIDE, 5.307E-05 TBq, FISSILE SXCEPTED,

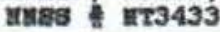

又 PCB COYIAIEER \#:SR3140093, DEBRIS, PCB Out of

Sarvice Date $6 / 01 / 1968$, PCB Weight $0.389 \mathrm{~kg}$

3. 2. Un3321, Waste Radioaotive material, low upecifio

RQ aetivity (LSA-II), 7, (PCB), AM-241, PU-239, PU-240, 30LID, OKIDE, 4.1638-04 TMq, FIsSTL

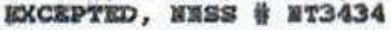

X PCB COKTRIMER Service Date $6 / 01 / 1968$, pCB Woight $0.485 \mathrm{Kg}$

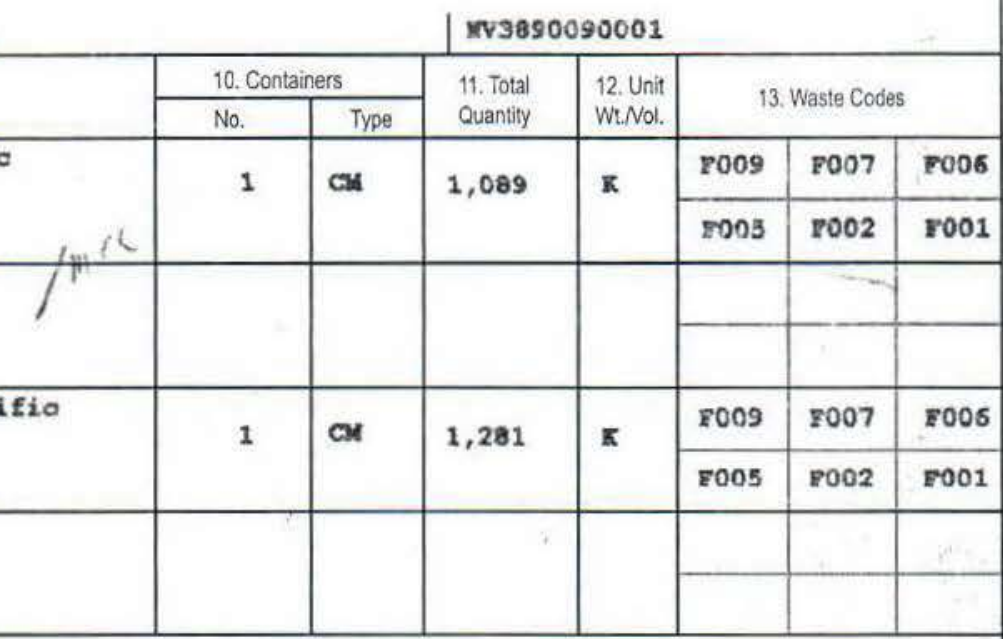

14. Special Handling Instructions and Additional Information

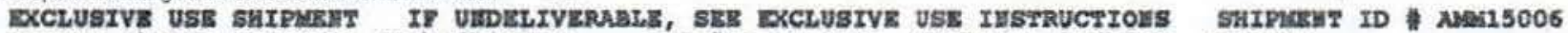

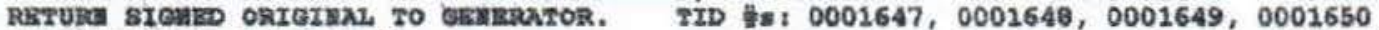

GROSS VEIGHT: 35, 112 LeS TRUCK औ 307 TRAILER H 5015

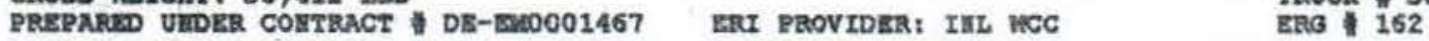

15. GENERATOR'SIOFFEROR'S CERTIFICATION: I hereby dedare that the contents of this consignment are fully and accurately described above by the proper shipping name, and are classified, packaged, marked and labeled/placarded, and are in all respects in proper condition for transport according to applicable international and national governmental regulations. If export shipment and I am the Primary

Exporter, I certify that the contents of this consignment conform to the lerms of the attached EPA Acknowledgment of Consent.

I certify that the waste minimizatign statement íentified in 40 CFR 262.27(a) (if I am a large quantily generator) or (b) (if I am a small quantity generator) is true.

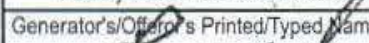

q) 101

튼

16. International Shipments

Transporter signature (for exports only)

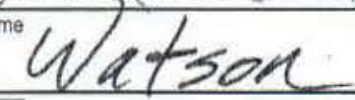

$\square$ import to U.S

Signature

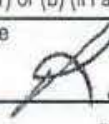

17. Transporter Acknowledgment of Receipt of Materials

Transporter TPinted Typed Name FURSL

Transporter 2 Pnifed Typed Name

18. Discrepancy

18a. Discrepancy Indication Space $\square$ Quantity

$\square$ Type

$\square$ Residue

Port of entrylexit:

$\square$ Export from U.S Date leaving U.S

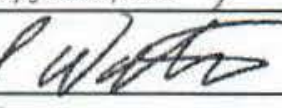

18b. Alternate Facility (or Generator)

Manifest Reference Number:
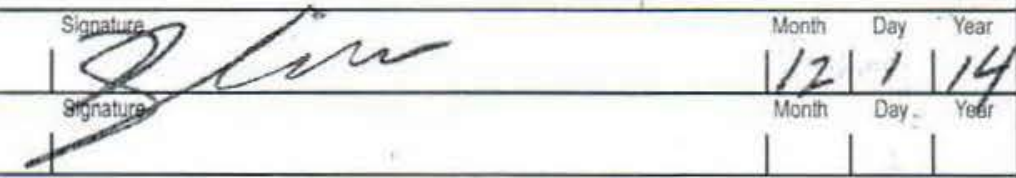

a

20. Designated Facility Owner or Operator: Certification of receipt of hazardous materials covered by the manifest except as noted in litem 18 a

Printed/Typed Name

Chris Chalupka

EPA Form 8700-22 (Rev. 3-05) Previous edfitions are obsolete.

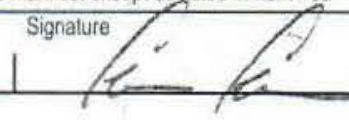


Please printor type. (Form designed for use on elite (12-pitch) typewriter.)

Form Approved. OMB No. 2050-0039

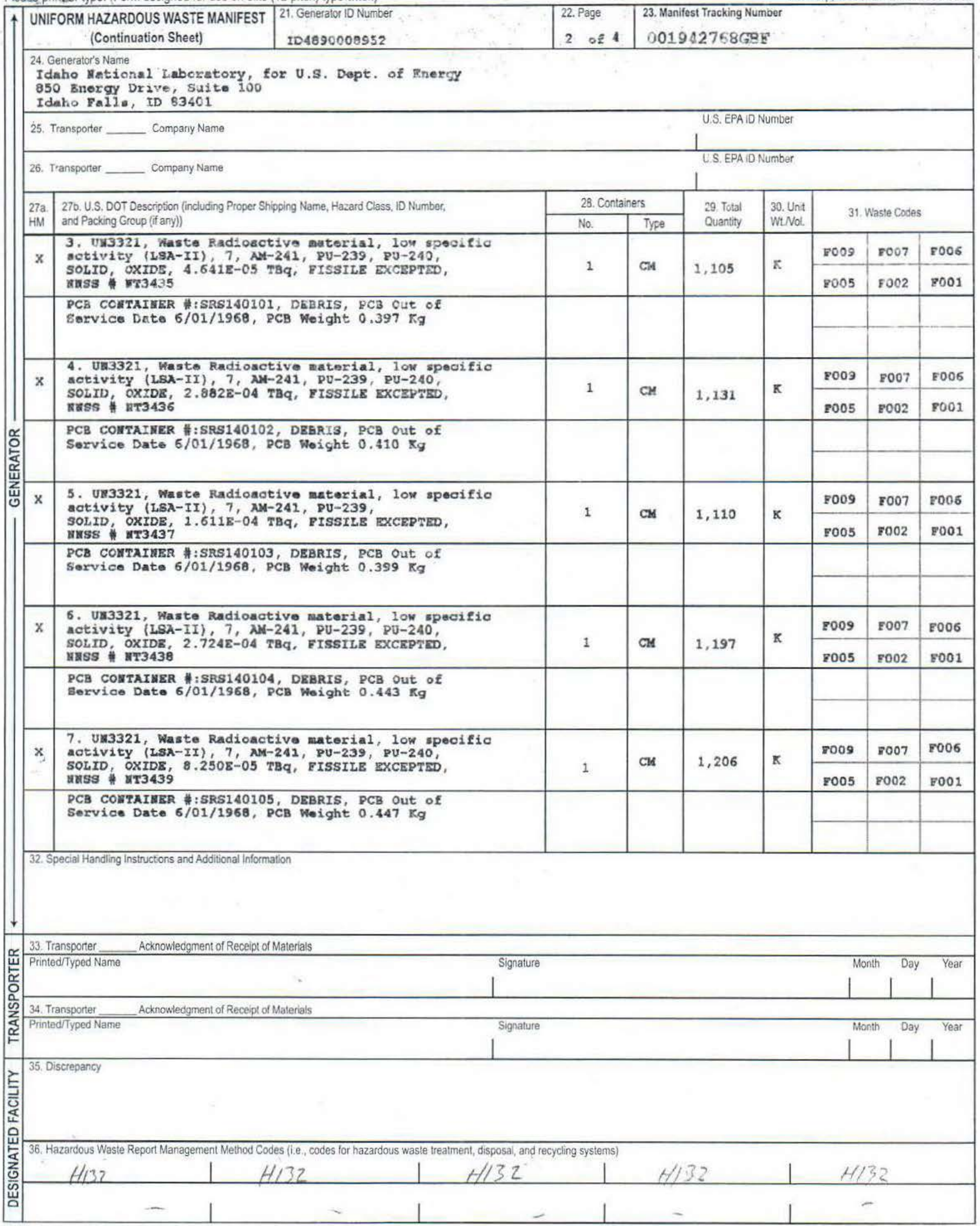


Please print or type. (Form designed for use on elite (12-pitch) typewriter.)

Form Approved. OMB N0. 2050-0039

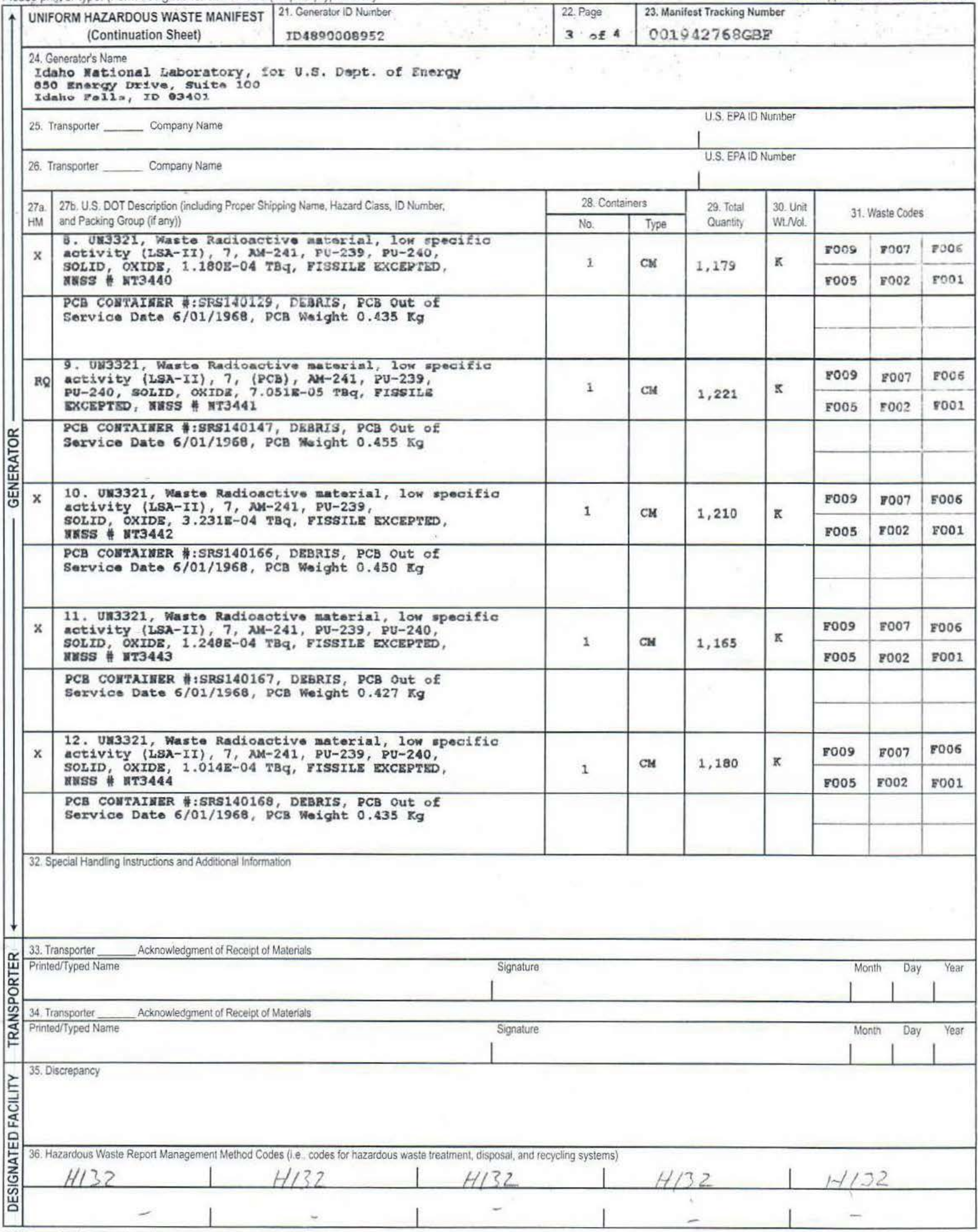


Please print or type. (Form designed for use on elite (12-pitch) typewriter.)

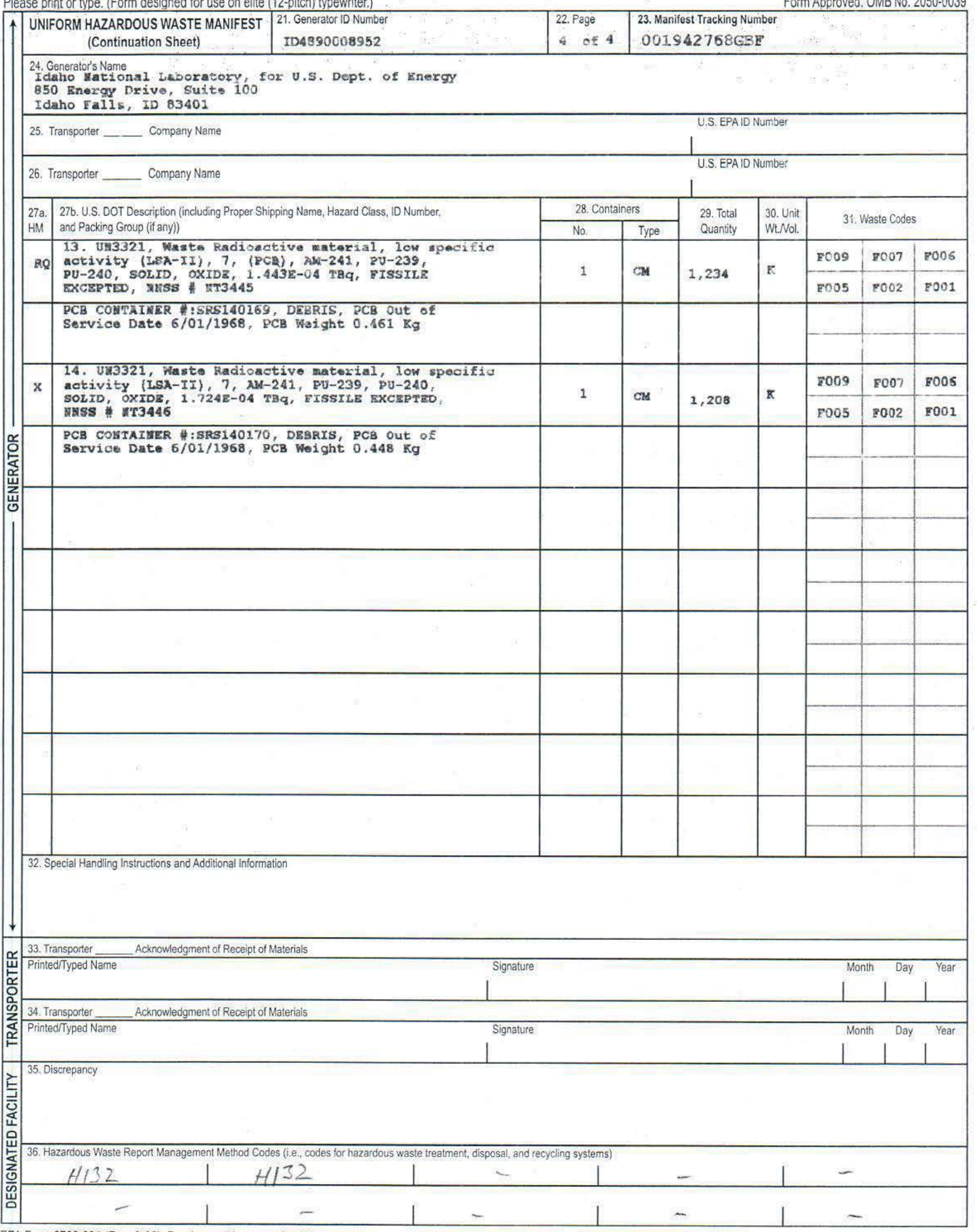


H000-PA-15-0025

December 8, 2014

Jared Dominick

Waste Certification Official

Idaho Treatment Group

850 Fnergy Drive, Suite 100

Idaho Falls, ID 83401- 1502

Subject: CERTIFICATE OF DISPOSAL FOR POLYCHLORINATED BIPHENYL (PCB) WASTE AT THE NEVADA NATIONAL SECURITY SITE RADIOACTIVE WASTE MANAGEMENT SITE (RWMS)

Enclosed is the certificate acknowledging disposal of manifested PCB shipments AMM15006 and AMM15015 in the Mixed Waste Disposal Unit, at the Nevada National Security Site RWMS.

If you have any questions, please contact me at 702-295-2261.

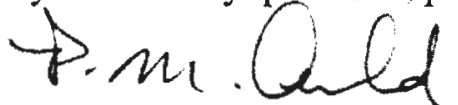

Patrick M. Arnold, Division Manager

Environmental Management

RCD:saq

Fnclosure: as stated

cc w/enc.

Correspondence Control

EWO Correspondence

J. T. Carilli, NNSA/NFO

R. C. Denton, NSTec

R. G. Geisinger, NSTec

M. Libidinsky, NNSA/NFO

C. P. Moke, NSTec

K. M. Small, NNSA/NFO

K. C. Tanaka, NSTec

A. V. Tauber, NNSANFO

R. A. Wagner, NSTec

\author{
National Security Technologies, LLC \\ Vision - Service - Partnership \\ WWW NSTec com \\ P.O. Box 98521, Las Vegas, NV 89193-8521 \\ 2621 Losee Road, N. Las Vegas, NV 89030-4129
}




\section{National Security Technologies LLC \\ For U.S. Department of Energy \\ Waste Management \\ Nevada National Security Site - Zone 2 \\ Mercury, NV 88023}

EPA ID NV3890090001

This Certificate acknowledges that the following shipment(s) of manifested POLYCHLORINATED BIPHENYL (PCB) waste have been disposed at the Nevada National Security Site Radioactive Waste Management Site.

\begin{tabular}{|c|c|c|c|c|}
\hline $\begin{array}{c}\text { Shipment } \\
\text { Number }\end{array}$ & $\begin{array}{c}\text { Uniform Hazardous Waste } \\
\text { Manifest Number }\end{array}$ & Date(s) of Disposal & Volume $\left.\mathbf{F t}^{\mathbf{3}} \mathbf{m}^{\mathbf{3}}\right)$ & Disposal Process \\
\hline AMM15006 & $001942768 \mathrm{GBF}$ & $12 / 02 / 2014$ & $1,259.76(35.67)$ & Landfill \\
\hline AMM15015 & $001942804 \mathrm{GBF}$ & $12 / 02 / 2014$ & $1,259.76(35.67)$ & Landfill \\
\hline & & & & \\
\hline & & & & \\
\hline
\end{tabular}

Under civil and criminal penalties of law for the making or submission of false or fraudulent statements or representations (18 U.S.C. 1001 and 15 U.S.C. 2615), I certify that the information contained in or accompanying this document is true, accurate, and complete.

As to the identified section(s) of this document for which I cannot personally verify truth and accuracy, I certify as the company official having supervisory responsibility for the persons who, acting under my direct instructions, made the verification that this information is true, accurate, and complete.
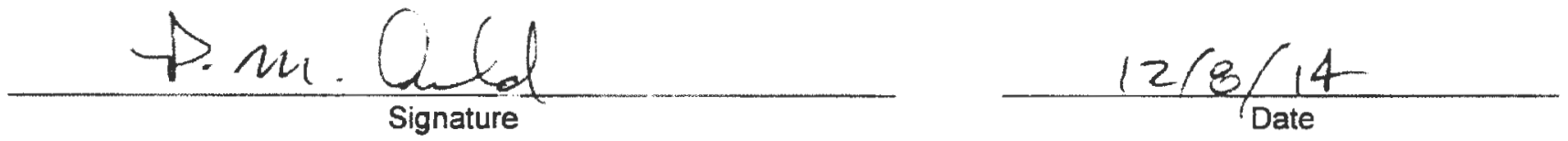

\footnotetext{
Division Manager, Environmental Management

\section{Title}

\section{Instructions:}

Shipment Number - enter shipment number from LWIS database.

Uniform Hazardous Waste Manifest Number - enter number from UHWM provided by generator.

Date of Disposal - enter date waste was placed in disposal cell.

Volume - enter shipment volume in cubic feet and equivalent cubic meters in parenthesis.

Disposal Process - enter Landfill. 


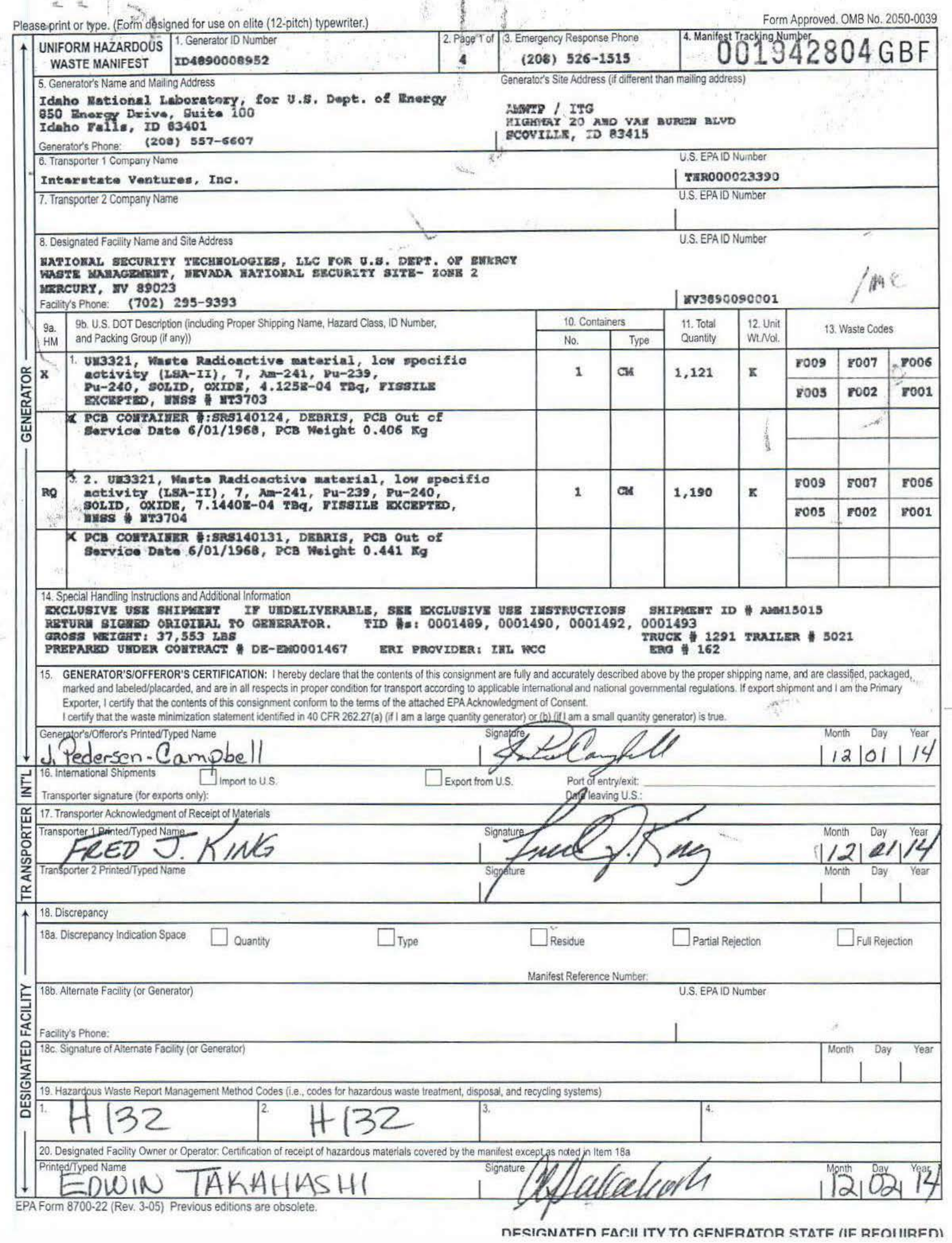


$\pi \cdot 2$.

Please print ơ type. (Form designed for use on elite (12-pitch) typewriter.)

Form Approved. OMB No. 2050-0039

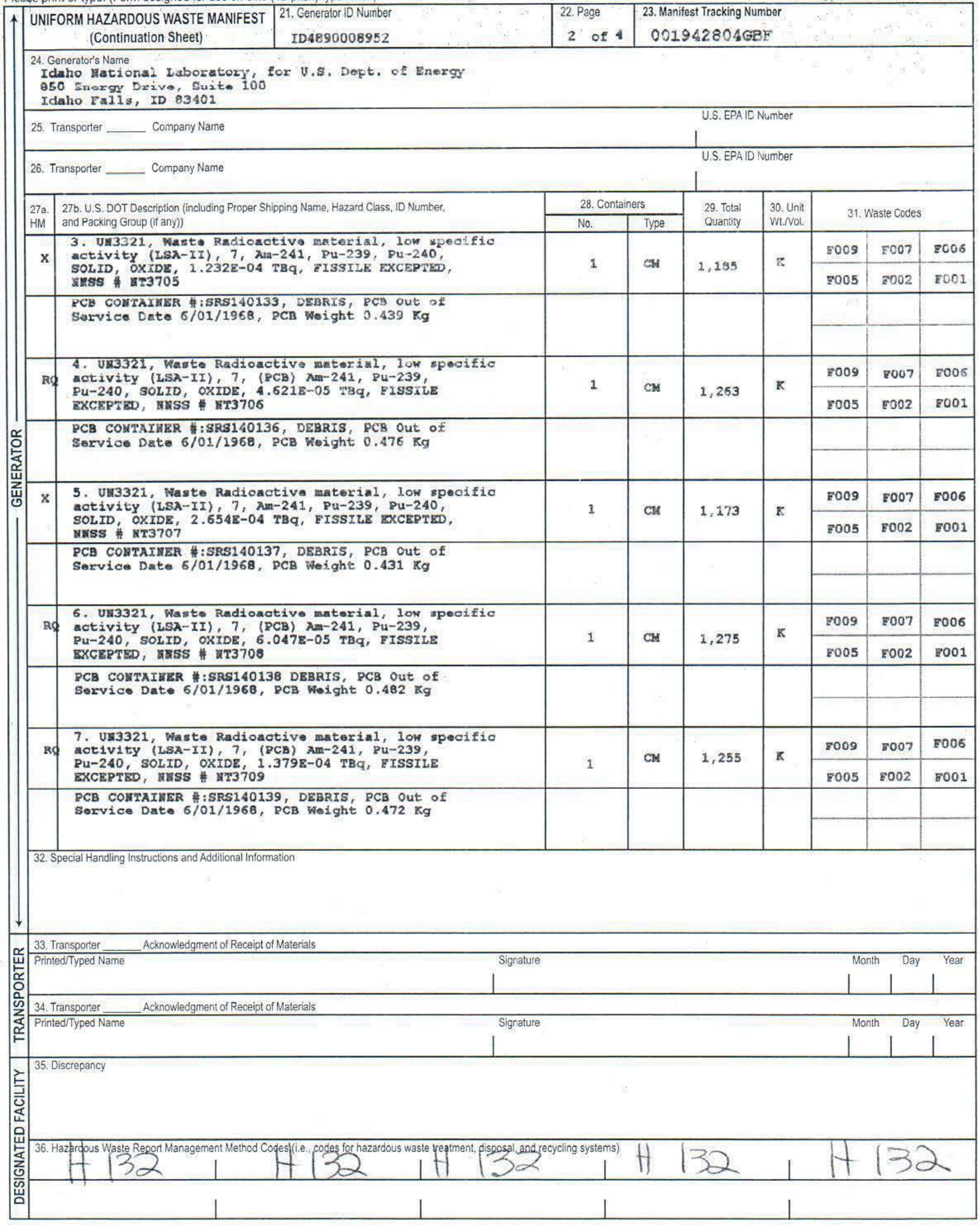


The to

Please print or type. (Form designed for use on elite (12-pitch) typewriter.)

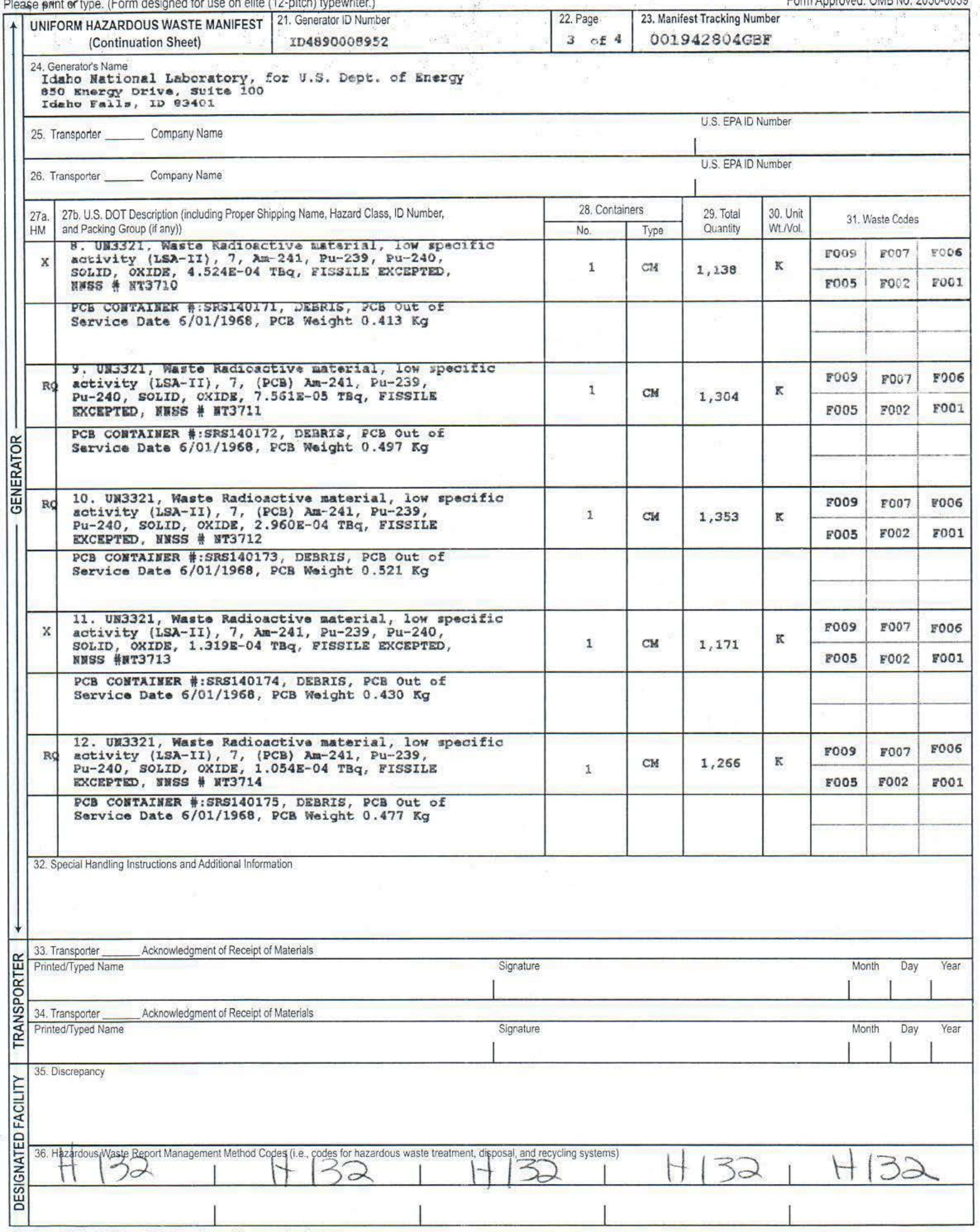




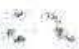

Please printor type. (Form designed for use on elite (12-pitch) typewriter.)

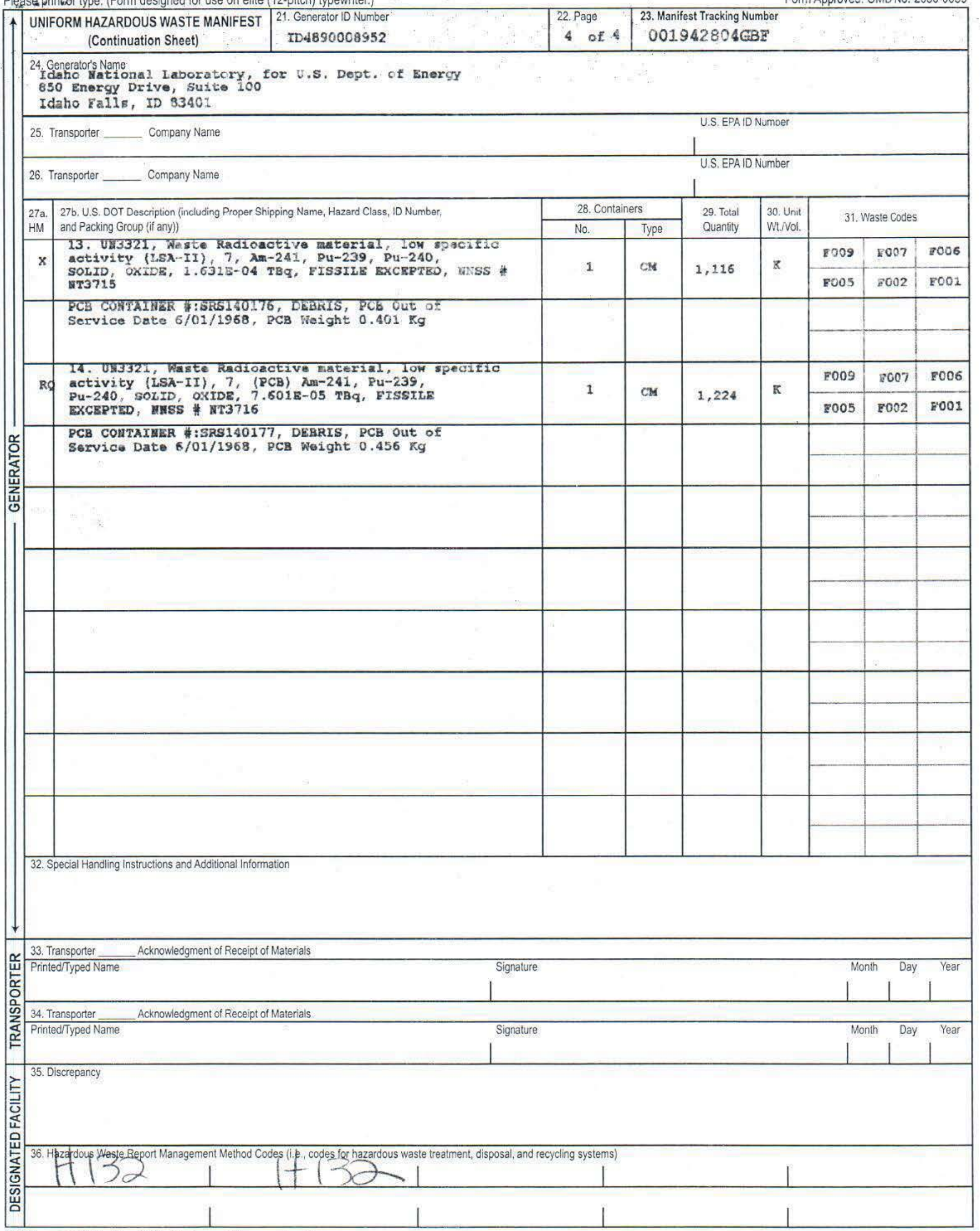


H000-PA-15-0025

December 8, 2014

Jared Dominick

Waste Certification Official

Idaho Treatment Group

850 Fnergy Drive, Suite 100

Idaho Falls, ID 83401- 1502

Subject: CERTIFICATE OF DISPOSAL FOR POLYCHLORINATED BIPHENYL (PCB) WASTE AT THE NEVADA NATIONAL SECURITY SITE RADIOACTIVE WASTE MANAGEMENT SITE (RWMS)

Enclosed is the certificate acknowledging disposal of manifested PCB shipments AMM15006 and AMM15015 in the Mixed Waste Disposal Unit, at the Nevada National Security Site RWMS.

If you have any questions, please contact me at 702-295-2261.

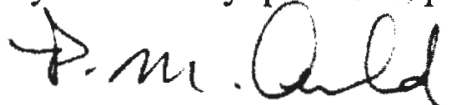

Patrick M. Arnold, Division Manager

Environmental Management

RCD:saq

Fnclosure: as stated

cc w/enc.

Correspondence Control

EWO Correspondence

J. T. Carilli, NNSA/NFO

R. C. Denton, NSTec

R. G. Geisinger, NSTec

M. Libidinsky, NNSA/NFO

C. P. Moke, NSTec

K. M. Small, NNSA/NFO

K. C. Tanaka, NSTec

A. V. Tauber, NNSANFO

R. A. Wagner, NSTec

\author{
National Security Technologies, LLC \\ Vision - Service - Partnership \\ WWW NSTec com \\ P.O. Box 98521, Las Vegas, NV 89193-8521 \\ 2621 Losee Road, N. Las Vegas, NV 89030-4129
}




\section{National Security Technologies LLC \\ For U.S. Department of Energy \\ Waste Management \\ Nevada National Security Site - Zone 2 \\ Mercury, NV 88023}

EPA ID NV3890090001

This Certificate acknowledges that the following shipment(s) of manifested POLYCHLORINATED BIPHENYL (PCB) waste have been disposed at the Nevada National Security Site Radioactive Waste Management Site.

\begin{tabular}{|c|c|c|c|c|}
\hline $\begin{array}{c}\text { Shipment } \\
\text { Number }\end{array}$ & $\begin{array}{c}\text { Uniform Hazardous Waste } \\
\text { Manifest Number }\end{array}$ & Date(s) of Disposal & Volume $\left.\mathbf{F t}^{\mathbf{3}} \mathbf{m}^{\mathbf{3}}\right)$ & Disposal Process \\
\hline AMM15006 & $001942768 \mathrm{GBF}$ & $12 / 02 / 2014$ & $1,259.76(35.67)$ & Landfill \\
\hline AMM15015 & $001942804 \mathrm{GBF}$ & $12 / 02 / 2014$ & $1,259.76(35.67)$ & Landfill \\
\hline & & & & \\
\hline & & & & \\
\hline
\end{tabular}

Under civil and criminal penalties of law for the making or submission of false or fraudulent statements or representations (18 U.S.C. 1001 and 15 U.S.C. 2615), I certify that the information contained in or accompanying this document is true, accurate, and complete.

As to the identified section(s) of this document for which I cannot personally verify truth and accuracy, I certify as the company official having supervisory responsibility for the persons who, acting under my direct instructions, made the verification that this information is true, accurate, and complete.
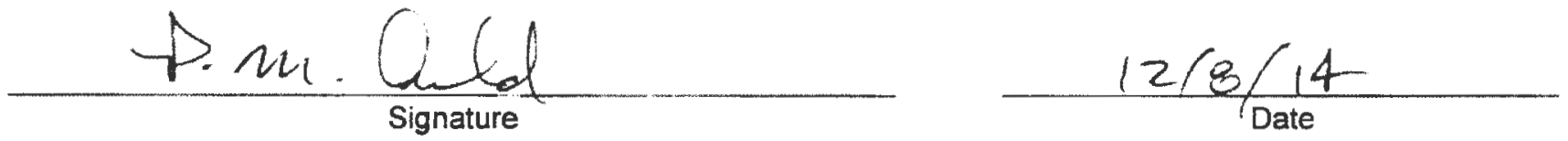

\footnotetext{
Division Manager, Environmental Management

\section{Title}

\section{Instructions:}

Shipment Number - enter shipment number from LWIS database.

Uniform Hazardous Waste Manifest Number - enter number from UHWM provided by generator.

Date of Disposal - enter date waste was placed in disposal cell.

Volume - enter shipment volume in cubic feet and equivalent cubic meters in parenthesis.

Disposal Process - enter Landfill. 
Please print or type. (Form designed tor usa on elite (12-pitch) typewriter.)

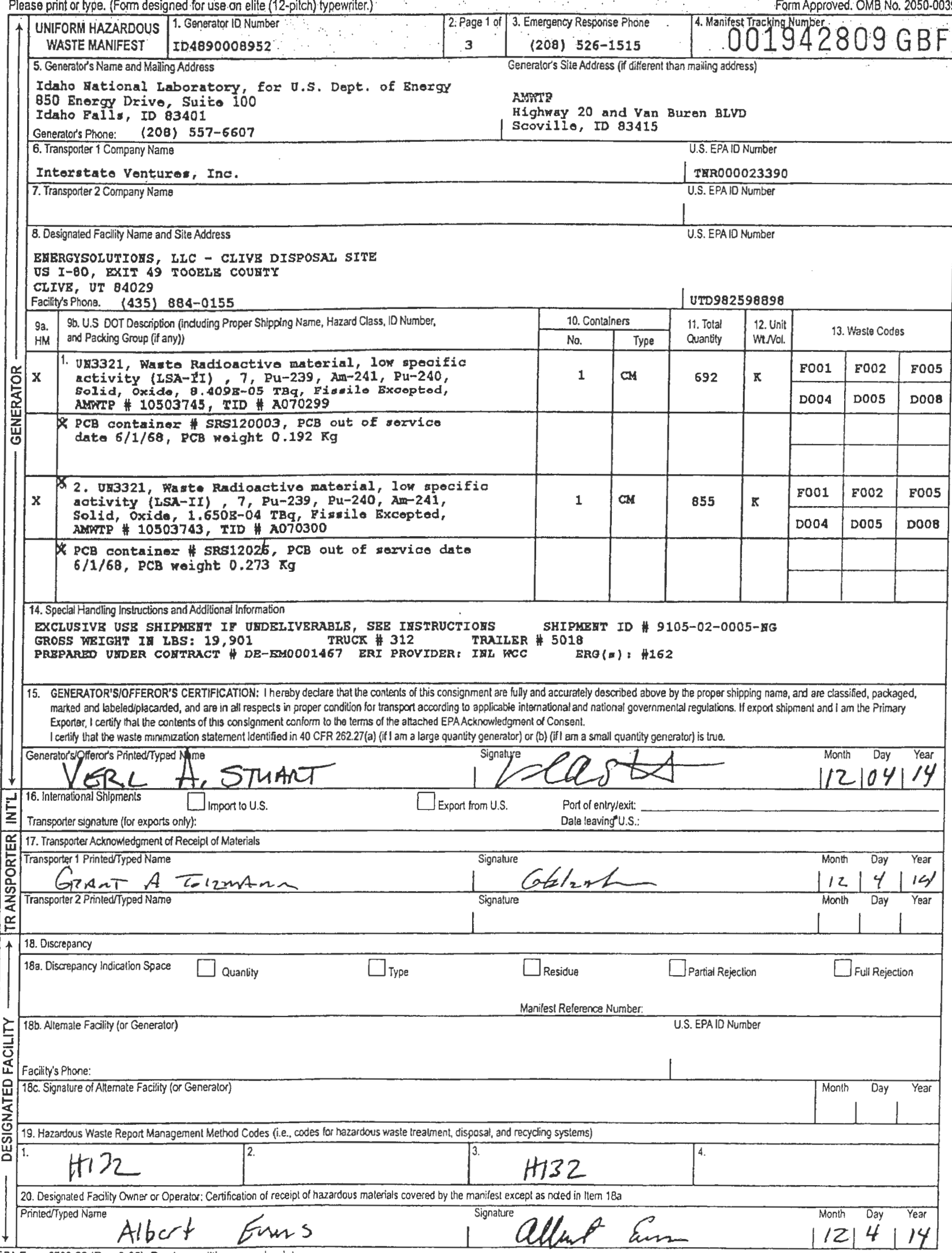


Please print or type. (Form designed for use on elite (12-pitch) typewriter.)

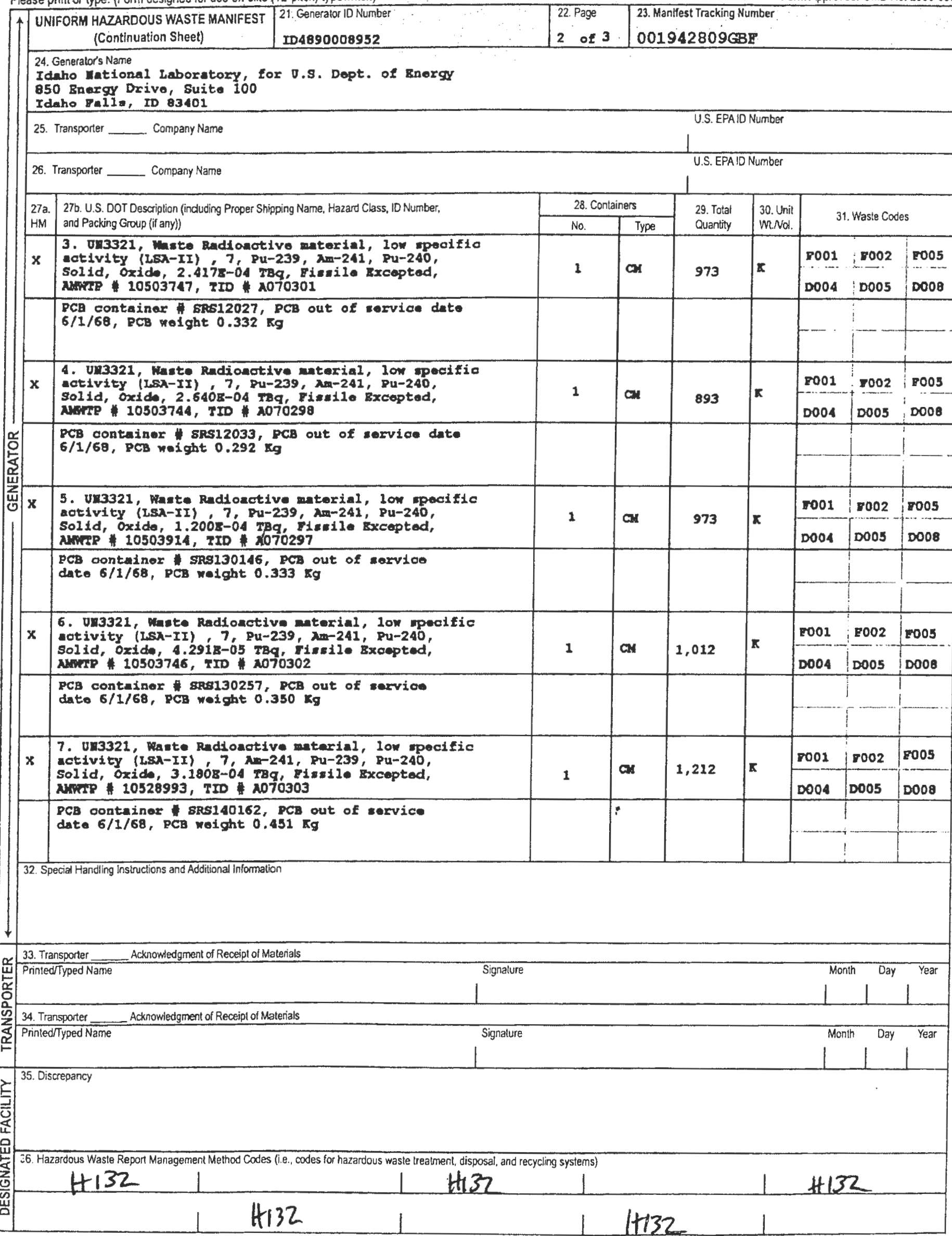

EPA Form 8700-22A (Rev. 3-05) Previous editions are obsolete. 
Please print or type. (Form designed for use on ellite (12-pilch) typewriter.)

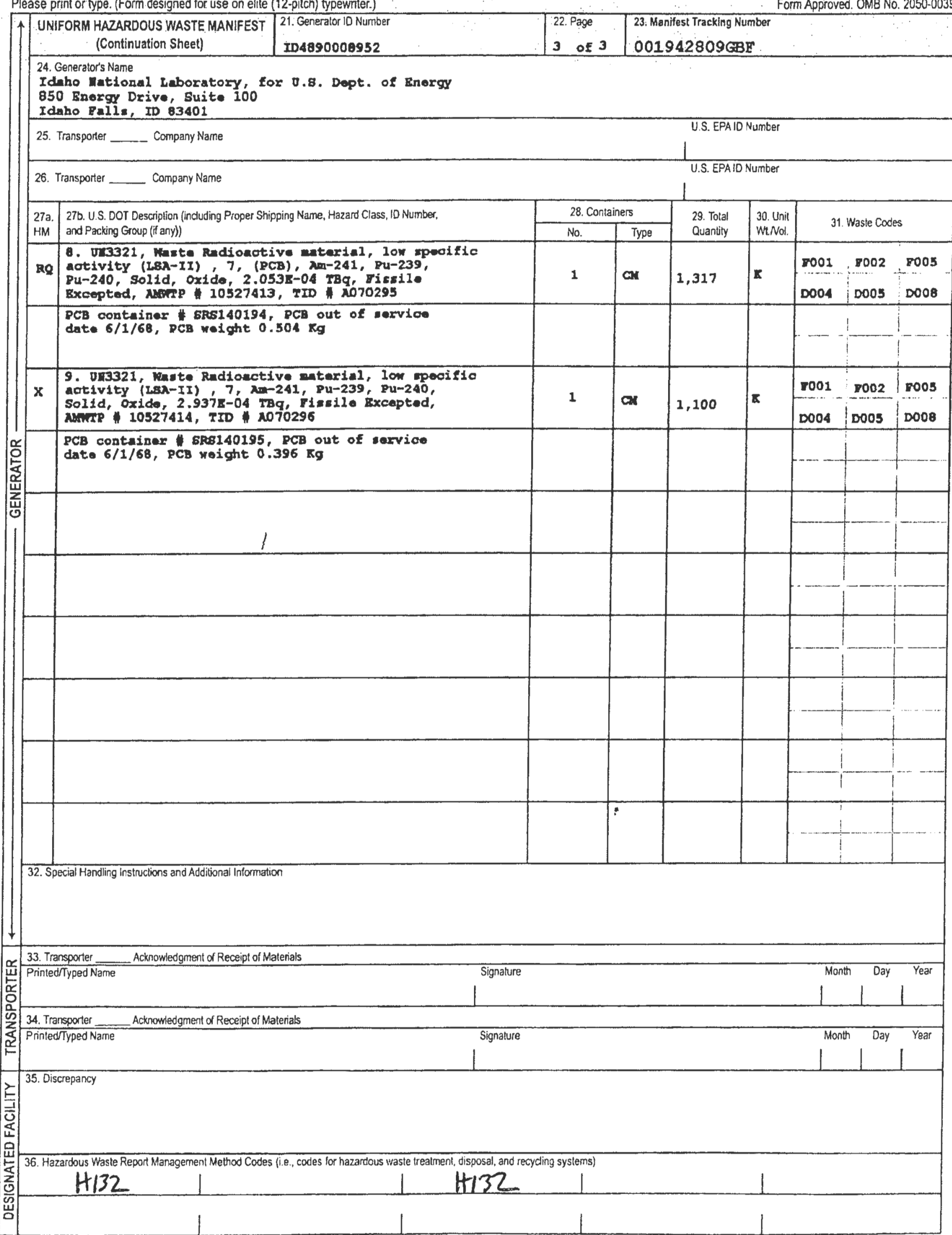




\section{ENERGiSolutions}

\section{CERTIFICATE OF DISPOSAL}

3 miles South, Exit $49,1-80$

Clive. Utah 84029

EPA ID: UTD982598898

INL - AMWTP, Idaho Falls

This certificate acknowledges that the following manifested shipments have been disposed of as listed below:

$\begin{array}{ll}\text { Shlpment } & \text { Manifest } \\ 9105-01-0103 & 42808 \\ 9105-01-0104 & 42813 \\ 9105-02-0005 & 42809 \\ 9105-03-0090 & 42798 \\ 9105-03-0091 & 42799\end{array}$

Dlsposal Daia
$12 / 18 / 2014$
$12 / 18 / 2014$
$12 / 18 / 2014$
$12 / 22 / 2014$
$12 / 22 / 2014$

Yolumo (Culf)
$2,560.0$
$2,560.0$
810.0
$2,560.0$
$2,560.0$

Process
Landfill
Landfill
Landfill
Landfill
Landfill

Disposal hocation

Mixed Waste

Mixed Waste

Mixed Waste

Mlxed Weste

Mixed Waste

The total volume above represents the cubic feet of waste disposed of at EnergySolutions' Disposal Facility Landfill. Disposal is subject to EnergySolutions' Radioactive Material License, all other applicable licenses, permits and regulations, and the Disposal Agreement.

Under civil and criminal penalties of law for the making or submission of faise or Iraudutent stelements or representations (18 U.S.C 1001 and 15 U.S.C. 2615) I certify that the information conteined in or accompanying this document is true. accurate and complete. As to the identification section(s) or this document lor which I cannot personally verify inuth and accuracy, I centify es the compeny official heving supervisory responsibility for the persons who, ecting under my direct instructions, made the verification that this information is true, accurate and complele. 
Pleasê print ô type. (Form designed for use on elite (12-pitch) typewriter.)

$\uparrow$ UNIFORM HAZARDOUS 1 . Generator ID Number \begin{tabular}{l|l} 
WASTE MANIFEST & ID4890008952
\end{tabular}

5. Generator's Name and Mailing Address

Ideho Wational Ieboratory, for V.S. Dept. of Inergy

650 Rnergy Driva, Suite 100

Idaho Fails, ID 83401

Generator's Phone: (208) 557-6607

6. Transporter 1 Company Name

Interstate Ventures, Ino.

7. Transporter 2 Company Name

Form Approved. OMB No. 2050-0039

8. Designated Facility Name and Site Address

IATIOWAL SECURITY TECHBOLOGISS, LLC POR U.S. DEPT. OF EMERGY

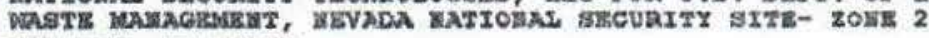

MERCURY, IVV 89023

Facility's Phone: (702) 295-5876

9a. 9b. U.S. DOT Description (Including Proper Shipping Name, Hazard Class, ID Number,

HM and Packing Group (if any))

1. Un3321, Nasto Radioactive anterial, Ion apecilic

X activity (LSA-II), 7, Xn-241, Pu-239.

SOLID, OXIOS, $1.352 \mathrm{E}-04 \mathrm{TR}$, FISSILE EXCEPTE,

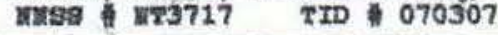

X PCB COMWAIER :SIE140075, DEARIS, PCB Out of Sexvice Date $6 / 01 / 1968$, PCB Woight $0.412 \mathrm{~kg}$

3. 2, Uil3321, Waste Radioactive anterial, low apeodfio

$\mathrm{Rg}$ activity (LsA-II), 7, (PCB), $\mathrm{na}-241, \mathrm{Pu}-239$, SOLID, OXIDE, 2.650B-04 TBQ, FISSILE EXCEPTD,

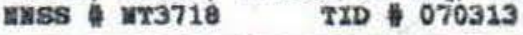

XK PCB COMTAIHRR H A IRS140090, DEBRT3, PCB Out of Service Date $6 / 01 / 1968$, PCB Weight $0.463 \mathrm{Kg}$

14. Special Handing Instructions and Additional Information

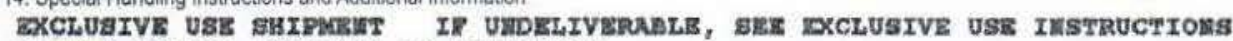

RBTURM SIOSISD ORIGINAL TO GRIERATOR.

GROSS WEIGKT; 35,893 LBS

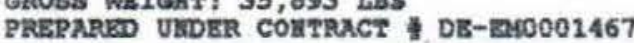

5ENERATOR'S/OFFEROR'S CERTIFICATION: I hereby declare that the contents of this consignment are fully and accurately described above by the proper shipping name, and are classified, packaged, marked and labeled/placarded, and are in all respects in proper condition for transport according to applicable international and national governmental regulations. If export shipment and I am the Primary Exporter, I certify that the contents of this consignment conform to the terms of the attached EPA Acknowledgment of Consent.

I certify that the waste minimization statement identified in 40 CFR 262.27(a) (if I am a large quantity generator) or (b) (ff I am a small quantity generator) is true. Generator's/Offeror's Printed/Typed Name

Richard A. Ne Smith

Transporter signature (for exports only): $\square_{\text {import to U.S. }}$

Signature

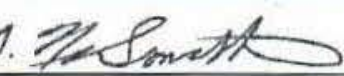
Month Day Year $12107 \mid 14$

17. Transporter Acknowledgment of Receipt of Materials

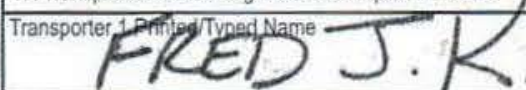

Transporter 2 Printed/Typed Name

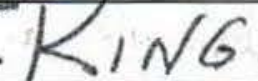

18. Discrepancy 18a. Discrepancy indication Space $\square$ Quantity

$a^{3} \square^{3} \square_{\text {Type }}$

Dexport from U.S

Porjeffentry/exit:
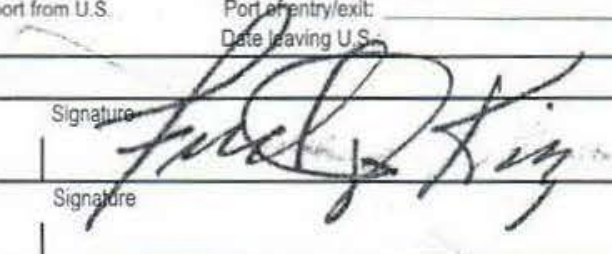

\begin{tabular}{|l}
12 \\
nis \\
\hline \\
\hline \\
10
\end{tabular}

Irv3890090001 
Please print os type. (Form designed for use on elite (12-pitch) typewriter.)

Form Approved. OMB No. 2050-0039

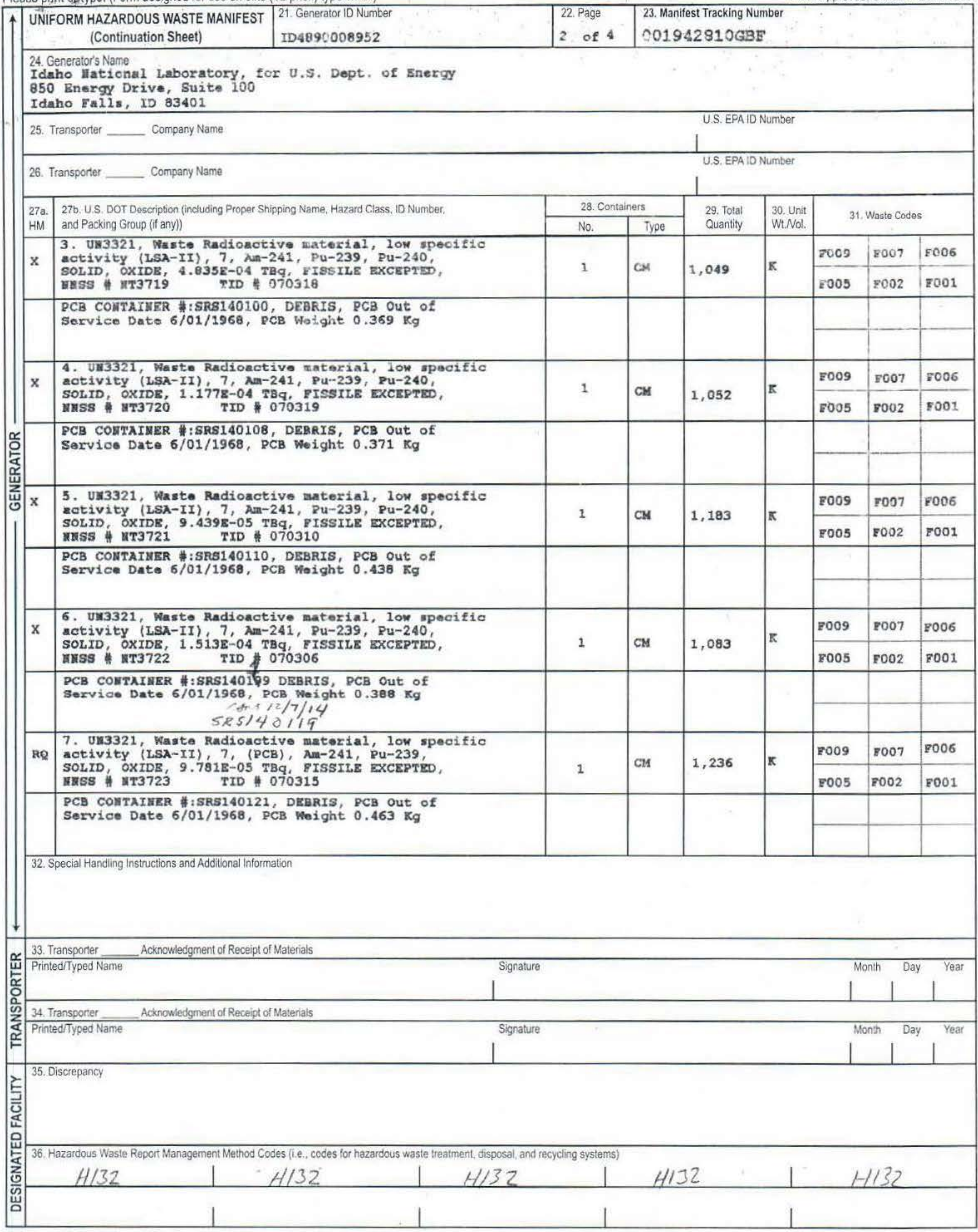


Please print or type. (Form designed for use on elite (12-pitch) typewriter.)

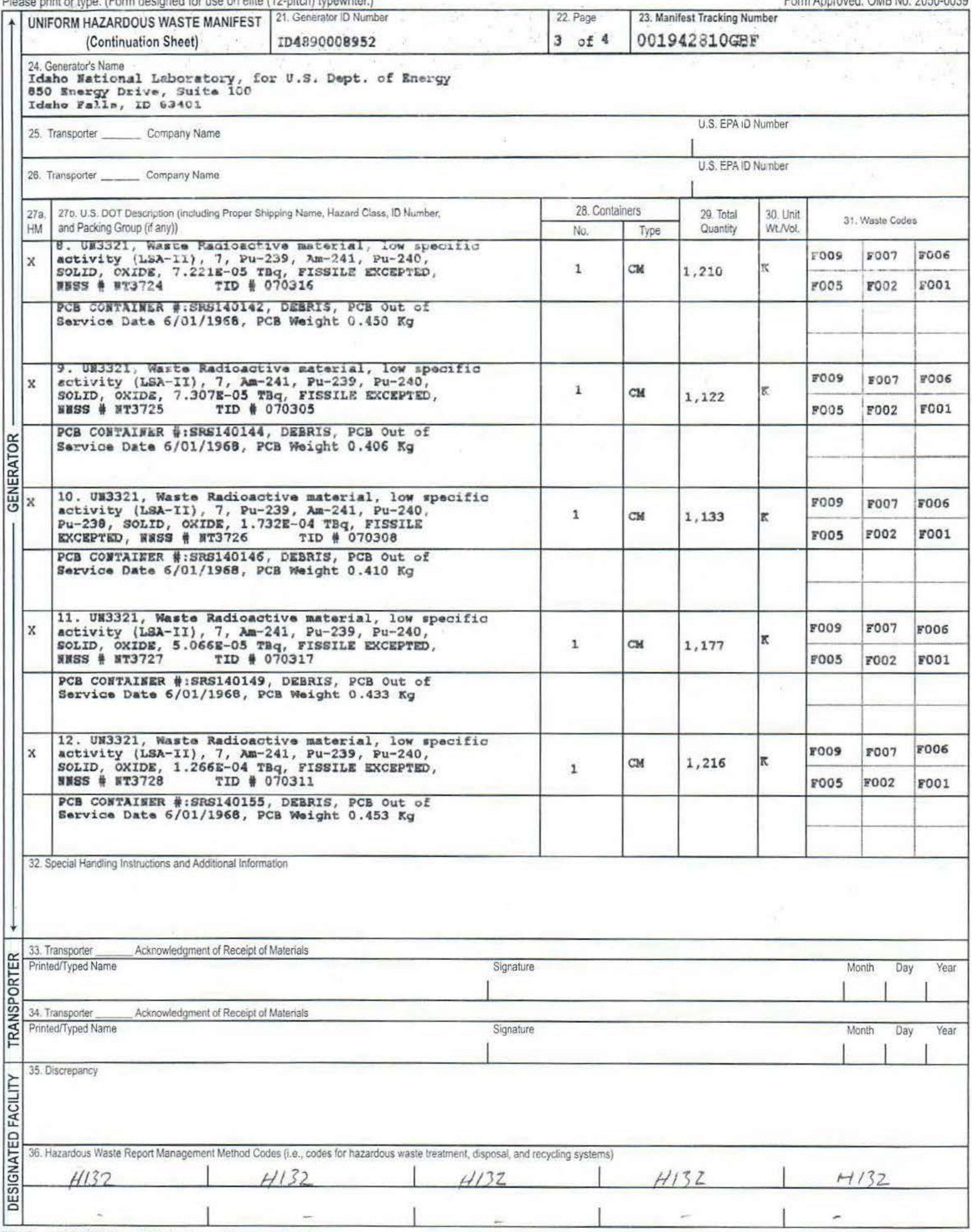




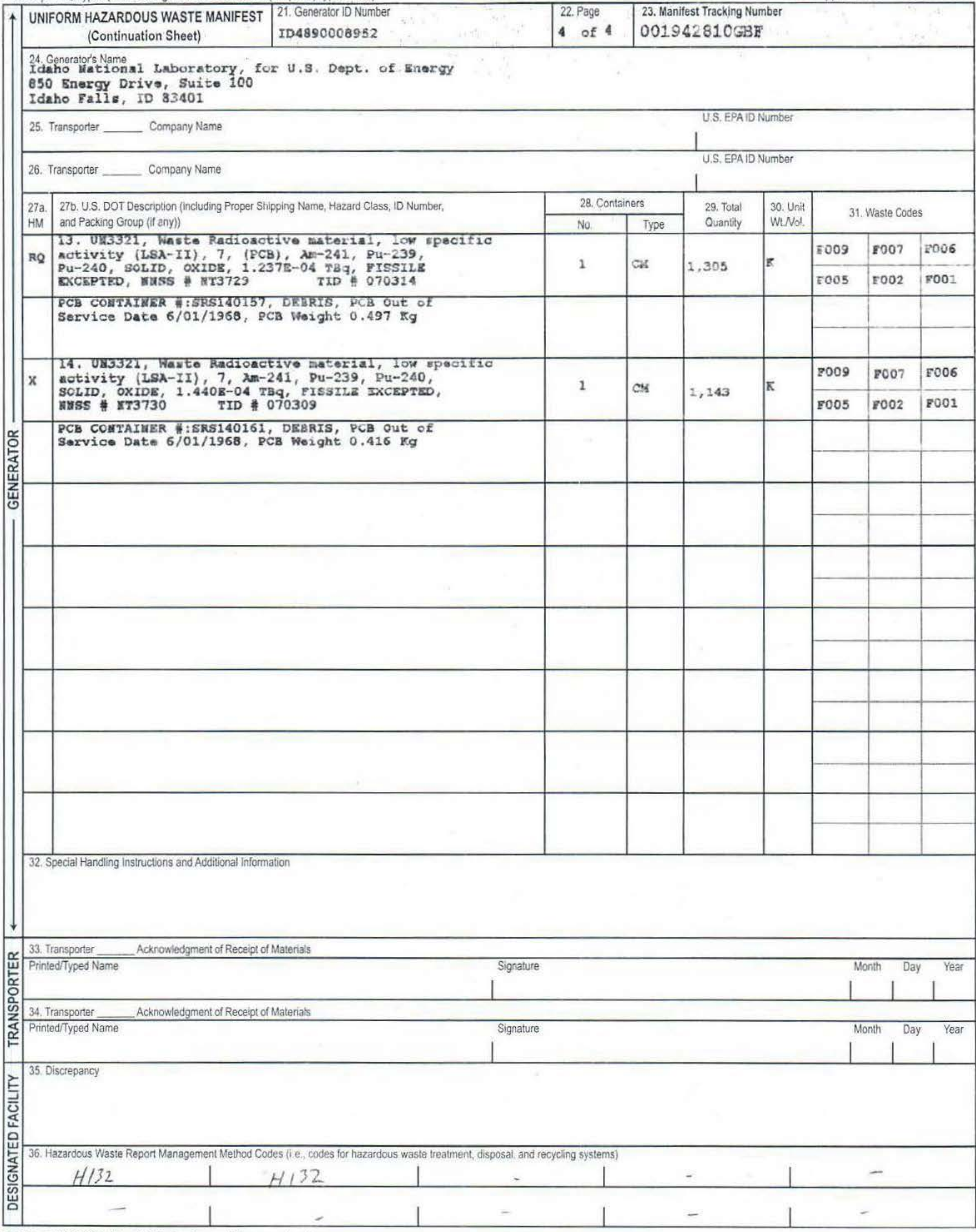


$\underset{\substack{\text { National Security Technologies Luc } \\ \text { Vision. Senice. Partnership }}}{ }$

H000-PA-15-0027

December 15, 2014

Jared Dominick

Waste Certification Official

Idaho Treatment Group

850 Energy Drive, Suite 100

Idaho Falls, ID 83401-1502

Subject: CERTIFICATE OF DISPOSAL FOR POLYCHLORINATED BIPHENYL (PCB) WASTE AT THE NEVADA NATIONAL SECURITY SITE RADIOACTIVE WASTE MANAGEMENT SITE (RWMS)

Enclosed is the certificate acknowledging disposal of manifested PCB shipment AMM15016 in the Mixed Waste Disposal Unit, at the Nevada National Security Site RWMS.

If you have any questions, please contact me at 702-295-2261.

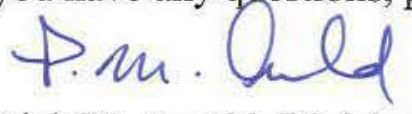

Patrick M. Arnold, Division Manager

Environmental Management

RCD:saq

Enclosure: as stated

cc w/enc.

Correspondence Management

EWO Correspondence

J. T. Carilli, NNSA/NFO

R. C. Denton, NSTec

R. G. Geisinger, NSTec

L. B. Gregory, NSTec

M. Libidinsky, NNSA/NFO

C. P. Moke, NSTec

K. M. Small, NNSA/NFO

K. C. Tanaka, NSTec

A. V. Tauber, NNSA/NFO

R. A. Wagner, NSTec

National Security Technologies, LLC

Vision • Service • Partnership

WWW.NSTEC.com

P.O. Box 98521, Las Vegas, NV 89193-8521

2621 Losee Road, N. Las Vegas, NV 89030-4129 
National Security Technologies LLC

For U.S. Department of Energy

Waste Management

Nevada National Security Site - Zone 2

Mercury, NV 89023

EPA ID NV3890090001

This Certificate acknowledges that the following shipment(s) of manifested POLYCHLORINATED BIPHENYL (PCB) waste have been disposed at the Nevada National Security Site Radioactive Waste Management Site.

\begin{tabular}{|c|c|c|c|c|}
\hline $\begin{array}{c}\text { Shipment } \\
\text { Number }\end{array}$ & $\begin{array}{c}\text { Uniform Hazardous Waste } \\
\text { Manifest Number }\end{array}$ & Date(s) of Disposal & Volume $\mathbf{F t}^{\mathbf{3}}\left(\mathbf{m}^{\mathbf{3}}\right)$ & Disposal Process \\
\hline AMM15016 & $001942810 \mathrm{GBF}$ & $12 / 08 / 2014$ & $1,259.76(35.67)$ & Landfill \\
\hline & & & & \\
\hline & & & & \\
\hline & & & & \\
\hline
\end{tabular}

Under civil and criminal penalties of law for the making or submission of false or fraudulent statements or representations (18 U.S.C. 1001 and 15 U.S.C. 2615), I certify that the information contained in or accompanying this document is true, accurate, and complete.

As to the identified section(s) of this document for which I cannot personally verify truth and accuracy, I certify as the company official having supervisory responsibility for the persons who, acting under my direct instructions, made the verification that this information is true, accurate, and complete.
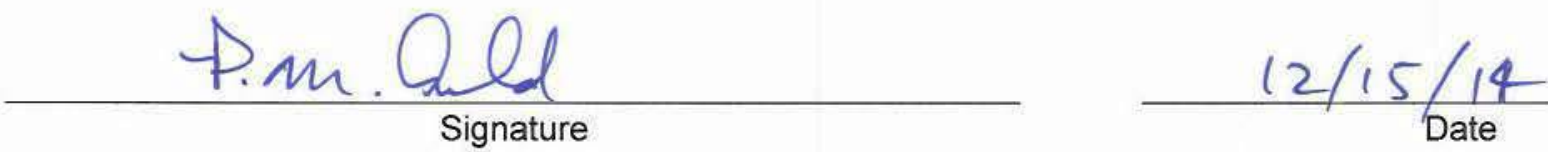

Division Manager, Environmental Management

$$
\text { Title }
$$

\section{Instructions:}

Shipment Number - enter shipment number from LWIS database.

Uniform Hazardous Waste Manifest Number - enter number from UHWM provided by generator.

Date of Disposal - enter date waste was placed in disposal cell.

Volume - enter shipment volume in cubic feet and equivalent cubic meters in parenthesis.

Disposal Process - enter Landfill. 
Please print or type. (Form designed for use on elite (12-pitch) typewiter.)

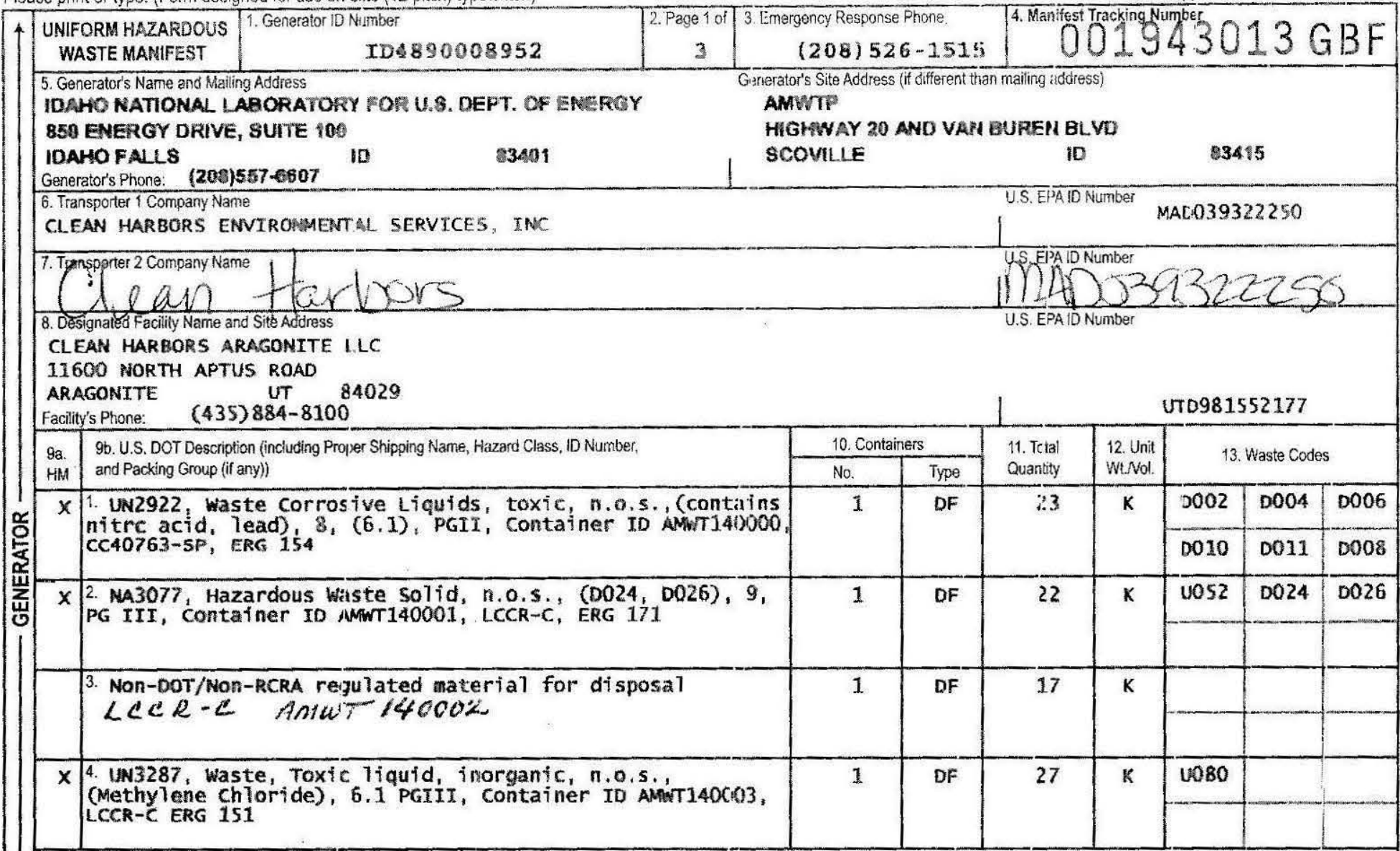

14. Special Handling Instructions and Additional Information

RETURN STGNED ORIGINAL. TO GENERATOR

PREPARED UNDER CONTRACT ;FDE-EMDO01.467

ERI PROVIDER: INL WCC.

\section{1. $1 \times 20$ \\ $3 \cdot 1 \times 20$ \\ $3,1 \times 20$ \\ $4.1 \times 20$}

15. GENERATOR'S/OFFEROR'S CERTIFICATION: i hereby deciare that the contents of this consignment are fully and accurately described above by the proper shipping name, and are classified, packiaged, marked and labelediplacarded, and are in all respects in proper condition for transport according to applicable international and national governmental regulations. If export shipment and I am the Priniary Exporter, $i$ certify that the contents of this consignment conform to the terms of the attached EPAAckrowledgment of Consent.

I certify that the waste minimization statement identified in 40 C.FR 262.27 (a) (f $\}$ am a large quantity generator) or (b) (ifl am a small quantity generator) is true.

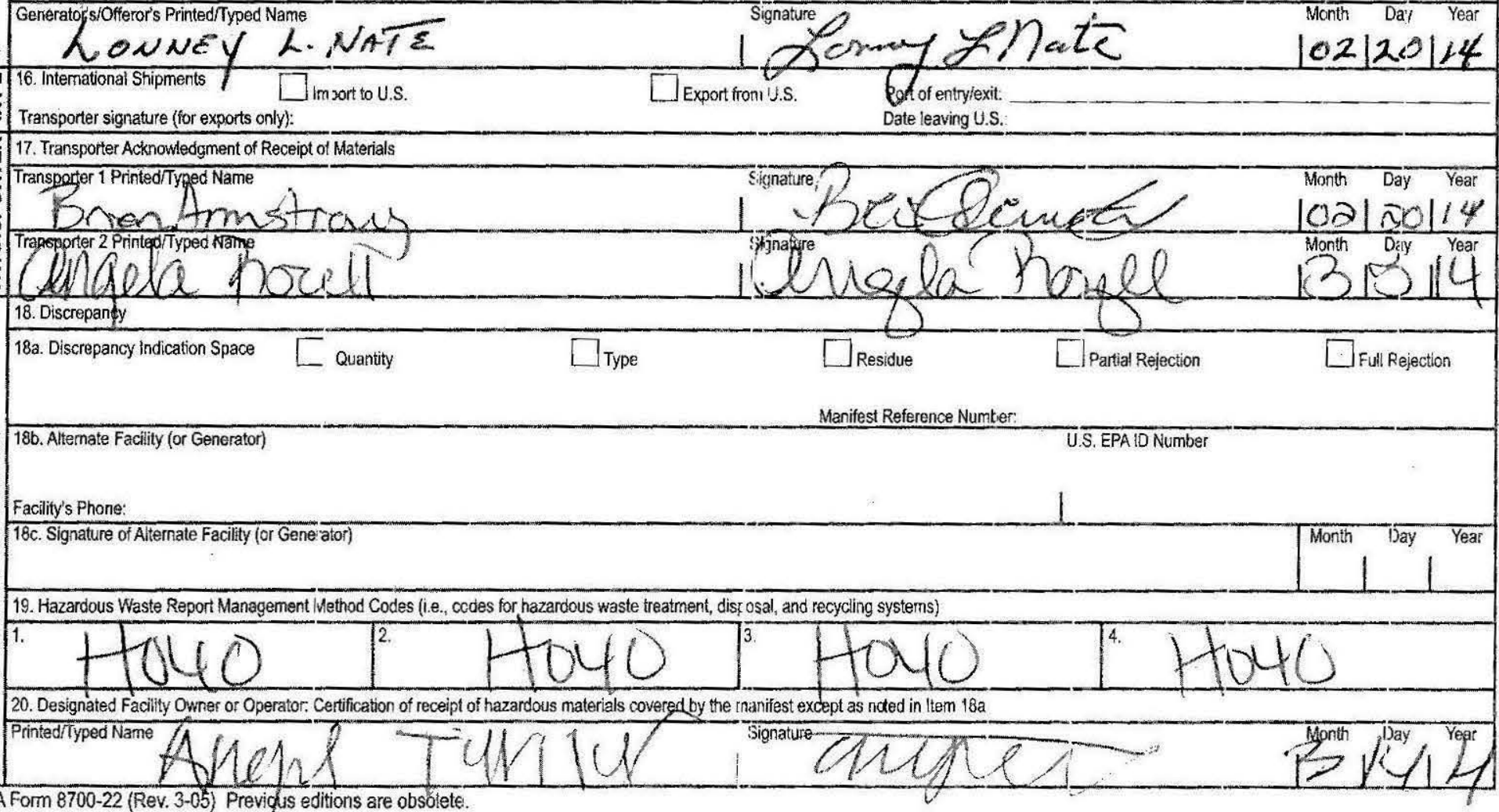

EPA Form 8700-22 (Rev. 3-05) Previgus editions are obsolete. 
Please print or type. (Form designed for use on elite (12-pitch) typewriter.)

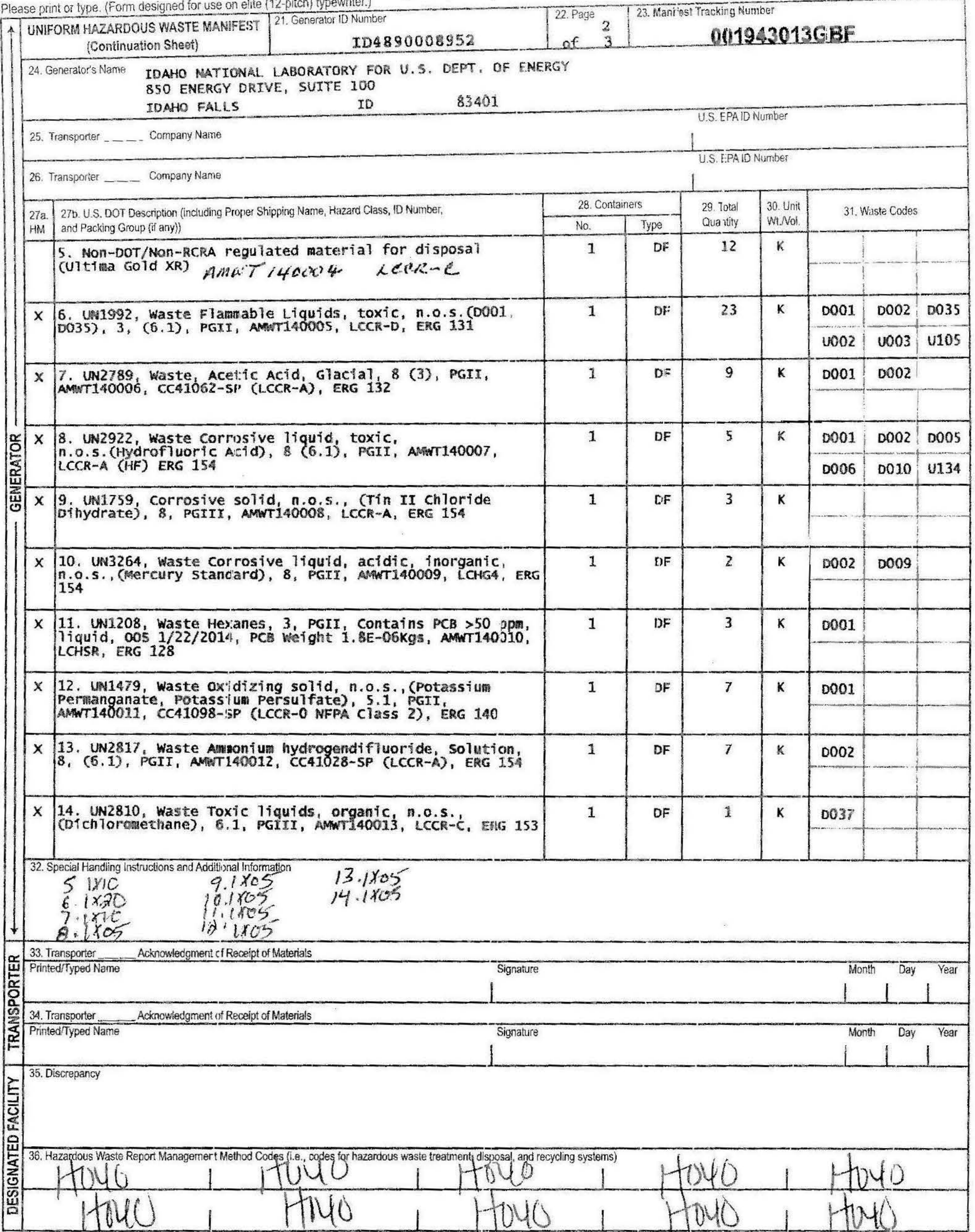


Please print or type. (Form designed for use on slite (12-pitch) typewriter.)

699247251

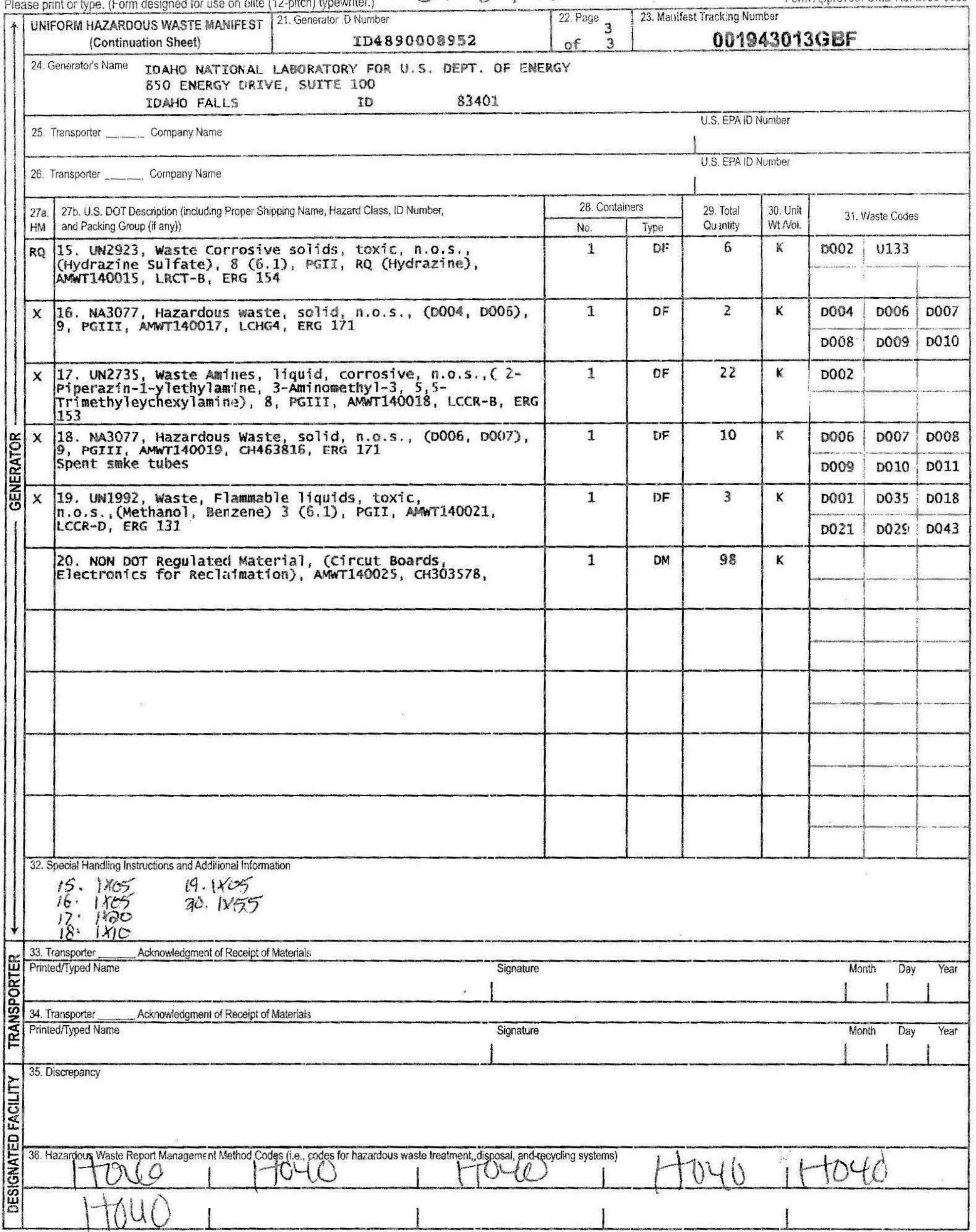




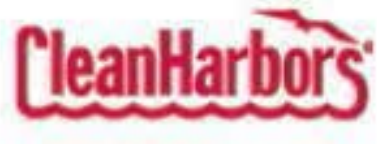
Clean Harbors Aragonite LLC
11600 North Aptus Road
Grantsville UT, 84029
UTD981552177
(435) $884-8100$

\section{CERTIFICATE OF DISPOSAL}

$\begin{array}{llll}\text { Generator F acility Name: } & \text { Idaho Treatment Group-AMWTP } & \text { Sales Order\#: } & 699247251 \\ \text { Generator Address } & 850 \text { EnergyWay } & \text { Date Received: } & 3 / 14 / 2014 \\ & \text { Ryan Johnson } & \\ & \text { Idaho Falls, ID, 83402 } & \end{array}$

Generator Contad Name:

\begin{tabular}{llll}
\hline Generator EPAID: & ID 4890008952 & Load \#: & 67336 \\
& Manifest \#: & $001943013 \mathrm{GBF}$
\end{tabular}

\begin{tabular}{|c|c|c|c|c|c|c|c|}
\hline $\begin{array}{l}\text { Original } \\
\text { CH ID \# }\end{array}$ & $\begin{array}{l}\text { Date Removed } \\
\text { From Service }\end{array}$ & $\begin{array}{l}\text { Unit } \\
\text { Type }\end{array}$ & $\begin{array}{c}\text { Serial \# i } \\
\text { Customer ID }\end{array}$ & $\begin{array}{c}\text { Material } \\
\text { Description }\end{array}$ & $\begin{array}{c}\text { Disposal } \\
\text { Date }\end{array}$ & $\begin{array}{l}\text { Method of } \\
\text { Disposal }\end{array}$ & Disposal Facility \\
\hline 36454864 & $1 / 22 / 2014$ & $\mathrm{DF}$ & AMTOUT1 $40010 /$ & $\begin{array}{l}\text { Labpack Mixed PCBs \& Rara } \\
\text { Wiaste For Incineration }\end{array}$ & $3 / 26 / 2014$ & Incineration & Aragonite, UT Facility \\
\hline
\end{tabular}

Under Civil and Crimina Penalties of Law for the making or sukmission of false or fraudulent statements or representations (18 U.S.C. 1001 and 15 U.S.C. 2615), I certify that the information contained in or acoompanying this document is true, accurate, and complete. As to the identified section(s) of this document for which I cannot personally verify truth and accuracy, I certify as the company official having supervisory responsibility for the persons who, ading under my dired instructions, made the verification that this information is true, acourate, and complete.

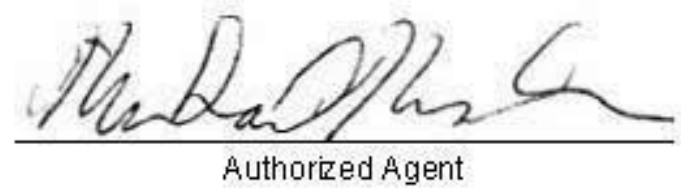

Friday, March 28, 2014

Authorized Agent

Date

Page 1 of 1 
Plêase print or type. (Form designed for use on elite (12-pitch) typewriter.)

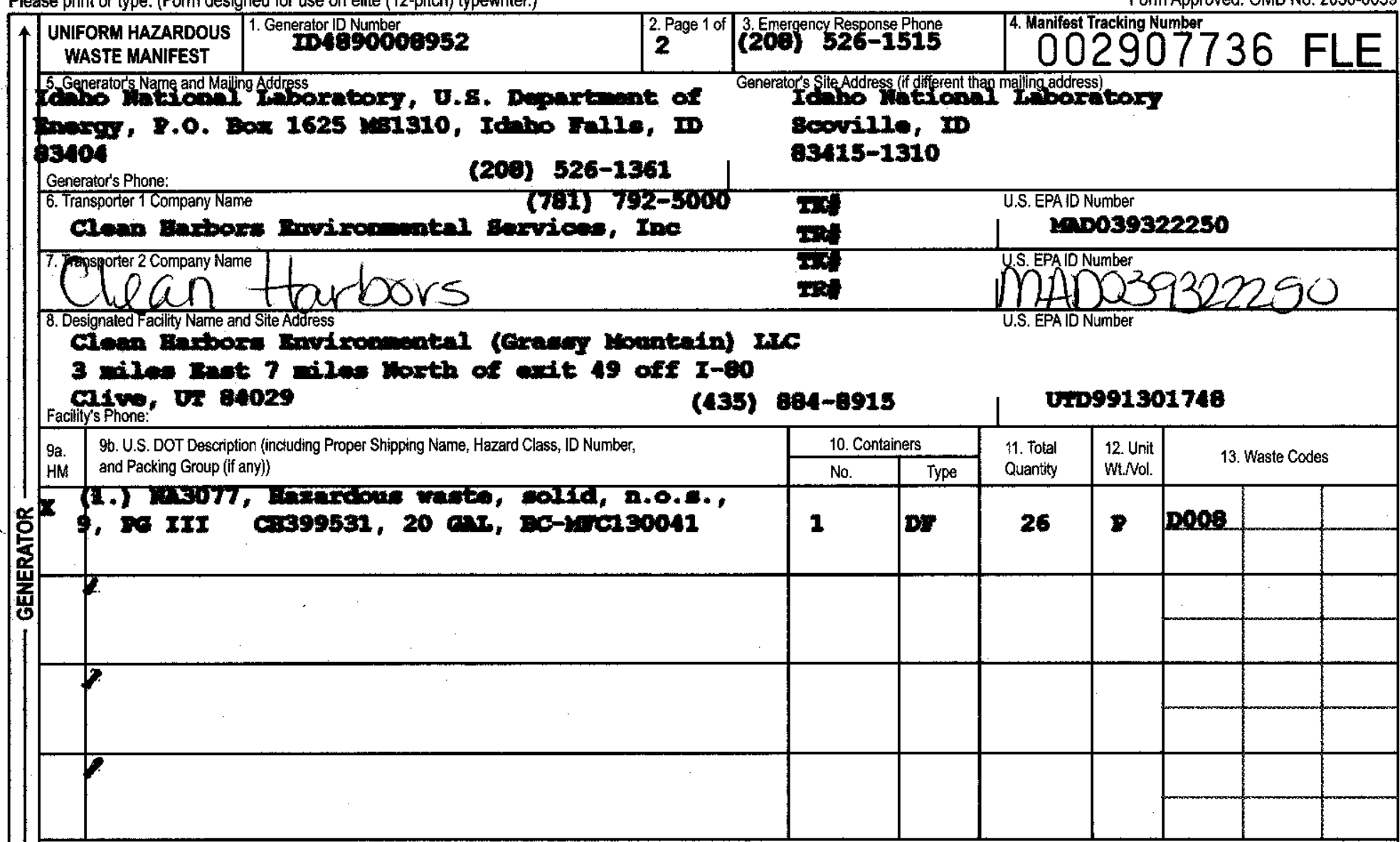

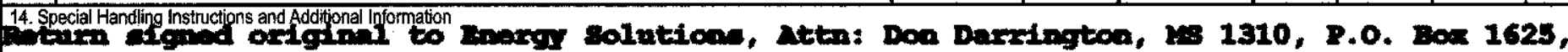

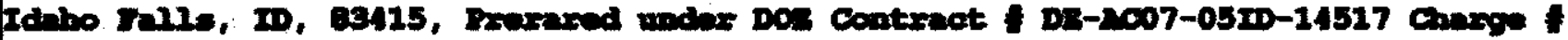

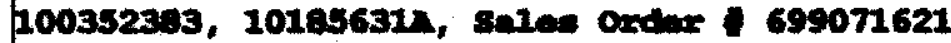

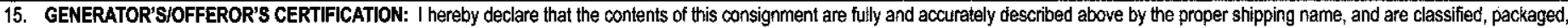
marked and labeled/placarded, and are in all respects in proper condition for transport according to applicable international and national govemmental regulations. If export shipment and I am the Primary Exporter, 1 certify that the contents of this consignment conform to the terms of the attached EPAAcknowledgment of Consent.

I certify that the waste minimization statement identified in 40 CFR 262.27(a) (if I am a large quantity generator) or (b) (bf I am a f prail quanitif onerator) is true.

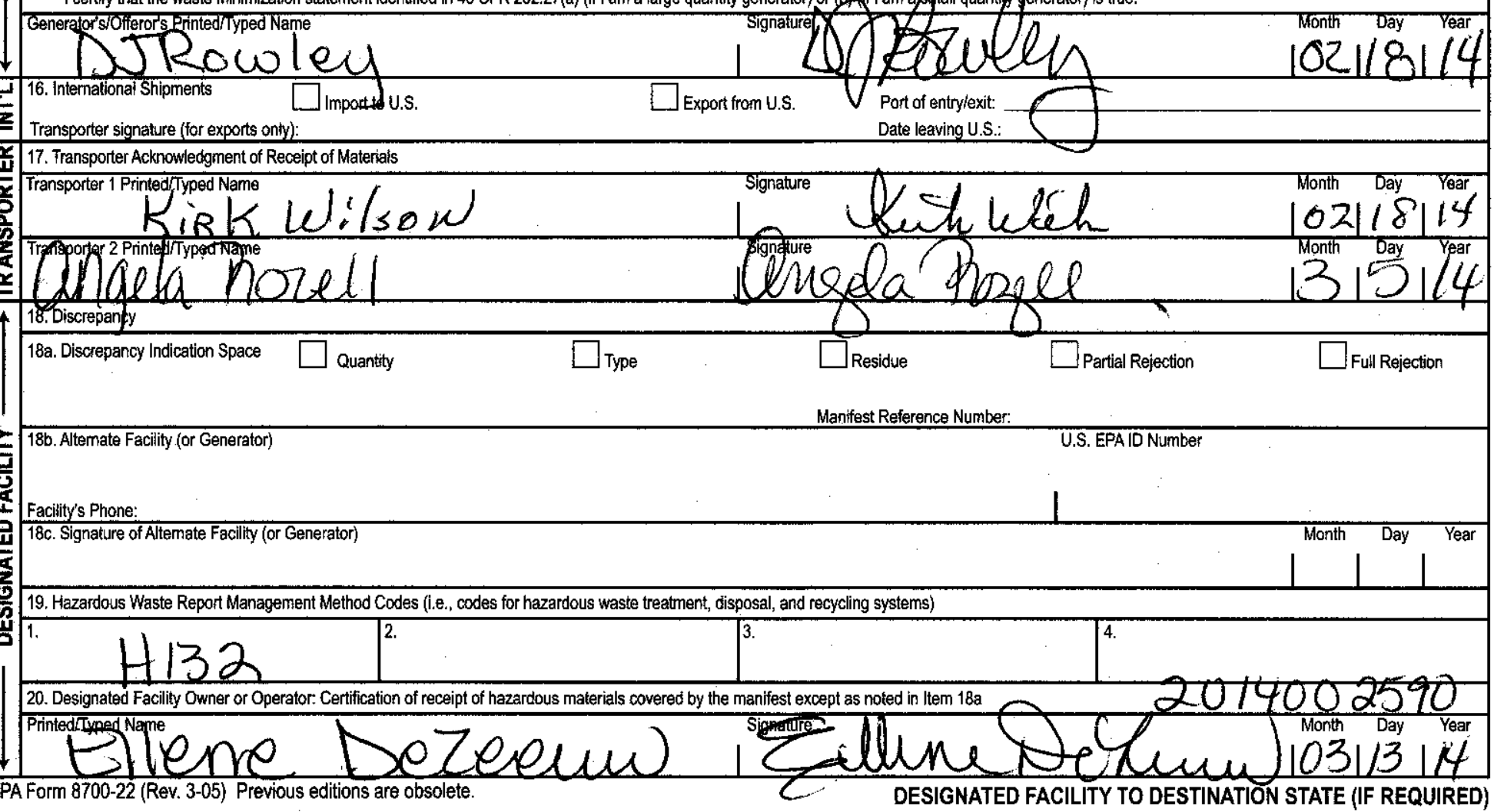




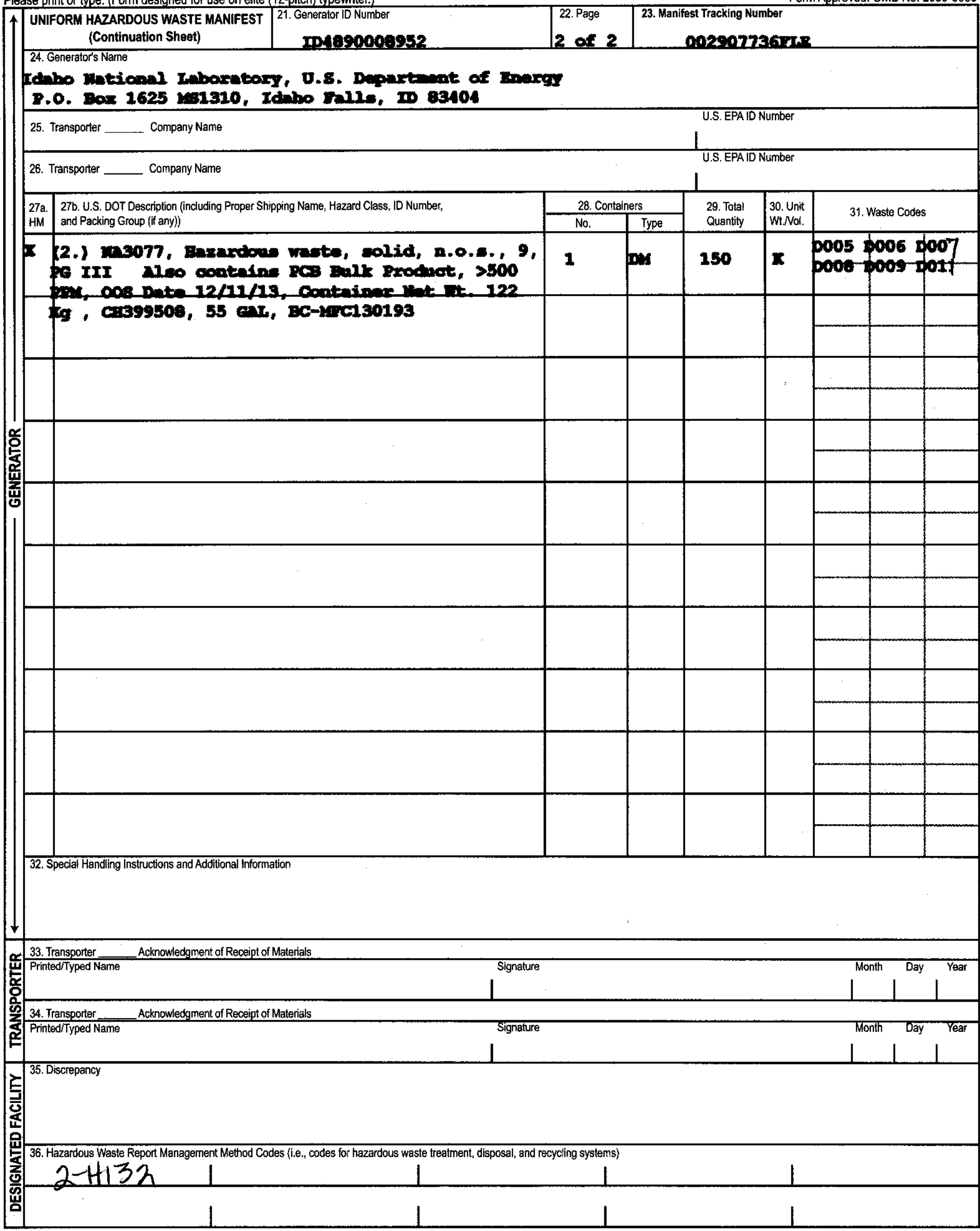


UTD991301748

(435) 884-8900

\section{CERTIFICATE OF DISPOSAL}

Generator Facility Name:

Generator Address:
INL Materials \& Fuels Complex MFC

35 Miles West of Idaho Falls via Hwy 20 west

Idaho Falls, ID, 83415
Sales Order\#:

699071622

Date Received: 3/13/2014

Generator Contact Name:

Generator EPA ID: $\quad$ ID4890008952

\section{Original Date Removed Unit Serial \# I CH ID \# From Service Type Customer ID}

36409938
$12 / 11 / 2013$

DM BC-MFC130193 /

\section{Material Description}

Tsca Debris For Microencapsulation

$\begin{array}{ll}\text { Load \#: } & 14002590 \\ \text { Manifest \#: } & \text { 002907736FLE }\end{array}$

\section{Disposal} Date

$3 / 21 / 2014$

\section{Method of} Disposal

Disposal Facility

Landfill

$$
\text { Facility }
$$

Under Civil and Criminal Penalties of Law for the making or submission of false or fraudulent statements or representations (18 U.S.C. 1001 and 15 U.S.C. 2615), I certify that the information contained in or accompanying this document is true, accurate, and complete. As to the identified section(s) of this document for which I cannot personally verify truth and accuracy, I certify as the company official having supervisory responsibility for the persons who, acting under my direct instructions, made the verification that this information is true, accurate, and complete.

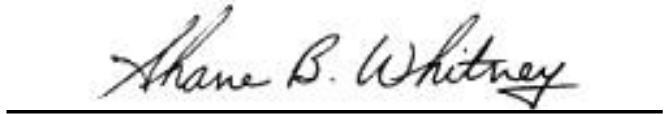

Authorized Agent
Thursday, April 17, 2014

Date 
Plèase print or type. (Form designed for use on elite (12-pitch) typewriter.)

\section{UNIFORM HAZARDOLS 1 . Generator IJ Number WASTE MANIFEST 2041390008932 \\ 5. Generator's Name and Wailing Address}

fdaho National Eaboratory, U. Departacte of

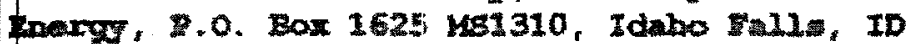
830.

neratôt's Phone:

6. Transporter 1 Company Name

$12091 \quad 26-1361$

(791) 792-5000

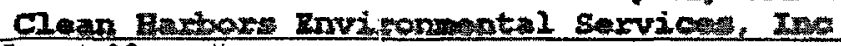

7. Tounsponter 2 Company Nam

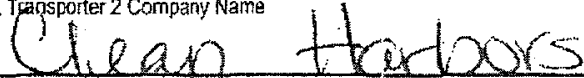

8. Designated Facility Name and Site Address

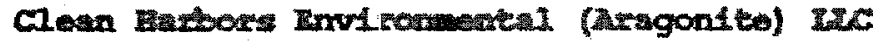

12600 Woxth aptu inoad

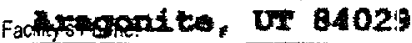

9a. 9h. U.S. DOT Description (including Proper Shipping Name, Hazard Class, ID Number,

HM and Packing Group (if any)?

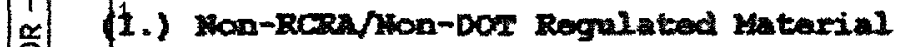

1.wo contains pcs Ballasts, 500 pat, 005 Date $9 / 4 / 13$, Containar Het it. $33 \times \mathrm{xa}$ ca400010, 10

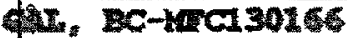

2. Page 1 of 3. Emergency Response Phone (208) $526-1515$ Generator's Site Address (if different than mai ing address'

Form: Approvec: OMB No, 2050-0039

Idaho Matesal I aloon

aecri11: 13

83415-1310

20.

\%.

(4355) $884-6100$

UTD98155:2177

\section{(4)}

14. Special Handling Instructions and Adeditional Informaticn

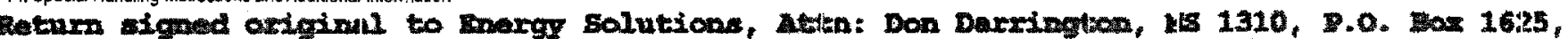

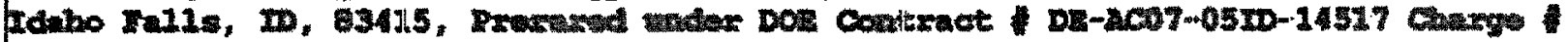

\section{0, 540157503، Sale Oxder 69071621}

15. GENERATOR'SHOFFEROR'S CERTIFICATION: I hereby declare that the contents of this consignment are fully and acourately described alove by the roper shipping name, and are classified, packiged, marked and labelediplacarded, and are in all respects in proper condifion for transpot according to applizable intemational and national govemmental re julations. If export shicment and I am the Prinany Exporier, I certify that the contents of this consignment conform to the terms of the attached EPA Acknou leadgment of Consent.

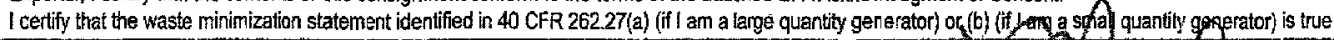

Generators offeror's Finted/lyped Namea

16. Intemational Shipments $\quad[]_{\text {mport touls }}$

Transporter signalure (for exports only):

采 17. Transporter Acknowiedgment of Receipt of Miaterials

兽

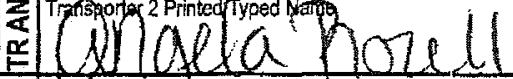

4 18. Discrepancy)

18a. Discrepancy Indication Space $\square$ Qtantity

186. Alternate Facility (cr Generator)

Export from U.S.
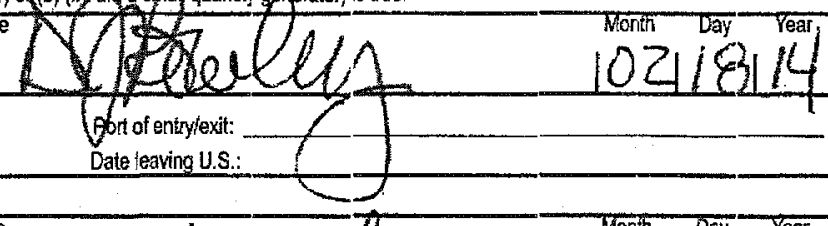

18c. Signature of Alternate Facility (or Generator I Date feaving U.S.:

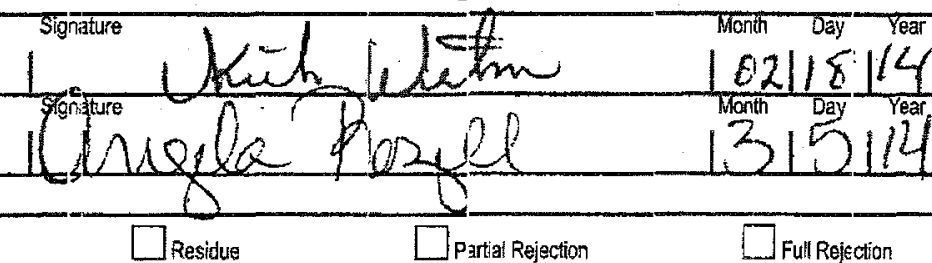

19. Hazardous Waste Report Management Meth od Codes (i.e., codes for hazardous waste treaiment, disposal, and recycling systems)

Manifest Reference Number:

20. Designated Facility Owner ar Operator: Certilication of receipt of hazardous matertals covered by the manifest except as noted in item $18 \mathrm{a}$

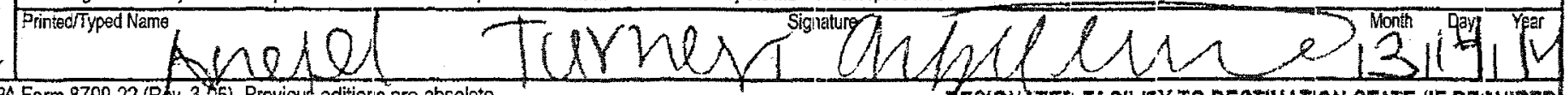


Please print or type. (Form designed for use on elite (12-pitch) tycewriter.)

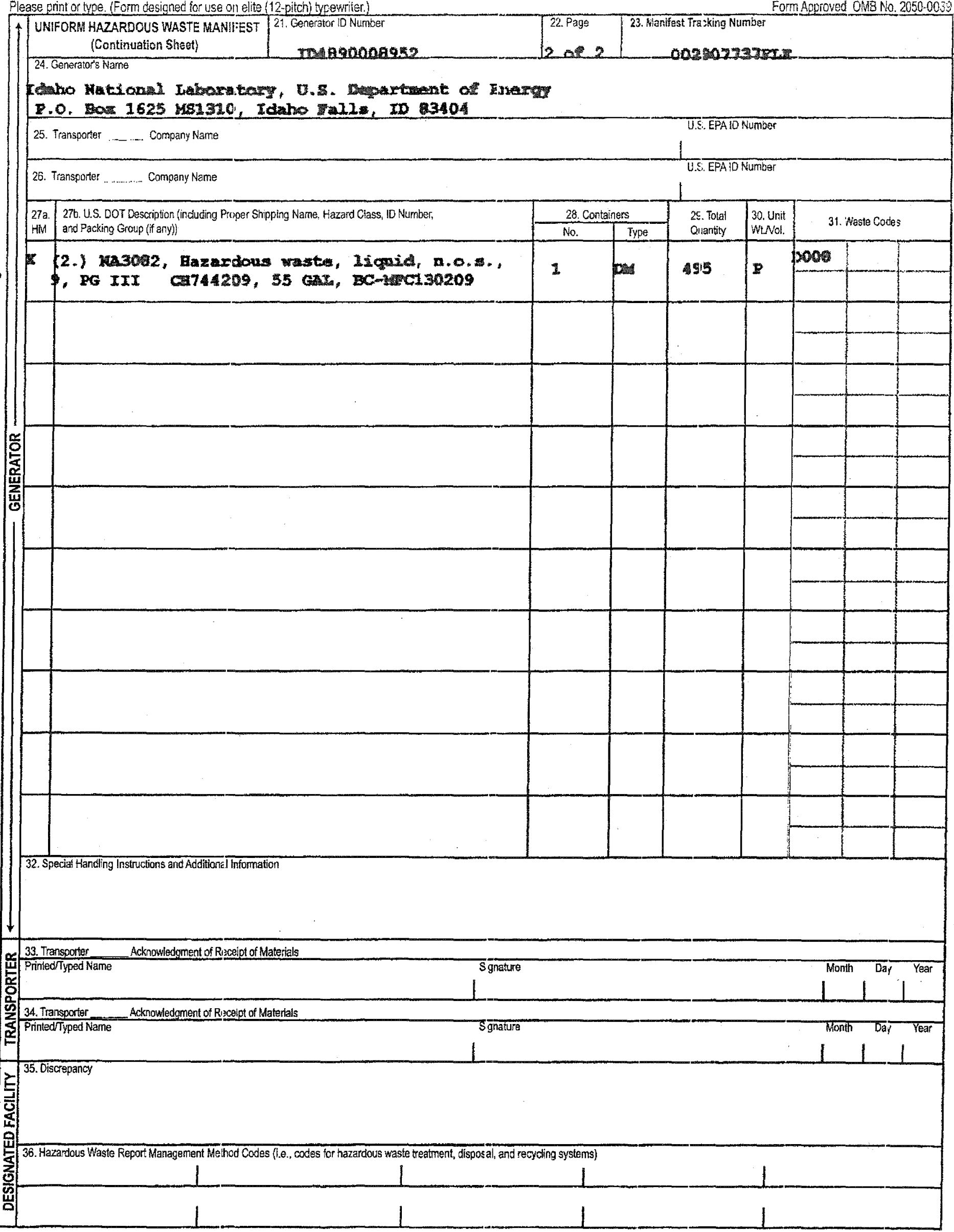


UTD981552177

(435) 884-8100

\section{CERTIFICATE OF DISPOSAL}

Generator Facility Name:

Generator Address:
INL Materials \& Fuels Complex MFC

35 Miles West of Idaho Falls via Hwy 20 west

Idaho Falls, ID, 83415
Sales Order\#: $\quad 699071622$

Date Received: 3/14/2014

Generator Contact Name:

Generator EPA ID: $\quad$ ID4890008952

$\begin{array}{ccc}\text { Original } & \text { Date Removed Unit } & \text { Serial \# I } \\ \text { CH ID \# } & \text { From Service Type } & \text { Customer ID }\end{array}$

$36401707 \quad 9 / 4 / 2013 \quad$ DM MFC130166/

\section{Material Description}

\section{Load \#: \\ Manifest \#:}

\section{6}

002907737FLE

Under Civil and Criminal Penalties of Law for the making or submission of false or fraudulent statements or representations (18 U.S.C. 1001 and 15 U.S.C. 2615), I certify that the information contained in or accompanying this document is true, accurate, and complete. As to the identified section(s) of this document for which I cannot personally verify truth and accuracy, I certify as the company official having supervisory responsibility for the persons who, acting under my direct instructions, made the verification that this information is true, accurate, and complete.

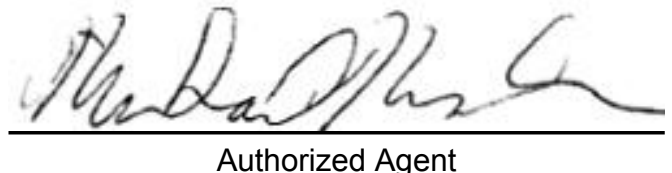

Thursday, April 10, 2014

Authorized Agent

Date 
Please print or type. (Form designed for use on elite (12-pitch) typewriter.)

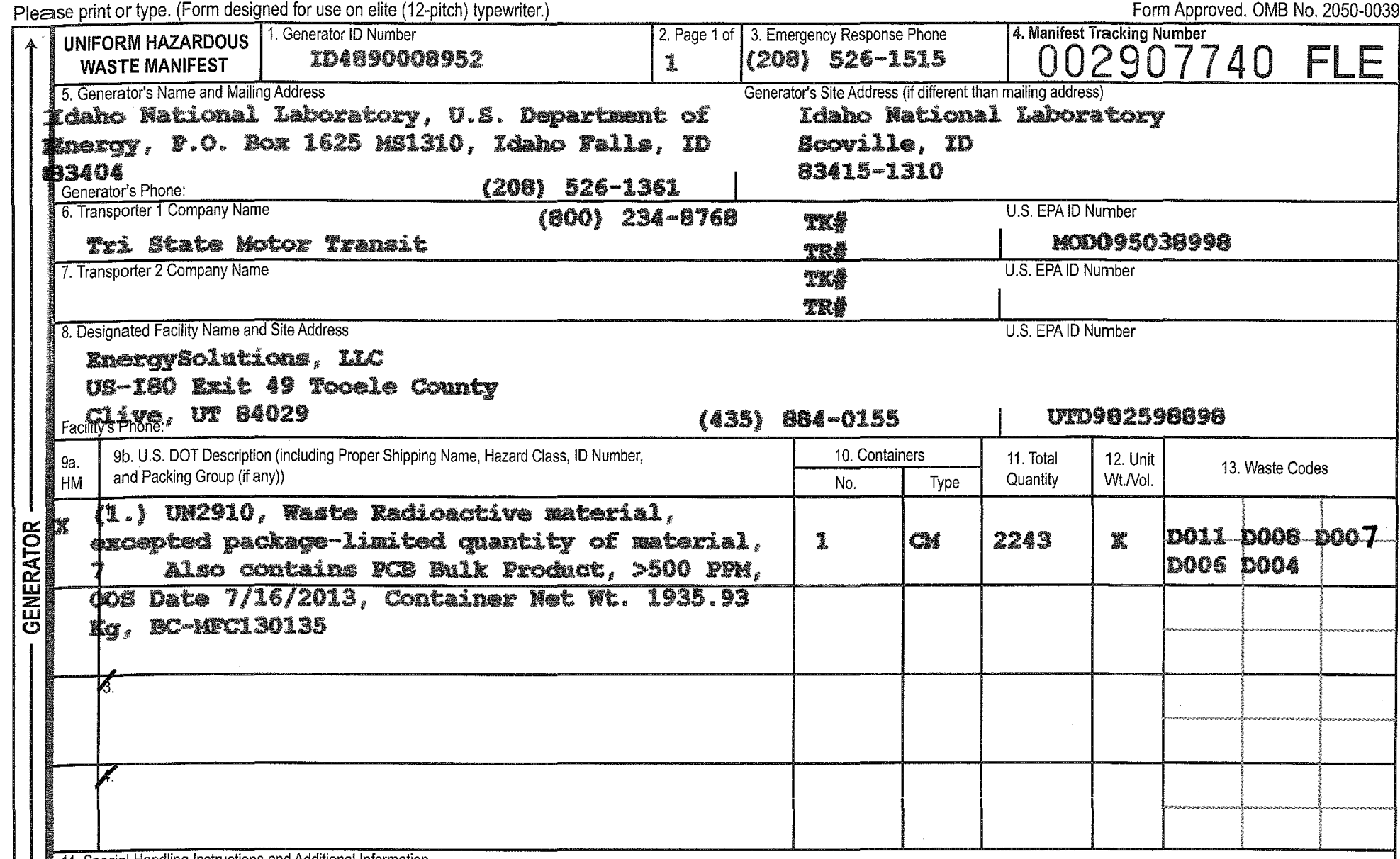

14. Special Handling Instructions and Additional Information

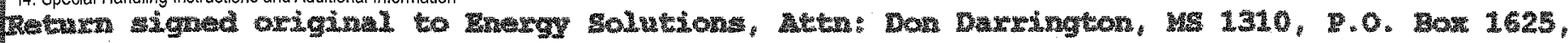

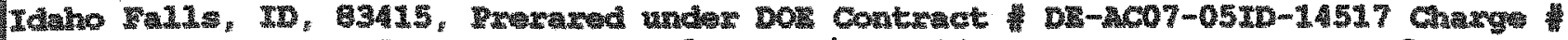

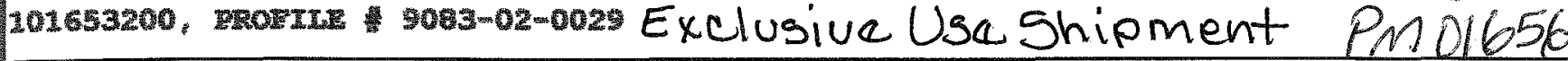

15. GENERATOR'S/OFFEROR'S CERTIFICATION: I hereby declare that the contents of this consignment are fully and accurately described above by the proper shipping name, and are classified, packaged, marked and labeled/placarded, and are in all respects in proper condition for transport according to applicable international and national governmental regulations. If export shipment and I am the Primary Exporter, I certify that the contents of this consignment conform to the terms of the attached EPAAcknowledgment of Consent.

I certify that the waste minimization statement identified in 40 CFR 262.27(a) (if I am a large quantity generator) or (b) $\mathrm{bif}$ I ama a small quantity generator) is true.

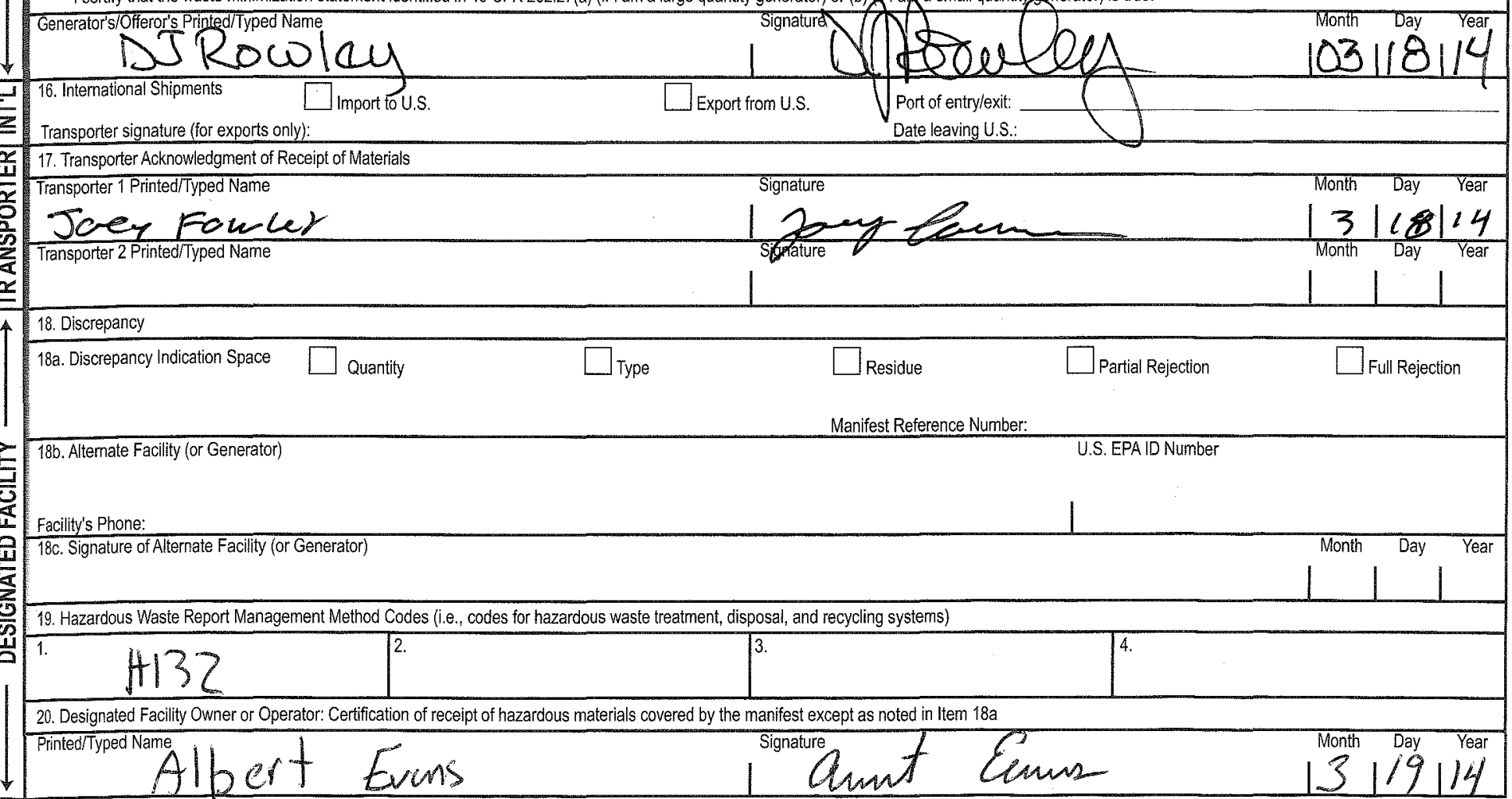




\section{ENERGYSOLUTIONS}

\section{CERTIFICATE OF DISPOSAL}

3 miles South, Exit 49, I-80

Clive, Utah 84029

EPA ID: UTD982598898

\section{BEAINL for US DOE, Idaho Falls}

This certificate acknowledges that the following manifested shipments have been disposed of as listed below:

shioment

9083-02-0029

9083-02-0030

Manifias:
07740
11381

07740

Disnesal Date
$03 / 24 / 2014$
$03 / 24 / 2014$

Process
Lendfill
Landfill

Dlsposal Lecation
Mixed Waste

Mixed Waste

The total volume above represents the cubic feet of waste disposed of at EnergySolutions' Disposal Facility Landfill. Disposal is subject to EnergySolutions' Radioactive Material License, all other applicable licenses, permits and regulations, and the Disposal Agreement.

Under civil and criminal penalttes of law for the making or submission of false or fraudulent statements or representattons (18 U.S.C 1001 and 15 U.S.C. 2615 ) । certfy that the information contained $h$ or accompanying this document is true, accurate and complete. As to the idientification section(s) of this document for which I cannot personally verify fryth-and-acquracy, I certify as the company official having supenisory responsibility for the persons who, acting under my direct instrisetions, mate the vesifiction that this intormation is true, accurate and complete.

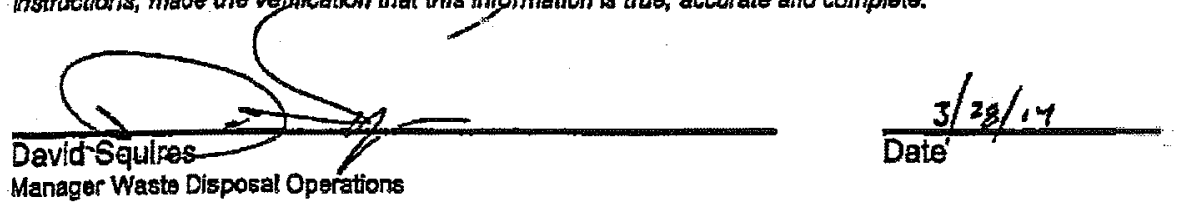

423 West 300 South, Salt Lake City, Utah 84101 Telephone (801) 649-2000 
Flease print or type. (Form dosigned for use on glite (12-pitch) typewniter.)

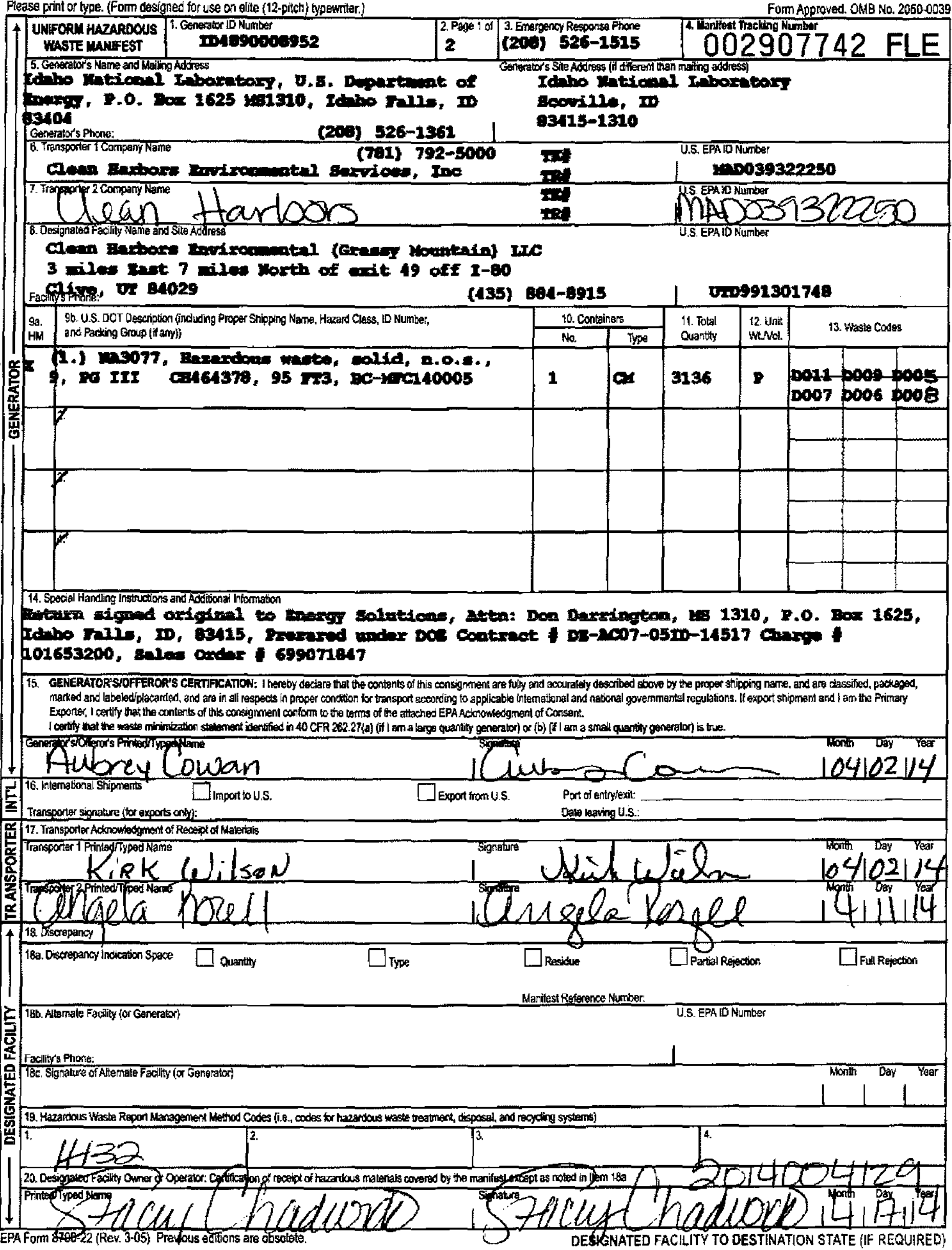


Please pint or type. (Form designed tor use on elite (12-pitchi) browriter.)

4 UNIFORM HAZARDOUS MASTE MANIFEST 21. Generator ko Number

(Continuation Sheet)

Insoporaser

Form Aporoved. OMB No. 2050.0039

24. Generalor's Name

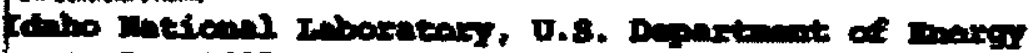

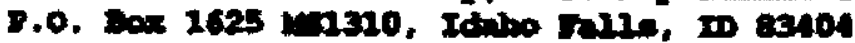

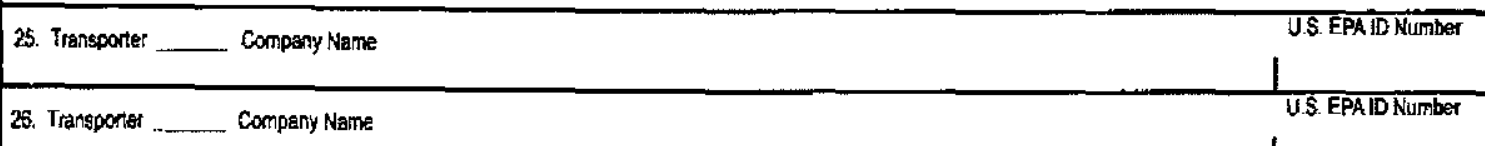

27a. 27b. U.S. DOT Description (including Proper Shipping Namo, Hazard Class, iD Number, HM End Packing Group (if any)]

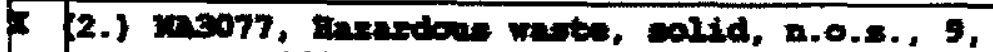
to III Con64378, 9s Fr3, be-ifalcoo6

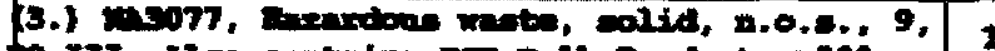

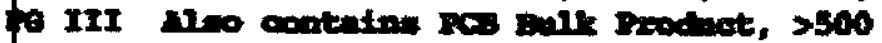

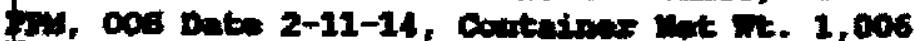

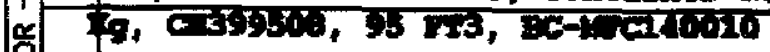

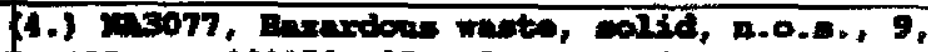

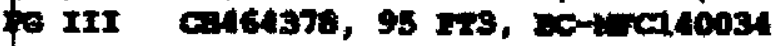

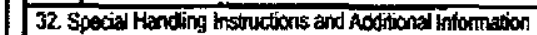

$+$

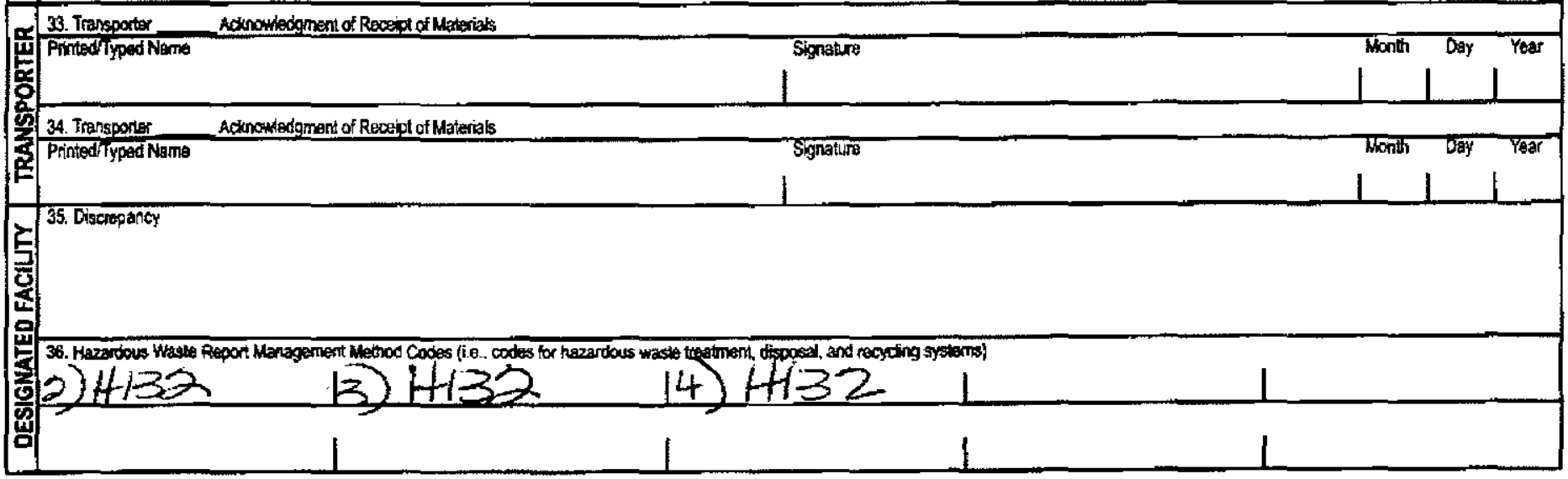




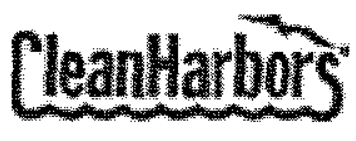

Cleantharbors'

Clean Harbors Grassy Mountain LLC

3 Miles East 7 Miles North of Knolls

Grantsville UT, 84029

UTD991301748

(435) $884-8900$

\section{CERTIFICATE OF DISPOSAL}

Generator Facility Name:

Generator Address:

Generator Contact Name:
INL Materials \& Fuels Complex MFC

35 Miles West of Idaho Falls via Hwy 20 west

Idaho Falls, ID, 83415
Sales Order\#: 699446361

Date Received: $\quad 4 / 17 / 2014$
Generator EPA ID:

Original Date Removed Unit CH ID \# From Service Type

37328700
ID4890008952

$\mathrm{CM}$
Customer ID

MFC $140010 /$

\section{Material Description}

Tsca Debris For Microencapsulation

$\begin{array}{ll}\text { Load \#: } & 14004129 \\ \text { Manifest \#: } & \text { 002907742FLE }\end{array}$

Disposal Method of Date Disposal

Disposal Facility

4/22/2014 Landfill

Under Civil and Criminal Penalties of Law for the making or submission of false or fraudulent statements or representations (18 U.S.C. 1001 and 15 U.S.C. 2615), I certify that the information contained in or accompanying this document is true, accurate, and complete. As to the identified section(s) of this document for which I cannot personaly verify truth and accuracy, I certify as the company official having supervisory. responsibility for the persons who, acting under my direct instructions, made the verification that this information is true, accurate, and complete.

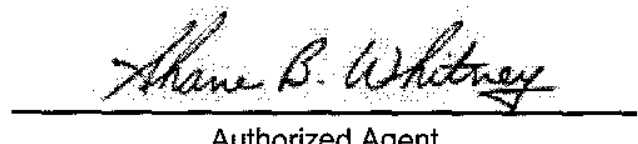

Authorized Agent
Tuesday, May 20, 2014

Date 


$$
47006 / 448200
$$

Please print or type. (Form designed for use on elite (12-pitch) ypewriter.)

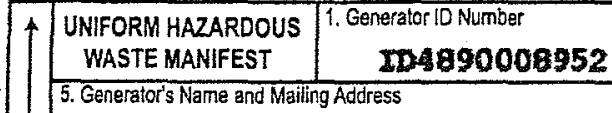

fdabo Kational Inboratory, 0.8. Depaxtuent of

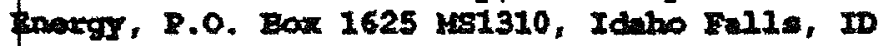

G3epertors Phone:

6. Transporter 1 Company Name

Tri state wotor inanit

Troos ongen AVC 83204

Pocatello, ID 8340\% RonLorenz

8 Designaied Facility Name and Site Address Due

Bnoxglsolutione, IIC $\$ / 9 / 14$

US-I80 l-it 49 toosle county

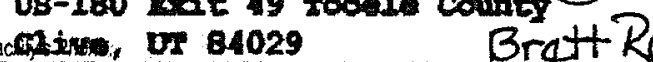

(209) $526-1961$

(800) $234-8768$

97 96 U.S. DOT Description (including Proper Shipping Name, Hazard Class, ID Nunber،

HM and Packng Group (ff any))

$<$

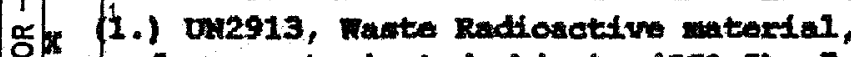

quifice contaminated object (BCO-I), 7,

$1 n-239$ \&n-90 pu-238 co-137. nolid ortde

1.820I-05 tBa 12 so contains PCa Bulk product,

50 PIX, cos Date 6-12-14, Container Het Nt.

535 Ige, BC-BH+12-10

5 .

r

4

14 Special. Handling Instructions and Addifional Infermation

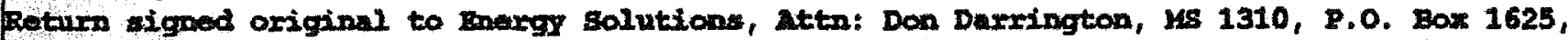

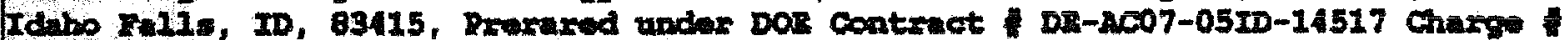
101856386, 530226210, Profile 9083-02-0031

EXCIUSIVE USE SHIPMENT PMOL689

5. GENERATOR'SIOFFEROR'S CERTIFICATION: I hereby dectare that the contents of this consignnent are fully and accuralejy described above by the proper shipoing name, and are classified, pack8ged, makiked and tabelediplacarded, and are in all respecis in proper conditon for transport according to applicable intemalional and national governmental regulations. If export shipment and I am the Primary Expotter, I certify that the contents of this consignment contorm to the terms of the attached EPAAcknowledgment of Consent.

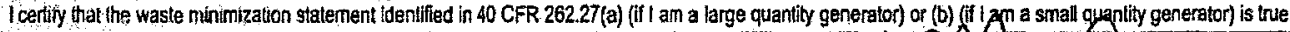

\section{CTROCOLley}

Transporter signature (for exports only):

Import to U.S

17. Transporter Acknowledgmenl of Receipl of Materials

Fref thotmeister

Transporter 2 Printedityped Name

18. Discrepancy

18a. Discrepancy Indication Space $\square$ Quantily

$\square$ Type

$\square_{\text {Residue }}$

$\square$ Partial Rejection

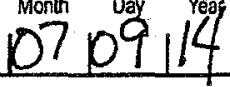

Export from U.S

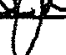

Port of entrylexit: Date leaving U.S.

Idabo Iational Iaboratory

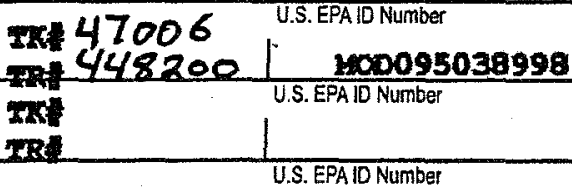

UTD982598898

\begin{tabular}{|c|c|c|}
\hline 11. Total & 12. Unit & 13. Waste Codes \\
Quentiby & Wt Nol & .
\end{tabular}

2727 $\quad$ :

$727-15-14$

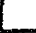

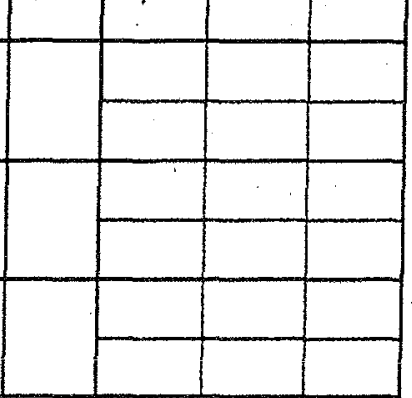

(1)

486. Altemale Facility (or Generalor)

Manifest Relerence Number.

Facility's Phone:

18c. Signature of Altemate Facility (or Generator)

9. Hazardous Waste Report Managemen! Method Codes (i,e, codes for hazardous waste trealment, disposal, and recycing systems)

$1+132$

2.

$\int^{3 .} * 4$.

20. Designated facility Owner or Operator: Certification of receipt of hazardous malerials covered by the manifest except as noled in liem 18 a

Printediryoed Name Signature

172

U.S. EPA ID Number

- Thomas ulaight

EPA Form 8700-22 (Rev. 3.05) Filevious editions are obsolete. 
Please print or type. (Form designed for use on elite (12-pitch) typewriter.)

UNIFORM HAZARDOUS WASTE MANIFEST 21. Generator ID Number (Continuation Sheet)

ID4890008952

22. Page

$\begin{array}{lll}2 & \text { of } 2 & 002907759 \mathrm{FLE}\end{array}$

24.Generator'same

2.0. Box 1625 M81310, Idaho Fils, ID 83404

\begin{tabular}{|l|l|l|l|}
\hline 25. Transporter & Company Name & U.S. EPAID Number \\
\hline 26. Transponter _ Company Name & U.S. EPA ID Number
\end{tabular}

(1)

27a. 27b. U.S. DOT Description (including Proper Shipping Name, Hazard Class, ID Number,

HM and Packing Group (ff any))

12.) uk2913, Nant Radionctive Matorial, burface contaminated objects (sco-I), 7, Ru-239

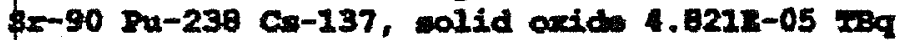

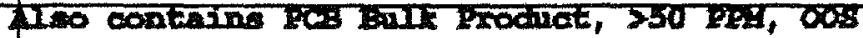
Dat 6-12-14, Contwinax Het wt. $4535.92 \mathrm{kgs}$. , BC-BMR-9

(3.) U13321, wast Radionctive metrial, low

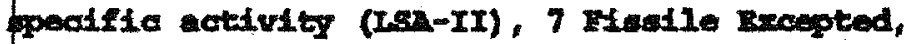
L-211 8x-90 pu-239 Cs-137 Co-144, wolid axida

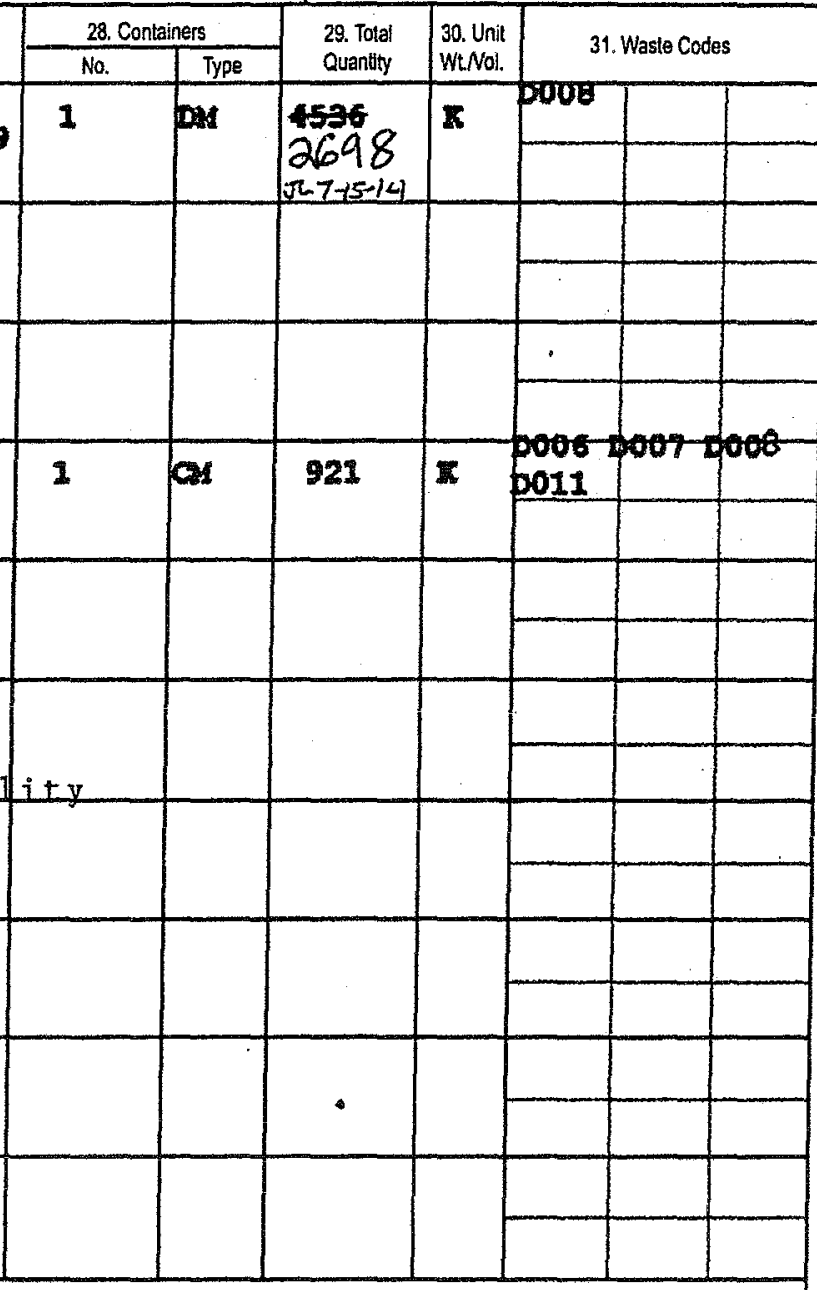

32. Special Handling Instructions and Additional Information

50 ppar, cos dite 6-3-14, container liet Wt.

\$10.54 Igs, Miso contrins Asentos Material,

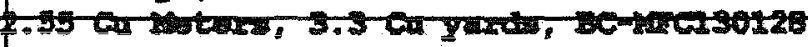

NESHAP Program Administrator:

Ida of Enironmental Qula ity 1410 North Hilton

Boise, ID 83706

33. Transponter Acknowledgment of Receipl of Materials

wi Printed/Typed Name 


\section{ENERGYSOLUTTONS}

\section{CERTIFICATE OF DISPOSAL}

3 miles South, Exit 49. I-80

Clive, Utah 84029

EPA ID: UTD982598898

\section{BEAINL for US DOE, Idaho Falls}

This certifcate acknowledges that the following manifested shipments have been disposed of as listed below:

Shipment 0083-01-0037

9083-01-0038

9083-02-0031

$9083-02-0032$

\section{Manifest}

09476

11307

07759

41398

Disnosal Date
$07 / 21 / 2014$
$07 / 21 / 2014$
$07 / 21 / 2014$
$07 / 21 / 2014$

Process
Landfill
Landfill
Landfill
Landfill

\section{Depasal Location}

Mixed Waste

Mixed Waste

Mixed Waste

Mixed Waste

The total volume above represents the cubic feet of waste disposed of at EnergySolutions' Dlsposal Facility Landfill. Disposal is subject to EnergySolutions' Radioactive Material License, all other applicable licenses, permits and regulations, and the Disposal Agreement.

Under cWil and criminal penaitibs of law for the meking or submission of false or fraudulent statements or representations (18 U.S.C 1001 and 15 U.S.C. 2615) I certhy that the information contained in or accompanying this document is irue, accurate and complete. As to the identification section(s) of this document for which I cannot personaly verify truth and accuracy. I certify as the company offteial having supervisary responsibility for the persons who, acting under my direct instructions, made the verification that this information is thes, eccurate and complete.

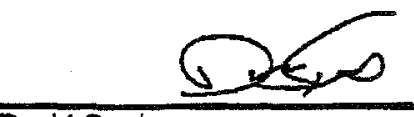

Duve Squirize

Mmingr Wrate Ditposal Operations

Sul 242014 10:10 AM

David Squires

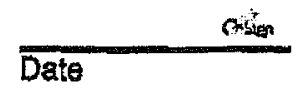

Maneger Waste Disposal Operations 
Please print or type. (Form designed for use on vilite (12-pitch) typewiter.)

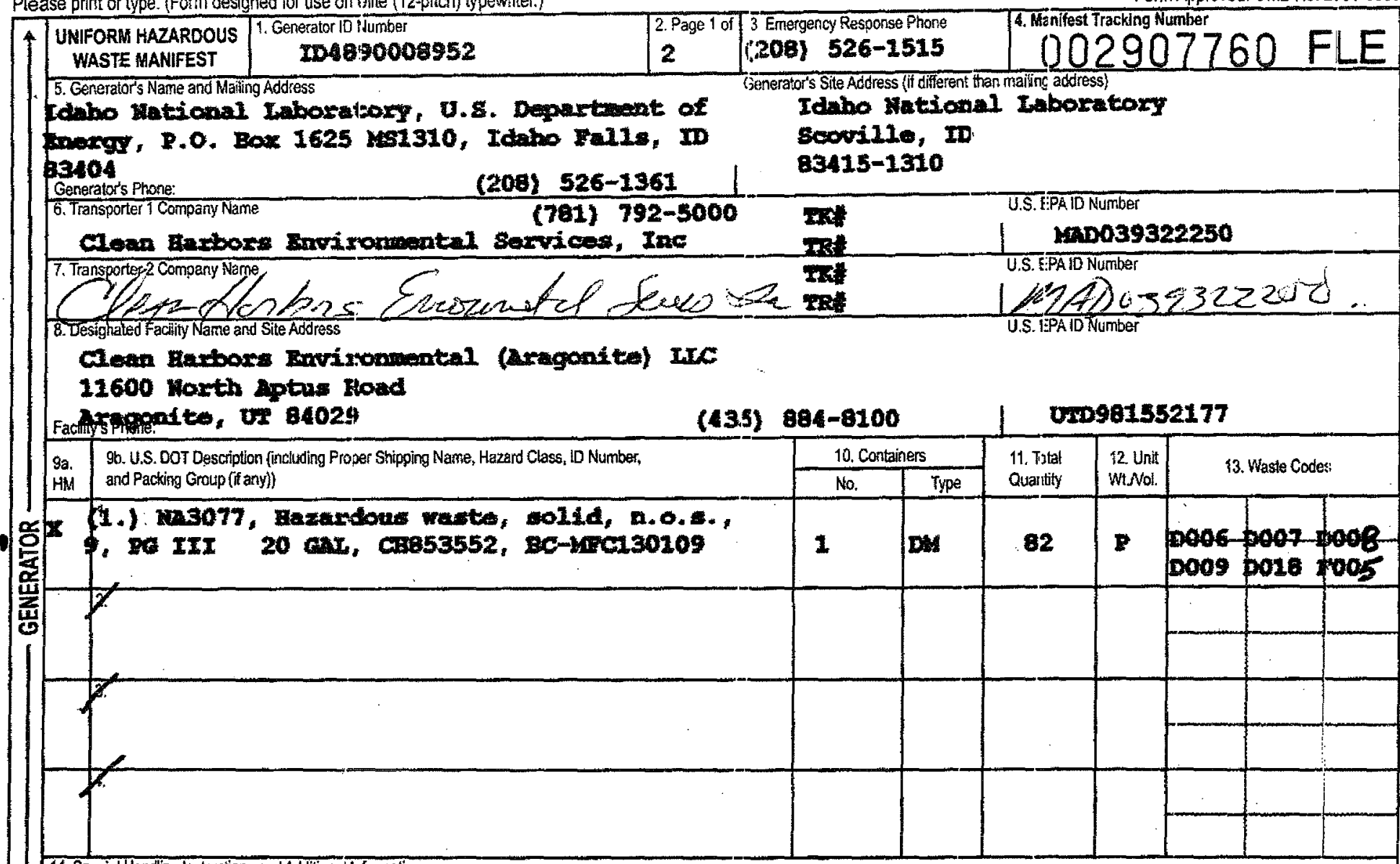

14. Special Handling Instructions and Additional Information

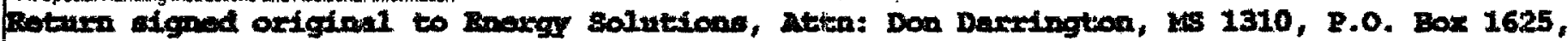

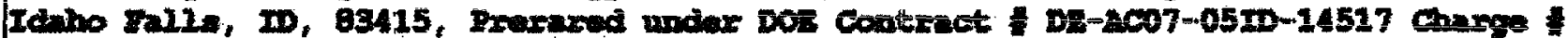

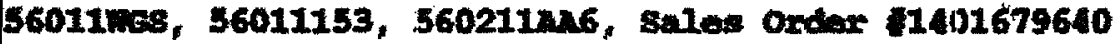

15. GENERATOR'SIOFFEROR'S CERTIFICATION: I hereby declare that the contents of this consignment are fully and acuurately described above by the proper sthipping name, and are classified, packaged, marked and labeled/placarded, and are in all respects in proper condition for transport according to applicjolo intemational and national govertmental regulations. If export shipment and I am the Primary Exporter, 1 certify that the contents of this sonsignment conform to the terms of the attached EPAAcknovitedgment of Consent.

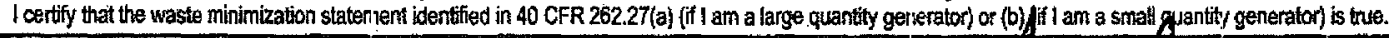

Generator's Ofters's Printed typed. Name

M. Anderson

17. Transporter Acknowiedgnent of Receipt of hlaterials

Trassporter 1 Printed Typed Nam

KiR KWU: Sou

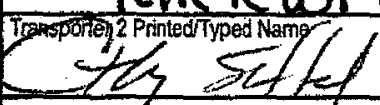

18. Discrepand

18a. Discrepancy Indication Space $\square$ Quantity

$\sqrt{2}$
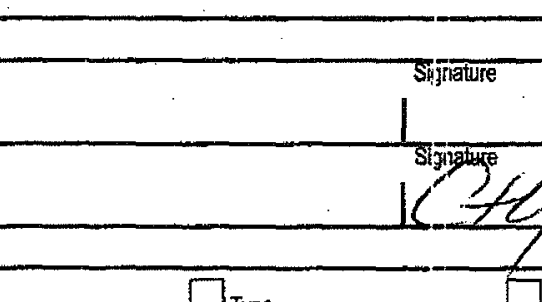

Date leaving U.S.

18b. Alternate Facillyy (or Generator)

Manifest Reference Numbe:

Facility's Phone:

18c. Signature of Altemate Facility (or Generator)

$\square$ Type

$\square$ Residue

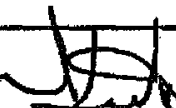

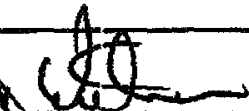

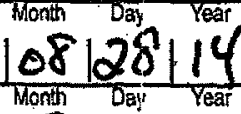

19. Hazardous Waste Raport Management Mathod Codes (i.e., codes for hazardous waste treatment, disposal, and recycling systems)
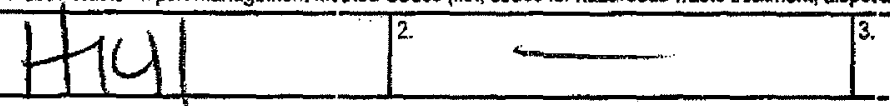

3.

20. Designated Facility Ownet or Operator. Certification of receipt of hazardous materials covered by the ma ifest except as noted in ltem 18 a<smiles>C1CCCCCC1</smiles>

(1)

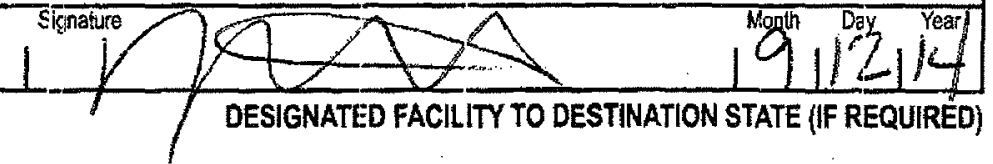




\section{CERTIFICATE OF DISPOSAL}

Generator Facility Name:
Generator Address:

Generator Contact Name:
INL Materials \& Fuels Complex MFC

35 Miles West of Idaho Falls via Hwy 20 west

Idaho Falls, ID, 83415
Sales Order\#: $\quad 1401679640$

Date Received: $\quad 9 / 12 / 2014$

\begin{tabular}{|c|c|c|c|c|c|c|c|}
\hline \multirow{2}{*}{\multicolumn{2}{|c|}{ Generator EPA ID: }} & \multirow{2}{*}{\multicolumn{2}{|c|}{ ID4890008952 }} & & \multicolumn{2}{|c|}{ Load \#: } & 69611 \\
\hline & & & & & Mar & t\#: & 7760FLE \\
\hline $\begin{array}{l}\text { Original } \\
\mathrm{CH} \text { ID \# }\end{array}$ & $\begin{array}{l}\text { Date Removed } \\
\text { From Service }\end{array}$ & $\begin{array}{l}\text { Unit } \\
\text { Type }\end{array}$ & $\begin{array}{c}\text { Serial \# I } \\
\text { Customer ID }\end{array}$ & $\begin{array}{c}\text { Material } \\
\text { Description }\end{array}$ & $\begin{array}{c}\text { Disposal } \\
\text { Date }\end{array}$ & $\begin{array}{l}\text { Method of } \\
\text { Disposal }\end{array}$ & Disposal Facility \\
\hline 40384944 & $1 / 28 / 2014$ & DM & mfc140007! & PCB Solids For Incineration & $9 / 30 / 2014$ & Incineration & Aragonite, UT Facility \\
\hline
\end{tabular}

Under Civil and Criminal Penalties of Law for the making or submission of false or fraudulent statements or representations (18 U.S.C. 1001 and 15 U.S.C. 2615), I certify that the information contained in or accompanying this document is true, accurate, and complete. As to the identified section(s) of this document for which I cannot personally verify truth and accuracy, I certify as the company official having supervisory responsibility for the persons who, acting under my direct instructions, made the verification that this information is true, accurate, and complete.

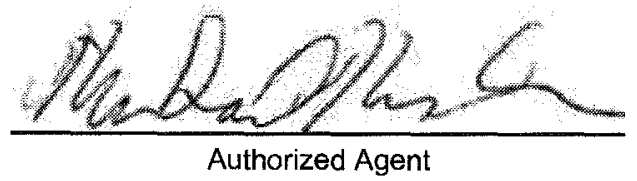

Friday, October 10, 2014

Authorized Agent 
Please print or type. (Fom designed for use an eirte (12-pitch) typentiter.)

$$
6532
$$

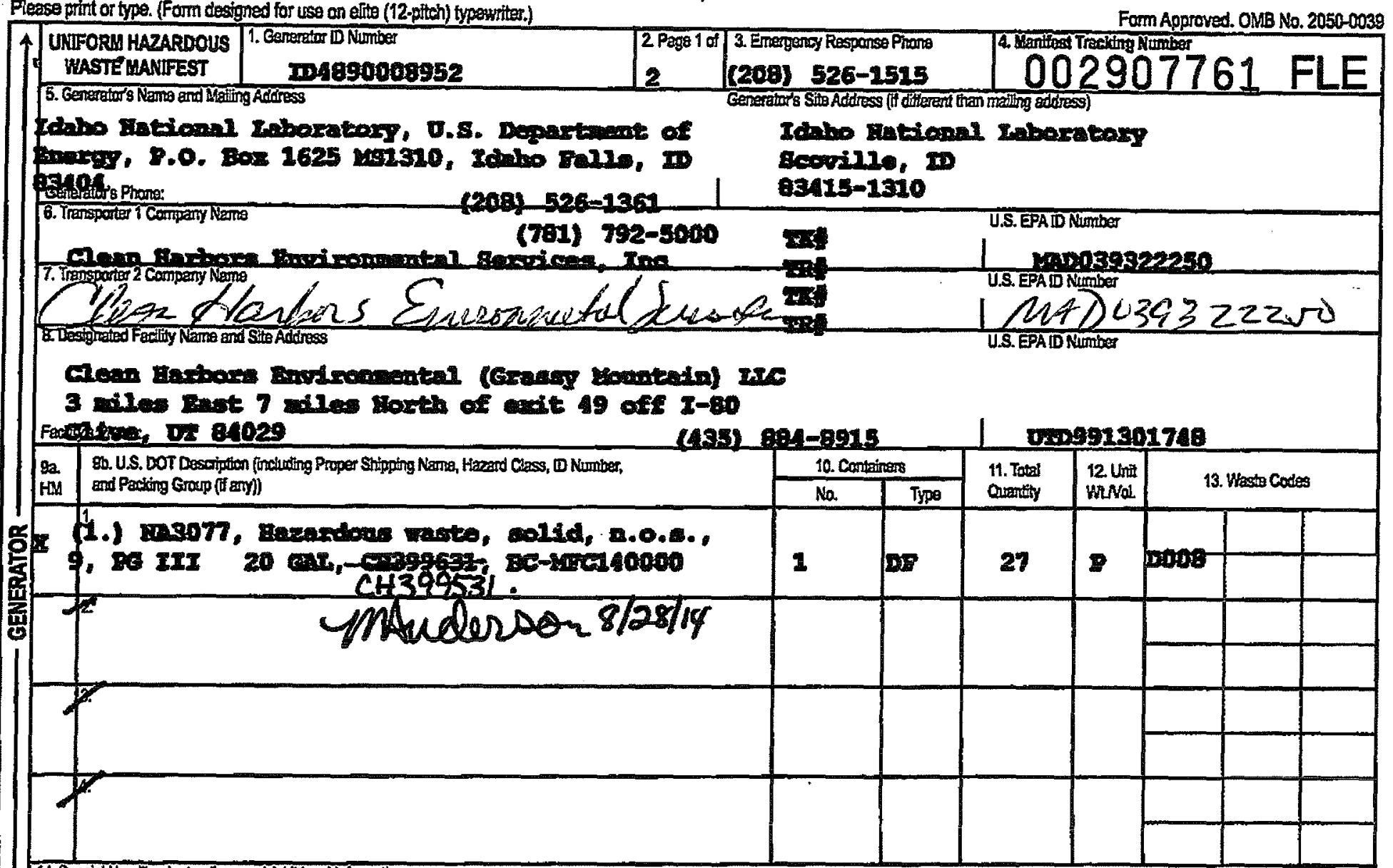

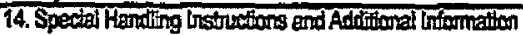

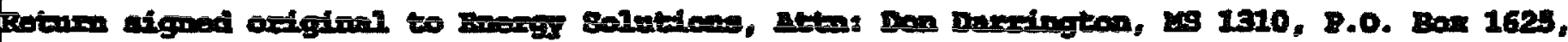

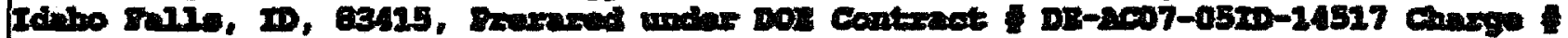

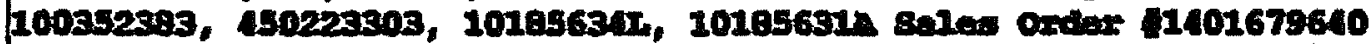

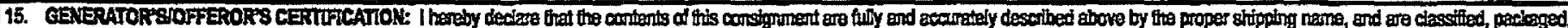

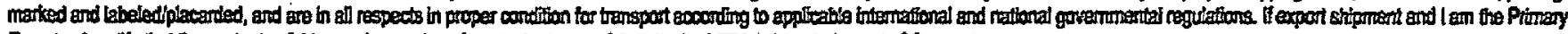

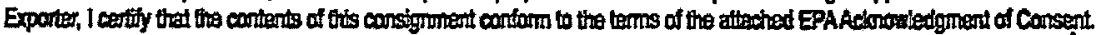

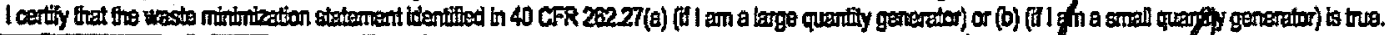

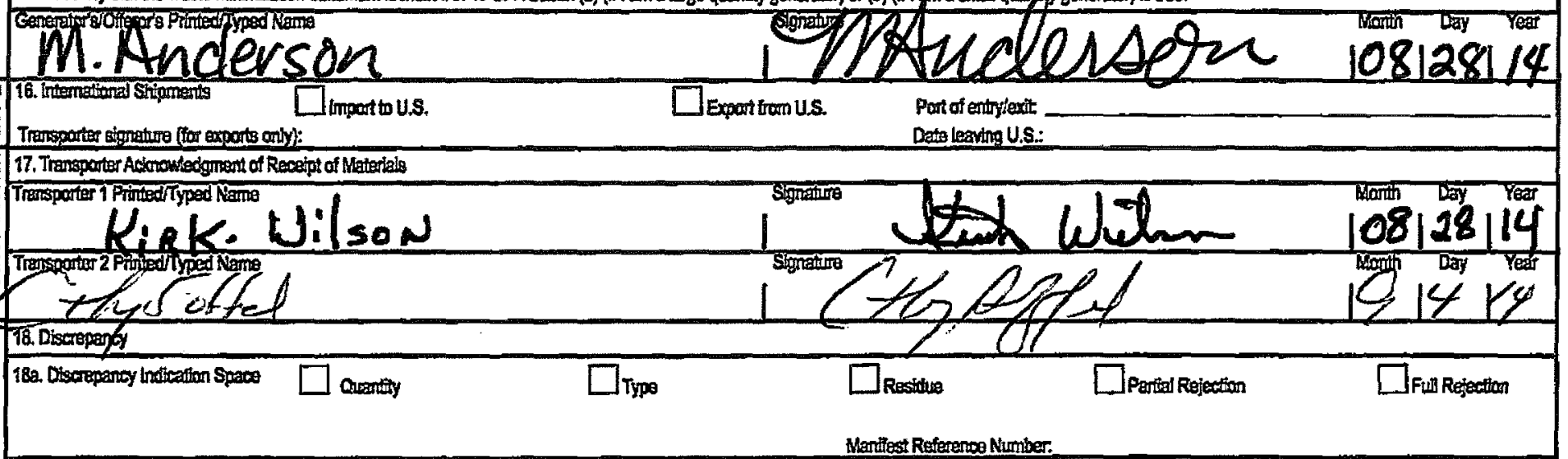

186. Atramate Fecelity (or Centerator)

U.S. EPAD Number

Fecility Prons:

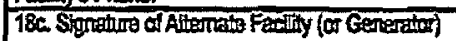

1

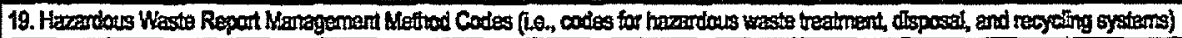

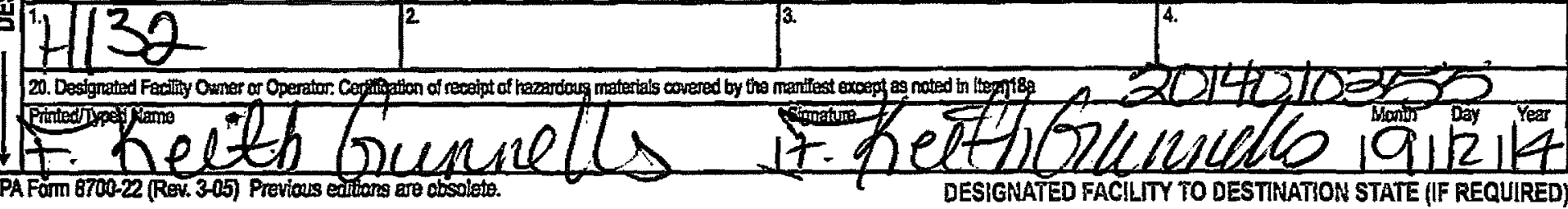

EPA Fơm 8700-22 (Rov. 305) Previous exitions are chsolete. 
Please urint or type. (Form designed for use on efite (12-pitch) typewiter)

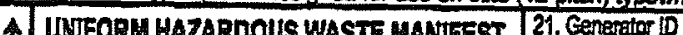

(Continuation Sheat)

ma890009gse

24. Generaters Name

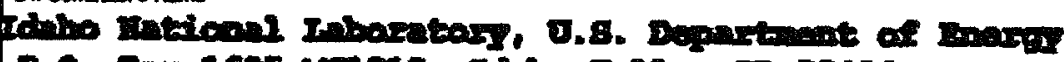

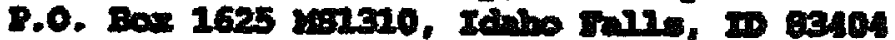
25. Trensporter
Compeny Nams
U.S. EPAD Number
28. Thansperter
Conngany Name
J.S. EPA DNomber

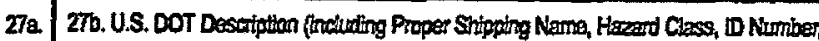

HM and Packing Group (iI ary)

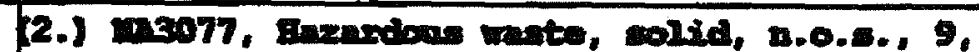

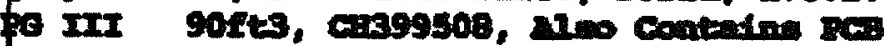

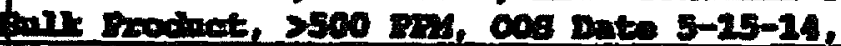

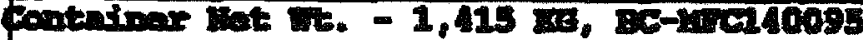

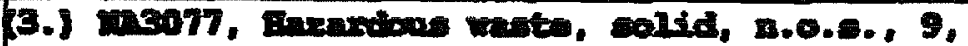

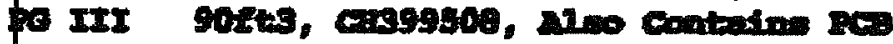

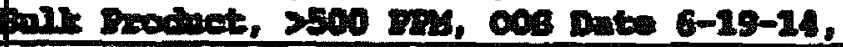

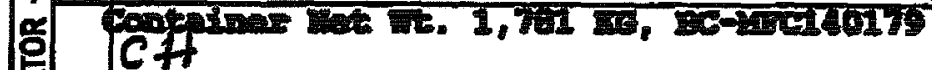

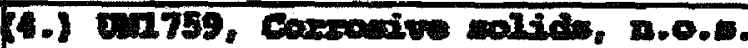

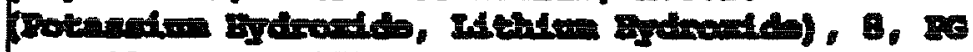

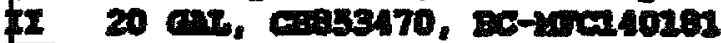

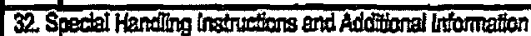

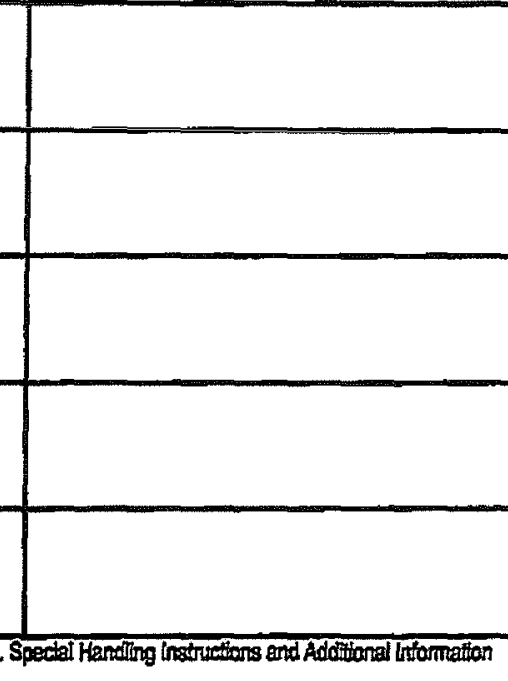

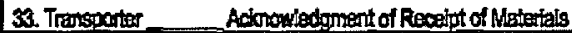


Grantsville UT, 84029

UTD991301748

(435) $884-8900$

\section{CERTIFICATE OF DISPOSAL}

Generator Facility Name:

Generator Address:

Generator Contact Name:
INL Materials \& Fuels Complex MFC

35 Miles West of Idaho Falls via Hwy 20 west

Idaho Falls, ID, 83415
Sales Order\#: $\quad 1401679640$

Date Received: $\quad 9 / 12 / 2014$
Generator EPA ID: CH ID \#

40384763
ID4890008952

Serial \# I Customer ID

CM BC-MFC140095/
$5 / 15 / 2014$

\section{Material Description}

Tsca Debris For Macroencapsulation

\section{Load \#:}

14010355

Manifest \#: $002907761 \mathrm{FLE}$

Under Civil and Criminal Penalties of Law for the making or submission of false or fraudulent statements or representations (18 U.S.C. 1001 and 15 U.S.C. 2615), I certify that the information contained in or accompanying this document is true, accurate, and complete. As to the identified section(s) of this document for which I cannot personally verify truth and accuracy, I certify as the company official having supervisory responsibility for the persons who, acting under my direct instructions, made the verification that this information is true, accurate, and complete.

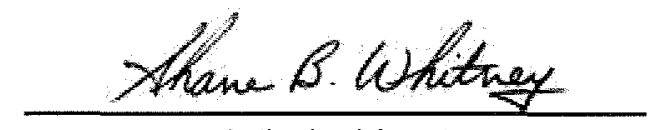

Authorized Agent
Thursday, September 25, 2014

Date 


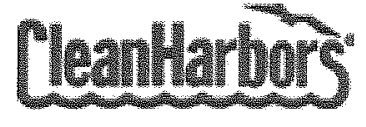

Generator Address:

INL Materials \& Fuels Complex MFC

35 Miles West of Idaho Falls via Hwy 20 west

Idaho Falls, ID, 83415
Clean Harbors Grassy Mountain LLC

3 Miles East 7 Miles North of Knolls

Grantsville UT, 84029

UTD991301748

(435) $884-8900$

\section{CERTIFICATE OF DISPOSAL}

Generator Contact Name:

Generator EPA ID:
ID4890008952

\section{Original Date Removed Unit Serial \# I CH ID \# From Service Type Customer ID}

40384764
CM BC-MFC140179/
Tsca Debris For Macroencapsulation
Sales Order\#:
1401679640
Date Received:
$9 / 12 / 2014$

Under Civil and Criminal Penalties of Law for the making or submission of false or fraudulent statements or representations (18 U.S.C. 1001 and 15 U.S.C. 2615), I certify that the information contained in or accompanying this document is true, accurate, and complete. As to the identified section(s) of this document for which I cannot personally verify truth and accuracy, I certify as the company official having supervisory responsibility for the persons who, acting under my direct instructions, made the verification that this information is true, accurate, and complete.

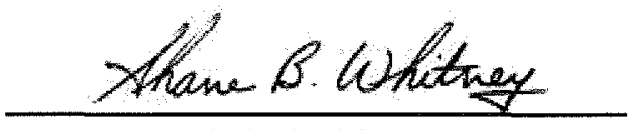

Authorized Agent
Thursday, September 25, 2014

Date 
Please print or type. (Form designed for use on elite (12-pitch) typewriter.)

$$
\text { Trailer } 532658
$$

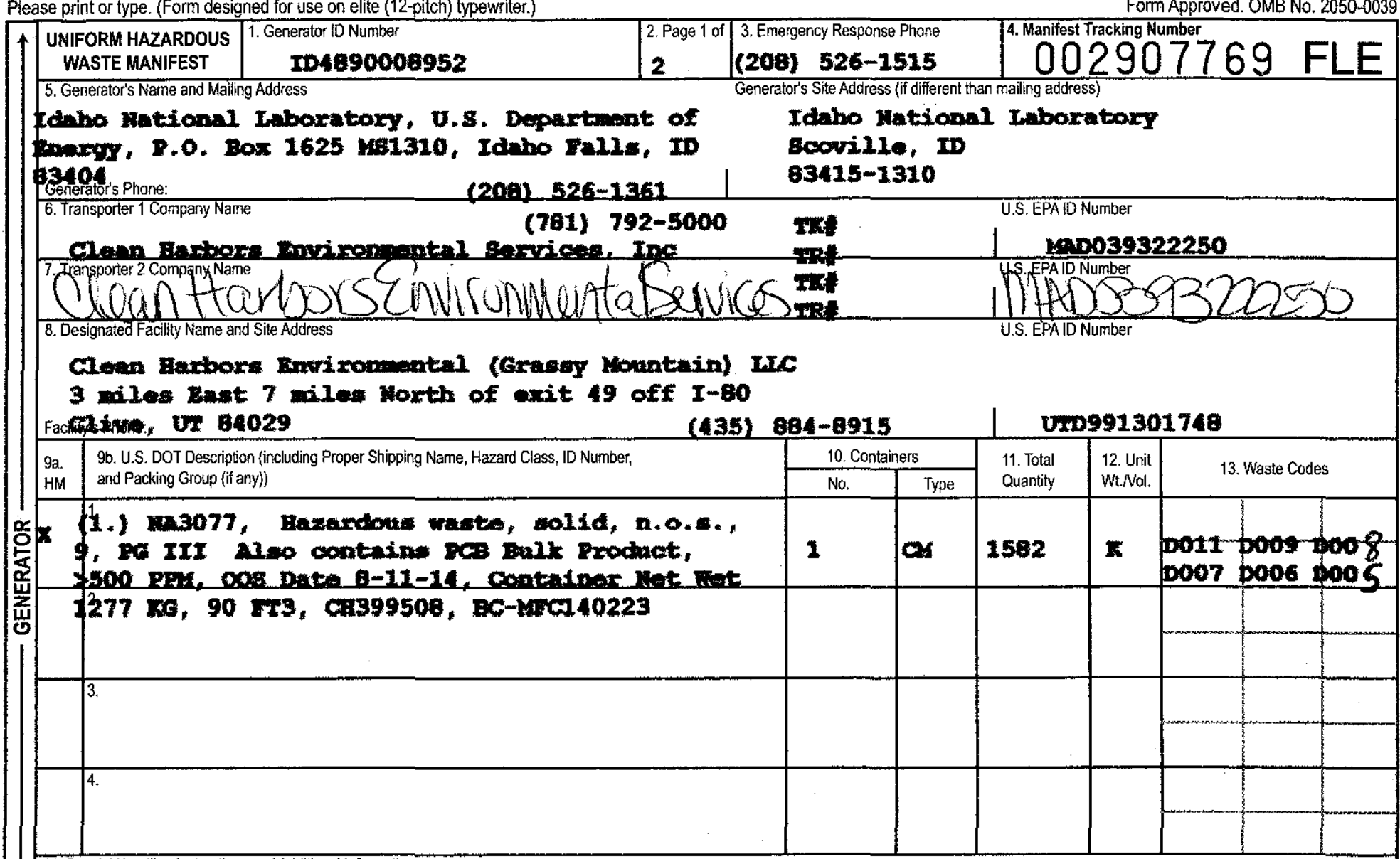

14. Special Handling Instructions and Additional information

Beturn aigned oxiginal to Bnexgy Solutions, Attn: Don Darrington, us 1310, P.0. Box 1625,

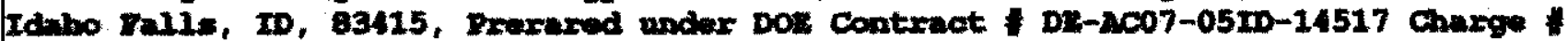

102209879, 592010720, Salese Oxdax 1402461744

15. GENERATOR'S/OFFEROR'S CERTIFICATION: I hereby declare that the contents of this consignment are fully and accurately described above by the proper shipping name, and are classified, packaged,

marked and labeled/placarded, and are in all respects in proper condition for transport according to applicable international and national governmental regulations. if export shipment and I am the Primary

Exporter, I certify that the contents of this consignment conform to the terms of the attached EPAAcknowedgment of Consent.

I certify that the waste minimization statement identified in 40 CFR 262.27(a) (if 1 am a large quantity generator) or (b) (if I am a small quantity generator) is true.

Generator's/Offeror's Printed//yped Name

S.M. $\operatorname{Lin} T \mathrm{~S}$

\section{International Stipments}

Transporter signature (for exports onty):
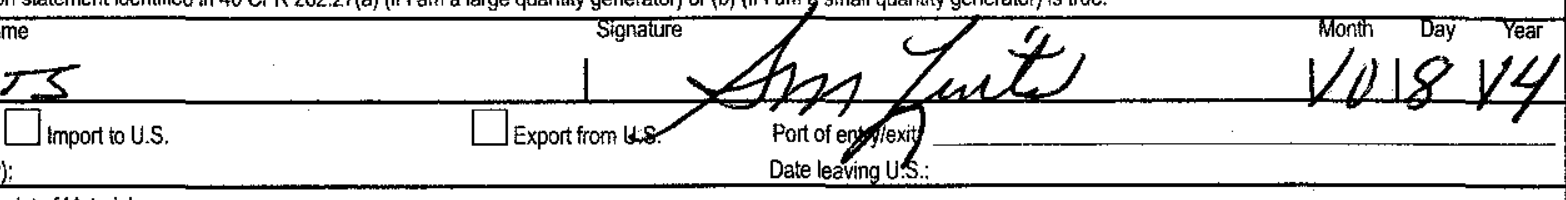

17. Transporter Acknowiedgment of Receipt of Materials

KiRK Wilson

Fransporter 2 Printed/7yped Name?

足 $x$ (a) 0

18. Discrepancy

88a. Discrepancy Indication Space $\quad \square$ Quantity

Signature

Date leaving U.S.

18b. Altemate Facility (or Generator)

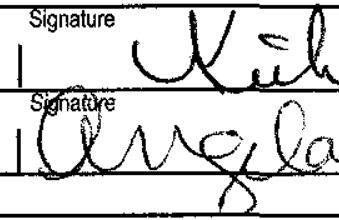

$\square$ Residue

Manifest Reference Numbe
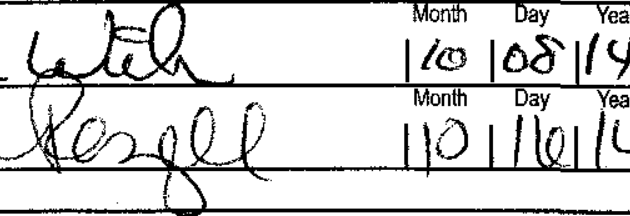

$1 / 0 \quad 108.14$

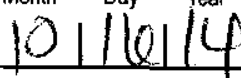

Type

$\square$ Partial Rejection

$\square$ Full Rejection

U.S. EPA ID Number

Facility's Phone:

18c. Signature of Aliernate Facility (or Generator)

19. Hazardous Waste Report Management Method Codes (i.e., codes for hazardous waste treatment, disposal, and recycling systems)

$1+132$ 2.

3.

20. Designated Facility Owner or Operator: Certification of receipt of hazardous materials covered by the manifest except as noted in Item 18a

Printed/Typed Name

$\downarrow$
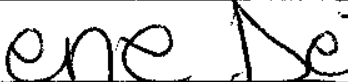

$>00$

$\operatorname{ll}(1)$
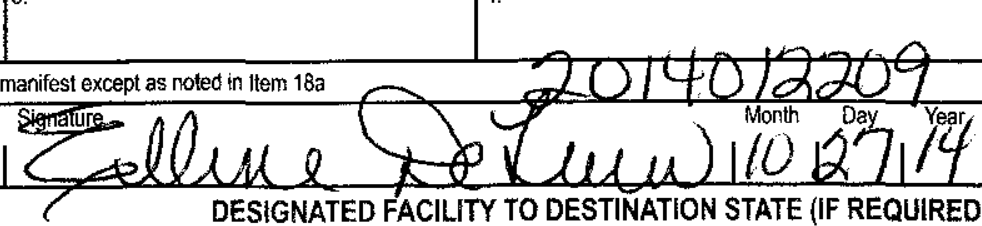

DESIGNATED FACILITY TO DESTINATION STATE (IF REQUIRED) 


\section{UNIFORM HAZARDOUS WASTE MANIFEST 21. Generator ID Number (Continuation Sheet)

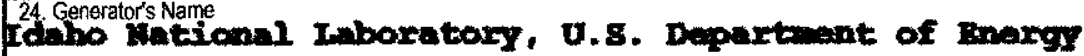

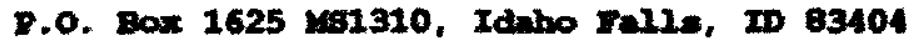
25. Transporter
Company Name
U.S. EPA ID Number
26. Transporter
Company Name
1
U.S. EPA ID Number

\begin{tabular}{l|l} 
27a. & 27b. U.S. DOT Description (including Proper Shipping Name, Hazard Class, ID Number,
\end{tabular}

HM and Packing Group (if any))

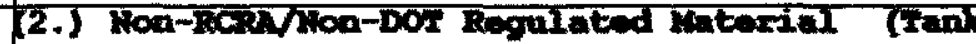
pinentes), IBC, CBB77010, BC-19FC140256

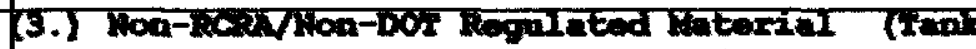
kindated), IBC, CaP77010, BC-kAPC140257

年

(1) .

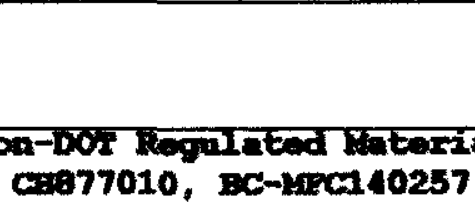

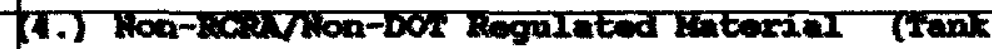
finsates), IBC, CB877010, BC-MFC140258

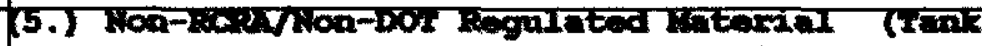
pinsates), IBC, CBa77010, BC-LPC140259

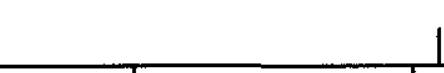

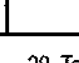

\begin{tabular}{|c|c|}
\hline \multicolumn{2}{|c|}{28. Containers } \\
\hline No. & Type \\
\hline 1 & $\boldsymbol{c o r}$ \\
&
\end{tabular}

29. Total 30 . Unit Quantity Wt.Nol.

\begin{tabular}{l|l}
1946 & P
\end{tabular}

31. Waste Codes

\begin{tabular}{l|l|l|l|}
\hline $\boldsymbol{2}$ & & & \\
\cline { 2 - 3 } & &
\end{tabular}

1

\begin{tabular}{l|l|l}
1 & & \\
\hline & 2336
\end{tabular}

1

\section{1}

(1)

.

33. Transporter _... Acknowledgment of Receipt of Materials PrintedrTyped Name 
Clean Harbors Grassy Mountain LLC

3 Miles East 7 Miles North of Knolls

Grantsville UT, 84029

UTD991301748

(435) $884-8900$

\section{CERTIFICATE OF DISPOSAL}

Generator Facility Name:

Generator Address:

Generator Contact Name:
INL Materials \& Fuels Complex MFC

35 Miles West of Idaho Falls via Hwy 20 west

Idaho Falls, ID, 83415
Sales Order\#: 1402461744

Date Received: $\quad$ 10/27/2014

Generator EPA ID:

ID4890008952

Load \#:

14012209

Manifest \#: $\quad$ 002907769FLE

\section{Original Date Removed Unit Serial \# I \\ CH ID \# From Service Type Customer ID}

\section{Material Description}

Tsca Debris For Microencapsulation

\section{Disposal Method of \\ Date \\ Disposal}

$10 / 30 / 2014$
Landfill
Disposal Facility

Grassy Mountain, UT

Under Civil and Criminal Penalties of Law for the making or submission of false or fraudulent statements or representations (18 U.S.C. 1001 and 15 U.S.C. 2615), I certify that the information contained in or accompanying this document is true, accurate, and complete. As to the

identified section(s) of this document for which I cannot personally verify truth and accuracy, I certify as the company official having supervisory responsibility for the persons who, acting under my direct instructions, made the verification that this information is true, accurate, and complete.

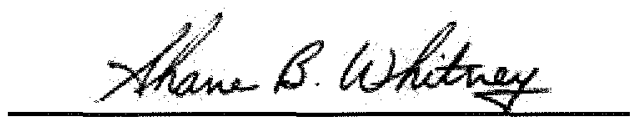

Authorized Agent
Friday, October 31, 2014 
Please print or type. (Form designed for use on elite (12-pitch) typewriter.)

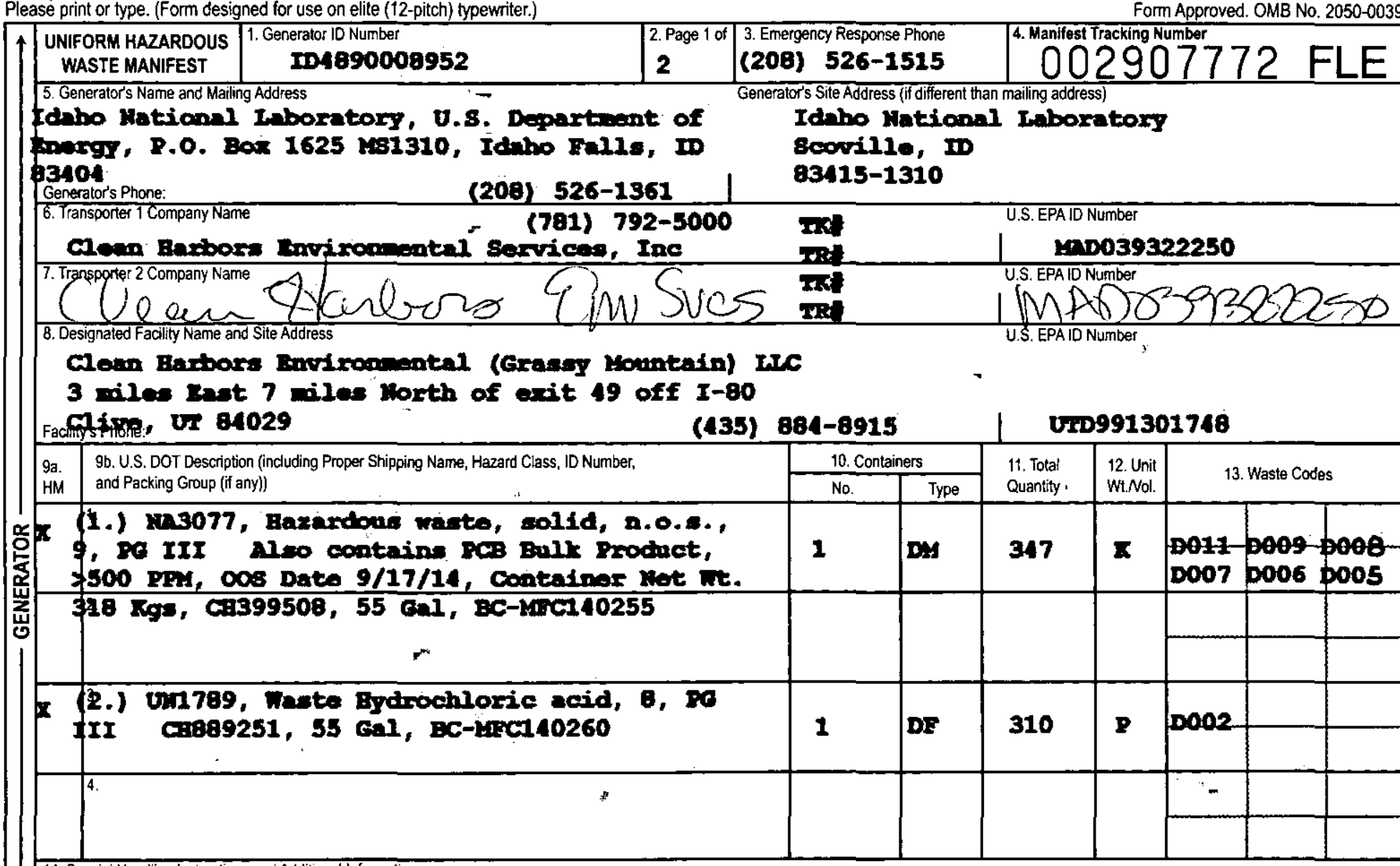

14. Special Handling Instructions and Additional Information

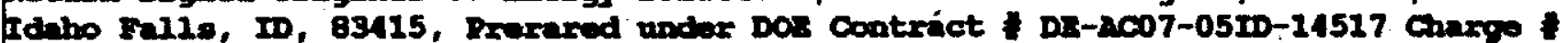
1018563ar, 102050Rrs, gales Oxdax 1402915287

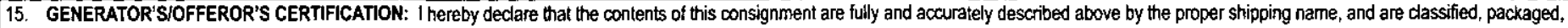

marked and labeled/placarded, and are in all respects in proper condition for transport according to applicable international and nationai govemmental regulations. If export shipment and I am the Primary

Exporter, I certify that the contents of this consignment conform to the terms of the attached EPAAcknowledgment of Consent.

I certify that the waste minimization statement identified in 40 CFR 262.27 (a) (if I am a large quantity neneratof or (b/N I am a small quantity generator) is true.

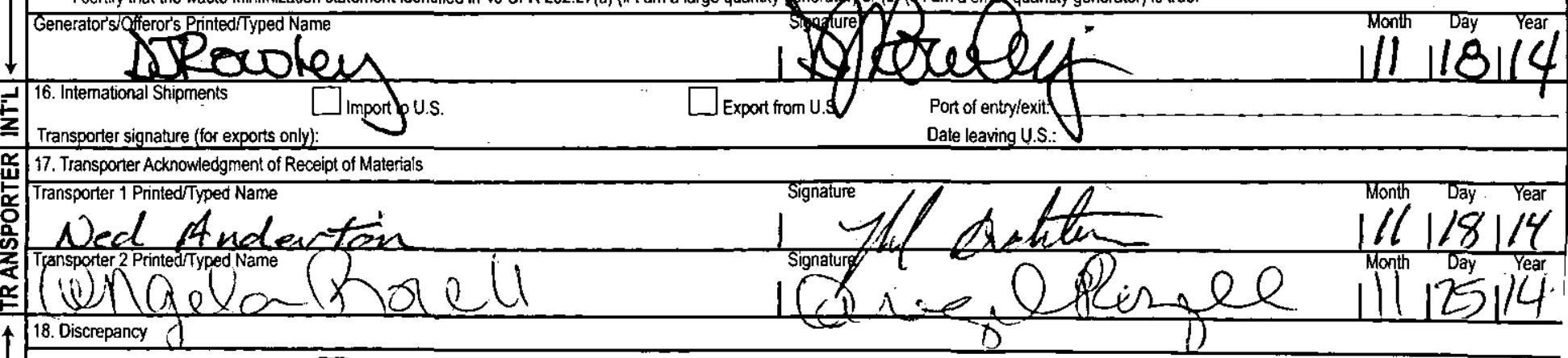

18a. Discrepancy Indication Space

$\square$ Quantity

$\square$ Type

$\square$ Residue

$\square$ Partial Rejection

$\square$ Full Rejection
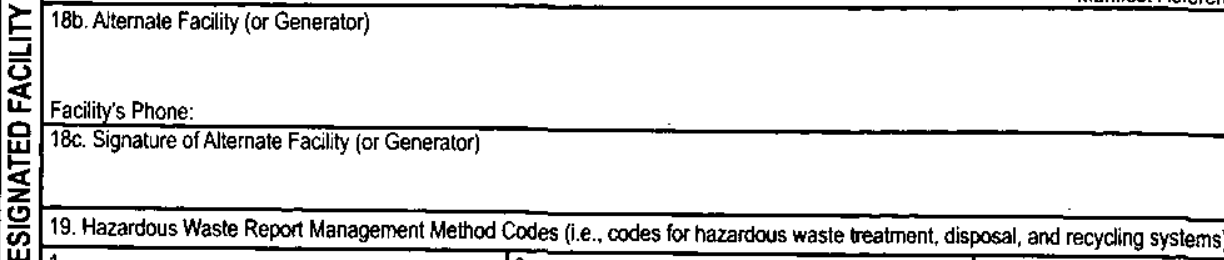

20. Designated Facility Omer or Operator: Certifeation of receipt of hazardous materials covered by the manifest except as noted in ltem $18 \mathrm{a}$ 
$r$.

Please print or type. (Form designed for use on elite (12-pitch) typewriter.)

\begin{tabular}{|l|l|l}
\hline$\uparrow$ & UNIFORM HAZARDOUS WASTE MANIFEST & 21. Generator ID Number \\
\hline
\end{tabular}

(Continuation Sheet)

IDie90008952

2 of 2

23. Manifest Tracking Number

Form Approved. OMB No. 2050-0039

24. Generato's Name

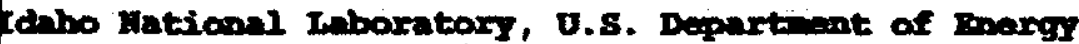

B.0. Dox 1625 M31310, Iatho Fa11s, ID 83404

\begin{tabular}{ll|l} 
25. Transporter __ Company Name & U.S. EPA ID Number \\
\hline 26. Transporter ___ Company Name & U.S. EPA ID Number
\end{tabular}

27a. 27 b. U.S. DOT Description (including Proper Shipping Name, Hazard Class, 10 Number,

HM and Packing Group (if any))

3 (3.) Un789, Waste Bydrochloric acid, B, po III Ca899251, 55 Gal, BC-MFG140261

4.) un789, Nante Eydrochloric acid, 8, Po III C:8089251, $30 \mathrm{Gal}$, BC-MFC140262

(5.) Un789, Wate Bydrochloric acid, 8, Po III Crab9251, $30 \mathrm{Gal}$, Bc-rFct10263

of (6.) Un789, waste Bydrochloric acid, 8, Do III

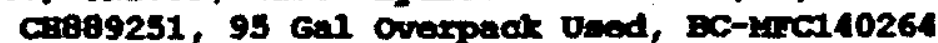

32. Special Handling Instructions and Additional Information

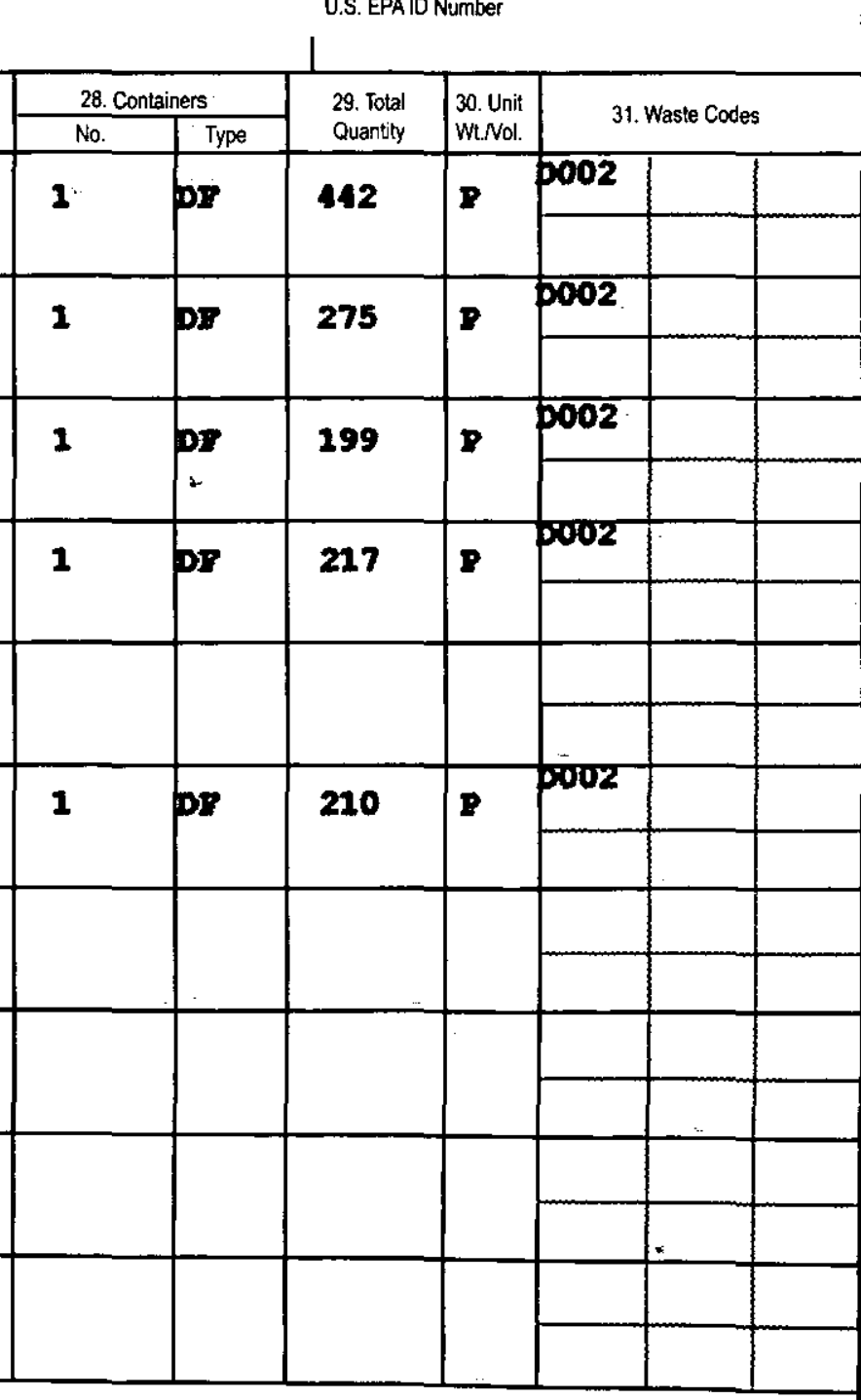

7.) Un789, Waste Eydrochloric acid, 8, po III Ca889251, 30 Gal, EC-MFC140265

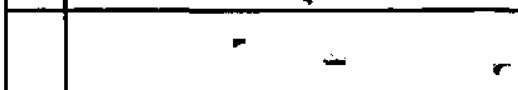

\begin{tabular}{|l|l|}
\hline & \\
\hline & \\
\hline
\end{tabular}

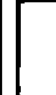

$\downarrow$

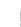

33. Transporter

Acknowledgment of Receipt of Materials

iv Printed/Typed Name

空

34. Transporter

Printed/7yped Name

Acknowledgment of Receipt of Materials

Signature

35. Discrepancy

Signature

L

1

틈

36. Hazardous Waste Report Management Method Codes (i.e., codes for hazardous waste treatment, disposal, and recycling systems) 
UTD991301748

(435) 884-8900

\section{CERTIFICATE OF DISPOSAL}

Generator Facility Name:

Generator Address:
INL Materials \& Fuels Complex MFC

35 Miles West of Idaho Falls via Hwy 20 west

Idaho Falls, ID, 83415
Sales Order\#:

1402915287

Date Received:

Generator Contact Name:

Generator EPA ID:

ID4890008952

\section{Original Date Removed Unit Serial \# I CH ID \# From Service Type Customer ID}

42007940
9/17/2014

DM BC-MFC140255 /

\section{Material Description}

Tsca Debris For Microencapsulation

$\begin{array}{ll}\text { Load \#: } & 14013490 \\ \text { Manifest \#: } & 002907772 \text { FLE }\end{array}$

\section{Disposal}

Date

$12 / 10 / 2014$

\section{Method of} Disposal

Disposal Facility

Landfill
Grassy Mountain, UT Facility

Under Civil and Criminal Penalties of Law for the making or submission of false or fraudulent statements or representations (18 U.S.C. 1001 and 15 U.S.C. 2615), I certify that the information contained in or accompanying this document is true, accurate, and complete. As to the identified section(s) of this document for which I cannot personally verify truth and accuracy, I certify as the company official having supervisory responsibility for the persons who, acting under my direct instructions, made the verification that this information is true, accurate, and complete.

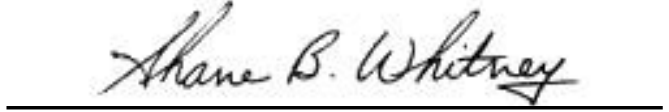

Authorized Agent
Monday, December 22, 2014

Date 
Please print or type. (Form designed for use on elite (12-pitch) typewiter.)

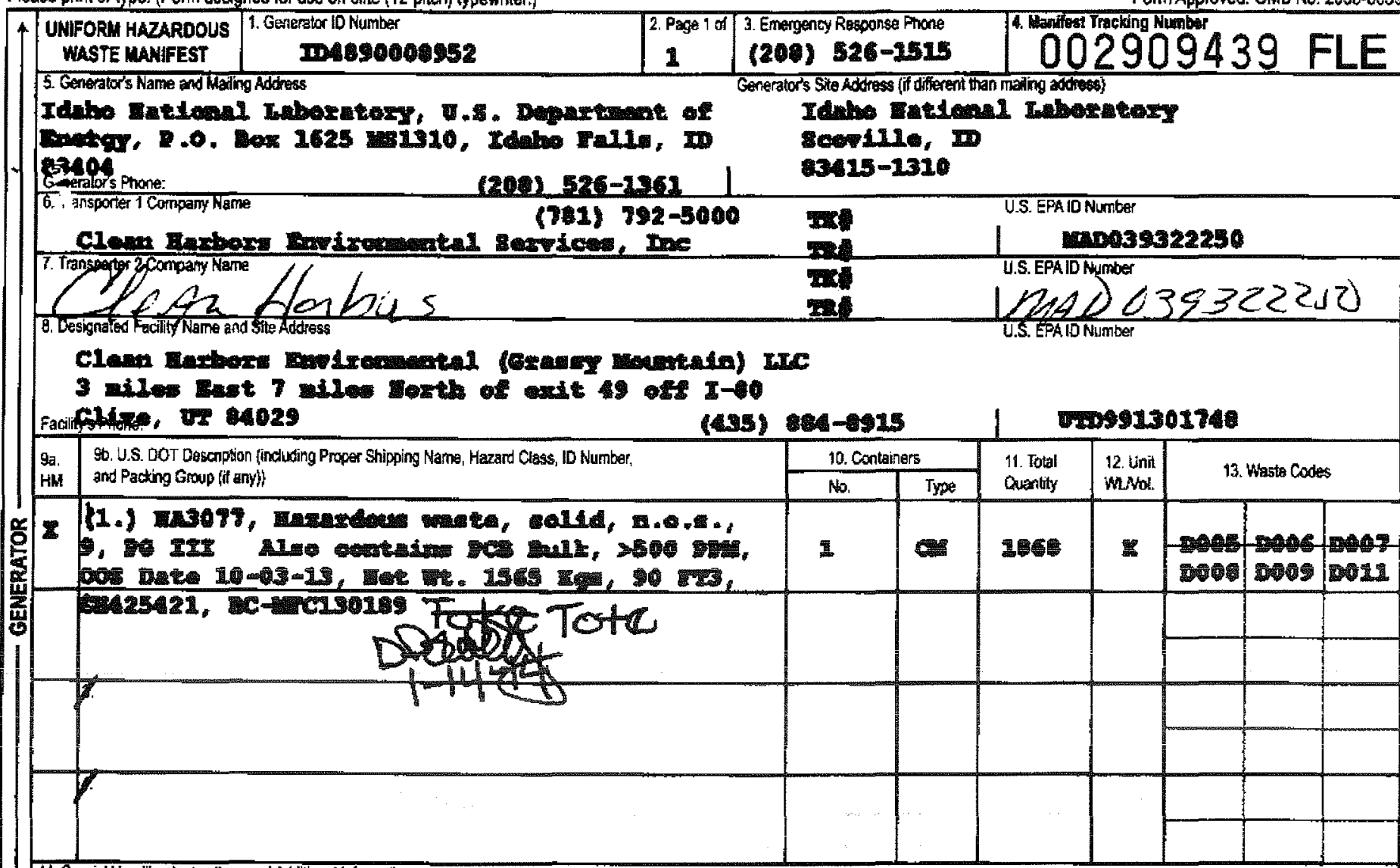

14. Special Handling Instructions and Addfional Informalion

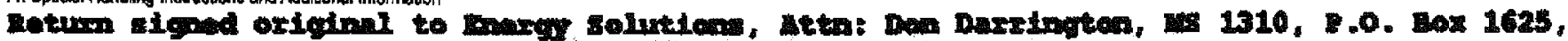

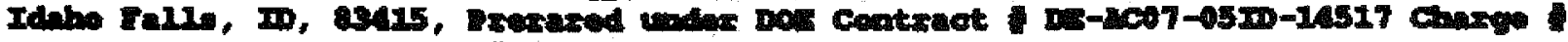
330212230 cin an: 690774262

15. GENERATOR'SIOFFEROR'S CERTIFICATION: I hereby ceclare that the conkent of this consignment are fully and accurately cescribed abowe by the proper shipping name, and are classified, packaged, marked and labeledplacarded, and sre in al respects in proper condition for transport according to applicable intonational and national govemmental regulasions. If export shipmenl and I am the Primary

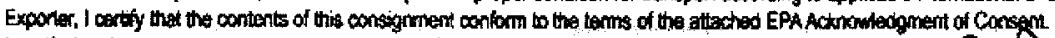

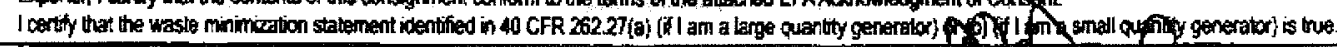

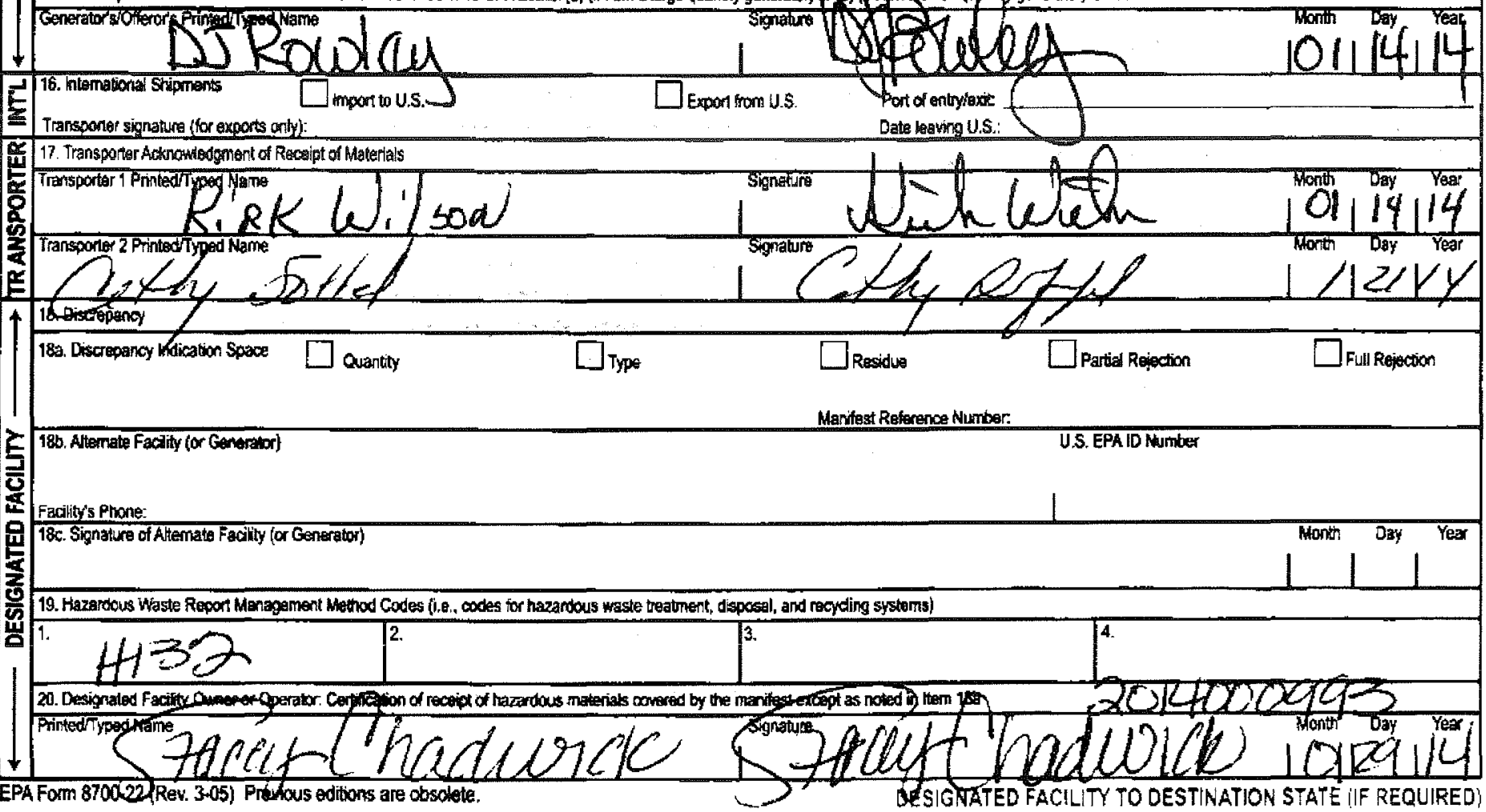


UTD991301748

(435) $884-8900$

\section{CERTIFICATE OF DISPOSAL}

Generator Facility Name:

Generator Address:

INL Materials \& Fuels Complex MFC

35 Miles West of Idaho Falls via Hwy 20 west

Idaho Falls, ID, 83415 $\begin{array}{ll}\text { Sales Order\#: } & 698774263 \\ \text { Date Received: } & 1 / 29 / 2014\end{array}$

Generator Contact Name:

Generator EPA ID:
ID4890008952

\section{Load \#:}

Manifest \#:
14000993

O02909439FLE

\begin{tabular}{|c|c|c|c|c|c|c|c|}
\hline $\begin{array}{l}\text { Original } \\
\mathrm{CH} \text { ID \# }\end{array}$ & $\begin{array}{l}\text { Date Removed } \\
\text { From Service }\end{array}$ & $\begin{array}{l}\text { Unit } \\
\text { Type }\end{array}$ & $\begin{array}{c}\text { Serial \#I } \\
\text { Customer ID }\end{array}$ & $\begin{array}{c}\text { Material } \\
\text { Description }\end{array}$ & $\begin{array}{l}\text { Disposal } \\
\text { Date }\end{array}$ & $\begin{array}{l}\text { Method of } \\
\text { Disposal }\end{array}$ & Disposal Facility \\
\hline 35823792 & $10 / 3 / 2013$ & $\mathrm{CM}$ & BC-MFC130189/ & $\begin{array}{c}\text { Tsca Debris For } \\
\text { Macroencapsulation }\end{array}$ & $2 / 5 / 2014$ & Landfill & $\begin{array}{l}\text { Grassy Mountain, UT } \\
\text { Facility }\end{array}$ \\
\hline
\end{tabular}

Under Civil and Criminal Penalties of Law for the making or submission of false or fraudulent statements or representations (18 U.S.C. 1001 and 15 U.S.C. 2615), i certify that the infomation contained in or accompanying this document is true, accurate, and complete. As to the identified section(s) of this document for which I cannot personally verify truth and accuracy, I certify as the company official having supervisory responsibility for the persons who, acting under my direct instructions, made the verification that this information is true, accurate, and complete.

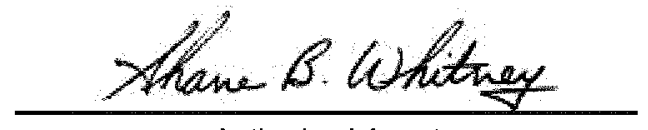

Authorized Agent
Thursday, February 13, 2014

Date 
Please print or type. (Form designed for use on slite (12-pitch) iypewriter.)

Form Approved. OMB No. 2C50-0039

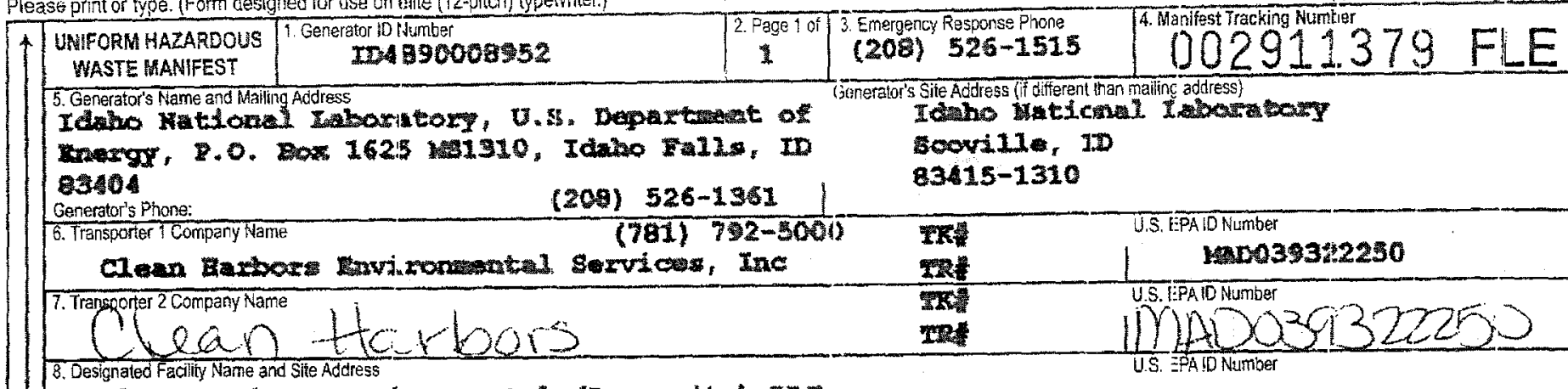

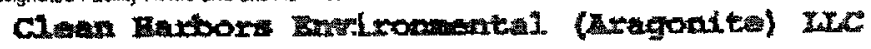

11600 Woxth Agras road

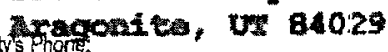

(435) 804-8100

HDS81592177

9a. 9b. U.S. Dor Description (including Priper Shipping Name, Hazard Class. ID Number.

HM and Packing Group (if amy))

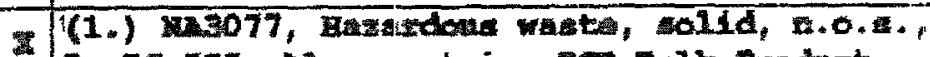

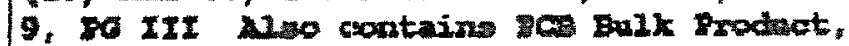

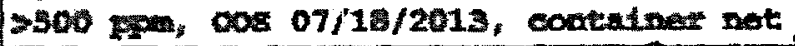

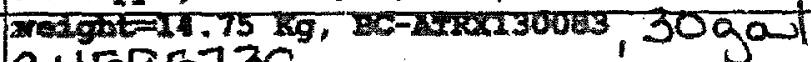
$c+1595739$

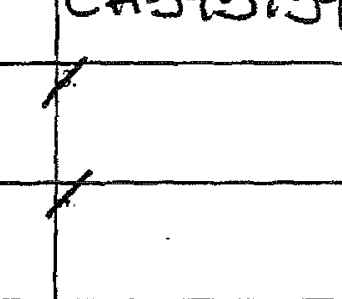

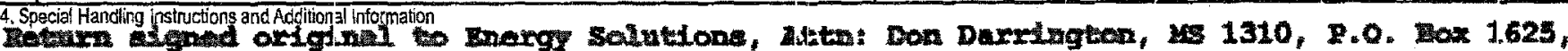

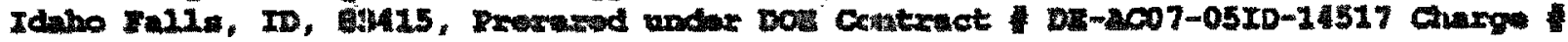
1016532we, sales Onclex 09071047

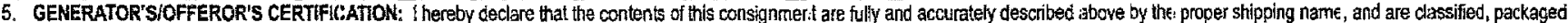
marked and labejediplacarded, and are in all respects in proper condition for transport according to appilisable international and national governmental regulations. If export shipment and I am the Prinary Exporter, 1 cartity that the contents of this consignment contorm to the terms of the attached EFAAckncwledgment of Consent.

I certify that the waste minimization statement identified in 40 CFR 262.27 (a) (if I am a large quantity ger erafor) or (b) (if I am a spall quantity generator) is true.

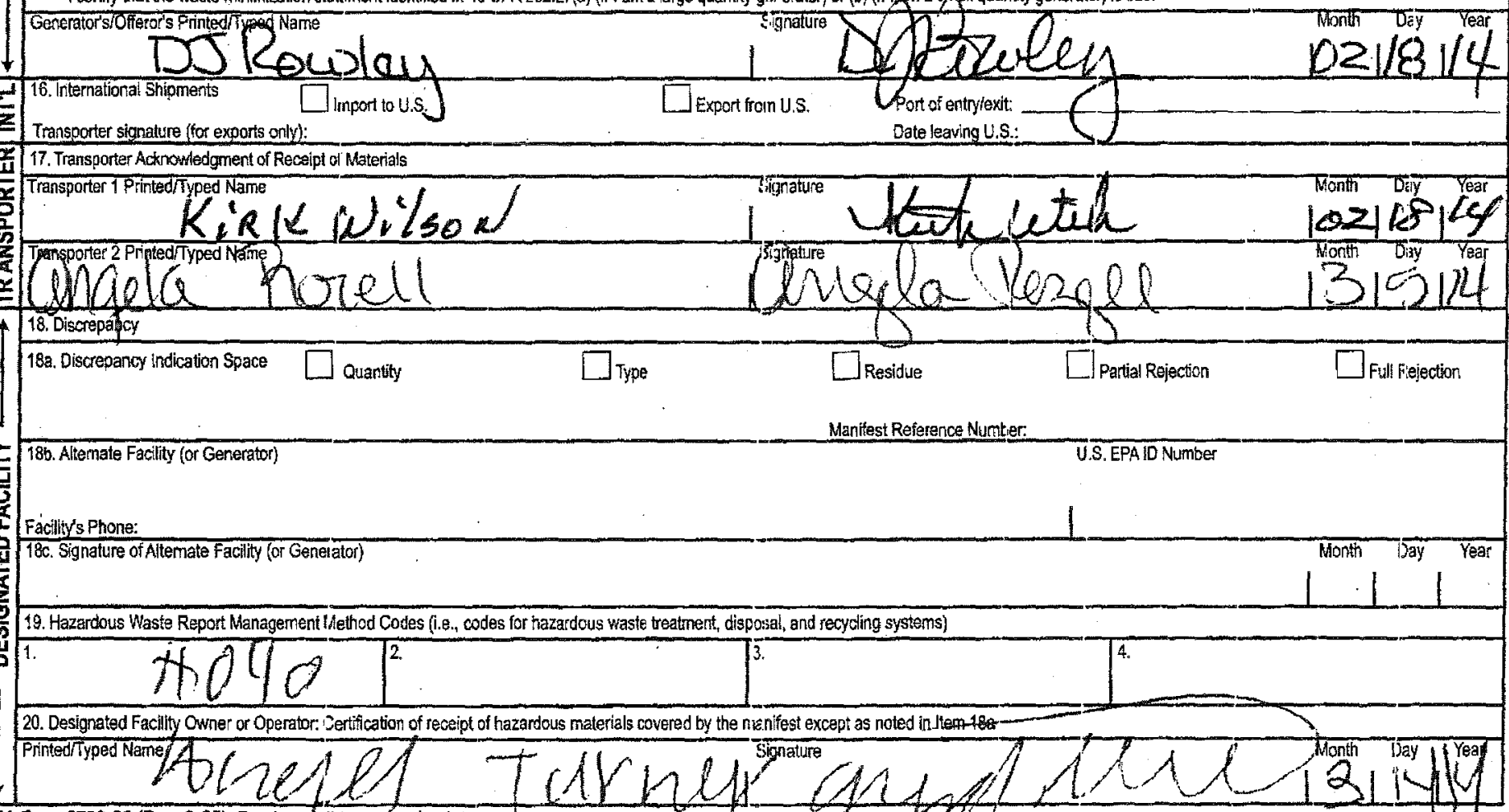


Grantsville UT, 84029

UTD981552177

(435) $884-8100$

\section{CERTIFICATE OF DISPOSAL}

Generator Facility Name:

Generator Address:
INL Advanced Test Reactor (ATRC)

58 Miles West of Idaho Falls, ID via HWY 20 west, 9 miles

Miles North of CFA

Idaho Falls, ID, 83415
Sales Order\#: $\quad 699071848$

Date Received: 3/14/2014

Generator Contact Name:

Generator EPA ID: $\quad$ ID4890008952

$\begin{array}{ccc}\text { Original } & \text { Date Removed Unit } & \text { Serial \# I } \\ \text { CH ID \# } & \text { From Service Type } & \text { Customer ID }\end{array}$

36402626

$7 / 18 / 2013$

DM ATRX130083/

\section{Material Description}

PCB Solids For Incineration

\section{Load \#:}

67336

Manifest \#:

002911379FLE

Under Civil and Criminal Penalties of Law for the making or submission of false or fraudulent statements or representations (18 U.S.C. 1001 and 15 U.S.C. 2615), I certify that the information contained in or accompanying this document is true, accurate, and complete. As to the identified section(s) of this document for which I cannot personally verify truth and accuracy, I certify as the company official having supervisory responsibility for the persons who, acting under my direct instructions, made the verification that this information is true, accurate, and complete.

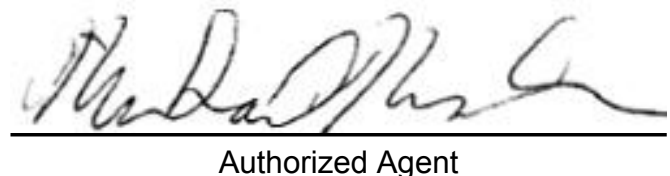

Friday, March 28, 2014

Authorized Agent

Date 
Please print or type. (Form designed for use on elite (12-pitch) typewriter.)

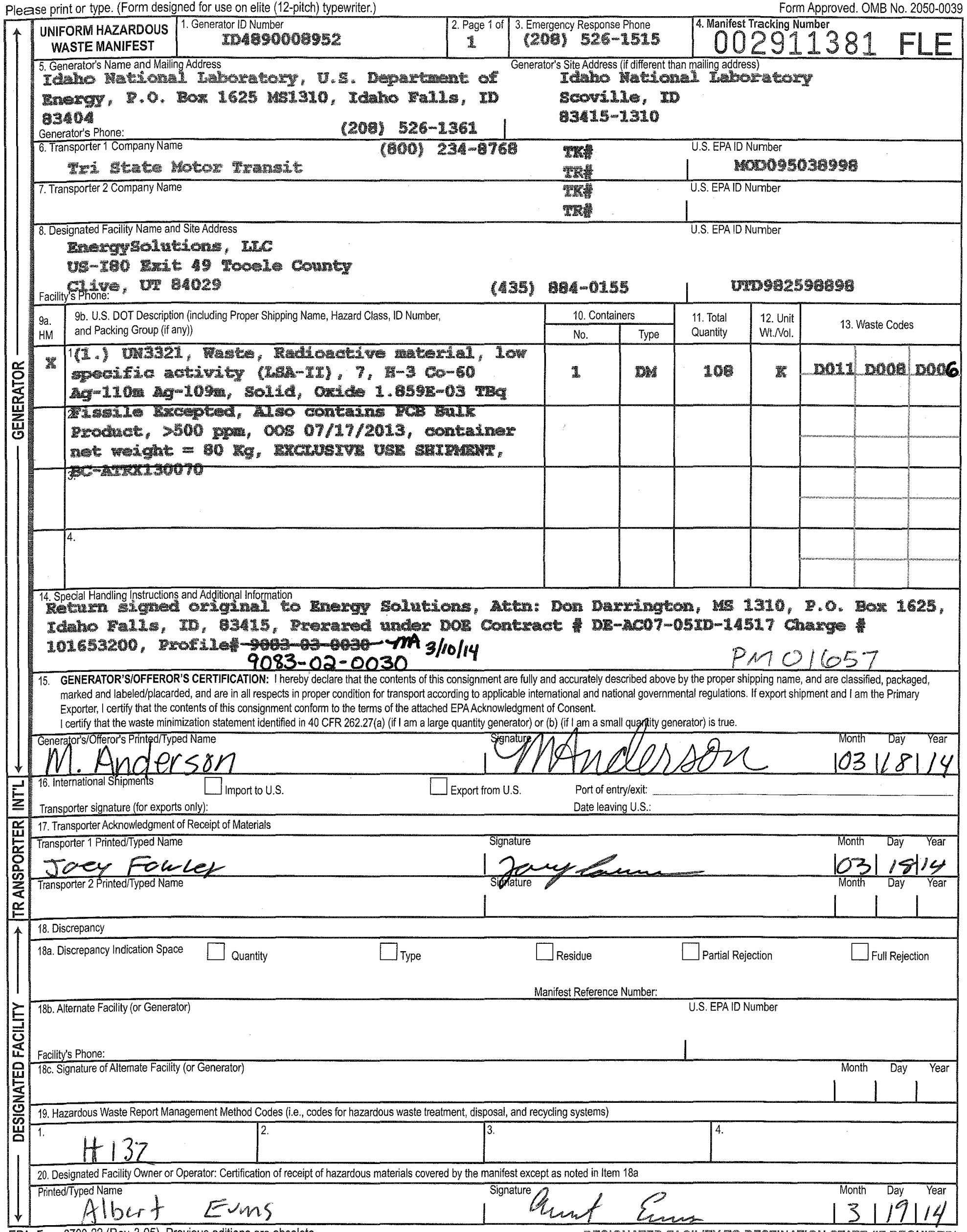




\section{ENERGYSOLUTIONS}

\section{CERTIFICATE OF DISPOSAL}

3 miles South, Exit 49, I-80

Clive, Utah 84029

EPA ID: UTD982598898

BEAINL for US DOE, Idaho Falls

This certificate acknowledges that the following manifested shipments have been disposed of as listed below:

\begin{tabular}{|c|c|c|c|c|c|}
\hline shlomant & Amentest & Disnosal Oate & Yolumin (eutr) & Procens & Direneal Lorestion \\
\hline $\begin{array}{r}9083-02-0029 \\
9083-02-0030\end{array}$ & $\begin{array}{l}07740 \\
11381\end{array}$ & $\begin{array}{l}03 / 2412014 \\
03 / 24 / 2014\end{array}$ & $\begin{array}{l}96.0 \\
7.4\end{array}$ & $\begin{array}{l}\text { Landfill } \\
\text { Landffil }\end{array}$ & $\begin{array}{l}\text { Wxed Waste } \\
\text { Mxed Waste }\end{array}$ \\
\hline
\end{tabular}

The total volume above represents the cubic feet of waste disposed of at EnergySolutions' Disposal Facility Landfill. Disposal is subject to EnergySolutions' Radioactive Material License, all other applicable licenses, permits and regulations, and the Disposal Agreement.

Under civil and criminal penattes of law for the making or submissian of false or fraudulent statements or rapresentations (18 U.S.C 1001 and 15 U.S.C. 2615) I certfy that the information contained in or accompariying this document is trite, accurate and complote. As to the lcientification section(s) of this document for which I cannot personally verify frith abdaccuracy, I cartify as the compeny official having supenisory responsiblity for the persons who, acting under my direct instructions, mato the verifiction that this intormation is trut, accurate and complote.

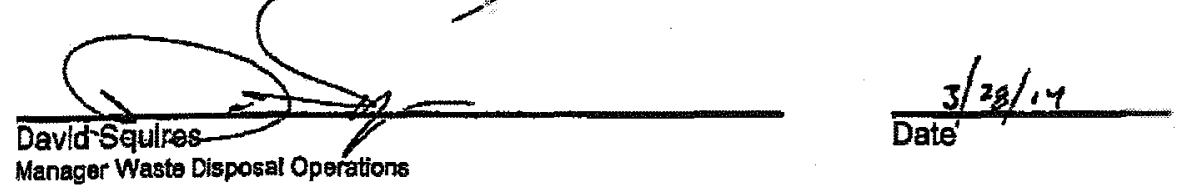


Please print or type. (Form designed for use on elite (12-pitch) typewriter.)

Form Approved. OMB No. $2050-0039$

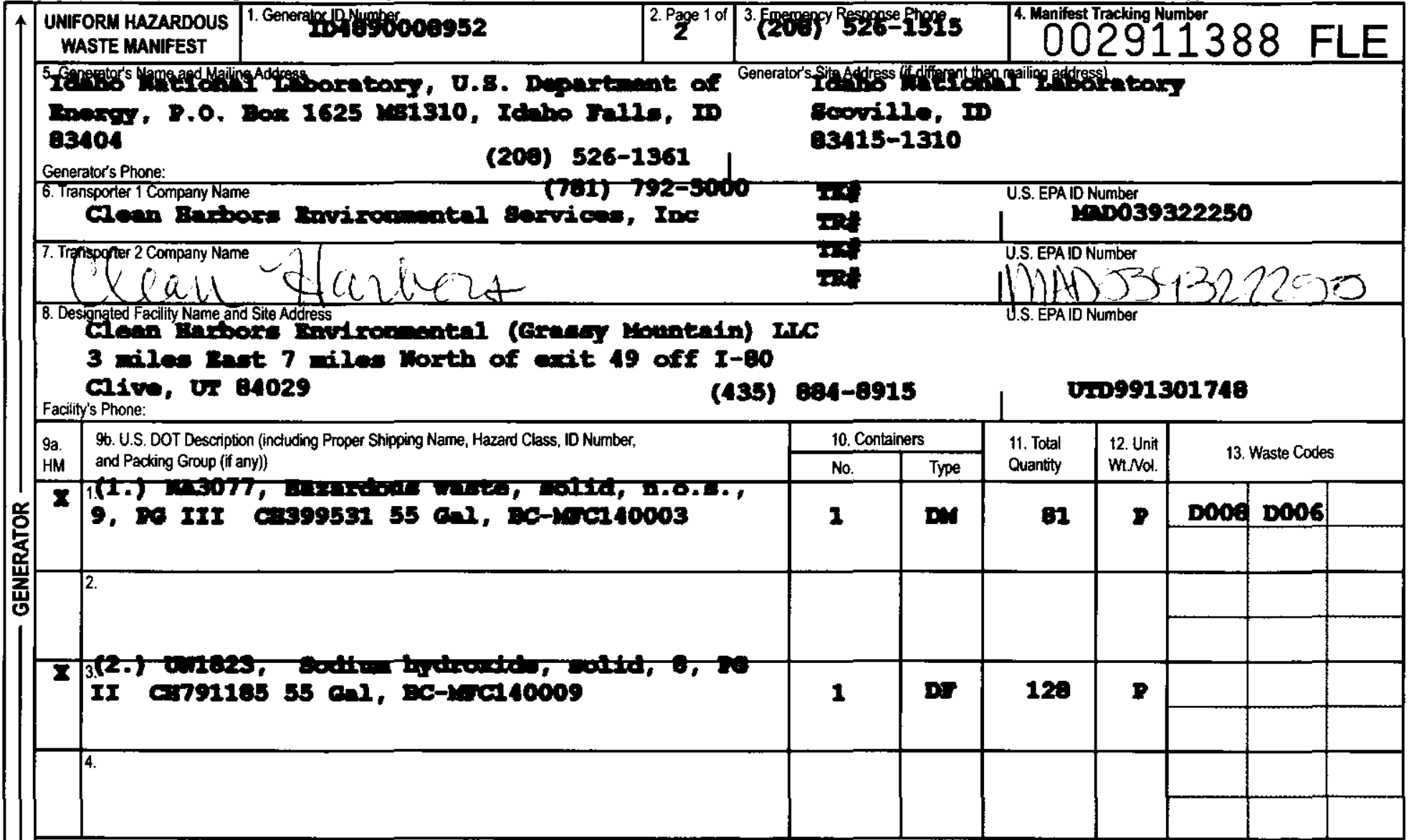

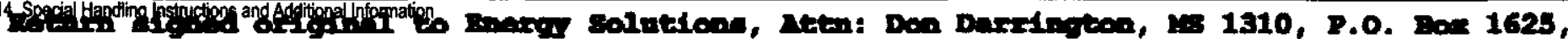

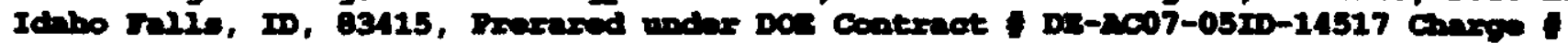
101286 Fis 1018563w 450223306, Beles ordar 1400188785

15. GENERATOR'SHOFFEROR'S CERTIFICATON: I hereby declare that the contents of this consignment are fully and accurately described above by the proper shipping name, and are classified, packaged, marked and labeled/placarded, and are in all respects in proper condition for transport according to applicable international and national governmental regulations. If export shipment and I am the Primary Exporter, I certify that the contents of this consignment conform to the terms of the attached EPAAcknowledgment of Consent.

I certify that the waste minimization statement identified in 40 CFR 262.27(a) (if I am a large quantity generator) or (b) (if I am a small quantity generator) is true.

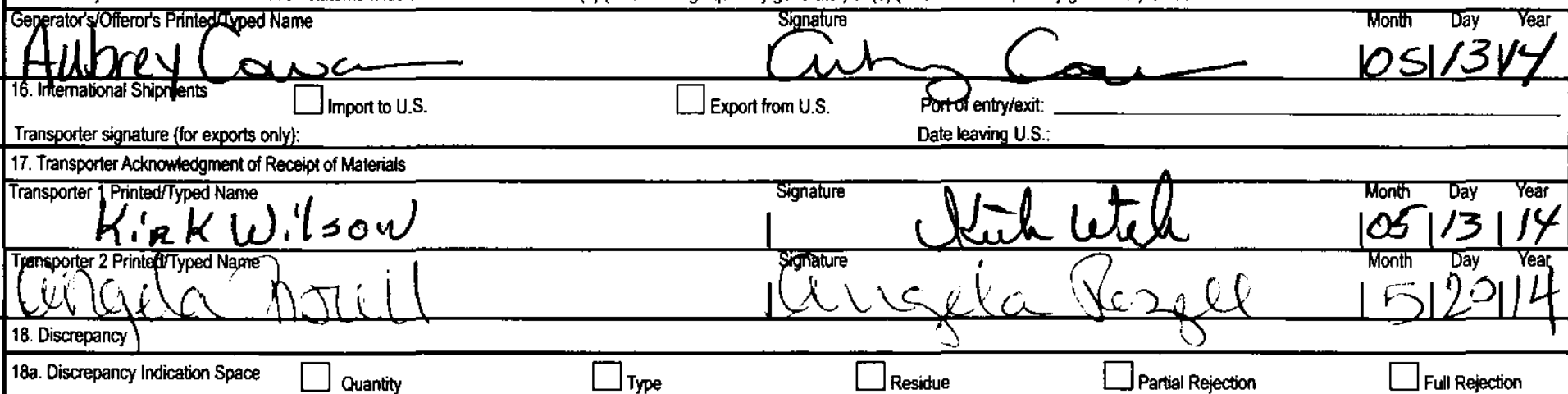

Manifest Reference Number:

\begin{tabular}{l} 
18b. Attemate Facility (or Generator) \\
Facility's Phone: \\
\hline $18 \mathrm{c}$ Signature of Alternate Facility (or Generator) \\
\hline 19. Hazardous Waste Report Management Method Codes (i.e., codes for hazardous waste treatment, disposal, and recycling systems)
\end{tabular} 
UTD991301748

(435) $884-8900$

\section{CERTIFICATE OF DISPOSAL}

Generator Facility Name:

Generator Address:
INL Materials \& Fuels Complex MFC

35 Miles West of Idaho Falls via Hwy 20 west

Idaho Falls, ID, 83415
Sales Order\#:

1400188787

Date Received: 5/29/2014

Generator Contact Name:

Generator EPA ID: $\quad$ ID4890008952

$\begin{array}{ccc}\text { Original } & \text { Date Removed Unit } & \text { Serial \# I } \\ \text { CH ID \# } & \text { From Service } & \text { Type } \\ \text { Customer ID }\end{array}$

38017338
DM BC-MFC140045 /

\section{Material Description}

Tsca Debris For Microencapsulation

$\begin{array}{ll}\text { Load \#: } & 140069287 \\ \text { Manifest \#: } & \text { 002911388FLE }\end{array}$

\section{Disposal}

Date

6/3/2014

\section{Method of} Disposal

Landfill
Disposal Facility

Grassy Mountain, UT Facility

Under Civil and Criminal Penalties of Law for the making or submission of false or fraudulent statements or representations (18 U.S.C. 1001 and 15 U.S.C. 2615), I certify that the information contained in or accompanying this document is true, accurate, and complete. As to the identified section(s) of this document for which I cannot personally verify truth and accuracy, I certify as the company official having supervisory responsibility for the persons who, acting under my direct instructions, made the verification that this information is true, accurate, and complete.

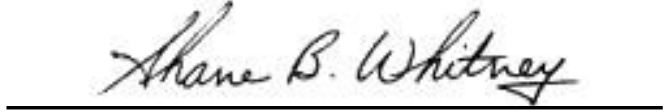

Authorized Agent
Thursday, June 05, 2014

Date 
UTD991301748

(435) $884-8900$

\section{CERTIFICATE OF DISPOSAL}

\begin{abstract}
Generator Facility Name:
Generator Address:
\end{abstract}

INL Materials \& Fuels Complex MFC

35 Miles West of Idaho Falls via Hwy 20 west

Idaho Falls, ID, 83415
Sales Orde\#: 1400188787

Date Received: $\quad$ 5/29/2014

Generator Contact Name:

Generator EPA ID:

ID4890008952

$\begin{array}{ll}\text { Load \#: } & 140069287 \\ \text { Manifest \#: } & \text { 002911388FLE }\end{array}$

Original Date Removed Unit Serial \#I CH ID \# From Service Type Customer ID

\section{Material Description}

DM BC-MFC140046/
Tsca Debris For Microencapsulation

$\begin{array}{cc}\text { Disposal } & \begin{array}{c}\text { Method of } \\ \text { Date }\end{array} \\ \text { Disposal }\end{array}$

6/3/2014 Landfill
Disposal Facility

Grassy Mountain, UT Facility

Under Civil and Criminal Penalties of Law for the making or submission of false or fraudulent statements or representations (18 U.S.C. 1001 and 15 U.S.C. 2615), I certify that the information contained in or accompanying this document is true, accurate, and complete. As to the identified section(s) of this document for which I cannot personally verify truth and accuracy, I certify as the company official having supervisory responsibility for the persons who, acting under my direct instructions, made the verification that this information is true, accurate, and complete.

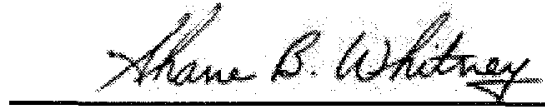

Authorized Agent
Thursday, June 05, 2014

Date 
Please print or type. (Form designed for use on elite (12-pitch) typewriter.)

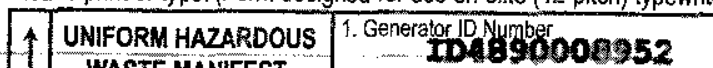
WASTE MANIFEST

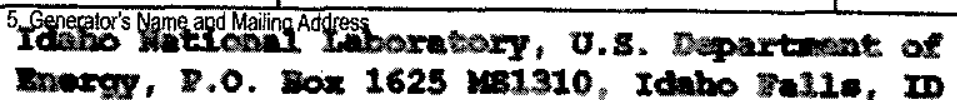

\section{8sus}

Generator's Phone:

6. Transporter 1 Company Name

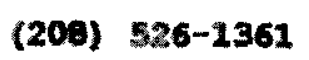

(208) $526-1361$ (78I) 792-3000

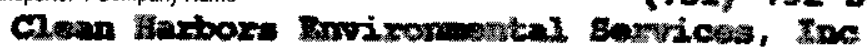

7. Tpanspoter 2 Company Name
8. Designated Facility Name and Site Address

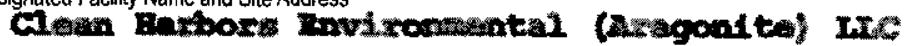

11600 liorth iptens Bond

Insgenitw, un 34025

Facility's Phone:

\begin{tabular}{|l|l}
\hline 9a. & 96. U.S. DOT Description (including Proper Shipping Name, Hazard Class, ID Number,
\end{tabular}

HM and Packing Group (if any))

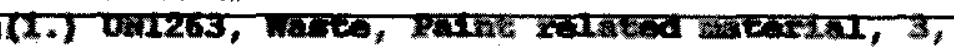

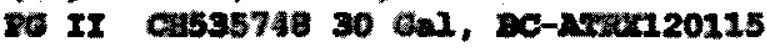

(435) $884-8100$

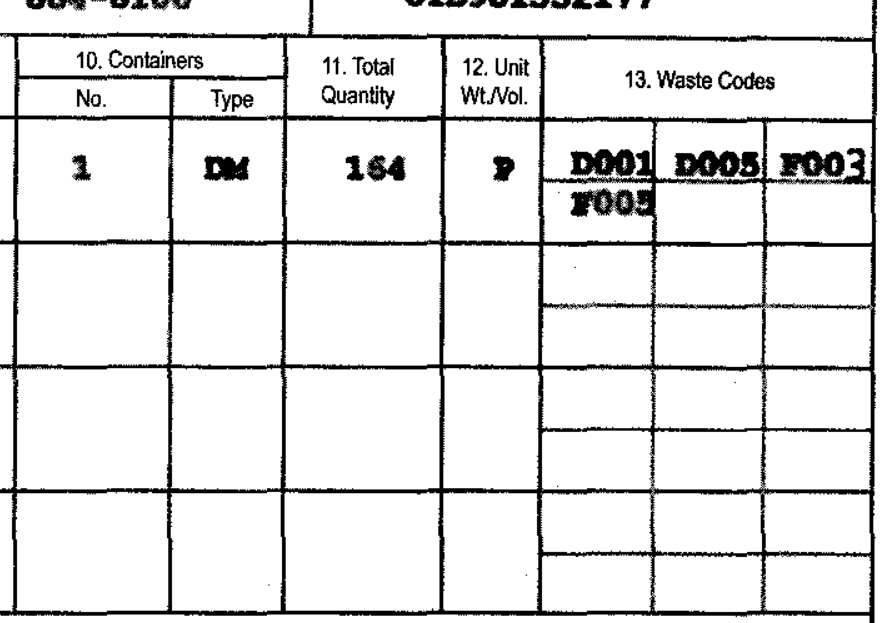

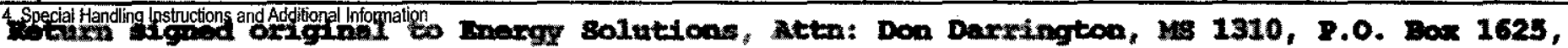

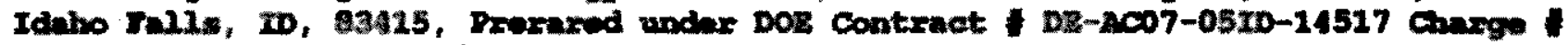
101633200, sales Oxder 1400741033

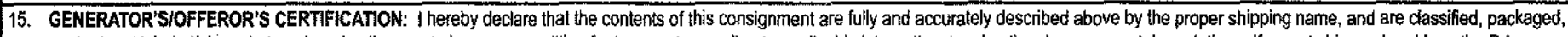
marked and labelediplacarded, and are in all respects in proper condition for transport according to applicable international and national governmental regulations. If export shipment and I am the Primary

Exporter, I certify that the contents of this consignment conform to the terms of the attached EPAAcknowledgment of Consent.

I certify that the waste minimization statement identified in 40 CFR 262.27(a) (if I am a large quantity generator) or (b) (if I afr a smail quantity generator) is true.

Generator's Ofíror's Printed/Typed Name

$\sum \begin{aligned} & 16 . \text { Internationail Sfipments } \\ & \text { Transporter signative (for exports only): }\end{aligned}$
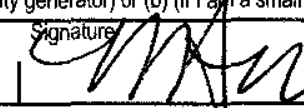

$\square$ Export from U.S.

Port of entrylexit:

us explowntar

$\operatorname{mos} 932220$

MDADSPS322250

Form Approved. OMB No. 2050-0039

Scovilite, I0

20:

Manifest Tracking Number

002911392 FLE

17. Transporter Acknowledgment of Receipt of Materials

Tिransporter 1Printed/Typed Nam

PJames Baldwin

Transporter 2 Prnted/Typed Name

(x) 100

18. Discrepancy)

18a. Discrepancy Indication Space $\square$ Quantity

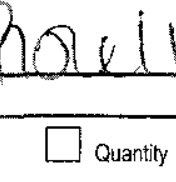

\section{L}

$+2$

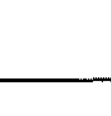
Date leaving U.S.

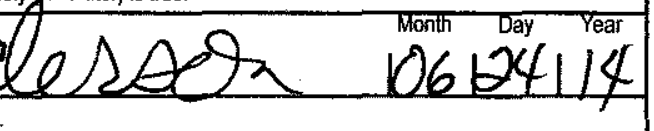
.: 
Please prini or type. (Form designed for use on elite (12-pisch) typewriter.)

T UNIFORM HAZARDOUS WASTE MANIFEST 21 . Generator ID Number

(Continuation Sheet)

IDABEDOOSZ

22. Page

2 of 2

23. Manffest Tracking Number

Form Approved. OMB №. 2050-0030

24. Generato's Name

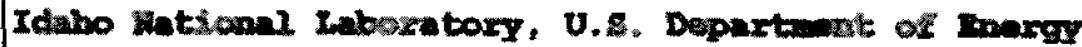

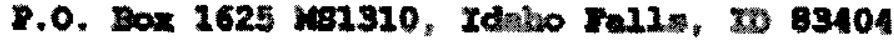

\begin{tabular}{|lll|l}
\hline 25. Transporter ___ Company Name & U.S. EPA DO Number \\
\hline 26. Transporter ___ Company Name & U.S. EPA ID Number
\end{tabular}

\begin{tabular}{l|l}
\hline $\begin{array}{l}\text { 27a. } \\
\text { HM }\end{array}$ & $\begin{array}{l}\text { 27b. U.S. DOT Description (including Proper Shipping Name, Hazard Class, to Number, } \\
\text { and Packing Group (if any)) }\end{array}$ \\
\hline
\end{tabular}

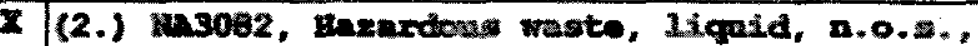

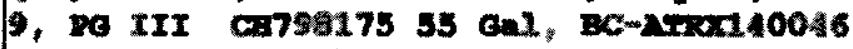

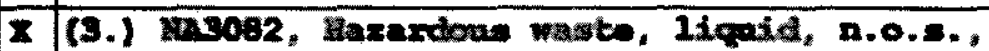

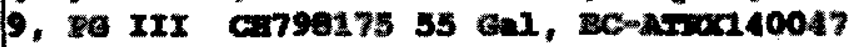

(4.) Da3077, Bazardow wate, colid, m.0.s.., 9, 1 pe III Niwo contains pos sulik Product, $>300$ pren, 003 04/23/14, Containex Het Nexight=15.50

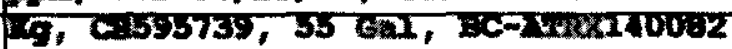

32. Special Handing !nstructions and Additional information

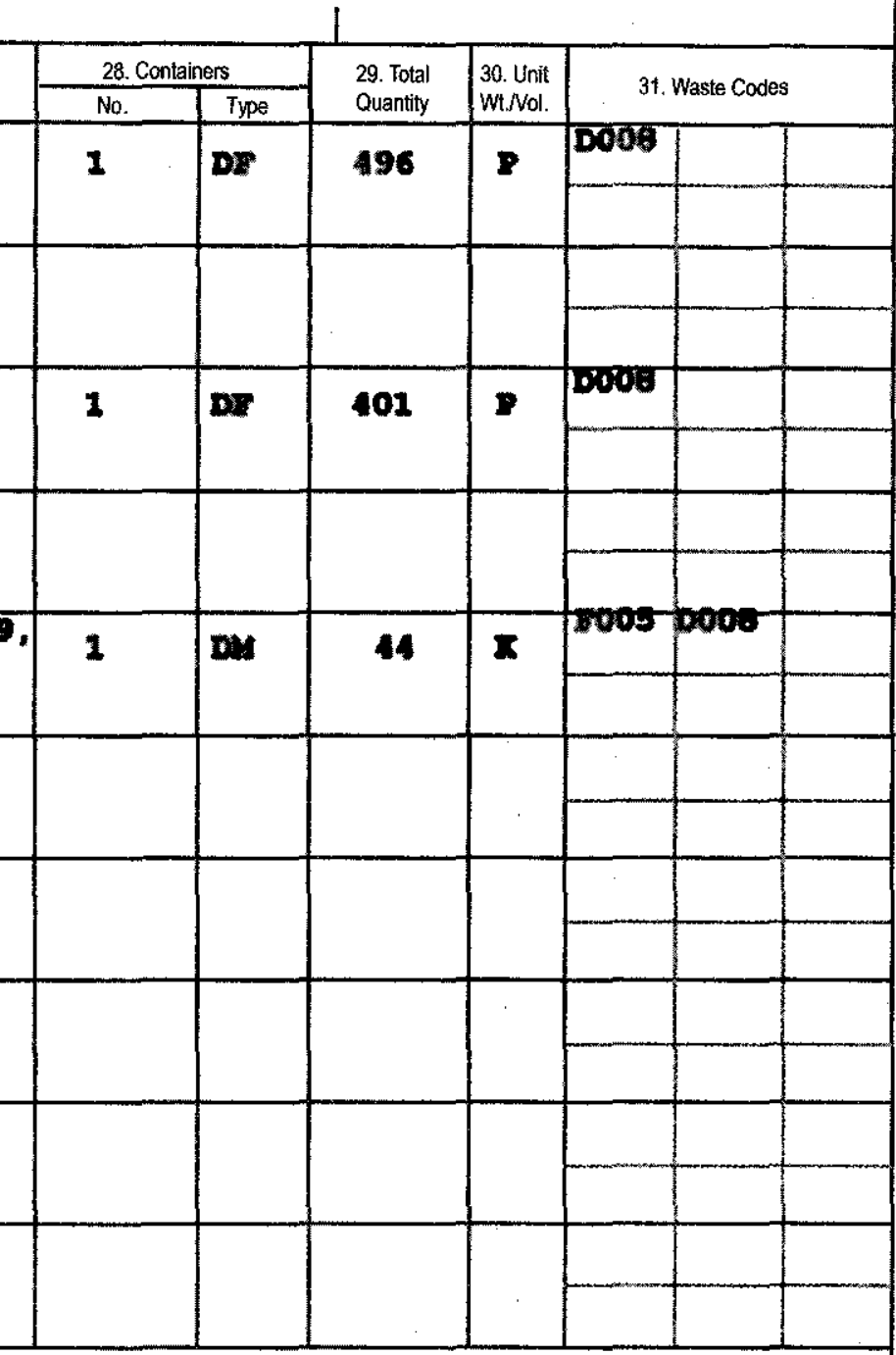

33. Transporter

Acknowiedgment of Receipt of Materials

Printed/Typed Name

政

34. Transporter___Acknowledgment of Receipt of Materials

Printed/Typed Name

35. Discrepancy

0029113925 Lx 
UTD981552177

(435) $884-8100$

\section{CERTIFICATE OF DISPOSAL}

Generator Facility Name:

Generator Address:

INL Advanced Test Reactor (ATRC)

58 Miles West of Idaho Falls, ID via HWY 20 west, 9 miles

Miles North of CFA

Idaho Falls, ID, 83415

\author{
Sales Order\#: $\quad 1400741034$ \\ Date Received: $\quad 7 / 11 / 2014$
}

Generator Contact Name:

\begin{tabular}{|c|c|c|c|c|c|c|c|}
\hline \multirow{2}{*}{\multicolumn{2}{|c|}{ Generator EPA ID: }} & \multirow{2}{*}{\multicolumn{2}{|c|}{ ID4890008952 }} & & \multirow{2}{*}{\multicolumn{2}{|c|}{$\begin{array}{l}\text { Load \#: } \\
\text { Manifest \#: }\end{array}$}} & 68922 \\
\hline & & & & & & & $002911392 F L E$ \\
\hline $\begin{array}{l}\text { Original } \\
\text { CH ID \# }\end{array}$ & $\begin{array}{l}\text { Date Removed } \\
\text { From Service }\end{array}$ & $\begin{array}{l}\text { Unit } \\
\text { Type }\end{array}$ & $\begin{array}{c}\text { Serial \# I } \\
\text { Customer ID }\end{array}$ & $\begin{array}{c}\text { Material } \\
\text { Description }\end{array}$ & $\begin{array}{l}\text { Disposal } \\
\text { Date }\end{array}$ & $\begin{array}{l}\text { Method of } \\
\text { Disposal }\end{array}$ & Disposal Facility \\
\hline 39000279 & $4 / 23 / 2014$ & DM & ATRX140082/ & PCB Solids For Incineration & $8 / 6 / 2014$ & Incineration & Aragonite, UT Facility \\
\hline
\end{tabular}

Under Civil and Criminal Penalties of Law for the making or submission of false or fraudulent statements or representations (18 U.S.C. 1001 and 15 U.S.C. 2615), I certify that the information contained in or accompanying this document is true, accurate, and complete. As to the identified section(s) of this document for which I cannot personally verify truth and accuracy, I certify as the company official having supervisory responsibility for the persons who, acting under my direct instructions, made the verification that this information is true, accurate, and complete.

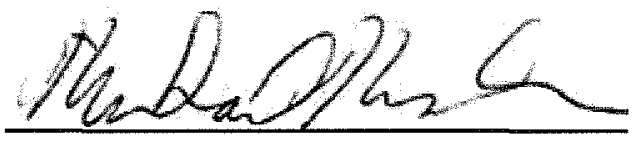

Authorized Agent
Tuesday, August 12, 2014

Date 


\section{$47006 / 448200$}

Please print or type. (Form designed for use on elite (12-pitch) typewriter.)

Form Approved. OMB No. 2050-0039

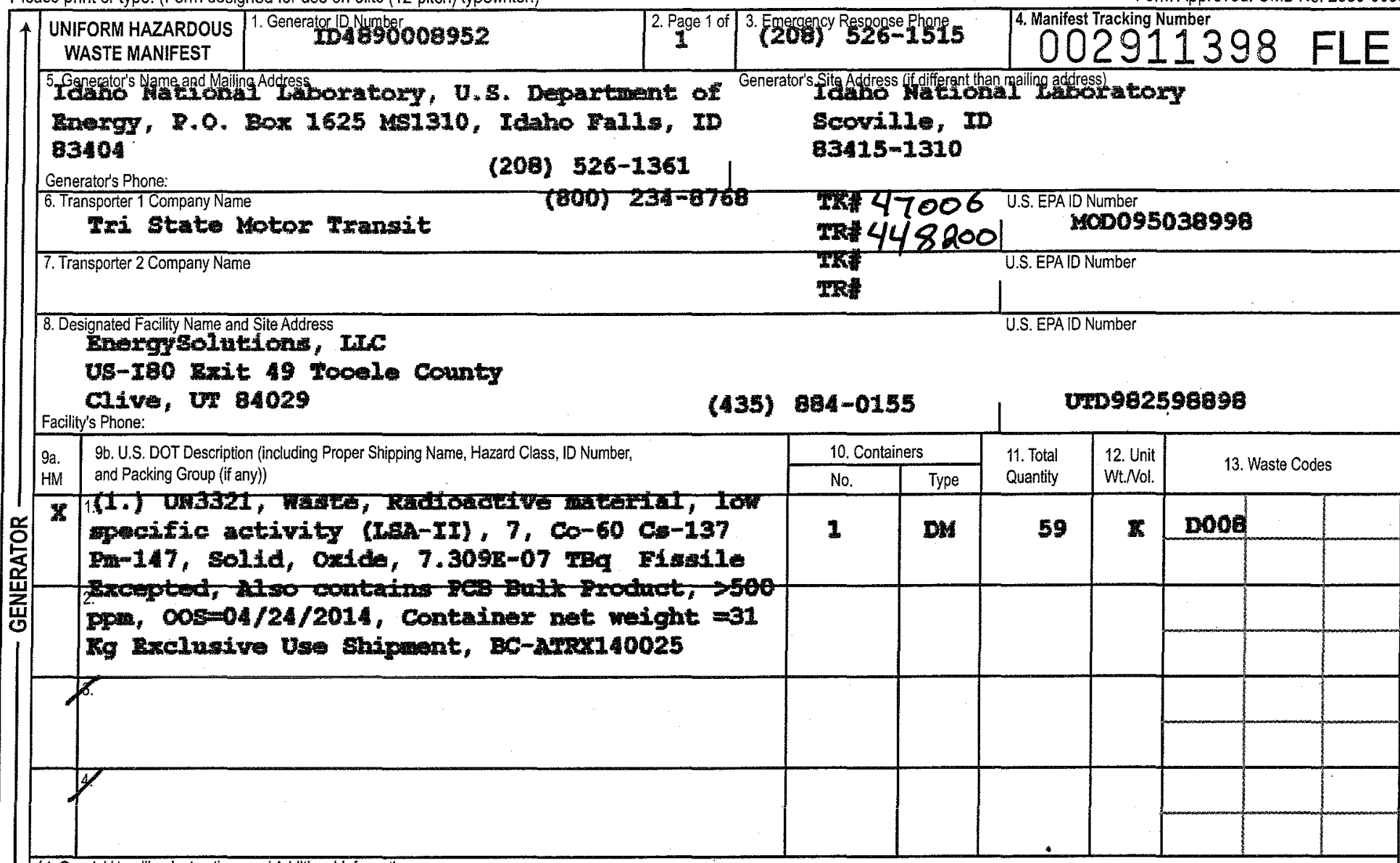

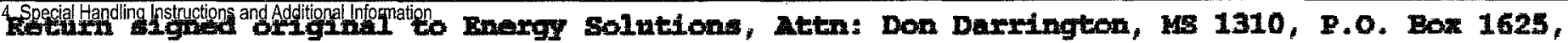
Idaho Fa11s, ID, 83415, Prerared under DOF Contract DE-AC07-05ID-14517 Chaxge 101653200, Profile 9083-02-0032

$P M 01690$

15. GENERATOR'S/OFFEROR'S CERTIFICATION: I hereby declare that the contents of this consignment are fully and accurately described above by the proper shipping name, and are classified, packaged, marked and labeled/placarded, and are in all respects in proper condition for transport according to applicable international and national governmental regulations. If export shipment and I am the Primary Exporter, I certify that the contents of this consignment conform to the terms of the attached EPAAcknowledgment of Consent.

I certify that the waste minimization statement identified in 40 CFR 262.27(a) (if I am a large quantity generator) or (b) (fif I am a small gagntity generator) is true.

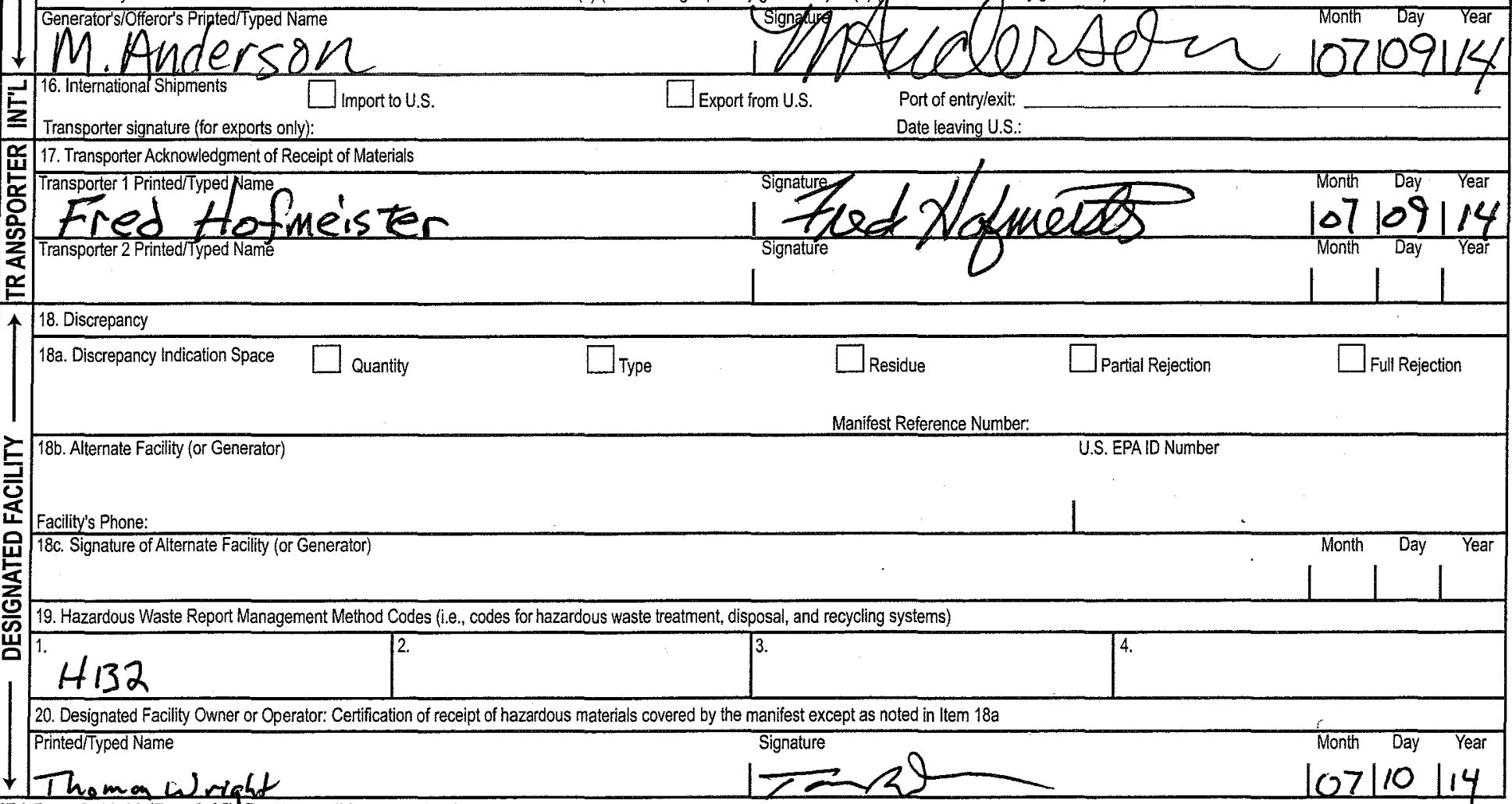




\section{ENERGYSOLUTIONS}

\section{CERTIFICATE OF DISPOSAL}

3 miles South, Exit 49 I-80

Clive, Utah 84029

EPA ID: UTD 982598898

\section{BEAINL for US DOE, Idaho Falls}

This certificate acknowledges that the following manifested shipments have been disposed of as listed below:

\begin{tabular}{|c|c|c|c|c|c|}
\hline $\begin{array}{l}\text { Shipment } \\
9083-01-0037 \\
9083-01-0038 \\
9083-02-0031 \\
9083-02-0032\end{array}$ & $\begin{array}{l}\text { Mantfent } \\
09476 \\
11397 \\
07759 \\
11398\end{array}$ & $\begin{array}{l}\text { Disponal pate } \\
07 / 21 / 2014 \\
07 / 21 / 2014 \\
07 / 21 / 2014 \\
07 / 21 / 2014\end{array}$ & $\begin{array}{l}\text { Yolume (Cufft) } \\
22.7 \\
7.4 \\
141.2 \\
7.4\end{array}$ & $\begin{array}{l}\text { Propes: } \\
\text { Landfll } \\
\text { Landit|l } \\
\text { Landîll } \\
\text { Landall }\end{array}$ & $\begin{array}{l}\text { Dignosal Loction } \\
\text { Mixed Waste } \\
\text { Mixed Waste } \\
\text { Mixed Waste } \\
\text { Mixed Waste }\end{array}$ \\
\hline
\end{tabular}

The total volume above represents the cubic feet of waste disposed of at EnergySolutions' Disposal Facility Landfill. Disposal is subject to EnergySolutions' Radioactive Material License, all other applicable licenses, permits and regulations, and the Disposal Agreement.

Under chil and criminal penalties of law for the making or submission of faise or frautulent statements or representations (18 U.S.C 1001 and 15 U.S.C. 2615) I centhy that the information contained in or accompanying this document is true, accurate and complete. As to the identification saction(s) of this document for which I gannot personaly werify truth and accuracy, I certify as the company official having supervisary responsibility for the persons who, acting under my direct instructions, made the verification that ithis information is tres, eccurate and complete.

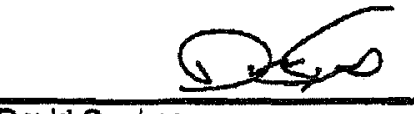

Dwe Squites

Mineger Fiste Dimond Opertions

Jul 24 2014 10:10 AM

Davld Squires

Manager Waste Disposal Operations

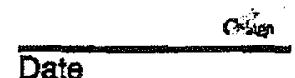

423 West 300 South, Salt Lake City, Utah 84101 Telephone (801) 649-2000 
Please print or type. (Form ciesigned for use on elite (12-pitch) typewriter.)

$$
6332
$$

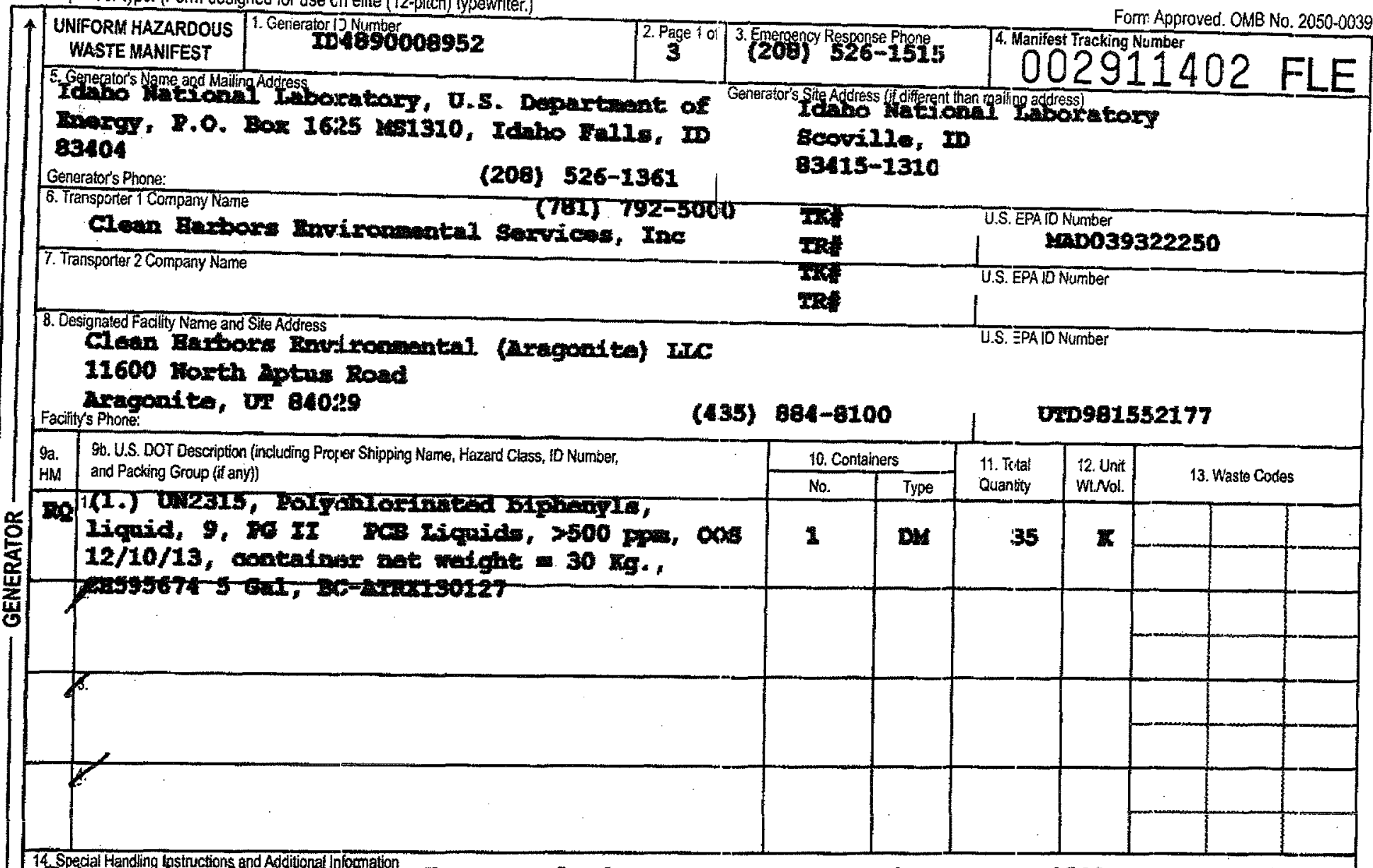

14. Spectal Handing hstructiong and Adfitional In

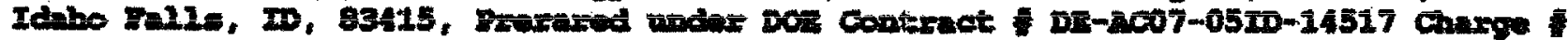
101653200 seles Ondex 1401682374

15. GENERATOR'SIOFFEROR'S CERTIFICATIJN: Thereby dectare that the contents of this consignment art fully and accurately described above by the pro ser shipping name, and are ciassified, packaged,

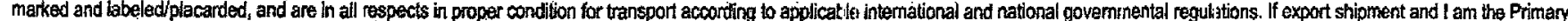
Exporter, I certify that the contents of this consigniment conform to the terns of the altached EPAAcknowledg nent of Consent.

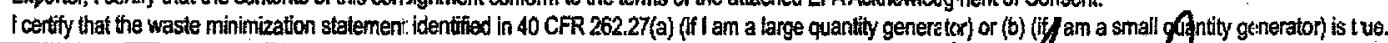

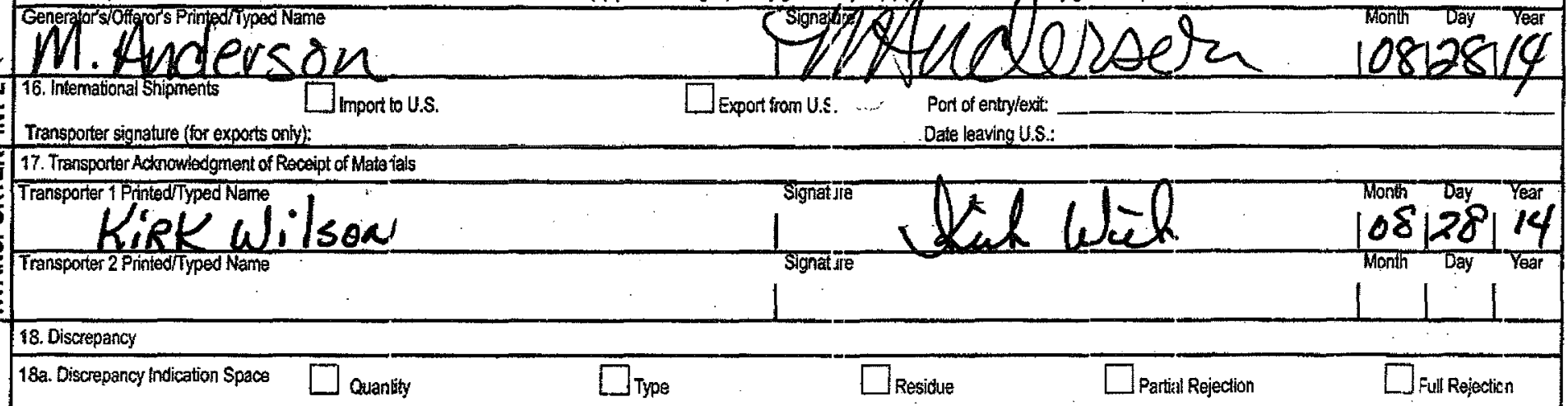
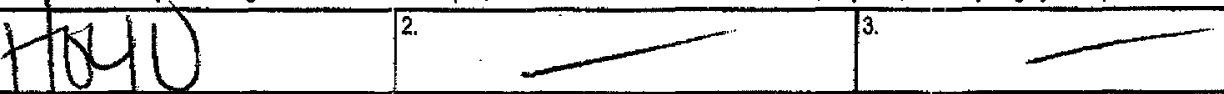

20. Designated Facility Cwner or Operator: Certification of receipt of hazardous materials covered by the manifest akcept as noted in them 18a 


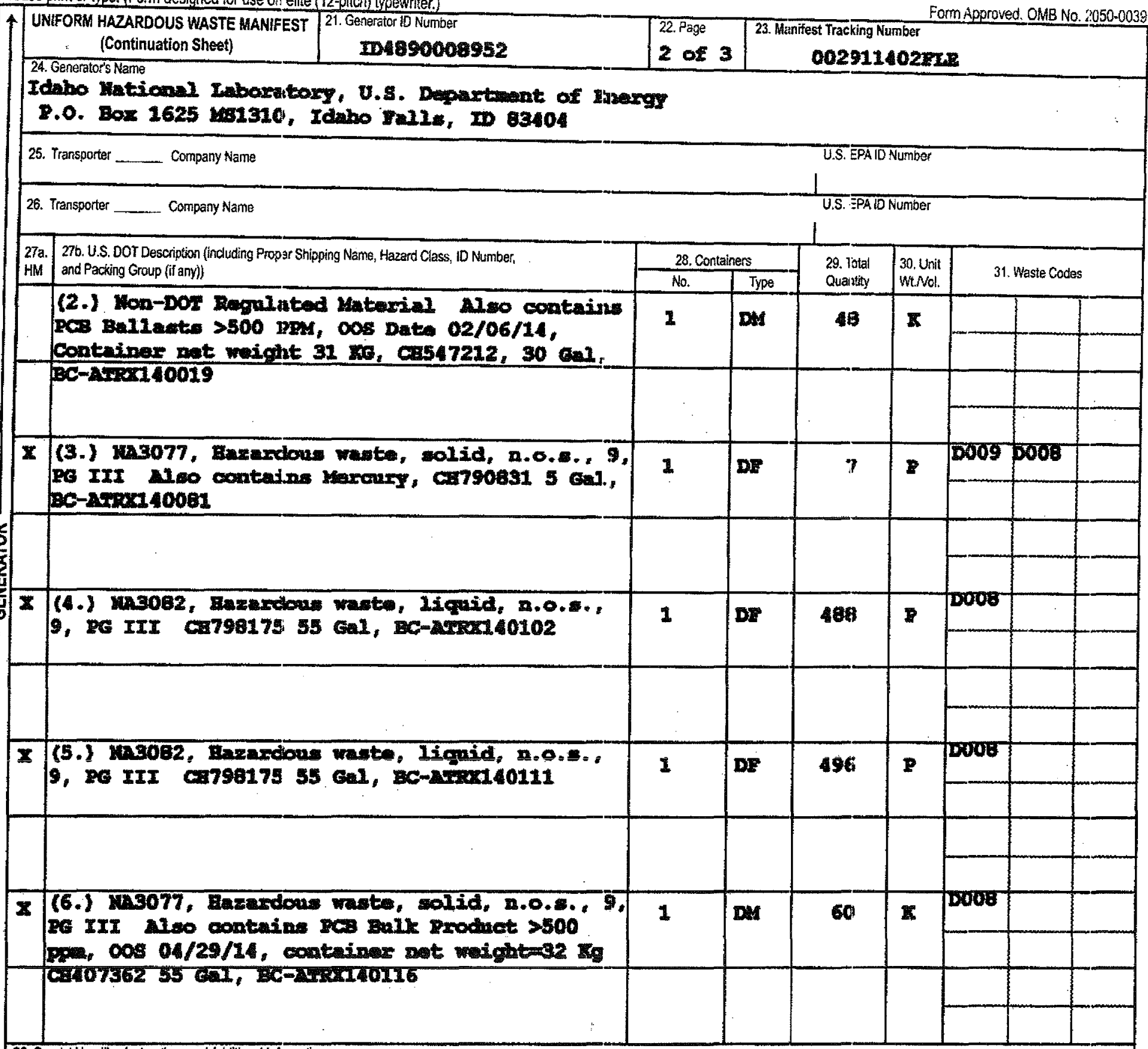

32. Special Handling Instructions and Adeditional Infinmation

33. Transporter

Acknowledgrnent of Receip of Materials

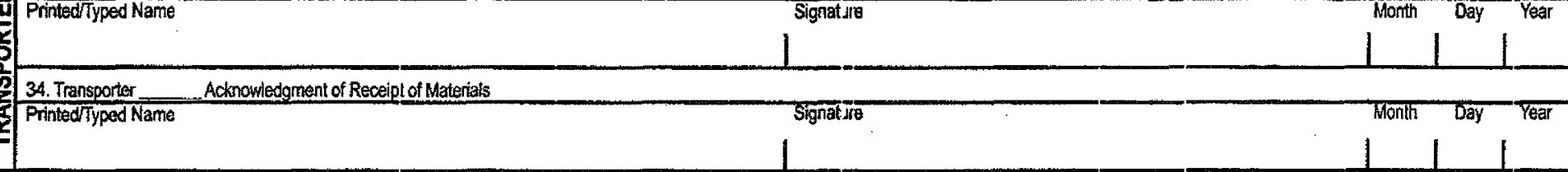

35. Discrepancy

36. Hazzdo is Waste Regort Management Method isodes (fie., codes for hazardous waste treatnen disposal and racycling systerts) 
Id tho National Iabortcory, U.S. Departant of Enemer

P.0. Eow 1625 va1310, Idnho Fu11s, m 83404

\begin{tabular}{ll|l} 
25. Transpoter ___ Company Name & U.S. EPA ID Nuriber \\
\hline 26. Transporter ___ Company Name & \\
\hline
\end{tabular}

27a. 27b. U.S. DOF Description (including Propar Shipping Name, Hazard Class, ID Number,

HM and Packing Group (if any))

8 (7.) ba2000, Waste, Batterios, wot, non-gillabie, 0, RG III ca399432 2 cal. EC-Arac140119

$x$ (8.) U2800, wastes, Batteries, wet,

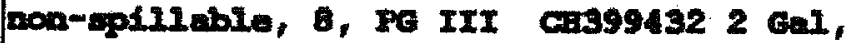
ac- $25+240120$

$x(9$.$) ur2923, Thete, Cormosive molide, toric,$ 0.0.3. (Ruming sulturio actd, 30-35 है), 8

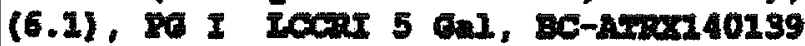

$x$ (10.) 012759, Fatre, Corrobive wolide, n.o.i. (Eydrazine Eydrate, sulfurla said 5 i), 8, ze

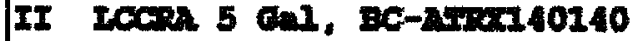

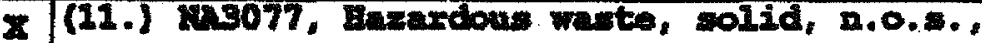

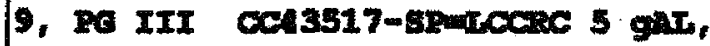
Do-25+140141

32. Special Handing Instructions and Additional Infirmation

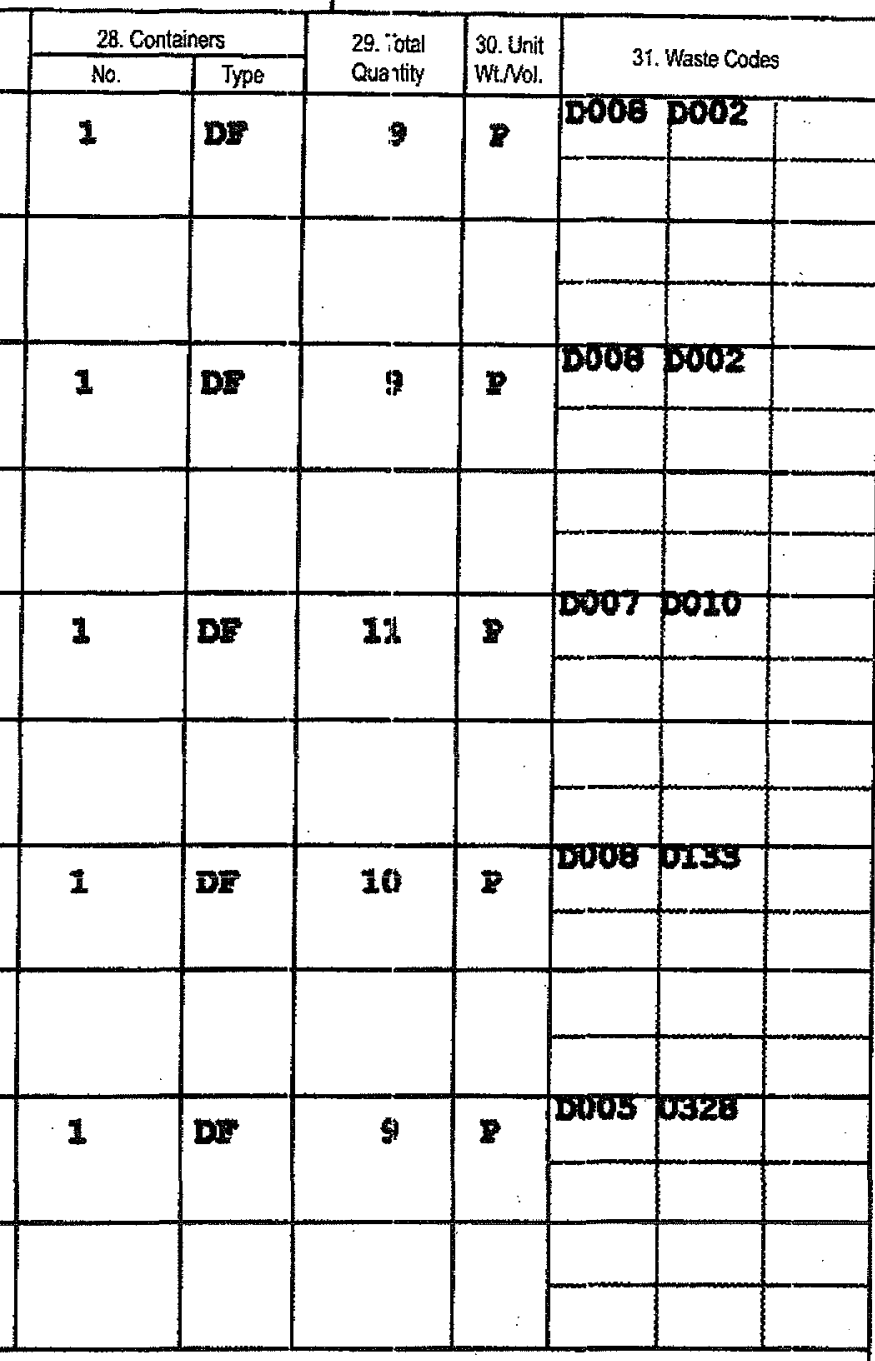

33. Traksportior Acknowladgment of Rexeipt of Materials

34. Transponter. Acknowiedgment of Receipt of Waterials




\section{CERTIFICATE OF DISPOSAL}

\section{Generator:}

INL Advanced Test Reactor (ATRC)

58 Miles West of Idaho Falls,

ID via HWY 20 west, 9 miles

North of CFA,

Idaho Falls, ID 83415

Load\# 69611

SO\# 1401682374

Date Received:09/12/2014

EPA ID\#: IDL4890008952

Manifest\# 002911402FLE

\section{Drum Number Removal Date Disposal Date Unique ID \# Material Description}

$40313442 \quad 12 / 10 / 2013 \quad 10 / 22 / 2014 \quad$ ATRX130127 PCB Liquids for Incineration

This is to certify that the hazardous material manifested to Clean Harbors was disposed of by incineration in accordance with 40 CFR 761 (and 40 CFR 264 if applicable) as of the above certification date.

Under civil and criminal penalties of law for the making or submission of false or fraudulent statements or representations (18 U.S.C. 1001 and 15 U.S.C. 1615), I certify that the information

contained in or accompanying this document is true, accurate, and complete. As to the identified sections of this document for which I cannot personally verify truth and accuracy, I certify as the

company official having supervisory responsibility for the persons who, acting under my direct instructions, made the verification that this information is true, accurate, and complete.

Clean Harbors Aragonite, LLC,

EPA WD \# UTD981552177

Facility Representative
$10 / 29 / 2014$

Date 
Clean Harbors Aragonite LLC

11600 North Aptus Road

Grantsville UT, 84029

UTD981552177

(435) $884-8100$

\section{CERTIFICATE OF DISPOSAL}

Generator Facility Name:

Generator Address:
INL Advanced Test Reactor (ATRC)

58 Miles West of Idaho Falls, ID via HWY 20 west, 9 miles

Miles North of CFA

Idaho Falls, ID, 83415
Sales Order\#: $\quad 1401682374$

Date Received: 9/12/2014

Generator Contact Name:

Generator EPA ID:
ID4890008952

Serial \# I

Original Date Removed Unit

CH ID \# From Service Type

Customer ID

DM

$\operatorname{atr} \times 140019 /$

PCB Solids For Incineration

Material Description

\section{Load \#:}

Manifest \#:
69611

002911402FLE

40313443

$2 / 6 / 2014$

\section{Disposal \\ Date}

9/30/2014
Method of

Disposal

Disposal Facility

Incineration

Under Civil and Criminal Penalties of Law for the making or submission of false or fraudulent statements or representations (18 U.S.C. 1001 and 15 U.S.C. 2615), I certify that the information contained in or accompanying this document is true, accurate, and complete. As to the identified section(s) of this document for which I cannot personally verify truth and accuracy, I certify as the company official having supervisory responsibility for the persons who, acting under my direct instructions, made the verification that this information is true, accurate, and complete.

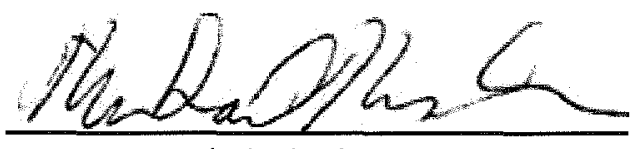

Authorized Agent
Wednesday, October 29, 2014

Date 


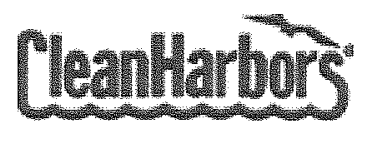

Generator Address:

INL Advanced Test Reactor (ATRC)

58 Miles West of Idaho Falls, ID via HWY 20 west, 9 miles

Miles North of CFA

Idaho Falls, ID, 83415

Clean Harbors Aragonite LLC

11600 North Aptus Road

Grantsville UT, 84029

UTD981552177

(435) $884-8100$

\section{CERTIFICATE OF DISPOSAL}

Generator Contact Name:
ID4890008952

Serial \# I

Original Date Removed Unit CH ID \# From Service Type
Sales Order\#:
1401682374
Date Received:

40313447

$4 / 29 / 2014$

DM ATRX140116/

PCB Solids For Incineration

Material Description
Load \#:

Manifest \#:

\section{1}

002911402FLE

Under Civil and Criminal Penalties of Law for the making or submission of false or fraudulent statements or representations (18 U.S.C. 1001 and 15 U.S.C. 2615), I certify that the information contained in or accompanying this document is true, accurate, and complete. As to the identified section(s) of this document for which I cannot personally verify truth and accuracy, I certify as the company official having supervisory responsibility for the persons who, acting under my direct instructions, made the verification that this information is true, accurate, and complete.

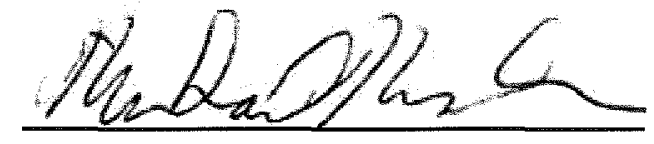

Authorized Agent
Friday, October 10, 2014

Date 


\section{2}

Please print or type. (Form designed for use on elite (12-pitch) typewriter.)

Form Approved. OMB №. 2050-0039

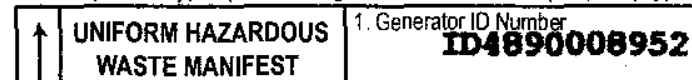

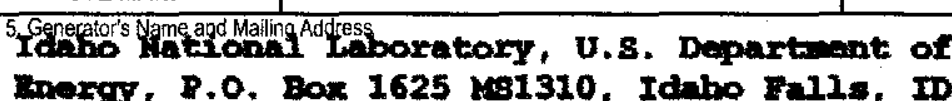

83404

Generator's Phone:

(208) 526-1361

6. Transporter 1 Company Name (781) $792-5000$

Clean Barbors Bnvixomental Sexvices, Ine

7. Transporten 2 Company Name

$\mathrm{C}^{\mathrm{T}} \mathrm{O}$ a

tonline

$G \mathrm{SW}$ SUS

8. Designated Facility Name and Site Address

Claun Rarbors Rnvironantal (Mragonito) we

11600 Noxth Aptum Road

Aragonite, or 84029

Faciility's Phone:

9a. 9 b. U.S. DOT Description (induding Proper Shipping Name, Hazard Class, ID Number,

HM and Packing Group (if any))

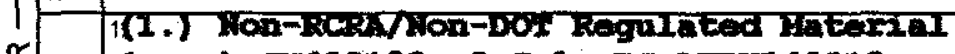

(raga) Cu425129, 5 Ga1, BC-ximat40012

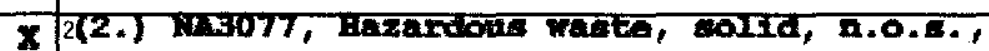

9, DO III Almo contein Bos Bull Product,

$\$ 500$ ppm, $00507 / 07 / 14$, contelner not welght $=$

(435) $884-8100$

Sitc Address (if different than mailing address) torory

Ecori110, ID

83415-1310

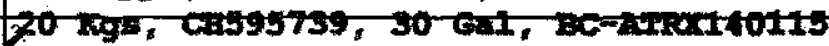

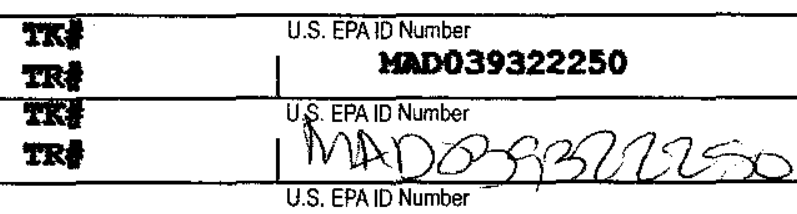

.

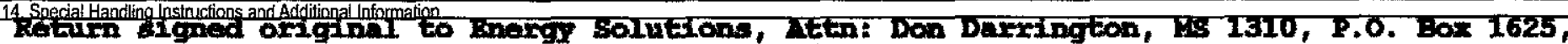

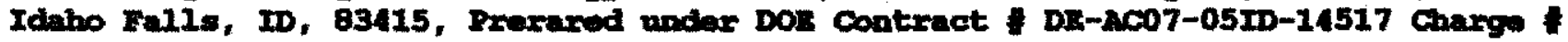
101653200, sales Oxder 1402915907

15. GENERATOR'S/OFFEROR'S CERTIFICATION: I hereby dectare that the contents of this consignment are fully and accurately described above by the proper shipping name, and are classified, packaged, marked and labelediplacarded, and are in all respects in proper condition for transport according to appicable international and national governmental regulations. If export shipment and I am the Primary

Exporter; I certify that the contents of this consignment conform to the torms of the attached EPAAcknowledgment of Consent.

I certify that the waste mirimization statement identifited in 40 CFR 262.27(a) (if I am a large quantity generator) or (b) (ff I am a small quantity generator) is true.

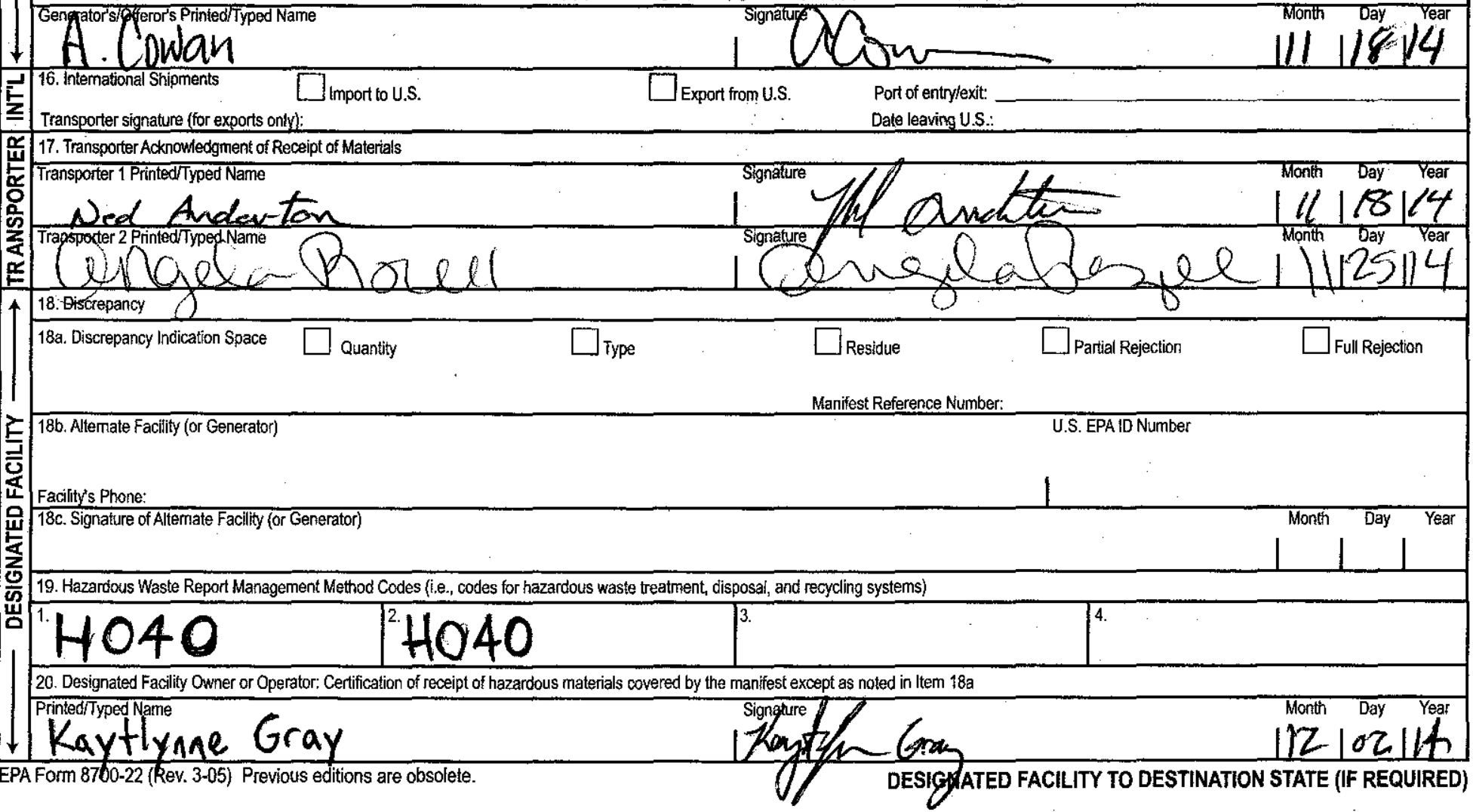




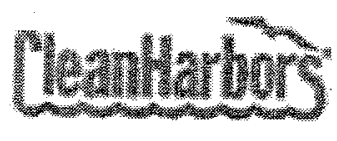

Clean Harbors Aragonite LLC

11600 North Aptus Road

Grantsville UT, 84029

UTD981552177

(435) $884-8100$

\section{CERTIFICATE OF DISPOSAL}

Generator Faclity Name:
Generator Address:
INL Advanced Test Reactor (ATRC)

58 Miles West of Idaho Falls, ID via HWY 20 west, 9 miles

Miles North of CFA

Idaho Falls, ID, 83415
Sales Orderts: $\quad 1402915907$

Date Received: $\quad 12 / 2 / 2014$

Generator Contact Name:

\begin{tabular}{|c|c|c|c|c|c|c|c|}
\hline \multirow{2}{*}{\multicolumn{2}{|c|}{ Generator EPA ID: }} & \multirow{2}{*}{\multicolumn{2}{|c|}{104890008952}} & & \multicolumn{2}{|c|}{ Load \#: } & 70721 \\
\hline & & & & & \multicolumn{2}{|c|}{ Manifest \#: } & 002811406FLE \\
\hline $\begin{array}{l}\text { Original } \\
\mathrm{CHID}\end{array}$ & $\begin{array}{l}\text { Date Removed } \\
\text { From Service }\end{array}$ & $\begin{array}{l}\text { Unit } \\
\text { Type }\end{array}$ & $\begin{array}{c}\text { Serial \# I } \\
\text { Customer ID }\end{array}$ & $\begin{array}{c}\text { Material } \\
\text { Description }\end{array}$ & $\begin{array}{c}\text { Disposal } \\
\text { Date }\end{array}$ & $\begin{array}{l}\text { Method of } \\
\text { Disposal }\end{array}$ & Disposal Facility \\
\hline 41984730 & $7 / 7 / 2014$ & $\mathrm{DM}$ & ATRX $140 \div 151$ & PCB Solida For incineration & $12 / 31 / 2014$ & Incineration & Aragonlte, UT Facillty \\
\hline
\end{tabular}

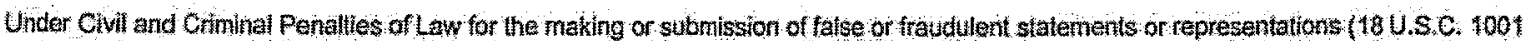

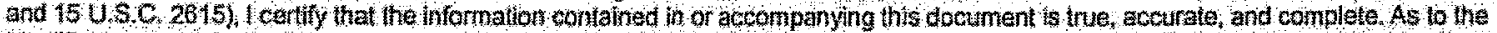

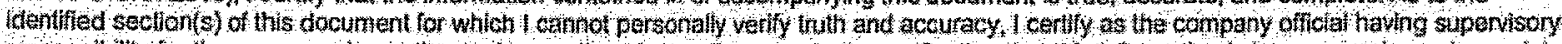

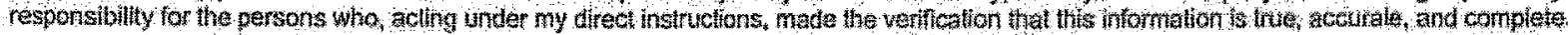

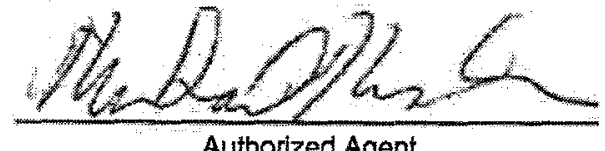

Thursday, January 08,2015

Authorized Agen

Date

Page 1 of 1 
iracer 552658

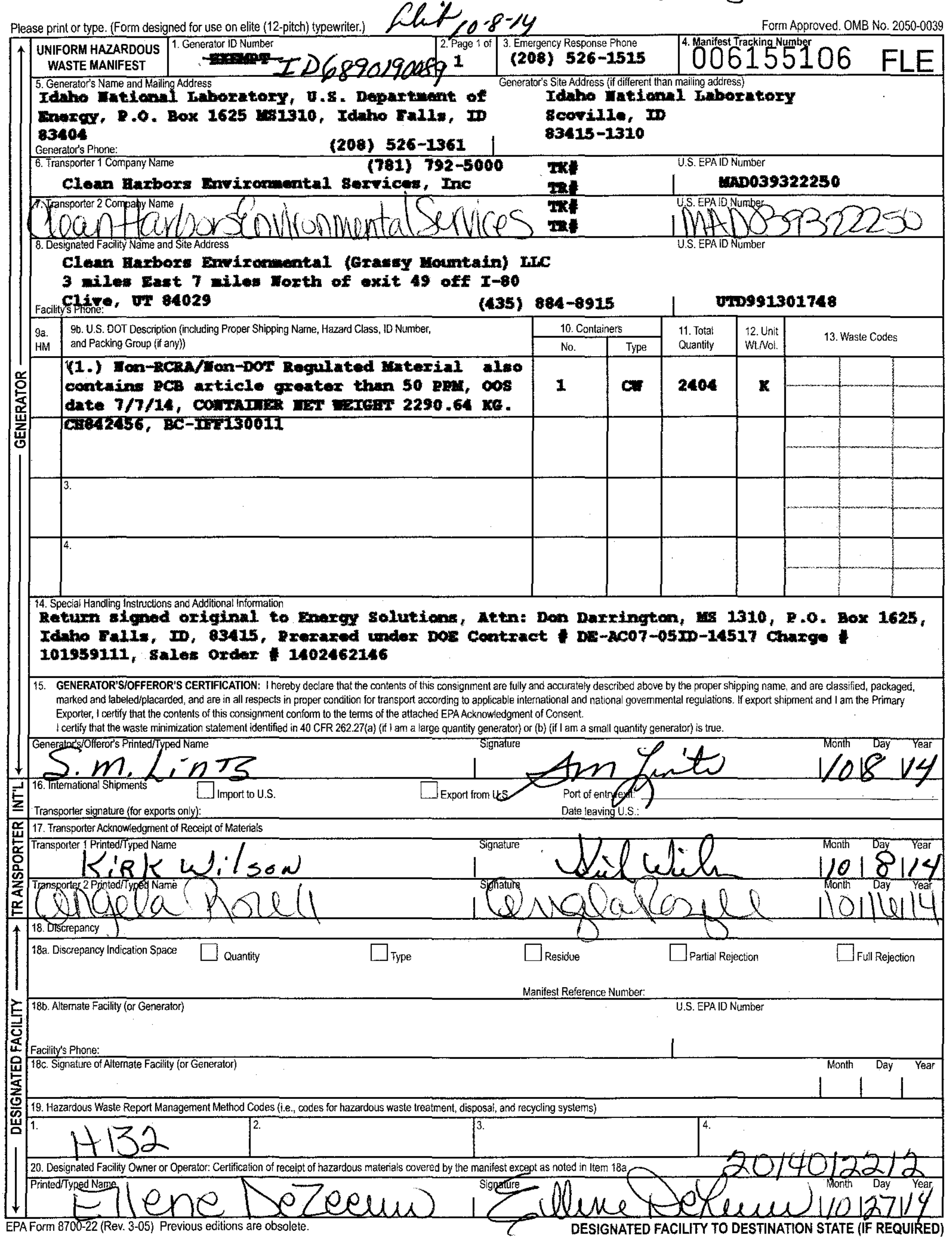




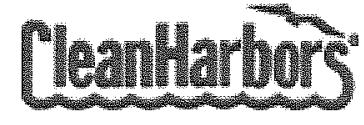

Clean Harbors Grassy Mountain LLC

3 Miles East 7 Miles North of Knolls

Grantsville UT, 84029

UTD991301748

(435) $884-8900$

\section{CERTIFICATE OF DISPOSAL}

Generator Facility Name:

Generator Address:

INL Research Center (IRC)

Idaho National Laboratory, U.S. Department of Energy

PO Box 1625

Idaho Falls, ID, 83415
Sales Order\#: $\quad 1402462146$

Date Received: $\quad$ 10/27/2014

Generator Contact Name:

Generator EPA ID:

ID6890190089

Load \#:

14012212

Manifest \#:

006155106FLE

Original Date Removed Unit Serial \# I

CH ID \# From Service Type Customer ID

\section{Material \\ Description}

PCB Solids For Landfill

\section{Method of Disposal}

Disposal Facility

Landfill
Grassy Mountain, UT Facility

Under Civil and Criminal Penalties of Law for the making or submission of false or fraudulent statements or representations (18 U.S.C. 1001 and 15 U.S.C. 2615), I certify that the information contained in or accompanying this document is true, accurate, and complete. As to the identified section(s) of this document for which I cannot personally verify truth and accuracy, I certify as the company official having supervisory responsibility for the persons who, acting under my direct instructions, made the verification that this information is true, accurate, and complete.

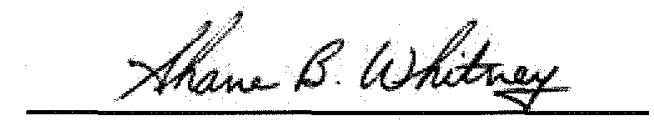

Authorized Agent
Thursday, October 30, 2014

Date 


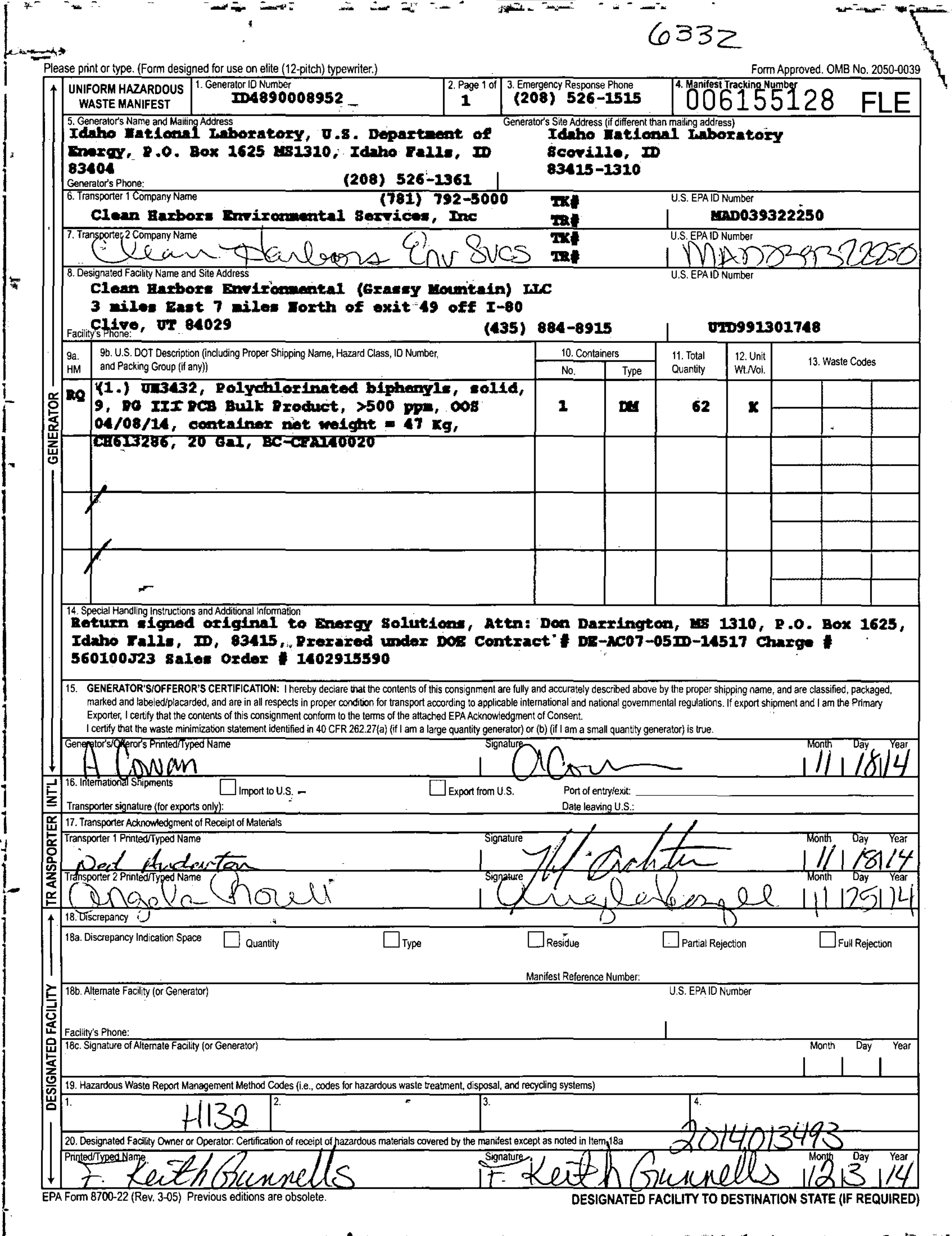




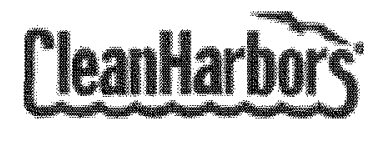

Clean Harbors Grassy Mountain LLC

3 Miles East 7 Miles North of Knolls

Grantsville UT, 84029

UTD991301748

(435) $884-8900$

\section{CERTIFICATE OF DISPOSAL}

Generator Facility Name:

Generator Address:
INL Central Facilities Area CFA

Idaho National laboratory, U.S. Department of Energy

PO Box 1625

Idaho Falls, ID, 83415 $\begin{array}{ll}\text { Sales Order\#: } & 1402915590 \\ \text { Date Received: } & 12 / 3 / 2014\end{array}$

Generator Contact Name:

\begin{tabular}{|c|c|c|c|c|c|c|c|}
\hline & \multirow{2}{*}{\multicolumn{2}{|c|}{ ID4890008952 }} & & \multicolumn{2}{|c|}{ Load \#: } & 14013493 \\
\hline \multicolumn{2}{|c|}{ Generator EPA ID: } & & & & \multicolumn{2}{|c|}{ Manifest \#: } & 006155128FLE \\
\hline $\begin{array}{l}\text { Original } \\
\text { CH ID \# }\end{array}$ & $\begin{array}{l}\text { Date Removed } \\
\text { From Service }\end{array}$ & $\begin{array}{l}\text { Unit } \\
\text { Type }\end{array}$ & $\begin{array}{c}\text { Serial \# I } \\
\text { Customer ID }\end{array}$ & $\begin{array}{c}\text { Material } \\
\text { Description }\end{array}$ & $\begin{array}{l}\text { Disposal } \\
\text { Date }\end{array}$ & $\begin{array}{l}\text { Method of } \\
\text { Disposal }\end{array}$ & Disposal Facility \\
\hline 41984753 & $4 / 8 / 2014$ & $\mathrm{DM}$ & BC-CFA140020 / & $\begin{array}{c}\text { PCB Ballasts Or Capacitors For } \\
\text { Landfill }\end{array}$ & $12 / 9 / 2014$ & Landfill & $\begin{array}{l}\text { Grassy Mountain, UT } \\
\text { Facility }\end{array}$ \\
\hline
\end{tabular}

Under Civil and Criminal Penalties of Law for the making or submission of false or fraudulent statements or representations (18 U.S.C. 1001 and 15 U.S.C. 2615), I certify that the information contained in or accompanying this document is true, accurate, and complete. As to the identified section(s) of this document for which I cannot personally verify truth and accuracy, I certify as the company official having supervisory responsibility for the persons who, acting under my direct instructions, made the verification that this information is true, accurate, and complete.

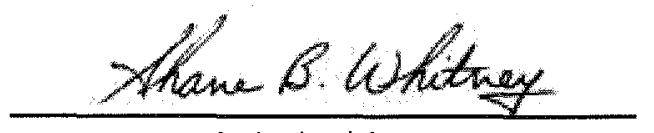

Authorized Agent
Monday, December 22, 2014

Date 


\section{APPENDIX 2}

Manifests Generated during Calendar Year 2014 that did not receive a Certificate of Disposal/Destruction during calendar year 2014 (manifests on following pages)

\begin{tabular}{|c|c|c|c|}
\hline Item No. & Manifest No. & Identification No. & $\begin{array}{c}\text { Disposal/Destruction } \\
\text { Date }\end{array}$ \\
\hline 1 & 000372277JJK & INTC140207 & \\
\hline \multirow[t]{3}{*}{2} & $000372278 \mathrm{JJK}$ & NRF140052 & \\
\hline & 000372278JJK & NRF140080 & \\
\hline & $000372278 \mathrm{JJK}$ & NRF140081 & $12 / 30 / 2014$ \\
\hline 3 & 000372279JJK & NRF140071 & \\
\hline \multirow[t]{20}{*}{4} & $001600965 \mathrm{GBF}^{*}$ & 10485651 (BN10509608) & \\
\hline & $001600965 \mathrm{GBF}^{*}$ & 10488566 (BN10509608) & \\
\hline & $001600965 \mathrm{GBF}^{*}$ & 10488567 (BN10509600) & \\
\hline & $001600965 \mathrm{GBF}^{*}$ & 10488569 (BN10509600) & \\
\hline & $001600965 \mathrm{GBF}^{*}$ & 10488574 (BN10509600) & \\
\hline & $001600965 \mathrm{GBF}^{*}$ & 10488579 (BN10509600) & \\
\hline & $001600965 \mathrm{GBF}^{*}$ & 10488581 (BN10509608) & \\
\hline & $001600965 \mathrm{GBF}^{*}$ & $10493531(\mathrm{BN} 10509600)$ & \\
\hline & $001600965 \mathrm{GBF}^{*}$ & 10493536 (BN10509608) & \\
\hline & $001600965 \mathrm{GBF}^{*}$ & 10493538 (BN10509608) & \\
\hline & $001600965 \mathrm{GBF}^{*}$ & 10493539 (BN10509608) & \\
\hline & $001600965 \mathrm{GBF}^{*}$ & 10493586 (BN10509600) & \\
\hline & $001600965 \mathrm{GBF}^{*}$ & 10493613 (BN10509600) & \\
\hline & $001600965 \mathrm{GBF}^{*}$ & 10493615 (BN10509608) & \\
\hline & $001600965 \mathrm{GBF}^{*}$ & 10493616 (BN10509608) & \\
\hline & $001600965 \mathrm{GBF}^{*}$ & 10493617 (BN10509608) & \\
\hline & $001600965 \mathrm{GBF}^{*}$ & $10493620(\mathrm{BN} 10509608)$ & \\
\hline & $001600965 \mathrm{GBF}^{*}$ & 10493621 (BN10509600) & \\
\hline & $001600965 \mathrm{GBF}^{*}$ & $10493622(\mathrm{BN} 10509600)$ & \\
\hline & $001600965 \mathrm{GBF}^{*}$ & $10493623(\mathrm{BN} 10509600)$ & \\
\hline \multirow[t]{4}{*}{5} & $001600968 \mathrm{GBF}^{*}$ & 10480204 (BN10509686) & \\
\hline & $001600968 \mathrm{GBF}^{*}$ & 10480228 (BN10509686) & \\
\hline & $001600968 \mathrm{GBF}^{*}$ & 10490496 (BN10509686) & \\
\hline & $001600968 \mathrm{GBF}^{*}$ & 10491200 (BN10509686) & \\
\hline
\end{tabular}




\section{APPENDIX 2}

Manifests Generated during Calendar Year 2014 that did not receive a Certificate of Disposal/Destruction during calendar year 2014 (manifests on following pages)

\begin{tabular}{|c|c|c|c|}
\hline \multirow[t]{17}{*}{ Item No. } & Manifest No. & Identification No. & $\begin{array}{c}\text { Disposal/Destruction } \\
\text { Date }\end{array}$ \\
\hline & $001600968 \mathrm{GBF}^{*}$ & 10493598 (BN10509604) & \\
\hline & $001600968 \mathrm{GBF}^{*}$ & 10502815 (BN10509604) & \\
\hline & $001600968 \mathrm{GBF}^{*}$ & 10502819 (BN10509604) & \\
\hline & $001600968 \mathrm{GBF}^{*}$ & 10502863 (BN10509604) & \\
\hline & $001600968 \mathrm{GBF}^{*}$ & 10503233 (BN10509604) & \\
\hline & $001600968 \mathrm{GBF}^{*}$ & $10503241(\mathrm{BN} 10509686)$ & \\
\hline & $001600968 \mathrm{GBF}^{*}$ & 10503243 (BN10509604) & \\
\hline & $001600968 \mathrm{GBF}^{*}$ & 10503245 (BN10509686) & \\
\hline & $001600968 \mathrm{GBF}^{*}$ & $10503252(\mathrm{BN} 10509686)$ & \\
\hline & $001600968 \mathrm{GBF}^{*}$ & $10503260(\mathrm{BN} 10509686)$ & \\
\hline & $001600968 \mathrm{GBF}^{*}$ & 10503263 (BN10509604) & \\
\hline & $001600968 \mathrm{GBF}^{*}$ & 10503267 (BN10509604) & \\
\hline & $001600968 \mathrm{GBF}^{*}$ & $10503268(\mathrm{BN} 10509604)$ & \\
\hline & $001600968 \mathrm{GBF}^{*}$ & 10503366 (BN10509686) & \\
\hline & $001600968 \mathrm{GBF}^{*}$ & 10503369 (BN10509686) & \\
\hline & $001600968 \mathrm{GBF}^{*}$ & $10503370(\mathrm{BN} 10509604)$ & \\
\hline \multirow[t]{15}{*}{6} & $001600969 \mathrm{GBF}^{*}$ & 10489120 (BN10503776) & \\
\hline & $001600969 \mathrm{GBF}^{*}$ & 10492983 (BN10503776) & \\
\hline & $001600969 \mathrm{GBF}^{*}$ & 10492993 (BN10503776) & \\
\hline & $001600969 \mathrm{GBF}^{*}$ & $10494620(\mathrm{BN} 10509684)$ & \\
\hline & $001600969 \mathrm{GBF}^{*}$ & 10494661 (BN10509684) & \\
\hline & $001600969 \mathrm{GBF}^{*}$ & 10494674 (BN10509684) & \\
\hline & $001600969 \mathrm{GBF}^{*}$ & $10495822(\mathrm{BN} 10503776)$ & \\
\hline & $001600969 \mathrm{GBF}^{*}$ & 10495823 (BN10503776) & \\
\hline & $001600969 \mathrm{GBF}^{*}$ & 10495944 (BN10509684) & \\
\hline & $001600969 \mathrm{GBF}^{*}$ & 10495947 (BN10509684) & \\
\hline & $001600969 \mathrm{GBF}^{*}$ & 10495954 (BN10509684) & \\
\hline & $001600969 \mathrm{GBF}^{*}$ & 10495955 (BN10509684) & \\
\hline & $001600969 \mathrm{GBF}^{*}$ & 10495956 (BN10509684) & \\
\hline & $001600969 \mathrm{GBF}^{*}$ & 10495957 (BN10509684) & \\
\hline & $001600969 \mathrm{GBF}^{*}$ & 10495976 (BN10509684) & \\
\hline
\end{tabular}




\section{APPENDIX 2}

Manifests Generated during Calendar Year 2014 that did not receive a Certificate of Disposal/Destruction during calendar year 2014 (manifests on following pages)

\begin{tabular}{|c|c|c|c|}
\hline Item No. & Manifest No. & Identification No. & $\begin{array}{c}\text { Disposal/Destruction } \\
\text { Date } \\
\end{array}$ \\
\hline & $001600969 \mathrm{GBF}^{*}$ & $10496168(\mathrm{BN} 10503776)$ & \\
\hline & $001600969 \mathrm{GBF}^{*}$ & 10496194 (BN10503776) & \\
\hline & $001600969 \mathrm{GBF}^{*}$ & $10496310(\mathrm{BN} 10503776)$ & \\
\hline & $001600969 \mathrm{GBF}^{*}$ & 10496395 (BN10503776) & \\
\hline & $001600969 \mathrm{GBF}^{*}$ & $10496412(\mathrm{BN} 10503776)$ & \\
\hline \multirow[t]{20}{*}{7} & $001600972 \mathrm{GBF}^{*}$ & $10483112(\mathrm{BN} 10509602)$ & \\
\hline & $001600972 \mathrm{GBF}^{*}$ & 10488876 (BN10509602) & \\
\hline & $001600972 \mathrm{GBF}^{*}$ & 10489237 (BN10509602) & \\
\hline & $001600972 \mathrm{GBF}^{*}$ & 10490477 (BN10509602) & \\
\hline & $001600972 \mathrm{GBF}^{*}$ & 10490488 (BN10509602) & \\
\hline & $001600972 \mathrm{GBF}^{*}$ & 10490541 (BN10509603) & \\
\hline & $001600972 \mathrm{GBF}^{*}$ & 10491183 (BN10509603) & \\
\hline & $001600972 \mathrm{GBF}^{*}$ & 10491208 (BN10509603) & \\
\hline & $001600972 \mathrm{GBF}^{*}$ & 10491219 (BN10509603) & \\
\hline & $001600972 \mathrm{GBF}^{*}$ & 10493484 (BN10509603) & \\
\hline & $001600972 \mathrm{GBF}^{*}$ & 10493529 (BN10509603) & \\
\hline & $001600972 \mathrm{GBF}^{*}$ & 10493534 (BN10509603) & \\
\hline & $001600972 \mathrm{GBF}^{*}$ & 10493543 (BN10509603) & \\
\hline & $001600972 \mathrm{GBF}^{*}$ & 10493575 (BN10509603) & \\
\hline & 001600972GBF* & 10493587 (BN10509602) & \\
\hline & $001600972 \mathrm{GBF}^{*}$ & 10493599 (BN10509602) & \\
\hline & $001600972 \mathrm{GBF}^{*}$ & $10493611(\mathrm{BN} 10509602)$ & \\
\hline & $001600972 \mathrm{GBF}^{*}$ & 10493618 (BN10509602) & \\
\hline & $001600972 \mathrm{GBF}^{*}$ & 10493619 (BN10509602) & \\
\hline & $001600972 \mathrm{GBF}^{*}$ & 10495950 (BN10509603) & \\
\hline \multirow[t]{6}{*}{8} & $001600973 \mathrm{GBF}^{*}$ & 10480205 (BN10507558) & \\
\hline & $001600973 \mathrm{GBF}^{*}$ & 10480225 (BN10507558) & \\
\hline & $001600973 \mathrm{GBF}^{*}$ & 10491188 (BN10507558) & \\
\hline & $001600973 \mathrm{GBF}^{*}$ & $10491211(\mathrm{BN} 10507558)$ & \\
\hline & $001600973 \mathrm{GBF}^{*}$ & 10493478 (BN10507558) & \\
\hline & $001600973 \mathrm{GBF}^{*}$ & 10493523 (BN10507558) & \\
\hline
\end{tabular}




\section{APPENDIX 2}

Manifests Generated during Calendar Year 2014 that did not receive a Certificate of Disposal/Destruction during calendar year 2014 (manifests on following pages)

\begin{tabular}{|c|c|c|c|}
\hline Item No. & Manifest No. & Identification No. & $\begin{array}{c}\text { Disposal/Destruction } \\
\text { Date } \\
\end{array}$ \\
\hline & $001600973 \mathrm{GBF}^{*}$ & 10493552 (BN10507545) & \\
\hline & $001600973 \mathrm{GBF}^{*}$ & 10493747 (BN10507545) & \\
\hline & $001600973 \mathrm{GBF}^{*}$ & 10493779 (BN10507545) & \\
\hline & $001600973 \mathrm{GBF}^{*}$ & $10494178(\mathrm{BN} 10507545)$ & \\
\hline & $001600973 \mathrm{GBF}^{*}$ & 10494654 (BN10507545) & \\
\hline & $001600973 \mathrm{GBF}^{*}$ & $10494660(\mathrm{BN} 10507545)$ & \\
\hline & $001600973 \mathrm{GBF}^{*}$ & $10495952(\mathrm{BN} 10507558)$ & \\
\hline & $001600973 \mathrm{GBF}^{*}$ & $10502860(\mathrm{BN} 10507545)$ & \\
\hline & $001600973 \mathrm{GBF}^{*}$ & $10503240(\mathrm{BN} 10507558)$ & \\
\hline & $001600973 \mathrm{GBF}^{*}$ & 10503257 (BN10507558) & \\
\hline & $001600973 \mathrm{GBF}^{*}$ & $10503266(\mathrm{BN} 10507558)$ & \\
\hline & $001600973 \mathrm{GBF}^{*}$ & $10503341(\mathrm{BN} 10507545)$ & \\
\hline & $001600973 \mathrm{GBF}^{*}$ & $10503353(\mathrm{BN} 10507545)$ & \\
\hline & $001600973 \mathrm{GBF}^{*}$ & $10503840(\mathrm{BN} 10507545)$ & \\
\hline \multirow[t]{17}{*}{9} & $001942816 \mathrm{GBF}^{*}$ & 10141087 & \\
\hline & $001942816 \mathrm{GBF}^{*}$ & 10145188 & \\
\hline & $001942816 \mathrm{GBF}^{*}$ & 10227060 & \\
\hline & $001942816 \mathrm{GBF}^{*}$ & 10268531 & \\
\hline & $001942816 \mathrm{GBF}^{*}$ & 10270823 & \\
\hline & $001942816 \mathrm{GBF}^{*}$ & 10272421 & \\
\hline & $001942816 \mathrm{GBF}^{*}$ & 10288488 & \\
\hline & $001942816 \mathrm{GBF}^{*}$ & 10291381 & \\
\hline & $001942816 \mathrm{GBF}^{*}$ & 10295844 & \\
\hline & $001942816 \mathrm{GBF}^{*}$ & 10302522 & \\
\hline & $001942816 \mathrm{GBF}^{*}$ & 10303995 & \\
\hline & $001942816 \mathrm{GBF}^{*}$ & 10305954 & \\
\hline & $001942816 \mathrm{GBF}^{*}$ & 10306562 & \\
\hline & $001942816 \mathrm{GBF}^{*}$ & 10307413 & \\
\hline & $001942816 \mathrm{GBF}^{*}$ & 10308175 & \\
\hline & $001942816 \mathrm{GBF}^{*}$ & 10309591 & \\
\hline & $001942816 \mathrm{GBF}^{*}$ & 10309608 & \\
\hline
\end{tabular}




\section{APPENDIX 2}

Manifests Generated during Calendar Year 2014 that did not receive a Certificate of Disposal/Destruction during calendar year 2014

(manifests on following pages)

\begin{tabular}{|c|c|c|c|}
\hline Item No. & Manifest No. & Identification No. & $\begin{array}{c}\text { Disposal/Destruction } \\
\text { Date }\end{array}$ \\
\hline & $001942816 \mathrm{GBF}^{*}$ & 10310233 & \\
\hline & $001942816 \mathrm{GBF}^{*}$ & 10313213 & \\
\hline & $001942816 \mathrm{GBF}^{*}$ & 10319462 & \\
\hline & $001942816 \mathrm{GBF}^{*}$ & 10333747 & \\
\hline & $001942816 \mathrm{GBF}^{*}$ & 10349170 & \\
\hline & $001942816 \mathrm{GBF}^{*}$ & 10459538 & \\
\hline & $001942816 \mathrm{GBF}^{*}$ & 10505966 & \\
\hline & $002079960 \mathrm{FLE}$ & MFC140002 & \\
\hline & $002079960 \mathrm{FLE}$ & MFC140007 & \\
\hline & & & \\
\hline
\end{tabular}

* Indicates AMWTP manifests 
Please prist or type. (Fom designed for use on elile (12-pitch) typewriter.)

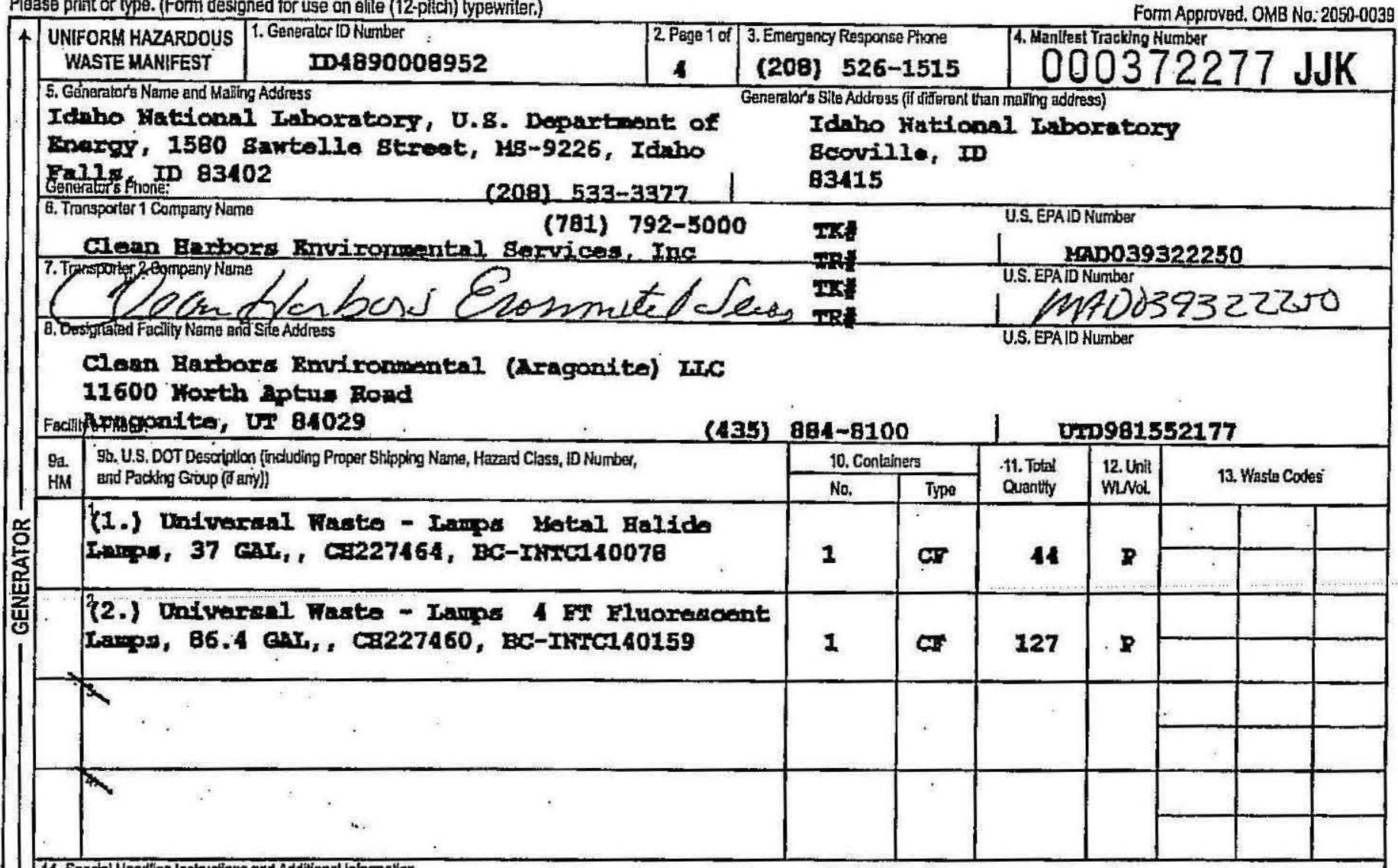

14. Spectal Handiling Instructions and Additional Information

Retrim aigned arfiginal within 30 dags to: ChI for U.8. DOB, Attentelon: Cpad Minlum,

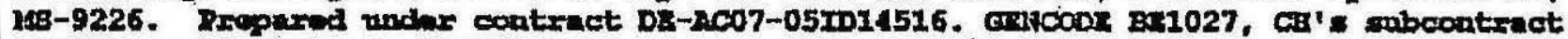
B00480, Iond 1409,80 \%1403252309.

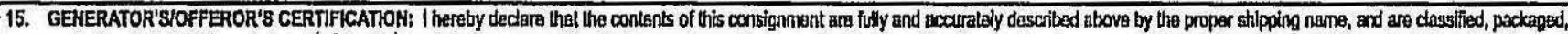

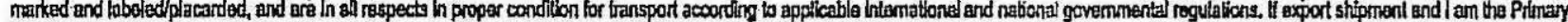
Expertar, 1 cartfy that tha contents of this consignmenl conform to the terms of the altachad EPAAdarowladgment of Consent.

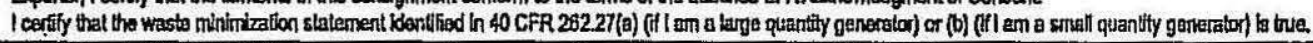

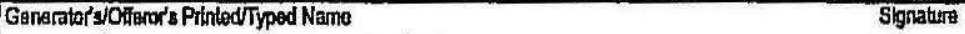
Tanton I Ebopher

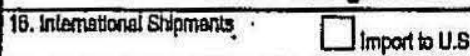

Transporter signatura (for axports onily):

Export trom U.S.

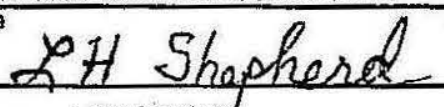

17. Transporler Ackquowiodgment of Recelpl of Malartais

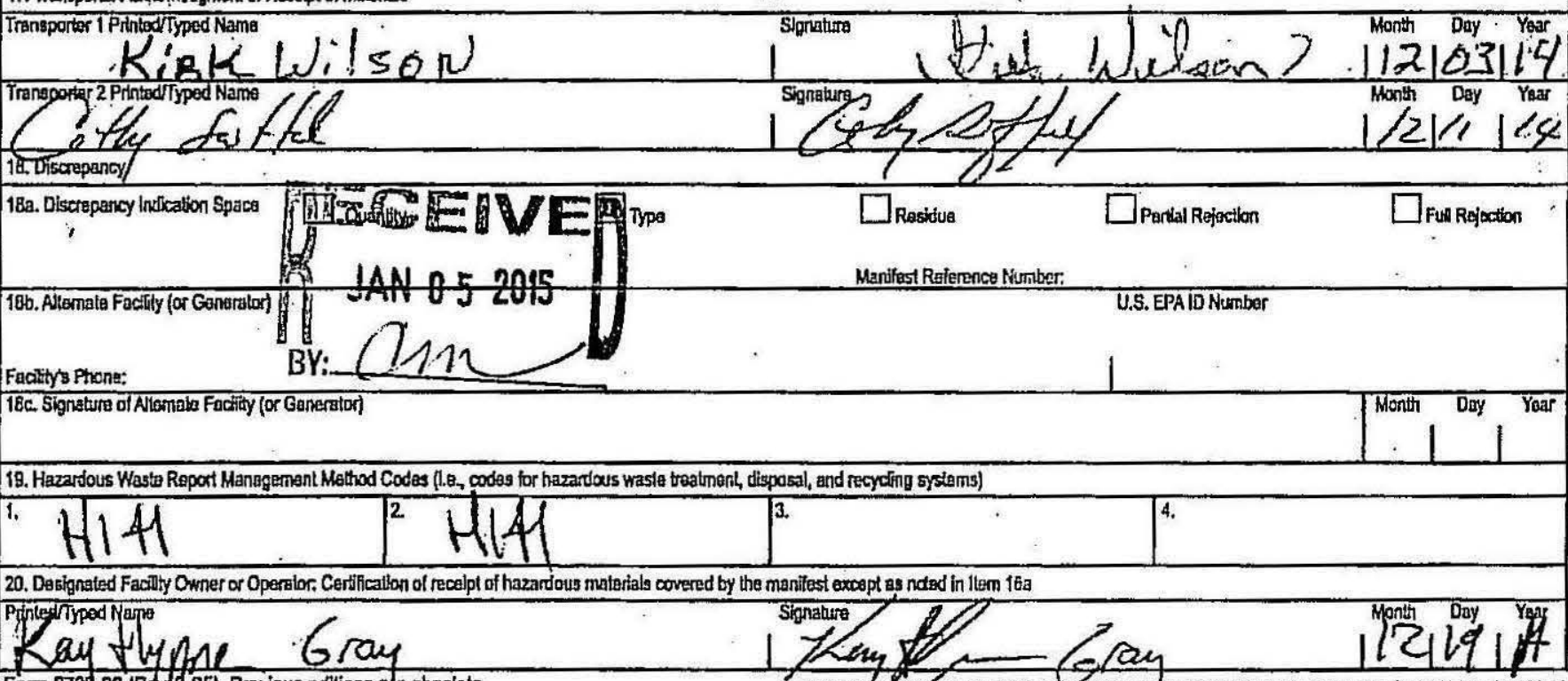


Please prinl ar lype. (Form desioned for use on elite (12-pitch) typewriler.)

$\uparrow$ UNIFORM HAZARDOUS WASTE MANIFEST 21. Genoralor IO NAUTber

(Continuation Sheel)

I04890008952

\begin{tabular}{|l|c|}
\hline $\begin{array}{l}\text { 22. Fage } \\
2 \text { of } 4\end{array}$ & Form Approved. OMB No. 2050-0039 \\
\hline
\end{tabular}

24. Generatcr's Namie

Idino Aational Ixboxatory, U.s. Department of Inergy

1560 sawtel2 streat, Mg-9226, Idaho Filln, ID 83402

25. Transporlar ___ Company Name

U.S. EPA ID Number

26. Transportur

Company Nate

U.S. EPA10 Numbe

27a. 27b. US. DOT Description (induding Propar Shipping Name, Hazard Class, ID Number,

HM and Packiving Group (ff any))

$x$ (3.) UN2800, Butteries, wot, non-epilleble, $\mathrm{B}$ PG III 5 II3, Pallet conteins 63 mealed

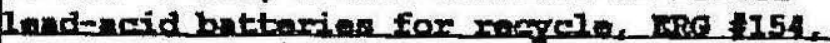
C.89812, BC-INicl10180

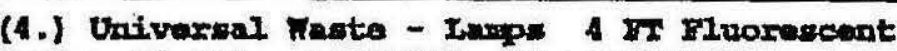

range, 11 cxr, Cr227460, BC-Inisct10203

(5.) Univeranl Faste - Inmpe Hetal Balide Fanpes, 36.65 EaI, , CR227464, BC-IFrCI.10206

RQ (6.) Wi2315, Polpchlorinuted bipberyls, 1iquid, 9, IG II Containa 10 Balluats/3 Capiaitors

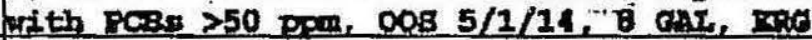
171, C. C227472, BC-IATC140207

7.) Univereal Farte - Lampe Hetal Balide Thine, 36.65 EN, CA227464, BC-Irxct10209

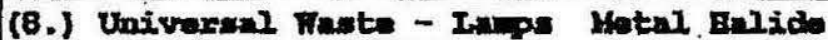

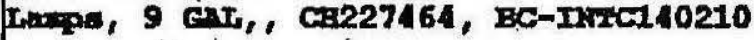

U.S. EPAIO Number

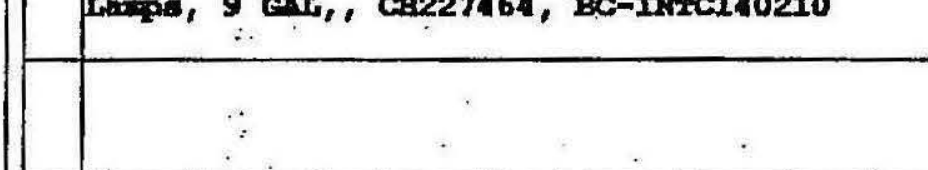

32. Spedal Handling listructions and Addillonal Information

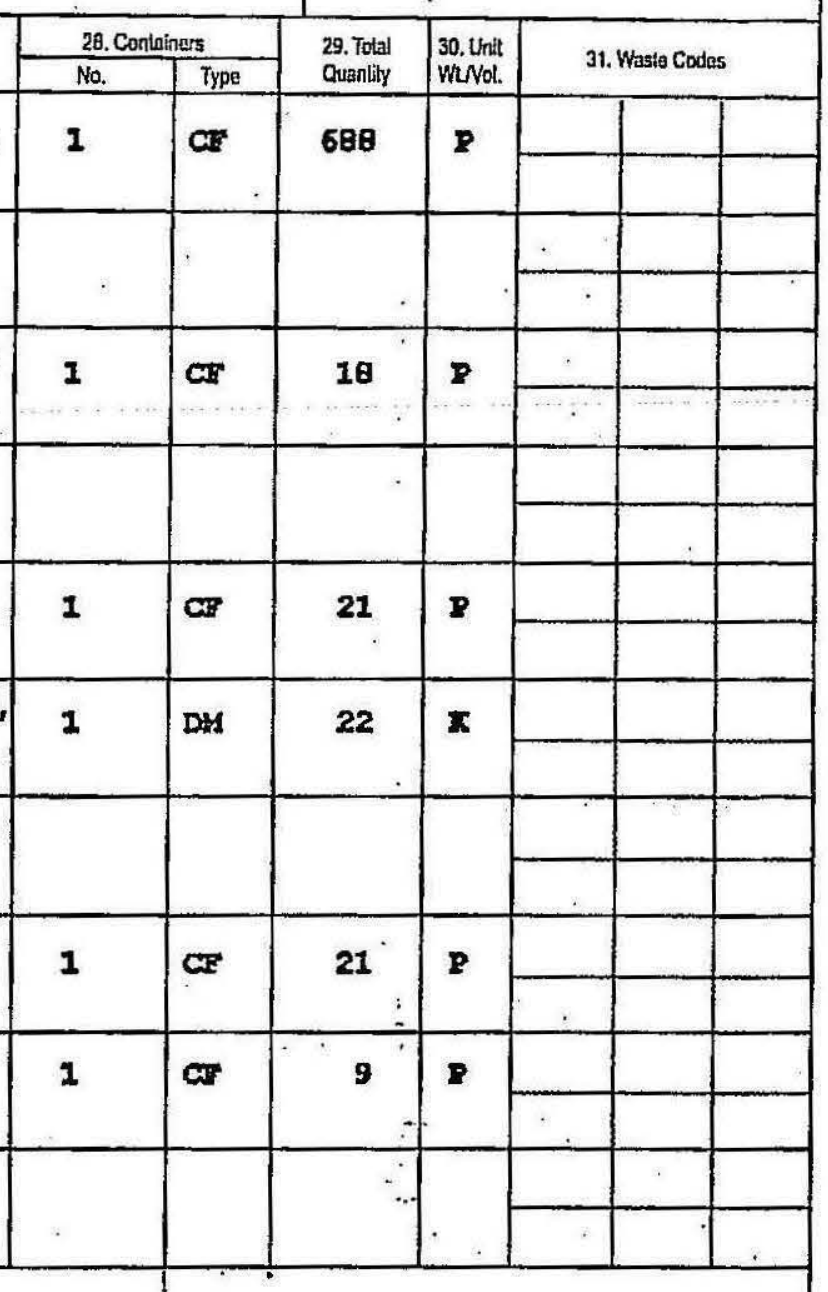

$\downarrow$

33. Traneporles - Acknowladgment of Receipt of Malerials

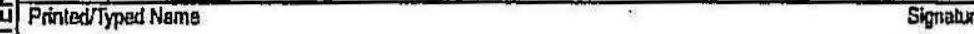

통.

34. Transporter Ackrowledgrenl of Receipl of Materiats

⿷匚⿳丨コ丨 
Please print or type. (Form designed for use on elike (12-pilch) lypewriler.)

(Continuation Sheet)

24. Gentador's Name

ID4890008952

Idmbo National Imboratory, U.8. Departmant of Energy

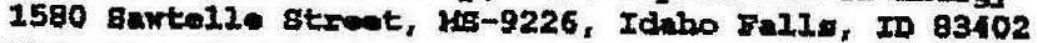

25. Transporter __ Company Name U.S. EPAID Number

26. Transpoter ___ Company Name

U.S. EPA ID Number

27a. 27b. U.S. DoT Desciptlon finduxting Proper Shipping Name, Hazard Class, ID Number,

HM and Pacding Group (if any)

$x$ (9.) Ux2735, Amines, 1iquid, corzomive, n.0.s. (Tetraethylenepentamine, Benzenamino), B, PG II

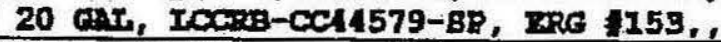
BC-IFic140236

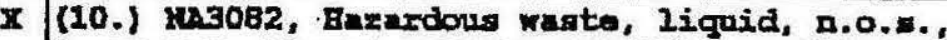
9. DO III 30 car, roctic, RRG4171, Ca51997xp1, EC-IVtC140237

(11.) Kon-RCRA/Lon-DOK Regulated Haterial 10 (NAT, ICCRC, , CH51997LE1, BC-INIC140238

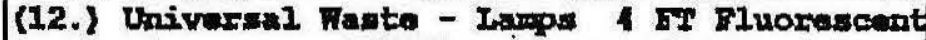
Iranges, 9 esr, Ca227460, BC-INYC140242

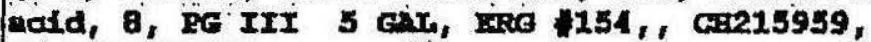
mo-Irxch10213

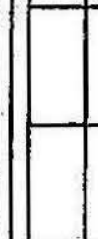

32. Special Handling Instructions and Additional Information

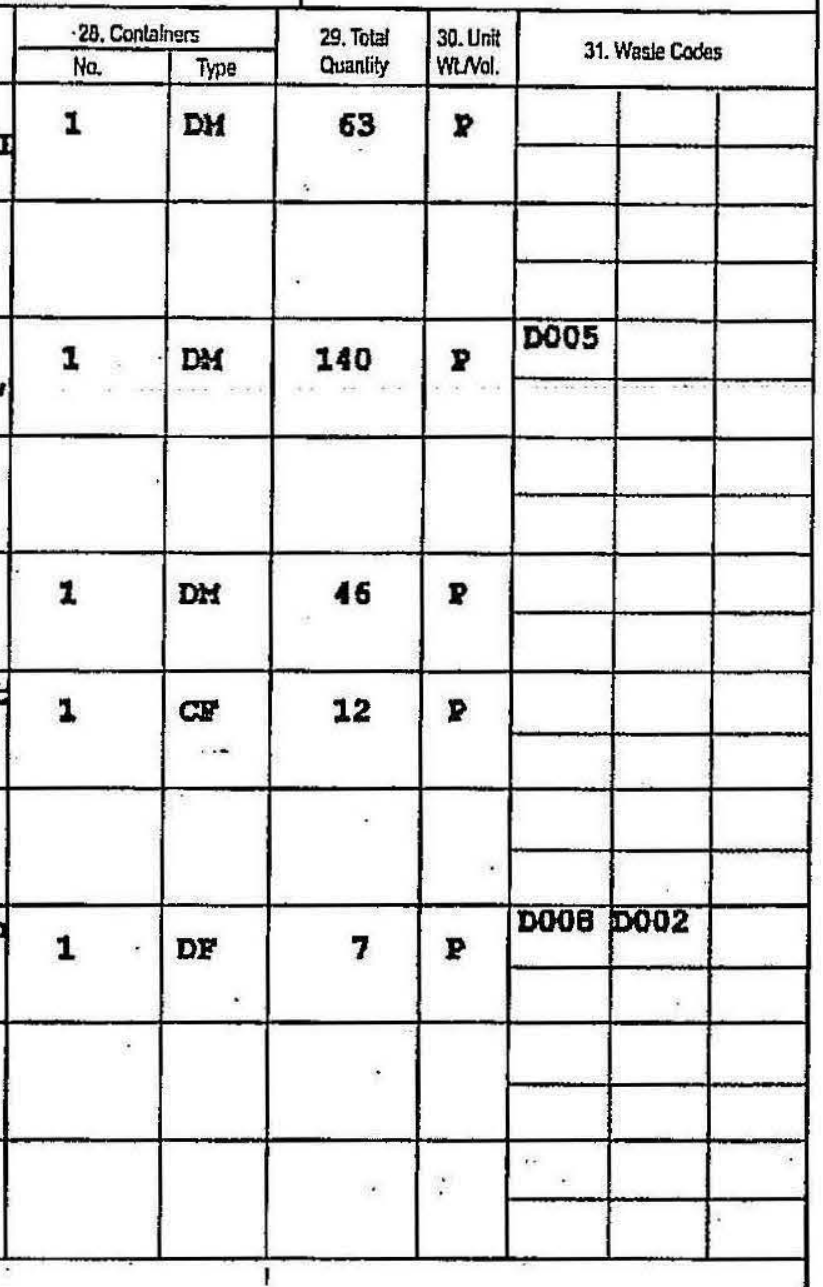

$\downarrow$

a 33. Transportes Acknowledgment ol Receppl ol Materials

出 Printed firped Name

응

34. Transporler Acknowledgment of Recelpl of Maleriala

\$ PrinladTyped Name

- Slanature

3 of 4

23. Manlfest Trachling Number

Form Apgroved. OMB No. 2050-0039 000372277 JTK 
Flease print or type. (Form designed far use on elile (12-pitch) typewriter.)

4 UNIFORM HAZAROOUS WASTE MANIFEST 21 . Ganeralor IONEmber

(Continuation Sheet)

24. Generalo's Namie

I04890008952

\begin{tabular}{|l|l|l}
\hline $\begin{array}{l}\text { 22. Page } \\
\text { of }\end{array}$ & $\begin{array}{c}\text { 23. Manilest Tracking Number } \\
000372277 \mathrm{JJK}\end{array}$ \\
\hline
\end{tabular}

Idaho kational Inboratory, U.8. Departwant of Bnexgr

1580 Bewtelle streat, Mg-9226, Idnho InI19, ID 83402

\begin{tabular}{|lll}
\hline 25. Trensporter __ Company Name & U.S. EPA ID Number \\
\hline 26. Transporter ___ Company Name & U.S. EPAID Number
\end{tabular}

\begin{tabular}{l|l}
\hline 27a: & $\begin{array}{l}\text { 27b. U.S. Dot Description (linciulting Proper Shlpping Name, Hazard Class, } 10 \text { Number, } \\
\text { HMM Packing Group (if any)) }\end{array}$
\end{tabular}

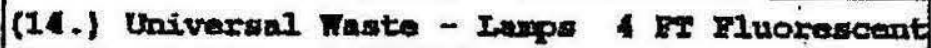

rangs, 11 Car., CB227460, BC-INTCH40245

(15.) Univaran. Raste - Iamps Ketal Bulido

ramps, 9 CxI, , Ca227464, BC-IFYC140246 $+$

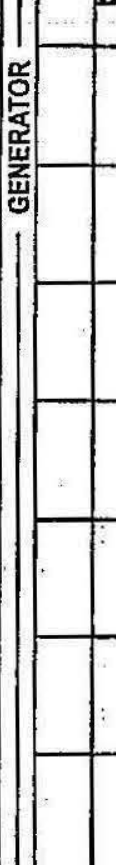

32 Special Handling Instruclions and Additional Information

\begin{tabular}{|c|c|c|c|c|c|c|}
\hline \multicolumn{2}{|c|}{ 28. Containers } & \multirow{2}{*}{$\begin{array}{c}\begin{array}{c}29, \text { Total } \\
\text { Quantiy }\end{array} \\
\mathbf{2 0}\end{array}$} & \multirow{2}{*}{ 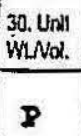 } & \multicolumn{3}{|c|}{ 31. Waste Codes } \\
\hline 1 & $C F$ & & & & & \\
\hline & & & & & & \\
\hline & & & & & 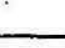 & \\
\hline 1 & $C F$ & 10 & $P$ & & & \\
\hline & & & & & & \\
\hline & & & & & & \\
\hline & & & & & & \\
\hline$=$ & & & & & & \\
\hline & & & & & & \\
\hline & & & & & & \\
\hline & & & & & & $\cdot$ \\
\hline & & & & & & \\
\hline & & & & & & \\
\hline & . & & & & & \\
\hline & & & & & & \\
\hline & & & & . & & \\
\hline & & & & & & \\
\hline & & & & $\therefore$ & & \\
\hline & & r. & & & & \\
\hline
\end{tabular}

$+$

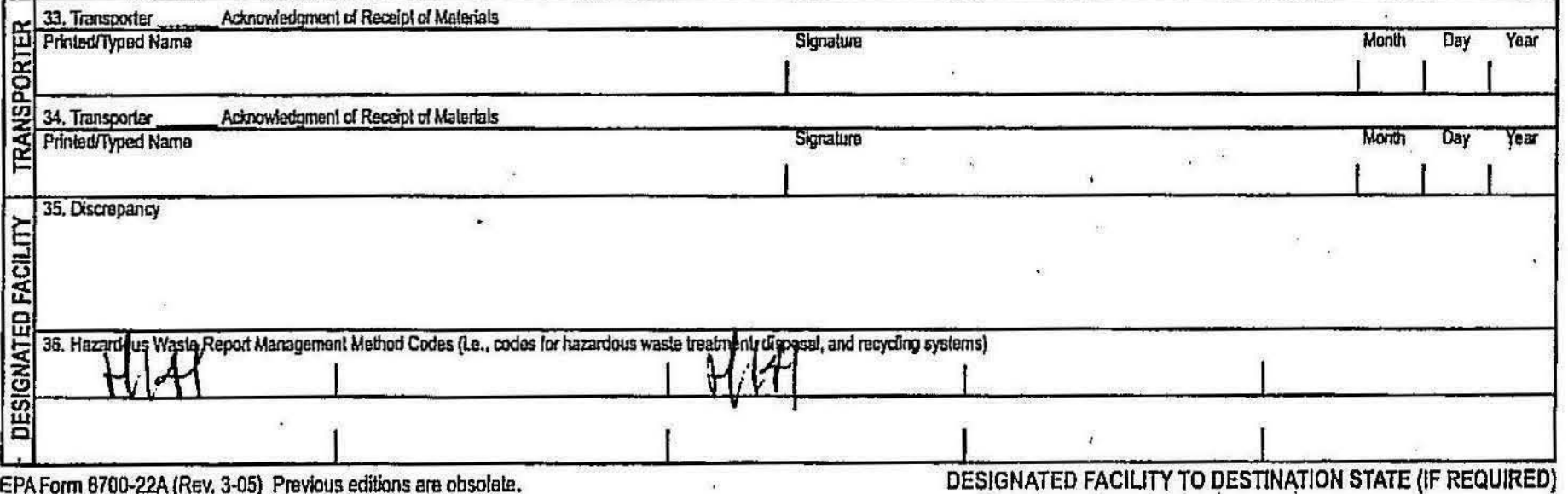


Please print or type. (F̈̈rm designed for use on elite (12-pitch) lypewriter.)

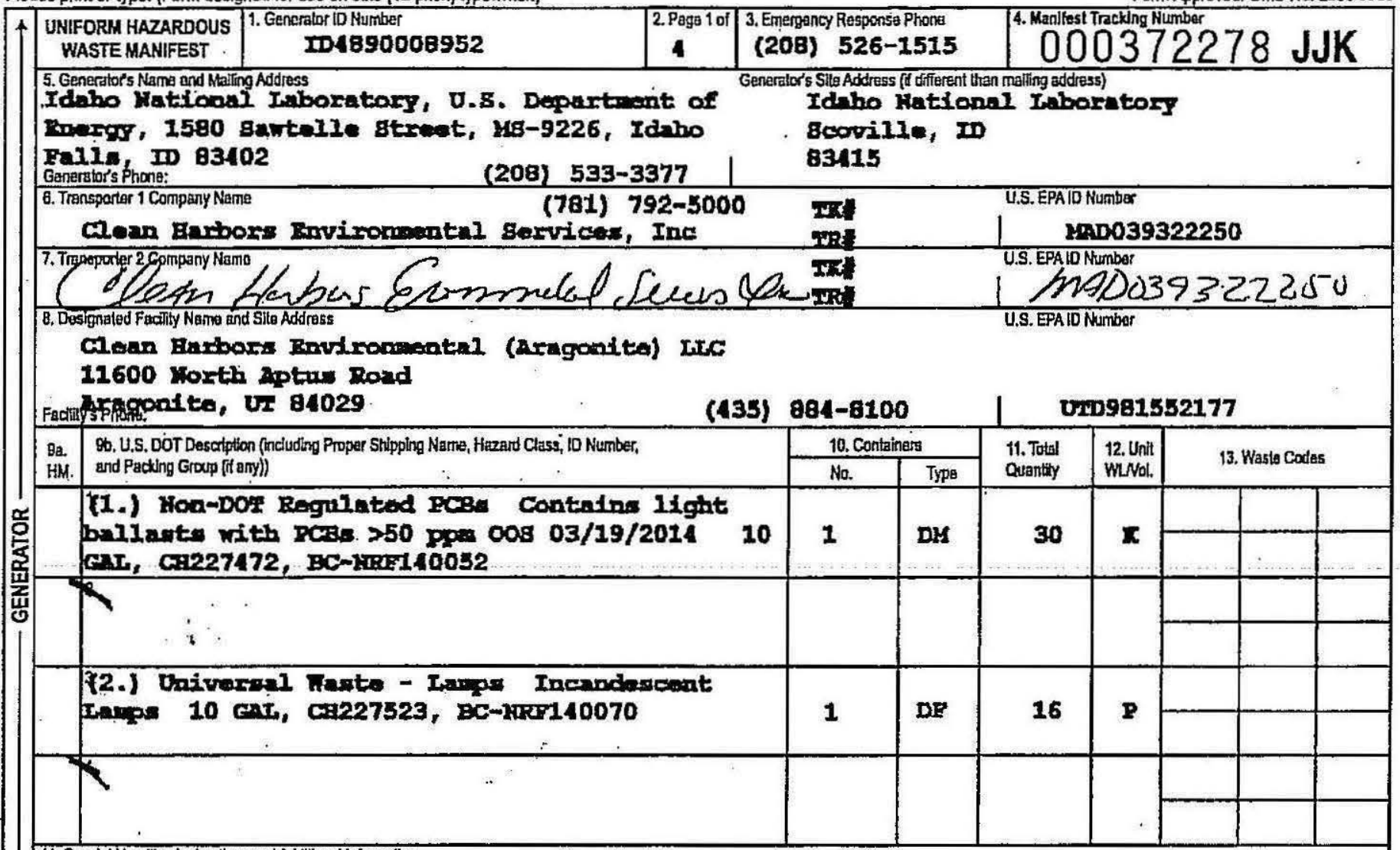

14. Special Handling Instructions and Addilional Infortiation

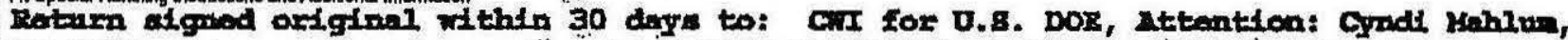

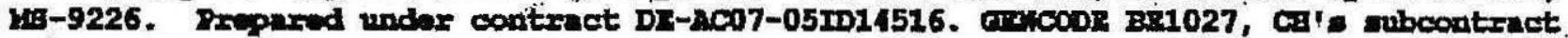

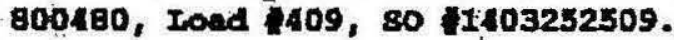

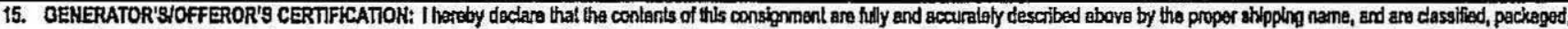

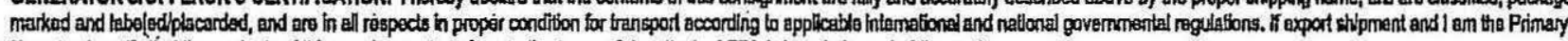

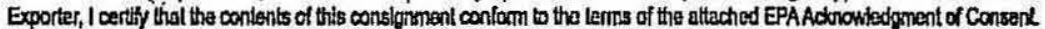

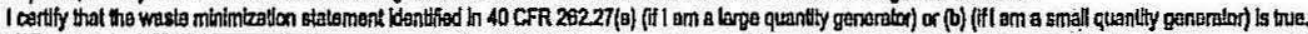

Generalo's : Ofero's Prinled/yped Name

Inatbar I Bhphond

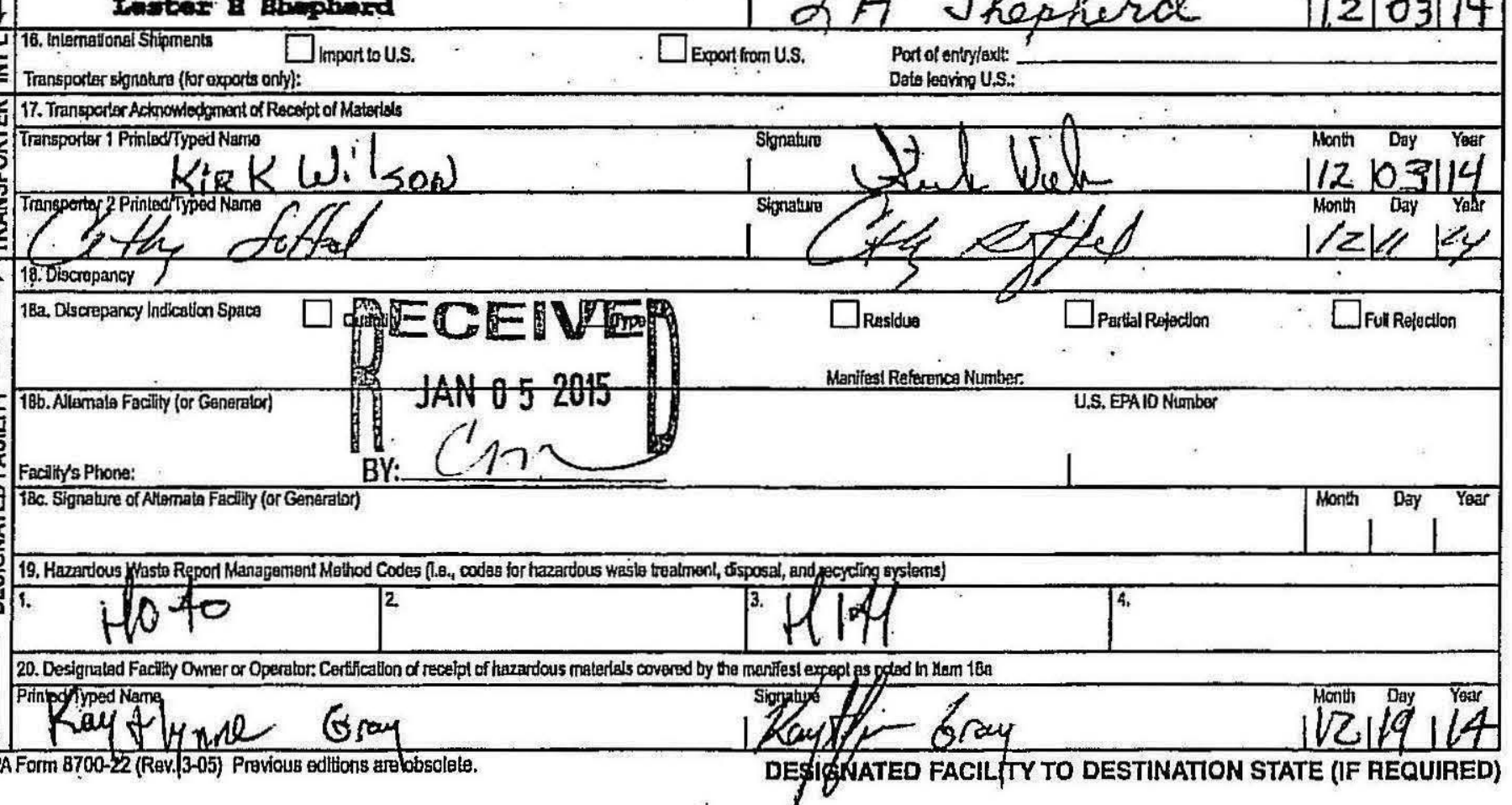

EPAForm 8700-22 (R日v. (3-05) Pravious aditions arelobsolete. 
Pleese print or type. (Form designed for use on elite (12-pitch) typewriter.)

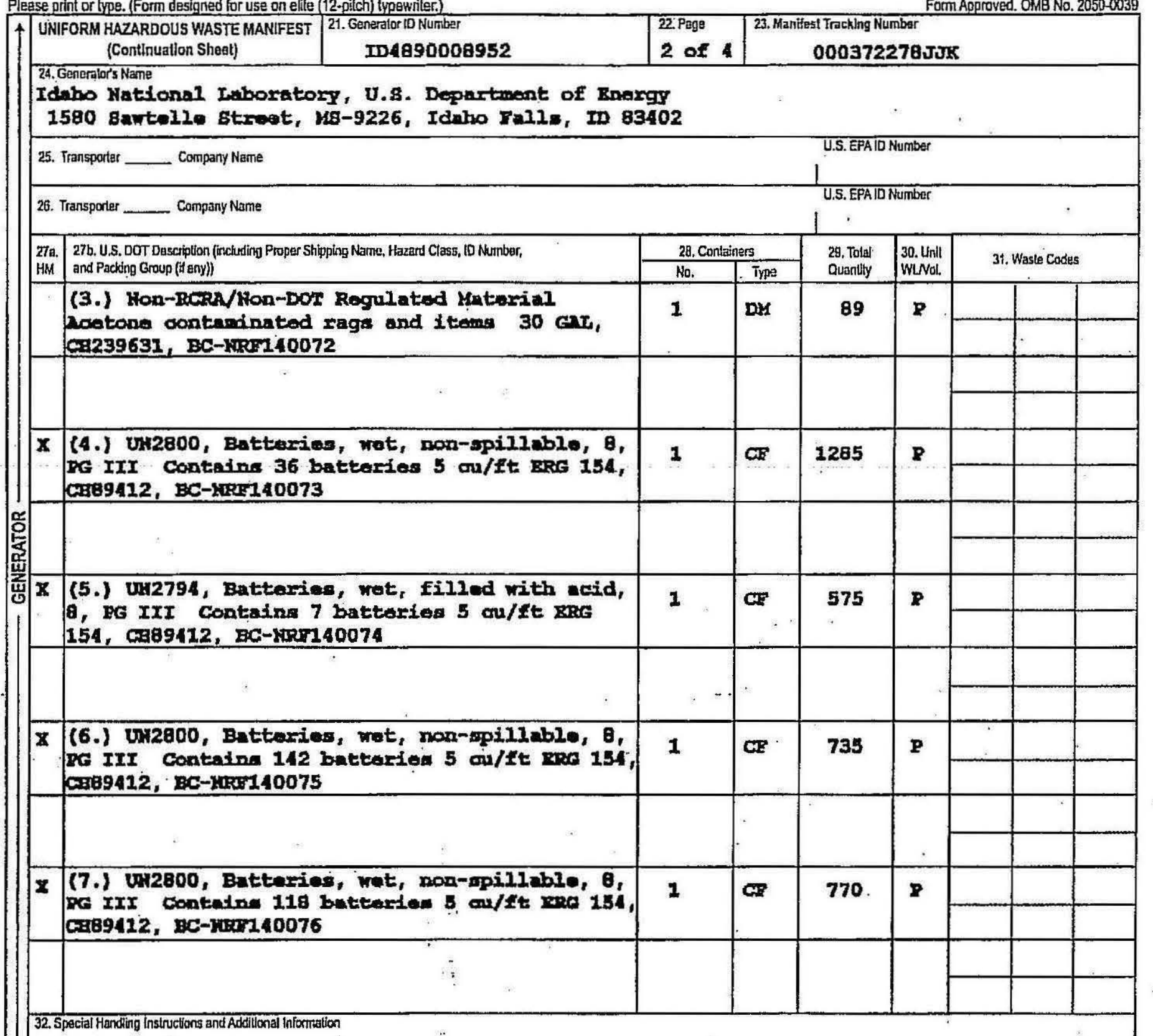

32. Special Handing Instructions and Addritlonal Information

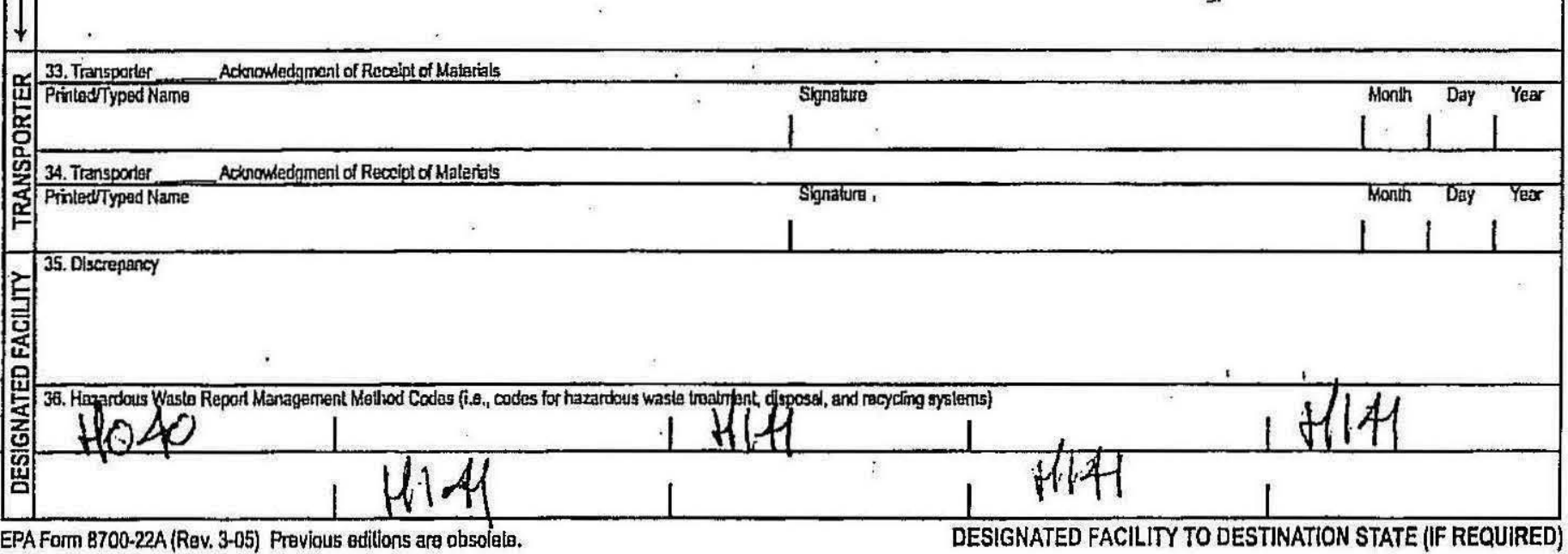


Please print or type. (Form desioned for use on elite (12-pitch) typewriler.)

(Continuation Sheet)

ID4890008952

3 of 4

23. Nanllest Tracking Number

Form Approved. OMB No. 2050-0039 24. Generalor's Name

Idaho Kational Iuboratory, U.S. Departmant of Bnargy 1580 santelle 8treot, MB-9226, Idabo Fa11s, ID 83402

\begin{tabular}{l|l} 
25. Transporter __ Company Name & U.S. EPAID Numbar \\
\hline 26. Transporter __ Company Name & U.S. EPAID Number
\end{tabular}

27a. 27 b. U.S. Dor Desciplion (ind luxing Proper Shipping Name, Hazard Class, ID Number.

HM and Packing Group (if any))

Ma (B.) Un1993, Wasto Fla...ble liquids, n.0.s. (Aromaticic Eydrocarbons, H-butylacetate), 3, PG

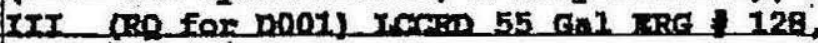
Ca51997IR1, BC-XIRE140078

$x$ (9.) Un1993, Fiate Hlanable Iiquids, n.o.s. (d-Ifimenene, Pxopylene glyool wothyl etbar), 3,

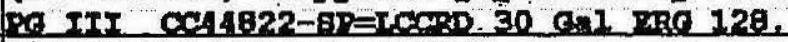
Cx51997LP1, BC-KLiY140079

(10.) Mon-DOI Regallated PCBs Conitain: Debris with PCases $>30$ ppm $00804 / 16 / 201430$ car, ca227451, $\mathrm{BC}-\mathrm{NrR2} 40080$

26 (11.) Ma3077, gazerdous waste, wolid, n.0.5., 9, PG III Contains Dobelis with PCBs > 50 Ppe

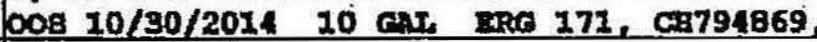
DC-KIRE110081

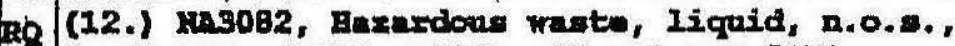
9, PE III (D007, D011) $85 \mathrm{Gal}$ MRT 171 ,

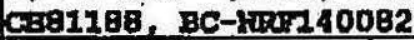

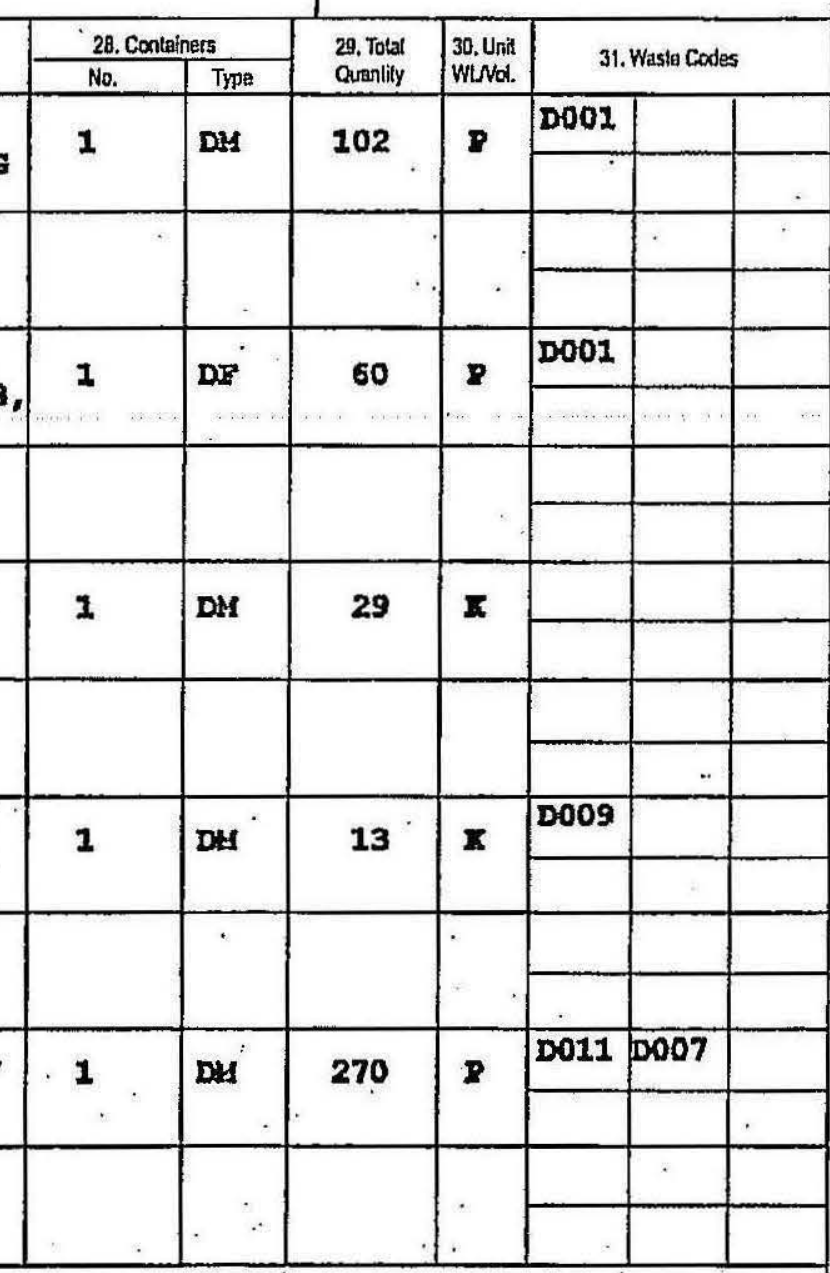

32 Speciai Handing instructions end Additional linlormalion

33. Transporter Aclerowlodgment of Receipl af Materials

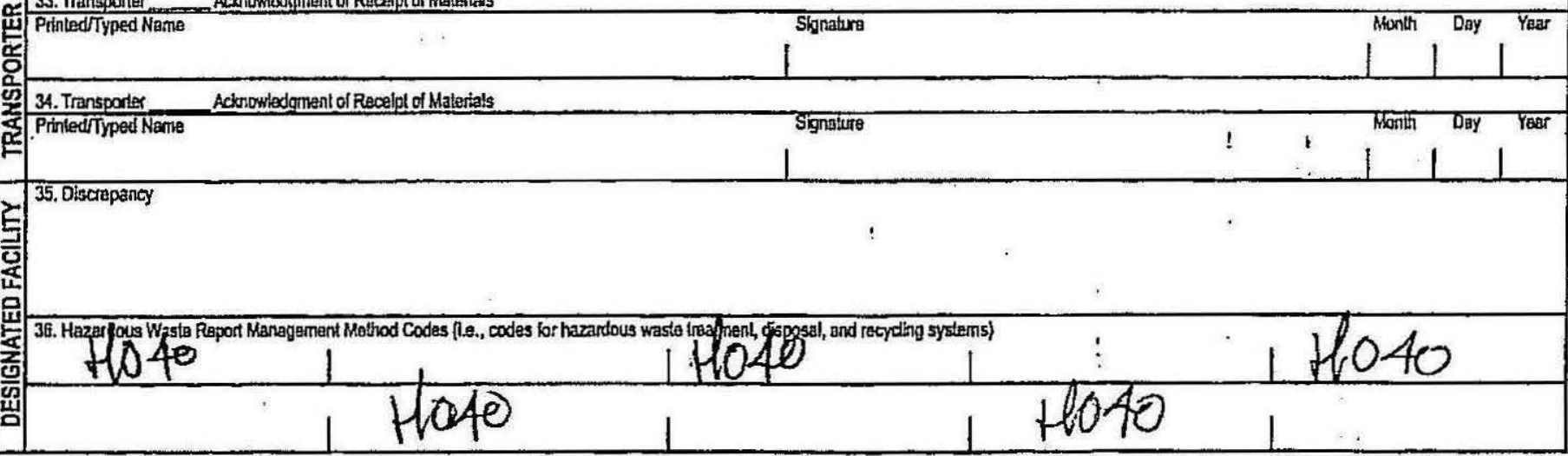


Please prinl or type. (Form designed for use on elile (12-pilch) typewriter.)

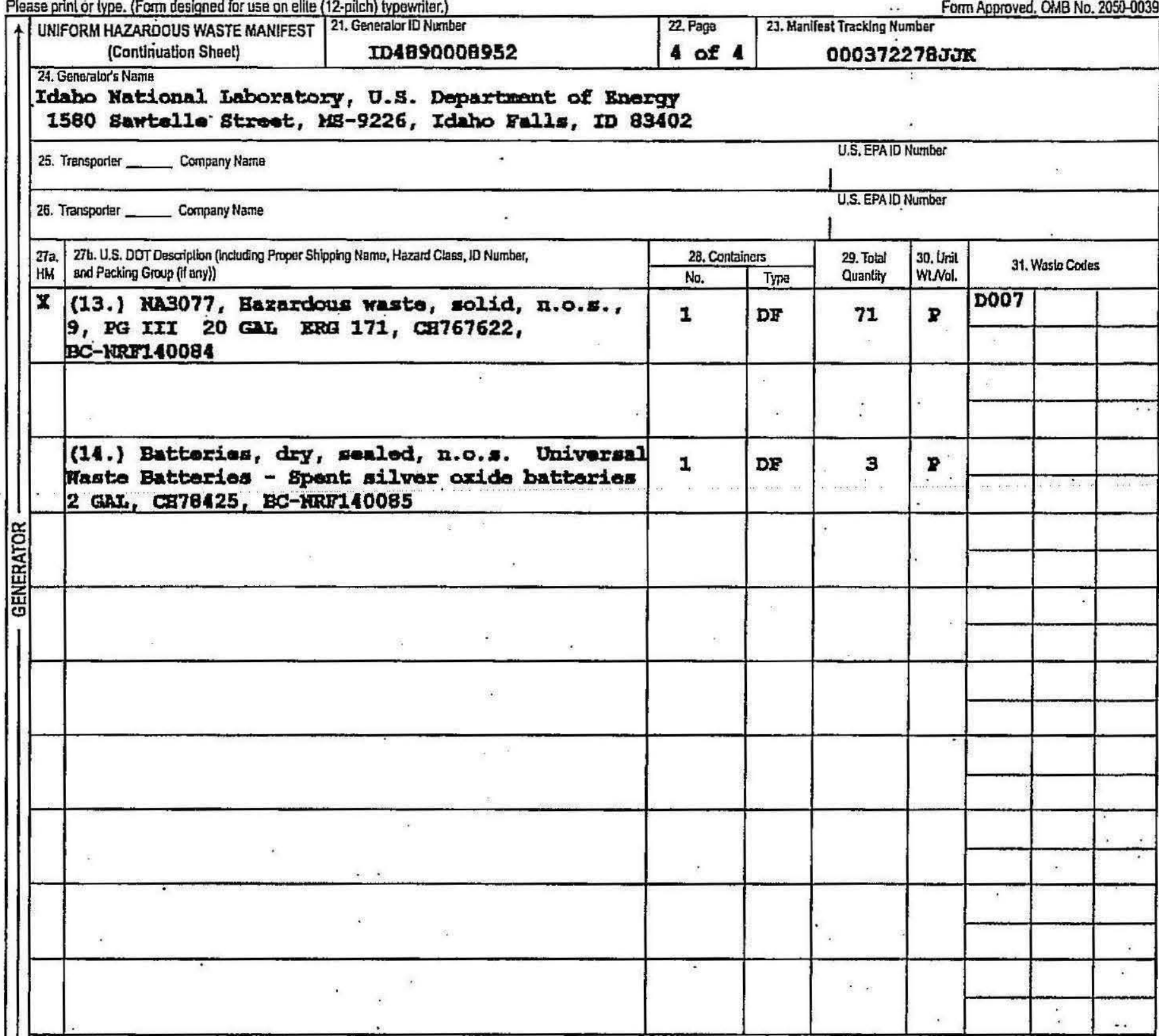

32. Spedal Hendling Instruclions and Addilional Information

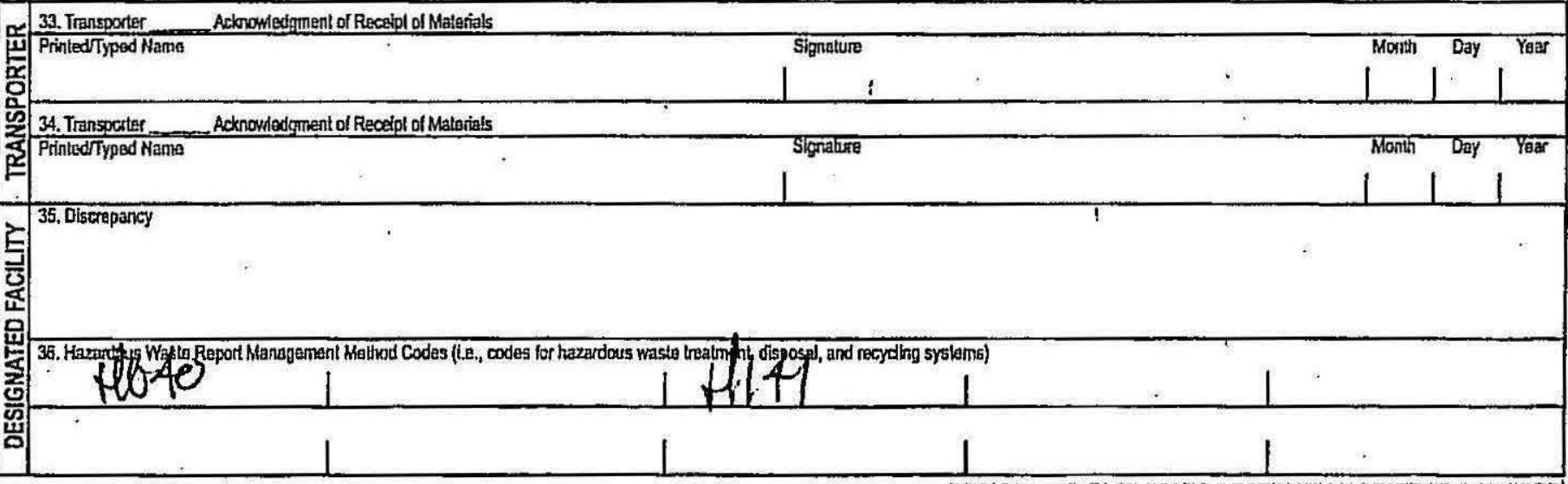


000372278JJK COD

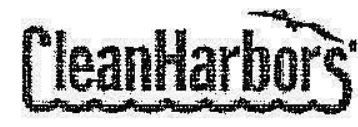

\author{
Clean Harbors Aragonite LLC \\ 11600 North Aptus Road \\ Grantsville UT, 84029 \\ UTD981552177 \\ (435) $884-8100$
}

CERTIFICATE OF DISPOSAL

Generator Facility Name:

Generator Address:
CH2M-WG Idaho LLC

PO Box 2010 MS 9226

1580 Sawlelle Street

Idaho Falls, ID, 83403
Sales OrderH: $\quad 1403252509$

Date Received: $\quad$ 12/19/2014

Generator Contact Name:

\begin{tabular}{|c|c|c|c|c|c|c|c|}
\hline \multirow{2}{*}{\multicolumn{2}{|c|}{ Generator EPA ID: }} & \multirow{2}{*}{\multicolumn{2}{|c|}{ NONEREQUIRED }} & & \multirow{2}{*}{\multicolumn{2}{|c|}{$\begin{array}{l}\text { Load \#: } \\
\text { Manifest \#: }\end{array}$}} & 70941 \\
\hline & & & & & & & $000372278 \mathrm{JJK}$ \\
\hline $\begin{array}{l}\text { Original } \\
\mathrm{CH} \text { ID \# }\end{array}$ & $\begin{array}{l}\text { Date Removed } \\
\text { From Service }\end{array}$ & $\begin{array}{l}\text { Unit } \\
\text { Type }\end{array}$ & $\begin{array}{c}\text { Serial \#/ } \\
\text { Customer ID }\end{array}$ & $\begin{array}{c}\text { Material } \\
\text { Description }\end{array}$ & $\begin{array}{l}\text { Disposal } \\
\text { Date }\end{array}$ & $\begin{array}{l}\text { Method of } \\
\text { Disposal }\end{array}$ & Disposal Facility \\
\hline 42280967 & $10 / 30 / 2014$ & DM & NRF140081/ & PCB Solids For Incineration & $12 / 30 / 2014$ & Incineration & Araganite, UT Facillty \\
\hline
\end{tabular}

Under Civil and Criminal Penalties of Law for the making or submission of false or fraudulent statements or representations (18 U.S.C. 1001 and 15 U.S.C. 2615), I certify that the Informatlon contained in or accompanying this document is true, accurate, and complete. As to the identified section(s) of this document for which I cannot personally verify truth and accuracy, I certify as the company official having supervisory responsibility for the persons who, acting under my direct instructions, made the verification that this information is true, accurate, and complete.

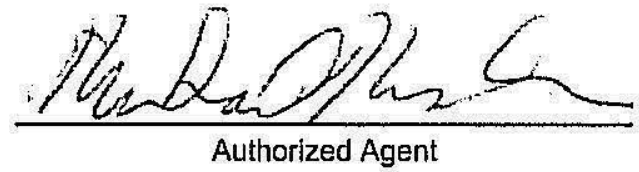

Authorized Agent
Wednesday, April 01, 2015

Date

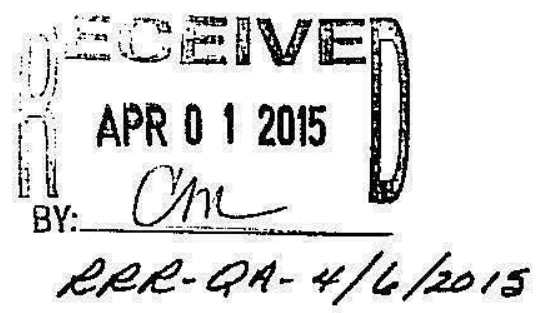


Please print or type. (Form designed for use on elite (12-pitch) typewriter.)

\section{$\uparrow$ UNIFORM HAZARDOUS 1 . Generalor ID Number WASTE MANIFEST \\ TDA690008952}

5. Generator's Namie and Mailing Address

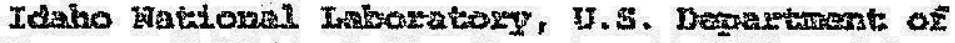

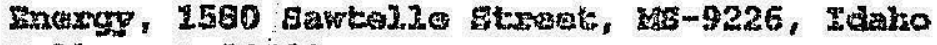

Fan.1.3. ID 23402

Generator's Phone:

6. Transporter 1 Company Name
Form Approved. OMB №. 2050-0039

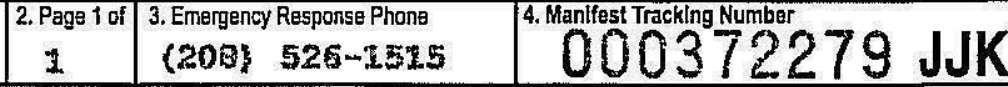
Generator's Sile Address (if cififerent than malling address)

\section{Idalus itational Isabonatury}

scooti.1.

0315

(761) 192-5000 The (761) $792-5000$

mate

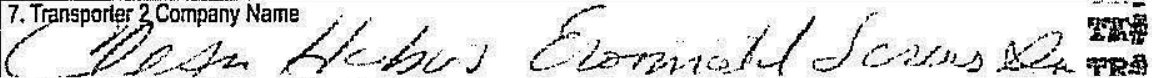
7. Transporter Company Nane

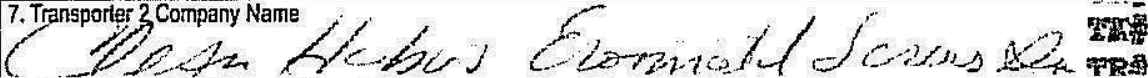
7. Transporter 3 Company Name

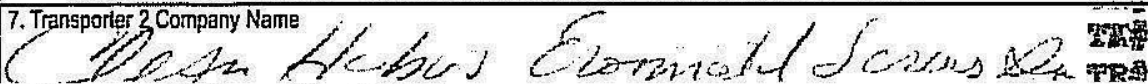

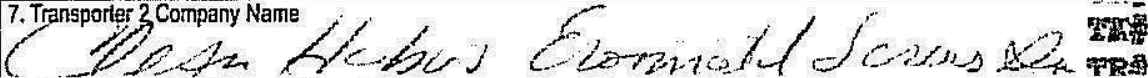

8. Designated Facilliy Name and Site Address

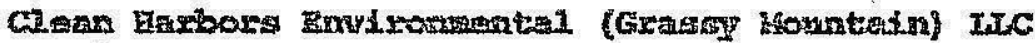

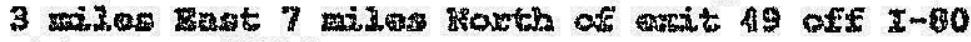

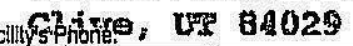

\begin{tabular}{l|l} 
9a. & 9b. U.S. DOT Description (including Proper Shipping Name, Hazard Class, ID Number,
\end{tabular}

HM. and Packing Group (II any)

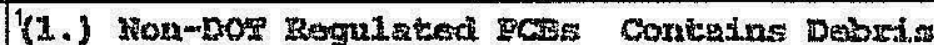

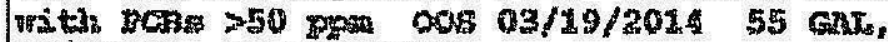

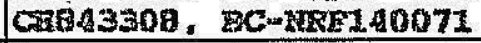

(135) 684-9815

2.

3r.

4

14. Special Handiling Instructlons and Additional Information

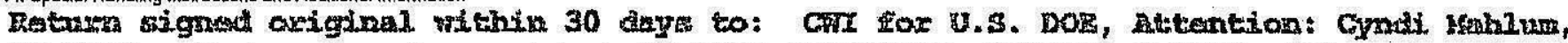

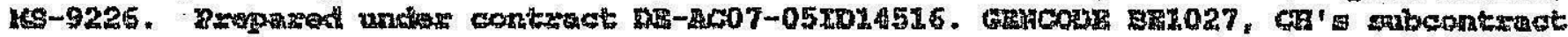

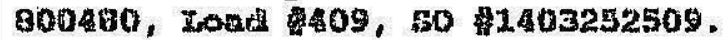

15. GENERATOR'S/OFFEROR'S CERTIFICATION: Thereby declafe that the contents of this consignment are fully end accurately described above by the proper shipplng namie, and are classified, packaged marked and labeled/placarded, and are in all respects in proper condilion for trensport according to applicable international and national govemmental regulations. If export stipment and I am the Primary Exporter, I certify that the contents of tils consignment conform to the terms of the attached EPAAcknowledgment of Consent.

I certify Ithat the waste minlmization statement identified in 40 CFR 262.27(a) (if I am a large quanlity generator) or (b) (if I am a small quantity gennerator) is true.

Generator's/Offeror's Prinled/Typed Name

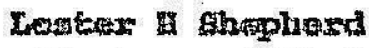

16. Intemational Shipments $\quad \square$ Import to U.S.

Transporter signature (for axparts only):

Signature

of $x+7$

$\square$ Export from U.S.

Port of entrylexit: 1 Date leaving U.S.:

Month Day Ye日r $1121031 / 4$

17. Transporier Acknowedgment of Recelpt of Malerials

Kisk $(1)$ is son reanspoiter 2 Printed//yped Name g. 12

18. Discrepancy'

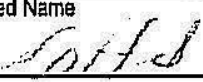

18a. Discrepancy Indication Space

18b. Allemale Facility (or Generator)

Facillty's Phone:

18c. Signature of Alternale Facility (or Generator)

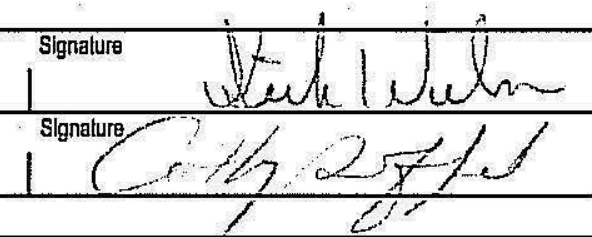

$\square$ Residue

Partial Rejection

Manilest Reference Number.

9. Hazardous Waste Report Menagement Method Codes (i.e., codes for hazardous waste treatment, disposal, and recycling systems)

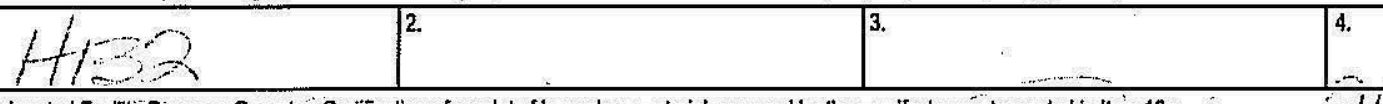

20, Designaled. Facility Owner or Operator. Certifitication of recelpt of hazardous materials covered by the manifest except as nded in ltem $18 \mathrm{a}$ 
Please print or type. (Form designed for use on elite (12-pitcn) typewriter.)

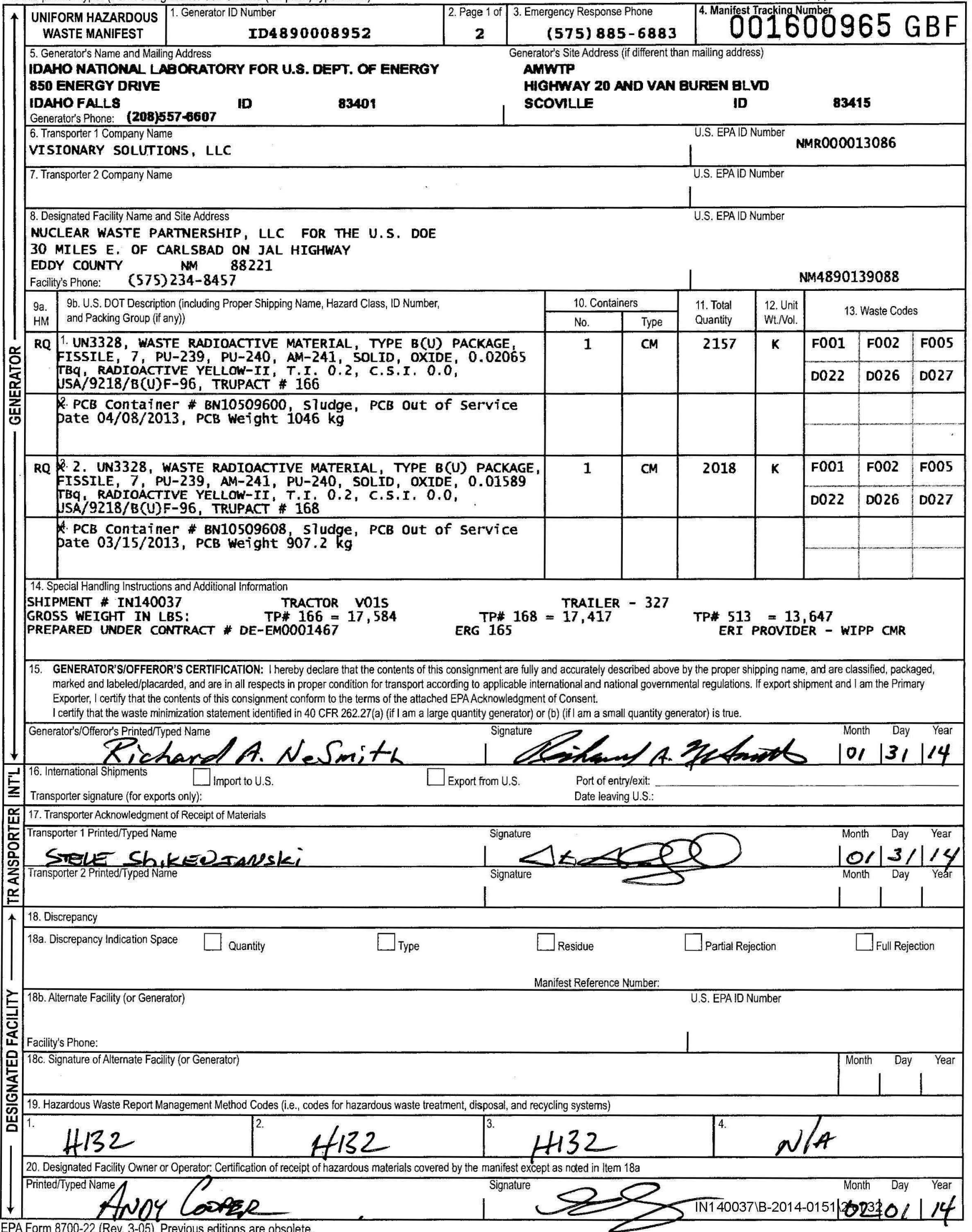




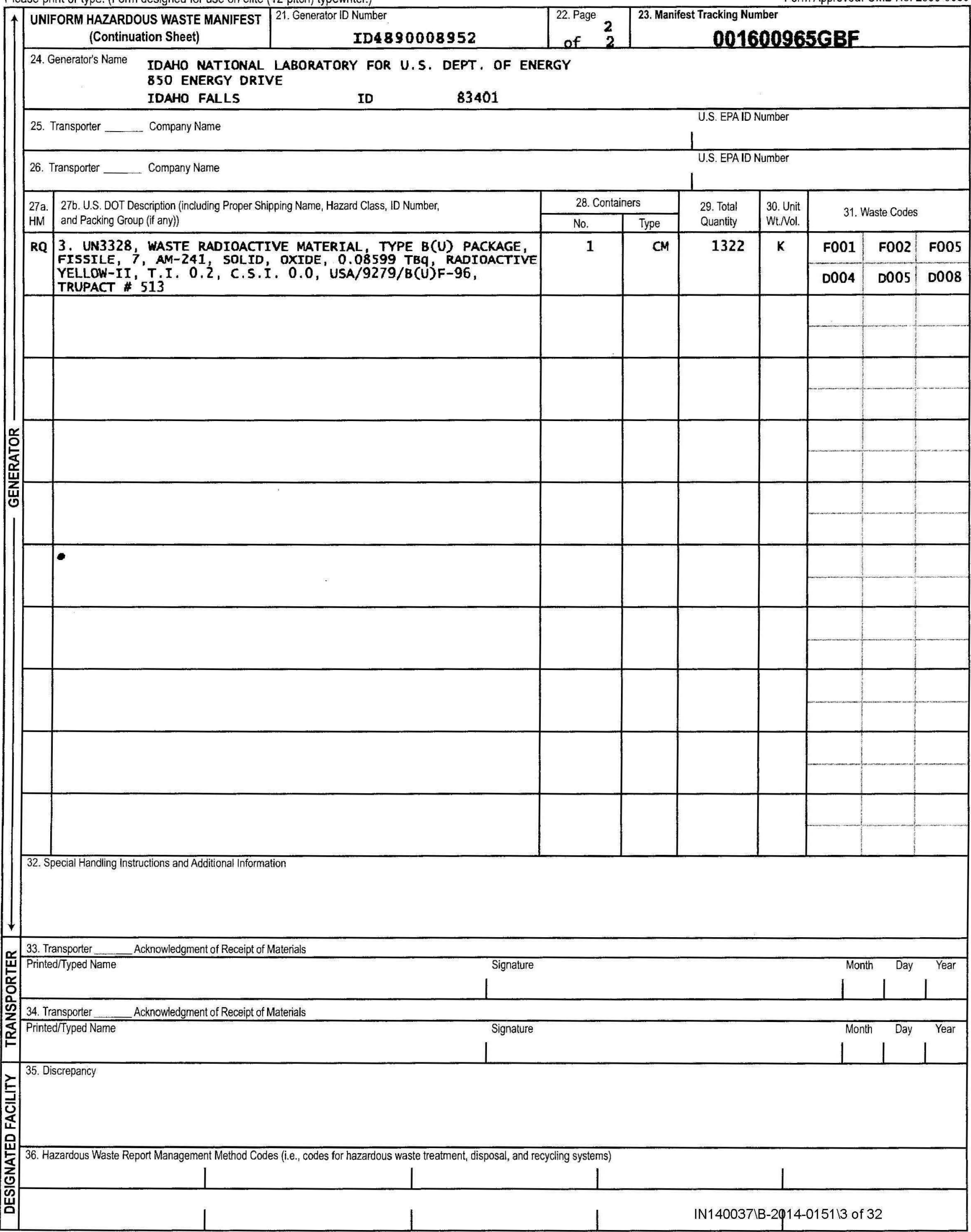


Please print or type. (Form designed for use on elite (12-pitch) typewriter.)

\section{$\uparrow$ UNIFORM HAZARDOUS 1 . Generator ID Number \\ WASTE MANIFEST \\ ID4890008952}

5. Generator's Name and Mailing Address

IDAHO NATIONAL LABORATORY FOR U.8. DEPT. OF ENERGY 850 ENERGY DRIVE

\section{IDAHO FALLS}

ID

83401

\section{2.}

2. Page 1 of 3 . Emergency Response Phone

(575) $885-6883$

4. Manifest Tracking Number

Generator's Site Address (if different than mailing address)

AMWTP

HGHWAY 20 NWD VAN BUREN BLVD

SCOVUE

ID

83415

VISIONARY SOLUTIONS, LLC

7. Transporter 2 Company Name

8. Designated Facility Name and Site Address

NUCLEAR WASTE PARTNERSHIP, LLC FOR THE U.S, DOE

30 MILES E. OF CARLSBAD ON JAL HIGHWAY

EDDY COUNTY NM 88221

Facility's Phone: (575) 234-8457

9a. 96. U.S. DOT Description finduding Proper Shipping Name, Hazard Class, ID Number,

HM and Packing Group (ff any))

RQ 1. UN3328, WASTE RADIOACTIVE MATERIAL, TYPE B(U) PACKAGE

FISSILE, 7, PU-239, AM-241, PU-240, SOLID, OXIDE, 0.02081

TBq, RADIOACTIVE YELLOW-II, T.I, O.2, C.S.I, 0.0,

USA/9218/B(U)F-96, TRUPACT * 186

2. PCB container \# BN10509686, Sludge, PCB out of service

pate $1 / 29 / 2013$, РСв weight $1063.6 \mathrm{~kg}$

RQ 2. 2. U3328, WASTE RADIOACTIVE MATERIAL, TYPE B(U) PACKAGE,

FI5SILE, 7, PU-239, AM-241, PU-240, SOLID, OXIDE, 0.008511

TBq, RADTOACTIVE YELLOW-II, T. I. 0.2, C.S.I. 0.0,

USA $/ 9218 / B(U) F-96$, TRUPACT \# 208

* PCB contajner \# BN10509604, sludge, РCB out of service pate $6 / 7 / 2013$, РСB weight $946.6 \mathrm{~kg}$

14. Special Handling Instructions and Additional Information

SHIPMENT \# IN140040 TRACTOR - V22

GROSS WEIGHT IN LBS: TP $186=17,416$

PREPARED UNDER CONTRACT * DE-EMO001467

TRATLER - 323

TP* $208=17,343 \quad$ TP* $505=13,635$

ERI PROVIDER IS WIPP CMR

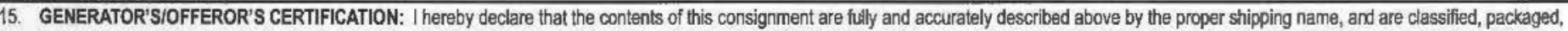
marked and labelediplacarded, and are in all respects in proper condition for transport according to applicable intemational and national governmental regulations. If export shipment and I am the Primary Exporter, I certify that the contents of this consignment conform to the terms of the attached EPAAcknowledgment of Consent.

I certify that the waste minimization statement identified in 40 CFR 262.27(a) (if I am a large quantity generator) or (b) (if I am a small quantity generator) is true.

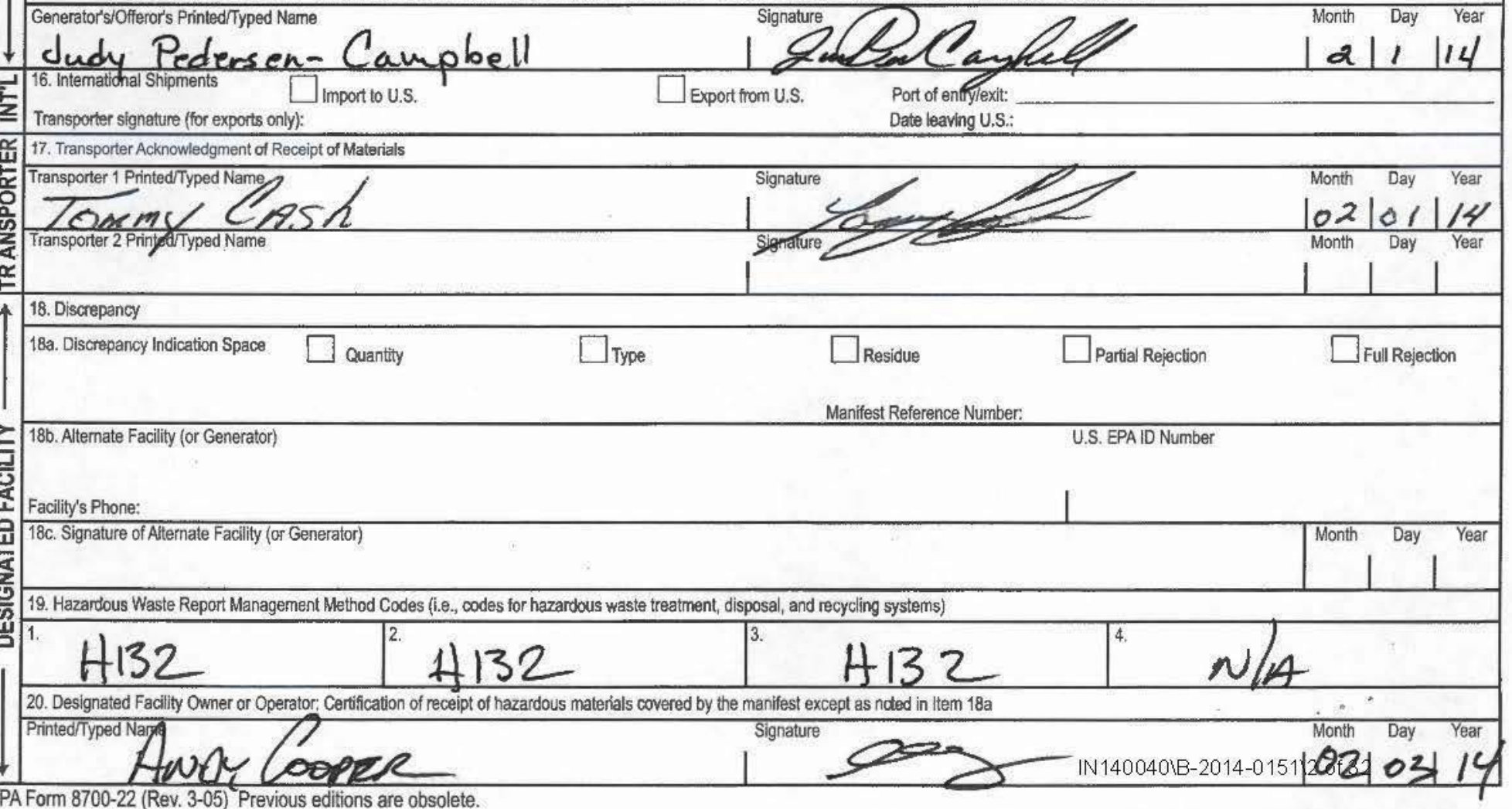

EPA Form 8700-22 (Rev. 3-05) Previous editions are obsolete. 
Please print or type. (Form designed for use on elite (12-pitch) typewriter.)

Form Approved. OMB No. 2050-0039

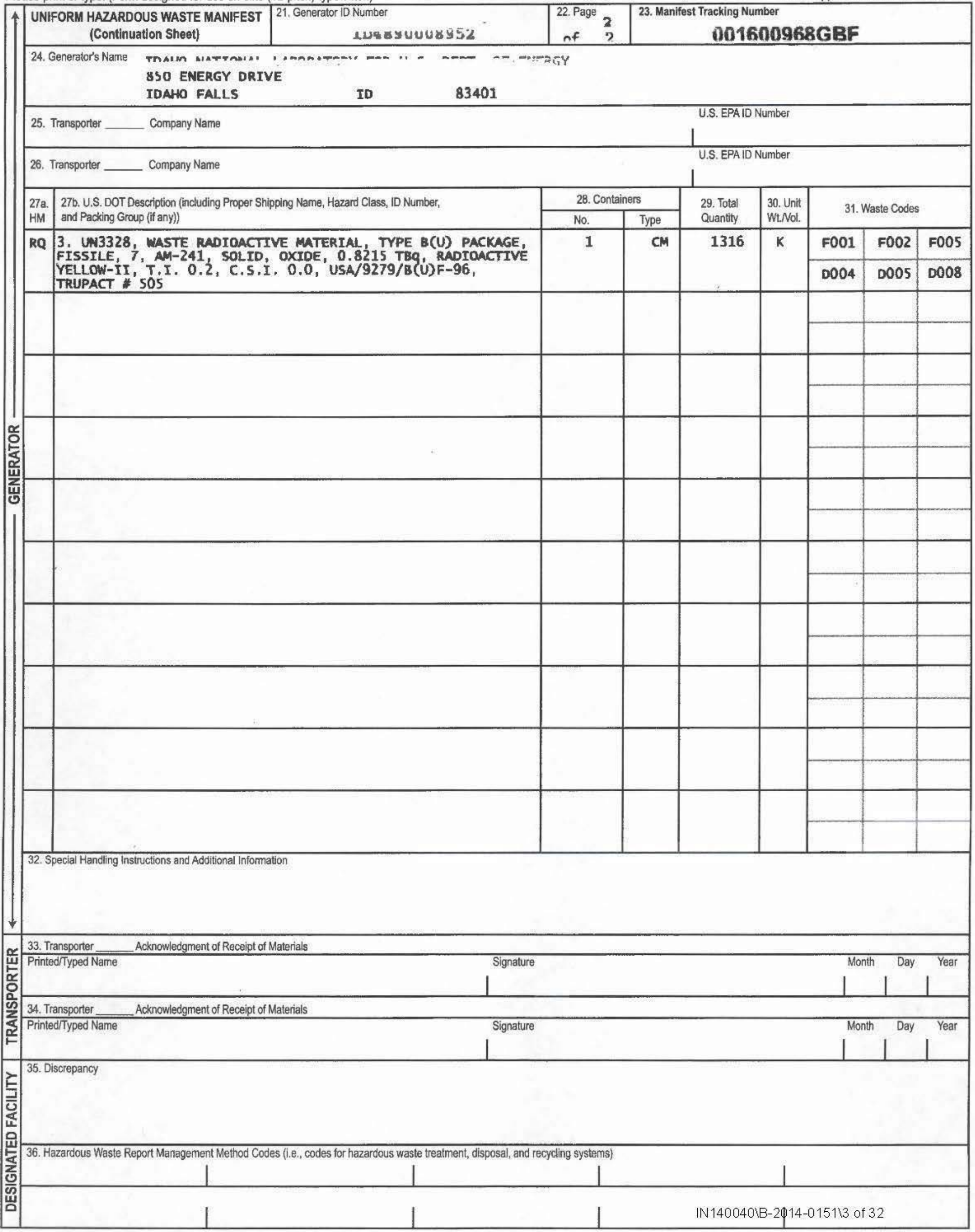


Please print or type. (Form designed for use on elite (12-pitch) typewriter.)

Form Approved. OMB No. 2050-0039

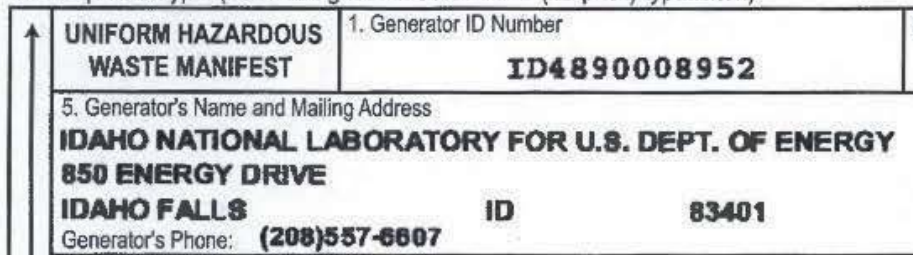

Generator's Phone: (208)557-6607

6. Transporter 1 Company Name
VISIONARY SOLUTIONS, LLC

7. Transporter 2 Company Name

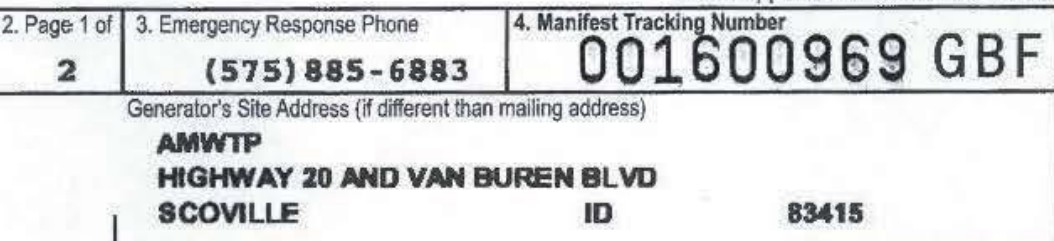

8. Designated Facility Name and Site Address

NUCLEAR WASTE PARTNERSHIP, LLC FOR THE U.5, DOE

30 MILES E. OF CARL SBAD ON JAL HIGHWAY

EDDY COUNTY 88221

Facility's Phone: (575) 234-8457

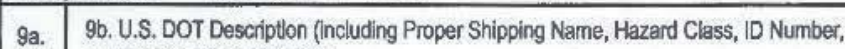

$\mathrm{HM}$ and Packing Group (if any))

RQ 1. UN3328, WASTE RADTOACTIVE MATERIAL, TYPE B(U) PACKAGE

FISSILE, 7, PU-239, AM-241, PU-240, SOLID, OXIDE, 0.007936

TBQ, RADIOACTIVE YELLOW-II, T.I. 0.2, C.S.T. 0.0 ;

JSA $/ 9218 / \mathrm{B}(\mathrm{U}) \mathrm{F}-96$, TRUPACT \# 125

2. PCB Container \# BN10509684, S7udge, PCB out of service

pate $6 / 20 / 2013$, РCB Weight $1032 \mathrm{~kg}$

RQ 2, UN3328, WASTE RADIOACTIVE MATERTAL, TVPE B(U) PACKAGE,

FISSILE, 7, PU-239, AM-241, PU-240, SOLID, OXIDE, 0.01587

rBq, RADIOACTIVE YELLOW-II, T.I. 0,2, C.S.I. 0.0,

USA $/ 9218 / B(U) F-96$, TRUPACT \# 203

4. PCB Container \# BN10503776, sludge, PCB out of service

pate $4 / 16 / 2013$, РСB weight $928.6 \mathrm{~kg}$

14. Special Handling Instructions and Additional Information

SHTPMENT * IN140041

GROSS WEIGHT IN LBS:

TRACTOR - V - 20

TP\# $125=17,372$

PREPARED UNDER CONTRACT DE-EMOOO1467

$\sqrt{3} \%_{\text {TRAILER }-349}$

TP* $203=17,149$

ERG - 165

U.S. EPAID Number NMR000013086
U.S. EPAID Number
U.S. EPA ID Number

U.S. EPA ID Number

15. GENERATOR'S/OFFEROR'S CERTIFICATION: I hereby declare that the contents of this consignment are fully and accurately described above by the proper shipping name, and are classified, packaged, marked and labeled/placarded, and are in all respects in proper condition for transport according to applicable international and national governmental regulations. If export shipment and I am the Primary Exporter, I certify that the contents of this consignment conform to the terms of the altached EPA Acknowledgment of Consent.

I certify that the waste minimization statement identified in 40 CFR 262.27(a) (if I am a large quantity generator) or (b) (ifl am a small quantity generator) is true.

Judy Pedersen - Camp be ll
16. Internatiohal Shipments

18. Discrepancy

18a. Discrepancy Indication Space

(1):

17. Transporter Acknowledgment of Receipt of Materials

Transporter 1 Printed/Typed Name

Donglis

$2009 \angle A S$
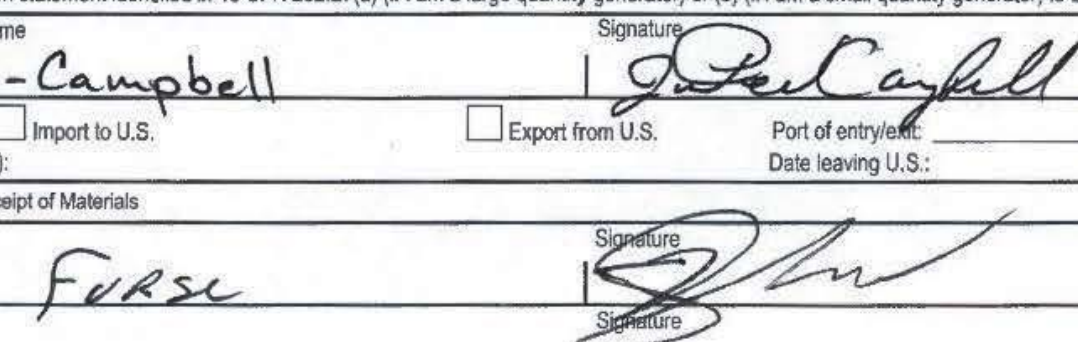

Port of entrylefit:

Date leaving U.S:

TP* $509=13,769$

ERI PROVIDER - WIPP CMR

NM4890139088

13. Waste Codes

\begin{tabular}{l|l|l|} 
F001 & F002 & F005 \\
\hline
\end{tabular}

\begin{tabular}{l|l|l}
0022 & 0026 & 0027
\end{tabular}

1

2040

k

Fo0

\begin{tabular}{|l|l|l|}
\hline 1 & $F 002$ & $F 005$ \\
\hline 2 & 0026 & $D 027$ \\
\hline & & \\
\hline
\end{tabular}

\begin{tabular}{|l|l|l|}
\hline & & \\
\hline F001 & F002 & F005 \\
\hline D022 & D026 & D027 \\
\hline
\end{tabular}

$8 b$. Alternate Facility (or Generator)

Manifest Reference Number:

Facility's Phone:

18c. Signature of Alternate Facility (or Generator)

19. Hazardous Waste Report Management Method Codes (i.e, codes for hazardous waste treatment, disposal, and recycling systems)

\begin{tabular}{l|l|l|l}
$H 132$ & $H B 2$ & $H 132$
\end{tabular}

20. Designated Facility Owner or Operator. Certification of receipt of hazardous materials covered by the manifest except as nded in Item 18 a

Printed/Typed yame

EPA Form 8700-22 (Rev. 3-05) Previous editions are obsolete.

$1^{\text {Signature }} \times \ln 2$

|N1400411B-2014-0151|lO223103//4 


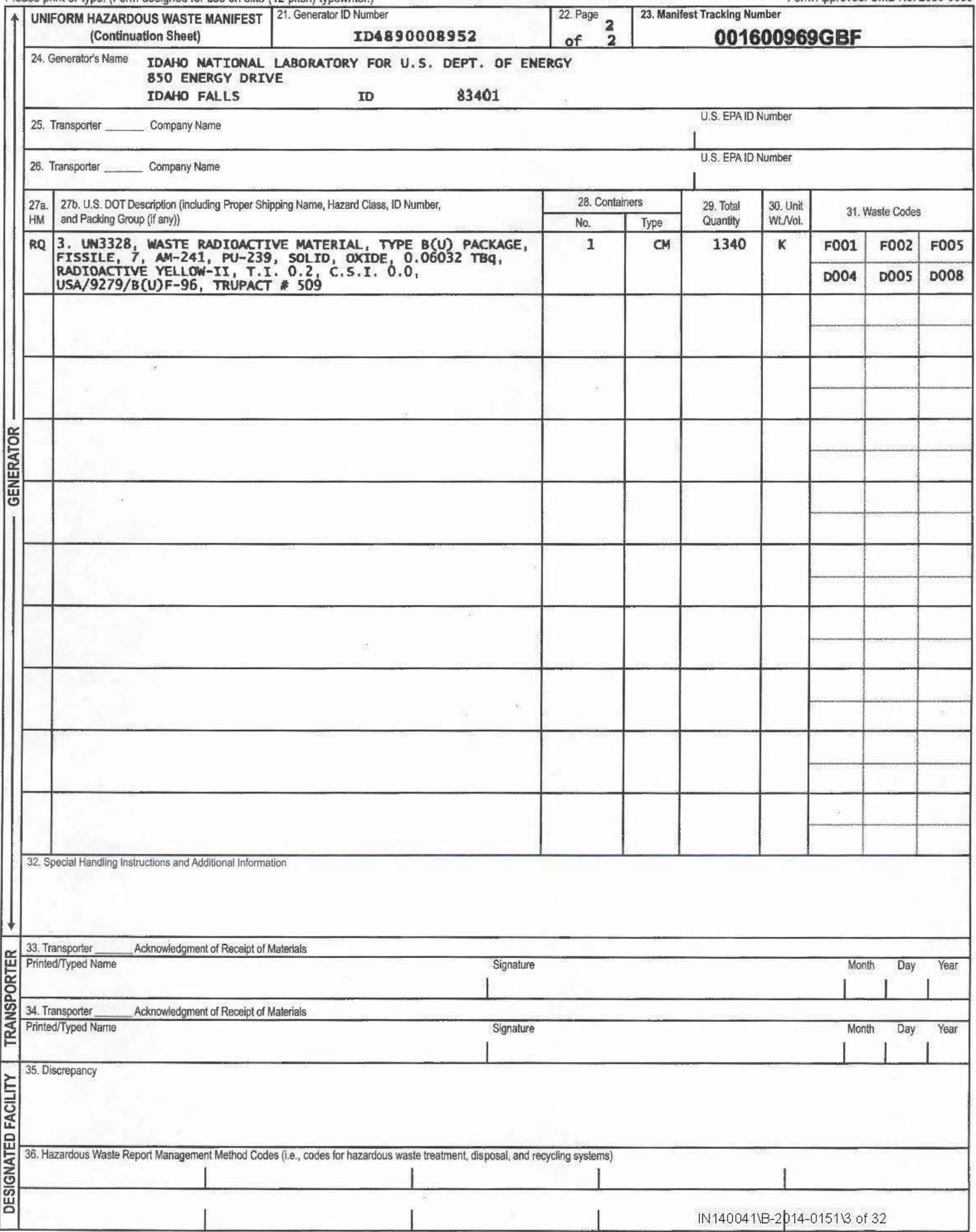


Please print or type. (Form designed for use on elite (12-pitch) typewriter.)

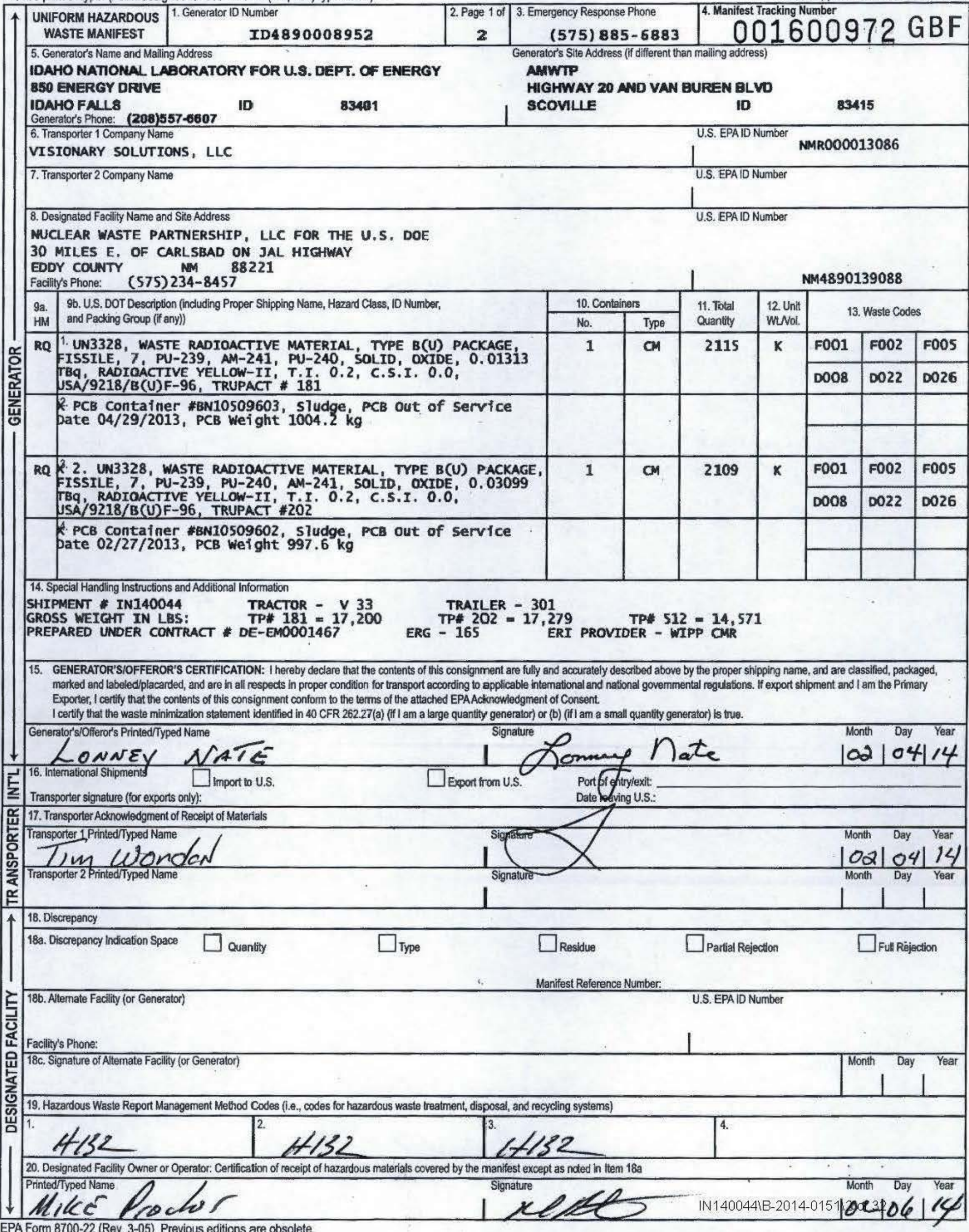


Please print or type. (Form designed for use on elite (12-pitch) typewriter.)

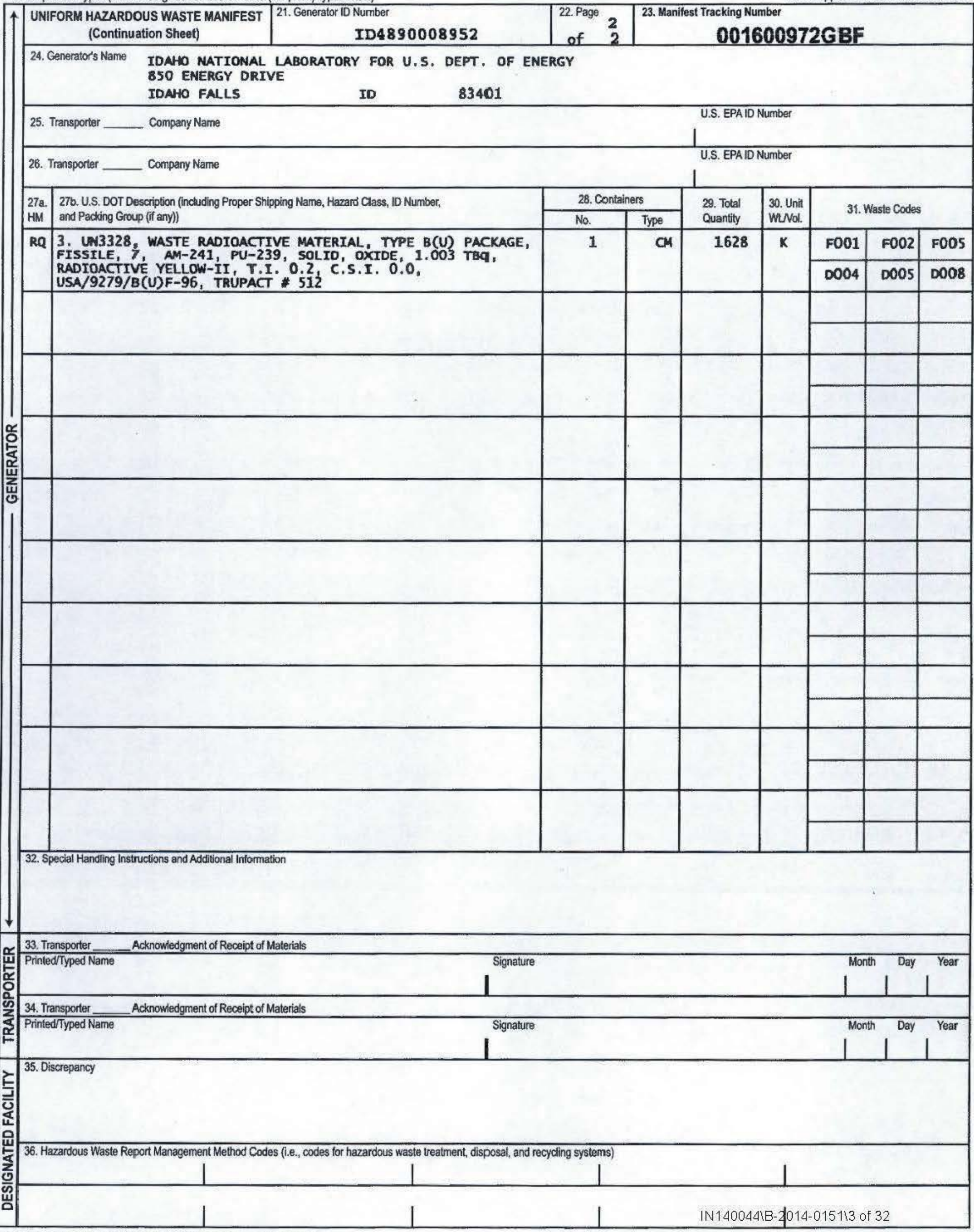


Please print or type. (Form designed for use on elite (12-pitch) typewriter.)

Form Approved. OMB No. 2050-0039

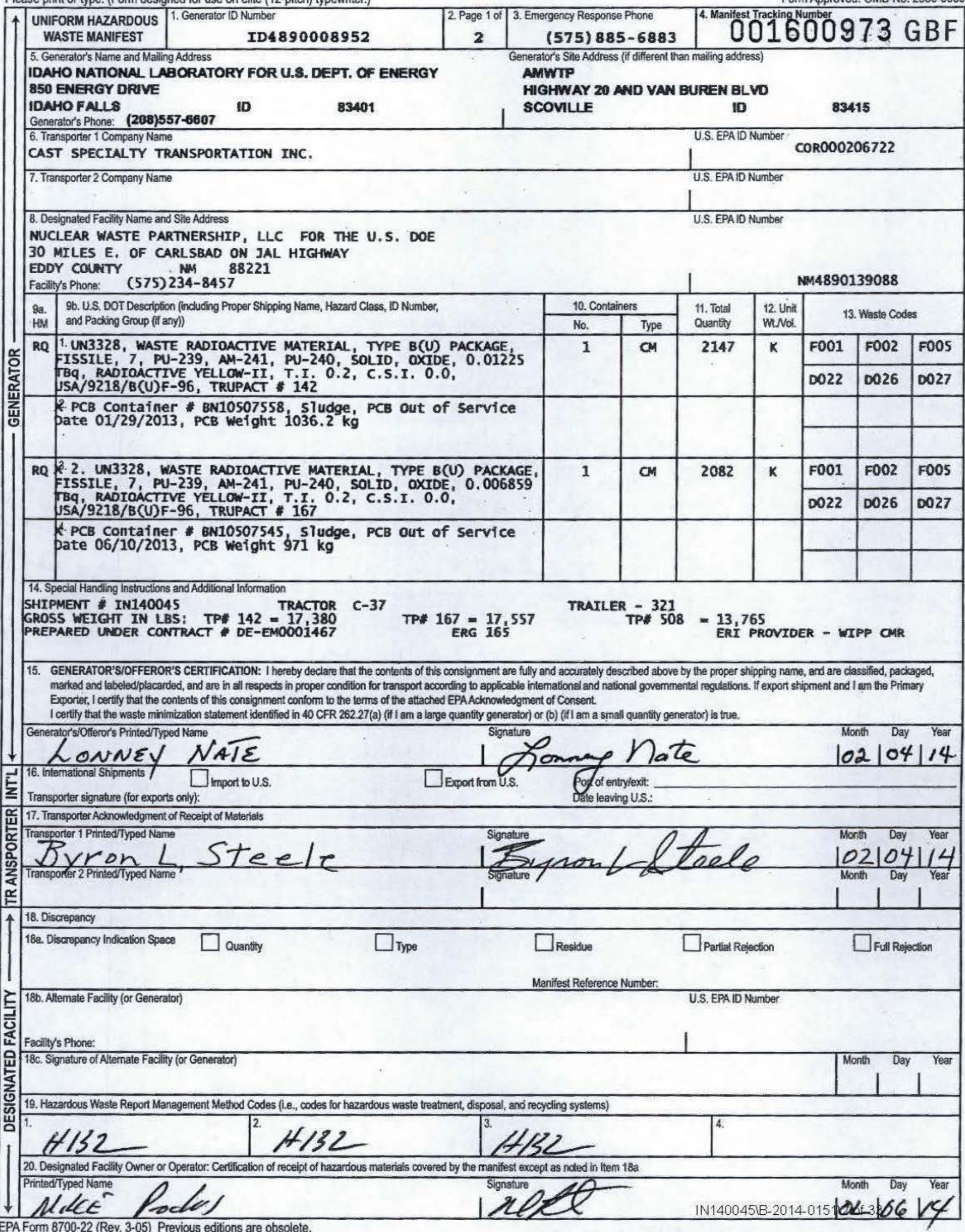




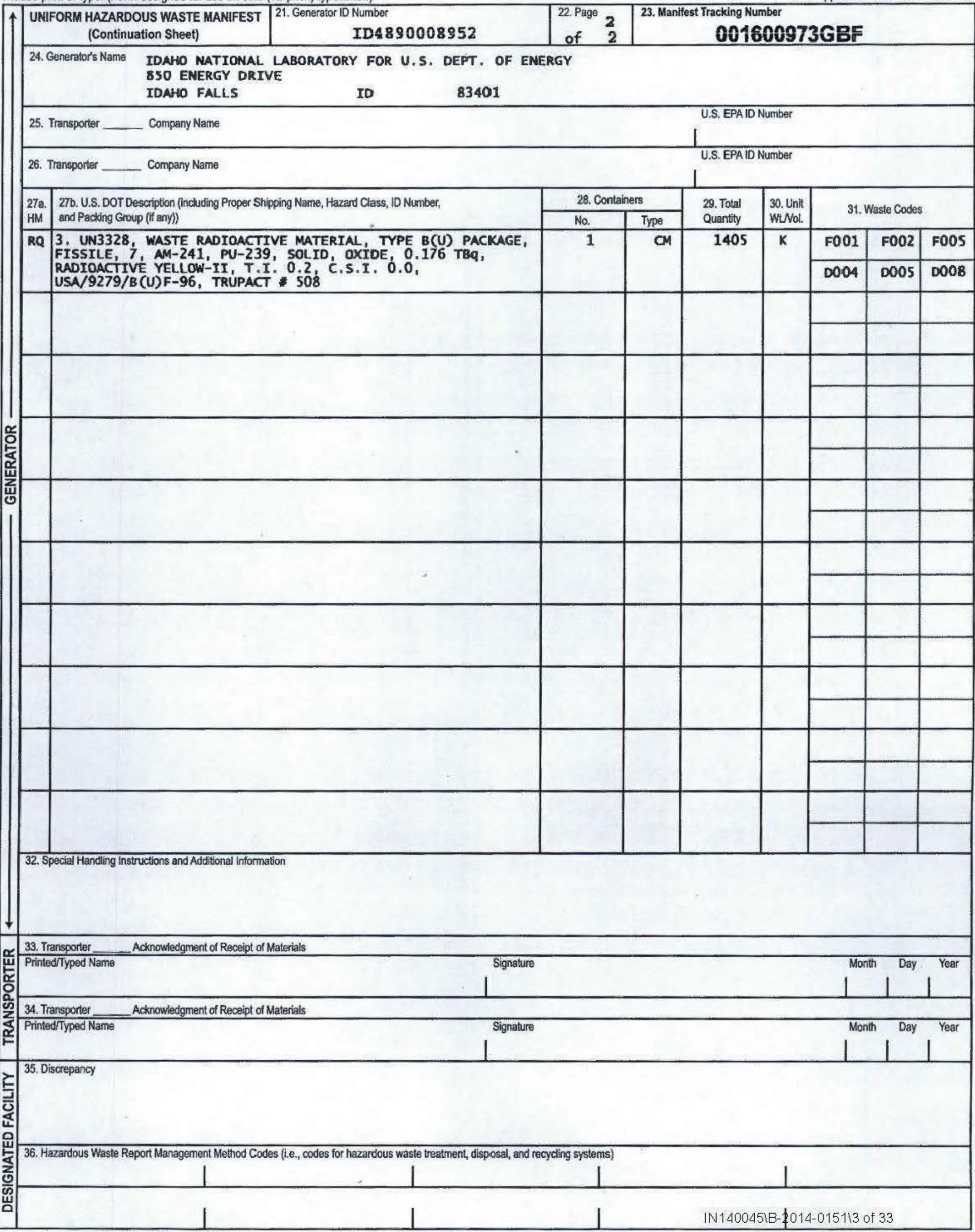


Please print or type. (Fom designed for use on ellte (12-pitch) typewriter.)

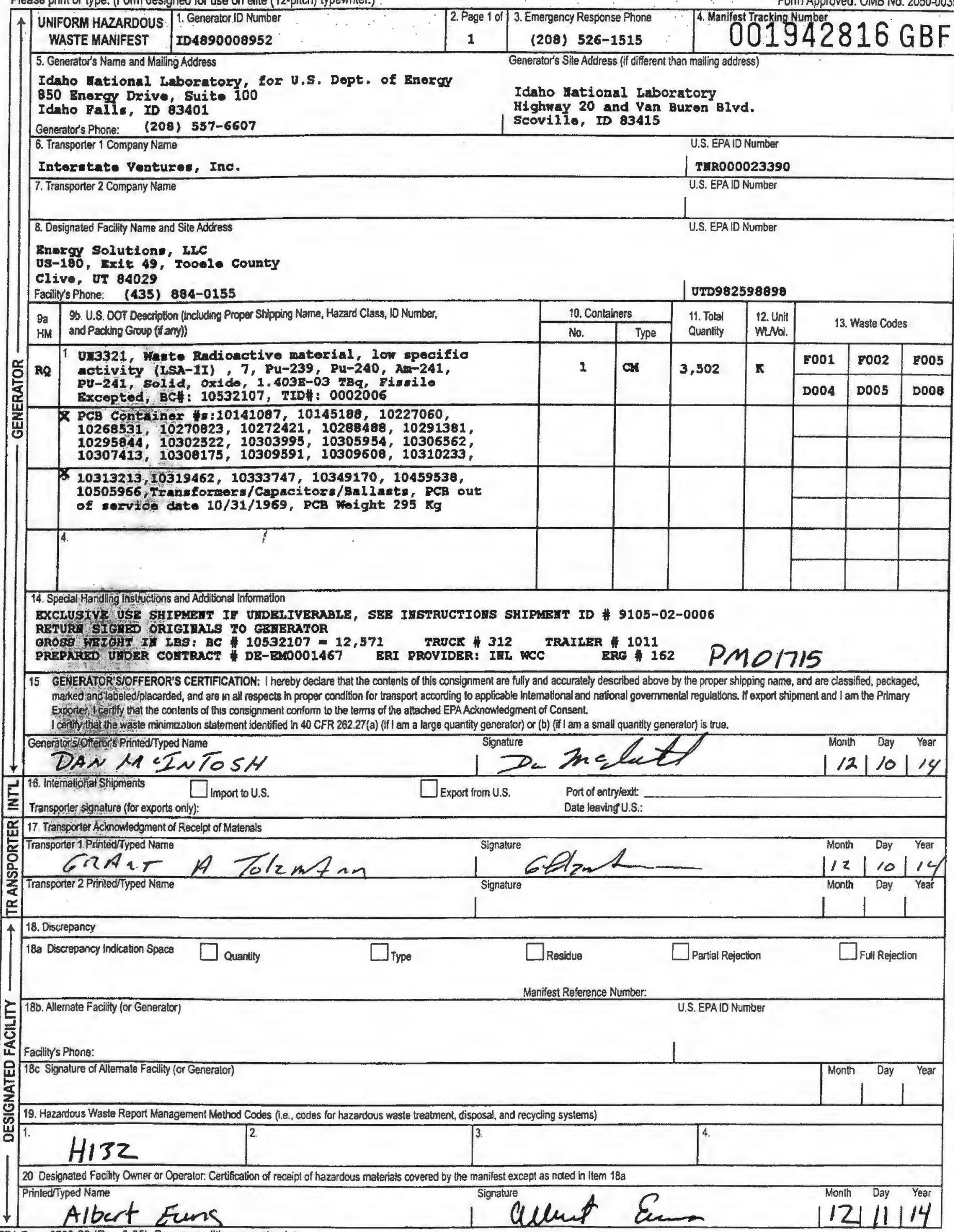


Please print or type. (Form designed for use on vilite (12-pitch) typewiter.)

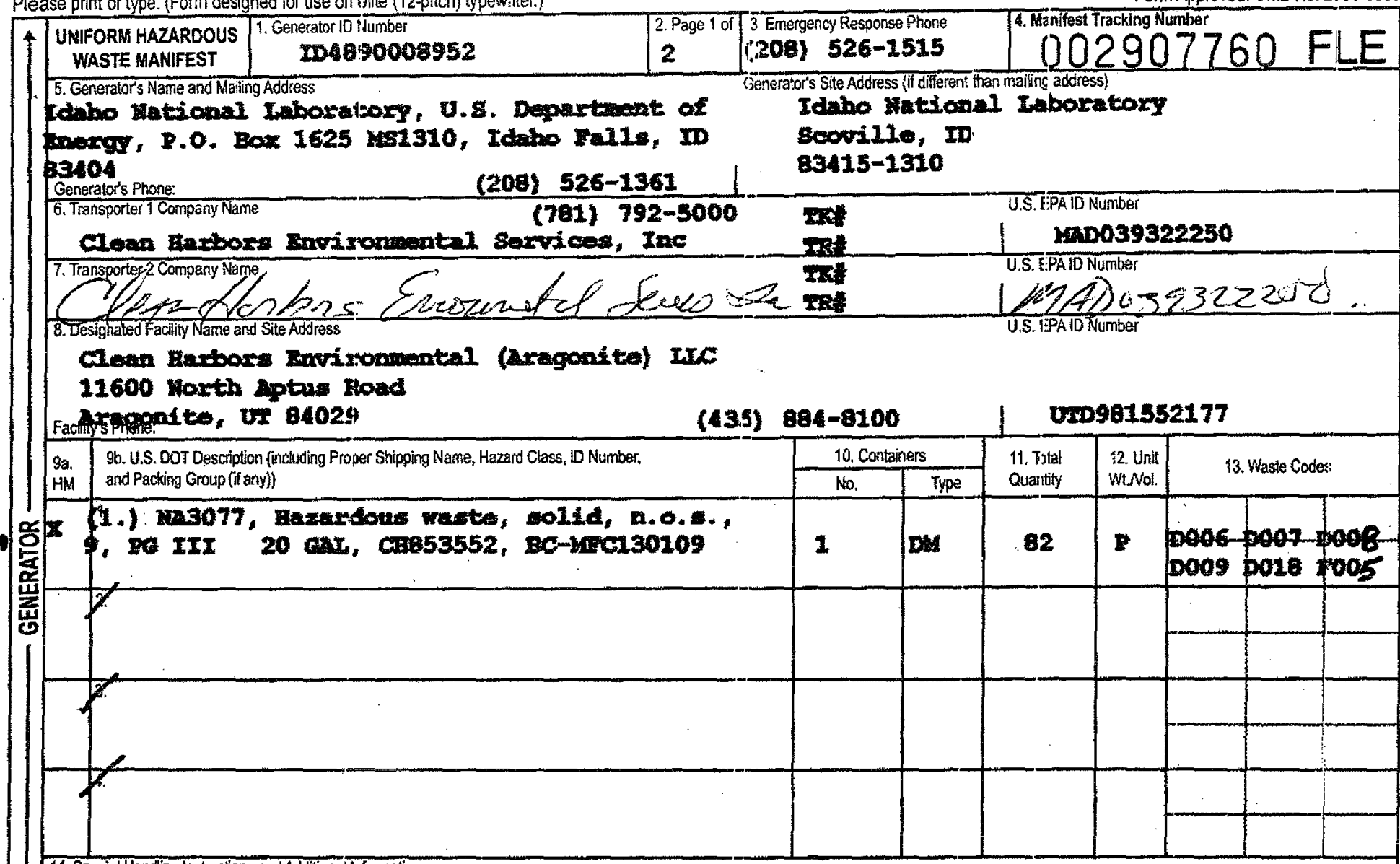

14. Special Handling Instructions and Additional Information

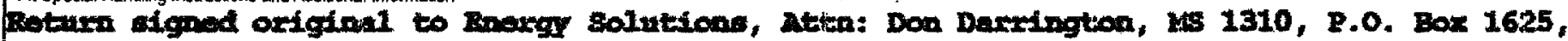

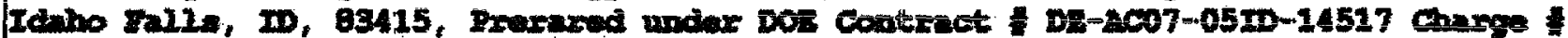

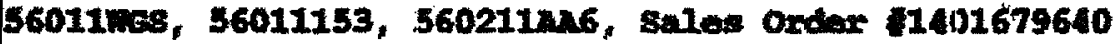

15. GENERATOR'SIOFFEROR'S CERTIFICATION: I hereby declare that the contents of this consignment are fully and acuurately described above by the proper sthipping name, and are classified, packaged, marked and labeled/placarded, and are in all respects in proper condition for transport according to applicjolo intemational and national govertmental regulations. If export shipment and I am the Primary Exporter, 1 certify that the contents of this sonsignment conform to the terms of the attached EPAAcknovitedgment of Consent.

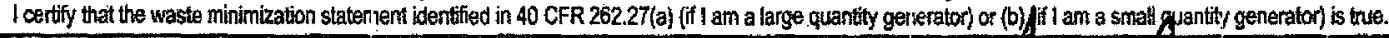

Generator's Ofters's Printed typed. Name

M. Anderson

17. Transporter Acknowiedgnent of Receipt of hlaterials

Trassporter 1 Printed Typed Nam

KiR KWU: Sou

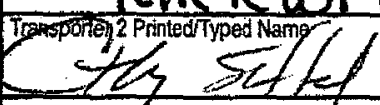

18. Discrepand

18a. Discrepancy Indication Space $\square$ Quantity

$\sqrt{2}$
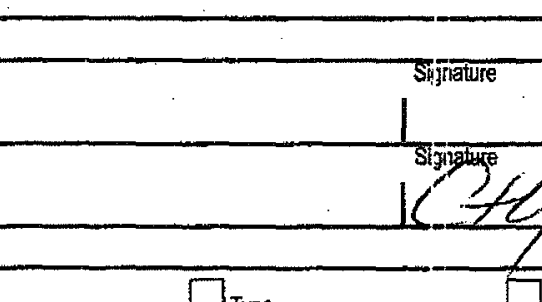

Date leaving U.S.

18b. Alternate Facillyy (or Generator)

Manifest Reference Numbe:

Facility's Phone:

18c. Signature of Altemate Facility (or Generator)

$\square$ Type

$\square$ Residue

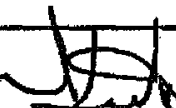

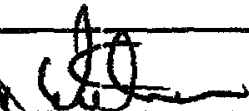

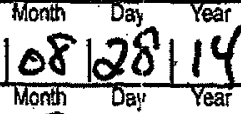

19. Hazardous Waste Raport Management Mathod Codes (i.e., codes for hazardous waste treatment, disposal, and recycling systems)
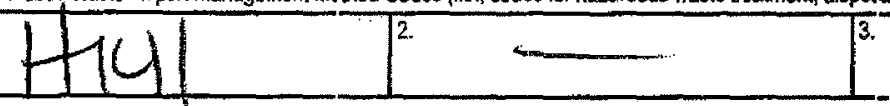

3.

20. Designated Facility Ownet or Operator. Certification of receipt of hazardous materials covered by the ma ifest except as noted in ltem 18 a<smiles>C1CCCCCC1</smiles>

(1)

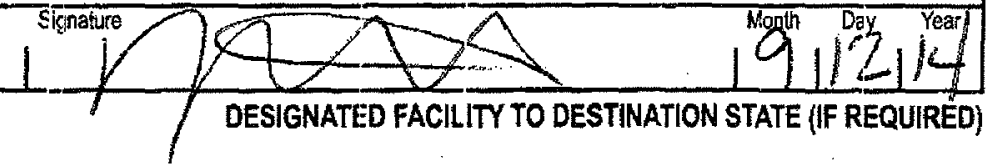




\section{CERTIFICATE OF DISPOSAL}

Generator Facility Name:
Generator Address:

Generator Contact Name:
INL Materials \& Fuels Complex MFC

35 Miles West of Idaho Falls via Hwy 20 west

Idaho Falls, ID, 83415
Sales Order\#: $\quad 1401679640$

Date Received: $\quad 9 / 12 / 2014$

\begin{tabular}{|c|c|c|c|c|c|c|c|}
\hline \multirow{2}{*}{\multicolumn{2}{|c|}{ Generator EPA ID: }} & \multirow{2}{*}{\multicolumn{2}{|c|}{ ID4890008952 }} & & \multicolumn{2}{|c|}{ Load \#: } & 69611 \\
\hline & & & & & Mar & t\#: & 7760FLE \\
\hline $\begin{array}{l}\text { Original } \\
\mathrm{CH} \text { ID \# }\end{array}$ & $\begin{array}{l}\text { Date Removed } \\
\text { From Service }\end{array}$ & $\begin{array}{l}\text { Unit } \\
\text { Type }\end{array}$ & $\begin{array}{c}\text { Serial \# I } \\
\text { Customer ID }\end{array}$ & $\begin{array}{c}\text { Material } \\
\text { Description }\end{array}$ & $\begin{array}{c}\text { Disposal } \\
\text { Date }\end{array}$ & $\begin{array}{l}\text { Method of } \\
\text { Disposal }\end{array}$ & Disposal Facility \\
\hline 40384944 & $1 / 28 / 2014$ & DM & mfc140007! & PCB Solids For Incineration & $9 / 30 / 2014$ & Incineration & Aragonite, UT Facility \\
\hline
\end{tabular}

Under Civil and Criminal Penalties of Law for the making or submission of false or fraudulent statements or representations (18 U.S.C. 1001 and 15 U.S.C. 2615), I certify that the information contained in or accompanying this document is true, accurate, and complete. As to the identified section(s) of this document for which I cannot personally verify truth and accuracy, I certify as the company official having supervisory responsibility for the persons who, acting under my direct instructions, made the verification that this information is true, accurate, and complete.

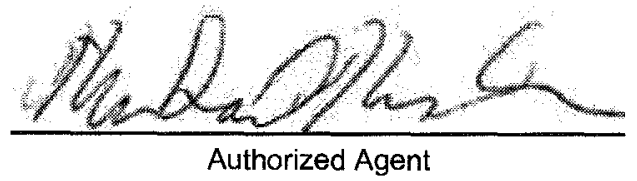

Friday, October 10, 2014

Authorized Agent 


\section{APPENDIX 3}

Manifests Generated during Calendar Year 2013

that received a Certificate of Disposal/Destruction

during calendar year 2014

(manifests on following pages)

\begin{tabular}{|c|c|c|c|}
\hline Item No. & Manifest No. & Identification No. & $\begin{array}{c}\text { Disposal/Destruction } \\
\text { Date }\end{array}$ \\
\hline 1 & $000372369 J J K$ & INTC130019 & $2 / 21 / 2014$ \\
\hline 2 & $000372380 J J K$ & NRF130088 & $3 / 17 / 2014$ \\
\hline 3 & $000372387 J J K$ & NRF130101 & $1 / 13 / 2014$ \\
\hline 4 & $00297730 \mathrm{FLE}$ & MFC130038 & $1 / 23 / 2014$ \\
\hline & & & \\
\hline
\end{tabular}


Please print or type. (Fotm designed for use or ailts (12-pitchj) lyfewriler.)

$000372369 \mathrm{JJK}$

6hin

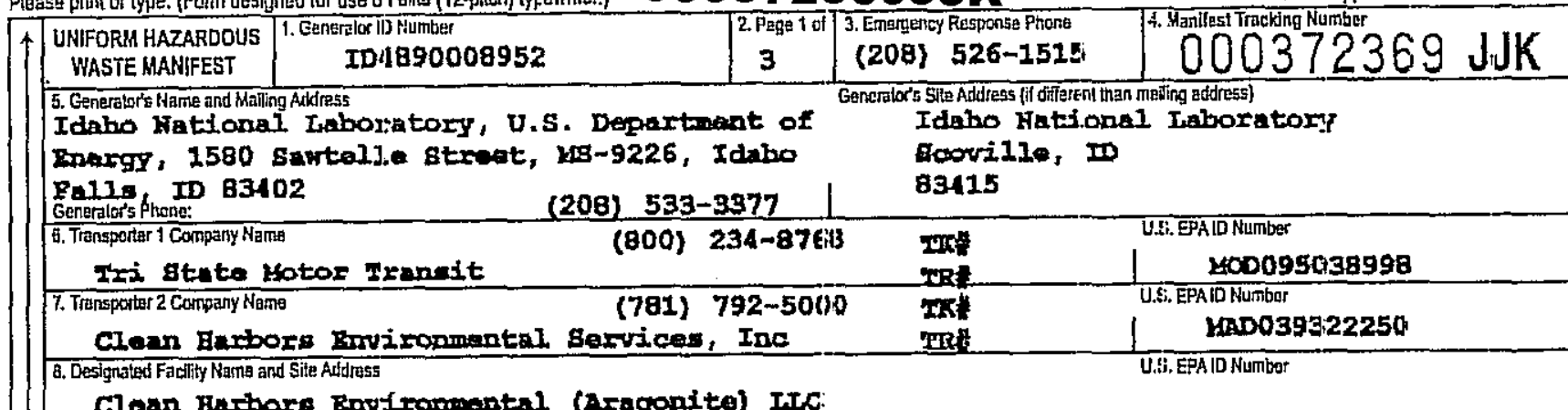

Cloan Burhore Enviromental (Aragonite) IIS:

11600 North Aptons Road

Facility

(135) 884-6100

U\%Og151552177

9a. Bb, U.S. Dor Description fincluding Froper Shilpphrog Namia, Hizand Class, ID Number,

HiM and Packing Grotp \{fit any\})

(1.) Univaraal Fisten - Inopo Oltra Violat

둥 Imps, 36.65 car, , Ga98488, BC-IXxC120308

$x$ (2.) 0N3028, Eatiterien, dry, contenining potersium hydraxide solid, B, DO III

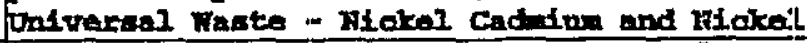

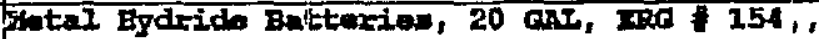
Ca227518, BC-IFHal20309

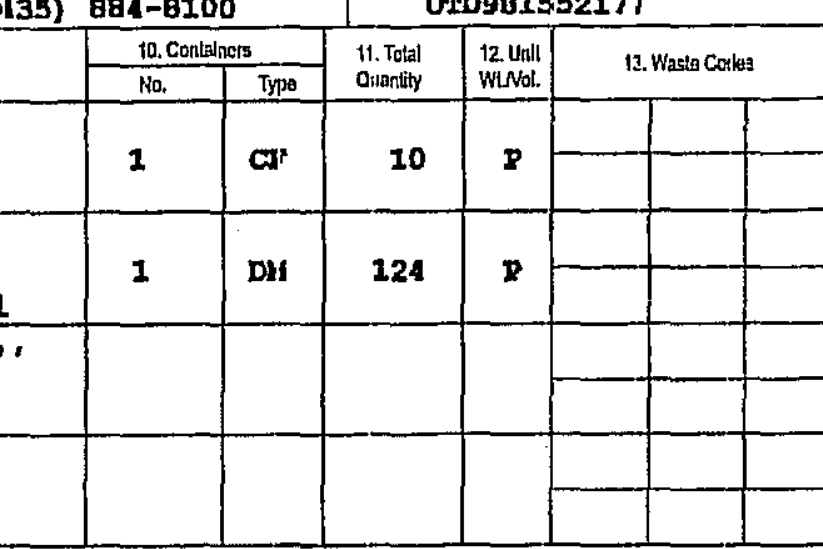

14. Special Handling Instructions and Addilional Intormalion

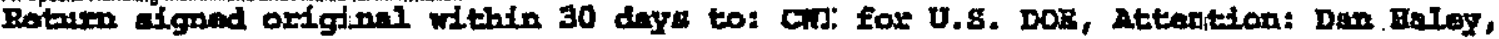

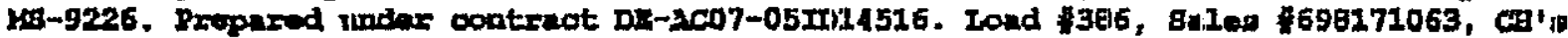

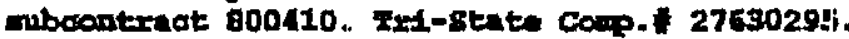

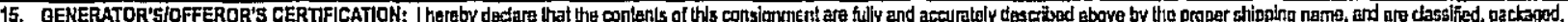

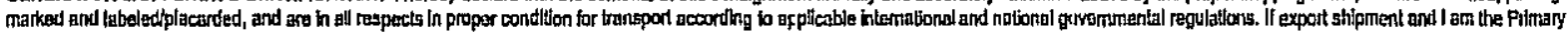

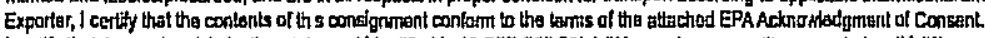

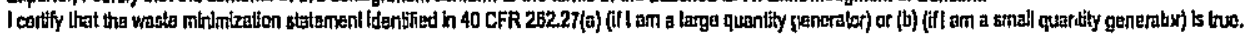

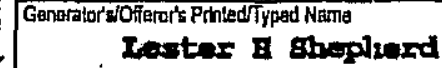

Transporler slignature (io exports oniy):

$\square$ inport to U.S.

17. Transporlar Adonowedgment of Recaiph of Malatiats

Trabisor ar I Printedityped Nama

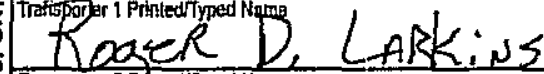

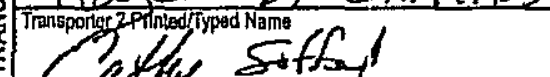

4 to. orstepancy

16ia. Dlscrepancy Indication Spaco [a Quantily

口l ouantily $\square$ Type

$\square$ Exportitronus.

Signaturat

theaherd

Port of ontryidxit: Dala leaving U.S:

160110113

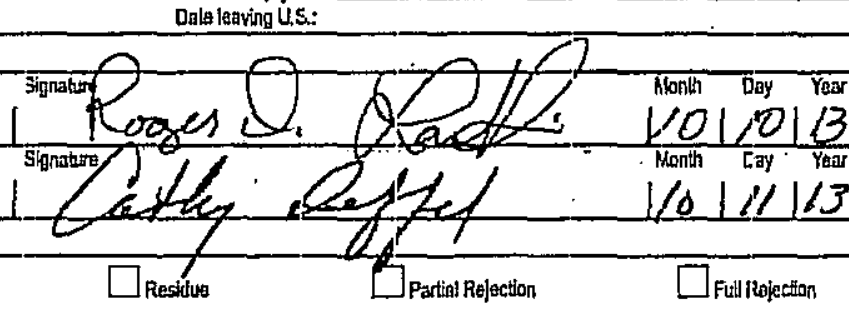

Marliagt Roferences Number:

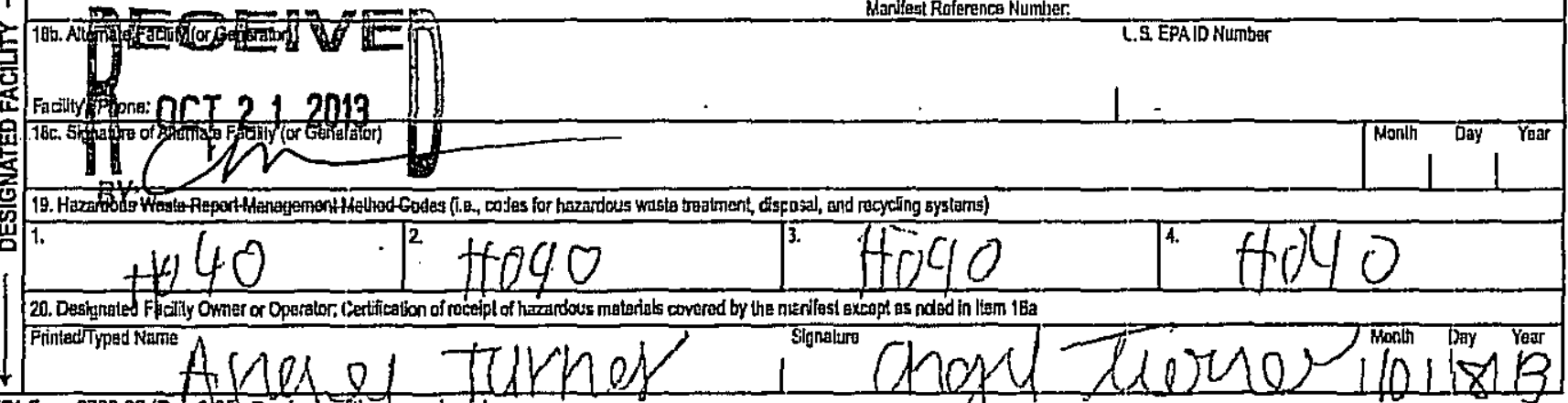

EPA Form B700-22 (Rev. 3-25) Previous etilionts ate obsolets.

DESIGNATENGACILITY TO DESTINATIOIN STATE (IF RIEQUIAED)

可 


\section{Generator's Name}

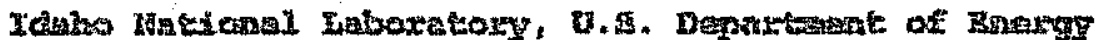

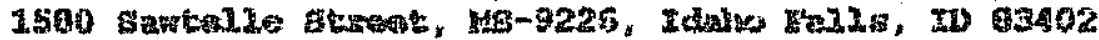

\begin{tabular}{lll|l} 
25. Transporter __ Company Name & U:S. EPAID Number \\
\hline 26. Transporter __ Company Name & U.S. EPA ID Number
\end{tabular}

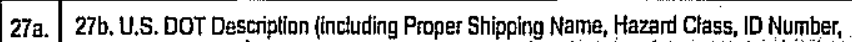

HM and Packing Group (fi any)) ta

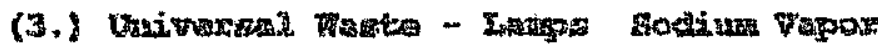

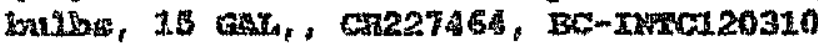

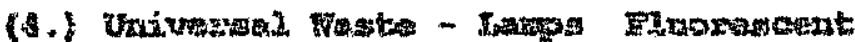

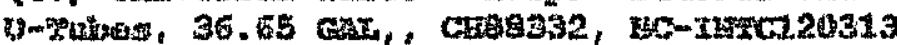

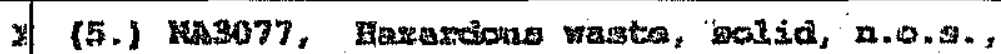

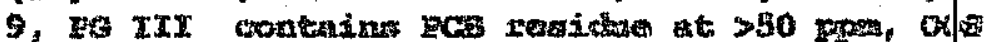

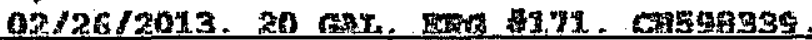
FCim Iroct 30019

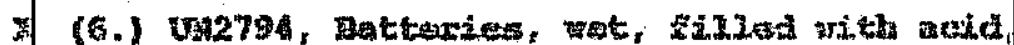

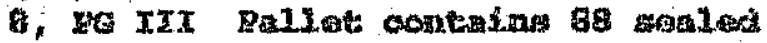

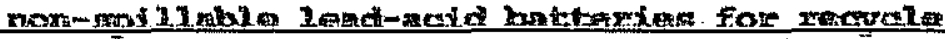

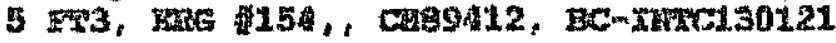

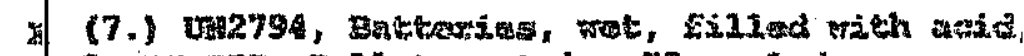

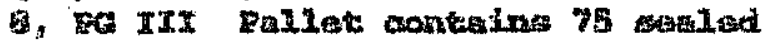

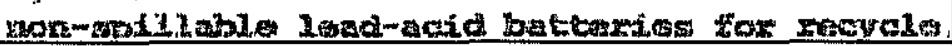

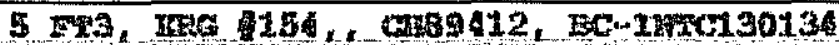

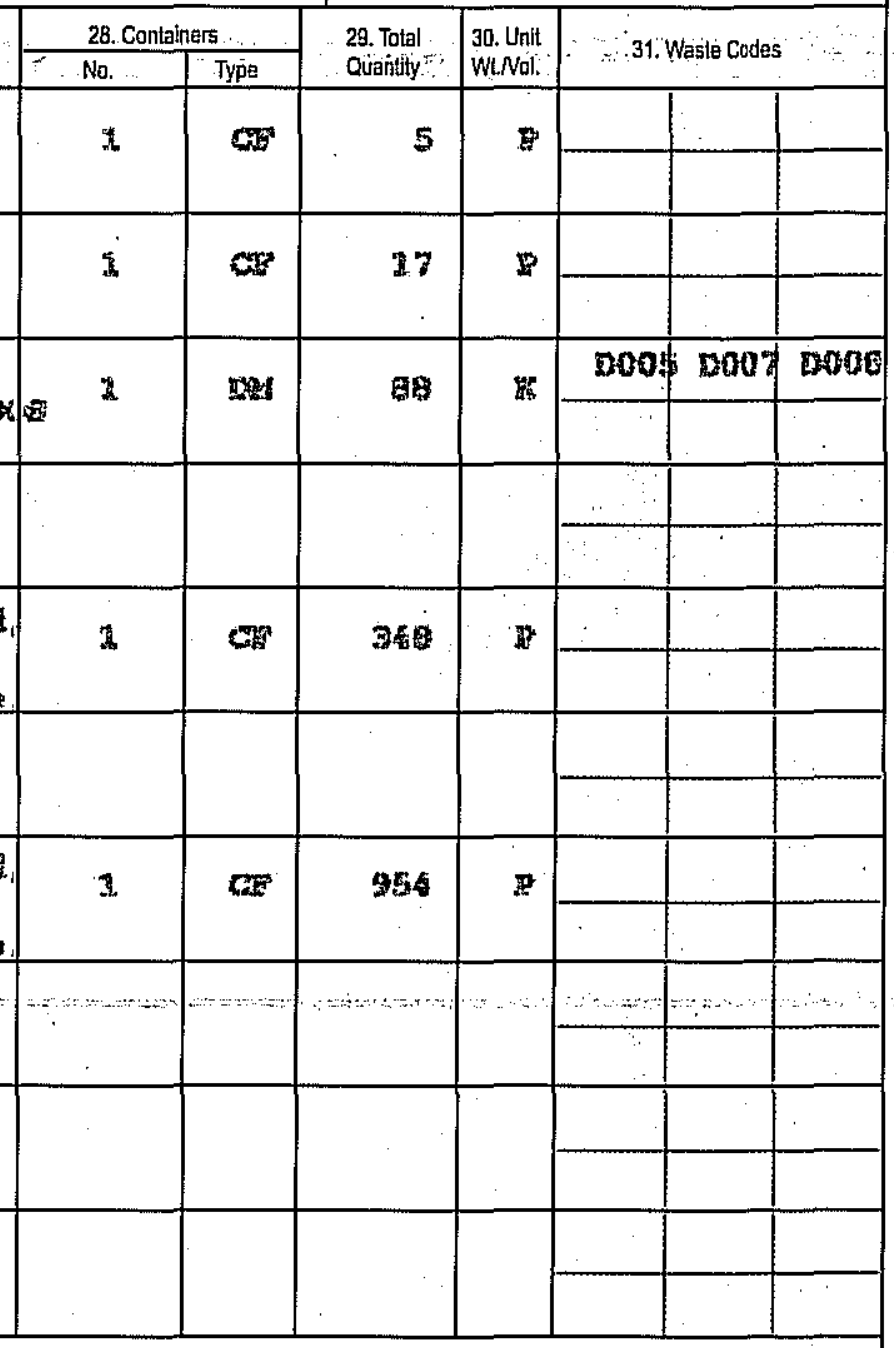

32. Special Handling lenstructions and Additional Infomation

Acknowledgment of Receipl of Malesials

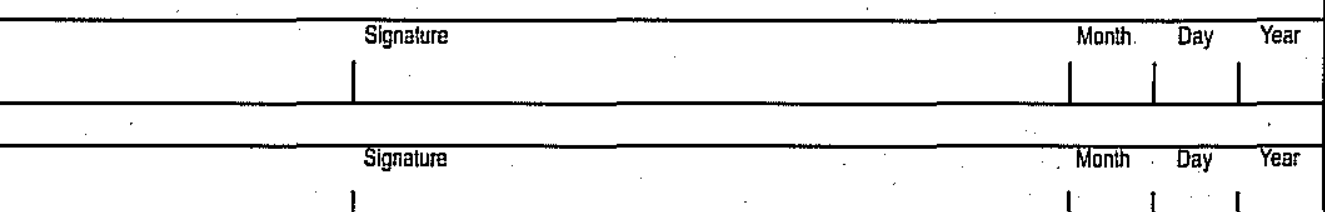

35. Discrepancy

1 
24. Generalor's Name

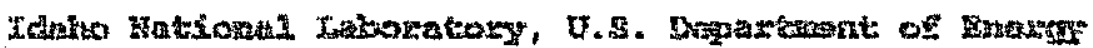

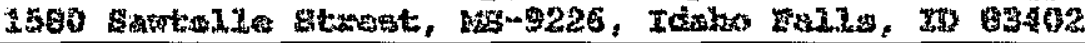

\begin{tabular}{|lll}
\hline 25. Trensporter $\_$Company Name & U.S. EPA ID Number \\
\hline 26. Transporter —_ Company Name & U.S. EPA ID Number
\end{tabular}

27a. $27 b$. U.S. DOT Description (including Proper Shipping Neme, Hazard Class, ID Number,

28. Conteiners

HM and Packing Group $\{$ il any\}) $\cdots$

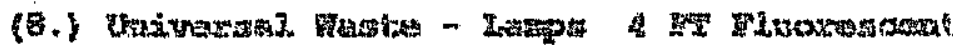

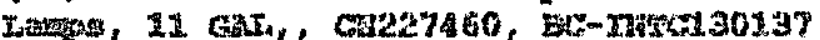

Anח

32. Special Handling Instructions and Addilional Information

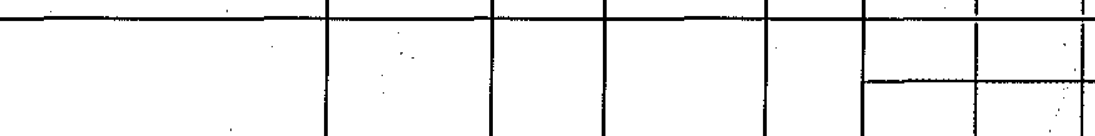

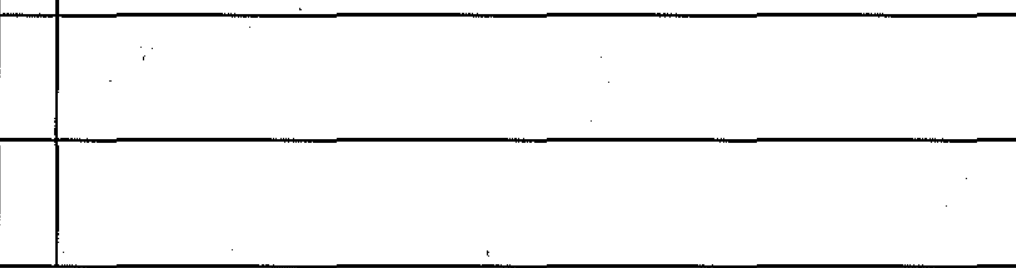

.

\begin{tabular}{|c|c|}
\hline & \\
\hline &
\end{tabular}

29, Tọtal , . 30 . Unit Quiantily $-:$ WL $N$ ol:

\begin{tabular}{l|l|l|l|l|}
\hline \multirow{2}{*}{20} & & & & \\
\hline
\end{tabular}

33. Transporter Acknowledument of Receipl of Materials

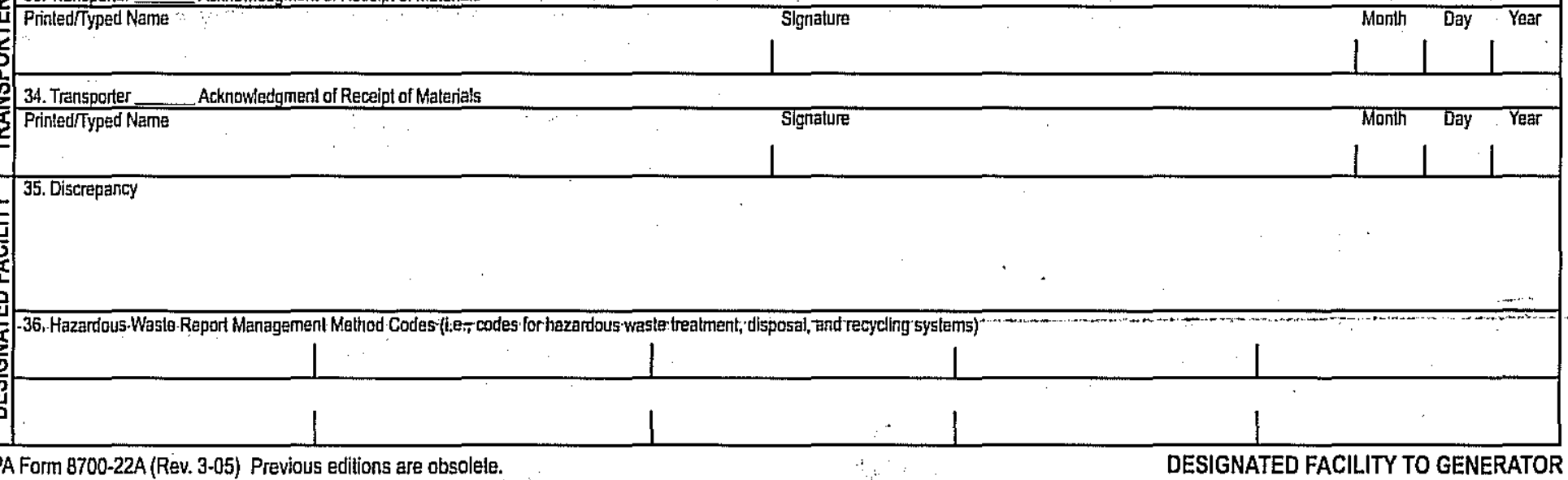




\title{
000372369JJK COD
}

Cleanhlarbors'

\author{
Clean Harbors Aragonite LLC \\ 11600 North Aptus Road \\ Grantsville UT, 84029 \\ UTD981552177 \\ (435) $884-8100$
}

\section{CERTIFICATE OF DISPOSAL}

Generalor Facility Name:

Generalor Address:
Idaho National Laboratory US Department of Energy

CH2M-WG Idaho, LLC- Dan Haley - MS 9226

PO Box 2010

Idaho Falls, ID, 83415
Sales Order\#: $\quad 698171064$

Date Received: $\quad$ 10/18/2013

Generator Contact Name:

\begin{tabular}{|c|c|c|c|c|c|c|c|}
\hline \multirow{2}{*}{\multicolumn{2}{|c|}{ Generator EPA ID: }} & \multirow{2}{*}{\multicolumn{2}{|c|}{ CESQG }} & & \multicolumn{2}{|c|}{ Load \#: } & 65430 \\
\hline & & & & & \multicolumn{2}{|c|}{ Manifest \#: } & 000372369JJK \\
\hline $\begin{array}{l}\text { Original } \\
\text { CH ID \# }\end{array}$ & $\begin{array}{l}\text { Date Removed } \\
\text { From Service }\end{array}$ & $\begin{array}{l}\text { Unit } \\
\text { Type }\end{array}$ & $\begin{array}{c}\text { Serial \# I } \\
\text { Customer ID }\end{array}$ & $\begin{array}{c}\text { Material } \\
\text { Description }\end{array}$ & $\begin{array}{l}\text { Disposal } \\
\text { Date }\end{array}$ & $\begin{array}{l}\text { Method of } \\
\text { Disposal }\end{array}$ & Disposal Facility \\
\hline 34050885 & $2 / 26 / 2013$ & DM & NONE $/$ & PCB Sollds For Incineration & $2 / 21 / 2014$ & Inclneration & Aragonite, UT Facillity \\
\hline
\end{tabular}

Under Civil and Criminal Penalties of Law for the making or submission of false or fraudulent statements or representations (18 U.S.C. 1001 and 15 U.S.C. 2615), I certify that the information contained In or accompanying this document is true, accurate, and complele. As to the Idenlified section(s) of this document for which I cannot personally verify truth and accuracy, I certify as the company oficiclal having supervisory responsibility for the persons who, acting under my direct Instructions, made the verification that this information is true, accurate, and complele.
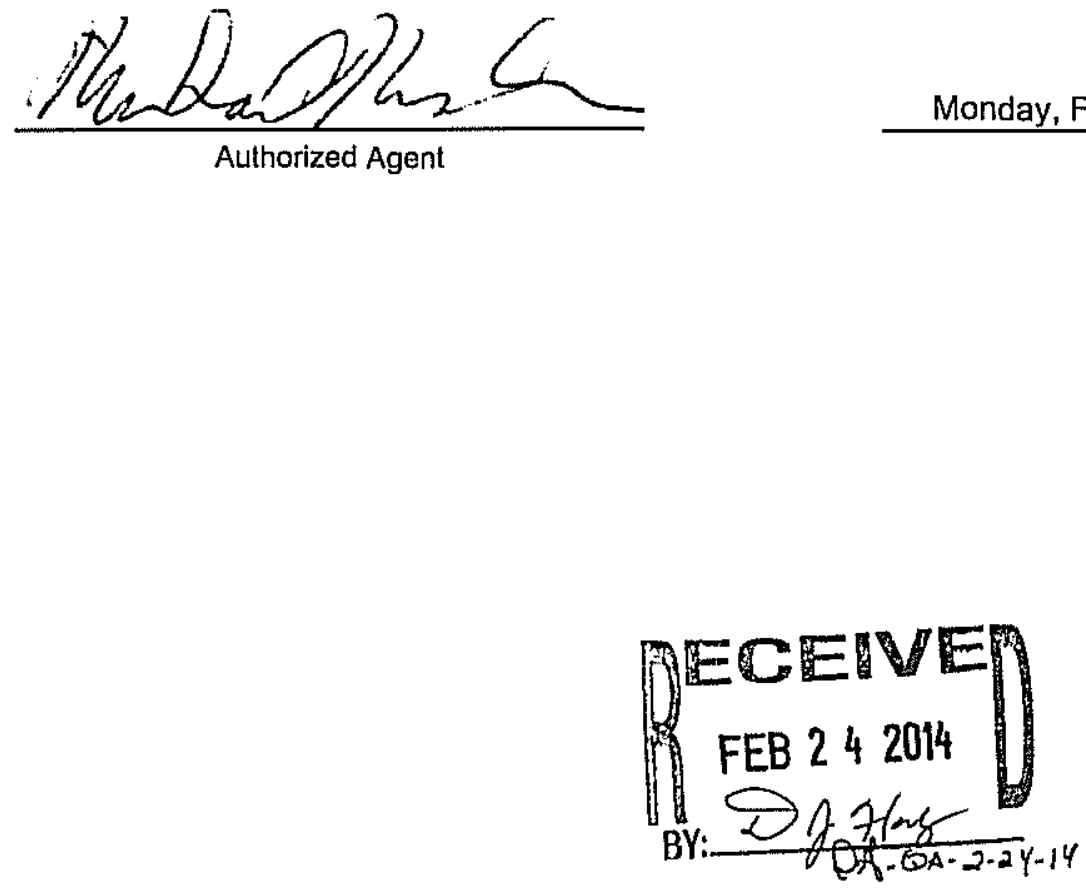
Please print or type. (Form designed for use on elite (12-pitch) typewriter.)

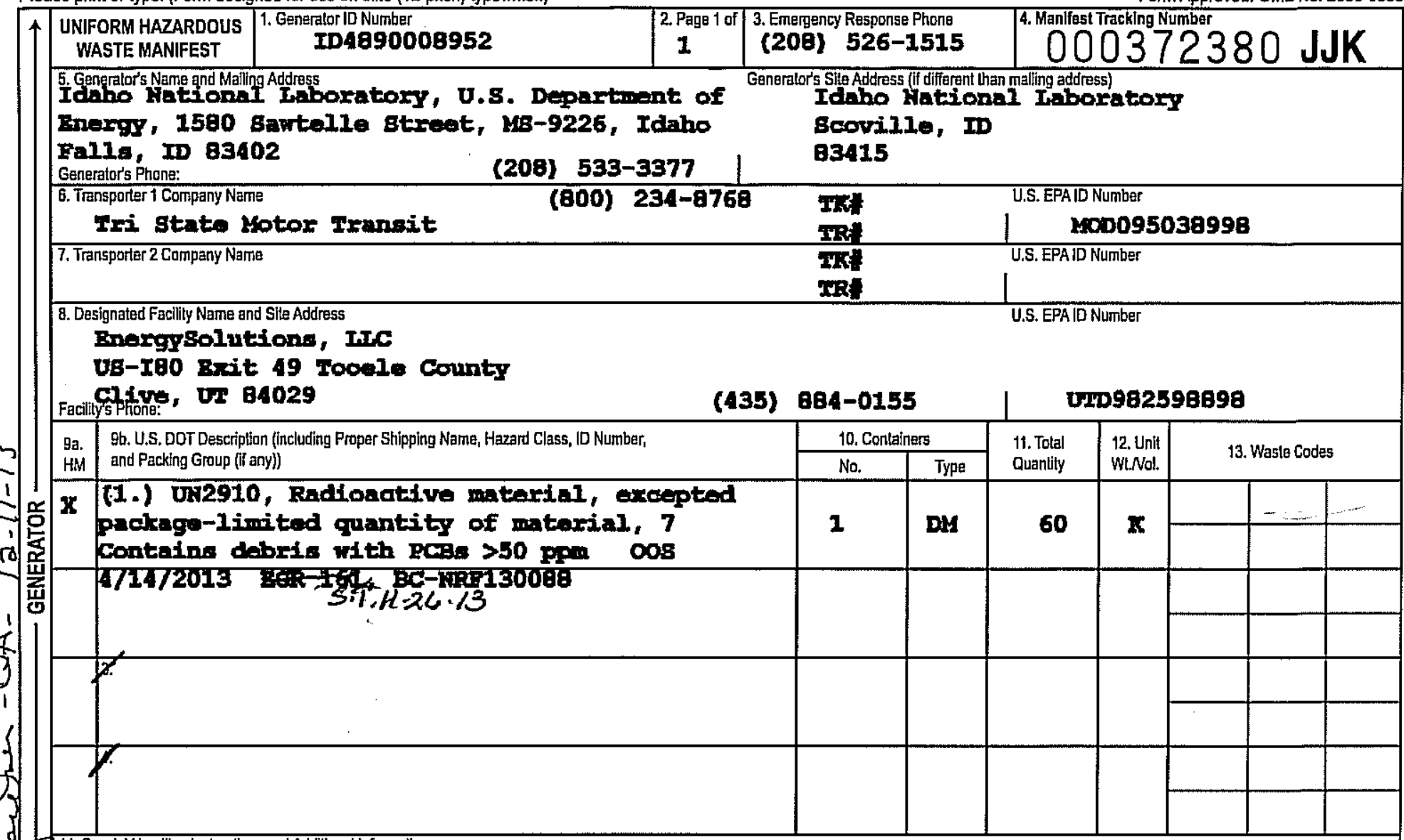

Returin algned original within 30 days to: CwI for U.S. DOB, Atta: Cyndi. Mahlum, Ms-9226. Prepared under contract No. DE-AC07-05ID14516. Bhipment 9113-31-0002. Comp 27631881.

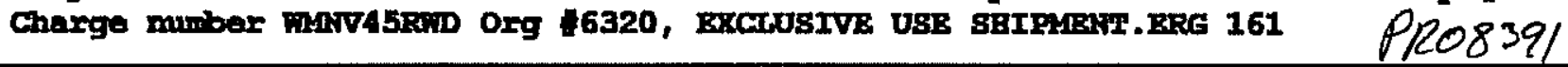

15. GENERATOR'S/OFFEROR'S CERTIFICATION: I hereby deciare that the contents of thls consignment are fully and accurately described above by the proper stalpping namie, and are classified, packeged, marked and labeled/placarded, and are in all respects in proper condition for transport according to applicable international and national governmental regulations. If export stipment and l am the Primary Exporter, I certify that the contents of this consignment conlorm to the lerms of the attached EPAAcknowledgment of Cansent.

I certify that the waste minimization statement identified in 40 CFR 262.27(a) (it I am a large quantity generator) or (b) (ifl am a small quantily generator) Is trute.

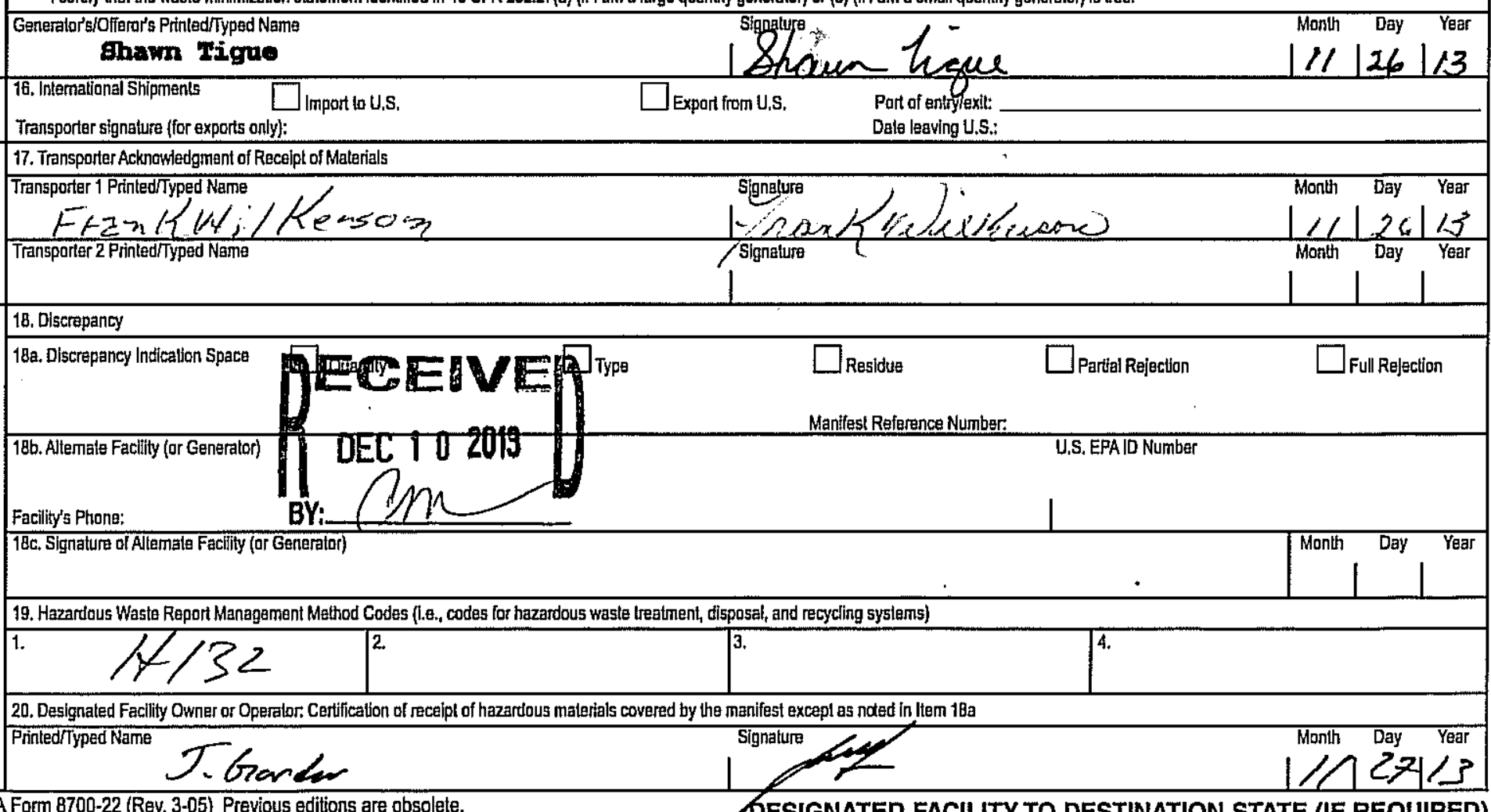




\section{ENERGYSOLUTIONS}

\section{CERTIFICATE OF DISPOSAL}

3 miles Sunth. Exit $49,1-80$

Clive, Utah $\$+420$

EPA ID; UTD982598898

\section{CH2M-WG Idaho of USA DOE, Idaho Falls}

This certificate acknowledges that the following manifested shipments have been disposed of as listed below:

$\begin{array}{llllll}\text { Shlpment } & \text { Manifest } & \text { Dtsposal Date } & \text { Volume (CulFt) } & \text { Proco5s } & \text { Dlsposal Location } \\ \text { M113-01-0391 } & 72384 & 03 / 17 / 2014 & 29.4 & \text { Landfill } & \text { Mlixed Waste } \\ 9113-01-0392 & 72410 & 03 / 17 / 2014 & 14.7 & \text { Landfll } & \text { Mixed Waste } \\ 9113-10-0022 & 72385 & 03 / 17 / 2014 & 58.8 & \text { Landfill } & \text { Mixed Waste } \\ 9113-10-0023 & 72408 & 03 / 17 / 2014 & 10.7 & \text { Landfill } & \text { Mixed Waste } \\ 9113-31-0002 & 72380 & 03 / 17 / 2014 & 7.4 & \text { Landfill } & \text { Mixed Waste }\end{array}$

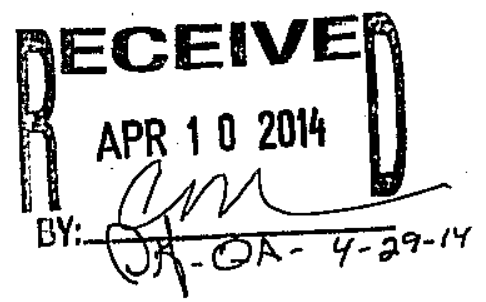

The total volume above represents the cubic feet of waste disposed of at EnergySolutions' Disposal Facility Landfill. Disposal is subject to EnergySolutions' Radioactive Material License; all other applicable licenses, permits and regulations, and the Disposal Agreement.

Under civil and criminal penallies of law for the making or submission of false or fraudulent statements or representalions (10 U.S.C 1001 and 15 U.S.C. 2615) I cartify that the infornation contained in or accompanying itsis document is thie. accurate and complete. As to the identificalion section(s) of this document for which I cannot personally verify thith and.accuracy. I certify as the company official having supervisory responsibilly for the persons who, acting under iny direct instructions, made the verification that this information is true. accurate and complete.
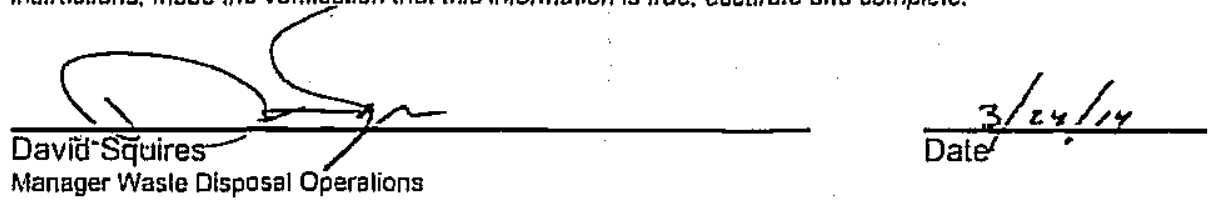

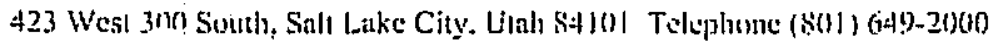


Pleáse print or type. (Form designed for use on elite (12-pitch) typewriter.)

\begin{tabular}{|c|c|}
\hline $\begin{array}{c}\text { 2. Page } 1 \text { of } \\
3\end{array}$ & 3 \\
\hline
\end{tabular}

5. Generator's Name and Mailing Address

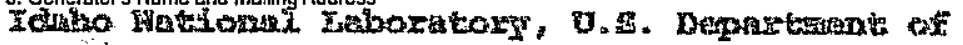

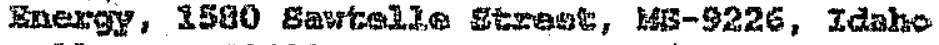

Fa11. in 83402

Generator's Phone:

(208) $523-9377$

6. Transpodter 1 Company Name

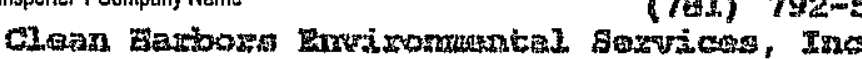

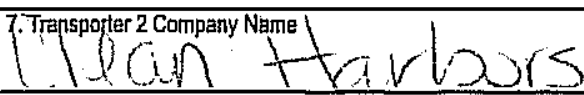

8. Designated Facility Name and Site Address

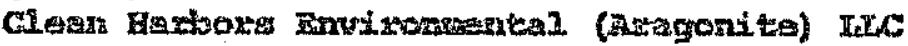

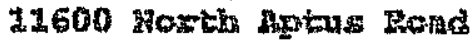

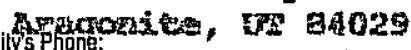

\begin{tabular}{|l|l|l}
\hline 9a. & 9b. U.S. DOT Description (inncluding Proper Shipping Name, Hazerd Cless, ID Niumber,
\end{tabular}

HM and Packing Group (if any))

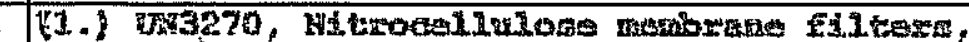

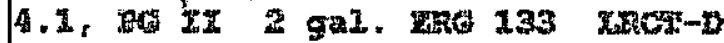

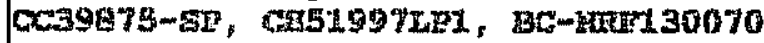
西

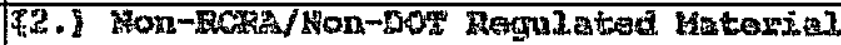

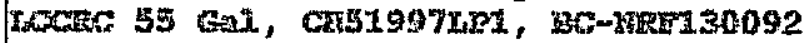

\author{
(4.35)
}

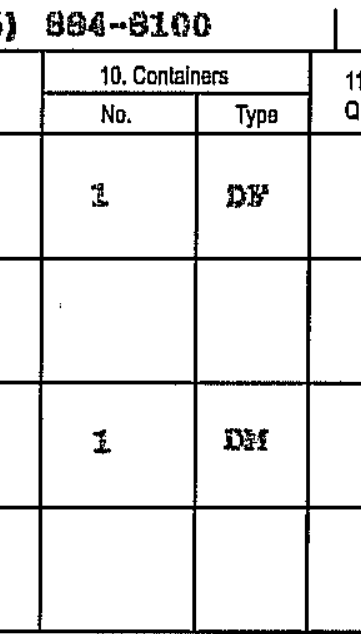

Seroridie, ID

1930.5

4

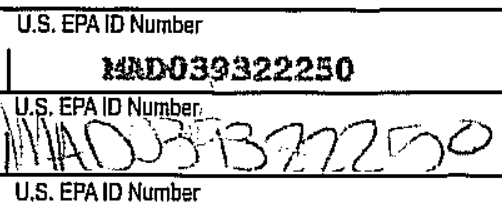

UETPa1s5ax 77

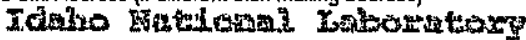

\begin{tabular}{|c|c|}
\hline \multicolumn{2}{|c|}{ U.S. EPA ID Nurnber } \\
\hline 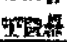 & 8420039322230 \\
\hline 25 & \\
\hline
\end{tabular}

\section{(1)}

\begin{tabular}{l|l|l|l} 
11. Tatal & 12. Unil & 13. Waste Codes \\
Quantity & WiLNol. &
\end{tabular}

14. Special Handling Insiructions and Additiongl Information

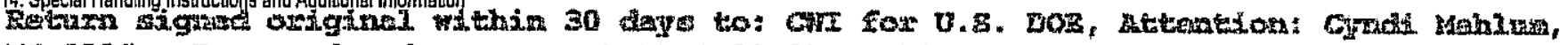

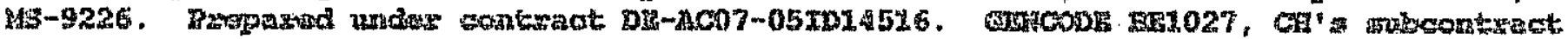

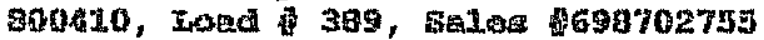

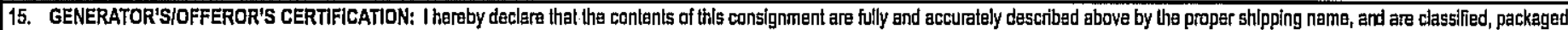

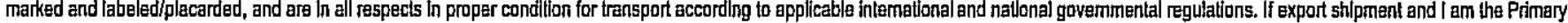
Expofter, I certify that the contents of this consignment conform to the terms of the allactied EPAAcknowiedgment of Consent.

I certily that the waste minirnlzation statement Identified in 40 CFR 262.27(a) (fi I am a legge quantity generator) or (b) (if I am a small quantity generator) Is trua.

Generator's/Offerar's Printed/Typed Name

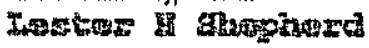

T6. Jaternalional Shipments
Transporter slgnature (for exports only):

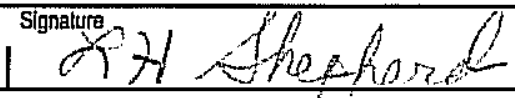

$\begin{array}{ll}\square \text { Export from U.S. } & \text { Port of entrylexil: } \\ \text { Date leaving U.S.: }\end{array}$

17. Transporter Acknowledgment of Receipl ol Materia!s

$$
\text { KiR K Lilsod }
$$

Tensportere? Printed (Typed Name

)ी

18-Discrepancy

2 JAN O 82014

18b. Altemate Facilly po
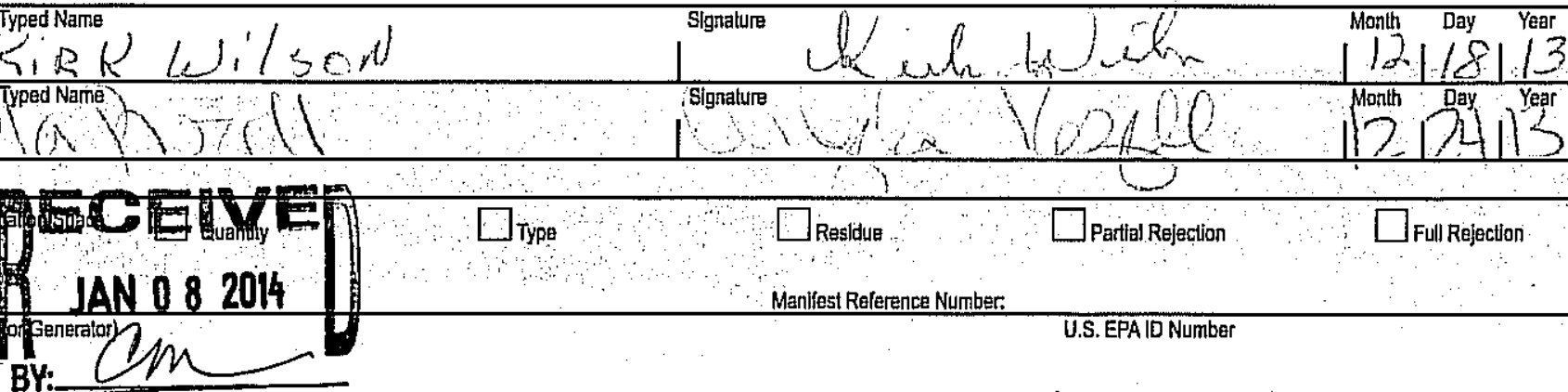

Facility's Phone:

18c. Signature of Alternate Facility (or Generator)

19. Hazardous Waste Report Management Method Codes (l.e., codes for hazardous waste traalment, disposal, and recyciling systems)

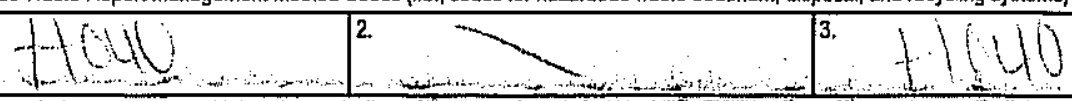

20. Deslgnated Facility Owner or Operator. Certilicalion of recelph of hazartous materials covered by the manilest excepl as nded in ltem $18 \mathrm{a}$ 


\section{Generato's Name}

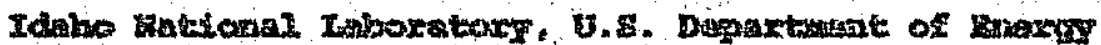

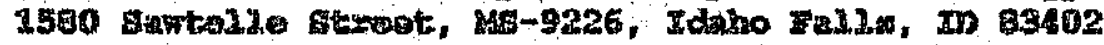

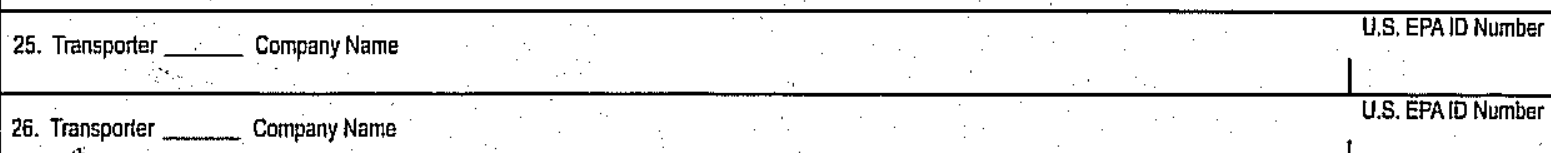

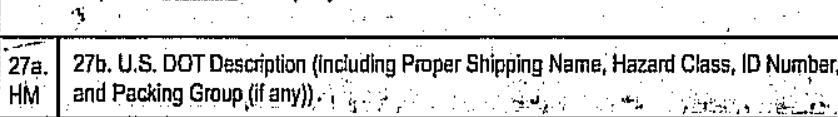

\begin{tabular}{|c|c|c|c|c|c|}
\hline \multirow{2}{*}{$\begin{array}{lll} & \vdots \\
4 & \vdots\end{array}$} & \multicolumn{2}{|c|}{ 28. Containers } & \multirow{2}{*}{$\begin{array}{l}\text { 29. Total } \\
\text { Quantity }\end{array}$} & \multirow{2}{*}{$\begin{array}{l}30 . \text { Unt } \\
\text { WiNol. }\end{array}$} & \multirow{2}{*}{ 31. Waste Codés } \\
\hline & $1 \mathrm{No}$ & Type & & & \\
\hline
\end{tabular}

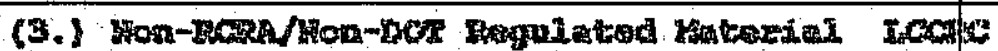

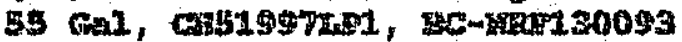

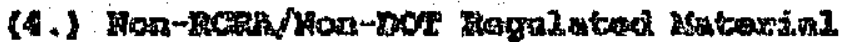

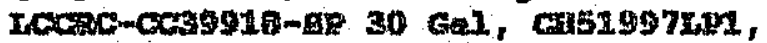
BC-1201813009A

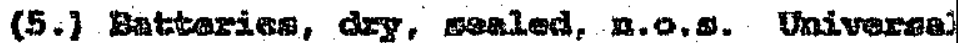

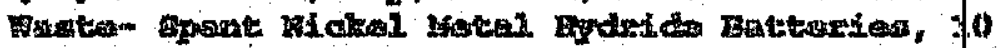

Goj, cons16390, DC-1709130095

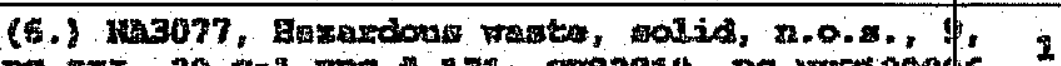

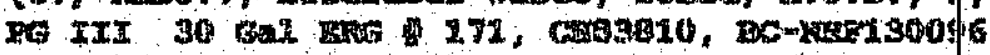

1

1

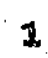

1

.
$0003723870 \mathrm{~m}$

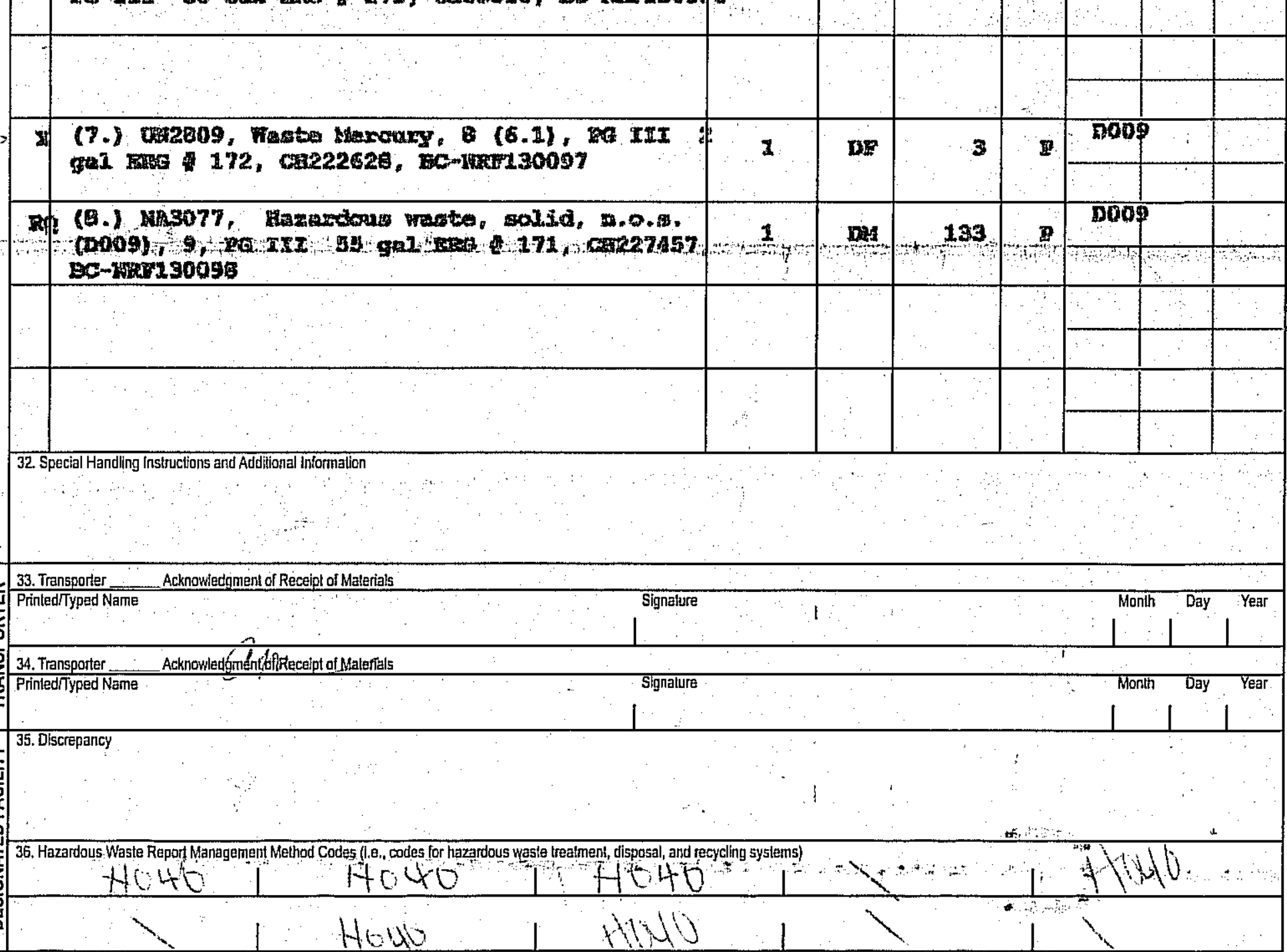


Please print or type: (Form designied for use on elite (12-pitch) typewiter.)

UNIFORM HAZARDOUS WASTE MANIFEST 21: Gejerator ID NUImbe

(Continuation Sheet)

Ins 890000952

\section{4: Generator's Name}

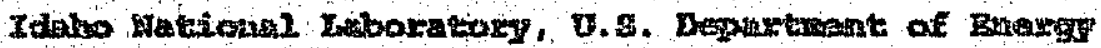

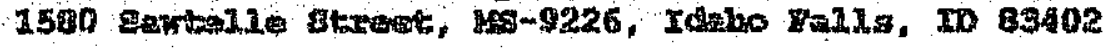

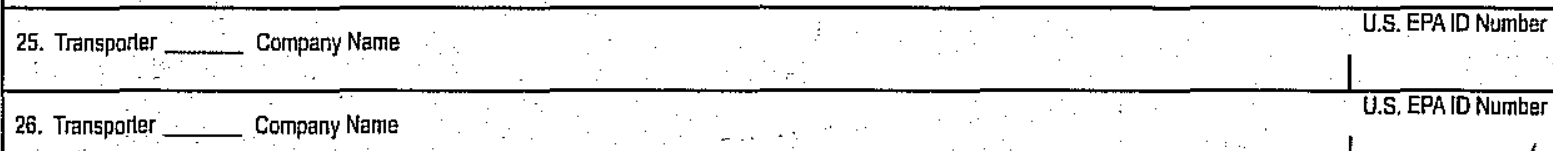

27a. 27b. U.S. DOT Description (inciuding Proper Shipping Name, Hezard Class, ID Number
HM. and Packiog Group (if anyl),

28. Containers

32. Special Handling insiructions and Additianal Infomation

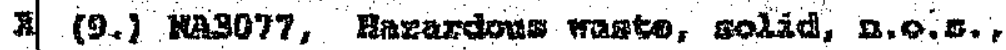

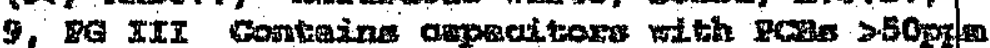

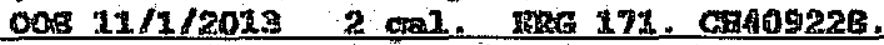
10--inkt 30101

1

10

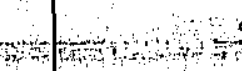

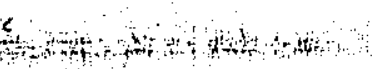

A

$0003729870 \mathrm{THR}$

1 


\section{JJK COD}

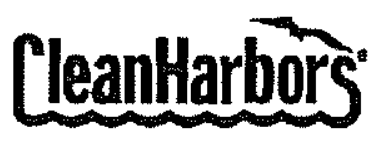

CleanHarbors'

\author{
Clean Harbors Aragonite LLC \\ 11600 North Aptus Road \\ Grantsville UT, 84029 \\ UTD981552177 \\ (435) $884-8100$
}

\section{CERTIFICATE OF DISPOSAL}

Generator Facility Name:

Generator Address:
Idaho National Laboratory US Department of Energy

CH2M-WG Idaho, LLC- Dan Haley - MS 9226

PO Box 2010

Idaho Falls, ID, 83415

\section{Sales Order\#: $\quad 698702757$}

Date Received: $\quad$ 1/2/2014

Generator Contact Name:

\begin{tabular}{lcccccc}
\hline Generator EPA ID: & CESQG & & Load \#: & $\begin{array}{c}66380 \\
\text { Manifest \#: }\end{array}$ \\
$000372387 J J K$ & \\
Original \\
CH ID \#
\end{tabular}

Under Civil and Criminal Penaltes of Law for the making or submission of false or fraudulent statements or representations (18 U.S.C. 1001 and 15 U.S.C. 2615), I certify that the Information contained in or accompanying this document is true, accurate, and complete. As to the identified section(s) of this document for which I cannot personally verify truth and accuracy, I certify as the company official having supervisory responsibility for the persons who, acting under my direct instructions, made the verification that this information is true, accurate, and complete.

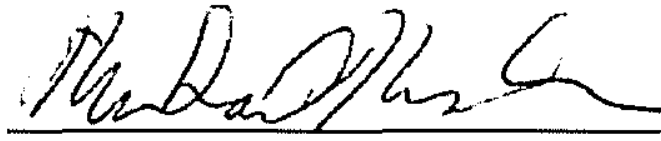

Authorized Agent
Wednesday, January 22, 2014

Date

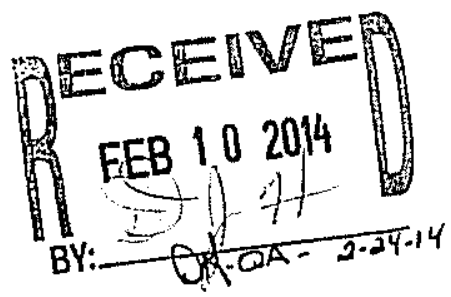


Please print or type. (Form designed for use on elite (12-pitch) typewriter.)

Form Approved. OMB No. 2050-0039

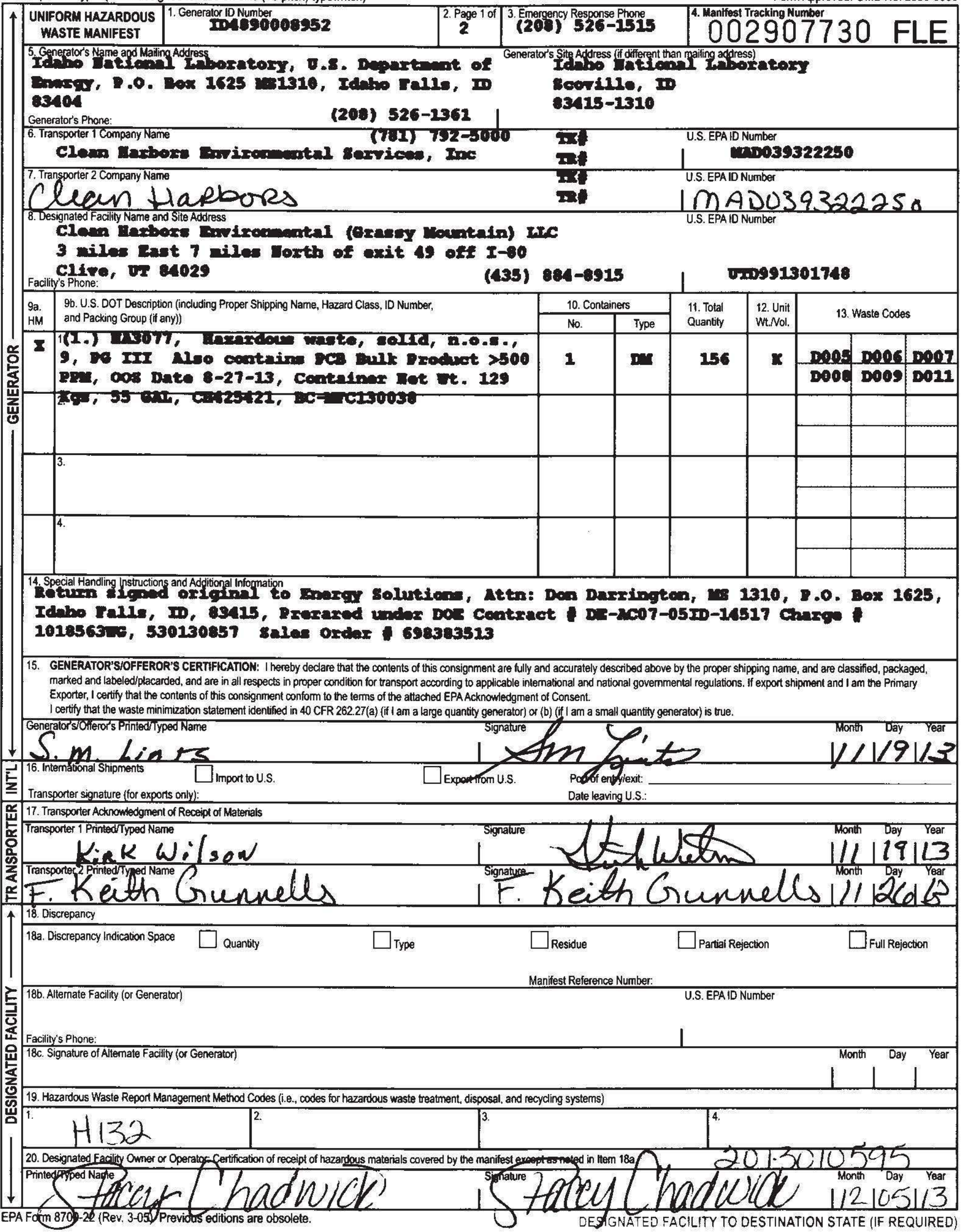




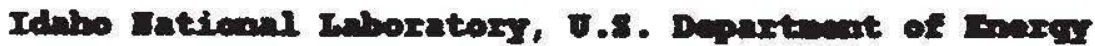

P.0. Dor $1625 \mathrm{~m} 1310$, Idhe ralle in eses

25. Transporter Company Name

26. Transporter

Company Name

27a. 27b. U.S. DOT Description (including Proper Shipping Name, Hazard Class, ID Number,

HM and Packing Group (if any))

I (2.) Exsorn, Earardoen waste, solid, n.0.9., g

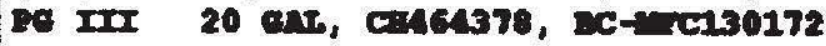
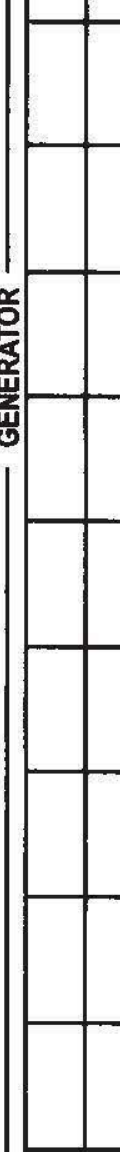

32. Special Handling Instructions and Additional Information

-2)
U.S. EPAID Number

U.S. EPA 1D Number

31. Waste Codes

30. Unit

31. Waste codes

No.
\begin{tabular}{l|l} 
No. & Type
\end{tabular} 1

I.

59

\begin{tabular}{|l|l|l|l|}
\hline \multirow{2}{*}{.} & D000 & D009 & D011 \\
\hline & & & \\
\hline
\end{tabular}

$\downarrow$

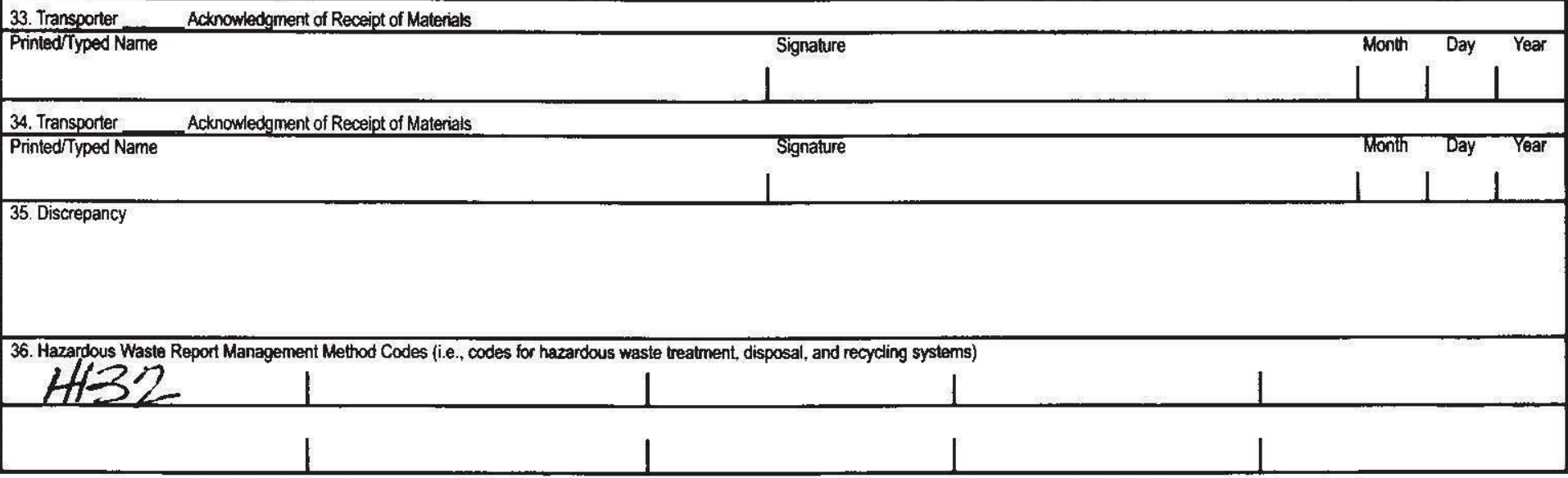


UTD991301748

(435) $884-8900$

\section{CERTIFICATE OF DISPOSAL}

Generator Facility Name:

Generator Address:
INL Materials \& Fuels Complex MFC

35 Miles West of Idaho Falls via Hwy 20 west

Idaho Falls, ID, 83415
Sales Order\#:

698383514

Date Received: $\quad$ 12/5/2013

Generator Contact Name:

Generator EPA ID: $\quad$ ID4890008952

$\begin{array}{ccc}\text { Original } & \text { Date Removed Unit } & \text { Serial \# I } \\ \text { CH ID \# } & \text { From Service } & \text { Type } \\ \text { Customer ID }\end{array}$

34887409

DM

MFC130038 /

Material
Description

Tsca Debris For Macroencapsulation

$\begin{array}{ll}\text { Load \#: } & 13010595 \\ \text { Manifest \#: } & \text { 002907730FLE }\end{array}$

\section{Disposal}

Date

$1 / 23 / 2014$

\section{Method of} Disposal

Landfill
Disposal Facility

Grassy Mountain, UT Facility

Under Civil and Criminal Penalties of Law for the making or submission of false or fraudulent statements or representations (18 U.S.C. 1001 and 15 U.S.C. 2615), I certify that the information contained in or accompanying this document is true, accurate, and complete. As to the identified section(s) of this document for which I cannot personally verify truth and accuracy, I certify as the company official having supervisory responsibility for the persons who, acting under my direct instructions, made the verification that this information is true, accurate, and complete.

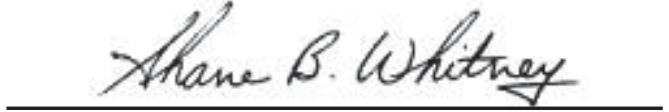

Authorized Agent
Wednesday, February 05, 2014

Date 